$(20)$

(2)

p最管

$=$

\title{
TWENTY-FIRST ANNUAL REPORT
}

OF THE

\section{United States Geological Survey}

TO THE

\author{
SECRETARY OF THE INTERIOR
}

$$
1899-1900
$$

CHARLES D. WALCOTT

DIRECTOR

IN SEVEN PARTS

PART VI-MINERAL RESOURCES OF THE UNITED STATES, 1899 METALLIC PRODUCTS, COAL, AND COKE

DAVID T. DAY. Chief of Division
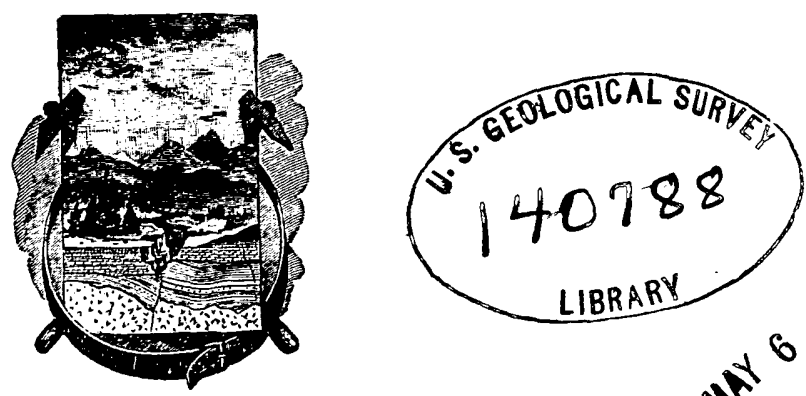

WASHINGTON

GOVERNMENT PRINTING OFFIOE 1901 

TWENTY-FIRST ANNUAL REPORT

OF THE

\section{UNITED STATES GEOLOGICAL SURVEY}

PART VI-MINERAL RESOURCES OF THE UNITED STATES, 1899 METALLIC PRODUCTS, COAL, AND COKE 



\section{CON'TENTS.}

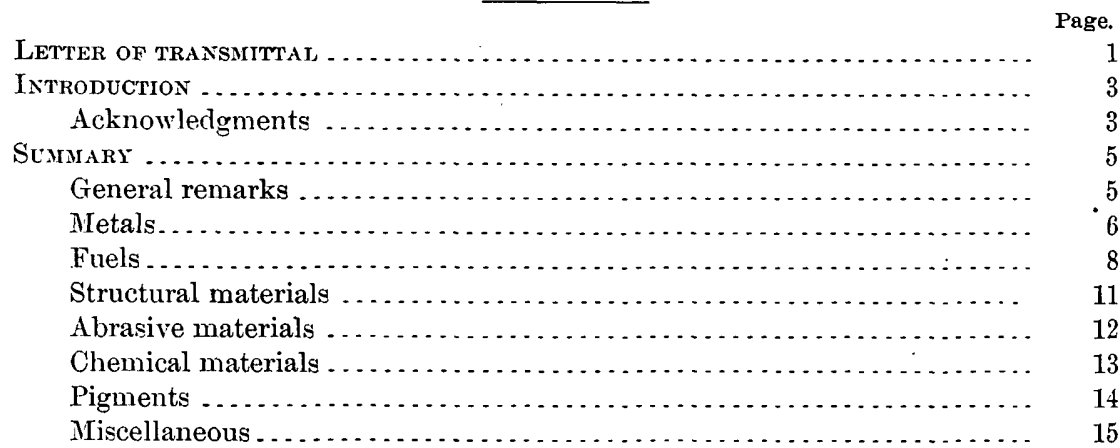

IRON ORES, BY JOHN BIRKINBINE.

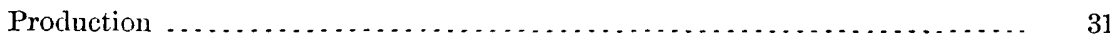

Classification of iron ores......................................... 32

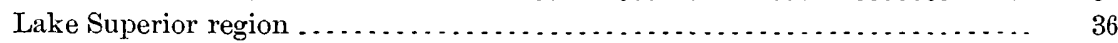

The iron-ore industry of the various States in $1899 \ldots \ldots \ldots \ldots \ldots \ldots \ldots \ldots . . .64$

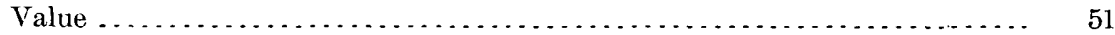

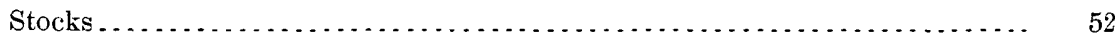

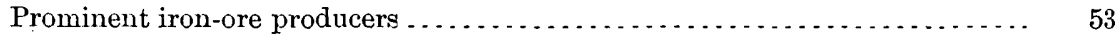

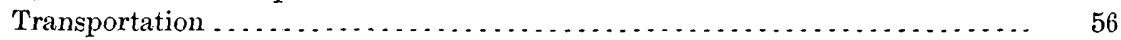

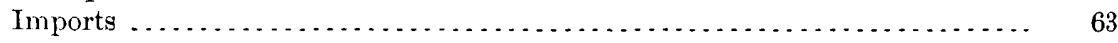

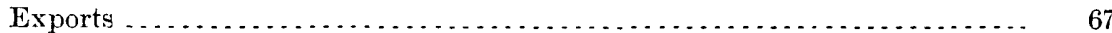

THE aMERicax aNi) Foreigin iron trades in 1899, By James ar. SWANK.

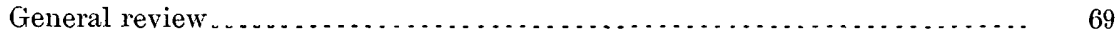

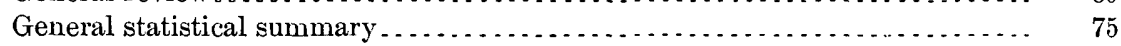

Average monthly prices of iron and steel ........................... 78

Average yearly prices of iron and steel. . . . . . . . . . . . . . . . 80

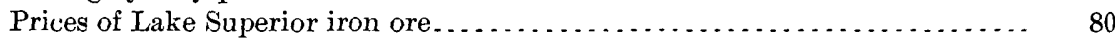

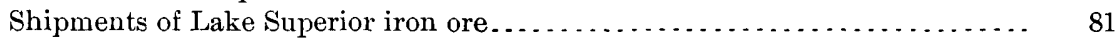

Receipts of iron ore at Lake Erie ports.......................... 81

Shipments of iron ore from New Jersey mines. . . . . . . . . . . . . . . . . 82

Shipments of iron ore from the Cornwall mines ..................... . 83

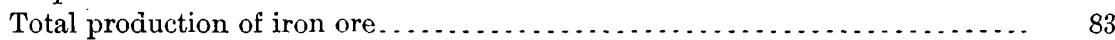

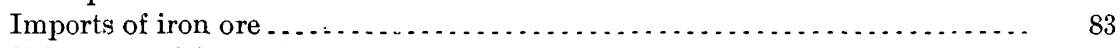

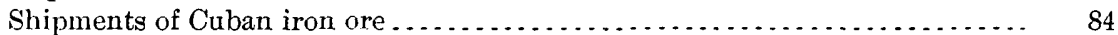

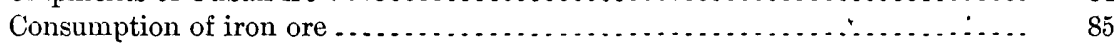

Production of manganese ore .................................. 85

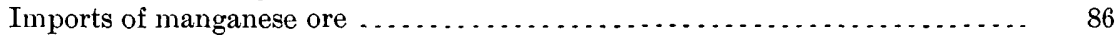

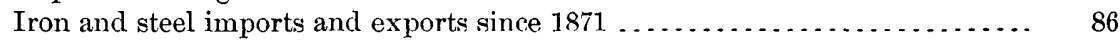

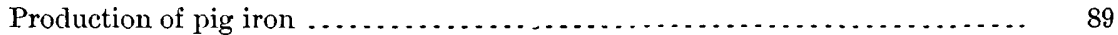

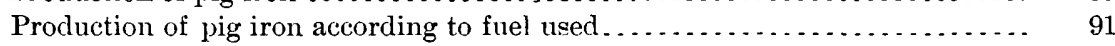

Production of Bessemer pig iron.................................. 92 
Page.

Production of basic pig iron....................................... 92

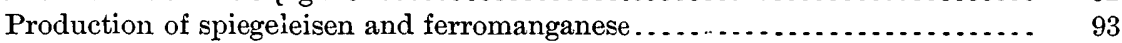

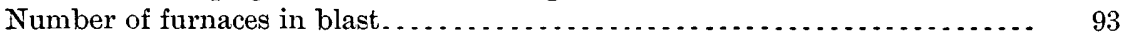

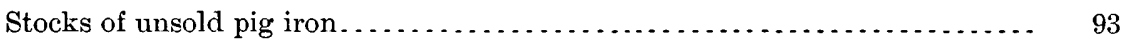

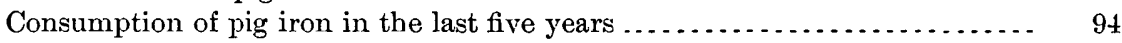

Production of pig iron from 1895 to 1899 , by States ....................... 95

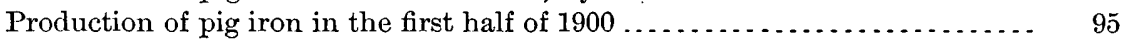

Limestone consumed in making pig iron......................... 96

Production of Bessemer steel................................. $\quad 96$

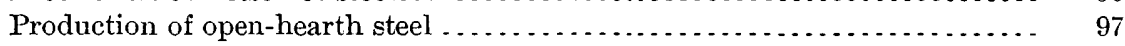

Production of crucible steel .................................... 99

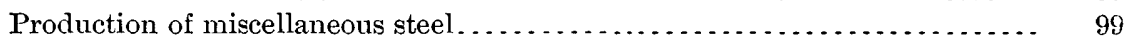

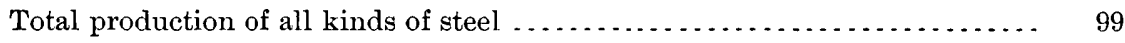

Production of Bessemer steel rails . . . . . . . . . . . . . . . . . . . . . . . . . 100

Total production of rails . . . . . . . . . . . . . . . .

Production of iron and steel structural shapes ...................... 102

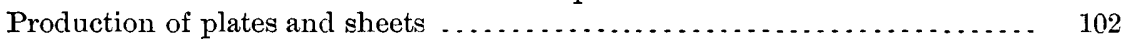

Production of wire rods. . . . . . . . . . . . . . . . . . . . . . . . . . . . . . 102

Production of wire nails ...................................... 103

Production of cut nails . . . . . . . . . . . . . . . . . . 103

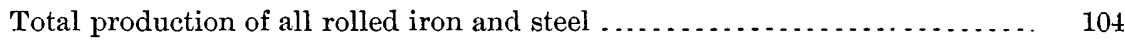

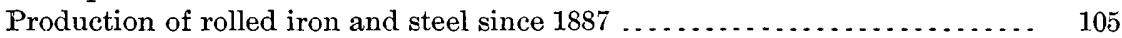

Production of iron blooms and billets ........................... 105

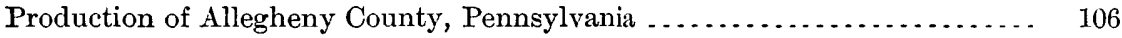

Production of tin plates....................................... 106

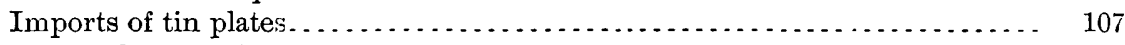

Iron and steel shipbuilding .................................... 107

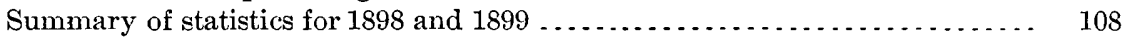

A verage monthly prices of steel rails at mills in Pennsylvania from 1868 to 1899 . $\quad 109$

Average prices per long ton of No. 1 foundry pig iron at Philadelphia since

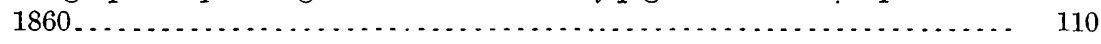

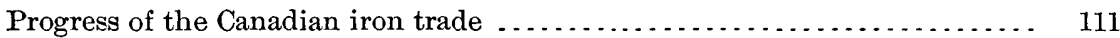

The world's production of iron ore and coal..................... 113

The world's production of pig iron and steel...................... 114

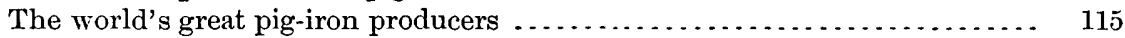

Production of Bessemer steel ingots and rails in the United States and Great

Britain . . . . . . . . . . . . . . . . . . . . . . . . . . . . . . . . . . . . .

Production of open-hearth steel ingots in the United States and Great Britain.

Production of all kinds of steel in the United States and Great Britain . . . . . . .

GOLD AND SILVER.

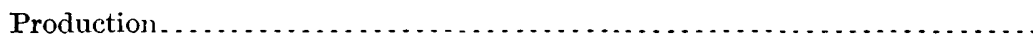

MANGANESE ORES, BY JOHN BIRKINBINE.

Production of manganese ores . . . . . . . . . . . . . . . . . . . . . . . . . . 129

Production of manganiferous iron ores . . . . . . . . . . . . . . . . 132

Production of manganiferous silver ores. . . . . . . . . . . . . . . . . . . . . . 133

Production of manganiferous zinc ores . . . . . . . . .

Production of manganese and manganiferous ores reported in $1899 \ldots \ldots \ldots . . .134$

Production of manganese by States . . . . . . . . . . . . . . .

Imports of manganese ores................................... 141

Production of manganese in foreign countries....................... 144

World's production of manganese ore . . . . . . . . . 
General trade conditions. . . . . . . . . . . . . . . . . . . . . . . . . . . . . 163

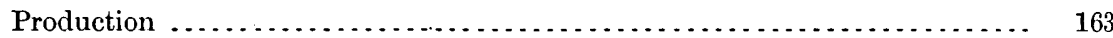

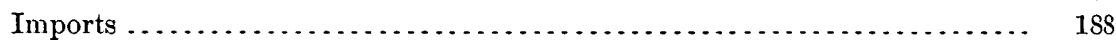

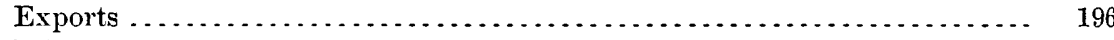

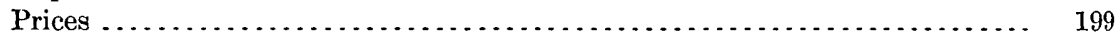

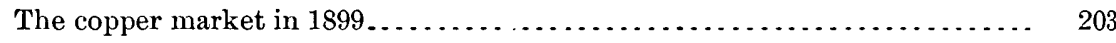

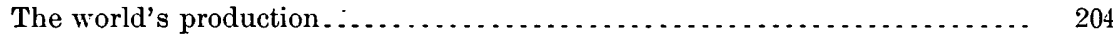

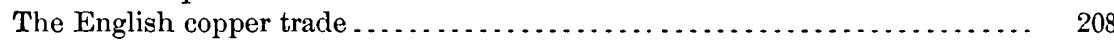

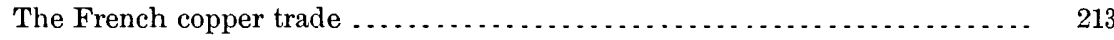

The German copper trade. . . . . . . . . . . . . . . . . . . . . . . . . . . . . 215

The Russian copper trade. . . . . . . . . . . . . . . . . . . . . . . . . . . 217

The leading foreign producers. . . . . . . . . . . . . . . . . . . . . . . . . . . . . . 218

LEAD, BI CHARLES KIRCHFOFF.

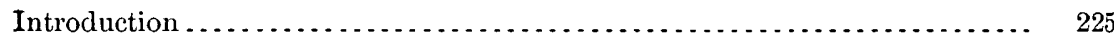

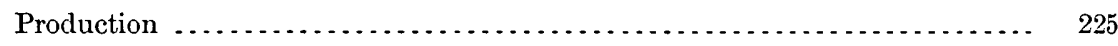

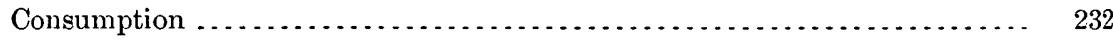

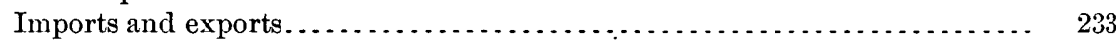

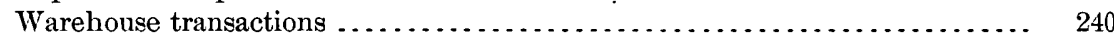

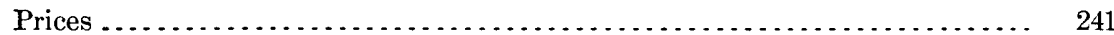

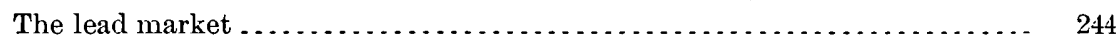

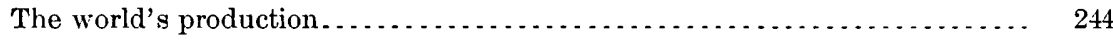

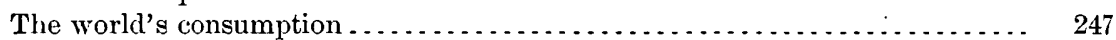

ZINC, BY CHARLES KIRCHHOFF.

Production ...................................................... 249

Zinc mining in the Galena-Joplin district ......................... 252

Consumption ... . .

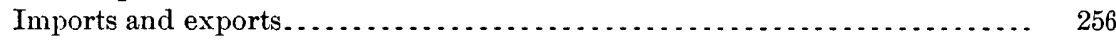

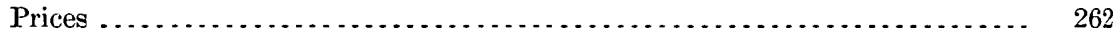

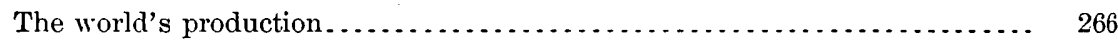

ALUMINUM AND BAUXITE.

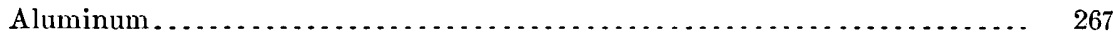

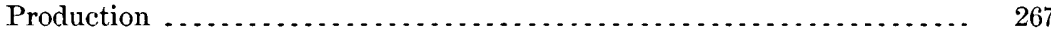

New uses for aluminum................................... 268

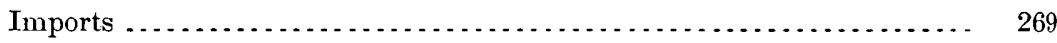

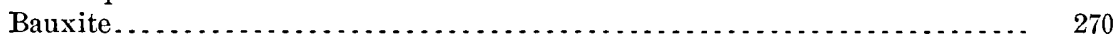

Production. . . . .

QLICKSILVER, BY EDWARD W. PARKER.

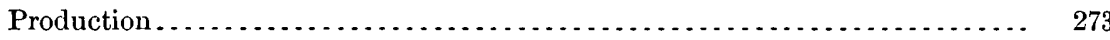

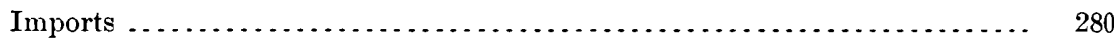

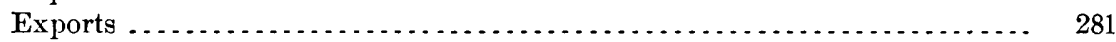

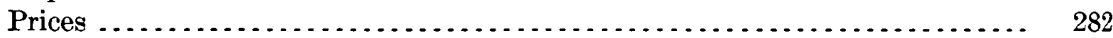

NICKEL AND COBAIT.

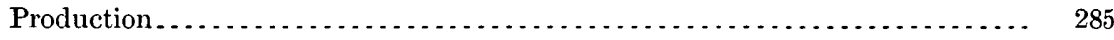

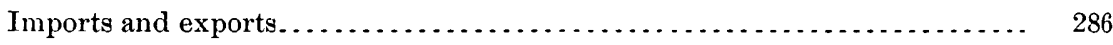

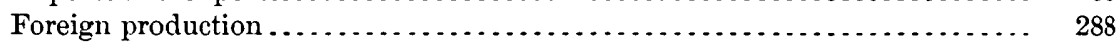


Production ...................... Page.

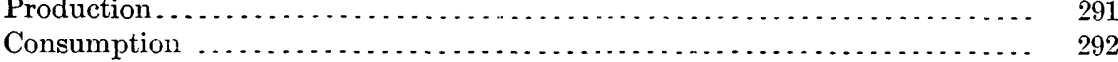

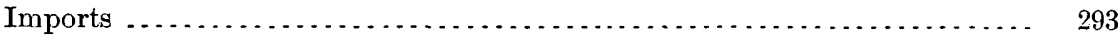

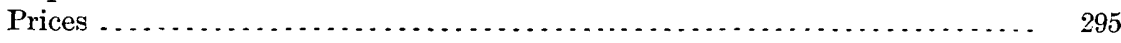

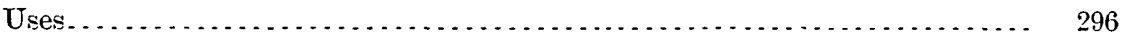

TUNGSTEN, MOLYBDENUM, URANIUM, AND VANADIUM, BY JOSEPF HYDE PRATT.

Tungsten . . . . . . . . . . . . . . . . . . . . . . . . . . . . . . . 299

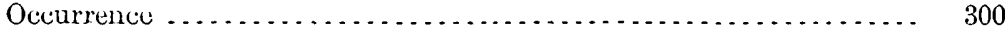

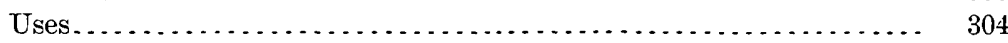

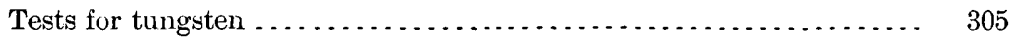

Molybdenum . . . . . . . . . . . . . . . . . . . . . . . . . . . . . . . . . . 305

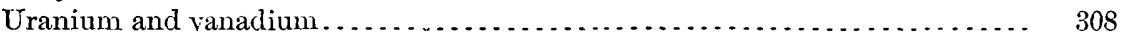

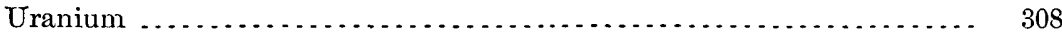

Uses. . . . . . . .

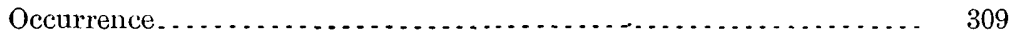

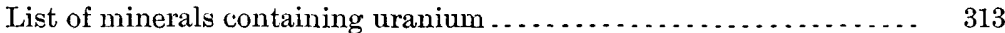

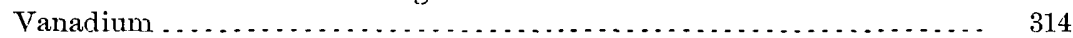

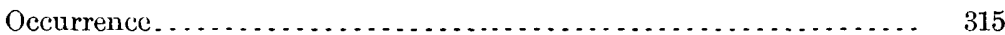

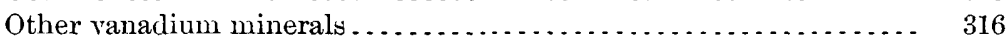

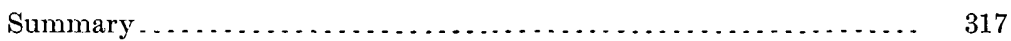

Tests for uranium and vanadium $\ldots \ldots \ldots \ldots \ldots \ldots \ldots \ldots \ldots \ldots \ldots \ldots \ldots$

AN OCCURRENGE OF TUNGSTEN ORE IN EASTERN NEVADA, BY F. B. WEEKS ... 319

COAL, BY EDWARD W. PARKER.

Introduction . . . . . . . . . . . . . . . . . . . . . . . . . . . . . . . . . 321

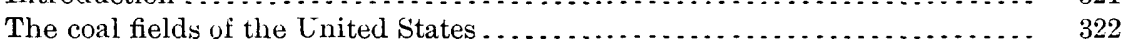

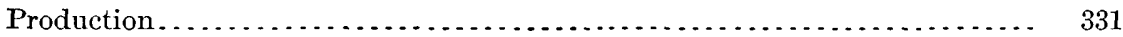

Anthracite . . . . . . . . . . . . . . . . . . . . . . . . . . . . . . . . 332

Bituminous . . . . . . . . . . .

Labor statistics. . . . . . . . . . . . . . . . . . . . . . . . . . . . . . .

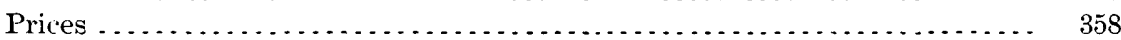

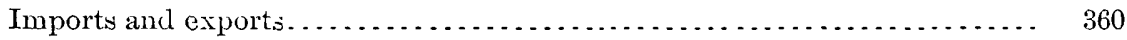

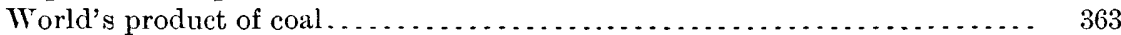

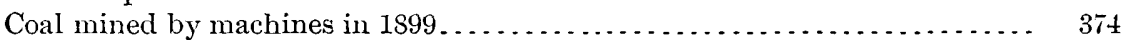

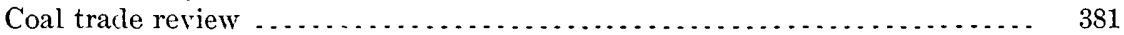

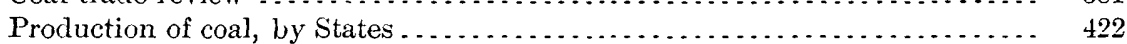

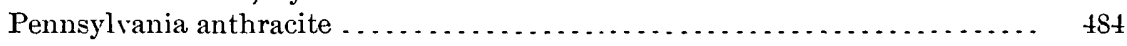

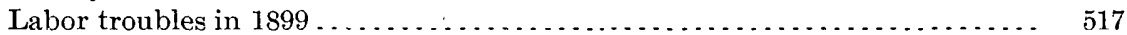

COKE, BY EDWARD W. PARKER.

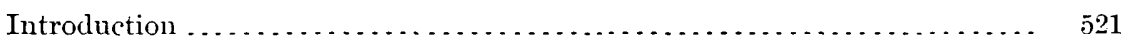

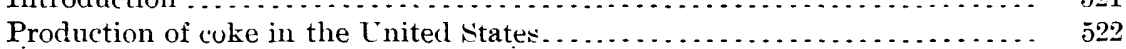

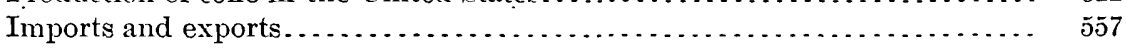

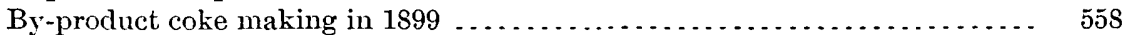

Production of coke, by States. . . . . . . . . . . . . . . . . . . . . . . . . 


\title{
LETTER OF TRANSMITTAL.
}

\author{
Department of the Interior, \\ United States Geological Survey, \\ Division of Mining and Mineral Resources, \\ Washington, D. C., February 23, 1901.
}

SIR: I have the honor to transmit the sixteenth annual report on the mineral resources of the United States. It bear's the title Mineral Resources of the United States, 1899. As usual, it carries the statistical record of the mineral development of this country to the end of the calendar year concerned, in this case to December 31, 1899, and contains in addition much descriptive matter collected while the statistical canvass was being finished. Practically all of the matter has found prompt publication in accordance with the law providing for the printing of each chapter as soon as completed.

In accordance with your instructions, the report for the calendar year 1900 is in preparation.

Very respectfully, your obedient servant,

$$
\begin{aligned}
& \text { David T. DaY, } \\
& \text { Geologist in Charge. }
\end{aligned}
$$

Hon. Charles D. Walcott,

Director, United States Geological Survey.

21 GEOL, PT $6-1$ 



\title{
MINERAL RESOORCES OF THE UNITED STATES, 1899.
}

\author{
David T. DAY, Chief of Divisiom.
}

\section{INTRODUCTION.}

The arrangement and scope of this volume are practically the same as in the fifteen volumes of the series, Mineral Resources of the United States, which have preceded it. The object of the volume is to record the developments in the mineral industries of the United States since the last report. The reports should be consulted together. Every chapter treated in this report is a census of the productive features of the industry as complete as possible with the means at disposal. The statistics of the production of gold and silver, as usual, are the work of the Director of the Mint, Treasury Department, and are. accepted as official. The statistics of the imports and exports of minerals, which form an essential part of the volume, are obtained through the courtesy of the Chief of the Bureau of Statistics, Treasury Department.

The totals given below will be found to differ somewhat from those published on the chart showing the mineral products of the United States from 1890 to 1899 . This is caused by the receipt of revised figures from special agents in charge of the statistics of some of the more important minerals.

\section{ACKNOWLEDGMENTS.}

Except as noted above and in a few isolated instances where some other well-established agency already exists by which the statistics are collected accurately, the figures are obtained direct from the producers, and it is impossible to acknowledge here, otherwise than by brief mention, the invaluable assistance which has been freely rendered by them and the voluntary contributions of many local experts. The names of the statistical experts who, acting under the authority of the United States, have collected statistics from the producers are given at the heads of the special chapters. The technical press, besides 
affording much information concerning new mining enterprises, has been largely drawn upon for prices, market reports, and new technical processes.

As heretofore, the publication of this volume has been anticipated to a great extent by the issuance in advance, in pamphlet form, of the several chapters which compose it. Before the issuance of this volume all of the chapters, except a few of the minor minerals, will have been so given to the public.

The following summary gives the principal statistical information in this report.

In presenting these statistics unnecessary duplication has been avoided. The coke product discussed in the following pages, amounting to over $19,000,000$ short tons, with a value of approximately $\$ 34,000,000$, is excluded from the tabulation, as the quantity and value of the coal used in its manufacture is included in the statistics of coal production. Similarly, white lead, red lead, and litharge, whose average aggregate value for the past ten years has exceeded $\$ 10,000,000$, are not given in the table, the base from which they are made being included in the output of pig lead. Zinc oxide or zinc white, made direct from the ores and consequently not included in spelter production, is tabulated. 'The product of pig iron and its value are given in the tabulation as the best means of presenting the statistics of production in the first marketable condition. The value of brick and pottery clays rather than the value of the manufactured products is embraced in the tabular statement, although the statistics of brick, tile, and pottery production are presented in detail in the report. Inflation of valuation and all unnecessary duplication are thus avoided. 


\section{SUMMARY OF THE MINERAL PRODUCTION OF THE UNITED STATES IN 1899.}

\section{GENERAI REMARKS.}

Owing to the great variety in the units of measurement the only factor common to all mineral products and the only means by which the totals can be expressed is the value. The figures given in the following summary show the remarkable activity in the mineral industries of the United States, in common with other industries, during the year under review-1899. The total value of our mineral products in that year was the enormous sum of $\$ 972,560,093$, as compared with a grand total of $\$ 697,817,581$ in 1898 , a gain of $\$ 274,742,512$, or 39.37 per cent. The largest gain in any year since 1880 , except that of 1899 over 1898 , was in 1895 , when the product increased $\$ 94,634,861$, or 17.97 per cent. The next greatest increase was that of 1887 over 1886 , when it was $\$ 74,927,880$, or 16.81 per cent. In 1890 it was $\$ 68,641,328$, or 12.46 per cent. In 1898 it was $\$ 66,963,652$, or 10.61 per cent, while it was in $1881 \$ 36,856,552$, or 9.98 per cent.

In other years between 1880 and 1898, the gains were not noteworthy, while in some of the years, notably 1884, the product decreased $\$ 40,451,968$, or nearly 9 per cent. During the industrial depression of 1892-1895 the product would have been expected to decline, which it did, going from $\$ 648,675,081$ in 1892 to $\$ 574,299,8 \Omega 6$ in 1893 and $\$ 526,624,139$ in 1894 and $\$ 621,259,000$ in 1895 , not reaching the output of 1892 until 1898 .

While the normal rate of increase in the mineral products of the United States from 1880 to 1898 was in the neighborhood of $\$ 25,000,000$, the enormous gain of $\$ 274,742,512$ in 1899 over 1898 only serves to emphasize the great demand for mineral products and the consequent increase in value of the product, for while the value increased over 39 per cent the output of the mines probably did not increase much more than 10 per cent.

As will be noted from the summary, nearly every important mineral participated in this increase, and while the production of some of the leading minerals, such as pig iron, increased only slightly in quantity, and while lead showed an actual decline, still the extraordinarily high prices ruling in the mineral markets produced the great increase 
in value of the product. Pig iron increased from 11,773,934 long tons in 1898 to $13,620,703$ in 1899 , a gain of $1,846,769$ tons, or less than 16 per cent; yet the value of the product increased from $\$ 116,557,000$ in 1898 to $\$ 245,172,654$ in 1899 , or a gain of $\$ 128,615,654$, or over 110 per cent, or nearly one-half of the total gain in all minerals. While copper increased its product about 8.01 per cent, its value increased 63.62 per cent.

Among the nonmetallic products the coals, natural gas, petroleum, cement, and stone made notable gains, and almost all of the minor mineral products kept pace to the quickened industrial activity; yet a study of the table will show that the metallic products made the greatest gains. Of the total gain of $\$ 274,742,512$ the metallic products contributed $\$ 182,072,026$, or 66.27 per cent, and the nonmetallic products $\$ 92,670,486$, or 33.73 per cent.

\section{METALS.}

Iron and steel.-The pig-iron industry was in an extraordinarily prosperous condition in 1899, as shown by the enormous production of that year, the product being $13,620,703$ long tons, valued at $\$ 245,172$,654 , as compared with $11,773,934$ long tons, valued at $\$ 116,557,000$, in 1898. The increase in production in 1899 over that of 1898 was therefore $1,846,769$ long tons, or 15.69 per cent, while the value of the product increased from $\$ 116,557,000$ in 1898 to $\$ 245,172,654$ in 1899 , a gain of $\$ 128,615,654$, or 110.35 per cent. In this year it reached its maximum in both product and value, the latter being $\$ 93,972,244$, or 62.1.5 per cent, greater than the value of the product in 1890, which was the maximum value of this product until 1899. The average value per long ton of pig iron increased from $\$ 9.90$ in 1898 to $\$ 18$ in 1899. This was the highest price reached since 188t, with the exception of 1887 , when it was $\$ 19$, the average prices per long ton in recent years being as follows: $1897, \$ 9.85 ; 1896, \$ 10.47 ; 1895, \$ 11.1 \pm ; 1894$, $\$ 9.76 ; 1893, \$ 11.90$.

The production of Bessemer steel ingots increased from 6,609,017 long tons in 1898 to $7,586,354$ tons in 1899 , a gain of nearly a million tons. The production of open-hearth steel in 1899 was $2,947,316$ long tons, as compared with 2,230,292 long tons in 1898. The production of Bessemer steel rails increased from 1,976,702 tons in 1898 to $2,270,585$, while all kinds of rails increased from $1,981,2 \pm 1$ tons in 1898 to $2,272,700$ tons in 1899 .

The production of all rolled iron and steel, including cut nails and excluding rails, was $8,084,697$ long tons in 1899 , as compared with $6,532,129$ tons in 1898 .

The production of iron and steel structural shapes increased from 702,197 long tons in 1898 to 906,277 tons in 1899 , an increase of 29.06 per cent. 
Iron ores.- The production of iron ores in the United States during 1899 amounted to $24,683,173$ long tons, an increase of $5,249,457 \mathrm{long}$ tons, or 27 per cent, over the production of 1898. This was accompanied by an increase in value from $\$ 22,060,887$ to $\$ 34,999,077$, a gain of $\$ 12,938,190$, or 58.65 per cent.

The production of iron ores in the United States in 1899 was the largest output by any country in a single year; the product of 1898 was also a record breaker, when $19,433,716$ long tons were mined. The nearest approach to these figures was the production of Great Britain in 1880, when 18,026,049 long tons were mined.

Copper.-The industry was marked by an increase from $526,512,987$ pounds in 1898 , valued at $\$ 61,865,276$, to $568,666,921$ pounds in 1899 , valued at $\$ 101,222,712$, a gain of $42,153,934$ pounds and $\$ 39,357,436$. The product in 1899, as in the preceding year, was the largest obtained up to that time, both in amount and in value. Extraordinary prices prevailed in 1899, considering the large production, the average price per pound for the year being 17.8 cents, as against 11.75 cents in 1898 and 11 cents in 1897 .

Lead.-This is the only important product which showed a decline in 1899. It decreased from 222,000 short tons in 1898 to 210,500 short tons in 1899 . The value increased from $\$ 16,650,000$, to $\$ 18,945,000$.

Zinc.-The amount of zinc produced in the United States in 1899 was 129,051 short tons, valued at $\$ 14,840,865$, against 115,399 short tons, valued at $\$ 10,385,910$, in 1898 .

Gold.-The product of gold continued to increase, rising from $3,118,398$ fine ounces in 1898 , valued at $\$ 64,463,000$, to $3,437,210$ ounces in 1899 , valued at $\$ 71,053,400$. In 1897 the value of the gold product was $\$ 57,363,000$.

Silver.-The coining value of the silver product in 1899, was $\$ 70,806,626$, as compared with $\$ 70,384,485$ in 1898 . The commercial value of the product in 1899 was $\$ 32, \$ 58,700$, while in 1898 its commercial value was $\$ 32,118,420$. This is an increase of $\$ 422,141$ in the coining value and $\$ 740,280$ in the commercial value.

The product in 1899 was $5 \pm, 764,500$ fine ounces, while in 1898 it was $54,438,000$ ounces. The average value per ounce commercially in 1899 was 60 cents, and in 1898 it was 59 cents.

Quicksilver.-This product showed a decline in production of 638 flasks, while the value of the product increased $\$ 264,118$, being a decrease of 2.05 per cent in production and an increase of 22.22 per cent in value. The product in 1899 was 30,454 flasks, valued at $\$ 1,452,745$, as compared with 31,092 flasks in 1898 , valued at $\$ 1,188,627$. Texas for the first time enters the field as a producer of quicksilver in commercial quantities.

Aluminum.-The production and value of aluminum was the same in 1899 as in 1898 , viz, $5,200,000$ pounds, valued at $\$ 1,716,000$. 
Antimony.-Including the antimony contained in hard or antimonial lead, the amount of this metal obtained from ores of domestic production in 1899 was 234 short tons, valued at $\$ 43,600$. If to this product is added the amount of antimony contained in foreign ores smelted in the United States, the total amount of metal produced in this country in 1899 is estimated to have been 1,275 short tons, having a total value of $\$ 251,875$. In addition to the antimony produced in the United States we imported in $18992,990,915$ pounds, or 1,495 short tons, of metal, crude and regulus, valued at $\$ 241,685$. The total domestic consumption of antimony in 1899 amounted approximately to 2,770 short tons, the total value of which, based on the average price for the year, was about $\$ 550,000$.

Manganese ores. - The production of manganese ores in 1899 fell off considerably, or from 15,957 long tons in 1898 , valued at $\$ 129,185$, to 9,935 tons in 1899 , valued at $\$ 82,278$-a decline of 37.74 per cent in product and 36.31 per cent in value. Virginia has resumed her position of leading producer of this mineral, being credited with 62.7 per cent of the 1899 product.

Nickel.-The production of nickel increased quite markedly, from. 11,145 pounds in 1898 , valued at $\$ 3,956$, to 22,541 pounds in 1899 , worth $\$ 8,566$, which is an increase of over 100 per cent in both product and value, nearly reaching the output of 23,707 pounds in 1897 , which was the largest product since 1893 , when it was 49,399 pounds.

Platinum.-The production of crude platinum continues to be small, though it has constantly increased since 1893. In 1899 the product was 300 ounces, valued at $\$ 1,800$, while in 1898 it was 225 ounces, valued at $\$ 1,913$. In 1898 the average value of the product was $\$ 8.50$ per ounce, while in 1899 it was $\$ 6$ per ounce.

\section{FUELS.}

Coal. - The total product of anthracite coal in Pennsylvania in 1899 was $53,944,647$ long tons, equivalent to $60,418,005$ short tons, valued at the mines at $\$ 88,142,130$.

The total product of bituminous coal in 1899 (including lignite or brown coal, cannel, splint, and block coals, and the small anthracite product of Colorado and New Mexico) was 172,608,917 long tons, or $193,321,987$ short tons, valued at the mines at $\$ 167,935,304$.

The aggregate product of anthracite and bituminous coal in 1899 was $226,553,564$ long tons, or $253,739,992$ short tons, valued at $\$ 256,077,434$.

The record made in 1899 is an important one. Not only did the production exceed all previous records, but it placed the United States at the head of the coal-producing countries of the world. The production in each of the last three years has been the largest up to that time. In 1897 the output reached, for the first time, a total of 
$200,000,000$ short tons. The product in 1898 was $219,974,667$ short tons, an increase of nearly 10 per cent over 1897 . The statistics for 1899 show an increase of $33,765,325$ short tons, or 15.35 per cent, over 1898 , and of $53,518,327$ short tons, or 26.73 per cent, over 1897 . Comparing the product in 1899 with some of the earlier years of our history, a still more remarkable advance is shown. In 1889 our total production of coal was $1+1,229,613$ short tons, showing an increase in ten years of $112,510,379$ short tons, or nearly 80 per cent. In 1879 our production amounted to only $66,452,960$ short tons, compared with which the output in 1899 shows an increase of about 280 per cent; while in thirty years the production has increased about 700 per cent, the yield in 1899 being eight times that of 1869 , less than one generation ago. In the same period the production of Great Britain has about doubled, that of Germany has been multiplied by 4 , and that of France by 2.5. In 1869 the coal product of Great Britain was nearly four times that of the United States, and that of Germany exceeded ours by about 20 per cent.

One of the interesting features of the history of coal production in the United States in the last three year's is that the operators were prepared by the preceding years of depression to meet the demands made upon them by the period of prosperity through which the country has been passing. During the four or five years of "hard times" coal operators were contending with steadily declining prices, brought about by a continued overproduction and a keen competition for a market for the output. To meet these conditions methods were adopted wherever possible for cheapening the cost of production by the installation of coal-cutting machines, mechanical haulage, etc., so that when the extraordinary demands of the last two years developed many operators were able to expand their production 25 or 50 per cent without materially increasing the length of their pay rolls.

Another feature worthy of note which is shown in the statistics for 1899 is the advance in the average price per ton and a consequent increase in the value of the product proportionately greater than the increase in product. As shown in the subsequent table, this is the first time in a period of twelve years when there has been an advance in the general average price. The improvement in the price of coal, however, is not so marked as that shown in many other commodities. Much of the coal marketed in 1899 was sold on contract made the preceding year, as it was not until the latter part of the year that the operators began to reap actual benefit from the improved condition.

The statistics regarding the use of mining machines show that the amount of bituminous coal undercut by machines in 1899 was 43,963 ,933 short tons, against $32,413,144$ short tons in $1898,22,649,220$ tons in 1897 , and $16,424,932$ tons in 1896 .

The total number of men employed in all the coal mines of the 
United States in 1899 was 410,635 , working an average of $21 \pm$ days, as compared with 401,221 men working 190 days in 1898 , and 397,701 working 179 days in 1897 .

In considering the coal product these reports include not only the coal marketed, either by shipments to distant points or sold locally, but also that consumed by the mine employees and by the mine operators themselves in locomotives, under stationary boilers, etc., in working the mine, and technically known as colliery consumption. There are occasional exceptions, where operators use only slack or waste, which would otherwise be thrown on the dump and not get recorded, the miner not even being paid for it. These exceptions are few and the amount is so comparatively small as not materially to affect the total. Coal consumed in the manufacture of coke is also included in this report.

The coal shipped, sold to local trade and employees, and used in the manufacture of coke is considered the marketable product. The colliery consumption averages about 8 per cent of the total product in anthracite production and about $1 \frac{1}{2}$ per cent in bituminous mining. The marketable product in 1899 amounted to $244,612,654$ short tons, as compared with $212,053,378$ short tons in 1898 .

Coke.-The unprecedented activity which prevailed throughout the iron and steel trade in 1899 stimulated the production of coke to a remarkable degree. The production increased from 16,047,209 short tons in 1898 to $19,668,569$ short tons in 1899 , a gain of $3,621,360$ tons, or nearly 23 per cent. As the production in 1898 was 20 per cent larger than that of 1897 , the output of the coke ovens of the United States in 1899 amounted to 50 per cent more than that of two years before. This phenomenal increase in production was accompanied by a still larger proportionate increase in the value, which advanced from $\$ 25,586,699$ in 1898 to $\$ 34,670, \pm 17$ in 1899 , an increase of $\$ 9,083,718$, or 35.5 per cent. A little over one-half of the entire coke production in 1899 was from the Connellsville region of Pennsylvania, and the total product of Pennsylvania amounted to about 70 per cent of the entire output of the United States. The coke product of Pennsylvania in 1899 amounted to $13,577,870$ short tons, against $10,715,302$ tons in 1898. West Virginia, the second State in amount of coke produced, had an output in 1899 of $2,278,577$ short tons, against $1,925,071$ tons in 1898. The production of Alabama, which ranks third, increased from $1,663,020$ short tons to $1,787,809$ tons. Virginia, fourth, increased her production from 531,161 short tons to 618,707 tons, and the production of Colorado, which comes fifth, increased from $\pm i t, 808$ short tons to $530,42 \pm$ tons. No other State produced as much as 500,000 tons in 1899 or any preceding year.

The manufacture of coke in by-product ovens showed an increase even more remarkable than the increase in the total product. in 1898 
there were in existence in the United States 520 by-product ovens, and the production of by-product coke in that year amounted to 294,445 short tons. In 1899 the number of these ovens completed amounted to 1,020 , and the production to 906,534 short tons. There are a number of other by-product coke plants in course of construction or in contemplation, and before the close of 1901 the total number of. by-product coke ovens in the United States will be more than double.

Petroleum.-The production rallied from 55,364,233 barrels in 1898 to $57,070,850$ barrels in 1899 , a gain of $1,706,617$ barrels, or 3.08 per cent, although it did not reach the output of 1897 , which was $60,475,516$ barrels, its maximum output. The value increased from $\$ 44,193,359$ in 1898 to $\$ 64,603,904$ in 1899 , a gain of $\$ 20,410,545$, or 46.18 per cent. The average value per barrel for the whole United States in 1898 was $79 \frac{4}{5}$ cents; in 1899 it was $\$ 1.13 \frac{1}{5}$.

Natural gas. - The value of the natural gas product increased to $\$ 20,024,873$ from $\$ 15,296,813$ in 1898 . The amount of natural gas used shows a decrease on account of the gradual exhaustion of the supply, but owing to the high prices obtained for it, the value shows a noteworthy increase.

\section{STRUCTURAL MATERIALS.}

Stone.-The value of stone of all kinds increased from $\$ 38,441,354$ in 1898 to $\$ 44,713,660$ in 1899 , a gain of $\$ 6,272,306$, or 16 per cent. All of the varieties of stone participated in this increase, limestone and granite, however, making the greatest gain-nearly three-fourths of the whole.

The large export of slate, which for several years has been one of the astonishing features of the industry, continued, though the increase in 1899 over 1898 was only $\$ 6,458$, while the increase in 1898 over 1897 was $\$ 589,963$. The total value of the exports in 1899 was $\$ 1,363,617$.

Clays. - The great activity in all branches of the clay-working industries in 1899 was one of the results of the general prosperity which the country enjoyed during that year. The value of the raw clay entering into the manufactured product is estimated to have been $\$ 12,500,000$, being divided as follows: Brick, tile, and terra-cotta clays, $\$ 11,250,000$; clays for pottery, paper manufacture, etc., $\$ 1,731,537$.

As in the case of coke and salt, the collection of the statistics of the clay-working industries for 1899 was undertaken in cooperation with the Twelfth Census. Mr. Jefferson Middleton, who has had charge of this work for the Survey, was appointed an expert special agent to prepare this report, and on account of the detailed information asked on the schedules and the widespread nature of the industry, the figures are not available at this time.

Cement.-The Portland-cement industry in 1899 showed great gains over 1898 , the product increasing from $3,692,284$ barrels in 1898 to 
$5,652,266$ barrels in 1899 , a gain of $1,959,982$ barrels, or 53.08 per cent. The number of establishments reporting showed a large increase, from 31 in 1898 to 36 in 1899 . This industry was in a very prosperous condition and is rapidly gaining in importance.

The natural-rock cement showed a slight increase, from $8,418,924$ barrels in 1898 to $9,868,179$ barrels in 1899 , an increase of $1,449,255$ barrels, or 17.21 per cent.

The total production of cement was $15,520,445$ barrels, valued at $\$ 12,889,142$, as compared with $12,111,208$ barrels in 1898 , valued at $\$ 9,859,501$. The most of this increase, as shown above, was in the Portland-cement industry.

\section{ABRASTVE MATERIATS.}

Corundum and emery. - The combined product of this class of abrasives increased from 4,064 short tons in 1898 to 4,900 in 1899 , but owing to the falling off in the production of the higher-priced corundum from North Carolina the value of the product was considerably less in 1899 than in the preceding year, the amounts being $\$ 275,064$ in 1898 and $\$ 150,600$ in 1899 .

Garnet. - The amount of the product decreased slightly, from 2,967 short tons in 1898 to 2,765 tons in 1899 . In this case the conditions were reversed, and the value increased from $\$ 86,850$ to $\$ 98,325$.

Grindstones. - The value of the grindstones produced in the United States in 1899 was, with one exception, the largest on record, amounting to $\$ 675,586$, and was $\$ 185,817$, or 38 per cent, larger than the value of the product in 1898 , when it was valued at $\$ 489,769$. The largest production of grindstones reported in the history of the United States was in 1882, and was estimated at $\$ 700,000$.

Infusorial earth. - The product increased from 2,733 tons, valued at $\$ 16,691$ in 1898 , to 3,302 tons in 1899 , valued at $\$ 25,302$.

Millstones. - The value of the product increased from $\$ 25,934$ in 1898 to $\$ 28,115$ in 1899 . The value of the product in 1899 was the largest in ten years.

Oilstones. - The value of oilstones and whetstones made in the United States in 1899 was the maximum in our history, amounting to $\$ 208,283$, which, compared with 1898 , when the value was $\$ 180,738$, indicates an increase of $\$ 27,545$, or 15 per cent.

Tripoli.--Including the product from Newton County, Missouri, which for want of a better name is called tripoli, the output in 1899 amounted to 1,032 short tons of crude earth. In addition to this, 300 pounds of refined material was produced at Framingham, Massachusetts. The total value of the product from all sources was $\$ 11,730$.

Borax.-While the product of borax increased over one and onehalf times, or from $16,000,000$ pounds in 1898 to $40,714.000$ pounds in 1899 , the value of the product increased only $\$ 19,882$, or 1 i is per 
cent. The value of the product in 1898 was $\$ 1,120,000$, while in 1899 it was $\$ 1,139,882$.

Bromine.-The product decreased in 1899 from that of 1898 by 53,975 pounds, making the total 433,004 pounds, valued at $\$ 108,251$, as compared with 486,979 pounds in 1898 , worth $\$ 126,614$.

Fluorspar.-The principal producing region for this material is Rosiclare, Ill., and Marion and Crittenden counties, Ky. The product increased more than 100 per cent over that of 1898. The total production in 1899 was 15,900 short tons, against 7,675 short tons in 1898. The value increased from $\$ 63,050$ to $\$ 96,650$.

Gypsum.-This industry showed remarkable activity during 1899 , the output for the year being 66.73 per cent larger than that of 1898 , which was the previous year of maximum production; the value also increased in the same proportion as the product, the gain being $70 . \pm 1$ per cent. The total product in 1899 was 486,235 short tons, against 291,638 short tons in 1898 and 288,982 short tons in 1897. The value of the output, taken in its marketable condition, was $\$ 1,287,080$ in 1899 , as against $\$ 755,280$ in 1898 and $\$ 755,864$ in 1897 In arriving at the value of the gypsum, that portion of the product which is sold crude is taken at its value in the crude state, while the value of that which is made into calcined plaster is taken for the calcined plaster produced.

\section{CHEMICAL MATERIALS.}

Phosphate rock.-The phosphate-rock industry in 1899 is marked by considerable increase in production in Florida and Tennessee, decreased production in South Carolina, and the beginning of a phosphatemining industry in Pennsylvania. In Florida the increase in production was entirely in hard rock and in river pebble. No production of what is known as soft rock was reported in 1898 or 1899, and the amount of land pebble mined in 1899 was less than in the preceding year. The decrease in South Carolina production was in the output of land rock, which was only 75,000 tons less than in 1898; this was only partly made up by an increase of 30,000 tons in the production of river rock. Tennessee production increased about $37 \frac{1}{2}$ per cent. Pennsylvania entered the phosphate-mining industry with an output of 2,000 tons. The total amount of phosphate rock reported from all sources in 1899 was $1,515,702$ long tons, valued at $\$ 5,084,076$, as compared with $1,308,885$ long tons in 1898 , valued at $\$ 3,453,460$, indicating a total gain in product of 206,817 long tons, valued at $\$ 1,630,616$.

Pyrite.-The product decreased somewhat, from 193,364 long tons in 1898 to 174,734 long tons in 1899 . The value declined about $\$ 50,000$, it being $\$ 593,801$ in 1898 and $\$ 543,249$ in 1899 .

Salt.-The total production in 1899, including salt in brine used in the manufacture of soda ash, caustic soda, etc., at chemical works in 
New York and Michigan, amounted to $19,708,614$ barrels of 280 pounds net. This was an increase of 2,095,980 barrels, or about 12 per cent, over the product in 1898, which was in turn the largest output up to that time. The value of the product in 1899 increased slightly less than its amount, and amounted to $\$ 6,867,467$, which was a gain of 10.5 per cent over 189s. The large amount of salt in brine used at chemical works, and upon which a lower value is placed than on either evaporated or rock salt, is responsible for the comparatively less increase in the value. The principal feature of interest connected with the salt industry in 1899 was the securing of the control of a large number of producing plants by a few concerns whose interests are supposed to be allied. The principal producing plants in the Warsaw district, New York, have been combined under one management. A number of Michigan works have also combined under one management, as have the larger plants in the vicinity of Hutchinson, Kans.; Salt Lake City, Utah, and along Alameda Bay, in California. Several Ohio plants, formerly independent, have also been absorbed by combined interests.

Sulphur.-The mines of Louisiana, which were idle in 1897 and 1898 , resumed operations in 1899; and some sulphur was also produced in Nevada and Utah. The total product amounted to 4,830 short tons, valued at $\$ 107,500$, against 1,200 short tons, valued at $\$ 32,960$, in 1898 .

\section{PigMENTS.}

Burytes.--The production of barytes, or heavy spar, used as a substitute for or adulterant in white lead, was the largest in our history and amounted to 41,894 short tons, valued at $\$ 139,528$, against 31,306 short tons, valued at $\$ 108,339$, in 1898 . The year of previous largest production was 1892 , when the amount was 32,108 short tons.

Cobalt oxide. - The production increased from 6,247 pounds in 1898 , worth $\$ 9,371$, to 10,230 pounds in 1899 , worth $\$ 18,512$, which exceeds the product of 1896 , but does not equal that of 1897 , when it reached its maximum of 19,520 pounds, valued at $\$ 31,232$.

Metallic paint.-Exclusive of mortar color, the amount of iron ore ground for pigment in 1899 was 23,423 short tons, a gain of 2,451 short tons over 1898 , when the product amounted to 20,972 short tons. The value of the product decreased $\$ 14,034$, it being $\$ 263,979$ in 1898 and $\$ 249,945$ in 1899.

Ocher, umber, and sienna.-The production of ocher.in 1899 amounted to 14,124 short tons, valued at $\$ 140,168$, as against 11,963 short tons, valued at $\$ 123,832$, in 1898 . The production of umber decreased from 537 short tons in 1898 to 473 short tons in 1899 , and the production of sienna decreased from 689 short tons to 588 short tons, with proportionate decrease in value.

Venetian red.-The production of this pigment increased from 10,271 short tons, valued at $\$ 160,711$, in 1898 to 11,991 short tons, valued at $\$ 210,361$, in 1899 . 
White lead, red lead, litharge, and orange minerol.- - The production of all lead pigments showed substantial increases in 1899 . The output of white lead in oil increased from $153,036,302$ pounds to $170,214,565$ pounds; dry white lead increased from $39,058,581$ pounds to $50,178,486$ pounds. Red-lead production rose from $18,435,016$ pounds to $22,157,694$ pounds; litharge from $18,176,591$ pounds to $21,937,704$ pounds, and orange mineral from $1,462,715$ pounds to $2,024,302$ pounds. Values increased in satisfactory proportion. In each case the figures for 1899 were the maximum.

Zinc white. - The consumption of zinc oxide as a basis for white and colored pigments continues to increase, the amount of this material produced in 1899 being 40,146 short tons, valued at $\$ 3,211,680$, against 33,000 tons in 1898 , valued at $\$ 2,310,000$.

\section{MISCELLANEOUS.}

Asbestos. - As for several years, the output of this mineral came from two States-California and Georgia. The total product in 1899 amounted to 681 short tons, worth, crude at the mines, $\$ 11,7 \pm 0$, an increase from a product of 605 tons, worth $\$ 10,300$, in 1898 , and with one exception the largest output both in amount and value within the last fifteen years.

Asphaltrom.-This title includes the numerous varieties of bitumens or hydrocarbons occurring in the United States, and not discussed in the chapter on petroleum. The total product of these minerals in 1899 was 75,085 short tons, valued at $\$ 553,904$, as compared with 76,337 in 1898 , worth $\$ 675,649$, a decrease of 1,252 tons and $\$ 121,745$. This is the smallest product and value since 1896 .

Banxite.-The production of this ore of aluminum continues to increase, rising from 25,149 long tons in 1898 to 35,280 long tons in 1899. The value of the product increased from $\$ 75,437$ in 1898 to $\$ 125,598$ in 1899 .

Feldspar.-This product, whose principal use is in the pottery industry, more than kept pace with the great increase in the flint product, the output increasing from 13,440 short tons in 1898, valued at $\$ 32,395$, to 27,202 tons, valued at $\$ 238,545$ in 1899 , being a gain of 13,762 tons in output and $\$ 206,150$ in value, or 636.36 per cent in the value of the output.

Fibrous talc.-The production of this, mineral increased from 54,356 short tons in 1898 , valued at $\$ 411,430$, to 54,655 tons in 1899 , worth $\$ 438,150$. With the exception of 1891 and 1892 the value of the output in 1899 was the greatest ever attained. In those years it was $\$ 493,068$ and $\$ 472,485$, respectively.

Flint.-The production of flint (quartz) in 1899 was 36,852 short tons, valued at $\$ 229,345$, as compared with 21,426 short tons in 1898 , worth $\$ 42,670$, a gain in production of 15,426 tons, or 72 per cent, and in value $\$ 186,675$, or 437.49 per cent. The rapid gain in this 
industry has been remarkable, the rise being from $\$ 26,227$ in 1897 , $\$ 42,670$ in 1898 , and $\$ 229,345$ in 1899 .

Fuller's earth.-This product showed a decline in 1899 from 1898, the amounts being 14,860 short tons in the earlier year, valued at $\$ 106,500$, and 12,381 short tons in the later year, valued at $\$ 79,644$.

Graphite.-The production of crystalline graphite in 1899 was $2,900,732$ pounds, and of the amorphous variety 2,324 tons. The aggregate value of these products was $\$ 167,106$. The production of crystalline graphite in 1898 was $2,360,000$, and of the amorphous 890 short tons. The value of both of these products in 1898 was $\$ 75,200$.

Limestone for iron flux.-This product naturally kept pace with the increased production of pig iron, and $6,707,435$ long tons were used in 1899 for this purpose, valued at $\$ 4,695,205$; in 1898 the product was $5,275,819$ long tons, valued at $\$ 2,638,000$. This was an increase of $1,431,616$ tons, or 27.14 per cent, while the value incressed $\$ 2,057,205$, or 77.98 per cent.

Magnesite. - This product was practically the same in 1898 and 1899, or 1,263 short tons in the former and 1,280 short tons in the latter year. The value of the product showed a greater difference, or $\$ 19,075$ in 1898 and $\$ 18, \pm \$ 0$ in 1899 . This product comes entirely from California.

Marls. - It is estimated that the production of marl in New Jersey for fertilizing purposes in 1899 was about the same as that in 1898 , viz, 60,000 tons, valued at $\$ 30,000$.

Mica. - The mica production of the United States in 1899 consisted of 108,570 pounds of sheet mica, valued at $\$ 70,587$, and 1,505 short tons of scrap mica, worth $\$ 30,878$. The production in 1898 amounted to 129,520 pounds of sheet and 3,999 short tons of scrap, valued, respectively, at $\$ 103,534$ and $\$ 27,564$. This indicates a decrease of 20,950 pounds in the production of sheet mica in 1899 as compared with the preceding year, with a loss in value of $\$ 32,947$. The production of scrap mica was 2,494 short tons less than in 1898 , a decrease of over 60 per cent, while there was an increase of $\$ 3,314$, or 12 per cent in value.

The reason for the decrease in the domestic production in 18.99 may be ascribed to the large importations of foreign mica.

Mineral waters. - This industry showed an increase from $28,853,464$ gallons sold in 1898 to $39,562,136$ gallons in 1899 , a gain of $10,708,672$ gallons, or 37.11 per cent, while the value decreased from $\$ \$, 051,833$ in 1898 to $\$ 6,948,030$ in 1899 , a loss of $\$ 1,103,803$, or 13.71 per cent. In 1898 the average value per gallon was 27.9 cents; in 1899 it was 17.56 cents. This reduction in value is due to the fact that a number of new springs have reported with a large production at a low rateabout one-half a cent a gallon.

Monazite.-This product increased from 250,776 pounds in 1898 , valued at $\$ 13,5 \pm 2$, to 350,000 pounds in 1899 , valued at $\$ 20,000$. 
Precious stones. - The value of the product increased from $\$ 160,920$ in 1898 to $\$ 185,770$ in 1899 . Among the principal features of interest in the indastry in 1899 may be mentioned an increase in the output of the sapphire mines of Fergus County, Montana, and the discovery of remarkably brilliant sapphires in Granite County, Montana, the continued output of turquoise in New Mexico, the development of turquoise localities in Nevada and California, a great increase in the amount of diamond cutting in the United States, and a continued search for minor gems in North Carolina, Maine, Connecticut, and other States.

Pumice stone.-This product showed a decline from 600 short tons. in 1898 , valued at $\$ 13,200$, to 400 tons in 1899 , worth $\$ 10,000$.

Rutile. - This product showed a slight increase from 140 pounds in 1898 , worth $\$ 700$, to 230 pounds in 1899 , valued at $\$ 1,030$. Its principal use is as a coloring matter in artificial teeth.

Soapstone.-In 1899 the production of soapstone in the United States, 24,765 short tons, was larger than that of any preceding year, but the value, $\$ 330,805$, was considerably less than the value of the product in $1892,1894,1896$, and 1897 , when it was $\$ 423,449, \$ 401,325, \$ 354,065$, and $\$ 365,629$, respectively. While the value in 1899 was less than that of some preceding years, as just shown, nevertheless it was greater than that of 1898 , when the value was $\$ 287,112$.

21 GEOL, PT $6-2$ 
Mineral products of the

\begin{tabular}{|c|c|c|c|}
\hline & \multirow{2}{*}{ Products. } & \multicolumn{2}{|c|}{$189 \mathrm{~s}}$. \\
\hline & & Quantitș: & Value. \\
\hline & METAL & & \\
\hline 1 & Pig iron, spot value.. & $11,773,934$ & $\$ 116,557,000$ \\
\hline & Silver, coining value. & $54,438,000$ & $70,384,485$ \\
\hline 3 & Gold, coining value. & $3,118,398$ & $64,463,000$ \\
\hline 4 & Copper, value at New Yor & $526,512,987$ & $61,865,276$ \\
\hline 5 & Lead, value at New York City. & 222,000 & $16,650,000$ \\
\hline 6 & Zinc, value at New York City & 115,399 & $10,385,910$ \\
\hline & Quicksilver, value at San & 31,092 & $1,188,627$ \\
\hline & Aluminum, value at Pittsburg & $5,200,000$ & $1,716,000$ \\
\hline & Antimony, value at San Francise & 1,120 & 184,050 \\
\hline 10 & Nickel, value at Philadelphia & 11,145 & 3,956 \\
\hline 11 & $\operatorname{Tin}, \ldots \ldots \ldots \ldots \ldots \ldots$ & None. & \\
\hline $12 !$ & Platinum, value (crude) & 225 & 1,913 \\
\hline 13 . & Total value of me & . & $343,400,217$ \\
\hline & NONMETALI & . & \\
\hline 14 & Bituminous coal.. & $166,592,023$ & $132,586,313$ \\
\hline 15 & Pennsylvania anthracit & $47,663,076$ & $75,414,537$ \\
\hline 16 & Natural gas . ............ & (n............ & $15,296,813$ \\
\hline $\begin{array}{l}17 \\
18\end{array}$ & $\begin{array}{l}\text { Petroleum } \ldots \ldots \ldots \ldots \\
\text { Brick clay } . . . \ldots \ldots\end{array}$ & $55,364,233$ & $44,193,359$ \\
\hline 19 & 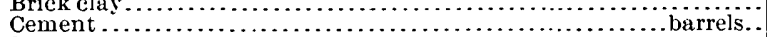 & $12,111,208$ & $\begin{array}{l}9,000,000 \\
9,859,501\end{array}$ \\
\hline 20 & Stone & & $36,607,264$ \\
\hline 21 & Corundum and emery. & 4,064 & 275,064 \\
\hline 22 & Garnet for abrasive purposes. & 2,967 & 86,850 \\
\hline 23 & 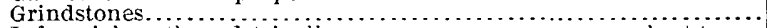 & & 489,769 \\
\hline 24 & Infusorial earth and tripoli. & 2,733 & 16,691 \\
\hline 25 & Millstones.............. & & 25,934 \\
\hline 26 & Oilstones, etc.. & & 180,738 \\
\hline 27 & Borax .......... & $16,000,000$ & $1,120,000$ \\
\hline 28 & Bromine.... & 486,979 & 126,614 \\
\hline & short tons.. & 7,675 & 63,050 \\
\hline 30 & ............ & 291,638 & 755,280 \\
\hline 31 & .......do.... & 60,000 & 30,000 \\
\hline 32 & Phosphate rock. & $1,308,885$ & $3,453,460$ \\
\hline 33 & Pyrite............ & 193,364 & 593,801 \\
\hline 34 & ..... barrels.. & $17,612,634$ & $6,212,554$ \\
\hline & .. short tons.. & 1,200 & 32,960 \\
\hline 36 & Barytes (crude). & 31,306 & 108,339 \\
\hline 37 & Cobalt oxide........ & 6,247 & 9,371 \\
\hline 38 & Mineral paints........ & 58,850 & 694,856 \\
\hline 39 & Zinc white....... & 33,000 & $2,310,000$ \\
\hline 40 & Asbestos ........... & 605 & 10,300 \\
\hline 41 & Asphaltum ............. & 76,337 & 675,649 \\
\hline 42 & .. long tons.. & 25,149 & 75,437 \\
\hline 43 & Chromic iron ore ........ & None. & None. \\
\hline 44 & Clay (all other than brick). & & $1,000,000$ \\
\hline 45 & 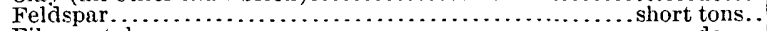 & 13,440 & 32,395 \\
\hline & Fibrous tale & 54,356 & 411,430 \\
\hline 47 & ........do.... & 21,426 & 42,670 \\
\hline 48 & Fuller's earth. & 14,860 & 106,500 \\
\hline & Graphite (crystalline). & $2,360,000$ & 75200 \\
\hline 50 & Graphite (amorphous). & & 75,200 \\
\hline 51 & Limestone for iron flux & $5,275,819$ & $2,638,000$ \\
\hline 52 & Magnesite ............. & 1,263 & 19,075 \\
\hline 53 & Manganese ore .......... & 15,957 & 129,185 \\
\hline 54 & Mica (sheets).. & 129,520 & 103,534 \\
\hline & Mica (scrap) $\ldots \ldots \ldots$ & 3,999 & 27,564 \\
\hline 56 & Mineral waters............. & $2 S, 853,464$ & $8,051,833$ \\
\hline 57 & ............ pounds.. & 250,776 & 13,542 \\
\hline 58 & 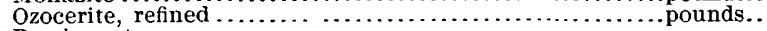 & None. & None. \\
\hline 59 & Precious stones & & 160,920 \\
\hline 60 & Pumice stone.. & 600 & 13,200 \\
\hline 61 & 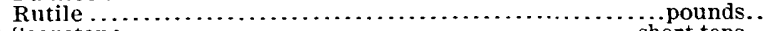 & 140 & 700 \\
\hline 62 & 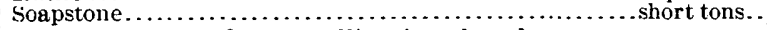 & 22,231 & 287,112 \\
\hline 63 & Total value of nonmetallic mineral products......... & & $353,417,364$ \\
\hline 64 & value of metallic pr & & $343,400,217$ \\
\hline 65 & Estimated value of mineral products & & $1,000,000$ \\
\hline 66 & Grand total ........... & & $697,817,581$ \\
\hline
\end{tabular}


United States in 1898 and 1899.

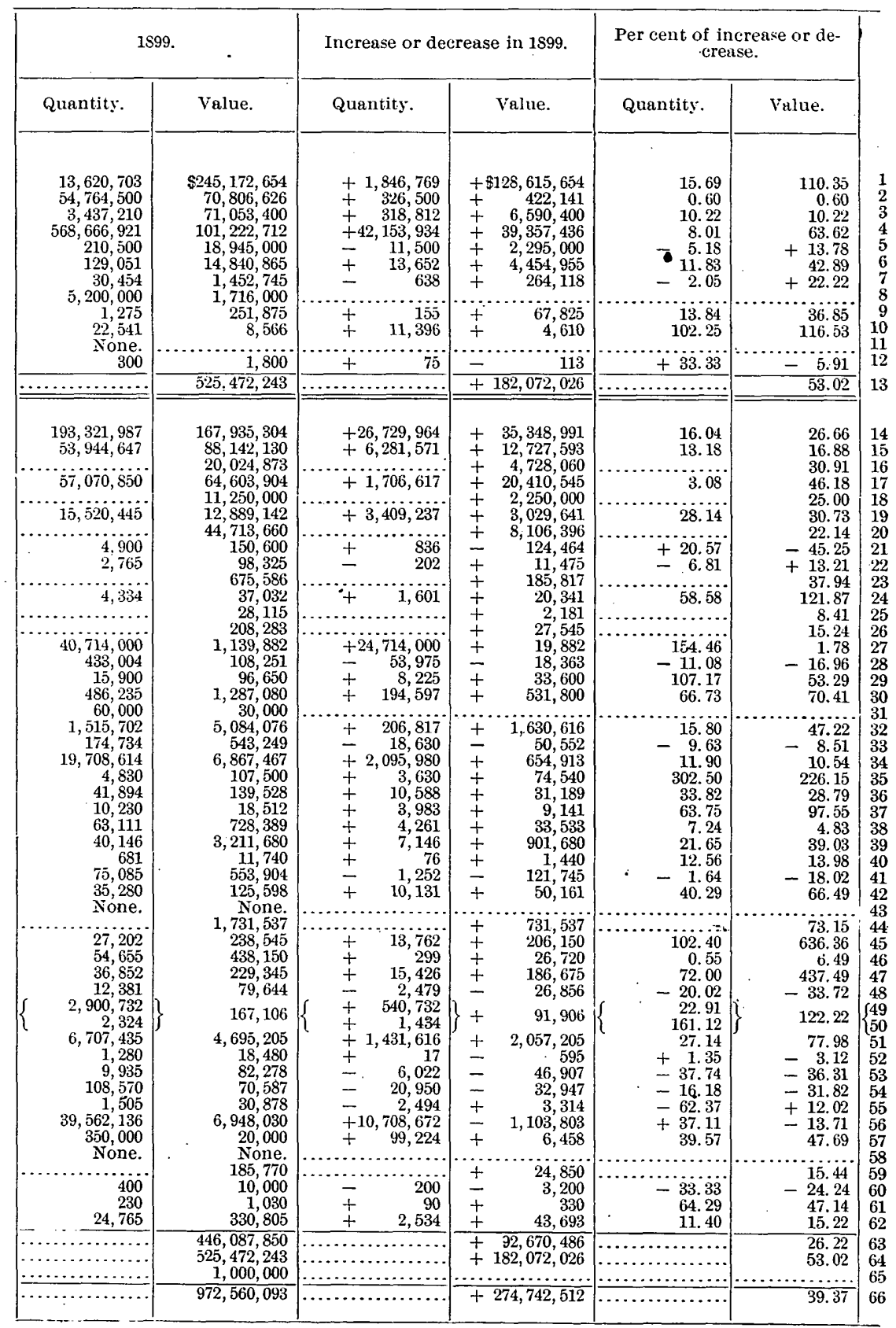




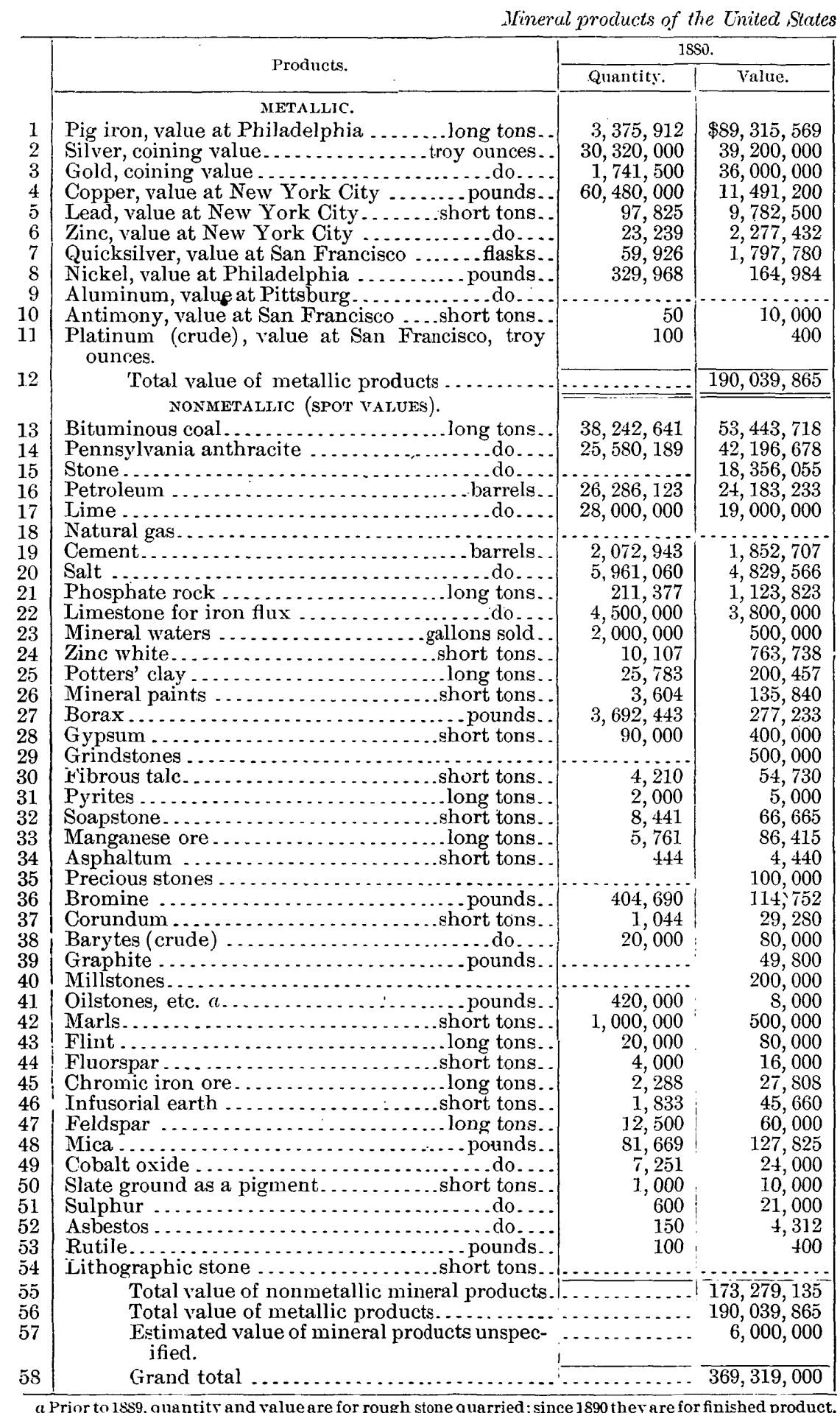


for the calendar years 1880 to 1899 .

\begin{tabular}{|c|c|c|c|c|c|c|}
\hline \multicolumn{2}{|c|}{1881.} & \multicolumn{2}{|c|}{1882.} & \multicolumn{2}{|c|}{$18 S 3}$. & \\
\hline Quantity. & Value: & Quantity. & Value. & Quantity. & Valne. & \\
\hline $4,144,254$ & $\$ 87,029,334$ & $4,623,323$ & $\$ 106,336,429$ & $4,595,510$ & $\$ 91,91.0,200$ & 1 \\
\hline $33,077,000$ & $43,000,000$ & $36,197,695$ & $46,800,000$ & $35,733,622$ & $46,200,000$ & 2 \\
\hline $1,676,300$ & $34,700,000$ & $1,572,186$ & $32,500,000$ & $1,451,249$ & $30,000,000$ & 3 \\
\hline $71,680,000$ & $12,175,600$ & $91,646,232$ & $16,038,091$ & $117,151,795$ & $18,064,807$ & 4 \\
\hline 7,085 & $11,240,160$ & 132,890 & $12,624,550$ & 143,957 & $12,322,719$ & 5 \\
\hline 26,800 & $2,680,000$ & 33,765 & $3,646,620$ & 36,872 & $3,311,106$ & 6 \\
\hline 60,851 & $1,764,679$ & 52,732 & $1,487,042$ & 46,725 & $1,253,632$ & 7 \\
\hline 265,668 & 292,235 & 281,616 & 309,777 & 58,800 & 52,920 & 8 \\
\hline & & & 5 & 83 & 875 & 9 \\
\hline 50 & 10,000 & 60 & 12,000 & 60 & 12,000 & 10 \\
\hline 100 & 400 & 200 & 600 & 200 & 600 & 11 \\
\hline$\cdots$ & $192,892,408$ & $\ldots \ldots \ldots \ldots \ldots$ & $219,755,109$ & $\ldots$ & $203,128,859$ & 2 \\
\hline 48 & 60,224 & 190 & 87 & 500 & $82,237,800$ & 13 \\
\hline 28,500 & $64,125,036$ & $31,358,264$ & $70,556,094$ & $34,336,469$ & $77,257,055$ & 14 \\
\hline & $20,000,000$ & & $21,000,000$ & & $20,000,000$ & 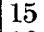 \\
\hline $27,661,238$ & $25,448,339$ & $30,510,830$ & $24,065,988$ & $23,449,633$ & $25,790,252$ & 16 \\
\hline $30,000,000$ & $20,000,000$ & $31,000,000$ & $21,700,000$ & $32,000,000$ & $19,200,000$ & 17 \\
\hline - - - - & & & 00 & $\ldots$ & 475,000 & 8 \\
\hline 2,500 & 2,000 & 000 & $3,672,750$ & 000 & $4,293,500$ & 19 \\
\hline $6,200,000$ & $4,200,000$ & $6,412,373$ & $4,320,140$ & $6,192,231$ & $4,211,042$ & 20 \\
\hline 266,734 & 1, 980,259 & 332,077 & $1,992,462$ & 378,380 & 0,280 & 1 \\
\hline $6,000,000$ & $4,100,000$ & $3,850,000$ & $2,310,000$ & $3,814,273$ & $1,907,136$ & 22 \\
\hline 3,700 & 700,000 & $5,000,000$ & 800,000 & $7,529,423$ & $1,119,603$ & 3 \\
\hline 10 & 700 & 10,000 & 700,000 & 12,000 & 840,000 & 24 \\
\hline 25 , & 200 & 30,000 & 240,000 & 32,000 & 250,000 & 25 \\
\hline 00 & 100 & 7,000 & 105,000 & 7,000 & 84,000 & 26 \\
\hline $4,046,000$ & 304,461 & $4,236,291$ & 338,903 & $6,500,000$ & 585,000 & 27 \\
\hline 85,000 & 350,000 & 100,000 & 450,000 & 90,000 & 420,000 & 28 \\
\hline & 500 , & $\ldots$. & 700,000 & $\ldots$ & 600,000 & 29 \\
\hline 5,000 & 60,000 & 6,000 & 75,000 & 6,000 & 300 & 30 \\
\hline 10,000 & 60,000 & 12,000 & 72,000 & 25,000 & 137 , & 31. \\
\hline 00 & 75, & 00 & 90,000 & 00 & 150,000 & 32 \\
\hline 95 & 73 & 32 & 67,980 & 55 & 92 , & 33 \\
\hline 00 & 8,000 & 3,000 & 10,500 & 3,000 & 10 & 34 \\
\hline & 110,000 & & 150,000 & & 207,050 & 35 \\
\hline 300,000 & 75,000 & 250,000 & 75,000 & 301,100 & 72,264 & 36 \\
\hline 500 & & 500 & & 550 & 100,000 & 37 \\
\hline 20,000 & 80, & 00 & 80,000 & 27,000 & 108,000 & 38 \\
\hline 400,000 & 30 & 425,000 & 34, & 575,000 & 00 & 39 \\
\hline & 150 & & 200,000 & & 150 & 40 \\
\hline 00 & 8, & 60 & 00 & 00 & 00 & 41 \\
\hline 1,000 & 500 , & 1, 080, & 540 & 972,000 & 486 , & 42 \\
\hline 25 & 100 & 25,000 & 100,000 & 25,000 & 100,000 & 43 \\
\hline & & & 20,000 & & 20,000 & 44 \\
\hline & & 2,500 & 50,000 & 3,000 & 60,000 & 45 \\
\hline & 10,000 & 1,000 & 8,000 & 1,000 & 5,000 & 46 \\
\hline & 70,000 & 14,000 & 70,000 & 14,100 & 71,112 & 47 \\
\hline 100 & 250 & 100 & 250,000 & 114,000 & 285,000 & 48 \\
\hline & 0 & 11,653 & 32,046 & 1,096 & 2,795 & 49 \\
\hline 1,000 & 10,000 & 2,000 & 24,000 & 2,000 & 24,000 & 50 \\
\hline 600 & & & 21,000 & 1,000 & 27,000 & 51 \\
\hline 200 & 7,000 & 1,200 & 36,000 & 1,000 & 30,000 & 52 \\
\hline 200 & 700 & 500 & 1,800 & 550 & 2,000 & 53 \\
\hline 50 & 1,000 & $\cdots$ & ...... & $\ldots$ & $\ldots \ldots$ & 54 \\
\hline & 83,144 & & $231,340,150$ & & $243,812,214$ & 55 \\
\hline & $192,892,408$ & & $219,755,109$ & & $203,128,859$ & 56 \\
\hline & $6,500,000$ & & $6,500,000$ & & $6,500,000$ & 57 \\
\hline & $406,175,552$ & & $457,595,259$ & & $453,441,073$ & 58 \\
\hline
\end{tabular}


Mineral products of the Linited States for

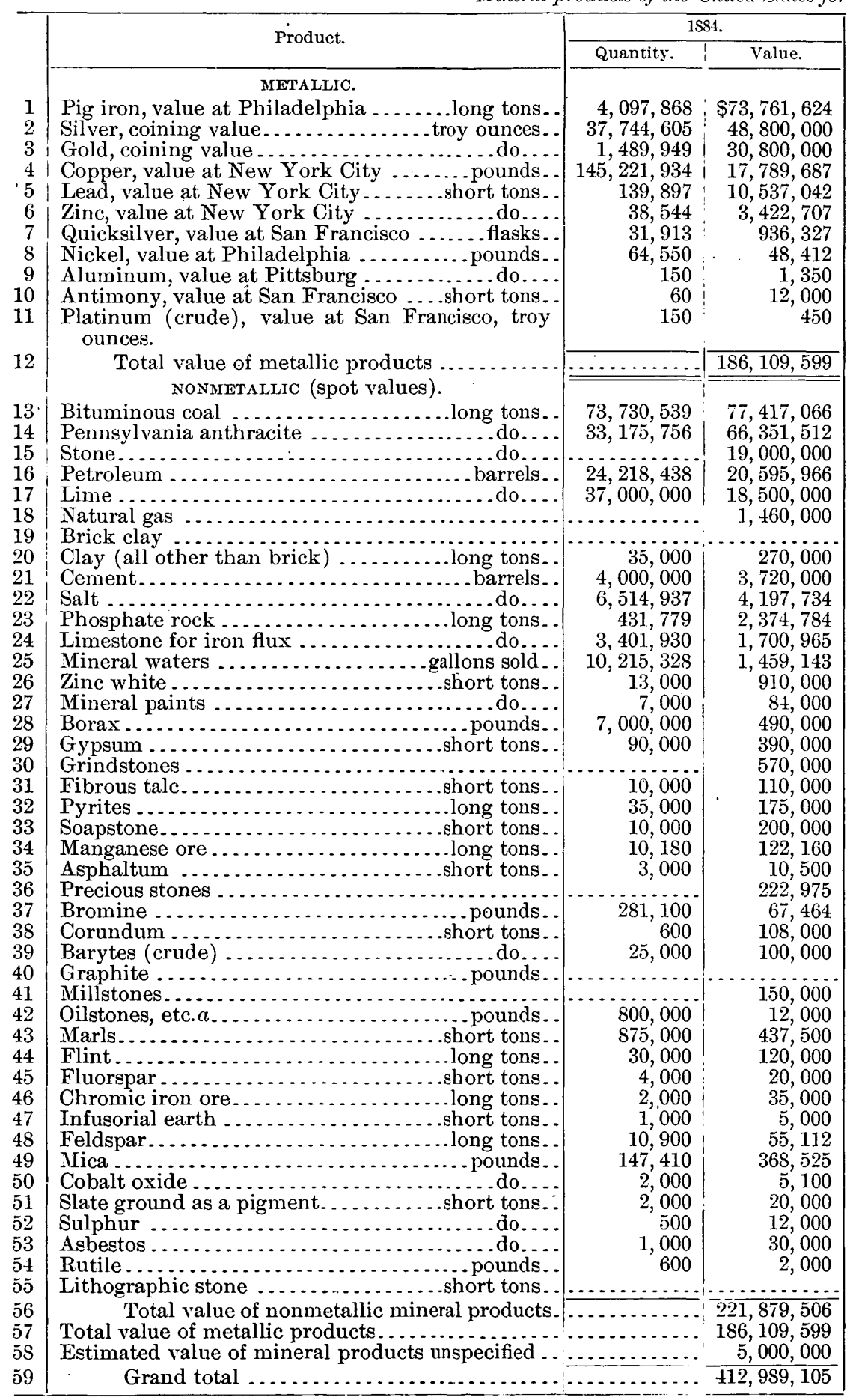

a Prior to $18 \$ 9$, quantity and value are for rough stone quarried; since 1890 they are for finished product. 
the calendar years 1880 to 1899-Continued.

\begin{tabular}{|c|c|c|c|c|c|c|}
\hline \multicolumn{2}{|c|}{$18 S 5$} & \multicolumn{2}{|c|}{1886.} & \multicolumn{2}{|c|}{1887.} & \\
\hline Quantity. & Value. & Quantity. & Value. & Quantity. & Value. & \\
\hline $4,044,425$ & $\$ 64,712,400$ & $5,683,329$ & $\$ 95,195,760$ & $6,417,148$ & $\$ 121,925,800$ & \\
\hline $39,910,279$ & $51,600,000$ & $39,445,312$ & $51,000,000$ & $41,269,240$ & $53,350,000$ & 2 \\
\hline $1,538,376$ & $31,800,000$ & $1,881,250$ & $35,000,000$ & 1,596500 & $33,000,000$ & \\
\hline $170,962,607$ & $18,292,999$ & $161,235,381$ & $16,527,651$ & $185,227,331$ & $21,115,916$ & \\
\hline 129,412 & $10,469,431$ & 130,629 & $12,200,749$ & 145,700 & $13,113,000$ & 5 \\
\hline 40,688 & $3,539,856$ & 42,641 & $3,752,408$ & 50,340 & $4,782,300$ & \\
\hline 32,073 & 979,189 & 29,981 & $1,060,000$ & 33,825 & $1,429,000$ & 7 \\
\hline 277,904 & 179,975 & 214,992 & 127,157 & 205,566 & 133,200 & \\
\hline 283 & 2,550 & 3,000 & 27,000 & 18,000 & 59,000 & \\
\hline 50 & 10,000 & 35 & 7,000 & 75 & 15,000 & 0 \\
\hline 250 & 187 & 50 & 100 & 448 & 1, 838 & 1 \\
\hline & $181,586,587$ & 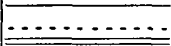 & $214,897,825$ & $\cdots$ & $248,925,054$ & 2 \\
\hline $64,840,668$ & $82,347,648$ & $73,707,957$ & $78,481,056$ & $87,887,360$ & $98,004,656$ & 13 \\
\hline $34,228,548$ & $76,671,948$ & $34,853,077$ & $76,119,120$ & $37,578,747$ & 84,55 & 14 \\
\hline & $19,000,000$ & & $19,000,000$ & & 000 & $b$ \\
\hline 21,8 & $19,198,243$ & $28,064,841$ & $19,996,313$ & $28,278,866$ & $18,87 \overline{7}, 094$ & 16 \\
\hline $40,000,000$ & $20,000,000$ & $\cdot$ & inis & & & 17 \\
\hline & $4,857,200$ & & $10,012,000$ & & $15,817,500$ & 18 \\
\hline & - & & $6,200,000$ & & $7,000,000$ & 9 \\
\hline 36,000 & 275,000 & 40,000 & 325,000 & 43,000 & 340,000 & 20 \\
\hline $4,150,000$ & $3,492,500$ & $4,500,000$ & $3,990,000$ & $6,692,744$ & $5,674,377$ & 1 \\
\hline $7,038,653$ & $4,825,345$ & $7,707,081$ & $4,736,585$ & $7,831,962$ & $4,093,846$ & 2 \\
\hline 437,856 & $2,846,064$ & 430,549 & $1,872,936$ & 480,558 & $1,836,818$ & 23 \\
\hline $3,356,956$ & $1,678,478$ & $4,717,163$ & $2,830,297$ & $5,377,000$ & $3,226,200$ & 24 \\
\hline $9,148,401$ & $1,312,845$ & $8,950,317$ & $1,284,070$ & $8,259,609$ & $1,261,463$ & 25 \\
\hline 15,000 & $1,050,000$ & 18,000 & $1,440,000$ & 18,000 & $1,440,000$ & 26 \\
\hline 3,950 & 43,575 & 18,800 & 315,000 & 22,000 & 330,000 & 27 \\
\hline $8,000,000$ & 480,000 & $9,778,290$ & 488,915 & $11,000,000$ & 550,000 & 28 \\
\hline . $\quad 90,405$ & 405,000 & 95,250 & 428,625 & 95,000 & 425,000 & 29 \\
\hline$\ldots \ldots$ & 500,000 & $\ldots$ & 250,000 & & 224,400 . & 30 \\
\hline & 110,000 & & 125,000 & 15,000 & 160,000 & 1 \\
\hline 00 & 220,500 & 00 & 220,000 & 52,000 & 210,000 & 2 \\
\hline 00 & 200,000 & 00 & 225 & 12,000 & 225,000 & 3 \\
\hline 23,258 & 190,281 & 30 , & 277,636 & 34,524 & 333,844 & 4 \\
\hline 3,000 & 10 & 3,500 & 00 & 4,000 & 16,000 & 35 \\
\hline & 209,900 & & 119 , & & 163,600 & 36 \\
\hline 310,000 & 89,900 & 428,334 & 141,350 & 199,087 & 61,717 & 7 \\
\hline 600 & 108,000 & & 116,190 & 600 & 108,000 & 8 \\
\hline 15,000 & 75,000 & 00 & 50,000 & 15,000 & 75,000 & 9 \\
\hline 327,883 & 26,231 & 415,525 & 33,242 & 416,000 & 000 & 40 \\
\hline$\cdots$ & 100,000 & $\because \cdots$ & 140,000 & & 100,000 & 41 \\
\hline 1,00 & 15,000 & 1,160 & 00 & 1,200 & 16,000 & 42 \\
\hline 875 & 437 & 800,000 & 400 & 600,000 & 300,000 & 43 \\
\hline 30 , & 120 , & 00 & 120,000 & 32,000 & 128,000 & 44 \\
\hline 00 & 22,500 & 00 & 22,000 & 5,000 & 20,000 & 45 \\
\hline & 40,000 & & 30,000 & 3,000 & 40,000 & 46 \\
\hline 1,000 & 5,000 & 1,200 & 6,000 & 3,000 & 15,000 & 47 \\
\hline 13,600 & 68,000 & 14,900 & 74,500 & 10,200 & 61,200 & 48 \\
\hline 92,000 & 161,000 & 40,000 & 70,000 & 70,000 & 142,250 & 49 \\
\hline 68,723 & 65 & 35,000 & 36,878 & 18,340 & 18,774 & 50 \\
\hline 975 & 24,687 & & & & & \\
\hline 715 & 17,875 & 2,500 & 75,000 & 3,000 & 100,000 & 52 \\
\hline 300 & 9,000 & 200 & 6,000 & 150 & 4,500 & 53 \\
\hline 600 & 2,000 & 600 & 2,000 & 1,000 & 3,000 & a \\
\hline$\ldots$ & $\ldots \ldots$ & $\ldots$. & $\because$ & $\cdots$ & $\ldots \ldots \ldots$ & \\
\hline & $241,312,093$ & 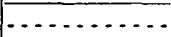 & $230,088, \overline{769}$ & & $270,989,420$ & 56 \\
\hline & $181,586,587$ & & $214,897,825$ & $\cdots$ & $248,925,054$ & 57 \\
\hline & $5,000,000$ & 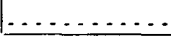 & 800,000 & $\ldots \ldots$ & 800,000 & \\
\hline & $427,898,680$ & & $445,786,594$ & & $520,714,474$ & 59 \\
\hline
\end{tabular}


Mineral products of the United States for

\begin{tabular}{|c|c|c|c|}
\hline & \multirow{2}{*}{ Product. } & \multicolumn{2}{|c|}{1888.} \\
\hline & & Quantity. & Value. \\
\hline & & & \\
\hline 1 & Pig iron, value at Philadelphia ....... long tons. . & $6,489,738$ & $\$ 107,000,000$ \\
\hline 2 & Silver, coining value ........... troy ounces. & $45,783,632$ & $59,195,000$ \\
\hline 3 & Gold, coining value..... & $1,604,927$ & $33,175,000$ \\
\hline 4 & Copper, value at New York City . . . . . pounds. . & $231,270,622$ & $33,833,954$ \\
\hline 5 & Lead, value at New York City........ short tons.. & 151,919 & $13,399,256$ \\
\hline 6 & Zinc, value at New York City $\ldots . . . . . .$. do... & 55,903 & $5,500,855$ \\
\hline 7 & Quicksilver, value at San Francisco ........ flasks. & 33,250 & $4,113,125$ \\
\hline 8 & at Pittsburg.......... pou & 19,000 & 65,000 \\
\hline 9 & $y$, value at San Francisco . . . . short tons. - & 100 & 20,000 \\
\hline 10 & Nickel, value at Philadelphia .... . & 204,328 & 127,632 \\
\hline 11 & Tin $\ldots$. & & \\
\hline 12 & $\begin{array}{l}\text { Platinum (crude), value at San Francisco, troy } \\
\text { ounces. }\end{array}$ & 500 & 000 \\
\hline 13 & Total value of metallic products ........ & & $253,731,822$ \\
\hline & (spot $v$ & & \\
\hline 14 & . sho & 838 & $101,860,529$ \\
\hline 15 & sylvania anthracite ............ long & $41,624,611$ & $89,020,483$ \\
\hline 16 & 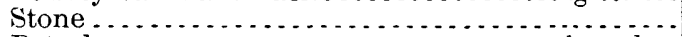 & & 500,000 \\
\hline 17 & $\ldots \ldots$ ba & $27,612,025$ & 947,620 \\
\hline 18 & $\ldots \ldots \ldots$ & $\ldots$ & $22,629,875$ \\
\hline 19 & 1 & & $7,500,000$ \\
\hline 20 & Clay (all other than brick) .... & 36,750 & 300,000 \\
\hline 21 & 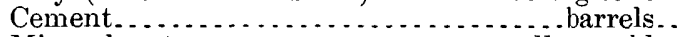 & $6,503,295$ & $5,021,139$ \\
\hline 22 & . . gallons sold.. & $9,578,648$ & $1,679,302$ \\
\hline 23 & Phosphate rock & 448,567 & $2,018,552$ \\
\hline 24 & ...... bar & 8,05 & $4,374,203$ \\
\hline 25 & for iron flux $\ldots \ldots \ldots \ldots$ & 5,438 & $2,719,000$ \\
\hline 26 & vhite $\ldots \ldots \ldots \ldots \ldots$ nhor & 000 & $1,600,000$ \\
\hline 27 & ${ }^{\prime} \ldots \ldots \ldots$ & 00 & 000 \\
\hline 28 & $\ldots \ldots$ & 7,58 & 340 \\
\hline 29 & . $\ldots \ldots . . .$. & 26,500 & 00 \\
\hline 30 & $\ldots \ldots$ & & 300 \\
\hline 31 & . . . . - . - short & 00 & 210,000 \\
\hline 32 & . & 00 & 331,500 \\
\hline 33 & ....do. & 15,000 & 000 \\
\hline 34 & $\operatorname{Pr}$ & & 139,850 \\
\hline 35 & ...... long & 54,331 & $\mathbf{1 6 7}, 658$ \\
\hline 36 & $\ldots . .$. short & 589 & 320 \\
\hline 37 & $\ldots \ldots \ldots$ po & $1,500,000$ & 18,000 \\
\hline 38 & . . . . & 00 & 70,000 \\
\hline 39 & .... short & 00 & 110,000 \\
\hline 40 & $\ldots \ldots \ldots$ po & 307,386 & 95,290 \\
\hline 41 & . . . . . . . short & & 30,000 \\
\hline 42 & . & 8,700 & 50,000 \\
\hline 43 & ........ do. & 29,198 & 279,571 \\
\hline 44 & 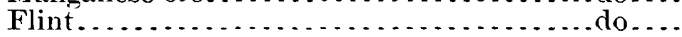 & & 127,500 \\
\hline 45 & $\ldots \ldots$ & 400 & 000 \\
\hline 46 & ....... long & & \\
\hline 47 & . . . . . short & & \\
\hline 48 & $\tilde{n}$ & 300,000 & 150,000 \\
\hline 49 & al eartl & 1,500 & $\overline{7}, 500$ \\
\hline 50 & & & $\$ 1,000$ \\
\hline 51 & ..... long & 1,500 & 20,000 \\
\hline 52 & .... pounds. . & 8,491 & $15,7 S 2$ \\
\hline 53 & . short & & \\
\hline 54 & $\ldots . . . . d$ & 100 & 3,000 \\
\hline 55 & - . - & 1,000 & 3,000 \\
\hline 56 & Ozocerite (refined) & 43,500 & 3,000 \\
\hline 57 & letallic mineral product & & $286,150,114$ \\
\hline 58 & value of metallic & & $253,731,822$ \\
\hline 59 & of mineral products & & 900,000 \\
\hline 60 & Grand total. & & $540,781,936$ \\
\hline
\end{tabular}

$a$ Prior to 1S\$9, quantity and value are for rough stone quarried; since 1\$90 they are for finished product. 
SUMMARY.

the calendar years 1880 to $1899-C o n t i n u e d$.

\begin{tabular}{|c|c|c|c|c|c|c|}
\hline \multicolumn{2}{|c|}{1889.} & \multicolumn{2}{|c|}{1890.} & \multicolumn{2}{|c|}{1891.} & \\
\hline Quantity. & Value. & Quantity. & Value. & Quantity. & Value. & \\
\hline $7,603,642$ & $\$ 120,000,000$ & $9,202,703$ & $\$ 151,200,410$ & 70 & $\$ 128,33$ & \\
\hline $51,354,851$ & $66,396,988$ & $54,500,000$ & $70,464,645$ & $58,330,000$ & $75,416,565$ & 2 \\
\hline 1, 590, 869 & $32,886,744$ & $1,588,880$ & $32,845,000$ & $1,604,840$ & $33,175,000$ & 3 \\
\hline $231,246,214$ & $26,907,809$ & $265,115,133$ & $30,848,797$ & $295,812,076$ & $38,455,300$ & 4 \\
\hline 156,397 & $13,794,235$ & 143,630 & $12,668,166$ & 178,554 & $15,534,198$ & 5 \\
\hline, 860 & $5,791,824$ & 63,683 & $6,266,407$ & 80,873 & $8,033,700$ & \\
\hline 484 & $1,190,500$ & 22,926 & $1,203,615$ & 22,904 & $1,036,386$ & \\
\hline 47,468 & 97,335 & 61,281 & 61,281 & 150,000 & 100,000 & \\
\hline 115 & 28,000 & 129 & 40,756 & 278 & 47,007 & \\
\hline 252,663 & 151,598 & 223,488 & 134,093 & 118,498 & 71,099 & 0 \\
\hline 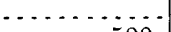 & $\ldots .$. & & $0=00$ & 125,289 & 25,058 & \\
\hline 500 & 2,000 & 600 & 2,500 & 100 & 500 & 2 \\
\hline & $267,247,033$ & $\cdots$ & $305,735,670$ & $\ldots \ldots$ & $300,232,798$ & \\
\hline 95 & 94,5 & 16 & $110,420,801$ & 237 & 38,400 & \\
\hline & 65,879 & $41,489,858$ & $66,383,772$ & $45,236,992$ & $73,944,735$ & 5 \\
\hline & $42,809,706$ & & $47,000,000$ & & $47,294,746$ & 16 \\
\hline $35,163,513$ & $26,963,340$ & $45,822,672$ & $35,365,105$ & $54,291,980$ & $30,526,553$ & 17 \\
\hline & $21,097,099$ & $\ldots \ldots \ldots$ & $18,742,725$ & $\ldots . . .6$. & $15,500,084$ & 18 \\
\hline & $8,000,000$ & & $8,500,000$ & $\ldots$. & $9,000,000$ & 19 \\
\hline 294,344 & 635,578 & 350,000 & 756,000 & 400,000 & 900,000 & 20 \\
\hline $7,000,000$ & 5,000 & $8,000,000$ & $6,000,000$ & $8,222,792$ & $6,680,951$ & 21 \\
\hline $12,780,471$ & $1,748,458$ & $13,907,418$ & $2,600,750$ & $18,392,732$ & 96,259 & 2 \\
\hline 55 & $2,937,776$ & 510,499 & $3,213,795$ & 587,988 & $3,651,150$ & 3 \\
\hline 8,005 & $4,195,412$ & $8,776,991$ & $4,752,286$ & $9,987,945$ & $4,716,121$ & 84 \\
\hline $6,318,000$ & $3,159,000$ & $5,521,622$ & $2,760,811$ & $5,000,000$ & $2,300,000$ & \\
\hline 16,970 & $1,357,600$ & $\ldots \ldots$ & $1,600,000$ & 23,700 & $1,600,000$ & \\
\hline 769 & 764,118 & 182,995 & 574,523 & 208,126 & 628,051 & 7 \\
\hline $8,000,000$ & 500,000 & $9,500,000$ & 617,500 & $13,380,000$ & 869,700 & 88 \\
\hline 34,307 & 483,766 & 47,732 & 681,992 & 49,652 & 678,478 & 9 \\
\hline- & 587 & $\cdots$ & 450 & $\cdots$ & 476,113 & 30 \\
\hline 46 & 244,170 & 41 & 389 & 4 & 068 & \\
\hline 51 & 37 & 40 & 190 & 54 & 242,264 & 32 \\
\hline & 08 & 13,670 & 252 & 16,514 & 243,981 & \\
\hline & & & 333 & & 235,300 & \\
\hline 93,705 & 202,119 & 99,854 & 273,745 & 106,536 & 338,880 & \\
\hline 2,245 & 105,565 & 1,970 & 89,395 & 2,265 & 90,230 & \\
\hline $5,982,000$ & 32,980 & & 69,909 & $1,375,000$ & 150,000 & \\
\hline 49,500 & 50,000 & 60 , & 75,000 & 75,000 & 100,000 & \\
\hline 161 & 106,313 & 21, & 86,505 & 31,069 & 118,363 & \\
\hline 418 & 125,667 & 387,847 & 104 & 343,000 & 54,880 & \\
\hline 600 & 45,835 & 50 & 55 & 10,044 & 78,330 & \\
\hline 70 & 0 & 00 & 00 & 00 & 50,000 & \\
\hline $24,19 \bar{\imath}$ & 240,559 & 25,684 & 219,050 & 23,416 & 239,129 & \\
\hline 21,113 & 89,730 & 000 & 57,400 & 15,000 & 60,000 & \\
\hline & 72,662 & & 77,500 & $\cdots$ & 110,000 & \\
\hline 728 & 2,366 & 1,844 & 6,012 & 3,593 & 11,675 & \\
\hline 1,150 & 7,850 & & & 1,200 & 39,600 & 47 \\
\hline 139,522 & 63,956 & 153,620 & 69 & 135,000 & 67,500 & \\
\hline 3,466 & 72 & 2,532 & 50 , & - & 21,988 & \\
\hline & & & 23,720 & & 16,587 & \\
\hline & 30,000 & & & 1,372 & 20,580 & \\
\hline & 31,092 & 6,788 & 16,291 & 7,200 & 18,000 & \\
\hline & & & & 439 & 4,390 & \\
\hline 30 & 1,800 & 71. & 4,560 & 66 & 3,960 & \\
\hline 000 & 3,000 & 400 & 1,000 & 300 & 800 & \\
\hline 50,000 & 2,500 & 350,000 & 26,250 & 50,000 & 7,000 & \\
\hline & $282,623,812$ & & $312,776,503$ & & $321,767,846$ & \\
\hline & 47,033 & & $305,735,670$ & & $300,232,798$ & \\
\hline & $1,000,000$ & & $1,000,000$ & $\begin{array}{lll}\cdots & \ldots\end{array}$ & $1,000,000$ & \\
\hline & $550,870,845$ & & $619,512,173$ & $\ldots \ldots \ldots \ldots$ & $623,000,644$ & \\
\hline
\end{tabular}


Mineral products of the United States for

\begin{tabular}{|c|c|c|c|}
\hline & & 18 & 992. \\
\hline & & Quantity. & Value. \\
\hline & MET & & \\
\hline 1 & Pig iron (spot value) & $9,157,000$ & $\$ 131,16 \mathrm{i}, 039$ \\
\hline 2 & Silver, coining value. & $63,500,000$ & $82,099,150$ \\
\hline 3 & Gold, coining value....... & $1,596,375$ & $33,000,000$ \\
\hline 4 & Copper, value at New York Ci & $352,971,744$ & $37,977,142$ \\
\hline 5 & Lead, value at New & $\mathbf{1 7 3}, 654$ & $13,892,320$ \\
\hline$\frac{6}{7}$ & Zinc, value at New York City & 87,260 & \\
\hline$\stackrel{7}{s}$ & Quicksilver, value at San Francisc & 27,993 & $1,245,689$ \\
\hline $\begin{array}{l}8 \\
9\end{array}$ & Aluminum, value at & 259,885 & 172,824 \\
\hline 10 & $\begin{array}{l}\text { Antumony, value at } \\
\text { Nickel, value at Phil }\end{array}$ & 92,252 & $\begin{array}{l}56,466 \\
50,739\end{array}$ \\
\hline 11 & $\operatorname{Tin} \ldots \ldots \ldots \ldots$ & 162,000 & 32,400 \\
\hline & Platinum, value (crude) & & 550 \\
\hline 13 & Total value & & $307,716,239$ \\
\hline & & & \\
\hline 14 & Bituminous coal. & $126,856,567$ & $125,124,381$ \\
\hline 15 & Pennsylvania anthracit & $46,850,450$ & $82,442,000$ \\
\hline $\begin{array}{l}16 \\
17\end{array}$ & Natural gas...... & & $14,800,714$ \\
\hline $\begin{array}{l}17 \\
18\end{array}$ & Petroleum ....... & $50,509,136$ & $\begin{array}{r}26,034,196 \\
9,000,000\end{array}$ \\
\hline 19 & Cement.......... & $3,758,621$ & $7,152,750$ \\
\hline 20 & Stor & & $48,706,625$ \\
\hline 21 & Corundum and eme & 1,771 & 181,300 \\
\hline 22 & Garnet for abrasive purposes. & & \\
\hline & Grindstones.................... & & 272,244 \\
\hline 24 & $\begin{array}{l}\text { Infusorial earth and Tripoli. } \\
\text { Millstones } \ldots \ldots \ldots \ldots \ldots \ldots \ldots\end{array}$ & & 43,655 \\
\hline $\begin{array}{l}25 \\
26\end{array}$ & ......pounds.. & & $\begin{array}{r}23,417 \\
146,730\end{array}$ \\
\hline 27 & Borax ........... & $13,500,000$ & 900,000 \\
\hline 28 & Bromine & 379,480 & 64,502 \\
\hline 29 & Fluorspar ... & 12,250 & 89,000 \\
\hline 30 & .......do..... & 256,259 & 695,492 \\
\hline 31 & ...do.... & 125,000 & 65,000 \\
\hline 32 & Phosphate rock & 681,571 & $3,296,227$ \\
\hline 33 & Pyrite............ & 109,788 & 305,191 \\
\hline 34 & ..... barrels.. & $11,698,890$ & $5,654,915$ \\
\hline 35 & Sulphur & 2,688 & 80,640 \\
\hline 36 & Barytes (crude) & 32,108 & 130,025 \\
\hline 37 & xide... & 7,869 & 15,738 \\
\hline 38 & Mineral paints... & 51,704 & 767,766 \\
\hline & ........d d & 27,500 & $2,200,000$ \\
\hline 40 & ....... do... & 104 & 6,416 \\
\hline 41 & $\ldots$ do.... & 680 & 445,375 \\
\hline 42 & ...long tons.. & $10,51 \mathrm{~s}$ & 34,183 \\
\hline 43 & ....... do... & 1,500 & 25,000 \\
\hline 44 & .........do.... & 420,000 & $1,000,000$ \\
\hline 45 & Felds & 15,000 & 75,000 \\
\hline 46 & Fibrous talc. & 41,925 & 472,485 \\
\hline 47 & Flint & 20,000 & 80,000 \\
\hline 48 & Fuller & & \\
\hline 49 & Gra & & 104,000 \\
\hline 50 & ....long & $5,172,114$ & $3,620,480$ \\
\hline 51 & ...short & 1,004 & 10,040 \\
\hline 52 & lese ore. & 13,613 & 129,586 \\
\hline 53 & Mica & 75,000 & 100,000 \\
\hline 54 & Mineral waters ....... & $21,876,604$ & $4,905,970$ \\
\hline 55 & .....po & & \\
\hline 56 & ........do.... & 60,000 & 8,000 \\
\hline $\begin{array}{l}57 \\
58\end{array}$ & n.............. short tons. & & \\
\hline 59 & Rutile....... & 100 & 300 \\
\hline 60 & Soapstone................... & 23,908 & 437,449 \\
\hline 61 & of nonmetallic & & 339 \\
\hline 62 & & & $307,716,239$ \\
\hline 63 & Estimated value of mineral products unspecified........... & & $1,000,000$ \\
\hline 64 & Grand total & & $648,675,081$ \\
\hline
\end{tabular}


the calendar years 1880 to 1899 -Continued.

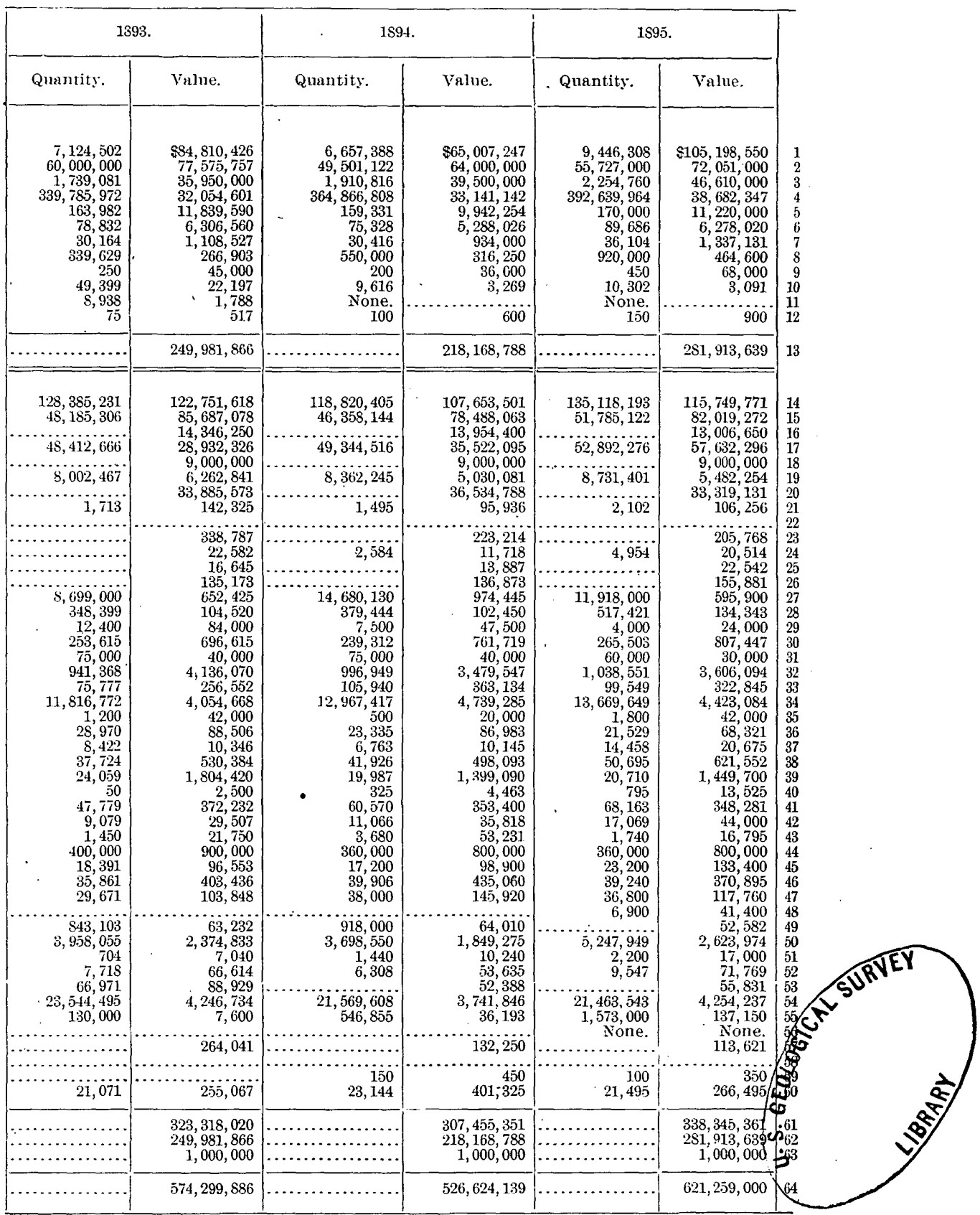


Mineral products of the Linited. States for

\begin{tabular}{|c|c|c|c|}
\hline & \multirow{2}{*}{ Product. } & \multicolumn{2}{|c|}{1896.} \\
\hline & & Quantity. & Valne. \\
\hline & $M E$ & & \\
\hline 1 & Pig iron (spot value) ... & $8,623,127$ & $\$ 90,250,000$ \\
\hline & Silver, coining value . & $58,834,800$ & $76,069,236$ \\
\hline 3 & Gold, coining value.. & $2,568,132$ & $53,088,000$ \\
\hline 4 & Copper, value at New York City & $460,061,430$ & $49,456,603$ \\
\hline 5 & Lead, value at New York City & 188,000 & $10,528,000$ \\
\hline 6 & Zinc, value at New York City & 81,499 & $6,519,920$ \\
\hline 7 & Quicksilver, value at San Francisco & 30,765 & $1,075,449$ \\
\hline 8 & Aluminum, value at Pittsburg... & $1,300,000$ & 520,000 \\
\hline 9 & Antimony, value at San Fran & 601 & 84,290 \\
\hline 10 & Nickel, value at Philadelphia & 17,170 & 4,464 \\
\hline 11 & Tin $\ldots \ldots \ldots \ldots \ldots \ldots$ & None. & \\
\hline 12 & Platinum, value (crude) at & 163 & 944 \\
\hline 13 & Total value of $\mathrm{m}$ & & $287,596,906$ \\
\hline & NONMETAILIC (SPOT VALUES). & & \\
\hline 14 & Bituminous conl.... & $137,640,276$ & $114,891,515$ \\
\hline 15 & Pennsylvania anthracite & $48,523,287$ & $81,748,651$ \\
\hline $\begin{array}{l}16 \\
17\end{array}$ & $\begin{array}{l}\text { Natural gas } \ldots \ldots \ldots \ldots \ldots \\
\text { Petroleum } . . . \ldots \ldots \ldots\end{array}$ & $60,960,361$ & $\begin{array}{l}13,002,512 \\
58,518,709\end{array}$ \\
\hline $\begin{array}{l}17 \\
18\end{array}$ & Brick clay ............ & $60,900,301$ & $\begin{array}{r}58,018,709 \\
9,000,000\end{array}$ \\
\hline 19 & Cement............ & $9,513,473$ & $6,473,213$ \\
\hline 20 & Stone $\ldots \ldots \ldots \ldots \ldots$ & & $30,142,661$ \\
\hline $\begin{array}{l}21 \\
22\end{array}$ & $\begin{array}{l}\text { Corundum and enuery .......... } \\
\text { Garnet for a brasive purposes. }\end{array}$ & 2,120 & 113,246 \\
\hline 23 & 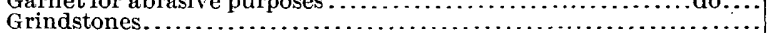 & & 326,826 \\
\hline 24 & Infusorial earth and i & 3,846 & 26,792 \\
\hline 25 & Millstones ..... & & 22,567 \\
\hline $\begin{array}{l}20 \\
26\end{array}$ & Oilstones, etc... & & $\begin{array}{r}22, \\
127,098\end{array}$ \\
\hline 27 & Borax ........... & $13,508,000$ & 675,400 \\
\hline 28 & Bromine.... & 546,580 & 144,501 \\
\hline 29 & Fluorspar.... & 6,500 & 52,000 \\
\hline 30 & Gypsum ...... & 224,139 & 573,344 \\
\hline 31 & ....do.... & 60,000 & 30,000 \\
\hline 32 & Phosphate rock. & 930,779 & $2,803,372$ \\
\hline 33 & Pyrite............... & 115,483 & 320,163 \\
\hline 34 & ...barrels.. & $13,850,726$ & $4,040,839$ \\
\hline 35 & short tons.. & 5,260 & 87,200 \\
\hline 36 & Barytes (crude) ... & 17,068 & 46,513 \\
\hline 37 & Cobalt oxide ........ & 10,700 & 15,301 \\
\hline 38 & Mineral paints...... & 48,032 & 530,455 \\
\hline 39 & Zine white $\ldots \ldots \ldots \ldots \ldots \ldots$ & 20,000 & $1,400,000$ \\
\hline 40 & Asbestos...... & 504 & 6,100 \\
\hline 41 & Asphaltum ... & 80,503 & 577,563 \\
\hline 42 & Bauxite ............. & 18,364 & 47,338 \\
\hline 43 & Chromic iron ore..... & 786 & 6,667 \\
\hline 44 & Clay (all other than brick) & 360,000 & 800,000 \\
\hline 45 & Feldspar $\ldots \ldots \ldots \ldots \ldots \ldots$ & 9,114 & 35,200 \\
\hline 46 & Fribrous tale ........ & 46,089 & 399,443 \\
\hline 47 & ...long tons.. & 11,124 & 24,226 \\
\hline 48 & Fuller's earth... & 9,872 & 59,260 \\
\hline 49 & Graphite (crystalline).. & 535,858 & \\
\hline 50 & Graphite (amorphous). & & 48,400 \\
\hline 51 & Limestone for iron flux. & $4,120,102$ & $2,060,000$ \\
\hline 52 & Magnesite ................. & 1,500 & 11,000 \\
\hline 53 & Manganese ore.......... & 10,088 & 90,727 \\
\hline 54 & Mica (sheet).. & .... & 65,441 \\
\hline 55 & Mica (scrap)..... & & 1,750 \\
\hline 56 & Mineral waters...... & $25,795,312$ & $4,136,192$ \\
\hline 57 & Monazite ............ & 30,000 & 1,500 \\
\hline 58 & Ozocerite, refined..... & None. & None. \\
\hline 59 & Precious stones ........ & & 97,850 \\
\hline 60 & Pumice stone.... & & \\
\hline 61 & $\ldots \ldots \ldots \ldots \ldots \ldots$ pounds.. & 100 & 350 \\
\hline 62 & Soapstone.............. & 22,183 & 354,065 \\
\hline 63 & Total value of nonmetallic mineral products. & & $333,936,110$ \\
\hline 64 & Total value of $\mathrm{m}$ & $\cdots . .$. & $287,596,906$ \\
\hline 65 & Estimated value of mineral products unspecified & .......... & $1,000,000$ \\
\hline 66 & Grand total & & $622,533,016$ \\
\hline
\end{tabular}


SUMMARY.

the calendar years 1880 to 1899.-Continued.

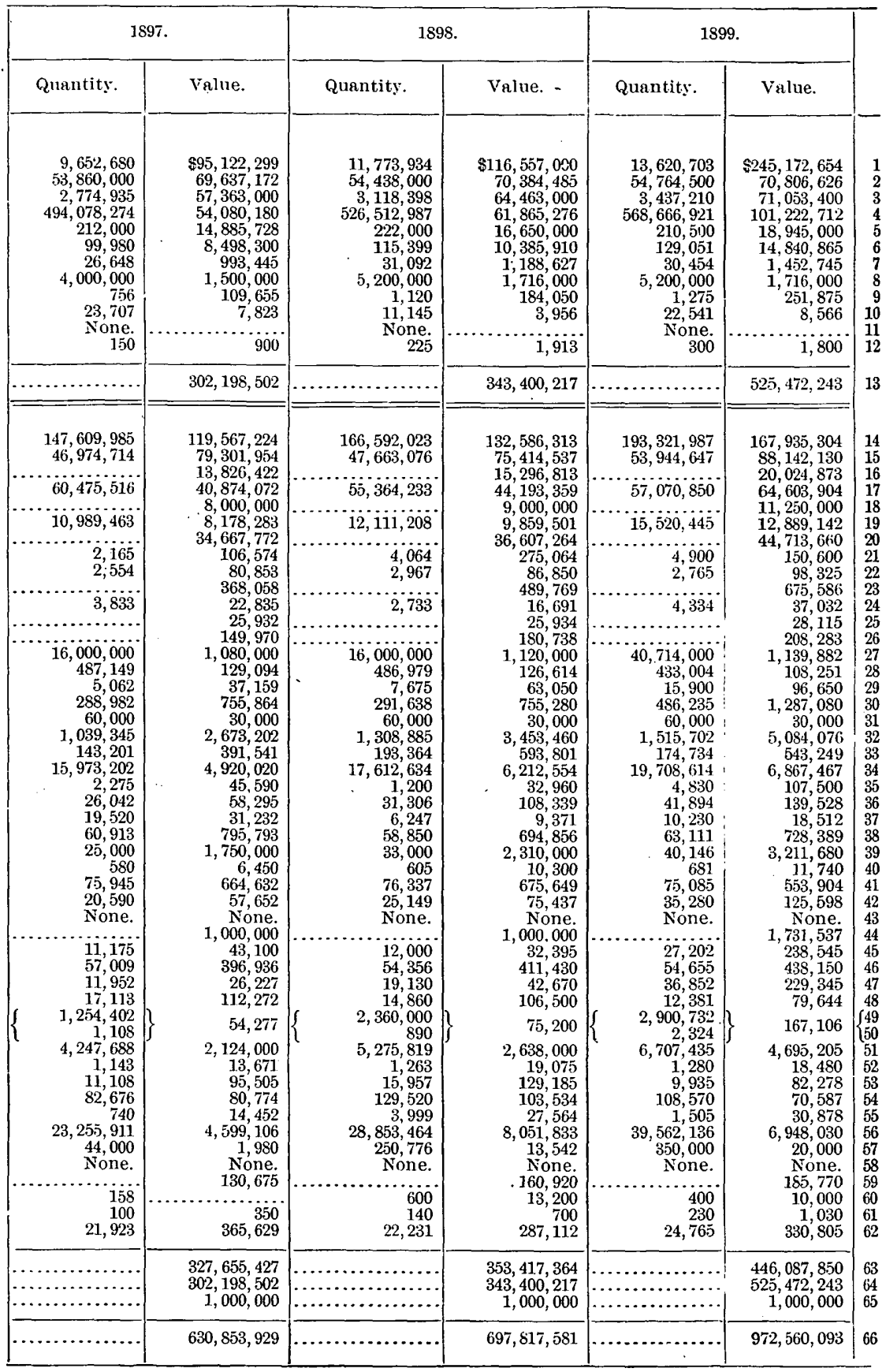





\title{
IRON ORES.
}

\author{
By John Birkinbine.
}

\section{PRODUCTION.}

The production of iron ore in the United States in the year ending December 31,1899 , amounted to $24,683,173$ long tons, which was $5,249,457$ long tons, or 27 per cent, in excess of the previous maximum of 19,433,716 long tons in the year 1898. The records of 1898.and 1899 represent maxima of iron ore mined in any country in one year, the nearest approach to these being a total of 18,026,049 long tons, won in the year 1880 in Great Britain.

Twenty-four States and Territories-the same number as in 1898contributed to this total, but Montana was not reported as a producer, and West Virginia was returned to the active list in 1899. Practically all of the States, with the exception of Colorado, New Jersey, Maryland, and the far Western group, showed an increase in output. Missouri may also be counted as having a larger output than in 1898, for a quantity of lean ore mined in former years was not marketed until 1898. This augmented production, however, was principally from the States of Minnesota and Michigan, the former being credited with an increase of 2,197,780 long tons over the 1898 output and the latter with an increase of $1,799,311$ long tons.

The amount of pig iron manufactured in the year 1899 was $13,620,703$ long tons, and if all the ore mined in the United States in that year had been smelted in the production of this pig iron it would show that 1.81 tons of iron ore were required to make a ton of pig iron, but allowance must be made for the difference in the stocks of ore, the foreign ore imported, the ore used for other purposes than pig iron manufactures, and the other iron-bearing material fed to the furnaces.

If to the amount mined in $\mathbf{1 8 9 9}$ is added the decrease in the stocks of ore on hand at the mines, the amount of foreign ore imported, etc., the grand total sent to the consumers will approximate $26,000,000$ tons. 
The output of iron ore in the United States for the years 1859 to 1899 , inclusive, the period during which data were systematically collected by the United States Geological Survey, is shown in the annexed table.

Production of iron ore in the United States from 1889 to 1899.

\begin{tabular}{|c|c|c|c|}
\hline Year. & Production. & Year. & Production. \\
\hline & Long tons. & \multirow{8}{*}{$\begin{array}{c}1896 \ldots \\
1897 \ldots \ldots \\
1898 \ldots \\
1899 \ldots \\
\text { Total } \ldots\end{array}$} & \multirow{5}{*}{$\begin{array}{l}\text { Long tons. } \\
\begin{array}{l}16,005 ; 449 \\
17,518,046 \\
19,433,716 \\
24,683,173\end{array}\end{array}$} \\
\hline $1889 \ldots \ldots$ & $14,518,041$ & & \\
\hline $1890 \ldots \ldots$ & $16,036,043$ & & \\
\hline $1891 \ldots \ldots$ & $14,591,178$ & & \\
\hline $1892 \ldots$ & $16,296,666$ & & \\
\hline $1893 \ldots$ & $11,587,629$ & & \multirow{3}{*}{$178,507,234$} \\
\hline $1894 \ldots \ldots \ldots \ldots$ & $\cdot 11,879,679$ & & \\
\hline $1895 \ldots \ldots \ldots$ & $15,957,614$ & & \\
\hline
\end{tabular}

From this it will be seen for eleven years the average product has been 16,227,930 tons per annum. In the years above mentioned, viz, 1889 to 1899 , inclusive, when $178,507,234$ long tons of iron ore were mined, 101,141,857 long tons of pig iron were smelted, representing an average of 1.76 tons of domestic iron ore mined per ton of pig iron made.

\section{CLASSIFICATION OF IRON ORES.}

The iron ores of this country have been subdivided, as in previous reports, into the following general classes:

1. Red hematite, being all anhydrous hematites, although known by various names, such as red hematite, specular, micaceous, fossil, slate iron ore, martite, blue hematite, etc.

2. Brown hematite, including the varieties of hydrated sesquioxide of iron, recognized as limonite, göthite, turgite, bog ores, pipe ores, etc.

3. Magnetite, those ores in which the iron occurs as magnetic oxide and including some martite, which is mined with the magnetite.

4. Carbonate, those ores which contain a considerable amount of carbonic acid, such as spathic ore, blackband, siderite, clay ironstone, etc.

The red hematites continue to be the most prominent of the class of iron ore, contributing 20,004,399 Jong tons, or 81 per cent, of the total for 1899 . But while this was an increase of $3,853,715$ long tons, or 24 per cent, over the 1898 output, the percentage of the total iron ore mined represented by the red hematites decreased from 83.1 per cent in 1898 to 81 per cent in 1899. 
Of the brown hematites $2,869,785$ long tons were won, which was 11.6 per cent of the iron ore mined in the United States, as against $1,989,681$ long tons, or 10.2 per cent, in 1898, and represents an advance over 1898 of 880,104 long tons, or 44 per cent.

The magnetite product amounted to $1,727,430$ long tons, or 7 per cent of the total for the United States, as against 1,237,978 long tons, or 6.4 per cent, in 1898 , an increase of 489,452 long tons and an advance of 40 per cent.

The balance, 81,559 long tons, or 0.33 per cent of the iron ore produced in the United States, was of the carbonate variety, as against 55,373 long tons, or 0.3 per cent of the total, for 1898, showing an increase of 26,186 tons, or 47 per cent.

From this it will be seen that there was a general increase in the amounts of all the different classes, due to active demand upon local mines to supplement ore obtained from the large producers.

A number of iron-ore deposits which had not been wrought for years resumed operations in 1899, and in some instances exploitations will be continued. The advantages to blast furnaces of at least a partial local supply of ores and the application of improved mining methods will probably encourage the working of some of the denosits which were inactive during the business depression.

Michigan is the largest producer of red hematites, followed in order by Minnesota and Alabama. Virginia heads the list as a source of supply for brown hematites, Alabama and Tennessee taking second and third places, respectively. Pennsylvania produced the largest amount of magnetite, followed by New York and New Jersey, while Ohio contributed the greatest amount of carbonate ore.

The following table gives the amounts of different classes of iron ore by States in the year 1899, in accordance with the classification. mentioned above, as closely as this can be obtained. In some mines. red hematite and magnetite are intimately associated, or the hydration of the hematites is variable, while the weathered ores of carbonate formations may be considered as brown hematites. Hence a close classification is impracticable. The table, however, gives in a general way the proportions of the different classes of ores which contribute to the total supply of iron ores obtained from mines in the United. States.

21 GEOL, PT $6-3$ 
Production of iron ores in the Uniled Stutes in 1899, l!y States and Territories.

[Long tons,]

\begin{tabular}{|c|c|c|c|c|c|}
\hline State or Territory. & Red hematite. & $\underset{\text { hematite. }}{\text { Brown }}$ & Magnetite. & $\begin{array}{c}\text { Carbon- } \\
\text { ate. }\end{array}$ & Total. \\
\hline Michigan . . . . . . . . & $8,863,942$ & 44,645 & 237,570 & $\ldots \ldots$ & $9,146,157$ \\
\hline Minnesota... & $8,161,289$ & 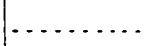 & & -. & $8,161,289$ \\
\hline Alabama .......... & $1,911,097$ & 751,846 & $\ldots \ldots$ & $\ldots \ldots$ & $2,662,943$ \\
\hline Pennsylvania ....... & 38,331 & 152,468 & 815,771 & 2,757 & $1,009,327$ \\
\hline $\begin{array}{c}\text { Virginia and West } \\
\text { Virginia .......... }\end{array}$ & 17,173 & 968,143 & 1,160 & & 986,476 \\
\hline Tennessee ........ & 298,704 & 333,342 & $\ldots \ldots$ & $\ldots$ & 632,046 \\
\hline Wisconsin ... & 531,636 & 48,162 & $\ldots \ldots$ & $\ldots$ & 579,798 \\
\hline New York: & 45,503 & 31,975 & 344,159 & 22,153 & 443,790 \\
\hline Colorado ....... & 12,327 & 295,230 & $\ldots \ldots$ & 10 & 307,557 \\
\hline New Jersey .... & $\ldots \ldots$ & $\ldots \ldots \ldots$ & 256,185 & -. & 256,185 \\
\hline Georgia ... & 57,000 & 179,748 & & & 236,748 \\
\hline $\begin{array}{l}\text { Nevada, New Mexi- } \\
\text { co, Utah, and Wy- } \\
\text { oming........... }\end{array}$ & 11,541 & 6,850 & 35,757 & $\ldots \ldots$ & 54,148 \\
\hline Ohio ..... & ...... & $\ldots . .$. & ...... & 53,221 & 53,221 \\
\hline North Carolina & - & 10,788 & 36,828 & & 47,616 \\
\hline Kentucky ........ & 35,384 & $\ldots \ldots$ & & $\ldots$ & 35,384 \\
\hline $\begin{array}{l}\text { Connecticut and } \\
\text { Massachusetts..... }\end{array}$ & & 29,611 & & & 29,611 \\
\hline Missouri... & 20,472 & 2,248 & & .. & 22,720 \\
\hline Texas ....... & $\ldots$ & 14,729 & & & 14,729 \\
\hline Maryland .. & & - & & 3,428 & 3,428 \\
\hline Total ..... & $20,004,399$ & $2,869,785$ & $1,727,430$ & 81,559 & $24,683,173$ \\
\hline
\end{tabular}

Considering the production of the different classes of iron ore for a period of eleven years, during which the United States Geological Survey has collated statistics, it is found that the red hematite mines have furnished about three-fourths of the total, followed in order by those producing brown hematite, magnetite, and carbonate ore.

The amounts of each variety of ore mined in the United States from 1889 to 1899 inclusive, the average percentage of each class during that period, and the percentages of the total in 1899 will be found in the following table: 
Production of iron ores in the United States, by classes.

[Maxima in italic figures.]

\begin{tabular}{|c|c|c|c|c|c|}
\hline Year. & Red hematite. & $\begin{array}{c}\text { Brown hema- } \\
\text { tite. }\end{array}$ & Magnetite. & Carbonate. & Total. \\
\hline & Long tons. & Long tons. & Long tons. & Long tons. & Long tons. \\
\hline 1889 & $9,056,288$ & $2,523,087$ & $2,506,415$ & 432,251 & $14,518,041$ \\
\hline 1890. & $10,527,650$ & $2,559,938$ & $2,570,838$ & 377,617 & $16,036,043$ \\
\hline 1891. & $9,327,398$ & $2,757,564$ & $2,31 \bar{\imath}, 108$ & 189,108 & $14,591,178$ \\
\hline 1892. & $11,646,619$ & $2,485,101$ & $1,971,965$ & 192,981 & $16,296,666$ \\
\hline 1893. & $8,272,637$ & $1,849,272$ & $1,330,886$ & 134,834 & $11,587,629$ \\
\hline 1894 & $9,347,434$ & $1,472,748$ & 972,219 & 87,278 & $11,879,679$ \\
\hline $1895 \ldots$ & $12,513,995$ & $2,102,358$ & $1,268,222$ & 73,039 & $15,957,614$ \\
\hline 1896. & $12,576,288$ & $2,126,212$ & $1,211,526$ & 91,423 & $16,005,449$ \\
\hline 1897 & $14,413,318$ & $1,961,954$ & $1,059,479$ & 83,295 & $17,518,046$ \\
\hline 1898 & $16,150,684$ & $1,989,681$ & $1,237,978$ & 55,373 & $19,433,716$ \\
\hline 1899 & $20,004,399$ & $2,869,785$ & $1,727,430$ & 81,559 & $24,683,173$ \\
\hline Total & $133,836,710$ & $24,697,700$ & $18,174,066$ & $1,798,758$ & $178,507,234$ \\
\hline $\begin{array}{l}\text { Percentages of } \\
\text { totals for } \\
\text { eleven years. }\end{array}$ & 75 & - $\quad 13.8$ & 10.2 & 1 & 100 \\
\hline $\begin{array}{r}\text { Percentages of } \\
\text { total for } 1899\end{array}$ & 81.04 & 11.63 & 7 & 0.33 & 100 \\
\hline
\end{tabular}

Notwithstanding the active demand in the year 1899, it will be noted that the output of brown hematite is but slightly above the previous maximum of 1891. The amount of magnetite won was greater in $1889,1890,1891$, and 1892 than in 1899 , and prior to 1895 , as well as in 1896 and 1897, the quantity of carbonate ores annually mined exceeded the record of 1899 . In addition to the iron ore mined there was 65,010 long tons of zinc residuum, or clinker, produced, which was utilized in the production of spiegeleisen. There was also an increased production of concentrated magnetic iron ore, the amount reported in 1899 being 94,217 long tons as against 38,434 long tons in 1898. Rollingmill cinder and scale, silicate of iron, copper residuum, etc., are also used in charges for blast furnaces to a limited extent.

Owing to the fact that most of the iron ore mines make contracts with the consumers in the early portion of the year the prices for iron ore did not show such a marked advance in the year 1899 as they will in the year 1900, when the miners participated to a greater degree in the increased demand and good prices for iron and steel. It is possible also that the control by steel manufacturers of a large proportion of the important mines may exert a restraining influence on the sales and the shipment of ores from the Lake Superior mines to distributing ports on the lower lakes. 


\section{LAKE SUPERIOR REGION.}

The Lake Superior region increased its former maximum output of 13,779,308 long tons in 1898 to $17,802,955$ long tons in 1899. These figures are those of production and not of shipments, for the latter are considerably in excess for 1899, owing to the fact that stock piles at the mines were reduced during the year, as will be noted under the subhead of stocks.

The amounts mined from the various ranges during the last eleven years is as follows:

Production of Lake Superior iron ores by ranges.

[Maxima in italics.]

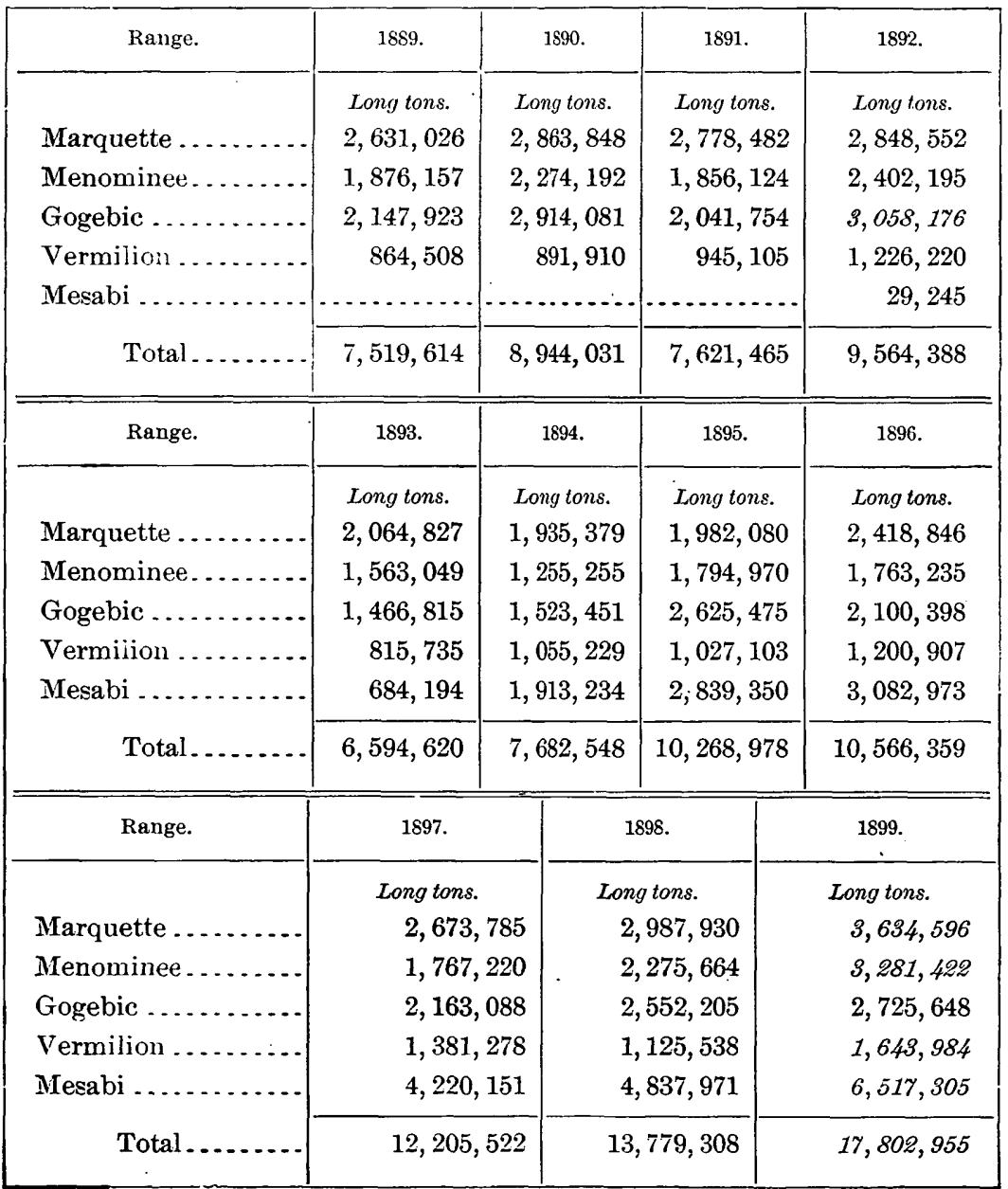


In the above tables the ranges have been placed in the order of their opening, and it will be noted that with the exception of the Gogebic all of the ranges mined their maximum product in the year 1899, the Gogebic reaching its greatest total in the year 1892.

Considering the ranges in the order of their product in 1899 , the Mesabi range, with its rich, easily mined ores, is first with a total of $6,517,305$ long tons.

The Marquette range, the one first opened, continues to furnish a large proportion of the output of Lake Superior region, 3,634,596 long tons being the record for 1899. This range has shown a continued increase since the year 1894 .

The Menominee range reached the three-million mark for the first time in 1899, when it contributed 3,281,422 long tons.

The Gogebic range, while a constant producer, mining 2,725,648 long tons in 1899, has not equaled its 1892 output, when $3,058,176$ tons were mined, nor even the 1890 total.

The Vermilion range attained its maximum of $1,643,984$ tons in the year 1899.

The product of the Lake Superior mines, representing over 70 per cent of the total for the United States, is marketed upon a careful system of cargo analyses, which have, as in former reports, been given place as adding interest to this report.

Cargo analyses of Lake Superior iron ores, season 1899.

[The upper line of figures opposite each ore represent its analysis when dried at $212^{\circ} \mathrm{F}$.; the lower line, when in its natural condition.]

GOGEBIC RANGE.

\begin{tabular}{|c|c|c|c|c|c|c|c|c|c|c|}
\hline Name of ore. & Iron. & Silica. & $\begin{array}{l}\text { Phos- } \\
\text { pho- } \\
\text { rus. }\end{array}$ & $\begin{array}{c}\text { Man- } \\
\text { ga- } \\
\text { nese. }\end{array}$ & $\begin{array}{l}\text { Alum- } \\
\text { ina. }\end{array}$ & Lime. & $\begin{array}{c}\text { Mag- } \\
\text { nesia. }\end{array}$ & $\begin{array}{c}\text { Sul- } \\
\text { phur. }\end{array}$ & $\begin{array}{l}\text { Loss } \\
\text { by ig- } \\
\text { nition. }\end{array}$ & $\begin{array}{l}\text { Mois- } \\
\text { ture. }\end{array}$ \\
\hline \multirow[b]{2}{*}{ Ashland*.............. } & Per ct. & Peir ct. & Per ct. & Per ct. & Perct. & Perct. & Perct. & Perct. & Per ct. & Per cent. \\
\hline & 63.00 & $\cdots \cdots \cdots$ & 0.045 & $\cdots$ & $\cdots$ & *... & 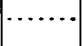 & $\cdots \cdots \cdot$ & $\because$ & \\
\hline \multirow[t]{2}{*}{ Atlantic*............. } & 62.77 & 4.16 & .043 & 1.04 & 1.11 & 0.19 & 0.105 & 0.015 & & \\
\hline & 55.2438 & 3.6612 & .0378 & .9153 & .9769 & .1672 & .0924 & .0132 & $\ldots$ & 11.99 \\
\hline \multirow[t]{2}{*}{ Aurora ............... } & 61.81 & 5.48 & .027 & .43 & 1.11 & .07 & .10 & .010 & 4.02 & .. \\
\hline & 55.72 & 4.94 & .024 & .39 & 1.00 & .063 & .09 & .009 & 3. 62 & 9.86 \\
\hline \multirow[t]{2}{*}{ Best ................ } & 55.482 & 13.94 & .056 & 1.00 & 1.62 & .35 & .26 & .025 & 3.03 & \\
\hline & 48.28 & 12.13 & .0487 & .87 & 1.40 & .30 & .22 & .021 & 2.63 & 12.98 \\
\hline \multirow[t]{2}{*}{ Bonnie ............... } & 53.45 & 11.04 & .0275 & 5.11 & 1.40 & .14 & 1.10 & .025 & 3.51 & $\cdots$ \\
\hline & 47.372 & 9.78 & .0243 & 4.52 & 1.24 & .12 & .97 & .022 & 3.11 & 11.37 \\
\hline \multirow[t]{2}{*}{ Brotherton ........... } & 63.03 & 7.04 & .029 & .405 & .756 & .400 & .046 & .009 & 1.150 & $\cdots$ \\
\hline & 56.27 & 6.292 & .026 & .362 & .676 & .358 & .041 & .008 & 1.03 & 10.73 \\
\hline \multirow[t]{2}{*}{ Buckeye............. } & 58.29 & 10.50 & .059 & .43 & 1.97 & .14 & .46 & .025 & 2.55 & $\cdots$ \\
\hline & 50.94 & 9.17 & .052 & .38 & 1.72 & .12 & .40 & .022 & 2.23 & 12.61 \\
\hline \multirow[t]{2}{*}{ Cary Empire ........ } & 57.79 & 4.54 & .057 & 3.97 & .77 & .18 & .10 & .005 & 5.75 & \\
\hline & 52.2306 & 4.1033 & .0515 & 3.5881 & .6959 & .1627 & .0904 & .0045 & 5.1969 & 9.62 \\
\hline \multirow[t]{2}{*}{ Colby No. $1 \ldots \ldots \ldots$} & 57.66 & 3.61 & .064 & 6.12 & 1.345 & .34 & .28 & .009 & 6.94 & \\
\hline & 51.89 & 3.25 & .058 & 5.51 & 1.211 & .31 & .25 & .0081 & 6.25 & 10.00 \\
\hline
\end{tabular}

Above are average cargo analyses of the season 1899, except when marked thus: *. Ores so marked show the expected analyses for the season 1900 . 
Cargo analyses of Lake Superior iron ores, season 1899-Continued. GOGEBIC RANGE-Continued.

\begin{tabular}{|c|c|c|c|c|c|c|c|c|c|c|}
\hline Name of ore. & Iron. & Silica. & $\begin{array}{c}\text { Phos- } \\
\text { pho- } \\
\text { rus. }\end{array}$ & $\begin{array}{c}\text { Man- } \\
\text { ga- } \\
\text { nese. }\end{array}$ & $\underset{\text { ina. }}{\text { Alum. }}$ & Lime. & $\begin{array}{l}\text { Mag. } \\
\text { nesia. }\end{array}$ & $\begin{array}{l}\text { Sul- } \\
\text { phur. }\end{array}$ & $\begin{array}{c}\text { Loss } \\
\text { by ig- } \\
\text { nition. }\end{array}$ & $\begin{array}{l}\text { Mois- } \\
\text { ture. }\end{array}$ \\
\hline \multirow{3}{*}{ Colby No. $2 \ldots \ldots \ldots$} & Per ct. & Per ct. & Per ct. & Per ct. & Per ct. & Per ct. & Per ct. & Per ct. & Per ct. & Per cent. \\
\hline & 60.37 & 3.74 & 0.092 & 2.80 & 1.28 & 0.17 & 0.23 & 0.006 & 4.60 & \\
\hline & 54.94 & 3.40 & .084 & 2.55 & 1.16 & .15 & .21 & .005 & 4.19 & 9.00 \\
\hline \multirow[t]{2}{*}{ Cass *................. } & 53.65 & 8.14 & .053 & 7.22 & .86 & .21 & 2.17 & .019 & 3.13 & \\
\hline & 47. 335 & 7.41 & .0467 & 6.67 & .75 & .18 & 1.91 & .016 & 2.76 & 11.77 \\
\hline \multirow[t]{2}{*}{ Day ..................... } & 62.370 & & .0723 & & & & & & & \\
\hline & 55.8061 & $\ldots \ldots$ & .0646 & ... & & & & & & 10.524 \\
\hline \multirow[t]{2}{*}{ Fairfax............. } & 63.287 & & .0736 & .756 & & & & & & \\
\hline & 54.6774 & ....... & .0635 & .6531 & & & & & & 13.604 \\
\hline \multirow[t]{2}{*}{ Globe....$\ldots \ldots \ldots$} & 64.23 & 6.68 & .117 & .19 & & & & & & \\
\hline & 56.5224 & 5.8784 & $.1029^{\prime}$ & .1672 & $\cdots$ & $\cdots$ & $\cdots$ & & & 12.00 \\
\hline \multirow[t]{2}{*}{ Iron Belt . .......... } & 60.66 & 8.35 & .045 & .35 & 1.60 & .18 & .13 & .011 & 2.40 & $\cdots$ \\
\hline & 53.59 & 7.38 & .040 & .31 & 1.41 & .16 & .11 & .010 & 2.12 & 11.66 \\
\hline \multirow[t]{2}{*}{ Lawrence ........... } & 61.83 & 5.90 & .057 & .57 & 1.38 & .15 & .13 & .020 & 3.30 & $\cdots \cdots$ \\
\hline & 55.61 & 5.31 & .051 & .51 & 1.24 & .13 & .12 & .018 & 2.97 & 10.06 \\
\hline \multirow[t]{2}{*}{ Melrose............. } & 62.19 & 4.72 & .0302 & .91 & .96 & .16 & .09 & .018 & 3.86 & .... \\
\hline & 55.025 & 4.17 & .0267 & .80 & .84 & .14 & .07 & .015 & 3.41 & 11.52 \\
\hline \multirow[t]{2}{*}{ Mikado.............. } & 56.35 & 15.05 & .138 & .35 & 1.10 & .24 & .17 & .010 & 2.30 & $\cdots \cdots$ \\
\hline & 48.6582 & 12.9957 & .1192 & .3022 & .9499 & .2072 & .1468 & .0086 & 1.9861 & 13.65 \\
\hline \multirow[t]{2}{*}{ Montreal ........... } & 65.42 & 3.14 & .041 & .84 & .71 & .13 & .12 & .017 & 3.34 & 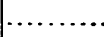 \\
\hline & 60.09 & 2.88 & .038 & .77 & .65 & .12 & .11 & .016 & 3.07 & S. 14 \\
\hline \multirow[t]{2}{*}{ Newport............ } & 53.702 & 5.63 & .0392 & 7.66 & 1.12 & .17 & .14 & .009 & 5.06 & $\cdots$ \\
\hline & 48.267 & 5.06 & .0352 & 6.88 & 1.00 & .15 & .12 & .008 & 4.54 & 10.12 \\
\hline \multirow[t]{2}{*}{ New Era............ } & 57.105 & 11.40 & .0285 & 1.41 & 1.24 & .19 & .10 & .011 & 3.43 & $\cdots$ \\
\hline & 50.44 & 10.06 & .0251 & 1.24 & 1.09 & .16 & .08 & .009 & 3.02 & 11.67 \\
\hline \multirow{2}{*}{ Norrie ............... } & 62.957 & & .0420 & & & & 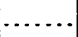 & & & \\
\hline & 56.4736 & $\cdots \cdots$ & .0376 & .. & & $\cdots$ & …. & $\cdots$ & & $10.298^{\prime}$ \\
\hline \multirow[t]{2}{*}{ North Vein .......... } & 62.58 & 5.50 & .048 & .41 & 1.20 & .09 & .08 & .004 & & 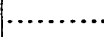 \\
\hline & 56.26 & 4.94 & .043 & .37 & 1.08 & .08 & .07 & .004 & 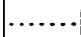 & 10.10 \\
\hline \multirow[t]{2}{*}{ Palms ................. } & 61.856 & 5.28 & .0556 & .90 & 1.31 & .17 & .12 & .012 & 3.26 & $\cdots \cdots$ \\
\hline & 52.633 & 4.49 & .047 & .76 & 1.11 & .14 & .10 & .010 & 2.77 & 14.91 \\
\hline \multirow[t]{2}{*}{ Rand $\ldots \ldots \ldots \ldots \ldots$} & 62.340 & ....... & .0460 & 3.610 & & & $\cdots$ & & & $\cdots$ \\
\hline & 54.7968 & $\ldots \ldots \ldots$ & .0404 & 3.1731 & & $\cdots$ & $\cdots \cdot$ & $\ldots \ldots$ & $\cdots \cdot$ & 12.100 \\
\hline \multirow[t]{2}{*}{ Sunday Lake *....... } & 63.00 & 7.00 & .030 & .32 & 1.34 & .16 & .06 & .006 & .59 & $\cdots \cdots$ \\
\hline & 56.07 & 6.23 & .0267 & .285 & 1.193 & .143 & .054 & .005 & .53 & 11.00 \\
\hline \multirow[t]{2}{*}{ Taylor $* \ldots \ldots \ldots \ldots$} & 62.00 & & .065 & . & & & & & & \\
\hline & 54.56 & & .0572 & …. & & & & & & 12.00 \\
\hline \multirow[t]{2}{*}{ Tilden................ } & 62.737 & & .0476 & .784 & & & & & & ....... \\
\hline & 54.2386 & & .0411 & .6777 & & & & & & 13.546 \\
\hline \multirow[t]{2}{*}{ Tilden No.s......... } & $62.35 S$ & & .0400 & 1.678 & & & & & & …........ \\
\hline & 54.1398 & & .0347 & 1.4568 & & & & & & 13.179 \\
\hline
\end{tabular}

MENOMINEE RANGE.

\begin{tabular}{|c|l|c|c|c|c|c|c|c|c|c|}
\hline Amasa ............ & 55.64 & 6.84 & 0.218 & 0.29 & 2.95 & 2.05 & 1.92 & 0.015 & 5.30 & $\ldots \ldots \ldots$ \\
& 53.6982 & 6.6013 & .2104 & .2799 & 2.8470 & 1.9785 & 1.8530 & .0145 & 5.1150 & 3.49 \\
Ajax $\ldots \ldots \ldots \ldots \ldots \ldots \ldots$ & 52.17 & 11.14 & .0607 & .86 & 2.22 & 1.56 & 4.70 & .022 & 3.94 & $\ldots \ldots \ldots \ldots$ \\
& 48.612 & 10.38 & .0565 & .80 & 2.06 & 1.45 & 4.37 & .020 & 3.67 & 6.82 \\
Badger $\ldots \ldots \ldots \ldots \ldots .$. & 59.91 & 4.47 & .120 & .22 & 2.52 & 1.20 & 1.97 & .100 & $\ldots \ldots \ldots \ldots \ldots \ldots$ \\
& 54.39 & 4.06 & .110 & .20 & 2.29 & 1.09 & 1.79 & .091 & $\ldots \ldots \ldots$ & 9.22 \\
\hline
\end{tabular}

Above are average cargo analyses of the season 1899, except when marked thus: *. Ores so marked show the expected analyses for the season 1900 . 
IRON ORES.

Cargo analyses of Lake Superior iron ores, season 1899-Continued.

MENOMINEE RANGE-Continued.

\begin{tabular}{|c|c|c|c|c|c|c|c|c|c|c|}
\hline Name of ore. & Iron: & Silica. & $\begin{array}{l}\text { Phos- } \\
\text { pho- } \\
\text { rus. }\end{array}$ & $\begin{array}{c}\text { Man- } \\
\text { ga- } \\
\text { nese. }\end{array}$ & $\begin{array}{c}\text { Alum- } \\
\text { ina. }\end{array}$ & Lime. & $\begin{array}{l}\text { Mag. } \\
\text { nesia. }\end{array}$ & $\begin{array}{l}\text { Sul- } \\
\text { phur. }\end{array}$ & $\begin{array}{c}\text { Loss } \\
\text { by ig- } \\
\text { nition. }\end{array}$ & $\begin{array}{l}\text { Mois- } \\
\text { ture. }\end{array}$ \\
\hline \multirow{3}{*}{ Barton } & Per ct. & Per ct. & Per ct. & Per ct. & Per ct. & Per ct. & Per ct. & Per ct. & Per ct. & Per cent. \\
\hline & 59.828 & & 0.530 & & 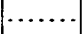 & in & $x^{2}$ & & & \\
\hline & 56.4752 & & .5002 & & & & & & & 5.604 \\
\hline \multirow[t]{2}{*}{ Bristol.............. } & 50.00 & 6.10 & .738 & 2.69 & 3.34 & 3.77 & 1.97 & 0.033 & 7.95 & $\cdots$ \\
\hline & 46.09 & 5.62 & .680 & 2.48 & 3.08 & 3.48 & 1.82 & .030 & 7.33 & 7.82 \\
\hline \multirow[t]{2}{*}{ Cedar. } & 52.00 & 10.26 & .190 & .30 & 3.95 & 1.75 & 4.87 & .130 & 3.68 & . \\
\hline & 47.59 & 9.39 & .174 & .27 & 3.61 & 1.60 & 4.46 & .119 & 3.37 & 8.49 \\
\hline \multirow[t]{2}{*}{ Chapin $* \ldots \ldots \ldots \ldots$} & 58.13 & 6.20 & .065 & .54 & 1.41 & 1.235 & 3.565 & .019 & 3.22 & \\
\hline & 54.08 & 5.76 & .060 & .485 & 1.31 & 1.145 & 3.31 & .017 & 3.00 & 6.96 \\
\hline \multirow[t]{2}{*}{ Clifford } & 41.01 & 39.10 & .014 & .09 & .97 & .49 & .29 & .003 & .45 & $\cdots$ \\
\hline & 39.96 & 38.10 & .0136 & .087 & .945 & .48 & .28 & .0029 & .44 & 2.55 \\
\hline \multirow[t]{2}{*}{ Columbia No. $1 . . .}$. & 60.00 & 5.10 & .52 & .23 & 1.99 & .61 & .90 & .050 & 4.15 & \\
\hline & 53.28 & 4.52 & .461 & .20 & 1.76 & .54 & .79 & .044 & 3.68 & 11.20 \\
\hline \multirow[t]{2}{*}{ Columbia No. $2 \ldots \ldots$} & 54.48 & 12.15 & .46 & .21 & 1.95 & 1.20 & .65 & .049 & 2.56 & .... \\
\hline & 48.378 & 10.78 & .408 & .18 & 1.73 & 1.09 & .57 & .043 & 2.27 & 11.20 \\
\hline \multirow[t]{2}{*}{ Crystal Falls......... } & 58.40 & 4.09 & .71 & .31 & 1.40 & 2.62 & 2.02 & .007 & 3.51 & 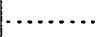 \\
\hline & 53.84 & 3.77 & .655 & .29 & 1.29 & 2.42 & 1.86 & .006 & 3.24 & 7.80 \\
\hline \multirow[t]{2}{*}{ Davidson...$\ldots \ldots \ldots$} & 56.03 & 7.64 & .180 & .24 & 3.43 & 1.27 & 2.89 & .080 & 5.00 & \\
\hline & 50.78 & 6.92 & .163 & .22 & 3.11 & 1.15 & 2.62 & .073 & 4.53 & 9,37 \\
\hline \multirow[t]{2}{*}{ Florence.........} & 56.02 & 4.85 & .325 & .38 & 2.86 & 1.70 & 2.50 & .125 & 5.44 & \\
\hline & 51.459 & 4.45 & .298 & .34 & 2.62 & 1.56 & 2.29 & .114 & 4.99 & 8.14 \\
\hline \multirow[t]{2}{*}{ Granada.................. } & 61.52 & 4.60 & .061 & .23 & 1.53 & .36 & 1.63 & .015 & 2.30 & \\
\hline & 56.64 & 4.23 & .056 & .21 & 1.41 & .33 & 1.50 & .014 & 2.12 & 7.93 \\
\hline \multirow[t]{2}{*}{ Great Western * ..... } & 60.40 & 5.80 & .385 & .61 & 1.21 & 2.24 & 1.65 & .009 & 2.43 & 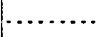 \\
\hline & 55.39 & 5.32 & .353 & .56 & 1.11 & 2.05 & 1.51 & .008 & 2.23 & 8.30 \\
\hline \multirow[t]{2}{*}{ Hemlock ............. } & 58.72 & 5.70 & .272 & .20 & 2.66 & 1.92 & 1.55 & .006 & 2.95 & \\
\hline & 56.4064 & 5.4754 & .2613 & .1921 & 2.5552 & 1.8444 & 1.4889 & .0058 & 2.8338 & 3.94 \\
\hline \multirow[t]{2}{*}{ Keel Ridge............ } & 40.64 & 37.42 & .046 & .20 & .90 & 1.35 & 1.00 & .006 & 1 & \\
\hline & 39.46 & 36.33 & .045 & .19 & .87 & 1.31 & .97 & .0058 & 3. & 2.90 \\
\hline \multirow[t]{2}{*}{ Lamont ............. } & 58.10 & 4.31 & .673 & .35 & 1.25 & 1.92 & 2.34 & .009 & 3.60 & \\
\hline & 53.39 & 3.96 & .618 & .32 & 1.15 & 1.76 & 2.15 & .008 & 3.31 & 8.10 \\
\hline \multirow[t]{2}{*}{ Lincoln * } & 60.20 & 5.05 & .290 & .66 & 1.67 & 2.29 & 2.35 & .010 & 2.95 & \\
\hline & 55.38 & 4.65 & .267 & .61 & 1.54 & 2.11 & 2.16 & .0092 & 2.71 & 8.00 \\
\hline \multirow[t]{2}{*}{ Loretto.. } & 57.067 & 13.20 & .0205 & .20 & 2.12 & .32 & .57 & .062 & 1.59 & \\
\hline & 52.09 & 12.04 & .0187 & .18 & 1.93 & .29 & .52 & .056 & 1.45 & 8.72 \\
\hline \multirow[t]{2}{*}{ Manganate.. } & 50.00 & 4.45 & .626 & 4.82 & 2.50 & 2.53 & 2.73 & .021 & 7.98 & \\
\hline & 47.70 & 4.24 & .597 & 4.60 & 2.38 & 2.41 & 2.60 & .020 & 7.61 & 4.61 \\
\hline Millie & 63.705 & 2.97 & .0275 & .12 & .94 & 1.14 & 1.49 & .008 & 2.12 & \\
\hline & 60.092 & 2.80 & .0259 & .11 & .88 & 1.07 & 1.40 & .007 & 1.99 & 5.67 \\
\hline Nimick . & 62.72 & 4.35 & .071 & .22 & 1.25 & .65 & 2.24 & .03 & 1.65 & \\
\hline & 57.71 & 4.00 & .065 & .20 & 1.15 & .60 & 2.06 & .027 & $1.52 !$ & 7.99 \\
\hline Pewabic & 63.21 & 5.48 & .009 & .11 & 1.04 & .86 & 1.12 & .003 & 1.20 & - \\
\hline & 58.7853 & 5.0964 & .0084 & .1023 & .9672 & .7995 & 1.0416 & .0028 & 1.1160 & 7.00 \\
\hline Pewabic Genor. & 45.97 & $32.40 !$ & .009 & .09 & 1.30 & .79 & 1.08 & .002 & 1.24 & \\
\hline & 43.5566 & 30.6990 & .0085 & .0853 & 1.2318 & .7485 & 1.0233 & .0019 & 1.1749 & 5.25 \\
\hline Quinnesec* $\therefore$.. & 49.61 & 27.80 & .028 & .27 & .56 & .82 & .48 & .010 & 2.40 & $\cdots \cdot \cdot$ \\
\hline & 48.53 & 27.19 & .027 & .26 & .54 & .80 & .47 & .010 & 2.35 & 2.18 \\
\hline Russell . & 54.10 & 10.00 & .067 & .32 & 2.15 & 3.02 & 2.65 & .032 & 4.57 & $\ldots$ \\
\hline & 50.432 & 9.32 & .0624 & .29 & 2.00 & 2.81 & 2.47 & .029 & 4.26 & 6.78 \\
\hline San Jose... & 64.405 & 4.64 & .014 & .30 & 1.24 & .19 & .39 & .027 & .64 & …. \\
\hline & 59.072 & 4.25 & .0128 & .27 & 1.13 & .17 & .35 & .024 & .58 & 8.28 \\
\hline
\end{tabular}

Above are average cargo analyses of the season 1899, except when marked thus: *. Ores so marked show the expected analyses for the season 1900. 
Cargo analyses of Lake Superior iron ores, season 1899-Continued.

MENOMINEE RANGE-Continued.

\begin{tabular}{|c|c|c|c|c|c|c|c|c|c|c|}
\hline Name of ore. & Iron. & Silica. & $\begin{array}{l}\text { Phos- } \\
\text { pho- } \\
\text { rus. }\end{array}$ & $\begin{array}{c}\text { Man- } \\
\text { ga- } \\
\text { nese. }\end{array}$ & $\begin{array}{l}\text { Alum- } \\
\text { ina. }\end{array}$ & Lime. & $\begin{array}{l}\text { Mag- } \\
\text { nesia. }\end{array}$ & $\begin{array}{l}\text { Sul- } \\
\text { phur. }\end{array}$ & $\begin{array}{c}\text { Loss } \\
\text { by ig- } \\
\text { nition. }\end{array}$ & $\begin{array}{l}\text { Mois- } \\
\text { ture. }\end{array}$ \\
\hline \multirow{3}{*}{ Sheridan } & Per ct. & Per ct. & Per ct. & Per ct. & Perct. & Per ct. & Per ct. & Perct. & Per ct. & Per cent. \\
\hline & 55.48 & 7.37 & 0.224 & 0.25 & 4.48 & 0.75 & 0.59 & 0.610 & 5.35 & \\
\hline & 49.5880 & 6.5873 & .2002 & .2234 & 4.0042 & .6703 & .5273 & .5452 & 4.7818 & 10.62 \\
\hline \multirow[t]{2}{*}{ Toledo } & 54.21 & 19.80 & .010 & .11 & 1.20 & .88 & 1.08 & .004 & 1.20 & 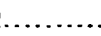 \\
\hline & 50.9574 & 18.6120 & .0094 & .1034 & 1.1280 & .8272 & 1.0152 & .0038 & 1.1280 & 6.00 \\
\hline \multirow[t]{2}{*}{ Tyrone .............. } & 60.40 & 6.59 & .088 & .16 & 1.38 & 1.25 & 2.15 & .001 & 2.05 & \\
\hline & 56.1720 & 6.1287 & .0818 & .1488 & 1.2834 & 1.1625 & 1.9995 & .0009 & 1.9065 & 7.00 \\
\hline \multirow[t]{2}{*}{ Walpole. } & 58.75 & 10.51 & .120 & .13 & 1.30 & .79 & 1.96 & .002 & 1.22 & $\ldots$ \\
\hline & 55.8125 & 9.9845 & .1140 & .1235 & 1.2350 & .7505 & 1.8620 & .0019 & 1.1590 & 5.00 \\
\hline
\end{tabular}

MARQUETTE RANGE.

\begin{tabular}{|c|c|c|c|c|c|c|c|c|c|c|}
\hline \multirow[t]{2}{*}{ Abbottsford*. } & 1.22 & 4.42 & 033 & .18 & 1. 69 & .31 & .17 & .014 & & \\
\hline & 62.6530 & 4.3121 & .0321 & .1756 & 1.6487 & .3024 & .1658 & .0136 & & 2.44 \\
\hline \multirow[t]{2}{*}{ Alford $* \ldots \ldots \ldots$. } & 63.74 & 3.39 & .052 & .35 & 1.83 & .31 & .20 & .020 & & \\
\hline & 55.4856 & 2.9509 & $.0+52$ & .3046 & 1.5930 & .2698 & .1741 & .0174 & & 12.95 \\
\hline \multirow[t]{2}{*}{ Angeline, Hard ..... } & 66.71 & 2.19 & .016 & .11 & 1.47 & .10 & .05 & .013 & .66 & $\ldots$. \\
\hline & 63.3278 & 2. 0789 & .0151 & .1044 & 1. 3954 & .0949 & 0474 & .0123 & .6265 & 5.07 \\
\hline \multirow[t]{2}{*}{ Angeline, Hematite. } & 64.40 & 4.05 & .045 & .32 & 1. 31 & .15 & .09 & .012 & 2.01 & \\
\hline & 57.7539 & 3.6320 & .0403 & .2869 & 1.1748 & .1345 & .0807 & .0107 & 1.8025 & 10.32 \\
\hline \multirow[t]{2}{*}{ Angeline, South..... } & 62.17 & 5.04 & .099 & .40 & 1.56 & .18 & .12 & .025 & 3.40 & \\
\hline & 54.6722 & 4. 4321 & .0870 & .3517 & 1. 3718 & .1582 & .1055 & .0219 & 2.9899 & 12.06 \\
\hline \multirow[t]{2}{*}{ Bell ...................... } & 39.985 & 38.27 & .0332 & .22 & 1.28 & .13 & .16 & .028 & 2.29 & \\
\hline & $38 . \$ 53$ & 37.18 & .0322 & .21 & 1.14 & .12 & .15 & .027 & 2.22 & 2. 83 \\
\hline \multirow[t]{2}{*}{ Bedford *............ } & 59.05 & 8.84 & .122 & .52 & 1.49 & .41 & .31 & .027 & & \\
\hline & 51.9640 & 7. 7792 & .1073 & .4576 & 1.3112 & .3608 & .2728 & .0237 & & 12.00 \\
\hline \multirow[t]{2}{*}{ Beresford * .......... } & 63.61 & 4.88 & .105 & .39 & 2.57 & .43 & .43 & $.013 \vdots$ & $\cdots$ & \\
\hline & 62.8721 & 4. 8233 & .1037 & .3854 & 2.5401 & .4250 & .4250 & .0128 & & 1.16 \\
\hline \multirow{2}{*}{ Buffalo ............... } & 60.973 & & 069 & & & & & & & \\
\hline & 53.3013 & & .0934 & & & & & & & 12. 582 \\
\hline \multirow[t]{2}{*}{ Cameo................ } & 6 & & $.116 ?$ & & & & & & & \\
\hline & 51. 3627 & $\cdots$ & .1014 & $\cdots$ & & $\ldots$ & ...... & $\cdots$ & & 12.687 \\
\hline \multirow[t]{2}{*}{ Cambria............. } & 60.20 & 6.49 & .056 & .31 & 2.03 & .88 & .37 & .010 & 2.53 & \\
\hline & 53.46 & 5. 76 & .050 & .28 & 1.80 & .78 & .33 & .0089 & 2.25 & 11.20 \\
\hline \multirow{2}{*}{ Cambridge...$\ldots \ldots$} & 59.71 & 7.10 & .610 & .42 & 1.25 & 2.50 & .52 & .004 & 1.81 & \\
\hline & 50.5803 & 6.0144 & .5167 & .3557 & 1.0588 & 2.1177 & .4404 & .0033 & 1.5332 & 15.29 \\
\hline \multirow[t]{2}{*}{ Castleford $* \ldots \ldots \ldots$} & 58.64 & 10.43 & .094 & .36 & 2.87 & .40 & .40 & .020 & & \\
\hline & 58.1356 & 10.3403 & .0931 & .3569 & 2.8453 & .3965 & .3965 & .0198 & & .86 \\
\hline \multirow[t]{2}{*}{ Champion No. $1 * \ldots$} & 64.00 & 4.55 & .060 & .20 & 2.38 & .32 & .29 & .013 & & \\
\hline & 63.44 & 4.51 & .0594 & .198 & 2.36 & .317 & .287 & .0128 & & .88 \\
\hline \multirow[t]{2}{*}{ Chatiord * ........... } & 50.72 & 17.70 & .105 & .78 & 1.25 & .31 & .31 & .027 & & \\
\hline & 44.9683 & $15.692 \mathrm{~S}$ & .0930 & .6915 & 1.1082 & .2748 & .2748 & .0239 & & 11.34 \\
\hline \multirow[t]{2}{*}{ Cliffs Shaft $\ldots \ldots \ldots}$. & 60.90 & 4.030 & .109 & .384 & 2.446 & $1.14 S$ & 1.339 & .025 & 2.710 & $\ldots$ \\
\hline & 60.00 & 3.970 & .107 & .378 & 2.410 & 1.131 & 1.319 & .024 & 2.670 & 1.47 \\
\hline \multirow[t]{2}{*}{ Comrade ............. } & 56.51 & 11.11 & .126 & .073 & 3.817 & .27 & .70 & .037 & 2.70 & \\
\hline & 55.89 & 10.99 & .124 & .072 & 3.775 & .26 & .69 & .036 & 2.67 & 1.09 \\
\hline \multirow[t]{2}{*}{ Imperial. .............. } & 52.70 & 12. $\$ 90$ & .281 & .161 & 1.004 & 1.027 & 1.218 & .015 & 7.470 & \\
\hline & 47.95 & 11.730 & .255 & .146 & .913 & .934 & 1.108 & .016 & 6. 797 & 9.00 \\
\hline \multirow[t]{2}{*}{ Jackson Pit $7 . . . . .}$. & 55.00 & 14.38 & .076 & .37 & 2.49 & .14 & .11 & .022 & 3.73 & \\
\hline & 51.05 & 13.35 & .071 & .34 & 2.31 & .13 & .10 & .020 & 3.46 & 7.18 \\
\hline
\end{tabular}

Above are average cargo analyses of the season 1899, except when marked thus: *. Ores so marked show the expected analyses for the season 1900 . 
IRON ORES.

Cargo analyses of Lake Superior iron ores, season 1899-Continued.

MARQUETTE RANGE-Continued.

\begin{tabular}{|c|c|c|c|c|c|c|c|c|c|c|}
\hline Name of ore. & Iron. & Silica. & $\begin{array}{c}\text { Phos- } \\
\text { pho- } \\
\text { rus. }\end{array}$ & $\begin{array}{c}\text { Man- } \\
\text { ga- } \\
\text { nese. }\end{array}$ & Alum- & Lime. & $\begin{array}{l}\text { Mag- } \\
\text { nesia. }\end{array}$ & $\begin{array}{c}\text { Sul- } \\
\text { phur. }\end{array}$ & $\begin{array}{l}\text { Loss } \\
\text { by ig. } \\
\text { nition. }\end{array}$ & $\begin{array}{l}\text { Mois- } \\
\text { ture. }\end{array}$ \\
\hline \multirow{3}{*}{ Jackson, So. Silica... } & Per ct. & Per ct. & Per ct. & Per ct. & Per ct. & Per ct. & Per ct. & Per ct. & Per ct. & Percent. \\
\hline & 43.50 & 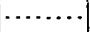 & 0.055 & $3.50^{\circ}$ & & & - & & & \\
\hline & 40.0417 & $\ldots \ldots \ldots$ & .0508 & 3.2475 & s. & $\cdots$ & $\cdots$ & & & 7.50 \\
\hline \multirow[t]{2}{*}{ Lake ................. } & 59.90 & 6.010 & .100 & .443 & 2. 784 & 0.408 & 0.597 & 0.017 & 3.570 & \\
\hline & 51.61 & 5.178 & .086 & .381 & 2.398 & .351 & .514 & .014 & 3.075 & 13.84 \\
\hline \multirow[t]{2}{*}{ Lake Bessemer ...... } & 63.67 & 5.460 & .040 & .295 & 1.447 & .230 & .226 & .016 & 1.400 & \\
\hline & 55.74 & 4.779 & .035 & .258 & 1.266 & .201 & .197 & .014 & 1.225 & 12.46 \\
\hline \multirow[t]{2}{*}{ Lillie ................ } & 62.55 & 5.14 & .077 & .37 & 2.22 & .28 & .09 & .011 & 2.40 & \\
\hline & 55.61 & 4.57 & .068 & .33 & 1.97 & .25 & .080 & .010 & 2.13 & 11.10 \\
\hline \multirow[t]{2}{*}{ Marquette........... } & 42. 793 & 35.37 & .050 & .25 & .99 & .21 & .21 & .021 & 1.67 & 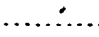 \\
\hline & 40.251 & 33.26 & .047 & .23 & .93 & .19 & $: 19$ & .019 & 1.57 & 5.94 \\
\hline \multirow[t]{2}{*}{ Norfolk * ............ } & 55.00 & 14.25 & .055 & .17 & 3.30 & .57 & .56 & .032 & & \\
\hline & 54.50 & 14.12 & .0544 & .168 & 3.27 & .56 & .55 & .0317 & . & .91 \\
\hline \multirow[t]{2}{*}{ Peninsular ........... } & 52.00 & & .080 & & & $\cdots$ & & & & \\
\hline & 47.8400 & & .0736 & $\cdots$ & & $\cdots$ & $\cdots$ & $\cdots$ & & 8.00 \\
\hline \multirow[t]{2}{*}{ Princeton No.1...... } & 62.81 & 5.95 & .063 & .14 & 1.25 & .80 & .68 & .004 & 1. 69 & \\
\hline & 53.6962 & 5.0866 & .0538 & .1196 & 1.0686 & .6839 & .5813 & .0034 & 1. 4447 & 14.51 \\
\hline \multirow[t]{2}{*}{ Princeton No. $2 \ldots$.... } & 61.63 & 8.50 & .109 & .24 & 1.21 & .70 & .54 & .005 & 2. 60 & \\
\hline & 53.1065 & 7.3244 & .0939 & .2068 & 1.0426 & .6031 & .4653 & .0043 & 2. 2404 & 13.83 \\
\hline \multirow[t]{2}{*}{ Republic Special .... } & 67.82 & 1.30 & .021 & Trace & .63 & .15 & .08 & .045 &.$\dot{60}$ & \\
\hline & 67.5148 & 1.2941 & .0209 & Trace & .6271 & .1493 & .0796 & .0447 & .5973 & .45 \\
\hline \multirow[t]{2}{*}{ Republic Specular... } & 66.77 & 2.70 & .037 & .09 & .93 & .17 & .12 & .01 & .35 & \\
\hline & 66.2558 & 2.6792 & .0367 & .0893 & .9228 & .1686 & .1190 & .0099 & .3473 & .77 \\
\hline \multirow[t]{2}{*}{ Republic Kingston .. } & 63.84 & 6.40 & .041 & .16 & 1.08 & .40 & .33 & .028 & .19 & \\
\hline & 63.1505 & 6.3308 & .0405 & $.158_{2}$ & 1.0683 & .3956 & .3264 & .0276 & .1879 & 1.08 \\
\hline \multirow[t]{2}{*}{$\begin{array}{c}\text { Republic Magnetic } \\
\text { (Non-Bess.) } . . . . . .\end{array}$} & 69.00 & 3.23 & .12 & $.14^{7}$ & .664 & .20 & .216 & .021 & .46 & \\
\hline & 68.6550 & 3.128 & .1194 & .1462 & .6606 & .1990 & .2149 & .0208 & .4577 & .50 \\
\hline \multirow{2}{*}{ 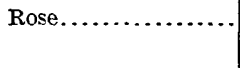 } & 61.05 & 6.33 & .117 & .257 & 2.379 & .42 & .061 & .018 & 2.98 & $\cdots .$. \\
\hline & 53.66 & 5.56 & .103 & .226 & 2.091 & .37 & .054 & .016 & 2.62 & 12.10 \\
\hline \multirow[t]{2}{*}{ Richmond........... } & 44.00 & 35.06 & .041 & .15 & .52 & .30 & .15 & .006 & 1.50 & $\cdots$ \\
\hline & 43.12 & 34.36 & .040 & .15 & .51 & .29 & .15 & .006 & 1.47 & 2.00 \\
\hline \multirow{2}{*}{ Salisbury $\ldots \ldots \ldots \ldots$} & 61.87 & 5.570 & .092 & .161 & 1.807 & .262 & .147 & .014 & 2.910 & $\cdots \cdots$ \\
\hline & 52.65 & 4.740 & .078 & .137 & 1.537 & .222 & .125 & .011 & $2.4 \overline{7}$ & 14.90 \\
\hline \multirow[t]{2}{*}{ Salisbury Bessemer*. } & 63.60 & 3.43 & .044 & .25 & 1.38 & .13 & .18 & .017 & 4.45 & .... \\
\hline & 54.11 & 2.91 & .037 & .21 & 1.17 & .11 & .15 & .014 & 3.78 & 14.91 \\
\hline \multirow[t]{2}{*}{ Scotch...........} & 59.00 & & & & & & & & & \\
\hline & 58.41 & & …. & -. & & . & & $\cdots$ & & 1.00 \\
\hline \multirow[t]{2}{*}{ Sheffield...$\ldots \ldots \ldots$} & 60.45 & 10.69 & .021 & .11 & 1.57 & .10 & .09 & .026 & 1.03 & ....... \\
\hline & 59.0354 & 10.4398 & .0205 & .1074 & 1. 5332 & .0976 & .0878 & .0253 & 1. 0058 & 2.34 \\
\hline \multirow[t]{2}{*}{ Tilden Silica ......... } & 42.50 & 37.49 & .029 & .103 & .908 & .150 & .142 & .012 & .800 & ..... \\
\hline & 41.28 & 36.41 & .028 & .100 & .882 & .145 & .137 & .011 & .777 & 2.86 \\
\hline
\end{tabular}

MESABA RANGE.

\begin{tabular}{|c|c|c|c|c|c|c|c|c|c|c|}
\hline \multirow[t]{2}{*}{ Adams .............. } & 63.80 & 3.00 & .034 & .41 & 1.17 & .12 & .05 & .002 & 3.74 & \\
\hline & 57.30 & 2.69 & .031 & .37 & 1.05 & .11 & .04 & .0018 & 3.36 & 10.19 \\
\hline \multirow[t]{2}{*}{ Admiral .............. } & 64.20 & 5.04 & .028 & .31 & .41 & .35 & .27 & .004 & 2,06 & .. \\
\hline & 59.26 & 4.65 & .026 & .29 & .38 & .32 & .25 & .004 & 1.90 & 7. 70 \\
\hline \multirow[t]{2}{*}{ Ainslie ............. } & 62.47 & 3.47 & .077 & .71 & 2.57 & .21 & .15 & .020 & 3.17 & $\ldots \ldots$ \\
\hline & 56.65 & 3.15 & .070 & .64 & 2.33 & .19 & .14 & .018 & 2.87 & 9.31 \\
\hline
\end{tabular}

Above are average cargo analyses of the season 1899, except when marked thus: *. Ores so marked show the expected analyses for the season 1900. 
Cargo analyses of Lake Superior iron ores, season 1899-Continued.

MESABA RANGE-Continued

\begin{tabular}{|c|c|c|c|c|c|c|c|c|c|c|}
\hline Name of ore. & Iron. & Silica. & $\begin{array}{c}\text { Phos- } \\
\text { pho- } \\
\text { rus. }\end{array}$ & $\begin{array}{c}\text { Man- } \\
\text { ga- } \\
\text { nese. }\end{array}$ & $\begin{array}{c}\text { Alum- } \\
\text { ina. }\end{array}$ & Lime. & $\begin{array}{l}\text { Mag- } \\
\text { nesia. }\end{array}$ & $\begin{array}{c}\text { Sul- } \\
\text { phur. }\end{array}$ & $\begin{array}{c}\text { Loss } \\
\text { by ig- } \\
\text { nition. }\end{array}$ & $\begin{array}{l}\text { Mois- } \\
\text { ture. }\end{array}$ \\
\hline \multirow{3}{*}{ Auburn ............. } & Per ct. & Per ct. & Per ct. & Per ct. & Per ct. & Per ct. & Per ct. & Per ct. & Per ct. & Per cent. \\
\hline & 64.10 & 2.86 & 0.049 & 0.43 & 1.80 & 0.53 & 0.27 & 0.010 & 2.44 & \\
\hline & 56.9400 & 2.5405 & .0435 & .3820 & 1.5989 & .4708 & .2398 & .0089 & 2.1675 & 11.17 \\
\hline \multirow[t]{2}{*}{ Audrey ................ } & 62.15 & 3.24 & .058 & .85 & 1.86 & .62 & .23 & .007 & 4.00 & 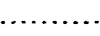 \\
\hline & 54.2383 & 2.8275 & .0506 & .7418 & 1.6232 & .5411 & .2007 & .0061 & 3.4908 & 12.73 \\
\hline \multirow[t]{2}{*}{ Beaver .................. } & 62.66 & 3.53 & .0794 & .34 & 1.92 & .20 & .13 & .015 & 3.90 & \\
\hline & 54.865 & 3.09 & .0695 & .29 & 1.68 & .17 & .10 & .013 & 3.27 & 12.44 \\
\hline \multirow[t]{2}{*}{ Biwabik ................. } & 63.56 & 3.00 & .038 & .49 & .95 & .12 & .07 & .006 & 3.41 & $\ldots$ \\
\hline & 58.4307 & 2.7579 & .0349 & .4504 & .8733 & .1103 & .0643 & .0055 & 3.1348 & 8.07 \\
\hline \multirow[t]{2}{*}{ Canton .............. } & 60.95 & 3.16 & .048 & .44 & .84 & .64 & .18 & Trace. & 7.10 & 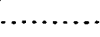 \\
\hline & 53.6909 & 2.7836 & .0422 & .3876 & .7400 & .5638 & .1586 & Trace. & 0.2544 & 11.91 \\
\hline \multirow[t]{2}{*}{ Commodore .......... } & 63.60 & 4.21 & .038 & .44 & 1.21 & .34 & .12 & .007 & 3.39 & 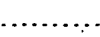 \\
\hline & 56.73 & 3.76 & .034 & .39 & 1.08 & .30 & .11 & .006 & 3.02 & 10.80 \\
\hline \multirow[t]{2}{*}{$\begin{array}{c}\text { Commodore } \quad \text { Non- } \\
\text { Bess ............... }\end{array}$} & 62.70 & 4.21 & .058 & .44 & 1.29 & .34 & .12 & .006 & 3. 72 & \\
\hline & 55.80 & 3.75 & .052 & .39 & 1.15 & .30 & .11 & .005 & 3.31 & 11.00 \\
\hline \multirow[t]{2}{*}{ Duluth } & 60.19 & 5.12 & .048 & .90 & 1.24 & .15 & .08 & .011 & 6.90 & 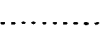 \\
\hline & 52.30 & 4.45 & .042 & .78 & 1.07 & .13 & .07 & .0096 & 6.00 & 13.11 \\
\hline \multirow[t]{2}{*}{ Fayal................... } & 63.41 & 3.15 & .085 & .63 & .81 & .42 & .19 & None. & 4.10 & . $\ldots \ldots \ldots$ \\
\hline & 56.8597 & 2.8246 & .0314 & .5649 & .7263 & .3766 & .1704 & None. & 3.6765 & 10.33 \\
\hline \multirow[t]{2}{*}{ Franklin ............. } & 62.78 & 4.85 & .040 & .49 & 1.03 & .30 & .46 & .016 & 3.41 & \\
\hline & 58.5046 & 4.5197 & .0372 & .4566 & .9598 & .2795 & .4286 & .0149 & 3.1777 & 6.81 \\
\hline \multirow[t]{2}{*}{ Genoa...$\ldots \ldots \ldots \ldots$} & 63.42 & 3.38 & .030 & .50 & .86 & .47 & .16 & Trace. & 3.23 & $\ldots$ \\
\hline & 57.3444 & 3.0562 & .0271 & .4521 & .7776 & .4250 & .1447 & Trace. & 2.9206 & 9.58 \\
\hline \multirow[t]{2}{*}{ Hale*................ } & 60.00 & 5.00 & .080 & .55 & .52 & 1.58 & . & .016 & $\ldots \ldots$ & \\
\hline & 54.00 & 4.50 & .072 & .495 & .468 & 1.422 & $\cdots$ & .014 & & 10.00 \\
\hline \multirow[t]{2}{*}{ Hartley ............... } & 64.74 & 2.50 & .038 & .41 & 1.29 & .18 & .04 & .007 & 3.10 & 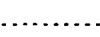 \\
\hline & 57.77 & 2.23 & .034 & .37 & 1.15 & .16 & .035 & .006 & 2.77 & 10.76 \\
\hline \multirow[t]{2}{*}{ Hibbing ................ } & 64.85 & 2.68 & .033 & .46 & 1.40 & .14 & .13 & .009 & 2.31 & 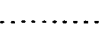 \\
\hline & 57.92 & 2.39 & .029 & .41 & 1.25 & .13 & .12 & .008 & 2.06 & 10.69 \\
\hline \multirow[t]{2}{*}{ 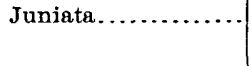 } & 58.971 & . & .0578 & .401 & & & & & & \\
\hline & 50.3022 & . & .0493 & .3420 & & & & & & 14.700 \\
\hline \multirow[t]{2}{*}{ Kanawha* } & 60.00 & 5.50 & .067 & .46 & 1.10 & 1.40 & .25 & .004 & 2.00 & 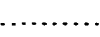 \\
\hline & 54.00 & 4.95 & .060 & .414 & .99 & 1.26 & .225 & .004 & 1.80 & 10.00 \\
\hline \multirow[t]{2}{*}{ Malta............... } & 62.60 & 4.07 & .029 & .46 & .86 & .64 & .22 & Trace. & 2. 78 & \\
\hline & 57.5795 & 3.7436 & .0267 & .4231 & .7910 & .5887 & .2024 & Trace. & 2.5570 & 8.02 \\
\hline \multirow[t]{2}{*}{ Mountain ............ } & 62.830 & & .0474 & .307 & & & & & & \\
\hline & 53.9640 & & .0407 & .2636 & & & & & & 14.111 \\
\hline \multirow[t]{2}{*}{ Oliver ................ } & 61.893 & 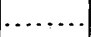 & $.05,6$ & $.34 \mathrm{~S}$ & & & & & & \\
\hline & 53.2991 & & .0496 & .2996 & & & $\cdots$ & & $\cdots \cdots$ & 13.885 \\
\hline $\mathrm{Pe}$ & 61.435 & 6.44 & .0335 & .46 & 1.43 & .20 & .10 & .013 & 3.39 & $\ldots \ldots \ldots$ \\
\hline & 53.878 & 5.64 & .0293 & .40 & 1.25 & .17 & .08 & .011 & 2.97 & 12.30 \\
\hline Pillsbury ... & 62.32 & 5.00 & .028 & .30 & 1.29 & .11 & .14 & .005 & 3.80 & \\
\hline & 56.67 & 4.55 & .025 & .27 & 1.17 & .10 & 3 & .0045 & 3.46 & 9.06 \\
\hline $\mathrm{P}$ & 59.400 & - & .0840 & 1.345 & & & & & & \\
\hline & 51.7718 & & .0732 & 1.1722 & $\cdots$ & $\cdots$ & $\cdots$ & ... & & 12.842 \\
\hline Rober & 61.35 & 7.46 & .028 & .44 & 1.07 & .46 & .19 & .008 & $1.9 \overline{7}$ & ..... \\
\hline & 55.78 & 6.77 & .0254 & .40 & .973 & .418 & .173 & .007 & 1. 79 & $9.0 \mathrm{~S}$ \\
\hline Sauntr & 62.50 & 4. 75 & .069 & .30 & 1.90 & .19 & .11 & .01 & & ....... \\
\hline i & 56.25 & $4.2 \overline{7}$ & .062 & .27 & 1.71 & .17 & .099 & .009 & & 10.00 \\
\hline
\end{tabular}

Above are average cargo analyses of the season 1899, except when marked thus: *. Ores so marked show the expected analyses for the season 1900 . 
IRON ORES.

Cargo analyses of Lake Superior iron ores, season 1899-Continued.

MESABA RANGE-Continued.

\begin{tabular}{|c|c|c|c|c|c|c|c|c|c|c|}
\hline Name of ore. & Iron. & Silica. & $\begin{array}{c}\text { Phos- } \\
\text { pho- } \\
\text { rus. }\end{array}$ & $\begin{array}{c}\text { Man- } \\
\text { ga- } \\
\text { nese. }\end{array}$ & $\begin{array}{c}\text { Alum- } \\
\text { ina. }\end{array}$ & Lime. & $\begin{array}{c}\text { Mag- } \\
\text { nesia. }\end{array}$ & $\begin{array}{c}\text { Sul- } \\
\text { phur. }\end{array}$ & $\begin{array}{c}\text { Loss } \\
\text { by ig- } \\
\text { nition. }\end{array}$ & $\begin{array}{l}\text { Mois- } \\
\text { ture. }\end{array}$ \\
\hline \multirow{3}{*}{ Sellers ................ } & Per ct. & Per ct. & Per ct. & Per ct. & Perct. & Per ct. & Per ct. & Per ct. & Perct. & Per cent. \\
\hline & 63.95 & 3.82 & .039 & .46 & 1.29 & .17 & .13 & .032 & 2.45 & ...... \\
\hline & 57.72 & 3.45 & .035 & .42 & 1.16 & .15 & .12 & .029 & 2.21 & 9.74 \\
\hline \multirow[t]{2}{*}{ Sparta............. } & 64.08 & 3.90 & .030 & .37 & .84 & .53 & .15 & .006 & 1.57 & \\
\hline & 59.0561 & 3.5942 & .0276 & .3410 & .7741 & . 4884 & .1382 & .0055 & 1.4469 & 7.84 \\
\hline \multirow[t]{2}{*}{ Stevenson*......... } & 63.40 & 5.10 & .040 & .32 & .62 & .24 & .18 & .009 & 3.20 & . \\
\hline & 57.06 & 4.59 & .036 & .288 & .558 & .216 & .162 & .008 & 2.88 & 10.00 \\
\hline \multirow[t]{2}{*}{ Top Brown .......... } & 61.26 & 4.04 & .065 & 1.30 & 1.29 & .55 & .15 & .007 & 4.35 & $\ldots$ \\
\hline & 55.2443 & 3.6433 & .0586 & 1.1723 & 1.1633 & .4960 & .1353 & .0063 & 3.9228 & 9. 82 \\
\hline \multirow[t]{2}{*}{ Vulcan } & 62.55 & 4.27 & .042 & .94 & & & & Trace. & & 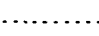 \\
\hline & 57.0018 & 3.8913 & .0383 & .8566 & & & & Trace. & & 8.87 \\
\hline \multirow[t]{2}{*}{ West Drift........... } & 63.84 & 2.51 & .052 & .72 & & & & Trace. & & . \\
\hline & 57.7688 & 2.2713 & .0471 & .6515 & & & & Trace. & & 9.51 \\
\hline
\end{tabular}

VERMILION RANGE.

\begin{tabular}{|c|c|c|c|c|c|c|c|c|c|c|}
\hline \multirow[t]{2}{*}{ Chandler............ } & 64.43 & 4.20 & .040 & .22 & 2.20 & .63 & .14 & .002 & .90 & \\
\hline & 60.9250 & 3.9715 & .0378 & .2080 & 2.0802 & .5957 & .1324 & .0019 & .8510 & 5.54 \\
\hline \multirow[t]{2}{*}{ Jura . } & 62.142 & & .0760 & & & & & & & \\
\hline & 57.5565 & $\cdots \cdots$ & .0703 & $\cdots$ & $\cdots$ & $\cdots$ & $\cdots$ & $\cdots$ & & 7.379 \\
\hline \multirow[t]{2}{*}{ Long Lake.......... } & 60.47 & 7.67 & .044 & .13 & 3.65 & .86 & .28 & .012 & 1.45 & ... \\
\hline & 56.1948 & 7.1277 & .0409 & .1208 & 3.3919 & .7992 & .2602 & .0112 & 1.3475 & 7.07 \\
\hline \multirow[t]{2}{*}{ Pioneer............ } & 63.506 & $\cdots$ & .0422 & & & . & & & & $\because$ \\
\hline & 58.4534 & $\ldots \ldots$ & .0388 & & & & & & $\cdots$ & 7.956 \\
\hline \multirow[t]{2}{*}{ Red Lake........... } & 63.72 & 4.08 . & .131 & .09 & 2.01 & 1.02 & .34 & .022 & .80 & $\cdots$ \\
\hline & 61.8976 & 3.9633 & .1273 & .0874 & 1.9525 & .9908 & .3303 & .0214 & .7771 & 2. 86 \\
\hline \multirow[t]{2}{*}{ Savoy.................. } & 63.452 & $\cdots \cdots$ & .0479 & & & & & & & \\
\hline & 58.9887 & $\ldots \ldots$ & .0445 & & & $\cdots$ & $\cdots \cdots$ & & $\cdots \cdots$ & 7.034 \\
\hline \multirow[t]{2}{*}{ Vermilion ........... } & 66.22 & 2.55 & .127 & .06 & 1.04 & .92 & .30 & .007 & .45 & *- \\
\hline & 65.2598 & 2.5130 & .1252 & .0591 & 1.0249 & .9067 & .2957 & .0069 & .4435 & 1.45 \\
\hline \multirow[t]{2}{*}{ Vermilion, Special... } & 66.43 & 2.60 & .087 & .04 & .85 & .63 & .30 & Trace. & .30 & $\cdots$ \\
\hline & 65.3937 & 2.5594 & .0856 & .0394 & .8367 & .6202 & .2953 & Trace. & .2953 & 1.56 \\
\hline \multirow[t]{2}{*}{ Zenith. } & 64.715 & & .0403 & & & & & & & \\
\hline & 61.0378 & & .0380 & & & & & & & 5.682 \\
\hline
\end{tabular}

Above are average cargo analyses of the season 1899, except when marked thus: *. Ores so marked show the expected analyses for the season 1900.

\section{THE IRON ORE INDUSTRY OF THE VARIOUS STATES} DURING 1899.

\section{MICHIGAN.}

Michigan continues to hold fir st place as a producer of iron ore, and the only State which is likely to contest this position in the near future is Minnesota.

The amount contributed by Michigan in 1899, 9,146,157 long tons, was 37.1 per cent of the total for the United States, practically the same proportion as in 1898 , when but $7,346,846$ long tons were mined. The increase on the 1898 record was $1,799,311$ long tons, or 24.5 per cent. Of the product in $18998,863,942$ long tons, or 96.9 per cent, was 
red hematite, 237,570 long tons, or 2.6 per cent, magnetite, and 44,645 long tons, or 0.5 per cent, brown hematite.

The State ranked first as a producer of red hematite, fourth in the list of magnetite producers, and eighth in the supply of brown hematite.

The total value of the $9,146,157$ tons of ore mined was $\$ 13,707,899$, or $\$ 1.50$ per ton. This is the value for the ore at the mine, not including transportation.

Owing to the great demand for iron ores, some deposits which had been classed as abandoned, or were temporarily inactive, were again exploited and exploration work was quite active. Lean Bessemer ores, and also some relatively high phosphorus ores, were shipped, which in previous years could not have been marketed, but these aided in swelling the total production of the State in 1899 .

The semicentennial celebration of the Cleveland Cliffs Company, at Ishpeming, emphasizes the marvelous development which has made the Lake Superior region famous. The Cleveland mine was one of the pioneer enterprises which in fifty years has resulted in a mining industry unequaled in the history of the world.

Among the efforts made to obtain value from lean material necessarily mined is the ore-concentrating plant at the Pewabic mine, described by Mr. L. M. Hardenburgh. The material treated consists of fragmental iron ore varying from the size of a pea to pieces weighing 200 pounds, carried in soft sandstone. The distribution is reported to be fairly uniform, but occasional pockets are found containing several tons of clean ore. The ore being much harder than the sandstone, the amount of fine ore resulting from mining and crushing is comparatively small. As there is no cementing of the ore to the sandstone, the ore breaks free from the rock, and no middle product containing rock with more or less ore results. The lean ore from the open cut and mine drifts is fed over a grizzly, the fine material passing through and the balance being discharged onto a picking table, where about 20 per cent of the ore is obtained by hand sorting. The ore and sandstone remaining on the table go to a crusher, and then to rolls set to crush to three-fourths-inch size. The crushed ore is then screened and passed through Hartz jigs. Four sizes of ore are produced, the bulk being between seven-eighths and one-half inch in size. The smallest size is that which passes over a 20 -mesh screen. The capacity of the mill is from 280 to 390 tons of raw material per day.

\section{MINNESOTA.}

All of the 8,161,289 long tons of iron ore contributed by Minnesota was of the red hematite variety, in which class the State occupied second place, with the same rank in the list of iron ore producers. The 
increase was $2,197,780$ long tons, or 36.9 per cent, over the 1898 total of $5,963,509$ long tons.

On both the Mesabi and Vermilion ranges exploration work has been carried on, and the claim is made that the reserves on the Mesabi range represent double the quantity of iron ore which has been mined from the Lake Superior region in its history of fifty years.

The use of steam shovels at some of the large deposits of the Mesabi range and the prominence given to these by published articles has resulted in a widespread opinion that most of the Mesabi ore is won in this way. Such, however, is not the case, for some of the largest producers win the ore from underground exploitations.

The handling of the stripping and of the ore by steam shovels at the important mines has reached a degree of perfection which is most creditable. A record of 6,000 tons of ore dug and loaded by one machine in nine hours indicates what can be done under favorable conditions, but it would be unfair to gage a season's work by this or by shorter records, when from 9 to 12 tons per minute were placed upon cars. The statement on the following pages concerning the product of important mines in 1899 will show that the combined output of three of the Mesabi mines operated by steam shovel approximated 2,500,000 tons, which is a better index of possibilities.

\section{ALABAMA.}

A total of 2,662,943 tons of iron ore contributed by this State in 1899 gave it third place as a producer, this amount being 261,195 tons, or 10.9 per cent, in excess of the quantity mined in 1898 . Of the total product in $1899,1,911,097$ tons, or 71.8 per cent, was red hematite, and 751,846 tons, or 28.2 per cent, brown hematite.

Alabama occupies third position as a producer of red hematite, and second rank as a miner of brown hematite.

Dr. William B. Phillips, in an article in the American Manufacturer, states that in the construction of the waterworks tun el through Red Mountain, near Birmingham, Alabama, the various seums of iron ore that are mined in the district were cut through at a depth of 150 feet below the crest of the ridge and the foot and hanging walis penetrated. The uppermost seam was the Ida seam, 6 feet in thickness; underneath it was 25 feet of lean ore and sandstone; then the Irondale seam, 3 feet thick; then 41. feet of red sandstone with slate partings; then the Big seam, sometimes called the Eureka or Ishkooda seam, 21 feet thick; under this was reddish sandstone, and finally bluish siates and magnesian limestone to the base of the hill. Of these three seams the Ida is not worked at all, the Irondale is not worked southwest of Red Gap, and the Big seam is not worked northeast of Grace's Gap, which is 4 miles southwest of the tunnel. 
The Irondale seam, worked by the Sloss Iron and Steel Company, northeast of Red Gap, affords the best soft red ore on the mountain, the average content of metallic iron being about 52 per cent, but the alumina is also above the average for the district.

One of the companies in the district striving for a supply of soft red ore has undertaken to use the lower bench of the Big seam below Grace's Gap. The upper 10 feet have long since been removed, and now the other part of the seam is to be taken, although the metallic iron will not exceed 40 per cent, and the lime is very low.

At the time of writing the article Dr. Phillips summarized the ore situation in the Birmingham district as follows:

The cheap soft red ore, carrying from 45 to 50 per cent of iron and comparatively free from lime, is nearly exhausted; more and more of the limy ore, which costs more to mine and more to smelt, is being used, and there is a great and pressing demand for brown hematite ores to take the place of the soft red ore.

\section{PENNSYLVANIA.}

In 1899 Pennsylvania increased the 1898 total of 773,082 long tons by 236,245 long tons, or 30.6 per cent, reaching a production of $1,009,327$ long tons.

All four classes of ore were mined, 815,771 long tons, or 80.8 per cent, being magnetite, chiefly from the Cornwall ore hills; 152,468 tons, or 15.1 per cent, brown hematite; 38,331 tons, or 3.8 per cent, was red hematite, and 2,757 tons, or 0.3 per cent, carbonate.

The State occupied first position as a miner of magnetite, sixth place as a producer of brown hematite, eighth rank in supplying red hematites, and fourth as a contributor of carbonate.

\section{VIRGINIA AND WEST VIRGINIA.}

West Virginia mined a small quantity of ore in 1899, but to preserve the confidential nature of the statements this has been included in Virginia report, and practically all of the ore is to be credited to the latter State.

In 1899 these States contributed 986,476 long tons, being 428,763 tons, or 76.9 per cent, greater than the 1898 output of 557,713 tons. They take first rank as brown hematite producers, with a total of 968,143 long tons, more than one-third of the nation's output and 98.2 per cent of the State's total. The balance, 17,173 tons, or 1.7 per cent, was red hematite, and 1,160 tons, or 0.1 per cent, magnetite.

$\mathrm{Mr}$. Charles Catlett, in a recent paper, ${ }^{1}$ presents some notes regarding the brown hematite iron ore deposits in the Potsdam formation, along the eastern side of the Valley of Virginia and north of Roanoke, from which the following is excerpted:

The Blue Ridge consists, in ideal section, of the older crystalline rocks to the east, overlain by flags and conglomerates and sandstones, with heavily bedded white quartzite ridges commonly marking its western border. Overlying this quartzite,

1 Trans. Am. Inst. Mining Engineers, 1899. 
and usually (by reason of their soft character) occurring only as foothills, are heary beds of clay and partially decomposed shale. These are, in turn, overlain by the characteristic limestone of "The Valley."

The irregularities in thickness, folding, and erosion bring the older rocks close to the valley at some places, while at others they are separated from it by a great expanse of the stratified formations.

All of the formations above referred to contain more or less iron ore, but the heavy clays and shales overlying the quartzite are the repository of beds of iron ore, which, by their extent and persistency, mark this as one of the two great ore-bearing formations in Virginia. The ores of this formation are found over a distance of 150 miles or more, in a greater or less state of development, along a definite horizon. The soft nature of the inclosing strata and the absence of any distinctly marked foot or hanging wall have no doubt contributed largely to the irregularity of the bed from point to point, and often render exceedingly difficult the determination of its exact position and the problem of its practical development.

The average of a series of analyses made by Dr. A. S. McCreath from his own sampling gives to these ores:

Average composition of some Virginia iron ores.

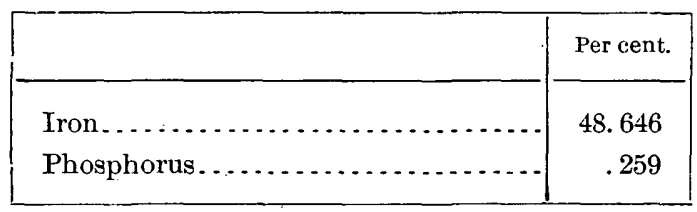

These samples were taken from the surface workings. As a rule the ores have been found to improve somewhat in quality and to become more massive at a short distance below the surface.

At times the ores become highly manganiferous, and deposits of manganese ore are also found in this formation closely associated with the iron ore. In some places the manganese ore seems to exclude the iron ore.

There are few mines of any extent based upon these ores from Roanoke northward. The most celebrated operations near Roanoke are the Rorer mines, just south of the city; the Upton mines, of the Crozer company, about 12 miles east of the city, and mines adjoining these, known as the Lynchburg mines.

The Crozer mines consist of two open cuts of great magnitude, in which the indication of the displaced and broken division of the vein is very apparent. While there is a good deal of good ore, much is lean, and there is a large amount of dead material handled, which necessarily more or less contaminates the ore.

One of the mines near Roanoke averages 42 per cent iron; another 45 per cent. The general opinion of those using the ores from the mines near Roanoke is that as mined and handled they will not average over 42 or 43 per cent, and it is unsafe to assume that the ores of these measures in large quantities, and under the ordinary method of mining and washing, will run higher in iron than betwen 42 and 43 per cent.

The chemists at all the furnaces and mines agree that these ores could be improved by better picking, by jigging, and by excluding well-recognized lean ore, which, under present conditions of operating, the miner can not afford to throw away; but it is difficult to say how much the ore could be improved.

Most of the silica occurs combined in silicates representing all grades from pure clay up to a clayey iron ore.

The phosphorus in the ores near Roanoke runs high, varying from 0.6 to 0.9 per cent. In the mines farther north the amount seems to be less. The ore from the 
mines near Vesuvius varies as a whole between 0.2 and 0.4 per cent, but considerable quantities of ore can often be found quite low in phosphorus. The manager of the Shenandoah Iron Works reports that the phosphorus in the ore used varies between 0.2 and 0.25 per cent.

One dollar per ton of concentrated ore is assumed as a safe estimate of cost when operations are carried on with sufficient capital to permit economic work.

In these ores the impurity consists of a tough clay, requiring an excess of water, and making it difficult to wash the ore thoroughly. This, and the fact that water is often scarce, makes the washing often inadequate. There could be, therefore, a decided improvement in this respect.

As developed near Roanoke, these ores carry more manganese and phosphorus than is desired; consequently all the furnaces use other ores as "mixers."

This description could be applied to a larger territory and embrace many of the brown hematite deposits along the Blue Ridge and South Mountain, in Pennsylvania, Maryland, the Virginias, North Carolina, Georgia, Tennessee, and Alabama.

\section{TENNESSEE.}

Tennessee's total of 632,046 long tons gave it sixth position in 1899 , and exceeded its product of 593,227 tons in 1898 by 38,819 tons, or 6.5 per cent. Of the amount mined, 333,342 tons, or 52.7 per cent, was brown hematite, and 298,704 tons, or 47.3 per cent, red hematite, the State occupying, respectively, third and fifth rank in these classes of ore.

\section{WISCONSIN.}

The output of Wisconsin in $1898(509,645$ long tons) was increased 70,153 tons, or 13.8 per cent, in 1899 , reaching a total of 579,798 tons, and giving the State seventh place in rank. Of this total, 531,636 long tons, or 91.7 per cent, was red hematite, obtained chiefly from the Gogebic Range of the Lake Superior region, in which class it occupied fourth place, and 48,162 tons, or 8.3 per cent, brown hematite, giving it seventh place in the production of this variety of ore.

\section{NEW YORK.}

New York was the only State except Pennsylvania which mined all four varieties of iron ore in 1899. Of the total of 443,790 long tons, 344,159 tons, or 77.5 per cent, was magnetite, 45,503 tons, or 10.3 per cent, red hematite, 31,975 tons, or 7.2 per cent, brown bematite, and 22,153 tons, or 5 per cent, carbonate ores. In the different classes of ore New York occupied, respectively, second, seventh, ninth, and second positions.

The increase, 263,839 tons, was nearly one and a half times the output of 179,951 long tons in 1898 .

\section{COLORADO.}

Colorado's total of 307,557 long tons in 1899 gave it ninth place as an ore producer, being a decrease of 10,923 long tons, or 3.4 per cent, from the 318,480 tons contributed in 1898 . 
Of the amount mined in $1899,295,230$ long tons, or 96 per cent, was brown hematite, and 12,327 tons, or 4 per cent, was red hematite. The decrease in Colorado's production was largely influenced by the opening of ore deposits in Wyoming and New Mexico for the use of the blast furnaces of the Colorado Fuel and Iron Company, and by the use of liberal amounts of lead ores from Idaho in the Colorado silver smelters.

\section{NEW JERSEY.}

New Jersey's contribution in 1899 was 256,185 long tons of magnetite ore, in which class it occupied third position. This was a decrease of 19,253 long tons, or 7 per cent, from the output of 275,438 tons in the preceding year.

The expense of mining some of the New Jersey ores and the necessity of roasting or concentrating the mineral interferes with the exploitation of its mines, but there are liberal ore reserves which, if properly prepared, may contribute to a local supply for near-by furnaces at prices per unit of iron below the cost of ores brought from Lake Superior or imported from foreign countries.

The use of the clinker resulting from roasting franklinite-an ore of zinc, manganese, and iron-is referred to in the report on manganese.

\section{GEORGIA.}

This State supplied 236,748 long tons of iron ore in the year 1899. Of this amount 179,748 tons, or 75.9 per cent, was brown hematite and 57,000 tons, or 24.1 per cent, red hematite, giving it fifth and sixth place in these classes of ore. The production shows an increase of 76,665 long tons, or 47.9 per cent, over the 160,083 tons mined in 1898, when Georgia and North Carolina were reported together.

In the summer of $1899 \mathrm{Mr}$. S. W. McCallie, assistant State geologist, made an examination of the brown hematite ores of Georgia, which are found mainly in the northwestern part of the State, in what is known as the Paleozoic area. He reports that the ores occur chiefly in the Lower Silurian formation, but are also found associated with the Carboniferous and the Cambrian deposits. The most abundant iron deposits of the Lower Silurian are in the Knox dolomite series. This magnesian formation often contains an abundance of chert, and usually gives rise to low, well-rounded ridges, along which the iron-ore deposits occur. The ore is found in pockets or irregular deposits in the residual clays that have resulted from the weathering of the magnesian limestones. In connection with these ores more or less chert and manganese are frequently found. The extent of the deposits is variable, in some cases only a few tons being obtained, while in others several thousand carloads have been won. Where the ore was found in large quantities the former method of mining was by means of shovel, pick, and screen, but at present these have been superseded by

21 GEOL, PT $6-4$ 
steam shovels and log washers, greatly reducing the cost. The screen method of working the ores is still adopted where the banks are small or unfavorably located for obtaining water for washing. This method is wasteful, however, the fine-grained ore being left on the dumps, and some of these old dumps are now profitably reworked by means of the $\log$ washer.

The ore is generally won in open cuts varying from 5 to 60 feet in depth, or to water level. The extent of the ore bodies varies greatly in depth in different localities. At Oredell a bore hole showed the ore to extend to a depth of more that 175 feet, while valuable deposits near Cedartown have been worked to a depth of 70 feet without apparent decrease in richness. The ore deposit is often interrupted by huge masses of white or vari-colored clay "horses."

The locations of the ore deposits are as a rule indicated by the occurrence of more or less float on the surface; but the abundance of the float ore is not always a criterion of the quantity of ore beneath, as one of the best deposits in the vicinity of Cedartown had a remarkably poor surface prospect.

The ores of the Knox dolomite series show 48.45 to 51.10 per cent metallic iron, from 0.20 to 5.60 per cent manganese, from 2.40 to 7.87 per cent silica, and from 0.147 to 0.58 . per cent phosphorus.

The iron ores of the Cambrian formation occul associated with sandstone, mica schists, and slates. They have been worked extensively in Bartow County, where they occur in the vicinity of what is known as the Cartersville fault, which is the line of demarcation between the crystalline and Paleozoic areas. The Cambrian brown ores differ somewhat in their character and mode of occurrence from those of the Knox dolomite series. In some cases these ores have been metamorphosed, and in a few instances partake of the nature of a true hematite. The ore deposits near Emerson often assume the character of true veins, and vary in thickness from a few feet to several rods. At the Wheeler mine the ore is variable in thickness, and has been worked along the outcroppings for nearly one-fourth of a mile, and to a depth, in places, of 40 feet or more.

In the northern part of Bartow County, in the Sugar Hill district, the ores partake of the nature of a blanket deposit, and are found principally in the residual clays and partially decomposed slates overlying the sandstone. These blanket deposits are valuable on account of their richness and the cheapness with which they can be mined. In other localities in the neighborhood of Buford the ores occur in pockets and irregular deposits, as in the Knox dolomite series.

The Cambrian ores are always free from cherty material, but this impurity is frequently replaced by siliceous material in the form of sandstone, which renders the chemical analyses of the Knox dolomite and the Cambrian ores very similar in character. 
The Carboniferous ores occur chiefly in the lower division of this formation, associated with the Fort Payne chert. These deposits have been more or less extensively worked along the eastern foothills of the Horn Mountain, in Sugar Valley. They are also reported to occur upon the western side of Big Texas Valley. These deposits are apparently not so extensive or valuable as the Knox dolomite or Cambrian deposits, nevertheless are of considerable economic importance.

Besides the brown ore deposits of the Paleozoic area, there are also to be found in the crystalline area along the Atlanta, Knoxville and Northern Railroad valuable deposits of brown ores, which are practically undeveloped. The more extensive mining operations are confined mainly to Polk and Bartow counties.

OTHER STATES.

None of the remaining States mined 100,000 tons of iron ore in 1899. Nevada, New Mexico, Utah, and W yoming contributed red and brown hematite and magnetite ore. Ohio's output was all of the carbonate variety, in which class it occupied first place. North Carolina mined brown hematite and magnetite, Kentucky red hematite, Connecticut and Massachusetts brown hematite, Missouri red and brown hematites, Texas brown hematite, and Maryland carbonate ores.

Active exploitation of the red-hematite deposit near the Platte River, in northeastern Wyoming, was inaugurated in 1899, but the railroad connections to Sunrise were not completed until the spring of 1900 . It is probable that Wyoming will rank as an important producer of iron ore in the report for 1900.

\section{VALUE OF IRON ORES.}

The total value at the mines of the $24,683,173$ long tons of iron ore produced in the year ending December 31, 1899, as reported by próducers, was $\$ 34,999,077$, or $\$ 1.42$ per long ton, an increase of 28 cents, or 24.6 per cent, over the average value of $\$ 1.14$ per ton, as given in 1898.

The highest average value placed on iron ore at the mines is for the State of New Jersey. There the expense of mining is considerable, and as the ores do not have long hauls to reach the blast furnaces they command a higher price per ton at the mine than many other ores. The lowest average cost, 90 cents per ton, was in Texas, where a portion of the iron ore is produced by convict labor.

The following table will show the production and total value, together with the value per ton, of the iron ore mined in the United States in 1899, reported by States. This valuation does not represent either the cost or the selling price of ores, but in many cases is the selling price less the cost of transportation from the mines to points of consumption. 
Value of iron ore mined in 1899, by States.

\begin{tabular}{|c|c|c|c|}
\hline State. & Production. & Total value. & $\begin{array}{l}\text { Value per } \\
\text { ton. }\end{array}$ \\
\hline Michigan $\ldots \ldots \ldots \ldots$ & $\begin{array}{l}\text { Long tons. } \\
9,146,157\end{array}$ & $\$ 13,707,899$ & $\$ 1.50$ \\
\hline Minnesota ......... & $8,161,289$ & $9,924,853$ & 1.22 \\
\hline Alabama............... & $2,662,943$ & $2,601,609$ & .98 \\
\hline Pennsylvania ......... & $1,009,327$ & $1,991,772$ & 1.97 \\
\hline Virginia and West Virginia... & 986,476 & $1,766,410$ & 1. 79 \\
\hline Tennessee ........... & 632,046 & 694,372 & 1. 10 \\
\hline Wisconsin ............ & 579,798 & 837,766 & 1.44 \\
\hline New York..... & 443,790 & $1,241,985$ & 2.80 \\
\hline Colorado .... & 307,557 & 749,734 & 2.44 \\
\hline New Jersey.... & 256,185 & 814,920 & 3.18 \\
\hline Georgia & 236,748 & 235,343 & .99 \\
\hline 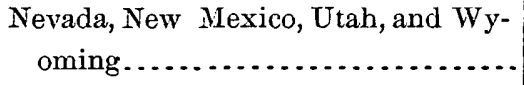 & 54,148 & 108,720 & 2.01 . \\
\hline Ohio ........ & 53,221 & 77,606 & 1.46 \\
\hline North Carolina .... & 47,616 & 72,622 . & 1.53 \\
\hline Kentucky ... & 35,384 & 35,384 & 1.00 \\
\hline Connecticut and Massachusetts. & 29,611 & 77,989 & 2.63 \\
\hline Missouri... & 22,720 & 42,203 & 1.86 \\
\hline Texas ....... & 14,729 & 13,262 & .90 \\
\hline Maryland... & 3,428 & 4,628 & 1.35 \\
\hline Total. & $24,683,173$ & $34,999,077$ & 1.42 \\
\hline
\end{tabular}

\section{STOCKS.}

The stock of ore on hand at the various mines in the United States on December 31, 1899, was $2,320,278$ long tons, a decrease of 526,179 tons, or 18.5 per cent, from the amount on hand at the same date in 1898 , viz, 2,846,457 long tons. With the exception of seven States, all show a smaller amount of ore on hand in 1899 than in 1898.

As the major portion of the iron ore in the Lake Superior region is sent forward by water before the close of lake navigation, the ore, which is necessarily taken out in winter, is stocked at the mines to await the resumption of traffic in the spring. It is therefore the States of Michigan, Minnesota, and Wisconsin which report the greatest stocks of ore, these three having on hand December 31, 1899, $1,905,148$ long tons, or 82.1 per cent of the total reported. The large stock on hand in Missouri is, as previously stated, owing to lean ore, won in previous years, which was not then marketable without further 
treatment, but which is being sold. In the Southern States but little ore is stocked, most of it being shipped directly to blast furnaces as soon as mined.

The table given below will show the stocks of ore on hand at the mines at the close of the year 1899, by States:

Stocks of iron ore on hand December 31, 1899.

\begin{tabular}{|c|c|}
\hline State. & Stock. \\
\hline & Long tons. \\
\hline Michigan ............... & $1,100,419$ \\
\hline 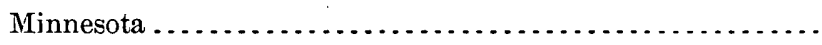 & 719,529 \\
\hline Missouri .................... & 150,774 \\
\hline 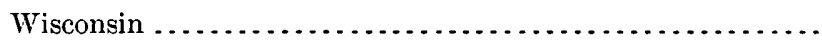 & 85,200 \\
\hline 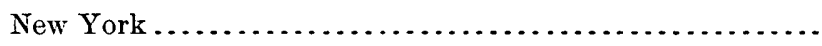 & 67,613 \\
\hline Alabama ..................... & 46,739 \\
\hline Pennsylvania.....$\ldots \ldots \ldots$. & 25,720 \\
\hline Tennessee .................. & 24,053 \\
\hline New Jersey $\ldots . . . \ldots \ldots \ldots$. & 23,484 \\
\hline 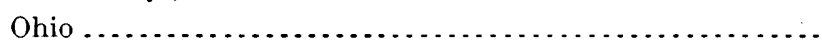 & $\cdots \quad 22,250$ \\
\hline Virginia and West Virginia ................ & 13,850 \\
\hline 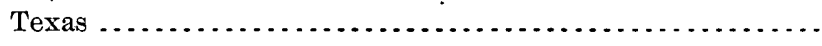 & 12,500 \\
\hline 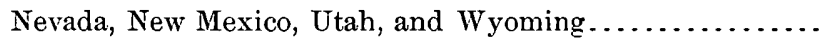 & 11,000 \\
\hline 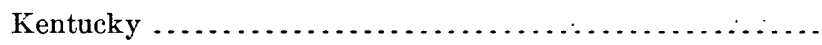 & 8,200 \\
\hline 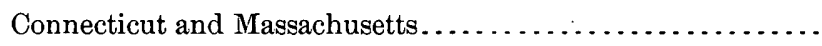 & 4,034 \\
\hline Georgia ......... & 2,350 \\
\hline Colorado $\ldots \ldots \ldots \ldots$ & 1,355 \\
\hline North Carolina......... & 844 \\
\hline Vermont .............. & 300 \\
\hline 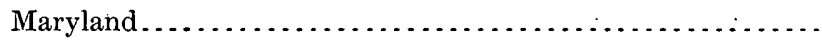 & 64 \\
\hline Total ... & $2,320,278$ \\
\hline
\end{tabular}

\section{PROMINENT IRON-ORE PRODU்CERS.}

The concentration of effort by combining adjacent mines and working them on a liberal scale was more pronounced in 1899 than in previous ycars. During the year ending December 31, 1899, ninety operations produced $21,788,169$ long tons, or 88.3 per cent of the total amount mined in that year. This represented an average output of 242,091 tons per mine.

Of the prominent producers tabulated four contributed over $1,000,000$ tons each, three between 700,000 and 800,000 tons, three between 600,000 and 700,000 tons, two between 500,000 and 600,000 tons, four between 400,000 and 500,000 tons, four between 300,000 and 400,000 tons, nine 
between 200,000 and 300,000 tons, thirty between 100,000 and 200,000 tons, and thirty-one between 50,000 and 100,000 tons. Of these large mines 35 were located in Michigan, 22 in Minnesota, 13 in Alabama, 4 each in Tennessee, Virginia, and Wisconsin, 3 in New York, 2 in New Jersey, and 1 each in Colorado, Georgia, and Pennsylvania.

Sixty-six of these large operations mined red hematite, contributing $18,754,219$ long tons; 15 , brown hematite, with a total of $1,403,498$ tons; 7, magnetite, yielding 1,302,497. tons, while the remaining 2 produced mixed magnetite and red hematite with a total of 327,955 long tons.

In the following table will be found the names of those operations which produced over 50,000 long tons in 1899, the management of which gave permission for such publication, those grouped together at the end of the table representing mines whose production was reported but whose names are withheld because of lack of permission to publish in this connection.

List of prominent iron-ore producers in 1899.

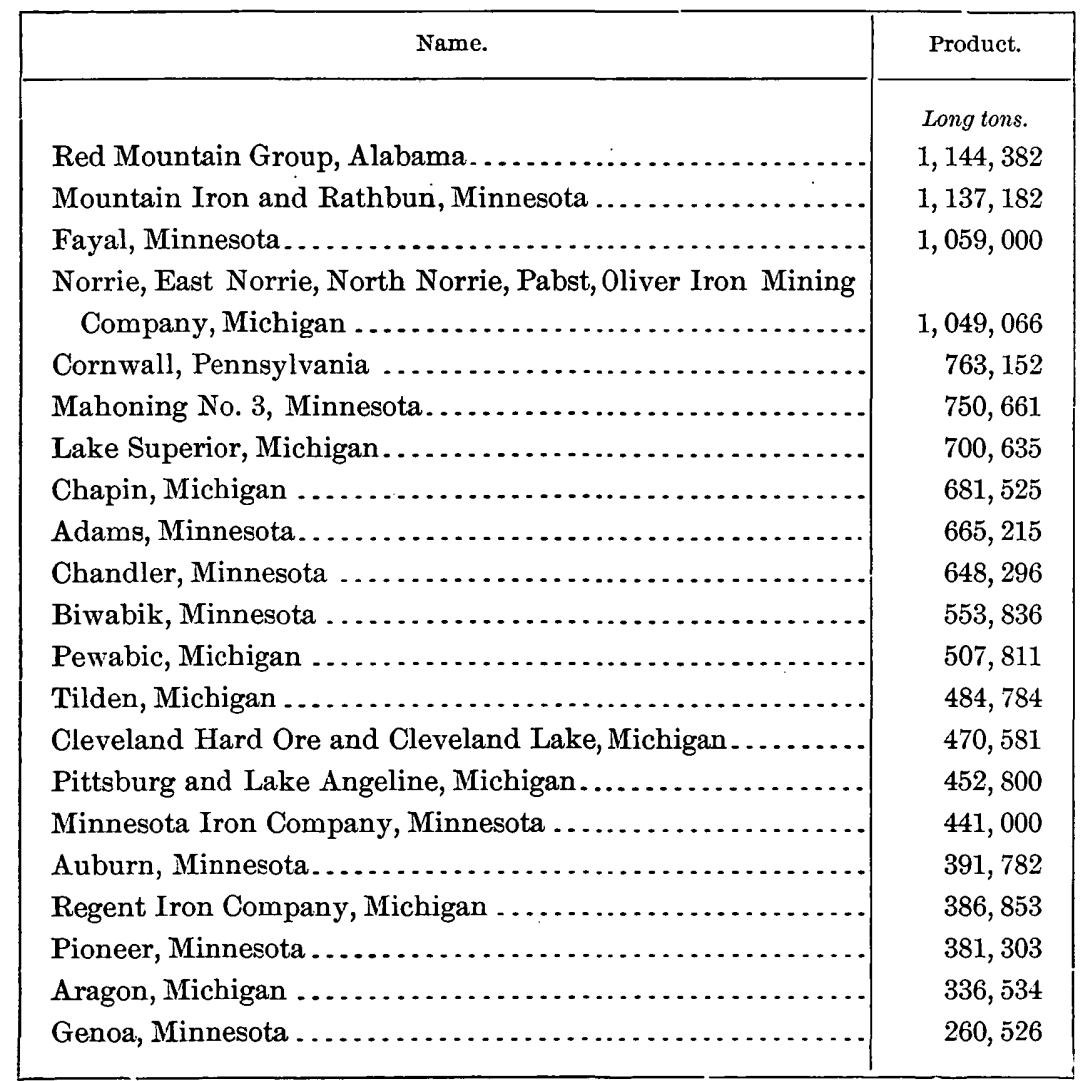


List of prominent iron-ore producers in 1899-Continued.

\begin{tabular}{|c|c|}
\hline Name. & Product. \\
\hline & Long tons. \\
\hline Ludington, Michigan : & 253,427 \\
\hline Cliff's Shaft, Michigan .. & 250,252 \\
\hline Sparta Iron Company, Minnesota.......... & 237,145 \\
\hline 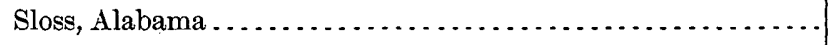 & 222,683 \\
\hline Penn Iron Mining Company, Michigan & 219,445 \\
\hline Newport. Michigan............. & 219,378 \\
\hline Orient, Colorado ................ & 198,347 \\
\hline Brown Mining Company, Tennessee ....... & 193,560 \\
\hline Champion, Michigan .. & 186,487 \\
\hline Commodore, Minnesota......... & 183,479 \\
\hline Marquette Ore (open pit), Michigan ........ & 171,718 \\
\hline Palms, Michigan ..................... & 168,308 \\
\hline Aurora, Michigan ........ & 167,834 \\
\hline Duluth, Minnesota...$\ldots \ldots \ldots \ldots \ldots$ & 163,986 . \\
\hline Crystal Falls, Michigan . . . . . . . . . . . . & 158,824 \\
\hline Sellers, Minnesota ....................... & 158,381 \\
\hline Republic and West Republic, Michigan ............. & 141,468 \\
\hline Salisbury, Michigan ..... & 137,436 \\
\hline Franklin, Minnesota.............. & 131,366 \\
\hline 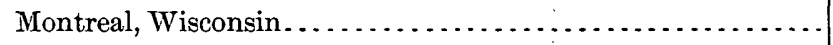 & 129,754 \\
\hline Ashland, Michigan...$\ldots \ldots \ldots \ldots \ldots \ldots \ldots \ldots \ldots$ & 125,547 \\
\hline 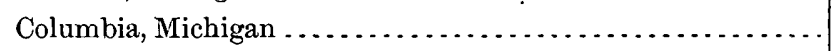 & 125,141 \\
\hline Georgia Iron and Coal Company, Georgia... & 123,176 \\
\hline Old and New Bed, New York............. & 115,220 \\
\hline Commonwealth, Wisconsin.............. & 112,300 \\
\hline Pillsbury, Minnesota......... & 111,831 \\
\hline Hemlock River, Michigan.............. & 109,026 \\
\hline Port Henry Iron Ore Company No. 21, New York...... & 107,963 \\
\hline Tecumseh, including State Line and Baker, Alabama.... & 103,378 \\
\hline Cundy, Michigan........... & 100,048 \\
\hline Savoy and Sibley, Minnesota ... & 97,081 \\
\hline Colby, Michigan. . ............ & 94,708 \\
\hline Penobscot, Minnesota.......... & 93,294 \\
\hline Clifford, Michigan........ & 93,025 \\
\hline Greeley Group, Alabama....... & 91,896 \\
\hline Florence, Wisconsin ............. & 88,932 \\
\hline Richards, New Jersey . . . . . . . . . . . . . . . & 87,523 \\
\hline Mansfield, Michigan .......... & 83,860 \\
\hline Clare (now Bristol), Michigan..... & 83,365 \\
\hline
\end{tabular}


List of prominent iron-ore producers in 1899-Continued.

\begin{tabular}{|c|c|}
\hline Name. & Product. \\
\hline & Long tons. \\
\hline Longdale, Virginia............. . & 80,452 \\
\hline Lawrence Ore Bank, Tennessee................ & 79,829 \\
\hline Zenith, Minnesota. ....................... & 76,304 \\
\hline Iron Belt, Wisconsin. . . . . . . . . . . . & 75,527 \\
\hline Rust, Minnesota.......... & 69,530 \\
\hline Lamont, Michigan ............. & 69,303 \\
\hline Champion, Alabama ................... & 68,586 \\
\hline Wharton Hibernia, New Jersey ........... & 66,591 \\
\hline Loretto, Michigan ............. & 64,824 \\
\hline Irondale, Alabama. . . . . . . . . . . & 58,824 \\
\hline 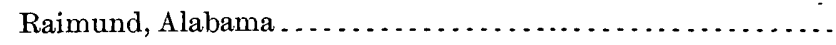 & 58,135 \\
\hline Roberts Mining Company, Minnesota........... & 57,847 \\
\hline Total . & $19,733,268$ \\
\hline ' 18 mines not reported by names.... & $2,054,901$ \\
\hline Total . & $21,788,169$ \\
\hline
\end{tabular}

This table shows that the twelve mines which in 1899 each produced over a half million tons of ore contributed 40 per cent of the total ore taken during the year from all of the iron mines in the country.

\section{TRANSPORTATION.}

As most of the ore from the Lake Superior region is sent forward to lower lake ports by vessel, the railroad companies connecting the mines with Lakes Superior and Michigan, to reduce the cost of unloading cars and give the boats their cargoes promptly, have constructed large shipping docks, a detailed list of which was given in the report for 1898. These docks are located at the ports of Escanaba, Marquette, and Gladstone, in the State of Michigan; Two Harbors and Duluth in Minnesota, and Ashland and Superior in Wisconsin. All of these ports are on Lake Superior, with the exception of Escanaba and Gladstone, which are on Lake Michigan.

In 1899 Two Harbors was the banner shipping port, with a total of 3,973,733 long tons forwarded from the Vermilion and Mesabi ranges. Escanaba, which stood second, sent down 3,720,218 tons from the Marquette and Menominee ranges. Duluth's quota of 3,509,965 tons is all credited to the Mesabi range. Marquette shipped 2,733,596 tons mined from the Marquette range, and Ashland obtained its 
$2,703,447$ tons from the Gogebic range. Superior and Gladstone each shipped relatively smaller quantities of ore, but each of them handled large amounts.

The following table will show the shipments of iron ore from the upper lake shipping ports for the years 1892 to 1899 (the figures being collected by the Iron Trade Review), with the all-rail shipments added to indicate the total amount forwarded.

The Duluth, Missabe and Northern Railroad is building a new dock at Duluth, having a capacity of 40,320 tons, the Eastern Minnesota Railroad one at Superior with a capacity of 65,000 tons, and the capacity of the two docks building at Escanaba, Michigan, and Michipicoton, Canada, is about 45,000 tons.

Lake shipments of iron ore.

\begin{tabular}{|c|c|c|c|c|}
\hline Shipping port. & 1899. & 1898. & 1897. & 1896. \\
\hline Escanaba.... & $\begin{array}{l}\text { Long tons. } \\
3,720,218\end{array}$ & $\begin{array}{l}\text { Long tons. } \\
2,803,513\end{array}$ & $\begin{array}{l}\text { Long tons. } \\
2,302,121\end{array}$ & $\begin{array}{l}\text { Long tons. } \\
2,321,931\end{array}$ \\
\hline Two Harbors ........ & $3,973,733$ & $2,693,245$ & $2,651,465$ & $1,813,992$ \\
\hline Duluth & $3,509,965$ & $2,635,262$ & $2,376,064$ & $1,988,932$ \\
\hline Ashland... & $2,703,447$ & $2,391,088$ & $2,067,637$ & $1,566,236$ \\
\hline Marquette.... & $2,733,596$ & $2,245,965$ & $1,945,519$ & $1,564,813$ \\
\hline Superior.. & 878,942 & 550,403 & 531,825 & 167,245 \\
\hline Gladstone . & 381,457 & 335,956 & 341,014 & 220,887 \\
\hline Total. & $17,901,358$ & $13,655,432$ & $12,215,645$ & $9,644,036$ \\
\hline All-rail shipments... & 350,446 & 369,241 & 253,993 & 290,792 \\
\hline Grand total & $18,251,804$ & $14,024,673$ & $12,469,638$ & $9,934,828$ \\
\hline Shipping port. & 1895. & 1894. & 1893. & 1892. \\
\hline & Long tons. & Long tons. & Long tons. & Long tons. \\
\hline Escanaba & $2,860,172$ & $1,644,776$ & $2,048,681$ & $4,010,085$ \\
\hline Two Harbors ... & $2,118,156$ & $1,373,253$ & 903,329 & $1,165,076$ \\
\hline Duluth ........ & $1,598,783$ & $1,369,252$ & 440,592 & (.......... \\
\hline Ashland... & $2,350,219$ & $1,738,590$ & $1,117,520$ & $2,223,684$ \\
\hline Marquette. & $1,079,485$ & $1,424,850$ & $1,086,934$ & $1,026,338$ \\
\hline Superior... & 117,884 & $\ldots$ & 80,273 & 4,245 \\
\hline Gladstone & 109,211 & 79,108 & 203,589 & 115,886 \\
\hline Total. & $10,233,910$ & $7,629,829$ & $5,880,918$ & $8,545,314$ \\
\hline All-rail shipments... & 195,127 & 118,394 & 178,037 & 525,768 \\
\hline Grand total. & $10,429,037$ & $7,748,223$ & $6,058,955$ & $9,071,082$ \\
\hline
\end{tabular}


The difference between total shipment, 18,251,804 tons, less the total production, 17,802,955 tons, represents the apparent decrease in stocks at the mines. This is also influenced by the record of production covering the calendar year, while shipments seldom extend beyond the last of November.

To reach the lake shipping ports the iron ores from the different ranges are transported varying distances, according to the range from which they are obtained and the railroad over which they are carried.

The Mesabi ores are transported from 71 to 1.06 miles to Duluth and Superior, or from 58 to 70 miles to Two Harbors. The Vermilion range ores, all of which are shipped from Two Harbors, are brought distances varying from 68 to 87 miles. The Marquette iron ores are carried 12 to 36 miles to Marquette, or 62 to 81 miles to Escanaba. The Gogebic ores are sent from 39 to 59 miles to Ashland, or 67 to 89 miles to Escanaba. The Menominee iron ores are shipped at Escanaba, to reach which they are transported from 43 to 72 miles by railroad.

To illustrate the distance which the iron ore from the Lake Superior region is transported the following table has been prepared from United States Government reports showing the number of statute miles which ressels necessarily cover in going from the various shipping ports on the upper lakes to the receiving ports on Lake Erie, where the major portion of the ore is delivered, and also to Chicago and Milwaukee on Lake Michigan, important consuming points which are directly reached by water.

From the table it will be seen that Duluth and Superior are the most distant from the receiving ports, the other shipping docks being, respectively, the following distances nearer to the ports of Lake Erie, as follows:

Differences in distance from lake shipping ports to ports on Lake Erie.

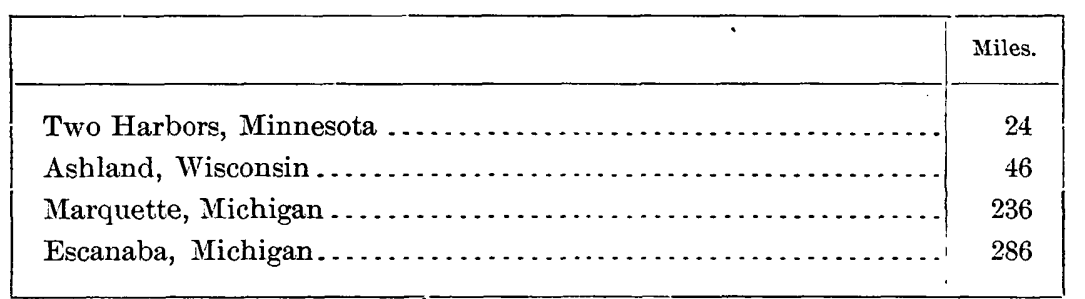

There is also the same difference in distance to Chicago and Milwaukee, with the exception of Escanaba, which is 532 and 551 miles nearer these cities than Duluth or Superior. 
Distance in statute miles between lake iron ore shipping and receiving docks.

\begin{tabular}{|c|c|c|c|c|c|}
\hline \multirow{2}{*}{ To- } & \multicolumn{5}{|c|}{ From- } \\
\hline & $\begin{array}{l}\text { Duluth and } \\
\text { Superior. }\end{array}$ & $\begin{array}{c}\text { Two } \\
\text { Harbors. }\end{array}$ & Ashland. & Marquette. & Escanaba. \\
\hline Lake Erie ports: & Miles. & Miles. & Miles. & Miles. & Mriles. \\
\hline Buffalo ........ & 985 & 961 & 939 & 749 & 699 \\
\hline Erie ....... & 917 & 893 & 871 & 681 & 631 \\
\hline Conneaut....... & 889 & 865 & 843 & 653 & 603 \\
\hline Ashtabula... & 876 & 852 & 830 & 640 & 590 \\
\hline Fairport........ & 851 & 827 & 805 & 615 & 565 \\
\hline Cleveland .. & 834 & 810 & 788 & 598 & 548 \\
\hline Lorain & 814 & 790 & 768 & 578 & 528 \\
\hline Huron .... & 805 & 781 & 759 & 569 & 519 \\
\hline Sandusky & 800 & 776 & 754 & 564 & 514 \\
\hline Toledo ... & 784 & 760 & 728 & 548 & 498 \\
\hline Lake Michigan ports: & & & & & \\
\hline Chicago ... & 809 & 785 & 763 & 573 & 277 \\
\hline Milwaukee & 743 & 719 & 697 & 507 & 192 \\
\hline
\end{tabular}

Gladstone is near and to the north of Escanaba, but the distance to lower lake is practically the same as from Escanaba.

In the statistics of the Sault Ste. Marie Canal for 1899 will be found cargo records of some of the largest vessels carrying iron ore. The steamer Malietoa moved 8,215 net tons in one cargo, the steel tow barge John Smeaton moved 8,339 net tons in a single cargo. The steamer Presque Isle during the season received and discharged 187,816 net tons, the steamer Andrew Carnegie covered 42,027 miles during the season, and the steamer $H$. W. Oliver is computed to have carried $141,475,588$ mile tons during the season.

Ten steel vessels of the largest size had average cargoes throughout the season of 7,385 net tons, 18 averaged 6,423 tons, 19 averaged 5,420 tons, 13 averaged 4,525 tons, 114 averaged 3,404 tons, and 74 averaged 2,511 tons. Of the tow barges 4 averaged 8,179 net tons, 9 averaged 6,404 net tons, 13 averaged 5,790 tons, 9 averaged 4,445 tons, 25 averaged 3,552 tons, and 35 averaged 2,309 tons.

During the year 1899 there was received at the docks on Lake Erie, according to the Iron Trade Review, of Cleveland, 15,222,187 long tons of ore, the greatest quantity delivered in any one ycar. The difference of 2,679,171 long tons between this amount and the total shipments from the upper lake ports, 17,901,358 long tons, represents the amount sent to Chicago, Milwaukee, and adjacent territory. 
Ashtabula, Ohio, still holds first position as a receiving port, although closely pressed by Cleveland, and all of the ports, with the exception of Sandusky, show increased receipts.

The following table gives the receipts of iron ore by ports from the years 1892 to 1899 , inclusive:

Iron ore receipts at Lake Erie ports.

\begin{tabular}{|c|c|c|c|c|}
\hline Port. & 1899. & 1898. & 1897. & 1896. \\
\hline & Long tons. & Long tons. & Long tons. & Long tons. \\
\hline Ashtabula, Ohio..... & $3,341,526$ & $2,684,563$ & $3,001,914$ & $2,272,822$ \\
\hline Cleveland, Ohio ..... & $3,222,582$ & $2,645,318$ & $2,456,704$ & $2,313,170$ \\
\hline Conneaut, Ohio ...... & $2,320,696$ & $1,404,169$ & 495,327 & 327,623 \\
\hline Erie, $\mathrm{Pa} \ldots . . . . .$. & $1,309,961$ & $1,092,364$ & $1,311,526$ & 847,849 \\
\hline $\begin{array}{l}\text { Buffalo and Tona- } \\
\text { wanda, N. Y ..... }\end{array}$ & $1,530,016$ & $1,075,975$ & 797,446 & 545,101 \\
\hline Fairport, Ohio ...... & $1,241,013$ & 912,879 & $1,008,340$ & 941,446 \\
\hline Lorain, Ohio . . . . . . . & $1,112,946$ & 536,086 & 355,188 & 191,445 \\
\hline Toledo, Ohio ........ & 792,348 & 414,012 & 416,438 & 301,794 \\
\hline Sandusky, Ohio & 87,499 & 136,200 & 79,792 & 58,667 \\
\hline Huron, Ohio .. & 263,600 & 126,755 & 198,231 & 226,515 \\
\hline Total........... & $15,222,187$ & $11,028,321$ & $10,120,906$ & $8,026,432$ \\
\hline Port. & 1895. & 1894. & 1893. & 1892. \\
\hline & Long tons. & Long tons. & Long tons. & Long tons. \\
\hline Ashtabula, Ohio..... & $2,474,791$ & $1,987,722$ & $1,845,738$ & $2,555,416$ \\
\hline Cleveland, Ohio..... & $2,312,370$ & $1,624,573$ & $\mathbf{1}, 260,716$ & $1,950,224$ \\
\hline Conneaut, Ohio ..... & 244,967 & 237,905 & 203,207 & 1,130 \\
\hline Erie, $\mathrm{Pa} \ldots . . . .$. & 811,989 & 624,438 & 469,299 & 645,230 \\
\hline $\begin{array}{l}\text { Buffalo and 'Tona- } \\
\text { wanda, } \mathrm{N} . \mathrm{Y} \ldots . . .\end{array}$ & 719,742 & 395,339 & 308,238 & $a 197,000$ \\
\hline Fairport, Ohio ...... & 914,617 & 976,222 & 792,517 & 866,611 \\
\hline Lorain, Ohio ........ & 214,219 & 150,424 & 165,667 & 190,400 \\
\hline Toledo, Ohio ........ & 260,730 & 158,384 & 145,515 & 139,987 \\
\hline Sandusky, Ohio & 12,361 & 23,043 & 4,464 & 49,736 \\
\hline Huron, Ohio. & 146,442 & 172,775 & 137,700 & 65,000 \\
\hline Total... & $8,112,228$ & $6,350,825$ & $5,333,061$ & $6,660,734$ \\
\hline
\end{tabular}

a Buffalo alone in 1892 .

Large stocks of iron ore are carried at all the lower lake ports, but in order to obtain the rebate allowed on iron ores which are not stocked and to utilize dock room for winter storage, the major portion of the ore is handled from vessels directly to railroad cars for shipment to its destination. 
Owing to the enormous demand every effort was made to send down all the ore possible before the close of lake navigation, and on December 1,1899 , the stock of ore on hand at lower lake ports reached $5,530,283$ long tons, or 393,876 long tons more than on December 1 , 1898 , when the stock was $5,136,407$ tons.

During the winter months shipments are made from the piles on receiving dock to the furnaces, and on May 1, 1900, the date of opening of lake navigation, the stocks had been reduced to 1,720,656 long tons, the smallest amount reported since 1892, the shipments during the winter being the maximum on record, viz, 3,809,627 long tons. The shipments to furnaces during the seven months from May 1, 1899, to December 1, 1899, were 11,765,158 long tons, and if to this is added the winter shipments, $3,809,627$ long tons, the total amount of iron ore shipped during the year from May 1, 1899, to May 1, 1900, is found to have been $15,574,785$ long tons.

The following table will show the stocks of iron ore at lower lake ports on December 1 from 1895. to 1899 inclusive, and on May 1 from 1896 to 1900 inclusive, those being the dates of the closing and opening of navigation:

Stocks of iron ore at lower lake ports.

\begin{tabular}{|c|r|r|r|r|r|}
\hline & \multicolumn{5}{|c|}{ At close of navigation, December 1. } \\
\cline { 2 - 6 } & \multicolumn{1}{|c|}{1895.} & \multicolumn{1}{|c|}{1896.} & \multicolumn{1}{c|}{1897.} & \multicolumn{1}{c|}{1898.} & \multicolumn{1}{c|}{1899.} \\
\hline & Long tons. & Long tons. & Long tons. & Long tons. & Long tons. \\
\hline Ashtabula, Ohio. & $1,301,302$ & $1,441,666$ & $1,835,694$ & $1,732,671$ & $1,902,598$ \\
Cleveland, Ohio. & $1,200,792$ & $1,419,311$ & $1,478,355$ & $1,175,970$ & $1,200,806$ \\
Fairport, Ohio .. & 605,470 & 773,905 & 825,312 & 719,794 & 692,147 \\
Erie, Pa....... & 335,718 & 355,222 & 484,871 & 439,167 & 361,335 \\
Lorain, Ohio .... & 224,264 & 231,288 & 317,509 & 324,034 & 337,822 \\
Conneaut, Ohio. & 292,460 & 275,800 & 360,895 & 288,101 & 468,808 \\
Toledo, Ohio.... & 113,132 & 115,959 & 194,644 & 146,568 & 186,422 \\
Huron, Ohio.... & 101,000 & 200,075 & 230,029 & 139,982 & 164,480 \\
Buffalo, N. Y ... & 207,199 & 82,267 & 111,660 & 121,620 & 192,681 \\
Sandusky, Ohio . & 34,375 & 59,491 & 84,786 & 48,500 & 23,184 \\
\hline Total....... & $4,415,712$ & $4,954,984$ & $5,923,755$ & $5,136,407$ & $5,530,283$ \\
\hline
\end{tabular}


MINERAL RESOURCES.

Stocks of iron ore at lower lake ports—Continued.

\begin{tabular}{|c|c|c|c|c|c|}
\hline \multirow{2}{*}{ Port. } & \multicolumn{5}{|c|}{ At opening of navigation, May 1.} \\
\hline & 1896. & 1897. & 1898. & 1899. & 1900. \\
\hline & Long tons. & Long tons. & Long tons. & Long tons. & Long tons. \\
\hline Ashtabula, Ohio. & 636,254 & 926,865 & $1,031,441$ & 855,691 & 678,789 \\
\hline Cleveland, Ohio. & 506,693 & 979,705 & 853,776 & 472,946 & 386,291 \\
\hline Fairport, Ohio .. & 346,847 & 480,984 & 501,592 & 289,417 & 282,298 \\
\hline Erie, $\mathrm{Pa} \ldots . . .$. & 137,826 & 153,261 & 236,485 & 95,626 & 97,894 \\
\hline Lorain, Ohio . & 118,820 & 180,605 & 158,797 & 168,646 & 126,212 \\
\hline Conneaut, Ohio & 112,406 & 207,034 & 69,047 & 6,115 & 8,649 \\
\hline Toledo, Ohio.... & 10,593 & 66,337 & 71,726 & 22,915 & 52,616 \\
\hline Huron, Ohio.... & 55,173 & 162,292 & 143,170 & 82,055 & 48,412 \\
\hline Buffalo, N. Y ... & 16,644 & 50,477 & 53,081 & 72,757 & 35,195 \\
\hline Sandusky, Ohio & 8,442 & 48,937 & 48,800 & 7,086 & 4,300 \\
\hline Total. & $1,949,698$ & $3,256,497$ & $3,167,915$ & $2,073,254$ & $1,720,656$ \\
\hline
\end{tabular}

To control deliveries and freight rates on iron ore one of the large steel companies built a railroad from the receiving port at Conneaut, on Lake Erie, to Pittsburg. Mr. J. T. Odell, vice-president of the Pittsburg, Bessemer and Lake Erie Railroad, in an interesting article describing the road, states that the ore equipment consists mostly of steel cars weighing 17 tons and carrying 50 tons of iron ore. To haul these ore trains some of the heaviest locomotives in the world, weighing 217,000 pounds, are used.

The total weight of an ore train, including one locomotive and the light weight of cars, will be about 2,600 tons. He states that each ore train earned on a $3 \frac{1}{2}$ mill rate per long ton mile $\$ 5.13$ per train mile during the year 1899 .

At Conneaut, on Lake Erie, the terminus of this road, the orehandling appliances are of the latest and most economical pattern. Nine ships can be docked at once, and 25,000 tons of freight can be handled in ten hours. A 6,000-ton ship can be cleared in fourteen hours, and in the same length of time the ore can be at the furnaces at Pittsburg. A new steam shovel was completed last winter, by which a train of 35 or 40 cars can be loaded with ore in two hours.

At these docks in the latter part of 1899 a new unloading machine was constructed to shorten the time necessary in unloading a vessel and be independent of labor disturbances. This machine, which weighs about 400 tons and has a height of 55 feet, consists of a foundation trestle mounted on wheels, which may be mored lengthwise along the dock, the rails bearing its forward end being on the edge of the dock. 
Moving backward and forward on this foundation span at right angles to the dock is a heavy walking beam, attached to the outer end of which is the depending leg or mast carrying a clam-shell bucket to dig the ore out of the hold of the vessel. The parallel motion keeps this leg in a vertical position, and the weight of the end of the walking beam, from which the bucket is suspended, is counterbalanced by a hydraulic accumulator. To operate the bucket the walking beam is run forward until the depending leg is over the hatch of the vessel: This mast, which revolves in a complete circle and on which the oper. ator is stationed, is lowered into the hold and turned in any direction. When fully open the clam-shell bucket has a spread of 19 feet. After the bucket has been closed by hydraulic power it is lifted from the boat and run back over the dock, where the ore is discharged directly into railroad cars, or through a hopper into small car's which carry it to stock piles at the rear of the dock. The machine takes out 10 tons of ore at a time, and its capacity is stated to range, under ordinary conditions, from 250 to 300 tons per hour. It is claimed that, although the cost of installing the unloader is large, it will reduce the labor employed 75 per cent and that but six men are necessary for the operation of each machine, three being in the hold to clean up the ore which the machine can not reach, and the other three engaged in the operation of the unloader.

The cost of operating the hoisting and conveying machinery under present conditions is stated to be 14 cents per ton for labor in the hold; the wages of engineers, cost of fuel, and other incidentals bringing the total expense of unloading to 20 cents per ton.

Other large installations of unloading appliances are in course of construction at Chicago.

\section{IMPORTS.}

The Bureau of Statistics of the United States Treasury Department has courteously supplied data as to the quantity and value of iron ores imported into the United States in the year 1899, both by countries and customs districts. The statement shows that 674,082 tons of iron ore were imported in the year ending December 31,1899 , an increase of 486,874 tons, or 260 per cent, over the total of 187,208 long tons in the year 1898 . The importations in 1899 were valued at $\$ 1,082,847$, or $\$ 1.61$ per ton, as against $\$ 1.37$ in 1898 .

These values do not include freight on the ore from the point of shipment or the duty of 40 cents per ton.

The termination of the war with Spain was speedily followed by resumption of large shipments of iron ores from that country and its former dependency, the island of Cuba. French Africa and Italy also resumed shipments, and Newfoundland was an important contributor to the supply of iron ore in 1899 . 
The following table shows the amount and value of iron ores imported into the United States, by countries, from 1896 to 1899 inclusive:

Quantity and value of iron ores imported into the Lnited States in 1896, 1897, 1898, and 1899.

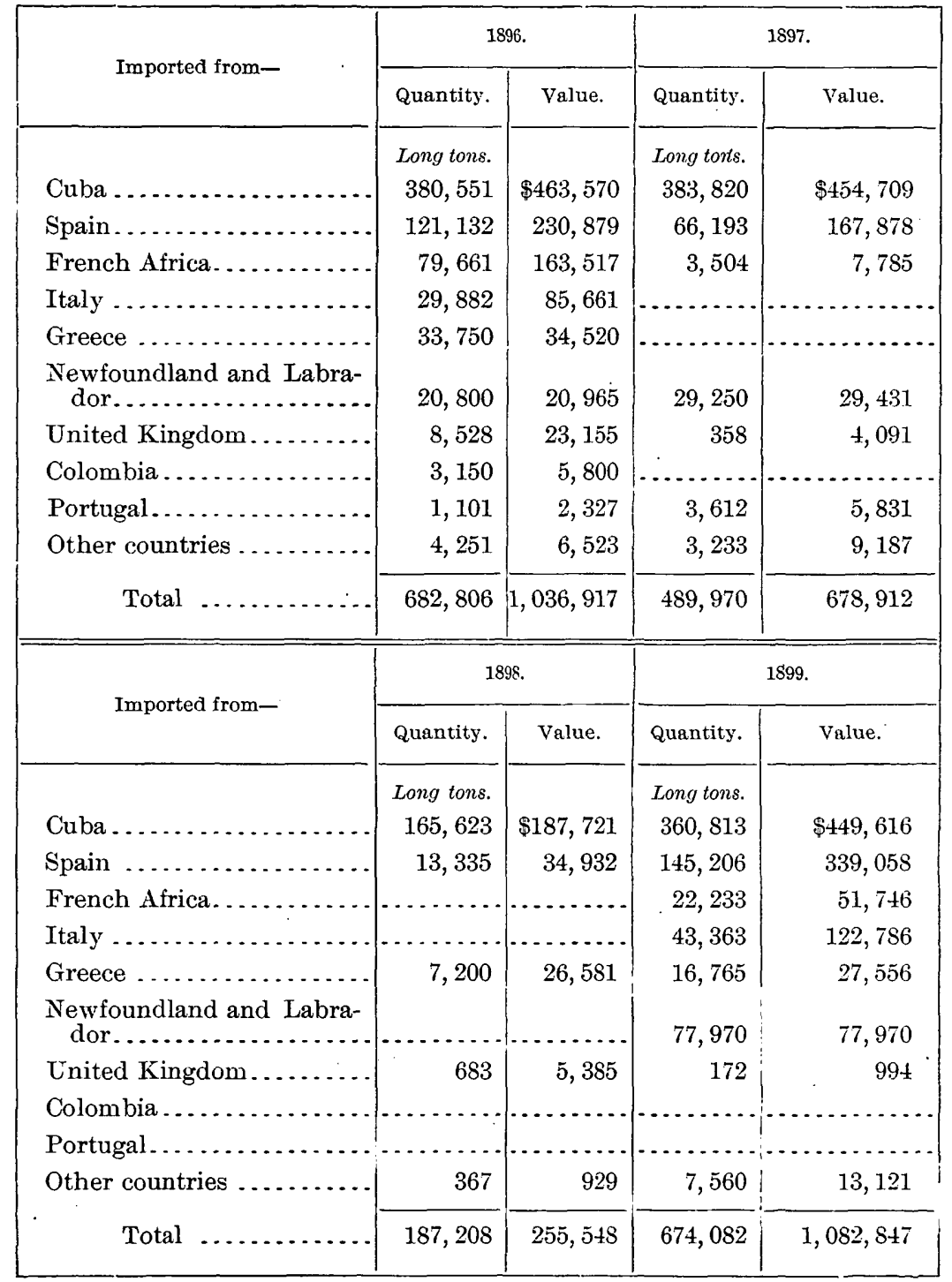


IRON ORES.

The imports of iron ore by customs districts in 1896, 1897, 1898, and 1899 were as follows:

Imports of iron ore into the United States in 1896, 1897, 1898, and 1899, by customs districts.

\begin{tabular}{|c|c|c|c|c|}
\hline \multirow{2}{*}{ Port. } & \multicolumn{2}{|c|}{1896.} & \multicolumn{2}{|c|}{1897.} \\
\hline & Quantity. & Value. & Quantity. & Value. \\
\hline $\begin{array}{l}\text { Baltimore, Md . . . . . . . . . } \\
\text { Delaware . . . . . }\end{array}$ & $\begin{array}{c}\text { Long tons. } \\
368,761 \\
\ldots . . . . .\end{array}$ & $\begin{array}{l}\$ 577,135 \\
\ldots \ldots\end{array}$ & $\begin{array}{r}\text { Long tons. } \\
292,613 \\
\end{array}$ & $\$ 369,483$ \\
\hline Philadelphia, Pa ... & 308,217 & 444,687 & 194,814 & 302,211 \\
\hline New York, N. Y....... & 4,199 & 10,499 & 309 & 1,272 \\
\hline $\begin{array}{l}\text { Boston, Mass......... } \\
\text { Newport News, Va..... }\end{array}$ & 78 & 216 & 46 & $\begin{array}{r}112 \\
- \\
-\end{array}$ \\
\hline Total Atlantic ports. . & 681,255 & $1,032,537$ & 487,792 & 673,078 \\
\hline Cape Vincent, N. Y.... & & & & \\
\hline Buffalo Creek, N. Y ... & $\ldots \ldots$ & & & \\
\hline Cuyahoga, Ohio..... & 1,033 & 1,911 & $\cdots$ & \\
\hline Champlain, N. Y.... & ........ & $\ldots .$. & 104 & 156 \\
\hline $\begin{array}{l}\text { Detroit, Mich . . . . . . . } \\
\text { Oswegatchie, N. Y..... }\end{array}$ & Not given. & 10 & 139 & 186 \\
\hline Vermont. & - & …. & 21 & 81 \\
\hline Total lake ports..... & 1,033 & 1,921 & 264 & 423 \\
\hline $\begin{array}{l}\text { Paso del Norte, Tex. (total } \\
\text { Gulf ports) ............... }\end{array}$ & 257 & 159 & 919 & 2,525 \\
\hline Saluria, Tex $\ldots \ldots \ldots \ldots$ & $\ldots$ & $\ldots$ & & $\cdots$ \\
\hline $\begin{array}{l}\text { Puget Sound, Wash. (total } \\
\text { Pacific ports) } \ldots . . . . . .\end{array}$ & 126 & 350 & 1,000 & 2,826 \\
\hline Pittsburg, Pa. (interior port) & 135 & 1,950 & 5 & 60 \\
\hline Total imp & 682,806 & $1,036,917$ & 489,970 & 678,912 \\
\hline
\end{tabular}

21 GEOL, P' $6-5$ 
Imports of iron ore into the United States, etc.-Continued.

\begin{tabular}{|c|c|c|c|c|}
\hline \multirow{2}{*}{ irt. } & \multicolumn{2}{|c|}{1898.} & \multicolumn{2}{|c|}{1899.} \\
\hline & Quantity & Value. & Quantity. & Value. \\
\hline Baltimore, Md ... & $\begin{array}{r}\text { Long tons. } \\
144,213\end{array}$ & $\$ 178,905$ & $\begin{array}{r}\text { Long tons. } \\
333,258\end{array}$ & $\$ 516,888$ \\
\hline Delaware.......... & $\ldots \ldots \ldots$ & $\ldots \ldots \ldots$ & 5,757 & 7,375 \\
\hline Philadelphia, Pa... & 42,861 & 74,226 & 330,594 & 549,143 \\
\hline New York, N. Y... & 119 & 1,815 & 120 & 703 \\
\hline Boston, Mass . . . . . . . & & ..... & 75 & 175 \\
\hline Newport News, Va .... & 15 & 602 & & \\
\hline Total Atlantic ports. . & 187,208 & 255,548 & 669,804 & $1,074,284$ \\
\hline Cape Vincent, N. Y & & & 195 & 489 \\
\hline Buffalo Creek, N. Y & & $\cdots$ & 20 & 52 \\
\hline Cuyahoga, Ohio......... & & & $\cdots$. & $\ldots$ \\
\hline Champlain, N. Y...... & & & 641 & 1,555 \\
\hline Detroit, Mich ....... & & $\ldots$ & 304 & 168 \\
\hline Oswegatchie, N. Y..... & 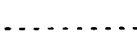 & $\cdots$ & 125 & 260 \\
\hline Vermont .............. & $\cdots$ & $\cdots$ & 1,039 & 2,045 \\
\hline Total lake ports & & & 2,324 & 4,569 \\
\hline $\begin{array}{l}\text { Paso del Norte, Tex. (total } \\
\text { Gulf ports) }\end{array}$ & & & & \\
\hline Saluria, Tex.... & & & 2 & 4 \\
\hline $\begin{array}{l}\text { Puget Sound, Wash. (total } \\
\text { Pacific ports) ............. }\end{array}$ & & & 1,912 & 3,746 \\
\hline Pittsburg, Pa. (interior port) & & $\cdots$ & 40 & 244 \\
\hline Total imports .. & 187,208 & 255,548 & 674,082 & $1,082,847$ \\
\hline
\end{tabular}


IRON ORES.

EXPORTS.

Of late years the United States has also exported some iron ore, the greater part of which was sent from the Lake Superior region to the Canadian blast furnaces. The amount exported during the year ending December 31 , 1899 , was 40,665 long tons, valued at $\$ 76,287$, as against 31,579 tons exported in 1898 . The exports, by customs districts, were as follows:

Iron-ore exportations from the United States in 1899, by customs districts.

\begin{tabular}{|c|c|c|}
\hline Customs district. & Quantity. & Value. \\
\hline Niacrara & Long tons. & \\
\hline Niagara $\ldots \ldots \ldots \ldots$ & 17,857 & $\$ 30,000$ \\
\hline Superior ......... & 11,389 & 20,012 \\
\hline Duluth ......... & 10,534 & 22,465 \\
\hline Paso del Norte .................... & 703 & 2,930 \\
\hline 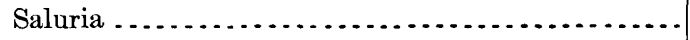 & 172 & 823 \\
\hline Detroit ......... & 7 & 42 \\
\hline Huron........... & 3 & 15 \\
\hline Total. & 40,665 & 76,287 \\
\hline
\end{tabular}





\title{
THE AMERICAN AND FOREIGN IRON TRADES IN 1899.
}

\author{
By James M. Swank, \\ General Manager of the American Iron and Steel Association.
}

GENERAI REVIEW.

In the spring of 1899 the industries of this country, with scarcely an exception, had entered upon a season of extraordinary prosperity. The activity in these industries in 1898 had been intensified in the early months of 1899 . The aids to complete prosperity which had been lacking in 1898, namely, higher prices for manufactured products and higher wages for labor, had now become generally effective. Everybody saw that the active demand for manufactured products and for the products of our mines and forests was certain to continue for some time to come and that it would be accompanied by a still higher range of values. After this hopeful outlook was everywhere recognized a whole year had passed until May, 1900, and there had been developed in the meantime a more pressing demand and higher prices than had been foreshadowed. The mills and factories and workshops of the country were operated to their fullest capacity, and our mining and lumber industries were never so actively employed. This great activity gave increased business to the railroads in the transportation of both manufactured products and crude materials. The abundant agricultural crops of 1899 also contributed to increase the business of the railroads, so that, with the increased tonnage from the other sources mentioned, they too were operated to their fullest capacity. The home and foreign demand for these crops was so large that previous high prices for most of them were maintained, while cotton, which had been an exception to the general advance in agricultural prices, commanded unusually high prices-higher than at any time since 1893. Because of their increased business the railroad companies were compelled in 1899 to order new cars and locomotives and to improve and extend their railroad tracks, and the farmers' prosperity, following that of 1897 and 1898, enabled them to make still more extensive purchases of manufactured articles. In all the leading industries of the country there was a material increase in wages after the spring of 
1899, supplementing the increase that had then taken place. Labor, both skilled and unskilled, has never been in greater demand in this country than in 1899 and the first six months of 1900. Prosperity, in brief, was general; the prosperity of one industry helped that of another. All in all the year 1899 was the most prosperous year in our history.

\section{BOOM IN THE AMERICAN IRON TRADE.}

The industrial prosperity of this country in 1899 and during the early part of 1900 was shared in a greater degree by the iron trade than by any other leading industry, and to an extent which produced in 1899 a boom of the first magnitude-a boom of far larger proportions and of longer continuance than the celebrated iron and steel boom which began in the latter part of 1879 and came to a sudden termination in February, 1880. A moderate advance in iron and steel prices had commenced in December, 1898, following two whole years of expanding markets but of low prices. This moderate advance continued until February, 1899, when it was succeeded by a more active demand and by a sharper advance, lasting all through March, when prices virtually ceased to advance. Throughout April and the first half of May they were practically stationary, but after the middle of May, to the surprise of almost everybody, they took a fresh start, advancing by leaps and bounds until October, a period of five months, when the advance in some lines was checked. In November the boom practically ended. The prices which had been established at this time averaged an increase of over 100 per cent upon the prices which had prevailed eleven months before, in December, 1898, and in some cases they greatly exceeded an increase of 100 per cent. Within the eleven months mentioned No. 1 foundry pig iron at Philadelphia rose from $\$ 11.75$ to $\$ 25$ per ton; gray forge pig iron in the same market from $\$ 10.25$ to $\$ 20.25$; gray forge pig iron at Pittsburg from $\$ 9.25$ to $\$ 21.75$; Bessemer pig iron in the same market from $\$ 10.45$ to $\$ 25$; steel rails at mills in Pennsylvania from $\$ 17$ to $\$ 35$; steel billets at Pittsburg from $\$ 15.25$ to $\$+3$; refined bar iron from store at Philadelphia from $\$ 1.25$ per 100 pounds to $\$ 2.50$; refined bar iron at Pittsburg from $\$ 1$ to $\$ 2.75$; steel ship plates at Philadelphia from $\$ 1.40$ to $\$ 3.15$; cut nails from store at Philadelphia from $\$ 1.30$ per keg to $\$ 2.80$; and wire nails at Chicago from $\$ 1.35$ to $\$ 3.28$.

From November, 1899, until March, 1900, there was only moderate yielding in any iron and steel prices, notwithstanding a serious reaction in the stock market and heavy failures in December, but early in March a distinct weakening in the prices of many iron and steel products was everywhere recognized, and this weakening in prices is still in progress in July, when this record ends. 
The remarkable character of the demand for iron and steel in 1899 is well illustrated in the large orders for cars and locomotives and steel rails that were placed in the single month of October of that year. The cars ordered in that month from car-building companies exceeded 33,000 ; about 350 locomotives were ordered from locomotive builders; and the orders for steel rails exceeded 500,000 tons. These orders were all for home railroads except a few locomotives. One of the reasons for taking a hopeful view of the immediate future of our iron and steel industries is the certainty that the extraordinary demand for iron and steel for new railroad building and for new equipment for existing railroads will continue for some time without material abatcment. In addition to cars and locomotives and rails many steel bridges will be needed. But prices will show great reductions.

CHARACTERISTICS OF THE BOOM OF 1899.

Foreign competition was at no time a factor in determining prices or in bringing the boom of 1899 to an end. Europe needed all the iron and steel that its manufacturers could supply, and prices for these products rose rapidly in all European markets. Tariff duties on iron and steel were lost sight of by American manufacturers. Prices of iron and steel in American markets advanced in 1899 because the demand was greater than bad ever before been known, and because early in the year the impression became general and was thereafter sedulously cultivated that our capacity for the production of iron and steel and iron ore and coke was not equal to the country's wants. To the persistency with which this famine cry was repeated for at least six months of 1899 may be traced much of the excitement that prevailed in that year in our iron and steel markets, the haste to place orders for future delivery never before having been equaled. And yet, with few exceptions, there was no scarcity of iron or steel or of raw materials. The production of iron and steel and of iron ore and coal and coke was of phenomenal magnitude. All the furnaces and rolling mills and steel works and foundries that were in operation at the beginning of the year or that could be put in operation were constantly employed. Our producing capacity was greatly increased. Furnaces and other plants that had long been idle were revived, additions were made to plants already active, new iron and steel works and coke ovens were built, new coal mires were opened, and old iron-ore mines were reopened. The reaction from the four years of depression following the financial panic of 1893 was at full tide all through 1899.

Another distinguishing feature of the iron and steel boom of 1899 was the organization during the year of a large number of powerful consolidations of iron and steel and other manufacturing companies, erroneously styled trusts-continuing the movement which had its 
beginning in 1898. The enormous capitalization of so many manufacturing corporations, accompanied by the expectation of large profits in these enterprises, and accompanied also by an increase in the business of the railroads, produced an active and excited demand for industrial and railroad securities, creating a boom also in the stock market, and this boom in the stock market naturally increased the excitement in the iron and steel markets. Since November, 1899, the market for industrial and railroad stocks has been less active and prices have materially declined.

REACTION FROM THE BOOM OF 1899.

As has already been stated, the prices of iron and steel began to decline in a marked degree in March, 1900, and have since continued to decline. This decline has been accompanied by a shrinkage in the demand for iron and steel in all forms. The causes of this reaction in the American iron trade are not difficult to discover. One cause is that the abnormal demand during the boom period, when orders for future delivery upon a rising market were too freely placed, could not in the nature of things be continued. Another cause is that the extraordinary demand for.iron and steel greatly increased the country's productive capacity, and this led naturally to an increase of capacity beyond the country's wants and to lower prices.

The reaction in demand did not particularly affect the operations of the mills and furnaces during the first six months of the present year, as they were all or nearly all busily engaged in filling old orders or in meeting immediate orders, but it did seriously affect the prospect for active business during the last six months of the year; hence concessions in prices to book what orders could be secured and to induce the placing of further orders. When the 1st of July came some furnaces that had been operated to the full extent of their capacity for a long time had been blown out or banked, and many mills that had been running night and day since the beginning of the boom were then closed. This reduction in the activity of the furnaces and mills has been continued in July. At some furnaces wages were reduced in June, and wages at some of the mills have been reduced in July. The production of furnace coke declined in June and July, and coke prices have also declined. In other lines of trade, not connected directly with the iron trade, there has occurred a marked change in the conditions which prevailed only a few months ago; orders are falling off and prices are not being maintained. Much of the activity in these lines in the past year or two has been due to the impetus given to all business by the prosperity of the iron trade, and much of their present dullness is due to the overproduction that was bound to follow extraordinary stimulation. 
The highest prices for mosí products of iron and steel were reached in October and Noyember of last year. The decline that has since taken place is startling. From the bimonthly period mentioned until the close of July the decline in the price of No. 1 foundry pig iron at Philadelphia, taking the highest average price in the two months, has been from $\$ 25$ to $\$ 17.50$; in gray forge pig iron at Philadelphia, from $\$ 20.19$ to $\$ 14$; in gray forge pig iron at Pittsburg, from $\$ 21.56$ to $\$ 15$; in Bessemer pig iron at Pittsburg, from $\$ 24.69$ to $\$ 17$; and in steel billets at Pittsburg, from $\$ 41.50$ to $\$ 19$. The decline has been most marked in May, June, and July. Notwithstanding these sharp declines and the shrinkage in demand, consumption is still above that of the years immediately preceding the boom, and as a rule prices are still higher than they were before the boom commenced.

THE EUROPEAN IRON MARKETS IN 1899.

It would not have been possible to advance the prices of iron and steel in this country to the figures obtained in 1899 if there had not been in the same year an unusual advance in the prices of European iron and steel, which prevented orders from going abroad. This advance in our markets followed active iron and steel markets in Great Britain and on the Continent in 1898 and in immediately preceding years. The advance in Great Britain from January, 1899, during the year was as follows for a few representative products: No. 3 foundry pig iron at Middlesborough, from 44s. 6d. to $74 \mathrm{~s}$. $10 \mathrm{~d}$. per ton; Scotch warrants at Glasgow, from $49 \mathrm{~s} .4 \mathrm{~d}$. to $75 \mathrm{~s} .7 \mathrm{~d}$.; steel rails at Middlesborough, from $£ 412 \mathrm{~s}$. 6 d. to $£ 7$; Welsh tin plates, from 10s. 9d. to 16s. 6d. Since January, 1900, British prices have still further advanced-No. 3 pig iron at Middlesborough to $79 \mathrm{~s}$.; Scotch warrants at Glasgow to $77 \mathrm{~s}$. 6d.; steel rails at Middlesborough to $£ 715 \mathrm{~s}$., and Welsh tin plates to 16s. 9d. In Germany No. 1 foundry pig iron in Westphalia rose from 69 marks per metric ton in January, 1899, to 93 marks in January, 1900; Thomas pig iron, from 61 marks to 86 marks; bar iron in Westphalia, from 138 marks to 215 marks; steel rails in Westphalia, from 125 marks to 155 marks. Since January last German prices have still further advanced. In France and Belgium and other Continental countries there has been a corresponding advance since the beginning of 1899. In most European countries prices of iron and steel were higher in April of the present year than in January last, owing chiefly to a great scarcity of coal and to an increase in its price, particularly in Great Britain and Germany. These conditions reached a very acute stage in the early part of the year, although they had affected iron and steel prices all through 1899. But toward the middle of 1900 prices of iron and steel in all European markets began to decline, and this decline is still in progress. 
INCREASED EXPORTS AND DECREASED IMPORTS OF IRON AND STEEL.

The favorable condition of our export trade in iron and steel continued in 1899, notwithstanding our high prices. Our exports of iron and steel in that year, not including agricultural implements, aggregated in value the enormous total of $\$ 105,689,077$, against $\$ 82,771,550$ in 1898 and $\$ 62,737,250$ in 1897 . Our exports in 1899 included 228,665 tons of pig iron, 76,633 tons of old and scrap iron, 271,272 tons of steel rails, 54,244 tons of structural iron and steel, 56,831 tons of plates and sheets, 25,487 tons of billets, 116,317 tons of wire, and 484 locomotives. Our exports of agricultural implements, not included above, rose from a value of $\$ 5,302,807$ in 1897 to $\$ 9,073,384$ in 1898 and $\$ 13,594,524$ in 1899 . Of the pig iron we sent abroad in 1899 Great Britain took 80,988 tons, against 76,356 tons in 1898 and 91,196 tons in 1897, and of the steel we sent abroad in 1899 Great Britain took 59,375 tons, against 29,374 tons in 1898 and 25,917 tons in 1897. It will be seen from the foregoing figures that a very considerable part of the extraordinary demand for iron and steel in our country in 1899 was to fill foreign orders. This demand still continues.

Our imports of iron and steel in 1899 amounted in foreign value to $\$ 15,800,579$, against $\$ 12,474,572$ in 1898 and $\$ 13,835,950$ in 1897 . Our imports in 1899 included 40,372 tons of pig iron, spiegeleisen, ferromanganese, and ferro-silicon, and 58,915 tons of tin plates. In 1898 we imported 66,775 tons of tin plates, in 1897 we imported 83,851 tons, and in 1896 we imported 119,171 tons.

CAUSES OF THE GREAT DEMAND FOR IRON AND STEEL.

The immediate and direct causes which had been instrumental in restoring prosperity to our country in 1898 and 1899 included the large exports in recent years of our agricultural and manufactured products, the practical cessation of the shipments of gold abroad and the increase in our imports of gold, the stimulating influence of the Spanish war, the increase in the circulation of money, and the settlement of the tariff question in 1897 by the passage of the Dingley bill. To these favorable influences must now be added the passage of the currency bill which was approved March 14, 1900. But what remote causes have operated to create our own prosperity and the world-wide prosperity of the last few years? European countries have been relatively as prosperous in recent years as the United States; indeed the boom in American industries in 1899 followed active markets and rising prices in the leading European countries. And then again, why was so much iron and steel needed in Europe as well as in America? These questions are more easily asked than answered. 
Undoubtedly the great increase in the last few years in the world's supply of gold and its conversion into a circulating medium must be credited with a stimulating effect upon business generally in all progressive countries. Perhaps the absence of destructive European wars for nearly thirty years is a prime cause of the world's prosperity, for this freedom has promoted the welfare of European countries which are laige consumers of agricultural and manufactured products, and it has led enterprising nations to develop the resources of less favored and even benighted people. The strengthening of the protective policy in many Continental countries in the last thirty years has surely had a benefical effect upon the industries of those countries. Their people have not only been generally employed, but they have received higher wages than formerly.

Without indulging in further speculation upon the broad question of the world's prosperity in late years, we can probably indicate with more certainty the leading causes of the increased consumption of iron and steel by other countries as well as by our own. The enlarged use of iron and steel in ship building and bridge building is one cause. The increasing use of steel in the construction of public buildings and private dwellings is another cause. The magnitude of this latter use has only recently been recognized. In the United States we have commenced to substitute steel cars for wooden cars on our railroads, and in this new use of steel we find another cause of the present activity in the iron and steel industries of our own country. We are also now making our own tin plates. We are using heavier rails for our railroads than formerly. The various uses to which electricity has been applied in late years, the water supply of cities, and all kinds of engineering enterprises have also greatly increased the demand for iron and steel in all countries. Lastly, a new era in railroad building has commenced in Russia, the United States, and some other countries, the great Siberian enterprises of Russia alone calling for immense quantities of railway material.

\section{GENERAL STATISTICAL SUMMARY.}

In 1899 the United States made 13,620,703 long tons of pig iron, $7,586,354$ tons of Bessemer steel ingots, $2,947,316$ tons of open-hearth steel, and 10,639,857 tons of steel of all kinds, and rolled in all 10,357,397 tons of finished iron and steel, including rails; there were also shipped in the same year 18,251,804 long tons of Lake Superior iron ore and $10,129,764$ short tons of Connellsville coke. The following table gives the shipments of Lake Superior iron ore and Connellsville coke and the production of leading articles of iron and steel in 1899 as compared with 1898: 
Production of leading articles of iron and steel in 1899 compared with 1898.

\begin{tabular}{|c|c|c|}
\hline Articles-Long tons, except coke and nails. & 1598. & 1899. \\
\hline Shipments of iron ore from Lake Superior & $14,024,673$ & $18,251,804$ \\
\hline $\begin{array}{l}\text { Shipments of Connellsville coke, in short tons. } \\
\text { Production of- }\end{array}$ & $8,460,112$ & $10,129,764$ \\
\hline Pig iron, including spiegel and ferro & $11,773,934$ & $13,620,703$ \\
\hline Spiegeleisen and ferromanganese .... & 213,769 & 219,768 \\
\hline Bessemer steel ingots and castings... & $6,609,017$ & $7,586,354$ \\
\hline Open-hearth steel ingots and castings & $2,230,292$ & $2,947,316$ \\
\hline All kinds of steel ........ & $8,932,857$ & $10,639,857$ \\
\hline Structural shapes, not including plates. & 702,197 & 906,277 \\
\hline Plates and sheets, except nail plate.. & $1,448,301$ & $1,903,505$ \\
\hline All rolled iron and steel, except rails & $6,532,12 \dot{9}$ & $8,084,697$ \\
\hline Bessemer steel rails.. & $1,976,702$ & $2,270,585$ \\
\hline All kinds of rails............ & $1,981,241$ & $2,272,700$ \\
\hline Street rails, included above ..... & 143,815 & 154,246 \\
\hline Iron and steel wire rods. & $1,071,683$ & $1,099,376$ \\
\hline All rolled iron and steel, including $r$ & $8,513,370$ & $10,357,397$ \\
\hline Iron and steel cut nails, in kegs ... & $1,572,221$ & $1,904,340$ \\
\hline Iron and steel wire nails, in kegs. & $7,418,475$ & $7,599,522$ \\
\hline
\end{tabular}

The shipments of Lake Superior iron ore in 1899 increased 4,227,131 tons as compared with the shipments of 1898 , and the shipments of Connellsville coke increased $1,669,652$ tons. The production of pig iron increased 1,846,769 tons; spiegeleisen and ferromanganese, 5,999 tons; Bessemer steel ingots, 977,337 tons; open-hearth steel ingots and castings, 717,024 tons; all kinds of steel, 1,707,000 tons; structural shapes, 204,080 tons; plates and sheets, 455,20t tons; Bessemer steel rails, 293,883 tons; wire rods, 27,693 tons, and all rolled iron and steel, including rails, $1,8 \pm 4,027$ tons. There was also an increase in the production of iron and steel cut nails in 1899 as compared with 1898 of $332,119 \mathrm{kegs}$, and in iron and steel wire nails of $181,047 \mathrm{kegs}$. The production of tin plates in 1899 is estimated to bave amounted to 397,767 tons, against 326,915 tons in 1898 .

The number of miles of new railroad in the United States on which track was laid in 1899, not including double tracks or sidings, was about 4,600 . The new railroad constructed in $189 \mathrm{~S}$ is definitely reported in "Poor's Manual of Railroads" for 1899 as amounting to 3,199 miles, against 2,161 miles in 1897 and 2,068 miles in 1896. At the end of 1898 there were 186,810 miles of railroad in operation in the United States.

The "Railroad Gazette" reports that the contracting shops built 2,452 locomotives in 1899 , against 1,875 in 1898, an increase of 577 . The number built in 1899 was the largest ever recorded for a single year. Of the whole number of locomotives built in 1899 there were 514 built for export to foreign countries, against 554 in 1898 . Re- 
turns have not been obtained from the railroad shops. The following figures show the number of locomotives built by contracting shops since 1888: 1899, 2,452;1898, 1,875; 1897, 1,251;1896, 1,175; 1895, 1,$101 ; 1894,695 ; 1893,2,011 ; 1892,2,012 ; 1891,2,165 ; 1890,2,240$; $1889,1,860 ; 1888,2,180$.

The number of locomotives built by the Baldwin Locomotive Works in 1899 was 901 , against 755 in 1898,501 in 1897,547 in 1896,401 in 1895,313 in 1894, and 772 in 1893 . The number built by the Schenectady Locomotive Works in 1899 was 356, against 283 in 1898, 131 in 1897, 119 in 1896, 148 in 1895, 56 in 1894, and 219 in 1893. The number of locomotives built by the Brooks Locomotive Works in 1899 was 300 , against 225 in 1898,157 in 1897,100 in 1896, 125 in 1895,90 in 1894, and 197 in 1893.

The "Railroad Gazette" says that the number of freight cars built by contracting shops in 1899 was 117,982 , against 99,809 in 1898 and 43,588 in 1897. The number of passenger cars built in 1899 was 1,201, against 699 in 1898 and 494 in 1897 . The number of street railroad cars built in 1899 was 4,710 , against 4,650 in 1898 . Of the freight cars built last year 10,500 were built of steel. The whole number of cars built in 1899 was 123,893 , against 105,158 in 1898 . The number of cars built in 1898 was greater than in any previous year since 1890 , when 103,774 cars were built. Returns have not been obtained from the railroad shops.

The foreign value of all the iron and steel and manufactures thereof which were imported into the United States in the calendar year 1899 was $\$ 15,800,579$, against $\$ 12,474,572$ in 1898 and $\$ 13,835,950$ in 1897 . In the above figures are included our imports of tin plates, which amounted to 58,915 tons in 1899 , valued at $\$ 3,738,567$. In 1889 , only ten years ago, we; imported 331,311 tons of tin plates, valued at $\$ 21,726,707$. As late as 1891 our imports of tin plates amounted in value to $\$ 25,900,305$.

The imports of pig iron, spiegeleisen, ferromanganese, and ferrosilicon in the calendar year 1899 amounted to 40,372 tons, against 25,152 tons in 1898 and 19,212 tons in 1897.

The exports of iron and steel from the United States in 1899, including all manufactures of iron and steel except agricultural implements, amounted to $\$ 105,689,077$, against $\$ 82,771,550$ in 1898 and $\$ 62,737,250$ in 1897. The exports of agricultural implements in 1899 amounted to $\$ 13,594,524$, against $\$ 9,073,384$ in 1898 and $\$ 5,302,807$ in 1897.

The imports of iron ore in 1899 amounted to 674,082 long tons, against 187,093 tons in 1898. The exports of iron ore in 1899 amounted to 40,665 long tons, against 31,579 tons in 1898 . The imports of manganese ore in 1899 amounted to 188,349 tons.

The shipments of coke from the Connellsville region in 1899 amounted to $10,129,764$ short tons, against $8,460,112$ short tons in 1898 , an increase of $1,669,652$ tons. The average price of all coke shipped from the Connellsville region was $\$ 1.55$ per short ton in 1898 and $\$ 2$ in 1899. 
The shipments of Pocahontas Flat Top coke in 1899 amounted to $1,317,246$ short tons, against $1,276,172$ tons in 1898 , an increase of 41,074 tons.

The shipments of anthracite coal from the Pennsylvania mines in 1899 amounted to $47,665,204$ long tons, against $41,899,751$ tons in 1898 , an increase of $5,765,453$ tons.

The shipments of Cumberland coal from the mines of Western Maryland and West Virginia in 1899 amounted to 6,131,461 long tons, against $5,533,636$ tons in 1898 , an increase of 597,825 tons.

The shipments of bituminous coal in 1899 through the locks and pools of the Monongahela River amounted to $146,578,075$ bushels, against $153,020,000$ bushels in 1898 . No record was kept of the coke shipped in 1898, but in 1899 it amounted to 31,000 bushels. A bushel of coal weighs 76 pounds; of coke, 40 pounds.

The imports of coal in 1899 amounted to 1,393,640 long tons, against $1,273,706$ tons in 1898. The exports of coal in 1899 amounted to $5,752,150$ long tons, against $4,503,405$ tons in 1898 . The exports of coke in 1899 amounted to 280,196 long tons, against 199,562 tons in 1898. The imports of coke in 1898 amounted to 44,584 long tons and in 1899 to 37,808 tons.

Statistics of the production of coal in 1899 have been compiled by Edward W. Parker, statistician of the United States Geological Survey, as follows: Anthracite coal, 53,944,647 long tons; bituminous coal, $172,608,917$ tons; total production of coal in $1899,226,553,564$ long tons. For the first time the production of coal by the United States exceeded that of Great Britain in 1899, preliminary statistics of the production by Great Britain in that year claiming only $220,085,303$ tons.

The number of iron and steel vessels built in the United States in the fiscal year ended June 30, 1899, not including vessels for the Navy, was 91 , with a tonnage of 131,379 long tons, against 63 iron and steel vessels in the fiscal year 1898, with a tonnage of 62,266 long tons, an increase of 28 vessels and of 69,113 tons.

The production of pig iron in Great Britain in 1899 was 9,305,319 long tons, according to the British Iron Trade Association, against $8,609,719$ tons in 1898; the production of Bessemer steel ingots in 1899 was $1,825,074$ tons; the production of open-hearth steel ingots was $3,030,251$ tons; and the total production of steel in Great Britain in 1899 was in round numbers $5,000,000$ tons, which was less than onehalf the production in the Cnited States.

\section{AVFRAGE MONTHLY PRICES OF IRON AND STEEL.}

In the following table we give the arerage monthly prices of various leading articles of iron and steel in Pennsylvania in 1897, 1898, and 1899 , and in the first seven months of 1900 . The prices named are per long ton of 2,240 pounds, except for bar iron, which is quoted by the pound: 
AMERICAN AND FOREIGN IRON TRADES.

Arerage monthly prices of iron and steel from January, 1897, to July, 1900.

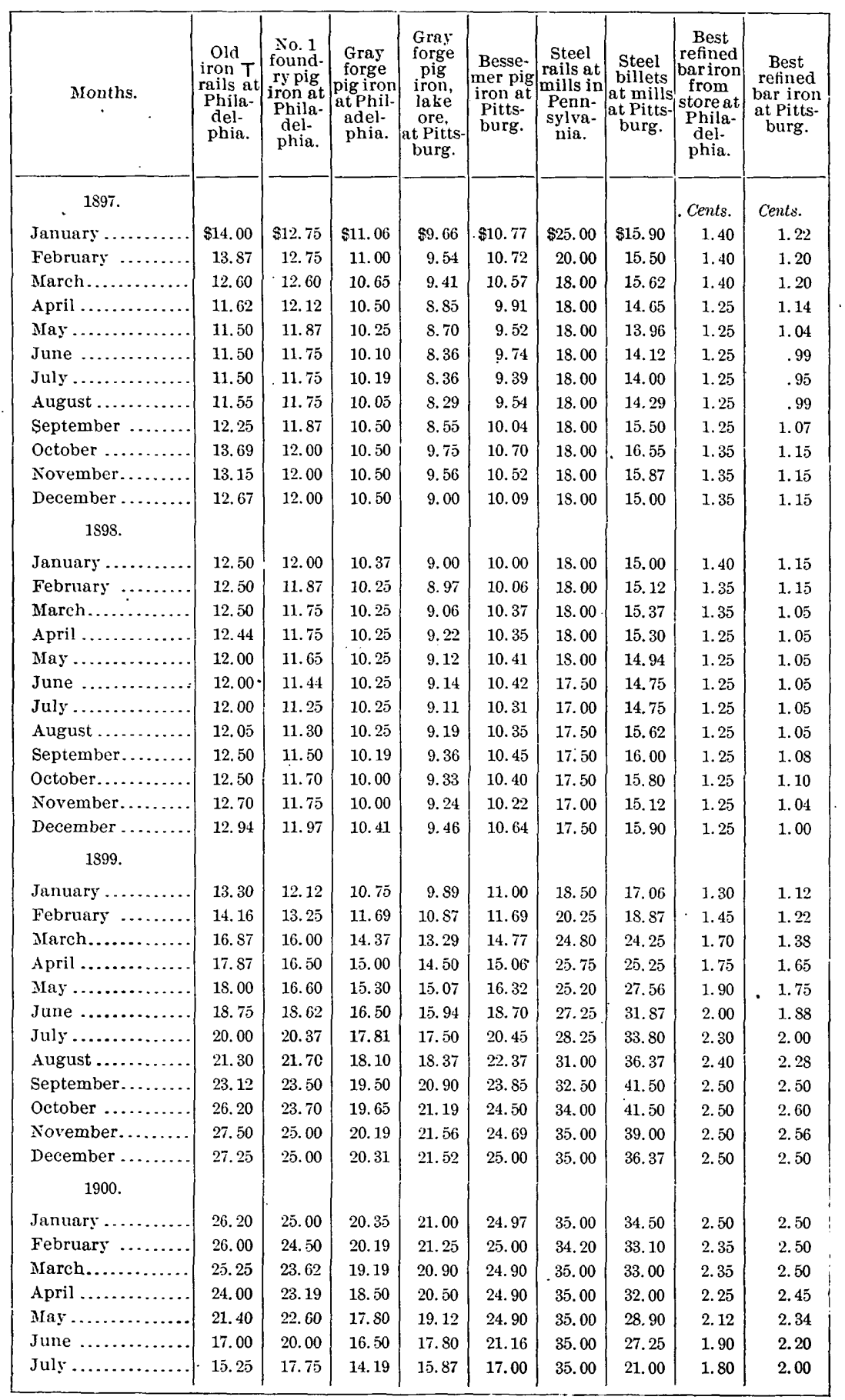




\section{AVERAGE YEARIY PRICES OF IRON AND STEEL.}

The following table gives the average yearly prices of leading articles of iron and steel in Pennsylvania for the years 1895, 1896, 1897, 1898 , and 1899. These prices are obtained by averaging monthly quotations, and these have in turn been averaged from weekly quotations. The prices given are per ton of 2,240 pounds, except for bar iron, which is quoted by the 100 pounds.

Average yearly prices of iron and steel from 1895 to 1899.

\begin{tabular}{|c|c|c|c|c|c|}
\hline Articles. & 1895. & 1896. & 1897. & 1898. & 1899. \\
\hline Old iron $T$ rails at Philadelphia ....... & $\$ 14.09$ & $\$ 14.16$ & $\$ 12.49$ & $\$ 12.39$ & $\$ 20.36$ \\
\hline No. 1 foundry pig iron at Philadelphia...... & 13.10 & 12.95 & 12.10 & 11.66 & 19.36 \\
\hline Gray forge pig iron at Philadelphia.. & 11.49 & 11.09 & 10.48 & 10.23 & 16.60 \\
\hline Gray forge pig iron at Pittsburg........ & 10.94 & 10.39 & 9.03 & 9.18 & 16. 72 \\
\hline Bessemer pig iron at Pittsburg ..... & 12. 72 & 12.14 & 10.13 & 10.33 & 19.03 \\
\hline Steel rails at mills in Pennsylvania. & 24.33 & 28.00 & 18.75 & 17.62 & 28.12 \\
\hline Steel billets at mills at Pittsburg ...... & 18.48 & 18. 83 & 15.08 & 15.31 & 31.12 \\
\hline Best bar iron from store at Philadelphia.... & 1.44 & 1.40 & 1.31 & 1.28 & 2.07 \\
\hline Best bar iron at Pittsburg ...... & 1.25 & 1.21 & 1.10 & 1.07 & 1.95 \\
\hline
\end{tabular}

\section{PRICES OF IAKE SUPERIOR IRON ORE.}

Below are given the prices at which Lake Superior iron ore has been sold upon season contracts in 1898 and 1899, per long ton, delivered at lower' ports on Lake Erie; also the prices at which sales were made in December, 1899, and early in 1900 for season delivery. These prices have been furnished to the author by Mr. A. I. Findley, editor of the Iron Trade Review, of Cleveland.

Prices of Lake Superior iron ore in 1898, 1899, and 1900, by grades.

\begin{tabular}{|c|c|c|c|}
\hline Grades. & 1898. & 1899. & 1900. \\
\hline 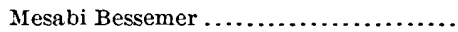 & $\$ 2.15 @ \$ 2.25$ & $\$ 2.25 @ \$ 2.40$ & $\$ 4.40 @ \$ 4.90$ \\
\hline Mesabi non-Bessemer...$\ldots \ldots \ldots \ldots \ldots$ & $1.70 @ 1.85$ & $1.90 @ 2.10$ & $4.00 @ 4.25$ \\
\hline Marquette specular No. 1 Bessemer ..... & $3.10 @ 3.35$ & $3.21 @ 3.50$ & $5.93 @ 6.48$ \\
\hline Marquette specular No. 1 non-Bessemer. & $2.35 @ 2.45$ & 2.50 & 5.00 \\
\hline Chapin $\ldots \ldots \ldots \ldots \ldots \ldots \ldots$ & 2.56 & 2. $73 \frac{1}{4}$ & 4.96 \\
\hline Soft hematites, No. 1 non-Bessemer ..... & 1.S0@2.00 & $2.00 @ 2.15$ & $4.15 @ 4.25$ \\
\hline $\begin{array}{l}\text { Gogebic, Marquette, and Menominee } \\
\text { No. } 1 \text { Bessemer hematites ............ }\end{array}$ & $2.75 @ 2.95$ & $2.80 @ 3.25$ & $5.50 @ 5.75$ \\
\hline Vermilion No. 1 hard non-Bessemer .... & 2.50 & 2.65 & 5.10 \\
\hline Chandler No. 1 Bessemer................ & 3.13 & 3.35 & 6.00 \\
\hline Marquette extra low-phos. Bessemer.... & 3.65 & $3.85 @ 3.90$ & $6.80 @ 6.90$ \\
\hline
\end{tabular}

The base price for 1900 of "old range" Bessemer ores, those from the Marquette, Menominee, Gogebic, and Vermilion ranges, have been fixed at $\$ 5.50$, against $\$ 2.95$ in 1899 . The base adopted, says Mr. Findley, is a supposititious ore containing 63 per cent of iron, 
0.045 per cent of phosphorus, and $10 \mathrm{per}$ cent of moisture. The ore most closely approaching this analysis is the Norrie ore, of the Gogebic range, hence it is often spoken of as the base ore. The base price for 1900 for "old range" non-Bessemer ores with 62 per cent of iron and 12 per cent of moisture is $\$ 4.15$.

\section{SHIPMENTS OF LAKE SUPERIOR IRON ORE.}

The Iron Trade Review, of Cleveland, gives complete and detailed statistics of the shipments of iron ore from the Lake Superior region in 1897,1898 , and 1899, from which we take the following summary statement of shipments by ranges and by ports, with all-rail shipments added. The all-rail shipments for 1899 were less than for 1898. The figures include shipments to local furnaces.

Shipments of Lake Superior iron ore in 1897, 1898, and 1899, by ranges.

\begin{tabular}{|c|c|c|c|}
\hline Range. & 1897. & 1898. & 1899. \\
\hline & Long tons. & Long tons. & Longtons. \\
\hline Marquette Range, Michigan ...................... & $2,715,035$ & $3,125,039$ & $3,757,010$ \\
\hline Menominee Range, Michigan and Wisconsin ...... & $1,937,013$ & $2,522,265$ & $3,301,052$ \\
\hline Gogebic Range, Michigan and Wisconsin.......... & $2,258,236$ & $2,498,461$ & $2,795,856$ \\
\hline Vermilion Range, Minnesota................... & $1,278,481$ & $1,265,142$ & $1,771,502$ \\
\hline Mesabi Range, Minnesota................. & $4,280,873$ & $4,613,766$ & $6,626,384$ \\
\hline Total. & $12,469,638$ & $14,024,673$ & $18,251,804$ \\
\hline
\end{tabular}

Shipments of Lake Superior iron ore in 1897, 1898, and 1899, by ports.

\begin{tabular}{|c|c|c|c|}
\hline Port. & 1897. & 1898. & 1899. \\
\hline Escanaba & Long tons. & Long tons. & Long tons. \\
\hline Marquette :............ & $1,945,519$ & $2,245,965$ & $2,733,596$ \\
\hline Ashland .......... & $2,067,637$ & $2,391,088$ & $2,703,447$ \\
\hline Two Harbors ......... . & $2,651,465$ & $2,693,245$ & $3,973,733$ \\
\hline Gladstone ............. & 341,014 & 335,956 & 381,457 \\
\hline Superior .............. & 531,825 & 550,403 & 878,942 \\
\hline 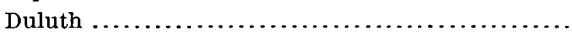 & $2,376,064$ & $2,635,262$ & $3,509,965$ \\
\hline All rail $\ldots . . . \ldots \ldots \ldots . . . .$. & 253,993 & 369,241 & 350,446 \\
\hline Total ... & $12,469,638$ & $14,024,673$ & $18,251,804$ \\
\hline
\end{tabular}

RECEIPTS OF IRON ORE AT LAKE ERIE PORTS:

The Iron Trade Review annually publishes the statistics of the receipts of Lake Superior iron ore at Cleveland and other ports on Lake Erie, the ports of Buffalo and Erie included, the principal receipts being at Ashtabula and Cleveland; also the quantity left on the docks at the close of navigation. From these statistics we compile 21 GEOI, PT $6-6$ 
the following summary of the receipts at all Lake Erie ports from 1886 to 1899 and of the stocks on dock at the close of navigation in each of these years:

Receipts of iron ore at Lake Erie ports from 1886 to 1899.

\begin{tabular}{|c|c|c|c|c|c|}
\hline Year. & Receipts. & On dock. & Year. & Receipts. & On dock. \\
\hline $1886 \ldots$ & $\begin{array}{l}\text { Long tons. } \\
2,270,554\end{array}$ & $\begin{array}{l}\text { Long tons. } \\
\quad 966,472\end{array}$ & $1893 \ldots$ & $\begin{array}{l}\text { Long toms. } \\
5,333,061\end{array}$ & $\begin{array}{l}\text { Long tons. } \\
4,070,710\end{array}$ \\
\hline $1887 \ldots$ & $3,439,198$ & $1,558,861$ & $1894 \ldots$ & $6,350,825$ & $4,834,24$ \\
\hline 1888. & $3,783,659$ & $1,848,555$ & 1895. & $8,112,228$ & $4,415,712$ \\
\hline $1889 \ldots$ & $5,856,344$ & $2,607,106$ & 1896. & $8,026,432$ & $4,954,984$ \\
\hline $1890 \ldots$ & $6,874,664$ & $3,893,487$ & $1897 \ldots$ & $10,120,906$ & $5,923,755$ \\
\hline $1891 \ldots$ & $4,939,684$ & $3,508,489$ & 1898. & $11,028,321$ & $5,136,407$ \\
\hline 1892. & $6,660,734$ & $4,149,451$ & 1899. & $15,222,187$ & $5,530,283$ \\
\hline
\end{tabular}

The receipts of Lake Superior iron ore at the ports of Buffalo (including Tonawanda), Erie, and Conneaut in the last seven years are given by the Iron Trade Review as follows, in long tons:

Receipts of Lake Superior iron ore from 1893 to 1899, by ports.

\begin{tabular}{|c|c|c|c|c|c|c|c|}
\hline Port. & 1893. & 1894. & 1895. & 1896. & 1897. & $189 \mathrm{~s}$. & 1899. \\
\hline Buffalo & $\begin{array}{r}\text { Long tons. } \\
308,238\end{array}$ & $\begin{array}{r}\text { Long tons. } \\
\quad 395,339\end{array}$ & $\begin{array}{r}\text { Long tons. } \\
719,742\end{array}$ & $\begin{array}{r}\text { Long tons. } \\
545,101\end{array}$ & $\begin{array}{r}\text { Long tons. } \\
797,446\end{array}$ & $\begin{array}{r}\text { Long tons. } \\
1,075,975\end{array}$ & $\begin{array}{r}\text { Long tons. } \\
1,530,016\end{array}$ \\
\hline Erie ... & 469,299 & 624,438 & 811,989 & 847,849 & $1,311,526$ & $1,092,364$ & $1,309,961$ \\
\hline Conneaut & 203,207 & 237,905 & 244,967 & $32 \overline{7}, 623$ & 495,327 & $1,404,169$ & $2,320,696$ \\
\hline Total & 980,744 & $1,257,682$ & $1,776,698$ & $1,720,573$ & $2,604,299$ & $3,572,508$ & $5,160,673$ \\
\hline
\end{tabular}

SHIPMENTS OF IRON ORE FROM NEW JERSEY MINES.

The shipments of iron ore from the mines in New Jersey have been as follows from 1891 to 1899 , in long tons:

Shipments of iron ore from New Jersey mines since 1891.

\begin{tabular}{|c|c|c|c|c|c|}
\hline Year. & Long tons. & Year. & Long tons. & lear. & Long tons. \\
\hline 1891. & 449,046 & 1894. & $27 \bar{\imath}, 483$ & 1897. & 239,634 \\
\hline 1892 & 469,236 & 1895. & $2 S 5,41\rceil$ & 1898. & 269,771 \\
\hline 1893. & 328,028 & $1896 \ldots$ & 262,070 & 1899. & 300,758 \\
\hline
\end{tabular}




\section{SHIPMENTS OF IRON ORE FROM THE CORNWALC MINES.}

The following table shows the shipments of iron ore, in long tons, by the Cornwall mines, in Pennsylvania, from 1891 to 1899:

Shipments of iron ore from the Cornwall mines from 1891 to 1899.

\begin{tabular}{|c|c|c|c|c|c|}
\hline Year. & Long tons. & Year. & Long tons. & Year. & Long tons. \\
\hline 1891. & 663,755 & 1894 & 371,710 & 1897 & 419, S7S \\
\hline 1892. & 634,714 & 1895. & 614,598 & $189 S_{\text {. . }}$ & 584,342 \\
\hline $1893 \ldots$ & 439,705 & $1896 \ldots$ & 463,059 & 1899. & 763,152 \\
\hline
\end{tabular}

\section{TOTAL PRODUCTION OF IRON ORE.}

Previous to 1870 no iron ore statistics for the United States are complete. The figures for 1870 and 1880 are for the census year's ending on May 31. For 1889 (also the census year) and all subsequent years they are for calendar years. The statistics since 1889 have been compiled by John Birkinbine for the United States Geological Survey.

Total production of iron ore since $18 \% 0$.

\begin{tabular}{|c|c|c|c|c|c|}
\hline Year. & Long tons. & Year. & Long tons. & Year. & Long tons. \\
\hline $1870 \ldots$ & $3,031,891$ & $1892 .$. & $16,296,666$ & $1897 \ldots \ldots$ & $17,518,046$ \\
\hline 1880 & $7,120,362$ & $1893 \ldots$ & $11, \tilde{587}, 629$ & $1898 \ldots$ & $19,433,716$ \\
\hline $1889 \ldots$ & $14,518,041$ & $1894 \ldots$ & $11, \dot{879}, 679$ & $1899 \ldots$ & $24,683,173$ \\
\hline $1890 \ldots$ & $16,036,043$ & 1895. & $15,957,614$ & & \\
\hline $1891 \ldots$ & $14,591,178$ & $1896 \ldots$ & $16,005,449$ & & \\
\hline
\end{tabular}

\section{IMPORTS OF IRON ORE.}

The following table, compiled by the Bureau of Statistics of the Treasury Department, gives the imports of iron ore into the United States during the calendar years 1897, 1898, and 1899.

Imports of iron ore in 1897, 1898, and 1899.

\begin{tabular}{|c|c|c|c|c|c|c|}
\hline \multirow{2}{*}{ District. } & \multicolumn{2}{|c|}{1897.} & \multicolumn{2}{|c|}{1898.} & \multicolumn{2}{|c|}{1899.} \\
\hline & Long tons. & value. & Long tons. & Value. & Long tons. & value. \\
\hline Baltimore . & 292,613 & $\$ 369,483$ & 143,925 & $\$ 177,764$ & 333,258 & $\$ 516,888$ \\
\hline New York & 309 & 1,272 & 139 & 440 & 120 & 703 \\
\hline Philadelphia. & 194,814 & 302,211 & 42,861 & 74,226 & 330,594 & 549,130 \\
\hline Puget Sound.. & 1,919 & 5,351 & $\ldots$ & $\cdots$ & 1,912 & 3,746 \\
\hline Vermont .. & 21 & 81 & 29 & 113 & 1,039 & 2,045 \\
\hline All other. & 294 & 514 & 139 & 700 & 7,159 & 10,335 \\
\hline Tota1. & 489,970 & 678,912 & 187,093 & 253,243 & 674,082 & $1,082,847$ \\
\hline
\end{tabular}




\section{SHIPMENTS OF CUBAN IRON ORE.}

The imports of Cuban iron ore into the United States from 1884 to 1899 , included above, were as follows. Owing to the war with Spain the mines were in operation for a part of 1898 only.

Imports of iron ore from Cuba into Linited States since 1884.

\begin{tabular}{|c|c|c|c|c|c|}
\hline Vear. & Long tons. & Year. & Long tons. & Year. & Long tons. \\
\hline $1884 \ldots$ & 21,798 & 1890. & 362,068 & 1896. & 409,883 \\
\hline 1885 & 81,106 & 1891. & 266,377 & 1897. & 397,173 \\
\hline $1886 \ldots$ & 111,710 & 1892. & 330,357 & 1898. & 164,077 \\
\hline $1887 \ldots$ & 97,711 & $1893 \ldots$ & 362,685 & $1899 \ldots$ & 368,759 \\
\hline $1888 \ldots$ & 198,048 & $1894 \ldots$ & 150,439 & & \\
\hline $1889 \ldots$ & 256,278 & $1895 \ldots$ & 386,044 & & \\
\hline
\end{tabular}

During 1899 the Juragua Iron Company, Limited, exported to the United States 161,707 long tons of iron ore from its Cuban mines, which was an increase of 77,855 tons as compared with its exports of 83,852 tons in 1898. All the ore shipped by this company in 1899 was sent to ports in the United States, as follows: Baltimore, 40 cargoes, aggregating 130,861 tons; Philadelphia, 9 cargoes, aggregating 30,846 tons; total, 49 cargoes, aggregating 161,707 tons. The production of the Juragua mines from the beginning of operations in 1884 to the close of 1899 amounted to $3,339,844$ long tons; of which 1,177 cargoes, aggregating $3,316,454$ tons, were exported to the United States; 2 cargoes, aggregating 5,932 tons, were shipped to Nova Scotia; 4 cargoes, aggregating 10,131 tons, were lost at sea, and 7,327 tons remained on hand in Cuba and in transit on December 31, 1899.

The Spanish-American Iron Company exported 207,052 tons of iron ore from Daiquiri, Cuba, in 1899, as follows: To Baltimore, 28 cargoes, aggregating 106,240 tons; to Philadelphia, 24 cargoes, aggregating 95,056 tons; to Wilmington, 2 cargoes, aggregating 5,756 tons: total shipments to the United States, 207,052 tons. No foreign shipments were made by this company in 1899 . It first commenced shipping iron ore from its Cuban mines in 1895, 74,992 long tons having been sent to the United States in that year. In 1896 the shipments to the United States amounted to $111,58 \pm$ tons, in 1897 to 152,356 tons, and - in 1898 to 80,225 tons. The same company shipped 51,537 tons of ore to foreign countries in 1897 , but in 1898 no foreign shipments were made. Its total shipments to the close of 1899 amounted to 677,746 tons.

No iron ore has been shipped from the Cuban mines of the Sigua Iron Company for several years. This company exported to the 
United States 14,022 tons in 1893 and 7,830 tons in 1892, when its first shipments were made. Shipments ceased in 1893.

The Cuban Steel Ore Company has been recently organized in Philadelphia to mine iron ore in Cuba. Its mines are situated about 50 miles west of Santiago. The company is at present pushing the work of development and the building of railroad and other connections with shipping facilities. It is expected that shipments of ore will begin before the close of the present year.

The Cuban Mining Company, has been prospecting for a year or two on the north coast of Cuba and has located and purchased 10 or 12 copper properties and several iron-ore properties. Among the iron mines is one that is represented to be a mountain of hematite ore, running from 65 per cent to $6 \mathrm{~S}$ per cent in iron, and below the Bessemer limit in phosphorus, with but a trace of sulphur. This mine; however, is about 20 miles from railroad connections.

\section{CONSUMPTION OF IRON ORE.}

We estimate our total consumption of iron ore in 1899 at $25,200,000$ long tons, against $21,193,000$ tons in $1898,17,375,000$ tons in 1897 , $15,525,000$ tons in $1896,17,253,000$ tons in $1895,12,235,000$ tons in $1894,13,480,000$ tons in $1893,17,400,000$ tons in 1892 , and $15,740,000$ tons in 1891. Our imports of iron ore in 1899 amounted to 674,082 long tons. This quantity subtracted from the quantity consumed leaves $24,525,918$ tons as the probable consumption of domestic iron ore in 1899, against $21,005,907$ tons in 1898 and $16,885,030$ tons in 1897. Our small exports of iron ore are not considered in the above estimates.

\section{PRODUCTION OF MANGANESE ORE.}

The following table, for which we are indebted to the Annual Report of the United States Geological Survey for 1899-1900, gives the production of strictly manganese ore in the United States in the calendar years from 1880 to 1899 , the statistics having been compiled for the Survey by the late Joseph D: Weeks for the years prior to 1896, and for subsequent years by John Birkinbine.

Production of manganese ore since 1880.

\begin{tabular}{|c|c|c|c|c|c|c|c|}
\hline Year. & Long tons. & Year. & Long tons. & Year. & Long tons. & Year. & Long tons \\
\hline 1880 & 5,761 & $1885 \ldots$ & 23,258 & 1890. & 25,684 & 1895 & 9,547 \\
\hline 1881. & 4,895 & $1886 \ldots$ & 30,193 & $1891 \ldots$ & 23,416 & 1896 & 10,088 \\
\hline 1882. & 4,532 & $188 \bar{t}$ & 34,524 & 1892. & 13,613 & $189 \bar{\tau}$ & 11,108 \\
\hline 1883. & 6,155 & 1888 & 29,198 & 1893. & 7,718 & 1898 & 15,957 \\
\hline 1884 & 10,780 & 1889 & 24,197 & 1894 & 6,303 & 1899 & 9,935 \\
\hline
\end{tabular}




\section{IMPORTS OF MANGANESE ORE.}

The following table, for which we are indebted to the Bureau of Statistics of the Treasury Department, gives the imports of manganese ore into the United States from 1889 to 1899:

Imports of manganese ore from 1889 to 1899.

\begin{tabular}{|c|c|c|c|c|c|}
\hline Year. & Long tons. & Year. & Long tons. & Year. & Long tons. \\
\hline $1889 \ldots$ & 4,286 & $1893 \ldots$ & 68,113 & $1897 \ldots$ & 119,961 \\
\hline $1890 \ldots \ldots$. & 34,154 & $1894 \ldots$ & 44,655 & $1898 \ldots$ & 114,885 \\
\hline $1891 \ldots$ & 28.825 & $1895 \ldots$ & 86,111 & $1899 \ldots \ldots$ & 188,349 \\
\hline $1892 \ldots$ & 58,572 & 1896. & 31,489 & & \\
\hline
\end{tabular}

The Ponupo Mining and Transportation Company owns the manganese mines at Ponupo, in the province of Santiago de Cuba, in Cuba, and a controlling interest in the Sabanillo and Moroto Railroad, running from Santiago to Ponupo. During 1899 there were mined at Ponupo and shipped to the United States about 18,000 tons of rich manganese ore. In March, 1900, about 2,000 tons were being mined and shipped monthly.

\section{IRON AND STEEL IMPORTS AND EXPORTS SINCE 1871.}

The following table, which we have compiled from the reports of the Bureau of Statistics of the Treasury Department, shows the foreign value of the imports of iron and steel and manufactures of iron and steel into the United States in the calendar years from 1871 to 1899 ; also the value of the exports of iron and steel and manufactures thereof, not including agricultural implements, from the United States for the same years:

Imports and exports 'of iron and steel since 1871.

\begin{tabular}{|c|c|c||c|c|c|}
\hline $\begin{array}{c}\text { Calendar } \\
\text { year. }\end{array}$ & $\begin{array}{c}\text { Imports- } \\
\text { value. }\end{array}$ & $\begin{array}{c}\text { Exports- } \\
\text { value. }\end{array}$ & $\begin{array}{c}\text { Calendar } \\
\text { year. }\end{array}$ & $\begin{array}{c}\text { Imports- } \\
\text { value. }\end{array}$ & $\begin{array}{c}\text { Exports- } \\
\text { value. }\end{array}$ \\
\cline { 1 - 4 } $1871 .$. & $\$ 57,866,299$ & $\$ 14,185,359$ & $1886 .$. & $\$ 41,630,779$ & $\$ 14,865,087$ \\
$1872 .$. & $75,617,677$ & $12,595,539$ & $1887 .$. & $56,420,607$ & $16,235,922$ \\
$1873 .$. & $60,005,538$ & $14,173,772$ & $1888 .$. & $42,311,689$ & $19,578,489$ \\
$1874 .$. & $37,652,192$ & $17,312,239$ & $1889 .$. & $42,027,742$ & $23,712,814$ \\
$1875 .$. & $27,363,101$ & $17,976,833$ & $1890 .$. & $44,540,413$ & $27,000,134$ \\
$1876 .$. & $20,016,603$ & $13,641,724$ & $1891 .$. & $41,983,626$ & $30,736,507$ \\
$1877 .$. & $19,874,399$ & $18,549,922$ & $1892 .$. & $33,882,447$ & $27,900,862$ \\
$1878 .$. & $18,013,010$ & $15,101,899$ & $1893 .$. & $29,656,539$ & $30,159,363$ \\
$1879 .$. & $33,331,569$ & $14,223,646$ & $1894 .$. & $20,843,576$ & $29,943,729$ \\
$1880 .$. & $80,443,362$ & $15,156,703$ & $1895 .$. & $25,772,136$ & $35,071,563$ \\
$1881 .$. & $61,555,077$ & $18,216,121$ & $1896 .$. & $19,462,561$ & $48,670,218$ \\
$1882 .$. & $67,075,125$ & $22,348,834$ & $1897 .$. & $13,835,950$ & $62,737,250$ \\
$1883 .$. & $47,506,306$ & $22,716,040$ & $1898 .$. & $12,474,572$ & $82,771,550$ \\
$1884 .$. & $37,075,122$ & $19,290,895$ & $1899 .$. & $15,800,579$ & $105,689,077$ \\
$1885 .$. & $31,144,552$ & $16,622,511$ & & & \\
\hline
\end{tabular}




\section{EXPORTS OF IRON AND STEEL.}

We are indebted to the Bureau of Statistics of the Treasury Department for the quantities and values of our exports of iron and steel in the calendar years 1898 and 1899 , as follows. These statistics are given by the Bureau with more than usual fullness.

Exports of iron and steel in 1898 and 1899.

\begin{tabular}{|c|c|c|c|c|}
\hline \multirow{2}{*}{ Article. } & \multicolumn{2}{|c|}{1898.} & \multicolumn{2}{|c|}{1899.} \\
\hline & Quantity. & Value. & Quantity. & Value. \\
\hline Pig iron, ferromanganese......... long tons. & 3,700 & $\$ 155,299$ & 13 & $\$ 816$ \\
\hline Pig iron, all other..................... do... & 249,357 & $2,547,252$ & 228,665 & $3,281,825$ \\
\hline Scrap and old............................ & 73,845 & 771,590 & 76,633 & 952,422 \\
\hline 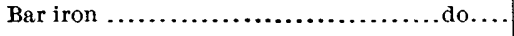 & $\overline{7}, 0 \overline{7} 4$ & 241,499 & 10,603 & 407,161 \\
\hline Steel bars or rods, other than wire rods.do. & 24,806 & 676,113 & 30,724 & $1,038,336$ \\
\hline Steel-wire rods........................ do... & 18,510 & 390,144 & 16,992 & 524,466 \\
\hline 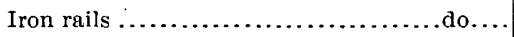 & 8,311 & 101,109 & 6,442 & 96,135 \\
\hline Steel rails............................ do.. & 293,592 & $5,838,464$ & 271,272 & $6,122,382$ \\
\hline Billets, ingots, and blooms ............ do... & 28,600 & 544,771 & 25,487 & 533,241 \\
\hline Hoop, band, and scroll ................ do. . & 1,593 & 58,731 & 2,869 & 117,002 \\
\hline Iron sheets and plates ............... do... & 4,466 & 204,170 & 6,196 & 356,791 \\
\hline Steel sheets and plates............ do... & 27,075 & 787,245 & 50,635 & $1,690,490$ \\
\hline Tin plates and terne plates............ do... & 46 & 5,510 & 133 & 14,279 \\
\hline Structural iron and steel .............. do.. & 34,038 & $1,255,451$ & 54,244 & $2,059,289$ \\
\hline 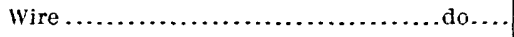 & 74,666 & $3,036,818$ & 116,317 & $5,526,930$ \\
\hline Cut nails and spikes ................. do.. & 15,735 & 641,779 & 9,974 & 482,882 \\
\hline Wire nails and spikes................ do.. & 13,714 & 574,909 & 33,517 & $1,667,976$ \\
\hline All other, including tacks............ do.. & 2,094 & 264,390 & 2,076 & 289,797 \\
\hline Car wheels ......................number.. & 21,721 & 124,069 & 26,924 & 163,323 \\
\hline Castings, not elsewhere specified......... & & 780,830 & & $1,348,133$ \\
\hline Cutlery................. & & 172,982 & & 252,156 \\
\hline Firearms..$\ldots \ldots \ldots \ldots \ldots \ldots \ldots$ & & 641,005 & & 892,620 \\
\hline Locks, hinges, and other hardware.. & & $4,308,799$ & & $5,464,913$ \\
\hline 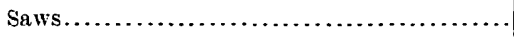 & & 232,095 & & 231,837 \\
\hline Tools, not elsewhere specified.. & & $2,404,327$ & & $3,246,780$ \\
\hline Electrical machinery ........... & & $2,523,644$ & & $3,145,838$ \\
\hline Metal-working machinery.............. & & $5,741,750$ & & $6,840,924$ \\
\hline Printing presses, and parts of ........... & & 843,688 & & $1,037,644$ \\
\hline Pumps and pumping machinery . & & $2,300,811$ & & $3,016,645$ \\
\hline Sewing machines.......... & & $3,062,471$ & & $4,103,828$ \\
\hline Shoemaking machinery............. & & 939,671 & & 961,736 \\
\hline Fire engines ....................number.. & 7 & 6,588 & 4 & 21,848 \\
\hline Locomotive engines ........................ & 576 & $5,190,782$ & 484 & $4,767,850$ \\
\hline Stationary engines....................... & 522 & 352,668 & 872 & 494,939 \\
\hline Parts of engines and boilers........... & & $1,145,508$ & ... & $1,439,363$ \\
\hline Typewriting machines, and parts of ... & & $2,0 \overline{7}, 250$ & $\cdots$ & $2,776,363$ \\
\hline All other machinery ...... & & $16,413,893$ & & $19,721,191$ \\
\hline Pipes and fittings..$\ldots \ldots \ldots \ldots \ldots \ldots \ldots \ldots \ldots \ldots \ldots \ldots$ & & $4,595,451$ & ........ & $6,763,396$ \\
\hline Safes ..........................number.. & 1,542 & 106,085 & 2,766 & 164,710 \\
\hline Scales and balances.................. & $\cdots \cdots \cdot$ & 328,940 & & 487,113 \\
\hline Stoves, ranges, and parts of ............ & & 449,007 & & 524,324 \\
\hline All other manufactures... & & $9,933,992$ & & $12,659,383$ \\
\hline Total ........ & & $82,771,550$ & & $105,689,077$ \\
\hline Agricultural implements, additional. . & $\cdots$ & $9,073,384$ & $\cdots$ & $13,594,524$ \\
\hline Iron ore.............. & 31,579 & 67,548 & 40,665 & 76,287 \\
\hline
\end{tabular}


Our exports of iron and steel first exceeded our imports in value in the calendar year 1893. In 1899, six years later, the exports of iron and steel exceeded the imports by $\$ 89,888,498$.

IMPORTS OF IRON AND STEEL.

The following table, which has been compiled from statistics supplied by the Bureau of Statistics of the Treasury Department, gives the quantity and value of our imports of iron and steel and manufactures thereof in the calendar years 1898 and 1899.

Imports of iron and steel in 1898 and 1899.

\begin{tabular}{|c|c|c|c|c|}
\hline \multirow{2}{*}{ Article. } & \multicolumn{2}{|c|}{1898.} & \multicolumn{2}{|c|}{1899.} \\
\hline & Quantity. & Value. & Quantity. & Value. \\
\hline & Longtons. & & Longtons. & \\
\hline Pig iron, spiegel, and ferromanganese ........ & 25,152 & $\$ 704,431$ & 40,372 & $\$ 1,339,405$ \\
\hline Scrap iron and scrap steel............ & 1,783 & 33,330 & 10,925 & 168,045 \\
\hline Bar iron $\ldots \ldots \ldots \ldots \ldots \ldots \ldots \ldots \ldots \ldots \ldots$ & 19,119 & 844,363 & 19,792 & 942,347 \\
\hline 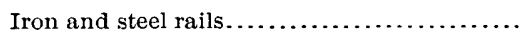 & 200 & 5,181 & 2,134 & 70,751 \\
\hline Hoop, band, and scroll iron or steel.......... & 3 & 224 & 663 & 33,392 \\
\hline Steel ingots, billets, blooms, slabs, etc........ & 10,656 & $1,008,360$ & 12,601 & $1,287,725$ \\
\hline Sheet, plate, and taggers iron or steel ........ & 2,270 & 181,021 & 7,043 & 464,297 \\
\hline 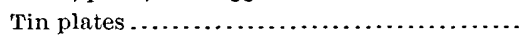 & 66,775 & $3,311,658$ & 58,915 & $3,738,567$ \\
\hline Wire rods, of iron or steel............... & 15,985 & 767,909 & 17,964 & 873,396 \\
\hline Wire and wire rope, of iron or steel..... & 2,016 & 318,553 & 2,363 & 400,952 \\
\hline 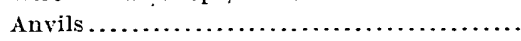 & 309 & 43,166 & 240 & 32,842 \\
\hline Chains.......................... & 117 & 15,967 & 188 & 26,564 \\
\hline Cutlery $\ldots \ldots \ldots \ldots \ldots \ldots \ldots \ldots \ldots$ & ............ & $1,059,536$ & .. & $1,40 \mathrm{~S}, 811$ \\
\hline Files, file blanks, rasps, and floats.... & & 40,492 & (......... & $4 \overline{7}, 624$ \\
\hline Firearms..$\ldots \ldots \ldots \ldots \ldots \ldots \ldots$ & $\ldots \ldots \ldots$ & 611,862 & & 798,742 \\
\hline Machinery ..... & $\cdots \cdots \cdots$ & $1,930,436$ & & $2,185,566$ \\
\hline Needles ................. & $\mid \ldots \ldots \ldots$ & 409,427 & & 366.412 \\
\hline 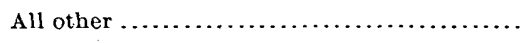 & (n......... & $1,188,656$ & …...... & $1,615,141$ \\
\hline Total ................... & 144,385 & $12,474,572$ & 173,200 & $15,800,579$ \\
\hline
\end{tabular}

Of the pig iron imported in 1898 and immediately preceding years much the larger part was spiegeleisen and ferromanganese, which pay duty as pig iron, but in 1899 the imports of these two articles and of ferrosilicon only slightly exceeded one-half of the total imports of pig iron. No cotton ties were imported in 1898 or 1899, and only 105 tons were imported in 1897.

\section{EXPORTS OF AGRICULTURAL IMPLEMENTS.}

The exports of agricultural implements in 1899 amounted to $\$ 13,594,524$, against $\$ 9,073,384$ in 1898 and $\$ 5,302,807$ in 1897 . Mowers and reapers formed more than two-thirds of the total value of the agricultural implements exported in 1898 and 1899, the exports of 
mowers and reapers in 1899 amounting to $\$ 9,739,129$. During the same year the value of the plows exported amounted to $\$ 1,779,805$ and of other agricultural implements to $\$ 2,075,589$.

\section{PRODUCTION OF PIG IRON.}

Twenty-one States made pig iron in 1899, against 19 in 1897 and 1898. In 1899 Minnesota and North Carolina again entered the list of pig-iron producing States. North Carolina has two furnaces, one of which, at Greensboro, was blown in for the first time in the first half of 1899. This furnace has since been supplied in part with iron ore from the mines near Blacksburg, South Carolina, which may be noted as probably the first step in the revival of the long-abandoned iron industry of that State. Since the opening of the new year the other furnace, at Cranberry, North Carolina, has also been blown in, making two furnaces active in that State in the spring of 1900 . Minnesota bas but one furnace.

The total production of pig iron in 1899 was 13,620,703 long tons, against $11,773,934$ tons in 1898 , an increase of $1,846,769$ tons, or nearly 16 per cent. Large as was the increase in production in 1899 as compared with the production in 1898 this increase was considerably exceeded in two late years. In 1898 we made $2,121,254$ tons more than in 1897 , and in 1895 we made $2,788,920$ tons more than in 1894 . The following table gives the total production of pig iron in the last twenty-eight years:

Total production of pig iron in United States since 1872.

\begin{tabular}{|c|c|c|c|c|c|c|c|}
\hline year. & Long tons. & Year. & Long tons. & Year. & Long tons. & Year. & Long tons. \\
\hline 1872. & $2,548,713$ & 1879 & $2,741,853$ & 1886. & $5,683,329$ & 1893. & $7,124,502$ \\
\hline 1873. & $2,560,963$ & $1880 \ldots$ & $3,835,191$ & $1887 .$. & $6,417,148$ & 1894. & $6,657,388$ \\
\hline $1874 .$. & $2,401,262$ & 1881. & $4,144,254$ & 1888. & $6,489,738$ & 1895. & $9,446,308$ \\
\hline $1875 \ldots$ & $2,023,733$ & $1882 \ldots$ & $4,623,323$ & $1889 \ldots$ & $7,603,642$ & $1896 .$. & $8,623,127$ \\
\hline $1876 \ldots$ & $1,868,961$ & 1883. & $4,595,510$ & $1890 .$. & $9,202,703$ & $1897 .$. & $9,652,680$ \\
\hline $1877 \ldots$ & $2,066,594$ & $1884, \ldots$ & $4,097,868$ & $1891 . .$. & $8,279,870$ & $1898 \ldots$ & $11,773,934$ \\
\hline $1878 . .$. & $2.301,215$ & 1885. & $4,044,526$ & 1892. & $9, \mathbf{1 5 7}, 000$ & 1899. & $13,620,703$ \\
\hline
\end{tabular}

The great decline in the production of pig iron in 1893 and 1894 was caused by the financial panic of 1893 and the subsequent serious depression in all branches of business. The decline in 1884 and 1885 and again in 1891, although not so serious as in 1893 and 1894, was also largely due to financial panics-in the former period beginning with bank failures in New York in May, 1884, and in the latter period following the Baring failure in London in November, 1890. 
The following table gives the production of pig iron by States in 1898 and 1899, in the order of their prominence in 1899:

Production of pig iron in the Lnited States in 1898 and 1899, by States.

\begin{tabular}{|c|c|c|c|c|c|}
\hline State. & 1898. & 1899. & State. & 1898. & 1899. \\
\hline & Long tons. & Long tons. & & Long tons. & Long tons. \\
\hline Pennsylvania .... & $5,537,832$ & $6,558,878$ & Michigan........ & $147,6_{7} 0$ & 134,443 \\
\hline Ohio........... & $1,986,3.58$ & $2,378,212$ & Missouri and & $49,788\}$ & 138,880 \\
\hline Illinois ..... & $1,365,898$ & $1,442,012$ & Colorado ....... & $91,222\}$ & 138,880 \\
\hline Alabama... & $1,033,676$ & $1,083,905$ & New Jersey....... & 100,681 & 127,598 \\
\hline Virginia........... & 283,274 & 365,491 & Kentucky . & 100,724 & 119,019 \\
\hline Tennessee......... & 263,439 & 346,166 & $\begin{array}{l}\text { North Carolina } \\
\text { and Georgia... }\end{array}$ & 13,762 & 17,835 \\
\hline New York.... & 228,011 & 264,346 & Connecticut ..... & 6,336 & 10,129 \\
\hline Maryland ........ & 190,974 & 234,477 & Texas ........... & 5,178 & 5,803 \\
\hline $\begin{array}{l}\text { Wisconsin a } \mathrm{n} d \\
\text { Minnesota...... }\end{array}$ & 172,781 & 203,175 & Massachusetts... & 3,661 & 2,476 \\
\hline West Virginia .... & 192,699 & $1 S 7,858$ & Total & $11,773,934$ & $13,620,703$ \\
\hline
\end{tabular}

All the above-named States increased their production of pig iron in 1899 over 1898 except Massachusetts, West Virginia, Georgia, Michigan, and Missouri. In Pennsylvania the increase was over a million tons, or more than 55 per cent of the total increase.

Pennsylvania made nearly 49 per cent of the total production of pig iron in 1899; Ohio over 17 per cent; Illinois over 10 per cent; and Alabama almost 8 per cent. None of the other States made 3 per cent.

The production of pig iron in Pennsylvania by districts in 1899 was as follows: Lehigh Valley, 427,649 tons; Schuylkill Valley, 422,347 tons; Upper Susquehanna Valley, 163,234 tons; Lower Susquehanna Valley, 560,720 tons; Juniata Valley, 112,077 tons; Shenango Valley, 937,215 tons; Allegheny County, 3,255,678 tons; Western Pennsylvania, except Allegheny County and the Shenango Valley, 676,227 tons; charcoal (whole State,) 3,731 tons; total, 6,558,878 tons.

Allegheny County produced more than one-half of the pig iron made in Pennsylvania in 1897 and 1898 and more than one-fourth of the country's production in each year, but in 1899 it lost both of these prominent positions, making slightly less than one-half the production of Pennsylvania in that year and considerably less than one-fourth the country's production. In 1898 it increased its production 359,808 tons over 1897, and in 1897 it increased its production 601,824 tons over 1896 , but in 1899 it increased its production only 232,777 tons over 1898 .

The Shenango Valley increased its production 167,538 tons in 1899 over 1898; Western Pennsylvania, outside of Allegheny County and the Shenango Valley, 153,16t tons; the Lehigh Valley, 159,381 tons; the Schuylkill Valley, 119,926 tons; the Upper Susquehanna Valley, 
66,568 tons; the Lower Susquehanna Valley, 65, 879 tons; the Juniata Valley, 55,273 tons; charcoal, 540 tons.

The production of pig iron in Ohio in 1899 by districts was as follows: Mahoning Valley, including the Leetonia furnaces, 932,165 tons; Hocking Valley, 26,297 tons; Lake counties, 464,696 tons; miscellaneous bituminous, 724,436 tons; Hanging Rock bituminous, 224,142 tons; Hanging Rock charcoal, 6,476 tons; total, 2,378,212 tons.

The increase in the Mahoning Valley in 1899 over 1898 was 162,831 tons; in the Lake counties, 75,820 tons; in the miscellaneous bituminous district, 50,637 tons; in the Hanging Rock bituminous district, 78,909 tons; in the Hanging Rock charcoal district, 125 tons; in the Hocking Valley, 23,532 tons.

The production of pig iron in the Mahoning Valley in Ohio and in the Shenango Valley in Pennsylvania in 1898 was almost exactly the same, the former producing 769,334 tons and the latter 769,677 tons. In 1899 the Mahoning Valley, including the Leetonia furnaces, made 932,165 tons and the Shenango Valley made 937,215 tons. It was a close race in these valleys in both years, with the Shenango Valley slightly ahead.

Before passing to further details the following summary may here be given: The production of Bessemer pig iron in 1899, including a small quantity made with charcoal, was $8,202,778$ tons, against $7,337,384$ tons in 1898 . The production of basic pig iron in 1899, all made with coke or mixed anthracite coal and coke, was 985,033 tons, against 785,444 tons in 1898 . The production of spiegeleisen and ferromanganese in 1899 was 219,768 tons, against 213,769 tons in 1898. The production of charcoal pig iron in 1899 was 284,766 tons, against 296,750 tons in 1898 .

PRODUCTION OF PIG IRON ACCORDING TO FUEL USED.

The production of pig iron in 1899, classified according to the fuel used, was as follows, compared with the four preceding years:

Production of pig iron according to fuel used from 1895 to 1899.

\begin{tabular}{|c|c|c|c|c|c|}
\hline Fuel used. & 1895. & 1896. & 1897. & 1898. & 1899. \\
\hline Bituminous, chiefly coke & $\begin{array}{r}\text { Long tons. } \\
7,950,068\end{array}$ & $\begin{array}{r}\text { Long tons. } \\
7,166,471\end{array}$ & $\begin{array}{l}\text { Long tons. } \\
8,464,692\end{array}$ & $\begin{array}{l}\text { Long tons. } \\
10,273,911\end{array}$ & $\begin{array}{l}\text { Long tons. } \\
11,736,385\end{array}$ \\
\hline Anthracite and coke.. & $1,214,297$ & $1,034,745$ & 911,628 & $1,180,999$ & $1,558,521$ \\
\hline Anthracite alone.. & 56,602 & 111,667 & 21,149 & 22,274 & 41,031 \\
\hline Charcoal ........... & 225,341 & 310,244 & 255,211 & 296,750 & 284,766 \\
\hline Total & $9,446,308$ & $8,623,127$ & $9,652,680$ & $11,773,934$ & $13,620,703$ \\
\hline
\end{tabular}

The steadily increasing use of coke as a blast furnace fuel is again emphasized in the above table, as is also the steadily decreasing use of unmixed anthracite. 
PRODUCTION OF BESSEMER PIG IRON.

The following table gives the production of Bessemer pig iron by States in each year from 1894 to 1899:

Production of Bessemer pig iron from 1894 to 1899, by Slates.

\begin{tabular}{|c|c|c|c|c|c|c|}
\hline State. & 1594. & 1895. & 1896. & 1897. & 1898. & 1899. \\
\hline Pennsylvania.. & $\begin{array}{r}\text { Long toms. } \\
2,494,098\end{array}$ & $\begin{array}{r}\text { Long tons. } \\
3,430,880\end{array}$ & $\begin{array}{r}\text { Long tons. } \\
2,796,884\end{array}$ & $\begin{array}{r}\text { Long tons. } \\
3,434,930\end{array}$ & $\begin{array}{r}\text { Long tons. } \\
4,040,965\end{array}$ & $\begin{array}{r}\text { Lomg tons. } \\
4 .+73,493\end{array}$ \\
\hline Ohio ......... & 589,940 & $1,031,735$ & 799,061 & $1,027,897$ & $1,570,535$ & $1,852,965$ \\
\hline Illinois.......... & 543,309 & $885 \tilde{,}, 744$ & $80 \overline{7}, 511$ & 1,017,99: & $1,210,124$ & ], 330,169 \\
\hline Maryland ....... & 2,309 & 10,916 & 74,628 & 151,105 & $1 S 6,563$ & 210,670 \\
\hline West Virginia....... & 80,781 & $141,96 \mathrm{~S}$ & 105,275 & 132,907 & 192,699 & 187,858 \\
\hline Colcrado...... & 69,524 & 55,455 & 40,193 & 6,582 & 88,701 & \\
\hline Missouri ............ & s92 & 25,938 & 3,198 & 5,000 & 30,238 & 96,364 \\
\hline $\begin{array}{c}\text { Kentucky and Ten- } \\
\text { nessee } \ldots \ldots \ldots \ldots \ldots\end{array}$ & 2,895 & 10,000 & $\cdot 600$ & & & 22,756 \\
\hline Wisconsin......... & 5,207 & 16,979 & 21,957 & 15,699 & 14,620 & \\
\hline Michigan ...... & $\ldots .$. & 1,789 & 3,497 & 3,473 & 2,939 & 14,519 \\
\hline Minnesota. & & & & & & \\
\hline New Jersey ... & & ..... & 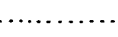 & & & 13,984 \\
\hline New York..... & 19,612 & $11,93 \mathrm{~S}$ & & & & \\
\hline North Carolina. & & 323 & 2,151 & & & \\
\hline Total. & $3,808,567$ & $5,623,695$ & $4,654,955$ & $5,795,584$ & $7,337,384$ & $8,202,778$ \\
\hline
\end{tabular}

Of the total production of Bessemer pig iron in Pennsylvania in 1899 the Lehigh Valley produced 67,103 tons; the Schuylkill Valley, 80,121 tons; the Upper Susquehanna Valley, 159,553 tons; the Lower Susquehanna Valley and the Juniata Valley, 423,357 tons; Allegheny County, $2,582,071$ tons; the Shenango Valley, 742,422 tons, and the remainder of the State, 418,866 tons: total, 4,473,493 tons.

In Ohio in 1899 the Mahoning Valley produced 633,563 tons of Bessemer pig iron; the Hanging Rock bituminous district, 81,966 tons; the Lake counties, 431,059 tons, and the remainder of the State, 706,377 tons: total, 1,852,965 tons. The Hocking Valley, did not make any Bessemer pig iron in 1898 or 1899.

\section{PRODUCTION OF BASIC PIG IRON.}

The production of basic pig iron in 1896 was 336,403 tons; in 1897 it was 556,391 tons; in 1898 it was 785,444 tons, and in 1899 it was 985,033 tons, or almost exactly 200,000 tons more than in 1898 . The production by States in these years was as follows:

Production of basic pig iron from 1896 to 1899, by States.

\begin{tabular}{|c|c|c|c|c|}
\hline State. & 1896. & 1897. & $189 S$. & 1899. \\
\hline New England, New York, and New Jersey.... & $\begin{array}{c}\text { Long tons. } \\
22,692\end{array}$ & $\begin{array}{c}\text { Long tons. } \\
79,041\end{array}$ & $\begin{array}{c}\text { Long tons. } \\
645\end{array}$ & $\begin{array}{l}\text { Long tons. } \\
\ldots \ldots\end{array}$ \\
\hline Pennsylvania, Alleghens County ............ & $168,09 \overline{5}$ & 265,548 & $37 \mathrm{~S}, 156$ & 470,818 \\
\hline Pennsylvania, other counties ....... & 51.768 & 84,520 & 204,547 & 267,760 \\
\hline Maryland, Virginia, and Alabama ............. & 73,604 & $9 \overline{7}, \overline{562}$ & $154,8 \div 9$ & 166,093 \\
\hline Ohio, Illinois, Wisconsin, and Missouri ... & 20,244 & $29,7 \div 20$ & $4 \overline{7}, 26 \overline{7}$ & 80,332 \\
\hline Total ..... & 336,403 & 556,391 & 785,444 & 985,033 \\
\hline
\end{tabular}




\section{PRODUCTION OF SPIEGEIJEISEN AND FERROMANGANESE.}

The production of spiegeleisen and ferromanganese in 1899, included in the total production of pig iron, was 219,768 tons, against 213,769 tons in 1898. The spiegeleisen and ferromanganese produced in 1899 were made in Pennsylvania, New Jersey, Maryland, Illinois, and Colorado. The production has been as follows during the last twentyeight years, in long tons:

Production of spiegeleisen and ferromanganese from 1872 to 1899.

\begin{tabular}{|c|c|c|c|c|c|c|c|}
\hline Year. & $\begin{array}{l}\text { Long } \\
\text { tons. }\end{array}$ & Year. & $\begin{array}{l}\text { Long } \\
\text { tons. }\end{array}$ & Year. & $\begin{array}{l}\text { Long } \\
\text { tons. }\end{array}$ & Year. & $\begin{array}{l}\text { Long } \\
\text { tons. }\end{array}$ \\
\hline 1872. & $\cdot 4,072$ & $1879 .$. & 12,438 & 1586. & 42,841 & 1893. & $81,11 S$ \\
\hline 1873. & 3,930 & $1880 \ldots \ldots$ & 17,503 & 1887. & 42,498 & 1894. & 120,180 \\
\hline $1874 .$. & 4,070 & $1 S \$ 1$. & 18,827 & 1888 & 48,901 & 1895 & 171,724 \\
\hline $1875 \ldots$ & 6,993 & $1882 \ldots \ldots \ldots$ & 19,610 & 1889. & 76,628 & $1896 \ldots$ & 131,940 \\
\hline $1876 .$. & 5,907 & $1883 \ldots$ & 21,941 & 1890. & 133,180 & 1897. & 173,695 \\
\hline $1877 \ldots$ & 7,897 & $1884 \ldots \ldots$ & 30,262 & $1891 .$. & 127,766 & $1898 \ldots$ & 213,769 \\
\hline $1878 \ldots$ & 9,530 & $1885 \ldots$ & 30,956 & 1892. & 179,131 & 1899. & 219,768 \\
\hline
\end{tabular}

\section{NUMBER OF FURNACES IN BLAST.}

The whole number of furnaces which were in blast at the close of 1899 was 289 , against 202 at the close of 1898,191 at the close of 1897 , 159 at the close of 1896,242 at the close of 1895 , and 185 at the close of 1894. The following table shows the number of furnaces in blast at the close of each year since 1894, classified according to the fuel used:

Number of furnaces in blast from 1894 to 1899.

\begin{tabular}{|c|r|r|r|r|r|r|}
\hline Fuel used. & 1894. & 1895. & 1896. & 1897. & 1898. & 1899. \\
\hline Bituminous coal and coke........ & 127 & 163 & 105 & 146 & 152 & 191 \\
Anthracite and anth. and coke ... & 34 & 56 & 32 & 29 & 30 & 68 \\
Charcoal .................... & 24 & 23 & 22 & 16 & 20 & 30 \\
\hline Total ..................... & 185 & 242 & 159 & 191 & 202 & 289 \\
\hline
\end{tabular}

The number of furnaces out of blast at the close of 1899 was 125 , of which a large majority will certainly never run again. At the close of 1898 there were 212 furnaces out of blast.

\section{STOCKS OF UNSOLD PIG IRON.}

Our statistics of stocks of unsold pig iron do not include pig iron sold and not removed from the furnace bank, or pig iron in the hands of creditors, or pig iron made by the owners of rolling mills or steel works for their own use, or pig iron in the hands of consumers.

The stocks of pig iron which were unsold in the hands of manufacturers or which were under their control at the close of 1899 , and were not intended for their own consumption, amounted to 63,429 tons, against 291,233 tons at the close of 1898 . Included in the stocks of 
unsold pig iron on hand on December 31, 1899, were 20 tons in the yards of the American Pig Iron Storage Warrant Company which were yet under the control of the makers, the part in these yards not under their control amounting to 4,880 tons, which quantity, added to the 63,429 tons above mentioned, makes a total of 68,309 tons which were on the market at that date, against a similar total of 415,333 tons on December 31, 1898.

The following table gives the quantity of unsold pig iron which was in the hands of manufacturers or under their control in warrant yards and elsewhere at the close of each year since 1874. Stocks in second hands in warrant yards are not included:

Stocks of unsold pig iron on hand at the close of each year since 1874 .

\begin{tabular}{|c|c|c|c|c|c|}
\hline Year. & Long tons. & $\begin{array}{l}\text { Per cent of } \\
\text { production. }\end{array}$ & Year. & Long tons. & $\begin{array}{l}\text { Per cent of } \\
\text { production. }\end{array}$ \\
\hline $1874 \ldots$ & 710,521 & 29.5 & $1887 \ldots \ldots \ldots$ & 301,913 & 4.7 \\
\hline 1875 & $679,38:$ & 33.5 & $1888 \ldots . .$. & 300,144 & 4.6 \\
\hline 1876 & 613,213 & 33.0 & 1889 & 247,679 & 3.2 \\
\hline $1877 \ldots \ldots$ & 573,528 & 28.0 & $1890 \ldots \ldots \ldots$ & 608,921 & 6.6 \\
\hline 1878 & 513,004 & 22.0 & $1891 . \ldots . \ldots . .$. & 596,333 & 7.2 \\
\hline 1879 & 126,495 & 5.0 & 1892. & 506,116 & 5.5 \\
\hline $1880 \ldots \ldots \ldots$ & $40 \overline{7} ; 730$ & 11.0 & $1893 \ldots \ldots \ldots$ & 662,068 & 9.2 \\
\hline $1881 \ldots$. & 188,300 & 5.0 & $1894 \ldots \ldots \ldots . . . .$. & $597,68 S$ & 8.9 \\
\hline $1882 \ldots$ & 383,655 & 8.0 & $1895 \ldots \ldots \ldots$ & 444,332 & 4.7 \\
\hline $1883 \ldots$ & 476,607 & 10.0 & $1896 \ldots \ldots \ldots$ & 711,649 & 8.2 \\
\hline $1884 \ldots$ & 529,464 & 13.0 & $1897 \ldots \ldots \ldots$ & 656,489 & 6.8 \\
\hline $1885 \ldots$ & 371,886 & 9.0 & $1898 \ldots \ldots \ldots$ & 291,233 & 2.4 \\
\hline $1886 \ldots$ & 225,629 & 4. 0 & $1899 \ldots \ldots$ & 63,429 & 0.46 \\
\hline
\end{tabular}

\section{CONSUMPTION OF PIG IRON IN THE LAST FIVE YEARS.}

Our consumption of pig iron in the last five years is approximately shown in the following table, the comparatively small quantity of foreign pig iron held in bonded warehouses not being considered. Warrant stocks are included in unsold stocks.

Approximate consumption of pig iron since 1895.

\begin{tabular}{|c|c|c|c|c|c|}
\hline Pig iron. & 1895. & 1896. & 1897. & $189 \mathrm{~s}$. & 1899. \\
\hline Domestic production & $\begin{array}{l}\text { Long tons. } \\
9,446,308\end{array}$ & $\begin{array}{r}\text { Long tons. } \\
8,623,127\end{array}$ & $\begin{array}{r}\text { Long tons. } \\
9,652,680\end{array}$ & $\begin{array}{l}\text { Long tons. } \\
11,773,934\end{array}$ & $\begin{array}{l}\text { Long tons. } \\
13,620,703\end{array}$ \\
\hline Imported. & 53,232 & 56,272 & 19,212 & 25,152 & 40,372 \\
\hline Stocks unsold January 1. & $661,32 S$ & 506,132 & $S 47,686$ & $874,97 \mathrm{~s}$ & 415,333 \\
\hline Total supply. & $10,160,868$ & $9,185,531$ & $10,519,578$ & $12,674,064$ & $14,076,40 \mathrm{~S}$ \\
\hline Deduct stocks December 31 & 506,132 & $84 \overline{7}, 686$ & $874,97 s$ & 415,333 & $6 \$, 309$ \\
\hline Also exports. & 26,164 & 62,071 & 262,656 & $2 \overline{5} 3,0 \overline{\bar{\imath}} \overline{\mathrm{r}}$ & $228,67 \mathrm{~s}$ \\
\hline Approximate consumption & 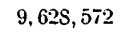 & $S, 275,7 \pi 4$ & $9,381,914$ & $12,005,674$ & 13. 779,421 \\
\hline
\end{tabular}




\section{PRODUC'TION OF PIG IRON FROM 1S95 TO 1S99, BY STATES.}

In the following table will be found a statement of the production of pig iron in the United States for the last five years, by States:

Production of pig iron from 1895 to 1899 , by States.

\begin{tabular}{|c|c|c|c|c|c|}
\hline State. & 1995. & 1596. & 1897. & 1598. & 1899. \\
\hline & Long tons. & Long tons. & Long tons. & Long tons. & Longtons. \\
\hline Massachusetts & 4,710 & 1,873 & 3,284 & 3,661 & 2,476 \\
\hline Connecticut & 5,615 & 10,187 & 8,336 & 6,336 & 10,129 \\
\hline New York. & 181,702 & 206,075 & 243,304 & 228,011 & 264,346 \\
\hline New Jersey.. & 55,502 & 59,163 & 95,696 & 100,681 & 127,598 \\
\hline Pennsylvania & $4,701,163$ & $4,024,166$ & $4,631,634$ & $5,537,832$ & $6,558,878$ \\
\hline Maryland & 10,916 & 79,472 & 193,702 & 190,974 & $234,4 \overline{7} \overline{7}$ \\
\hline Virginia .... & 346,559 & $.386,277$ & 307,610 & 283,274 & 365,491 \\
\hline North Carolina.. & 323 & 2,151 & 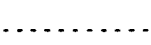 & & \\
\hline Georgia .. & 31,034 & 15,593 & 17,092 & 13,762 & 17,835 \\
\hline Alabama & 854,667 & 922,170 & 947,831 & $1,033,676$ & $1,083,905$ \\
\hline Texas ...... & - 4,682 & 1,221 & 6,175 & 5,178 & 5,803 \\
\hline West Virginia. & 141,968 & 108,569 & 132,907 & 192,699 & 187,858 \\
\hline Kentucky & 63,780 & 70,660 & 35,899 & 100,724 & 119,019 \\
\hline Tennessee & 248,129 & 248,338 & 272,130 & 263,439 & 346,166 \\
\hline Ohio .... & $1,463,789$ & $1,196,326$ & $1,372,889$ & $1,986,35 \mathrm{~s}$ & $2,378,212$ \\
\hline Illinois . . . . & $1, \mathrm{C} 06,091$ & 925,239 & $1,117,239$ & $1,365,898$ & $1,442,012$ \\
\hline Michigain ....... & 91,222 & 149,511 & $132,57 \mathrm{~S}$ & 147,640 & 134,443 \\
\hline Wisconsin & 148,400 & 158,484 & 103,909 & 172,781 & 203.175 \\
\hline Minnesota & 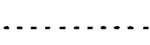 & & & & 200,170 \\
\hline Missouri... & 27,518 . & 12,548 & 23,883 & 141010 & 138890 \\
\hline Colorado . . . . . . & 58,508 & 45,104 & 6,582 & 141,010 & 100,800 \\
\hline Total. & $9,446,308$ & $8,623,127$ & $9,652,680$ & $11,773,934$ & $13,620,703$ \\
\hline
\end{tabular}

\section{PRODUCTION OF PIG IRON IN THE FIRST HALF OF 1900.}

The total production of pig iron in the first half of 1900 was $7,642,569$ long tons, against $6,289,167$ tons in the first half of 1899 and $7,331,536$ tons in the second half. The increased production in the îrst half of 1900 over the second half of 1899 was 311,033 tons. The production in the second half of 1899 and the first half of 1900 aggregated $14,974,105$ tons, or almost 15,000,000 tons. The enormous production of the first half of 1900 will not be continued in the second half, as demand has slackened. A check in production began in June, when some furnaces were banked and others were blown out.

The production of Bessemer pig iron in the first half of 1900 was $4,461,391$ long tons, against 3,788,907 tons in the first balf of 1899 and $4,413,871$ tons in the second half. 
The production of basic pig iron in the first half of 1900 , all made with coke or mixed anthracite coal and coke as fuel, was 581,868 long tons, against 482,389 tons in the first balf of 1899 and 502,644 tons in the second half.

The production of charcoal pig iron in the first half of 1900 was 167,146 long tons, against 128,485 tons in the first half of 1899 and 156,281 tons in the second half. In addition there were produced in the first six months of this year 25,042 tons of pig iron with mixed charcoal and coke.

The production of spiegeleisen and ferromanganese in the first half of 1900 was 148,102 long tons, against 104,496 tons in the first half of 1899 and 115,272 tons in the second half.

The whole number of furnaces in blast on .June 30, 1900, was 283 , against 289 on December 31, 1899. The number out of blast on June 30 was 128 , against 125 on December $31,1899$.

The stocks of pig iron which were unsold in the hands of manufacturers or their agents on June 30, 1900, amounted to 338,053 tons, against 63,429 tons on December 31,1899 . Included in the stocks of unsold pig iron on June 30 were 946 tons in the yasds of the American Pig Iron Storage Warrant Company which were yet under the control of the makers, the part in these yards not under their control amounting to 4,854 tons, which quantity, added to the 338,053 tons above mentioned, makes a total of 342,907 tons which were on the market at that date, against a similar total of 68,309 tons on December 31,1899 .

\section{LIMESTONE CONSUMED IN MAKING PIG IRON.}

The limestone consumed for fluxing purposes by the blast furnaces of the United States in the production of $13,620,703$ tons of pig iron in 1899 amounted to $6,707,435$ tons. The average consumption of limestone per ton of pig iron produced in 1899 was about half a ton. The Muirkirk furnace at Muirkirk, Maryland, which blew in late in 1899 , uses oyster shells only as a flux.

\section{PRODUCTION OF BESSEMIER STEEL.}

The production of Bessemer steel ingots in the United States in 1899 , counting a few thousand tons of direct castings as ingots, was $7,586,35 \pm$ tons, against $6,609,017$ tons in 1898 , showing an increase in 1899 of 977,337 tons, or over 14 per cent. It need scarcely be added that the production of 1899 was very much the largest in our history. It was more than twice the production of 1894 , and was almost twice the production of 1896 . Of the total production there were 3,939 tons of castings, against a similar production in 1898 of 3,539 tons. There were no Clapp-Griffiths works in operation in 1899 and only one Robert-Bessemer plant was active. Four Tropenas plants were at work in that year, and all were employed in the production of steel castings. 
The following table gives the production of Bessemer steel ingots in the United States in the last six years, including a small quantity of steel castings that was made each year:

Production of Bessemer steel ingots from 1894 to 1899.

\begin{tabular}{|c|c|c|c|c|c|}
\hline Year. & $\begin{array}{c}\text { Bessemer } \\
\text { ingots. }\end{array}$ & Year. & $\begin{array}{l}\text { Bessemer } \\
\text { ingots. }\end{array}$ & Year. & $\begin{array}{l}\text { Bessemer } \\
\text { ingots. }\end{array}$ \\
\hline & Long tons. & & Long tons. & & Long tous. \\
\hline $1894 \ldots$. & $3,571,313$ & $1896 \ldots \ldots$ & $3,919,906$ & $1898 \ldots \ldots$ & $6,609,017$ \\
\hline 1895 . & $4,909,128$ & $1897 \ldots \ldots$ & $5,475,315$ & 1899 & $7,586,354$ \\
\hline
\end{tabular}

The following table gives the production of Bessemer steel ingots in the United States in the last five years, by States:

Production of Bessemer steel ingots from 1895 to 1899, by States.

\begin{tabular}{|c|c|c|c|c|c|}
\hline State. & 1895. & 1896. & 1897. & 1898. & 1899. \\
\hline & Long tons. & Long tons. & Long tons. & Long tons. & Long tons. \\
\hline Pennsylvania & $2,978,924$ & $2,292,814$ & $3,060,049$ & $3,402,254$ & $3,968,779$ \\
\hline Ohio ........ & 719,954 & 568,535 & $1,041,541$ & $1,489,115$ & $1,679,237$ \\
\hline Illinois ....... & 866,531 & 780,105 & 943,774 & $1,105,040$ & $1,211,246$ \\
\hline Other States . - & 343,719 & 278,452 & 429,951 & 612,608 & 727,092 \\
\hline Total... & $4,909,128$ & $3,919,906$ & $5,475,315$ & $6,609,017$ & $7,586,354$ \\
\hline
\end{tabular}

It will be noticed that Pennsylvania alone made more Bessemer steel in 1899 than the whole country made as late as 1896 .

\section{PRODUCTION OF OPEN-HEARTH STEEL.}

The total production of open-hearth steel in the United States in 1899 was $2,947,316$ long tons, against 2,230,292 tons in 1898, an increase of 717,024 tons, or over 32 per cent.

The following table gives the production of open-hearth steel ingots and direct castings, by States, during the past six years:

Production of open-hearth steel from 1894 to 1899.

\begin{tabular}{|c|c|c|c|c|c|c|}
\hline State. & 1894. & 1895. & 1896. & 1897. & 1898. & 1899. \\
\hline New England ....... & $\begin{array}{r}\text { Long tons. } \\
26,204\end{array}$ & $\begin{array}{r}\text { Lûng tôno. } \\
36,733\end{array}$ & $\begin{array}{r}\text { Long tons. } \\
48,055\end{array}$ & $\begin{array}{r}\text { Cong tons. } \\
51,402\end{array}$ & $\begin{array}{r}\text { Long tono. } \\
47,381\end{array}$ & $\begin{array}{r}\text { Lông tons. } \\
57,124\end{array}$ \\
\hline 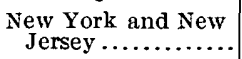 & 21,363 & 32,203 & 32,120 & 39,521 & 47,957 & 61,461 \\
\hline Pennsylvania ... & 659,969 & 904,352 & $1,009,608$ & $1,271,751$ & $1,817,521$ & $2,393,811$ \\
\hline Ohio.......... & 54,182 & 75,637 & 64,691 & 78,357 & 79,886 & 117,458 \\
\hline Illinois ... & & 49,500 & 101,832 & 120,609 & 183,103 & 246,183 \\
\hline Other States & 23,218 & 38,757 & 42,394 & 47,031 & 54,444 & 71,279 \\
\hline Total & 784,936 & $1,137,182$ & $1,298,700$ & $1,608,671$ & $2,230,292$ & $2,947,316$ \\
\hline
\end{tabular}

21 GEOL, PT $6-7$ 
Our total production of open-hearth steel ingots and castings has more than doubled since 1896, when we made 1,298,700 tons. In 1899 our open-hearth steel production came very close to that of Great Britain, which was 3,030,251 tons.

The open-hearth steel made in 1899 was produced by 76 works in 14 States-Massachusetts, Connecticut, New York, New Jersey, Pennsylvania, Maryland, Alabama, Ohio, Indiana, Illinois, Michigan, $\mathrm{W}$ isconsin, Minnesota, and Missouri.

Of the total production of open-hearth steel in 1899, 2,080,426 tons were made by the basic process and 866,890 tons by the acid process. In 1898 the production by the basic process was $1,569,412$ tons and 660,880 tons by the acid process. In 1897 the production of basic steel amounted to $1,056,043$ tons and of acid steel to 552,628 tons. In 1896 the production of basic steel amounted to 776,256 tons and of acid steel to 522,444 tons.

Sixteen works made basic open-hearth steel only in 1899,42 made acid open-hearth steel only, and 18 made both acid and basic open-hearth steel. The following table gives the production separately of basic and acid open-hearth steel, by States, in 1899:

Production of basic and acid open-hearth steel in 1899.

\begin{tabular}{|c|c|c|c|}
\hline State. & $\begin{array}{l}\text { Basie open- } \\
\text { hearth steel. }\end{array}$ & $\begin{array}{c}\text { Acid open- } \\
\text { hearth steel. }\end{array}$ & Total. \\
\hline & Long tons. & Long tons. & Long tons. \\
\hline New England $\ldots \ldots \ldots \ldots \ldots \ldots \ldots$ & 16,171 & 40,953 & 57,124 \\
\hline New York and New Jersey ........ & 26,439 & 35,022 & 61,461 \\
\hline Pennsylvania $\ldots \ldots \ldots \ldots \ldots \ldots$ & $1,716,017$ & 677,794 & $2,393,811$ \\
\hline Ohio $\ldots \ldots \ldots \ldots \ldots \ldots \ldots \ldots$ & 64,462 & 52,996 & 117,458 \\
\hline Illinois . . . . . . & 213,643 & 32,540 & 246,183 \\
\hline Other States..... & 43,694 & 27,585 & 71,279 \\
\hline Total ........... & $2,080,426$ & 866,890 & $2,947,316$ \\
\hline
\end{tabular}

The total production of direct open-hearth steel castings in 1899 , included above, amounted to 169,729 long tons, of which 39,689 tons were made by the basic process and 130,040 tons were made by the acid process. In 1898 the production of open-hearth steel castings amounted to 120,587 tons, of which 28,460 tons were made by the basic process and 92,127 tons by the acid process. The total number of open-hearth steel plants which produced castings in 1899 was 41 , and of this number 33 produced castings by the acid process only, 5 by the basic process only, and 3 by both processes. 
The following table gives the production of open-hearth steel castings by both the acid and basic processes in 1899, by States:

Production of open-hearth steel castings in 1899.

\begin{tabular}{|c|c|c|c|}
\hline State: & Acid castings. & Basic castings. & Total. \\
\hline $\begin{array}{l}\text { Massachusetts, Connecticut, New } \\
\text { York, and New Jersey............... }\end{array}$ & $\begin{array}{r}\text { Long tons. } \\
21,640\end{array}$ & Long tors. & $\begin{array}{l}\text { Long tons. } \\
\qquad 21,640\end{array}$ \\
\hline Pennsylvania ..... . & 66,117 & 3,879 & 69,996 \\
\hline Ohio and Indiana .. & 28,395 & $\cdots$ & 28,395 \\
\hline Other States & 13,888 & 35,810 & 49,698 \\
\hline Total. & 130,040 & 39,689 & 169,729 \\
\hline
\end{tabular}

\section{ṔRODUCTION OF CRUCIBLE STEEL.}

The production of crucible steel in the United States in 1899 amounted to 101,213 long tons, against 89,747 tons in $1898,69,959$ tons in $1897,60,689$ tons in $1896,67,666$ tons in $1895,51,702$ tons in 1894, and 63,613 tons in 1893 . Ten States produced crucible steel in 1899, namely, Connecticut, New York, New Jersey, Pennsylvania, Maryland, Tennessee, Ohio, Indiana, Illinois, and Wisconsin. The direct castings produced in 1899 by the crucible process amounted to 3,500 tons.

Of the total production in 1899, of 101,213 long tons of crucible steel, Connecticut and New York contributed 9,581 tons; New Jersey, 12,585 tons; Pennsylvania, 75,528 tons; the Western States, 1,713 tons, and the Southern States, 1,806 tons.

\section{PRODUCTION OF MISCELIANEOUS STEEL.}

The production of steel in the United States in 1899 by various minor processes amounted to 4,974 long tons, of which 3,944 tons were direct castings, against 3,801 tons in $1898,3,012$ tons in $1897,2,394$ tons in 1896,858 tons in $1895,4,081$ tons in $1894,2,806$ tons in 1893 , 4,548 tons in 1892 , and 4,484 tons in 1891 .

\section{TOTAL PRODUCTION OF ALI KINDS OF STEEL.}

The production of all kinds of steel in the United States in 1899 was as follows: Bessemer steel, 7,586,354 long tons; open-hearth steel, 2,947,316 tons; crucible steel, 101,213 tons; all other steel, 4,974 tons; total, $10,639,857$ tons, against $8,932,857$ tons in $1898,7,156,957$ tons in $1897,5,281,689$ tons in $1896,6,114,834$ tons in $1895,4,412,032$ tons in $1894,4,019,995$ tons in 1893 , and $4,927,581$ tons in 1892 . The total for 1899 includes 181,112 tons of Bessemer, open-hearth, crucible, and miscellaneous castings. 


\section{PRODUCTION OF BESSEMER STEEL RAILS.}

The total production of Bessemer steel rails in 1899 amounted to $2,270,585$ long tons, against $1,976,702$ tons in 1898 . Of the production in 1899 , Pennsylvania made $1,224,807$ tons, as compared with $1,053,326$ tons in 1898; Illinois and the remainder of the country made $1,045,778$ tons, against 923,376 tons in 1898 .

\section{TOTAL PRODUCTION OF RAILS.}

The production of all kinds of rails in the United States in 1899, including light and heavy rails, and street, electric, and mine rails, was 2,272,700 long tons, against 1,981,241 tons in 1898, an increase of 291,459 tons, or over 14 per cent. The production of 1899 was composed of $2,240,767$ tons of Bessemer steel rails rolled by the producers of domestic ingots, 29,818 tons of Bessemer steel rails rolled from purchased blooms and rerolled from old steel rails, 523 tons of openhearth steel rails, and 1,592 tons of iron rails. The rail tonnage in late years has been increased by the increased weight of standard sections.

Ten States made rails in 1899, namely, Pennsylvania, Maryland, Alabama, Tennessee, Ohio, Illinois, Wisconsin, Kansas, Colorado, and Wyoming. All made Bessemer steel rails except Alabama and Wyoming. The production of Bessemer steel rails outside of Pennsylvania, Illinois, Ohio, Maryland, Colorado, and Wisconsin was very small. The iron rails were made in Pennsylvania, Tennessee, Alabama, Ohio, Illinois, and Wyoming. The open-hearth steel rails were produced in Pennsylvania and Alabama.

Of the total production of rails in 1899 Pennsylvania made almost 54 per cent, against over 53 per cent in 1898 . Illinois made almost 26 per cent in 1899, against over 27 per cent in 1898. These two States made almost 80 per cent of all the rails rolled in 1899, against almost 81 per cent in 1898 .

The total production of $2,272,700$ tons of rails in 1899 was divided as follows: weighing under 45 pounds to the yard, 133,836 tons; weighing 45 pounds and less than 85 pounds, $1,559,340$ tons; weighing 85 pounds and over, 579,524 tons.

The following table gives in detail the quantity of rails of all kinds rolled in 1898 and 1899 that weighed under 45 pounds to the yard, the quantity that weighed 45 pounds and less than 85 pounds, and the quantity that weighed 85 pounds and over: 
Weight per yard of all kinds of rails produced in 1898 and 1899.

\begin{tabular}{|c|c|c|c|c|c|c|}
\hline \multirow{2}{*}{ Weight per yard. } & \multicolumn{3}{|c|}{1898.} & \multicolumn{3}{|c|}{1899.} \\
\hline & $\begin{array}{l}\text { Pennsyl- } \\
\text { vania. }\end{array}$ & $\begin{array}{l}\text { Other } \\
\text { States. }\end{array}$ & Total. & $\begin{array}{l}\text { Pennsyl- } \\
\text { vania. }\end{array}$ & $\begin{array}{l}\text { Other } \\
\text { States. }\end{array}$ & Total. \\
\hline Under 45 pounds ...... & $\begin{array}{r}\text { Long tons. } \\
67,724\end{array}$ & $\begin{array}{c}\text { Long tons. } \\
56,157\end{array}$ & $\begin{array}{r}\text { Long tons. } \\
123,881\end{array}$ & $\begin{array}{r}\text { Long tons. } \\
62,786\end{array}$ & $\begin{array}{r}\text { Long tons. } \\
71,050\end{array}$ & $\begin{array}{c}\text { Longtons. } \\
133,836\end{array}$ \\
\hline $\begin{array}{l}45 \text { pounds and less } \\
\text { than } 85 \ldots \ldots \ldots \ldots \ldots\end{array}$ & 671,232 & 732,918 & $1,404,150$ & 836,183 & 723,157 & $1,559,340$ \\
\hline 85 pounds and over... & 315,265 & 137,945 & 453,210 & 326,367 & 253,157 & 579,524 \\
\hline Total & $1,054,221$ & 927,020 & $1,981,241$ & $\mathbf{1}, 225,336$ & $1,047,364$ & $2,272,700$ \\
\hline
\end{tabular}

The rails reported to us which are known to have been rolled for street and electric railways in 1899 amounted to 154,246 tons, against 143,815 tons in 1898 , an increase of 10,431 tons. With the exception of a few hundred tons, all were steel rails. The following table gives the production of street rails in this country from 1892 to 1899 , in long tons, as reported to us. The figures for the last few years are given with some reservation, but the errors, if any, do not materially affect the general result:

Production of rails for street and electric railways from 1892 to 1899.

\begin{tabular}{|c|c|c|c|c|c|c|c|}
\hline Year. & $\begin{array}{l}\text { Long } \\
\text { tons. }\end{array}$ & Year. & $\begin{array}{l}\text { Long } \\
\text { tons. }\end{array}$ & Year. & $\begin{array}{l}\text { Long } \\
\text { tons. }\end{array}$ & Year. & $\begin{array}{l}\text { Long } \\
\text { tons. }\end{array}$ \\
\hline 1892. & 111,580 & $1894 .$. & 157,457 & $1896 \ldots$ & 145,210 & $1898 \ldots$ & 143,815 \\
\hline $1893 \ldots$ & 133,423 & $1895 \ldots \ldots \ldots$ & 163,109 & $1897 \ldots \ldots \ldots$ & 122,244 & $1899 \ldots \ldots$ & 154,246 \\
\hline
\end{tabular}

The following table gives the total production of iron and steel rails in the United States from 1892 to 1899, in long tons:

Production of rails of all kinds from 1892 to 1899.

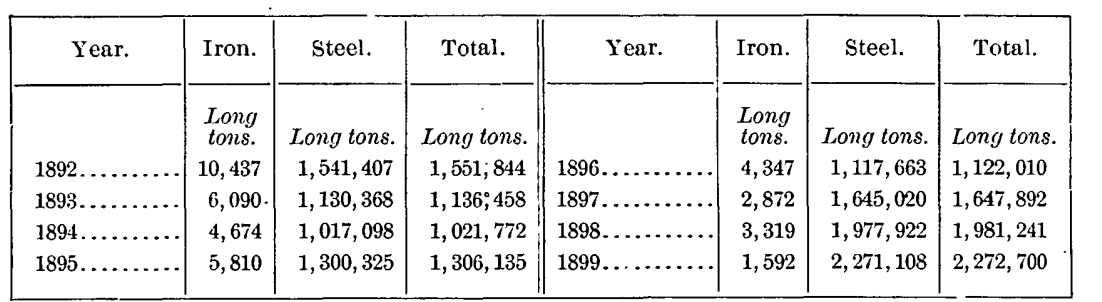

More rails were produced in 1899 than in any other year in our history. The year of next largest production was 1887, the production in that year being $2,139,640$ tons. The year of next largest production was 1898 , when $1,981,241$ tons were made. 


\section{PRODUCTION OF IRON AND STEEL STRUCTURAL SHAPES.}

Our statistics of iron and steel structural shapes embrace the production of beams, beam girders, zee bars, tees, channels, angles, and other structural forms, but they do not include plate girders made from plates. Plates are provided for under other classifications, and under the general statistics of plates are included all plates cut to specifications. Nearly all the structural shapes and plates used for structural purposes are made of steel. The total production in 1898 and 1899 , by States, was as follows:

Production of iron and steel structural shapes in 1898 and 1899.

\begin{tabular}{|r|r|r||r|r|r|}
\hline & 1898. & 1899. & States. & 1898. & 1899. \\
\hline States. & & & & \\
New Englan d, New & 27,919 & 29,604 & Ohio..................... & 21,233 & 20,941 \\
York, and New Jersey. & & Long tons. & & \\
Pennsylvania ............ & $641,726$. & 847,371 & Colorado and California.. & 7,731 & 8.057 \\
Kentucky and Alabama. & 3,588 & 304 & Total ................ & 702,197 & 906,277 \\
\hline
\end{tabular}

The increased production of structural shapes in 1899 as compared with 1898 was 204,080 long tons, or over 29 per cent. Pennsylvania made over 93 per cent of the total production in 1899, New Jersey over 3 per cent, and Ohio over 2 per.cent. No other State made 1 per cent. The total production of structural shapes in 1898 was 702,197 tons; in 1897 it was 583,790 tons; in 1896 it was 495,571 tons, and in 1895 it was 517,920 tons.

\section{PRODUC'TION OF PLATES AND SHEETS.}

The production of plate and sheet iron and steel in the United States in 1899, excluding nail plate, amounted to $1,903,505$ long tons, against $1,448,301$ tons in $1898,1,207,286$ tons in $1897,965,776$ tons in 1896 , 991,459 tons in $1895,682,900$ tons in $1894,674,345$ tons in 1893 , and 751,460 tons in 1892. Skelp iron and steel are not included in our totals with plates and sheets, but are classed with other rclled products.

\section{PRODUCTION OF WIRE RODS.}

The production of iron and steel wire rods in the United States in 1899 amounted to $1,099,376$ long tons, against $1,071,683$ tons in 1898 and 970,736 tons in 1897, showing an increase of only 27,693 tons, or a little over 2.5 per cent in 1899 over 1898 . As compared with 1897 the increase in 1899 amounted to 128,640 tons, or over 13 per cent. The production in 1899 was the largest in our history, the average production in the last three years exceeding a million tons.

Pennsylvania made the largest quantity of wire rods in 1899, with Ohio second, Illinois third, and Massachusetts fourth. Three other 
States, New Jersey, Kentucky, and Indiana, also rolled wire rods in 1899-seven States in all.

We still import considerable quantities of the finer grades of iron and steel wire rods, particularly steel wire rods, our total imports of rods amounting to 17,964 long tons in the calendar year 1899 and to 15,985 tons in 1898 . Our exports of steel wire rods amounted to 16,992 tons in 1899 and to 18,510 tons in 1898 .

\section{PRODUCTION OF WIRE NAILS.}

The production of iron and steel wire nails in the United States in 1899 amounted to $7,599,522 \mathrm{kegs}$ of 100 pounds each, as compared with $7,418,475 \mathrm{kegs}$ in 1898 , an increase of $181,047 \mathrm{kegs}$, or over 2 per cent. In 1897 the production amounted to $8,997,245 \mathrm{kegs}$, in 1896 to $4,719,860 \mathrm{kegs}$, in 1895 to $5,841,403 \mathrm{kegs}$, in 1894 to $5,681,801 \mathrm{kegs}$, and in 1893 to $5,095,945$ kegs. The wire nails produced in 1899 were manufactured by 58 works, one less than were in operation in 1898 .

The following table gives the production of wire nails, by States, in 1898 and 1899 , in kegs of 100 pounds:

Production of wire natls in 1898 and 1899, by States.

\begin{tabular}{|c|c|c|c|c|c|}
\hline States. & 1898. & 1899. & States. & 1898. & 1899. \\
\hline \multirow{3}{*}{$\begin{array}{l}\text { Mass a chuset } t \text {, } \\
\text { Rhode Island, and } \\
\text { Connecticut ....... }\end{array}$} & Kegs. & Kegs. & \multirow{8}{*}{ 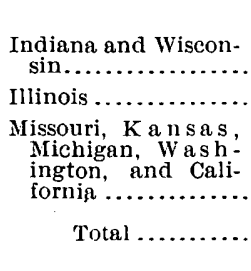 } & Kegs. & Kegs. \\
\hline & \multirow[b]{2}{*}{3} & \multirow[b]{2}{*}{176,877} & & \multirow{2}{*}{$\begin{array}{r}494,378 \\
1,394,981\end{array}$} & \multirow{2}{*}{$\begin{array}{r}511,228 \\
1,755,568\end{array}$} \\
\hline & & & & & \\
\hline $\begin{array}{l}\text { New York and New } \\
\text { Jersey ................. }\end{array}$ & \multirow{2}{*}{$\begin{array}{r}109,833 \\
3,408,504\end{array}$} & 49,603 & & & \\
\hline Pennsylvania ....... & & $2,919,645$ & & & \\
\hline Maryland and West & & & & 168,127 & 69,830 \\
\hline Virginia............ & 5,000 & 33,125 & & $7,418,475$ & $7,599,522$ \\
\hline Ohio.......... & $1,711,399$ & $2,083,646$ & & & \\
\hline
\end{tabular}

\section{PRODUCTION OF CUT' NAILS.}

Our statistics of the production of iron and steel cut nails and cut spikes in the United States do not embrace railroad and other spikes made from bar iron, wire nails of any size, or machine-made horseshoe nails. Cut spikes are included with cut nails.

The total production of cut nails in 1899 was 1,904,340 kegs of 100 pounds each, against 1,572,221 kegs in 1898, an increase of 332,119 kegs, or over $21 \mathrm{pcr}$ cent. In 1886 the maximum production of $8,160,973 \mathrm{kegs}$ was reached. In 1899 the production of wire nails exceeded the production of cut nails by $5,695,182$ kegs. In 1897 the wire-nail production exceeded the cut-nail production by $6,890,446$ kegs. 
Ten States made cut nails in 1899 . The following table shows the production of iron and steel cut nails by States from 1894 to 1899, in kegs of 100 pounds. The wire-nail production for the same years is added to the table.

Production of cut nails since 1894.

\begin{tabular}{|c|c|c|c|c|c|c|}
\hline State. & 1894. & 1895. & 1896. & $189 \overline{7}$. & 1598. & 1899. \\
\hline Pennsylvania .......... & $\begin{array}{c}\text { Kegs. } \\
1,061,931\end{array}$ & $\begin{array}{l}\text { Kegs. } \\
938,865\end{array}$ & $\begin{array}{l}\text { Kegs. } \\
646,011\end{array}$ & $\begin{array}{c}\text { Kegs. } \\
1,057,964\end{array}$ & $\begin{array}{l}\text { Kegs. } \\
768,171\end{array}$ & $\begin{array}{l}\text { Kegs. } \\
920,133\end{array}$ \\
\hline Ohio................... & 490,461 & 347,162 & 264,272 & 411,396 & 392,003 & 386,215 \\
\hline $\begin{array}{l}\text { West Virginia } \ldots \ldots \ldots \ldots \\
\text { Indiana } \ldots \ldots \ldots \ldots \ldots\end{array}$ & $\begin{array}{l}273,822 \\
125,000\end{array}$ & 347,022 & 286,210 & 290,203 & 184,942 & 178,006 \\
\hline $\begin{array}{r}\text { Massachusetts and New } \\
\text { Jersey }\end{array}$ & 166,350 & 161,888 & 137,005 & 142,021 & 127,706 & 149,700 \\
\hline Illinois . . . . . . . . . . . . & 94,462 & 81,773 & 91,145 & 34,000 & & \\
\hline $\begin{array}{l}\text { Maryland, Virginia, and } \\
\text { Kentucky .............. }\end{array}$ & 213,034 & 246,184 & 167,227 & 164,465 & 87,399 & 255,286 \\
\hline $\begin{array}{l}\text { Missouri, Colorado, Wyo- } \\
\text { ming, and California .. }\end{array}$ & & 7,000 & 24,000 & 6,750 & 12,000 & 15,000 \\
\hline Total cut nails..... & $2,425,060$ & $2,129,894$ & $1,615,870$ & $2,106,799$ & $1,572,221$ & $1,904,340$ \\
\hline Total wire nails... & $5,681,801$ & $5,841,403$ & $4,719,860$ & $8,997,245$ & $7,418,475$ & $7,599,522$ \\
\hline Grand total.. & $8,106,861$ & $7,971,297$ & $6,335,730$ & $11,104,044$ & $8,990,696$ & $9,503,862$ \\
\hline
\end{tabular}

TOTAL PRODUCTION OF ALL ROLLED IRON AND STEEL.

By the phrase rolled iron and steel we include all iron and steel rolled into finished forms, as follows: (1) All sizes of iron and steel rails; (2) plate and sheet iron and steel; (3) iron and steel plates for cut nails and cut spikes; (4) wire rods; (5) iron and steel structural shapes; (6) bar, bolt, hoop, skelp, rolled axles, and other miscellaneous forms. Hammered axles and other forgings are not included, nor muck and scrap bars, billets, tin plate and sheet bars, and other intermediate products.

The production of all iron and steel rolled into finished forms in the United States in 1899 was 10,357,397 long tons, against 8,513,370 tons in 1898 , an increase of $1,844,027$ tons, or over 21 per cent. Twentyseven States rolled either iron or steel or both iron and steel in 1899, the same number as in 1898.

It has been impossible for many years to separate rolled iron from rolled steel, but the use of puddled iron in this country has been increasing in late years, particularly in 1899 and 1900. 


\section{PRODUCTION OF ROLLED IRON AND STEEL SINCE 1857.}

The production of all kinds of iron and steel rolled into finished forms in the United States from 1887 to 1899 is given below:

Production of (ull kinds of rolled iron and steel from 1887 to 1899.

\begin{tabular}{|c|c|c|c|c|c|c|}
\hline Year. & $\begin{array}{l}\text { Iron and } \\
\text { steel rails. }\end{array}$ & $\begin{array}{l}\text { Bars, hoops, } \\
\text { axles, skelp, } \\
\text { and shapes. }\end{array}$ & Wire rods. & $\begin{array}{c}\text { Plates and } \\
\text { sheets, except } \\
\text { nail plate. }\end{array}$ & Cut nails. & Total. \\
\hline $1887 \ldots$ & $\begin{array}{l}\text { Long tons. } \\
2,139,640\end{array}$ & $\begin{array}{l}\text { Long tons. } \\
2,184,279\end{array}$ & $\begin{array}{l}\text { Long tons. } \\
\ldots \ldots \ldots \ldots\end{array}$ & $\begin{array}{l}\text { Long tons. } \\
\quad 603,355\end{array}$ & $\begin{array}{l}\text { Long tons. } \\
308,432\end{array}$ & $\begin{array}{l}\text { Long tons. } \\
5,235,706\end{array}$ \\
\hline $1888 \ldots$ & $1,403,700$ & $2,034,162$ & 279,769 & 609,827 & 289,891 & $4,617,349$ \\
\hline 1889. & $1,522,204$ & $2,374,968$ & 363,851 & 716,496 & 259,409 & $5,236,928$ \\
\hline $1890 \ldots$ & $1,885,307$ & $2,618,660$ & 457,099 & 809,981 & 251,828 & $6,022,875$ \\
\hline $1891 \ldots$ & $1,307,176$ & $2,644,941$ & 536,607 & 678,927 & 223,312 & $5,390,963$ \\
\hline $1892 \ldots$ & $1,551,844$ & $3,033,439$ & 627,829 & 751,460 & 201,242 & $6,165,814$ \\
\hline $1893 \ldots$ & $1,136,458$ & $2,491,497$ & 537,272 & 674,345 & 136,113 & $4,975,685$ \\
\hline 1894 & $1,021,772$ & $2,155,875$ & 673,402 & 682,900 & 108,262 & $4,642,211$ \\
\hline $1895 \ldots$ & $1,306,135$ & $3,005,765$ & 791,130 & 991,459 & 95,085 & $6,189,574$ \\
\hline 1896. & $1,122,010$ & $2,731,932$ & 623,986 & 965,776 & 72,137 & $5,515,841$ \\
\hline $1897 .$. & $1,647,892$ & $3,081,760$ & 970,736 & $1,207,286$ & 94,054 & $7,001,728$ \\
\hline $1898 \ldots$ & $1,981,241$ & $3,941,957$ & $1,071,683$ & $1,448,301$ & 70,188 & $8,513,370$ \\
\hline 1899. & $2,272,700$ & $4,996,801$ & $1,099,376$ & $1,903,505$ & 85,015 & $10,357,397$ \\
\hline
\end{tabular}

\section{PRODUCTION OF IRON BLOOMS AND BILLETS.}

The blooms and billets produced in forges directly from the ore in 1899 amounted to 3,142 long tons, against 1,767 tons in $1898,1,455$ tons in $1897,1,346$ tons in 1896,40 tons in 1895,40 tons in 1894, 864 tons in 1893, and 2,182 tons in 1892. All the ore blooms produced in 1898 and 1899 were made by the Chateaugay Ore and Iron Company, of Plattsburg, New York.

The iron blooms produced in forges from pig and scrap iron in 1899 , and which were for sale and not intended for the consumption of the makers, amounted to 9,932 long tons, against 6,345 tons in $1898,7,159$ tons in $1897,6,494$ tons in $1896,7,185$ tons in $1895,3,221$ tons in 1894 , and 6,605 tons in 1893 . All the pig and scrap blooms made in forges in $1895,1896,1897,1898$, and 1899, and for sale, were produced in Pennsylvania and Maryland. 


\section{PRODLCTION OF ALLEGHENY COUNTY, PENNSYLVANIA.}

The following table gives the number of blast furnaces, rolling mills, and steel works, and the production in long tons of pig iron and crude steel and of iron and steel rails and structural shapes in Allegheny County, Pennsylvania, in 1897, 1898, and 1899.

Iron and sleel statistics of Allegheny County, Pennsylvania, for 1897, 1898, and 1899.

\begin{tabular}{|c|c|c|c|}
\hline Details. & 1897. & 1898. & 1899. \\
\hline Blast furnaces.... & $\begin{array}{r}\text { Long tons. } \\
a 30\end{array}$ & $\begin{array}{r}\text { Long tons. } \\
a 30\end{array}$ & $\begin{array}{r}\text { Long tons. } \\
\text { a } 30\end{array}$ \\
\hline Production of pig iron & $2,663,093$ & $3,022,901$ & $3,255,678$ \\
\hline Rolling mills and steel works..... & $a 61$ & $a 60$ & $a 63$ \\
\hline Production of Bessemer steel .. & $2,061,837$ & $2,338,087$ & $2,606,220$ \\
\hline Production of open-hearth steel .... & 725,262 & $1,042,350$ & $1,470,271$ \\
\hline Production of crucible and other steel.. & 42,231 & 52,352 & 58,426 \\
\hline Total production of steel................. & $2,829,330$ & $3,432,789$ & $4,134,917$ \\
\hline Production of rails ............ & 533,798 & 564,085 & 606,017 \\
\hline Production of structural shapes..................... & 367,702 & 451,323 & 585,880 \\
\hline
\end{tabular}

$a$ Number.

Allegheny County produced in 1899 almost 24 per cent of the total production of pig iron in the United States; over 34 per cent of the total production of Bessemer steel ingots and castings; almost 50 per cent of the total production of open-hearth steel ingots and castings; over 57 per cent of the total production of crucible steel; almost 39 per cent of the total production of all kinds of steel; over 26 per cent of the total production of Bessemer steel rails, and over 64 per cent of the total production of structural shapes.

\section{PRODUCTION OF TIN PLA'TES.}

The duty on tin plates and terne plates provided for in the tariff act of 1890 went into effect on July 1, 1891. From that date until the close of the fiscal year ending on June 30,1897, the statistics of our production of tin plates and terne plates were regularly collected for the Treasury Department by Col. Ira Ayer, special agent. For the second half of 1897 and the year 1898 they were collected by the editor of the Metal Worker, of New York, and for 1899 they have been estimated by the editor of the Metal Worker and the editor of Tin and Terne, of Pittsburg, the difference between their estimates not being very great. From the data thus obtained we have compiled the following table in long tons of our production of tin plates and terne plates in the calendar years 1891 to 1899, the figures for 1891 being for the last six months only. The production of dipping plants is included in the figures given for each year. 
AMERICAN AND FOREIGN IRON TRADES.

Production of tin plates in the Lnited States from 1891 to 1899.

\begin{tabular}{|c|c|c|c|}
\hline Calendar year. & Long tons. & Calendar year. & Long tons. \\
\hline 1891 (last six months) & ' 999 & $1896 \ldots$ & 160,362 \\
\hline $1892 \ldots \ldots$ & 18,803 & 1897. & 256,598 \\
\hline $1893 \ldots \ldots$ & 55,182 & $1898 \ldots$ & 326,915 \\
\hline 1894. & 74,260 & $1899 \ldots$ & 397,767 \\
\hline $1895 \ldots$ & 113,666 & Total & $1,404,552$ \\
\hline
\end{tabular}

\section{IMPORTS OF TIN PLATES.}

The following table, compiled from official sources of information, gives the quantities and foreign values of the tin plates imported into the United States in the calendar years 1871 to 1899 :

Imports of tin plates from 1871 to 1899.

\begin{tabular}{|c|c|c|c|c|c|}
\hline Year. & Long tons. & Value. & Year. & Long tons. & Value. \\
\hline $1871 \ldots \ldots$ & 82,969 & $\$ 9,946,373$ & $1886 \ldots \ldots$ & 257,822 & $\$ 17,504,976$ \\
\hline 1872 & 85,629 & $13,893,450$ & $1887 \ldots \ldots$ & 283,836 & $18,699,145$ \\
\hline $1873 \ldots \ldots$ & 97,177 & $14,240,868$ & 1888 & 298,238 & $19,762,961$ \\
\hline 1874. & 79,778 & $13,057,658$ & 1889. & 331,311 & $21,726,707$ \\
\hline 1875 . & 91,054 & $12,098,885$ & $1890 \ldots$ & 329,435 & $23,670,158$ \\
\hline 1876. & 89,946 & $9,416,816$ & $1891 \ldots$ & 327,882 & $25,900,305$ \\
\hline 1877 . & 112,479 & $10,679,028$ & $1892 \ldots$ & 268,472 & $17,102,487$ \\
\hline 1878. & 107,864 & $9,069,967$ & $1893 \ldots$ & $.253,155$ & $15,559,423$ \\
\hline 1879. & 154,250 & $13,227,659$ & $1894 \ldots$ & 215,068 & $12,053,167$ \\
\hline 1380. & 158,049 & $16,478,110$ & 1895 & 219,545 & $11,482,381)$ \\
\hline 1881 & 183,005 & $14,886,907$ & $1896 \ldots$ & 119,171 & $6,140,161$ \\
\hline $1882 \ldots$ & 213,987 & $17,975,161$ & $1897 \ldots$ & 83,851 & $4,366,828$ \\
\hline 1883. & 221,233 & $18,156,773$ & 1898. & 66,775 & $3,311,658$ \\
\hline $1884 \ldots$ & 216,181 & $16,858,650$ & 1899. & 58,915 & $3,738,567$ \\
\hline $1885 \ldots$ & 228,596 & $15,991,152$ & & & \\
\hline
\end{tabular}

IRON, AND STEEL SHIPBUILDING.

In the fiscal year 1899 the United States built 91 steel vessels, against 63 iron and steel vessels in the fiscal year 1898 . The gross tonnage of the vessels built in the fiscal year 1899 was 131,379 tons, against 62,266 tons in the preceding year. Vessels for the United States Navy are not included in the figures here given, which have all been furnished by the Hon. Eugene T. Chamberlain, Commissioner of Navigation of the Treasury Department. All the vessels built in the fiscal year 1899 were built of steel. 
SUMMARY OF STATISTICS FOR 1898 AND 1899.

The statistics of the iron and steel trade and allied industries for 1898 and 1899 are summarized in the following table:

Summary of statistics for 1898 and 1899.

\begin{tabular}{|c|c|c|}
\hline Subject. & 1898. & 1899. \\
\hline Production of pig iron.$\ldots \ldots \ldots \ldots \ldots \ldots \ldots \ldots \ldots$ ong tons.. & $11,773,934$ & $13,620,703$ \\
\hline 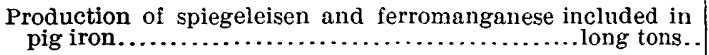 & 213,769 & 219,768 \\
\hline 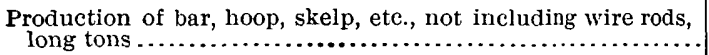 & $3,239,760$ & $4,090,524$ \\
\hline Production of iron and steel structural shapes ....... long tons.. & 702,197 & 906,277 \\
\hline Production of iron and steel wire rods....................... & $1,071,683$ & $1,099,376$ \\
\hline 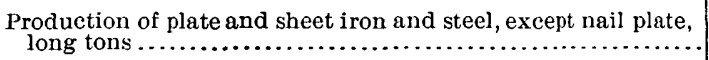 & $1,448,301$ & $1,903,505$ \\
\hline 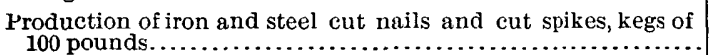 & $1,572,221$ & $1,904,340$ \\
\hline Production of iron and steel wire nails.... kegs of 100 pounds.. & $7,418,475$ & $7,599,522$ \\
\hline 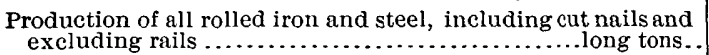 & $6,532,129$ & $8,084,697$ \\
\hline $\begin{array}{l}\text { Production of all rolled iron and steel, including both cut nails } \\
\text { and rails.................................................... }\end{array}$ & $8,513,370$ & $10,357,397$ \\
\hline Production of Bessemer steel rails.................... do... & $1,976,702$ & $2,270,585$ \\
\hline Production of open-hearth steel rails..................... & 1,220 & 523 \\
\hline 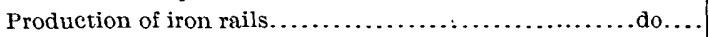 & 3,319 & 1,592 \\
\hline 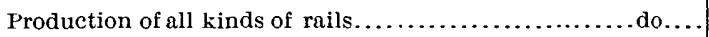 & $1,981,241$ & $2,272,700$ \\
\hline Production of street rails, included above $\ldots . . . . . . .$. do.... & 143,815 & 154,246 \\
\hline Production of Bessemer steel............................. & $6,609,017$ & $7,586,354$ \\
\hline Production of open-hearth steel........................... & $2,230,292$ & $2,947,316$ \\
\hline Production of crucible steel $\ldots \ldots \ldots \ldots \ldots \ldots \ldots \ldots \ldots$ do $\ldots \ldots$ & 89,747 & 101,213 \\
\hline Production of blister and patented steel............... do... & 3,801 & 4,974 \\
\hline 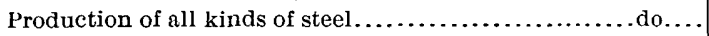 & $8,982,857$ & $10,639.857$ \\
\hline Production of ore, pig, and scrap blooms for sale ........ do... & 8,112 & 13,074 \\
\hline Production of tin plates and terne plates...$\ldots \ldots \ldots \ldots$. do... & 326,915 & 397,767 \\
\hline Value of imports of iron and steel....................... & $\$ 12,474,572$ & $\$ 15,800,579$ \\
\hline 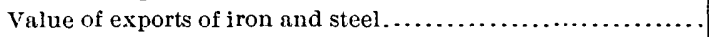 & $\$ 82,771,550$ & $\$ 105,689,077$ \\
\hline Production of iron ore........................ long tons.. & $19,433,716$ & $24,683,173$ \\
\hline 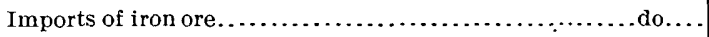 & 187,093 & 674,082 \\
\hline 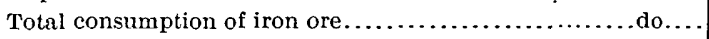 & $21,193,000$ & $25,200,000$ \\
\hline Production of all kinds of coal $\ldots \ldots \ldots \ldots \ldots \ldots \ldots \ldots$ do.... & $196,405,953$ & $226,553,564$ \\
\hline Shipments of Pennsylvania anthracite $\ldots \ldots \ldots \ldots \ldots \ldots$ do..... & $41,899,751$ & $47,665,204$ \\
\hline 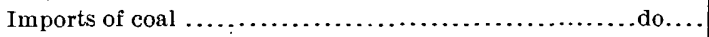 & $1,273,706$ & $\mathbf{1}, 393,640$ \\
\hline 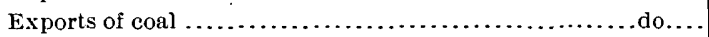 & $4,503,405$ & $5,752,150$ \\
\hline Iron and steel ships built in the year ended June $30 . \ldots$ & 63 & 91 \\
\hline Miles of new ralload completed............. & 3,199 & a 4,600 \\
\hline
\end{tabular}

a About. 


\section{AVERAGE MONTHLY PRICES OF STEEL RAILS AT MILLS IN PENNSYLVANIA FROM 1868 TO 1899.}

The following table of average monthly prices of steel rails has been compiled by the American Iron and Steel Association from weekly quotations and are per ton of 2,240 pounds.

A ierage monthly prices of steel rails at Pennsylvania mills since 1868.

\begin{tabular}{|c|c|c|c|c|c|c|c|c|c|c|c|c|c|}
\hline Year. & Jan. & Feb. & Mar. & Apr. & May. & June. & July. & Aug. & Sept. & Oet. & Nov. & Jer. & $\begin{array}{l}\text { Aver- } \\
\text { age. }\end{array}$ \\
\hline 1568 & $\$ 165.00^{\prime}$ & $\$ 16$ & $\$ 174.00$ & $\$ 172.00$ & $\$ 165.00$ & $\$ 162.50$ & $\$ 150.00$ & $\$ 150.00$ & $\$ 150.00$ & $\$ 150.00$ & $\$ 148.00$ & $\frac{147}{4}$ & $\$ 158.50$ \\
\hline 1869 & $145.00^{\prime}$ & 143.25 & 135.00 & 134.00 & 130.25 & 128.00 & 130.00 & 130.00 & 130.00 & 130.50 & 130.25 & 120.00 & 132.25 \\
\hline 1870 & 110.00 & 110.00 & 108.50 & 107.00 & 106.00 & 109.25 & 110.00 & 110.00 & 108.75 & 101.50 & 102.50 & 98.00 & 106.75 \\
\hline 1871 & 95.00 & 96.00 & 106.00 & 95.00 & 103.00 & 104.00 & 103.75 & 104.00 & 106.00 & 105.75 & 105.25 & 106.50 & $10^{\prime} 2.50$ \\
\hline 1872 & 104.50 & 104.00 & 104.25 & 111.50 & 110.00 & 113.00 & 114.50 & 115.25 & 114.00 & 113.50 & 118.00 & 120.75 & 112.00 \\
\hline 1873 & 121.00 & 120.00 & 122.50 & 120.25 & 120.00 & 121.75 & 121.75 & 121.75 & 118.00 & 120.00 & 120.00 & 120.00 & $1: 0.50$ \\
\hline 1874 & 117.50 & 117.50 & 115.00 & 98.67 & 98.33 & 96.25 & 91.00 & 89.25 & 78.25 & 78.25 & 5.67 & 75.67 & 94.25 \\
\hline 1875 & 71.00 & 71.00 & 71.00 & 69.00 & 69.00 & 69.00 & 69.00 & 69.00 & 69.00 & 67.00 & 66.00 & 65.00 & 68.75 \\
\hline 1876 & 00 & 65.00 & 62.00 & 62.00 & 62.00 & 60.00 & 59.00 & 59.00 & 56.00 & 54.00 & 53.00 & 52.00 & 59.25 \\
\hline 1877 & 49.00 & 49.00 & 49.00 & 49.00 & 47.25 & 46.50 & 45.25 & 44.75 & 44.00 & 42.25 & 40.50 & 40.50 & 45.50 \\
\hline 1878 & 00 & 41.50 & 41.50 & 42.00 & 43.50 & 43.00 & 43.50 & 42.50 & 42.50 & 42.50 & 42.00 & 41.00 & 42.25 \\
\hline 1879 & 0 & 42.00 & 43.00 & 42.50 & 42.00 & 43.00 & 44.00 & 48.00 & 50.00 & 55.00 & 61.00 & 67.00 & 48.25 \\
\hline 1880 & 75.00 & 85.00 & 82.00 & 75.00 & 65.00 & 63.75 & 62.50 & 63.75 & 61.25 & 60.00 & 59.00 & 58.00 & 67.50 \\
\hline 1881 & 60.00 & 62.00 & 62.50 & 63.00 & 63.00 & 60.00 & 61.00 & 60.00 & 60.00 & 60.00 & 61.50 & 60.00 & 61.13 \\
\hline 1882 & 58.00 & 55.00 & 54.00 & 52.75 & 48.75 & 48.25 & 48.00 & 47.00 & 45.00 & 44.25 & 42,00 & 39.00 & 48.50 \\
\hline 1883 & 00 & 39.50 & 39.00 & 38.50 & 38.00 & 38.00 & 38.00 & 38.00 & 37.50 & 37.00 & 35.00 & 34.50 & 37.75 \\
\hline 1884 & 34.00 & 34.00 & 34.00 & 34.00 & 33.00 & 32.00 & 30.00 & 28.00 & 27.00 & 28.00 & 28.00 & 27.00 & 30.75 \\
\hline 1885 & 00 & 27.00 & 26.50 & 26.00 & 27.00 & 27.25 & 27.25 & 7.25 & 29.00 & 30.50 & 33.00 & 34.50 & 28.50 \\
\hline 1856 & 34.50 & 34.50 & 34.50 & 34.50 & 34.50 & 34.50 & 34.50 & 34.25 & 34.00 & 34.00 & 34.50 & 36.00 & 34.50 \\
\hline 1857 & 50 & 39.50 & 39.50 & 39.25 & 39.00 & 39.00 & 38.50 & 7.00 & 36.00 & 34.25 & 2.50 & 32.00 & 37.08 \\
\hline 1888 & 31.50 & 31.50 & 31.50 & 31.50 & 31.00 & 30.00 & 30.00 & 29.00 & 28.50 & 28.00 & 27.50 & 28.00 & 29.83 \\
\hline 1889 & 27.50 & 27.50 & 27.50 & 27.50 & 27.00 & 27.50 & 28.00 & 28.00 & 29.50 & 32.00 & 34.00 & 35.00 & 29.25 \\
\hline 1890 & 35.25 & 35.00 & 34.00 & 33.50 & 31.35 & 31.50 & 31.50 & 31.25 & 30.50 & 30.00 & 29.00 & 28.50 & 31.75 \\
\hline 1891 & 29.00 & 30.00 & 30.00 & 30.00 & 30.00 & 30.00 & 30.00 & 30.00 & 30.00 & 30.00 & 30.00 & 30.00 & 29.92 \\
\hline 1892 & 30.00 & 30.00 & 30.00 & 30.00 & 30.00 & 30.00 & 30.00 & 30.00 & 30.00 & 30.00 & 30.00 & 30.00 & 30.00 \\
\hline 1893 & 29.00 & 29.00 & 29.00 & 29.00 & 29.00 & 29.00 & 29.00 & 29.00 & 29.00 & 27.50 & 25.00 & 24.00 & 28.12 \\
\hline 1894 & 24.00 & 24.00 & 24.00 & 24.00 & 24.00 & 24.00 & 24.00 & 24.00 & 24.00 & 24.00 & 24.00 & 24.00 & 24.00 \\
\hline 1895 & 22.00 & 22.00 & 22.00 & 22.00 & 22.00 & 22.00 & 24.00 & 24.00 & 28.00 & 28.00 & 28.00 & 28.00 & 24.33 \\
\hline 1896 & 28.00 & 28.00 & 28.00 & 28.00 & 28.00 & 28.00 & 28.00 & 28.00 & 28.00 & 28.00 & 28.00 & 28.00 & 28.00 \\
\hline 1897 & 25.00 & 20.00 & 18.00 & 18.00 & 18.00 & 18.00 & 18.00 & 18.00 & 18.00 & 18.00 & 18.00 & $\quad 18.00$ & 18. 75 \\
\hline 1898 & 18.00 & 18.00 & 18.00 & 18,00 & 18.00 & 17.50 & 17.00 & 17.50 & 17.50 & 17.50 & 17.50 & 17.50 & 17.62 \\
\hline 1899 & 18.50 & 20.25 & 24.80 & 25.75 & 25.20 & 27.25 & 28.25 & 31.00 & 32.50 & 34.00 & 35.00 & 35.00 & 28.12 \\
\hline
\end{tabular}




\section{AVERAGE PRICES PER LONG TON OF NO. 1 FOUNDRY PIG IRON AT PHILADELPHIA SINCE 1860.}

The following table of average monthly prices of No. 1 foundry pig iron at Philadelphia has been compiled by the American Iron and Steel Association from weekly quotations, per ton of 2,240 pounds.

A veruge inonthly prices of No. 1 frundry pig irom al Philadelphia since 1860.

\begin{tabular}{|c|c|c|c|c|c|c|c|c|c|c|c|c|c|}
\hline Year! & Jan. & Feb. & Mar. & Apr. & May. & June. & July. & . & Sept. & Oet. & Nov. & De & $\begin{array}{l}\text { Aver- } \\
\text { age. }\end{array}$ \\
\hline 1860 & $\$ 23.00$ & $\$ 23.00$ & $\$ 23.37$ & $\$ 22.37$ & $\$ 22.75$ & $\$ 22.75$ & $\$ 22.75$ & $\$ 22.50$ & $\$ 22.25$ & $\$ 22.37$ & $\$ 22.75$ & $\$ 22.50$ & $\$ 22.75$ \\
\hline 1861 & 22.12 & 21.75 & 21.25 & 21.87 & 21.12 & 20.50 & 19.87 & 18.75 & 18.75 & 18.62 & 18.87 & 19.62 & 20.25 \\
\hline 1862 & 20.00 & 20.75 & 20.75 & 21.50 & 21.50 & 22.75 & 24.00 & 24.37 & 24.50 & 25.25 & 30.50 & 31.12 & .88 \\
\hline 1863 & 32.00 & 33.25 & 35.50 & 36.00 & 34.75 & 33.50 & 32.75 & 31.75 & 33.00 & 35.75 & 41.12 & 43.50 & 35.25 \\
\hline 1864 & 43.17 & 48.62 & 50.12 & 54.50 & 57.25 & 57.62 & 69.12 & 73.62 & 72.25 & 63.75 & 61.50 & 59.12 & .25 \\
\hline $186 \bar{~}$ & 58.12 & 53.12 & 50.37 & 45.50 & 39.12 & 35.00 & 35.67 & 40.12 & 44.33 & 49.87 & 51.00 & 50.75 & 46.12 \\
\hline 1866 & 50.37 & 49.00 & 46.12 & 41. 75 & 41.37 & 43.87 & 46.50 & 47.25 & 48.12 & 48.75 & 49.50 & 49.50 & \\
\hline 1867 & 48.75 & 46.50 & 44.75 & 41.00 & 42. 75 & 43.00 & 43.33 & 44.00 & 44.50 & 44.50 & 43.75 & 42.12 & 44.12 \\
\hline 1868 & 38.67 & 36.75 & 37.87 & 38. 33 & 37.00 & 37.00 & 38.17 & 39.50 & 40.17 & 41.37 & 42.87 & 43. & \\
\hline 1869 & 42.00 & 40.25 & 41.50 & 40.00 & 39.50 & 40.87 & 41.62 & 41.12 & 40.75 & 40.50 & 39.75 & 39.50 & .63 \\
\hline 1870 & 36.25 & 34.50 & 34.50 & 33.25 & 33.25 & 32.50 & 32.75 & 33.50 & 33.25 & 32.25 & 31.50 & 31.25 & .25 \\
\hline 1871 & 30.50 & 30.87 & 34.25 & 35.37 & 35.50 & 35.00 & 35.75 & 36.00 & 36.50 & 36.67 & 37.25 & 37.25 & 35. 12 \\
\hline 1872 & 37.00 & 40.75 & 47.00 & 49.50 & 49.50 & 53.37 & 51.33 & 52.75 & 53.87 & 53.33 & 51.25 & 47. & 48.88 \\
\hline 1873 & 45.17 & 48.00 & 48.37 & 47.75 & 46.00 & 45.00 & 43.75 & 43.50 & 42.50 & 38.00 & 33.00 & 32.50 & 42.75 \\
\hline 1874 & 32.00 & 32.60 & $\$ 2.00$ & 32.00 & 31.50 & 31.50 & 31.50 & 31.00 & 29.50 & 29.00 & 26.25 & 24.0 & 30.25 \\
\hline 1875 & 25.67 & 26.50 & 27.00 & 27.00 & 26.00 & 26.00 & 26.00 & 26.00 & 25.00 & 24.00 & 23.75 & 23. & 25.50 \\
\hline 1876 & 23.25 & 23.00 & 23.00 & 22.75 & 22.00 & 22.00 & 22.00 & 2.00 & 21.75 & 21.75 & 21.50 & 21.2 & 22.25 \\
\hline 1877 & 20.75 & 20.00 & 20.00 & 19.50 & 19.00 & 18.75 & 18.25 & 8.00 & 18.25 & 18.50 & 18.00 & 18. & .88 \\
\hline 1878 & 18.50 & 18.50 & 18.50 & 18.50 & 18.00 & 17.25 & 17.25 & 7.50 & 17.50 & 17.00 & 16.50 & 17. & 17.63 \\
\hline 1879 & 17.25 & 17.50 & 17.87 & 18.00 & 18.50 & 18.75 & 19.25 & 20.75 & 24.25 & 30.00 & 28.00 & 30. & 21.50 \\
\hline 1850 & 40.00 & 41.00 & 37.50 & 31.00 & 25.00 & 23.00 & 23.50 & 25.00 & 23.25 & 23.00 & 24.50 & 25.00 & 28.50 \\
\hline 1881 & 25.00 & 25.50 & 26.00 & 25.00 & 25.00 & 24.00 & 24.50 & 24.50 & 25.25 & 25.50 & 25.75 & 26. & 25.12 \\
\hline 1882 & 26.00 & 26.00 & 25.75 & 25.50 & 25.50 & 25.50 & 25.50 & 25.50 & 26.00 & 26.25 & 26.00 & 25.75 & 25.75 \\
\hline 1883 & 25.00 & 24.50 & 24.00 & 23.50 & 22.00 & 21.00 & 21.50 & 22.00 & 22.00 & 21.50 & 21.00 & 21.0 & 22.38 \\
\hline 1854 & 20.50 & 20.50 & 20.50 & 20.00 & 20.00 & 20.00 & 20.00 & 19.50 & 19.50 & 19.50 & 19.25 & 18.50 & 19.88 \\
\hline 1885 & 18.00 & 18.00 & 18.00 & 18. & 17.87 & 17.75 & 17.75 & 17.75 & 18.00 & 18.25 & 18.25 & 18.2 & 18.00 \\
\hline 1886 & 18.50 & 18.50 & 18.75 & 18.50 & 18.50 & 18.25 & 18.25 & 8.25 & 18.50 & 19.00 & 19.50 & 20.00 & 18. 71 \\
\hline $18 S 7$ & 21.50 & 21.50 & 21.00 & 20.7 & 20.85 & 21.00 & 21.00 & 21.00 & 21.00 & 20.50 & 20.50 & 20.5 & 92 \\
\hline 1888 & 21.00 & 20.75 & 20.50 & 19. 75 & 18.50 & 18.00 & 18.00 & 8.00 & 18.00 & 18.00 & 18.00 & 18.00 & .88 \\
\hline 1889 & 18.00 & 18.00 & 18.00 & 17.35 & 17.00 & 17.25 & 17.25 & 17.50 & 17.50 & 17.50 & 18.50 & 19. & 17.75 \\
\hline 1890 & 19.90 & 19.50 & 19.25 & 18.25 & 18.00 & 18.00 & 18.00 & 18.00 & 18.00 & 18.00 & 18.00 & 18.00 & 18.40 \\
\hline 1891 & 17.50 & 17.50 & 17.50 & 17.50 & 17.50 & 17.50 & 17.50 & 17.50 & 17.50 & 17.75 & 17.50 & 17.50 & 17.52 \\
\hline 1892 & 17.50 & 17.00 & 16.50 & 16.00 & 15.95 & 15.69 & 15.06 & 15.00 & 15.00 & 15.00 & 15.17 & 15.12 & 15.75 \\
\hline $1 S 93$ & 14. S0 & 14.75 & 14.69 & $14.5 \mathrm{~s}$ & 14.85 & 15.00 & 15.00 & 14.50 & 14.33 & 14.20 & 13.75 & 13.75 & 14.52 \\
\hline 1894 & 13.37 & 13.00 & 13.00 & 12.60 & 12.50 & 12.50 & 12.50 & 12.50 & 12.50 & 12.50 & 12.50 & 12.50 & 12.66 \\
\hline 1895 & 12.08 & 12.00 & 12.06 & 12.00 & 12.06 & 12.50 & 13. S0 & 13.75 & 14.20 & 14.50 & 14.44 & 13.85 & 13.10 \\
\hline 1896 & 13.56 & 13.50 & 13.45 & 13.25 & 12.83 & 12.75 & 12.75 & 12.75 & 12.50 & 12.56 & $12 . S 1$ & 12.75 & 12.95 \\
\hline 1897 & 12.75 & 12.75 & 12.60 & 12.12 & 11.87 & 11.75 & 11.75 & 11.75 & 11.87 & 12.00 & 12.00 & 12.00 & 12.10 \\
\hline 1898 & 12.00 & 11.87 & 11.75 & 11.75 & 11.65 & 11.44 & 11.25 & 11. 30 & 11.50 & 11.70 & 11.75 & 11.97 & 11.66 \\
\hline 1899 & 12.12 & 13.25 & 16.00 & 16.50 & 16.60 & 18. 62 & 20.37 & 21. 70 & 23.50 & 23.70 & 25.00 & 25.00 & 19. 36 \\
\hline
\end{tabular}




\section{PROGRESS OF THE CANADIAN IRON TRADE.}

We are glad to record a marked improvement in the iron and steel industries of Canada in 1899. Relatively these industries made as much progress in that year as those of the United States and of European countries. New iron and steel enterprises were undertaken, chiefly in the Province of Ontario, and the production of works that had alieady been established was increased. Canada now bids fair to become in a few years an important contributor to the world's supply of iron and steel, and possibly it may contribute in a still larger degree to its supply of iron ore and coal.

The progress of the Canadian iron and steel industries in 1899, as in the two preceding years, has been greatly promoted by the action of the Dominion Parliament in enacting the bounty act of June 29, 1897, which provided for the payment of liberal bounties by the Dominion government to the manufacturers of "steel ingots, puddled iron bars, and pig iron," $\$ 3$ per ton to be paid "on steel ingots manufactured from ingredients of which not less than 50 per cent of the weight thereof consists of pig iron made in Canada;" $\$ 3$ per ton "on puddled iron bars manufactured from pig iron made in Canada;" $\$ 3$ per ton "on pig iron on the proportion produced from Canadian ore," and $\$ 2$ per ton "on pig iron on the proportion produced frow foreign ore." By the terms of the act referred to these bounties were to terminate on April 23, 1902, but an act of the Dominion Parliament dated August 11, 1899, extended the bounty provisions to June 30, 1907, provided, however, that they should be annually reduced after April 23, 1902, as follows: from that date to June 30, 1903, 90 per cent shall be paid; from July 1, 1903, to June $30,1904,75$ per cent; from July 1, 1904, to June 30, 1905, 55 per cent; from July 1, 1905, to June 30, 1906, 35 per cent; from July 1, 1906, to June 30, 1907, 20 per cent. The act of August 11, 1899, also provided that, "notwithstanding anything in the statutes of 1897 , or in this act, no bounty shall be paid under this act on steel ingots made from puddled iron bars manufactured in Canada." The bounty provisions of the act of June 29, 1897, were held to have come into force on April 23, 1897. We have quoted from the official copy of the acts of the Dominion Parliament.

PRODUCTION OF IRON AND STEEL IN CANADA.

The production of pig iron in the Dominion of Canada was first ascertained from the manufacturers by the American Iron and Steel Association for the year 1894, when it amounted to 44,791 long tons. In 1895 the production amounted to 37,829 tons, in 1896 to 60,030 tons, in 1897 to 53,796 tons, and in 1898 to 68,755 tons. In 1899 the production of all kinds of pig iron, including spiegeleisen and ferro- 
manganese, was 94,077 tons, of which 17,796 tons were charcoal and 76,281 tons were charcoal and coke mixed and coke pig iron. The production of Bessemer pig iron in 1899, included in the figures given above, was 5,120 tons, and the production of basic pig iron was 22,666 tons-all made by one company. The total production of pig iron in 1899 as compared with that of 1898 shows an increase of 25,322 tons. The consumption of limestone by the Canadian furnaces in 1899 amounted to 50,726 tons, against 30,302 tons in 1898 .

Canada produced spiegeleisen and ferromanganese for the first time in the spring of 1899, the Mineral Products Company, of Hillsboro, New Brunswick, having blown in its leased furnace at Bridgeville, Nova Scotia, on May 11 of that year. A mixture of charcoal and coke was used for fuel. The furnace did not run continuously on spiegeleisen and ferro-manganese in 1899, about one-fourth of its production during the year being ordinary pig iron.

On December 31, 1899, the unsold stocks of pig iron in Canada which were in the hands of the manufacturers or their agents amounted to 9,932 tons, as compared with 9,979 tons on December 31, 1898, 20,265 tons on December 31, 1897, 29,320 tons on December 31, 1896, and 17,800 tons on December 31, 1895. Of the unsold pig iron on hand on December 31, 1899, a little less than one-half was charcoal pig iron, the remainder being coke.

On December 31,1899 , there were 9 completed blast furnaces in the Dominion, and of this number 4 were in blast and 5 were out of blast. On December 31, 1898, there were also 9 completed furnaces, of which 3 were in blast and 6 were out of blast.

The production of Bessemer and of basic and acid open-hearth steel ingots and castings in 1899 was 22,000 long tons, against 21,540 tons in 1898. . Of the total production of open-hearth steel in 1899 about one-third was made by the acid process. The production of iron rails and open-hearth steel rails in 1899 amounted to 835 long tons, against 600 tons in 1898; structural shapes, 2,899 tons, against 1,565 tons in 1898; cut nails made by rolling mills and steel works having cut-nail factories connected with their plants, $235,981 \mathrm{kegs}$ of 100 pounds, against 152,688 kegs in 1898; plates and sheets, 2,220 tons, against about 1,000 tons in 1898; all other rolled products, excluding muck and scrap bars, blooms, billets, sheet bars, etc., 94,153 tons, against s0,322 tons in 1898. Changing the cut nail production from kegs to long tons, the total quantity of all kinds of iron and steel rolled into finished products in the Dominion in 1899, excluding muck and scrap bars, billets, and other intermediate products, amounted to 110,642 tons, against 90,303 tons in $1898,77,021$ tons in $1897,75,043$ tons in 1896 , and 66,402 tons in 1895 .

The total number of completed rolling mills and steel works in Canada on December 31, 1899, was 16 . Of this number at least 3 were idle during the whole of 1899 . 
THE WORLD'S PRODUCTION OF IRON ORE ANI COAT.

The following table gives the production of iron ore and coal in all countries in 1899, or for the latest year for which complete statistics are available. Coal is the principal fuel used in the production of iron and steel, and hence deserves a place in this table. Long tons of $2,2 \pm 0$ pounds are used in giving the production of the United States, Great Britain, Canada, Cuba, India, Natal, New South Wales and other Australasia, and "other countries," and metric tons of 2,204 pounds are used for all other countries, the latter being used as the equivalent of long tons in ascertaining the total production of all countries. As far as possible the statistics given have been obtained from official sources.

The world's production of iron ore and coul.

\begin{tabular}{|c|c|c|c|c|c|c|}
\hline \multirow{2}{*}{ Countries } & \multicolumn{3}{|c|}{ Iron ore. } & \multicolumn{3}{|c|}{ Coal and lignite. } \\
\hline & Years. & Tons. & Per cent. & Years. & Tons. & Por cent. \\
\hline United States ... & 1899 & $24,683,173$ & 29.47 & 1899 & $226,553,564$ & 31. 54 \\
\hline Great Britain . ......... & 1898 & $14,176,938$ & 16.93 & 1899 & $220,085,303$ & 30.65 \\
\hline $\begin{array}{l}\text { Germany and Luxem- } \\
\text { burg } \ldots \ldots \ldots \ldots\end{array}$ & 1899 & $17,989,665$ & 21.48 & 1899 & $135,824,427$ & 18. 91 \\
\hline France........ & 1898 & $4,731,394$ & 5.65 & 1898 & $32,356,104$ & 4.50 \\
\hline Belgium ....... & 1898 & 217,370 & .26 & 1899 & $21,917,740$ & 3.05 \\
\hline Austria-Hungary .. & 1898 & $3,400,485$ & 4.06 & 1898 & $37,786,963$ & 5.26 \\
\hline Russia.... & 1897 & $4,107,470$ & 4.91 & 1898 & $12,862,033$ & 1. 79 \\
\hline Sweden ............... & 1898 & $2,302,914$ & 2. 75 & 1898 & 236,277 & .03 \\
\hline Spain ...... & 1899 & $9,234,302$ & 11.03 & 1899 & $2,742,389$ & .38 \\
\hline Italy .... & 1898 & 201,260 & .24 & 1898 & 341,327 & .05 \\
\hline Canada. . & 1899 & 68,891 & .08 & 1899 & $4,397,367$ & .61 \\
\hline Cuba...... & 1899 & 368,759 & .44 & $\cdots .$. & & $\cdots$ \\
\hline South African Republic & $\cdots \cdot$ & & $\cdots$ & 1898 & $1,938,424$ & .27 \\
\hline Natal. & & & $\ldots$ & 1898 & 387,811 & .05 \\
\hline India..... & 1897 & 43,314 & .05 & 1898 & $4,136,813$ & .58 \\
\hline Greece .... & 1898 & 485,159 & .58 & 1898 & 17,310 & $\cdots$ \\
\hline New South Wales. & 1897 & 234 & 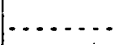 & 1899 & $4,597,028$ & .64 \\
\hline Other Australasia & ....... & …..... & $\cdots \cdots$ & 1898 & $1,601,968$ & .22 \\
\hline Japan .... & 1896 & 27,421 & .03 & 1897 & $5,647,751$ & .79 \\
\hline Algeria.... & 1898 & 473,569 & .50 & 1898 & 200 & $\ldots$ \\
\hline Other countries (about) & 1899 & $1,234,855$ & 1.48 & 1899 & $4,849,380$ & .68 \\
\hline Total. & & $83,747,173$ & 100.00 & & $718,280,179$ & 100.00 \\
\hline
\end{tabular}

21 GEOL, PT $6-8$ 


\section{THE WORLD'S PRODUC'TION OF PIG IRON AND STEEL.}

In the following table is given the production of pig iron and steel in all countries in 1899 or in the most recent year for which statistics have been received. English tons of 2,240 pounds are used for Great Britain, Canada, the United States, and "other countries" and metric tons of 2,204 pounds for all other countries, metric tons being used as the equivalent of English tons in ascertaining the total production for all countries. The statistics of steel production for the United States, Great Britain, France, Belgium, Austria-Hungary, Russia and Finland, Sweden, Spain, and Canada embrace ingots and direct castings, but for Germany and Luxemburg and Italy complete ingot statistics are not available and the statistics for finished steel have been used.

The world's production of pig iron and steel.

\begin{tabular}{|c|c|c|c|c|c|c|}
\hline \multirow{2}{*}{ Country. } & \multicolumn{3}{|c|}{ Pig iron. } & \multicolumn{3}{|c|}{ Steel. } \\
\hline & Years. & Tons. & Per cent. & Years. & Tons. & Per cent. \\
\hline United States. & 1899 & $13,620,703$ & 34.56 & 1899 & $10,639,857$ & 39.25 \\
\hline Great Britain $\ldots \ldots \ldots$ & 1899 & $9,305,319$ & 23.61 & 1899 & $5,000,000$ & 18.44 \\
\hline $\begin{array}{l}\text { Germany and Luxem- } \\
\text { burg } \ldots \ldots \ldots\end{array}$ & 1899 & $8,142,017$ & 20.66 & 1899 & $6,290,434$ & 23.20 \\
\hline France ........ & 1899 & $2,567,388$ & 6.51 & 1899 & $1,554,354$ & 5. 73 \\
\hline Belgium .... & 1899 & $1,036,185$ & 2.63 & 1899 & 729,920 & 2. 70 \\
\hline A ustria-Hungary ....... & 1898 & $1,427,240$ & 3.62 & 1896 & 880,696 & 3.25 \\
\hline Russia and Finland. & 1898 & $2,222,469$ & 5.64 & 1898 & $1,494,000$ & 5.51 \\
\hline Sweden.... & 1898 & 531,766 & 1.35 & 1898 & 265,121 & .98 \\
\hline Spain & 1899 & 295,840 & .75 & 1899 & 122,954 & .45 \\
\hline Italy . . . & 1897 & 8,393 & .02 & 1898 & 94,667 & .35 \\
\hline Canada... & 1899 & 94,077 & .24 & 1899 & 22,000 & .08 \\
\hline Japan ........ & 1897 & 57,678 & .15 & & & - \\
\hline Other countries (about) & 1899 & 100,925 & .26 & 1899 & 15,997 & .06 \\
\hline Total. & & $39,410,000$ & 100.00 & & $27,110,000$ & 100.00 \\
\hline
\end{tabular}

In tables that we have heretofore published we have given the world's probable total production of pig iron in 1800 as 825,000 long tons; in 1830 as $1,825,000$ tons; in 1850 as $4,750,000$ tons; in 1870las $11,900,000$ tons; in 1880 as $17,950,000$ tons; in 1890 as $27,157,000$ tons; and now we give the total production in 1899 as $39,410,000$ tons, of which the United States made 34.56 per cent.

From the most trustworthy sources of information that were available more than twenty years ago we then estimated the world's production of steel in 1878 as amounting to 3,021,000 long tons. Subsequently we estimated the production in 1889 as amounting to $10,948,000$ tons. The figures given in the above table show that the production had increased in 1899 to $27,110,000$ tons, of which the United States made 39.25 per cent. 


\section{THE WORLD'S GREAT PIG IRON PRODUCERS.}

For the United States and Great Britain long tons of 2,240 pounds are used in the table below, and for France, Germany and Luxemburg, and Russia metric tons of 2,204 pounds are used.

Production of pig iron, by principal countries, since 1869.

\begin{tabular}{|c|c|c|c|c|c|}
\hline Year. & United States. & Great Britain. & $a$ Germany. & France. & $b$ Russia. \\
\hline & Long tons. & Long tons. & Metric tons. & Metric tons. & Metric tons. \\
\hline 1869. & $1,711,287$ & $5,445,757$ & $1,409,429$ & $1,380,965$ & . \\
\hline 1870. & $1,665,179$ & $5,963,515$ & $1,391,124$ & $1,178,114$ & 359,531 \\
\hline 1871. & $1,706,793$ & $6,627,179$ & $1,563,682$ & 859,641 & 359,253 \\
\hline 1872 & $2,548,713$ & $6,741,929$ & $1,988,395$ & $1,217,838$ & 399,253 \\
\hline $1873 \ldots$ & $2,560,963$ & $6,566,451$ & $2,240,575$ & $1,381,626$ & 384,221 \\
\hline 1874 & $2,401,262$ & $5,991,408$ & $1,906,263$ & $1,415,897$ & 380,219 \\
\hline 1875 . & $2,023,733$ & $6,365,462$ & $2,029,389$ & $1,448,272$ & 427,182 \\
\hline 1876. & $1,868,961$ & $6,555,997$ & $1,846,345$ & $1,435,212$ & 441,433 \\
\hline $1877 \ldots$ & $2,066,594$ & $6,608,664$ & $1,932,725$ & $1,506,827$ & 398,238 \\
\hline $1878 \ldots$ & $2,301,215$ & $6,381,051$ & $2,147,641$ & $1,521,274$ & 417,239 \\
\hline 1879 & $2,741,853$ & $5,995,337$ & $2,226,587$ & $1,400,286$ & 432,636 \\
\hline 1880 & $3,835,191$ & $7,749,233$ & $2,729,038$ & $1,725,293$ & 448,411 \\
\hline $1881 \ldots$ & $4,144,254$ & $8,144,449$ & $2,914,009$ & $1,886,350$ & 469,476 \\
\hline 1882. & $4,623,323$ & $8,586,680$ & $3,380,806$ & $2,039,067$ & 462,530 \\
\hline 1883. & $4,595,510$ & 8,$529 ; 300$ & $3,469,719$ & $2,069,430$ & 481,679 \\
\hline 1884 & $4,097,868$ & $7,811,727$ & $3,600,612$ & $1,871,537$ & 509,519 \\
\hline 1885 & $4,044,526$ & $7,415,469$ & $3,687,434$ & $1,630,648$ & 527,536 \\
\hline $1886 \ldots$ & $5,683,329$ & $7,009,754$ & $3,528,658$ & $1,516,574$ & 532,104 \\
\hline 1887 & $6,417,148$ & $7,559,518$ & $4,023,953$ & $1,567,622$ & 612,447 \\
\hline 1888 & $6,489,738$ & $7,998,969$ & $4,337,121$ & $1,683,349$ & 683,315 \\
\hline 1889 & $7,603,642$ & $8,322,824$ & $4,524,558$ & $1,733,964$ & 740,067 \\
\hline 1890 & $9,202,703$ & $7,904,214$ & $4,658,451$ & $1,962,196$ & 926,482 \\
\hline 1891. & $8,279,870$ & $7,406,064$ & $4,641,217$ & $1,897,387$ & $1,004,923$ \\
\hline 1892 & $9,157,000$ & $6,709,255$ & $4,937,461$ & $2,057,258$ & $1,071,813$ \\
\hline 1893. & $7,124,502$ & $6,976,990$ & $4,986,003$ & $2,003,096$ & $1,148,937$ \\
\hline 1894 & $6,657,388$ & $7,427,342$ & $5,380,038$ & $2,069,714$ & $1,332,505$ \\
\hline 1895 & $9,446,308$ & $7,703,459$ & $5,465,414$ & $2,003,868$ & $1,452,380$ \\
\hline $1896 \ldots$ & $8,623,127$ & $8,659,681$ & $6,372,575$ & $2,339,537$ & $1,612,069$ \\
\hline $1897 \ldots$ & $9,652,680$ & $8,796,465$ & $6,881,466$ & $2,484,191$ & $1,868,671$ \\
\hline 1898. & $11,773,934$ & $8,609,719$ & $7,312,766$ & $2,525,075$ & $2,222,469$ \\
\hline $1899 .$. & $13,620,703$ & c $9,305,319$ & $d 8,142,017$ & $d 2,567,388$ & ........... \\
\hline
\end{tabular}

$a$ Including Luxemburg. $\quad b$ Includes Finland. $\quad c$ British Iron Trade Association. $d$ Provisional.

Austria and Hungary annually produce over a million tons of pig iron, Belgium about a million tons, Sweden about half a million tons, and Spain about 300,000 tons. See table on the preceding page. 


\section{PRODUCTION OF BESSEMER STEEL INGOTS AND RAILS IN THE UNITED STATES AND GREAT BRITAIN.}

The production of Bessemer steel ingots and of Bessemer steel rails in the United States from 1867 to 1899 and in Great Britain as far back as statistics are available was as follows, in long tons.

Production of Bessemer steel ingots and rails in the United States and Great Britain from 1867 to 1899.

\begin{tabular}{|c|c|c|c|c|}
\hline \multirow{2}{*}{ Year. } & \multicolumn{2}{|c|}{ United States. } & \multicolumn{2}{|c|}{ Great Britain. } \\
\hline & Ingots. & Rails. & Ingots. & Rails. \\
\hline $1867 \ldots$ & $\begin{array}{l}\text { Long tons. } \\
\qquad 2,679\end{array}$ & $\begin{array}{l}\text { Long tons. } \\
\quad 2,277\end{array}$ & $\begin{array}{l}\text { Long tons. } \\
\ldots \ldots \ldots\end{array}$ & $\begin{array}{c}\text { Long tons. } \\
\ldots \ldots\end{array}$ \\
\hline 1868. & 7,589 & 6,451 & 110,000 & $\ldots \ldots$ \\
\hline 1869. & 10,714 & 8,616 & 160,000 & \\
\hline 1870. & 37,500 & 30,357 & 215,000 & \\
\hline $1871 \ldots$ & 40,179 & 34,152 & 329,000 & \\
\hline $1872 .$. & 107,239 & 83,991 & 410,000 & . \\
\hline 1873. & 152,368 & 115,192 & 496,000 & \\
\hline $1874 .$. & 171,369 & 129,414 & 540,000 & - \\
\hline 1875. & 335,283 & 259,699 & 620,000 & . \\
\hline $1876 .$. & 469,639 & 368,269 & 700,000 & 400,000 \\
\hline $1877 \ldots$ & 500,524 & 385,865 & 750,000 & 508,400 \\
\hline 1878. & 653,773 & 491,427 & 807,527 & 622,390 \\
\hline 1879. & 829,439 & 610,682 & 834,511 & 520,231 \\
\hline 1880. & $1,074,262$ & 852,196 & $1,044,382$ & 732,910 \\
\hline $1881 \ldots$ & $1,374,247$ & $1,187,770$ & $1,441,719$ & $1,023,740$ \\
\hline 1882 & $1,514,687$ & $1,284,067$ & $1,673,649$ & $1,235,785$ \\
\hline $1883 .$. & $1,477,345$ & $1,148,709$ & $1,553,380$ & $1,097,174$ \\
\hline $1884 \ldots$ & $1,375,531$ & 996,983 & $1,299,676$ & 784,968 \\
\hline 1885. & $1,519,430$ & 959,471 & $1,304,127$ & 706,583 \\
\hline 1886. & $2,269,190$ & $1,574,703$ & $1,570,520$ & 730,343 \\
\hline $1887 \ldots$ & $2,936,033$ & $2,101,904$ & $2,089,403$ & $1,021,847$ \\
\hline $1888 \ldots$ & $2,511,161$ & $1,386,277$ & $2,032,794$ & 979,083 \\
\hline $1889 \ldots$ & $2,930,204$ & $1,510,057$ & $2,140,791$ & 943,048 \\
\hline $1890 \ldots$ & $3,688,871$ & $1,867,837$ & $2,014.843$ & $1,019,606$ \\
\hline $1891 .$. & $3,247,417$ & $1,293,053$ & $1,642,005$ & 662,676 \\
\hline $1892 \ldots$ & $4,168,435$ & $1,537,588$ & $1,500,810$ & 535,836 \\
\hline $1893 \ldots$ & $3,215,686$ & $1,129,400$ & $1,493,454$ & 579,386 \\
\hline 1894 & $3,571,313$ & $1,016,013$ & $1,535,384$ & 598,530 \\
\hline $1895 \ldots$ & $4,909,128$ & $1,299,628$ & $1,535,225$ & 604,338 \\
\hline $1896 .$. & $3,919,906$ & $1,116,958$ & $1,815,842$ & 817,476 \\
\hline $1897 \ldots$ & $5,475,315$ & $1,644,520$ & $1,884,155$ & 921,131 \\
\hline $1898 \ldots$ & $6,609,017$ & $1,976,702$ & $1,759,386$ & 751,591 \\
\hline $1899 .$. & $7,586,354$ & $2,270,585$ & $1,825,074$ & 838,148 \\
\hline
\end{tabular}




\section{PRODUCTION OF OPEN-HEARTH STEEL INGOTS IN THE} UNITED STATES AND GREAT BRITAIN.

The following table gives, in long tons, the production of openhearth steel ingots in the United States from 1869 to 1899 , and in Great Britain from 1873 to 1899 .

Production of open-hearth steel ingots in the United States and Great Britain from 1869 to 1899.

\begin{tabular}{|c|c|c|c|c|c|}
\hline Year. & United States. & Great Britain. & Year. & United States. & Great Britain. \\
\hline & Long tons. & Long tons. & & Long tons. & Long tons. \\
\hline 1869 & 893 & & 1885. & 133,376 & 583,918 \\
\hline 1870. & 1,339 & & 1886. & 218,973 & 694,150 \\
\hline 1871. & 1,785 & & 1887. & 322,069 & 981,104 \\
\hline 1872. & 2,679 & ( & 1888. & 314,318 & $1,292,742$ \\
\hline 1873 & 3,125 & $7 \overline{7}, 500$ & 1889 & 374,543 & $1,429,169$ \\
\hline 1874 & 6,250 & 90,500 & 1890 & 513,232 & $1,564,200$ \\
\hline 1875 & 8,080 & 88,000 & $1891 \ldots$ & 579,753 & $1,514,538$ \\
\hline $1876 \ldots$ & 19,187 & 128,000 & 1892 & 669,889 & $1,418,830$ \\
\hline 1877. & 22,349 & 137,000 & 1893. & 737,890 & $1,456,309$ \\
\hline $1878 \ldots$ & 32,255 & 175,500 & 1894. & 784,936 & $1,575,318$ \\
\hline $1879 .$. & 50,259 & 175,000 & 1895 & $1,137,182$ & $1,754,737$ \\
\hline $1880 \ldots$ & 100,851 & 251,000 & 1896 & $1,298,700$ & $2,317,555$ \\
\hline $1881 \ldots$ & 131,202 & 338,000 & 1897 & $1,608,671$ & $2,601,806$ \\
\hline $1882 \ldots$ & 143,341 & 436,000 & 1898 & $2,230,292$ & $2,806,600$ \\
\hline 1883. & 119,356 & 455,500 & 1899 & $2,947,316$ & $3,030,251$ \\
\hline $1884 \ldots$ & 117,515 & 475,250 & & & \\
\hline
\end{tabular}




\section{PRODUCTION OF ALL KINDS OF STEEL IN THE UNITED STATES AND GREAT BRITAIN.}

The following table gives, in long tons, the production of all kinds of crude steel in the United States from 1867 to 1899, and in Great Britain from 1873 to 1899 . For the United States we have added to the Bessemer and open-hearth production the actual production of crucible and miscellaneous steel, and for Great Britain an estimated production of crucible and miscellaneous steel.

Production of all kinds of steel in the United States and Great Britain from 1867 to 1899.

\begin{tabular}{|c|c|c|c|c|c|}
\hline Year. & United States. & Great Britain. & Year. & United States. & Great Britain. \\
\hline & Long tons. & Long tons. & & Long tons. & Long tons. \\
\hline 1867 & 19,643 & 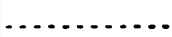 & $1884 \ldots \ldots$ & $1,550,879$ & $1,854,926$ \\
\hline 1868. & 26,786 & & $1885 \ldots \ldots$ & $1,711,920$ & $1,968,045$ \\
\hline 1869. & 31,250 . & - & $1886 \ldots \ldots$ & $2,562,503$ & $2,344,670$ \\
\hline 1870. & 68,750 & & $1887 \ldots \ldots$ & $3,339,071$ & $3,150,507$ \\
\hline 1871. & 73,214 & - & $1888 \ldots$ & $2,899,440$ & $3,405,536$ \\
\hline 1872. & 142,954 & & 1889. & $3,385,732$ & $3,669,960$ \\
\hline 1873. & 198,796 & 653,500 & 1890. & $4,277,071$ & $3,679,043$ \\
\hline 1874. & 215,727 & 710,500 & 1891. & $3,904,240$ & $3,256,543$ \\
\hline 1875. & 389,799 & 788,000 & 1892. & $4,927,581$ & $3,019,640$ \\
\hline 1876. & 533,191 & 908,000 & 1893. & $4,019,995$ & $3,049,763$ \\
\hline $1877 \ldots$ & 569,618 & 967,000 & $1894 \ldots$ & $4,412,032$ & $3,210,702$ \\
\hline 1878. & 731,977 & $1,063,027$ & 1895 & $6,114,834$ & $3,389,962$ \\
\hline 1879. & 935,273 & $1 ; 089,511$ & $1896 \ldots$ & $5,281,689$ & $4,233,397$ \\
\hline 1880 & $1,247,335$ & $1,375,382$ & $1897 \ldots$ & $7,156,957$ & $4,585,961$ \\
\hline 1881 & $1,588,314$ & $1,859,719$ & 1898. & $8,932,857$ & $4,665,986$ \\
\hline 1882 & $1,736,692$ & $2,189,649$ & $1899 \ldots$ & $10,639,857$ & $5,000,000$ \\
\hline 1883 & $1,673,535$ & $2,088,880$ & & & \\
\hline
\end{tabular}




\section{GOLD AND SILVER.}

\section{PRODUCTION.}

The product of gold in the United States for the calendar year 1899 amounted to $3,437,210$ fine ounces, worth $\$ 71,053,400$, according to the statistics collected by the Director of the Mint. This is greater than the product of any other year in our history. The greatest increase was from Alaska, especially from the Cape Nome district. It is probable that this district will continue as a large producer. Large increases in gold production are also reported from Colorado, Utah, and South Dakota.

The product of silver amounted to $54,764,500$ ounces, with a coining value of $\$ 70,806,626$, or with a commercial value of $\$ 32,858,700$. The total silver product showed only a very slight gain over the previous year. The greatest increase came from Montana, which showed a decrease in gold production. Utah also increased quite markedly, while Arizona and Idaho declined sufficiently to offset the increases.

The production by States is given in the tables below:

Product of gold and silver in the United States from 1792.

[The estimates for 1792 to 1873 are by Dr. R. W. Raymond, United States Mining Commissioner, und since by the Director of the Mint.]

\begin{tabular}{|c|c|c|c|}
\hline Year. & Total. & Gold. & Silver. \\
\hline April 2,1792 , to July $31,1834 \ldots$ & $\$ 14,000,000$ & $\$ 14,000,000$ & Small. \\
\hline July 31,1834 , to Dec. $31,1844 \ldots$ & $7,750,000$ & $7,500,000$ & $\$ 250,000$ \\
\hline $1845 \ldots \ldots \ldots \ldots \ldots \ldots \ldots \ldots \ldots$ & $1,058,327$ & $1,008,327$ & 50,000 \\
\hline 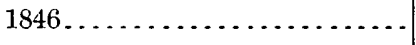 & $1,189,357$ & $1,139,357$ & 50,000 \\
\hline $1847 \ldots \ldots \ldots$ & 939,085 & 889,085 & 50,000 \\
\hline $1848 \ldots \ldots \ldots \ldots \ldots \ldots$ & $10,050,000$ & $10,000,000$ & 50,000 \\
\hline 1849 & $40,050,000$ & $40,000,000$ & 50,000 \\
\hline 1850 . & $50,050,000$ & $50,000,000$ & 50,000 \\
\hline $1851 \ldots . .$. & $55,050,000$ & $55,000,000$ & 50,000 \\
\hline 1852 & $60,050,000$ & $60,000,000$ & 50,000 \\
\hline 1853 & $65,050,000$ & $65,000,000$ & 50,000 \\
\hline $1854 \ldots \ldots$ & $60,050,000$ & $60,000,000$ & 50,000 \\
\hline $1855 \ldots . .$. & $55,050,000$ & $55,000,000$ & 50,000 \\
\hline
\end{tabular}


Product of gold and silver in the United States from 1792-Continued.

\begin{tabular}{|c|c|c|c|}
\hline Year. & Total. & Gold. & Silver. \\
\hline $1856 \ldots \ldots \ldots \ldots$ & $\$ 55,050,000$ & $\$ 55,000,000$ & $\$ 50,000$ \\
\hline $1857 \ldots \ldots \ldots$ & $55,050,000$ & $55,000,000$ & 50,000 \\
\hline $1858 \ldots . . . \ldots$ & $50,500,000$ & $50,000,000$ & 500,000 \\
\hline 1859 & $50,100,000$ & $50,000,000$ & 100,000 \\
\hline$\ldots \ldots$. & $46,150,000$ & $46,000,000$ & 150,000 \\
\hline $1861 \ldots \ldots \ldots \ldots \ldots \ldots$ & $45,000,000$ & $43,000,000$ & $2,000,000$ \\
\hline$\ldots \ldots \ldots$ & $43,700,000$ & $39,200,000$ & $4,500,000$ \\
\hline 1863. & $48,500,000$ & $40,000,000$ & $8,500,000$ \\
\hline $1864 \ldots \ldots \ldots$ & $57,100,000$ & $46,100,000$ & $11,000,000$ \\
\hline 1865. & $64,475,000$ & $53,225,000$ & $11,250,000$ \\
\hline 1866. & $63,500,000$ & $53,500,000$ & $10,000,000$ \\
\hline 1867 & $65,225,000$ & $51,725,000$ & $13,500,000$ \\
\hline $1868 \ldots \ldots \ldots \ldots$ & $60,000,000$ & $48,000,000$ & $12,000,000$ \\
\hline $1869 \ldots \ldots \ldots$ & $61,500,000$ & $49,500,000$ & $12,000,000$ \\
\hline$\ldots \ldots \ldots \ldots$ & $66,000,000$ & $50,000,000$ & $16,000,000$ \\
\hline 1871 . & $66,500,000$ & $43,500,000$ & $23,000,000$ \\
\hline $1872 \ldots$. & $64,750,000$ & $36,000,000$ & $28,750,000$ \\
\hline 1873 & $71,750,000$ & $36,000,000$ & $\quad 35,750,000$ \\
\hline $1874 \ldots \ldots \ldots \ldots$ & $70,800,000$ & $33,500,000$ & $37,300,000$ \\
\hline $1875 \ldots \ldots \ldots$ & $65,100,000$ & $33,400,000$ & $31,700,000$ \\
\hline $1876 \ldots \ldots \ldots \ldots \ldots$ & $78,700,000$ & $39,900,000$ & $38,800,000$ \\
\hline $1877 \ldots \ldots \ldots \ldots \ldots \ldots$ & $86,700,000$ & $46,900,000$ & $39,800,000$ \\
\hline 1878. & $96,400,000$ & $51,200,000$ & $45,200,000$ \\
\hline 1879 . & $79,700,000$ & $38,900,000$ & $40,800,000$ \\
\hline 1880 & $75,200,000$ & $36,000,000$ & $39,200,000$ \\
\hline 1881. & $77,700,000$ & $34,700,000$ & $43,000,000$ \\
\hline 1882. & $79,300,000$ & $32,500,000$ & $46,800,000$ \\
\hline 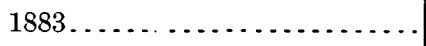 & $76,200,000$ & $30,000,000$ & $46,200,000$ \\
\hline $1884 \ldots \ldots \ldots \ldots \ldots$ & $79,600,000$ & $30,800,000$ & $48,800,000$ \\
\hline $1885 \ldots \ldots \ldots \ldots \ldots \ldots$ & $83,400,000$ & $31,800,000$ & $51,600,000$ \\
\hline 1886 & $86,000,000$ & $35,000,000$ & $51,000,000$ \\
\hline 1887. & $86,350,000$ & $33,000,000$ & $53,350,000$ \\
\hline 1888 & $92,370,000$ & $33,175,000$ & $59,195,000$ \\
\hline 1889: & & & \\
\hline & $9 \bar{\tau}, 446,000$ & $32,800,000$ & $64,646,000$ \\
\hline Census .... & $99,282,866$ & $32,886,180$ & $66,396,686$ \\
\hline $1890 \ldots \ldots . . . \ldots$ & $103,309,645$ & $32,845,000$ & $70,464,645$ \\
\hline $1891 \ldots \ldots \ldots$ & $108,591,565$ & $33,175,000$ & $75,416,565$ \\
\hline 1892. & $115,009,150$ & $33,000,000$ & $\$ 2,099,150$ \\
\hline 1893. & $113,525,757$ & $35,950,000$ & $77,575,757$ \\
\hline $1894 \ldots \ldots \ldots \ldots$ & $103,500,000$ & $39,500,000$ & $64,000,000$ \\
\hline $1895 \ldots \ldots \ldots \ldots$ & $118,661,000$ & $46,610,000$ & $72,051,000$ \\
\hline 1896 & $129,157,236$ & $53,088,000$ & | $76,069,236$ \\
\hline 1897. & $127,000,172$ & $57,363,000$ & $\quad 69,637,172$ \\
\hline 1898 & $134,847,485$ & $64,463,000$ & $70,384,485$ \\
\hline $1899 \ldots \ldots \ldots$ & $141,860,026$ & $71,053,400$ & $70,806,626$ \\
\hline
\end{tabular}


GOLD AND SILVER.

Production of silver in the Cnited States in 1897 ard $189 S$, and the increase or decrease in 1898 , by States and Territories.

[Fine ounces.]

\begin{tabular}{|c|c|c|c|c|}
\hline State or Territory. & 1597. & 1898. & Increase. & Decrease. \\
\hline Alaska & 116,400 & 92,400 & & 24,000 \\
\hline Arizona ... & $2,239,900$ & $2,246,800$ & 6,900 & \\
\hline California .... & 474,400 & 642,300 & 167,900 & \\
\hline Colorado ... & $21,636,400$ & $22,815,600$ & 1., 179,200 & $\ldots \ldots$ \\
\hline Georgia & 600 & 500 & $\cdots$ & 100 \\
\hline Idaho ...... & $4,901,200$ & $5,073,800$ & 172,600 & \\
\hline Michigan .... & 60,300 & 32,400 & $\ldots$ & 27,900 \\
\hline Montana .... & $15,667,900$ & $14,807,200$ & .. & 860,700 \\
\hline Nevada.. & $1,228,900$ & 805,000 & - & 423,900 \\
\hline New Mexico... & 539,500 & 425,300 & $\cdots$ & 114,200 \\
\hline North Carolina. & 300 & 700 & 400 & \\
\hline Oregon & 69,000 & 130,000 & 61,000 & \\
\hline South Carolina. & 200 & 300 & 100 & \\
\hline South Dakota. & 147,600 & 152,300 & 4,700 & \\
\hline Texas .... & 404,700 & 472,900 & 68,200 & \\
\hline Utah ........ & $6,265,600$ & $6,485,900$ & 220,300 & \\
\hline Washington & 106,900 & 254,400 & 147,500 & \\
\hline Alabama .... & & & & \\
\hline Connecticut ... & & & & \\
\hline Minnesota ..... & & & & \\
\hline Nebraska... & 200 & 200 & & \\
\hline Tennessee .... & & & & \\
\hline Virginia ....... & $\therefore$ & & & \\
\hline Wyoming ..... & & & & \\
\hline Total. & $53,860,000$ & $54,438,000$ & 578,000 & \\
\hline
\end{tabular}


Production of silver in the United States in 1898 and 1899, and the increase or decrease in 1899, by States and Territories.

[Fine ounces.]

\begin{tabular}{|c|c|c|c|c|}
\hline State or Territory. & 1598. & 1899. & Increase. & Decrease. \\
\hline Alaska ............. & 92,400 & 140,100 & 47,700 & \\
\hline Arizona ............ & $2,246,800$ & $1,578,300$ & $\ldots \ldots \ldots \ldots$ & 668,500 \\
\hline California ...... & 642,300 & 824,300 & 182,000 & $\ldots \ldots$ \\
\hline Colorado ... & $22,815,600$ & $22,662,900$ & & 152,700 \\
\hline Georgia ........... & 500 & 400 & - & 100 \\
\hline Idaho ......... & $5,073,800$ & $3,851,800$ & & $1,222,000$ \\
\hline Maine ...... & $\ldots \ldots$ & 500 & 500 & $\cdots$ \\
\hline Michigan ....... & 32,400 & 112,800 & 80,400 & \\
\hline Montana ..... & $14,807,200$ & $16,096,000$ & $1,288,800$ & \\
\hline Nevada......... & 805,000 & 843,400 & 38,400 . & \\
\hline New Mexico ......... & 425,300 & 503,300 & 78,000 & \\
\hline North Carolina.. & 700 & 300 & & 400 \\
\hline Oregon...... & 130,000 & 134,300 & 4,300 & \\
\hline South Carolina.. & 300 & 400 & 100 & . \\
\hline South Dakota... & 152,300 & 145,600 & 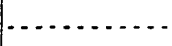 & 6,700 \\
\hline Texas .......... & 472,900 & 520,000 & 47,100 & $\cdots$ \\
\hline Utah ........ & $6,485,900$ & $7,093,300$ & 607,400 & \\
\hline Washington ... & 254,400 & 256,000 & 1,600 & \\
\hline Other States .... & 200 & 800 & 600 & \\
\hline Total.... & $54,438,000$ & $54,764,500$ & 326,500 & $\cdots$ \\
\hline
\end{tabular}


GOLD AND SILVER.

Production of gold in the United States in 1897 and 1898, and the increase or decrease in 1898, by States and Territories.

[Fine ounces.]

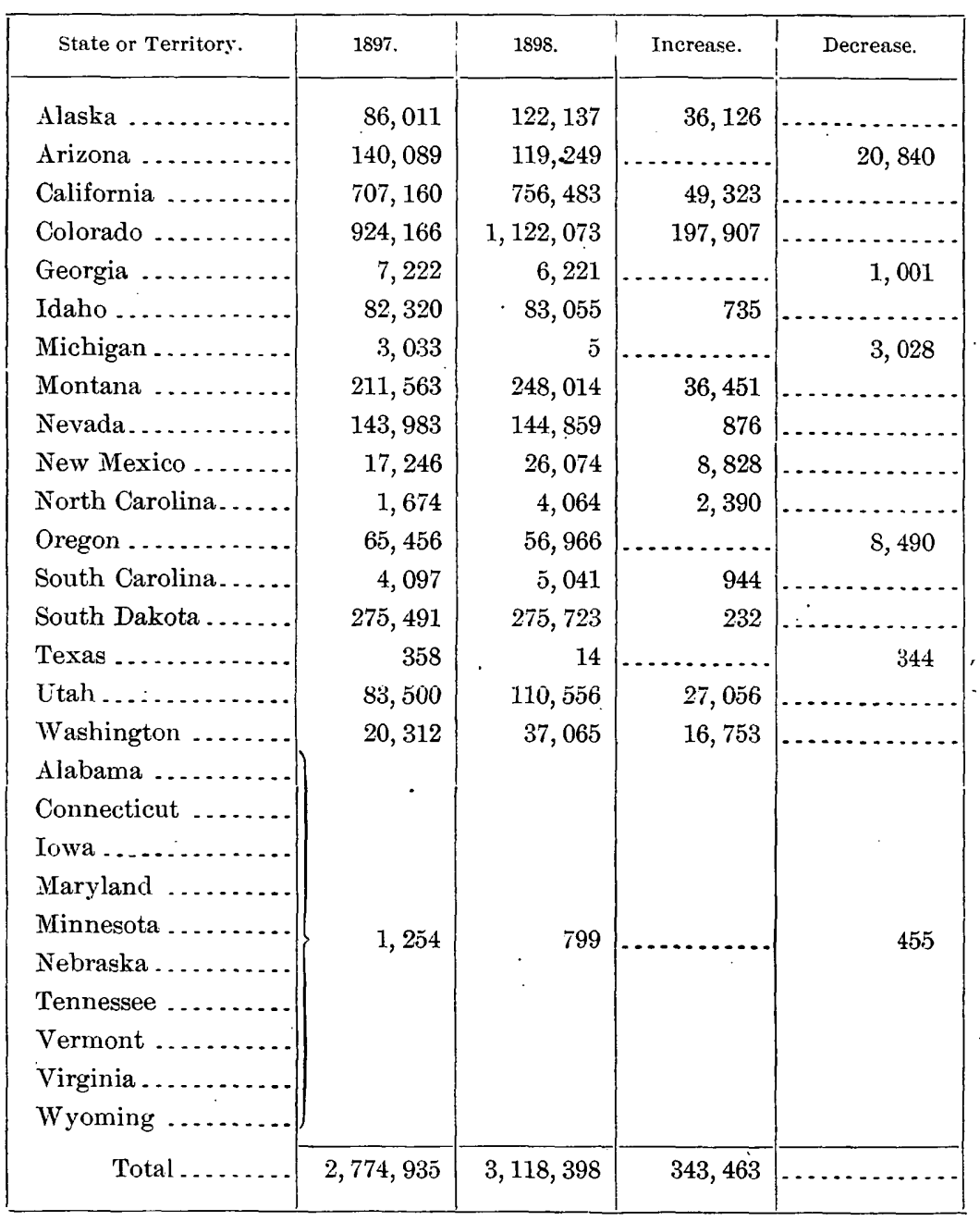


Production of gold in the United States in 1898 and 1899, and the increase or decrease in 1899, by States and Territories.

[Fine ounces.]

\begin{tabular}{|c|c|c|c|c|}
\hline State or Territory. & 1898. & 1899. & Increase. & Decrease. \\
\hline Alaska ............ & 122,137 & 264,104 & 141,967 & \\
\hline Arizona ............ & 119,249 & 124,133 & 4,884 & \\
\hline California ......... & 756,483 & 735,194 & $\ldots \ldots \ldots$ & 21,289 \\
\hline Colorado ........... & 1, 122,073 & $1,256,920$ & 134,847 & $\ldots \ldots$ \\
\hline Georgia .......... & 6,221 & 5,466 & $\ldots \ldots$ & 755 \\
\hline 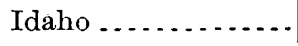 & 83,055 & 91,380 & 8,325 & \\
\hline Maine ...... & & 174 & 174 & \\
\hline Michigan ........... & 5 & 5 & $\ldots \ldots$ & $\ldots \ldots \ldots$ \\
\hline Montana ........... & 248,014 & 230,270 & 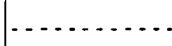 & 17,744 \\
\hline Nevada......... & 144,859 & 107,344 & . & 37,515 \\
\hline New Mexico......... & 26,074 & 28,256 & 2,182 & $\ldots \ldots \ldots$ \\
\hline North Carolina... & 4,064 & 1,669 & (........ & 2,395 \\
\hline Oregon $\ldots . . . . .$. & 56,966 & 69,152 & 12,186 & \\
\hline South Carolina...... & 5,041 & 7,745 & 2,704 & \\
\hline South Dakota....... & 275,723 & 312,962 & 37,239 & \\
\hline Texas......... & 14 & 334 & 320 & \\
\hline 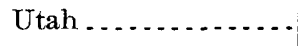 & 110,556 & 166,933 & 56,377 & \\
\hline Washington ........ & 37,065 & $33,15 C$ & $\ldots \ldots$ & 3,909 \\
\hline Wyoming $\ldots \ldots \ldots$ & 257 & 1,413 & 1,156 & $\ldots$ \\
\hline Other States ... & $5+2$ & 600 & 58 & $\ldots$ \\
\hline Total. - & $3,118,398$ & $3,437,210$ & 318,812 & $\ldots$ \\
\hline
\end{tabular}


Approximate distribution, by producing States and Territories, of the product of gold and silver in the United States for the calendar year 1897.

[As estimated by the Director of the Mint.]

\begin{tabular}{|c|c|c|c|c|c|}
\hline \multirow{2}{*}{ State or Territory. } & \multicolumn{2}{|c|}{ Gold. } & \multicolumn{2}{|c|}{ Silver. } & \multirow{2}{*}{ Total value. } \\
\hline & Fine ounces. & Value. & Fine ounces. & Coining value. & \\
\hline Alabama & 358. & $\$ 7,400$ & 100 & $\$ 129$ & $\$ 7,529$ \\
\hline Alaska & 86,011 & $1,778,000$ & 116,400 & 150,497 & $1,928,497$ \\
\hline Arizona & 140,089 & $2,895,900$ & $2,239,900$ & $2,896,032$ & $5,791,932$ \\
\hline California . & 707,160 & $14,618,300$ & 474,400 & 613,366 & $15,231,666$ \\
\hline Colorado. & 924,166 & $19,104,200$ & $21,636,400$ & $27,974,335$ & $47,078,535$ \\
\hline Georgia & 7,222 & 149,300 & 600 & 776 & 150,076 \\
\hline Idaho... & 82,320 & $1,701,700$ & $4,901,200$ & $6,336,905$ & $8,038,605$ \\
\hline Iowa - & 5 & 100 & & & 100 \\
\hline Maryland & 5 & 100 & ... & & 100 \\
\hline Michigan. & 3,033 & 62,700 & 60,300 & 77,964 & 140,664 \\
\hline Minnesota ... & 145 & 3,000 & $\cdots$ & $\therefore$ & 3,000 \\
\hline Montana & 211,563 & $4,373,400$ & $15,667,900$ & $20,257,487$ & $24,630,887^{\circ}$ \\
\hline Nevada. & 143,983 & $2,976,400$ & $1,228,900$ & $1,588,881$ & $4,565,281$ \\
\hline New Mexico. & 17,246 & 356,500 & 539,500 & 697,535 & $1,054,035$ \\
\hline North Carolina & 1,674 & 34,600 & 300 & 388 & 34,988 \\
\hline Oregon ...... & 65,456 & $1,353,100$ & 69,000 & 89,212 & $1,442,312$ \\
\hline South Carolina. & 4,097 & 84,700 & 200 & 259 & 84,959 \\
\hline South Dakota . & 275,491 & $5,694,900$ & 147,600 & 190,836 & $5,885,736$ \\
\hline Tennessee . & 5 & 100 & & $\cdots$ & 100 \\
\hline Texas ..... & 358 & $7 ; 400$ & 404,700 & 523,249 & $530 ; 649$ \\
\hline Utah..... & 83,500 & $1,726,100$ & $6,265,600$ & $8,100,978$ & $9,827,078$ \\
\hline Vermont . & 5 & 100 & $\cdots \ldots \ldots$ & & 100 \\
\hline Virginia ..... & 189 & 3,900 & -..... & $\cdots$ & 3,900 \\
\hline Washington .. & 20,312 & 419,900 & 106,900 & 138,214 & 558,114 \\
\hline Wyoming ... & 542 & 11,200 & 100 & 129 & 11,329 \\
\hline Total & $2,774,935$ & $57,363,000$ & $53,860,000$ & $69,637,172$ & $127,000,172$ \\
\hline
\end{tabular}


Approximate distribution, by producing States and Territories, of the product of gold and silver in the United States for the calendar year 1898.

[As estimated by the Director of the Mint.]

\begin{tabular}{|c|c|c|c|c|c|}
\hline \multirow{2}{*}{ State or Territory. } & \multicolumn{2}{|c|}{ Gold. } & \multicolumn{2}{|c|}{ Silver. } & \multirow{2}{*}{ Total value } \\
\hline & Fine ounces. & Value. & Fine ounces. & Coining value. & \\
\hline Alabama ...... & 242 & $\$ 5,000$ & 100 & $\$ 129$ & $\$ 5,129$ \\
\hline Alaska ... & 122,137 & $2,524,800$ & 92,400 & 119,467 & $2,644,267$ \\
\hline Arizona ...... & 119,249 & $2,465,100$ & $2,246,800$ & $2,904,954$ & $5,370,054$ \\
\hline California ...... & 756,483 & $15,637,900$ & . $\quad 642,300$ & 830,448 & $16,468,348$ \\
\hline Colorado ....... & $1,122,073$ & $23,195,300$ & $22,815,600$ & $29,498,958$ & $52,694,258$ \\
\hline Georgia .... & 6,221 & 128,600 & 500 & 646 & 129,246 \\
\hline Idaho ......... & 83,055 & $1,716,900$ & $5,073,800$ & $6,560,065$ & $8,276,965$ \\
\hline Iowa .......... & 5 & 100 & $\ldots \ldots \ldots$ & $\ldots \ldots$ & 100 \\
\hline Maryland ..... & 29 & 600 & , & $\cdots$ & 600 \\
\hline Michigan ....... & 5 & 100 & 32,400 & 41,891 & 41,991 \\
\hline Minnesota ....... & 5 & 100 & $\ldots \ldots \ldots$ & $\mid \ldots \ldots . . . . .$. & 100 \\
\hline Montana ... & 248,014 & $5,126,900$ & $14,807,200$ & $19,144,663$ & $24,271,563$ \\
\hline Nevada...... & 144,859 & $2,994,500$ & 805,000 & $1,040,808$ & $4,035,308$ \\
\hline New Mexico.... & 26,074 & 539,000 & 425,300 & 549,883 & $1,088,883$ \\
\hline North Carolina.. & 4,064 & 84,000 & 700 & 905 & 84,905 \\
\hline Oregon ......... & 56,966 & $1,177,600$ & 130,000 & 168,081 & $1,345,681$ \\
\hline South Carolina. & 5,041 & 104,200 & 300 & 388 & 104,582 \\
\hline South Dakota.. & 275,723 & $5,699,700$ & 152,300 & 196,913 & $5,896,613$ \\
\hline Tennessee ... & 43 & 900 & $\ldots \ldots \ldots$ & $\ldots \ldots \ldots$ & 900 \\
\hline Texas ............. & 14 & 300 & 472,900 & 611,426 & 611,726 \\
\hline Utah ..... & 110,556 & $2,285,400$ & $6,485,900$ & $8,385,810$ & $10,671,210$ \\
\hline Virginia ... & 218 & 4,500 & $\ldots \ldots . .$. & $\ldots . .$. & 4,500 \\
\hline Washington .. & 37,065 & 766,200 & 254,400 & 328,921 & $1,095,121$ \\
\hline Wyoming .. & 257 & 5,300 & 100 & 129 & 5,429 \\
\hline Total & $3,118,398$ & $64,463,000$ & $54,438,000$ & $70,384,485$ & $134,847,485$ \\
\hline
\end{tabular}


GOLD AND SILVER.

Approximate distribution, by producing States and Territories, of the product of gold and silver in the United States for the calendar year 1899.

[As estimated by the director of the Mint.]

\begin{tabular}{|c|c|c|c|c|c|}
\hline \multirow{2}{*}{ State or Territory. } & \multicolumn{2}{|c|}{ Gold. } & \multicolumn{2}{|c|}{ Silver. } & \multirow{2}{*}{ Total value. } \\
\hline & Fine ounces. & value. & Fine ounces. & Coiningvalue. & \\
\hline Alabama & 208 & $\$ 4,300$ & 100 & $\$ 129$ & $\$ 4,429$ \\
\hline Alaska. & 264,104 & $5,459,500$ & 140,100 & 181,140 & $5,640,640$ \\
\hline Arizona & 124,133 & $2,566,100$ & $1,578,300$ & $2,040,630$ & $4,606,730$ \\
\hline California & 735,194 & $15,197,800$ & 824,300 & $1,065,762$ & $16,263,562$ \\
\hline Colorado & $1,256,920$ & $25,982,800$ & $22,662,900$ & $29,301,527$ & $55,284,327$ \\
\hline Georgia & 5,466 & 113,000 & 400 & 517 & 113,517 \\
\hline Idaho... & 91,380 & $1,889,000$ & $3,851,800$ & $4,980,105$ & $6,869,105$ \\
\hline Maine .... & 174 & 3,600 & 500 & 646 & 4,246 \\
\hline Maryland. & 39 & 800 & 100 & 129 & 929 \\
\hline Michigan & 5 & 100 & 112,800 & 145,843 & 145,943 \\
\hline Missouri. & 5 & 100 & 100 & 129 & 229 \\
\hline Montana & 230,270 & $4,760,100$ & $16,096,000$ & $20,810,990$ & $25,571,090$ \\
\hline Nevada.. & $107,34 t$ & $2,219,000$ & 843,400 & $1,090,457$ & $3,309,457$ \\
\hline New Mexico. & 28,256 & 584,100 & 503,300 & 650,731 & $1,234,831$ \\
\hline North Carolina & 1,669 & 34,500 & 300 & 388 & 34,888 \\
\hline Oregon ... & 69,152 & $1,429,500$ & 134,300 & 173,641 & $1,603,141$ \\
\hline South Carolina. & 7,745 & 160,100 & 400 & 517 & 160,617 \\
\hline South Dakota. & 312,962 & $6,469,500$ & 145,600 & 188,251 & $6,657,751$ \\
\hline Texas ... & 334 & 6,900 & 520,000 & 672,323 & 679,223 \\
\hline Utah..... & 166,933 & $3,450,800$ & $7,093,300$ & $9,171,135$ & $12,621,935$ \\
\hline Vermont . & 5 & 100 & $\cdots$ & ....... & 100 \\
\hline Virginia... & 343 & 7,100 & 100 & 129 & 7,229 \\
\hline Washington & 33,156 & 685,400 & 256,000 & 330,990 & $1,016,390$ \\
\hline Wyoming .. & 1,413 & 29,200 & 400 & 517 & 29,717 \\
\hline Total. & $3,437,210$ & $71,053,400$ & $54,764,500$ & $70,806,626$ & $141,860,026$ \\
\hline
\end{tabular}





\title{
MANGANESE ORES.
}

\author{
By John Birkinbine. \\ PRODUCTION OF MANGANESE ORES.
}

Although the year 1899 was one of great activity in all branches of the iron and steel industry, there was less manganese ore mined in the United States than for several years, the total being 9,935 long tons. In fact there have been but seven years in the last two decades when the production of American manganese ores was less than in 1899. This was in spite of the fact that the advancing prices for raw or manufactured material encouraged some new exploitations, but as will be seen later the importations of manganese ores in 1899 were largely in excess of 1898 , and the domestic output of manganiferous iron ores was considerably augmented.

It is unfortunate that present developments have produced such a limited supply of domestic manganese ores and that most of those used are imported from other countries. Foreign complications may, by restricting the importations of manganese ores, handicap the steel industry of the United States, which is the principal source of consumption of manganese ores and of much of the manganiferous ores.

In rating the mineral as manganese ores or as manganiferous iron ores the distinction which has been generally accepted is made on a content of 44 per cent manganese. That is, ores which when dried at $212^{\circ}$ contain 44 per cent or more of manganese are classed as manganese ores, while those carrying smaller percentages are rated as manganiferous iron ores, unless they have less than 3 per cent of iron.

In this connection it will be interesting to quote the decisions of the United States Treasury Department as to what is a manganese ore.

Treasury Decision 4114 provides that ore to be classed as manganese ore must contain 50 per cent or over of manganese, and not over 10 per cent of iron. This was modified in Treasury Decision 16550, which allowed certain ore containing less than 50 per cent of manganese to be classed as manganese ore when the iron therein was less than 3 per cent.

The total production of manganese ores in the United States in the year 1899 . was 9,935 long tons, valued at $\$ 82,278$, or $\$ 8.28$ per ton. Nine States contributed to the total. Virginia, after occupying a subordinate position for seven years, again heads the list of States with a production of 6,228 tons, or 62.7 per cent of the total for the country, followed by Georgia. Arkansas has shown a marked decline in production. Alabama bas ceased to mine any manganese ore, but Missouri bas been added to the list, while North Carolina, Pennsylvania, and West Virginia have resumed as small contributors.

21 GEOL, PT $6-9$ 
Colorado produces ores which in this report are, according to custom, classed as manganiferous iron ores, but locally they are considered as ores of manganese, as they contain from 20 to 43 per cent of this metal.

While there has been a falling off in the amount of manganese mined in 1899 of 6,022 tons, or 37.7 per cent, from the product of 1898 , the average value has increased from $\$ 8.10$ per ton in 1898 to $\$ 8.28$ in 1899 , a gain of 18 cents per ton, or 2.2 per cent.

The production and value at the mines of manganese ores by States in $1896,1897,1898$, and 1899 are as follows, the earlier year's being given for the purpose of comparison:

Amount and value of manganese ores produced in the Lnited States in 1896, 1897, 1898, and 1899.

\begin{tabular}{|c|c|c|c|c|c|c|}
\hline \multirow{2}{*}{ State. } & \multicolumn{3}{|c|}{1896.} & \multicolumn{3}{|c|}{1897.} \\
\hline & Product. & $\begin{array}{l}\text { Total } \\
\text { value. }\end{array}$ & $\begin{array}{l}\text { Average } \\
\text { value } \\
\text { per ton. }\end{array}$ & Product. & $\begin{array}{l}\text { Total } \\
\text { value. }\end{array}$ & $\begin{array}{l}\text { Average } \\
\text { value } \\
\text { per ton. }\end{array}$ \\
\hline Alabama .......... & $\begin{array}{l}\text { Long tons. } \\
-\ldots \ldots \ldots\end{array}$ & $\cdots$ & $\cdots$ & Long tons. & & \\
\hline Arkansas ........... & 3,421 & $\$ 36,686$ & $\$ 10.72$ & 3,240 & $\$ 33,708$ & $\$ 10.40$ \\
\hline California ......... & 284 & 3,415 & 12.02 & 484 & 2,788 & 5.76 \\
\hline Georgia ............ & 4,085 & 27,032 & 6.62 & 3,332 & 22,084 & 6.63 \\
\hline Michigan .......... & $\ldots \ldots .$. & $\ldots \ldots$ & $\ldots \ldots$ & 37 & 370 & 10.00 \\
\hline Missouri... & $\ldots \ldots$ & $\ldots \ldots$ & $\ldots \ldots$ & $\ldots \ldots$ & $\ldots \ldots \ldots$ & $\cdots$ \\
\hline North Carolina .. & 2 & 17 & 8.50 & $\mid \ldots \ldots$ & $\ldots \ldots \ldots$ & $\ldots .$. \\
\hline Pennsylvania ....... & 265 & 1,988 & 7.50 & 354 & $2,832^{\circ}$ & S. 00 \\
\hline Tennessee . . . . . . . . . & None. & None. & $\ldots \ldots$ & 11 & 93 & 8.45 \\
\hline Virginia ...... & 2,018 & 21,485 & 10.65 & 3,650 & 33,630 & 9.21 \\
\hline West Virginia ...... & 13 & 194 & 8.00 & None. & None. & None. \\
\hline Total. & 10,088 & 90,727 & 8.99 & 11,108 & 95,505 & 8. 60 \\
\hline \multirow[b]{2}{*}{ State. } & \multicolumn{3}{|c|}{1898.} & \multicolumn{3}{|c|}{1899.} \\
\hline & Product. & $\begin{array}{c}\text { Total } \\
\text { value. }\end{array}$ & $\begin{array}{l}\text { Average } \\
\text { value } \\
\text { per ton. }\end{array}$ & Product. & $\begin{array}{l}\text { Total } \\
\text { value. }\end{array}$ & $\begin{array}{l}\text { Average } \\
\text { value per } \\
\text { ton. }\end{array}$ \\
\hline Alabama ....... & $\begin{array}{c}\text { Long tons. } \\
22\end{array}$ & $a \$ 143$ & $a \$ 6.50$ & \begin{tabular}{|l} 
Long tons. \\
$\ldots \ldots$
\end{tabular} & & \\
\hline Arkansas .... & 2,662 & 26,035 & 9.78 & 356 & $\$ 3,781$ & $\$ 10.62$ \\
\hline California .......... & 541 & 3,222 & 5.96 & 115 & 855 & 7.43 \\
\hline Georgia ............ & 6,689 & 41,571 & 6.21 & 3,089 & 23,377 & 7.57 \\
\hline Michigan ....... . & $\ldots \ldots$ & $\ldots . .$. & $\ldots \ldots$ & $\ldots . .$. & $\ldots \ldots$ & $\ldots \ldots$ \\
\hline Missouri... & & $\ldots$ & $\cdots$ & 16 & 160 & 10.00 \\
\hline North Carolina . & & . & $\ldots \ldots$ & 90 & 765 & S. 50 \\
\hline Pennsylvania ... & $\ldots$ & $\ldots$ & $\ldots \ldots$ & 12 & 58 & 4.83 \\
\hline Tennessee .... & 381 & 2,276 & 5.97 & 19 & 133 & 7.00 \\
\hline Virginia ...... & 5,662 & 55,938 & 9.88 & 6,228 & $53,069 !$ & S. 52 \\
\hline West Virginia & & $\ldots \ldots$ & $\ldots \ldots \ldots$ & 10 & 80 & 8.00 \\
\hline Total. & $15,95 \overline{7}$ & 129,185 & 8.10 & 9,935 & $S 2,27 S$ & S. 28 \\
\hline
\end{tabular}


This table indicates a decided decline in the more important producing States, with the exception of Virginia, where a considerable amount of prospecting was done during the last year or two. The 1899 product for the country, 9,935 tons, is the lowest since the year 1895 , and with but three exceptions the smallest since 1883 .

The falling off in Arkansas is due to the curtailed output of the largest producer; but this State, as well as Georgia, has deposits of manganese ore in reserve. Georgia, however, shows a decline, and has been relegated to second position as a contributor of manganese ore.

The remaining States mine but little manganese ore, and have been grouped together in the table, which shows the output of manganese ores in the three principal States, and the total for the United States, from the year 1880 to 1899 , inclusive.

Production of manganese ores in the United States from 1880 to 1899:

[Maxima are given in italics.]

\begin{tabular}{|c|c|c|c|c|c|c|}
\hline Year. & Virginia. & Arkansas. & Georgia. & $\begin{array}{l}\text { Other } \\
\text { States. }\end{array}$ & Total. & Total value. \\
\hline 1880 & $\begin{array}{c}\text { Long tons. } \\
\quad 3,661\end{array}$ & $\begin{array}{c}\text { Long tons. } \\
\ldots \ldots \ldots\end{array}$ & $\begin{array}{c}\text { Long tons. } \\
1,800\end{array}$ & $\begin{array}{c}\text { Long tons. } \\
300\end{array}$ & $\begin{array}{c}\text { Long tons. } \\
5,761\end{array}$ & $\$ 86,415$ \\
\hline 1881 & 3,295 & 100 & 1,200 & 300 & 4,895 & 73,425 \\
\hline 1882 & 2,982 & 175 & 1,000 & 375 & 4,532 & 67,980 \\
\hline 1883. & 5,355 & 400 & 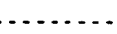 & 400 & 6,155 & 92,325 \\
\hline 1884 & 8,980 & 800 & ...... & 400 & 10,180 & 122,160 \\
\hline 1885 & 18,745 & 1,483 & 2,580 & 450 & 23,258 & 190,281 \\
\hline 1886 & 20,567 & 3,316 & 6,041 & 269 & 30,193 & $277 ; 636$ \\
\hline 1887 & 19,835 & 5,651 & 9,024 & 14 & 34,524 & 333,844 \\
\hline 1888. & 17,646 & 4,312 & 5,568 & 1,672 & 29,198 & 279,571 \\
\hline 1889 & 14,616 & 2,528 & 5,208 & 1,845 . & 24,197 & 240,559 \\
\hline 1890 & 12,699 & 5,339 & 749 & 6,897 & 25,684 & 219,050 \\
\hline $1891 \ldots$ & 16,248 & 1,650 & 3,575 & 1,943 & 23,416 & 239,129 \\
\hline 1892. & 6,079 & 6,708 & 826 & $\ldots$ & 13,613 & 129,586 \\
\hline 1893 & 4,092 & 2,020 & 724 & 882 & 7,718 & 66,614 \\
\hline 1894 & 1,797 & 1,934 & 1,277 & 1,300 & 6,308 & 53,635 \\
\hline 1895 & 1,715 & 2,991 & 3,856 & 985 & 9,547 & 71,769 \\
\hline $1896 \ldots$ & 2,018 & 3,421 & 4,085 & 564 & 10,088 & 90,727 \\
\hline 1897. & 3,650 & 3,240 & 3,332 & 886 & 11,108 & 95,505 \\
\hline 1898 & 5,662 & 2,662 & 6,689 & 944 & 15,957 & 129,185 \\
\hline 1899 & 6,228 & 356 & 3,089 & 262 & 9,935 & 82,278 \\
\hline $\begin{array}{l}\text { Total } \\
\text { for } 20 \\
\text { years }\end{array}$ & 175,870 & 49,086 & 60,623 & 20,688 & 306,267 & $2,941,674$ \\
\hline
\end{tabular}




\section{PRODUCTION OF MANGANIFEROCS IRON ORES.}

As in former reports, the production of manganiferous iron ores in the year 1899 are included in the report on iron ores, but the production and value are also given here. Some of the Colorado ores are used in the manufacture of spiegeleisen, but a considerable portion of the ores of that State are used as a flux by the smelters of the precious metals.

Some of the Lake Superior iron ores contain small percentages of manganese, which moderately affect their values.

The quantity of manganiferous iron ore produced in the United States during 1899, the percentages of manganese which they contain, and the value of ores at the mines are given in the following table:

Production of manganiferous iron ores in 1899.

\begin{tabular}{|c|c|c|c|c|}
\hline Locality. & Quantity. & Manganese. & $\begin{array}{c}\text { Average } \\
\text { value per } \\
\text { ton at mine. }\end{array}$ & Total value. \\
\hline Colorado ..... & $\begin{array}{c}\text { Long tons. } \\
29,355\end{array}$ & $\begin{array}{c}\text { Per cent. } \\
16.00 \text { to } 43\end{array}$ & $\$ 2.95$ & $\$ 86,697$ \\
\hline Lake Superior region.. & 732,490 & .68 to 8 & 1.45 & $1,060,350$ \\
\hline Total . & 761,845 & .68 to 43 & 1.51 & $1,147,047$ \\
\hline
\end{tabular}

The following table gives the production, the total value, and the average value per ton of the manganiferous iron ores mined in the United States from 1889 to 1899 , inclusive. It indicates that the quantity of this ore which was won in 1899 approximates the combined output for the three preceding years.

Total production of manganiferous iron ores in the United States from 1889 to 1899. [Maxima in italics.]

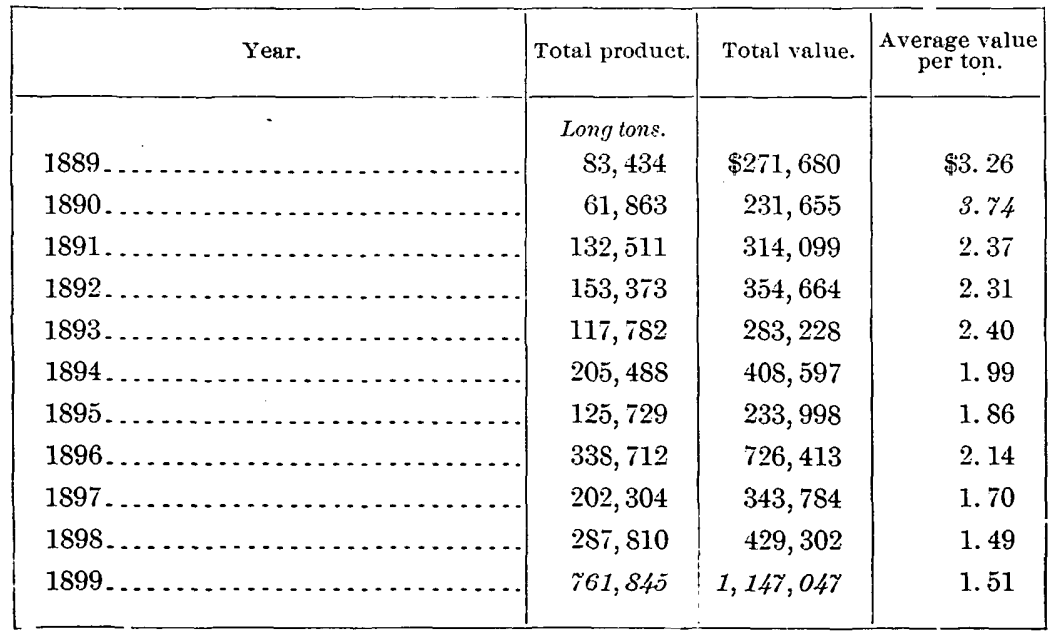


In mining the precious metals a considerable amount of ore is won which contains manganese, iron, and a moderate quantity of silver, the latter metal often being insufficient to make the ore valuable on that account, but it is used as a flux at the smelters and is classed as an iron ore, being included in the report for 1899 on iron ores. The quantity of this class of ore mined in the United States from 1859 to 1899 , inclusive, the value, and the average value per ton, is as follows:

Production of manganiferons silver ores in the United States from 1889 to 1899.

[Maxima in italics.]

\begin{tabular}{|c|c|c|c|}
\hline Tear. & Quantity. & Value. & $\begin{array}{c}\text { Average } \\
\text { value per } \\
\text { ton. }\end{array}$ \\
\hline$=$ & Long tons. & & \\
\hline $1889 \ldots \ldots \ldots \ldots \ldots \ldots$ & 64,987 & $\$ 22 \overline{7}, 455$ & $\$ 3.50$ \\
\hline $1890 \ldots \ldots$ & 51,840 & 181,440 & 3.50 \\
\hline 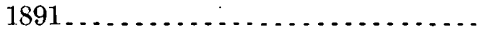 & 79,511 & 397,555 & 5.00 \\
\hline $1892 \ldots$ & 62,309 & 323,794 & 5.20 \\
\hline $1893 \ldots$ & a 55,962 & 258,695 & 4. 75 \\
\hline $1894 \ldots \ldots \ldots$ & $b 31,687$ & 148,292 & 4. 84 \\
\hline $1895 \ldots$ & 54,163 & 229,651 & 4. 24 \\
\hline $1896 \ldots$ & 138,079 & 416,020 & 3.01 \\
\hline $1897 \ldots \ldots \ldots$ & 149,502 & 424,151 & 2.84 \\
\hline $1898 \ldots$ & 99,651 & 295,412 & 2.96 \\
\hline 1899 & 79,855 & 266,343 & 3.34 \\
\hline
\end{tabular}

$a$ Including 1,500 tons from Montana, for which no value is given. $b$ Including 1,049 tons from Montana, for which no value is given.

Large quantities of franklinite are obtained in New Jersey, and after the zinc is extracted by roasting, the residuum or clinker contains considerable iron and manganese and also a small quantity of zinc. This is used in the manufacture of spiegeleisen in small blast furnaces in New Jersey and eastern Pennsylvania. The annual production of this zinc residuum, its value, and the average value per ton, from 1889 to 1899 , inclusive, is given in the accompanying table. 
It will be noted that the quantity of clinker used as iron ore in 1899 exceeded the previous maximum of 1890 by 16,450 tons:

Production of manganiferous zinc ore residuum in the United States from 1889 to 1899.

[Maxima in italies.]

\begin{tabular}{|c|c|c|c|}
\hline Year. & Quantity. & Value. & $\begin{array}{l}\text { Average value } \\
\text { per ton. }\end{array}$ \\
\hline & Long tons. & . & \\
\hline $1889 \ldots \ldots$ & 43,648 & $\$ 54,560$ & $\$ 1.25$ \\
\hline $1890 \ldots \ldots \ldots \ldots \ldots \ldots \ldots \ldots \ldots \ldots$ & 48,560 & 60,700 & 1.25 \\
\hline $1891 \ldots \ldots \ldots$ & 38,228 & 57,432 & 1.50 \\
\hline $1892 \ldots$ & 31,859 & 25,937 & .81 \\
\hline $1893 \ldots$ & 37,512 & 30,535 & .81 \\
\hline $1894 \ldots \ldots \ldots$ & 26,981 & 20,464 & .76 \\
\hline 1895 & 43,249 & 24,451 & .57 \\
\hline $1896 \ldots . . .$. & 44,953 & 20,455 & .46 \\
\hline 1897 & 33,924 & 18,713 & .55 \\
\hline $1898 \ldots . .$. & 48,502 & $a 26,676$ & $a .55$ \\
\hline 1899 & 65,010 & 32,505 & $.50^{\circ}$ \\
\hline
\end{tabular}

a Estimated.

\section{PRODUCTION OF MANGANESE AND MANGANIFEROUS ORES REPORTED IN 1899.}

To give a résumé of the production, total value, and average value of the ores of manganese and those which also contain smaller percentages of this metal the accompanying statement, prepared from the various classifications mentioned, has been prepared:

Production of manganese and manganiferous ores in the United States in the year 1899.

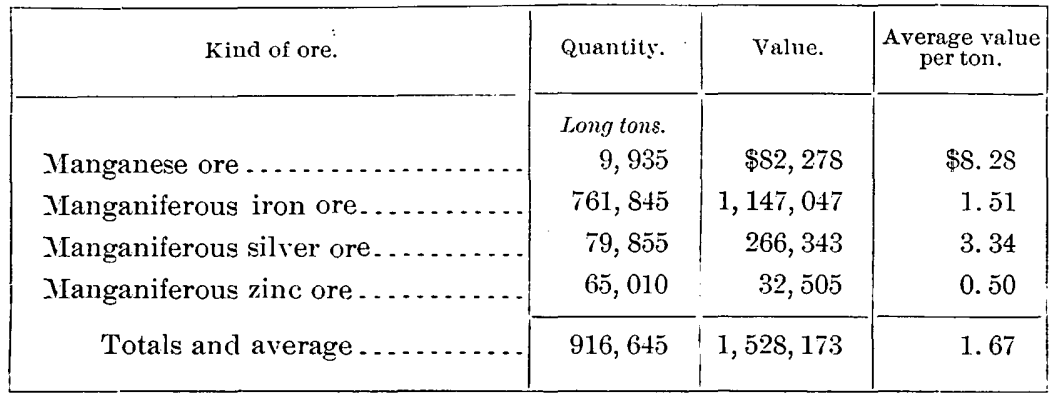

Although the nation's product of manganese ore is small, the utilization of manganiferous ores indicates that a considerable quantity is required. 
PRODUCTION OF MANGANESE BY STATES.

The production of manganese ore by individual States will next receive consideration.

\section{ARKANSAS.}

The Batesville district, in the northern central part of Arkansas, produced all of the manganese ore credited to that State in 1899, but owing to the restricted operations of the principal producer the total amount was much less than in 1898.

Some ore is of good quality, the better class containing 50 per cent of 'manganese, but much of it carries phosphorus above the limit prescribed. The extent of the deposits is uncertain, operations upon them are limited, and there is considerable distance to be covered to points of consumption.

The total production of manganese ore in the Batesville district from 1850 to 1899 , inclusive, was 49,656 long tons, and the detailed record found below shows that the maximum output, 6,708 tons, was in 1892.

Production of manganese in the Batesville district of Arkansas to December 31, 1899.

[Maximum in italics.]

\begin{tabular}{|c|c|c|}
\hline lear. & Authority. & Quantity. \\
\hline & & Long tons. \\
\hline 1.850 to $1867 \ldots$. & Estimated $\ldots \ldots \ldots \ldots \ldots \ldots$ & 400 \\
\hline 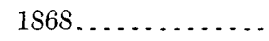 & 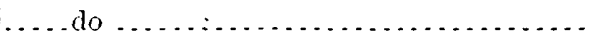 & 10 \\
\hline $18 s 1 \ldots \ldots . . . . . . .$. & Railroad reports of shipments. . . . . . . . . & 100 \\
\hline $1882 \ldots$ & $\ldots$ do $\ldots . . . . . . .$. & 175 \\
\hline $1883 \ldots \ldots \ldots \ldots$ & $\ldots$. do $\ldots \ldots \ldots \ldots \ldots . . . .$. & 400 \\
\hline $1884 \ldots .$. & $\ldots$ do $\ldots . . . . . . . .$. & 800 \\
\hline $1885 \ldots$ & Mineral Resources of the Cinited States:... & 1,483 \\
\hline $1886 \ldots$ & 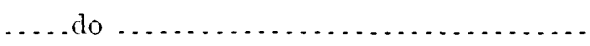 & 3,316 \\
\hline $18 S 7 \ldots$ & $\ldots$ do ................ & 5,651 \\
\hline 1888. & $\ldots$ do $\ldots . . . . . . .$. & 4,312 \\
\hline 1889 & Eleventh Census . . . . . . . . . . . . . . & 2,528 \\
\hline 1890 . & Mineral Resources of the Cnited States .... & 5,339 \\
\hline $1891 \ldots$ & $\ldots$ do $\ldots . . . . . . . . . . . . .$. & 1,650 \\
\hline 1892 & $\ldots$ do $\ldots . . . . . . . . . . . . . .$. & 6,708 \\
\hline $1893 \ldots$ & ....do ...... & 2,180 \\
\hline $1894 \ldots$ & $\ldots$. . do ....... & 1,934 \\
\hline $1895 .$. & .....do.. & 2,991 \\
\hline 1896. & $\ldots$. . do .. & 3,421 \\
\hline $1897 \ldots$ & ..... 10....... & 3,240 \\
\hline $1898 \ldots$ & . . . . do ....... & 2,662 \\
\hline 1899. & . . . . do ... & 356 \\
\hline Total & & 49,656 \\
\hline
\end{tabular}




\section{CALIFORNIA.}

Manganese ores occur in several of the counties of California, but Alameda is the only county in which these ores have been mined in late years. The ores are of high grade and are used to a considerable extent in the production of chlorine. The annual output from 1874 to 1899 , inclusive, is given below, the total being 9,771 long tons, the product in 1899 of 115 tons being the lowest since 1892 .

Total production of manganese ores in California to December 31, 1899.

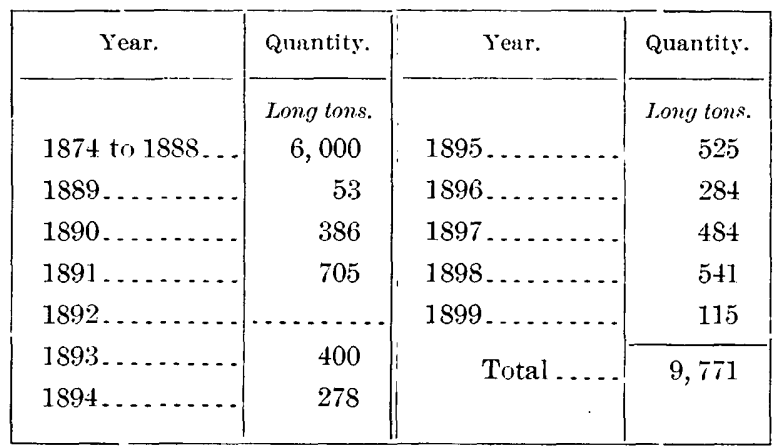

COLORADO.

The ores of Colorado which carry manganese are not, truly speaking, manganese ores (although some true manganese ores have been reported), but are manganiferous and argentiferous iron ores carrying varying percentages of manganese. Some are used in the manufacture of spiegeleisen and the balance as a flux by the smelters. The ores used in the manufacture of spiegeleisen contain from 20 to 43 per cent of manganese. The growing steel industry of Colorado, added to the shipments to other steel works, indicate a continued liberal exploitation of deposits of manganiferous iron ores. Most of those now used are mined in the vicinity of Leadville.

The appended table gives the production of these ores from 1889 to 1899 inclusive.

Production of manganiferous ores in Colorado from 1889 to 1899.

\begin{tabular}{|c|c|c|c|c|c|c|}
\hline & 1889. & 1890. & 1891. & 1592. & 1893. & 1894. \\
\hline & Longtons. & Longtons. & Long tons. & Longtons. & Longtons.' & Long tons. \\
\hline $\begin{array}{l}\text { ores used for pro- } \\
\text { ducingspiegeleisen }\end{array}$ & 2,075 & & 964 & 3,100 & 5,766 & 7,022 \\
\hline $\begin{array}{l}\text { Manganiferous sil- } \\
\text { ver ores ........... }\end{array}$ & 64,987 & 51,840 & 79,511 & 62,309 & 54,462 & 30,157 \\
\hline Total... & $6 \bar{\imath}, 062$ & $51,8+0$ & 80,475 & 65,409 & 60,228 & $3 \bar{\imath}, 209$ \\
\hline
\end{tabular}


MANGANESE ORES.

Production of manganiferous ores in Colorado from 1889 to 1899-Continued.

\begin{tabular}{|c|c|c|c|c|c|}
\hline & 1895. & 1896. & 1897. & 1898. & 1899. \\
\hline & Long toms. & Long tons. & Long tons. & Long tons. & Long tons. \\
\hline $\begin{array}{l}\text { Manganiferous iron } \\
\text { ores used for pro- } \\
\text { ducing spiegeleisen }\end{array}$ & 13,464 & 9,072 & 16,519 & 18,848 & 29,355 \\
\hline $\begin{array}{l}\text { Manganiferous sil- } \\
\text { ver ores ........... }\end{array}$ & 53,506 & 137,597 & 149,502 & 99,651 & 79,855 \\
\hline Total... & 66,970 & 146,669 & 166,021 & 118,499 & 109,210 \\
\hline
\end{tabular}

\section{GEORGIA.}

The greater portion of the manganese ores mined in Georgia comes from the Cartersville district, but the State as a whole showed a decline from 6,689 long tons in 1898, when it occupied first position, to but 3,089 long tons in 1899 . The deposits are mostly limited in size and scattered.

The total production in Georgia to date, as near as can be ascertained, is 80,573 long tons, the accompanying table giving the yearly output:

Production of manganese ores in Georgia from 1866 to 1899, inclusive.

\begin{tabular}{|c|c|c|c|}
\hline Year. & Quantity. & Year. & Quantity. \\
\hline & Long tons. & & Long tons. \\
\hline From 1866 to & & 1887 & 9,024 \\
\hline $\begin{array}{l}1873(\text { esti- } \\
\text { mated }) . .\end{array}$ & 5,550 & 1888 & 5,568 \\
\hline $1874 \ldots$ & 2,400 & 1889 . & 5,208 \\
\hline 1875 & 2,400 & 1890 & 749 \\
\hline $1876 \ldots$ & 2,400 & 1891. & 3,575 \\
\hline $1877 \ldots$ & 2,400 & 1892. & 826 \\
\hline $1878 \ldots$ & 2,400 & $1893 \ldots$ & 724 \\
\hline $1879 \ldots$ & 2,400 & 1894. & 1,277 \\
\hline $1880 \ldots \ldots$ & 1,800 & 1895 . & 3,856 \\
\hline $1881 \ldots$ & 1,200 & 1896.. & 4,085 \\
\hline $1882 \ldots$. & 1,000 & $1897 \ldots$ & 3,332 \\
\hline 1883 and 1884 & (a) & $1898 \ldots$ & 6,689 \\
\hline $1885 \ldots$ & 2,580 & $1899 \ldots$ & 3,089 \\
\hline $1886 \ldots$ & 6,041 & Total & 80,573 \\
\hline
\end{tabular}

$a$ None reported. 


\section{LAKE SUPERIOR REGION.}

Occasionally small amounts of manganese ores are produced in the States tributary to Lake Superior, but a considerable amount of iron ore, containing usually from 4 to 8 per cent of manganese, is mined, which is included in the annual report on iron ores. The amount of this variety of iron ore produced in the year 1899, together with that of previous years subsequent to 1885 , as well as the average per cent of manganese, is given in the following table, and demonstrates a greatly augmented output over preceding years.

Production of manganiferous iron ores in the Lake Superior region from 1886 to 1899.

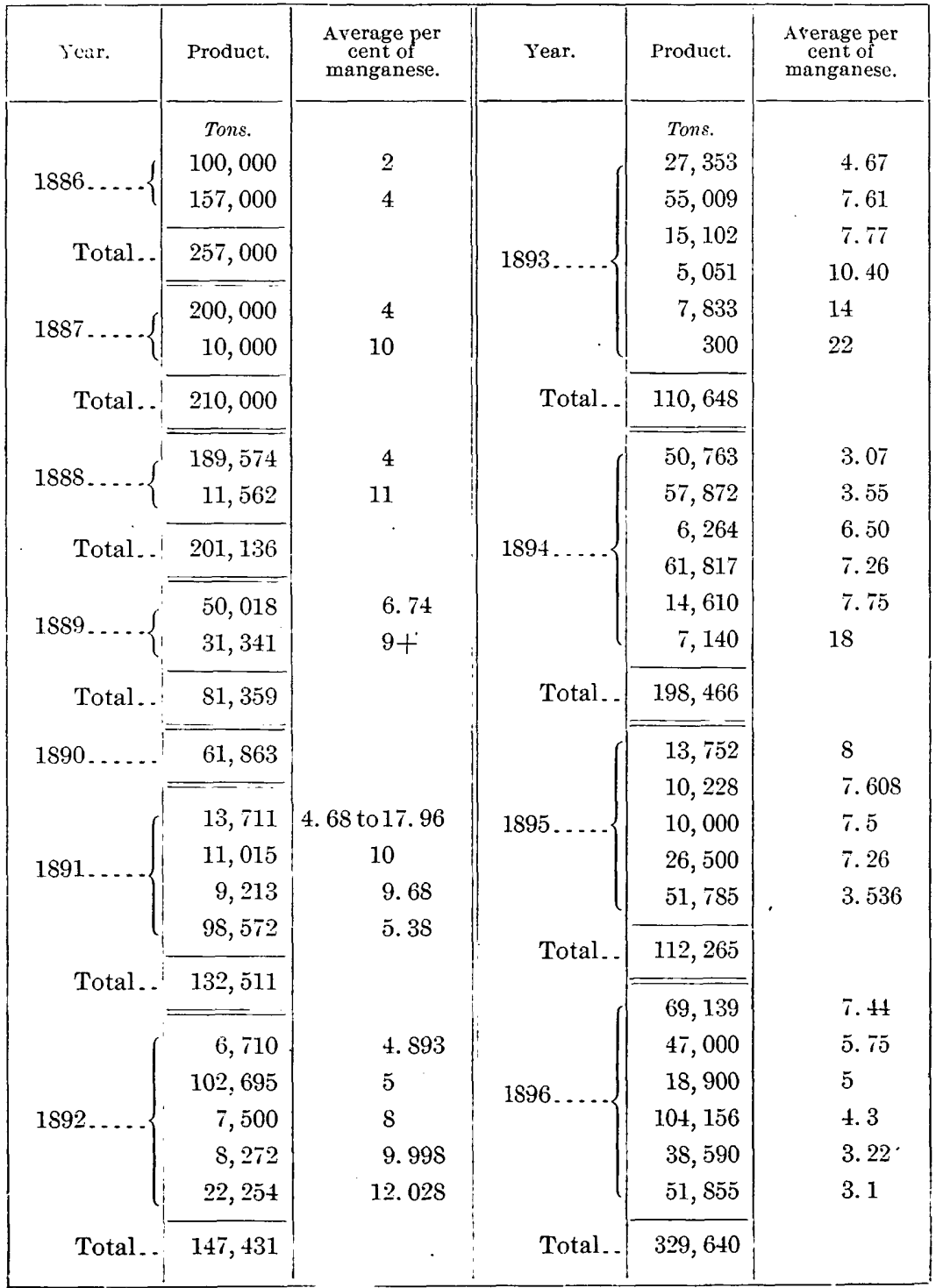


Production of manganiferous iron ores in the Lake Superior region from 1886 to $1899-$ Continued.

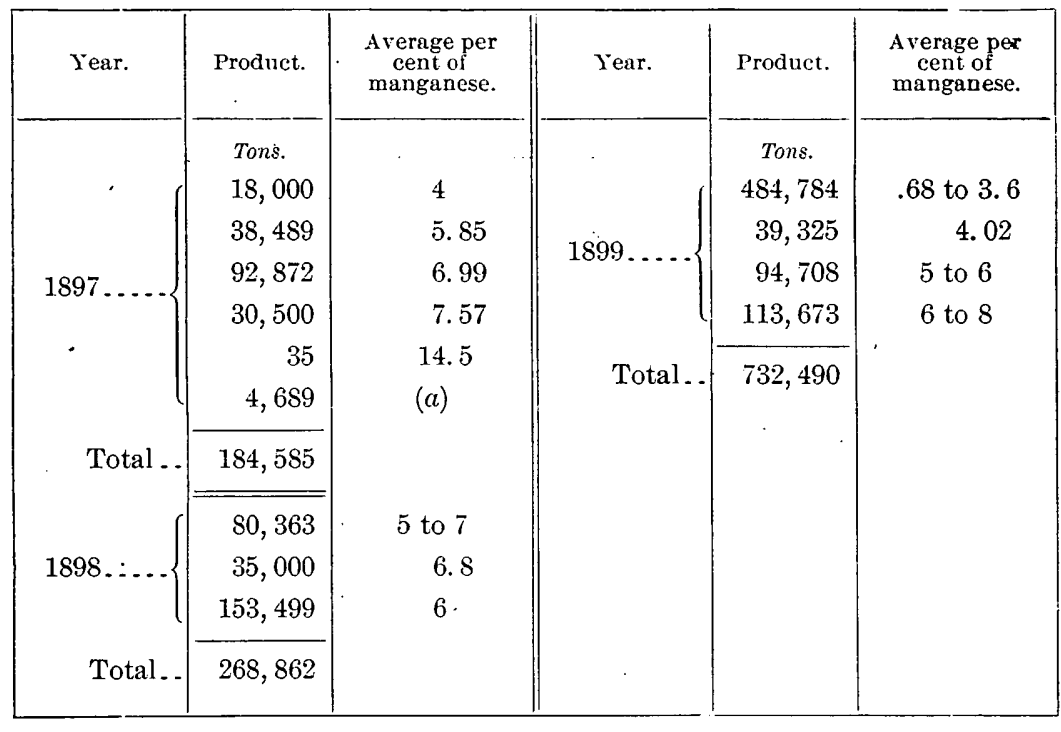

$a$ Not given.

\section{MISSOURI.}

Missouri sent a shipment of 16 tons of manganese ore to one of the steel companies, in 1899, more in the nature of a sample carload than as the opening of regular mining operations.

\section{NORTH CAROLINA.}

North Carolina is stated to have deposits of good manganese ore, which have been from time to time exploited in a small way, but the amount mined in 1899 was only 90 tons.

\section{PENNSYLVANIA.}

Mr. C. Wharton, jr., in describing the mines operated in Cumberland County, states that there is considerable ore cbtainable, averaging from 40 to 45 per cent manganese, but high in phosphorus, viz, 0.2 to 0.6 per cent. After the clay covering was removed a bed of manganiferous iron ore, 10 to 12 feet thick, was encountered, the ore carrying 40 to 50 per cent of iron and 4 to 10 per cent of manganese; under this was a second bed containing the manganese ore. Owing to the composition of the ore and the business depression in 1898 mining: was abandoned, but another mine in this vicinity contributed a small amount in 1899. 
The annual production of manganese ore in Pennsylvania from 1894 to 1899 is shown in the following table:

Production of manganese ores in Pennsylvania from 1894 to 1899.

\begin{tabular}{|c|c|c|}
\hline Year. & Production. & Value. \\
\hline & Long tons. & \\
\hline $1894 \ldots \ldots$. & 35 & - . . . . \\
\hline 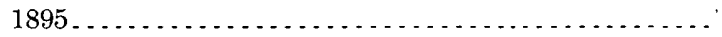 & 460 & $\$ 2,300$ \\
\hline $1896 \ldots$ & 265 & 1,988 \\
\hline 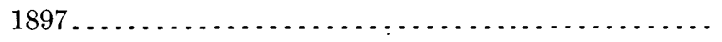 & 354 & 2,832 \\
\hline $1898 \ldots \ldots . . . \ldots$ & $\cdots$ & $\cdots$ \\
\hline $1899 \ldots \ldots \ldots \ldots \ldots \ldots$ & 12 & 58 \\
\hline
\end{tabular}

TENNESSEE.

This State has mined small amounts of manganese ore at intervals. The abandonment of manganese mining by the principal contributor to the total for 1898 has reduced the output of 1899 to 19 tons. The production in 1897,1898 , and 1899 was as follows:

Production of manganese ores in Tennessee from 1897 to 1899.

\begin{tabular}{|c|c|}
\hline Year. & Production. \\
\hline & Long tons. \\
\hline $1897 \ldots$ & 11 \\
\hline $1898 \ldots \ldots \ldots$ & 381 \\
\hline 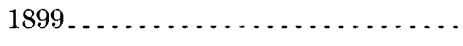 & 19 \\
\hline
\end{tabular}

\section{VIRGINIA.}

Prior to 1894 when the Crimora mine was producing liberally, Virginia annually contributed the major portion of the manganese ores mined in the United States, but when this deposit became depleted the output declined to 1,797 tons in 1894 and 1,715 tons in 1895. There has since been a gradual revival of the industry, each year showing an increase over its predecessor, until in 1899 6,228 tons were mined, the largest amount since 1891 . 
The annual production from 1880 to 1899 , inclusive, was as follows:

Production of manganese ores and manganiferous iron ores in Virginia from 1880 to 1899.

[Maxima in italies.]

\begin{tabular}{|c|c|c|c|c|c|}
\hline Year. & $\begin{array}{l}\text { Manga- } \\
\text { nese ores. }\end{array}$ & $\begin{array}{l}\text { Manganif- } \\
\text { erous iron } \\
\text { ores. }\end{array}$ & Year. & $\begin{array}{l}\text { Manga- } \\
\text { nese ores. }\end{array}$ & $\begin{array}{l}\text { Manganif- } \\
\text { erous iron } \\
\text { ores. }\end{array}$ \\
\hline $1880 \ldots \ldots$ & $\begin{array}{l}\text { Long tons. } \\
\qquad 3,661\end{array}$ & $\begin{array}{l}\text { Long toms. } \\
\text {. }\end{array}$ & $1891 \ldots \ldots \ldots$ & $\begin{array}{c}\text { Long tons. } \\
16,248\end{array}$ & Long tons. \\
\hline $18 s 1 \ldots \ldots \ldots$ & 3,295 & & 1892 . & 6,079 & 2,842 \\
\hline $1882 \ldots$ & 2,982 & $\ldots$. & 1893. & 4,092 & 1,188 \\
\hline $1883 \ldots \ldots$ & 5,355 & & 1894. & 1,797 & 132 \\
\hline 1884 & s, $980^{\circ}$ & - & 1895. & 1,715 & \\
\hline $1885 \ldots$ & 18,745 & $\ldots$ & 1896. & 2,018 & \\
\hline $1886 \ldots$ & 20,567 & & $1897 \ldots$ & 3,650 & \\
\hline 1887. & 19,835 & & 1898 . & 5,662 & \\
\hline 1888 & 17,646 & $\ldots \ldots$ & 1899 . & 6,228 & \\
\hline 1889 & 14,616 & -- & $\mathrm{T}$ & 17 & \\
\hline $1890 \ldots$ & 12,699 & $\ldots$ & & & \\
\hline
\end{tabular}

\section{IMPORTS OF MLANGANESE ORES.}

The ferromanganese and spiegel industry of the United States, owing to the small native production of manganese ores, is dependent mostly upon foreign sources of supply for this mineral, but some of the domestic manganiferous iron ores are utilized to produce these metals. The imports of manganese ores in 1899 were 188,349 long tons, an increase of 73,464 long tons, or 64 per cent, over the quantity received in 1898, owing principally to augmented shipments from Russia, Brazil, Chile, and British East Indies, and the resumption of commercial relations with Cuba.

The average value of the manganese ore imported in 1899 was $\$ 8.41$ per ton as against but $\$ 7.24$ in 1898 . The high valuation placed by the customs officers on the ores imported from the United Kingdom, Nova Scotia, New Brunswick, etc., and Germany is probably due to other chemical components than manganese.

The following figures, supplied by the Bureau of Statistics of the Treasury Department, show the amount and value, by countries, of manganese ores imported during the year 1899: 
Manganese ores imported into the Linited States during the calendar year 1899.

\begin{tabular}{|c|c|c|}
\hline Country. & Quantity. & Value. \\
\hline & Long toms. & \\
\hline Russia, Black Sea $\ldots \ldots \ldots \ldots \ldots \ldots \ldots \ldots$ & 73,397 & $\$ 598,6+4$ \\
\hline Brazil ............ & 28,115 & $299,87 T$ \\
\hline British East Indies . . . . . . . . . . . . . . . . & 17,950 & $54,4 i 1$ \\
\hline Chile. . . . . . . . . . . . . . . . . & 17,575 & 111,726 \\
\hline Cuba ....... & 16,359 & 221,785 \\
\hline Colombia........ & 8,900 & 82,489 \\
\hline Turkey in Europe. . . . . . . . . . . . . . . . . . . & 8,310 & 61,241 \\
\hline Turkey in Asia.... & 5,782 & 46,822 \\
\hline Japan .... & 4,492 & 31,657 \\
\hline Greece .......... & 3,030 & 10,526 \\
\hline France ..... & 2,953 & 21,080 \\
\hline Germany ................ & 1,274 & 34,927 \\
\hline United Kingdom . . . . . . . . . . . . . & 134 & 6,697 \\
\hline Nova Scotia, New Brunswick, etc.............. & 78 & 2,586 \\
\hline Total ...... & 188,349 & $1,584,528$ \\
\hline
\end{tabular}

The table suggests that the American steel industry draws upon various portions of the world for the manganese ores which are used, and that it is possible to find contributions from most of the countries named, in the stock yard of a blast furnace operated to produce ferromanganese.

The importations of manganese ores, by customs districts, show that nearly one-half the ore came to the port of Philadelphia, followed by Baltimore, New York, etc., as indicated by the accompanying table.

Manganese ore imported into the United States during the calendar year 1899, by customs districts.

\begin{tabular}{|c|c|c|}
\hline Customs district. & Quantity: & value. \\
\hline & Long tons. & \\
\hline Philadelphia, Pennsylvania. . ..... & 90,583 & $\$ 655,061$ \\
\hline Baltimore, Maryland.... & 80,006 & $739,5 \pm 7$ \\
\hline 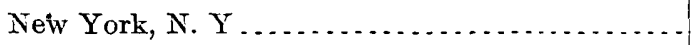 & 14,762 & 152,959 \\
\hline Norfolk, Virginia................ & 2,901 & 32,248 \\
\hline Pittsburg, Pennsylvania... & 4 & 2,473 \\
\hline Newport News, Virginia . . . . . . . . & 26 & 1,351 \\
\hline 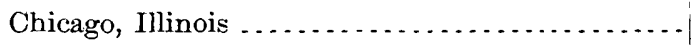 & 16 & 595 \\
\hline Boston, Massachusetts . . . . . . . . . . . . . . . . & 5 & 116 \\
\hline Passamaquoddy, Maine . . . . . . . . . . . . . . . . & 4 & 82 \\
\hline All others ........ & 2 & 96 \\
\hline Total. . & $18 S, 349$ & $1,584,528$ \\
\hline
\end{tabular}


Comparison of the amounts of manganese ore produced in this country in the last eleven years and those imported demonstrate that an average of nearly five times as much ore was imported as produced, and the percentage of importations has been increasing in late years, as will be seen from the annexed table.

Relalive quantities and values of domestic and imported manganese ores from 1889 to 1899.

\begin{tabular}{|c|c|c|c|c|}
\hline \multirow{2}{*}{ Year. } & \multicolumn{2}{|c|}{ Domestic production. } & \multicolumn{2}{|c|}{ Imports. } \\
\hline & Quantity. & Value. & Quantity. & value. \\
\hline $1889 \ldots$ & $\begin{array}{l}\text { Long tons. } \\
24,197\end{array}$ & $\$ 240,559$ & $\begin{array}{c}\text { Long tons. } \\
\text { 4, } 286\end{array}$ & $\$ 78,391$ \\
\hline 1890. & 25,684 & 219,050 & 34,154 & 516,900 \\
\hline $1891 \ldots$ & 23,416 & 239,129 & 28,825 & 380,618 \\
\hline $1892 \ldots$ & $13, \dot{613}$ & 129,586 & 58,572 & 840,811 \\
\hline 1893. & 7,718 & $66,61.4$ & 68,113 & 880,238 \\
\hline $1894 \ldots$ & 6,308 & 53,635 & 44,655 & 432,561 \\
\hline 1895. & 9,547 & 71,769 & 86,111 & 747,910 \\
\hline $1896 \ldots$ & 10,088 & 90,727 & 31,489 & 250,468 \\
\hline $1897 \ldots$ & 11,108 & 95,505 & 119,961 & $1,023,824$ \\
\hline $1898 \ldots$ & 15,957 & 129,185 & 114,885 & 831,967 \\
\hline $1899 \ldots$ & 9,935 & 82,278 & 188,349 & $1,584,528$ \\
\hline Total for 11 years & 157,571 & $1,418,037$ & 779,400 & $7,568,216$ \\
\hline Average for 11 years. . . . & 14,325 & 128,912 & 70,855 & 688,020 \\
\hline
\end{tabular}




\section{PRODUCTION OF MANGANESE IN FOREIGN COUNTRIES.}

\section{CANADA.}

The limited amount of manganese ore mined in Canada is from New Brunswick and Nova Scotia. The data showing the annual production and value, as well as the exports, of manganese ore were supplied by Mr. George M. Dawson, director of the geological survey of Canada. The annual production of manganese ore in Canada and the total value and value per ton from 1886 to 1899 , inclusive, has been as follows:

Sroduction of manganese ore in Canada from 1886 to 1899.

\begin{tabular}{|c|c|c|c|}
\hline Year. & $\begin{array}{l}\text { Produc- } \\
\text { tion. }\end{array}$ & Value. & $\begin{array}{l}\text { Value per } \\
\text { ton. }\end{array}$ \\
\hline $1886 \ldots$ & $\begin{array}{c}\text { Short tons. } \\
1,789\end{array}$ & $\$ 41,499$ & $\$ 23.20$ \\
\hline $1887 \ldots$ & 1,245 & 43,658 & 35.07 \\
\hline $1888 \ldots \ldots \ldots \ldots$ & 1,801 & 47,944 & 26.62 \\
\hline $1889 \ldots \ldots$ & 1,455 & 32,737 & 22.50 \\
\hline $1890 \ldots$ & 1,328 & 32,550 & 24.51 \\
\hline $1891 \ldots \ldots \ldots$ & 255 & 6,694 & 26.25 \\
\hline $1892 \ldots \ldots \ldots$ & 115 & 10,250 & 89.13 \\
\hline $1893 \ldots . . . . .$. & 213 & 14,578 & 68.44 \\
\hline $1894 \ldots$ & 74 & 4,180 & 56.49 \\
\hline $1895 \ldots$ & 125 & 8,464 & $6 \overline{7} .71$ \\
\hline $1896 a \ldots \ldots \ldots$ & $123 \frac{1}{2}$ & 3,975 & 32.19 \\
\hline $1897 a \ldots \ldots \ldots$ & $15 \frac{1}{4}$ & 1,166 & 76.46 \\
\hline $1898 \ldots \ldots \ldots$ & 50 & 1,600 & 32.00 \\
\hline $1899 b \ldots \ldots \ldots$ & 1,581 & 20,004 & 12.66 \\
\hline
\end{tabular}


The exports of manganese ore from Nova Scotia and New Brunswick from 1873 to 1899 , inclusive, are as follows:

Exports of manganese ore from Canada, 1879 to 1899, inclusive.

\begin{tabular}{|c|c|c|c|c|c|c|}
\hline \multirow{2}{*}{ Year. } & \multicolumn{2}{|c|}{ Nova Scotia. } & \multicolumn{2}{|c|}{ New Brunswick. } & \multicolumn{2}{|c|}{ Total. } \\
\hline & Quantity. & Value. & Quantity. & Value. & Quantity. & Value. \\
\hline $1873 \ldots$ & $\begin{array}{l}\text { Short tons. } \\
\text {........... }\end{array}$ & ......... & $\begin{array}{c}\text { Short tons. } \\
1,031\end{array}$ & $\$ 20,192$ & $\begin{array}{c}\text { Short tons. } \\
1,031\end{array}$ & $\$ 20,192$ \\
\hline 1874 & 6 & $\$ 12$ & 776 & 16,961 & 782 & 16,973 \\
\hline 1875. & $\ldots \ldots \ldots$ & 200 & 194 & 5,314 & 203 & 5,514 \\
\hline 1876 . & 21 & 723 & 391 & 7,316 & 412 & 8,039 \\
\hline 1877 & 106 & 3,699 & 785 & 12,210 & 891 & 15,909 \\
\hline $1878 \ldots \ldots$ & $\cdot 106$ & $\dot{4}, 889$ & 520 & 5,971 & 626 & 10,860 \\
\hline 1879 & 154 & $7 ; 420$ & 1,732 & 20,016 & 1,8866 & 27,436 \\
\hline 1880. & 79 & 3,090 & 2,100 & 31,707 & 2,179 & 34,797 \\
\hline $1881 \ldots \ldots$ & 200 & 18,022 & 1,504 & 22,532 & 1,704 & 40,554 \\
\hline 1882 & 123 & 11,520 & 771 & 14,227 & 894 & 25,747 \\
\hline 1883. & 313 & 8,635 & 1,013 & 16,708 & 1,326 & 25,343 \\
\hline $1884 \ldots$ & 134 & 1,054 & 469 & 9,035 & 603 & 20,089 \\
\hline $1885 \ldots$ & 77 & 5,054 & 1,607 & 29,695 & 1,684 & 34,649 \\
\hline 1886 & $a 441$ & 854 & 1,377 & 27,484 & a 1,818 & 58,338 \\
\hline $1887 \ldots$ & 578 & 14,240 & 837 & 20,562 & 1,415 & 34,802 \\
\hline $1888 \ldots \ldots$ & 87 & 5,759 & 1,094 & 16,073 & 1,181 & 21,832 \\
\hline 1889 & อั9 & 3,024 & 1,377 & 26,326 & 1,436 & 29,350 \\
\hline $1890 \ldots$ & 177 & 2,583 & 1,729 & 34,248 & 1,906 & 36,831 \\
\hline 1891. & 22 & 563 & 233 & 6,131 & 255 & 6,694 \\
\hline 1892 & 84 & 6,180 & 59 & 2,025 & 143 & 8,205 \\
\hline $1893 \ldots$ & .123 & 12,409 & 10 & 112 & 133 & 12,521 \\
\hline $1894 \ldots$ & 11 & 720 & 45 & 2,400 & 56 & 3,120 \\
\hline 1895. & 108 & 6,348 & $\frac{3}{10}$ & 3 & $108 \frac{3}{10}$ & 6,351 \\
\hline 1896 & $123 \frac{1}{2}$ & 3,975 & $\ldots$. & ..... & $123 \frac{1}{2}$ & 3,975 \\
\hline 1897 & $15_{4}^{1}$ & 1,166 & $\cdots$ & $\ldots \ldots \ldots$ & $15 \frac{1}{4}$ & 1,166 \\
\hline 1898 & 11 & 325 & $0 .-1$ & 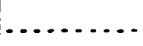 & 11 & 325 \\
\hline $1899 \ldots$ & .67 & 2,328 & 3 & 82 & 70 & 2,410 \\
\hline
\end{tabular}

$a 250$ tons should be more correctly classed under the heading of mineral pigments.

\section{rova SCOTrA.}

Mr. E. Gilpin, jr., A. M., in a report on "The Minerals of Nova Scotia, Canada," prepared for the Paris Exposition, says:

Manganese ores are common in the Carboniferous and Devonian rocks of several parts of the Province. The most continuous mining of this ore has been carried on at Tene Cape, in Hants County. Here the ore is a very pure binoxide, presented as pockets and irregular veins in limestone. The annual production from this district has seldom exceeded 200 tons, most of which, it is said, is used by glass makers.

21 GEOL, PT $6-10$ 
Near Truro, and in connection with the limonite deposits of Pictou County, considerable amounts of a similar grade of manganese ore have been mined at different times. Promising deposits occur on the College lands, Lunenburg County.

In Cape Breton County, near Loch Lomond, a good quality of the ore occurs in connection with limestone and slates, and is worked to a small extent. Hitherto only the higher grade ores have been worked in Nova Scotia.

\section{NEWFOUNDLAND.}

Newfoundland mined 1,500 long tons of manganese ore in 1897.

WEST INDIES.

CUBA.

During the years 1890 to 1893 , inclusive, considerable quantities of manganese ores were shipped from Cuba, but these ceased in 1895, owing to the depression of the iron and steel industry, and were not resumed until the close of the Spanish-American war, in the latter part of 1898 . In 1899, 13,686 tons were shipped from the Ponupo mines.

The exports from 1888 to 1899 were as follows:

Exports of manganese ore from Santiago district, Cuba, from 1888 to 1899.

\begin{tabular}{|c|c|}
\hline Year. & Quantity. \\
\hline - & Tons. \\
\hline $1888 \ldots \ldots \ldots \ldots$ & 1,942 \\
\hline $1889 \ldots \ldots \ldots$ & 704 \\
\hline $1890 \ldots$ & 21,810 \\
\hline $1891 \ldots$ & 21,987 \\
\hline 1892 & 18,751 \\
\hline $1893 \ldots$ & 10,640 \\
\hline $1895 \ldots$ & 1,394 \\
\hline $1896 \ldots$ & None. \\
\hline $1897 \ldots$ & None. \\
\hline $1898 \ldots \ldots \ldots \ldots$ & 950 \\
\hline $1899 \ldots \ldots \ldots \ldots \ldots \ldots$ & 13,686 \\
\hline
\end{tabular}

Mr. Eduardo J. Chibas, C. E., in a report dated 1899, on the Ponupo manganese mines, states that the mines of this group, the Vencedora, Sultana, Balcanee, Inca, Generala, and Mascota, are located at the terminal of the Ponupo branch of the Sabanilla and Maroto Railroad, both the railroad and the mines being controlled by the Ponupo Mining and Transportation Company. The main line of the Sabanilla and Maroto Railroad extends from Santiago de Cuba through Cristo to San Luis, in the prorince of Santiago de Cuba, a distance of $20 \frac{1}{4}$ miles. 
Just above Cristo station ( $11 \frac{1}{2}$ miles from Santiago) a branch goes to Ponupo, making the total distance from the mines to Santiago $22 \frac{3}{4}$ miles.

The Ponupo manganese deposits are located on the tops and flanks of small hills that branch out from the Sierra Maestra range of mountains, the hill on which the Vencedora deposit is located rising 240 feet above its foot, around part of which flows the Ponupo River.

The rocks in the neighborhood of the deposit are much decomposed, with the exception of some bowlders of porphyry and the jasper which comes associated with the ore, and this and the thick vegetation make it difficult to determine the exact geological formation.

At the Ponupo mines it is probable that the manganese may have been derived from one of the igneous rocks, where it is often present in the form of silicate. This was chemically decomposed when the rocks began to disintegrate by the action of atmospheric agencies, and the manganese was carried in solution in the surface waters, and when aided by favorable conditions was deposited in the form of oxide. The deposition of the ore was governed by local conditions, and consequently the extent and continuity of the deposits have to be investigated in each particular case.

The ore is found in pockets of greater or less extent, embedded in clay, resulting from the decomposition of the original inclosing rock. This clay in places assumes various shades of color-red, white, and yellow-due to the different stages of oxidation of the iron and manganese it contains. The ore is also found associated with red or yellow jasper.

The Vencedora claim is the only one worked and all the ore shipped has come from four open cuts. The portion developed in cut No. 1 presents a face 7 feet high and about 200 feet long. It rests on clay and is capped by 3 to 5 feet of soil and jasper. The ore is easily mined with pick and shovel, no blasting being required. The pocket of ore does not lie horizontally, but follows more or less the rise and fall of the ground. The ore is generally of unifor'm quality and does not require washing. Most of the ore shipped was mined in this cut.

Cut No. 2 is 80 feet long, 15 feet wide at the bottom, and 18 feet deep at the deepest portion. On the eastern wall and along the whole length of the cut is a 5-foot layer of wash ore resting on clay. The western wall shows no marketable ore; it is composed of clay, rock, and highly silicious ore. The south end of the cut presents a face 18 feet high, which is the whole depth of the cut, and about 10 feet wide. The capping covering the ore around this cut consists of a few inches of soil.

The southern wall of cut No. 3 shows wash ore near the surface and for a depth varying from 3 to 5 feet. On the western wall is a capping of about 3 feet of clay and dirt and 5 feet of manganese ore of light weight. In this cut some bowlders of porphyry are found. 
Cut No. 4 is about 50 feet wide by 75 feet long, showing good ore at the bottom. The southern portion of the cut has been stripped for 40 feet and shows wash ore 5 feet deep. A little farther south of the stripping there is a pit showing good, heavy ore. About 100 feet farther in the same direction is another pit showing only jasper, and marking the southern end of the pocket. Some bowlders of porphyry are found in this pocket.

Fifty-one test pits were sunk in order to determine the nature and character of the deposit, and of these 34 struck ore and 17 clay or jasper, or both.

Most of the ore is pyrolusite, but there are four or more distinct varieties. Class No. 1, like that found in cut No. 1, is of good uniform variety and yields, with little or no sorting, 47 and 48 per cent of metallic manganese. Class No. 2 is the black or steel-gray'ore, which looks good but is light in weight. Class No. 3 is the ore mixed with clay or soil, and requires washing; and class No. 4 is so high in silica that it can be easily picked out by inspection as an unmarketable ore.

As there is no laboratory at the mines the quality of the ore is judged by inspection, and in a new cut it is difficult to tell the percentages of impurities or of metallic manganese in the ore.

There is no question that the deposit is extensive, and it is well to remember that the workings at Vencedora have been confined thus far to the pockets of ore near the surface, resting on the clay; but this bottom clay has not been pierced to any great depth to determine whether it lies directly on the underlying rock or whether ore bodies intervene. The Ponupo formation seemed to be more regular and uniform than the formation at Nombre de Dios, Colombia, when the same amount of development had been performed.

A log washer has been erected which has a capacity of 30 tons per day of ten hours. It is operated by mules, water being pumped from the Ponupo River 240 feet to a tank on the top of the hill, where it descends by gravity to the washer. The pump is too small and cannot supply sufficient water, and the washer is run only on half time.

The ore is transported from the open cuts to the railroad cars on wheelbarrows. All the mining operations so far have been confined to the portion above the track which is inclosed in the area surrounded by the railroad loop. The ore on the hillside below the level of the railroad can be easily handled by the use of-an incline. It is said that two new 35-ton log washers are to be prorided to be run by steam.

Little blasting is required in the ore itself, but explosives are used to break up the rocks covering the pockets of ore.

Before the construction of the Ponupo Branch Railroad several thousand tons of manganese ore were mined and carried from Ponupo to Cristo on mule back. From the latter part of November, 1898, until the 1st of April, 1899, about 6,000 tons of ore were mined and shipped. 
The number of men employed is about 80 , the wages being 75 cents a day. The cost of mining the ore is estimated at $\$ 1.50$ to $\$ 2$ per ton, and the royalty is 85 cents per ton.

Freight from Ponupo to Santiago is $\$ 1.60$ per ton. When the vessel which is to transport the ore is in port the cars are run alongside the boat and the ore is carried into the hold in buckets. When the vessel is not in port, the ore is piled on the ground in Santiago, and on the arrival of the ship is again loaded and taken alongside.

The Sultana mine is located east of the Vencedora. Ten test pits, most of which show good ore, have been sunk, but no working is carried on. The eastern bank of the Ponupo River is very steep and towers about 100 feet above the river, showing along its face here and there for about 200 feet outcrops of manganese ore, some of which are of good quality.

\section{SOUTH AMERICA.}

BRAZIL.

The manganese deposits of Bahia and Minas, Brazil, are described by Prof. John C. Branner, Stanford University, California, in the Transactions of the American Institute of Mining Engineers, 1899, from which the following excerpts have been taken:

Thus far the manganese ore shipped from the State of Bahia has come from two mines, the principal one of which is known as the Pedras Pretas mine. This was the first mine opened, is the best developed, and was the original discovery, the second is on an adjoining tract, and the general geology and natural conditions are about the same in both.

The Pedras Pretas mine, on the railway, 26 kilometers west of the town of Nazareth, at the head of navigation, is reached from the city of Bahia by a small steamer that runs across the bay of Bahia and up the Rio Jaguaripe.

The geology of the deposit is of special interest. The rocks are decomposed crystalline schists. Mr. Nack ${ }^{1}$ speaks of them as decomposed gneiss, and the rocks have a certain semblance to gneiss.

The city of Bahia stands upon crystalline schists cut by eruptive dikes. Immediately west of the eity is a Cretaceous basin that rests unconformably upon these crystalline rocks and extends westward to within a couple of kilometers of the town of Nazareth. At Nazareth the schists are so decomposed that solid rocks in place are to be seen only in the stream beds and here and there in the hills. It is in these decomposed rocks that the manganese is found.

The Brazilian manganese beds are in rocks"of approximately the same geologic age and certainly of the same general appearance and characteristics as the great ironbearing series of the northwestern United States. The mine is 198 meters above tide level and 70 meters above the track of the Amargosa Railway, near by. The ore is psilomelane, and, compared with the Arkansas and Georgia ores, it appeared to be unusually clean, though all of it is somewhat stained with red clay. Some of the lumps are botryoidal in form, but most of them are angular, and many of them are more than 2 feet in diameter. Lumps have been found that weigh $1 \frac{1}{2}$ tons. The smallest pieces on the ore piles are larger than one's fist, and these pieces make but a small part of the ore on the heaps.

1 Chief owner of the Pedras Pretas property. 
The Pedras Pretas mine is in soft earth save where large masses of solid ore have been drifted into. Most of the ore thus far shipped has come from the great horizontal sheet that spreads out almost or quite on the surface of the ground.

It seems evident that there is a sheet, bed, or vein of ore standing at an angle of $60^{\circ}$ and varying in thickness from a few decimeters to 10 meters. The surface deposits are taken to be the accumulation from the breaking up and weathering out of the bed and the removal of the clays about it, just as the Arkansas ores come from the decomposition of limestones.

For removing clay a pit is covered with railroad iron, the rails lying close against each other and sloping towards the shed. A fire is kept beneath these rails, and all the ore that comes from the pits covered with clay is dumped upon these hot bars and left there until the clay dries. It is then raked off, the clay is removed by rapping the ore lumps with hammers, and the ore is then dropped on the chutes. This ore cleaning is done by women. When the ore comes from the mines clean, the cars are dumped immediately into the chute.

The company owns a tramway over which its ore is hauled to the railway by which it is taken to the wharf at Nazareth. At this place it is loaded on small sailing vessels and sent to Itaparica, a small town on the bay of Bahia, where it is put on board sailing vessels for Europe or the United States.

The Government charges are a little more than 1 milreis a ton on the exported ore. It is stated that sailing vessels charge $10 \mathrm{~s}$. a ton to carry the ore from Bahia to Philadelphia. As reported by the mine owners, the total cost (to them) of this manganese ore, laid down in Philadelphia, is $\$ 4.95$ a ton.

The Minas Geraes manganese deposits are near the Miguel Burnier station on the Ouro Preto branch of the Central Railway (496 kilometers north of Rio) and at Queluz on the main line (463 kilometers from Rio). They are all open cuts in rocks decomposed in place. The general geology of the region is very much like that of the Bahia manganese mines.

Dr. Antonio Olyntho dos Santos Pires has furnished the following information regarding the Minas manganese deposits:

In the zone between Miguel Burnier and Itabira, on the Central Brazil Railway, two iron furnaces had been started alongside of iron deposits, but the difficulty of getting charcoal for fuel caused the directors of one of these furnaces to turn attention to the manganese and to attempt its exportation. The result of this attempt was farorable, and from this began the regular mining and shipping of this mineral. At present there are three companies engaged in this work, besides the small organizations that are formed and disappear from time to time. These companies operate in the zone between Lafayette and Burnier stations, along the branch railway running from Burnier to Ouro Preto, and lately in the vicinity of the last-named city. It is only within the last two years that these mining operations have become systematized. Of the geology of these deposits no careful studies have been made. The order of the beds, as shown in most of the cuts along the Ouro Preto branch of the railway, is about as follows:

1. Limestone.

2. Ferruginous quartzite, or itabirite.

3. Clays.

4. Compact itabirite.

5. Manganese.

6. Jacutinga, or friable itabirite.

7. Clays.

8. Stratified crystalline rocks, with limonite and impure manganese oxides.

9. Clay shales.

10. Canga, or ferruginous conglomerate. 
The kinds of manganese most frequently found are manganite $\left(\mathrm{Mn}_{2} \mathrm{O}_{3} \mathrm{H}_{2} \mathrm{O}\right)$ and pyrolusite $\left(\mathrm{MnO}_{2}\right)$ and less frequently the other oxides. The itabirite with which the manganese is generally interbedded is composed of hematite and layers of quartz. It is sometimes so compact that it is called ironstone; and again it is friable, when it is known as jacutinga.

The exportation of manganese from the State of Minas began (by way of Rio de Janeiro), upon a small scale, in 1894. In subsequent years it was as follows:

Exports of manganese from Minas, via Rio de Janeiro.

\begin{tabular}{|c|c|}
\hline Year. & Metric tons. \\
\hline $1895 \ldots \ldots \ldots \ldots$ & 6,765 \\
\hline $1896 \ldots$ & 13,020 \\
\hline $1897 \ldots \ldots$ & 17,967 \\
\hline $1898 \ldots \ldots . . . .$. & 29,630 \\
\hline 1899 (to September).... . & $a 60,107$ \\
\hline
\end{tabular}

a Macqueen gives the exports from Brazil in 1899 as 62,178 tons.

There has also been some manganese exported from Lafayette station and from Ouro Preto, but the export became regular only during the year 1899 . To the figures given above there should, therefore, be added at least 15 or 20 per cent, to show the total export of manganese from the State of Minas.

Other districts, such as that of Sabara and Bello Horizonte, along the line of the Central railway, contain deposits of importance which must be developed shortly.

Analyses of manganese ore furnished by Dr. Antonio Olyntho show metallic manganese ranging from 29.8 per cent to 62 per cent; phosphorus ranging from trace to 0.154 per cent.

A statement furnished by Ledoux \& Co., of New York City, gave the average analysis of 40,000 tons of Brazilian manganese ore, as follows:

Average analysis of Brazilian manganese ore.

\begin{tabular}{|c|c|}
\hline & Per cent. \\
\hline Moisture ......... & 7.60 \\
\hline 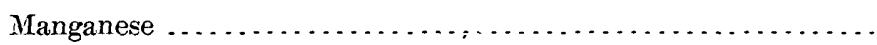 & 54.08 \\
\hline Phosphorus...... & .03 \\
\hline Silica................... & 1.05 \\
\hline Iron $\ldots \ldots \ldots \ldots \ldots$ & .90 \\
\hline
\end{tabular}

COLOMBIA.

The manganese deposits which are at present worked are on the isthmus of Panama, about 45 miles northeast of Aspinwall, near the shore of the Caribbean Sea. 
The mines of this district have been described in a previous report, and the shipments from there have been as follows:

Shipments of manganese ore from the United States of Colombia.

\begin{tabular}{|c|c|}
\hline Year. & Shipments. \\
\hline & Long tons. \\
\hline To the close of $1896 \ldots \ldots \ldots \ldots$ & 18,215 \\
\hline $1897 \ldots \ldots \ldots$ & $(a)$ \\
\hline $1898 \ldots \ldots \ldots$ & 8,595 \\
\hline $1899 \ldots \ldots \ldots \ldots \ldots \ldots \ldots \ldots \ldots \ldots \ldots$ & 8,955 \\
\hline
\end{tabular}

CHILE.

In the report for 1898 a detailed description of the various manganese deposits of Chile were given, together with the analyses of the ores, etc.

It is difficult to obtain exact statistics of the production, the figures of exportation only being procurable. From these it appears that the exports from 1885 to 1899 have been as follows:

Exports of Chilean manganese ores, 1885 to 1899.

\begin{tabular}{|c|c|c|c|c|c|}
\hline Year. & Quantity. & Total value. $a$ & Year. & Quantity. & Total value. $a$ \\
\hline $1885 \ldots$ & $\begin{array}{c}\text { Long tons. } \\
4,041\end{array}$ & & 1893 & $\begin{array}{c}\text { Long tons. } \\
36,162\end{array}$ & $\$ 284,262$ \\
\hline 1886 & 23,928 & & 1894. & 47,238 & 371,374 \\
\hline 1887 & 47,521 & & 1895. & 23,696 & 186,747 \\
\hline 1888. & 18,713 & & 1896. & 25,740 & 202,335 \\
\hline 1889. & 28,683 & & 1897. & 23,156 & 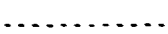 \\
\hline 1890. & 47,986 & & $1898 .$. & 20,522 & 163,165 \\
\hline 1891 & 34,462 & $\ldots \ldots$ & 1894. & 36.996 & 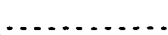 \\
\hline 1892. & 50,871 & $\$ 399,881$ & & & \\
\hline
\end{tabular}

$a$ The English pound is taken as $\$ 4.8665$.

EUROPE.

GREAT BRITAN.

The United Kingdom does not produce true manganese ores, but does produce manganiferous iron ores, and Mr. Bennett H. Brough states that the output continues to decline, owing to the competition of richer ores of Russia, India, Chile, and Turkey. The amount produced in the sear 1898 was 231 tons, ralued at $\$ 974$. 
The amounts mined and their value, from 1884 to 1898 , inclusive, are given in the accompanying table:

Production and value of manganiferous iron ores in the United Kingdom from 1884 to 1898.

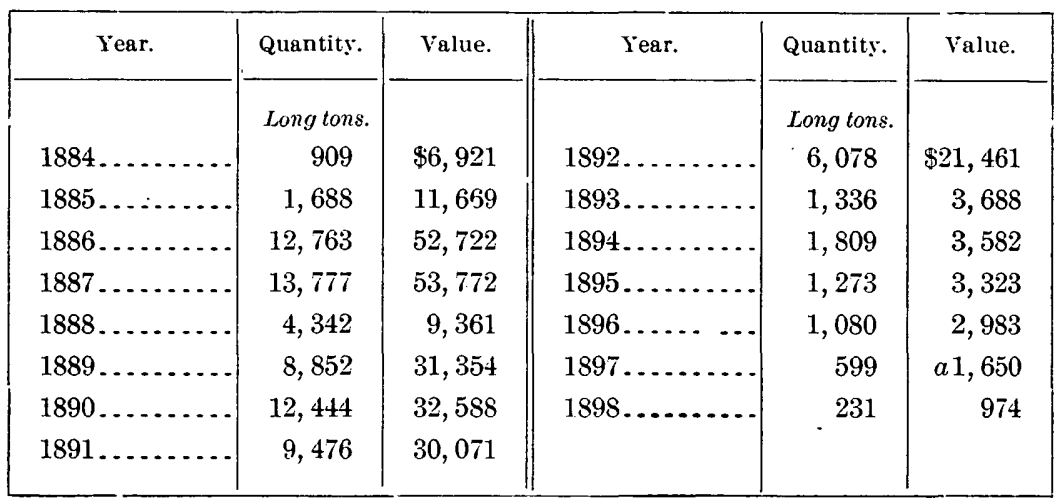

$a$ Estimated.

FRANCE.

M. Alexandre Pourcel, of Paris, supplied the following data in regard to the French manganese mines. In the year 1898 there were nine mines exploited, two of which have not yet reached the productive stage. The greater portion of the ore has been taken from the mines of Las Cabesses (Oriege), which furnished 7,000 tons of calcined carbonate of manganese and 6,400 tons of sorted carbonate ore, and the mines of Romaneche and the Grand Filon (Saône-et-Loire), from which about 7,200 tons of bioxide of manganese were taken.

The amount and value of manganese ores produced in France from 1886 to 1898 , inclusive, appear in the following table:

Production and value of manganese ores in France from 1886 to 1898.

\begin{tabular}{|r|r|r|r|r|r|r|r|}
\hline Year. & $\begin{array}{c}\text { Produc- } \\
\text { tion. }\end{array}$ & \multicolumn{1}{c|}{$\begin{array}{c}\text { Total } \\
\text { value. }\end{array}$} & $\begin{array}{c}\text { Value } \\
\text { per ton. }\end{array}$ & Year. & $\begin{array}{c}\text { Produc- } \\
\text { tion. }\end{array}$ & $\begin{array}{c}\text { Total } \\
\text { value. }\end{array}$ & $\begin{array}{c}\text { Value } \\
\text { per ton. }\end{array}$ \\
\hline 1886. & $\begin{array}{r}\text { Long tons. } \\
7,555\end{array}$ & $\$ 53,099$ & $\$ 7.03$ & $1893 \ldots$ & 37,406 & $\$ 290,073$ & $\$ 7.75$ \\
1887. & 11,932 & 50,501 & 4.23 & $1894 \ldots$ & 32,239 & 192,264 & 5.96 \\
1888. & 10,873 & 60,757 & 5.59 & $1895 \ldots$ & 30,385 & 177,698 & 5.85 \\
$1889 .$. & 9,842 & 59,000 & 5.99 & $1896 \ldots$ & 30,797 & 179,297 & 5.82 \\
$1890 .$. & 15,731 & 89,517 & 5.69 & $1897 \ldots$ & 36,612 & 200,720 & 5.48 \\
$1891 .$. & 15,101 & 90,316 & 5.98 & $1898 \ldots$ & 31,396 & 160,383 & 5.11 \\
$1892 .$. & 31,894 & 205,074 & 6.43 & & & & \\
\hline
\end{tabular}




\section{BELGIUM.}

Belgium does not mine manganese ores, but produces some manganiferous iron ore. Mr. P. Trasenter states that in 189816,440 metric tons of this class of ore were won, valued at 211,500 francs $(\$ 40,820)$.

The production of manganiferous iron ore from 1880 to 1898 , inclusive, and the value of the ore are as follows:

Production of manganiferous iron ores in Belgium from 1880 to 1898 .

\begin{tabular}{|c|c|c|c|c|c|}
\hline Year. & Product. & Value. & Year. & Product. & value. \\
\hline 1880 & $\begin{array}{c}\text { Metric tons } \\
700\end{array}$ & $\begin{array}{l}\text { Francs. } \\
\quad 4,000\end{array}$ & 1890. & $\begin{array}{c}\text { Metric tons } \\
14,255\end{array}$ & $\begin{array}{c}\text { Francs. } \\
176,000\end{array}$ \\
\hline 1881. & 770 & 4,000 & 1891. & 18,498 & 254,600 \\
\hline 1882 & 345 & 1,750 & 1892. & 16,775 & 208,300 \\
\hline 1883. & 820 & 4,100 & 1893. & 16,800 & 201,000 \\
\hline 1884 & 750 & 3,750 & 1894. & 22,048 & 277,700 \\
\hline 1885 & $\ldots$. & $\ldots \ldots$ & 1895 & 22,478 & 286,270 \\
\hline 1886. & 750 & 9,000 & 1896. & 23,265 & 345,020 \\
\hline 1887. & 12,750 & 155,850 & 1897. & 28,372 & 342,700 \\
\hline 1888. & 27,787 & 325,000 & $1898 \ldots$ & 16,440 & 211,500 \\
\hline 1889. & 20,905 & 248,000 & & & \\
\hline
\end{tabular}

\section{GERMANY.}

The German Empire mines some manganese ores, but they are probably like those of Belgium, more truly manganiferous iron ores, as will be seen by the price, which amounts to but about $\$ 2$ per ton.

The production of these ores from 1890 to 1898 is given in the following table:

Production of manganese ores in Germany from 1890 to 1898.

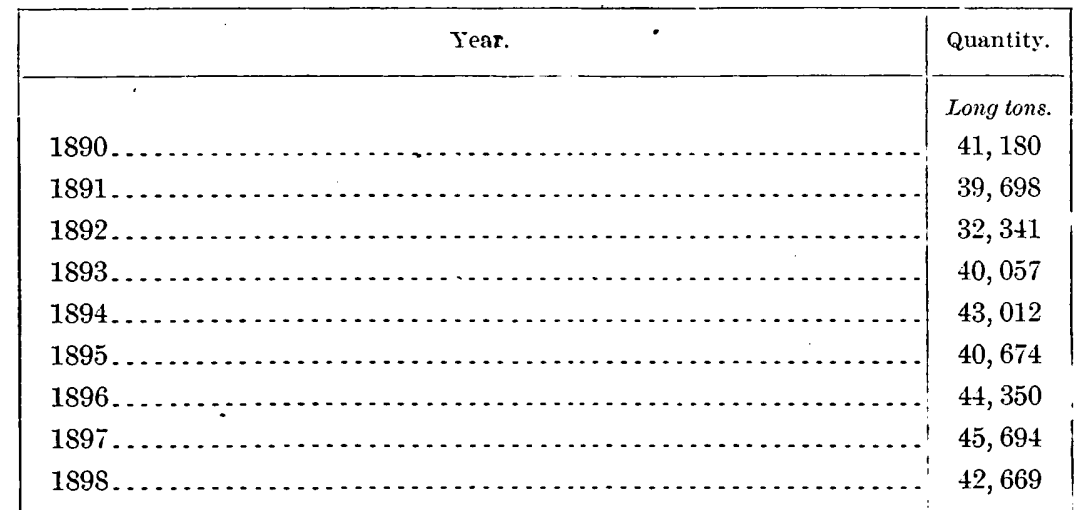


The major portion of this ore comes from Prussia, which contributed 41,565 tons out of the total of 42,669 tons.

The amount and value of the ores mined in Prussia from 1881 to 1898 is given in the following table:

Production and value of manganese ores in Prussia from 1881 to 1898.

\begin{tabular}{|c|c|c|c|c|c|}
\hline Year. & Product. & Value. & Year. & Product. & Value. \\
\hline $1881 \ldots$ & $\begin{array}{c}\text { Long tons. } \\
10,911\end{array}$ & $\$ 79,104$ & 1890 & $\begin{array}{c}\text { Long tons. } \\
39,497\end{array}$ & $\$ 174,428$ \\
\hline 1882 & 4,597 & 33,745 & 1891. & 36,278 & 174,624 \\
\hline 1883. & 4,502 & 28,423 & 1892 & 30,892 & 101,844 \\
\hline 1884 & 7,629 & 43,118 & 1893. & 38,384 & 93,506 \\
\hline 1885 & 14,464 & 81,302 & 1894 & 41,854 & 94,992 \\
\hline 1886 & 24,649 & 177,066 & 1895 & 39,266 & 100,832 \\
\hline 1887 & 35,957 & $22 S, 439$ & 1896 & 42,925 & 97,469 \\
\hline 1888 & 26,877 & 147,250 & 189.7 & 44,538 & 98,185 \\
\hline 1889. & 43,311 & 216,381 & $1898 \ldots$ & 41,565 & 92,050 \\
\hline
\end{tabular}

\section{ITALY.}

The Kingdom of Italy contributes a small amount of manganese ore, and also mangariferous iron ores. The amounts and values of these classes of ores produced each year from 1860 to 1898 are given below:

Production of manganese and manganiferous iron ores in Italy from 1860 to 1898.

\begin{tabular}{|c|c|c|c|c|}
\hline \multirow{2}{*}{ Year. } & \multicolumn{2}{|c|}{ Manganese ores. } & \multicolumn{2}{|c|}{ Manganiferous iron ores. } \\
\hline & Production. & Value. & Production. & Value. \\
\hline & Long tons. & & Long tons. & \\
\hline 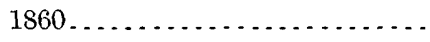 & 642 & $\$ 12,373$ & $\ldots \ldots$ & \\
\hline $1861 \ldots \ldots$ & 515 & 9,174 & & \\
\hline 1862. & 1,714 & 15,661 & & \\
\hline $1863 \ldots \ldots \ldots \ldots$ & 714 & 6,674 & 1- & \\
\hline $1864 \ldots$ & 712 & 8,567 & - & \\
\hline $1865 \ldots$ & 571 & 6,716 & & \\
\hline $1866 \ldots \ldots$ & 711 & 7,191 & i- & 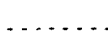 \\
\hline $1867 \ldots \ldots$ & 677 & 8,079 & - & $\therefore$ \\
\hline $1868 \ldots$ & 661 & 7,894 & & \\
\hline $1869 \ldots \ldots$ & 758 & 10,403 & & \\
\hline $1870 \ldots \ldots$ & 630 & 8,646 & $\ldots$. & \\
\hline $1871 \ldots \ldots$ & 779 & 9,793 & & \\
\hline $1872 \ldots . .$. & 1,125 & 12,311 & & \\
\hline $1873 \ldots \ldots$ & 3,103 & 46,548 & $\ldots$ & \\
\hline
\end{tabular}


Production of manganese and manganiferous iron ores in Italy from 1860 to 1898-Cont'd.

\begin{tabular}{|c|c|c|c|c|}
\hline \multirow{2}{*}{ Year. } & \multicolumn{2}{|c|}{ Manganese ores. } & \multicolumn{2}{|c|}{ Manganiferous iron ores. } \\
\hline & Production. & Value. & Production. & Value. \\
\hline $1874 \ldots \ldots \ldots$ & $\begin{array}{c}\text { Long tons. } \\
\quad 3,169\end{array}$ & $\$ 58,697$ & $\begin{array}{c}\text { Long tons. } \\
3,445\end{array}$ & $\$ 6,755$ \\
\hline $1875 \ldots$ & 3,750 & 64,341 & 19,684 & 96,500 \\
\hline $1876 \ldots . .$. & 6,800 & 61,074 & 22,878 & 93,315 \\
\hline $1877 \ldots$ & 6,704 & 56,546 & 7,874 & 26,248 \\
\hline 1878 & 6,550 & 46,567 & 6,368 & 15,297 \\
\hline $1879 \ldots \ldots$ & 5,614 & 33,842 & 1,366 & 2,679 \\
\hline $1880 \ldots \ldots$ & 6,373 & 40,682 & 20,148 & 63,214 \\
\hline 1881 & 8,629 & 45,219 & $a 29,526$ & $a 92,640$ \\
\hline $1882 \ldots$ & 6,868 & 67,201 & $a 29,526$ & $a .92,640$ \\
\hline $1883 \ldots \ldots$ & 11,204 & 52,975 & 8,858 & 27,792 \\
\hline $1884 \ldots \ldots \ldots$ & 871 & 7,570 & $\cdots$ & \\
\hline $1885 \ldots$ & 1,774 & 10,899 & & \\
\hline $1886 \ldots \ldots$ & 5,473 & 30,943 & & \\
\hline 1887 & 4,363 & 21,872 & & \\
\hline $1888 \ldots$ & 3,573 & 15,054 & & \\
\hline $1889 \ldots \ldots \ldots \ldots \ldots \ldots \ldots \ldots$ & 2,168 & 9,998 & $\cdots$ & \\
\hline $1890 \ldots . .$. & 2,113 & 10,050 & $\ldots$ & - \\
\hline $1891 \ldots \ldots \ldots \ldots \ldots . . . . . . . . .$. & 2,391 & 12,467 & 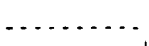 & \\
\hline $1892 \ldots \ldots$ & 1,223 & 8,067 & 4,549 & 8,028 \\
\hline $1893 \ldots$ & 797 & 6,320 & 8,666 & 14,445 \\
\hline $1894 \ldots \ldots$ & 748 & 4,536 & 5,718 & 8,971 \\
\hline $1895 \ldots . .$. & $1,5+4$ & 13,634 & $-\ldots$ & $\ldots \ldots$ \\
\hline $1896 \ldots$ & 1,860 & 19,734 & 9,842 & 19,300 \\
\hline $1897 \ldots \ldots$ & 1,608 & 14,483 & 20,926 & 32,829 \\
\hline $1898 \ldots . . .$. & 2,955 & 18,052 & 10,974 & 25,823 \\
\hline
\end{tabular}

$a$ In original, 30,000 metric tons valued at 480,000 lire, possibly an estimate.

SPAIN.

With the exception of a few hundred tons of oxide of manganese obtained in the provinces of Oveido and Tereul, all the manganese ores mined in Spain are of the carbonate and silicate rarieties, obtained in the province of Huelva.

Mr. Carlos Sundheim, M. E., has supplied statistics in regard to the manganese ore mined in Spain in the year ending December 31, 1899 , together with the countries to which it was exported. 
Exports of Huelva manganese ores in 1899.

\begin{tabular}{|c|c|}
\hline Country. & Quantity. \\
\hline & Metric tons. \\
\hline Belgium and Luxemburg $\ldots \ldots \ldots \ldots \ldots \ldots \ldots \ldots \ldots \ldots \ldots$ & 127,743 \\
\hline 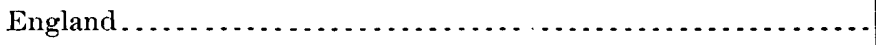 & 4,842 \\
\hline 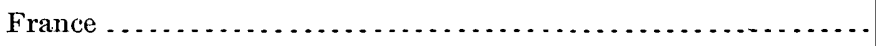 & 4,449 \\
\hline 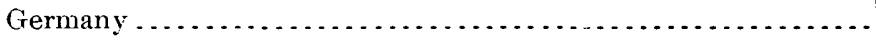 & 1,385 \\
\hline Total . . . . . . . . . . . . . . . . & 138,419 \\
\hline
\end{tabular}

The production of manganese ores in Spain from 1890 to 1899, inclusive, is as follows:

Production of manganese ores in Spain from 1890 to 1899.

\begin{tabular}{|c|c|c|c|}
\hline Year. & Quantity. & Year. & Quantity. \\
\hline & Long tons. & & Long tons. \\
\hline $1890 \ldots . . . .$. & 9,716 & $1895 \ldots \ldots \ldots \ldots \ldots$ & 26,946 \\
\hline $1891 \ldots$ & 6,883 & $1896 \ldots \ldots \ldots \ldots$ & 90,546 \\
\hline $1892 \ldots \ldots \ldots \ldots$ & 16,643 & $1897 \ldots \ldots \ldots \ldots \ldots$ & 101,937 \\
\hline $1893 \ldots$ & 1,437 & $1898 \ldots \ldots \ldots \ldots \ldots$ & 136,182 \\
\hline $1894 .=\ldots \ldots \ldots \ldots$ & 423 & $1899 \ldots \ldots \ldots \ldots$ & 136,533 \\
\hline
\end{tabular}

\section{AUSTRIA-HUNGARY.}

This empire mines each year a small amount of manganese ore. The following tables show the amount produced in Austria from 1876 to 1898, also in late years in Hungary and Bosnia and Herzegovina:

Production af manganese ore in Austria from 1876 to 1895.

\begin{tabular}{|c|c|c|c|}
\hline Year. & Product. & Year. & Product. \\
\hline - & Centners. & & Centners. \\
\hline $1876 \ldots \ldots \ldots \ldots \ldots$ & 67,817 & $1888 \ldots \ldots \ldots \ldots \ldots \ldots$ & 65,541 \\
\hline $1877 \ldots$ & 78,999 & $1889 \ldots$ & 39,261 \\
\hline $1878 \ldots \ldots \ldots \ldots \ldots$ & 41,836 & $1890 \ldots \ldots . . . . . . . . . .$. & 80,068 \\
\hline $1879 \ldots \ldots \ldots \ldots \ldots \ldots$ & 34,337 & $1891 \ldots \ldots \ldots \ldots$ & 52,793 \\
\hline $1880 \ldots \ldots$ & 88,744 & $1892 \ldots$ & 46,000 \\
\hline $1881 \ldots \ldots \ldots \ldots \ldots$ & 91,097 & $1893 \ldots \ldots \ldots \ldots \ldots$ & 54,000 \\
\hline $1882 \ldots$ & 84,183 & $1894 \ldots \ldots . . . . . . . .$. & 101,120 \\
\hline $1883 \ldots$ & 93,821 & $1895 \ldots \ldots$ & a 92,270 \\
\hline $1884 \ldots$ & 79,423 & & Metric tons. \\
\hline $1885 \ldots$ & 61,577 & $1897 \ldots \ldots \ldots \ldots \ldots$ & 6,012 \\
\hline $1886 \ldots \ldots \ldots \ldots \ldots$ & 92,464 & $1898 \ldots$ & 6,123 \\
\hline $1 S S 7 \ldots$ & 93,108 & & \\
\hline
\end{tabular}

$a$ Including Bosnia. 
Production of manganese ore in Hungary. (a)

\begin{tabular}{|c|c|}
\hline Year. & Metric tons. \\
\hline $1897 \ldots \ldots \ldots \ldots$ & 3,976 \\
\hline $1898 \ldots \ldots \ldots \ldots$ & 8,055 \\
\hline
\end{tabular}

$a$ Ungarisches Statistiches Jahrbuch.

Production of manganese ore in Bosnia and Herzegovina.

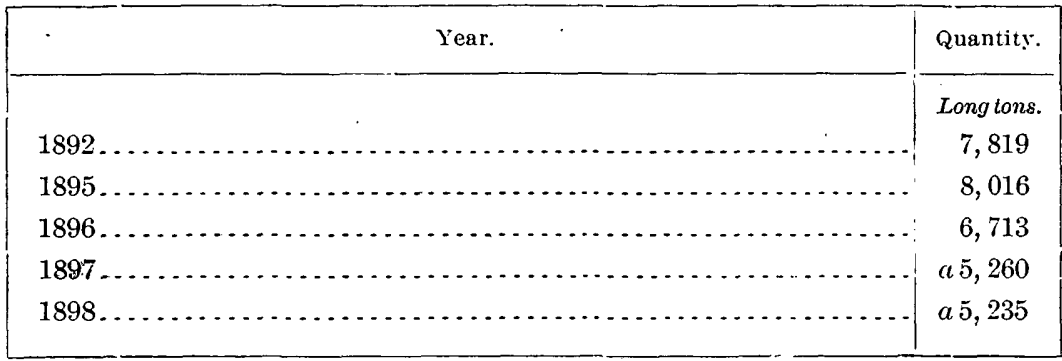

$a$ Bosniches Bureaú Montan Abtheilung.

SWEDEN.

Sweden has been a continuous producer of small amounts of manganese ore, Dr. Richard Akerman, of Stockholm, reporting that in the year 18982,358 metric tons, valued at 41,270 crowns, were won.

The production from 1888 to 1898 , inclusive, is as follows:

Production of manganese ores in Sweden, 1888 to 1898.

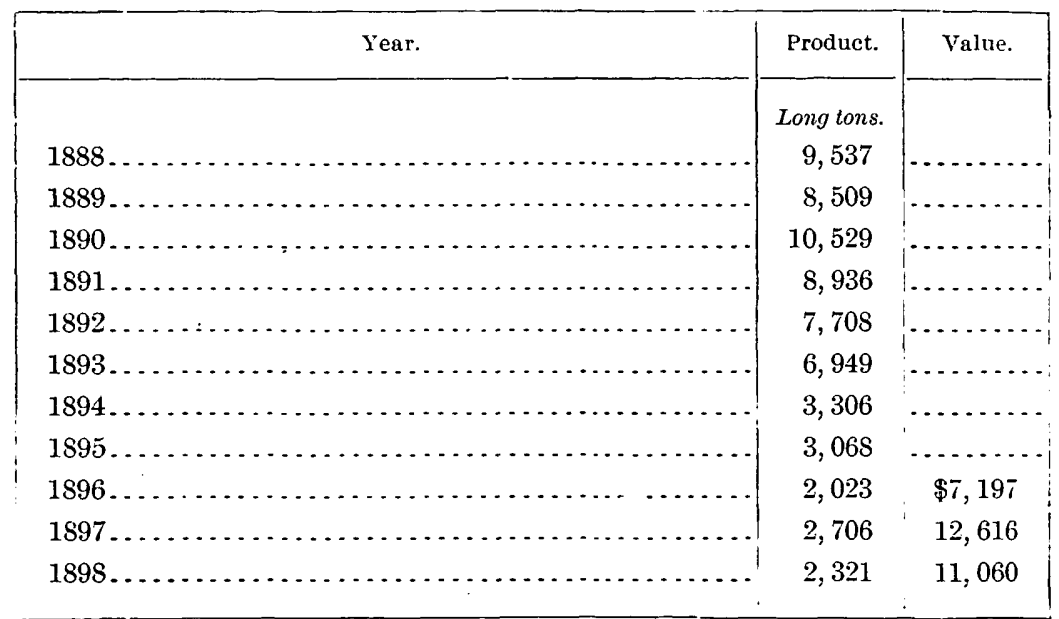


RUSSIAN EMPIRE.

Probably the richest and at present the most extensively exploited manganese deposits in the world are found in the trans-Caucasian district of Russia, and the major portion of the product is exported to various foreign countries. Macqueen gives the total exports of manganese ore in the year 1899, from the Caucasus district, as 348,162 tons, and from South Russia 28,283 tons, a total export of 376,445 metric tons (370,499 long tons).

The table below gives the production and exports of Caucasian manganese ore from 1885 to 1899 , together with the distribution of exports from 1893 to 1897 , inclusive:

Production and exports of Caucasian manganese ore.

\begin{tabular}{|c|c|c|c|c|c|}
\hline Year. & Production. & Exports. & Year. & Production. & Exports. \\
\hline 1885. & $\begin{array}{r}\text { Long tons. } \\
58,722\end{array}$ & $\begin{array}{r}\text { Long tons. } \\
41,396\end{array}$ & 1893. & $\begin{array}{r}\text { Long tons. } \\
166,420\end{array}$ & $\begin{array}{r}\text { Long tons. } \\
126,630\end{array}$ \\
\hline 1886 & 67,985 & 53,751 & $1894 \ldots$ & 180,533 & 157,275 \\
\hline 1887 & 51,890 & 59,523 & 1895 & 160,277 & 185,718 \\
\hline 1888. & 29,401 & 49,076 & $1896 \ldots$ & $\ldots \ldots \ldots$ & 166,224 \\
\hline 1889. & 68,439 & 55,489 & $1897 \ldots$ & 231,868 & 210,106 \\
\hline 1890. & 168,840 & 135,492 & $1898 \ldots$ & & 277,857 \\
\hline 1891. & 98,670 & 84,040 & $1899 \ldots$ & & 370,499 \\
\hline 1892. & 165,101 & 129,835 & & & \\
\hline
\end{tabular}

Distribution of exports of Caucasian manganese ore.

\begin{tabular}{|c|c|c|c|c|c|}
\hline Country. to which exported. & 1893. & 1894. & 1895. & 1896. & 1897. \\
\hline Great Britain & $\begin{array}{c}\text { Long tons. } \\
42,930\end{array}$ & $\begin{array}{c}\text { Long tons. } \\
65,110\end{array}$ & $\begin{array}{c}\text { Long tons. } \\
60,616\end{array}$ & $\begin{array}{c}\text { Long tons. } \\
7 \overline{7}, 754\end{array}$ & $\begin{array}{c}\text { Long tons. } \\
68,650\end{array}$ \\
\hline France .......... & 4,100 & & 150 & 5,650 & . \\
\hline Russia. & $\ldots \ldots . .$. & 9,890 & 9,600 & 20,175 & 28,446 \\
\hline Belgium . . . . . . & 3,125 & 2,520 & $\ldots$ & 220 & $\ldots$. \\
\hline Germany ... & 40,405 & 51,455 & 59,565 & 58,825 & 70,810 \\
\hline Enited States & 36,070 & 28,300 & 55,787 & 3,600 & 42,200 \\
\hline Total exports ... & 126,630 & 157,275 & 185,718 & 166,224 & 210,106 \\
\hline
\end{tabular}

TURKEY.

Turkey has deposits of manganese ore, but no official statistics of the amount mined are obtainable. Macqueen gives the total exports from the Kassandra district in 1899 as 38,305 tons. 


\section{PORTUGaI.}

Portugal has a few manganese beds, which are worked in a spasmodic way, the exports in 1899 , as given by Macqueen, being 4,130 tons. In 1897, 1,652 metric tons were mined, and in 1898, 907 metric tons.

\section{GREECE.}

Greece has both manganese ores and manganiferous iron ores, the exports of the former variety being reported as 15,300 tons in 1899 , as against 14,097 metric tons in 1898 and 11,710 metric tons in 1897 .

\section{INDIA.}

India, particularly in 1899, exported considerable manganese ore, the most of which has come from the Madras Presidency. Mr. Herbert $\mathrm{K}$. Scott states that the ore is high in phosphorus. Macqueen gives the exports from India in 1899 as 77,348 tons. .

The exports from 1892 to 1899 are as follows:

Exports of manganese ore from British India by sea to other countries, from 1892 to 1899 .

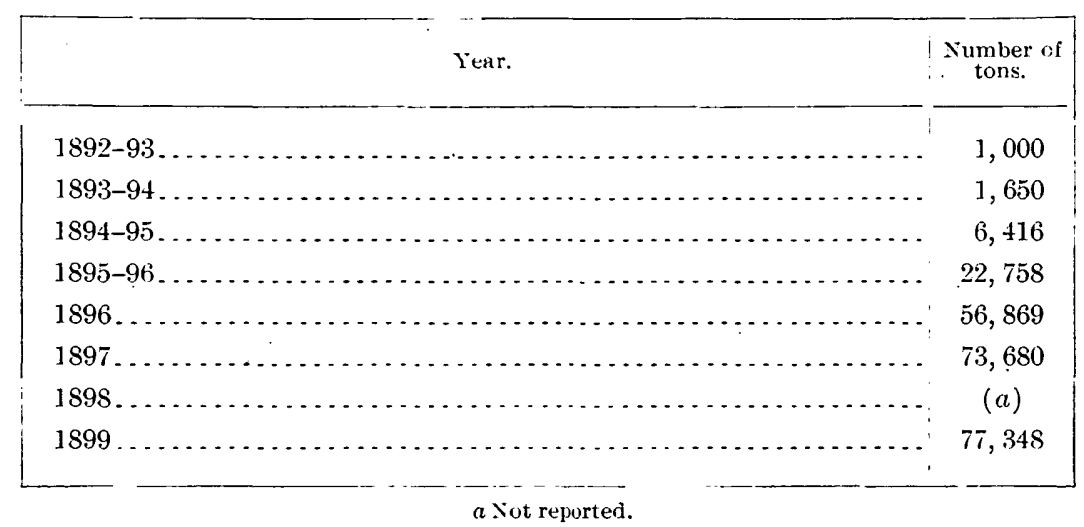




\section{JAPAN.}

The manganese deposits of Japan are said by Mr. Scott to be of small extent and hence not likely to become a prominent source of supply.

The production and exports from 1881 to 1899 are as follows:

Production and exports of manganese ores in Japan from 1881 to 1899. (a)

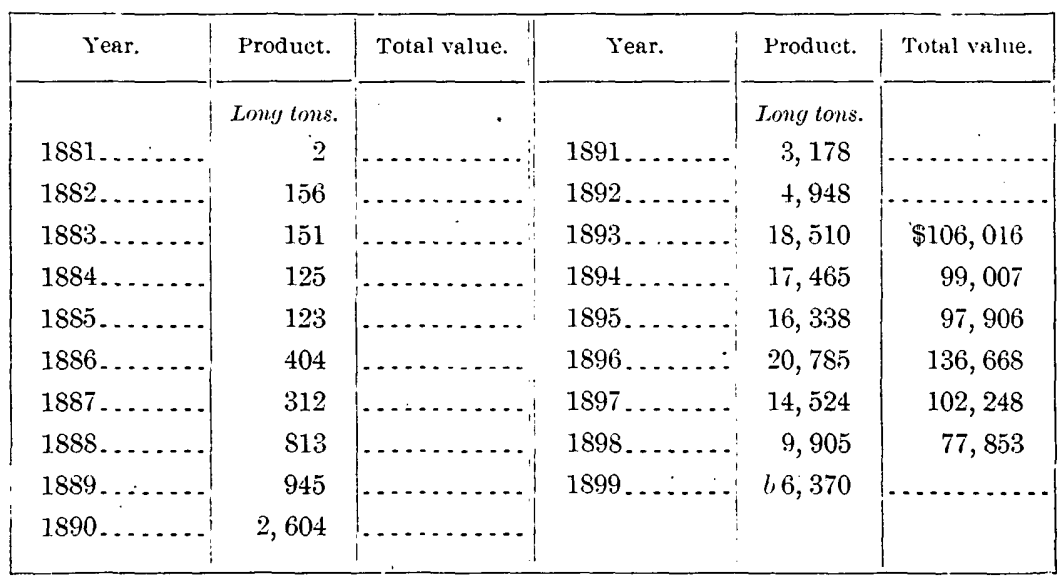

« Reports Department Finance, Empire of Japan.

$b$ Reported by Macqueen.

JAVA.

This island exported in 1899 about 910 tons of manganese ore, all of which went to European ports. This ore is produced in the regencies of Pengasih and Nanggoelan. In 1896, 3,000 tons were exported, and 5,200 tons in 1897 .

\section{NEW ZEALAND.}

New Zealand produces small amounts of manganese ore, furnishing 180 long tons in 1897 and 217 tons in 1898.

21 GEOL, PT $6--11$ 
WORLD'S PRODLCTION OF MANGANESE ORE.

The following table gives the production of manganese ores in various countries in the latest years for which statistics were available, those which exported ores to the United States being marked (a).

World's production of manganese ores.

\begin{tabular}{|c|c|c|}
\hline Country. & Year. & Product. \\
\hline North America: & & Tons. \\
\hline United States $\ldots \ldots \ldots \ldots \ldots \ldots \ldots \ldots \ldots$ & 1899 & 9,935 \\
\hline Canada $a \ldots \ldots \ldots \ldots \ldots \ldots \ldots \ldots \ldots$ & 1899 & 1,581 \\
\hline Cuba $a \ldots \ldots \ldots \ldots$ & 1899 & $b 13,686$ \\
\hline Newfoundland ................. & 1897 & 1,500 \\
\hline \multicolumn{3}{|l|}{ South America: } \\
\hline Brazil $a \ldots \ldots \ldots \ldots \ldots \ldots \ldots \ldots \ldots \ldots \ldots$ & 1899 & $b 62,178$ \\
\hline Chile $a \ldots \ldots \ldots \ldots \ldots$ & 1899 & 636,996 \\
\hline Colombia $a \ldots \ldots \ldots \ldots . . . .$. & 1899 & $b 8,955$ \\
\hline \multicolumn{3}{|l|}{ Europe: } \\
\hline Austria. $\ldots \ldots \ldots \ldots \ldots \ldots \ldots \ldots \ldots$ & 1898 & 6,132 \\
\hline Bosnia and Herzegovina . . . . . . . . . . . . . . . . . & 1898 & 5,235 \\
\hline 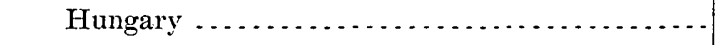 & 1898 & 8,055 \\
\hline France $a_{\ldots} \ldots \ldots \ldots \ldots \ldots \ldots \ldots \ldots \ldots$ & 1898 & 31,396 \\
\hline 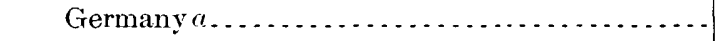 & 1898 & 42,669 \\
\hline 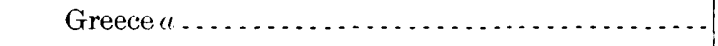 & 1899 & $b 15,300$ \\
\hline Italy ............ & 1898 & 2,955 \\
\hline Portugal $\ldots \ldots \ldots \ldots \ldots \ldots$ & $1 S 99$ & $b+, 130$ \\
\hline Russia & 1899 & $b 376,445$ \\
\hline Spain ...................... & 1899 & $b 136,533$ \\
\hline 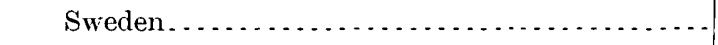 & 1898 & 2,321 \\
\hline Turkey $a \ldots$. & 1899. & 638,305 \\
\hline \multicolumn{3}{|l|}{ Asia: } \\
\hline India $\ell \ldots \ldots \ldots \ldots \ldots \ldots \ldots \ldots \ldots \ldots$ & 1899 & $677,3 \pm 8$ \\
\hline $\operatorname{Japan}(1 \ldots \ldots \ldots \ldots \ldots \ldots \ldots \ldots$ & 1899 & $b 6,370$ \\
\hline Java $\ldots \ldots \ldots \ldots \ldots$ & 1899 & $b 910$ \\
\hline \multicolumn{3}{|l|}{ Oceania: } \\
\hline 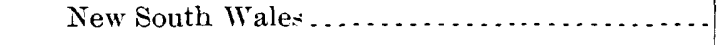 & 1898 & 1 \\
\hline New Zealand .. & 1898 & 217 \\
\hline Queensland.. & 1898 & 67 \\
\hline
\end{tabular}

$a$ Countries so marked contributed to the manganese supply of the Cnited States in 1899. $b$ Exports. 


\section{COPPER.}

By Charles Kirchhoff.

\section{GENERAL TRADE CONDITIONS.}

The year 1899 will go down in the annals of the copper industry as one of the most exceptional in its history. It was a year of extraordinary speculation in copper stocks, of profits due to high prices justified by an unprecedented consumption the world over. It is safe to say that not a single one of the older properties which had been in full normal operation closed the year without handsome returns to its stockholders. Under the stimulus of such a record, capital was easily induced to undertake new ventures, yet so extensive are the preparations needed to reach the productive stage that as yet few new concerns have become regular contributors to the country's supply of metal. Nor have the steps taken to increase the output of the old mines yet led to any marked expansion. It must not be inferred, however, from the fact that additions to production can not be made at short notice, that they will not ultimately make themselves felt.

\section{PRODUCTION.}

The following table shows the production of copper in the United States since its rise to the dignity of an industry. For the earlier years the best available sources have been drawn upon for the estimates given. Since 1882 the figures are those collected by this office:

Production of copper in the United States from 1845 to 1899.

[Long tons.]

\begin{tabular}{|c|c|c|c|}
\hline Year. & $\begin{array}{c}\text { Total } \\
\text { production. }\end{array}$ & $\begin{array}{c}\text { Lake } \\
\text { Superior. }\end{array}$ & $\begin{array}{l}\text { Percentage } \\
\text { of Lake } \\
\text { Superior } \\
\text { of total } \\
\text { product. }\end{array}$ \\
\hline $1845 \ldots \ldots \ldots$ & 100 & 12 & 12 \\
\hline $1846 \ldots \ldots \ldots \ldots \ldots$ & 150 & 26 & 17.3 \\
\hline $1847 \ldots \ldots$ & 300 & 213 & 71 \\
\hline $1848 \ldots \ldots \ldots$ & 500 & 461 & 92.2 \\
\hline $1849 \ldots \ldots$ & 700 & 672 & 96 \\
\hline $1850 \ldots \ldots \ldots$ & 650 & 572 & 88 \\
\hline
\end{tabular}


Production of copper in the United States from 1845 to 1899-Continued.

[Long tons.]

\begin{tabular}{|c|c|c|c|}
\hline Years. & $\begin{array}{c}\text { Total } \\
\text { production. }\end{array}$ & $\begin{array}{l}\text { Lake } \\
\text { Superior. }\end{array}$ & $\begin{array}{l}\text { Percentage } \\
\text { of Lake } \\
\text { Superior } \\
\text { of total } \\
\text { product. }\end{array}$ \\
\hline $1851 \ldots$ & 900 & 779 & 86.6 \\
\hline 1852. & 1,100 & 792 & 72 \\
\hline $1853 \ldots \ldots \ldots$ & 2,000 & 1,297 & 64.9 \\
\hline $1854 \ldots \ldots$ & 2,250 & 1,819 & 80.8 \\
\hline 1855. & 3,000 & 2,593 & 86.4 \\
\hline $1856 \ldots .$. & 4,000 & 3,666 & 91.7 \\
\hline $1857 \ldots \ldots \ldots$ & 4,800 & 4,255 & 88.6 \\
\hline $1858 \ldots \ldots$ & 5,500 & 4,088 & 74.3 \\
\hline 1859. & 6,300 & 3,985 & 63.3 \\
\hline $1860 \ldots$ & 7,200 & 5,388 & 74.8 \\
\hline $1861 \ldots$ & 7,500 & 6,713 & 89.5 \\
\hline $1862 \ldots$ & 9,000 & 6,065 & 67.4 \\
\hline $1863 .$. & 8,500 & 5,797 & 68.2 \\
\hline $1864 \ldots$ & 8,000 & 5,576 & 69.7 \\
\hline 1865. & 8,500 & 6,410 & 75.4 \\
\hline 1866. & 8,900 & 6,138 & 69 \\
\hline $1867 \ldots$ & 10,000 & 7,824 & 78.2 \\
\hline $1868, \ldots \ldots \ldots$ & 11,600 & 9,346 & 80.6 \\
\hline $1869 \ldots \ldots \ldots$ & 12,500 & 11,886 & 95.1 \\
\hline $1870 \ldots \ldots$ & 12,600 & 10,992 & 87.2 \\
\hline $1871 \ldots \ldots \ldots$ & 13,000 & 11,942 & 91.9 \\
\hline $1872 \ldots \ldots \ldots$ & 12,500 & 10,961 & 87.7 \\
\hline $1873 \ldots \ldots$ & 15,500 & 13,433 & 86.7 \\
\hline $1874 \ldots$ & 17,500 & 15,327 & 87.6 \\
\hline $1875 \ldots$ & 18,000 & 16,089 & 89.4 \\
\hline $1876 \ldots$ & 19,000 & 17,085 & 89.9 \\
\hline $1877 \ldots$ & 21,000 & 17,422 & 83 \\
\hline $1878 \ldots$ & 21,500 & 17,719 & 82.4 \\
\hline $1879 \ldots \ldots$ & 23,000 & 19,129 & 83.2 \\
\hline $1880 \ldots \ldots \ldots$ & 27,000 & 22,204 & 82.2 \\
\hline
\end{tabular}


COPPER.

Production of copper in the United States from 1845 to 1899-Continued.

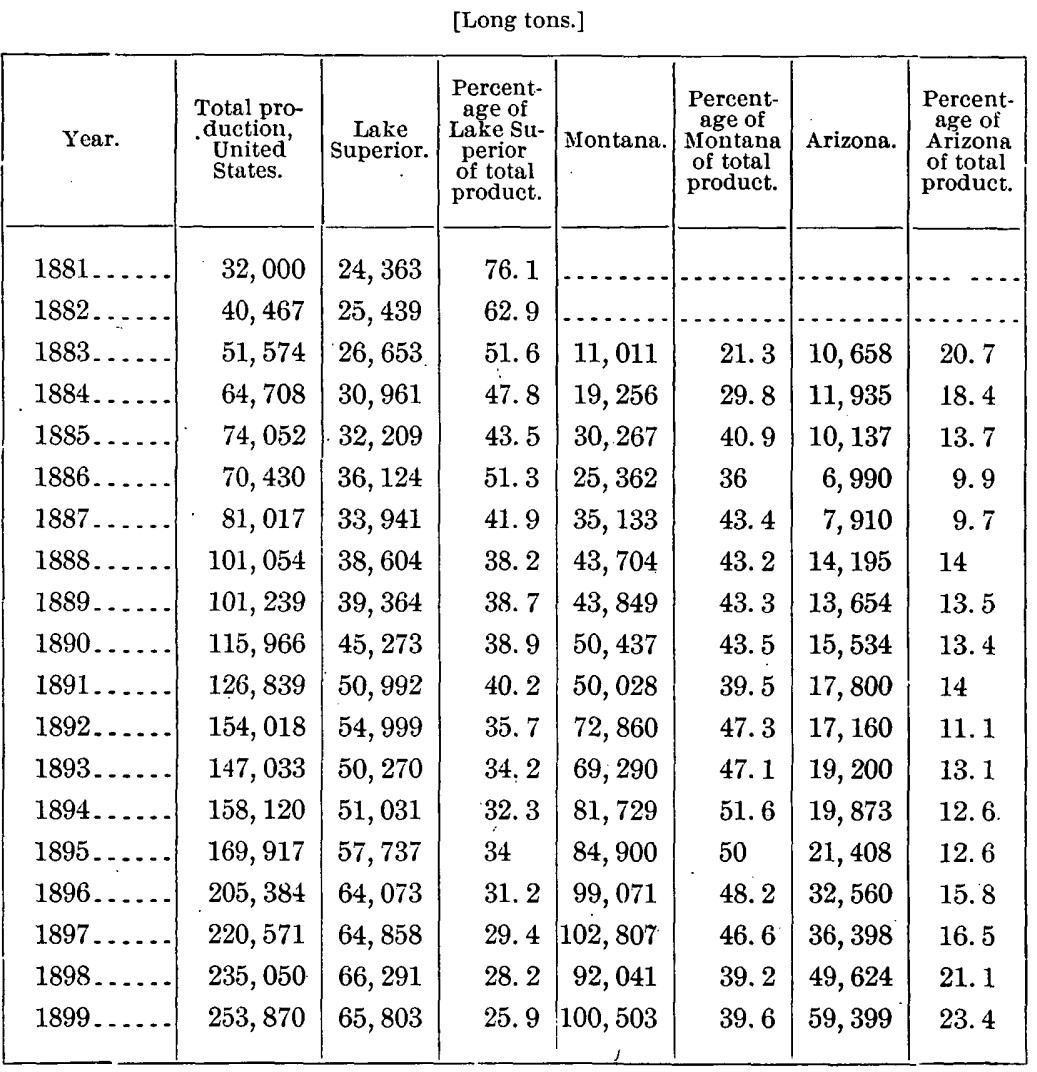


In detail, the production of copper, territorially distributed, has been as follows since 1883:

Total copper production in the United States, 1883 to $188 \%$.

\begin{tabular}{|c|c|c|c|}
\hline Source. & 1883. & 1884. & 1885. \\
\hline & Pounds. & Pounds. & Pounds. \\
\hline Lake Superior ............. & $59,702,404$ & $69,353,202$ & $72,147,889$ \\
\hline Arizona ..... & $23,874,963$ & $26,734,345$ & $22,706,366$ \\
\hline Montana ....... & $24,664,346$ & $43,093,054$ & $67,797,864$ \\
\hline New Mexico ............ & 823,511 & 59,450 & 79,839 \\
\hline California ..... & $1,600,862$ & 876,166 & 469,028 \\
\hline Utah ........ & 341,885 & 265,526 & 126,199 \\
\hline Colorado ........ & $1,152,652$ & $2,013,125$ & $1,146,460$ \\
\hline Wyoming ............ & 962,468 & $\ldots \ldots \ldots$ & ..... \\
\hline Nevada...... & 288,077 & 100,000 & 8,871 \\
\hline Idaho ..... & $\cdots$ & 46,667 & 40,381 \\
\hline Missouri $\ldots \ldots \ldots \ldots \ldots$ & 260,306 & 230,000 & \\
\hline Maine and New Hampshire.. & 212,124 & 249,018 & 911609 \\
\hline Vermont ....... & 400,000 & 655,405 & 211,002 \\
\hline Southern States. & 395,175 & 317,711 & 40,199 \\
\hline Middle States ......... & 64,400 & 2,114 & 190,641 \\
\hline Lead desilverizers, etc. & 782,880 & 950,870 & 910,144 \\
\hline Total domestic copper. & $115,526,053$ & $144,946,653$ & $165,875,483$ \\
\hline 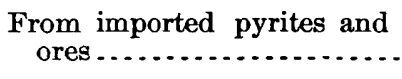 & $1,625,742$ & $2,858,754$ & $5,086,841$ \\
\hline $\begin{array}{l}\text { Total (including cop- } \\
\text { per from imported } \\
\text { pyrites) }\end{array}$ & $117,151,795$ & $147,805,407$ & $170,962,324$ \\
\hline
\end{tabular}


Total copper production in the United States, 1883 to.188\%-Continued.

\begin{tabular}{|c|c|c|}
\hline Source. & 1886. & $1 S 8 \bar{T}$. \\
\hline Lake Superior . . . . . . & $\begin{array}{l}\text { Pounds. } \\
\text { So, } 918,460\end{array}$ & $\begin{array}{c}\text { Pounds. } \\
76,028,697\end{array}$ \\
\hline Arizona.... & $15,657,035$ & $17,720,462$ \\
\hline Montana................. & $57,611,621$ & $78,699,677$ \\
\hline New Mexico ........... & 558,385 & $.283,664$ \\
\hline California . ...... & 430,210 & $1,600,000$ \\
\hline Utah .............. & 500,000 & $2,500,000$ \\
\hline Colorado.............. & 409,306 & $2,012,027$ \\
\hline Wyoming .......... & & \\
\hline Nevada .............. & 50,000 & \\
\hline Idaho.......... & & \\
\hline Missouri ................ & & \\
\hline Maine and New Hampshire ... & 315,719 & 200,000 \\
\hline Vermont............. & 510,810 & 200,000 \\
\hline Southern States ............ & 29,811 & \\
\hline Viddle States . . . . . . . . . . . & $\cdots \cdot$ & $\cdots$ \\
\hline Lead desilverizers, etc.............. & $1,282,496$ & $2,432,804$ \\
\hline Total domestic copper.. & $157,763,043$ & $181,477,331$ \\
\hline From imported pyrites and ores ........ & $4,500,000$ & $3,750,000$ \\
\hline $\begin{array}{l}\text { Total (including copper from imported } \\
\text { pyrites) } . . \ldots \ldots \ldots \ldots \ldots \ldots \ldots \ldots \ldots\end{array}$ & $162,263,043$ & $185,227,331$ \\
\hline
\end{tabular}


Since 1888 the production has been as follows, in detail:

Total copper production in the United States, 1888 to 1899.

\begin{tabular}{|c|c|c|c|c|}
\hline Source. & 1888. & 1889. & 1890. & 1891. \\
\hline & Pounds. & Pounds. & Pounds. & Pounds. \\
\hline Lake Superior & $86,472,034$ & $88,175,675$ & $101,410,277$ & $114,222,709$ \\
\hline Arizona ..... & $31,797,300$ & $31,586,185$ & $34,796,689$ & $39,873,279$ \\
\hline Montana :.... & $97,897,968$ & $98,222,444$ & $112,980,896$ & $112,063,320$ \\
\hline New Mexico & $1,631,271$ & $3,686,137$ & 850,034 & $1,233,197$ \\
\hline Cálifornia & $1,570,021$ & 151,505 & 23,347 & $3,397,405$ \\
\hline Utah......... & $2,131,047$ & 65,467 & $1,006,636$ & $1,562,098$ \\
\hline $\begin{array}{l}\text { Colorado, including } \\
\text { copper smelters } a .\end{array}$ & $1,621,100$ & $1,170,053$ & $3,585,691$ & $6,336,878$ \\
\hline Wyoming & 232,819 & 100,000 & & \\
\hline Nevada........ & 50,000 & 26,420 & $\cdots$ & 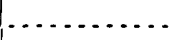 \\
\hline Idaho ........ & 50,000 & 156,490 & 87,243 & 146,825 \\
\hline Washington ..... & & & & \\
\hline $\begin{array}{c}\text { Maine and } \mathrm{New} \\
\text { Hampshire } . . . . .\end{array}$ & 271,631 & 72,000 & & \\
\hline Vermont........ & & & & \\
\hline $\begin{array}{l}\text { Southern States ... . . } \\
\text { Middle States . . . . . }\end{array}$ & 18,201 & 18,144 & 378,840 & 296,463 \\
\hline $\begin{array}{r}\text { Lead desilverizers, } \\
\text { etc ................ }\end{array}$ & $2,618,074$ & $3,345,442$ & $4,643,439$ & $4,989,590$ \\
\hline $\begin{array}{l}\text { Total domes- } \\
\text { tic copper... }\end{array}$ & $226,361,466$ & $226,775,962$ & $259,763,092$ & $284,121,764$ \\
\hline $\begin{array}{l}\text { From imported py- } \\
\text { rites and ores } . . .\end{array}$ & $4,909,156$ & $5,190,252$ & $6,017,041$ & $11,690,312$ \\
\hline $\begin{array}{l}\text { Total (includ- } \\
\text { ing copper } \\
\text { f ro m i m- } \\
\text { ported py- } \\
\text { rites) ....... }\end{array}$ & $231,270,622$ & $231,966,214$ & $265,780,133$ & $295,812,076$ \\
\hline
\end{tabular}

$a$ Copper smelters in Colorado, purchasing argentiferous copper ores and mattes in the open mar. ket, sources not known. The quantity of Montana matte which goes to one of these works has been deducted. 
COPPER.

Total copper production in the Linited States, 1888 to 1899 -Continued.

\begin{tabular}{|c|c|c|c|c|}
\hline Source. & 1892. & 1893. & 1894. & $189 \overline{.}$ \\
\hline & Pounds. & Pounds. & Pounds. & Pounds. \\
\hline Lake Superior . & $123,198,460$ & $112,605,078$ & $114,308,870$ & $129,330,749$ \\
\hline Arizona ......... & $38,436,099$ & $43,902,824$ & $44,514,894$ & $47,953,553$ \\
\hline Montana ...... & $163,206,128$ & $155,209,133$ & $183,072,756$ & $190,172,150$ \\
\hline New Mexico .... & $1,188,796$ & 280,742 & 31,884 & 143,719 \\
\hline California ........ & $2,980,944$ & 239,682 & 120,000 & 218,332 \\
\hline 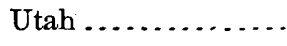 & $2,209,428$ & $1,135,330$ & $1,147,570$ & $2,184,70 \mathrm{~S}$ \\
\hline $\begin{array}{l}\text { Colorado, including } \\
\text { copper smelters } a \text {. }\end{array}$ & $7,593,674$ & $7,695,826$ & $6,481,413$ & $6,079,243$ \\
\hline Wyoming ......... & 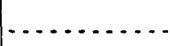 & ............ & $\ldots$. & $\ldots \ldots \ldots \ldots$ \\
\hline Nevada........... & $\ldots \ldots . . . .$. & 20,000 & 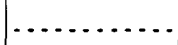 & $\ldots \ldots \ldots$ \\
\hline Idaho .......... & 226,000 & $36,36 \vec{r}$ & & $1,425,914$ \\
\hline Washington ........ & $\ldots \ldots \ldots$ & 39,785 & $\cdots$ & $\ldots \ldots \ldots$ \\
\hline $\begin{array}{c}\text { Maine and } \mathrm{New} \\
\text { Hampshire } . . . . .\end{array}$ & & . & & \\
\hline Vermont .......... & 467,448 & 732,793 & $2,374,514$ & $3,105,036$ \\
\hline Southern States ..... & & & & \\
\hline Middle States ....... & r & & & \\
\hline $\begin{array}{l}\text { Lead desilverizers, } \\
\text { etc. } b \ldots \ldots \ldots . .\end{array}$ & $5,491,702$ & $7,456,838$ & $2,136,473$ & $\cdots$ \\
\hline $\begin{array}{l}\text { Total domes- } \\
\text { tic copper... }\end{array}$ & $344,998,679$ & $329,354,398^{\prime}$ & $354,188,374$ & $380,613,404$ \\
\hline $\begin{array}{l}\text { From imported py- } \\
\text { rites and ores and } \\
\text { regulus } \ldots \ldots\end{array}$ & $7,973,065$ & $10,431,574$ & $10,678,434$ & $c 5,300,000$ \\
\hline $\begin{array}{l}\text { Total (includ- } \\
\text { ing copper } \\
\text { f ro m i m- } \\
\text { ported py - } \\
\text { rites)....... }\end{array}$ & $352,971,744$ & $339,785,972$ & $364,866,808$ & $385,913,404$ \\
\hline
\end{tabular}

$a$ Copper smelters in Colorado, purchasing argentiferous copper ores and mattes in the open mar. ket, sources not known. The quantity of Montana matte which goes to one of these works has been deducted.

$b$ For 1894 the quantity stated covers only that part of the incidental copper product the source of which could not be ascertained. $c$ Estimated. 
MINERAL RESOURCES.

Total copper production in the United States, 1888 to 1899-Continued.

\begin{tabular}{|c|c|c|c|c|}
\hline Source. & 1896. & 1897. & 1898. & 1899. \\
\hline & Pounds. & Pounds. & Pounds. & Pounds. \\
\hline Lake Superior & $143,524,069$ & $145,282,059$ & $158,491,703$ & $147,400,338$ \\
\hline Arizona ... & $72,934,927$ & $81,530,735$ & $111,158,246$ & $133,054,860$ \\
\hline Montana ........... & $221,918,179$ & $230,288,141$ & $206,173,157$ & $225,126,855$ \\
\hline New Mexico........ & $2,701,664$ & 701,892 & $1,592,371$ & $3,935,441$ \\
\hline California & 690,237 & $11,987,772$ & $16,925,634$ & $26,221,897$ \\
\hline Utah ........ & $3,502,012$ & $3,919,010$ & $3,750,000$ & $9,584,746$ \\
\hline $\begin{array}{l}\text { Colorado, including } \\
\text { copper smelters } a .\end{array}$ & $6,022,176$ & $11,873,033$ & $16,274,561$ & $11,643,608$ \\
\hline Wyoming .... & & & 233,044 & $3,104,827$ \\
\hline Nevada....... & & $\ldots \ldots \ldots$ & 437,396 & 556,775 \\
\hline Idaho . . . . . . . . & & 183,277 & $1,266,920$ & 110,000 \\
\hline South Dakota... & & $2,440,338$ & $1,261,393$ & 17,020 \\
\hline $\begin{array}{c}\text { Maine and New } \\
\text { Hampshire....... }\end{array}$ & & & & \\
\hline Vermont ........... & $4,704,993$ & $4,472,017$ & $5,395,226$ & $4,410,554$ \\
\hline $\begin{array}{l}\text { Tennesseeand South- } \\
\text { ern States ........ }\end{array}$ & $4,64,993$ & $4, \pm 12,016$ & $3,090,2<0$ & $4,410,004$ \\
\hline Middle States.... & & & & \\
\hline $\begin{array}{l}\text { Lead desilverizers, } \\
\quad \text { etc. } b \ldots \ldots \ldots \ldots\end{array}$ & $4,063,173$ & $1,400,000$ & $3,553,336$ & $3,500,000$ \\
\hline $\begin{array}{c}\text { Total domestic } \\
\text { copper ..... }\end{array}$ & $460,061,430$ & $494,078,274$ & $526,512,987$ & $568,666,921$ \\
\hline $\begin{array}{l}\text { From imported py- } \\
\text { rites and ores and } \\
\text { regulus } .\end{array}$ & $c 5,900,000$ & $c 12,000,000$ & $c 19,750,000$ & $c 23,800,000$ \\
\hline $\begin{array}{l}\text { Total (includ- } \\
\text { ing copper } \\
\text { f rom im- } \\
\text { ported py- } \\
\text { rites) }\end{array}$ & $465,961,430$ & $506,078,274$ & $546,262,987$ & $592,466,921$ \\
\hline
\end{tabular}

$a$ Copper smelters in Colorado, purchasing argentiferous copper ores and mattes in the open market, sources not known. The quantity of Montana matte which goes to one of these works has been deducted.

$b$ For 1896 the quantity stated covers only that part of the incidental copper product, the source of which could not be ascertained.

$c$ Estin ated. 
The available supply for the domestic markets may be computed as follows:

Supply of copper for the United States, 1892 to 1899.

\begin{tabular}{|c|c|c|c|c|}
\hline Source. & 1892. & 1893. & 1894. & 1895. \\
\hline $\begin{array}{l}\text { Production of domes- } \\
\text { tic copper.......... }\end{array}$ & $\begin{array}{c}\text { Pounds. } \\
344,998,679\end{array}$ & $\begin{array}{c}\text { Pounds. } \\
329,354,398\end{array}$ & $\begin{array}{c}\text { Pounds. } \\
354,188,374\end{array}$ & $\begin{array}{c}\text { Pounds. } \\
380,613,404\end{array}$ \\
\hline Imports: & & & & \\
\hline $\begin{array}{l}\text { Fine copper in } \\
\text { ore, entered } \\
\text { for consump- } \\
\text { tion } \ldots . . .\end{array}$ & $7,669,978$ & $7,256,015$ & $4,804,614$ & 0 \\
\hline $\begin{array}{l}\text { Fine copper in } \\
\text { regulus, en- } \\
\text { tered for con- } \\
\text { sumption ..... }\end{array}$ & 303,087 & $3,175,559$ & $5,873,820$ & \\
\hline Bars and ingots. - & 22,097 & 554,348 & 606,415 & $7,979,322$ \\
\hline Old copper...... & 71,485 & 59,375 & 160,592 & $1,336,901$ \\
\hline Total .... & $353,065,326$ & $340,399,695$ & $365,633,815$ & $395,229,627$ \\
\hline Exports: & & & & \\
\hline Ingots and bars.. & $30,515,736$ & $138,984,128$ & $162,393,000$ & $121,328,390$ \\
\hline $\begin{array}{l}\text { Estimated fine } \\
\text { copper con- } \\
\text { tents of matte. }\end{array}$ & $66,000,000$ & $50,000,000$ & $5,750,000$ & $15,200,000$ \\
\hline Total........ & $96,515,736$ & $188,984,128$ & $168,143,000$ & $136,528,390$ \\
\hline $\begin{array}{l}\text { Availablesup- } \\
\text { ply.......... }\end{array}$ & $256,549,590$ & $151,415,567$ & $197,490,815$ & $258,701,337$ \\
\hline
\end{tabular}


Supply of copper for the Cnited States, 1892 to 1893-Continued.

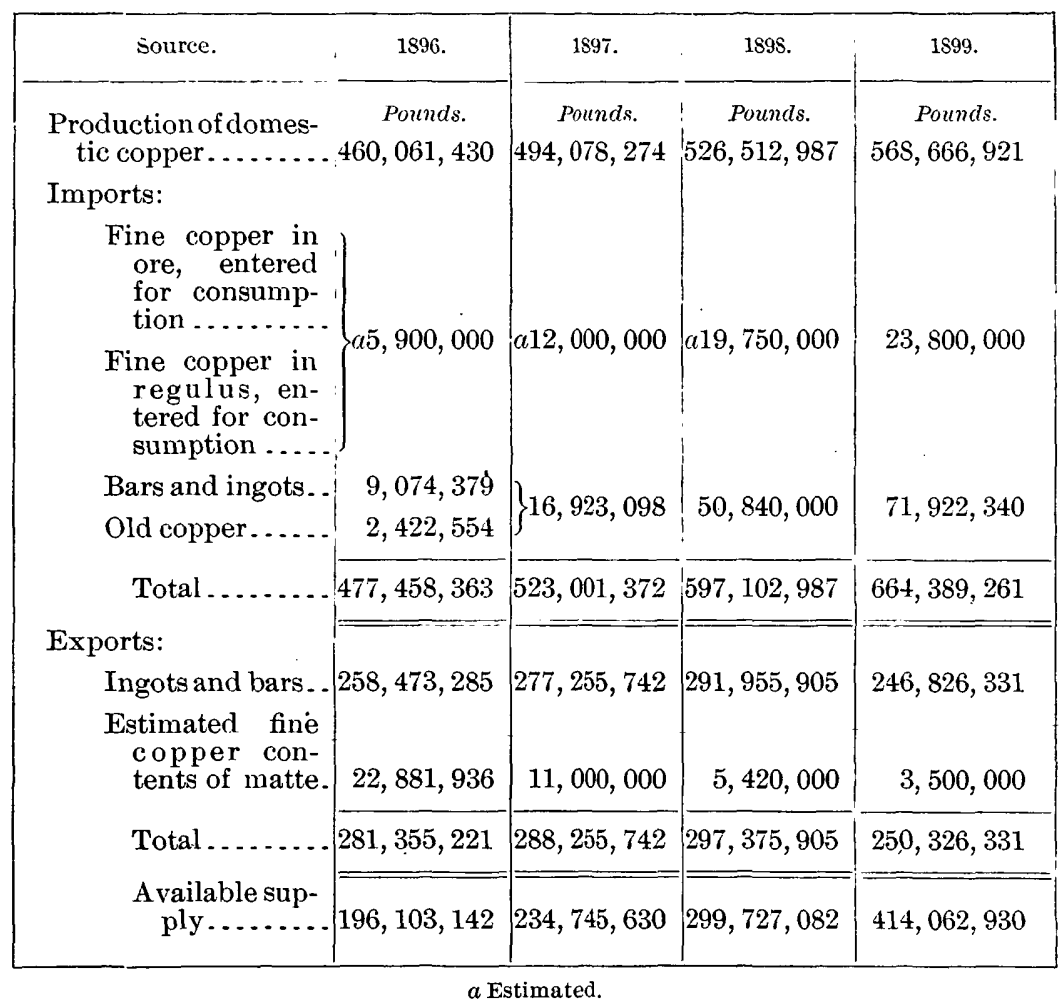

Since July, 1892, Mr. John Stanton, of New York, has collected monthly, from sworn returns, the following figures showing the production of the leading mines of Lake Superior, Montana, and Arizona. The estimate of outside sources is drawn, particularly recently, from official returns of the principal smaller mines.

American product of copper.

[Long tons.]

\begin{tabular}{|c|c|c|c|}
\hline Year. & $\begin{array}{c}\text { Reporting } \\
\text { mines. }\end{array}$ & $\begin{array}{l}\text { Outside } \\
\text { sources. }\end{array}$ & Total. \\
\hline Second six months of 1892 . & 59,239 & 6,287 & 65,526 \\
\hline $1893 \ldots$ & 129,760 & 12,730 & 142,490 \\
\hline $1894 \ldots$ & 142,543 & 17,080 & 159,623 \\
\hline 1895. & 155,497 & 15,700 & 171,197 \\
\hline $1896 \ldots$ & 189,494 & 14,400 & 203,894 \\
\hline 1897. & 204,206 & 11,900 & 216,106 \\
\hline $1898 \ldots$ & 216,222 & 18,050 & $23+, 2\rceil 2$ \\
\hline $1899 \ldots \ldots$ & 230,806 & 31,400 & 262,206 \\
\hline
\end{tabular}


The monthly reports, in detail, for the years 1892, 1893, and 1894 are published in Mineral Resources for 1895; for the years 1895 and 1896 in Mineral Resources for 1896; and for 1897 and 1898 in Mineral Resources for 1898. For 1898, 1899, and the first nine months of 1900 the monthly production was as follows:

American product of copper, monthly, 1898, 1899, and the first nine months of 1900 .

[Long tons.]

\begin{tabular}{|c|c|c|c|}
\hline lear and month. & $\begin{array}{l}\text { Reporting } \\
\text { mines. }\end{array}$ & $\begin{array}{l}\text { Outside } \\
\text { sources. }\end{array}$ & Total. - \\
\hline 1898. & & & \\
\hline January........ & 16,544 & 1,200 & 17,744 \\
\hline February ... & 16,072 & 1,250 & 17,322 \\
\hline March . .... & 19,131 & 1,250 & 20,381 \\
\hline April............. & 21,609 & 1,300 & 22,909 \\
\hline Yay $\ldots \ldots \ldots \ldots$ & 21,391 & 1,350 & 22,741 \\
\hline June ....... & 17,940 & 1,450 & 19,390 \\
\hline July ...... & 14,452 & 1,600 & 16,052 \\
\hline August $\ldots . . . . . .$. & 17,908 & 1,600 & 19,508 \\
\hline September................. & 17,064 & 1,700 & 18,764 \\
\hline October ..... & 19,429 & 1,700 & 21,129 \\
\hline November... & 18,050 & 1,800 & 19,850 \\
\hline December . ...... & 16,632 & 1,850 & 18,482 \\
\hline Total & 216,222 & 18,050 & 234,272 \\
\hline 1899. & & & \\
\hline January ... & 16,774 & 1,850 & 18,624 \\
\hline February ... & 17,899 & 2,000 & 19,899 \\
\hline March...... & 19,918 & 2,000 & 21,918 \\
\hline April...... & 17,854 & 2,100 & 19,954 \\
\hline May ...... & 19,832 & 2,250 & 22,082 \\
\hline June ....... & 19,710 & 2,300 & 22,010 \\
\hline July .... & 18,533 & 2,800 & 21,333 \\
\hline August .... & 19,886 & 2,800 & 22,686 \\
\hline September & 19,515 & 3,200 & 22,715 \\
\hline October ... & 20,680 & 3,300 & 23,980 \\
\hline November ... & 19,817 & 3,400 & $2 \dot{3}, 217$ \\
\hline December & 20,388 & 3,400 & 23,788 \\
\hline Total. & 230,806 & 31,400 & 262,206 \\
\hline
\end{tabular}


MINERAL RESOURCES.

American product of copper, monthly, 1898, 1899, etc.-Continued.

[Long tons.]

\begin{tabular}{|c|c|c|c|}
\hline Year and month. & $\begin{array}{l}\text { Reporting } \\
\text { mines. }\end{array}$ & $\begin{array}{l}\text { Outside } \\
\text { sources. }\end{array}$ & Total. \\
\hline 1900. & & & \\
\hline 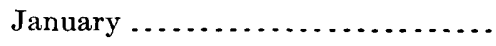 & 17,613 & 3,400 & 21,013 \\
\hline February ........ & 17,497 & 3,400 & 20,897 \\
\hline March..... & 19,883 & 3,400 & 23,283 \\
\hline April ........... & 20,667 & 3,400 & 24,067 \\
\hline May ............... & 19,282 & 3,400 & 22,682 \\
\hline June ........... & 19,235 & 3,400 & 22,635 \\
\hline July .......... & 19,612 & 3,400 & 23,012 \\
\hline August . ...... & 17,667 & 3,400 & 21,067 \\
\hline September ... & 17,986 & 3,400 & 21,386 \\
\hline Total nine months. & 169,442 & 30,600 & 200,042 \\
\hline
\end{tabular}

A considerable number of foreign mines, including those of the Peninsula, the Cape, Australasia, Germany, and Mexico, report monthly to a secretary in London since July, 1892. During the last six months of 1892 , and in $1893,1894,1895,1896,1897,1898,1899$, and the first nine months of 1900 , the product of this group, which maintains friendly relations with the American Producers' Association, has been as follows:

Foreign reporting mines.

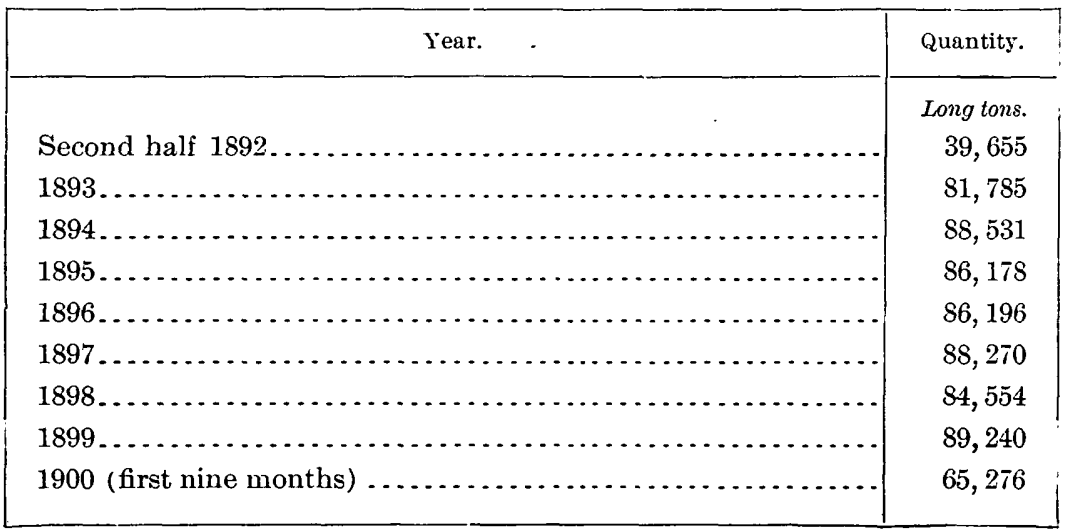


According to the careful compilations of Mr. John Stanton, the exports of fine copper during recent years have been as foilows:

Exports of fine copper from the United States.

\begin{tabular}{|c|c|}
\hline Year. & Quantity. \\
\hline & Long tons. \\
\hline $1893 \ldots \ldots \ldots \ldots$ & 80,392 \\
\hline $1894 \ldots . .$. & 77,527 \\
\hline $1895 \ldots$. & 64,722 \\
\hline $1896 \ldots \ldots \ldots$. & 125,605 \\
\hline $1897 \ldots \ldots \ldots \ldots \ldots$ & 129,210 \\
\hline $1898 \ldots \ldots \ldots \ldots$ & 145,115 \\
\hline $1899 \ldots$. & 119,811 \\
\hline 1900 (first nine months). & 126,669 \\
\hline
\end{tabular}

LAKE SUPERIOR DISTRICT.

The following is, in detail, the output of the Lake Superior mines, as reported by the companies, from 1884 to 1891:

Production of Lake Superior copper mines, 1884 to 1891.

\begin{tabular}{|c|c|c|c|c|}
\hline Mine. & 1884. & 1885. & 1886. & 1887. \\
\hline Calumet and Hecla. & $\begin{array}{c}\text { Pounds. } \\
40,473,585\end{array}$ & $\begin{array}{c}\text { Pounds. } \\
47,247,990\end{array}$ & $\begin{array}{c}\text { Pounds. } \\
50,518,222\end{array}$ & $\begin{array}{c}\text { Pounds. } \\
46,016,123\end{array}$ \\
\hline Quincy . & $5,650,436$ & $5,848,530$ & $5,888,511$ & $5,603,691$ \\
\hline Osceola.... & $4,247,630$ & $1,945,208$ & $3,560,786$ & $3,574,972$ \\
\hline Franklin ... & $3,748,652$ & $4,007,105$ & $4,274,297$ & $3,915,838$ \\
\hline Allouez... & $1,928,174$ & $2,170,476$ & $1,725,463$ & 885,010 \\
\hline Atlantic . & $3,163,585$ & $3,582,633$ & $3,503,670$ & $3,641,865$ \\
\hline Pewabic.. & 227,834 & $\cdots$ & $\cdots$ & $\cdots$ \\
\hline Central .... & $1,446,747$ & $2,157,408$ & $2,512,886$ & $2,199,133$ \\
\hline Grand Portage & 255,860 & 然 & & \\
\hline Conglomerate & $1,198,691$ & & & \\
\hline Mass .... & 481,396 & 363,500 & 247,179 & \\
\hline Copper Falls. & 891,168 & $1,150,538$ & $1,378,679$ & 719,150 \\
\hline Phœnix ... & 631,004 & 344,355 & $1,101,804$ & 11,000 \\
\hline Hancock & 562,636 & 203,037 & 150,000 & . \\
\hline Huron - & $1,927,660$ & $2,271,163$ & $1,992,695$ & $1 ; 881,760$ \\
\hline Ridge ..... & 74,030 & 63,390 & 158,272 & 84,902 \\
\hline St. Clair .... & 139,407 & 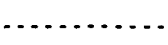 & - & \\
\hline Cliff... & 28,225 & $\ldots \ldots$ & 22,342 & \\
\hline Wolverine.. & 751,763 & 328,610 & 3,125 & 2,300 \\
\hline Nonesuch... & 23,867 & 28,484 & & \\
\hline Isle Royale. & 16,074 & $\cdots$ & & \\
\hline
\end{tabular}


Production of Lake Superior copper mines, 1884 to 1891-Continued.

\begin{tabular}{|c|c|c|c|c|}
\hline Mine. & 1884. & 1885. & 1886. & 1887. \\
\hline National....... & $\begin{array}{l}\text { Pounds. } \\
\quad 87,368\end{array}$ & $\begin{array}{l}\text { Pounds. } \\
162,252\end{array}$ & $\begin{array}{l}\text { Pounds. } \\
184,706\end{array}$ & $\begin{array}{l}\text { Pounds. } \\
\quad 25,187\end{array}$ \\
\hline Minnesota .. & 1,144 & 12,608 & & \\
\hline Belt $\ldots \ldots \ldots$ & 130,851 & 27,433 & 7,300 & \\
\hline $\begin{array}{l}\text { Sheldon and Colum- } \\
\text { bia } . . . . . . . . .\end{array}$ & 9,828 & & & \\
\hline Adventure.. & 4,333 & 4,000 & 1,000 & \\
\hline Peninsula & $1,225,981$ & $\cdots \cdots$ & $\ldots \ldots$ & $\ldots . .$. \\
\hline Tamarack & ...... & 181,669 & $3,646,517$ & $7,396,529$ \\
\hline Ogima.. & 1,106 & 12,000 & & \\
\hline Kearsarge . & $\cdots \cdots$ & $\cdots$ & & 21,237 \\
\hline Evergreen Bluff. & 954 & 1,500 & 1,000 & \\
\hline Ash Bed. & 1,517 & & & \\
\hline $\begin{array}{c}\text { Sundry companies- } \\
\text { tributers......... }\end{array}$ & 21,696 & 34,000 & 50,000 & 50,000 \\
\hline - Total. & $69,353,202$ & $72,147,889$ & $80,918,460$ & $76,028,697$ \\
\hline Mine. & 1888. & 1889. & 1890. & 1891. \\
\hline & Pounds. & Pounds. & Pounds. & Pounds. \\
\hline Caluniet and Hecla. & $50,295,720$ & $48,668,296$ & $59,868,106$ & $\cdots$ \\
\hline Quincy ........ & $6,367,809$ & $6,405,686$ & $8,064,253$ & $10,542,519$ \\
\hline Osceola... & $4,134,320$ & $4,534,127$ & $5,294,792$ & $6,543,358$ \\
\hline Franklin & $3,655,751$ & $4,346,062$ & $5,638,112$ & $4,319,840$ \\
\hline Allouez.... & 314,198 & $1,762,816$ & $1,407,828$ & $1,241,423$ \\
\hline Atlantic .... & $3,974,972$ & $3,698,837$ & $3,619,972$ & $3,653,671$ \\
\hline Central... & $1,817,023$ & $1,270,592$ & $1,413,391$ & $1,237,500$ \\
\hline Mass ...... & (.......... & 58,349 . & 62,187 & , n \\
\hline Copper Falls. & $1,199,950$ & $1,440,000$ & $1,330,000$ & $1,427,000$ \\
\hline Huron .... & $2,370,857$ & $2,219,473$ & $1,736,777$ & $1,257,059$ \\
\hline Ridge . & 50,924 & 28,000 & 21,569 & 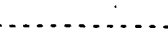 \\
\hline National... & $\cdots$ & 454,134 & 123,879 & 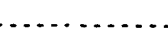 \\
\hline Adventure . & 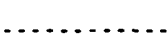 & 692 & 15,485 & \\
\hline Peninsula & $\ldots \ldots \ldots$ & 736,507 & $1,108,660$ & $1,599,670$ \\
\hline Tamarack .. & $11,411,325$ & $10,605,451$ & $10,106,741$ & $16,161,312$ \\
\hline Kearsarge .... & 829,185 & $1,918,849$ & $1,598,525$ & $1,727,390$ \\
\hline Evergreen Bluff. & & 21,580 & & \\
\hline $\begin{array}{l}\text { Sundry companies } \\
\text { tributers. }\end{array}$ & 50,000 & 6,224 & & \\
\hline T & $86,472,034$ & $88,175,675$ & $101,410,277$ & \\
\hline
\end{tabular}


The following table records only the output of some of the leading producers in that district:

Production of some of the leading Lake Superior copper mines, 1892 to 1899.

\begin{tabular}{|c|c|c|c|c|}
\hline Mine. & 1892. & 1893. & 1894. & 1895. \\
\hline & Pounds. & Pounds. & Pounds. & Pounds. \\
\hline Tamarack ...... & $16,426,633$ & $15,085,113$ & $15,375,281$ & $14,900,286$ \\
\hline Quincy ........... & $11,103,926$ & $14,398,477$ & $15,484,014$ & $16,304,721$ \\
\hline Osceola... & $7,098,656$ & $6,715,870$ & $6,918,502$ & $6,270,373$ \\
\hline Franklin ..... & $3,769,605$ & $3,504,244$ & $3,556,487$ & $3,086,933$ \\
\hline Atlantic ...... & $3,703,875$ & $4,221,933$ & $4,437,609$ & $4,832,497$ \\
\hline Kearsarge .... & $1,467,758$ & $1,627,030$ & $1,998,710$ & $1,946,163$ \\
\hline Tamarack, Jr... & 796,769 & $1,610,259$ & $2,349,329$ & $2,605,000$ \\
\hline Peninsula & $973,21.7$ & $\ldots$ & & \\
\hline Copper Falls. & $1,350,000$ & 750,000 & & \\
\hline Huron . - & 461,499 & 562,776 & & \\
\hline Allouez.. & 546,530 & $\ldots \ldots \ldots$ & - & \\
\hline Central . & $1,625,982$ & $1,180,040$ & 584,590 & 379,020 \\
\hline Centennial & 106,801 & $\ldots \ldots \ldots \ldots$ & $\ldots \ldots \ldots$ & $\ldots$. \\
\hline Wolverine. & 500,074 & $1,025,062$ & $1,665,255$ & $1,815,391$ \\
\hline Mine. & 1896. & 1897. & 1898. & 1899. \\
\hline & Pounds. & Pounds. & Pounds. & Pounde. \\
\hline Tamarack .. & $16,044,860$ & $20,222,529$ & $23,000,000$ & $18,565,602$ \\
\hline Quincy ... & $16,863,477$ & $16,924,618$ & $16,354,061$ & $14,301,182$ \\
\hline Osceola. & $6,251,304$ & & & \\
\hline Kearsarge .. & $1,377,226$ & $11,201,103$ & $11,900,000$ & $11,358,049$ \\
\hline Tamarack, Jr & $2,135,000$ & & & \\
\hline Franklin .. & $2,746,076$ & $2,908,284$ & $2,623,702$ & $1,230,000$ \\
\hline Atlantic ... & $4,895,985$ & $5,109,663$ & $4,377,399$ & $4,675,882$ \\
\hline Central... & 469,243 & 611,172 & 291,339 & $\ldots \ldots$ \\
\hline Wolverine.. & $2,220,933$ & $2,316,296$ & $4,588,114$ & $4,756,6+6$ \\
\hline
\end{tabular}

Since very elaborate preparations, both underground and on the surface, are necessary to develop new property or increase the production of old mines, the output of the Lake district can not be rushed. It is certain, however, from the work now under way and recently completed, that a considerable increase in output will be gradually attained. There are under construction or recently completed six heads of stamps at the Calumet and Hecla mine, three at the Osceola, three at the Arcadian, three at the Isle Royale, two at the Baltic, four at the Franklin, $\mathrm{Jr}$., and one at the Mass. The Wolverine is expected soon to add to its equipment, and the Mohawk, Trimountain, Adventure, and Michigan are planning to erect crushing plants.

21 GEOL, PT $6-12$ 
An interesting development in crushing rock in this region has been the improvement in the stamp mills, the Nordberg Manufacturing Company, of Milwaukee, having taken the initiative. Through changes in the design a largely increased screen area has been obtained and the openings in the screens themselves have been enlarged, they being now about five-eighths inch. In this manner the daily crushing capacity has been raised from about 350 tons to 550 tons. The Nordberg Manufacturing Company has also improved the valve gear of the stamp, so as to strike a dead blow and thus secure a more economical use of the steam. In practice it has been found that the steam consumption is not greater with the new than with the old-style stamps, so that the coal consumption is about the same crushing 550 tons per day as it was in the old type handling 350 tons per day.

The annual report of the Calumet and Hecla Mining Company for the fiscal year ending April 30 shows a product of 49,312 tons of refined copper, as compared with 44,450 tons during the previous fiscal year. The most interesting undertaking in progress in connection with this great company is its development of the Osceola amygdaloid belt. Three shafts are being sunk on it and extensive opening is in progress. from which a certain amount of rock is obtained which is crushed with one head. The foundations have been laid for a new stamp mill, to contain six heads, which it is expected will treat 2,500 tons of amygdaloid rock per day.

President Agassiz reports that experimental work is going on with washing machines differing from those generally in use in the Lake Superior district, with the aim of diminishing the loss of copper.

Extensive improvements are under way at the Buffalo works of the company. An electrolytic plant is under construction for the purpose of treating ore which carries the larger values in silver. Additional property has been purchased fronting on the Niagara River.

For the year 1899 the production of the Quincy Copper Company was $17,866,680$ pounds of mineral, yielding $14,301,182$ pounds of refined copper, for which was realized the gross sum of $\$ 2,450,178.66$. The running expenses at the mine were $\$ 969,741.09$; the construction account amounted to $\$ 404,481.09$. The tax in Michigan aggregated $\$ 40,117.06$, and the smelting, transportation, and all other expenses $\$ 153,752.08$, leaving as a mining profit $\$ 882,087.34$. There were realized from interest on loans $\$ 13,361.08$, and from Hancock real estate $\$ 33,218.57$, making the income for the year $\$ 928,666.99$. There were paid in dividends during the year $\$ 950,000$, thus reducing the balance of assets to $\$ 1,207,942.14$ on January 1,1900 . There were mined 602,409 tons of rock, of which there were hoisted 586,820 tons, and treated in the stamp mill 559,164 tons. The cost of stamping itself was 22.19 cents per ton of rock.

The Quincy Company has been completing a new stamp mill with three heads of stamps. Considerable construction work and additions to machinery were undertaken during the year 1899. 
The following table shows the operations of the Quincy mine for a series of years. It will be observed that until recent years the production has increased steadily; that the yield has very considerably fluctuated from year to year, and that the average monthly contract wages have shown a fairly steady increase for a series of years. In the table the average price realized is calculated from the gross income and product, the reports failing to show the quantity of copper on hand at the beginning of each fiscal year.

Operations of the Quincy mine, Lake Superior.

\begin{tabular}{|c|c|c|c|c|c|c|}
\hline Year. & Product. & $\begin{array}{l}\text { Yield } \\
\text { fine cop- } \\
\text { per per } \\
\text { fathom } \\
\text { broken. }\end{array}$ & $\begin{array}{c}\text { Price } \\
\text { obtained. }\end{array}$ & $\begin{array}{c}\text { Cost per } \\
\text { pound, } \\
\text { exclusive } \\
\text { of con- } \\
\text { struction. }\end{array}$ & $\begin{array}{c}\text { Number } \\
\text { of miners } \\
\text { on con- } \\
\text { tract. }\end{array}$ & $\begin{array}{l}\text { Average } \\
\text { monthly } \\
\text { contract } \\
\text { wages. }\end{array}$ \\
\hline & Pounds. & Pounds. & Cents. & Cents. & & \\
\hline 1864 & $2,498,574$ & 562 & 44.8 & 26.7 & 242 & $\$ 65.50$ \\
\hline 1865. & $2,720,980$ & 501 & $\ldots \ldots$ & $\ldots \ldots$ & 212 & 57.53 \\
\hline 1866 & $2,114,220$ & 451 & 31.3 & 29 & 227 & 53.16 \\
\hline $186 \overline{7}$. & $1,921,620$ & 526 & 22.7 & 18.9 & 167 & 50.83 \\
\hline $1868 \ldots$ & $1,417,941$ & 447 & 25.2 & 23.1 & 157 & 50.44 \\
\hline 1869. & $2,417,365$ & 446 & 21.9 & 16.7 & 210 & 51.10 \\
\hline 1870 & $2,496,774$ & 528 & 21.5 & 15.3 & 181 & 46.09 \\
\hline $1871 a$ & $2,409,501$ & 441 & 22.8 & 15.2 & 104 & 47.08 \\
\hline $1872 .$. & $2,269,104$ & 391 & 32.5 & 22.9 & 233 & 60.62 \\
\hline 1873 & $2,621,087$ & 491 & 26.5 & 18.6 & 223 & 62.42 \\
\hline 1874 & $3,050,154$ & 577 & 21.9 & 15.1 & 234 & 43.38 \\
\hline $1875 \ldots$ & $2,798,281$ & 485 & 22.7 & 15.8 & 217 & 46.74 \\
\hline $1876 .$. & $3,073,171$ & 507 & 20 & 15.7 & 227 & 47.13 \\
\hline $1877 \ldots$ & $2,837,014$ & 467 & 18.6 & 15.1 & 247 & 43.79 \\
\hline 1878 & $2,991,050$ & 395 & 14.9 & 14 & 234 & 41.50 \\
\hline 1879 & $2,639,958$ & 403 & 16.3 & 13.7 & 212 & 38.76 \\
\hline 1880 & $3,609,250$ & 563 & 18.5 & 11.8 & 192 & 49.10 \\
\hline $1881 \ldots$ & $5,702,606$ & 767 & 18.7 & 10 & 212 & 48.54 \\
\hline 1882 & $5,682,663$ & 800 & 17.1 & 9.5 & 152 & 48.83 \\
\hline 1883. & $6,012,239$ & 850 & 13.7 & 8.9 & 165 & 46.02 \\
\hline 1884 & $5,680,087$ & 722 & 12.2 & 8.6 & 157 & 43.35 \\
\hline 1885 & $5,848,497$ & 710 & 11.4 & 7.5 & 132 & 44.00 \\
\hline 1886 & $5,888,517$ & 638 & 11.1 & 6.8 & 140 & 45.80 \\
\hline 1887 & $5,603,691$ & 781 & 11.7 & 8.6 & 142 & 48.40 \\
\hline 1888 & $6,367,809$ & 690 & 15.9 & 10.1 & 158 & 49.60 \\
\hline $1889 \ldots$ & $6,405,686$ & 690 & 12 & 9.4 & 145 & 49.15 \\
\hline 1890. & $8,064,253$ & 769 & 15.7 & 8.2 & 146 & 52.60 \\
\hline 1891 & $10,542,519$ & 685 & 12.8 & 9.1 & 182 & 53.40 \\
\hline 1892 & $11,103,926$ & 572 & 11.27 & 8.8 & 238 & 53.75 \\
\hline
\end{tabular}

$a$ Introduction of steam drills. 
Operations of the Quincy mine, Lake Superior-Continued.

\begin{tabular}{|c|c|c|c|c|c|c|}
\hline Year. & Product. & $\begin{array}{c}\text { Yield } \\
\text { fine cop- } \\
\text { per per } \\
\text { fathom } \\
\text { broken. }\end{array}$ & $\begin{array}{c}\text { Price } \\
\text { obtained. }\end{array}$ & $\begin{array}{c}\text { Cost per } \\
\text { pound, } \\
\text { exclusive } \\
\text { of con- } \\
\text { struction. }\end{array}$ & $\begin{array}{c}\text { Number } \\
\text { of miners } \\
\text { on con- } \\
\text { tract. }\end{array}$ & $\begin{array}{c}\text { Average } \\
\text { monthly } \\
\text { contract } \\
\text { wages. }\end{array}$ \\
\hline & Pounds. & Pounds. & Cents. & Cents. & & \\
\hline $1893 \ldots \ldots \ldots$ & $14,398,477$ & 574 & 10.4 & 7.1 & 259 & $\$ 49.60$ \\
\hline $1894 \ldots \ldots \ldots \ldots$ & $15,484,014$ & 584 & 9.5 & 5.7 & 285 & 50.70 \\
\hline 1895 & $16,304,721$ & 517 & 10. 1 & 5.9 & 336 & 50.00 \\
\hline $1896 \ldots \ldots \ldots$ & $16,863,477$ & 477 & 10.9 & 6.5 & 379 & 52.00 \\
\hline 1897 & $16,924,618$ & 481 & 11.1 & 6.8 & 393 & $\dot{5} 2.52$ \\
\hline 1898. & $16,354,061$ & 513 & 12 & 6.8 & 381 & 52.50 \\
\hline 1899 & $14,301,182$ & 427 & 17.1 & 8.1 & 401 & 56.72 \\
\hline
\end{tabular}

The production of the Tamarack Mining Company shows a moderate increase during the year 1899, the production of mineral having been $31,713,752$ pounds, as compared with $31,127,623$ pounds in 1898 and $29,589,380$ pounds in 1897 . During the year 775,132 tons of rock ore were mined, and 631,090 tons of rock were stamped at an average cost of 22.727 cents per ton. Included in this were 51,090 tons of rock from the Osceola amygdaloid vein, which is considerably lower in grade than the average of the conglomerate, and therefore carries down the average somewhat. Rapid progress has been made during the year in sinking No. 5 shaft, which it is expected will be down to the estimated depth of 4,615 feet toward the end of 1900 . The necessary shaft and rock house has been ordered, together with the equipment and a large compressor. During the year 1899 the gross receipts from sales of copper, from interest, and from other sources aggregated $\$ 2,952,098.91$, while the costs were $\$ 2,211,588.30$, leaving a net income of $\$ 740,510.61$, out of which two dividends aggregating $\$ 600,000$ were paid. The total expenditures for construction, which were charged to operating expenses, were $\$ 400,651.91$. 'The cost of mining was somewhat larger than it was during the previous year, owing to an advance in wages and in all classes of material.

The annual report of the Osceola Consolidated Mining Company for the calendar year 1899 shows that there were mined 674,691 tons, of which 540,326 tons were put through the stamp mill, yielding $14,767,430$. pounds of mineral, the cost of stamping having been $26.36^{\circ}$ cents per ton of rock. The gross receipts during the year were $\$ 1,791,471.01$; the total cost having been $\$ 1,256,638.72$, leaving an income of $\$ 534,832.29$. Dividends aggregating $\$ 558,450$ were paid, thus leaving a deficit of $\$ 23,617.71$. At the beginning of the year there were available for the construction account $\$ 8 t, 969.18$, to which were added $\$ 32,787.96$ from the sale of treasury stock. Out of this there were paid for new stamp-mill construction $\$ 98,529.96$, and $\$ 1,958.8 \pm$ for sinking two shafts on the South Kearsarge property. Besides 
this there were expended for construction and shaft $\$ 72,945.47$ at the Osceola, the Tamarack, jr., and the Kearsarge; the sums being charged directly to operating expenses. Considerable delay was experienced in completing the new stamp mill, so that it was not in operation until early in November. The most interesting undertaking in connection with the mining operations was the opening out of what is known as the South Kearsarge property.

The new stamp mill of the Franklin Mining Company was put into commission in August, 1899, and during the remainder of the year crushed 89,789 tons, at an average cost of 32.30 cents. The result in product of mineral was $1,548,864$ pounds, equivalent to $1,230,000$ pounds of refined copper. The total expenditures on account of the Franklin, jr., mine and the new mill to January, 1900, were $\$ 1,002,951.75$, of which the stamp mill absorbed $\$ 269,000.12$. The mill has thus far stamped a little over 400 tons a day per head, there being four heads in the mill. The receipts for the year 1899 were $\$ 202,647.81$ from copper, $\$ 32,851.28$ from insurance on the old mill destroyed by fire, and $\$ 37,153.58$ from sales of 1,682 shares of stock. The running expenses at the mine were $\$ 360,087.96$; the expenses for smelting, freight, insurance, and interest, $\$ 28,981.13$, and the construction account during the year was $\$ 235,080.06$.

The annual report of the Wolverine Copper Company covers the fiscal year ending June 30,1900 . The product of the mine was $5,469,700$ pounds of mineral, which yielded 86.96 per cent, or $4,756,646$ pounds of refined copper, which sold at an average of 16.86 cents. During the year there were hoisted 215,951 tons of rock, of which 184,594 tons were stamped, the yield of the rock being 25.77 pounds per ton. The cost per ton of rock hoisted was $\$ 1.52$, while the cost per ton of rock stamped was $\$ 1.77$. The cost per pound of refined copper at the mine was 6.885 cents, and the smelting, freight, and marketing product 1.25 cents, making the total cost of refined copper 8.14 cents. During the year the cost per pound of refined copper, including the construction account, was 9.56 cents. The receipts during the year amounted to $\$ 806,810.32$, the average return per pound of copper having been 16.86 cents. The mining and smelting outlays were $\$ 387,204.17$, leaving a mining profit of $\$ 419,606.15$. The construction account and the price for the stamp-mill site aggregate $\$ 72,688.54$, thus leaving a net profit of $\$ 346,917.61$, and adding the surplus of the previous year of $\$ 277,689.45$, a total of $\$ 624,607.06$ was reached. Out of this there were paid in dividends $\$ 240,000$, leaving a surplus of $\$ 384,607.06$. The management confined the dividends to the sum named in order to provide a fund for the construction of a new stamp mill.

During the first seven months of 1899 the yield of the rock from the Atlantic mine reached the lowest point in the history of the enterprise, dropping to 11.56 pounds of copper per ton stamped. Then a change for the better began, the average for the last five months of the year being 13.28 pounds, carrying the average for the whole year up to 12.28 pounds per ton. In 1899 the mine produced $6,147,555$ pounds 
of mineral, yielding $4,675,882$ pounds of refined copper, for which there was realized an average of 17.15 cents per pound. The working expenses at the mine were $\$ 508,148.34$. The smelting, freight, and all other expenses were $\$ 63,009.03$, and balance of interest account was $\$ 1,870.11$, making the net running expenses $\$ 573,027.48$. Since the total income was $\$ 802,804.51$, the surplus was $\$ 229,777.03$. Of this there was expended in construction $\$ 78,527.18$, leaving a net gain of $\$ 151,249.85$. Adding $\$ 105,098.87$, the surplus from 1898 , there was reached a net surplus of $\$ 256,348.72$, out of which dividends aggregating $\$ 80,000$ were paid.

The following record of costs for a series of years shows how it was possible by close and intelligent management to treat profitably an ore yielding so small a percentage of copper.

Cost of copper at the Atlantic mine per ton of rock treated.

\begin{tabular}{|c|c|c|c|c|c|c|}
\hline Items of cost. & 1888. & 1889. & 1890. & 1891. & 1892. & 1893. \\
\hline $\begin{array}{l}\text { Mining, selecting, break- } \\
\text { ing, and all surface ex- } \\
\text { penses, including taxes. }\end{array}$ & $\begin{array}{l}\text { Cents. } \\
83.73\end{array}$ & $\begin{array}{l}\text { Cents. } \\
87.87\end{array}$ & $\begin{array}{c}\text { Cents. } \\
104.14\end{array}$ & $\begin{array}{l}. \text { Cents. } \\
95.29\end{array}$ & $\begin{array}{l}\text { Cents. } \\
83.98\end{array}$ & $\begin{array}{l}\text { Cents. } \\
79.49\end{array}$ \\
\hline Transportation to mill.... & 3.47 & 3.88 & 3.46 & 3.86 & 3.33 & 3.28 \\
\hline Stamping and separating. - & 26.89 & 27.78 & 27.78 & 25.82 & 25.09 & 24.95 \\
\hline $\begin{array}{l}\text { Freight, smelting, mar- } \\
\text { keting, and New York } \\
\text { expenses .................. }\end{array}$ & 21.42 & 20.22 & 20.37 & 18.47 & 17.67 & 18.22 \\
\hline $\begin{array}{l}\text { Total working ex- } \\
\text { penses............ }\end{array}$ & 135.51 & 139.75 & 155.75 & 143.44 & 130.07 & 125.94 \\
\hline $\begin{array}{l}\text { Total expenditures } \\
\text { including construc- } \\
\text { tion } . . . . . . . . . . . . .\end{array}$ & 142.82 & 153.27 & 166.70 & 154.51 & 133.51 & 160.24 \\
\hline Net profit. . . . . . & 54.36 & 6.23 & 27.71 & 0.16 & & \\
\hline Yield of copper, per cent.. & 0.667 & 0.663 & 0.650 & 0.615 & 0.615 & 0.669 \\
\hline Items of cost. & 1894. & 1895. & 1896. & 1897. & 1898. & 1899. \\
\hline $\begin{array}{l}\text { Mining, selecting, break- } \\
\text { ing, and all surface ex- } \\
\text { penses, including taxes.. }\end{array}$ & $\begin{array}{l}\text { Cents. } \\
75.18\end{array}$ & $\begin{array}{l}\text { Cents. } \\
75.25\end{array}$ & $\begin{array}{l}\text { Cents. } \\
76.43\end{array}$ & $\begin{array}{l}\text { Cents. } \\
73.43\end{array}$ & $\begin{array}{l}\text { Cents. } \\
89.11\end{array}$ & $\begin{array}{c}\text { Cents. } \\
103.60\end{array}$ \\
\hline Transportation to mill.... & 3.03 & 4.08 & 4.96 & 4.54 & 5.55 & 6.50 \\
\hline Stamping and separating. - & 23.30 & 22.20 & 24.87 & 23.94 & 24.11 & 23.35 \\
\hline $\begin{array}{l}\text { Freight, smelting, mar- } \\
\text { keting, and New York } \\
\text { expenses ................ }\end{array}$ & 17.71 & 18. 81 & 17.47 & 17.03 & 16. 04 & 17.04 \\
\hline $\begin{array}{r}\text { Total working ex- } \\
\text { penses............... }\end{array}$ & 119.22 & 120.34 & 123. 73 & 118.94 & 134.81 & 150.49 \\
\hline $\begin{array}{c}\text { Total expenditures, } \\
\text { including construc- } \\
\text { tion ................ }\end{array}$ & 165.07 & 156.05 & 135.99 & 129.69 & 153.59 & 171.11 \\
\hline Yield of copper, per cent. & 0.703 & 0.730 & 0.660 & 0.648 & 0.59 & 0.614 \\
\hline
\end{tabular}


At the mine of the Baltic Mining Company, one of the most promising discoveries within recent years on Lake Superior, good progress was made during 1899 . While almost exclusively engaged in development work, the mine produced 621,336 pounds of copper, which sold at an average price of 15.93 cents. The Baltic leased one small stamp of the Atlantic mill, which it ran very largely to the end of the year. In that time there were stamped 35,411 tons of rock, yielding 789,763 pounds of mineral. The company has purchased a site on Lake Superior near the Salmon Trout River and has begun the erection of a stamp-mill building to contain four heads of modern-style stamps, only two of which, however, will be started during the current year. The total receipts, including $\$ 227,250$ for assessment No. 3, payable September 18, 1899, were $\$ 338,450.40$; the expenditure at the mine was $\$ 195,416.89$, and other outlays carried the total to $\$ 210,318$. This left a balance of receipts of $\$ 128,132.40$. The surplus from 1898 was $\$ 39,711.38$, and there is a balance due on assessment of $\$ 72,751$, leaving net available assets on December 31,1899 , to the amount of $\$ 240,594.78$.

The Isle Royale Copper Company is a consolidation, effected on April 10, of the Isle Royale Consolidated and the Miners Copper Company. Work is actively progressing in the development of its property. Ground through the old Grand Portage and Isle Royale is being opened, and shafts and air compressors, engines, and other machinery have been placed. The erection of a stamp mill with three heads has begun. During 1899 the payments for mine work and machinery aggregated $\$ 330,677$. At the date of the consolidation there was cash on hand amounting to $\$ 1,794,069$, and the receipts for interest during the year were $\$ 23,057$. At the end of the year a balance of $\$ 1,486,449$ was on hand.

The Mayflower Mining Company owns 840 acres to the southeast of the Kearsarge and Wolverine mines. During the period of ten months ending February 28, 1900, a good deal of exploratory work was done on the surface and through the sinking of a number of shafts, the expenditures on that account having been $\$ 45,023$. The company has sold 100,000 shares of stock at $\$ 8$ and has received $\$ 3,525$ for interest. Payments for property aggregated $\$ 540,000$. At the end of the fiscal period there was a balance of $\$ 218,502$.

The Adventure Consolidated Copper Company is opening up the Butler and Knowlton lodes on its property of 1,696 acres. From November 1,1898 , to the end of 1899 the company spent $\$ 114,173$ for machinery, supplies, and labor, and paid $\$ 250,000$ for its property. The receipts were $\$ 504,023$, including $\$ 500,000$ from the sale of stock. The balance on hand at the end of the fiscal year was $\$ 139,850$.

The Victoria Copper Mining Company began work in March, 1899, and during the year $\$ 60,842.03$ were spent in preparatory work, min- 
ing, plant supplies, etc. The outlays for real estate, organization, etc., were $\$ 383,419.10$. The receipts aggregated $\$ 708,106.17$, of which $\$ 700,000$ was for capital stock.

\section{MONTANA.}

Production in Montana has recovered somewhat, and in spite of litigation is likely to show a further development. A new feature during 1899 was the shipment of considerable quantities of ore from the Liquidator mine to the pyritic smelting plant of the Golden Reward Company at Deadwood, South Dakota.

A dominating influence in the Butte district is exercised by the Amalgamated Copper Company, organized April 29, 1900, with a capital of $\$ 75,000,000$. The company owns the stock of the Washoe Copper Company of Butte, with a capital of $\$ 5,000,000$; of the Colorado Smelting and Mining Company of Butte, with a capital of $\$ 2,500,000$; of the Diamond Coal and Coke Company of Diamondville, Wyoming, with a capital of $\$ 1,500,000$, and of the Big Blackfoot Milling Company of Bonner, Montana, with a capital of $\$ 700,000$. The company also owns a majority of the stock of the Anaconda Copper Mining Company of Butte and Anaconda, with a capital stock of $\$ 30,000,000$; of the stock of the Parrott Silver and Copper Company of Butte, with a capital stock of $\$ 2,298,500$, and of the Hennessey Mercantile Company of Butte and Anaconda, with a capital stock of $\$ 1,500,000$. The Amalgamated Copper Company is also a large holder of the stock of the Boston and Montana Consolidated Copper and Silver Mining Company of Butte. During the year 1899 the companies owned by this company produced $130,682,168$ pounds of copper.

Since the Anaconda has passed into the control of the new interest very extensive changes and improvements have been undertaken in the concentrating and smelting plant at Anaconda.

The Boston and Montana Consolidated Copper and Silver Mining Company had an exceptionally prosperous year during 1899. The report shows gross receipts for the sales of copper, silver, gold, and bluestone of $\$ 11,257,280.18$; the costs were: expenses at Butte and Great Falls, and for electrolytic refining, $\$ 4,385,078.76$, and expenses of handling copper $\$ 817,352.19$, leaving a net income for the year of $\$ 6,05 \pm, 849.23$. There were expended for interest on bonded debts, less interest receipts, $\$ 37,504.48$, and $\$ 37,500$ that were added to the sinking fund. This left available for dividends $\$ 5,979,844.75$; out of this sum there were paid $\$ 5,400,000$, leaving a surplus for the year of $\$ 579,844.75$. Since the balance of assets on December 31, 1898, was $\$ 4,516,2 \pm 6.89$, the balance of assets on December 31,1899 , was $\$ 5,096,091.6 \pm$.

Mining developments hare been carried along until on January 1, 1900 , the estimated reserve and undercut were placed at 2,500,000 tons. 
In view of the fact that large reserves necessitate a corresponding expense of maintenance, it is proposed in the future to maintain the reserve at or about this figure.

During 1899 the company operated the Butte and Boston Smelting Works under lease, but surrendered the same on February 1, 1900.

Very considerable additions have been made to the Great Falls plant, two new blast furnaces having been put in operation, and twelve McDougall calciners having been installed. Work was begun on a new concentrating plant to double the capacity of the works, and it is proposed, in view of this increase in the output of concentrates, to add two blast furnaces, nine additional McDougall calciners, two large reverberatory furnaces, and four additional converter stands. These additions, which when completed will increase the capacity of the plant about two-thirds, will occupy the greater part of the year 1900 .

The annual report of the Parrott Silver and Copper Company of Butte for the fiscal year ending April 30, 1900, showed assets aggregating $\$ 3,767,558.54$, against liabilities of $\$ 2,300,000$ capital stock and $\$ 63,323.52$ for sundry accounts payable. There were paid during the year ending April 30, 1900, dividends aggregating $\$ 1,379,100$, the surplus at the end of the year being $\$ 1,404,235.02$.

\section{ARIZONA.}

Arizona continued during 1899 its extraordinary development as a copper producer, and will show a further increase in 1900 .

At Bisbee the Copper Queen has somewhat enlarged its product, while the other concerns in the district have not yet entered the ranks of producers.

In the Clifton district the Detroit has completed its converter plant and has moderately increased the capacity. A large concentrating mill has been erected to handle low-grade ores.

The Arizona Copper Company in the same district is controlled by a Scotch corporation, whose report for 1899 shows total receipts of $£ 672,813$, including $£ 555,715$ from the sale of copper, $£ 115,539$ from the Arizona and New Mexico Railroad, and $£ 1,559$ from miscellaneous sources. The expenditures include $£ 311,727$ for mining, £37,340 for railroad, and $£ 7,734$ for general purposes. For interest, preferred dividends, etc., $£ 121,517$ were expended, and $£ 45,000$ were assigned to reserve. Of the balance of $£ 149,495$, swollen to $£ 166,165$ by $£ 16,670$ brought forward from the previous year, dividends aggregating $£ 119,646$ on the common stock were paid and $£ 46,519$ were carried to surplus. The company is producing close to 10,000 short tons of copper per annum. The company is building special works for treating the tailings from the two sulphide concentrating mills which are being operated. The works are to have a capacity of 400 tons per day, and it is calculated that an extraction of one-half of 
1 per cent of copper will be obtained. No serious or comprehensive addition to the product in the capacity of the general concentrating and smelting plant is yet contemplated.

The United Verde during 1899, according to published reports, reached a total production of $43,390,590$ pounds of copper. The receipts were $\$ 5,775,621$ for copper, $\$ 293,221$ for silver, $\$ 288,598$ for gold, $\$ 16,719$ for anodes, and $\$ 21,708$ from miscellaneous sources, a total of $\$ 6,395,867$. Since the expenditures reached $\$ 2,660,346$, there was a mining profit of $\$ 3,735,521$, out of which $\$ 3,000,000$ were paid in dividends. Included in the expenses were $\$ 555,147$ for mine development, $\$ 102,916$ for ore roasting, $\$ 1,036,191$ for converter expenses, $\$ 427,412$ for freight, and $\$ 218,978$ for depreciation. The construction expenses paid out of surplus protit were $\$ 801,110$.

At Globe the Old Dominion contributed in a modest degree to the total of the Territory. Improvements and developments were inaugurated in 1899, which when completed will raise the output to about $8,000,000$ pounds per annum. This company has purchased the Continental mine.

The smelting plant at Williams, built by Lombard, Goode \& Co., is now owned by the Anita Consolidated Copper Company, which also owns most of the mines the development of which has been continued. They are located in the Grand Canyon district and have been made more accessible by the new Santa Fe and Grand Canyon Railroad. The smelter has not been in operation, all the ore mined in the course of development having been shipped to the El Paso works. It is possible that it may be moved to the mines.

The Helvetia Copper Company began smelting operations late in 1899 , and has become a regular, although as yet a small, contributor to the copper supply.

A number of smaller smelters have either started in 1899 or are under construction.

\section{UTAH.}

Among the recent producers of copper which are assuming some importance is the Highland Boy Mining Company, controlling the Consolidated Gold Mines of Utah. The deposit consists mainly of sulphides, which, according to the smelting operations of the first year, yielded 4.43 per cent of copper, 1.27 ounces of silver, and .11 ounce of gold. The smelter started in the middle of 1899, and up to June 30,1900 , produced from 73,331 tons of ore $6,497,205$ pounds of fine copper, 93,221 ounces of silver, and 8,254 ounces of gold. The smelter is being enlarged from a capacity of 225 tons per day to 450 tons per day, which will carry the annual output to $12,000,000$ pounds fine. The first annual report of the Utah Consolidated, which covers the period of fifteen months from April 1, 1899, to June 30, 1900, 
shows total receipts of $\$ 1,168,459$, including $\$ 859,308$ from the sale of copper, $\$ 37,224$ from silver, $\$ 116,386$ from gold, and $\$ 155,541$ from miscellaneous sources. The outlays were $\$ 126,782$ for mining, $\$ 284,228$ for smelting, $\$ 45,970$ for maintenance and development, and $\$ 49,852$ for general expenses and interest. This left $\$ 661,627$ of net receipts. Out of this $\$ 220,000$ are to be applied to improvements, including $\$ 178,000$ for the smelter extension.

Development work has been progressing at a property controlled by Lewisohn Brothers, near the Nevada line. The ore presents metallurgical problems which are still under consideration. While a large amount of ore has been proved, no metal product need be expected in the near future.

NEW MEXICO.

The Santa Fe Company is building a new smelting plant, which is expected to be in operation toward the close of 1900 . It will produce matte at the rate of about 200,000 to 250,000 pounds fine per month.

\section{COLORADO.}

The bulk of the copper obtained in Colorado is derived from the smelting of complex ores, the red metal being an incidental product. Nearly all the lead smelters make cupriferous mattes in which the copper contents of the ores have been concentrated. Leadville, however, continues to turn out increasing quantities of ores in which copper is the chief carrier of the precious metals, and the mines in the vicinity of Salida are assuming growing importance.

\section{WYOMING}

Wyoming is credited with having a series of very important copper belts, of which that in the vicinity of Grand Encampnent is being developed. A fair tonnage of high-grade ore has found its way from Wyoming to outside smelters, Chicago in particular treating it.

\section{CALIFORNIA.}

There has been a good deal of activity in copper mining in California, but as yet the number of important actual producers is small, being limited to the Mountain in Shasta County, the Madera, and the Ivanpah. It is understood, however, that important interests are developing property at no great distance from the Mountain, and the old mines of Copperopolis, which once made California famous, are being reopened. The old Newton mines, which for many years produced some precipitate, are also getting into working shape. 
IDAHO.

The Seven Devils district in Idaho does not yet possess transportation facilities, although the building of the connecting railroad has progressed. Until that is completed no notable quantities of metal need be expected from that source.

\section{NEVADA.}

In Nevada a few reduction plants have been started during 1899, but the quantity of copper produced thus far has been small, work having been intermittent.

\section{TENNESSEE.}

The Ducktown Copper, Sulphur and Iron Company is an English corporation operating in the Ducktown district in Tennessee and producing a little over 3,000,000 pounds per year. During the year 1899 the earnings of the company were $£ 28,291$, out of which there were paid 7 per cent on $£ 10,000$ preference shares, 15 per cent on $£ 50,000$ ordinary shares, and $£ 3210 \mathrm{~s}$. each on 200 founders' shares. There is an outstanding first mortgage of $£ 44,500$ at 5 per cent and a second mortgage of $£ 7,905$ at 7 per cent.

The Tennessee Copper Company has been building a large modern smelting plant, and is developing the property, so that when smelting begins in May, 1901, a monthly production of about 800,000 pounds fine copper will be attained.

\section{VERMONT}

The Ely and Copperfield mines in Vermont are now controlled by George Westinghouse, of Pittsburg, while at the Elizabeth mines at South Strafford smelting operations have been carried on for some time.

An interesting undertaking is the reopening and development of the famous old Schuyler mines near Arlington, where a concentrating plant is now in course of construction. It is proposed to roast the concentrates, dissolve with dilute sulphuric acid, and deposit the copper electrolytically.

\section{IMPORTS.}

The imports of fine copper contained in ores, and of regulus and black copper, and of ingot copper, old copper, plates not rolled, rolled plates, sheathing metal, and manufactures not otherwise specified, and of brass are given in the following tables: 
COPPER.

Fine copper contained in ores, and regulus and black copper, imported and entered for consumption in the United States, 1867 to 1899, inclusive.

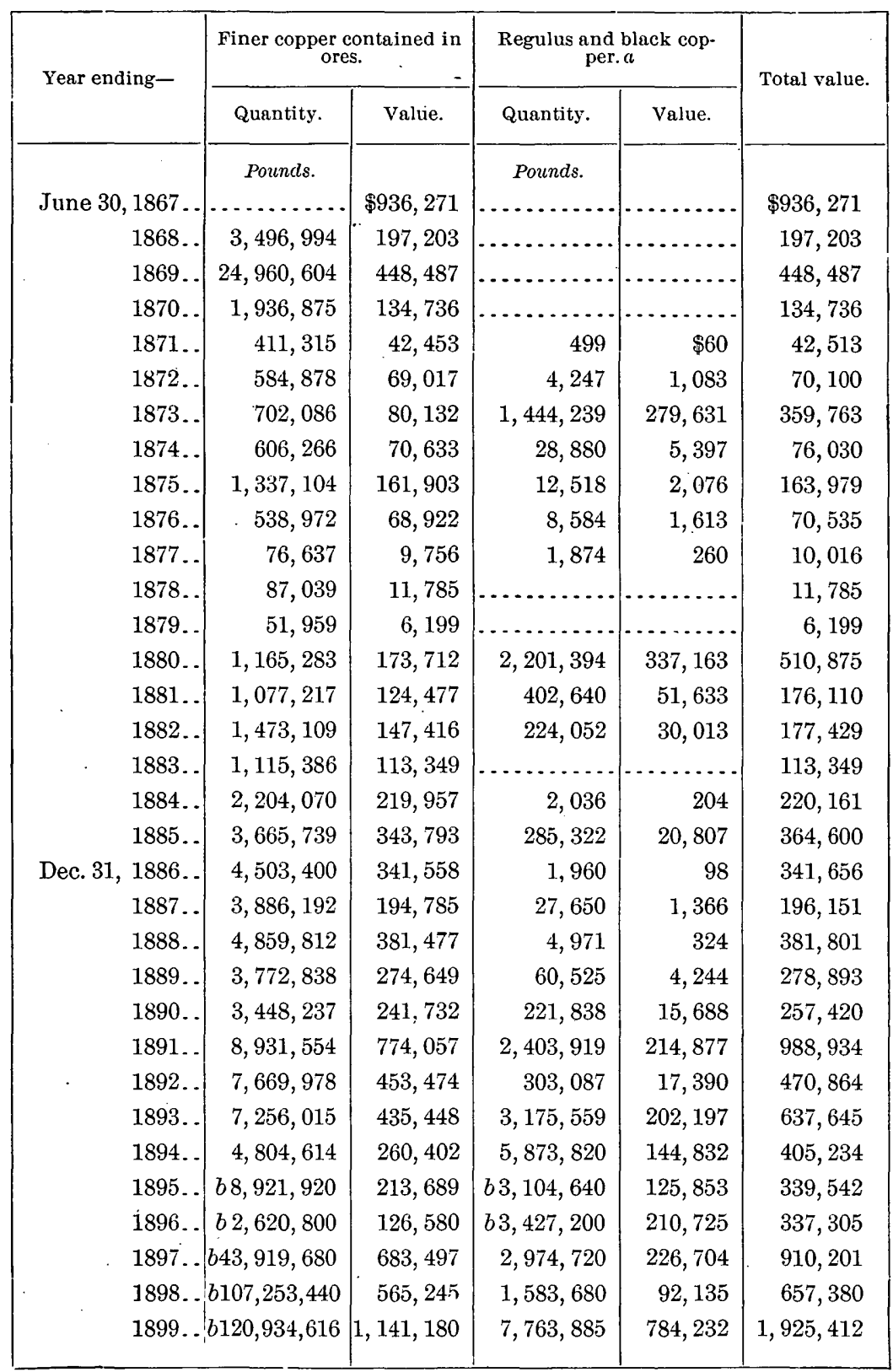

$a$ Not enumerated until 1871.

$b$ Ores. 
Copper imported and entered for consumption in the United States, 1867 to 1899, inclusive.

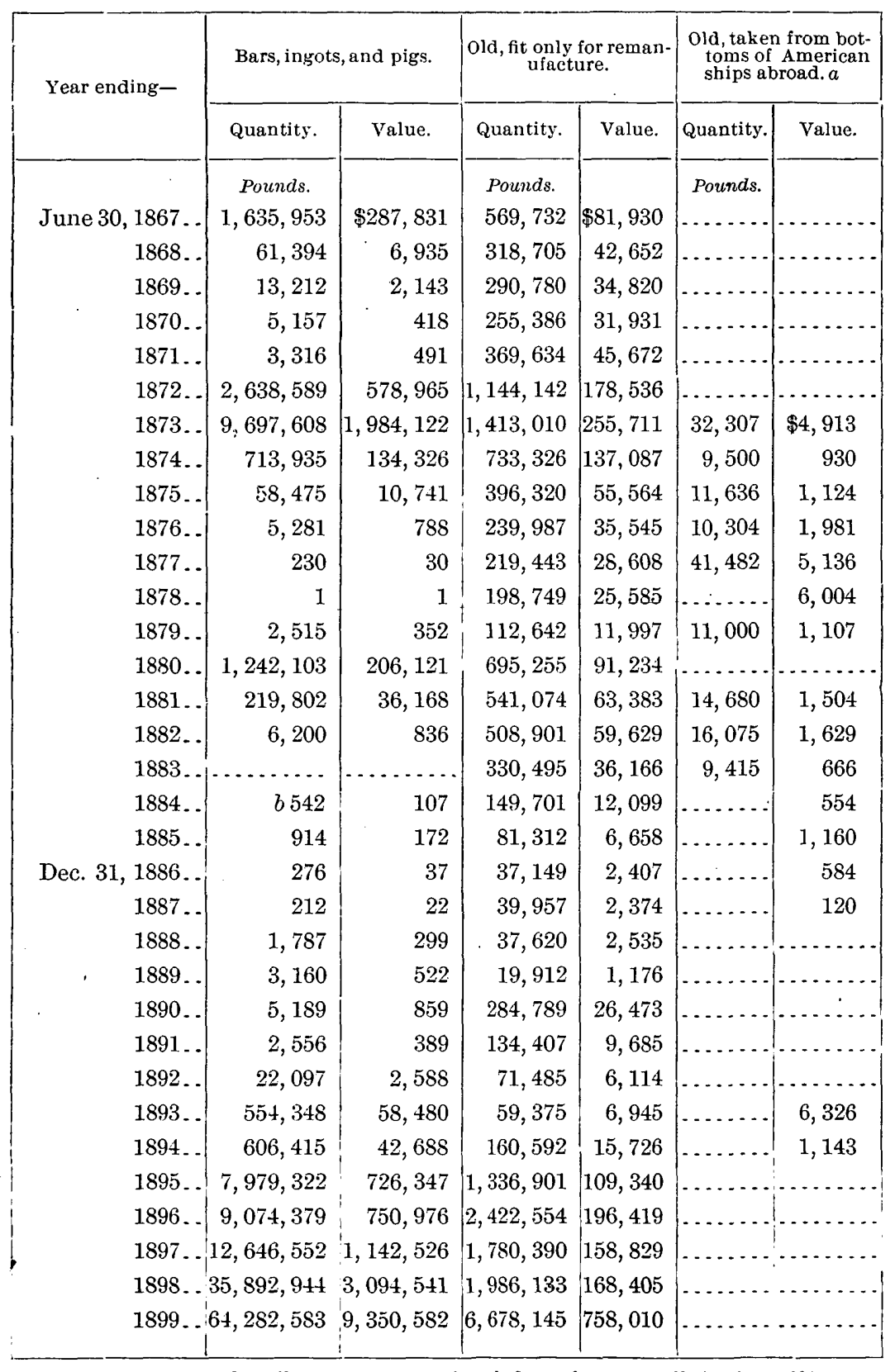


Copper imported and entered for consumption in the United States, etc.-Continued.

\begin{tabular}{|c|c|c|c|c|}
\hline \multirow{2}{*}{ Year ending- } & \multicolumn{2}{|c|}{ Plates not rolled. } & \multicolumn{2}{|c|}{$\begin{array}{l}\text { Plates rolled, sheets, pipes, } \\
\text { etc. }\end{array}$} \\
\hline & Quantity. & Value. & Quantity. & Value. \\
\hline & Pounds. & & Pounds. & \\
\hline June $30,1867 .$. & & & …..... & $\$ 1,101$ \\
\hline 1868. & & & & 1 \\
\hline $1869 \ldots$ & & & & 39 \\
\hline $1870 \ldots$ & $\cdots$ & 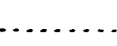 & & 2,039 \\
\hline $1871 \ldots$ & 430 & $\$ 129$ & . & 7,487 \\
\hline $1872 \ldots$ & 148,192 & 33,770 & $\ldots$ & 18,895 \\
\hline $1873 .$. & 550,431 & 97,888 & & 4,514 \\
\hline $1874 \ldots$ & & & & 27 \\
\hline $1875 \ldots$ & 8 & 4 & & 617 \\
\hline $1876 .$. & 5,467 & 600 & & 326 \\
\hline $1877 \ldots$ & & & & 203 \\
\hline $1878 \ldots$ & $\cdots$ & & & 1,201 \\
\hline $1879 .$. & 27,074 & 4,496 & & 786 \\
\hline $1880 \ldots$ & 120 & 11 & & 4,134 \\
\hline $1881 \ldots$ & 20 & 3 & $\ldots .$. & 82 \\
\hline $1882 \ldots$ & & & 5,855 & 1,551 \\
\hline 1883. & & & 2,842 & 379 \\
\hline $1884 .$. & & & 6,529 & 2,330 \\
\hline $1885 \ldots$ & & & 470 & 120 \\
\hline Dec. $31,1886 \ldots$ & & & 3,770 & 339 \\
\hline $1887 \ldots$ & & & 37,925 & 5,493 \\
\hline $1888 .$. & & & 5,208 & 737 \\
\hline 1889. & & & 13,848 & 2,082 \\
\hline $1890 \ldots$ & & & 4,209 & 917 \\
\hline $1891 \ldots$ & & & 122,219 & 23,291 \\
\hline $1892 \ldots$ & & & 1,788 & 600 \\
\hline 1893. & & & 7,056 & 1,065 \\
\hline $1894 \ldots$ & & & 12,681 & 1,821 \\
\hline $1895 \ldots$ & & & 27,156 & 2,586 \\
\hline $1896 \ldots$ & & & 34,481 & 4,834 \\
\hline $1897 .$. & & & 3,116 & 430 \\
\hline $1898 \ldots$ & & & 11,793 & 2,193 \\
\hline $1899 \ldots$ & 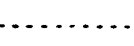 & & 827 & 331 \\
\hline
\end{tabular}


Copper imported and entered for consumption in the United States, etr.-Continued.

\begin{tabular}{|c|c|c|c|c|}
\hline \multirow{2}{*}{ Year ending- } & \multicolumn{2}{|c|}{$\underset{\text { Copper. } a}{\text { Sheathing metal, in part }}$} & \multirow{2}{*}{$\begin{array}{c}\begin{array}{c}\text { Manufactures } \\
\text { not otherwise } \\
\text { specified. }\end{array} \\
\text { Value. }\end{array}$} & \multirow{2}{*}{ Total value. } \\
\hline & Quantity. & Value. & & \\
\hline & Pounds. & & & \\
\hline June $30,1867 \ldots \ldots \ldots \ldots$ & 220,889 & $\$ 37,717$ & $\$ 15,986$ & $\$ 424,565$ \\
\hline $1868 \ldots \ldots \ldots$ & 101,488 & 18,852 & 21,492 & 89,932 \\
\hline $1869 \ldots$ & 43,660 & 6,592 & 43,212 & 86,806 \\
\hline $1870 \ldots$ & 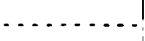 & $\ldots$. & 485,220 & 519,608 \\
\hline . 1871.. & $\cdots$ & & 668,894 & 722,673 \\
\hline 1872 & & - & $1,007,744$ & $1,817,910$ \\
\hline $1873 \ldots$ & . & $\ldots \ldots$ & 869,281 & $3,216,429$ \\
\hline $1874 \ldots .$. & 282,406 & 50,174 & 125,708 & 448,252 \\
\hline $1875 \ldots$ & 136,055 & 23,650 & 35,572 & 127,272 \\
\hline 1876. & 18,014 & 2,903 & 29,806 & 71,949 \\
\hline $1877 \ldots$. & 110 & 22 & 41,762 & 75,761 \\
\hline 1878. & 647 & 55 & 35,473 & 68,319 \\
\hline $1879 \ldots$ & 300 & 20 & 39,277 & 58,035 \\
\hline 1880 & 6,044 & 693 & 130,329 & 432,522 \\
\hline $1881 \ldots$ & 39,520 & 4,669 & 284,509 & 390,318 \\
\hline 1882. & $\ldots \ldots$ & $\ldots .$. & 77,727 & 141,372 \\
\hline 1883. & 6,791 & 1,047 & 40,343 & 78,601 \\
\hline $1884 \ldots$. & 19,637 & 926 & 55,274 & 71,290 \\
\hline $1885 \ldots$. & 86,619 & 9,894 & 61,023 & 79,027 \\
\hline Dec. $31,1886$. & 21,573 & 1,917 & 31,871 & 37,155 \\
\hline $1887 \ldots \ldots$ & 18,189 & 1,867 & 37,289 & 47,174 \\
\hline 1888. & 23,622 & 2,696 & 14,567 & 20,834 \\
\hline $1889 \ldots$ & 23,520 & 2,572 & 13,430 & 19,782 \\
\hline $1890 \ldots$ & 37,458 & 4,467 . & 24,752 & 57,468 \\
\hline $1891 \ldots$. & 228,486 & 29,112 & 12,926 & 75,403 \\
\hline $1892 \ldots$ & 417,134 & 51,380 & 49,764 & 110,446 \\
\hline 1893. & 1,670 & 167 & 16,166 & 89,149 \\
\hline $1894 \ldots$ & 8,422 & 1,470 & 3,851 & 66,699 \\
\hline 1895. & 5,698 & 389 & 13,166 & $851,82 S$ \\
\hline 1896. & 3,183 & 303 & 20,953 & 973,485 \\
\hline $1897 \ldots$ & 15,282 & . 1,929 & 30,729 & $1,334,443$ \\
\hline $189 \$ \ldots . .$. & 5,801 & 679 & 620,071 & $3,285,889$ \\
\hline $1899 \ldots$ & 13,763 & 6,310 & 13,629 & $10,128,862$ \\
\hline
\end{tabular}

$a$ Does not include copper sheathing in $1867,186 \mathrm{~S}$, and 1869 .

$b$ Including wire. 
By customs districts the imports of copper have been as follows in the calendar year 1899:

Imports of copper pigs, bars, ingots, plates, old and other unmanufactured, by customs districts, calendar year 1899.

\begin{tabular}{|c|c|c|}
\hline Customs district. & Quantity. & Value. \\
\hline & Pounds. & \\
\hline Baltimore, Md.. & $12,645,594$ & $\$ 2,086,086$ \\
\hline Newark, N. J . . . . . . & 563,071 & 56,308 \\
\hline New York, N. Y .... & $47,905,124$ & $6,785,681$ \\
\hline Passamaquoddy, Me. . & 63,459 & 5,738 \\
\hline Perth Amboy, N. J... & $1,548,221$ & 278,941 \\
\hline Corpus Christi, Tex $\ldots \ldots \ldots \ldots \ldots \ldots$ & $5,331,323$ & 551,739 \\
\hline Arizona ........... & $2,656,631$ & 247,445 \\
\hline San Francisco, Cal.. & 61,441 & 5,021 \\
\hline Champlain, N. Y... & 368,028 & 49,717 \\
\hline Detroit, Mich ........ & 341,067 & 19,928 \\
\hline All other districts ...... & 438,381 & 52,786 \\
\hline Total . & $71,922,340$ & $10,139,390$ \\
\hline
\end{tabular}

Imports of copper ore and regulus, by customs districts, during the calendar year 1899.

\begin{tabular}{|c|c|c|}
\hline Customs districts. & Quantity. & Value. \\
\hline . & Tons. & \\
\hline New York, N. Y. & 24,054 & $\$ 685,000$ \\
\hline Corpus Christi, Tex ........ & 136 & 42,114 \\
\hline Paso del Norte, Tex .... . & 56 & 9,588 \\
\hline Arizona & 1,585 & 317,926 \\
\hline Puget Sound, Wash ... & 2,753 & 747,049 \\
\hline Memphremagog, vt $\ldots \ldots \ldots \ldots \ldots \ldots \ldots$ & 361 & 29,540 \\
\hline Oswegatchie,, N. Y $\ldots \ldots \ldots \ldots \ldots \ldots \ldots \ldots$ & 1,802 & 244,451 \\
\hline All other districts ........ & 890 & 167,915 \\
\hline Total .. & 31,637 & $2,243,583$ \\
\hline
\end{tabular}

21 GEOL, PT $6-13$ 
The sources of the copper imports are shown in the following tables:

Imports of copper and copper ore.

PIGS, BARS, INGOTS, PLATES, OLD AND OTHER UNMANUFACTURED.

\begin{tabular}{|c|c|c|}
\hline Countries. & \multicolumn{2}{|c|}{ Calendur year 1899.} \\
\hline & Pounds. & \\
\hline France ..... & $7,121,944$ & $\$ 1,067,231$ \\
\hline Germany ........... & 896,972 & 134,982 \\
\hline United Kingdom............ & $34,188,172$ & $5,200,036$ \\
\hline Dominion of Canada: & & \\
\hline Quebec and Ontario ........... & 746,846 & 81,078 \\
\hline British Columbia ..... & 647,541 & 64,238 \\
\hline West Indies: & & \\
\hline British .. & 507,006 & $.52,675$ \\
\hline Cuba........ & $3,041,631$ & 328,929 \\
\hline San Domingo........... & 49,851 & 5,407 \\
\hline Mexico............ & $19,703,367$ & $2,511,760$ \\
\hline 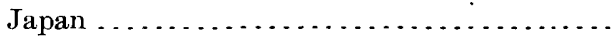 & 112,020 & 15,187 \\
\hline British Australasia ..... & $4,029,645$ & 584,698 \\
\hline All other countries... & 877,345 & 93,169 \\
\hline Total... & $71,922,340$ & $10,139,390$ \\
\hline
\end{tabular}

ORE AND REGULUS.

\begin{tabular}{|c|c|c|}
\hline Germany $\ldots \ldots \ldots \ldots \ldots \ldots \ldots \ldots \ldots$ & $\begin{array}{l}\text { Tons. } \\
\quad 377\end{array}$ & $\$ 103,618$ \\
\hline Dominion of Canada: & & \\
\hline Quebec and Ontario... & 1,424 & 268,292 \\
\hline British Columbia & 4,298 & 938,544 \\
\hline Newfoundland and Labrador... & 19,109 & 97,966 \\
\hline Mexico ..... & 3,681 & 606,859 \\
\hline All other countries.. & 2,748 & 228,304 \\
\hline Total & 31,637 & $2,243,583$ \\
\hline
\end{tabular}

For a number of years the official import statistics do not give the copper contents of ores and mattes imported, but report only the gross weight of the ores and of the regulus or matte, lumping the two together. The only means of ascertaining whether the material reported is ore or regulus is to study the source from which it came and to observe the valuation placed on it.

In the above table these indications point to the conclusion that the imports during 1899 from Germany, Quebec and Ontario, British 
Columbia, and Mexico consisted of matte, the total being 9,780 long tons. At 55 per cent fine copper contents this would represent imports of about 12,250,000 pounds of fine copper. The imports from "other countries" of 2,748 tons may be taken as low-grade matte and high-grade ore, for which an average of 25 per cent has been assumed, thus representing about $1,500,000$ pounds of the metal.

In addition thereto there is copper in some pyrites imported for sulphuric-acid manufacture from Spain and from Canada, the fine copper contents being estimated at 4,500,000 pounds in 1899 , this figure being checked to some extent by the returns of copper smelters and chemical works which handled the cinder.

Then there is usually left out of account in the import statistics the copper contents of the Sudbury nickel mattes, the quantity for 1899 being estimated at $5,550,000$ pounds.

Thus the supply through imports during 1899 may be stated as follows:

$$
\text { Imports of copper in furnace material and ores in } 1899 .
$$

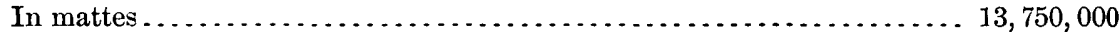

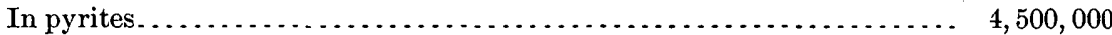

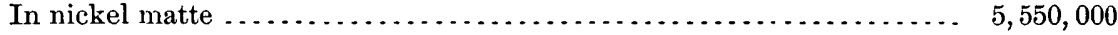

Total

$23,800,000$

For 1898 these sources of supply were estimated to account for $19,750,000$ pounds.

The import movement of pigs and bars has assumed very much larger dimensions and is significant from more than one point of view. The imports from the West Indies are old copper exclusively, and the same is true of the greater quantity of material from miscellaneous sources. A part of the imports from Mexico is copper in transit from Boleo to European refineries. It was in 1899, however, that the handling of foreign unrefined copper first became a very important feature. The bars from British Australasia and a large part of those from Great Britain were brought to this country to be worked by the electrolytic process, and to be subsequently reexported. Of course the copper coming from England originated in producing countries, a very large part of it being Chile bars. A large part of the Mexican copper is blister, produced at works in that country controlled by companies in the United States owning refineries at tide water. The refineries on New York Harbor and at Baltimore treat practically all of this material, as is clearly shown by the foregoing table, in which the imports are grouped by ports of entry. 
EXPOR'TS.

The exports of copper in the form of ore (including matte), ingots, and manufactured copper, for a series of years, have been as follows:

Copper and copper ore of domestic production exported from the Lnited States, 1864 to 1899.

[Cwts. are long hundredweights of 112 pounds.]

\begin{tabular}{|c|c|c|c|c|}
\hline \multirow{2}{*}{ Year ending- } & \multicolumn{2}{|c|}{ Ore and matte. } & \multicolumn{2}{|c|}{ Pigs, bars, sheets, and old. } \\
\hline & Quantity. & value. & Quantity. & value. \\
\hline June $30,1864 \ldots$ & $\begin{array}{c}\text { Cwts. } \\
109,551\end{array}$ & $\$ 181,298$ & $\begin{array}{l}\text { Pounds. } \\
\qquad 102,831\end{array}$ & $\$ 43,229$ \\
\hline $1865 \ldots \ldots \ldots$ & 225,197 & 5̄53, 124 & $1,572,382$ & 709,106 \\
\hline $1866 \ldots$ & 215,080 & 792,450 & 123,444 & 33,553 \\
\hline $1867 \ldots$ & 87,731 & 317,791 & $a 4,637,867$ & 303,048 \\
\hline $1868 \ldots$ & 92,612 & 442,921 & $1,350,896$ & 327,287 \\
\hline $1869 \ldots$ & 121,418 & 237,424 & $1,134,360$ & 233,932 \\
\hline $1870 \ldots$ & $a 19,198$ & 537,505 & $2,214,658$ & 385,815 \\
\hline $1871 \ldots \ldots \ldots$ & $a 54,445$ & 727,213 & 581,650 & 133,020 \\
\hline $1872 \ldots$ & 35,564 & 101,752 & 267,868 & 64,844 \\
\hline $1873 \ldots$ & 45,252 & 170,365 & 38,958 & 10,423 \\
\hline $1874 \ldots$ & 13,326 & 110,450 & 503,160 & 123,457 \\
\hline $1875 \ldots$ & $a 51,305$ & 729,578 & $5,123,470$ & $1,042,536$ \\
\hline $1876 \ldots$ & 15,304 & 84,471 & $14,304,160$ & $3,098,395$ \\
\hline $1877 \ldots$ & 21,432 & 109,451 & $13,461,553$ & $2,718,213$ \\
\hline $1878 \ldots$ & 32,947 & 169,020 & $11,297,876$ & $2,102,455$ \\
\hline $1879 \ldots$ & 23,070 & 102,152 & $17,207,739$ & $2,751,153$ \\
\hline $1880 \ldots$ & 21,623 & 55,763 & $4,206,258$ & 667,242 \\
\hline $1881 \ldots$ & 9,958 & 51,499 & $4,865,407$ & 786,860 \\
\hline $1882 \ldots$ & 25,936 & 89,515 & $3,340,531$ & 565,295 \\
\hline $1883 \ldots$ & 112,923 & 943,771 & $8,221,363$ & $1,293,947$ \\
\hline $1884 \ldots$ & 386,140 & $2,930,895$ & $17,044,760$ & $2,527,829$ \\
\hline $1885 \ldots \ldots \ldots$ & 432,300 & $4,739,601$ & $44,731,858$ & $5,339,887$ \\
\hline Dec. $31,1886 \ldots \ldots \ldots$ & 417,520 & $2,241,164$ & $19,553,421$ & $1,968,772$ \\
\hline $1887 \ldots . . .$. & 501,280 & $2,774,46 t$ & $12,471,393$ & $1,247,928$ \\
\hline $18 s s \ldots . . . .$. & 794,960 & $6,779,294$ & $31,706,527$ & $4,906,805$ \\
\hline $1889 \ldots$ & 818,500 & $8,226,206$ & $16,813,410$ & $1,896,752$ \\
\hline $1890 \ldots$ & 431,411 & $4,413,067$ & $10,971,899$ & $1,365,379$ \\
\hline $1891 \ldots \ldots \ldots$ & 672,120 & $6,565,620$ & $69,279,024$ & $8,844,304$ \\
\hline $1892 \ldots$ & 943,040 & $6,479,758$ & $30,515,736$ & $3,438,048$ \\
\hline $1893 \ldots . .$. & 835,040 & $4,257,128$ & $138,984,128$ & $14,213,378$ \\
\hline $1894 \ldots \ldots . .$. & 87,040 & 440,129 & $162,393,000$ & $15,324,925$ \\
\hline $1895 \ldots \ldots \ldots$ & 276,480 & $1,631,251$ & $121,328,390$ & $12,222,769$ \\
\hline $1 S 96 \ldots \ldots \ldots$ & 414,265 & $2,393,914$ & $259,223,924$ & $27,822,280$ \\
\hline $1897 \ldots . . . . .$. & 181,280 & $1,199,029$ & $277,255,742$ & $30,597,645$ \\
\hline $1898 \ldots \ldots \ldots$ & 186,860 & 755,443 & $291,955,905$ & $33,598,869$ \\
\hline $1899 \ldots \ldots \ldots$ & 70,080 & 382,989 & $24 \overline{7}, 370,681$ & $41,250,166$ \\
\hline
\end{tabular}

a Evidently errors in quantities. 
Copper and copper ore of domestic production exported, etc.-Continued.

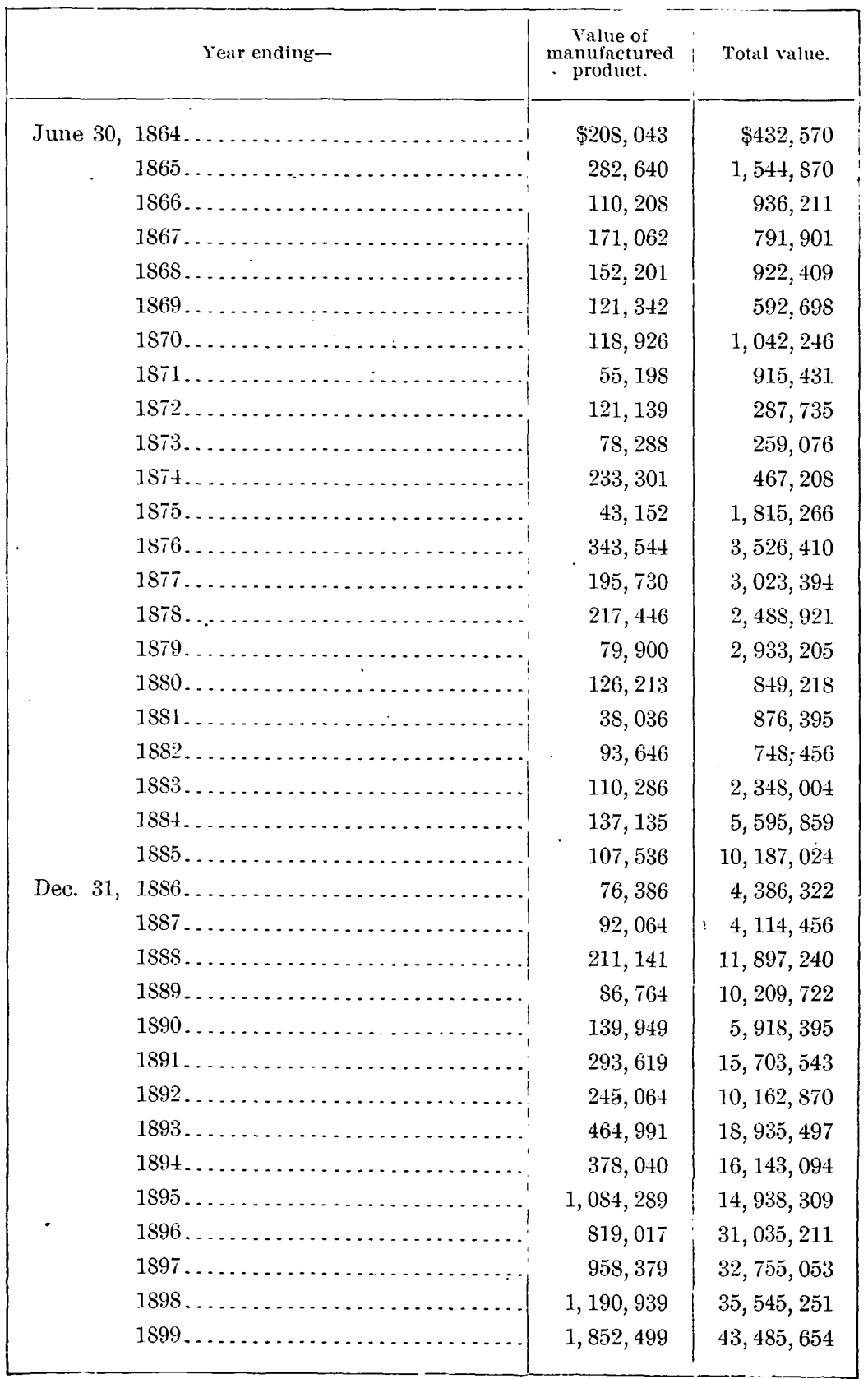


The destination of our exports of copper bars, ingots, plates, and old copper during the years $1895,1896,1897,1898$, and 1899 is shown by the following table, the data having been furnished by the Bureau of Statistics:

Exports of copper bars and ingots for 1895, 1896,1897, 1898, and 1899, and countries to which exported.

\begin{tabular}{|c|c|c|c|c|c|}
\hline Country. & 1895. & .1896. & 1897. & 1898. & 1899. \\
\hline & Pounds. & Pounds. & Pounds. & Pounds. & Pounds. \\
\hline United Kingdom & $24,064,694$ & $78,479,716$ & $63,774,004$ & $88,443,870$ & $50,738,291$ \\
\hline Austria & $3,228,545$ & $6,532,949$ & $5,918,993$ & $7,478,730$ & $6,354,287$ \\
\hline Belgium & $8,384,995$ & $9,648,271$ & $16,651,776$ & $13,613,183$ & $5,069,456$ \\
\hline France.... & $25,266,032$ & $45,502,864$ & $59,630,864$ & $53,909,508$ & $58,450,866$ \\
\hline Germany ... & $14,962,257$ & $29,609,837$ & $29,746,200$ & $42,891,345$ & $49,285,139$ \\
\hline Netherlands.. & $40,451,380$ & $72,994,600$ & $86,581 \quad 616$ & $72,418,633$ & $69,304,699$ \\
\hline Italy ... & 901,485 & $4,067,160$ & $3,757,920$ & $3,733,672$ & $3,449,565$ \\
\hline Russia . & $2,968,001$ & $10,741,821$ & $8,515,772$ & $7,340,276$ & $2,689,610$ \\
\hline Mexico ... & 151,664 & 170,340 & & 253,975 & 285,222 \\
\hline $\begin{array}{l}\text { British North Amer- } \\
\quad \text { ica } \ldots . . . . . .\end{array}$ & 398,906 & 234,845 & 597 & $1,523,505$ & 985,525 \\
\hline West Indies. & 1,721 & $1,241,705$ & & 6,143 & 5,599 \\
\hline Other countries. & 548,710 & & . & 343,065 & 208,072 \\
\hline Total & 121, & & & & \\
\hline
\end{tabular}

The following table shows the export ports:

Exports of ingots, bars, and old copper in 1897, 1898, and 1899, by ports.

\begin{tabular}{|c|c|c|c|}
\hline District. & 1897. & 1898. & 1899. \\
\hline Baltimore, Md ............ & $\begin{array}{l}\text { Pounds. } \\
88,389,939\end{array}$ & $\begin{array}{l}\text { Pounds. } \\
87,027,133\end{array}$ & $\begin{array}{l}\text { Pounds. } \\
90,786,853\end{array}$ \\
\hline $\begin{array}{l}\text { Boston and Charlestown, } \\
\text { Mass } \ldots \ldots\end{array}$ & 928,584 & 439,368 & $1,568,197$ \\
\hline Newark, N. J .... & …....... & 673,180 & $\cdots$ \\
\hline Newport News, Va.. & $5,899,609$ & $2,638,868$ & $4,085,580$ \\
\hline Norfolk, Va...... & - $\ldots \ldots \ldots$ & $5,249,820$ & $4,707,267$ \\
\hline New York, N. Y . ........ & $167,344,812$ & $178,400,314$ & $134,412,540$ \\
\hline Philadelphia, Pa .... & 227,023 & 68,624 & $2,733,692$ \\
\hline New Orleans, La ... & $13,882,408$ & $15,508,831$ & $7,459,623$ \\
\hline Galveston, Tex... & ......... & 444,920 & 3,700 \\
\hline Detroit, Mich .... & 164,317 & 728,689 & 320,121 \\
\hline Huron, Mich... & 229,226 & 118,827 & $10 \overline{7}, 562$ \\
\hline Burlington, Vt $\ldots$ & 102,718 & 410,410 & 434,340 \\
\hline All others ................. & 87,106 & 246,921 & 206,856 \\
\hline Total .. & $277,255,742$ & $291,955,905$ & $246,826,331$ \\
\hline
\end{tabular}


Summarizing the data presented, we have the following estimate of the copper supply to the United States markets for the years 1898 and 1899:

Copper supply of the United States for 1898 and 1899.

\begin{tabular}{|c|c|c|}
\hline . & 1898. & 1899. \\
\hline United States production ............. & $\begin{array}{c}\text { Pounds. } \\
526,512,987\end{array}$ & $\begin{array}{c}\text { Pounds. } \\
568,666,921\end{array}$ \\
\hline Imports: & & \\
\hline Bars $\ldots \ldots \ldots \ldots \ldots \ldots \ldots \ldots \ldots$ & $54,166,467$ & $71,922,340$ \\
\hline 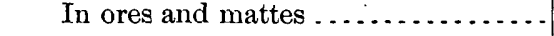 & $19,750,000$ & $23,800,000$ \\
\hline Total $\ldots \ldots \ldots \ldots \ldots \ldots$ & $600,429,454$ & $664,389,261$ \\
\hline Less exports: & & \\
\hline Bars ........ & $291,955,905$ & $246,826,331$ \\
\hline In ores and mattes $\ldots . \ldots \ldots \ldots . . .$. & $5,420,000$ & $3,500,000$ \\
\hline In blue vitriol at 25 per cent.... & $3,843,000$ & $7,350,000$ \\
\hline Available for home consumption.. & $299,210,549$ & $406,712,930$ \\
\hline
\end{tabular}

No attempt has been made to take account of fluctuations in stocks, because it is absolutely impossible to procure a sufficiently large aggregate of official figures to give them value.

\section{PRICES.}

The following table summarizes the highest and lowest prices obtained for Lake copper monthly in the New York markets from 1860 to 1899, both inclusive:

Highest and lowest prices of Lake Superior ingot copper, by months, from 1860 to 1899.

[Cents per pound.]

\begin{tabular}{|c|c|c|c|c|c|c|c|c|c|c|c|c|}
\hline \multirow[b]{2}{*}{ Year. } & \multicolumn{2}{|c|}{ January. } & \multicolumn{2}{|c|}{ February. } & \multicolumn{2}{|c|}{ March. } & \multicolumn{2}{|c|}{ April. } & \multicolumn{2}{|c|}{ May. } & \multicolumn{2}{|c|}{ June. } \\
\hline & 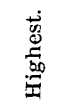 & 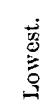 & 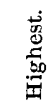 & 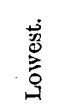 & 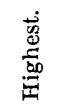 & 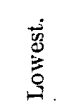 & 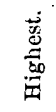 & $\frac{\dot{s}}{\dot{y}}$ & 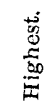 & 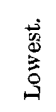 & 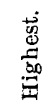 & 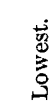 \\
\hline 1860 & 24 & $23 \frac{1}{2}$ & 24 & $23 \frac{3}{4}$ & $23 \frac{3}{4}$ & 23 & $23 \frac{1}{2}$ & 23 & $23 \frac{1}{4}$ & $22 \frac{3}{4}$ & $22 \frac{1}{3}$ & $21 \frac{3}{4}$ \\
\hline $1861 \ldots$ & 20 & 19 & $19 \frac{1}{2}$ & 19 & $19 \frac{3}{4}$ & $19 \frac{1}{4}$ & $19 \frac{3}{4}$ & 19 & $19 \frac{3}{4}$ & $19 \frac{1}{4}$ & 19 & 18 \\
\hline 1862. & 28 & 27 & 28 & 25 & 25 & 23 & 23 & $21 \frac{1}{2}$ & $21 \frac{1}{2}$ & $20 \frac{3}{4}$ & 23 & $20 \frac{3}{4}$ \\
\hline 1863. & 35 & 31 & 37 & 35 & 37 & 31 & 31 & 30 & $30 \frac{1}{2}$ & 30 & $30 \frac{1}{2}$ & 30 \\
\hline 1864 & $41 \frac{1}{4}$ & 39 & 42 & $41 \frac{1}{4}$ & $42 \frac{1}{2}$ & $41 \frac{1}{2}$ & 44 & $42 \frac{1}{2}$ & 44 & 43 & 49 & 44 \\
\hline 1865 & $50 \frac{1}{2}$ & 46 & 46 & 44 & $44 \frac{1}{2}$ & 34 & 35 & 34 & 34 & 30 & $30 \frac{1}{2}$ & $28 \frac{1}{2}$ \\
\hline 1866 & 42 & 38 & 38 & $35 \frac{1}{2}$ & $35 \frac{1}{2}$ & $29 \frac{1}{2}$ & 30 & $28 \frac{1}{2}$ & 31 & 29 & 33 & 31 \\
\hline 1867. & 292 & 27 & $27 \frac{3}{4}$ & $27 \frac{1}{2}$ & $27 \frac{1}{2}$ & 24 & $24 \frac{1}{2}$ & $23 \frac{1}{2}$ & $24 \frac{1}{4}$ & 24 & $24 \frac{1}{2}$ & 24 \\
\hline 1868. & $23 \frac{1}{2}$ & $21 \frac{1}{2}$ & 24 & $22 \frac{1}{2}$ & 24 & $23 \frac{1}{4}$ & $24 \frac{1}{4}$ & $23 \frac{1}{4}$ & $24 \frac{1}{4}$ & 24 & 24 & $23 \frac{1}{8}$ \\
\hline
\end{tabular}


MINERAL RESOURCES.

Highest and lowest prices of Lake Superior ingot copper, by months, etc.-Continued.

[Cents per pound.]

\begin{tabular}{|c|c|c|c|c|c|c|c|c|c|c|c|c|}
\hline \multirow[b]{2}{*}{ Year. } & \multicolumn{2}{|c|}{ January. } & \multicolumn{2}{|c|}{ February. } & \multicolumn{2}{|c|}{ March. } & \multicolumn{2}{|c|}{ April. } & \multicolumn{2}{|c|}{ May. } & \multicolumn{2}{|c|}{ June. } \\
\hline & 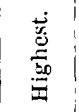 & 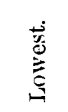 & 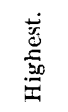 & 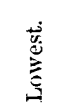 & 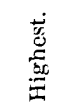 & 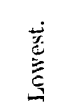 & $\frac{\stackrel{\dot{d}}{\tilde{g}}}{\stackrel{5 x}{\underline{x}}}$ & 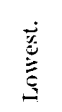 & 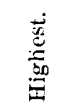 & 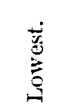 & 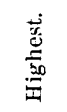 & 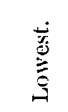 \\
\hline 1869 & $26 \frac{1}{4}$ & $23 \frac{3}{4}$ & 27 & 26 & $26 \frac{3}{4}$ & 24 & 24 & $23 \frac{1}{4}$ & $24 \frac{1}{4}$ & $23 \frac{3}{4}$ & $23 \frac{3}{4}$ & 22 \\
\hline 1870 & 22 & $21 \frac{1}{8}$ & $21 \frac{1}{4}$ & $20 \frac{7}{8}$ & $20 \frac{3}{4}$ & 19 & $19 \frac{3}{4}$. & $19 \frac{1}{4}$ & $19 \frac{1}{2}$ & 19 & $20 \frac{5}{8}$ & 19 \\
\hline 1871 & $22 \frac{7}{8}$ & 22 & $22 \frac{3}{8}$ & $21 \frac{7}{8}$ & 22 & $21 \frac{1}{2}$ & $21_{4}^{3}$ & $21 \frac{1}{4}$ & $21 \frac{3}{4}$ & $21 \frac{3}{8}$ & $21 \frac{1}{2}$ & $21 \frac{1}{4}$ \\
\hline 1872 & $28 \frac{1}{2}$ & $27 \frac{1}{8}$ & $28 \frac{3}{8}$ & 284 & $30 \frac{1}{2}$ & $28 \frac{3}{8}$ & 44 & $30 \frac{1}{2}$ & 42 & 36 & $34^{\frac{3}{4}}$ & 33 \\
\hline 1873. & 35 & $32 \frac{1}{2}$ & 35 & 34 & 35 & $3+\frac{1}{2}$ & $34 \frac{1}{2}$ & $33 \frac{1}{2}$ & $33 \frac{1}{2}$ & 32 & $31 \frac{1}{2}$ & 291 \\
\hline 1874 & 25 & $24 \frac{1}{2}$ & 25 & $24 \frac{1}{3}$ & $24_{4}^{3}$ & 24 & 25 & $24 \frac{3}{4}$ & 25 & $24 \frac{1}{2}$ & $24 \frac{3}{4}$ & $24 \frac{1}{4}$ \\
\hline 1875 & $23 \frac{1}{2}$ & $21 \frac{1}{2}$ & $22 \frac{3}{4}$ & $21 \frac{3}{4}$ & $21 \frac{3}{4}$ & $21 \frac{1}{2}$ & $21 \frac{3}{4}$ & $21 \frac{1}{2}$ & $23 \frac{1}{4}$ & $22 \frac{5}{8}$ & 23 & 23 \\
\hline 1876 & $23 \frac{1}{4}$ & 23 & $22 \frac{7}{8}$ & $22 \frac{1}{2}$ & $22 \frac{1}{4}$ & 22 & $22 \frac{5}{8}$ & 22 & $22 \frac{1}{8}$ & 21 & 21 & $19 \frac{1}{4}$ \\
\hline 1877 & $19 \frac{1}{2}$ & 19 & $20 \frac{1}{2}$ & $19 \frac{1}{2}$ & $19 \frac{1}{4}$ & 19 & $19 \frac{1}{2}$ & $19 \frac{1}{4}$ & $19 \frac{1}{4}$ & 19 & $19 \frac{3}{8}$ & 19 \\
\hline 1878 & $17 \frac{5}{5}$ & $17_{4}^{1}$ & $17 \frac{1}{2}$ & $17 \frac{1}{8}$ & $17 \frac{1}{8}$ & $16 \frac{7}{8}$ & 17 & $16 \frac{7}{8}$ & $16 \frac{3}{4}$ & $16 \frac{1}{4}$ & $16 \frac{3}{8}$ & $16 \frac{1}{4}$ \\
\hline 1879 & 16 & $15 \frac{1}{2}$ & $15 \frac{1}{2}$ & $15 \frac{1}{2}$ & $15 \frac{3}{4}$ & $15 \frac{3}{4}$ & 16 & $15_{4}^{3}$ & $16 \frac{1}{4}$ & 16 & $16 \frac{1}{4}$ & $16 \frac{1}{8}$ \\
\hline 1880 & 25 & $21 \frac{3}{8}$ & $24 \frac{1}{2}$ & 24 & 24 & 223 & $22 \frac{1}{2}$ & 24 & 21 & 18 & $18 \frac{1}{2}$ & $17 \frac{7}{8}$ \\
\hline 1881 & $19 \frac{3}{8}$ & $19 \frac{3}{8}$ & $19 \frac{3}{8}$ & $19 \frac{1}{8}$ & $19 \frac{3}{8}$ & 19 & 19 & $18 \frac{3}{4}$ & $18 \frac{7}{8}$ & $18 \frac{1}{4}$ & $18 \frac{1}{4}$ & $16 \frac{3}{8}$ \\
\hline 1882 & $20 \frac{3}{8}$ & $20 \frac{1}{4}$ & 20 & 19 & $19 \frac{1}{4}$ & $18 \frac{7}{8}$ & $18 \frac{7}{8}$ & $17 \frac{7}{8}$ & $18 \frac{1}{4}$ & 18 & $18 \frac{1}{4}$ & 18 \\
\hline 1883. & $18 \frac{1}{8}$ & 18 & $17 \frac{\pi}{8}$ & $17 \frac{3}{4}$ & $17 \frac{5}{8}$ & $17 \frac{1}{8}$ & 16 & $15 \frac{3}{4}$ & 16 & $15 \frac{\pi}{8}$ & $15 \frac{7}{8}$ & 15 \\
\hline 1884 & 15. & $14 \frac{7}{8}$ & 15 & $14 \frac{7}{8}$ & 15 & $1+\frac{\pi}{8}$ & 15 & $14 \frac{1}{2}$ & $14 \frac{1}{4}$ & $14 \frac{1}{8}$ & $14 \frac{1}{a}$ & $1 t$ \\
\hline 1885 & $11 \frac{1}{2}$ & $10 \frac{3}{8}$ & $11 \frac{7}{8}$ & $10 \frac{4}{5}$ & $11 \frac{1}{8}$ & $10 \frac{2}{5}$ & $11 t$ & $10 \frac{1}{10}$ & $11 \frac{1}{2}$ & $9 \frac{4}{5}$ & $11 \frac{1}{2}$ & 11 \\
\hline 1886 & $11 \frac{5}{8}$ & $11 \frac{3}{8}$ & $11 \frac{5}{8}$ & $11 \frac{3}{8}$ & $11 \frac{1}{2}$ & $11 \frac{3}{8}$ & $11 \frac{1}{2}$ & $11 \frac{3}{8}$ & $11 \frac{1}{8}$ & 10 & $10 \frac{1}{8}$ & 10 \\
\hline 1887 & 12 & $11 \frac{1}{8}$ & $11 \frac{1}{8}$ & $10 \frac{1}{5}$ & $10 \frac{1}{2}$ & $10 \frac{3}{8}$ & 101 & 10 & 10 & $9 \frac{19}{2} \frac{9}{0}$ & $10 \frac{1}{4}$ & 10 \\
\hline 1888 & $17 \frac{4}{10}$ & $15 \frac{1}{2} 0_{0}^{7}$ & $16 \frac{6}{10}$ & 16 & $162^{\frac{7}{0}}$ & $15 \frac{19}{2} 0$ & $16 \frac{9}{10}$ & 16 & $16 \frac{3}{4}$ & $16_{\frac{1}{\mathbf{1}}}^{3}$ & $16 \frac{1}{2}$ & $16_{\frac{9}{20}}$ \\
\hline 1889 & $17 \frac{1}{2}$ & $16 \frac{1}{2}$ & $16^{3}$ & $16 \frac{1}{2}$ & $15 \frac{3}{4}$ & 15 & 16 & $15 \frac{1}{2}$ & $12 \frac{1}{8}$ & 12 & $12 \frac{13}{4} \frac{3}{0}$ & 12 \\
\hline 1890 & $14 \frac{1}{2}$ & $14^{\frac{1}{4}}$ & $14 \frac{1}{4}$ & $14 \frac{1}{4}$ & $14 \frac{1}{4}$ & 14 & $14 \frac{1}{2}$ & $14 \frac{1}{4}$ & $15_{4}^{\frac{1}{4}}$ & $14 \frac{5}{8}$ & $16 \frac{3}{4}$ & $15 \frac{1}{4}$ \\
\hline $1891 \ldots$ & 15 & $14 \frac{5}{8}$ & $14 \frac{7}{8}$ & $14+$ & $14 \frac{1}{4}$ & $13 \frac{5}{8}$ & $13 \frac{3}{4}$ & $13 \frac{1}{2}$ & $13_{4}^{3}$ & $12 \frac{3}{4}$ & 13 & $12 \frac{7}{8}$ \\
\hline 1892 & 11 & $10_{4}^{3}$ & $10 \frac{3}{4}$ & $10 \frac{1}{2}$ & 12 & $10 \frac{3}{4}$ & 12 & $11 \frac{3}{4}$ & 121 & 12 & $11 \frac{7}{8}$ & $11 \frac{1}{2}$ \\
\hline 1893. & $12 \frac{1}{2}$ & $12 \frac{1}{4}$ & 121 & 12 & 12 & $11 \frac{3}{4}$ & $11 \frac{1}{2}$ & $11_{4}^{1}$ & $11 \frac{1}{8}$ & 11 & 11 & $10 \frac{3}{4}$ \\
\hline 1894 & $10 \frac{1}{4}$ & 10 & 10 & $9 \frac{5}{8}$ & $9 \frac{5}{8}$ & $9 \frac{3}{8}$ & $9 \frac{1}{2}$ & $9 \frac{3}{8}$ & $9 \frac{3}{8}$ & 91 & $9 \frac{1}{8}$ & 9 \\
\hline 1895 & 10 & $9 \frac{7}{8}$ & $9 \frac{7}{8}$ & $9 \frac{1}{2}$ & $9 \frac{1}{2}$ & $9 \frac{1}{4}$ & $9 \frac{3}{4}$ & $9 \frac{3}{8}$ & $10 \frac{5}{8}$ & $9 \frac{3}{1}$ & $10 \frac{3}{4}$ & $10 \frac{1}{2}$ \\
\hline 1896. & $10 \frac{1}{8}$ & $9 \frac{3}{4}$ & $11 \frac{1}{4}$ & 10 & $11 \frac{1}{4}$ & $10 \frac{\pi}{8}$ & 11 & $10 \frac{3}{4}$ & $11 \frac{1}{2}$ & $10 \frac{7}{8}$ & $11 \frac{3}{4}$ & $11 \frac{1}{2}$ \\
\hline $1897 .$. & 12 & $11 \frac{1}{2}$ & 12 & $11 \frac{7}{8}$ & $11 \frac{7}{8}$ & $11 \frac{1}{2}$ & $11 \frac{1}{2}$ & 11 & $11 \frac{1}{8}$ & $10 \frac{3}{4}$ & $11 \frac{1}{8}$ & $10 \frac{\pi}{8}$ \\
\hline 1898. & 11 & $10 \frac{9}{10}$ & $11 \frac{3}{4}$ & 11 & 12 & $11 \frac{\bar{T}}{\mathrm{~s}}$ & $12 \frac{1}{8}$ & $11 \frac{7}{8}$ & $12 \frac{1}{8}$ & 12 & $11 \frac{7}{8}$ & $11^{\frac{3}{4}}$ \\
\hline $1899 \ldots$ & 17 & $13 \frac{1}{4}$ & $1 \mathrm{~S}$ & 17 & $1 S$ & 17 & $19 \frac{1}{2}$ & 18 & 191 & $18 \frac{1}{2}$ & $18 \frac{1}{2}$ & 18 \\
\hline
\end{tabular}


COPPER.

Higliest and iowest prices of Lake Superior ingot copper, by months, etc.-Continued.

[Cents per pound.]

\begin{tabular}{|c|c|c|c|c|c|c|c|c|c|c|c|c|}
\hline \multirow[b]{2}{*}{ Year. } & \multicolumn{2}{|c|}{ July: } & \multicolumn{2}{|c|}{ August. } & \multicolumn{2}{|c|}{ September. } & \multicolumn{2}{|c|}{ October. } & \multicolumn{2}{|c|}{ November. } & \multicolumn{2}{|c|}{ December. } \\
\hline & 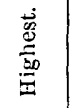 & 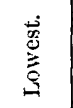 & 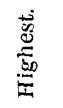 & 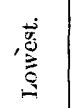 & 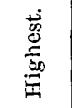 & 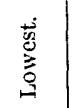 & 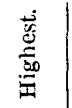 & $\begin{array}{l}\stackrel{+}{\dot{g}} \\
\stackrel{\vec{B}}{\mathrm{H}}\end{array}$ & 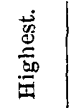 & 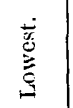 & 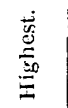 & 蒡 \\
\hline $1860 \ldots$ & $21 \frac{3}{4}$ & $21 \frac{1}{2}$ & $21 \frac{1}{2}$ & $21 \frac{1}{2}$ & 22 & $21 \frac{1}{4}$ & 22 & $21 \frac{1}{2}$ & $21 \frac{1}{2}$ & $20 \hat{4}$ & 201 & $19 \frac{3}{4}$ \\
\hline $1861 \ldots$ & 18 & $17 \frac{1}{2}$ & 19 & $17 \frac{3}{4}$ & 204 & 19 & $20 \frac{1}{4}$ & 20 & $22 \frac{1}{2}$ & $20 \frac{1}{4}$ & 27 & $22 \frac{1}{2}$ \\
\hline $1862 \ldots$ & $24 \frac{1}{2}$ & $22 \frac{1}{2}$ & $24 \frac{1}{2}$ & 24 & 27 & $24 \frac{1}{4}$ & $32 \frac{7}{8}$ & 27 & $32 \frac{7}{8}$ & $30 \frac{1}{2}$ & $31 \frac{1}{2}$ & $30 \frac{1}{2}$ \\
\hline 1863. & 32. & 29 & 31 & 29 & $32 \frac{1}{4}$ & 31 & $34 \frac{1}{4}$ & $32 \frac{1}{4}$ & $38 \frac{1}{2}$ & $34 \frac{1}{2}$ & $3 S_{\frac{3}{4}}^{3}$ & $38 \frac{1}{2}$ \\
\hline $1864 \ldots$ & 55 & 49 & $52 \frac{1}{2}$ & 50 & $52 \frac{1}{2}$ & $47 \frac{1}{2}$ & 48 & 47 & 49 & 47 & 50 & $48 \frac{1}{2}$ \\
\hline $1865 \ldots$ & $30 \frac{2}{4}$ & 28 & 32 & $30 \frac{1}{2}$ & $32 \frac{3}{4}$ & $31_{2}^{1}$ & 33 & $32 \frac{1}{2}$ & $45 \frac{1}{2}$ & 33 & $45 \frac{1}{2}$ & $39 \frac{1}{4}$ \\
\hline 1866. & $33 \frac{1}{2}$ & 31 & 31 & 30 & $31 \frac{1}{2}$ & $30 \frac{3}{4}$ & 31 & $30 \frac{3}{4}$ & $30_{4}^{3}$ & $26 \frac{1}{2}$ & 29 & $26 \frac{1}{2}$ \\
\hline $1867 \ldots$ & 26 & 24 & $26 \frac{1}{4}$ & $25 \frac{3}{4}$ & $27 \frac{1}{4}$ & $26 \frac{1}{4}$ & $26 \frac{3}{4}$ & $22 \frac{3}{4}$ & 23 & $22 \frac{3}{4}$ & 23 & $21 \frac{1}{2}$ \\
\hline 1868 & $24 \frac{1}{2}$ & $23 \frac{1}{8}$ & $24 \frac{1}{4}$ & $\dot{2}_{4}$ & 24 & $23_{4}^{3}$ & 24 & 23 & 24 & $22 \frac{1}{2}$ & $24 \frac{1}{2}$ & $23 \frac{3}{4}$ \\
\hline $1869 \ldots$ & $22_{4}^{1}$ & $21 \frac{7}{8}$ & $23 \frac{1}{8}$ & $21 \frac{7}{8}$ & 23 & 22 & $22 \frac{3}{4}$ & 22 & $22 \frac{1}{2}$ & 22 & 22 & $21 \frac{1}{2}$ \\
\hline $1870 \ldots$ & $20 \frac{1}{2}$ & $20 \frac{3}{8}$ & $21 \frac{3}{8}$ & $20 \frac{1}{8}$ & $21 \frac{1}{2}$ & $20 \frac{3}{4}$ & $21_{4}^{3}$ & $21 \frac{1}{2}$ & $23 \frac{3}{8}$ & $21 \frac{3}{4}$ & 225 & $22 \frac{2}{4}$ \\
\hline $1871 \ldots$ & $22 \frac{1}{4}$ & $21 \frac{5}{8}$ & 23 & $22 \frac{3}{8}$ & $23 \frac{7}{8}$ & $22 \frac{7}{8}$ & $23 \frac{7}{8}$ & $23 \frac{1}{4}$ & $24 \frac{1}{4}$ & $23 \frac{1}{4}$ & 27 & $24 \frac{1}{2}$ \\
\hline $1872 \ldots$ & 34 & 33 & 35 & $32 \frac{1}{2}$ & $35 \frac{1}{4}$ & 33 & $34_{4}^{3}$ & $31 \frac{1}{4}$ & $32 \frac{1}{4}$ & $30 \frac{3}{4}$ & $32 \frac{1}{2}$ & $30 \frac{1}{2}$ \\
\hline $1873 \ldots$ & 29 & $26 \frac{5}{5}$ & $27 \frac{1}{2}$ & 27 & 27 & $25 \frac{1}{2}$ & $25 \frac{1}{2}$ & 24 & 24 & 21 & 25 & 23 \\
\hline $1874 \ldots$ & $24 \frac{1}{4}$ & 20 & 21 & 19 & $21_{4}^{\lambda}$ & 21 & $22 \frac{1}{4}$ & $21 \frac{1}{4}$ & $23 \frac{3}{4}$ & $22 \frac{1}{4}$ & $23 \frac{1}{4}$ & $23 \frac{1}{4}$ \\
\hline $1875 \ldots$ & 23 & $22 \frac{5}{8}$ & $23 \frac{3}{8}$ & 23 & $23 \frac{7}{8}$ & $23 \frac{1}{8}$ & $23 \frac{1}{4}$ & 23 & $23 \frac{1}{4}$ & 23 & 233 & $23 \frac{3}{8}$ \\
\hline 1876. & 20 & $19 \frac{1}{2}$ & $19 \frac{1}{2}$ & $18 \frac{3}{4}$ & 21 & $18 \frac{3}{4}$ & $21 \frac{1}{4}$ & $20 \frac{1}{2}$ & $20 \frac{1}{2}$ & 20 & 20 & 195 \\
\hline $1877 \ldots$ & $19 \frac{1}{4}$ & 19 & 19 & $17 \frac{7}{8}$ & $18_{\frac{1}{2}}^{1}$ & $17^{\frac{7}{8}}$ & 18 & $17 \frac{3}{4}$ & $17_{4}^{3}$ & $17 \frac{5}{8}$ & $17 \frac{3}{4}$ & $17 \frac{1}{2}$ \\
\hline 1878 & $16 \frac{1}{4}$ & 16 & 16 & 16 & $16 \frac{1}{4}$ & 16 & 16 & $15 \frac{1}{2}$ & $15 \frac{7}{8}$ & $15^{\frac{1}{2}}$ & 16 & $15^{\frac{7}{8}}$ \\
\hline 1879 & $16 \frac{1}{8}$ & 16 & $16 \frac{3}{8}$ & 16 & 17 & $16_{4}^{1}$ & $21 \frac{1}{2}$ & 18 & $21 \frac{3}{4}$ & 21 & $21 \frac{1}{2}$ & 21 \\
\hline 1880 & $18 \frac{7}{8}$ & $18 \frac{1}{2}$ & $19 \frac{1}{8}$ & 19 & $18 \frac{7}{8}$ & $18 \frac{3}{4}$ & $18 \frac{7}{8}$ & $18_{4}^{3}$ & $18 \frac{\pi}{8}$ & $18_{4}^{3}$ & $19 \frac{1}{8}$ & $18 \frac{\pi}{8}$ \\
\hline $1881 \ldots$ & $16 \frac{1}{2}$ & 16 & 165 & $16 \frac{3}{8}$ & $18 \frac{1}{8}$ & $16 \frac{3}{4}$ & $18_{8}^{3}$ & 18 & 19 & $18 \frac{1}{8}$ & $20 \frac{3}{8}$ & $19 \frac{1}{4}$ \\
\hline $1882 \ldots$ & $18 \frac{1}{4}$ & $18 \frac{1}{8}$ & $18 \frac{1}{4}$ & $18 \frac{1}{8}$ & $18 \frac{1}{4}$ & .18 & $18 \frac{1}{4}$ & 18 & $18 \frac{1}{8}$ & 18 & 18 & $17 \frac{7}{8}$ \\
\hline $1883 \ldots$ & $15 \frac{1}{8}$ & 15 & 15 & 15 & $15 \frac{1}{4}$ & $15 \frac{1}{8}$ & $15 \frac{1}{4}$ & $15 \frac{1}{8}$ & 15 & $14 \frac{7}{8}$ & 15 & $14 \frac{7}{6}$ \\
\hline 1884 & $14 \frac{1}{8}$ & $13 \frac{7}{8}$ & 14 & $13 \frac{7}{8}$ & $13 \frac{1}{8}$ & 13 & 138 & $12 \frac{7}{8}$ & 13 & $12 \frac{1}{2}$ & 121 & 11 \\
\hline $1885 \ldots$ & $11 \frac{1}{4}$ & 107 & $11 \frac{1}{4}$ & 11 & $11 \frac{1}{2}$ & $10 \frac{1}{2} \frac{9}{0}$ & $11 \frac{1}{3}$ & $10 \frac{4}{5}$ & $11 \frac{1}{8}$ & $10 \frac{4}{5}$ & $11 \frac{1}{2}$ & $11_{T^{\prime} \bar{O}}^{x}$ \\
\hline $1886 \ldots$ & $10 \frac{1}{8}$ & 10 & $10 \frac{1}{4}$ & 10 & $11 \frac{1}{8}$. & $10 \frac{1}{4}$ & $11 \frac{3}{4}$ & $11 \frac{1}{8}$ & 12 & 113 & 121 & $11 \frac{7}{8}$ \\
\hline $1887 \ldots$ & $10 \frac{3}{4}$ & $10_{8}^{1}$ & $10 \frac{3}{4}$ & $10 \frac{3}{5}$ & 11 & $10^{5}$ & $12 \frac{3}{2} \overline{0}$ & $10_{\overline{1}}^{\frac{3}{0}}$ & $14 \frac{19}{2}$ & $11 \frac{1}{2} \frac{1}{0}$ & $17 \frac{3}{4}$ & $14 \frac{1}{2} \frac{9}{6}$ \\
\hline $1888 \ldots$ & $16_{\overline{1} \delta}^{9}$ & $16_{2}^{13}$ & 17 & $16 \frac{3}{5}$ & $17 \frac{7}{10}$ & $16_{\mathrm{I}}^{9}$ & $17 \frac{3}{5}$ & $17 \overline{2}^{7} \overline{0}$ & $17 \frac{3}{5}$ & $17 \frac{1}{4}$ & $17 \frac{9}{20}$ & $17_{10}^{\frac{1}{10}}$ \\
\hline 1889. & 12 & 12 & 12 & 12 & 12 & 11 & 11 & 11 & $13 \frac{1}{4}$ & $11 \frac{1}{4}$ & $14 \frac{1}{2}$ & 14 \\
\hline 1890 & $17 \frac{1}{4}$ & $16 \frac{1}{2}$ & $17 \frac{1}{4}$ & 17 & 17 & 17 & $16 \frac{7}{8}$ & $16 \frac{3}{4}$ & $16 \frac{3}{4}$ & $16 \frac{3}{4}$ & $\hat{i} 6$ & 15 \\
\hline 1891 & $12 \frac{7}{8}$ & $12 \frac{1}{2}$ & $12 \frac{3}{8}$ & 12 & $12 \frac{1}{2}$ & $12 \frac{1}{8}$ & $12 \frac{3}{8}$ & $11 \frac{3}{8}$ & $11 \frac{1}{2}$ & 11 & $11 \frac{1}{8}$ & $10 \frac{1}{4}$ \\
\hline 1892 & $11 \frac{3}{4}$ & $11 \frac{1}{4}$ & $11 \frac{3}{4}$ & $11_{\frac{6}{10}}^{\frac{6}{0}}$ & $11_{\frac{1}{1}}^{6}$ & $11_{\frac{1}{10}}^{1}$ & $11 \frac{3}{4}$ & $11_{I^{\frac{1}{0}}}^{1}$ & 12 & $11 \frac{3}{4}$ & $12 \frac{3}{8}$ & $12 \frac{1}{4}$ \\
\hline 1893. & $10 \frac{1}{2}$ & $10 \frac{x}{4}$ & $10 \frac{1}{8}$ & $9 \frac{3}{5}$ & $9 \frac{7}{8}$ & $9 \frac{3}{4}$ & $9 \frac{3}{4}$ & $9 \frac{3}{4}$ & $10 \frac{1}{4}$ & $9 \frac{3}{4}$ & $10 \frac{1}{2}$ & $10 \frac{3}{8}$ \\
\hline $1894 \ldots$ & $9 \frac{1}{8}$ & 9 & $9 \frac{1}{8}$ & 9 & $9 \frac{7}{8}$ & 91 & 93 & $9 \frac{1}{2}$ & $9 \frac{1}{2}$ & 93 & 10 & $9 \frac{1}{2}$ \\
\hline $1895 \ldots$ & $11_{4}^{3}$ & $10 \frac{1}{2}$ & $12 \frac{1}{4}$ & $11_{4}^{\frac{3}{4}}$ & $12 \frac{1}{4}$ & 12 & 12 & $11 \frac{3}{4}$ & 115 & 11 & 11 & 10 \\
\hline $1896 \ldots$ & $11_{4}^{3}$ & 11 & $11 \frac{1}{8}$ & $10 \frac{7}{8}$ & $10 \frac{7}{8}$ & $10 \frac{3}{8}$ & $10_{8}^{7}$ & $10 \frac{1}{2}$ & $11 \frac{1}{2}$ & $10 \frac{7}{8}$ & $11 \frac{1}{2}$ & $11 \frac{1}{4}$ \\
\hline $1897 \ldots$ & $11_{8}^{1}$ & 11 & $11 \frac{1}{4}$ & 11 & 118 & $11_{4}^{1}$ & $11_{4}^{\frac{1}{4}}$ & 11 & 11 & $10_{4}^{3}$ & 11 & $10 \frac{7}{8}$ \\
\hline $1898 \ldots$ & $11 \frac{3}{4}$ & $11 \frac{1}{2}$ & $12 \frac{1}{8}$ & 113 & $12 \frac{1}{4}$ & $12 \frac{1}{8}$ & $12 \frac{1}{2}$ & $12_{4}^{1}$ & $12 \frac{3}{4}$ & $12 \frac{1}{2}$ & $12 \frac{7}{8}$ & 125 \\
\hline $1899 \ldots$ & $18 \frac{1}{2}$ & $18_{4}^{1}$ & $18 \frac{1}{2}$ & $18 \frac{1}{4}$ & $18_{2}^{1}$ & $18 \frac{1}{4}$ & $18 \frac{1}{2}$ & 17 & $17 \frac{1}{4}$ & 17 & 17 & $16 \frac{1}{2}$ \\
\hline
\end{tabular}


The following table shows the fluctuations in prices in the English market:

Average values of copper in England.

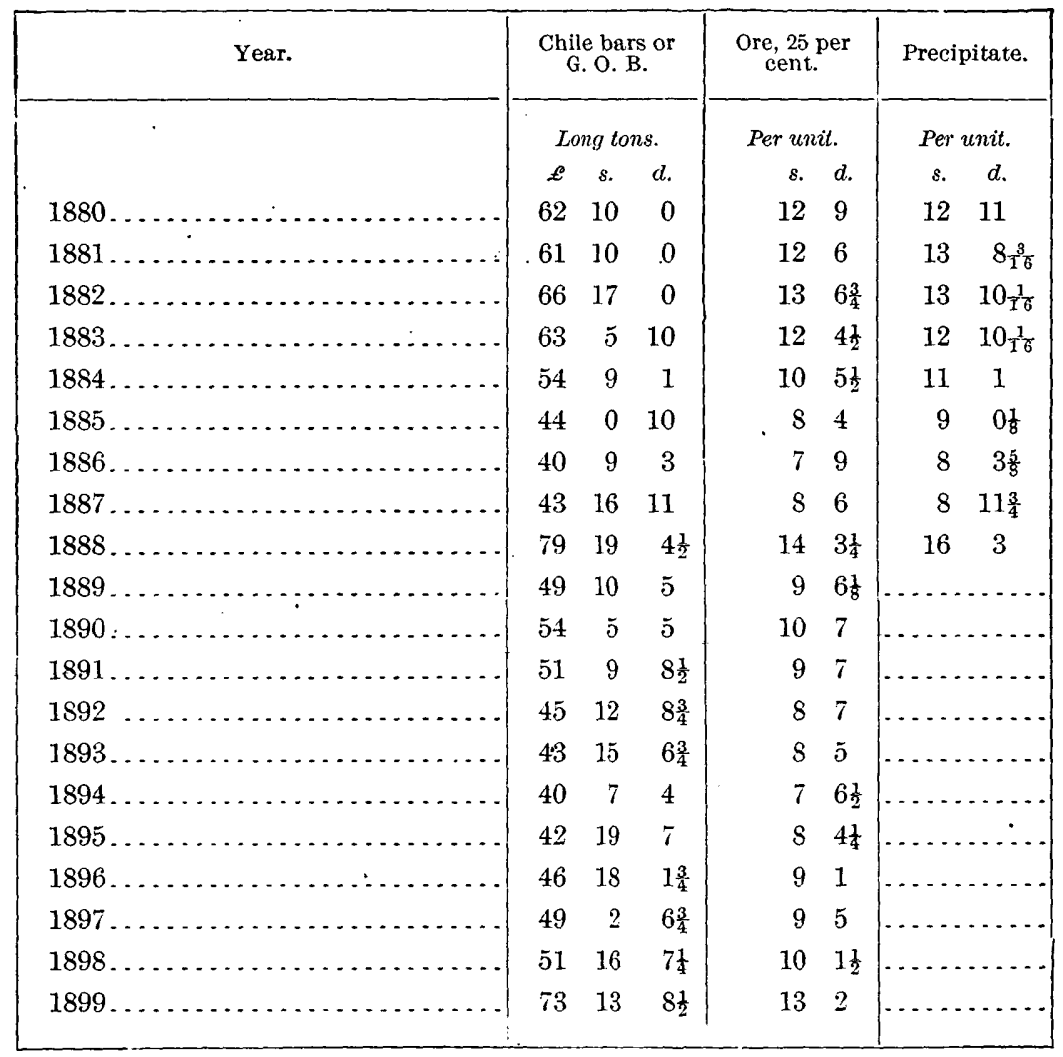


In detail, the fluctuations, monthly, of good merchant copper in the English market were as follows in 1895, 1896, 1897, 1898, and 1899:

Fluctuations in good merchart copper in England in 1895, 1896, 189\%, 1898, and 1899.

[Per long ton.]

\begin{tabular}{|c|c|c|c|c|c|c|c|c|c|c|c|c|c|c|c|}
\hline \multirow[t]{2}{*}{ Month. } & \multicolumn{3}{|c|}{1895.} & \multicolumn{3}{|c|}{1896.} & \multicolumn{3}{|c|}{1597.} & \multicolumn{3}{|c|}{1898.} & \multicolumn{3}{|c|}{1899.} \\
\hline & $\mathfrak{E}$ & $s$. & $d$. & $\mathscr{L}$ & s. & $d$. & $\mathscr{E}$ & $\varepsilon$. & d. & $\mathscr{E}$ & $s$. & $d$. & $£$ & 8. & d. \\
\hline January & 40 & 13 & $9 \frac{s}{4}$ & 41 & 13 & $8 \frac{1}{4}$ & 50 & 10 & $8 \frac{1}{4}$ & 48 & 19 & 2 & 62 & 18 & $1 \frac{1}{2}$ \\
\hline February & 39 & 14 & $3 \frac{3}{4}$ & 44 & 16 . & 114 & 51 & 6 & 6 & 49 & 12 & $8 \frac{1}{4}$ & 72 & 16 & 0 \\
\hline March. & 39 & 1 & 9 & 45 & $S$ & $0 \frac{3}{4}$ & 50 & 4 & $0 \frac{x}{4}$ & 50 & 13 & $2 \frac{1}{2}$ & 69 & 1 & 0 䖽 \\
\hline April.. & 40 & 3 & $6 \frac{3}{4}$ & 45 & 3 & $2 \frac{1}{4}$ & 48 & 16 & 9 & 51 & 14 & $2 \frac{1}{2}$ & 74 & 10 & $0 \frac{3}{4}$ \\
\hline May . & 43 & 0 & 0 & 46 & 6 & 6 & 48 & 10 & $11 \frac{1}{2}$ & 51 & 9 & $9 \frac{3}{4}$ & 77 & 5 & 11 \\
\hline June .. & 42 & 15 & $6 \frac{1}{2}$ & 48 & 18 & 0 & 49 & 1 & $1 \frac{1}{2}$ & 50 & 8 & 0 & 76 & 2 & $0 \frac{1}{2}$ \\
\hline July & 44 & 0 & 2 & 49 & 3 & $7 \frac{3}{4}$ & 48 & 1 & $0 \frac{1}{4}$ & 50 & 3 & 1 & 76 & 19 & $3 \frac{1}{2}$ \\
\hline August & 46 & 13 & 23 & 47 & 16 & $9 \frac{3}{4}$ & 48 & 12 & $10 \frac{1}{4}$ & 51 & 10 & $7 \frac{1}{2}$ & 76 & 4 & $7 \frac{1}{4}$ \\
\hline September & 46 & 15 & $7 \frac{1}{2}$ & 47 & 18 & $7 \frac{1}{2}$ & 49 & 8 & 5 & 52 & 2 & $8 \frac{3}{4}$ & 76 & 15 & 7 \\
\hline October & 46 & 4 & 10 & 47 & 11 & 7 & 48 & 10 & 3 & 53 & 8 & 2 & 75 & 3 & 101 \\
\hline November & 43 & 16 & 3 & 49 & 3 & 11 & 48 & 0 & $11 \frac{1}{2}$ & 55 & 18 & $8 \frac{1}{4}$ & 74 & 8 & $5 \frac{1}{2}$ \\
\hline December & 42 & 15 & 11 & 48 & 16 & $9 \frac{3}{4}$ & 48 & 7 & $0 \frac{1}{4}$ & 55 & 18 & $11 \frac{1}{4}$ & 71 & 19 & 8 \\
\hline
\end{tabular}

THE COPPER MARKET IN 1899.

The year opened with Lake copper at 13.25 cents, but under an enormous business the market rose rapidly during January until 16 cents was reached at its close. The movement continued in February until it culminated in the middle of the month with Lake copper selling at 18 cents. During this time an unprecedented speculation was progressing in copper-mining stocks on the Boston Stock Exchange, which was not without its influence upon the market for the metal. The activity of the market induced caution on the part of consumers, and realizing sales led to a reaction, which in March carried the price down to 17 cents for Lake copper. A recovery took place, however, and the Calumet and Hecla Company sold 5,000 tons to consumers at 18 cents. April brought a further rise, the market reaching $19 \frac{1}{2}$ cents, the highest price attained since the days of the famous Secretan syndicate in 1888. The market was fairly well maintained during the summer months, at the range of 18 to 18.50 cents, until the closing days of October, when a new basis was established by the sale of about 8,000 tons by the leading Lake company at 17 cents. Later in the year a fourth sale of 10,000 tons was made, for four months' delivery, the seller protecting the consumer against a decline. 


\section{THE WORLD'S PRODUCTION.}

Messrs. Henry R. Merton \& Co., of London, have compiled the following statement of the world's production, the figures being modified by this office where official statistics are available:

The copper production of the uorld, 1889 to 1899, inclusive.

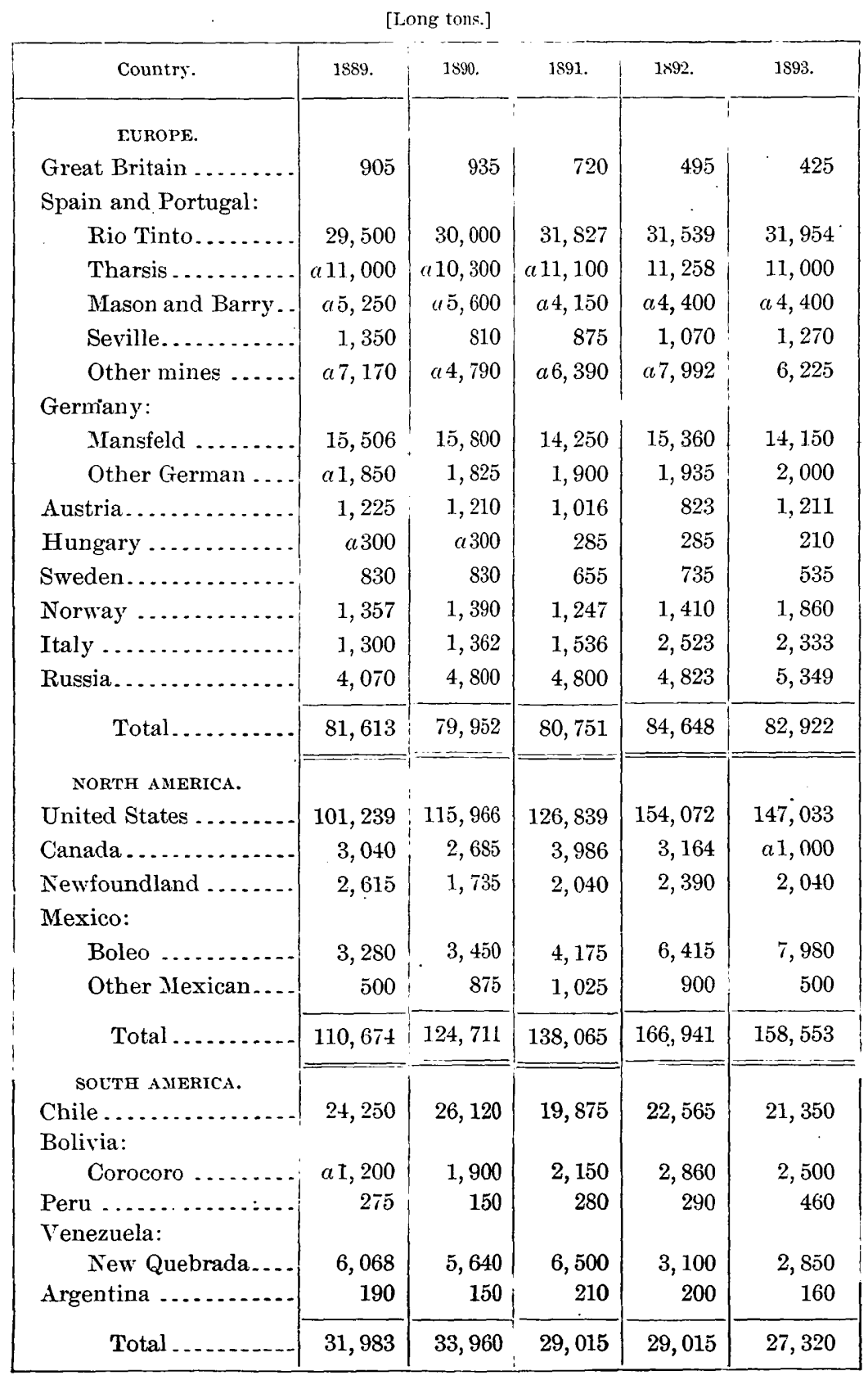

$a$ Estimated. 
COPPER.

The copper production of the world, 1889 to 1899, inclusive-Continued.

[Long tons.]

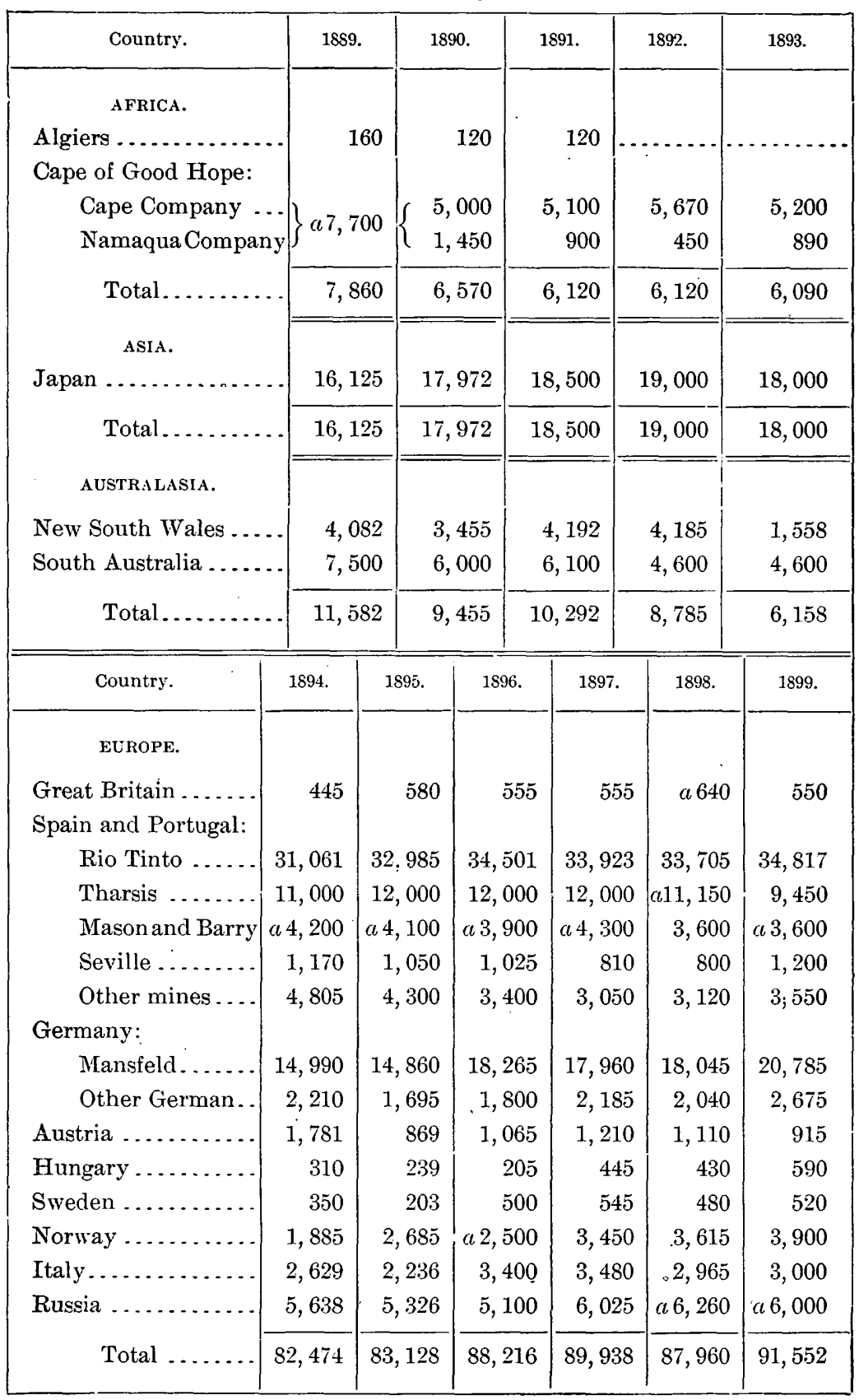

a Estimated. 
The copper production of the world, 1889 to 1899, inclusive-Continued.

[Long tons.]

\begin{tabular}{|c|c|c|c|c|c|c|}
\hline Country. & 1894. & 1895. & 1896. & 1897. & 1898. & 1899. \\
\hline $\begin{array}{l}\text { NORTH AMERICA. } \\
\text { United States...... }\end{array}$ & 158,120 & 169,917 & 205,384 & 220,571 & 235,050 & 253,870 \\
\hline Canada......... & 1,204 & 3,923 & 4,190 & 5,938 & 8,040 & 6,731 \\
\hline Newfoundland ........ & 1,900 & 1,800 & 1,800 & 1,800 & 2,100 & 2,700 \\
\hline Mexico: & & & & & & \\
\hline Boleo .......... & 10,370 & 10,450 & 9,940 & 10,170 & 9,435 & 10,335 \\
\hline Other Mexican.. & 1,400 & 1,170 & 1,210 & $a 4,200$ & $a 7,000$ & $a 9,000$ \\
\hline Total... & 172,994 & 187,260 & 222,524 & 242,679 & 261,625 & 282,636 \\
\hline SOUTH AMERICA. & & & & & & \\
\hline Chile............. & 21,340 & 22,075 & 23,500 & 21,900 & 24,850 & 25,000 \\
\hline Bolivia: & & & & & & \\
\hline Corocoro ....... & 2,300 & 2,250 & 2,000 & 2,200 & 2,050 & 2,500 \\
\hline Peru ......... & 440 & 450 & 740 & 1,000 & 3,040 & 5,165 \\
\hline Venezuela: & & & & & & \\
\hline New Quebrada... & 2,500 & & & & & \\
\hline Argentina ....... & 230 & 150 & 100 & 200 & 125 & 65 \\
\hline Total.... & 26,810 & 24,925 & 26,340 & 25,300 & 30,065 & 32,730 \\
\hline Algiers & & 35 & & & 50 & \\
\hline Cape of Good Hope: & & & & & & \\
\hline Cape Company.... & 5,000 & 5,350 & 5,470 & 5,290 & 4,660 & 4,140 \\
\hline Namaqua Company & 1,500 & 1,730 & 1,980 & 2,150 & 2,400 & 2,350 \\
\hline Total... & 6,500 & 7,115 & 7,450 & 7,440 & 7,110 & 6,490 \\
\hline ASIA. & & & & & & \\
\hline Japan .. & 20,050 & 18,430 & 21,000 & 23,000 & 25,175 & 27,560 \\
\hline AUSTRALASIA. & & & & & & \\
\hline New South Wales. & 1,847 & 3,322 & 4,467 & 6,922 & 5,743 & $a 5,900$ \\
\hline South Australia .. & 4,944 & 5,251 & 4,877 & 4,705 & $a 4,800$ & $a 5,000$ \\
\hline Tasmania. & $\cdots$ & 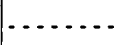 & 1,928 & 4,956 & $a 6,500$ & $a 7,000$ \\
\hline Total .......... & 6,791 & 8,573 & 11,272 & 16,583 & 17,043 & 17,900 \\
\hline
\end{tabular}


COPPER.

The copper production of the world, 1890 to 1899 , inclusive.

RECAPITULATION.

[Long tons.]

\begin{tabular}{|c|c|c|c|c|c|}
\hline Country. & 1890. & 1891. & 1892. & 1893. & 1894. \\
\hline Europe .............. & 79,952 & 80,751 & 84,648 & 82,922 & 82,474 \\
\hline North America.... & 124,711 & 138,065 & 166,941 & 158,553 & 172,994 \\
\hline South America........ & 33,960 & 29,015 & 29,015 & 27,320 & 26,810 \\
\hline Africa . & 6,570 & 6,120 & 6,120 & 6,090 & 6,500 \\
\hline Asia. & 17,972 & 18,500 & 19,000 & 18,000 & 20,050 \\
\hline Australasia . & 9,455 & 10,292 & 8,785 & 6,158 & 6,791 \\
\hline Total. & 272,620 & 282,743 & 314,509 & 299,043 & 315,619 \\
\hline Country. & 1895. & 1896. & 1897. & 1898. & 1899. \\
\hline Europe........ & 83,128 & 88,216 & 89,938 & 87,960 & 91,105 \\
\hline North America. & 187,260 & 222,524 & 242,679 & 261,625 & 282,636 \\
\hline South America. & 24,925 & 26,340 & 25,300 & 30,065 & 32,730 \\
\hline Africa & 7,115 & 7,450 & 7,440 & 7,110 & 6,490 \\
\hline Asia. & 18,430 & 21,000 & 23,000 & 25,175 & 27,560 \\
\hline Australasia & 8,573 & 11,272 & 16,583 & 17,043 & 17,900 \\
\hline Total. & 329,431 & 376,802 & 404,940 & 428,978 & 458,421 \\
\hline
\end{tabular}




\section{THE ENGLISH COPPER TRADE.}

Since England is one of the leading copper markets of the world, the following tables, showing the import and export movement, are of great interest:

British imports and exports of copper.

[Long tons.]

\begin{tabular}{|c|c|c|c|c|c|}
\hline \multirow[b]{2}{*}{ Year. } & \multicolumn{2}{|c|}{ Imports of- } & \multirow[b]{2}{*}{$\begin{array}{c}\text { Total } \\
\text { imports. }\end{array}$} & \multirow[b]{2}{*}{ Exports. } & \multirow{2}{*}{$\begin{array}{l}\text { Apparent } \\
\text { English } \\
\text { consump- } \\
\text { tion. }\end{array}$} \\
\hline & $\begin{array}{l}\text { Bars, cakes, } \\
\text { and ingots. }\end{array}$ & $\begin{array}{l}\text { Copper in } \\
\text { ores and } \\
\text { furnace } \\
\text { products. }\end{array}$ & & & \\
\hline 1860 & 13,142 & 13,715 & 26,857 & 26,117 & \\
\hline $1865 \ldots$ & 23,137 & 23,922 & 47,059 & 41,398 & \\
\hline $1870 \ldots$ & 30,724 & 27,025 & 57,749 & 53,006 & \\
\hline $1871 \ldots$ & 33,228 & 23,671 & 56,899 & 56,633 & \\
\hline $1872 \ldots$ & 49,000 & 21,702 & 70,702 & $\tilde{5} 3,195$ & \\
\hline 1873. & 35,840 & 26,756 & 62,596 & 55,716 & \\
\hline $1874 \ldots$ & 39,906 & 27,894 & 67,800 & 59,742 & \\
\hline 1875. & 41,931 & 29,483 & 71,414 & 51,870 & \\
\hline 1876. & 39,145 & 36,191 & 75,336 & 52,468 & \\
\hline $1877 \ldots$ & 39,743 & 53,582 & 93,325 & 54,088 & \\
\hline 1878. & 39,360 & 48,212 & $8 \overline{7}, 572$ & 55,001 & \\
\hline 1879. & 46,670 & 50,421 & 97,091 & 62,412 & 30,774 \\
\hline $1880 \ldots$ & 36,509 & 56,225 & 92,734 & 59,482 & 32,879 \\
\hline $1881 \ldots$ & 32,170 & $5+, 057$ & 86,227 & 61,689 & 31,607 \\
\hline 1882. & 35,509 & 58,366 & 93,875 & 55,683 & 42,877 \\
\hline 1883. & 35,653 & 63,493 & $99,1+6$ & 59,350 & 40,469 \\
\hline 1884 & 39,767 & 69,623 & 109,390 & 64,691 & 51,263 \\
\hline 1885. & 41,933 & 81,616 & $123,5+9$ & 62,080 & 54,323 \\
\hline $1886 \ldots$ & 42,969 & 65,046 & 108,015 & 60,511 & 41,158 \\
\hline $188 \bar{t} \ldots$ & 29,198 & 73,891 & 103,089 & 69,453 & 53,096 \\
\hline 1888. & 44,063 & 90,867 & 135,470 & $a 72,066$ & 42,562 \\
\hline 1889. & $b 38,576$ & 101,407 & 139,983 & 75,627 & 65,759 \\
\hline $1890 \ldots$ & $c 49,461$ & 91,788 & 141,249 & 89,747 & 66,170 \\
\hline $1891 \ldots$ & 44,213 & 94,403 & 138,616 & 76,056 & 59,223 \\
\hline 189.2. & $d 35,015$ & 99,356 & 134,371 & 82,542 & $e 48,367$ \\
\hline $1893 \ldots \ldots$ & 41,829 & 88,003 & 129,832 & 70,986 & 66,817 \\
\hline $1894 \ldots \ldots$ & 56,157 & 68,851 & $125,00 s$ & 54,689 & $f 50,330$ \\
\hline $1895 \ldots . .$. & 42,135 & 77,806 & 119,941 & 65,990 & $f 50,692$ \\
\hline $1896 \ldots \ldots$ & 60,458 & 75,398 & 135,856 & 59,334 & $f 76,036$ \\
\hline 1897. & 60,428 & $76,12 i$ & 136, 555 & $56, \overline{5}+2$ & $f 69,787$ \\
\hline $1898 \ldots$ & $6 \overline{7}, 97 \mathrm{~s}$ & 71,726 & $139,70 \pm$ & 63,370 & $f 69,284$ \\
\hline $1899 \ldots \ldots \ldots \ldots$ & 58,880 & $\$ 2,730$ & $1+1,610$ & 75,271 & $f 60,877$ \\
\hline
\end{tabular}

$a$ Including 22.557 tons of Chile bars transferred to France.

$b$ Including 1,166 tons of Chile bars transferred from France to England.

$c$ Including 3,501 tons of Chile bars transierred from France to England.

$d$ Including 3,585 tons of Chile bars transferred from France to England.

$e$ Add 4,001 tons for comparison with former years, the difference arising from the new method of making up stock.

$f$ Deducting copper contents of sulphate exported (13.07s tons in 1898 and 10,045 tons in 1899 ). 
The following figures from the board of trade returns, supplemented by Messrs. James Lewis \& Son, of Liverpool, for the last ten years show in detail the form in which the copper is brought into Great Britain and in what form it is exported:

Imports of copper into Great Britain from 1890 to 1899, inclusive.

[Long tons.]

\begin{tabular}{|r|r|r|r|r|c|}
\hline Character. & 1890. & 1891. & 1892. & 1893. & 1894. \\
\hline Pure in pyrites....... & 16,422 & 15,406 & 15,110 & 15,320 & 15,401 \\
Pure in precipitate .... & 25,562 & 29,326 & 28,444 & 24,988 & 24,878 \\
Pure in ore .......... & 18,000 & 14,172 & 13,585 & 11,701 & 12,804 \\
Pure in matte........ & 31,803 & 35,499 & 42,217 & 35,994 & 15,767 \\
Bars, cakes, etc....... & 49,461 & 44,213 & 35,015 & 41,829 & 56,158 \\
Total......... & 141,248 & 138,616 & 134,371 & 129,832 & 125,008 \\
\hline Character. & 1895. & 1896. & 1897. & 1898. & 1899. \\
\hline Pure in pyrites....... & 14,561 & 14,726 & 15,576 & 16,626 & 17,529 \\
Pure in precipitate .... & 26,508 & 23,160 & 25,932 & 21,558 & 24,387 \\
Pure in ore ........... & 15,240 & 12,499 & 11,980 & 14,576 & 19,514 \\
Pure in matte........ & $21,497$. & 25,013 & 22,639 & 18,966 & 21,300 \\
Bars, cakes, etc........ & 42,135 & 60,458 & 60,428 & 67,978 & 58,880 \\
\hline Total .......... & 119,941 & 135,856 & 136,555 & 139,704 & 141,610 \\
\hline
\end{tabular}

The following table gives the details relating to the British imports of precipitate and matte:

Imports of precipitate and matte into Great Britain from 1889 to 1899, inclusive.

[Long tons.]

\begin{tabular}{|r|r|r|r|r|r|}
\hline & \multicolumn{5}{|c|}{ Fine copper. } \\
\cline { 2 - 6 } Country. & \multicolumn{1}{|c|}{1889.} & \multicolumn{1}{|c|}{1890.} & \multicolumn{1}{c|}{1891.} & \multicolumn{1}{c|}{1892.} & \multicolumn{1}{c|}{1893.} \\
\hline Portugal and Spain ... & 28,157 & 28,018 & 32,425 & 32,509 & 29,359 \\
Chile .............. & 1,919 & 2,122 & 595 & 2,040 & 2,714 \\
United States......... & 26,581 & 18,897 & 19,109 & 24,668 & 20,700 \\
Other countries....... & 6,434 & 8,329 & 12,696 & 11,444 & 8,209 \\
\hline Total ......... & 63,091 & 57,366 & 64,825 & 70,661 & 60,982 \\
\hline
\end{tabular}

21 GEOL, PT 6-14 
Imports of precipitate and matte into Great Britain from 1889 to 1899, inclusice-Cont'd.

[Long tons.]

\begin{tabular}{|r|r|r|r|r|r|r|}
\hline \multicolumn{1}{|c|}{ Country. } & \multicolumn{7}{|c|}{ Fine copper. } \\
\cline { 2 - 7 } & \multicolumn{1}{|c|}{1894.} & \multicolumn{1}{|c|}{1895.} & 1896. & 1897. & 1898 & \multicolumn{1}{|c|}{1899.} \\
\hline Portugal and Spain .. & 28,645 & 30,196 & 28,596 & 32,821 & 28,137 & 30,669 \\
Chile .............. & 626 & 212 & 797 & 2,233 & 1,758 & 1,838 \\
United States........ & 2,133 & 8,337 & 10,016 & 5,259 & 2,181 & 354 \\
Other countries...... & 9,242 & 9,660 & 8,764 & 8,258 & 8,458 & 12,826 \\
Total .......... & 40,646 & 48,405 & 48,173 & 48,571 & 40,534 & 45,687 \\
\hline
\end{tabular}

Messrs. James Lewis \& Son, of Liverpool, estimate as follows the imports of copper product in Liverpool, Swansea, and London during the years from 1887 to 1899, which represent the total imports, with the exception of precipitate into Newcastle and Cardiff, reliable returns of which can not be obtained, but which were estimated to vary from 8,000 to 10,000 tons fine per annum in former years, and in the last few years have been placed as high as 12,000 tons, but in 1898 and 1899 were reduced to 6,000 tons:

Imports of copper product into Liverpool, S'wansea, and London.

[Long tons.]

\begin{tabular}{|c|c|c|c|c|c|c|}
\hline Country. & 1887. & 1888. & 1889. & 1890. & 1891. & 1892. \\
\hline Chile.............. & 20,008 & 24,479 & 22,070 & 22,909 & 14,378 & 17,619 \\
\hline United States.... & 16,534 & 25,730 & 30,729 & 20,171 & 26,120 & 26,475 \\
\hline Spain and Portugal. & 5,178 & 5,915 & 5,189 & 5,202 & 4,734 & 5,372 \\
\hline $\begin{array}{l}\text { Spain and Portugal } \\
\text { (precipitate)...... }\end{array}$ & 13,042 & 15,568 & 17,192 & 18,430 & 17,439 & 14,831 \\
\hline $\begin{array}{l}\text { Spain and Portugal } \\
\text { (pyrites) }\end{array}$ & 14,940 & 15,448 & 16,097 & 16,422 & 15,406 & 15,110 \\
\hline Australasia . . . . . . & 6,047 & 6,746 & 6,285 & 6,561 & 6,265 & 5,547 \\
\hline Cape of Good Hope... & 8,271 & 8,829 & 11,507 & 9,927 & 7,452 & 8,092 \\
\hline Venezuela ... & 2,261 & 3,574 & 4,299 & 5,245 & 5,017 & 5,028 \\
\hline Japan .... & 200 & 4,469 & 2,523 & 10,674 & 7,852 & 4,989 \\
\hline Italy ...... & 1,055 & 1,058 & 1,043 & 953 & 649 & 725 \\
\hline Nurway. & $\ldots \ldots$ & 545 & 234 & 800 & $30 \hat{0}$ & $3 \overline{8}$ \\
\hline Canada....... & 94 & 156 & 181 & 264 & 189 & 120 \\
\hline Newfoundland. & 359 & 465 & 631 & 1,552 & 1,617 & 3,229 \\
\hline Mexico ..... & 61 & 158 & 3,938 & 3,325 & 3,616 & 869 \\
\hline Peru . & 13 & 202 . & 271 & 254 & 279 & $2 S 7$ \\
\hline Plata River & 167 & 135 & 184 & 143 & 211 & 196 \\
\hline Other countries & 1,074 & 4,054 & 1,389 & 225 & 236 & 1,245 \\
\hline Total tons fine. & 89,304 & 117,531 & 123,762 & 122,337 & 111,490 & 109,772 \\
\hline
\end{tabular}


COPPER.

Imports of copper product into Liverpool, Swansea, and London-Continued.

[Long tons.]

\begin{tabular}{|c|c|c|c|c|c|c|c|}
\hline Country. & 1893. & 1894. & 1895. & 1896. & 1897. & 1898. & 1899. \\
\hline Chile......... & 14,875 & 16,971 & 18,197 & 15,923 & 14,982 & 17,734 & 19,752 \\
\hline United States . . . . & 35,647 & 30,495 & 17,098 & 39,676 & 32,792 & 38,979 & 20,773 \\
\hline Spain and Portugal. & 5,674 & 4,674 & 3,288 & 6,298 & 7,697 & 7,293 & 7,084 \\
\hline $\begin{array}{l}\text { Spain and Portugal } \\
\text { (precipitate)....... }\end{array}$ & 10,296 & 10,642 & 12,612 & 11,474 & 17,386 & 15,664 & 16,847 \\
\hline $\begin{array}{r}\text { Spain and } \\
\text { (pyrites) } \ldots \ldots \text {....... }\end{array}$ & 15,320 & 15,401 & 14,561 & 14,726 & 15,576 & 16,626 & 17,529 \\
\hline Australasia ... & 6,293 & 6,481 & 8,223 & 10,635 & 10,218 & 13,409 & 17,085 \\
\hline Cape of Good Hope... & 5,472 & 6,112 & 6,524 & 5,905 & 7,575 & 9,381 & 7,076 \\
\hline Venezuela & 1,434 & 2,327 & 360 & 107 & 21 & & $\cdots$ \\
\hline Japan & 2,370 & 3,299 & 4,258 & 3,492 & 3,654 & 2,086 & 7,812 \\
\hline Italy .... & 1,091 & 763 & 283 & 418 & 100 & 177 & 157 \\
\hline Norway & & 30 & 486 & 528 & 130 & & 182 \\
\hline Canada....... & 50 & 105 & $\ldots \ldots$ & $\ldots \ldots$ & 127 & & 10 \\
\hline Newfoundland... & 2,265 & 1,279 & 3,244 & 2,467 & 2,484 & 1,359 & 2,044 \\
\hline Mexico . & 1,185 & 1,408 & 4,623 & 7,792 & 6,217 & 4,888 & 5,679 \\
\hline Peru ..... & 462 & 443 & 449 & 741 & 998 & 3,041 & 5,163 \\
\hline Plata River... & 160 & 229 & 148 & 94 & 190 & 124 & 63 \\
\hline Other countries. & 1,944 & 855 & 930 & 797 & 1,613 & 1,807 & 8,232 \\
\hline Total tons fine. . & 104,538 & 101,514 & 95,284 & 121,073 & 121,760 & 132,568 & 135,488 \\
\hline
\end{tabular}

The quantities of copper in different forms imported to Great Britain and France from the United States are given in the following table:

Imports of copper into England and France from the United States.

[Long tons.]

\begin{tabular}{|c|c|c|c|c|c|c|}
\hline Country. & 1888. & 1889. & 1890. & 1891. & 1892. & 1893. \\
\hline England: & & & & & & \\
\hline Ore $\ldots . . . . . .$. & 298 & 349 & 5 & 4 & 18 & 23 \\
\hline Matte......... & 20,752 & 26,581 & 18,897 & 19,109 & 24,668 & 20,700 \\
\hline Bars and ingots.. & 4,680 & 3,799 & 1,269 & 7,007 & 1,427 & 14,924 \\
\hline Total.......... & 25,730 & 30,729 & 20,171 & 26,120 & 26,113 & 35,647 \\
\hline France ............... & 6,496 & 1,058 & 1,733 & 8,329 & 4,340 & 12,483 \\
\hline $\begin{array}{l}\text { United States into } \\
\text { England and France }\end{array}$ & 32,226 & 31,787 & 21,904 & 34,449 & 30,453 & 48,130 \\
\hline $\begin{array}{l}\text { Chile into England } \\
\text { and France....... }\end{array}$ & 32,947 & 22,020 & 24,641 & 18,820 & 19,840 & 19,717 \\
\hline
\end{tabular}


Imports of copper into England and France from the United States-Continued.

[Long tons.]

\begin{tabular}{|c|c|c|c|c|c|c|}
\hline Country. & 1894. & 1895. & 1896. & 1897. & 1898. & 1899. \\
\hline England: & & & & & & \\
\hline Ore $\ldots \ldots \ldots$ & -5 & $\ldots$ & $\ldots$ & $\ldots \ldots$ & $\ldots . .$. & \\
\hline Matte ......... & 2,133 & 8,337 & 10,016 & 5,259 & 2,181 & 354 \\
\hline Bars and ingots. - & 28,357 & 12,250 & 29,780 & 27,591 & 36,790 & 20,739 \\
\hline Total... & 30,495 & 20,587 & 39,796 & 32,850 & 38,971 & 21,093 \\
\hline France ............ & 9,248 & 11,806 & 21,998 & 26,165 & 22,753 & 24,695 \\
\hline United States into & & & & & & \\
\hline England and France & 39,743 & 32,393 & 61,794 & 59,015 & 61,724 & 45,788 \\
\hline $\begin{array}{l}\text { Chile into England } \\
\text { and France ....... }\end{array}$ & 20,783 & 22,161 & 22,593 & 20,842 & 24,303 & 25,482 \\
\hline
\end{tabular}

The exports of copper from Great Britain, estimating the fine contents of alloys, have been as follows:

Exports of copper from Great Britain from 1888 to 1899, inclusive. [Long tons.]

\begin{tabular}{|c|c|c|c|c|c|c|}
\hline Character. & 1888. & 1889. & 1890. & 1891. & 1892. & 1893. \\
\hline $\begin{array}{l}\text { English, wrought } \\
\text { and unwrought, } \\
\text { and sheets ........ }\end{array}$ & 32,058 & 48,189 & 58,571 & 51,765 & 58,518 & 45,349 \\
\hline $\begin{array}{l}\text { Yellow metal, at } 60 \\
\text { per cent .......... }\end{array}$ & 4,513 & 9,195 & 10,514 & 8,547 & 8,853 & 8,745 \\
\hline Brass, at 70 per cent. & 2,650 & 3,773 & 3,721 & 3,992 & 3,783 & 4,049 \\
\hline Total.... & 39,221 & 61,157 & 72,806 & 64,304 & 71,154 & 58,143 \\
\hline Fine foreign .. & $a 32,845$ & 14,470 & 16,941 & 11,752 & 11,388 & 12,843 \\
\hline Total & 72,066 & 75,627 & 89,747 & 76,056 & 82,542 & 70,986 \\
\hline Character. & 1894. & 1895. & 1896. & 1897. & 1898. & 1899. \\
\hline $\begin{array}{l}\text { English, wrought } \\
\text { and unwrought, } \\
\text { and sheets........ }\end{array}$ & 34,874 & 45,299 & 38,734 & 35,951 & 40,223 & 42,992 \\
\hline $\begin{array}{l}\text { Yellow metal, at } 60 \\
\text { per cent } \ldots . . . . .\end{array}$ & 9,514 & 8,978 & 6,773 & 6,609 & 6,172 & 4,156 \\
\hline Brass, at 70 per cent. & 3,808 & 3,747 & 4,172 & 3,936 & 3,733 & 3,994 \\
\hline Sulphate of copper.. & $b 10,000$ & $b 12,000$ & 13,155 & 14,844 & 13,078 & 10,045 \\
\hline Total... & 58,196 & 70,024 & 62,834 & 61,340 & 63,206 & 61,187 \\
\hline Fine foreign .... & 6,493 & 7,966 & 9,655 & 10,046 & 13,242 & 24,129 \\
\hline Total . & 64,689 & 77,990 & 72,489 & 71,386 & 76,448 & 85,316 \\
\hline
\end{tabular}

Since 1894 the copper contents of sulphate exported have been introduced into the table. 
THE FRENCH COPPER TRADE.

The direct imports of copper from different countries into France have been as follows for a series of years, according to Messrs. James Lewis \& Son:

Direct imports into France from 1887 to 1899, inclusive.

[Long tons.]

\begin{tabular}{|c|c|c|c|c|c|}
\hline Year. & Chile. & $\begin{array}{l}\text { United } \\
\text { States. }\end{array}$ & Mexico. & $\begin{array}{l}\text { Other } \\
\text { countries. }\end{array}$ & Total. \\
\hline $1887 \ldots$ & 9,011 & 3,910 & $\cdots$ & 1,048 & 13,969 \\
\hline $1888 \ldots \ldots \ldots \ldots$ & 8,468 & 6,496 & 2,700 & 6,905 & 24,569 \\
\hline $1889 \ldots$ & 2,470 & 1,058 & 738 & 1,715 & 5,981 \\
\hline $1890 \ldots$ & 2,803 & 1,733 & ... & 975 & 5,511 \\
\hline $1891 \ldots$ & 4,442 & 8,329 & $\ldots .$. & 2,118 & 14,889 \\
\hline $1892 \ldots$ & 2,221 & 4,340 & 2,515 & 2,208 & 11,284 \\
\hline $1893 \ldots$ & 3,842 & 12,483 & 7,620 & 2,908 & 26,853 \\
\hline $1894 \ldots$ & 3,812 & 9,248 & 6,299 & 1,588 & 20,947 \\
\hline $1895 \ldots$ & 3,964 & 11,806 & 4,520 & 2,505 & 22,795 \\
\hline $1896 \ldots$ & 7,030 & 21,998 & 3,627 & 3,700 & 36,355 \\
\hline $1897 \ldots$ & 4,806 & 26,165 & 5,677 & 2,557 & 39,205 \\
\hline $1898 \ldots$ & 6,612 & 22,753 & 5,722 & 2,350 & 37,437 \\
\hline $1899 \ldots$ & 5,730 & 24,695 & 6,032 & 3,735 & 40,192 \\
\hline
\end{tabular}

According to the French official statistics, the imports of bars, ingots, etc., have been as follows:

Imports of copper into France.

[Metric tons.]

\begin{tabular}{|c|r|r|r|r|r|}
\hline Source. & \multicolumn{1}{|c|}{1895.} & \multicolumn{1}{|c|}{1896.} & 1897. & \multicolumn{1}{|c|}{1898.} & \multicolumn{1}{c|}{1899.} \\
\hline England ............ & 8,250 & 5,596 & 3,884 & 5,970 & 8,650 \\
Chile ............ & 3,494 & 4,573 & 2,804 & 4,469 & 4,442 \\
United States........ & 11,157 & 21,279 & 28,118 & 26,210 & 24,470 \\
Other countries ...... & 11,717 & 12,197 & 14,830 & 10,712 & 13,650 \\
Total ........... & 34,618 & 43,645 & 49,636 & 47,361 & 51,212 \\
\hline
\end{tabular}


A comparison shows that there are striking discrepancies between the statistics collected by Messrs. James Lewis \& Son and the official returns, which it seems difficult to harmonize. Messrs. Aron Hirsch \& Sohn, of Halberstadt, Germany, in the annual statistical report, present the following as drawn from official sources:

French imports and exports of copper.

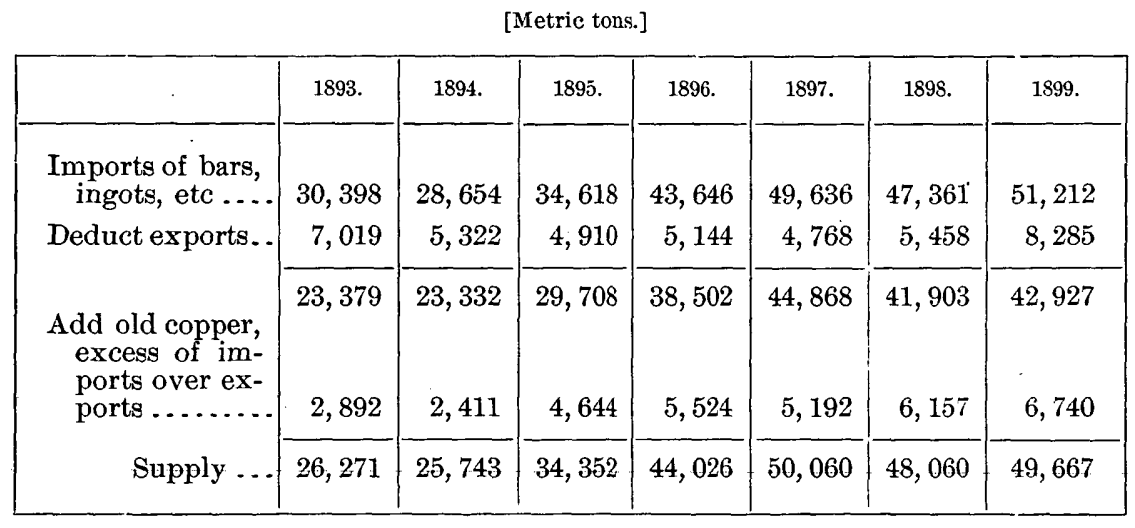

Imports and exports of ores, matte, etc.

[Metric tons.]

\begin{tabular}{|r|r|r|r|r|r|r|c|}
\hline & 1893. & 1894. & 1895. & 1896 & 1897. & 1898. & 1899. \\
\hline Imports ...... & 20,543 & 11,643 & 10,448 & 9,216 & 12,408 & 8,780 & 8,577 \\
Exports ....... & 10,214 & 5,021 & 1,771 & 1,260 & 2,161 & 1,784 & 2,139 \\
\hline Supply ... & 10,329 & 6,622 & 8,677 & 7,956 & 10,247 & 6,996 & 6,438 \\
\hline
\end{tabular}

Messrs. Hirsch \& Sohn, holding that the bulk of this material is rich, like Boleo mattes and Corocoro ores, estimate its contents at 70 per cent, and on this basis estimate the copper consumption of France as follows: 
Copper consumption of France.

[Metric tons.]

\begin{tabular}{|c|c|c|c|c|c|c|c|}
\hline & 1893. & 1894. & 1895. & 1896. & 1897. & 1598. & 1899. \\
\hline $\begin{array}{l}\text { Imports, raw } \\
\text { material ..... } \\
\text { Contents of ore.. }\end{array}$ & $\begin{array}{r}26,271 \\
7,230\end{array}$ & $\begin{array}{r}25,743 \\
4,635\end{array}$ & $\begin{array}{r}34,352 \\
6,074\end{array}$ & $\begin{array}{r}44,026 \\
5,570\end{array}$ & $\begin{array}{r}50,060 \\
8,685\end{array}$ & $\begin{array}{r}48,060 \\
7,024\end{array}$ & $\begin{array}{r}49,667 \\
6,004\end{array}$ \\
\hline $\begin{array}{r}\text { Total .... } \\
\text { Increase }(+) \text { or } \\
\text { decrease }(-) \\
\text { of stocks...... }\end{array}$ & 33,501 & $\begin{array}{r}30,378 \\
+1,459\end{array}$ & 40,426 & 49,596 & 58,745 & 55,084 & 55,671 \\
\hline $\begin{array}{l}\text { Consump- } \\
\text { tion }\end{array}$ & 33,856 & 31,837 & 40,323 & 49,007 & 58,366 & 54,569 & 56,341 \\
\hline
\end{tabular}

These figures are valuable as showing the very rapid increase in the consumption, slightly checked in $\mathbf{1 8 9 8 .}$

\section{THE GERMAN COPPER TRADE.}

German copper consumption has grown very rapidly. The following table, compiled by Messrs. Aron Hirsch \& Sohn, of Halberstadt, shows the principal figures. There is included in the production the copper extracted in German metallurgical works from imported ores and mattes. An allowance is made for this in the table.

Copper consumption of Germany.

[Metric tons.]

\begin{tabular}{|c|c|c|c|c|c|c|c|c|}
\hline & 1892. & 1893. & 1894. & 1895. & 1896. & 1897. & 1898 & 1899. \\
\hline Imports & 44,514 & 51,806 & 52,504 & 59,742 & 73,123 & 82,903 & 89,772 & 89,746 \\
\hline Exports .... & 9,817 & 11,304 & 10,406 & 10,893 & 12,452 & 12,568 & 14,957 & 20,304 \\
\hline $\begin{array}{l}\text { Excess of im- } \\
\text { ports } . . . .\end{array}$ & $|34,697|$ & 40,502 & 42,098 & 48,849 & 60,671 & 70,335 & 74,815 & 69,442 \\
\hline Production & 25,406 & 24,011 & 25,857 & 26,013 & 29,489 & 29,468 & 30,704 & $a 37,676$ \\
\hline Total ... & 60,103 & 64,513 & 67,955 & 74,862 & 90,160 & 99,803 & 105,519 & 107,118 \\
\hline $\begin{array}{l}\text { Copper contents } \\
\text { of imported } \\
\text { copperoreand } \\
\text { iron pyrites... }\end{array}$ & 4,000 & 4,000 & 5,000 & 4,500 & 5,000 & 3,500 & 4,000 & 4,500 \\
\hline $\begin{array}{l}\text { Home con- } \\
\text { sumption. }\end{array}$ & 56,103 & 60,513 & 62,955 & 70,362 & 85,160 & 96,303 & 101,519 & 102,618 \\
\hline
\end{tabular}

a Estimated. 
The imports for 1899 include 70,094 tons of bars and ingots, 4,992 tons of coin and scrap, 1,397 tons copper contents old brass, 2,720 tons of copper from imported ores, and 10,543 tons from imported pyrites.

The source of the imports of bars and ingots for a series of years is shown in the following table, which proves how important a contributor to the German markets this country has become:

Source of German imports of ingot copper.

[Metric tons.]

\begin{tabular}{|c|c|c|c|c|c|c|}
\hline Country. & 1894. & 1895. & 1896. & 1897. & 1898. & 1899. \\
\hline Free port (Hamburg) & 1,689 & 1,185 & 2,371 & 2,669 & 2,873 & 2,496 \\
\hline Belgium ..... & 356 & 356 & 115 & 9 & 216 & 19 \\
\hline France ..... & 303 & 152 & 81 & 268 & 121 & 93 \\
\hline Norway ..... & 128 & 362 & 71 & 45 & 32 & 1 \\
\hline Austria-Hungary. & 50 & 197 & 11 & 9 & 12 & 105 \\
\hline Sweden ....... & 33 & 83 & 198 & 250 & 328 & 215 \\
\hline Switzerland. & $\cdots$ & $\cdots$ & 5 & 6 & 2 & 1 \\
\hline Spain ....... & 10 & $\cdots \cdots$ & 10 & 41 & 69 & 31 \\
\hline England....... & 7,430 & 7,363 & 7,478 & 8,660 & 12,754 & 14,350 \\
\hline Netherlands... & 109 & 139 & 73 & 18 & 19 & 184 \\
\hline United States. & 23,795 & 31,311 & 42,504 & 50,420 & 52,473 & 47,742 \\
\hline Japan ..... & 2,072 & 1,932 & 1,916 & 2,655 & 2,196 & 3,050 \\
\hline Chile.......... & 884 & 825 & 827 & 2,217 & 1,216 & 1,187 \\
\hline Australasia .... & $\ldots$. & 313 & 183 & 259 & 742 & 581 \\
\hline Other countries. & 173 & 147 & 271 & 46 & 25 & 39 \\
\hline Total... & 37,032 & 44,365 & 56,114 & 67,572 & 73,078 & 70,094 \\
\hline
\end{tabular}

The production of Germany for a series of years has been as follows. The output of the Mansfeld Company is added, since that corporation is the dominating factor:

Copper production of Germany.

[Metric tons.]

\begin{tabular}{|c|c|c|}
\hline Year. & $\begin{array}{l}\text { Total pro- } \\
\text { duction. }\end{array}$ & $\begin{array}{l}\text { Production } \\
\text { of Mansfeld. }\end{array}$ \\
\hline $1891 \ldots \ldots \ldots$ & 24,688 & 15,365 \\
\hline $1892 \ldots \ldots \ldots \ldots \ldots$ & 25,406 & 15,588 \\
\hline $1893 \ldots \ldots$ & 24,011 & 14,358 \\
\hline $1894 \ldots$ & 25,857 & 15,217 \\
\hline $1895 \ldots$ & 26,013 & 15,083 \\
\hline $1896 \ldots \ldots \ldots \ldots$ & 29,489 & 18,541 \\
\hline $1897 \ldots$ & 29,468 & 18,248 \\
\hline $1898 \ldots$ & 30,704 & 18,335 \\
\hline $1899 \ldots \ldots \ldots$ & $a 36,000$ & 24,315 \\
\hline
\end{tabular}

$a$ Estimated. 
It will be observed that Mansfeld considerably increased its production in 1896, and has made another leap forward in 1899.

A very notable fact in connection with the German copper trade is the rapid expansion in exports of copper manufactures, which reached a climax in 1899. 'Since 1893 the exports have more than doubled, as is shown by the following table:

Exports of copper manufactures from 1892 to 1899, inclusive.

[Metric tons.]

\begin{tabular}{|r|r|r|r|r|r|r|r|r|}
\hline & 1892. & 1893. & 1894. & 1895. & 1896. & 1897. & 1898 & 1899. \\
\hline Rods and sheets.... & 4,507 & 4,889 & 5,009 & 4,700 & 5,429 & 5,712 & 5,369 & 4,869 \\
Wire........... & 2,565 & 3,052 & 4,433 & 3,975 & 5,909 & 6,175 & 5,930 & 7,578 \\
Cables........... & 1,526 & 1,957 & 2,193 & 3,713 & 7,631 & 8,119 & 10,432 & 11,481 \\
Miscellaneous...... & 492 & 563 & 501 & 556 & 279 & 245 & 263 & 548 \\
Coarse forgings..... & 1,902 & 2,050 & 2,538 & 2,643 & 2,648 & 2,703 & 2,988 & 3,162 \\
Cartridges, caps, etc. & 2,374 & 3,682 & 3,376 & 4,450 & 4,156 & 2,712 & 3,288 & 2,682 \\
Fine copper goods.. & 3,234 & 3,859 & 4,117 & 4,912 & 7,837 & 7,425 & 8,454 & 9,855 \\
Total ......... & 16,600 & 20,052 & 22,167 & 24,949 & 33,889 & 33,091 & 36,724 & 40,175 \\
\hline
\end{tabular}

THE RUSSIAN COPPER TRADE.

The following table shows the consumption of copper in Russia, to which American producers contribute to some extent:

Copper consumption of Russia.

[Metric tons.]

\begin{tabular}{|r|r|r|r|r|r|r|r|}
\hline & 1892. & 1893. & 1894. & 1895. & 1896. & 1897. & 1898. \\
\hline $\begin{array}{r}\text { Imports of fine } \\
\text { copper ....... }\end{array}$ & 7,803 & 12,340 & 10,442 & 11,033 & 14,090 & 15,280 & 14,458 \\
$\begin{array}{r}\text { Imports of manu- } \\
\text { factures........ }\end{array}$ & 1,032 & 1,442 & 1,049 & 655 & 723 & 673 & 716 \\
Production ....... & 4,901 & 5,436 & 5,730 & 5,413 & 5,721 & 6,596 & 6,500 \\
\hline $\begin{array}{r}\text { Con su m p- } \\
\text { tion ...... }\end{array}$ & 13,736 & 19,218 & 17,221 & 17,101 & 20,534 & 22,549 & 21,674 \\
\hline
\end{tabular}


The production of the Russian mines during 1894, 1895, 1896, and 1897 was as follows, by districts:

Copper production in Russia.

[Poods.]

\begin{tabular}{|c|c|c|c|c|}
\hline & 1894. & 1895. & 1896. & 1597. \\
\hline Caucasus ....... & 150,000 & 145,805 & 149,698 & 162,534 \\
\hline Ural .. & 155,000 & 149,032 & 166,205 & 192,839 \\
\hline Altai .......... & 17,000 & 12,566 & 13,240 & 15,427 . \\
\hline Steppes district ..... & ........ & $\ldots \ldots$ & 1,868 & 3,586 \\
\hline Finland: Pitkaranda ....... & 27,500 & 20,274 & 18,000 & 18,000 \\
\hline Total. . & 349,500 & 327,677 & 349,011 & 392,386 \\
\hline In metric tons ( 61 poods)... & 5,730 & 5,372 & 5,721 & 6,596 \\
\hline
\end{tabular}

Summarizing the estimates of Messrs. Aron Hirsch \& Sohn, we have the following as the copper consumption of the leading European countries:

Coppër consumption of leading European countries.

[Metric tons.]

\begin{tabular}{|c|c|c|c|c|c|c|c|}
\hline Country. & 1893. & 1894. & 1895. & 1896. & 1897. & 1898. & 1899. \\
\hline England ... & 96,615 & 90,069 & 91,184 & 115,557 & 110,210 & 105,816 & 88,624 \\
\hline Germany .. & 60,513 & 62,955 & 70,349 & 85,371 & 96,385 & 101,518 & 102,618 \\
\hline France..... & 33,856 & 31,837 & 40,323 & 49,007 & 58,366 & 54,569 & 56,341 \\
\hline Russia & 19,218 & 17,221 & 17,101 & 20,534 & 22,549 & 21,674 & 23,000 \\
\hline Austria .... & 14,901 & 16,457 & 15,735 & 16,498 & 18,288 & 20,599 & 18,770 \\
\hline Total .. & 225,103 & 218,539 & 234,692 & 286,967 & 305,798 & 304,176 & 289,353 \\
\hline
\end{tabular}

This is exclusive of the United States, whose consumption is estimated at 162,000 metric tons in 1899, based on the returns of the American Associated Companies, and neglecting stocks, a course which is justified by the absence of any reliable data on the subject.

THE LEADING FOREIGN PRODUCERS.

The high price of copper, brought about by the enormous expansion of the consumption and the very large profits earned by nearly every active mine in the world, bas led to an eager reach for and a feverish development of new copper properties. The marked technical improvements in copper metallurgy have made much low-grade ore available for profitable treatment, so that deposits attract capital now which it would have been impossible to touch a decade ago. Notable progress 
has been made in Canada and in Mexico. In South America there has been a revival of mining in Chile and in Bolivia, while the Cerro de Pasco district in Peru is looming up as a producer of international importance. In the Australian colonies there has been a very large production in recent years.

$$
\text { SPAIN. }
$$

The production of the Rio Tinto Company in 1899 was 34,817 long tons of copper, of which 20,230 tons were obtained by treatment at the mines and 14,587 tons were in the pyrites shipped. There were brought to market 32,099 tons in $1899,32,095$ tons in 1898 , and 33,431 tons in 1897. In 189916,893 tons were sold as refined copper, 1,067 tons in the form of sulphate, and 14,139 tons in pyrites. The reserve heaps of the company are now estimated to contain 118,651 tons of fine copper.

The year was an exceedingly profitable one for the company, the profit from the sale of product having been $£ 1,877,403$, as compared with about $£ 1,000,000$ during the previous year. After putting aside $£ 110,000$ to reserve, writing off $£ 72,000$ for depreciation, paying $£ 72,000$ for administration, $£ 66,580$ for taxes, and $£ 136,656$ as interest on debentures, then $£ 60,760$ were applied to redemption of debentures and $£ 78,540$ as 5 per cent dividend on preference shares. Finally there were paid in dividends on the common stock $£ 1,339,270$, as compared with $£ 850,417$ during the preceding year.

The Tharsis Copper and Sulphur Company mined, in 1899, 572,854 tons of ore, as compared with 586,090 tons in 1898 and 565,949 tons in 1897 , but the copper product fell from 11,147 long tons in 1898 to 9,448 tons in 1899 . The shipments of pyrites were 403,679 tons. The product of the Tharsis has always been to some extent dependent upon the rainfall for leaching, but it is stated that the yield of the ore, too, is falling off. The company has therefore taken an option on another property. The net profits in 1899 were the largest in the history of the company, aggregating $£ 478,878$, the dividends paid being $37 \frac{1}{2}$ per cent on a capital of $£ 1,250,000$.

The old Mason and Barry, Limited, which controls the San Domingo mine in Portugal, is decreasing in importance as a copper producer. Its shipments of pyrites for sulphur value were 332,452 tons. The total profit was $£ 95,440$, and dividends of 25 per cent on $£ 420,000$ were paid, as compared with $12 \frac{1}{2}$ per cent in 1898 .

\section{AUSTRALASIA.}

It is somewhat difficult to ascertain closely the copper product of Australasia, because the statistics of some of the colonies as to the metal output appear to be based on exports without being accompanied with estimates of fine copper contents of ore or of matte. Ore and furnace material, too, are forwarded for smelting and refining from one colony to the other. 
So far as New South Wales is concerned, recent data are available through a monograph by Mr. J. E. Carne, entitled The Copper Mining Industry and the Distribution of Copper Ores in New South Wales, published by the Department of Mines and Agriculture.

Generally speaking, the copper miners of the colony, after having exhausted the upper belts of oxidized ores, seem to be facing the problem of economically treating the leaner sulphurets. In some districts the problem is complicated by the arid character of the country.

The most important district is that of Cobar, in the interior, where the leading producer is the Great Cobar Copper Mining Syndicate, a dividend-paying concern. In 1898 there were smelted 111,557 tons of ore, yielding 3,520 long tons of copper, an average of 3.24 per cent. Another company developing a promising property is the Cobar Chesney Copper and Gold Company.

South of this district, at Gidalambone, is the Girilambone Copper Mining Company, Limited, which commenced smelting late in 1897, and during the first half of 1898 produced 215 long tons of copper from 2,371 tons of concentrates.

Another interior district is that in which the Nymagee is the principal property, having been a producer for a number of years. The greatest product was in 1884, when 2,207 long tons of copper were obtained by smelting ore which averaged 14.95 per cent. In 1898 17,152 tons of smelting material yielded 728 long tons of copper, or 4.53 per cent.

Farther south lies the Mount Hope district, where the two working mines are the New Mount Hope Company, which in 1898 produced 131 long tons of copper from 992 tons of ore, and the Great Central Company, which turned out 110 long tons from 1,100 tons of ore and concentrates.

Nearer the coast is a district with a number of producing mines, of which the Burraga is the largest. In 1898 the company raised 8,518 tons of ore, of which 5,678 tons were smelted, yielding 570 tons of copper. The Annandale, in the same district, resumed smelting on a small scale in 1898.

In the southern part of the colony are the Lake George Mines, Limited, at Captains Flat, where ores carrying the precious metals are handled, the copper merely being a carrier. During the first half of 1898 there were smelted 27,411 tons, producing a matte which contained 426 long tons of copper, 2,027 ounces of gold, and 70,379 ounces of silver.

A fair amount of copper is proauced annually as an incidental product in treating the silver-lead ores of the famous Broken Hill district.

Nearly every one of the companies named has its small smelting plant; besides, there are customs smelters in and out of the colony which handle copper ores mined in New South Wales. The English 
and Australian Copper Company, Limited, has a branch at Waratah, near Newcastle; the Smelting Company of Australia, Limited, treats copper ores at Lake Illawarra, near Dapto, New South Wales; the Great Cobar Copper Mining Syndicate has a refinery at Lithgow, New South Wales, and the works of Lewis Lloyd are at the same place. The Sulphide Corporation, Limited, at Cockle Creek, near Newcastle, originally established to treat complex lead ores from Broken Hill, has lately begun purchasing cupriferous material and has handled some South American ores. Outside smelters are the Australian Smelting Company, Limited, at Dry Creek Station, South Australia, and the Wallaroo Smelting Works, Wallaroo, South Australia.

Tasmania has come forward in recent years as one of the most interesting of the newer contributors to the copper supply, very large undertakings having been developed in the Mount Lyell field, both by British and by Australian capital. A large number of companies have been formed and a considerable increase in the production is likely. The district appears to furnish a variety of ores, some of them being pyritic, while others are siliceous. The leading concern is the Mount Lyell Mining and Railway Company, which owns the railway to the coast, mines almost entirely by open cut, and treats the ore in a large smelting plant. During the half year ending March 31, 1900, there were smeltered 150,735 tons of Mount Lyell ores and 18,736 tons of purchased ores, 4,028 tons of flue dust, 28,139 tons of first matte, 4,744 tons of converter slags, and 723 tons of converter linings, the product being 9,868 tons of matte. The latter yielded in the converters blister copper containing 4,742 tons of fine copper, 387,490 ounces of silver, and 14,605 ounces of gold. Including purchased ores, the ore yielded 2.81 per cent of copper, 2.30 ounces of silver, and 0.09 ounces of gold per ton; thus illustrating that it is a low-grade proposition, the successful operation of which is possible only through modern methods. The total receipts were $£ 394,813$, while the expenditures were $£ 260,518$, leaving a gross profit of $£ 134,295$. Dividends aggregating $£ 123,750$ were paid on an issued capital of $275,000 £ 3$ shares.

The second large corporation is the North Mount Lyell Company, which has opened up a very large body of siliceous ore, estimated to contain 12 per cent of copper and 5 ounces of silver per ton. Smelting works are now being built to handle the ore. The same interests which control the North Lyell hold the South Lyell, the Lyell Comstock, Tasman Lyell; and Crown Lyell, which are to join in the erection of a second smelting plant.

Queensland, which has not yet produced any copper, is reported to possess very extensive deposits, some of which are now being developed. The most conspicuous of these are in the back country, reached through the port of Cairns, under the control of the Chillagoe Conpany, whose Mungana and Redcap mines are the largest. The ore is low in grade, but carries some silver. To reach the mines a railroad 
over 100 miles long will have to be built. Six furnaces are approaching completion, which are to treat 3,000 to 4,000 tons per week. Farther inland is the Einasleigh group, where a reduction plant is also under way. Sixty miles from Chillagoe is the Mount Garnet mine, with a deposit of ore rather higher both in copper and in silver. There, too, smelting works are being erected. Development is proceeding also in the Rockhampton district, where furnaces are being erected.

South Australia continues a steady producer of copper, its exports of ingot baving been 4,705 long tons in 1897 and 4,771 tons in 1898 . The metal is obtained chiefly from mines in Yorkes Peninsula.

\section{CANADA.}

There has been only a moderate increase in the copper production of Canada, the official statistics showing a total output of $15,078,475$ pounds fine for 1899 . Of this about one-half-7,772,591 pounds-was produced in British Columbia in 1899 as compared with 7,271,678 pounds in 1898. The official returns make the copper product of Ontario 5,668,000 pounds, apparently all from the Sudbury nickelcopper ores. A considerable part of the ores of the Kootenai district is smelted at Northport, Washington. On Texada Island the Van Anda Company has produced some copper.

\section{MEXICO.}

Mexico's production is difficult to arrive at. The principal concern is the Boleo Company of Lower California, whose product for 1899 is given at 10,335 long tons. In recent years capitalists from the United States identified with the copper industry have taken an active interest in the development of the copper resources of the country. Guggenheim Brothers have built a smelting plant at Aguas Calientes, and Phelps, Dodge \& Co. are completing a very comprehensive establishment at Nacosari, Sonora, under the name of the Moctesuma Copper Company. Lewisohn Brothers are also developing property. Besides this considerable quantities of cupriferous material are treated at the El Paso plant of the American Smelting and Refining Company, and at the Silver City Reduction Works. Reports from refiners and smelters in the United States show that in 1899 they handled 7,275,753 pounds of copper derived from Mexican sources. It is understood also that European capitalists are investing heavily in opening up the Iguaran property in Michoacan.

\section{AFRICA AND NEWFOUNDLAND.}

In Cape Colony the Cape Copper Company and the Namaqua Copper Company remain the only active producers. The former has interests not only in Africa, but also in Newfoundland. For many 
years the Ookiep mine, with its rich ores, has been the mainstay of the company. During the last fiscal year it produced 24,262 net tons, averaging 18.5 per cent, while the Spektakel mine yielded 932 tons of 32 per cent. The reserves of the former mine are placed at 24,000 tons of 21 per cent ore undiminished by the year's working. A new property is being developed in the Nababeep mine, with large reserves of low-grade ore. The profit-and-loss account of the Cape Company shows a credit balance of $£ 485,287$, including $£ 153,301$ brought forward from the previous year. Out of this $£ 207,000$ were paid in dividends. The net profit earned by the Tilt Cove property in Newfoundland was $£ 47,353$. The production of these mines in 1899 was 62,138 tons of 3.5 per cent ore from the Tilt Cove and 3,699 tons of 11 per cent ore from the West mine.

The Namaqua Copper Company, Limited, produced in 1899 about 9,000 tons of shipping ore, averaging about 25 per cent of copper. The net profit was $£ 115,384$, out of which $£ 75,200$ were paid in dividends and $£ 20,000$ were set aside to provide funds for a new railroad. It is proposed to treat the low-grade ore locally.

\section{PERU.}

Peru promises to come to the front rapidly as a producer of copper. Reports of the character and extent of the deposits in the Cerro de Pasco district and of the vigorous manner in which they are being developed justify this belief. 


\section{LEAD.}

\section{By Charles Kirchioff.}

\section{INTRODUC'TION.}

The production of lead in the United States in 1899 did not reach the record production of 1898 , when it attained 222,000 short tons. Had it not been for the smelters' strike in Colorado and the stoppage of some of the important mines of the Cour d'Alene district in Idaho, it would probably have outstripped the maximum attained during the previous year. As it was, the output from domestic ores is estimated to have attained 210,500 short tons. The mines of the district of southwestern Missouri and southeastern Kansas, too, fell behind their record.

The most active preparations for development have been progressing in southeastern Missouri, but, with the leaner ores of that section, considerable preparation is required in prospecting with the drill, in opening up proven territory, and in putting down mining and concentrating plants, before notable additions to the metal output can be attained.

\section{PRODUCTION.}

The following series of tables present the figures of the total gross production of lead in the United States from 1825. Up to the year 1882 the figures have been compiled from the best data available. Since 1882 the statistics are those collected by this office, with the exception of the year 1889, when they were gathered by the Census Office:

Production of refined lead in the United States from 1825 to 1872, inclusive.

\begin{tabular}{|c|c|c|c|c|c|}
\hline Year. & Production. & Year. & Production. & Year. & Production. \\
\hline & Short tons. & & Short tons. & , & Short tons. \\
\hline 1825 & 1,500 & $1836 \ldots$ & 15,000 & $1843 \ldots$ & 25,000 \\
\hline 1830 & 8,000 & 1837 & 13,500 & 1844 & 26,000 \\
\hline 1831 & 7,500 & 1838 & 15,000 & 1845 & 30,000 \\
\hline 1832 & 10,000 & 1839 & 17,500 & $1846 \ldots$ & 28,000 \\
\hline 1833 & 11,000 & 1840 & $\cdot 17,000$ & $1847 \ldots$ & 28,000 \\
\hline 1834 & 12,000 & $1841 \ldots$ & 20,500 & $1848 \ldots$ & 25,000 \\
\hline 1835. & 13,000 & $1842 \ldots$ & 24,000 & 1849 & 23,500 \\
\hline
\end{tabular}

21 GEOL, PT 6- 15 
Production of refined lead in the United States from 1825 to 1872, inclusive-Cont'd.

\begin{tabular}{|c|c|c|c|c|c|}
\hline Year. & Production. & Year. & Production. I & Year. & Production. \\
\hline & Short tons. & & Short tons. & & Short tons. \\
\hline $1850 \ldots \ldots$ & 22,000 & 1858 & 15,300 & 1866 & 16,100 \\
\hline 1851 & 18,500 & 1859 & 16,400 & 1867 & 15,200 \\
\hline 1852 & 15,700 & 1860 & $15,6 \grave{0}$ & 1868 & 16,400 \\
\hline 1853 & 16,800 & 1861. & 14,100 & 1869 & 17,500 \\
\hline $185+\ldots \ldots$ & 16,500 & 1862 & 14,200 & 1870 & 17,830 \\
\hline 1855 & 15,800 & 1863 & 14,800 & 1871 & 20,000 \\
\hline 1856 & 16,000 & 1864. & 15,300 & $1872 \ldots$ & 25,880 \\
\hline 1857 & 15,800 & 1865 & 14,700 & & \\
\hline
\end{tabular}

The sources from which the lead which comes into the market are drawn are numerous, and since the metal passes through a number of channels from the ore, the complications are serious.

We have, first, the lead produced from the nonargentiferous ores of southeast Missouri, the bulk of which is treated in smelting works controlled and owned by the mining companies themselves. This is a directly marketable product. A part of the ores and some furnace material are purchased by outside smelters, chiefly those of the St. Louis district, although at times Eastern desilverizers have drawn upon the district for smelting material.

Second, there are the lead ores raised in the zinc-lead mines of southwest Missouri and southeast Kansas, known as the Joplin-Galena district. - A part of these is smelted in local works, one of them, however, marketing a certain quantity of metal annually in the form of a pigment. In Iowa a small quantity of lead ore is also smelted locally, being the product of the Dubuque district.

The lead thus obtained is directly marketable, being practically free from silver. It is known as "soft lead." In the tables of production this also includes a small amount of lead from Virginia, to which, at times, lots of metal produced in Tennessee have been added.

In former years there were some Scotch hearths in Wisconsin to treat local ores, but they have suspended work for many years.

A growing percentage of the ores of southwest Missouri and southeast Kansas, and of Wisconsin, Iowa, and Illinois, is purchased by desilverizers, by whom it is used in connection with the production of hard lead, and by lead smelters as a carrier for silver. The "soft lead" does not, therefore, represent the entire output to be credited to the Mississippi Valley.

$\mathrm{By}$ far the greatest quantity of lead, however, is obtained by the smelting of argentiferous lead ores mined in the Rocky Mountain region in mixture with ores of the precious metals free from lead, so-called "dry ores," which lead smelters can handle more economically than 
they can be treated locally by amalgamation or by other processes used for the extraction of gold and silver. Practically the lead in these ores has become the carrier for the precious metals in the "dry" ores, and, generally speaking, it may be stated that the offerings of "dry" ores have usually been so heavy for many years that suitable lead ores always find eager buyers. There are a few lead smelting plants, relaatively unimportant, in Idaho, Montana, New Mexico, and California, built to reduce the ores locally mined. The great mass of the ores, however, are hauled often great distances to meet the fuel and to encounter ores carrying the precious metals. The principal large plants are in Colorado, Utah, and Montana. An excellent illustration of this movement is afforded by the famous Cœur d'Alene district in Idaho, which yields over one-quarter of the lead mined in the United States. Not a pound is smelted locally, the concentrates and ore being shipped for reduction to the smelters in Colorado, Montana, Utah, Nebraska, Illinois, and the Puget Sound.

From 1873 to 1885 , inclusive, the production was separated into the two groups, that of desilverized lead obtained from smelting argentiferous ores drawn from the Rocky Mountain region and that of the "soft lead" from the nonargentiferous ores of the Mississippi Valley.

Production of refined lead in the United States from 1873 to 1885.

\begin{tabular}{|c|c|c|c|c|}
\hline Year. & $\begin{array}{l}\text { Total pro- } \\
\text { duction. (a) }\end{array}$ & $\begin{array}{c}\text { Desilverized } \\
\text { lead. }(a)\end{array}$ & Soft lead. $(b)$ & $\begin{array}{l}\text { Net Ameri- } \\
\text { can product. }\end{array}$ \\
\hline 1873 & Short tons. & Short tons. & Short tons. & Short tons. \\
\hline 1874 & 52,080 & ... & $\ldots$ & 52,080 \\
\hline $1875 \ldots$ & 59,640 & 34,909 & 24,731 & 59,640 \\
\hline $1876 \ldots$ & 64,070 & 37,649 & 26,421 & 64,070 \\
\hline 1877 & 81,900 & 50,748 & 31,152 & 81,900 \\
\hline 1878. & 91,060 & 64,290 & 26,770 & 91,060 \\
\hline 1879. & 92,780 & 64,650 & 28,130 & 92,780 \\
\hline $1880 \ldots$ & 97,825 & 70,135 & 27,690 & 97,825 \\
\hline $1881 \ldots$ & 117,085 & 86,315 & 30,770 & 117,085 \\
\hline $1882 \ldots$ & $.132,890$ & 103,875 & 29,015 & 132,890 \\
\hline 1883 & 143,957 & 122,157 & 21,800 & 143,957 \\
\hline $1884 \ldots$ & 139,897 & 119,965 & 19,932 & 139,897 \\
\hline $1885 \ldots$ & 129,412 & 107,437 & 21,975 & 129,412 \\
\hline
\end{tabular}

$a$ Including foreign base bullion refined in bond.

$b$ Including a small quantity of lead produced in the Southern States.

In 1886, however, another source of lead began to assume importance and became a factor, introducing further complications. The smelters of the Rocky Mountain regions, some of the desilverizers, and a number of border plants began to draw largely, first upon Mexico, and later upon British Columbia, for growing quantities of 
argentiferous lead ores. Before the advent of these supplies the product of the American mines was easily arrived at by adding together the desilverized and the soft lead. From 1886 on the third table was prepared, and for a series of years the lead production was held to be the total output, deducting the lead contents of the foreign ores smelted.

Later on the refining in bond of foreign base bullion became an important industry. Varying quantities of the metal so produced were retained in this country for home consumption. A certain quantity was "exempt" from payment of duty as representing the metallurgical loss, and varying amounts are entered for domestic consumption by the payment of duty. The overlapping of receipts and shipments from one year to the other and the time required for the completion of the treatment of the material to the marketable product introduced uncertainties which rendered unreliable the simple and direct method of deducting from the total product of refined lead the estimated lead contents of the foreign material imported during the year.

Since it was also deemed highly desirable to ascertain as closely as possible the source, territorially, of our home product, the system was adopted of ascertaining through the smelters the quantities of lead in the ores worked by them from different States and Territories. From these returns the estimates of the domestic product have been made which appear in the following table in the last column, the system having been adopted in 1894:

Production of refined lead in the United States from 1886 to 1899.

\begin{tabular}{|c|c|c|c|c|c|}
\hline Year. & $\begin{array}{l}\text { Total pro- } \\
\text { duction. (a) }\end{array}$ & $\begin{array}{c}\text { Desilverized } \\
\text { lead. }(a)\end{array}$ & Soft lead.(b) & $\begin{array}{l}\text { From for- } \\
\text { eign oresand } \\
\text { base bullion. }\end{array}$ & $\begin{array}{l}\text { Net Ameri- } \\
\text { can product }\end{array}$ \\
\hline $1886 \ldots$ & $\begin{array}{r}\text { Short tons. } \\
135,629\end{array}$ & $\begin{array}{r}\text { Short tons. } \\
114,829\end{array}$ & $\begin{array}{r}\text { Short tons. } \\
20,800\end{array}$ & $\begin{array}{r}\text { Short tons. } \\
\text { c5 } 5,000\end{array}$ & $\begin{array}{r}\text { Short tons. } \\
\text { c } 130,629\end{array}$ \\
\hline $1887 \ldots$ & 160,700 & 135,552 & 25,148 & $c 15,000$ & $c 145,700$ \\
\hline 1888 & 180,555 & 151,465 & 29,090 & 28,636 & 151,919 \\
\hline $1889 \ldots$ & 182,967 & 153,709 & 29,258 & 26,570 & 156,397 \\
\hline $1890 \ldots$ & 161,754 & 130,403 & 31,351 & 18,124 & 143,630 \\
\hline $1891 \ldots$ & 202,406 & 171,009 & 31,397 & 23,852 & 178,554 \\
\hline $1892 \ldots$ & 213,262 & 181,584 & 31,678 & 39,957 & 173,305 \\
\hline $1893 \ldots$ & 229,333 & 196,820 & 32,513 & 65,351 & 163,982 \\
\hline $1894 \ldots$ & 219,090 & 181,404 & 37,686 & 59,739 & $d 162,686$ \\
\hline 18ิ9ิ5. . & 241,882 & 201,992 & 39,890 & 76,173 & $d 170,000$ \\
\hline 1896. & 264,994 & 221,457 & 43,537 & 77,738 & $d 188,000$ \\
\hline $1897 .$. & 291,036 & 247,483 & 43,553 & 83,671 & $d 212,000$ \\
\hline $1898 \ldots$ & 310,621 & 267,842 & 42,779 & 99,945 & $d 222,000$ \\
\hline 1899 & 304,392 & 263,826 & 40,566 & 95,926 & $d 210,500$ \\
\hline
\end{tabular}

$a$ Including foreign base bullion refined in bond.

$b$ Including a small quantity of lead produced in the Southern States. $c$ Estimated.

d Arrived at from direct returns from smelters. 
Hard lead. - Since 1891 special returns from desilverizers have been made on the quantity of antimonial or hard lead produced. The quan. tity was 4,043 tons in 1891, 5,039 tons in 1892, and 5,013 tons in 1893. In 1896 the production of hard lead was 7,507 tons, rising to 8,867 tons in 1897, and declining again to 8,473 tons in 1898 . It amounted to 6,345 tons in 1899 .

\section{SOURCES OF LEAD.}

Since 1894, tbrough the courteous cooperation of the lead smelters and refiners, returns have been received showing the lead contents of the ores smelted by them, whether from domestic or from foreign ores. In 1899 some complications were created by the formation of the American Smelting and Refining Company. For some of the works which became properties of the new company figures were only available which covered the first year of its operations, from May, 1899, to May, 1900. The totals given in the table for the year 1899 do not in all cases cover the calendar year, and therefore are not exact as to that period. They are presented, however, as being the best available under the circumstances.

Lead contents of ores smelted by the works in the United States.

\begin{tabular}{|c|c|c|c|c|c|c|}
\hline State or Territory. & 1894. & 1895. & 1896. & 1897. & 1898. & 1899. \\
\hline & Shoit tons. & Short tons. & Short tons. & Short tons. & Short tons. & Short tons \\
\hline Colorado .. & 50,613 & 46,984 & 44,803 & 40,576 & 57,352 & 70,308 \\
\hline Idaho ......... & 33,308 & 31,638 & 46,662 & 58,627 & 59,142 & 52,154 \\
\hline Utah ........... & 23,190 & 31,305 & 35,578 & 40,537 & 39,299 & 29,987 \\
\hline Montana ....... & 9,637 & 9,802 & 11,070 & 12,930 & 10,745 & 10,227 \\
\hline New Mexico ... & 2,973 & 3,040 & 3,461 & 9,123 & 5,797 & 4,856 \\
\hline Nevada..... & 2,254 & 2,583 & 1,173 & 959 & 4,714 & 3,388 \\
\hline Arizona ..... & 1,480 & 2,053 & 1,165 & 2,184 & 2,224 & 3,377 \\
\hline California ......... & 478 & 949 & 691 & 383 & 482 & 487 \\
\hline $\begin{array}{l}\text { Washington, Oregon, } \\
\text { Alaska, South Da- } \\
\text { kota, Texas.......... }\end{array}$ & 150 & 381 & 1,006 & 638 & 1,349 & 862 \\
\hline $\begin{array}{l}\text { Missouri, Kansas, Wis- } \\
\text { consin, Ill in ois, } \\
\text { Iowa, Virginia....... }\end{array}$ & 46,300 & 53,596 & 51,887 & 56,542 & 54,469 & 54,444 \\
\hline $\begin{array}{l}\text { Total lead con- } \\
\text { tents Ameri- } \\
\text { c a n o res } \\
\text { smelted ..... }\end{array}$ & \multirow[t]{5}{*}{170,383} & \multirow{5}{*}{$\begin{array}{r}182,331 \\
16,437 \\
5,040\end{array}$} & \multirow{4}{*}{$\begin{array}{r}197,496 \\
15,403 \\
10,100\end{array}$} & 222,499 & 235,573 & 230,090 \\
\hline Contents Mexican ores. & & & & 13,430 & 10,520 & 10,293 \\
\hline Contents Canadian ores & & & & 19,515 & 17,377 & 5,110 \\
\hline Contents miscellane- & & & & & & \\
\hline ous or unknown & & & 2,118 & 344 & 428 & 772 \\
\hline
\end{tabular}

a Estimated. 
The figures presented for Missouri, Kansas, etc., are an aggregate of two sets of returns, one the pig lead made by local smelters and works in the St. Louis district, usually reported as "soft lead," and the other the lead contents of ores, concentrates, and furnace products purchased by desilverizing works and by smelters of argentiferous ores, according to the returns the second smelted material carrying 13,878 short tons of lead.

. In view of the fact that the smelter returns do not all cover the same period, they can not well be used for the year 1899, as the basis for the United States production, by the method usually adopted by this office since it first became necessary to resort to it in 1894 . From a study of the detailed figures available, an estimate of 210,500 short tons as the product of the lead mines of the United States has been accepted.

\section{DOMESTIC PRODUCERS.}

In spite of the fact that the majority of the largest smelting works in Colorado were closed down for two months in 1899, as the result of a strike, the lead product credited to the State shows a very important increase. This has been chiefly due to a larger output in the Leadville district and at Aspen.

Idaho suffered a decline, largely because of labor troubles, which led to the blowing up of the large concentrating plant of the Bunker Hill and Sullivan Company.

Utah has not come up to its usual tonnage.

A great deal of activity has been displayed in extending the older mines of southwest Missouri and in developing new territory. Interests identified with smelting in other sections and with lead manufactures have entered the field.

The St. Joseph Lead Company, of Bonneterre, by far the largest producer, has started two new shafts in Big River west of Desloge.

The Doe Run Lead Company has put down its No. 4 shaft. The Central Lead Company at Flat River has made general betterments and has had the benefit of the new Thacher shaft. The same interests have formed the Penicant Lead Company, having acquired lands at Bonneterre.

In southeast Washington County the Renault Lead Company is working the old Palmer mines much more systematically than ever before, and it is likely that the production, greater than in its best days, will become regular. Two new air furnaces have been added, making five in all, this company being the only one in Missouri which is running air furnaces regularly.

The most comprehensive recent undertaking is that of the National Lead Company, operating under the title of the St. Louis Smelting and Refining Company, all of whose stock it controls. Two shafts 
have been sunk, and a concentrating mill, to have an ultimate capacity of 1,000 tons of rock per day, is being built. A part of this plant was started in 1900 .

Interests identified with the Guggenheim Brothers have formed the Federal Lead Company, which has purchased the old Leadington property and the plant of the Missouri Smelting Company near St. Louis.

In 1899 the Columbia Lead Company finished its shaft, and a second one has been sunk. Early in January, 1900, this company started the concentrating mill, which is producing an average of 25 tons of concentrates daily, and this is to be doubled. The concentrates are being shipped to the Missouri Smelting Company at St. Louis, and to plants at Argentine, Kansas, Newark, and Pittsburg. The same interests, the Catharine Lead Company, of Fredericktown, are developing a property immediately adjoining the Mine La Motte, in Madison County, and are completing a concentrating mill capable of treating 200 tons of rock per day. For the purpose of smelting the concentrates of the Columbia and Catharine companies, a plant is being built to be known as the Continental Smelting Company. Mr. H. J. Cantwell is the leading spirit in these enterprises.

In 1899 the Derby Lead Company started two shafts, but have not as yet begun on a mill.

Exploration and development are going on in connection with a number of other properties. Thus, George Cole, of Farmington, Missouri, and associates are sinking a shaft at Irondale, Missouri, to reach ore deposits proved by very extensive diamond drilling. The ore zone is 48 feet thick at the shaft. Preparations are being made to build a mill to handle 200 tons of rock per day, with motive power enough to take care of double the quantity. It is expected that the product will be about 20 tons of concentrates per twenty-four hours, with 65 to 70 per cent of lead. The company is to be known as the Irondale Lead Company.

A similar plant will be opened by the same interests to develop ground proved by drilling at Fredericktown, Madison County. The company has been organized under the laws of Delaware, under the title of the Great Western Lead Company.

The Elizabeth Lead Company and the Standard Lead Company are also drilling, the latter at Big River.

The Joplin-Galena district showed a falling off in 1899, the total sales being reported as 23,953 tons in that year as compared with 26,475 short tons in 1898 and 29,578 short tons in 1897. Among the leading camps Joplin declined from 8,329 short tons of lead ore in 1898 to 6,513 tons in 1899; Galena, from 7,878 tons in 1898 to 7,083 tons in 1899, and Duenweg from 2,194 tons in 1898 to 1,272 tons in 1899. Carterville increased from 4,246 tons in 1898 to 5,193 short tons in 1899. 
The local smelters, the Picher Lead Company, the Granby Mining and Smelting Company, J. B. Serage, the Case Lead Company, and the Galena-Empire Lead Smelting Company produced 7,663 short tons of lead in 1899 as compared with 6,869 tons in 1898 and 6,975 tons in 1897.

\section{CONSUMPTION.}

Based on the data at hand, the following estimate is presented of the consumption of lead in recent years. The figures representing domestic stocks are aggregates of returns received by this office. They are not, however, complete:

Estimate of the consumption of lead in the United States from 1894 to 1899.

\begin{tabular}{|c|c|c|c|c|c|c|}
\hline & 1894. & 1895. & 1896. & 1897. & 1898. & 1899. \\
\hline \multicolumn{7}{|l|}{ Supply- } \\
\hline $\begin{array}{l}\text { Total product desilver- } \\
\text { ized lead............. }\end{array}$ & $\begin{array}{l}\text { Short tons. } \\
181,404\end{array}$ & Short tons. & $\begin{array}{l}\text { Short tons. } \\
221,457^{\circ}\end{array}$ & $\begin{array}{l}\text { Short tons } \\
247,483\end{array}$ & $\left\{\begin{array}{l}\text { Short tons } \\
267,827\end{array}\right.$ & $\begin{array}{l}\text { Short tons. } \\
263,826\end{array}$ \\
\hline Soft lead $\ldots \ldots \ldots \ldots \ldots$ & 37,686 & 39,890 & 43,537 & 43,553 & 42,779 & 40,566 \\
\hline Imports, foreign refined.. & 8,200 & 22,947 & 2,020 & 2,000 & 437 & 215 \\
\hline $\begin{array}{l}\text { Stock, domestic, begin- } \\
\text { ning of year........... }\end{array}$ & 7,496 & 8,586 & 9,557 & 9,299 & 17,608 & \\
\hline $\begin{array}{l}\text { Stock, foreign in bond, } \\
\text { beginning of year..... }\end{array}$ & 3,302 & 7,181 & 9,865 & 4,124 & 6,691 & 7,341 \\
\hline Total supply.. & 238,088 & 280,596 & 286,436 & 306,459 & 335,342 & 311,948 \\
\hline \multicolumn{7}{|l|}{ Deduct- } \\
\hline $\begin{array}{l}\text { Foreign base bullion and } \\
\text { ores refined in bond } \\
\text { and exported ............ }\end{array}$ & 29,000 & 18,130 & 57,612 & 62,409 & 84,666 & 73,313 \\
\hline $\begin{array}{l}\text { Lead in manufactures } \\
\text { exported under draw- } \\
\text { back ...................... }\end{array}$ & 950 & 2,000 & 1,500 & 500 & 1,200 & 1,000 \\
\hline $\begin{array}{l}\text { Stock, domestic, close of } \\
\text { year..................... }\end{array}$ & 8,586 & 9,557 & 9,299 & 17,608 & 14,683 & \\
\hline Stock, foreign in bond... & 7,181 & 9,865 & 4,124 & 6,694 & 7,341 & 11,320 \\
\hline Total . . & 45,717 & 39,552 & 72,535 & 87,211 & 107,890 & 85,633 \\
\hline Consumption ... & 192,371 & 241,044 & 213,901 & 219,248 & 227,452 & 226,315 \\
\hline
\end{tabular}

During the year 1899 no figures have been collected on domestic stocks. The apparent home consumption was nearly as heavy as that of the previous year. 


\section{IMPORTS AND EXPORTS.}

The following tables are from the records of the Bureau of Statistics:

Lead imported and entered for consumption in the United States, 1867 to 1899.

\begin{tabular}{|c|c|c|c|c|}
\hline \multirow{2}{*}{ Year ending- } & \multicolumn{2}{|c|}{ Ore and dross. } & \multicolumn{2}{|c|}{ Pigs and bars. } \\
\hline & Quantity. & Value. & Quantity. & Value. \\
\hline June $30-$ & Pounds. & & Pounds. & \\
\hline $1867 \ldots$ & 611 & $\$ 25$ & $65,322,923$. & $\$ 2,812,668$ \\
\hline 1868. & 6,945 & 239 & $63,254,677$ & $2,668,915$ \\
\hline $1869 .$. & & $\cdots \cdots$ & $87,865,471$ & $3,653,481$ \\
\hline $1870 .$. & 5,973 & 176 & $85,895,724$ & $3,530,837$ \\
\hline $1871 \ldots$ & 316 & 10 & $91,496,715$ & $3,721,096$ \\
\hline $1872 \ldots$ & 32,231 & 1,425 & $73,086,657$ & $2,929,623$ \\
\hline $1873 .$. & $\cdots$ & & $72,423,641$ & $3,233,011$ \\
\hline $1874 \ldots$ & 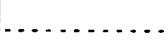 & $\ldots$ & $46,205,154$ & $2,231,817$ \\
\hline $1875 .$. & 13,206 & 320 & $32,770,712$ & $1,559,017$ \\
\hline 1876. & & & $14,329,366$ & 682,132 \\
\hline $1877 .$. & 1,000 & 20 & $14,583,845$ & 671,482 \\
\hline $1878 .$. & & $\cdots$ & $6,717,052$ & 294,233 \\
\hline 1879. & & $\cdots$ & $1,216,500$ & 42,983 \\
\hline 1880. & ...... & . & $6,723,706$ & 246,015 \\
\hline $1881 .$. & 5,981 & 97 & $4,322,068$ & 159,129 \\
\hline 1882. & 21,698 & 500 & $6,079,304$ & 202,603 \\
\hline $1883 .$. & 600 & 17 & $4,037,867$ & 130,108 \\
\hline $1884 \ldots$ & 419 & 13 & $3,072,738$ & 85,395 \\
\hline 1885. & 4,218 & 57 & $5,862,474$ & 143,103 \\
\hline 1886. & 715,588 & 9,699 & $17,582,298$ & 491,310 \\
\hline \multicolumn{5}{|l|}{ December 31- } \\
\hline $1887 .$. & 153,731 & 21,487 & $7,716,783$ & 219,770 \\
\hline $1888 \ldots$ & 88,870 & 2,468 & $2,582,236$ & 69,891 \\
\hline $1889 .$. & 328,315 & 7,468 & $2,773,622$ & 76,243 \\
\hline $1890 .$. & $11,065,865$ & 504,067 & $19,336,233$ & 593,671 \\
\hline $1891 \ldots$ & $40,692,478$ & $1,120,067$ & $3,392,562$ & 104,184 \\
\hline $1892 \ldots$ & $54,249,291$ & $1,278,114$ & $.1,549,771$ & 110,953 \\
\hline $1893 .$. & $58,487,319$ & $1,004,295$ & $3,959,781$ & 129,290 \\
\hline $1894 \ldots$ & $33,020,250$ & 437,999 & $39,168,529$ & 895,496 \\
\hline $1895 \ldots$ & $45,050,674$ & 687,222 & $109,551,082$ & $2,052,209$ \\
\hline $1896 \ldots$ & $37,829,583$ & 631,381 & $10,551,148$ & 191,479 \\
\hline $1897 \ldots$. & $31,036,882$ & 535,094 & $16,050,987$ & 314,549 \\
\hline 1898. & $16,610,607$ & 331,116 & 311,502 & 8,787 \\
\hline $1899 \ldots \ldots \ldots$ & $6,824,556$ & 125,344 & $3,473,252$ & 78,062 \\
\hline
\end{tabular}


Lead imported and entered for consumption in the United States, etc.-Continued.

\begin{tabular}{|c|c|c|c|c|c|c|}
\hline \multirow{2}{*}{ Year ending- } & \multicolumn{2}{|c|}{ Sheets, pipe, and shot. } & \multicolumn{2}{|c|}{ Shot. } & \multirow{2}{*}{$\begin{array}{c}\text { Not oth- } \\
\text { erwise } \\
\text { specified. }\end{array}$} & \multirow{2}{*}{ Total value. } \\
\hline & Quantity. & Value. & Quantity. & Value. & & \\
\hline June $30-$ & Pounds. & & Pounds. & & & \\
\hline $1867 \ldots \ldots \ldots \ldots$ & 185,825 & $\$ 9,560$ & . & & $\$ 6,222$ & $\$ 2,828,475$ \\
\hline $1868 \ldots$ & 142,137 & 7,229 & & & 6,604 & $2,682,987$ \\
\hline $1869 \ldots$ & 307,424 & 15,531 & $\ldots \ldots$ & $\cdots$ & 18,885 & $3,687,897$ \\
\hline $1870 \ldots$ & 141,681 & 6,879 & $\cdots$ & $\begin{array}{c}- \\
-\end{array}$ & 10,444 & $3,548,336$ \\
\hline $1871 \ldots \ldots \ldots$ & 86,712 & 4,209 & & & 8,730 & $3,734,045$ \\
\hline $1872 \ldots$ & 15,518 & 859 & - & $\cdots$ & 20,191 & $2,952,098$ \\
\hline $1873 \ldots$ & 105 & 12 & 420 & $\$ 50$ & 21,503 & $3,254,576$ \\
\hline 1874 & $\ldots \ldots$ & $\cdots$ & 30,219 & 1,349 & 36,484 & $2,269,650$ \\
\hline 1875 & & & 58 & 4 & 25,774 & $1,585,115$ \\
\hline 1876. & $\cdots$ & $\cdots$ & 20,007 & 1,204 & 27,106 & 710,442 \\
\hline $1877 \ldots$ & $\cdots$ & $\ldots$ & 16,502 & 1,242 & 1,041 & 673,785 \\
\hline 1878 . & 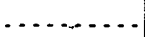 & & 15,829 & 963 & 113 & 295,309 \\
\hline 1879. & & - & 3,748 & 209 & 930 & 44,122 \\
\hline 1880 & $\ldots \ldots \ldots$ & & 1,120 & 54 & 371 & 246,440 \\
\hline $1881 \ldots$ & $\cdots$ & $\cdots$ & 900 & 65 & 1,443 & 160,734 \\
\hline 1882 . & & & 1,469 & 99 & 2,449 & 205,651 \\
\hline 1883. & $\ldots .$. & $\ldots$ & 1,510 & 79 & 8,030 & 138,234 \\
\hline $1884 \ldots \ldots$ & 15,040 & 630 & & & 1,992 & 88,030 \\
\hline $1885 \ldots$ & 971,951 & 22,217 & & & 1,372 & 166,749 \\
\hline $1886 \ldots \ldots$ & 27,357 & 1,218 & & & 964 & 503,191 \\
\hline December $31-$ & & & & & & \\
\hline $1887 \ldots$ & 27,941 & 1,286 & & & 302 & 242,845 \\
\hline $1888 \ldots$ & 23,103 & 1,202 & & & 977 & 74,538 \\
\hline 1899 & 35,859 & 1,417 & .. & & 1,297 & 86,425 \\
\hline 1890 & 91,660 & 5,591 & & & 1,136 & $1,104,465$ \\
\hline $1891 \ldots$ & 334,179 & 12,406 & & & 604 & $1,237,467$ \\
\hline 1892. & 90,135 & 6,207 & & & 2,063 & $1,397,337$ \\
\hline $1893 \ldots$ & 59,798 & 2,955 & & & 1,691 & $1,138,231$ \\
\hline $1894 \ldots$ & 44,080 & 2,050 & & & 536 & $1,336,081$ \\
\hline 1895 & 128,008 & 5,030 & & & 1,277 & $2,745,738$ \\
\hline $1896 \ldots$ & 96,010 & 3,818 & & & 644 & 827,322 \\
\hline $1897 \ldots$ & 95,891 & 4,042 & & & 513 & 854,198 \\
\hline 1898. & 242,759 & 9,389 & & & 312 & 349,604 \\
\hline $1899 \ldots \ldots$ & 110,372 & 4,402 & & & 8,626 & 216,434 \\
\hline
\end{tabular}


LEAD.

Old and scrap lead imported and entered for consumption into the United States, 1867 to 1889.

\begin{tabular}{|c|c|c|c|c|c|}
\hline Year ending - & Quantity. & Value. & Year ending- & Quantity. & Value. \\
\hline June $30-$ & Pounds. & & June $30-$ & Pounds. & \\
\hline 1867 & $1,256,233$ & $\$ 53,202$ & $1880 \ldots$ & 213,063 & $\$ 5,262$ \\
\hline 1868 & $2,465,575$ & 101,586 & $1881 \ldots$ & 123,018 & 2,729 \\
\hline $1869 \ldots$ & $2,983,272$ & 123,068 & 1882. & 220,702 & 5,949 \\
\hline $1870 \ldots$ & $3,756,785$ & 150,379 & $1883 \ldots$ & $1,094,133$ & 31,724 \\
\hline 1871. & $2,289,688$ & 94,467 & 1884. & 160,356 & 4,830 \\
\hline 1872 & $4,257,778$ & 171,324 & $1885 \ldots$ & 4,866 & 106 \\
\hline $1873 .$. & $3,545,098$ & 151,756 & December $31-$ & & \\
\hline $1874 \ldots$ & 395,516 & 13,897 & $1886 \ldots$ & 24,726 & 882 \\
\hline 1875. & 382,150 & 13,964 & 1887. & 136,625 & 4,323 \\
\hline $1876 \ldots$ & 265,860 & 9,534 & 1888. & 33,100 & 904 \\
\hline $1877 \ldots \ldots$ & 249,645 & 8,383 & $1889 \ldots$ & 50,816 & 1,494 \\
\hline $1878 \ldots$ & 106,342 & 3,756 & $1890 \ldots$ & (a) & (a) \\
\hline $1879 \ldots$ & 42,283 & 1,153 & & & \\
\hline
\end{tabular}

$a$ Included in pigs and bars after 1889.

Lead, and manufactures of lead, of domestic production, exported from the United States.

\begin{tabular}{|c|c|c|c|c|c|c|}
\hline \multirow{3}{*}{ Year ending- } & \multicolumn{3}{|c|}{ Manufactures of- } & \multirow{2}{*}{\multicolumn{2}{|c|}{ Pigs, bars, and old. }} & \multirow{3}{*}{$\begin{array}{c}\text { Total } \\
\text { value. }\end{array}$} \\
\hline & \multicolumn{2}{|c|}{ Lead. } & \multirow{2}{*}{$\begin{array}{c}\begin{array}{c}\text { Pewter } \\
\text { and lead. }\end{array} \\
\text { Value. }\end{array}$} & & & \\
\hline & Quantity. & Value. & & Quantity. & Value. & \\
\hline September 30 & Pounds. & & & Pounds. & & \\
\hline $1790 \ldots \ldots$ & 13,440 & $\$ 810$ & 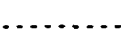 & 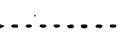 & 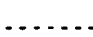 & $\$ 810$ \\
\hline $1803 \ldots \ldots$ & a 900 & . & $\ldots$ & $\ldots$ & $\ldots$ & $\ldots$ \\
\hline $1804 \ldots \ldots$ & 19,804 & 皮 & & & & \\
\hline $1805 \ldots$ & 8,000 & $\cdots$ & $\cdots$ & 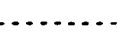 & 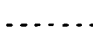 & \\
\hline 1808. & 40,583 & & & & & \\
\hline 1809 & 126,537 & 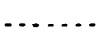 & & & 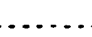 & \\
\hline $1810 \ldots$ & 172,323 & $\cdots$ & & & & \\
\hline 1811:. & 65,497 & & & & & \\
\hline $1812 \ldots$ & 74,875 & - & & & & \\
\hline $1813 \ldots$ & 276,940 & $\cdots$ & $\ldots$ & & & \\
\hline $1814 \ldots$. & 43,600 & $\ldots$ & - & & & \\
\hline $1815 \ldots$ & 40,245 & & & & & \\
\hline $1816 \ldots$ & 35,844 & 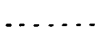 & $\ldots$ & & & 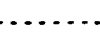 \\
\hline $1817 \ldots$ & 111,034 & 9,993 & $\ldots . .$. & $\cdots$ & & 9,993 \\
\hline $1818 \ldots \ldots$ & 281,168 & 22,493 & . & & & 22,493 \\
\hline
\end{tabular}

a Barrels. 
Lead, and manufactures of lead, of domestic production, exported, etc.-Continued.

\begin{tabular}{|c|c|c|c|c|c|c|}
\hline \multirow{3}{*}{ Year ending- } & \multicolumn{3}{|c|}{ Manufactures of- } & \multirow{2}{*}{\multicolumn{2}{|c|}{ Pigs, bars, and old. }} & \multirow{3}{*}{$\begin{array}{l}\text { Total } \\
\text { value. }\end{array}$} \\
\hline & \multicolumn{2}{|c|}{ Lead. } & \multirow{2}{*}{$\begin{array}{c}\begin{array}{c}\text { Pewter } \\
\text { and lead. }\end{array} \\
\text { Value. }\end{array}$} & & & \\
\hline & Quantity. & Value. & & Quantity. & Value. & \\
\hline September $30-$ & Pounds. & & & Pounds. & & \\
\hline 1819 & 94,362 & $\$ 7,5+9$ & & & & $\$ 7,549$ \\
\hline $1820 \ldots$ & 25,699 & 1,799 & 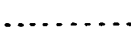 & & 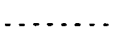 & 1,799 \\
\hline $1821 \ldots$ & 56,192 & 3,512 & . & & $\ldots \ldots$ & 3,512 \\
\hline 1822. & 66,316 & 4,244 & $\ldots \ldots$ & & & 4,244 \\
\hline $1823 \ldots$ & 51,549 & 3,098 & . & & & 3,098 \\
\hline $1824 \ldots$ & 18,604 & 1,356 & $\ldots .$. & 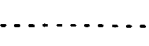 & $=-$ & 1,356 \\
\hline 1825. & 189,930 & 12,697 & . & & 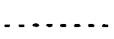 & 12,697 \\
\hline 1826 & 47,337 & 3,347 & $\$ 1,820$ & & & 5,167 \\
\hline $1827 \ldots$ & 50,160 & 3,761 & 6,183 & - & $\ldots$ & 9,944 \\
\hline 1828 & 76,882 & 4,184 & 5,545 & & -2 & 9,729 \\
\hline 1829 & 179,952 & 8,417 & 5,185 & & & 13,602 \\
\hline $1830 \ldots$ & 128,417 & 4,831 & 4,172 & & & 9,003 \\
\hline $1831 \ldots$ & 152,578 & 7,068 & 6,422 & 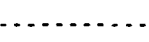 & & 13,490 \\
\hline $1832 \ldots$ & 72,439 & 4,483 & 983 & & & 5,466 \\
\hline 1833 & 119,407 & 5,685 & 2,010 & & & 7,695 \\
\hline 1834 & 13,480 & 805 & 2,224 & & & 3,029 \\
\hline 1835 & 50,418 & 2,741 & 433 & & & 3,174 \\
\hline 1836 & 34,600 & $2,21 \mathrm{~S}$ & 4,777 & & & 6,995 \\
\hline $1837 \ldots$ & 297,488 & 17,015 & 3,132 & & & 20,147 \\
\hline 1838 & 375,231 & 21,747 & 6,461 & - & $\therefore$ & 28,208 \\
\hline 1839 & 81,377 & 6,003 & 12,637 & & & 18,640 \\
\hline 1810 & 882,620 & 39,687 & 15,296 & & & 54,983 \\
\hline $1841 \ldots$ & $2,177,164$ & 96,748 & 20,546 & - & & 117,294 \\
\hline $1842 \ldots$ & $14,552,357$ & 523,428 & 16,789 & & & 540,217 \\
\hline \multicolumn{7}{|l|}{ June $30-$} \\
\hline $1843(a)$ & $15,366,918$ & 492,765 & 7,121 & & & 499,886 \\
\hline $1844 \ldots \ldots \ldots$ & $18,420,407$ & 595,238 & 10,018 & & & 605,256 \\
\hline $1845 \ldots . .$. & $10,188,024$ & 342,646 & 14,404 & & & 357,050 \\
\hline 1846. & $16,823,766$ & 614,518 & 10,278 & & & 624,796 \\
\hline 1847. & $3,326,028$ & $\overline{1} 2 \hat{2} \dot{4}, \hat{9} \bar{I}$ & 13,694 & & & 138,675 \\
\hline $1848 \ldots$. & $1,994,704$ & 84,278 & 7,730 & & & 92,017 \\
\hline $1849 \ldots$ & 680,249 & 30,198 & 13,196 & & & 43,394 \\
\hline $1850 \ldots$. & 261,123 & 12,797 & 22,682 & & 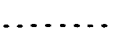 & 35,479 \\
\hline $185 \check{1}$ & & & 16,426 & 229,448 & $\$ 11,774$ & 28,200 \\
\hline 1852 & & & 18,469 & 747,930 & 32,725 & 51,194 \\
\hline
\end{tabular}

a Nine months. 
LEAD.

ILead, and manufactures of lead, of domestic production, exported, etc.-Continuerl.

\begin{tabular}{|c|c|c|c|c|c|c|}
\hline \multirow{3}{*}{ Year ending- } & \multicolumn{3}{|c|}{ Manufactures of- } & \multirow{2}{*}{\multicolumn{2}{|c|}{ Pigs, bars, and old. }} & \multirow{3}{*}{$\begin{array}{c}\text { Total } \\
\text { value. }\end{array}$} \\
\hline & \multicolumn{2}{|c|}{ Lead. } & \multirow{2}{*}{$\begin{array}{c}\begin{array}{c}\text { Pewter } \\
\text { and lead. }\end{array} \\
\text { Value. }\end{array}$} & & & \\
\hline & Quantity. & Value. & & Quantity. & Value. & \\
\hline June 30 & Pounds. & & & Pounds. & & \\
\hline 1853. & $\ldots \ldots$ & - & $\$ 14,064$ & 100,778 & $\$ 5,540$ & $\$ 19,604$ \\
\hline 1854 & - & & 16,478 & 404,247 & 26,874 & 43,352 \\
\hline 1855 & - & & 5,233 & 165,533 & 14,298 & 19,531 \\
\hline 1856. & $\cdots$ & - & 5,628 & 310,029 & 27,512 & 33,140 \\
\hline 1857. & $\ldots \ldots$ & & 4,818 & 870,544 & 58,624 & 63,442 \\
\hline 1858 & $\cdots$ & & 27,327 & 900,607 & $48,119^{\circ}$ & 75,446 \\
\hline 1859 & $\cdots$ & $\cdots$ & 28,782 & 313,988 & 28,575 & 57,357 \\
\hline 1860. & $\ldots$ & & 56,081 & 903,468 & 50,446 & 106,527 \\
\hline 1861. & & & 30,534 & 109,023 & 6,241 & 36,775 \\
\hline 1862 & $\therefore$ & & 28,832 & 79,231 & 7,334 & 36,166 \\
\hline 1863. & .. & - & . 30,609 & 237,239 & 22,634 & 53,243 \\
\hline 1864 & . & & 30,411 & 223,752 & 18,718 & 49,129 \\
\hline 1865. & $\cdots$ & $\ldots$ & 29,271 & 852,895 & 132,666 & 161,937 \\
\hline 1866. & - & & 44,483 & 25,278 & 2,323 & 46,806 \\
\hline $1867 \ldots$ & $\cdots$ & $\ldots \ldots$ & 27,559 & 99,158 & 5,300 & 32,859 \\
\hline 1868. & $\ldots \ldots$ & $\cdots$ & 37,111 & 438,040 & 34,218 & 71,329 \\
\hline 1869 & $\ldots$ & $\ldots \ldots$ & 17,249 & & & 17,249 \\
\hline 1870. & $\cdots$ & $\$ 28,315$ & $\ldots . .$. & - & & 28,315 \\
\hline 1871. & - & 79,880 & & & & 79,880 \\
\hline 1872. & -. & 48,132 & - . & & & 48,132 \\
\hline 1873. & & 13,392 & & & & 13,392 \\
\hline 1874. & & 302,044 & & & & 302,044 \\
\hline $1875 \ldots$ & ... & 429,309 & & & & 429,309 \\
\hline 1876 . & $\cdots$ & 102,726 & & & & 102,726 \\
\hline $187 \overline{7}$ & & 49,835 & & & & 49,835 \\
\hline 1878. & & 314,904 & & & & 314,904 \\
\hline 1879. & $\cdots$ & 280,771 & & & & 280,771 \\
\hline 1880 & - . & 49,899 & & & & 49,899 \\
\hline 1881. & -. & 39,710 & & & & 39,710 \\
\hline 1882. & $\ldots \ldots \ldots$ & 178,779 & & & & 178,779 \\
\hline $1883 \ldots$ & & 43,108 & & & & 43,108 \\
\hline 1884. & & 135,156 & & & & 135,156 \\
\hline 1885. & $\ldots$ & 123,466 & & 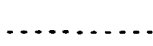 & & 123,466 \\
\hline December $31-$ & & & & & & \\
\hline 1886. & & 136,666 & $\cdots$ & & & 136,666 \\
\hline
\end{tabular}


Lead, and manufactures of lead, of domestic production, exported, etc.-Continued.

\begin{tabular}{|c|c|c|c|c|c|c|}
\hline \multirow{3}{*}{ Year ending- } & \multicolumn{3}{|c|}{ Manufactures of- } & \multirow{2}{*}{\multicolumn{2}{|c|}{ Pigs, bars, and old. }} & \multirow{3}{*}{$\begin{array}{c}\text { Total } \\
\text { value. }\end{array}$} \\
\hline & \multicolumn{2}{|c|}{ Lead. } & \multirow{2}{*}{$\begin{array}{c}\begin{array}{c}\text { Pewter } \\
\text { and lead. }\end{array} \\
\text { Value. }\end{array}$} & & & \\
\hline & Quantity. & Value. & & Quantity. & Value. & \\
\hline December $31-$ & Pounds. & \multirow[b]{2}{*}{$\$ 140,065$} & & Pounds. & & \multirow[b]{2}{*}{$\$ 140,065$} \\
\hline $1887 \ldots \ldots$ & $\ldots \ldots \ldots$ & & & & & \\
\hline $1888 \ldots \ldots \ldots$ & $\ldots \ldots \ldots \ldots$ & 194,216 & & - & $\ldots \ldots$ & 194,216 \\
\hline $1889 \ldots \ldots$ & ........ & 161,614 & & & & 161,614 \\
\hline $1890 \ldots \ldots$ & $\ldots \ldots$ & 181,030 & & & & 181,030 \\
\hline $1891 \ldots$ & ......... & 173,887 & & & $\ldots .$. & 173,887 \\
\hline $1892 \ldots$ & -. & 154,375 & & . & - & 154,375 \\
\hline 1893. & & 508,090 & & & & 508,090 \\
\hline $1894 \ldots .$. & $\ldots \ldots \ldots$ & 456,753 & & & $a \$ 41,240$ & 497,993 \\
\hline 1895. & $\cdots$ & 164,083 & & $1,696,879$ & 50,773 & 214,856 \\
\hline $1896 \ldots$ & - . & 164,877 & & $b 16,359,452$ & 442,496 & 607,373 \\
\hline & $c 150,473$ & $d 49,816$ & & & & \\
\hline 1897 & & $e 160,466$ & & $b 7,725,624$ & 223,037 & 433,319 \\
\hline 1898 & $\int c 265,062$ & $d 97,862$ & & 118960 & & \\
\hline 1898 & & $e 112,927$ & & 118,960 & 4,450 & 215,239 \\
\hline 189 & $\int c 314,348$ & $d 115,137$ & & $93 \quad 115$ & 4. 286 & 273979 \\
\hline & & $e 15$ & & บ5, 110 & 4,200 & 273,919 \\
\hline
\end{tabular}

$a$ Not enumerated between 1868 and July 1,1894 .

$b$ Part of this is foreign lead returned by collectors of customs by mistake as domestic lead.

$c$ Type.

$d$ Value of type.

$e$ Value of all other manufactures. 
According to the returns of the Treasury Department the sources of imports of lead in the calendar years 1894, 1895, 1896, 1897, 1898, and 1899 were as follows:

Sources of imports of lead.

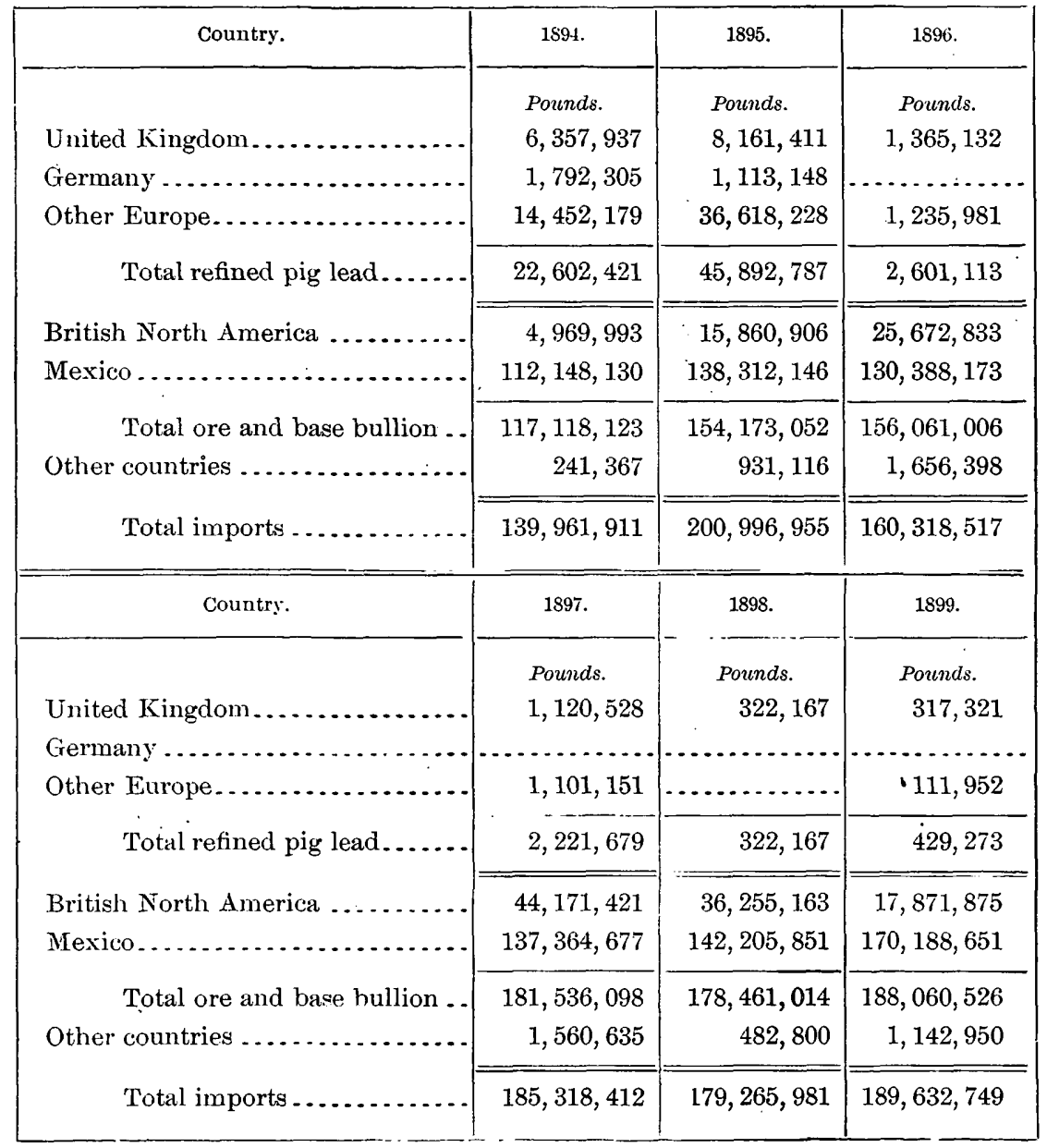

The subdivision by groups representing refined pig lead, and lead in ore and base bullion, is made by this office. 


\section{WAREHOUSE TRANSACTIONS.}

The following table shows the warehouse transactions of lead in ore and in base bullion, monthly, during 1899, and the corresponding totals for the years 1898 and 1897:

Imports of lead in ore and base bullion during calendar year 1899, showing uarehouse transactions by months.

\begin{tabular}{|c|c|c|c|c|}
\hline \multirow{2}{*}{ Month. } & \multirow{2}{*}{$\begin{array}{l}\text { Remaining in } \\
\text { warehouse first } \\
\text { day of each } \\
\text { month. }\end{array}$} & \multicolumn{2}{|c|}{ Entered warehouse. } & \multirow{2}{*}{$\begin{array}{l}\text { Addition by } \\
\text { liquidation. }\end{array}$} \\
\hline & & $\begin{array}{l}\text { Of direct impor- } \\
\text { tation. }\end{array}$ & $\begin{array}{l}\text { From other } \\
\text { districts. }\end{array}$ & \\
\hline January 1899 & $\begin{array}{l}\text { Pounds. } \\
\end{array}$ & $\begin{array}{l}\text { Pounds. } \\
24.850 .608\end{array}$ & $\begin{array}{l}\text { Pounds. } \\
19,945,043\end{array}$ & Pounds. \\
\hline February, 1899. & $18,483,661$ & $8,483,386$ & $14,722,445$ & 324 \\
\hline March, $1899 \ldots$ & $15,819,705$ & $23,237,093$ & $22,358,973$ & 76 \\
\hline April, $1899 \ldots$ & $20,593,091$ & $10,428,950$ & $24,266,490$ & 41,457 \\
\hline May, 1899 & $18,453,767$ & $18,920,397$ & $17,626,175$ & 4,820 \\
\hline June, 1899 & $18,511,755$ & $11,613,871$ & $20,419,811$ & 22,261 \\
\hline July, 1899 . & $17,399,593$ & $14,536,718$ & $13,225,535$ & \\
\hline August, 1899 & $17,530,363$ & $17,218,122$ & $19,022,160$ & 12,491 \\
\hline September, 1899 . & $20,035,710$ & $14,500,752$ & $12,729,296$ & 1,461 \\
\hline October, $1899 \ldots$ & $22,345,144$ & $10,983,796$ & $19,063,976$ & \\
\hline November, $1899 \ldots$ & $24,859,452$ & $15,441,651$ & $17,930,285$ & 56,288 \\
\hline December, 1899 . & $24,505,530$ & $18,297,110$ & $14,721,309$ & 7,392 \\
\hline January, 1900.. & $22,639,987$ & & $\cdots$ & \\
\hline Total, 1899 . & & $188,512,454$ & $216,031,498$ & $1,156,632$ \\
\hline Total, 1898 . & & $170,017,006$ & $177,837,309$ & $1,326,934$ \\
\hline Total, 1897... & $\ldots \ldots \ldots$ & $163,365,627$ & $167,963,673$ & 305,862 \\
\hline \multirow[b]{2}{*}{ Month. } & \multicolumn{3}{|c|}{ Withdrawn from warehouse. } & \multirow{2}{*}{$\begin{array}{l}\text { Deduction by } \\
\text { liquidation. }\end{array}$} \\
\hline & For exportation. & $\begin{array}{l}\text { For transporta- } \\
\text { tion. }\end{array}$ & $\begin{array}{l}\text { For consump- } \\
\text { tion. }\end{array}$ & \\
\hline January, 1899 & $\begin{array}{l}\text { Pounds. } \\
12,451,962\end{array}$ & $\begin{array}{l}\text { Pounds. } \\
26,732,404\end{array}$ & $\begin{array}{l}\text { Pounds. } \\
428,640\end{array}$ & $\begin{array}{c}\text { Pounds. } \\
2,392,030\end{array}$ \\
\hline February, 1899 & $13,379,257$ & $9,876,324$ & 898,649 & $1,715,881$ \\
\hline March, 1899 & $15,412,919$ & $23,479,117$ & 574,072 & $1,356,648$ \\
\hline April, $1899 \ldots$ & $11,916,397$ & $19,049,910$ & $3,695,992$ & $2,213,922$ \\
\hline May, $1899 \ldots$ & $11,968,351$ & $20,344,636$ & 856,915 & $3,323,502$ \\
\hline June, $1899 \ldots$ & $15,965,882$ & $13,256,126$ & 704,904 & $3,241,193$ \\
\hline July, $1899 \ldots$ & $11,348,459$ & $13,928,177$ & 539,194 & $1,815,653$ \\
\hline August, 1899. & $13,043,875$ & $17,485,408$ & 370,535 & $2,847,608$ \\
\hline September, 1899. & $10,554,582$ & $11,893,556$ & $2,067,767$ & 406,170 \\
\hline October, $1899 \ldots$ & $10,320,493$ & $12,846,312$ & $1,297,174$ & $3,069,485$ \\
\hline November, 1899. & $12,284,414$ & $15,668,635$ & $1,902,944$ & $3,926,153$ \\
\hline December, $1899 \ldots$. & $12,556,171$ & $19,985,211$ & $1,066,241$ & $1,283,731$ \\
\hline January, $1900 . . .$. & & & & $\ldots$ \\
\hline Total, 1899 & $151,202,762$ & $204,545,816$ & $14,403,027$ & $27,591,976$ \\
\hline Total, 1898. . & $147,978,938$ & $163,405,296$ & $7,844,184$ & $28,650,385$ \\
\hline Total, 1897... & $109,847,156$ & $183,006,461$ & $23,929,569$ & $7,769,593$ \\
\hline
\end{tabular}




\section{PRICES.}

The following table gives the highest and lowest prices monthly for a series of years, compiled from market quotations:

Highest and lowest prices of lead at New York City, monthly, from $18 \% 0$ to 1899, inclusive.

[Cents per pound.]

\begin{tabular}{|c|c|c|c|c|c|c|c|c|}
\hline \multirow{2}{*}{ Years. } & \multicolumn{2}{|c|}{ January. } & \multicolumn{2}{|c|}{ February. } & \multicolumn{2}{|c|}{ March. } & \multicolumn{2}{|c|}{ April. } \\
\hline & Highest. & Lowest. & Highest. & Lowest. & Highest. & Lowest. & Highest. & Lowest. \\
\hline 1870 & a 6.30 & 6.20 & 6.25 & 6.17 & 6.20 & 6.10 & 6.25 & 6.15 \\
\hline 1871. & a 6.30 & 6.15 & 6.25 & 6.20 & 6.20 & 6.15 & 6.20 & 6.10 \\
\hline 1872 & $a 6$ & 5.90 & 6 & 5.87 & 6 & 5.87 & 6.12 & 5.90 \\
\hline 1873. & a 6.37 & 6.25 & 6.50 & 6.40 & 6.50 & 6.25 & 6.50 & 6.25 \\
\hline 1874 & $a 6$ & 5.90 & 6.25 & 6 & 6.25 & 6.12 & 6.25 & 5.90 \\
\hline 1875. & $a 6.20$ & 6 & วั. 90 & 5.85 & 5.75 & 5.62 & 5.87 & 5.80 \\
\hline 1876 & $a 6$ & $5: 87$ & 6.37 & 6 & 6.50 & 6.40 & 6.40 & 6.12 \\
\hline 1877 & 66.15 & 6.12 & 6.40 & 6.20 & 6.75 & 6.50 & 6.50 & 6.25 \\
\hline 1878. & 4. 35 & 4 & 3.87 & 3.65 & 3.87 & 3.62 & 3.75 & 3. 50 \\
\hline 1879. & 4.50 & 4 & 4.50 & 4.50 & 4. 50 & 3.25 & 3.25 & 2.87 \\
\hline 1880 & 6.10 & 5. 50 & 6 & 5.87 & 5.95 & 5.30 & 5.75 & 5. 40 \\
\hline 1881. & 5 & 4. 30 & อ̆. 10 & 4. 80 & 4.85 & 4.62 & 4.85 & 4. 37 \\
\hline 1882. & 5.15 & 4.95 & 5. 20 & 5 & 5. 12 & 4.85 & 5 & 4. 90 \\
\hline 1883. & 4.70 & 4.60 & 4.60 & 4.50 & 4.65 & 4.50 & 4.62 & 4.40 \\
\hline 1884 & 4. 50 & 3. 75 & 4. $10^{\circ}$ & 3.75 & 4. 15 & 4. 10 & 4.05 & $3.62 \frac{1}{2}$ \\
\hline 1885 & 3.70 & 3.55 & 3.70 & 3.60 & 3. 70 & $3.62 \frac{1}{2}$ & 3.70 & $3.62 \frac{1}{2}$ \\
\hline 1886. & 4.70 & 4.50 & 4. 90 & 4. 60 & 4.95 & 4.85 & 4: 90 & 4.65 \\
\hline 1887. & 4.45 & 4. 15 & 4.50 & 4.25 & 4.45 & 4.25 & 4. $32 \frac{1}{2}$ & 4.20 \\
\hline 1888. & 4.90 & 4.50 & 5.15 & 4. 60 & 5.25 & 5 & 5.05 & 4.55 \\
\hline 1889. & 3.90 & 3.75 & 3.75 & 3.60 & 3.75 & 3.65 & $3.67 \frac{1}{2}$ & 3.60 \\
\hline 1890. & 3.85 & 3.80 & 3.85 & 3.75 & 3.95 & 3.85 & $4.07 \frac{1}{2}$ & 3.85 \\
\hline 1891 & 4.50 & 4.05 & 4.50 & 4. 25 & $4.37 \frac{1}{2}$ & 4.25 & 4. $32 \frac{1}{2}$ & 4. 10 \\
\hline 1892. & 4. 30 & 4. 10 & 4.25 & 4.05 & 4. $22 \frac{1}{2}$ & 4. 10 & 4.30 & 4. 20 \\
\hline $1893 \ldots$ & 3.90 & 3.85 & 3.95 & 3.90 & 4.05 & 3.85 & $4.12 \frac{1}{2}$ & 4.05 \\
\hline $1894 \ldots$. & 3.25 & 3.15 & 3.35 & 3.20 & 3.45 & 3.25 & 3.45 & $3.37 \frac{1}{2}$ \\
\hline 1895 & $3.12 \frac{1}{2}$ & 3.05 & $3.12 \frac{1}{2}$ & $3.07 \frac{1}{2}$ & 3. 10 & $3.07 \frac{1}{2}$ & $3.12 \frac{1}{2}$ & 3.05 \\
\hline 1896. & 3.15 & 3 & 3.20 & $3.07 \frac{1}{2}$ & $3.22 \frac{1}{2}$ & $3.07 \frac{1}{2}$ & $3.07 \frac{1}{2}$ & $3.02 \frac{1}{2}$ \\
\hline $1897 .$. & $3.12 \frac{1}{2}$ & $3.02 \frac{1}{2}$ & $3.37 \frac{1}{2}$ & $3.12 \frac{1}{2}$ & 3.40 & 3. 35 & 3.40 & 3.25 \\
\hline $1898 \ldots \ldots$ & 3. 70 & $3.55^{\circ}$ & 3.80 & 3.55 & 3. 70 & 3.60 & $3.62 \frac{1}{2}$ & 3.55 \\
\hline $1899 \ldots$ & 4.25 & 3.90 & 4.50 & 4.25 & 4. 45 & 4. 30 & 4.35 & 4. $27 \frac{1}{2}$ \\
\hline
\end{tabular}

21 GEOL, PT $6-16$ 
Highest and lowest prices of lead at New York City, etc.-Continued.

[Cents per pound.]

\begin{tabular}{|c|c|c|c|c|c|c|c|c|}
\hline \multirow{2}{*}{ Year. } & \multicolumn{2}{|c|}{ May. } & \multicolumn{2}{|c|}{ June. } & \multicolumn{2}{|c|}{ July. } & \multicolumn{2}{|c|}{ August. } \\
\hline & Highest. & Lowest. & Highest. & Lowest. & Highest. & Lowest. & Highest. & Lowest. \\
\hline $1870 \ldots$ & 6.25 & 6.20 & 6.25 & 6.20 & 6.30 & 6.20 & 6.37 & 6.32 \\
\hline 1871. & 6.18 & 6.10 & 6.15 & 6.12 & 6.15 & 6.10 & 6.12 & 6 \\
\hline 1872. & 6.62 & 6.25 & 6.62 & 6.40 & 6.62 & 6.40 & 6.50 & 6.40 \\
\hline 1873. & 6.62 & $6: 35$ & 6.55 & 6.12 & 6.12 & 6 & 6.25 & 6 \\
\hline 1874 & 6 & 5.75 & 6 & 5. 62 & 5.80 & 5.62 & 5.80 & 5.65 \\
\hline $1875 \ldots$ & 5.95 & 5.90 & 5.90 & 5.75 & 6 & 5.95 & 5.95 & 5.87 \\
\hline $1876 \ldots$ & 6.50 & 6.10 & 6.50 & 6.25 & 6.35 & 6.20 & 6.37 & 6.25 \\
\hline 1877 & 6 & 5.55 & 5.70 & 5.60 & 5.60 & 5.37 & 5.12 & 4.90 \\
\hline $1878 \ldots$ & 3.50 & 3.25 & 3.50 & 3.12 & 3.62 & 3.25 & 3.50 & 3.20 \\
\hline $1879 \ldots$ & 3.12 & 2.87 & 3. 80 & 3. 12 & 4. 10 & 3.90 & 4.05 & 4 \\
\hline 1880 . & 5.25 & 4. 40 & 4. 75 & 4.50 & 4.75 & 4. 25 & 5 & 4. 30 \\
\hline $1881 \ldots \ldots \ldots$ & 4. 70 & 4.25 & 4.50 & 4.25 & - $\underline{4 .}_{.90}$ & 4.50 & 4.95 & 4. 75 \\
\hline $1882 \ldots \ldots$ & 4.85 & 4. 60 & 4.90 & 4.55 & 5.15 & 4. 90 & 5.10 & 4.95 \\
\hline $1883 \ldots$ & 4.55 & 4.40 & 4. 45 & 4. 40 & 4.40 & 4. 30 & 4. 30 & 4. 20 \\
\hline $1884 \ldots$ & 3.75 & $3.52 \frac{1}{2}$ & 3.65 & $3.57 \frac{1}{2}$ & 3.70 & 3.55 & 3.70 & $3.52 \frac{1}{2}$ \\
\hline 1885 & 3.75 & 3. 60 & 3.85 & 3. $62 \frac{1}{2}$ & 4. 15 & $3.87 \frac{1}{2}$ & 4.25 & 4. 12 \\
\hline $1886 \ldots \ldots \ldots \ldots$ & 4. 75 & 4.65 & 4. 90 & 4.65 & 4.90 & 4. 75 & 4.80 & 4.75 \\
\hline $1887 \ldots \ldots \ldots$ & 4. 70 & 4. 30 & 5.70 & 4.50 & 4. $67 \frac{1}{2}$ & 4. 40 & 4. $62 \frac{1}{2}$ & 4.55 \\
\hline 1888 & 4. $62 \frac{1}{2}$ & 4 & 4. 10 & 3.65 & 4. $07 \frac{1}{2}$ & 3.85 & 4. $97 \frac{1}{2}$ & 4.15 \\
\hline $1889 \ldots \ldots \ldots$ & $3.87 \frac{1}{2}$ & 3.60 & 4. 05 & 3.90 & 4.05 & 3.80 & 3.95 & 3.75 \\
\hline $1890 \ldots \ldots . . .$. & 4.35 & 4 & 4.50 & 4.25 & 4.50 & 4. 40 & 4. $72 \frac{1}{2}$ & 4.35 \\
\hline 1891. & 4. $37 \frac{1}{2}$ & 4. 20 & 4.50 & 4.35 & 4.45 & 4. 30 & 4.53 & 4. 40 \\
\hline 1892 & 4.25 & 4. 20 & 4. 20 & 4.05 & 4.25 & 4 & 4.15 & 4 \\
\hline 1893 & 4 & 3.75 & 3.90 & 3.45 & 3.60 & 3. 30 & 3.75 & 3.25 \\
\hline $1894 \ldots . .$. & 3.40 & 3.30 & $3.37 \frac{1}{2}$ & 3.25 & 3.65 & $3.37 \frac{1}{2}$ & 3.70 & 3.30 \\
\hline 1895 & 3.25 & $3.07 \frac{1}{2}$ & 3.30 & 3.25 & 3.50 & 3.30 & 3.55 & 3.50 \\
\hline 1896 & 3.05 & 3 & 3.05 & 3 & 3 & 2. 90 & 2.90 & 2.65 \\
\hline 1897. & $3.37 \frac{1}{2}$ & 3. $22 \frac{1^{\prime}}{2}$ & 3. 60 & 3.25 & 3.90 & 3.65 & 4.10 & 3.70 \\
\hline 1898 . & 3.80 & 3.60 & 3.90 & 3.75 & 4 & 3.80 & 4.10 & 3.90 \\
\hline 1899 . & 4.50 & $4.37 \frac{1}{2}$ & 4.50 & 4.45 & 4.60 & 4.50 & 4.60 & 4.50 \\
\hline
\end{tabular}


LEAD.

Highest and lowest prices of lead at New York City, etc.-Continued.

[Cents per pound.]

\begin{tabular}{|c|c|c|c|c|c|c|c|c|}
\hline \multirow{2}{*}{ Year. } & \multicolumn{2}{|c|}{ September. } & \multicolumn{2}{|c|}{ October. } & \multicolumn{2}{|c|}{ November. } & \multicolumn{2}{|c|}{ December. } \\
\hline & Highest. & Lowest. & Highest. & Lowest. & Highest. & Lowest. & Highest. & Lowest. \\
\hline 1870 & 6.37 & 6.30 & 6.37 & 6.25 & 6.35 & 6.20 & 6.35 & 6.25 \\
\hline 1871. & 6.10 & 6 & 6 & 5.87 & 6 & 5. 90 & 6 & 5. 75 \\
\hline 1872. & 6.50 & 6.30 & 6.62 & 6.40 & 6.60 & 6.50 & 6.60 & 6.42 \\
\hline 1873. & 6.62 & 6.37 & 6.75 & 6.25 & 6.50 & 6 & 6.12 & 6 \\
\hline 1874. & 6.10 & 5. 65 . & 6.35 & 6.10 & 6.50 & 6.25 & 6.40 & 6. 12 \\
\hline 1875 . & 5.87 & 5. 70 & 5.65 & 5.60 & 5.87 & 5.65 & 5.95 & 5. 87 \\
\hline 1876. & 6.25 & 6 & 6 & 5.80 & 5.80 & 5. 70 & 5.70 & 5.65 \\
\hline 1877. & 4.85 & 4. 75 & 4.85 & 4.25 & 4. 75 & 4.50 & 4. 60 & 4.50 \\
\hline 1878. & 3.45 & 3.25 & 3.60 & 3.37 & 3.95 & 3.60 & 4 & 3.90 \\
\hline 1879. & 4 & 3.75 & 5.50 & 4 & 5.62 & 5 & 5.60 & 5.50 \\
\hline 1880. & 4.90 & 4.80 & 4.87 & 4.65 & 4.85 & 4.75 & 4. 75 & 4.25 \\
\hline 1881. & 5.37 & 4.95 & 5.25 & 4. 87 & 5.25 & 4.90 & 5.25 & 5 \\
\hline $1882 \ldots \ldots$ & 5.15 & 4.95 & 5.15 & 4.85 & 4.90 & 4.50 & 4. 75 & 4.50 \\
\hline 1883. & 4. 32 & 4.30 & 4. 32 & 4. 12 & 4.05 & 3.65 & 3.75 & 3.60 \\
\hline 1884 & 3.75 & 3.55 & 3.75 & 3.60 & 3.55 & $3.37 \frac{1}{2}$ & 3.75 & 3.50 \\
\hline $1885 \ldots \ldots \ldots$ & 4.25 & 4 & $4.2 b$ & 4 & 4. 60 & 4 & 4. $67 \frac{1}{2}$ & 4.50 \\
\hline 1886 & 4. 70 & 4.45 & 4. 30 & 4 & 4.40 & 4. 10 & 4. 35 & 4.25 \\
\hline 1887 & 4.55 & 4.25 & 4. 40 & 4.20 & 4. 75 & 4.25 & 5.15 & 4.90 \\
\hline $1888 \ldots \ldots$ & $5.12 \frac{1}{2}$ & 4. 90 & $5.12 \frac{1}{2}$ & 3. $62 \frac{1}{2}$ & $3.82 \frac{1}{2}$ & 3.60 & $3.82 \frac{1}{2}$ & 3.60 \\
\hline $1889 \ldots \ldots$ & 4 & 3.85 & 3.90 & 3.75 & 3.90 & 3.75 & 3.90 & 3.75 \\
\hline 1890 & 5 & $4.67 \frac{1}{2}$ & 5.25 & 5 & 5.25 & 4. 60 & 4. 60 & 4.05 \\
\hline $1891 \ldots \ldots$ & 4.55 & 4.40 & 4.55 & 4. 10 & 4.35 & 4. 10 & 4.25 & 4.25 \\
\hline 1892 & 4.15 & 4 & 3.95 & 3.85 & 3.85 & 3.70 & 3.85 & 3.70 \\
\hline 1893 & 3.95 & 3.75 & 3.75 & 3.25 & $3.37 \frac{1}{2}$ & 3.30 & 3.30 & 3.20 \\
\hline 1894. & 3.30 & 3.10 & 3.15 & 3.05 & $3.12 \frac{1}{2}$ & 3.10 & $3.12 \frac{1}{2}$ & $3.02 \frac{1}{2}$ \\
\hline 1895 & 3.45 & $3.32 \frac{1}{2}$ & 3.35 & 3.30 & $3.27 \frac{1}{2}$ & 3.15 & 3.30 & 3.20 \\
\hline 1896. & 2.80 & 2. $72 \frac{1}{2}$ & $2.92 \frac{1}{2}$ & $2.72 \frac{1}{2}$ & 3.05 & 2.85 & 3.05 & 2.95 \\
\hline $1897 \ldots$ & 4.35 & 4.25 & 4. 25 & 3.85 & 3.85 & 3.75 & 3.75 & 3.65 \\
\hline $1898 \ldots \ldots$ & 4.05 & 3.90 & 3.90 & 3.60 & 3. 70 & 3.65 & 3.80 & 3.60 \\
\hline 1899 & 4.60 & 4.55 & 4. 60 & $4.57 \frac{1}{2}$ & 4. 60 & $4.57 \frac{1}{2}$ & 4. 75 & $4.57 \frac{1}{2}$ \\
\hline
\end{tabular}


THE LEAD MARKET.

Commercially the lead industry has during 1899 witnessed the most radical change in its history, since it has been the year of the creation of the American Smelting and Refining Company, which practically controls the market for ores, and to a very large extent that of pig lead, as the competition of the Missouri lead is confined to a comparatively narrow district. The policy has been pursued of keeping the market steady and, as one means to that end, discouraging speculation by declining to sell large blocks to dealers or to speculators. It is stated that when the consolidation was formed it was found that refiners and dealers had entered the year 1899 with a very heavy stock of pig lead, and that therefore the disturbances in the production end were not so keenly felt as they might otherwise have been. Consumption was heavy in all branches, and the average price for the year was higher than it had been since 1891. A moderate amount of foreign lead refined in bond was withdrawn for domestic consumption, the quantity being 7,200 short tons.

\section{THE WORLD'S PRODUCTION.}

An effort to state correctly the lead production of the world is beset by many difficulties. In some countries there are no reliable official statistics whatever. In others the official statistics deal only with the production of lead ores or concentrates, without any reference to their metal contents. Metallurgical statistics, which after all are the only ones of commercial value, are not touched at all. 'Lead ores are shipped, often in large quantities, to distant countries for smelting, and base bullion travels from the country of origin to distant refineries and desilverizing works. This renders the danger of duplication very great and makes it almost impossible to assign the lead to its actual country of origin. Thus the mineral statistics of Great Britain deal only with the production of dressed lead ore. There is no attempt to present figures relating to the production of refined lead from domestic or foreign sources. The same is true of the Australian colonies.

The only comprehensive effort to deal with these difficulties is that of the Metallgesellschaft of Frankfort on the Main. The figures for the United States are those arrived at by this office. 
LEAD.

The world's production of lead during the years 1887 to 1899.

[Metric tons.]

\begin{tabular}{|c|c|c|c|c|c|}
\hline Country. & 1857. & 1888. & 1889. & 1890. & 1891. \\
\hline Germany . . . . . . . . . . . & 95,000 & 97,000 & 100,000 & 101,000 & 95,000 \\
\hline Spain ..... & $a 119,000$ & 129,200 & 136,900 & 140,300 & 145,700 \\
\hline Great Britain & $a 50,000$ & $a 50,000$ & $a 47,800$ & 49,800 & 49,000 \\
\hline Austria .... & 7,800 & 8,000 & 8,000 & 8,300 & 7,600 \\
\hline Hungary ......... & 1,800 & 2,000 & 2,300 & 1,200 & 2,100 \\
\hline Italy ........... & a 19,000 & 17,000 & 18,000 & 17,700 & 18,500 \\
\hline Belgium .. & 10,000 & 11,000 & 9,400 & 9,600 & 12,700 \\
\hline France .... & $a 5,000$ & 6,500 & 5,400 & 4,600 & 6,700 \\
\hline Greece. & 12,500 & 14,500 & 13,500 & 14,200 & 13,300 \\
\hline Other European countries & $a 2,000$ & $a 2,000$ & $a 2,000$ & $a 2,000$ & $a 2,000$ \\
\hline United States.. & 132,150 & 137,790 & 141,852 & 130,272 & 161,948 \\
\hline Mexico.. & 18,100 & 30,100 & 27,500 & 22,300 & 30,200 \\
\hline A ustralia $b$ & a 10,000 & $a 19,000$ & $a 35,000$ & 40,500 & 56,000 \\
\hline Other countries. & $a 1,000$ & $a 1,000$ & $a 1,000$ & $a 1,000$ & $a 1,000$ \\
\hline Total.... & 483,350 & 525,090 & 548,652 & 542,772 & 601,748 \\
\hline \multicolumn{2}{|l|}{ Country. } & 1892. & 1893. & 1894. & 1895. \\
\hline \multicolumn{2}{|c|}{ Germany $\ldots \ldots \ldots \ldots \ldots \ldots \ldots$} & 98,000 & 95,000 & 101,000 & 111,058 \\
\hline \multicolumn{2}{|c|}{ Spain ....................... } & 152,300 & 157,100 & 152,620 & 160,786 \\
\hline \multicolumn{2}{|c|}{ Great Britain . . . . . . . } & 44,900 & 38,200 & 42,800 & 55,300 \\
\hline \multicolumn{2}{|c|}{ 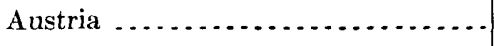 } & 7,300 & 7,200 & 7,500 & 8,085 \\
\hline \multicolumn{2}{|c|}{ Hungary $\ldots \ldots \ldots \ldots \ldots \ldots \ldots . . . . .}$. & 2,300 & 2,500 & 2,113 & 2,277 \\
\hline \multicolumn{2}{|c|}{ Italy $\ldots \ldots \ldots \ldots \ldots \ldots \ldots \ldots \ldots$} & 22,000 & 19,900 & 19,600 & 20,353 \\
\hline \multicolumn{2}{|c|}{ Belgium $\ldots \ldots \ldots \ldots \ldots \ldots \ldots$} & 10,100 & 12,000 & 13,500 & 15,573 \\
\hline \multicolumn{2}{|c|}{ 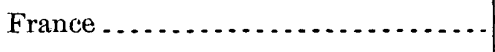 } & 8,800 & 8,100 & 8,758 & 7,627 \\
\hline \multicolumn{2}{|c|}{ Greece...$\ldots \ldots \ldots \ldots \ldots \ldots$} & 14,400 & 12,800 & 14,000 & 19,800 \\
\hline \multicolumn{2}{|c|}{ Other European countries . . . . . . . . } & $a 2,500$ & $a 3,000$ & $a 4,000$ & $a 4,000$ \\
\hline \multicolumn{2}{|c|}{ United States.......................... } & 157,187 & 147,627 & 147,600 & 154,265 \\
\hline \multicolumn{2}{|c|}{ Mexico $\ldots \ldots \ldots \ldots \ldots \ldots \ldots$} & 47,500 & 64,000 & 57,000 & 68,000 \\
\hline \multicolumn{2}{|c|}{ Canada $. . . . . \ldots \ldots \ldots, \ldots \ldots$} & & 1,000 & 2,586 & 10,467 \\
\hline \multicolumn{2}{|c|}{ Australia $b . \ldots \ldots \ldots \ldots \ldots \ldots \ldots$} & 54,000 & 58,000 & 50,000 & 38,000 \\
\hline \multicolumn{2}{|c|}{ Other countries $\ldots \ldots \ldots \ldots \ldots \ldots \ldots$} & $a 1,000$ & $a .1,000$ & $a 1,000$ & $\ldots \ldots$ \\
\hline \multicolumn{2}{|l|}{ Total . } & 622,287 & 627,427 & 624,077 & 675,591 \\
\hline
\end{tabular}

$a$ Estimated. $\quad b$ Exclusive of that part of product not exported to Europe and America. 
The world's production of lead during the years 1887 to 1899-Continued.

[Metric tons.]

\begin{tabular}{|c|c|c|c|c|}
\hline Country. & 1896. & 1897. & 1898. & 1899. \\
\hline Germany... & 113,792 & 118,881 & 132,742 & 129,225 \\
\hline Spain ............... & 167,017 & 189,000 & 193,000 & 180,000 \\
\hline Great Britain ..................... & 57,200 & 40,300 & 50,000 & 41,500 \\
\hline Austria ..... & 10,120 & 9,680 & 10,340 & $a 10,000$ \\
\hline Hungary ....... & 1,911 & 2,527 & 2,305 & 2,000 \\
\hline Italy ............ & 20,786 & 20,469 & 22,500 & 18,195 \\
\hline Belgium .............. & 17,222 & 17,023 & 19,330 & $a 16,500$ \\
\hline France......... & 8,232 & 9,916 & 10,920 & $a 11,200$ \\
\hline Greece ............. & 13,200 & 15,600 & 19,200 & 18,400 \\
\hline Other European countries ...... & $a 4,000$ & $a 4,500$ & $a 4,500$ & $a 4,500$ \\
\hline United States........ & 170,600 & 192,000 & 201,452 & 190,994 \\
\hline Mexico ... & 63,000 & 69,800 & 70,600 & 85,000 \\
\hline Canada .... & 10,977 & 17,719 & 14,500 & 10,932 \\
\hline Australia $b . . . . . .$. & 30,000 & 22,000 & 50,000 & 70,000 \\
\hline Other countries ....... & ......... & 1,200 & $a 1,200$ & 2,000 \\
\hline Total & 688,057 & 730,615 & 802,589 & 790,446 \\
\hline
\end{tabular}

$a$ Estimated. $\quad b$ Exclusive of that part of product not exported to Europe and America.

In these statistics the output of Great Britain includes the lead obtained from smelting foreign ores and material. 
THE WORLD'S CONSUMPTION.

The Metallgesellschaft of Frankfort on the Main figures the consumption of lead in the world as follows:

World's consumption of lead, 1890 to 1899.

[In metric tons.]

\begin{tabular}{|c|c|c|c|c|c|}
\hline Country. & 1890. & 1891. & 1892. & 1893. & 1894. \\
\hline Germany . & 82,432 & 88,268 & 89,595 & 94,571 & 100,678 \\
\hline Great Britain .. & 158,487 & 174,621 & 172,839 & 178,415 & 161,847 \\
\hline France ........... & 62,352 & 70,664 & 73,545 & 77,065 & $86, .160$ \\
\hline Austria-Hungary... & 12,785 & 14,011 & 16,600 & 15,604 & 18,442 \\
\hline Italy ... & 19,733 & 22,552 & 22,787 & 19,985 & 19,942 \\
\hline Switzerland.. & 2,753 & 1,738 & 1,922 & 1,941 & 1,412 \\
\hline Belgium..... & 19,738 & 19,834 & 13,779 & 23,088 & 22,478 \\
\hline Netherlands ... & $\iota 5,000$ & $a 5,000$ & $a 5,000$ & $a 5,000$ & $a 5,000$ \\
\hline Russia... & 18,700 & 16,900 & 22,000 & 24,500 & 26,700 \\
\hline Other European countries & 2,200 & 2,300 & $2, \overline{7} 00$ & 1,500 & 1,700 \\
\hline United States of America & 154,823 & 181,842 & 191,728 & 179,163 & $.173,413$ \\
\hline All other countries .. & 27,600 & 19,300 & 18,800 & 14,700 & 12,300 \\
\hline Total & 566,603 & 617,030 & 631,295 & 635,532 & 630,072 \\
\hline Country. & 1895. & 1896. & 1897. & 1898. & 1899. \\
\hline Germany.... & 111,652 & 121,980 & 129,898 & 155,372 & 160,369 \\
\hline Great Britain ..... & 170,130 & 196,200 & 182,334 & 212,163 & 204,944 \\
\hline France ......... & 64,657 & 77,773 & 86,735 & 82,498 & 77,449 \\
\hline Austria-Hungary ... & 19,276 & 18,814 & 18,038 & 22,038 & 20,703 \\
\hline Italy $\ldots \ldots \ldots \ldots$ & 18,747 & 20,533 & 18,858 & 18,061 & 19,688 \\
\hline Switzerland. & 1,837 & 2,485 & 2,640 & 3,441 & 2,700 \\
\hline Belgium ....... & 17,094 & 20,645 & 23,610 & 23,244 & 22,622 \\
\hline Netherlands.. & $a 5,000$ & $a 5,000$ & $a 5,000$ & $a 5,000$ & $a 5,000$ \\
\hline Russia...... & 21,400 & 20,300 & 24,750 & 22,650 & 23,300 \\
\hline Other European countries & 1,600 & 2,100 & 2,300 & 3,800 & 2,400 \\
\hline United States of America & 218,007 & $179, \dot{692}$ & 208,723 & 219,074 & 215,178 \\
\hline All other countries ....... & 10,600 & 12,100 & 9,400 & 8,500 & 8,000 \\
\hline Total............. & 660,000 & 677,622 & 712,286 & 775,841 & 762,353 \\
\hline
\end{tabular}





\section{ZINC.}

\section{By Charles Kirchioff.}

\section{PRODUCTION.}

So far as production is concerned, 1899 was the record year in the history of the zinc industry of the United States.

For a series of years the production of spelter has been as follows:

Production of spelter in the United States.

\begin{tabular}{|c|c|c|c|}
\hline Year. & Quantity. & Year. & Quantity. \\
\hline $1873 \ldots$ & $\begin{array}{r}\text { Short tons. } \\
7,343\end{array}$ & 1890 & $\begin{array}{r}\text { Short tons. } \\
63.683\end{array}$ \\
\hline $1875 \ldots$ & 15,833 & $1891 \ldots$ & 80,873 \\
\hline $1880 \ldots$ & 23,239 & $1892 \ldots$ & 87,260 \\
\hline $1882 \ldots$ & 33,765 & $1893 \ldots$ & 78,832 \\
\hline $1883 \ldots$ & 36,872 & $1894 \ldots$ & 75,328 \\
\hline $1884 .$. & 38,544 & $1895 \ldots$ & 89,686 \\
\hline 1885. & 40,688 & $1896 \ldots$ & 81,499 \\
\hline $1886 \ldots$ & 42,641 & $1897 \ldots$ & 99,980 \\
\hline $1887 \ldots$ & 50,340 & $1898 \ldots$ & 115,399 \\
\hline $1888 \ldots$ & 55,903 & $1899 \ldots \ldots$ & 129,051 \\
\hline $1889 \ldots$ & 58,860 & & \\
\hline
\end{tabular}

In the different States the production has been as follows:

Production of spelter in the United States, by States.

\begin{tabular}{|c|c|c|c|c|c|}
\hline Year. & $\begin{array}{l}\text { Eastern and } \\
\text { Southern } \\
\text { States. }\end{array}$ & Illinois. & Kansas. & Missouri. & Total. \\
\hline & Short tons. & Short tons. & Short tons. & Short tons. & Short tons. \\
\hline 1882 & 5,698 & 18,201 & 7,366 & $.2,500$ & 33,765 \\
\hline $1883 \ldots \ldots$ & 5,340 & 16,792 & 9,010 & 5,730 & 36,872 \\
\hline 1884 & 7,861 & 17,594 & 7,859 & 5,230 & 38,544 \\
\hline 1885 . & 8,082 & 19,427 & 8,502 & 4,677 & 40,688 \\
\hline $1886 \ldots \ldots$ & 6,762 & 21,077 & 8,932 & 5,870 & 42,641 \\
\hline
\end{tabular}


Production of spelter in the United States, by States-Continued.

\begin{tabular}{|c|c|c|c|c|c|}
\hline Year. & $\begin{array}{l}\text { Eastern and } \\
\text { Southern } \\
\text { States. }\end{array}$ & Illinois. & Kansas. & Missouri. & Total. \\
\hline $1887 \ldots$ & $\begin{array}{c}\text { Short tons. } \\
7,446\end{array}$ & $\begin{array}{c}\text { Short tons. } \\
22,279\end{array}$ & $\begin{array}{c}\text { Short tons. } \\
11,955\end{array}$ & $\begin{array}{c}\text { Short toins. } \\
8,660\end{array}$ & $\begin{array}{c}\text { Short tons. } \\
50,340\end{array}$ \\
\hline $1888 \ldots$ & 9,561 & 22,445 & 10,432 & 13,465 & 55,903 \\
\hline $1889 \ldots$ & 10,265 & 23,860 & 13,658 & 11,077 & 58,860 \\
\hline $1890 \ldots$ & 9,114 & 26,243 & 15,199 & 13,127 & 63,683 \\
\hline 1891. & $\left\{\begin{array}{l}a 8,945 \\
b 4,217\end{array}\right.$ & 28,711 & 22,747 & 16,253 & 80,873 \\
\hline 1892. & $\left\{\begin{array}{l}a 9,582 \\
b 4,913\end{array}\right.$ & $c 31,383$ & 24,715 & 16,667 & 87,260 \\
\hline 1893. & $\left\{\begin{array}{l}a 8,802 \\
b 3,882\end{array}\right.$ & \}$c 29,596$ & 22,815 & 13,737 & 78,832 \\
\hline 1894. & $\left\{\begin{array}{l}a 7,400 \\
b 1,376\end{array}\right.$ & \}$c 28,972$ & 25,588 & 11,992 & 75,328 \\
\hline 1895. & $\left\{\begin{array}{l}a 9,484 \\
b 3,697\end{array}\right.$ & $c c 35,732$ & ${ }_{25,775}$ & 14,998 & 89,686 \\
\hline 1896 & $\left\{\begin{array}{l}a 8,139 \\
b 2,427\end{array}\right.$ & $c 36,173$ & 20,759 & 14,001 & 81,499 \\
\hline 1897. & $\left\{\begin{array}{l}a 7,218 \\
b 3,365\end{array}\right.$ & $c 37,876$ & 33,396 & 18,125 & 99,980 \\
\hline $1898 \ldots$ & 8,631 & $c 47,103$ & 40,132 & 19,533 & 115,399 \\
\hline $1899 \ldots$ & 8,805 & $c 50,118$ & 52,021 & 18,107 & 129,051 \\
\hline
\end{tabular}

For semiannual periods the production of spelter has been as follows:

Production of spelter in the United States, by semiannual periods.

\begin{tabular}{|c|c|c|c|c|c|c|}
\hline State. & $\begin{array}{c}\text { First } \\
\text { half } 1892 .\end{array}$ & $\begin{array}{c}\text { Second } \\
\text { half } 1892 .\end{array}$ & $\begin{array}{c}\text { First } \\
\text { half } 1893 .\end{array}$ & $\begin{array}{c}\text { Second } \\
\text { half } 1893 .\end{array}$ & $\begin{array}{c}\text { First } \\
\text { half } 1894 .\end{array}$ & $\begin{array}{c}\text { Second } \\
\text { half } 1894 .\end{array}$ \\
\hline & ons. & Short tons & Short tons. & Short tons. & Short tons. & Short tons. \\
\hline Southern & 6,901 & 7,594 & 7,380 & 5,304 & 5,064 & 3,712 \\
\hline Illinois and Indiana & 15,483 & 15,900 & 16,427 & 16,169 & 13,392 & 15,580 \\
\hline Kansas & 14,161 & 10,554 & 13,269 & 9,546 & 11,250 & 14,338 \\
\hline Missouri . & 8,954 & 7,713 & 8,718 & $\tilde{5}, 019$ & 6,458 & 5,534 \\
\hline Total & 45,499 & 41,761 & 45,794 & 36,038 & 36,164 & 39,164 \\
\hline
\end{tabular}


Production of spelter in the Uniled States, by semiannual periods-Continued.

\begin{tabular}{|c|c|c|c|c|c|c|}
\hline State. & $\begin{array}{c}\text { First } \\
\text { half } 1896 .\end{array}$ & $\begin{array}{c}\text { Second } \\
\text { half } 1896 .\end{array}$ & $\underset{\text { half } 1897 .}{\text { First }}$ & $\begin{array}{c}\text { Second } \\
\text { half } 1897 .\end{array}$ & $\begin{array}{c}\text { First } \\
\text { half } 1898 .\end{array}$ & $\begin{array}{c}\text { Second } \\
\text { half } 1898 .\end{array}$ \\
\hline & Short tons. & Short tons. & Short tons. & Short tons. & Short tons. & Short tons. \\
\hline Eastern. . . . . . . . & 4,517 & 3,622 & 3,866 & 3,352 & 2,955 & \multirow{2}{*}{3,981} \\
\hline Southern ... & 1,200 & 1,227 & 1,305 & 2,060 & 1,695 & \\
\hline Illinois and Indiana & 16,305 & 19,868 & 18,054 & 19,822 & 22,129 & 24,974 \\
\hline Kansas & 11,351 & 9,408 & 15,722 & 17,674 & 21,464 & 18,668 \\
\hline Missouri . & 5,548 & 8,453 & 7,956 & 10,169 & 10,371 & 9,162 \\
\hline Total .... & 38,921 & 42,578 & 46,903 & 53,077 & 58,614 & 56,785 \\
\hline
\end{tabular}

For 1899 and the first half of 1900 the production of spelter was as follows:

Production of spelter in the United States in 1899 and the first half of 1900.

\begin{tabular}{|c|c|c|c|}
\hline State. & $\begin{array}{c}\text { First half } \\
1899 .\end{array}$ & $\begin{array}{c}\text { Second half } \\
1899 .\end{array}$ & $\begin{array}{c}\text { First half } \\
1900 .\end{array}$ \\
\hline Illinois and Indian & $\begin{array}{r}\text { Short tons. } \\
26,595\end{array}$ & $\begin{array}{r}\text { Short tons. } \\
23,523\end{array}$ & $\begin{array}{c}\text { Short tons. } \\
23,543\end{array}$ \\
\hline Kansas ..... & 25,972 & 26,049 & 28,283 \\
\hline Missouri . . & 9,376 & 8,731 & 7,109 \\
\hline East and South ... & 4,620 & 4,185 & 4,621 \\
\hline Total & 66,563 & 62,488 & 63,556 \\
\hline
\end{tabular}

As compared with 1899 , this shows a slightly reduced rate of output. Kansas, however, has gained, while Missouri has suffered a serious decline.

During 1899 further progress has been made in the transfer of the smelting industry to the gas territory of Kansas. In 1898 the plants in the gas belt produced 19,271 tons of spelter out of the total product of 51,665 tons made in southwestern Missouri and in southeastern Kansas. In 1899 the production of this district had increased to 61,852 tons, to which the plants operated with natural gas contributed 37,632 tons, while the coal furnaces yielded only 24,220 tons, against 32,394 tons in 1898. Were it not for the constant danger of an exhaustion of the supply of natural gas, it is probable that the migration of works drawing their ores almost exclusively from the Missouri-Kansas fields, but located in the Chicago and St. Louis coal district, would be far more pronounced. During 1898 these two districts produced 54,034 short tons of spelter.

No very important changes have taken place among the smelting works except that the Edgar Zinc Company, owning the older Carondelet works near St. Louis and the new plant at Cherryvale, Kansas, is now controlled by the American Steel and Wire Company, one of the largest consumers of spelter for galvanizing purposes. 
ZINC MINING IN THE GALENA-JOPLIN DISTRICT.

The output of the Galena-Joplin district of southwestern Missouri and southeastern Kansas far exceeds that of any other zinc-ore producing region. In 1898 the district increased its output enormously, and exceeded even that record in 1899, when, however, very much higher prices were realized, so that the profits in zinc mining during the year were unparalleled in its history.

The local newspapers collect weekly statistics of the production of the district, which, while they do not agree exactly, are in substantial accord. The Joplin Herald prints figures for the year 1899, from which the following statistics for the various camps are copied:

Production of zinc and lead ore in the Galena-Joplin district in 1899.

\begin{tabular}{|c|c|c|c|c|c|}
\hline \multirow{2}{*}{ Camp. } & \multicolumn{2}{|c|}{ Zinc ore. } & \multicolumn{2}{|c|}{ Lead ore. } & \multirow{2}{*}{ Total value. } \\
\hline & Quantity. & Value. & Quantity. & Value. & \\
\hline Galena.... & $\begin{array}{c}\text { Short tons. } \\
\quad 64,053\end{array}$ & $\$ 2,327,615$ & $\begin{array}{c}\text { Short tons. } \\
7,083\end{array}$ & $\$ 345,889$ & $\$ 2,673,504$ \\
\hline Joplin ..... . & 43,598 & $1,744,045$ & 6,513 & 362,278 & $2,106,323$ \\
\hline Carterville........ & 28,645 & $1,141,501$ & 5,193 & 272,664 & $1,414,165$ \\
\hline Aurora ....... & 27,331 & 922,934 & 491 & 31,244 & 954,178 \\
\hline Oronogo......... & 21,886 & 887,265 & 206 & 10,686 & 897,951 \\
\hline Webb City ... & 13,626 & 517,212 & 505 & 54,365 & 571,577 \\
\hline Duenweg .... & 8,969 & 347,497 & 1,272 & 70,534 & 418,031 \\
\hline Granby .... & 6,691 & 235,691 & 414 & 34,473 & 270,164 \\
\hline Stotts City.. & 6,420 & 271,738 & 197 & 10,322 & 282,060 \\
\hline Belville .. & 6,604 & 260,930 & 73 & 5,861 & 266,791 \\
\hline Central City & 9,172 & 355,185 & 386 & 20,504 & 375,689 \\
\hline Cave Springs. & 1,163 & 40,576 & 54 & 3,120 & 43,696 \\
\hline Gregg . & 1,769 & 120,306 & 199 & 10,669 & 130,975 \\
\hline Neck. & 2,600 & 105,343 & 439 & 22,911 & 128,254 \\
\hline Alba ... & 1,088 & 47,778 & & & 47,778 \\
\hline Carthage & 1,725 & 69,648 & 3 & 166 & 69,814 \\
\hline Sundries... & 5,032 & 181,814 & 925 & 48,700 & 230,514 \\
\hline Total. & 250,372 & $9,577,078$ & 23,953 & $1,304,386$ & $10,881,464$ \\
\hline
\end{tabular}


The figures collected by the Joplin Mining News for 1899 and for previous years are as follows:

Production of zinc and lead ore in the Galena-Joplin district.

\begin{tabular}{|c|c|c|c|}
\hline Year. & Zine. & Lead. & $\begin{array}{c}\text { Total value, } \\
\text { both ores. }\end{array}$ \\
\hline $1894 \ldots \ldots$ & $\begin{array}{r}\text { Short tons. } \\
147,310\end{array}$ & $\begin{array}{r}\text { Short tons. } \\
32,199\end{array}$ & $\$ 3,5: 35,736$ \\
\hline $1895 \ldots$ & 144,487 & 31,294 & $3,775,929$ \\
\hline $1896 \ldots$ & 155,333 & 27,721 & $3,857,355$ \\
\hline $1897 \ldots \ldots \ldots$ & 177,976 & 30,105 & $4,726,302$ \\
\hline 1898 & 234,455 & 26,687 & $7,119,867$ \\
\hline $1899 \ldots$ & 255,088 & 23,888 & $10,715,307$ \\
\hline
\end{tabular}

These figures show how large the production of zinc ore has grown in recent years, while the values indicate what an effect the high prices for ore have had. The nominal prices in each month are shown in the following table:

Average base prices of zinc and lead ores in 1899.

\begin{tabular}{|c|c|c|}
\hline Month. & $\begin{array}{l}\text { Zine, per } \\
\text { ton. }\end{array}$ & $\begin{array}{l}\text { Lead, per } \\
\text { 1,000 pounds. }\end{array}$ \\
\hline January . . . . . . . . & $\$ 32.25$ & $\$ 23.94$ \\
\hline February ........... & 43.38 & 26.50 \\
\hline 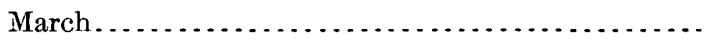 & 43.40 & 25.80 \\
\hline April........ & 51.50 & 25.25 \\
\hline May........ & 50.50 & 26.00 \\
\hline June ............ & 45.50 & 26.00 \\
\hline July $\ldots \ldots \ldots \ldots \ldots \ldots \ldots$ & 44.25 & 27.13 \\
\hline August . . . . . . . . . . & 45.00 & 27.25 \\
\hline September . . ... & 43.70 & 27.00 \\
\hline October . . . . . . . & 43.38 & 25.88 \\
\hline November . . . . . . . . & 35.00 & 26.88 \\
\hline December .......... & 35.00 & 27.30 \\
\hline Average, 1899. & 38.50 & 27.23 \\
\hline $1898 \ldots \ldots \ldots \ldots \ldots \ldots \ldots \ldots \ldots \ldots \ldots \ldots \ldots \ldots$ & 28.44 & \\
\hline $1897 \ldots \ldots \ldots \ldots \ldots \ldots \ldots \ldots$ & 22.28 & \\
\hline $1896 \ldots \ldots \ldots \ldots \ldots \ldots$ & 22.33 & \\
\hline
\end{tabular}


Prices realized vary according to the zinc contents of the ore, deduction being made for iron contents. The following ore schedule, adopted January 22, 1900, by the Missouri and Kansas Zinc Miners' Association, may serve to illustrate this:

Schedule of prices of ore per ton in the Galena-Joplin district.

\begin{tabular}{|c|c|c|c|c|c|}
\hline \multirow{2}{*}{ Per cent of zinc. } & \multirow{2}{*}{$\begin{array}{c}\text { Price of ore } \\
\text { free from } \\
\text { iron. }\end{array} \mid$} & \multicolumn{4}{|c|}{ Price of ore containing iron. } \\
\hline & & 1 per cent. & 2 per cent. & 3 per cent. & 4 per cent. \\
\hline 63. & $\$ 36.00$ & $\$ 35.00$ & $\$ 34.00$ & $\$ 33.00$ & $\$ 32.00$ \\
\hline $62 \ldots$ & 35.00 & 34.00 & 33.00 & 32.00 & 31.00 \\
\hline $61 \ldots$ & 34.00 & 33.00 & 32.00 & 31.00 & 30.00 \\
\hline 60. & 33.00 & 32.00 & 31.00 & 30.00 & 29.00 \\
\hline 59. & 32.00 & 31.00 & 30.00 & 29.00 & 27.50 \\
\hline $58 \ldots$ & 31.00 & 30.00 & 29.00 & 27.50 & 26.00 \\
\hline $57 \ldots$ & 30.00 & 29.00 & 27.50 & 26.00 & 24.50 \\
\hline $56 \ldots$ & 29.00 & 27.50 & 26.00 & 24.50 & 23.00 \\
\hline $55 \ldots$ & 27.50 & 26.00 & 24.50 & 23.00 & 21.50 \\
\hline $54 \ldots$ & 26.00 & 24.50 & 23.00 & 21.50 & 20.00 \\
\hline $53 .$. & 24.50 & 23.00 & 21.50 & 20.00 & 18.50 \\
\hline $52 \ldots$ & 23.00 & 21.50 & 20.00 & 18.50 & 17.00 \\
\hline $51 \ldots$ & 21.50 & 20.00 & 18.50 & 17.00 & 15.50 \\
\hline $50 \ldots$ & 20.00 & 18.50 & 17.00 & 15.50 & 14.00 \\
\hline
\end{tabular}

The year was one of extraordinary prices for ore in the district. The year opened with $\$ 29.50$ for top grades and before the middle of February the price had reached $\$ 45$. The maximum price of $\$ 55$ was reached in May. By the end of June, however, the price was down to $\$ 44$ for top grades. In July a two-weeks shut down was ordered by the miners' association to check the declining tendency. In August the association fixed a schedule, based on $\$ 43$ for 60 per cent ore, but even a fairly observed order to shut down during the whole of October did not prove sufficiently effective, in view of the adverse situation in the metal trade. Efforts to arrange for the export of a surplus of spelter were unsuccessful, and the ore market receded toward the end of the year to $\$ 31$ base.

The year was one of extraordinary development in prospecting, in mining, and in the construction of concentrating plants, and the unparalleled flow of outside capital into the district, which was begun in 1898 , continued in 1899 .

A good deal of work has been done in the Arkansas fields, and it is probable that extensive derelopments will soon follow.

The high prices of zinc ore attracted attention to the mineral in Colorado and considerable quantities were shipped during 1899 from Leadville, Creede, and Montezuma, a part going abroad via Galreston. 
In the East the output of the famous Franklin mines in New Jersey is being increased, and a large new concentrating mill has been begun. The New Jersey Zinc Company is also building at Palmerton, near Mauch Chunk, Pennsylvania, large works for the production of spelter, oxide, and spiegeleisen.

In Virginia and Tennessee there was considerable resumption of activity in zinc mining in 1899.

\section{CONSUMPTION.}

During 1899 the consumption of spelter reached its highest point. The following estimate may be presented, coupled with the statement, however, that the reports of stocks from the producers are only partial and are therefore in reality considerably larger. In a degree, however, the figures reflect the fluctuations in the stocks and thus possess some value as indicating the relative position from year to year:

Estimated consumption of spelter, 1895, 1896, 1897, 1898, and 1899.

\begin{tabular}{|c|c|c|c|c|c|}
\hline Source, etc. & 1895. & 1896. & 1897. & 1898. & 1899. \\
\hline & Short tons. & Short tons. & Short tons. & Short tons. & Short tons. \\
\hline Production $\ldots \ldots \ldots \ldots$ & 89,686 & 81,499 & 99,980 & 115,399 & 129,051 \\
\hline Imports ............... & 432 & 428 & 1,279 & 1,303 & 1,392 \\
\hline Stocks at beginning of year & 4,911 & 5,802 & 7,477 & 5,709 & 3,695 \\
\hline Total supply...... & 95,029 & 87,729 & 108,736 & 122,411 & 134,138 \\
\hline Deduct- & & & & & \\
\hline Exports of fore & $\cdots$ & 4 & . & 18 & \\
\hline Exports of domestic . & 1,530 & 10,130 & 14,245 & 10,499 & 6,755 \\
\hline Stock at end of year. & 5,802 & 7,477 & 5,709 & 3,695 & 2,798 \\
\hline Total & 7,332 & 17,611 & 19,954 & 14,212 & 9,553 \\
\hline $\begin{array}{c}\text { Apparenthome consump- } \\
\text { tion } . . . . . . . . . . . . . .\end{array}$ & 87,697 & 70,118 & 88,782 & 108,199 & 124,585 \\
\hline
\end{tabular}


During the first half of 1900 the consumption is estimated as follows: Consumption of spelter, first half of 1900.

\begin{tabular}{|c|c|}
\hline Source, etc. & Quantity. \\
\hline 7 & Short tons. \\
\hline 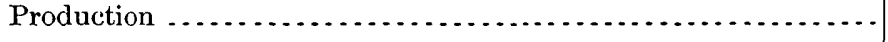 & 63,556 \\
\hline 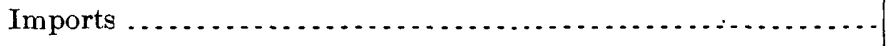 & 616 \\
\hline 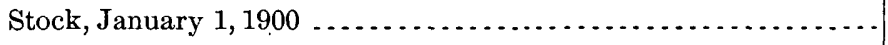 & 2,798 \\
\hline Total ................ & 66,970 \\
\hline Deduct- & \\
\hline 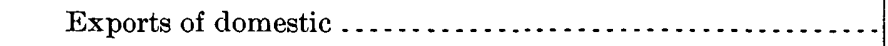 & 15,534 \\
\hline 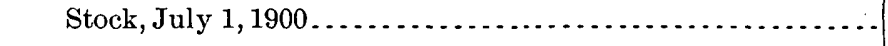 & 4,438 \\
\hline Total $\ldots \ldots \ldots \ldots \ldots \ldots \ldots$ & 19,972 \\
\hline Apparent home consumption ....... & 46,998 \\
\hline
\end{tabular}

There has therefore been a very marked decline in the consumption during the first half of 1900.

IMPORTS AND EXPORTS.

Zinc imported and entered for consumption in the United States, 1867 to 1899.

\begin{tabular}{|c|c|c|c|c|}
\hline \multirow{2}{*}{ Year ending- } & \multicolumn{2}{|c|}{ Blocks or pigs. } & \multicolumn{2}{|c|}{ Sheets. } \\
\hline & Quantity. & Value. & Quantity. & Value. \\
\hline June $30-$ & Pounds. & & Pounds. & \\
\hline $1867 \ldots$ & $5,752,611$ & $\$ 256,366$ & $5,142,417$ & $\$ 311,767$ \\
\hline 1868. & $9,327,968$ & 417,273 & $3,557,448$ & 203,883 \\
\hline $1869 .$. & $13,211,575$ & 590,332 & $8,306,723$ & 478,646 \\
\hline $1870 \ldots$ & $9,221,121$ & 415,497 & $9,542,687$ & 509,860 \\
\hline $1871 \ldots$ & $11,159,040$ & 508,355 & $7,646,821$ & 409,243 \\
\hline $1872 \ldots$ & $11,802,247$ & 522,524 & $10,704,944$ & 593,885 \\
\hline $1873 \ldots$ & $6,839,897$ & 331,399 & $11,122,143$ & 715,706 \\
\hline $1874 \ldots \ldots \ldots$ & $3,593,570$ & 203,479 & $6,016,835$ & 424,504 \\
\hline $1875 \ldots$ & $2,034,252$ & 101,766 & $7,320,713$ & 444,539 \\
\hline $1876 \ldots \ldots$ & 947,322 & 56,082 & $4,611,360$ & 298,308 \\
\hline $1877 \ldots$ & $1,266,894$ & 63,250 & $1,341,333$ & 81,815 \\
\hline $1878 \ldots \ldots$ & $1,270,184$ & 57,753 & $1,255,620$ & 69,381 \\
\hline $1879 \ldots$ & $1,419,791$ & 53,294 & $1,111,225$ & 53,050 \\
\hline $1880 \ldots .$. & $8,092,620$ & 371,920 & $4,069,310$ & 210,230 \\
\hline $1881 \ldots \ldots \ldots$ & $2,859,216$ & 125,457 & $2,727,324$ & 129,158 \\
\hline $1882 \ldots \ldots \ldots$ & $18,408,391$ & 736,964 & $4,413,042$ & $207 ; 032$ \\
\hline $1883 \ldots \ldots \ldots$ & $17,067,211$ & 655,503 & $3,309,239$ & 141,823 \\
\hline $1884 \ldots$ & $5,869,738$ & 208,852 & 952,253 & 36,120 \\
\hline $1885 \ldots \ldots$ & $3,515,840$ & 113,268 & $1,839,860$ & 64,781 \\
\hline
\end{tabular}


Zinc imported and entered for consumption in the United States, 1867 to 1899-Cont'd.

\begin{tabular}{|c|c|c|c|c|}
\hline \multirow{2}{*}{ Year ending- } & \multicolumn{2}{|c|}{ Blocks or pigs. } & \multicolumn{2}{|c|}{ Sheets. } \\
\hline & Quantity. & Value. & Quantity. & Value. \\
\hline December 31- & Pounds. & & Pounds. & \\
\hline 1886 & $4,300,830$ & $\$ 136,138$ & $1,092,400$ & $\$ 40,320$ \\
\hline 1887. & $8,387,647$ & 276,122 & 926,150 & 32,526 \\
\hline 1888. & $3,825,947$ & 146,156 & 295,287 & 12,558 \\
\hline 1889. & $2,052,559$ & 77,845 & $1,014,873$ & 43,356 \\
\hline 1890. & $1,997,524$ & 101,335 & 781,366 & 43,495 \\
\hline $1891 \ldots$ & 808,094 & 41,199 & 21,948 & 1,460 \\
\hline $1892 \ldots$ & 297,969 & 16,520 & 27,272 & 2,216 \\
\hline 1893. & 425,183 & 22,790 & 28,913 & 1,985 \\
\hline 1894 & 387,788 & 13,788 & 39,947 & 2,061 \\
\hline 1895. & 744,301 & 26,782 & 42,513 & 2,773 \\
\hline 1896. & $1,040,719$ & 32,096 & 27,321 & 1,358 \\
\hline 1897. & $2,905,451$ & 109,520 & 15,971 & 786 \\
\hline 1898 & $2,605,028$ & 104,669 & 39,712 & 2,724 \\
\hline 1899. & $2,783,329$ & 143,557 & 86,878 & 6,354 \\
\hline \multirow{2}{*}{ Year ending- } & \multicolumn{2}{|c|}{ old. } & \multirow{2}{*}{$\begin{array}{l}\text { Value of man- } \\
\text { ufactures. }\end{array}$} & \multirow[b]{2}{*}{ Total value. } \\
\hline & Quantity. & Value. & & \\
\hline June 30- & Pounds. & & & \\
\hline 1867 & & & $\$ 1,835$ & $\$ 569,968$ \\
\hline 1868. & & & 1,623 & 622,779 \\
\hline 1869 & & & 2,083 & $1,071,061$ \\
\hline $1870 .$. & & & 21,696 & 947,053 \\
\hline $1871 \ldots$ & & & 26,366 & 943,964 \\
\hline $1872 \ldots$ & & & 58,668 & $1,175,077$ \\
\hline 1873. & & & 56,813 & $1,103,918$ \\
\hline $1874 \ldots$ & & & 48,304 & 676,287 \\
\hline $1875 \ldots$ & & & 26,330 & 572,635 \\
\hline 1876. & & & 18,427 & 372,817 \\
\hline 1877. & & & 2,496 & 147,561 \\
\hline $1878 .$. & & & 4,892 & 132,026 \\
\hline $1879 \ldots$ & & & 3,374 & 109,718 \\
\hline $1880 \ldots$ & & & 3,571 & 585,721 \\
\hline $1881 \ldots$ & & & 7,603 & 262,218 \\
\hline $1882 \ldots \ldots$ & & & 4,940 & 948,936 \\
\hline $1883 \ldots \ldots$ & & & 5,606 & 802,932 \\
\hline $1884 \ldots .$. & & & 4,705 & 249,767 \\
\hline $1885 \ldots$ & & & 2,054 & 180,103 \\
\hline
\end{tabular}

21 GEOL, PT $6-17$ 
Zinc imported and entered for consumption in the United States, 1867 to 1899-Cont'd.

\begin{tabular}{|c|c|c|c|c|}
\hline \multirow{2}{*}{ Year ending- } & \multicolumn{2}{|c|}{ old. } & \multirow{2}{*}{$\begin{array}{l}\text { Value of man- } \\
\text { ufactures. }\end{array}$} & \multirow{2}{*}{ Total value. } \\
\hline & Quantity. & value. & & \\
\hline December 31- & Pounds. & & & \\
\hline 1886. & & & $\$ 9,162$ & $\$ 185,620$ \\
\hline 1887. & 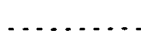 & 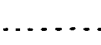 & 11,329 & 319,977 \\
\hline $1888 \ldots$ & & & 12,080 & 170,794 \\
\hline 1889. & & & 19,580 & 140,781 \\
\hline 1890. & $\therefore$ & …. & 9,740 & 154,570 \\
\hline 1891. & $\ldots$. & $\cdots$ & $\ldots \ldots$ & 42,659 \\
\hline 1892 & 115,203 & $\$ 6,556$ & 20,677 & 45,969 \\
\hline 1893. & 265 & 21 & 16,479 & 41,275 \\
\hline $1894 .$. & 27,754 & 530 & 11,816 & 28,195 \\
\hline 1895. & 64,398 & 899 & 9,953 & 40,407 \\
\hline $1896 \ldots$ & 14,855 & 267 & 9,800 & 43,521 \\
\hline $1897 \ldots \ldots$ & 41,643 & 886 & 11,459 & 122,651 \\
\hline $1898 \ldots \ldots$ & 96,899 & 3,417 & 11,211 & 122,021 \\
\hline $1899 \ldots \ldots$ & 167,954 & 6,932 & 8,824 & 165,667 \\
\hline
\end{tabular}

Imports of zinc oxide from 1885 to 1899.

\begin{tabular}{|c|c|c|c|c|c|}
\hline Year ending- & Dry. & In oil. & Year ending- & Dry. & In oil. \\
\hline . & Pounds. & Pounds. & December $31-$ & Pounds. & Pounds. \\
\hline June 30,1885 & $2,233,128$ & 98,566 & 1892. & $2,442,014$ & 111,190 \\
\hline December 31 & & & 1893. & $3,900,749$ & 254,807 \\
\hline 1886. & $3,526,289$ & 79,788 & 1894. & $3,371,292$ & 59,291 \\
\hline $1887 \ldots$ & $4,961,080$ & 123,216 & 1895. & $4,546,049$ & 129,343 \\
\hline $1888 \ldots$ & $1,401,342$ & 51,985 & 1896. & $4,572,781$ & 311,023 \\
\hline $1889 \ldots$ & $2,686,861$ & 66,240 & 1897 & $5,564,763$ & 502,357 \\
\hline $1890 \ldots$ & $2,631,458$ & 102,298 & 1898. & $3,342,235$ & 27,050 \\
\hline $1891 \ldots$ & $2,839,351$ & 128,140 & $1899 \ldots$ & $3,012,709$ & 41,699 \\
\hline
\end{tabular}


ZINC.

Exports of zinc and zinc ore of domestic production from 1864 to 1899.

\begin{tabular}{|c|c|c|c|c|c|c|}
\hline \multirow{2}{*}{ Year ending- } & \multicolumn{2}{|c|}{ Ore or oxide. } & \multicolumn{2}{|c|}{$\begin{array}{l}\text { Plates, sheets, pigs, or } \\
\text { bars. }\end{array}$} & \multirow{2}{*}{$\begin{array}{l}\text { Value of } \\
\text { manufac- } \\
\text { tures. }\end{array}$} & \multirow{2}{*}{ Total value } \\
\hline & Quantity. & value. & Quantity. & Value. & & \\
\hline June $30-$ & Cwt. & & Pounds. & & & \\
\hline 1864 & 14,810 & $\$ 116,431$ & 95,738 & $\$ 12,269$ & & $\$ 128,700$ \\
\hline 1865 & 99,371 & 114,149 & 184,183 & 22,740 & & 136,889 \\
\hline 1866. & 4,485 & 25,091 & 140,798 & 13,290 & & 38,381 \\
\hline 1867. & 3,676 & 32,041 & 312,227 & 30,587 & & 62,628 \\
\hline 1868 & 8,344 & 74,706 & $1,022,699$ & 68,214 & & 142,920 \\
\hline 1869. & ........ & 65,411 & ; n & $\ldots \ldots$ & & 65,411 \\
\hline 1870. & 15,286 & 81,487 & 110,157 & 10,672 & & 92,159 \\
\hline $1871 \ldots$ & 9,621 & 48,292 & 76,380 & $\overline{7}, 823$ & & 56,115 \\
\hline 1872. & 3,686 & 20,880 & 62,919 & 5,726 & & 26,606 \\
\hline 1873 & 234 & 2,304 & 73,953 & 4,656 & & 6,960 \\
\hline 1874. & 2,550 & 20,037 & 43,566 & 3,612 & $\cdots$ & 23,649 \\
\hline 1875. & 3,083 & 20,659 & 38,090 & 4,245 & $\$ 1,000$ & 25,904 \\
\hline 1876 & 10,178 & 66,259 & 134,542 & 11,651 & 4,333 & 82,243 \\
\hline 1877 & 6,428 & 34,468 & $1,419,922$ & 115,122 & 1,118 & 150,708 \\
\hline $1878 \ldots$ & 16,050 & 83,831 & $2,545,320$ & 216,580 & 567 & 300,978 \\
\hline 1879. & 10,660 & 40,399 & $2,132,949$ & 170,654 & & 211,053 \\
\hline 1880 & 13,024 & 42,036 & $1,368,302$ & 119,264 & & 161,300 \\
\hline 1881 & 11,390 & 16,405 & $1,491,786$ & 132,805 & 168 & 149,378 \\
\hline 1882. & 10,904 & 13,736 & $1,489,552$ & 124,638 & 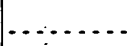 & 138,374 \\
\hline 1883. & 3,045 & 11,509 & 852,333 & 70,981 & 734 & 83,224 \\
\hline 1884. & 4,780 & 16,685 & 126,043 & 9,576 & 4,666 & 30,927 \\
\hline $1885 \ldots$ & 6,840 & 22,824 & 101,685 & 7,270 & 4,991 & 35,085 \\
\hline \multicolumn{7}{|l|}{ December $31-$} \\
\hline 1886. & 26,620 & 49,455 & 917,229 & 75,192 & 13,526 & 138,173 \\
\hline $1887 \ldots$ & 4,700 & 17,286 & 136,670 & 9,017 & 16,789 & 43,092 \\
\hline 1888. & 4,560 & 18,034 & 62,234 & 4,270 & 19,098 & 41,402 \\
\hline $1889 \ldots$ & 26,760 & 73,802 & 879,785 & 44,049 & 35,732 & 153,583 \\
\hline $1890 \ldots$ & 77,360 & 195,113 & $3,295,584$ & 126,291 & 23,587 & 344,991 \\
\hline $1891 \ldots$ & 115,820 & 149,435 & $4,294,656$ & 278,182 & 38,921 & 466,538 \\
\hline 1892 & 18,380 & 41,186 & $12,494,335$ & 669,549 & 166,794 & 877,529 \\
\hline $1893 .$. & 980 & 1,271 & $7,446,934$ & 413,673 & 224,787 & 639,731 \\
\hline 1894. & $\cdots$. & 5 & $3,607,050$ & 144,074 & 99,406 & 243,485 \\
\hline 1895. & 480 & 1,008 & $3,060,805$ & 153,175 & 50,051 & 204,234 \\
\hline 1896. & 41,500 & $47 ; 408$ & $20,260,169$ & $1,013,620$ & 51,001 & $1,112,029$ \\
\hline $1897 \ldots$ & 165,200 & 211,350 & $28,490,662$ & $1,356,538$ & 71,021 & $1,638,909$ \\
\hline 1898. & 210,400 & 299,870 & $20,998,413$ & $1,033,959$ & 138,165 & $1,471,994$ \\
\hline 1899. & 503,940 & 725,944 & $13,509,316$ & 742,521 & 143,232 & $1,611,697$ \\
\hline
\end{tabular}


The following table shows the exports of ore and of spelter by customs districts during the calendar year 1899:

Domestic exports of zinc, by customs districts, during the calendar year 1899.

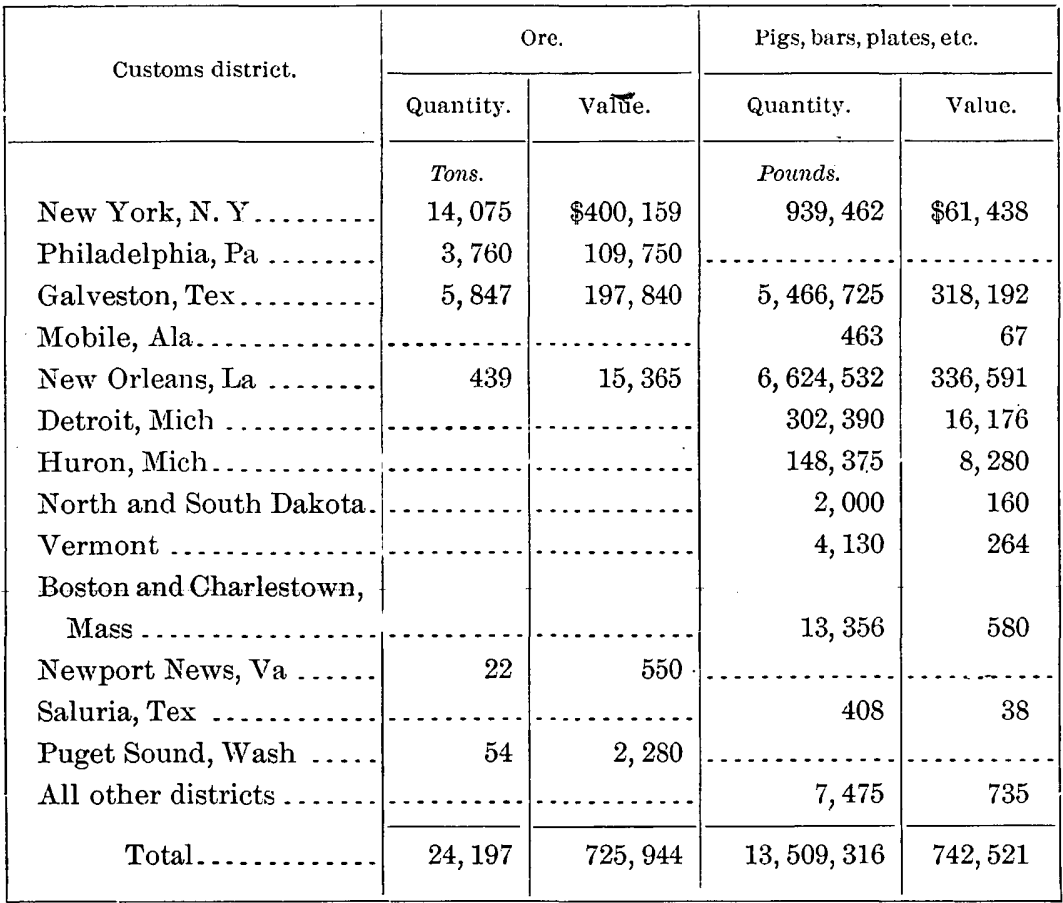

These figures are interesting, since they show that, with the exception of the high-grade spelter shipped from New York, the bulk of the exports is of western common spelter via Galveston and New Orleans.

The ore exports from New York and Philadelphia are from the New Jersey mines, while the bulk of the ore exported from Galveston is Colorado product. 
The destination of the ore and spelter exports during 1899 is exhibited in the following table:

Domestic exports of zinc, by countries, during the calendar year 1899.

\begin{tabular}{|c|c|c|c|c|}
\hline \multirow{2}{*}{ Country. } & \multicolumn{2}{|c|}{ Ore. } & \multicolumn{2}{|c|}{ Pigs, bars, plates, etc. } \\
\hline & Quantity. & Value. & Quantity. & Value. \\
\hline & Tons. & & Pounds. & \\
\hline Belgium $\ldots \ldots \ldots \ldots \ldots$ & 5,636 & $\$ 189,672$ & 226,500 & $\$ 11,325$ \\
\hline France ....... & $\ldots .$. & - ....... & 932,166 & 46,858 \\
\hline Germany ......... & 10 & 339 & 12,249 & 702 \\
\hline Netherlands $\ldots \ldots \ldots \ldots$ & 18,047 & 516,724 & 12,560 & 806 \\
\hline $\begin{array}{l}\text { Russia, Baltic and White } \\
\text { seas ....................... }\end{array}$ & $\cdots \cdot$ & & 224,000 & 13,440 \\
\hline United Kingdom......... & 450 & 16,929 & $11,541,072$ & 636,636 \\
\hline Dominion of Canada: & & & & \\
\hline $\begin{array}{c}\text { Nova Scotia, New } \\
\text { Brunswick........ }\end{array}$ & & & 1,245 & 98 \\
\hline Quebec, Ontario, etc. & $\ldots$ & $\ldots \ldots$ & 456,895 & 24,880 \\
\hline British Columbia... . & 54 & 2,280 & & $\cdots$ \\
\hline Central American States: & & & & \\
\hline Honduras & & & 98 & 10 \\
\hline Nicaragua & & & 1,902 & 157 \\
\hline Mexico ....... & & & 46,504 & 3,562 \\
\hline West Indies: & & & & \\
\hline British & & & 875 & 45 \\
\hline Haiti... & & & 3,289 & 289 \\
\hline Colombia .. & & & $11,5 \overline{75}$ & 1,064 \\
\hline Ecuador..... & & & 7,051 & 568 \\
\hline British Africa . & & & 660 & 33 \\
\hline All other countries & & & 30,675 & 2,048 \\
\hline Total. & 24,197 & 725,944 & $13,509,316$ & 742,521 \\
\hline
\end{tabular}

The ore forwarded to the Netherlands is, of course, in transit to smelters in Belgium and in western Germany.

Great Britain, it will be observed, takes by far the greater part of the spelter shipped from this country. 


\section{PRICES.}

During 1899 the spelter market was affected by a variety of causes, which led to somewhat violent fluctuations. In the earlier part of the year the extraordinary demand created higher prices for the metal, which in turn acted upon the prices for ore, which again reacted upon the cost of the metal. Simultaneously there had been a very marked advance in iron and steel, which culminated in prices checking consumption of galvanized sheets and wire. With the exception of a temporary reaction in March, the market advanced from the beginning of the year to the end of May. Then buying fell off until, in September, the inducement of low prices led consumers to come into the market again. It was then that the Missouri and Kansas Miners' Association made an effort to regulate the market by ordering a restriction, but prices continued to decline to the end of the year.

The fluctuations in prices during the year in St. Louis (the primary market), in New York, and in London are given in the following table:

Fluctuations in prices of spelter in 1899.

\begin{tabular}{|c|c|c|c|c|c|c|c|}
\hline Nonth. & St. Louis (per pound). & $\begin{array}{l}\text { New York (per } \\
\text { pound). }\end{array}$ & & ndor & (per long & ton) & \\
\hline & Conts. & Cents. & $\mathscr{E}$ & $\varepsilon$ & $\mathscr{E}$ & $\varepsilon$ & \\
\hline January . & 4.80 to 5.45 & 5.15 to 5.70 & 25 & 15 & 0 to 26 & 5 & 0 \\
\hline February . & 5.60 to 6 & 5.70 to 6.50 & 26 & 5 & 0 to 28 & 0 & 0 \\
\hline March.... & 5.80 to 6.10 & 6.25 to 6.50 & 26 & 15 & 0 to 27 & 17 & 6 \\
\hline April.. & 6.15 to 6.60 & 6.20 to 6.80 & 27 & 12 & 6 to 28 & 15 & 0 \\
\hline May & 6.45 to 7 & 6.75 to 7 & 28 & 10 & 0 to 28 & 15 & 0 \\
\hline June ... & $5.27 \frac{1}{2}$ to 6.50 & 6.15 to 6.75 & 25 & 0 & 0 to 28 & 2 & 6 \\
\hline July ... & 5.50 to $5.92 \frac{1}{2}$ & 6 to 6.25 & 25 & 0 & 6 to 26 & 2 & 6 \\
\hline August & 5.40 to 5.75 & 5.30 to 6 & 22 & 5 & 0 to 25 & 15 & 0 \\
\hline September. & 5.25 to 5.50 & 5.20 to 5.75 & 21 & 15 & 0 to 24 & 0 & 0 \\
\hline October... & 4.85 to 5.35 & 5.15 to 5.50 & 21 & $\bar{t}$ & 6 to 22 & 12 & 6 \\
\hline November & 4.20 to 4.80 & 4. 50 to 5 & 19 & 15 & 0 to 21 & 15 & 0 \\
\hline December . & 4.20 to 4.65 & 4.55 to 4.70 & 19 & 15 & 0 to 20 & 10 & 0 \\
\hline
\end{tabular}


The following table summarizes the prices of spelter since 1875:

Price of common Western spelter in New York City, 1875 to 1899.

[Cents per pound; figures in parentheses are combination prices.]

\begin{tabular}{|c|c|c|c|c|c|c|c|c|}
\hline \multirow{2}{*}{ Year. } & \multicolumn{2}{|c|}{ January. } & \multicolumn{2}{|c|}{ February. } & \multicolumn{2}{|c|}{ March. } & \multicolumn{2}{|c|}{ April. } \\
\hline & Highest. & Lowest. & Highest. & Lowest. & Highest. & Lowest. & Highest. & Lowest. \\
\hline 1875. & 6.75 & 6.37 & 6.67 & .6 .25 & 6.50 & 6.20 & $(7)$ & 6.50 \\
\hline 1876 & $(7.60)$ & 7.40 & $(7.75)$ & 7.50 & $(7.75)$ & 7.62 & (8) & 7.60 \\
\hline 1877 & 6.50 & 6.25 & 6.62 & $6.50^{\circ}$ & 6.50 & 6.37 & 6.37 & 6.25 \\
\hline 1878 & 5.75 & 5.50 & 5.62 & 5.25 & 5.62 & 5.25 & 5.25 & 5 \\
\hline 1879 & 4.50 & 4.25 & 4.62 & 4.40 & 4.62 & 4.37 & 4.75 & 4. 25 \\
\hline 1880 & 6.50 & 5.87 & 6.75 & 6.37 & 6.75 & 6.50 & 6.50 & 6.12 \\
\hline 1881 & 5.25 & 4.87 & 5.25 & 5. 12 & 5 & 4.87 & 5.12 & 4. 75 \\
\hline 1882. & 6 & 5.75 & 5.75 & 5.62 & 5.62 & 5.37 & 5.50 & 5.25 \\
\hline 1883. & 4.62 & 4.50 & 4.62 & 4.50 & 4. 75 & 4. 62 & 4.75 & 4. 60 \\
\hline 1884 & 4.37 & 4.20 & .4 .40 & 4.25 & 4. 60 & 4.40 & 4.65 & 4.50 \\
\hline 1885 & 4.50 & 4.12 & 4.30 & 4.25 & 4. 30 & 4. 12 & 4.30 & 4. 12 \\
\hline 1886. & 4.50 & 4.30 & 4.55 & 4.30 & 4.60 & 4.50 & 4.60 & 4.50 \\
\hline 1887 & 4.60 & 4.50 & 4.60 & 4.40 & 4.60 & 4.40 & 4.65 & 4.45 \\
\hline $188 S$. & 5.37 & 5. 20 & 5.35 & $5: 25$ & 5.25 & 4.87 & 4.87 & 4.60 \\
\hline 1889. & 5 & 5 & 5 & 4.90 & 4.87 & 4.70 & 4.65 & 4.65 \\
\hline 1890 & 5.45 & 5.35 & 5.35 & 4. 20 & 5.20 & 5 & 5 & 4.90 \\
\hline 1891. & 6 & 5.25 & 5.25 & 5 & 5.10 & 5 & 5.10 & 4.90 \\
\hline 1892 & 4. 70 & 4. 60 & 4.60 & 4.55 & 4. 60 & 4.50 & 4.80 & 4. 60 \\
\hline 1893. & 4.35 & 4. 30 & 4.30 & 4.25 & 4.25 & 4. 20 & 4.50 & 4. 30 \\
\hline $1894 \ldots$ & 3.60 & 3.50 & 4 & 3.60 & 3.85 & 3.80 & 3.75 & 3.50 \\
\hline 1895 & 3.35 & 3. 20 & 3.20 & 3.10 & 3. 20 & 3.15 & 3.30 & 3.25 \\
\hline 1896. & 4.05 & 4 & 4.15 & 4 & 4.15 & 4.10 & 4. 20 & 4.05 \\
\hline 1897. & 4. 10 & 3.90 & .4 .10 & 4 & 4.15 & 4.10 & 4. 15 & 4. 10 \\
\hline 1898 & 4 & 3.90 & 4. 10 & 3.90 & 4. 25 & 4.15 & 4.30 & 4.15 \\
\hline 1899 & 5. 70 & 5.15 & 6.50 & 5. 70 & 6.50 & -6.25 & 6.80 & 6.20 \\
\hline
\end{tabular}


Price of common Western spelter in New York City, 1875 to 1899-Continued.

\begin{tabular}{|c|c|c|c|c|c|c|c|c|}
\hline \multirow{2}{*}{ Year. } & \multicolumn{2}{|c|}{ May. } & \multicolumn{2}{|c|}{ June. } & \multicolumn{2}{|c|}{ July. } & \multicolumn{2}{|c|}{ August. } \\
\hline & Highest. & Lowest. & Highest. & Lowest. & Highest. & Lowest. & Highest. & Lowest. \\
\hline 1875. & $(7.25)$ & 7.15 & $(7.25)$ & 7.15 & $(7.35)$ & 7.25 & $(7.25)$ & 7.10 \\
\hline 1876. & (8) & 7.75 & $(8)$ & 7.25 & 7.25 & 7.12 & 7.25 & 7 \\
\hline 1877. & 6.25 & 6 & 6.12 & 5.87 & 5.87 & 5.62 & 5.90 & 5.80 \\
\hline 1878. & 5 & 4.62 & 4.62 & 4.25 & 4.75 & 4.50 & 4.87 & 4.50 \\
\hline 1879 & 4.50 & 4.25 & 4.37 & 4. 12 & 4. 75 & 4.37 & 5.62 & 4.80 \\
\hline 1880. & 6 & 4.62 & 5.50 & 5.12 & 5 & 4.87 & 5.25 & 4.87 \\
\hline 1881. & 5 & 4.87 & 5 & 4.75 & 5 & 4.75 & 5.12 & 5 \\
\hline 1882. & 5.62 & 5.25 & 5.37 & 5.25 & 5.37 & 5.12 & 5.50 & 5. 12 \\
\hline 1883. & 4.75 & 4.50 & 4. 62 & 4.37 & 4.50 & 4. 30 & 4. 40 & 4. 30 \\
\hline 1884. & 4.60 & 4.45 & 4.60 & 4.45 & 4.55 & 4.45 & 4. 62 & 4.52 \\
\hline 1885. & 4. 25 & 4. 10 & 4.10 & 4 & 4.40 & 4.10 & 4. 60 & 4. 40 \\
\hline 1886. & 4.60 & 4.40 & 4.40 & 4. $3 \check{~}$ & 4. 40 & 4. 30 & 4. 40 & 4.30 \\
\hline 1887. & 4.65 & 4.45 & 4.65 & 4.50 & 4.50 & 4.50 & 4.60 & 4.55 \\
\hline 1888. & 4.65 & 4.60 & 4.60 & 4. 50 & 4.55 & 4.50 & 4.87 & 4.50 \\
\hline 1889. & 4.85 & 4.62 & 5 & 5 & 5. 10 & 5 & 5.20 & 5.15 \\
\hline 1890. & 5.45 & 5 & 5.60 & 5.35 & 5.60 & 5.40 & 5.55 & 5.40 \\
\hline 1891. & 4. 90 & 4.85 & 5.10 & 4. 90 & 5. 10 & 5.05 & 5.10 & 5 \\
\hline 1892. & 4.90 & 4.80 & 4.90 & 4.80 & 4.85 & 4. 70 & 4. 70 & 4.65 \\
\hline 1893. & 4.40 & 4.20 & 4.25 & 4. 15 & 4. 15 & 3.90 & 3.90 & 3.55 \\
\hline $1894 \ldots$ & 3.55 & 3.45 & 3.50 & 3.40 & 3.50 & 3.45 & 3.45 & 3.40 \\
\hline $1895 \ldots$ & 3.65 & 3.30 & 3.75 & 3.30 & 3.85 & 3.70 & 4. 20 & 4 \\
\hline $1896 \ldots$ & 4.15 & 4 & 4.15 & 4 & 4. 10 & 3.90 & 3.90 & 3.65 \\
\hline $1897 \ldots$ & 4.20 & 4.10 & 4.25 & 4.15 & 4. 30 & 4.20 & 4. 35 & 4.25 \\
\hline $1898 \ldots$ & 4.30 & 4. 10 & 5.15 & 4. 30 & 4. $\mathrm{S} 0$ & 4.45 & 4.75 & 4.45 \\
\hline 1899 & 7.00 & 6.75 & 6.75 & 6.15 & 6.25 & 6.00 & 6.00 & 5.30 \\
\hline
\end{tabular}


ZINC.

Price of common Western spelter in New York City, 1S\%5 to 1899-Continued.

\begin{tabular}{|c|c|c|c|c|c|c|c|c|}
\hline \multirow{2}{*}{ Year. } & \multicolumn{2}{|c|}{ September. } & \multicolumn{2}{|c|}{ October. } & \multicolumn{2}{|c|}{ November. } & \multicolumn{2}{|c|}{ December. } \\
\hline & Highest. & Lowest. & Highest. & Lowest. & Highest. & Lowest. & Highest. & Lowest. \\
\hline 1875 & $(7.25)$ & 7.10 & $(7.40)$ & 7.15 & $(7.40)$ & 7.15 & $(7.40)$ & 7.15 \\
\hline 1876 & 7.12 & 6.80 & 6.75 & 6.62 & 6. 62 & 6.37 & 6.50 & 6.37 \\
\hline 1877. & 5.87 & 5.75 & 5.90 & 5. 70 & 5.87 & 5.62 & 5.75 & 5.50 \\
\hline 1878. & 4.87 & 4.75 & 4.82 & 4.50 & 4. 75 & 4.50 & 4.37 & 4.25 \\
\hline 1879 & 6 & 5.62 & 6.37 & 6 & 6.25 & 5.87 & 6.25 & 6 \\
\hline 1880 & 5.12 & 4.75 & 5 & 4.87 & 4.90 & 4.65 & 4. 75 & 4.65 \\
\hline 1881 & 5.25 & 5 & 5.37 & 5.25 & 5.87 & 5.50 & 6 & 5.87 \\
\hline 1882 & 5.37 & 5.12 & 5.37 & 5.12 & 5.12 & 4.87 & 4.87 & 4.50 \\
\hline 1883 & 4.50 & 4.40 & 4.45 & 4.35 & 4.40 & 4.37 & 4.37 & 4.35 \\
\hline 1884. & 4.62 & 4.50 & 4.55 & 4.40 & 4.40 & 4.30 & 4.25 & 4 \\
\hline 1885 & 4.62 & 4.50 & 4.62 & 4.50 & 4. 60 & 4.45 & 4.60 & 4.45 \\
\hline 1886 & 4.40 & 4.25 & 4.30 & 4.25 & 4. 30 & 4.25 & 4.50 & 4.35 \\
\hline 1887 & 4.65 & 4.60 & 4. 65 & 4.50 & 4. 80 & 4.52 & 5.87 & 5 \\
\hline 1888 & 5.12 & 4.75 & 5.12 & 4.87 & 5. 12 & 4.87 & 5.12 & 4.87 \\
\hline 1889 & 5.15 & 5.10 & 5.15 & 5.10 & 5.25 & 5.05 & 5.35 & 5.30 \\
\hline 1890 & 5.65 & 5.50 & 6 & 5.65 & 6. 10 & 5.90 & 6 & 5.90 \\
\hline 1891 & 5 & 4.85 & 5.15 & 4.95 & 4.90 & 4. 75 & 4. 75 & 4.65 \\
\hline $1892 \ldots$ & 4.65 & 4.50 & 4.50 & 4.35 & 4.40 & 4.35 & 4. 40 & 4.35 \\
\hline 1893. & 3.75 & 3.65 & 3.70 & 3.55 & 3.85 & 3.60 & 3.80 & 3. 70 \\
\hline $1894 \ldots$ & 3.50 & 3.40 & 3.50 & 3.37 & 3.40 & 3.35 & 3.35 & 3.25 \\
\hline 1895. & 4. 35 & 4.15 & 4.20 & 3.90 & 3.80 & $3 . \dot{4} 5$ & 3.50 & 3.40 \\
\hline 1896. & 3. 70 & 3.60 & 3.75 & 3.65 & 4.25 & 3.75 & 4.25 & 4.15 \\
\hline 1897. & 4.35 & 4.25 & 4.30 & 4.15 & 4.25 & 3.90 & 3.90 & 3.75 \\
\hline 1898. & $4.82 \frac{1}{2}$ & 4. 70 & 5.15 & 4. $82 \frac{1}{2}$ & 5.25 & 5.15 & 5.30 & 4.90 \\
\hline 1899. & 5.75 & 5. 20 & 5.50 & 5.15 & 5 & 4.50 & 4. 70 & 4.55 \\
\hline
\end{tabular}




\section{THE WORLD'S PRODUCTION.}

Messrs. Henry R. Merton \& Co., Limited, of London, on the basis of detailed reports make the production of spelter in Europe as follows:

Production of zinc in Europe from 1894 to 1899.

[Long tons.]

\begin{tabular}{|c|c|c|c|c|c|c|}
\hline & 1894. & 1895. & 1896. & 1897. & 1898. & 1899. \\
\hline $\begin{array}{l}\text { Rhine, Belgium, } \\
\text { and Holland... }\end{array}$ & 152,420 & 172,135 & 179,730 & 184,455 & 188,815 & 189,955 \\
\hline Silesia . . . . . . . . . & 91,145 & 94,015 & 95,875 & 94,045 & 97,670 & 98,590 \\
\hline Great Britain ..... & 32,065 & 29,495 & 24,880 & 23,550 & 27,940 & 31,715 \\
\hline Austria ......... & 8,580 & 8,355 & 9,255 & 8,185 & 7,115 & 7,190 \\
\hline France and Spain. & 21,245 & 22,895 & 28,450 & 32,120 & 32,135 & 32,955 \\
\hline Poland .......... & 5,015 & 4,960 & 6,165 & 5,760 & 5,575 & 6,225 \\
\hline Total...... & 310,470 & 331,855 & 344,355 & 348,115 & 359,250 & 366,630 \\
\hline United States . : & 67,257 & 80,076 & 72,767 & 89,268 & 103,061 & 115,224 \\
\hline $\begin{array}{l}\text { Total world's } \\
\text { production. }\end{array}$ & 377,727 & 411,931 & 417,122 & 437,383 & 462,311 & 481,854 \\
\hline $\begin{array}{l}\text { United States per- } \\
\text { centage of } \\
\text { world's produc- } \\
\text { tion ............. }\end{array}$ & 17.8 & 19.4 & 17.4 & 20.4 & 22.3 & 23.9 \\
\hline
\end{tabular}

It will be observed that the United States in 1899 produced nearly one-quarter of the world's output. 


\section{ALUMINUM AND BAUXITE.}

\section{ALUMINUM. \\ PRODUCTION.}

The production of aluminum in 1899 continued practically the same as in the previous year, amounting to $5,200,000$ pounds. The entire production is in the hands of a single company, the Pittsburg Reduction Company, which controls the Hall patents in the United States. The demand for the metal has been considerably in excess of the supply, although, owing to the policy of the producers, there has been no consequent increase in price; rather, a slight reduction was noticed toward the end of the year. The selling price in the United States for No. 1 ingots (99 per cent pure) ranged from 33 to 37 cents per pound, and for No. 2 (90 per cent pure) from 31 to 34 cents per pound, according to quantity purchased. Arrangements are being made by the Pittsburg Reduction Company for a considerable extension of their works, and an enlarged production may be looked for in 1900 . The following table shows the production for each year since the beginning of the industry in 1883:

Production of aluminum in the United States from 1883 to 1899.

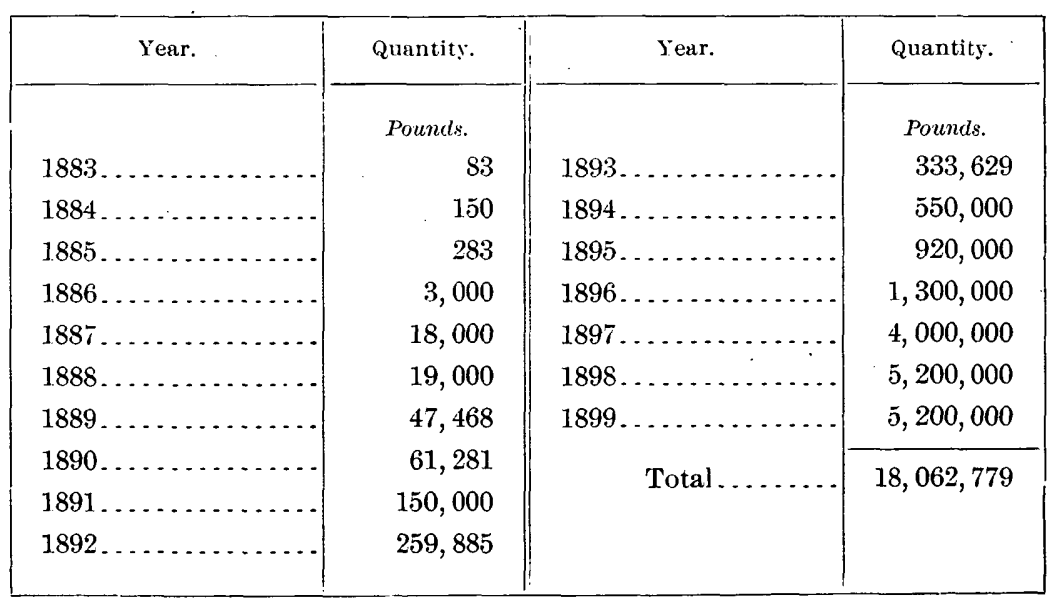




\section{NEW USES FOR ALUMINUM.}

Owing to the marked increase in the price of copper during the year the field for the utilization of aluminum has been greatly expanded. Successful experiments have been made during the year in the use of aluminum, both pure and alloyed with copper, for electrical conductors. The weight of a wire of pure aluminum is 48 per cent of the weight of a copper wire of equal conductivity. Hence the price of aluminum per pound might be a little more than twice that of copper and still the cost of the conductors for a given amount of electrical power would be the same if constructed of either metal. The price of aluminum, however, is only a little over 50 per cent greater per pound than that of copper. Aluminum, therefore, is considerably less expensive than copper for this purpose. The first actual application of the metal on a large scale for this purpose has been made during the year by the Chicago and Northwestern Elevated Road. Twenty miles of $1 \frac{1}{2}$-inch cables, weighing 150,000 pounds, have been put in place to distribute the motive power to the trolley cars of the new road.

Another important use for the metal is as a reducing agent in the preparation of the metals from such refractory materials as the oxides of chromium, titanium, tungsten, vanadium, molybdenum, etc. The finely powdered aluminum is intimately mixed with these metallic oxides in a refractory crucible and enough barium peroxide is added to start the reaction. The mixture is readily ignited, and the extremely active oxidation of the powdered aluminum reduces the oxides of the other metals present. The use of metals prepared in this way for combination with steel has been found very much more satisfactory than when the various alloys with iron are employed. The powdered metal is also coming into use for the production of flash lights for photography, replacing magnesium for this purpose. It is also extensively used as a paint, being simply mixed with a varnish like ordinary bronzing powders.

The field of investigation of the various alloys of aluminum is a wide one, and considerable attention has been given to it in the past year. A new alloy of aluminum and magnesium, called magnalium, has been prepared, containing from 75 to 90 per cent of the former metal with 10 to 25 per cent of the latter. The color of the resulting metal ranges from tin-white through blue-white to brass-yellow, as the proportion of magnesium increases. Since the latter metal is 40 per cent lighter in weight than aluminum, the alloy is also of less specific gravity. It is harder than aluminum, will take a fine polish, is unalterable in the air, and can be worked as readily as brass. Its principal application in the arts will probably be in the manufacture of scientific instruments where lightness is desirable and it is necessary at the same time to hare sufficient hardness to hold fine graduations. 
These are merely a few of the more important recent additions to the use of the metal in the arts. A complete list of the uses to which it has been successfully applied would be a very long one. The price of the metal will doubtless continue to decrease as the various processes in its preparation are improved, and particularly when the expiration of the present patent permits free competition in its production. Even at the present price it is considerably cheaper, bulk for bulk, than copper or brass, and if the supply were sufficient to meet the growing demand, its uses would increase even more rapidly than they have done.

IMPORTS.

Aluminum imported and entered for consumption in the United States from 1870 to 1890.

\begin{tabular}{|c|c|c|c|c|c|}
\hline Year ending- & Quantity. & value. & Year ending- & Quantity. & Value. \\
\hline June $30-$ & Pounds. & & June 30- & Pounds. & \\
\hline 1870 . & & $\$ 9 \$$ & 1881. & 517.10 & $\$ 6,071$ \\
\hline 1871 & $\therefore$ & 341 & $1882 .$. & 556.50 & 6,450 \\
\hline 1872. & & & 1883 & 426.25 & 5,070 \\
\hline 1873. & 2 & 2 & 1884. & 595 & 8,416 \\
\hline $1874 \ldots$ & 683 & 2,125 & 1885. & 439 & 4,736 \\
\hline $1875 \ldots$ & 434 & 1,355 & Dec. $31-$ & & \\
\hline $1876 \ldots$ & 139 & 1,412 & 1886 & 452.10 & 5,369 \\
\hline $1877 \ldots$ & 131 & 1,551 & 1887 & 1,260 & 12,119 \\
\hline $1878 \ldots$ & 251 & 2,978 & 1888. & $1,348.53$ & 14,086 \\
\hline $1879 \ldots$ & 284.44 & 3,423 & $1889 \ldots$ & 998 & 4,840 \\
\hline $1880 \ldots$ & 340.75 & 4,042 & 1890. & 2,051 & 7,062 \\
\hline
\end{tabular}

Imports of crude and manufactured aluminum from 1891 to 1899.

\begin{tabular}{|c|c|c|c|c|c|c|c|c|}
\hline \multirow{2}{*}{$\begin{array}{c}\text { Calendar } \\
\text { year. }\end{array}$} & \multicolumn{2}{|c|}{ Crude. } & \multicolumn{2}{|c|}{ Leaf. } & \multicolumn{2}{|c|}{$\begin{array}{c}\text { Plates, sheets, bars, } \\
\text { and rods. }\end{array}$} & \multirow{2}{*}{$\begin{array}{l}\text { Manufac- } \\
\text { tures. }\end{array}$} & \multirow{2}{*}{ Total value } \\
\hline & Quantity: & Value. & $\begin{array}{c}\text { Packs of } \\
100 .\end{array}$ & value. & Quantity. & Value. & & \\
\hline & Pounds. & & & & Pounds. & & & \\
\hline $1891 \ldots$ & 3,922 & $\$ 6,266$ & 10,033 . & $\$ 1,135$ & & & $\$ 1,161$ & $\$ 8,562$ \\
\hline $1892 \ldots$ & 43 & 51 & 11,540 & 1,202 & & & 1,036 & 2,289 \\
\hline 1893. & 7,816 & 4,683 & 18,700 & 1,903 & & & 1,679 & 8,265 \\
\hline 1894. & 5,306 & 2,514 & 10,780 & 1,210 & & & 386 & 4,110 \\
\hline 1.895 & 25,294 & 7,814 & 6,610 & 646 & & & 1,841 & 10,301 \\
\hline 1896. & 698 & 591 & $4,65 \overline{7}$ & 523 & 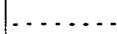 & & 2,365 & 3,479 \\
\hline $1897 .$. & 1,822 & 1,082 & 4,260 & 368 & 4,424 & $\$ 3,058$ & 221 & 4,729 \\
\hline 1898. & 60 & 30 & 2,000 & 174 & 18,442 & 8,991 & 4,675 & 13,870 \\
\hline 1899. & 53,622 & $9,42 \tilde{5}$ & 693 & 112 & 4,254 & 2,413 & 5,303 & 17,253 \\
\hline
\end{tabular}




\section{BAUXITE.}

\section{PRODUCTION.}

The production in 1899 amounted to 35,280 long tons, valued at $\$ 125,598$. This shows an increase over the production in 1898 of 10,131 long tons, or 40 per ceut, in quantity, and of $\$ 50,161$, or 66 per cent, in value.

Until the present year Georgia and Alabama have been the only States producing bauxite on a commercial scale. This year, however, Arkansas entered the field with a production of 5,045 long tons. The following table gives the output and value each year since the beginning of production in 1889:

Production of bauxite in the Lnited States from 1889 to 1899, by States.

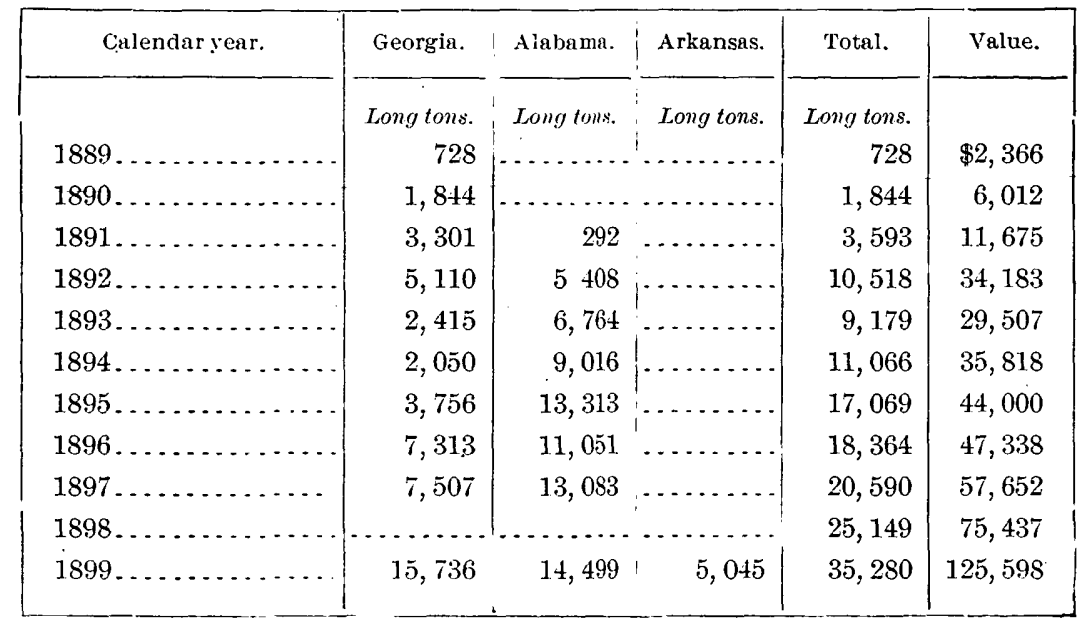

Of the 10,131 tons of increased production in 1899 over 1898 , about half is to be credited to the new field in Arkansas. The most important feature in the derelopment of the industry during 1899 has been the entry of this new field as a producer.

Georgia-Alabama field.-Many of the most important deposits in the Georgia-Alabama field are either entirely exhausted or are rapidly approaching that condition. Thus the Dykes, Warwhoop, Gaines Hill, and Washer banks in Alabama are entirely exhausted or have been worked to such a depth that the remaining ore can not be economically extracted by reason of the caving in of the surrounding clay. A few of the smaller deposits in the vicinity of the Dykes bank are still producing, but the amount of ore in sight is small compared with that which has already been mined in this district. In Georgia the deposits of the Hermitage district are mostly exhausted. The Church bank is still being worked, although at a depth which indicates its early 
exhaustion. The largest body of ore remaining in this district is probably at the Waters bank, which, at the present rate of mining, will undoubtedly continue to be productive for a number of year's. Several deposits of the Bobo district have recently become important producers, and, together with the Waters bank, will be the chief reliance of the Georgia-Alabama field in the future.

Arkansas. - Four companies have made more or less extensive investments in the Arkansas district, and are preparing for a large output in the near future. Considerable shipments have been made by Mr. E. E. Metznauer, partly to a plant established at Mabelvale, Arkansas, for the production of alumina and aluminum salts. This enterprise is as yet in the experimental stage. Mr. Metznauer has also made some shipments to Eastern consumers. Regular shipments were made for several months in the latter part of the year by the Illinois Chemical Company, chiefly to their own factory at Chicago Heights, Illinois. This ore was used entirely for the manufacture of alum. Some shipments were also made by the Pittsburg Reduction Company to eastern consumers at Pittsburg and elsewhere. The Southern Bauxite Mining and Manufacturing Company, which has acquired a large proportion of the bauxite deposits in this district, has as yet made only experimental shipments, but is doing extensive development work with a view to a large output in the near future.

The geologic conditions under which the bauxite occurs in Arkansas are entirely different from those in the Georgia-Alabama field. The ore in the Arkansas district forms a bed having great lateral extent as compared with its thickness. Mining will, therefore, be attended by much less uncertainty than in the Georgia-Alabama field, where the deposits are isolated pockets. With the rapid exhaustion of the latter deposits Arkansas must be looked to for supplying the demand for this ore. Other deposits of the ore may be discovered in the United States, but none of importance are at present known. These Arkansas deposits, therefore, become highly important to the aluminum and alum industries. They will be described at length in a,paper by Dr. C. W. Hayes soon to be issued. 


\title{
QUICKSILVER.
}

\author{
By Edwari) W. Parker.
}

\section{PRODUCIION.}

The production of quicksilver in the United States in 1899 amounted to 30,454 flasks of $76 \frac{1}{2}$ pounds, valued at $\$ 1,452,745$, against 31,092 flasks, valued at $\$ 1,188,627$, in 1898 . The amount of quicksilver produced in 1899 was less than in 1895,1896 , or 1898 , while the value exceeded that of any year since 1882, when the product was 52,732 flasks, or about 70 per cent more than in 1899 . The value of the 52,732 flasks produced in 1882 was $\$ 1,487,042$, only $\$ 34,297$ more than that of the 30,454 flasks produced in 1899, a difference of less than $2 \frac{1}{2}$ per cent. The past year was one of steadily advancing prices from January 1 to December 31 . When the year opened the quotations at San Francisco were $\$ 42$ per flask for local delivery and $\$ 37.50$ for export. At the close of the year the price for local delivery was $\$ 51.50$ and for export $\$ 47$ per flask. These were the highest prices obtained since 1890 .

The most interesting feature of the year, apart from the notable increase in value, was the development of the cinnabar deposits in Brewster County, Texas, which resulted in a production from that locality of approximately 1,000 flasks. All of the production, with this exception, was from California. In the following table is shown the amount and value of the quicksilver produced in the United States since 1880. The entire product during this period was from California, with the exception of 65 flasks from Oregon in 1887 and the 1,000 Hasks from Texas in 1899:

Amount and value of quicksilver produced in the United States from 1880 to 1899.

\begin{tabular}{|c|c|c|}
\hline Year. & $\begin{array}{c}\text { Flasks of } \\
76 \frac{1}{2} \text { pounds. }\end{array}$ & Value. \\
\hline $1880 \ldots \ldots . . .$. & 59,926 & $\$ 1,797,780$ \\
\hline $1881 \ldots \ldots$ & 60,851 & $1,764,679$ \\
\hline $1882 \ldots \ldots \ldots \ldots \ldots$ & 52,732 & $1,487,042$ \\
\hline $1883 \ldots \ldots \ldots$ & 46,725 & $1,253,632$ \\
\hline 1884. & 31,913 & 936,327 \\
\hline $1885 \ldots \ldots \ldots$ & 32,073 & 797,189 \\
\hline
\end{tabular}

21 GEOL, PT $6-18$ 
Amount and value of quicksilver produced in, the Lnited S'tates from 1880 to 1899- ('ont'd.

\begin{tabular}{|c|c|c|}
\hline Year. & $\begin{array}{c}\text { Flasks of } \\
76 \frac{1}{2} \text { pounds. }\end{array}$ & Value. \\
\hline 1886 & 29,981 & $\$ 1,060,000$ \\
\hline $1887 \ldots \ldots . . .$. & 33,825 & $1,429,000$ \\
\hline 1888. & 33,250 & $1,413,125$ \\
\hline 1889 & 26,484 & $1,190,500$ \\
\hline 1890 & 22,926 & $1,203,615$ \\
\hline $1891 \ldots \ldots \ldots \ldots$ & 22,904 & $1,036,386$ \\
\hline 1892 & 27,993 & $1,245,689$ \\
\hline 1893. & 30,164 & $1,108,527$ \\
\hline $1894 \ldots$ & 30,416 & $93+, 000$ \\
\hline $1895 \ldots$ & 36,104 & $1,33 \pi, 131$ \\
\hline $1896 \ldots$ & 30,765 & $1,075,449$ \\
\hline $1897 \ldots$ & 26,648 & 993,445 \\
\hline 1898 & 31,092 & $1,188,627$ \\
\hline 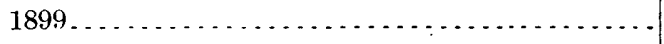 & 30,454 & $1,452,745$ \\
\hline
\end{tabular}

CALIFORNIA.

In the following table is shown the production of quicksilver in California, by mines, each year since 1850 . In the half century covered by this table the grand total of production has amounted to $1,831,022$ flasks of $76 \frac{1}{2}$ pounds net, an average of 36,620 flasks per year: Of this total the New Almaden mine in Santa Clara County has produced a little over 50 per cent. The period of greatest activity in the quicksilver mines of California was from 1875 to 1882 , when the output averaged 64,000 flasks a year. Since 1882 the product has averaged only a little more than 30,000 flasks annually. In the statistics for 1899 the production of "various mines" includes that of Chicago mine, Lake County; Manhattan and Vallejo mines, Napa County. and Santa Clara and Sunderland mines, San Luis Obispo County.

Total product of quicksilver in California.

[Flasks of $76 \frac{1}{2}$ pounds, net.]

\begin{tabular}{|c|c|c|c|c|c|c|}
\hline Year. & $\begin{array}{c}\text { New } \\
\text { Almaden. }\end{array}$ & New Idria. & Redington. & $\begin{array}{c}\text { Suiphur } \\
\text { Bank. }\end{array}$ & $\begin{array}{c}\text { Great } \\
\text { Western. }\end{array}$ & $\begin{array}{l}\text { Napa Con- } \\
\text { solidated. }\end{array}$ \\
\hline $1850 \ldots$ & 7,723 & - & & $\cdots$ & & \\
\hline 1851. & 27,779 & & & & & \\
\hline 1852 & 15,901 & & & & & \\
\hline 1853. & 22,284 & $\cdots$ & & $\cdots$ & & \\
\hline $1854 \ldots$ & 30,004 & $\ldots$. & & & & \\
\hline
\end{tabular}


QUICKSILVER.

Total product of quicksilver in California-Continued.

[Flasks of $76 \frac{1}{2}$ pounds, net.]

\begin{tabular}{|c|c|c|c|c|c|c|}
\hline Year. & $\begin{array}{c}\text { New } \\
\text { Almaden. }\end{array}$ & New Idria. & Redington. & $\begin{array}{c}\text { Sulphur } \\
\text { Bank. }\end{array}$ & $\begin{array}{c}\text { Great } \\
\text { Western. }\end{array}$ & $\begin{array}{l}\text { Napa Con- } \\
\text { solidated. }\end{array}$ \\
\hline 1855 & 29,142 & $\ldots$. & $\ldots \ldots$ & & & \\
\hline 1856. & $2 \overline{7}, 138$ & - & & & & \\
\hline 1857. & 28,204 & & & & & \\
\hline 1858 & 25,761 & & $\cdots$ & . & & \\
\hline 1859 . & 1,294 & - & $\ldots . .$. & & & \\
\hline 1860. & $\overline{7}, 061$ & & & & & \\
\hline 1861 & 34,429 & $\ldots \ldots$ & $\ldots \ldots \ldots$ & - -5 & & \\
\hline 1862. & 39,671 & . & 444 & & & \\
\hline 1863. & 32,803 & & 852 & & & \\
\hline 1864. & 42,489 & $\ldots$ & 1,914 & & & \\
\hline J 865 . & 47,194 & $(a)$ & 3,545 & 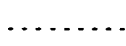 & & \\
\hline 1866. & 35,150 & 6,525 & 2,254 & & & \\
\hline 1867. & 24,461 & 11,493 & 7,862 & & & \\
\hline 1868. & 25,628 & 12,180 & 8,686 & & & \\
\hline 1869. & 16,898 & 10,315 & 5,018 & & & \\
\hline 1870 & 14,423 & 9,888 & 4,546 & & & \\
\hline 1871. & 18,568 & 8,180 & 2,128 & & & \\
\hline 1872. & 18,574 & 8,171 & 3,046 & & & \\
\hline 1873. & 11,042 & 7,735 & 3,294 & $\ldots$ & 340 & $\cdots$ \\
\hline 1874. & 9,084 & 6,911 & 6,678 & 573 & 1,122 & 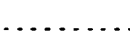 \\
\hline 1875. & 13,648 & 8,432 & 7,513 & 5,372 & 3,384 & 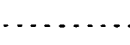 \\
\hline 1876. & 20,549 & 7,272 & 9,183 & 8,367 & 4,322 & 573 \\
\hline $1877 \ldots$ & 23,996 & 6,316 & 9,399 & 10,993 & 5,856 & 2,229 \\
\hline 1878 & 15,852 & 5,138 & 6,686 & 9,465 & 4,963 & 3,049 \\
\hline 1879 & 20,514 & 4,425 & 4,516 & 9,249 & 6,333 & 3,605 \\
\hline 1880. & 23,465 & 3,209 & 2,139 & 10,706 & 6,442 & 4,416 \\
\hline 1881. & 26,060 & 2,775 & 2,194 & 11,152 & 6,241 & 5,552 \\
\hline 1882 . & 28,070 & 1,953 & 2,171 & 5,014 & 5,179 & 6,842 \\
\hline 1883. & 29,000 & 1,606 & 1,894 & 2,612 & 3,869 & 5,890 \\
\hline 1884. & 20,000 & 1,025 & 881 & 890 & 3,292 & 4,307 \\
\hline 1885 & 21,400 & 1,144 & 385 & 1,296 & 3,469 & 3,506 \\
\hline $1886 \ldots \ldots$ & 18,000 & 1,406 & 409 & 1,449 & 1,949 & 5,247 \\
\hline 1887 & 20,000 & 1,890 & 673 & 1,490 & 1,446 & 5,574 \\
\hline 1888. & 18,000 & 1,320 & 126 & 2,164 & 625 & 5,024 \\
\hline 1889. & 13,100 & 980 & + 812 & 2,283 & 556 & 4,590 \\
\hline 1890. & 12,000 & 977 & 505 & $\cdot 1,608$ & 1,334 & 3,429 \\
\hline 1891. & 8,200 & 792 & 442 & 1,375 & 1,844 & 4,454 \\
\hline $1892 \ldots \ldots$ & 5,563 & 848 & 728 & 1,393 & 5,867 & 5,680 \\
\hline
\end{tabular}

$a$ Production from 1858 to 1866 was 17,455 flasks; no yearly details obtainable; they are included in the product of "Various mines." 
MINERAL RESOURCES.

Total product of quicksilver in California-Continued.

[Flasks of $76 \frac{1}{2}$ pounds, net.]

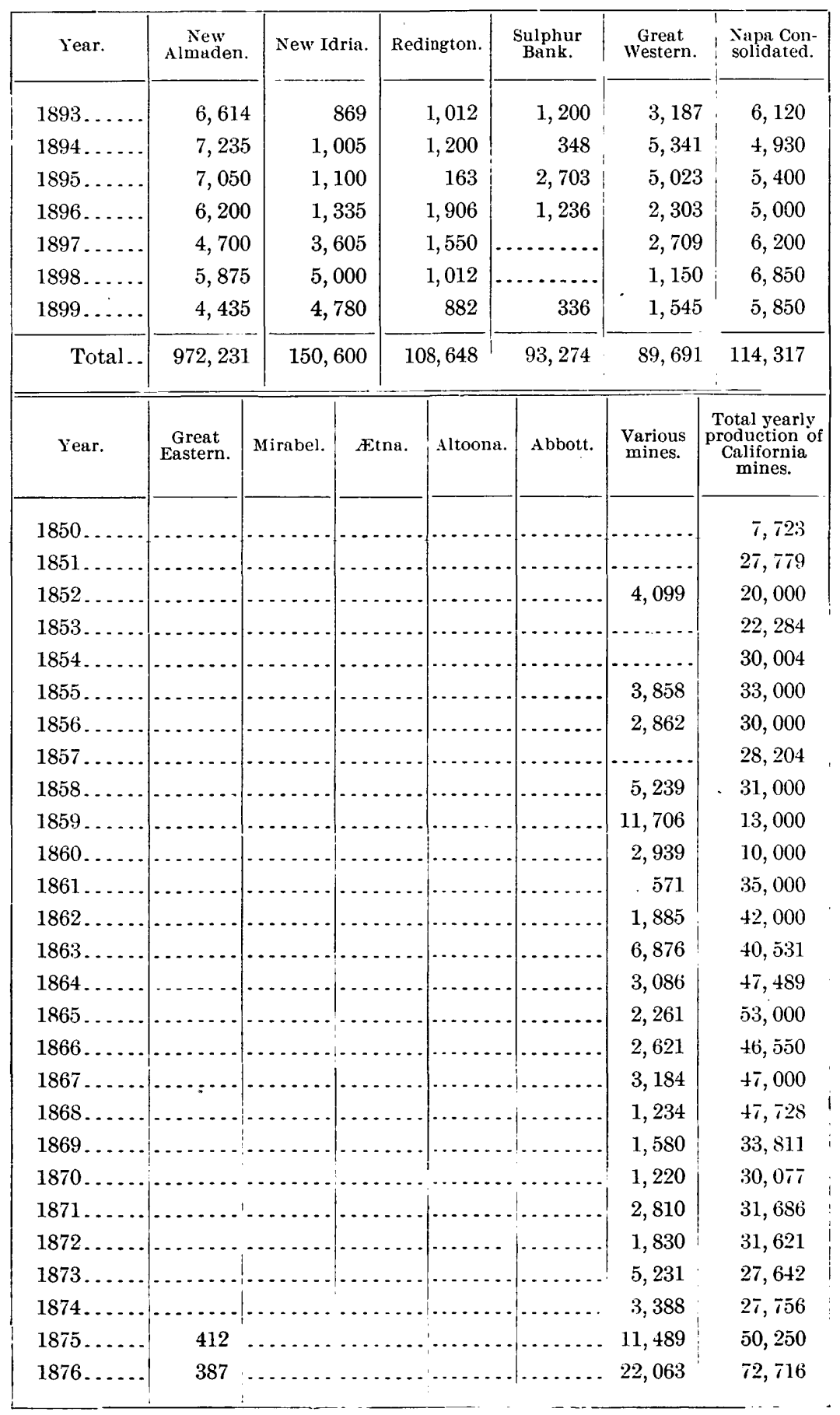


Total product of quicksilver in California-Continued.

[Flasks of $76 \frac{1}{\frac{1}{2}}$ pounds, net.]

\begin{tabular}{|c|c|c|c|c|c|c|c|}
\hline Year. & $\begin{array}{c}\text { Great } \\
\text { Eastern. }\end{array}$ & Mirabel. & Etna. & Altoona. & Abbott. & $\begin{array}{l}\text { Various } \\
\text { mines. }\end{array}$ & $\begin{array}{l}\text { Total yearly } \\
\text { production of } \\
\text { California } \\
\text { mines. }\end{array}$ \\
\hline $1877 \ldots .$. & 505 & $\ldots$ & & & & 20,101 & 79,395 \\
\hline $1878 \ldots \ldots$ & 1,366 & $\ldots . .$. & & & & 17,361 & 63,880 \\
\hline $1879 \ldots \ldots$ & 1,455 & $\ldots$ & 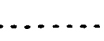 & -. & - & 23,587 & 73,684 \\
\hline $1880 \ldots$ & 1,279 & . & & & & 8,270 & 59,926 \\
\hline $1881 \ldots \ldots$ & 1,065 & $\ldots \ldots$. & & & & 5,812 & 60,851 \\
\hline 1882. & 2,124 & -. & & & & 1,379 & 52,732 \\
\hline $1883 \ldots$ & 1,669 & 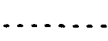 & & & & 185 & 46,725 \\
\hline $1884 \ldots$ & 332 & $\cdots$ & & & & 1,186 & 31,913 \\
\hline 1885. & 446 & - & & & & 427 & 32,073 \\
\hline 1886. & 735 & $\cdots$ & & & & 786 & 29,981 \\
\hline $1887 \ldots$ & 689 & 1,543 & & & & 520 & a 33,825 \\
\hline $1888 \ldots$ & 1,151 & 3,848 & & & & 992 & 33,250 \\
\hline $1889 \ldots$ & 1,345 & 1,874 & & & & 924 & 26,464 \\
\hline $1890 \ldots$ & 1,046 & 1,290 & & - & & 737 & 22,926 \\
\hline $1891 \ldots$ & 1,660 & 1,686 & & & 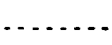 & 2,451 & 22,904 \\
\hline 1892. & 1,630 & 3,208 & 1,592 & & 672 & 812 & 27,993 \\
\hline $1893 \ldots$ & 1,445 & 5,211 & 3,795 & & 133 & 578 & 30,164 \\
\hline $1894 \ldots$ & 1,368 & 4,214 & 3,575 & $\ldots \ldots$ & 1,200 & $\ldots .$. & 30,416 \\
\hline 1895 & 1,813 & 3,900 & 3,300 & 3,926 & 1,223 & 466 & 36,067 \\
\hline $1896 \ldots$ & 1,126 & $\cdot 1,114$ & 3,800 & 4,205 & 1,200 & 1,340 & 30,765 \\
\hline $1897 \ldots$ & b 1,538 & 375 & 3,600 & 838 & 475 & $\mathbf{1}, 101$ & 26,691 \\
\hline 1898. & 1,704 & $\ldots$ & 3,450 & 4,032 & 500 & 1,519 & 31,092 \\
\hline 1899 & 2,119 & 543 & 3,800 & 3,076 & 500 & 1,588 & 29,454 \\
\hline Total.. & 30,409 & 28,806 & 26,912 & 16,077 & 5,903 & 194,154 & $1,831,022$ \\
\hline
\end{tabular}

To the advancing market in 1899 is due an increased activity in prospecting for quicksilver deposits, the rehabilitation of old mines, temporarily shut down, and the formation of a number of new companies organized for the ostensible purpose of operating quicksilver mines in different parts of the State. In Colusa County a new furnace and eighteen new condensers were installed at the Buckeye mine, which has not reported any production for a number of years. Steps have been taken to reopen the old Amador mine, in Eldorado County, which was abandoned at least ten year's ago. The Crystal Quicksilver Mining Company is reported to have opened up a rich ore body in Lake County, and the Black Butte Quicksilver Mining Company is opening a promising property in the same county. The California Quicksilver Mines Company has been incorporated under the laws of 
West Virginia to operate mines in Napa County; it owns 1,294 acres and has opened up four mines. The Twin Peaks Quicksilver Mining Company has been incorporated to operate in the same county. Twenty-one quicksilver mining locations are reported to have been made in Santa Clara County. The Bradford Quicksilver Mining Company, of San Jose, has been organized, and the old Guadalupe mine, idle for the last fifteen years, has been put in order for resumption of operations. In Solano County, the old St. John mine, 5 miles from Vallejo, was equipped with new machinery and is reported as one of the expected producers for 1900 . From 1873 to 1880 it was in operation, and produced 11,528 flasks. In Sonoma County, the old Cloverdale mine was reopened late in the year, but did not ship any quicksilver before the close of the year. The Siskiyou Quicksilver Mining Company is reported to have struck a good lead of ore in Siskiyou County, and a party of prospectors are said to have opened a promising location in Yolo County. The Crown Point Quicksilver Mining Company of San Francisco was organized early in 1900.

TEXAS.

Public attention was first directed to what now promises to be one of the most important quicksilver-producing districts of the United States, by Prof. William P. Blake, in a paper presented before the American Institute of Mining Engineers ${ }^{1}$ in 1895. The reports of the Texas Geological Survey and the monograph of Dr. George F. Becker upon the quicksilver deposits of the United States contain no account of this locality. According to Professor Blake the location of the deposit was made early in 1894 by Mr. George W. Wanless, of Jimenez, Mexico, and Mr. Charles Allen, of Socorro, New Mexico, who were led to an exploration of the region by reports of Mexicans having obtained some rich cinnabar" in the mountains of the "Great Bend" section of Texas. Professor Blake, in company with $\mathrm{Mr}$. James P. Chase, of Socorro, visited the locality in August, 1894.

The deposits" are located in Brewster County, about 68 miles in a direct line southwest from the station of Marathon on the Southern Pacific Railroad. The country is sparsely populated and presents few attractions for immigration apart from the mineral prospects. Professor Blake reports the cinnabar as occurring in massive limestone (designated by Mir. Robert $T$. Hill of the Cnited States Geological Survey as the Caprina limestone of the Cretaceous formation), and in a siliceous shale and a white earthy, clay-like rock; also, in part, in a true breccia of grayish white siliceous shale, dense and compact, embedded and cemented in a red and chocolate-colored ferruginous mass, also dense and hard. The cinnabar is more generally crystalline 
than amorphous and is found in distinctly separate grains and small but brilliant rhomboidal crystals having the brilliant red color characteristic of vermilion. In addition to these crystalline granules which occur in the brecciated shale and in the more massive white rock, there are amorphous bunches of cinnabar found in the shales and in the limestone and breccia.

Scarcity of fuel and water, as well as the distance from transportation, were pointed out by Professor Blake as difficulties in the way of working the deposits and concentrating or smelting the ore, and to these difficulties is probably due the length of time (five years) which has elapsed since the deposits were located and before any marketable product was obtained.

Mr. H. W. Turner, of the United States Geological Survey, visited the region (now termed the Terlingua Quicksilver Mining District) in the spring of the present year (1900). Mr. Turner also notes the difficulties presented in the scarcity of wood and water. The chief firewood at present is mesquite, but even this is scarce, and it is not suitable for mine timbering. At the time of Mr. Turner's visit a considerable amount of development work had been done and the ore extracted had yielded about 1,000 tlasks of quicksilver. All of this ore had come from surface workings or shallow shafts, and the prospecting work had not been carried far enough along to determine the depth of the workable ore bodies. Mr. Turner states, however, that as the limestone in which the cinnabar occurs is at this point at least 1,000 feet in thickness, and as the cinnabar undoubtedly comes from a source beneath the limestone, it is more than probable that the ore bodies will be found to a depth equal to the thickness of the limestone, with a good chance of their extending still deeper.

The cinnabar mines lie in a comparatively limited area, 4 miles long by 2 wide, though it is probable that the mineralized area will be found to extend a mile farther both ways. The general trend of the main lodes is in an easterly and westerly direction. The limestone of the district contains numerous brown veins composed of calcite and oxide of iron. The cinnabar occurs in these veins as stringers or pockets, many of the veins showing no trace of mercury, and even when cinnabar is present it often can not be seen until the rock is broken, owing to the discolored weathering of the surface.

In addition to cinnabar, mercury occurs in the native form--notably in what has been named the McKinley lode-and as a white coating and as yellow-green crystals. Prof. S. L. Penfield has identified the white coating as calomel, or chloride of mercury $\left(\mathrm{Hg}_{2} \mathrm{Cl}_{2}\right)$, and the greenish crystals as oxychloride of mercury, a new mineral species to which Mr. Turner has suggested the name of terlinguaite.

Among the mines which are now being worked are the Lindheim \& Dewees, owned by Louis Lindheim and Dell Dewees, of Del Rio; 
the Mariposa, belonging to Normand \& Galley, of Presidio; the California, owned by a California company, and the Excelsior, owned by J. J. Hess, of Marathon. At the time of Mr. Turner's visit the ore was being retorted at two points. At one place only a single retort was worked and at the other place there were four. Only the high-grade ore was being retorted. Since that time a furnace has been constructed by the Marfa and Mariposa Mining Company, and in Mr. Turner's opinion the output for 1900 will be considerably more than that of 1899 .

\section{IMPORTS.}

In the following table is given a statement of the imports of quick. silver from 1867 to 1899 :

Quicksilver imported and entered for consumption in the United States, 1867 to 1899 , inclusive.

\begin{tabular}{|c|c|c|c|c|c|}
\hline Year ending- & Quantity. & Value. & Year ending- & Quantity. & Value. \\
\hline June $30-$ & Pouncls. & & June $30-$ & Pounds. & \\
\hline $1867 \ldots$ & $\ldots \ldots \ldots$ & $\$ 15,248$ & $1884 \ldots$ & 136,615 & $\$ 44,035$ \\
\hline $1868 \ldots$ & 152 & 68 & 1885. & 257,659 & 90,416 \\
\hline 1869 & $\ldots \ldots$ & 11 & Dec. $31-$ & & \\
\hline $1870 \ldots$ & 239,223 & 107,646 & 1886. & 629,888 & 249,411 \\
\hline $1871 \ldots$ & 304,965 & $13 \overline{7}, 332$ & $1887 .$. & 419,934 & 171,431 \\
\hline 1872. & 370,353 & 189,943 & 1888. & 132,850 & 56,997 \\
\hline $1873 \ldots$ & 99,898 & 74,146 & $1889 \ldots$ & 341,514 & 162,064 \\
\hline $1874 \ldots$. & 51,202 & 52,093 & $1890 \ldots$ & 802,871 & 445,807 \\
\hline 1875. & 6,870 & 20,957 & $1891 \ldots$ & 123,966 & 61,355 \\
\hline $1876 \ldots$ & 78,902 & 50,164 & $1892 \ldots$ & 96,318 & 40,133 \\
\hline $1877 \ldots$ & 38,250 & 19,558 & 1893 & 41,772 & 17,400 \\
\hline 1878. & 294,207 & 135,178 & $1894 \ldots$ & 7 & 6 \\
\hline 1879 & 519,125 & 217,707 & $1895 .$. & 15,001 & 7,008 \\
\hline $1880 \ldots$ & 116,700 & 48,463 & $1896 \ldots$ & 305 & 118 \\
\hline $1881 \ldots$ & 138,517 & 57,733 & $1897 \ldots$ & 45,539 & 20,147 \\
\hline $1882 \ldots$ & $59 \overline{7}, 898$ & 233,057 & $1898 \ldots$ & 81 & 51 \\
\hline $1883 . .$. & $1,552,738$ & 598,367 & 1899. & 131. & S:3 \\
\hline
\end{tabular}


EXPORTS.

The exports of quicksilver from the United States for the last twenty years are shown in the following table. The quantities are expressed in flasks of $76 \frac{1}{2}$ pounds net. Nearly all of the quicksilver exported is shipped from San Francisco.

Exports of quicksilver from the United States since 1880

\begin{tabular}{|c|c|c|}
\hline Year. & Flasks. & Value. \\
\hline $1880 \ldots \ldots \ldots \ldots$ & 37,210 & $\$ 1,119,952$ \\
\hline $1881 \ldots$ & 35,107 & $1,025,299$ \\
\hline 1882 & 33,875 & 988,454 \\
\hline$\ldots \ldots \ldots$ & 30,072 & 808,353 \\
\hline $1884 \ldots$ & 7,370 & 199,685 \\
\hline 1885 . & 6,802 & 209,753 \\
\hline $1886 \ldots$ & 8,091 & 204,956 \\
\hline 1887 & 11,394 & 441,112 \\
\hline 1888 & 10,684 & 406,899 \\
\hline $1889 \ldots$ & 5,111 & 213,717 \\
\hline 1890. & 2,069 & 93,192 \\
\hline 1891. & 3,714 & 145,502 \\
\hline $1892 \ldots \ldots \ldots \ldots$ & 3,518 & 133,626 \\
\hline $1893 \ldots$ & 16,631 & 542,410 \\
\hline 1894 & 14,408 & 397,528 \\
\hline $1895 \ldots$ & 15,542 & 482,085 \\
\hline 1896 & 19,944 & 618,437 \\
\hline $1897 \ldots$ & 13,173 & 394,549 \\
\hline $1898 \ldots \ldots \ldots$. & 12,830 & 440,587 \\
\hline 1899 & 16,517 & 609,586 \\
\hline
\end{tabular}


PRICES.

The highest and lowest prices for quicksilver in London and San Francisco during a period of fifty years is shown in the following table:

Highest and lovest prices of quicksilver during the last fifty years.

\begin{tabular}{|c|c|c|c|c|c|c|c|c|}
\hline \multirow{3}{*}{ Year. } & \multicolumn{2}{|c|}{ Price in San Francisco. } & \multicolumn{6}{|c|}{ Price in London. } \\
\hline & \multirow[t]{2}{*}{ Highest. } & \multirow[t]{2}{*}{ Lowest. } & \multicolumn{3}{|c|}{ Highest. } & \multicolumn{3}{|c|}{ Lowest. } \\
\hline & & & & & & $£$ & s. & $d$. \\
\hline $1850 \ldots \ldots \ldots$ & $\$ 114.75$ & $\$ 84.15$ & 15 & 0 & 0 & 13 & 2 & 6 \\
\hline $1851 \ldots \ldots \ldots$ & 76.50 & 57.35 & 13 & 15 & 0 & 12 & 5 & 0 \\
\hline $1852 \ldots \ldots \ldots \ldots \ldots$ & 61.20 & 55.45 & 11 & 10 & 0 & 9 & 7 & $6{ }^{\circ}$ \\
\hline $1853 \ldots$ & 55.45 & 55.45 & 8 & 15 & 0 & 8 & 2 & 6 \\
\hline $185+\ldots \ldots \ldots \ldots \ldots \ldots \ldots \ldots$ & 55.45 & 55.45 & 7 & 15 & 0 & 7 & 5 & 0 \\
\hline $1855 \ldots \ldots \ldots \ldots$ & 55.45 & 51.65 & 6 & 17 & 6 & 6 & 10 & 0 \\
\hline $1856 \ldots \ldots \ldots \ldots$ & 51.65 & 51.65 & 6 & 10 & 0 & 6 & 10 & 0 \\
\hline $1857 \ldots \ldots \ldots \ldots$. & 53.55 & 45.90 & 6 & 10 & 0 & 6 & 10 & 0 \\
\hline $1858 \ldots \ldots \ldots \ldots$ & 49. 75 & 45.90 & 7 & 10 & 0 & 7 & 5 & 0 \\
\hline $1 \$ 59 \ldots$ & 76.50 & 49.75 & 7 & 5 & 0 & 7 & 0 & 0 \\
\hline $1860 \ldots \ldots \ldots \ldots \ldots \ldots . . . \ldots \ldots$ & 57.35 & 49.75 & 7 & 0 & 0 & 7 & 0 & 0 \\
\hline $1861 \ldots$ & 49. 75 & 34.45 & 7 & 0 & 0 & 7 & 0 & 0 \\
\hline $1862 \ldots$. & 38.25 & 34.45 & 7 & 0 & 0 & 7 & 0 & 0 \\
\hline $1863 \ldots \ldots \ldots \ldots \ldots \ldots \ldots$ & 45.90 & 38.25 & 7 & 0 & 0 & 7 & 0 & 0 \\
\hline $1864 \ldots$ & 45.90 & 45.90 & 9 & 0 & 0 & 7 & 10 & 0 \\
\hline $1865 \ldots \ldots \ldots \ldots \ldots \ldots$ & 45.90 & 45.90 & 8 & 0 & 0 & 7 & 17 & 6 \\
\hline $1866^{2} \ldots \ldots \ldots \ldots$ & 57.35 & 45.90 & 8 & 0 & 0 & 6 & 17 & 0 \\
\hline $1867 \ldots \ldots \ldots \ldots \ldots \ldots \ldots$ & 45.90 & 45.90 & 7 & 0 & 0 & 6 & 16 & 0 \\
\hline $1868 \ldots \ldots \ldots \ldots \ldots \ldots$ & 45.90 & 45.90 & 6 & 17 & 0 & 6 & 16 & 0 \\
\hline $1869 \ldots$ & 45.90 & 45.90 & 6 & 17 & 0 & 6 & 16 & 0 \\
\hline $1870 \ldots \ldots$ & 68.85 & 45.90 & 10 & 0 & 0 & 6 & 16 & 0 \\
\hline $1871 \ldots \ldots \ldots \ldots$ & 68.85 & 57.35 & 12 & 0 & 0 & 9 & 0 & 0 \\
\hline $1872 \ldots$. & 66.95 & 65.00 & 13 & 0 & 0 & 10 & 0 & 0 \\
\hline $1873 \ldots \ldots \ldots \ldots$ & 91.80 & 68.85 & 20 & 0 & 0 & 12 & 10 & 0 \\
\hline $1874 \ldots \ldots \ldots \ldots \ldots \ldots \ldots$ & 118.55 & 91.80 & 26 & 0 & 0 & 19 & 0 & 0 \\
\hline $1875 \ldots$ & 118.55 & 49.75 & 24 & 0 & 0 & 9 & 17 & 6 \\
\hline $1876 \ldots \ldots \ldots \ldots \ldots \ldots$ & 53.55 & 34.45 & 12 & 0 & 0 & 7 & 17 & 6 \\
\hline $1877 \ldots \ldots \ldots \ldots \ldots \ldots$ & 44.00 & 30.60 & 9 & 10 & 0 & 7 & 2 & 6 \\
\hline 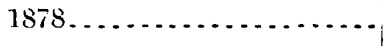 & 35.95 & 29.85 & 7 & 5 & 0 & 6 & 7 & 6 \\
\hline $1879 \ldots \ldots \ldots \ldots \ldots \ldots$ & 34.45 & 25.25 & 8 & 15 & 0 & 5 & 17 & 6 \\
\hline $1880 \ldots$ & 34.45 & 27.55 & 7 & 15 & 0 & 6 & 7 & 6 \\
\hline $1881^{\circ} \ldots \ldots \ldots \ldots \ldots$ & 31.75 & 27.90 & 7 & 0 & 0 & 6 & 2 & 6 \\
\hline $18 s 2 \ldots \ldots \ldots \ldots \ldots \ldots \ldots$ & 29.10 & 27.35 & 6 & 5 & 0 & 5 & 15 & 0 \\
\hline $1883 \ldots \ldots \ldots \ldots$ & 28.50 & 26.00 & 5 & 17 & 6 & 5 & 5 & 0 \\
\hline $1884 \ldots$. & 35.00 & 26.00 & 6 & 15 & 0 & 5 & 2 & 6 \\
\hline
\end{tabular}


QUICKSILVER.

Highest and lowest prices of quicksilver diuring the last fifty years-Continued.

[Per. flask.]

\begin{tabular}{|c|c|c|c|c|c|c|c|c|}
\hline \multirow{2}{*}{ Year. } & \multicolumn{2}{|c|}{ Price in San Francisco. . } & \multicolumn{6}{|c|}{ Price in London. } \\
\hline & \multirow[t]{2}{*}{ Highest. } & \multirow[t]{2}{*}{ Lowest. } & \multicolumn{3}{|c|}{ Highest. } & \multicolumn{3}{|c|}{ Lowest. } \\
\hline & & & $f$ & $s$. & & $\mathfrak{f}$ & s. & \\
\hline $1885 \ldots \ldots \ldots \ldots \ldots \ldots$ & $\$ 33.00$ & $\$ 28.50$ & 6 & 15 & 0 & 5 & 10 & 0 \\
\hline $1886 \ldots .$. & 39.00 & 32.00 & 7 & 10 & 0 & 5 & 16 & 3 \\
\hline $1887 \ldots \ldots \ldots$ & 50.00 & 36.50 & 11 & 5 & 0 & 6 & 7 & 6 \\
\hline$\ldots \ldots \ldots$ & 47.00 & 36.00 & 10 & 0 & 0 & 6 & 12 & 6 \\
\hline $1889 \ldots \ldots$ & 50.00 & 40.00 & 9 & 15 & 0 & 7 & 10 & 0 \\
\hline $1890 \ldots$ & 58.00 & 47.00 & 10 & 10 & 0 & 9 & 1. & 0 \\
\hline 1891. & 51.00 & 39.50 & 8 & 12 & 6 & 7 & 5 & 0 \\
\hline $1892 \ldots \ldots$ & 47.50 & 41.50 & 7 & 10 & 0 & 6 & 2 & 6 \\
\hline 1893. & 43.50 & 30.00 & 6 & 17 & 6 & 6 & 2 & 0 \\
\hline $1894^{\circ}$ & 37.00 & 28.50 & 6 & 15 & 0 & 5 & 7 & 6 \\
\hline $1895 \ldots$ & 41.00 & 35.90 & 7 & 10 & 0 & 6 & 10 & 0 \\
\hline $1896 \ldots \ldots \ldots$ & 40.00 & 36.00 & 7 & 7 & 6 & 6 & 7 & 6 \\
\hline $1897 \ldots$ & 40.50 & 36.50 & 7 & 7 & 6 & 6 & 12 & 6 \\
\hline 1898. & 40.00 & 30.00 & 7 & 15 & 0 & 7 & 0 & 0 \\
\hline $1899 \ldots$ & $51 . .50$ & 37.50 & 9 & 12 & 6 & 7 & 18 & 9 \\
\hline Extreme range...... & 118.55 & 25.25 & 26 & 0 & 0 & 5 & 2 & 6 \\
\hline
\end{tabular}

In the following table is shown the highest and lowest prices of quicksilver at San Francisco and London for each month during 1899:

Highest and lowest prices for quicksilver in 1899, by months.

[Per flask of $76 \frac{1}{2}$ pounds, net.]

\begin{tabular}{|c|c|c|c|c|c|c|c|c|}
\hline \multirow{3}{*}{ Month. } & \multicolumn{2}{|c|}{ In San Francisco. } & \multicolumn{6}{|c|}{ In London. } \\
\hline & \multirow[t]{2}{*}{ Highest. $a$} & \multirow[t]{2}{*}{ Lowest. $b$} & \multicolumn{3}{|c|}{ Highest. } & \multicolumn{3}{|c|}{ Lowest. } \\
\hline & & & $£$ & s. & & $£$ & $\varepsilon$. & $d$. \\
\hline 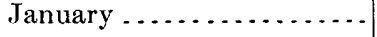 & $\$ 42.00$ & $\$ 37.50$ & 7 & $19^{\circ}$ & 0 & 7 & 18 & 9 \\
\hline February . . . . . . . . . . & 42.00 & 38. $\check{0} 0$ & 8 & 4 & 0 & 8 & 4 & 0 \\
\hline March..................... & 42.50 & 39.00 & 8 & 4 & 0 & 8 & 2 & 6 \\
\hline April................ & 42.50 & 38.00 & 8 & 1 & 3 & 7 & 17 & 6 \\
\hline May ... & 42.00 & 38.50 & 8 & 2 & 6 & 8 & 0 & 0 \\
\hline June ............... & 43.00 & 38.50 & 8 & 4 & 0 & 8 & 2 & 6 \\
\hline July $\ldots \ldots \ldots \ldots \ldots$ & 43.50 & 39.00 & 8 & 7 & 6 & 8 & 5 & 0 \\
\hline August $\ldots . . . \ldots \ldots \ldots \ldots$ & 43.50 & 39.50 & 8 & 10 & 0 & 8 & 7 & 6 \\
\hline September . ... & 46.00 & 40.50 & 8 & 12 & 7 & 8 & 12 & 6 \\
\hline October .... & 47.00 & 41.00 & 8 & 17 & 6 & 8 & 12 & 6 \\
\hline November... & 50.00 & 45.00 & 9 & 10 & 0 & 9 & 5 & 0 \\
\hline December ............... & 51.50 & 45.50 & 9 & 12 & 6 & 9 & 10 & 0 \\
\hline
\end{tabular}

$a$ For local delivery.

$b$ For export. 


\section{NICKEL AND COBALT.}

\section{PRODUC'IION.}

The domestic supply of nickel and cobalt in 1899 returned to about the product of 1897 , after a considerable decrease for 1898 . As before, nickel and cobalt remained by-products from the smelting of lead ores at Mine Lamotte, Missouri. The production of cobalt oxide increased correspondingly, from 6,247 pounds in 1898 to 10,230 pounds in 1899. Continued efforts are being made to develop the nickel from Oregon, and these will probably be successful with the future cheap means of transportation. The bulk of the nickel used in the United States continues to come from the well-known deposits of Sudbury, Canada.

The following tables show the production and importation to the close of 1899:

Production of nickel from domestic ores in the United States during the years $188 \%$ to 1899.

\begin{tabular}{|c|c|c|}
\hline Year. & Quantity. & Value. \\
\hline 1887 & Pounds. & $\$ 133200$ \\
\hline $1888 \ldots \ldots \ldots$ & 204,328 & 127,632 \\
\hline $1889 \ldots$ & 252,663 & 151,598 \\
\hline $1890 \ldots$. & 223,488 & 134,093 \\
\hline $1891 \ldots$ & 118,498 & 71,099 \\
\hline $1892 .$. & 92,252 & 50,739 \\
\hline $1893 \ldots$ & 49,399 & 22,197 \\
\hline $1894 \ldots$ & 9,616 & 3,269 \\
\hline $1895 \ldots$ & 10,302 & 3,091 \\
\hline 1896. & 17,170 & 4,464 \\
\hline $1897 \ldots$ & 23,707 & 7,823 \\
\hline $1898 \ldots$. & 11,145 & 3,956 \\
\hline $1899 \ldots \ldots \ldots$ & 22,541 & $8, \tilde{5} 66$ \\
\hline
\end{tabular}


Production of cobalt oxide in the United States, 1869 to 1899.

\begin{tabular}{|c|c|c|c|c|c|}
\hline Year. & Quantity. & Year. & Quantity. & Year. & Quantity. \\
\hline & Pounds. & & Pounds. & & Pounds. \\
\hline 1869. & 811 & $1880 \ldots \ldots$ & 7,251 & $1891 \ldots \ldots$ & 7,200 \\
\hline 1870. & 3,854 & $1881 \ldots \ldots$ & 8,280 & 1892. & 7,869 \\
\hline 1871. & 5,086 & $1882 \ldots \ldots$ & 11,653 & 1893. & 8,422 \\
\hline 1872 . & 5,749 & 1883. & 1,096 & 1894. & 6,763 \\
\hline 1873. & 5,128 & 1884. & 2,000 & $1895 \ldots \ldots$ & 14,458 \\
\hline 1874 & 4,145 & 1885 . & 8,423 & 1896 & 10,700 \\
\hline 1875 . & 3,441 & 1886 & 8,689 & 1897 & 19,520 \\
\hline 1876 . & 5,162 & $1887 \ldots \ldots$ & $\leadsto 18,340$ & $1898 \ldots$ & 6,247 \\
\hline 1877. & 7,328 & $1888 \ldots \ldots$. & 8,491 & 1899 & 10,230 \\
\hline $1878 \ldots$ & 4,508 & $1889 \ldots$ & $.13,955$ & & . \\
\hline 1879. & 4,376 & $1890 \ldots . . .$. & 6,788 & & \\
\hline
\end{tabular}

a Including cobalt oxide in ore and matte.

\section{IMPORTS AND EXPORTS.}

In the following tables are given the statistics of the imports of cobalt oxide and of nickel into the United States from 1868 to 1899:

Cobalt oxide imported and entered for consumption in the United States, 1868 to 1899.

\begin{tabular}{|c|c|c|c|c|c|}
\hline \multirow{2}{*}{ Year ending- } & \multicolumn{2}{|c|}{ Oxide. } & \multirow{2}{*}{ Year ending- } & \multicolumn{2}{|c|}{ Oxide. } \\
\hline & Quantity. & Value. & & Quantity. & Value. \\
\hline June $30-$ & Pounds. & & June $30-$ & Pounds. & \\
\hline 1868. & $\ldots .$. & $\$ 7,208$ & 1885. & 16,162 & $\$ 28,138$ \\
\hline 1869. & & 2,330 & Dec. $31-$ & & \\
\hline 1870. & & 5,019 & 1886 . & 19,366 & 29,543 \\
\hline 1871. & $\cdots$ & 2,766 & 1887. & 26,882 & 39,396 \\
\hline 1872. & & 4,920 & $1888 \ldots \ldots$ & 27,446 & 46,211 \\
\hline 1873. & 1,480 & 4,714 & 1889. & 41,455 & 82,332 \\
\hline 1874. & 1,404 & 5,500 & 1890. & 33,338 & 63,202 \\
\hline 1875. & 678 & 2,604 & 1891 & 23,643 & 43,188 \\
\hline 1876. & 4,440 & 11,180 & 1892 . & 32,833 & 60,067 \\
\hline 1877. & 19,752 & 11,056 & 1893. & 28,884 & 42,694 \\
\hline 1878. & 2,860 & 8,633 & $1894 \ldots .$. & $2 \dot{1}, 020$ & 29,857 \\
\hline 1879 & 7,531 & 15,208 & 1895. & 36,155 & 39,839 \\
\hline 1880. & 9,819 & 18,457 & $1896 \ldots$ & 27,180 & 36,212 \\
\hline 1881. & 21,844 & 13,837 & $1897 \ldots$ & 24,771 & 34,773 \\
\hline 1882 . & 17,758 & 12,764 & 1898 & 33,731 & 49,245 \\
\hline 1883 & 13,067 & 22,323 & $1899 \ldots$. & 46,791 & 68,847 \\
\hline 1884 & 25,963 & 43,611 & & & \\
\hline
\end{tabular}


NICKEL AND COBALT.

Nickel imported and entered for consumption in the United States, 1868 to 1899.

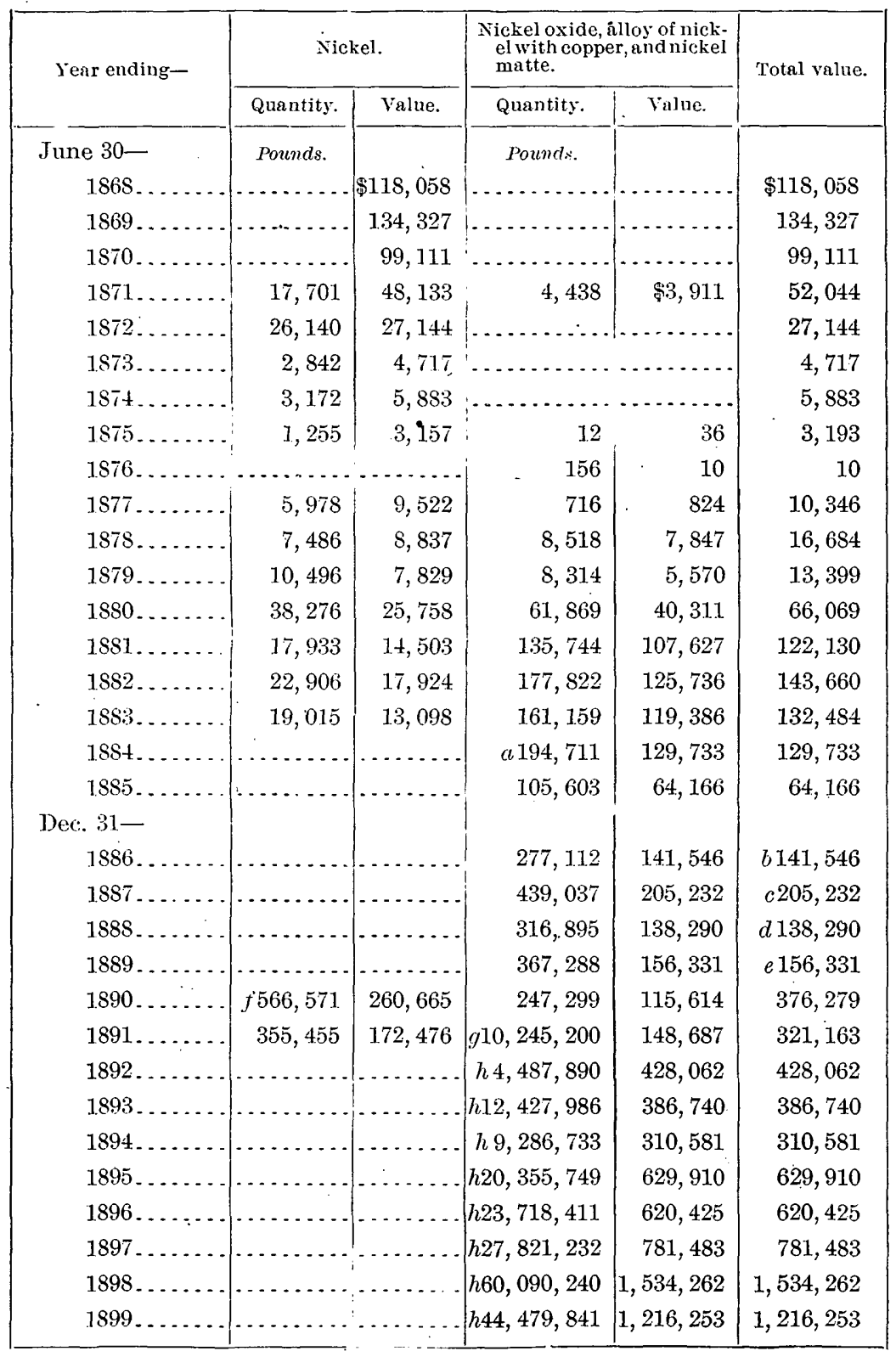

$a$ Including metallic nickel

$b$ Including $\$ 465$ worth of manufactured nickel.

$c$ Including $\$ 879$ worth of manufactured nickel.

$d$ Including $\$ 2,281$ worth of manufactured nickel.

$e$ Including $\$ 131$ worth of manufactured nickel.

$f$ Classified as nickel, nickel oxide, alloy of any kind $i_{i 1}$ which nickel is the element or material of chief value.

$g$ Classified as nickel and nickel matte.

$h$ Includes all nickel imports except manufactures; nearly all of this is nickel in matte from Canada, containing about 20 per cent nickel. 
Jixports of nickel oxide and matte from the United States from 1894 to 1899.

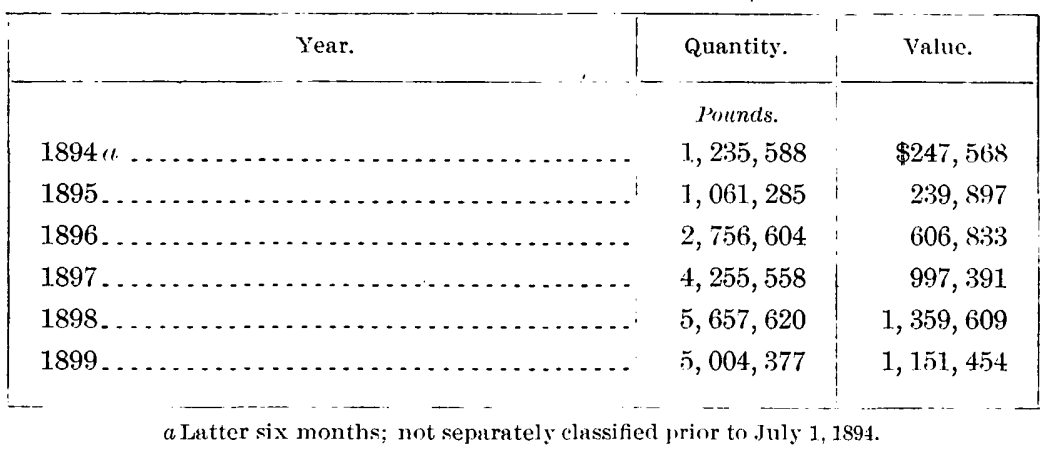

\section{FOREIGN PRODUCIION.}

In vicw of the fact that the United States obtains its chief supply of nickel from Canada, the following statement of production in that country since 1889 will be of interest. It should be observed that in this table the statistics are for metallic nickel, while in the table of imports into the United States the quantity of nickel matte is given.

Outside of Canada the principal producers of nickel are France and Germany. Statements of the production in these countries from 1886 to 1897 are appended:

Production of nickel in Canada from 1889 to 1899.

\begin{tabular}{|c|c|c|}
\hline Year. & Quantity. & Value. \\
\hline & Pounds. & \\
\hline 1889 & 830,477 & $\$ 498,286$ \\
\hline 1890 & $1,435,742$ & 933,232 \\
\hline 1891. & $4,626,627$ & $2,775,976$ \\
\hline 1892 & $2,413,717$ & $1,399,956$ \\
\hline 1893. & $3,992,982$ & $2,076,351$ \\
\hline $1894 \ldots$ & $4,907,430$ & $2,061,120$ \\
\hline 1895 & $3,888,525$ & $1,360,984$ \\
\hline $1896 \ldots$ & $3,397,113$ & $1,188,990$ \\
\hline $1897 \ldots$ & $3,997,746$ & $1,399,137$ \\
\hline $1898 \ldots$ & $5,517,690$ & $1,820,838$ \\
\hline $1899 \ldots \ldots \ldots \ldots$ & $5,744,000$ & $2,067,840$ \\
\hline
\end{tabular}


NICKEL AND COBALT.

Production of nickel in France from 1886 to 1898 .

\begin{tabular}{|c|c|c|c|}
\hline Year. & Quantity. & \multicolumn{2}{|c|}{ Value. } \\
\hline & Metric tons. & Francs. & \\
\hline $1886 \ldots \ldots \ldots \ldots \ldots$ & 30 & $1 S 0,000$ & $\$ 34,200$ \\
\hline $1887 \ldots \ldots \ldots \ldots . . . \ldots \ldots$ & 30 & 180,000 & 34,200 \\
\hline 1888. & 30 & 210,000 & 39,900 \\
\hline $1889 \ldots$ & 330 & $1,710,000$ & 324,900 \\
\hline $1890 \ldots$ & 330 & $1,670,000$ & 317,300 \\
\hline 1891. & 330 & $1,6 \$ 0,000$ & 319,200 \\
\hline $1892 \ldots$ & 1,244 & $6,182,000$ & $1,174,580$ \\
\hline 1893. & 2,045 & $6,1 S 8,000$ & $1,175,720$ \\
\hline $1894 \ldots$ & 1,545 & $6,1 S 8,000$ & $1,175,720$ \\
\hline 1895 & 1,545 & $\check{5}, 438,000$ & $1,033,220$ \\
\hline $1896 \ldots . . .$. & $1,5 \breve{5} 45$ & $4,607,000$ & 875,330 \\
\hline 1897. & 1,245 & $3,707,500$ & 704,425 \\
\hline 1898 & 1,540 & $4,600,000$ & 887,800 \\
\hline
\end{tabular}

Production of nickel in Germany (Prussia) from 1886 to 1898.

\begin{tabular}{|c|c|c|}
\hline Year. & Quantity. & Value. \\
\hline & Metric tons. & \\
\hline 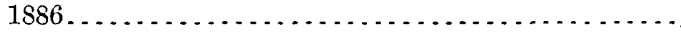 & 169 & $\$ 179,930$ \\
\hline $1887 \ldots$ & 169 & 179,930 \\
\hline 1888 & 288 & 273,030 \\
\hline $1889 \ldots \ldots \ldots \ldots$ & 282 & 279,680 \\
\hline $1890 \ldots . . . .$. & 434 & 436,430 \\
\hline 1891 & 594 & 644,480 \\
\hline $1892 \ldots \ldots \ldots \ldots$ & 747 & 698,630 \\
\hline $1893 \ldots$ & 893 & 774,630 \\
\hline $1894 \ldots$ & 522 & 449,350 \\
\hline 1895 & 698 & 575,890 \\
\hline 1896. & 822 & 666,900 \\
\hline 1897 & $\$ 98$ & 710,980 \\
\hline $1898 \ldots \ldots \ldots . . . . . . .$. & 1,108 & 670,482 \\
\hline
\end{tabular}

21 GEOL, P' $6-19$ 



\title{
ANTIMONY.
}

\author{
By Edward W. Parker.
}

\section{PRODUCTION.}

Including the antimony contained in hard or antimonial lead, the amount of this metal obtained from ores of domestic production in 1899 was 234 short tons, valued at $\$ 43,600$. If to this product is added the amount of antimony contained in foreign ores smelted in the United States, the total amount of metal produced in this country in 1899 is estimated to have been 1,275 short tons, having a total value of $\$ 251,875$. In making this estimate the ore imported (which for 1899 is reported by the Bureau of Statistics of the Treasury Department at $3,968,654$ pounds, or 1,984 short tons) is assumed to contain an average of $52 \frac{1}{2}$ per cent of available metal, and the value is computed at the average price for the year. In addition to the antimony produced in the United States we imported in 1899 2,990,915 pounds, or 1,495 short tons, of metal, crude and regulus, valued at $\$ 241,685$, this value being at shipping port, exclusive of freight and import duties. The total domestic consumption of antimony in 1899, assuming that stocks at the beginning and the close of the year were about equal, amounted approximately to 2,770 short tons, the total value of which, based on the average price for the year, was about $\$ 550,000$.

Compared with 1898, the amount of antimony produced from foreign and domestic ores in the United States in 1899 shows an increase of 155 short tons, with an increase of $\$ 67,825$ in value. Prices averaged about 2 cents per pound higher during 1899 than in 1898, indicating the extent to which the antimony market was affected by the industrial revival of 1899. The total domestic consumption increased from 2,272 short tons in 1898 to 2,770 tons in 1899 , a gain of nearly 500 tons, or about 22 per cent. The amount of antimony obtained from domestic ores, including that contained in antimonial lead, is less than 10 per cent of the total consumption.

The ore of domestic production in 1899 was mined principally in California and Idaho. Small amounts were produced in Arkansas and Nevada, but no output was reported from either Montana or Utah. The discovery of an extensive deposit of antimony ore has been reported in Kittitas County, Washington, from which shipments were expected to be made before the close of the present year. 
In the following table is shown the annual production of antimony in the United States since 1880:

Production of antimony. in the Lnited States since 1880.

\begin{tabular}{|c|c|c|c|c|c|}
\hline Year. & Quantity. & Value. & Year. & Quantity. & Value. \\
\hline & Short tons. & & & Short tons. & \\
\hline $1880 \ldots \ldots$ & 50 & $\$ 10,000$ & $1891 \ldots$ & 278 & $\$ 47,007$ \\
\hline $1881 \ldots$ & .50 & 10,000 & 1892: & & \\
\hline $1882 \ldots \ldots$ & 60 & 12,000 & Metallic & 150 & \\
\hline $1883 \ldots$ & 60 & 12,000 & Ore .... & 380 & 56,466 \\
\hline $1884 \ldots$ & 60 & 12,000 & 1893. & 250 & 45,000 \\
\hline $1885 \ldots \ldots$ & 50 & 10,000 & $1894 \ldots \ldots \ldots$ & 200 & 36,000 \\
\hline $1886 \ldots$ & 35 & 7,000 & 1895. & $a 450$ & $6 \mathrm{~S}, 000$ \\
\hline $1887 \ldots$ & 75 & 15,000 & 1896 & $a 601$ & 84,290 \\
\hline $1888 \ldots$ & 100 & 20,000 & $1897 \ldots \ldots$ & $a 844$ & 121,944 \\
\hline $1889 \ldots$ & 115 & 28,000 & $1898 \ldots$ & a 1,120 & 184,050 \\
\hline $1890 \ldots$ & 129 & 40,756 & 1899 & $a 1,275$ & 251,875 \\
\hline
\end{tabular}

$a$ Principally from imported ores, and includes antimony contained in antimonial lead.

\section{CONSUMPTION.}

In the following table is presented a statement of the consumption of antimony in the United States since 1880. The imported ore is estimated at $52 \frac{1}{2}$ per cent metallic antimony, and "crude and regulus" is taken to be equivalent to metal.

Estimated consumption of antimony in the United States since 1880.

\begin{tabular}{|c|c|c|c|c|}
\hline Year. & $\begin{array}{l}\text { From do- } \\
\text { mestic ores. }\end{array}$ & $\begin{array}{c}\text { From im- } \\
\text { ported ores. }\end{array}$ & $\begin{array}{l}\text { Imported } \\
\text { crude or } \\
\text { regulus. }\end{array}$ & Total. \\
\hline & Short tons. & Short tons. & Short tons. & Short tons. \\
\hline $1880 \ldots \ldots \ldots \ldots \ldots \ldots \ldots$ & 50 & 7 & 1,010 & 1,067 \\
\hline $1881 \ldots$ & 50 & 221 & 904 & 1,175 \\
\hline $1882 \ldots \ldots \ldots \ldots \ldots$ & 60 & 292 & 1,263 & 1,615 \\
\hline $1883 \ldots \ldots$ & 60 & 183 & 1,532 & 1,775 \\
\hline $1884 \ldots$ & 60 & 61 & 890 & 1,011 \\
\hline $1885 \ldots \ldots \ldots$ & 50 & 57 & 1,290 & 1,397 \\
\hline $1886 \ldots \ldots$ & 35 & 58 & 1,499 & 1,592 \\
\hline$\ldots \ldots \ldots \ldots$ & $7 \tilde{u}$ & $\widehat{\vartheta} \tilde{5}$ & i, 277 & $\overrightarrow{\mathbf{I}}, \dot{4} 4 \mathbf{i}$ \\
\hline $1888 \ldots \ldots \ldots \ldots \ldots$ & 100 & 18 & 1,407 & 1,525 \\
\hline $1889 \ldots \ldots$ & 115 & 38 & 1,338 & 1,491 \\
\hline 1890 . & 129 & 160 & 1,658 & 1,947 \\
\hline $1891 \ldots \ldots . . . . .$. & 278 & 377 & 1,309 & 1,964 \\
\hline $1892 \ldots . .$. & 150 & 50 & 1,975 & 2,175 \\
\hline $1893 \ldots$ & 250 & 30 & 1,390 & 1,670 \\
\hline 1894 & 200 & 100 & 1,327 & $1,62 \overline{7}$ \\
\hline 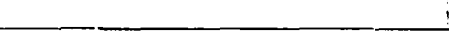 & & & & \\
\hline
\end{tabular}


Estimated consumption of antimony in the United States since 1880-Continued.

\begin{tabular}{|c|c|c|c|c|}
\hline Year. & $\begin{array}{c}\text { From do- } \\
\text { mestic ores. }\end{array}$ & $\begin{array}{c}\text { From im- } \\
\text { ported ores. }\end{array}$ & $\begin{array}{l}\text { Imported } \\
\text { crude or } \\
\text { regulus. }\end{array}$ & Total. \\
\hline $1895 \ldots . .$. & $\begin{array}{c}\text { Short tons. } \\
\quad \text { a } 275\end{array}$ & $\begin{array}{l}\text { Short tons. } \\
\quad a 175\end{array}$ & $\begin{array}{c}\text { Short tons. } \\
1,750\end{array}$ & $\begin{array}{c}\text { Short tons. } \\
2,200\end{array}$ \\
\hline $1896 \ldots$ & $a 291$ & a 310 & 1,288 & 1,889 \\
\hline $1897 \ldots$ & $a 245$ & a $599^{\circ}$ & 1,141 & 1,985 \\
\hline $1898 \ldots \ldots$ & $a 250$ & $a 870$ & 1,052 & 2,172 \\
\hline 1899 & 234 & $\cdot 1,041$ & 1,495 & 2,770 \\
\hline
\end{tabular}

a Separation estimated. All antimony smelted, whether from domestic or foreign ores, was reported as of domestic production.

An interesting feature presented in the foregoing table is the increased amount of antimony obtained from foreign ores during the last few years. This has been due to the removal of the principal smelting works from San Francisco to Staten Island. This was found to be necessary in order to obtain a more regular supply of ore than was to be secured from the localities developed in the United States. The removal was accomplished in 1894, since which time the production of regulus from imported ores has steadily increased.

\section{IMPORTS.}

The following table, compiled from the records of the Bureau of Statistics of the Treasury. Department, shows the amount and value of the antimony ore and metal imported into the United States since 1867. It will be observed that during the last twenty years the amount of crude antimony and regulus imported has been notably regular, with an increasing tendency, until the last few years. In the first five years of this period the imports averaged about $2,260,000$ pounds annually. 'In the five years from 1885 to 1889 , inclusive, the average imports were $2,724,000$ pounds a year. In the next five years the average had increased to $3,064,000$ pounds a year, while in the last five years the average has declined to $2,690,000$ pounds. The decrease in the last five years has been due to the larger imports of ore which was smelted in this country. The first year that any amount of imported ore is recorded is for 1875 , when 6,460 pounds, or a little over 3 short tons, were received. In the five years from 1875 to 1879 the total amount of ore imported was less than 50 tons. During the next fifteen years the total amount of ore imported was $6,650,550$ pounds, or about 3,325 short tons, an average of 222 tons a year. From 1895 to 1899 the imports have amounted to $13,286,500$ pounds, or 6,643 short tonsnearly double the total imports during the preceding fifteen years. In the last three years the imports of ore have amounted to $11,437,062$ pounds, about one and one-third times the aggregate imports from 1875 to 1896 , inclusive. 
These figures indicate that all of the normal increase in consumption during the last few years has been supplied by metal smelted in the United States, although the ores from which it was obtained were principally the product of foreign mines.

Antimony and antimony ore imported and entered for consumption in the United States, from 1867 to 1899.

\begin{tabular}{|c|c|c|c|c|c|}
\hline \multirow{2}{*}{ Year ending- } & \multicolumn{2}{|c|}{ Crude and regulus. } & \multicolumn{2}{|l|}{ Ore. } & \multirow{2}{*}{ Total value. } \\
\hline & Quantity. & Value. & Quantity. & Value. & \\
\hline June $30,1867 \ldots$ & \begin{tabular}{|c|} 
Pounds. \\
$\ldots$
\end{tabular} & $\$ 63,919$ & $\begin{array}{c}\text { Pounds. } \\
\text { P. }\end{array}$ & $\ldots \ldots$ & $\$ 63,919$ \\
\hline $1868 \ldots$ & 1, 033,336 & 83,822 & & $\ldots$ & 83,822 \\
\hline $1869 \ldots$ & $1,345,921$ & 129,918 & & $\ldots \ldots$ & 129,918 \\
\hline $1870 \ldots$ & $1,227,429$ & 164,179 & $\ldots$ & $\ldots \ldots$ & 164,179 \\
\hline $1871 \ldots$ & $1,015,039$ & 148,264 & & $\$ 2,364$ & 150,628 \\
\hline $1872 \ldots$ & $1,933,306$ & 237,536 & & 3,031 & 240,567 \\
\hline $1873 \ldots$ & $1,166,321$ & 184,498 & $\ldots$ & 2,941 & 187,439 \\
\hline 1874 & $1,253,814$ & 148,409 & $\because$ & 203 & 148,612 \\
\hline $1875 \ldots$ & $1,238,223$ & 131,360 & 6,460 & 609 & 131,969 \\
\hline 1876. & 946,809 & 119,441 & 8,321 & 700 & 120,141 \\
\hline $1877 \ldots$ & $1,115,124$ & 135,317 & 20,001 & 2,314 & 137,631 \\
\hline $1878 \ldots$ & $1,256,624$ & 130,950 & 20,351 & 1,259 & 132,209 \\
\hline $1879 \ldots$ & $1,380,212$ & 143,099 & 34,542 & 2,341 & 145,440 \\
\hline 1880 & $2,019,389$ & 265,773 & 25,150 & 2,349 & 268,122 \\
\hline $1881 \ldots$ & $1,808,945$ & 253,054 & 841,730 & 18,199 & 271,253 \\
\hline 1882 & $2,525,838$ & 294,234 & $1,114,699$ & 18,019 & 312,253 \\
\hline $1883 \ldots$ & $3,064,050$ & 286,892 & 697,244 & 11,254 & 298,146 \\
\hline $1884 \ldots$ & $1,779,337$ & 150,435 & 231,360 & 6,489 & 156,924 \\
\hline 1885 & $2,579,840$ & 207,215 & 215,913 & 7,497 & 214,712 \\
\hline Dec. $31,1886$. & $2,997,985$ & 202,563 & 218,366 & 9,761 & 212,324 \\
\hline 1887 & $2,553,284$ & 169,747 & 362,761 & 8,785 & 178,532 \\
\hline 1888 & $2,814,044$ & 248,015 & 68,040 & 2,178 & 250,193 \\
\hline 1889 & $2,676,130$ & 304,711 & 146,309 & 5,568 & 310,279 \\
\hline 1890 & $3,315,659$ & 411,960 & 611,140 & 29,878 & 441,838 \\
\hline 1891 & $2,618,941$ & 327,307 & $1,433,531$ & 36,232 & 363,539 \\
\hline 1892. & $3,950,864$ & 392,761 & 192,344 & 7,338 & 400,099 \\
\hline 1893. & $2,780,4.32$ & 243,341 & 116,495 & 5,253 & 248,594 \\
\hline 1894. & $2,653,487$ & 193,988 & 375,468 & $a 18,805$ & 212,793 \\
\hline 1895. & $3,499,901$ & 223,968 & 668,610 & 14,718 & 238,686 \\
\hline $1896 \ldots$ & $2,576,371$ & 158,975 & $1,180,828$ & 21,402 & 180,377 \\
\hline 1897 & $2,282,245$ & 143,370 & $3,719,186$ & 55,400 & 198,770 \\
\hline 1898 & $2,103,599$ & 148,671 & $3,749,222$ & 50,256 & 198,927 \\
\hline $1899 \ldots$ & $2,990,915$ & 241,685 & $3,968,654$ & 47,427 & 289,112 \\
\hline
\end{tabular}

a Includes $\$ 737$, value of ground antimony for which no quantity was given. 
PRICES.

The upward tendency of prices which began in 1898 continued during the first few months in 1899 and remained steady during the remainder of the year. The average prices throughout 1899 were from 2 to 4 cents higher than in 1898 and reached the highest point recorded since 1892.

The following tables show, by months and years, the ruling prices of the several brands of antimony as reported to the Iron Age from 1892 to 1899 , inclusive:

Prices of antimony at New York since 1892, by months.

[Cents per pound.]

\begin{tabular}{|c|c|c|c|c|c|c|}
\hline \multirow{2}{*}{ Mronth. } & \multicolumn{3}{|c|}{1892.} & \multicolumn{3}{|c|}{1893.} \\
\hline & Cookson's. & L. $\mathbf{X}$. & Hallett's. & Cookson's. & L. $X$. & Hallett's. \\
\hline January . . . . & $15 \frac{1}{2}$ to 16 & 12 to 15 & $12 \frac{1}{4}$ to $12 \frac{1}{2}$ & 11 & $10 \frac{1}{2}$ & $10 \frac{1}{4}$ \\
\hline February ... & 15 to $15 \frac{1}{2}$ & 12 to 14 & $11 \frac{1}{4}$ & $10 \frac{3}{4}$ & $10 \frac{1}{2}$ & $9 \frac{7}{8}$ to 10 \\
\hline March . . . . . & $14 \frac{3}{4}$ to 15 & $11 \frac{3}{4}$ to 13 & $10 \frac{3}{4}$ to $11 \frac{1}{8}$ & $10 \frac{3}{4}$ & 10 to 12 & 10 \\
\hline April....... & $14 \frac{1}{4}$ to $15 \frac{1}{2}$ & $12 \frac{1}{4}$ to $12 \frac{1}{2}$ & $10 \frac{7}{8}$ to 11 & $10 \frac{3}{4}$ & $10 \frac{3}{8}$ & 10 \\
\hline May ....... & 15 & $12 \frac{3}{4}$ & $11 \frac{1}{2}$ & $10 \frac{1}{2}$ & $10 \frac{1}{4}$ & 10 \\
\hline June..... & $14 \frac{1}{2}$ & $12 \frac{3}{4}$ & $11 \frac{1}{4}$ & $10 \frac{1}{2}$ & 107 & $9 \frac{7}{8}$ \\
\hline July ....... & $13 \frac{1}{4}$ & $12 \frac{1}{4}$ & $10 \frac{7}{8}$ & $10 \frac{3}{8}$ & $10 \frac{1}{8}$ & $9 \frac{7}{8}$ \\
\hline August ..... & 12 & $11 \frac{1}{2}$ & $10 \frac{3}{4}$ & $10 \frac{1}{4}$ & 10 & $9 \frac{3}{4}$ \\
\hline September.. & $11^{\frac{1}{2}}$ to $11^{\frac{3}{4}}$ & 11 to $11_{4}^{\frac{1}{4}}$ & 10 to $10 \frac{1}{4}$ & $10 \frac{1}{4}$ & 10 & $9 \frac{3}{4}$ \\
\hline October .... & 12 & $11 \frac{1}{4}$ & $10 \frac{5}{8}$ to $10 \frac{3}{4}$ & $10 \frac{1}{4}$ & 10 & $9 \frac{3}{4}$ \\
\hline November... & $11 \frac{3}{4}$ & 11 & $10 \frac{1}{2}$ & 10 & $9 \frac{3}{4}$ & $9 \frac{3}{8}$ \\
\hline December .. & $11 \frac{1}{4}$ & 11 & $10 \frac{1}{4}$ to $10 \frac{3}{8}$ & $10 \frac{1}{8}$ to $10 \frac{1}{4}$ & $9 \frac{1}{2}$ to $9 \frac{5}{8}$ & $9 \frac{1}{8}$ to $9 \frac{1}{4}$ \\
\hline \multirow{2}{*}{ Month. } & \multicolumn{3}{|c|}{1894.} & \multicolumn{3}{|c|}{1895.} \\
\hline & Cookson's. & Hallett's. & L. $\mathrm{X}$. & Cookson's. & Hallett's. & Japanese.' \\
\hline January .... & $104^{\circ}$ & $9 \frac{1}{2}$ & $9 \frac{1}{8}$ & $8 \frac{1}{2}$ to $8 \frac{5}{8}$ & $7 \frac{1}{8}$ to $7 \frac{1}{4}$ & \\
\hline February ... & 10 & $9 \frac{3}{8}$ & $8 \frac{7}{8}$ & $8 \frac{1}{4}$ to $8 \frac{1}{2}$ & $7 \frac{1}{8}$ to $7 \frac{1}{4}$ & \\
\hline March ... & $10 \frac{1}{8}$ & $9 \frac{1}{2}$ & $8 \frac{7}{8}$ & 81 & $7 \frac{1}{8}$ to $7 \frac{1}{4}$ & 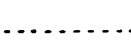 \\
\hline April....... & $10 \frac{1}{8}$ & $9 \frac{3}{8}$ & $8 \frac{7}{8}$ & $7 \frac{7}{8}$ to $8 \frac{1}{8}$ & 7 to $7 \frac{1}{8}$ & $6 \frac{7}{8}$ to 7 \\
\hline May .... & $10 \frac{1}{8}$ & $9 \frac{1}{4}$ & $8 \frac{3}{4}$ & $7 \frac{7}{8}$ to 8 & 7 & $6 \frac{7}{8}$ \\
\hline June ....... & $9 \frac{3}{4}$ & $9 \frac{1}{8}$ & $8 \frac{5}{8}$ & $7 \frac{7}{8}$ to 8 & 7 to $7 \frac{1}{8}$ & $6 \frac{7}{8}$ \\
\hline July ....... & 10 & $8 \frac{3}{4}$ & $8 \frac{3}{8}$ & 8 to $8 \frac{1}{8}$ & $7 \frac{1}{8}$ to $7 \frac{1}{4}$ & 7 \\
\hline August ..... & 10 & $8 \frac{7}{8}$ & $8 \frac{1}{4}$ & 8 & $7 \frac{1}{8}$ & 7 \\
\hline September.. & $9 \frac{1}{2}$ & $8 \frac{7}{8}$ & $7 \frac{5}{8}$ & 8 & $7 \frac{1}{8}$ & $6 \frac{7}{8}$ to 7 \\
\hline October & $9 \frac{5}{8}$ & $8 \frac{1}{4}$ & $7 \frac{1}{2}$ & $7 \frac{3}{4}$ to 8 & 7 to $7 \frac{1}{8}$ & $6 \frac{7}{8}$ \\
\hline November... & $8 \frac{1}{2}$ & $8 \frac{1}{4}$ & $7 \frac{3}{8}$ & $7 \frac{3}{4}$ to $7 \frac{7}{8}$ & 7 & $6 \frac{3}{4}$ to $6 \frac{7}{8}$ \\
\hline December .. & $8 \frac{3}{8}$ & $8 \frac{1}{8}$ & $7 \frac{3}{8}$ & $7 \frac{3}{4}$ to $7 \frac{7}{8}$ & $6 \frac{7}{8}$ to 7 & $6 \frac{3}{4}$ to $6 \frac{7}{8}$ \\
\hline
\end{tabular}


Prices of antimony at New York since 1892, by months-Continued.

[Cents per pound.]

\begin{tabular}{|c|c|c|c|c|c|c|}
\hline \multirow{2}{*}{ Month. } & \multicolumn{3}{|c|}{1896.} & \multicolumn{3}{|c|}{1897.} \\
\hline & Cookson's. & Hallett's. & Japanese. & Cookson's. & Hallett's. & Japanese. \\
\hline January .... & $8 \frac{1}{4}$ & $7 \frac{1}{4}$ to $7 \frac{1}{2}$ & 7 & $7 \frac{1}{4}$ to $7 \frac{1}{2}$ & $6 \frac{1}{2}$ to $6 \frac{3}{4}$ & $6 \frac{3}{8}$ to $6 \frac{5}{8}$ \\
\hline February .. & $8 \frac{1}{4}$ & $7 \frac{1}{2}$ & 7 & $7 \frac{1}{4}$ to $7 \frac{1}{2}$ & $6 \frac{5}{8}$ to $6 \frac{7}{8}$ & $6 \frac{1}{2}$ to $6 \frac{3}{4}$ \\
\hline March... & $8 \frac{1}{4}$ & $7 \frac{1}{2}$ & 7 & $7 \frac{1}{4}$ to $7 \frac{1}{2}$ & $6 \frac{3}{4}$ to $7 \frac{1}{8}$ & $6 \frac{5}{8}$ to 7 \\
\hline April....... & $8 \frac{1}{4}$ & $7 \frac{1}{2}$ & 7 & $7 \frac{1}{4}$ to $7 \frac{1}{2}$ & 7 to $7 \frac{1}{8}$ & 7 to $7 \frac{1}{8}$ \\
\hline May ..... & 8 to $8 \frac{1}{4}$ & $7 \frac{1}{4}$ to $7 \frac{1}{2}$ & $6 \frac{7}{8}$ to 7 & $7 \frac{1}{4}$ to $7 \frac{5}{8}$ & 7 to $7 \frac{1}{4}$ & $6 \frac{3}{4}$ to $7 \frac{1}{4}$ \\
\hline June ... & 8 & $7 \frac{1}{4}$ & $6 \frac{7}{8}$ to 7 & $7 \frac{1}{4}$ to $7 \frac{1}{2}$ & $6 \frac{1}{2}$ to 7 & $6 \frac{1}{2}$ to $6 \frac{3}{4}$ \\
\hline July ...... & 8 & $7 t$ & $6 \frac{7}{8}$ to 7 & 7 to $7 \frac{3}{4}$ & $6 \frac{7}{8}$ to $7 \frac{1}{2}$ & $6 \frac{3}{4}$ \\
\hline August .... & 8 & $7 \frac{1}{4}$ & $6 \frac{7}{8}$ to 7 & 7 to $8 \frac{1}{4}$ & $7 \frac{3}{8}$ to $7 \frac{1}{2}$ & $6 \frac{3}{4}$ to 7 \\
\hline September. . & 8 & $7 \frac{1}{4}$ & $6 \frac{7}{8}$ to 7 & 8 to $8 \frac{1}{4}$ & $7 \frac{1}{4}$ to $7 \frac{1}{2}$ & 7 to $7 \frac{1}{4}$ \\
\hline October .... & $7 \frac{1}{4}$ to $7 \frac{3}{8}$ & $6 \frac{1}{2}$ & $6 \frac{8}{8}$ & 8 to $8 \frac{1}{2}$ & $7 \frac{1}{4}$ to $7 \frac{1}{2}$ & 7 to $7 \frac{1}{8}$ \\
\hline November . . & $7 \frac{1}{8}$ to $7 \frac{3}{8}$ & $6 \frac{8}{8}$ to $6 \frac{1}{2}$ & $6 \frac{1}{4}$ to $6 \frac{8}{8}$ & 8 to $8 \frac{1}{2}$ & $7 \frac{1}{4}$ to $7 \frac{1}{2}$ & 7 to $7 \frac{1}{4}$ \\
\hline December .. & $7 \frac{1}{4}$ to $7 \frac{1}{2}$ & $6 \frac{1}{2}$ & $6 \frac{3}{8}$ & 8 to $8 \frac{1}{4}$ & $7 \frac{1}{4}$ to $7 \frac{3}{8}$ & 7 to $7 \frac{1}{4}$ \\
\hline \multirow{2}{*}{ Month. } & \multicolumn{3}{|c|}{1898.} & \multicolumn{3}{|c|}{1899.} \\
\hline & Cookson's. & Hallett's. & Japanese. & Cookson's. & Hallett's. & United States. \\
\hline January . . & 8 to $8 \frac{1}{4}$ & $7 \frac{1}{8}$ to $7 \frac{1}{4}$ & $7 \frac{1}{8}$ to $7 \frac{1}{4}$ & 10 to $10 \frac{5}{8}$ & $9 \frac{1}{2}$ to $9 \frac{3}{4}$ & $9 \frac{1}{2}$ \\
\hline February . & 8 to $8 \frac{1}{4}$ & $7 \frac{1}{4}$ to $7 \frac{1}{2}$ & $\ldots \ldots$ & $10 \frac{1}{4}$ to $10 \frac{3}{4}$ & $9 \frac{1}{2}$ to $10 \frac{1}{4}$ & $9 \frac{1}{2}$ to $9 \frac{3}{4}$ \\
\hline March.... & 8 to $8 \frac{1}{8}$ & $7 \frac{5}{8}$ to $7 \frac{3}{4}$ & $\ldots \ldots$ & $11 \frac{1}{2}$ to 12 & $10 \frac{1}{2}$ to $10 \frac{3}{4}$ & $10 \frac{1}{4}$ to $10 \frac{3}{4}$ \\
\hline April.. & $8 \frac{1}{8}$ to 9 & $7 \frac{3}{4}$ to. 8 & 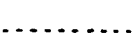 & $11 \frac{1}{2}$ to 12 & $10 \frac{1}{2}$ to $10 \frac{3}{4}$ & $10 \frac{1}{4}$ to $10 \frac{3}{4}$ \\
\hline May ... & $9 \frac{1}{4}$ to $9 \frac{1}{2}$ & $8 \frac{8}{8}$ to $8 \frac{3}{4}$ & $8 \frac{3}{4}$ & $11 \frac{1}{2}$ to 12 & $10 \frac{1}{2}$ to $10 \frac{3}{4}$ & $10 \frac{1}{4}$ to $10 \frac{1}{2}$ \\
\hline June :- & $9 \frac{1}{4}$ to $9 \frac{3}{4}$ & $8 \frac{3}{4}$ to 9 & $8 \frac{3}{4}$ to 9 & $11 \frac{1}{2}$ & $10 \frac{1}{2}$ & $10 \frac{1}{4}$ \\
\hline July ..... & $9 \frac{5}{8}$ to $9 \frac{3}{4}$ & 9 & 9 & $11 \frac{1}{2}$ & $10 \frac{1}{2}$ & $10 \frac{1}{4}$ \\
\hline August .. & $9 \frac{5}{8}$ to $9 \frac{3}{4}$ & 9 & 9 & $11 \frac{1}{2}$ & $10 \frac{1}{2}$ & $10 \frac{3}{4}$ to 11 \\
\hline September. & $9 \frac{5}{8}$ to $9 \frac{3}{4}$ & 9 & 9 & $11 \frac{1}{2}$ & $10 \frac{1}{2}$ & $10 \frac{3}{4}$ to 11 \\
\hline October .... & $9 \frac{5}{8}$ to $9 \frac{3}{4}$ & 9 & 9 & $11 \frac{1}{2}$ & $10 \frac{1}{2}$ & $10 \frac{1}{4}$ \\
\hline November . & $9 \frac{5}{8}$ to $9 \frac{3}{4}$ & 9 & $8 \frac{7}{8}$ to 9 & $11 \frac{1}{4}$ to $11 \frac{1}{2}$ & $10 \frac{1}{4}$ to $10 \frac{1}{2}$ & 10 to $10 \frac{1}{2}$ \\
\hline December & $9 \frac{5}{5}$ to $9 \frac{3}{4}$ & $8 \frac{3}{4}$ to 9 & $8 \frac{3}{4}$ to $8 \frac{7}{8}$ & $11 \frac{1}{4}$ to $11 \frac{1}{2}$ & $10 \frac{1}{4}$ to $10 \frac{1}{2}$ & 10 to $10 \frac{1}{4}$ \\
\hline
\end{tabular}

\section{USES.}

Antimony is chiefly valuable as an alloy with other metals. It is used to large extent with lead in the manufacture of type metal, to which it gives hardness, and, what is more valuable, it possesses the peculiarity, when used as an alloy, of expanding at the moment of solidifying, thus giving to the type a clean, sharp impression. From 10 to 16 parts of antimony in 100 are used in making britannia metal. Pewter contains about 7 per cent. It is also used in the manufacture 
of babbitt metal, an antifriction alloy used in the journals of railroad locomotives and cars and other rapidly moving machinery. It has lately been used as alloy with aluminum, to which it gives hardness and elasticity. Its effects on some metals is very injurious, particularly copper, an almost inappreciable amount (one part in a thousand) destroying its good qualities. The well-known medicinal preparation, tartar emetic, is a tartrate of antimony and potassium. The trisulphide is also used to some extent in medical practice. The sulphide was used to considerable extent by the ancients as a pigment, and women of the East are said to use it at the present day for darkening their eyebrows. 



\title{
TUNGSTEN，MOLYBDENUM，URANIUM，AND VANADIUM.
}

\author{
By Joseph Hyde Pratt.
}

\section{TUNGSTE்.}

There are but few minerals that are a source of tungsten, and of these wolframite is the commonest, while hübnerite and scheelite are more sparingly found. Wolframite is a dark-gray to grayish-black mineral with a submetallic to resinous luster. Its specific gravity is 7.2 to 7.5 and its hardness 5 to 5.5. The mineral crystallizes in the monoclinic system and is often found in terminated crystals. It is very brittle and has a perfect cleavage parallel to the pinacoid face, 010 , and an uneven fracture. It is more commonly found massive, with a more or less granular structure. The chemical composition of wolframite is tungstate of iron and manganese $(\mathrm{Fe}, \mathrm{Mn}) \mathrm{WO}_{4}$. There is another name that is constantly being confused with wolframite, and that is wulfenite; the latter is a lead molybdate, $\mathrm{PbMoO}_{4}$, and is a yellow to red mineral. Wolframite fuses easily before the blowpipe to a globule having a crystalline surface, which is sometimes magnetic.

Hübnerite is very similar to the wolframite, but usually occurs in bladed forms with rarely terminated crystals and has a brownish-red to nearly black color. Its chemical composition differs from that of wolframite in that the iron has been largely replaced by manganese and it is essentially manganese tungstate, $\mathrm{MnWO}_{4}$. Before the blowpipe it is less fusible than wolframite and gives a strong manganese reaction with sodium carbonate or borax.

Scheelite is a very heavy white to yellowish-white mineral with an adamantine to vitreous luster. Its specific gravity is 5.6 to 6.1 , and its hardness being 4.5 to 5 , it is readily scratched by steel. It crystallizes in the tetragonal system, but is more commonly found massive. It is a calcium tungstate, $\mathrm{CaWO}_{4}$. Before the blowpipe, scheelite is difficultly fusible to a semitransparent glass. It is decomposed by hydrochloric or nitric acid, leaving a yellow powder soluble in ammonia. 
Besides these, the following minerals, containing tungsten, are found in small quantities at a few localities: Cuprotungstite, a tungstate of copper, $\mathrm{CuWO}_{4}$, which passes into a tungstate of copper and calcium, $(\mathrm{Ca}, \mathrm{Cu}) \mathrm{WO}_{4}$. It is a highly vitreous mineral of a pistachio-green color, and occurs in crusts. Stolzite, a lead tungstate, $\mathrm{PbWO}_{4}$, is sparingly found in tetragonal crystals, with acute octahedral habit, and of a green to brown or red color. Tungstite, tungsten trioxide, $\mathrm{WO}_{3}$, is a pulverulent and earthy mineral of a bright-yellow to yellowish-green color, which occasionally occurs with wolframite at various loclities. Meymacite is a hydrated tungsten oxide formed from the alteration of scheelite.

Wolframite is usually found in metallic veins carrying the sulphides pyrite, galena, sphalerite, etc.; it is also often associated with tin ores. It frequently accompanies scheelite in the crystalline rocks and is embedded in quartz. It is widely distributed in nature, but it is only to be found in large quantities at a few localities. The occurrences of hübnerite are very similar to those just mentioned. Scheelite, on the other hand, is more commonly found associated with the crystalline rocks and embedded in quartz. It is in occurrences of this type that it is found in large quantities. In the metallic veins it is found in but very small quantity as an associate of wolframite and hübnerite.

\section{OCCURRENCE.}

Although tungsten minerals have been known for a long time, and the value of tungsten for making alloys has also been known, it is only within the past few years that there has been any considerable demand for this metal. Inquiries that have been made for tungsten minerals, and advertisements that have appeared asking for information regarding localities where these minerals could be found, have stimulated prospecting for them, which has met with more or less success. By far the greater number of localities of these minerals have been discorered in the Western States, the principal ones being Arizona, Nevada, and Colorado.

The source of tungsten ores for a number of years has been England, Austria-Hungary, Saxony, Germany, and Australia, and practically all the tungsten used in the United States was imported. With these recent discoreries of tungsten minerals in this country it is more than probable that instead of importing tungsten ores the United States will soon be in a position to export them.

Arizona.-In the Arivaca district in Pima County wolframite has been found in considerable quantity, and it is estimated that there are 4,000 pounds of ore on the dumps and as much more blocked out in the mine. A concentrating plant is being erected to treat these ores.

In the Dragoon Mountains, 13 miles from Benson and 6 miles north of Dragoon, Cochise County, quartz reins have been discorered traversing a coarse-grained granite. At intervals in the quartz there occur 
bunches of hübnerite. Little work has thus far been done to determine what quantity of tungsten ore can be obtained from this deposit.

Nevada.-In the early part of 1900 a vein was discovered about 12 miles south of Osceola, White Pine County, Nevada, which carried wolframite, as described by Mr. F. B. Weeks in another paper.

The mine is 100 miles from Frisco, Utah, on the Oregon Short Line Railway, which is the nearest railroad point.

Colorado.-At a number of the gold and silver mines of San Juan County ${ }^{1}$ hübnerite has been found in gold quartz veins. These veins, which may be from 4 to 8 feet wide, contain streaks from 4 to 24 inches wide that carry hübnerite, and these are usually nearest to one wall or the other. Although no large ore bodies of this mineral have yet been found, it has been observed in sufficient quantity to make it a valuable by-product. At a number of the unexplored veins it is very possible that wolframite could be cheaply and profitably mined. Scheelite has also been found occasionally associated with the hübnerite.

At Red Mountain, Ouray County, and in many of the mines in the vicinity of Leadville, Lake County, wolframite and hübnerite have been found. Some of the localities give evidence of containing a considerable quantity of these minerals.

Idaho.-Wolframite has been reported in the auriferous quartz veins near Murray, Shoshone County.

Oregon.-In the Virtue district, a few miles east of Baker City, Baker County, massive scheelite has been found. Little information, however, has thus far been obtained regarding the extent of the deposit or the nature of the occurrence.

South Dakota.-At the Harrison and Durango mines near Lead City, in the north Lead district, wolframite has been found in some quantity. At Sunday Gulch, near Oreville, Pennington County, wolframite has been found in such quantity that a number of tons have already been shipped.

Wolframite has been mined in the vicinity of Steins Pass, on the line of the Southern Pacific Railroad, near the New. Mexico-Arizona line. Deposits of tungsten minerals have also been found at Neihart, Montana, and in Washington, but no definite information has as yet been obtained regarding the character of the ore or the localities. Scheelite has been found in a gold mine on Howard Hill, in Grass Valley, Nevada County, California, and is reported to be in considerable abundance.

Connecticut.-The American Tungsten Milling and Mining Company have recently begun the mining of scheelite on a large scale near Long Hill, Fairfield County. The deposit of scheelite is situated on South Hill, about half a mile from Long Hill Station on the Bridgeport division of the Berkshire Railroad, in Trumbull Township, about 9 miles north of the city of Bridgeport. The country is formed of rolling hills, South Hill attaining a height of about 250 feet above the valley. ${ }^{2}$

\footnotetext{
IEng. and Min. Journal, Apr. 29, 1899.

${ }^{2}$ Am. Inst. Min. Eng., Vol. XXII, 1894, p. 236.
} 
This occurrence of scheelite has been known for more than fifty years, häving been first described by E. U. Shepard in a report of the Geological Survey of Connecticut in 1837. ${ }^{1}$ During its early history mining was carried on for bismuth, lead, silver, and copper. The scheelite occurs in a vein of quartz - that is, in what might be called a blanket formation, dipping at a considerable angle toward the east. This vein lies between an amphibole-gneiss of a dark-black color and a bed of crystalline limestone that is 35 to 45 feet thick. The hanging wall, which is of limestone, is well defined, while the foot wall of amphibole-gneiss is at times rather obscure, owing to the fact that the crystals and particles of scheelite and quartz are found embedded in the country rock.

The vein consists of a compact mass of vitreous and translucent quartz containing cavities studded with quartz crystals, which are frequently covered with a thin film of yellow tungstite (wolfram-ocher). The quartz penetrates into the limestone, but more especially into the gneiss, so that sometimes these rocks become part of the ore bed. As associated minerals in the quartz vein are found pyrite, epidote, garnet, pyroxene, amphibole, and wolframite. The latter mineral occurs embedded not only in the quartz but also in the gneiss, often in well-shaped crystals which are pseudomorph after the scheelite. Sometimes the crystals of scheelite are only partially converted into wolframite, and both minerals are observed in the same specimen. This vein of quartz is traceable almost continuously along the outcrop of the limestone and gneiss. The distribution of the tungsten minerals through the vein is irregular, there being some portions much richer than others. The percentage of scheelite in the vein is approximately 5 per cent, which is the average run of the vein as determined from actual mill tests.

This area appears to be one of contact metamorphism, which has been subjected later to folding and regional metamorphism. I am inclined to believe that the scheelite is a mineral of pegmatites, and was introduced at a later time than during the metamorphic action to which these rocks were subjected.

The location is well adapted for mining, and by running a drift into the hill from the valley to and along the vein it will act as a drain for all the works, and then by making an inclined shaft from the drift to the surface the vein can be readily opened along its natural dip. This, however, should not be done until sufficient work has demonstrated that the ore occurs in quantity.

A very complete plant for separating and concentrating the scheelite has been erected by the company and treats the ore very satisfactorily. In the separation of the tungsten minerals the Hooper pneumatic system is used, and six Hooper pneumatic concentrators. Briefly, the ore is handled as follows: When taken from the mine it is hand-cobbed

${ }^{1}$ Geol. Survey Connecticut, New Haven, 1837. 
and then hauled to the mill, a distance of about a quarter of a mile down grade, where it is dumped into a bin at the top of the mill, from which it is fed to a large crusher having a capacity of 150 tons per day. From this crusher it is conveyed to smaller ones, which reduce the ore to a size which enables it to be treated by the rolls. From these it is taken by an elevator belt to the finishing rolls, and from this it goes to the screens of three or more different mesh, and then to the hoppers, from which it is fed to the different Hooper concentrators, according to the size of the grains of ore. The ore that is too coarse to go through these sieves is reconveyed by an elevator belt to the finishing rolls, which reduce it to the desired size. By varying the speed, the inclination of the table, and the stroke of the concentrator, and by regulating the feed, an almost perfect separation can be made. The discharge is so arranged that the concentrates go into one channel and the tailings into another; the middlings are conveyed back to the hopper and refed to the concentrator. This process gives a nearly pure concentrate, with the exception of the pyrite, most of which goes with the scheelite. Analyses of the concentrates of scheelite gave values of tungstic oxide $\left(\mathrm{WO}_{3}\right)$ varying from 67 to 70 per cent, and of wolframite, from 55 to 60 per cent. As sulphur would be detrimental to the ore, experiments are being made as to the best method to employ in removing it. If no mechanical method can be devised, the ore can be roasted, thus eliminating the sulphur; but the pyrite could probably be removed by the electro-magnet, and if the cost of same was not too much it could be advantageously employed, except when there is wolframite present, which would also be removed with the pyrite.

North Carolina.-Tungsten minerals have been known to occur in North Carolina for a good many years and have been found in connection with some of the gold ores. At the time these minerals were discovered they had no value except as mineralogical specimens, and so no special attention was called to the localities where they occurred. Scheelite has been found at the following mines in Cabarrus County: At the Flowe mine, where it occurs in yellowish crystals; at the Cosby mine, where yellowish crystalline masses of considerable size were found; and at the Cullen mine, where it has been observed in rounded granular patches of a grayish-yellow color. Wolf ramite has also been found associated with the scheelite at all these mines, but from what information can be obtained the scheelite predominates. No work has been done at these mines for the tungsten minerals, and it is not known whether or not they occur in quantity.

Nova Scotia. - At Northeast Margaree, Cape Breton, Nova Scotia, ${ }^{1}$ a quartz vein was discovered in a ravine between and near the base of two mountains that attain an elevation of about 800 feet. The vein has been traced across the ravine and for over 200 feet up the mountain. A small amount of development work was done by driving

1A. C. Ross, Eng. and Min. Jour., Sept. 23, 1899. 
tunnels into the mountain, which shows the wolframite to occur abundantly in places in the vein while it is almost entirely absent in others. One block of quartz that was taken out contained upward of one-half ton of ore. To what extent this deposit may be a source of tungsten is not yet determined. ${ }^{1}$

USES.

Metallic tungsten has been obtained in the form of a metallic powder of a bright-gray luster which is sufficiently hard to scratch glass. In this form the metal is not changed by moist or dry air and at red heat it burns in the air to the trioxide. In 1781 the Swedish chemist, Scheele, proved that the mineral called wolframite contained a new mineral acid, to which the name tungsten (wolfram) was finally given.

The mineral wolframite had been known for a long time by both the German and Cornish tin miners and was looked upon with disfavor by them. The German miners had found by experience that when any of this mineral was smelted with the tin ore it impeded the reduction of the tin and facilitated its scorification. The Cornish miners called it "mock lead," because its high specific gravity had led them to believe that it contained lead. Considerable quantities of this mineral had been thrown aside by the Cornish miners and were not utilized until long afterwards when the real nature and value were discovered, and then these old dumps of the Cornish mines were reworked for this valuable mineral.

The uses of tungsten are varied, and the principal ones are in the manufacture of the alloys, ${ }^{2}$ ferro-tungsten and aluminum-tungsten. Until recent years about the only uses of tungsten were in the preparation of salts used to make colored cotton goods fast or washable and to make clothes used for theatrical and other purposes noninflammable. It was also used to a certain extent in the manufacture of stained and other papers.

The use of ferro-tungsten in the manufacture of steels $^{3}$ is becoming an industry of considerable importance. The tungsten makes the steel exceedingly hard and tough, and steel so treated is believed by many to be superior to any other steel manufactured. Projectiles made out of tungsten steel have penetrated through 14 inches of the best armor plate. It is also beginning to be used in the manufacture of tool steel and spring steel. Tools made of tungsten steel can be driven mucb faster in cutting other metals, and the tungsten spring steel has more carrying power than that made out of ordinary steel. It is also being used in sounding plates and wires for pianos, to which it gives additional strength and quality.

\footnotetext{
1 See also U. S. Geol. Survey, Mineral Resources, 1882, p. 431; 1883-84, p. 574; 1885, p. 366; and 18s6, p. 218 .

2See Sixteenth Ann. Rept. United States Geological Survey, Part III, p. 615.

${ }^{3}$ Jour. of Iron and Steel Institute, No. 1, 1895.
} 
There is a considerable difference of opinion among chemists and metallurgists as to the special qualities or properties that tungsten will give to steel, some of these men taking almost opposite views from the others. However true the views held by those who do not believe in the beneficial qualities of tungsten on steel, nevertheless steel manufacturers are using tungsten, and there is a growing demand for this metal to be made into ferro-tungsten which is to be used in the manufacture of tungsten steels.

Tungsten is used in the manufacture of aluminum-tungsten, known to the trade as "wolfram-aluminum," which has had an especial use for roll sheets and plates to be afterwards spun; it has also been largely used for military equipments. ${ }^{1}$ It is stated that the alloys of aluminum and tungsten can be advantageously used with the addition of copper. As usually made, the aluminum is hardened with some copper.

\section{TESTS FOR TUNGSTEN.}

It may be of value to give here a method for testing minerals for the presence of tungsten, and the following, which is that described by Professor Penfield, ${ }^{2}$ will be found to give satisfaction: If the mineral is decomposed by boiling with hydrochloric acid, an insoluble canary-yellow tungstic oxide, $\mathrm{WO}_{3}$, is obtained. If a little granulated tin is added to the solution and the boiling continued, a blue color is obtained, which finally changes to brown upon further boiling.

If the tungstate is insoluble or difficultly soluble in hydrochloric acid as the mineral wolframite, mix the fine powdered mineral with six times its volume of sodium carbonate; make this into a paste with water, and fuse. Pulverize the fusion and dissolve it in a test tube with a little water, the sodium tungstate formed during the fusion being soluble in water. Acidify the filtrate with hydrochloric acid, and upon boiling with tin the blue reduction test may be obtained.

\section{MOLYBDENUM.}

There has been considerable discussion during the past year or two as to the actual commercial value of molybdenum and the purposes for which it can be used. At the present time the market for the mineral molybdenite, which is the chief source of this metal, is very limited, the consumption being only about 50 tons per year, bringing from 10 to 15 cents per pound, and the reduction of the ore is confined to a few plants. They demand an ore which will carry, when concentrated, 50 per cent or over of molybdenum, and which must be free

1 Am. Mfg., Aug. 30, 1900

2 Penfield's Determinative Mineralogy, p. 128.

21 GEOL, PT $6-20$ 
from copper. The principal use of molybdenum is in the manufacture of certain chemical reagents, especially ammonium molybdate, which is used in the determination of phosphoric acid. It is also used in the preparation of "blue carmine" for the coloring of porcelain. Another more recent use is in the manufacture of the alloy, ferro-molybdenum, which is used in the preparation of a special steel. It is often supposed that molybdenum is used at times in place of tungsten in the manufacture of hard steels, but each have certain valuable properties that they give to steel, which the steel manufacturers are rapidly beginning to appreciate. It is not, then, unreasonable to expect that there will be an increased demand for this metal and a wider market, which will warrant persistent prospecting for the mineral carrying it.

The metal molybdenum was discovered in 1778 . When obtained in the metallic state it is in the form of a gray powder having a specific gravity of 8.6. It scarcely aggregates even under the influence of a most powerful heat. It is not acted upon by the air at the ordinary temperature. Molybdenum occurs but sparingly in nature and for the most part in the mineral molybdenite, $\mathrm{MoS}_{2}$, and less abundantly in the mineral wulfenite, $\mathrm{PbMoO}_{4}$. It also has been found sparingly as a trioxide, $\mathrm{MoO}_{3}$, in the mineral molybdite, which occurs in orthorhombic crystals that are grouped together in tufts or radiations of a straw-yellow color and of a silky to adamantine luster. It also occurs as incrustations and is usually associated with molybdenite. Wulfenite occurs commonly in square, tabular, tetragonal crystals that are sometimes very thin, also granularly massive. It has a resinous to adamantine luster and ordinarily an orange-yellow to bright red color. It is usually found in veins with other ores of lead.

In testing for molybdenum, consideration must be made as to whether it occurs as a sulphide or in an oxidized condition. A good test $^{1}$ for the sulphide of molybdenum is to heat a fragment of the mineral on the flat surface of a piece of charcoal for a considerable time in the oxidizing flame, there being deposited at a short distance from the assay a coating of molybdic oxide, $\mathrm{MoO}_{3}$. This is pale yellow when hot and almost white when cold. This oxide is volatile in the oxidizing flame, but if touched for an instant with a moderately hot reducing flame it assumes a beautiful ultramarine-blue color. Nearer the assay the charcoal is covered with a very thin tarnished coppercolored coating of $\mathrm{MoO}_{2}$ which is best seen when cold and by reflected light.

When the molybdenum occurs in the oxidized state, it is best tested for by treating a very small amount of the powdered molybdate with a scrap of paper about as large as the head of a pin in a test tube with about five drops of concentrated sulphuric acid and an equal amount

1 Penfield's Determinative Mineralogy, 1898, p. 95. 
of water and heating until copious white fumes arise. Then on cooling, the liquid will assume a magnificent deep blue color which has resulted from the reduction brought about by the organic matter of the paper. If heated the blue color will disappear, but will appear again upon cooling.

The principal source of this metal is the mineral molybdenite, which usually occurs in foliated masses or in scales with a perfect basal cleavage and a metallic luster. When crystallized it is in short or tabular hexagonal prisms. It is very soft, 1 to 1.5 in scale of hardness, being readily scratched with the finger nail, and is of a pure leadgray color. It is often mistaken for graphite (plumbago), which it sometimes very closely resembles, but can be distinguished from it by its color, which is of a more bluish gray; by its streak on paper, which is gray to bluish gray, while graphite is black, and by its behavior before the blowpipe, the molybdenite giving off sulphur dioxide, which can be readily detected by its odor, while there is no change when the graphite is heated.

Molybdenite generally occurs embedded in or disseminated through crystalline rocks, principally in granite, gneiss, syenite, and granular limestone, and it has been found sparingly in these rocks at many localities. It is found more abundantly in certain of the Western States, and it is in these that the greater amount of prospecting has been carried on. In Washington, near Skagit, and about 1,000 feet bolow the White Pass railroad tunnel, molybdenite is found in considerable quantity in a deposit 5 to 8 feet wide which has been uncovered for a distance of 800 feet. No determination of the percentage of molybdenite has been made. From the Castleman mine in the Mount Baker district, Whatcom County, occasional shipments of molybdenite ore have been made. In Okanogan County several deposits are reported, which are for the most part associated with copper; one in the vicinity of Lake Chelan is reported to be very rich.

A vein 5 feet wide and carrying 15 per cent of molybdenite has been found in the Santa Rita Mountain district, Pima County, Arizona. It has also been reported as being found in some quantity at the Leslie mine, near Mullan, Shoshone County, Idaho; near East Las Vegas, San Miguel County, New Mexico, and near Portage, Aitkin County, Minnesota. Molybdenite is also said to occur in considerable quantity in California, Colorado, and Montana.

In Canada the Geological Survey are encouraging prospectors to look for molybdenite, and in British Columbia there are a number of localities that have been found which are similar to those mentioned in Washington. At Rencontre, Fortune Bay, Newfoundland, a deposit of this mineral is being opened up. 


\section{URANIUM AND VANADIUM.}

The demand for these metals has been constantly increasing for the past few years, and considerable prospecting has been done for minerals containing them. 'This prospecting has been stimulated by advertisements that have appeared in some of the engineering papers asking for localities from which these minerals could be obtained. They are used at the present time in but very small quantities, due to the limited amount obtained, and not to the lack of uses to which they can be put. As they are found in larger quantities they will be used more extensively, for the demand for them is considerably greater than the supply.

\section{URANIUM.}

The reduction of the uranium compounds as they occur in nature, so as to obtain this metal in a chemically pure condition, is attended with considerable difficulty. For this reason chemical compounds and alloys of uranium are produced to a much greater extent than the metal. Uranium was first recognized as an' element in 1782 by the chemist Klaproth, and was named after the planet Uranus. It is a steel-gray nonmagnetic metal which is softer than steel, being readily scratched by a file.

USES.

Uranium is one of the metals that has been attracting the attention of steel manufacturers in regard to the beneficial results that a small percentage of it produces in steel. Experiments have shown that a certain amount of a ferro-uranium alloy added to a fluid steel increases its tensile strength and toughness to a remarkable degree. This manufacture of ferro-uranium will probably become one of if not the largest use for the uranium ores, not necessarily to the replacement of ferrotungsten or other alloys, but to make a steel having certain specific and valuable properties that the other metals will not give to it. Alloys of tungsten, molybdenum, or uranium, with iron, when mixed with fluid steel, increase its toughness; but at the same time each gives to the steel certain valuable properties that the other does not. Thus at the present time there is a demand for all these metals in the manufacture of ferro alloys, to be used in the making of various steels.

Other uses of uranium compounds are in the manufacture of porcelain and glass. The two oxides $\mathrm{U}_{2} \mathrm{O}_{5}$ and $\mathrm{U}_{3} \mathrm{O}_{8}$ are greatly prized for producing a pure black glaze on porcelain. For the decoration of glass and china ware, a hydrated sodium uranate, known as uranium vellow, and a hydrated ammonium uranate are used, which give permanent colors. These two compounds are also used in the manufacture of a uranium glass, which possesses the property of absorbing 
certain chemically active light rays, and has a green-yellow fluorescence and is sometimes employed for ornaments. Certain uranium salts are used to a considerable extent in photography.

\section{OCCURRENCE.}

There are many minerals containing uranium that are known at the present time, but they are for the most part found but sparingly and some of them are only known from one locality. The only ones that have been found in sufficient quantity to become a source of uranium are uraninite, gummite (an alteration product of uraninite), and carnotite.

Uraninite, or as it is more commonly known pitchblende, is a uranate of uranyl and lead with usually thorium (or zirconium) and sometimes with the metals of the lanthanum and yttrium groups. Certain varieties contain nitrogen, and several of the newly discovered and rare elements, as helium, radium, and polonium. This mineral is usually massive and botryoidal, with a conchoidal to uneven fracture, and is brittle. Crystals are rare, the octahedron being the common form. It has a hardness of 5.5 and a specific gravity of 9 to 9.7. In appearance it is often pitch-like, having a submetallic to greasy and dull luster, and a grayish, greenish-black to velvet-black color.

Uraninite, which is the name given to the crystallized variety, occurs as a constituent in many pegmatitic dikes and coarse granites, and is the variety that generally carries the rare earths and nitrogen. The massive variety, pitohblende, usually contains none or but a very small amount of the rare earths and nitrogen, and is more commonly found as an associate in metalliferous veins, with the sulphides of silver, lead, copper, nickel, iron, and zinc.

Uraninite suffers alteration quite readily going over into the hydrated mineral, gummite, which looks like gum, and whose exact composition is not known. Crystals of gummite are observed only as pseudomorphs after uraninite; and it is more often in rounded or flattened pieces, with a greasy luster and a reddish yellow to orange, hyacinth-red or reddish brown color, the brighter colors being the more prominent. It is only 2.5 to 3 in hardness and has a specific gravity of 3.9 to 4.2. As would be naturally expected, gummite is to be found at nearly all the uraninite localities, masses of this mineral . often being observed with nuclei of uraninite in the center. It has not been found as a distinct mineral. A further alteration of the uraninite, through gummite, is to the mineral uranophane or uranotil, which is found in masses of a fine fibrous structure, with a vitreous luster and a honey-yellow, lemon, or straw-yellow color. It is a hydrous silicate of calcium and uranium and besides being found as an alteration product, it also occurs as a distinct mineral. It is not 
uncommon to find the uranophane surrounding a mass of gummite, in the center of which is a nucleus of uraninite.

Analyses illustrating the chemical composition of uraninite and its alteration products, gummite and uranophane, are given in the following table:

Analyses of uraninite, gummite, and uranophane.

\begin{tabular}{|c|c|c|c|c|c|c|}
\hline & \multicolumn{4}{|c|}{ Uraninite. } & \multirow{2}{*}{$\frac{\text { Gummite. }}{\begin{array}{c}\text { 5. Flat } \\
\text { Rock, N.C. }\end{array}}$} & \multirow{2}{*}{ 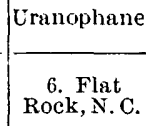 } \\
\hline & $\begin{array}{l}\text { 1. Glaston- } \\
\text { bury, Conn. }\end{array}$ & $\begin{array}{l}\text { 2. Branch- } \\
\text { ville, Conn. }\end{array}$ & $\begin{array}{c}\text { 3. Black } \\
\text { Hawk, Colo. }\end{array}$ & $\begin{array}{l}\text { 4. Flat } \\
\text { Rock, N.C. }\end{array}$ & & \\
\hline $\begin{array}{l}\text { Specific grav- } \\
\text { ity .............. }\end{array}$ & 9.62 & 9.73 & 8.07 & 9.49 & 4.84 & 3.83 \\
\hline $\mathrm{UO}_{2} \ldots \ldots \ldots$ & 59.93 & 72.25 & 58.51 & 46.56 & & \\
\hline $\mathrm{UO}_{3} \ldots$ & 23.03 & 13.27 & 25.26 & 44.11 & 75.20 & 64.36 \\
\hline $\mathrm{ThO}_{2}$ ) & $(\cdots \ldots \ldots)$ & 7.20 & $a 7.59$ & 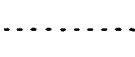 & & \\
\hline $\mathrm{CeO}_{2}$ & ${ }_{1}$ & & $\cdots$ & & & \\
\hline $\begin{array}{l}\mathrm{La}_{2} \mathrm{O}_{3} \\
\mathrm{Y}_{2} \mathrm{O}_{3}\end{array}$ & 11.10 & & .22 & 3.04 & & \\
\hline $\mathrm{PbO}$ & 3.08 & 4.35 & .70 & 4.53 & 5.57 & \\
\hline $\mathrm{CaO} \ldots$. & .11 & .18 & .84 & .23 & 2.05 & 7.49 \\
\hline$N \ldots \ldots$ & 2.41 & undet. & .15 & undet. & ...... & 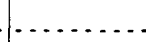 \\
\hline $\mathrm{H}_{2} \mathrm{O} \ldots \ldots$ & .43 & .68 & 1. 96 & undet. & 10.54 & 13.32 \\
\hline $\mathrm{Fe}_{2} \mathrm{O}_{3} \ldots$ & .29 & .11 & & & - & .47 \\
\hline Insol ..... & .89 & .04 & $\ldots$. & .06 & $\cdots$ & $\cdots$ \\
\hline $\mathrm{SiO}_{2} \ldots$ & .16 & .03 & 2.79 & .13 & 4.63 & 13.47 \\
\hline $\mathrm{x} \ldots \ldots \ldots$ & $b .06$ & c. 10 & $d 2.03$ & e. 25 & $f 1.73$ & $\mid \ldots \ldots \ldots$. \\
\hline Total... & 101.49 & 98.21 & 99.95 & 98.91 & 99.72 & 99.11 \\
\hline
\end{tabular}

$a=\mathrm{ZrO}_{2} . \quad b=\mathrm{P}_{2} \mathrm{O}_{5}$ and Fl. $c=\mathrm{MnO} . \quad d=\mathrm{ZnO}, \mathrm{FeO}, \mathrm{MnO}_{2} \mathrm{P}_{2} \mathrm{O}_{5}, \mathrm{As}_{2} \mathrm{O}_{5}, \mathrm{CuFeS}_{2}$, and $\mathrm{FeS}_{2} . e=\mathrm{MgO}$ and Alk. $f=\mathrm{BaO}, \mathrm{Mn}_{2} \mathrm{O}_{3}, \mathrm{Al}_{2} \mathrm{O}_{3}$, and $\mathrm{P}_{2} \mathrm{O}_{5}$.

Analyses 1 to 4 are by Hillebrand, ${ }^{1} 5$ by Genth, ${ }^{2}$ and 6 by $\mathrm{H}$. von Foullon. ${ }^{3}$

At present the principal occurrences of uraninite are at the Wood, Black Hawk, and Kirk mines, near Central City, Gilpin County, Colorado. It is also found in Colorado in the La Sal Mountains, at the head of Paradox Valley, in Montrose County, and at Cat Gulch, near Turret, Shasta County, and on Dolores River at the mouth of Disappointment Creek, 80 miles west of Dolores, Montezuma County. About 80 tons of the uranium minerals mentioned have been mined during the past three years, most of which was the mineral uraninite (pitchblende) from the Wood mine. Nearly all of this ore was shipped to France. In South Dakota, at the Ross-Hannibal mine, in the Ruby Basin of the Black Hills, uraninite has been found, but not in suffi-

1 Bull. U.S. Geol. Survey, No. 78; Am. Jour. Sci., Vol. XL, 1890, p. $3 \$ 4$. 2 Am. Chem. Jour., Vol. I, 1879, p. 89; Dana Min. 1892, p. 892. 3 Vh. G. Reichs 21, 1883; Dana Min. 1892, p. 69 ? 
cient quantity to mine. In many of the pegmatitic dikes and metalliferous veins of Montana, California, and New Mexico (in the President mine, near Elizabethtown, Colfax County) uranium minerals have been sparingly observed.

In the eastern part of the United States uraninite occurs in many of the pegmatitic dikes. At many of the feldspar quarries in Connecticut it has been sparingly found, as at a quarry near Middletown; at Hale's quarry in South Glastonbury; at Branchville, where it often occurs in small octahedral crystals embedded in albite. At a number of the mica mines of Yancey and Mitchell counties, North Carolina, it has been obtained in crystals and in masses. The Flat Rock and Deake mines, near Spruce Pine, Mitchell County, have furnished the greatest amount, some pieces having been found that weighed over 3 pounds, but which were largely altered to gummite and uranophane. This region is the most promising locality in North Carolina for finding uraninite in large quantities. At the Thompson mine, which is near the Deake, a mass of uraninite and gummite weighing 2 pounds and 10 ounces was found. Uraninite has been observed at Marietta, South Carolina, and at the famous gadolinite locality in Llano County, Texas.

Another uranium mineral that is worthy of note in connection with the above is autunite, sometimes called uranite, a hydrous calcium uranium phosphate, $\mathrm{CaO} .2 \mathrm{UO}_{3} \cdot \mathrm{P}_{2} \mathrm{O}_{5} \cdot 8 \mathrm{H}_{2} \mathrm{O}$, which is practically always found with uraninite and other uranium minerals. It occurs in small scales or foliated aggregates with micaceous structure on the feldspar and mica, or with galena, sphalerite, argentite, chalcopyrite, and the minerals associated with the uraninite in the dike or rein. It has a pearly and adamantine luster and a lemon to sulphur-yellow color, and is one of the indications of the presence of other uranium minerals. It is sometimes called uranium mica, as is also the mineral torbernite. (See below.)

The other uranium mineral that has become of economic importance is carnotite, ${ }^{1}$ which has been recently discovered in Montrose County, Colorado. It occurs as a yellow to reddish-yellow crystalline powder or in loosely cohering masses that are easily separated by the fingers and leave traces on whatever touches them. When tested, the mineral was found to contain not only uranium, but also a considerable percentage of the valuable metal vanadium. Analysis shors it to be composed mainly of a hydrous vanadate of uranium and potassium. The purer varieties contain about 52 per cent of uranic oxide $\left(\mathrm{UO}_{3}\right)$, about 18 per cent of vanadium pentoxide $\left(\mathrm{V}_{2} \mathrm{O}_{5}\right)_{3}$, about 5.5 per cent of potash $\left(\mathrm{K}_{2} \mathrm{O}\right)$, and only about 5 per cent of silica $\left(\mathrm{SiO}_{2}\right)$.

The following complete analyses of carnotite have been made by $\mathrm{Dr}$. W. F. Hillebrand ${ }^{2}$ on material from (I) the Yellow Boy Group mines,

1 Mining and Scientific Press, August 25, 1900 
La Sal Creek Canyon, and (II) Rock Creek, near Paradox, both in Montrose County, Colorado:

Analyses of carnotite.

\begin{tabular}{|c|c|c|}
\hline & $\underset{\text { (I) }}{\text { La Sal Creek. }}$ & $\begin{array}{c}\text { Rock Creek. } \\
\text { (II) }\end{array}$ \\
\hline $\mathrm{UO}_{3} \ldots$ & 52.28 & 52.25 \\
\hline $\mathrm{V}_{2} \mathrm{O}_{5} \ldots \ldots$ & 17.80 & 18.35 \\
\hline $\mathrm{K}_{2} \mathrm{O} \ldots \ldots \ldots \ldots \ldots$ & 5.32 & 6.73 \\
\hline $\mathrm{Na}_{2} \mathrm{O} \ldots \ldots \ldots \ldots \ldots \ldots \ldots$ & .07 & .09 \\
\hline $\mathrm{Li}_{2} \mathrm{O} \ldots \ldots \ldots \ldots$ & Trace. & None. \\
\hline $\mathrm{CaO} \ldots \ldots$. & 1.85 & 2.85 \\
\hline $\mathrm{BaO} \ldots \ldots \ldots \ldots$ & 3.21 & .72 \\
\hline 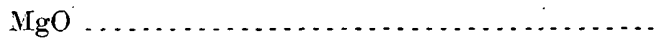 & .17 & .20 \\
\hline $\mathrm{PbO} \ldots . . .$. & ...... & .25 \\
\hline $\mathrm{CuO} \ldots \ldots . .$. & None. & .20 \\
\hline $\mathrm{Fe}_{2} \mathrm{O}_{3} \ldots \ldots \ldots \ldots \ldots$ & 3.36 & 1.77 \\
\hline $\mathrm{Al}_{2} \mathrm{O}_{3} \ldots \ldots \ldots \ldots$ & & 1. 08 app. \\
\hline $\mathrm{TiO}_{2} \ldots \ldots \ldots$ & None. & .10 \\
\hline $\mathrm{H}_{2} \mathrm{O}\left(105^{\circ}\right) \ldots \ldots \ldots$ & 4.52 & 2.59 \\
\hline 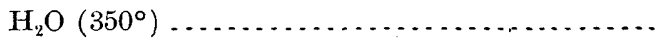 & 3.49 & 3.06 \\
\hline 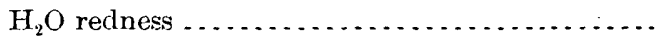 & .38 & None. \\
\hline $\mathrm{CO}_{2} \ldots \ldots \ldots \ldots \ldots \ldots \ldots \ldots \ldots$ & None. & .33 \\
\hline $\mathrm{SO}_{3} \ldots \ldots \ldots$ & None. & .12 \\
\hline 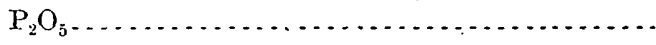 & Trace. & .33 \\
\hline $\mathrm{As}_{2} \mathrm{O}_{5} \ldots \ldots$ & Trace. & .25 \\
\hline 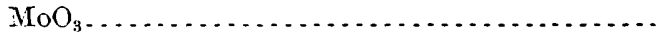 & & .23 \\
\hline $\mathrm{CrO}_{3} \ldots \ldots \ldots \ldots \ldots$ & None. & Trace. \\
\hline $\mathrm{SiO}_{2}, \ldots \ldots \ldots$ & 5.05 & 5.18 \\
\hline Insoluble residue except $\mathrm{SiO}_{2} \ldots \ldots \ldots \ldots$ & $\cdots$ & 3.16 \\
\hline $\mathrm{Al}_{2} \mathrm{O}_{3}, \mathrm{MoO}_{3}, \mathrm{PbO} \ldots$ & 2.50 & $\ldots \ldots$ \\
\hline Total... & 100.00 & 99.84 \\
\hline
\end{tabular}

Another specimen of carnotite was partially analyzed and gave only 15. 7 per cent of uranic oxide and 4.40 per cent of vanadium pentoxide, but 55.80 per cent of silica.

Dr. J. Ohly ${ }^{1}$ reports the discovery of a locality in a different part of the State from which he obtained a specimen of what was supposed to be carnotite, but when tested showed the presence of vanadium, but not of uranium, being a nearly pure vanadate. This mineral is now being investigated.

The only district in which the carnotite has been found is in Montrose County, Colorado, near the head of Paradox Valley, and in the

1 Mining and Scientific Press, Aug. 25, 1900, p. 221. 
La Sal Mountains. The carnotite ore occurs in fissures, sometimes over 2 feet in thickness and in a blanket formation. As mined the ore carries from 8 to 10 per cent metallic uranium. Over a carload of the ore has been mined and shipped.

The uranium minerals are readily separated from accompanying minerals and gangue by mechanical processes. That which has been mined in Colorado has been treated by chemical processes and shipped in the form of oxides to New York and then to France and Germany. The value of uranium ores, as quoted in New York, is $\$ 10$ per unit of metallic uranium, with a higher value for a more concentrated product. Uranium oxide is quoted at $\$ 4$ per pound.

\section{LIST OF MINERALS CONTAINING URANIUM.}

In the following list the name and composition of the minerals containing uranium in sufficient amount to classify them as uranium minerals are given:

Uranothallite, a hydrous calcium uranium carbonate, $2 \mathrm{CaCO}_{3}$. $\mathrm{U}\left(\mathrm{CO}_{3}\right)_{2} \cdot 10 \mathrm{H}_{2} \mathrm{O}$, occurs very sparingly as an incrustation of a siskingreen color on uraninite.

Liebigite, a hydrous calcium uranium carbonate, formula perhaps $\mathrm{CaCO}_{3}\left(\mathrm{UO}_{2}\right) \mathrm{CO}_{3} \cdot 20 \mathrm{H}_{2} \mathrm{O}$, occurs rarely as an apple-green erystalline incrustation on uraninite.

Voglite, a hydrous carbonate of uranium, calcium, and copper, of an emerald-green to grass-green color, is sparingly found in aggregates of crystalline scales implanted on uraninite.

Schröckinergite and randite are two uranium calcium carbonates of uncertain composition.

Some of the varieties of thorite contain a considerable quantity of uranium as uranothorite, which carries over 9 per cent of uranium oxide, $\mathrm{U}_{2} \mathrm{O}_{3}$, and is found in the Champlain iron district, New York, but whose exact locality is unknown.

A number of the niobium and tantalum minerals contain from 2 to 15 per cent uranium oxide. They are, in the order of their percentage of uranium: Blomstrandite, hatchettolite, samarskite, polycrase, euxenite, fergusonite, ythotantalite, annerödite, and hielmite.

Uranosphærite, a hydrous bismuth uranate, $(\mathrm{BiO})_{2} . \mathrm{U}_{2} \mathrm{O}_{7} \cdot 3 \mathrm{H}_{2} \mathrm{O}$, occurs sparingly in half-globular aggregated concentric forms of an orange-yellow color.

Torbernite, a hydrous phosphate of uranium and copper, $\mathrm{Cu}\left(\mathrm{UO}_{2}\right)_{2}$ $\mathrm{P}_{2} \mathrm{O}_{8}+8 \mathrm{H}_{2} \mathrm{O}$, occurs in foliated micaceous aggregates of an emerald to grass-green color, closely resembling autunite.

Zeunerite is a hydrous copper uranium phosphate, $\mathrm{Cu}\left(\mathrm{UO}_{2}\right) \mathrm{As}_{2} \mathrm{O}_{8}+$ $8 \mathrm{H}_{2} \mathrm{O}$, similar in appearance to torbernite.

Uranospinite is a hydrous calcium uranium arsenate, probably $\mathrm{Ca}\left(\mathrm{UO}_{2}\right)_{2} \mathrm{As}_{2} \mathrm{O}_{8}+8 \mathrm{H}_{2} \mathrm{O}$, and similar to autunite, but rare.' 
Uranocircite is a hydrous barium uranium phosphate, $\mathrm{Ba}\left(\mathrm{UO}_{2}\right)_{2}$ $\mathrm{P}_{2} \mathrm{O}_{8}+8 \mathrm{H}_{2} \mathrm{O}$, similar to autunite, but very rare.

Phosphuranylite, a hydrous uranium phosphate, $\left(\mathrm{UO}_{2}\right)_{3} \mathrm{P}_{2} \mathrm{O}_{8}+6 \mathrm{H}_{2} \mathrm{O}$, sometimes carrying lead, is found sparingly as a deep lemon-yellow incrustation on quartz and feldspar at some of the uranjnite localities in North Carolina.

Trögerite, a hydrous uranium arsenate, $\left(\mathrm{UO}_{2}\right)_{3} \mathrm{As}_{2} \mathrm{O}_{8}+12 \mathrm{H}_{2} \mathrm{O}$, in thin lemon-yellow crystals, has been found very sparingly at the Bald Mountain mining district, Black Hills, South Dakota.

Fritzscheite, a mineral resembling autunite, but of a reddish color, which is attributed to manganese, is of doubtful composition, but shows reactions for uranium, vanadium, manganese, phosphorus, and water.

Walpurgite, a basic arsenate of bismuth and uranium, $\mathrm{Bi}_{10}\left(\mathrm{UO}_{2}\right)_{3}$ $(\mathrm{OH})_{24}\left(\mathrm{AsO}_{4}\right)_{4}$, is very rare.

Johannite is a hydrous sulphate of uranium and copper, of a beautiful emerald-green color.

Uranopilite, a hydrous calcium uranium sulphate, perhaps $\mathrm{CaU}_{8} \mathrm{~S}_{2} \mathrm{O}_{31} \ldots 25 \mathrm{H}_{2} \mathrm{O}$, has been found as a velvety incrustation of a yellow color on uraninite.

Uraconite or uranocher is an amorphous earthy mineral of a fine lemon-yellow color, whose composition is principally a hydrous uranium sulphate.

Medjidite, uranochalcite, zippeite and voglianite are uranium sulphates of uncertain composition, containing from 36 to 79 per cent of uranium oxides.

\section{VANADIUM.}

Since the discovery of this metal in the early part of the nineteenth century, by Del Rio, and its rediscovery and investigation by the Swedish chemist Sefstroem in 1830 , it has been shown to be quite widely distributed in nature, but for the most part in very small quantities. The metal is obtained with difficulty in the form of a brilliant metallic powder of a silver-white color.

It is, however, the compounds of vanadium that are employed in the arts; and, as our knowledge of these increases, and more is known of the valuable properties which they possess, there is a growing demand for them. Its main use, in the form of vanadic acid $\left(\mathrm{V}_{2} \mathrm{O}_{5}\right)$, is as a mordant in dyeing (aniline black). Other vanadium compounds are used to a limited extent in the coloring of glass. Its value in the preparation of alloys is just beginning to be appreciated. Experiments have shown that a very small percentage of vanadium in iron, copper, or aluminum increases their tensile strength and ductility. It is, however, in the manufacture of a ferro-vanadium, to be used in the making of a special steel, that this metal will probably find its greatest use as an alloy. 


\section{OCCURRENCE.}

Up to the present time the supply of vanadium has come from France, where it is obtained from certain slags at Creusot. With the discovery, however, of the mineral carnotite and the pure vanadate mentioned above a new source of supply should be opened. As yet, however, no definite information is known regarding the amount of ore that can be obtained from these deposits.

The metal is widely distributed, having been found in certain clays, iron ores (especially magnetite), coals, and in trap and basaltic rocks, besides the numerous vanadium minerals. It is, however, usually in but minute quantities, although some magnetites have been found that contained sufficient vanadium to make them profitable working.

Another source of vanadium, and one that has attracted and is still attracting the interest of manufacturers and chemists, is its existence in the ash of certain coals. It was first discovered in a lignite coal found at San Rafael, in the province of Mendoza, Argentin Republic, by Dr. Juan J. J. Kyle. ${ }^{1}$ In testing the coal as to its value as a combustible, Dr. Kyle found that it left but a small amount of ash, which was of greenish color. On analyzing the ash it was found to contain vanadium, and in some quantity. From the results of the analyses, it shows that 1 ton of the coal will produce over 14 pounds of pure ash containing $4 \frac{1}{2}$ pounds of the vanadic acid $\left(\mathrm{V}_{2} \mathrm{O}_{5}\right)$, of which $3 \frac{1}{2}$ pounds may be extracted by simple treatment of the ash with an alkaline liquor, whlle the remainder can be extracted by a more elaborate chemical process. In Cordoba and San Louis, neighboring provinces of Mendoza, the vanadium minerals, vanadite, descloisite, and psittacinite, have been found at a number of localities.

Vanadium has also been found in an anthracite coal mined near Yauli, in Peru. With this discovery the probability of finding vanadium in coals in other parts of the world is increased, and it may be that a careful examination of the coals from the United States, especially of the Western States, will show the presence of this metal. ${ }^{2}$

In analyzing the peats of eastern North Carolina, Dr. Chas. Baskerville $^{3}$ found minute quantities of vanadium to be present in some of them, up to 0.003 per cent of $\mathrm{P}_{2} \mathrm{O}_{5}$.

In a recent investigation by Dr. W. F. Hillebrand ${ }^{4}$ on the distribution of vanadium, he shows that in the more basic igneous and metamorphic rocks there occurs up to 0.08 per cent or more of $\mathrm{V}_{2} \mathrm{O}_{3}$, but that it is apparently absent in the highly siliceous rocks. The source of the vanadium in the rocks appears to be the heavy ferric-aluminous silicates, biotites, amphiboles, pyroxenes. Sometimes the vanadium

${ }^{1}$ Buenos Ayres Standard, Jan. 30,1894, and U. S. Consular Reports, 1894.

2 Eng. and Min. Journal, Aug. 15, 1894; Jan. 26, 1896; Feb. 24, 1900.

3 Jour. Am. Chem. Soc., Vol. XXI, 1899, p. 707.

4 Bull. U. S. Geol. Survey, No. 167, 1900, p. 49. 
occurs in considerable amount in these minerals, when they are given distinctive names, as roscoelite,${ }^{1}$ the vanadium mica, and lavrovite, ${ }^{2}$ a variety of the pyroxene diopside.

Besides the two minerals referred to under "uranium" as containing an available source of vanadium, there are a number of other minerals that also carry this, but they have not been found as yet in sufficient quantity to be a source of vanadium. ${ }^{3}$

\section{OTHER VANADIUM MINERALS.}

The principal vanadium minerals are given below:

Vanadinite is a mineral usually occurring in hexagonal prisms which generally have smooth faces, but are apt to be cavernous, and are brittle, breaking with an uneven fracture. Its hardness is 2.75 to 3 , and its specific gravity 6.6 to 7.2. The color of vanadinite varies from ruby-red, reddish-brown, light brownish-yellow to straw-yellow, and it has a resinous luster. It is a lead vanadate, whose formula is $(\mathrm{PbCl}) \mathrm{Pb}_{4}\left(\mathrm{PO}_{4}\right)_{3}$, and is commonly found associated with other lead minerals, especially in the Western States, where it has been found in some quantity in the silver-mining regions of Arizona and New Mexico, in red and orange crystals; in the former State, at the Vulture and Phœnix mines, in Maricopa County; the Mammoth Gold mine, near Oracle, Pinal County, and in Yuma County. In New Mexico it has been found at Lake Valley, Sierra County; at the Mimbres mines, near Georgetown, Grant County, and at Los Cerillos. It has also been found in the Leadville district of Colorado. At Zimapan, in Mexico, vanadinite has been found in some quantity in yellowish, reddishbrown to red crystals, and it was from this locality that this mineral was first discovered.

Endlichlite is a variety of vanadinite that contains a considerable percentage of arsenic in a ratio that is nearly $\mathrm{P}: \mathrm{As}=1: 1$.

Descloizite has been found in small crystals, and also massive, with fibrous structure and mammillary surface of a cherry red and brownishred to light or dark brown color and greasy luster. In hardness this mineral is 3.5 , and has a specific gravity of 5.9 to 6.2 . Chemically it is a bydrous lead-zinc vanadate, having the formula $(\mathrm{PbZn})_{3} \mathrm{~V}_{2} \mathrm{O}_{8}$ $(\mathrm{PbZn})(\mathrm{OH})_{2}$. This is usually the composition of the crystallized varieties. Another variety, containing copper (as high as 11 per cent), occurs in crusts and reniform masses. It is found in some abundance at Lake Valley, Sierra County, and near Georgetown, Grant County, in New Mexico; near Tombstone, Cochise County; in Yavapai County, and at the Mammoth Gold Mine, near Oracle, Pinal County, in Arizona. 
Eusynchite, brackebuschite, and aræoxene are minerals similar and the first perhaps identical with descloizite.

Pucherite is a bismuth vanadate of a reddish-brown color, usually occurring in small tabular crystals.

Psittacinite is a vanadate of lead and copper, which has been found in thin coatings of a siskin to olive green color in the Silver Star district of Montana.

Mottramite is a vanadium mineral found in some considerable quantity at Alderly Edge and Mottram St. Andrews, in Cheshire, England, and may be identical with psittacinite.

There are a number of vanadium minerals of uncertain composition that are probably vanadates. These are chileite, a vanadate of lead and copper; vanadiolite, a dark emerald-green calcium vanadate containing silica; wicklowite, a doubtful lead vanadate.

Volborthite is a hydrous vanadate of copper, barium, and calcium of an olive-green color occurring in small six-sided tables.

Roscoelite is a vanadium mica that has been observed in minute scales of a clove-brown to greenish-brown color at the gold mine at Granite Creek, near Coloma, Eldorado County, California. In the Magnolia district, Colorado, earthy incrustations of this mineral have been found on calaverite.

Ardennite is a vanadio-silicate of aluminum and manganese, also containing arsenic, which is found rarely in small prismatic crystals of a yellow to yellowish-brown color, having a hardness of 6 to 7 .

In the pyroxene group of minerals a variety of diopside called lavrovite is colored green by vanadium.

Dechenite and calciovolborthite are two vanadates that have been found very sparingly, the former being a lead and the latter a hydrous copper-calcium vanadate.

\section{SUMMARY.}

It will be seen from the above that the occurrences of both uranium and vanadium are confined almost entirely to the Western States, but that in some of these it occurs in some quantity. As yet the vanadium minerals have not played a very important part in the production of this metal, but with the new discoveries of minerals and localities that have been recently made they will very probably be the source of this metal produced in the United States. 'The increasing demand for both these metals has made a new source of supply necessary, and it has to all appearances been realized in the deposits of the various minerals carrying these metals that have recently been found in Montana, Colorado, Utah, and California. There is an interesting field for research opened up for chemists in the investigation of the coals for vanadiuin, especially those found in Colorado and Montana. 


\section{TESTS FOR URANIUM AND VANADIUM.}

The following tests can be used to advantage in detecting uranium and vanadium in minerals:

Uranium. ${ }^{1}$-Make a small salt of phosphorus (hydrogen sodium ammonium phosphate, $\mathrm{HNaNH}_{4} \mathrm{PO}_{4} \cdot 4 \mathrm{H}_{2} \mathrm{O}$ ) bead on platinum wire. To this add a little of the powdered mineral to be tested. The oxide of uranium is soluble, and before the blowpipe in the oxidizing flame it converts the colorless bead to a clear yellow, which become yellowishgreen on cooling, while after heating in the reducing flame the bead assumes a fine green color. When there are other elements in the mineral that will impart color to the bead and for the detection of small quantities of uranium, it is best to proceed as follows: Dissolve the mineral in hydrochloric acid (after fusion with sodium carbonate, if necessary), nearly neutralize the excess of acid with ammonia, add solid anmonium carbonate, shake vigorously, and allow the liquid to stand a few minutes. The uranium is at first precipitated, but is soluble in excess of ammonium carbonate, and by filtering may be separated from a great many elements which are precipitated by that reagent. Sometimes there is difficulty in obtaining a, clear filtrate, and, if so, a few drops of ammonium sulphide may be added with the ammonium carbonate. Boil the filtrate containing uranium to expel carbon dioxide, add ammonia in excess, collect the precipitate containing uranium on a filter and test it with a salt of phosphorus bead, as described above.

Vanadium. ${ }^{2}$-Test with a salt of phosphorus bead, as described under "Uranium." The color of the bead in the oxidizing flame is yellow to deep amber, fading slightly on cooling, while in the reducing flame it is an indistinct dirty green, which changes to a fine green on cooling.

If there is but a small amount of vanadium in the mineral or there are other oxides that will impart color to the bead, the powered mineral should be fused with about four parts of sodium carbonate and two of potassium nitrate in a platinum or porcelain spoon. After cooling, the fusion should be digested with warm water, in order to dissolve out the soluble alkali vanadate. Filter, acidify the filtrate with a slight excess of acetic acid, and add a little lead acetate, which will precipitate a pale-yellow lead vanadate (lead chromate, which would be precipitated in the same process, is much yellower). The precipitate, after being collected on a filter paper, can be tested with the phosphorus bead. 


\title{
AN OCCURRENCE OF TUNGSTEN. ORE IN EASTERN NEVADA.
}

\author{
By F. B. WEEKS.
}

The existence of a hübnerite-bearing vein about 12 miles south of Osceola, Nevada, was discovered in the early part of 1900 . It occurs in the foothills on the west slope of the Snake Mountains, and near the base of Wheeler Peak, which is the culminating point of the range. The region is about 100 miles from Frisco, Utah, on the Oregon Short Line Railway, which is the nearest railroad point. A hasty examination of this locality was made in the course of a reconnaissance trip through this region in August, 1900. Prior to that time a small amount of ore had been gathered from the débris of the surface below the outcrop of the vein, and had been shipped in ton lots. 'The mineral was also seen to be disseminated through the loose soil of the mountain slopes.

The Tungsten mining district was organized in April, 1900. At the time of this examination a small gasoline plant with crusher and jigging apparatus was being installed so that shipment by the carload is now possible.

The vein in which the hübnerite occurs cuts across the country rock, which is a rather coarse porphyritic granite of the usual quartzmica-hornblende variety. This granite has a rudely bedded structure; parallel to that of the overlying Cambrian quartzite which dip $20^{\circ}$ to $25^{\circ} \mathrm{SSW}$. The strike of the vein is N. $68^{\circ} \mathrm{E}$., and the dip is $65^{\circ}$ $\mathrm{NW}$. The main vein is normally about 3 feet in width. In places it pinches to a few inches in thickness, but resumes its usual width within 30 to 40 feet. Several smaller veins from a few inches to a foot in thicinness were seen to outcrop on the slopes and could be traced to the main vein, with which they form a sharply acute angle. The main vein was traced for a distance of 2,100 feet by croppings and floats from its outcrop near the base of the lowest foothill up the slope of the mountain.

A sufficient development of the vein had not been made at the time of the examination to determine the extent of the ore deposition. A tunnel about 40 feet in length had been driven in at the lowest outcrop of the vein, and was the only opening that had been made. The walls of the vein are well defined. Where the vein has its average 
thickness it is formed of a milky-white quartz and carries a large amount of the hübnerite. Where the vein is pinched the quartz is schistose and the ore is in thin stringers and of small amount. The ore occurs in solid masses, frequently attaining a thickness of 6 to 12 inches. It is disseminated through the vein material in thick, platelike forms, and also occurs crystallized with the quartz crystals. Small shoots of ore were seen penetrating the country rock for a few inches. The vein material is readily crushed, and the mineral, on account of its weight, is easily separated by jigging.

Later information stated that the tunnel was extended to a length of 65 feet, the vein widened out to 4 feet, and that the mineral occurs in bunches across the full width of the vein. Scheelite has also been found in small bunches and streaks with the hübnerite.

On one locality on the vein there was a somewhat remarkable occurrence of the ore. It was found in large bunches or blocks averaging 75 per cent of tungstic acid, and from a small space $4 \frac{1}{2}$ tons of the tungsten ore had been obtained. From report it was learned that other smaller quartz veins carrying wolframite had been found and located in the immediate vicinity. The veins are said to carry gold in very small amount. 


\section{COA L.}

By Edward W. Parker.

\section{INTRODUCTION.}

The present chapter, dealing primarily with the statistics of coal production in 1899, contains also a résumé of the production in previous years. The statistics are presented as uniformly as possible with the preceding ieports of the series. They have been compiled, with a few exceptions, from direct returns to the Survey or its agents. In most of the cases where operators have failed to reply to the inquiries sent them from this office, the desired statements have been obtained from State officials, and in the few instances where, from unavoidable causes exact information could not be obtained, the shipments have been furnished by railroads, or the production has been carefully estimated upon the basis of tonnage reported in preceding years. Owing to the fact that many of the largest mines, particularly in western Pennsylvania, changed hands during the year, unusual difficulty and delay were experienced in securing the reports for the entire twelve months. This was not due to any unwillingness on the part of either the old or new owners to furnish the information, but to the fact that the books and records had been removed and were not available. The tracing up of these records is responsible largely for the slight delay in completing the report.

Acknowledgments. - The writer desires first of all to acknowledge the hearty cooperation of the coal operators in furnishing the statements of their production. Thanks are also due to Mr. R. M. Haseltine, chief inspector of mines of Ohio; Mr. David Ross, secretary of the Bureau of Labor Statistics of Illinois; Mr. Orson V. Smith, of the Bureau of Industrial Statistics of Pennsylvania; Messrs. H. F. Bain and S. W. Beyer, of the Iowa Geological Survey; Mr. Charles G. Yale, of the State Mining Bureau of California, and Mr. G. W. Stone, mine inspector of Kentucky, for assistance rendered in their respective States. The interesting report on the production of anthracite coal in Pennsylvania has been prepared as usual by Mr. William W. Ruley, of Philadelphia, chief of the Bureau of Anthracite Coal Statistics, and

21 GEOL, PT $6-21$. 
special agent of the Geological Survey. The preparation of the statistical tables bas been the special work of Mr. Theodore H. Johnson, one of the statistical experts of the Geological Survey, and acknowledgment is here made of his faithful and intelligent cooperation in this branch of the work.

Special features of the report.-In addition to the statistics of production in the United States, tables are presented showing the production in all the countries of the world for which records are available and covering a period of thirty-two years. The steady advance made by the United States from third to first place and from 14.35 to 32 per cent of the world's total is graphically shown in these tables.

Particular attention has been given in the preparation of this report to the collection of information regarding the increased use of machines for undercutting the coal in the bituminous mines of the United States. The inquiries have been extended to show the types of machines employed and to what extent air and electricity are used as motive power.

Reviews of the coal trade at the important centers and shipping ports have been contributed by secretaries of boards of trade, etc., or compiled from official sources, and they form an important and interesting feature of these reports. The names of the writers are given in connection with their contributions, and when reference is made to official reports or trade papers due credit is given the authority.

Unit of measurement.- - Some confusion is apt to occur by the fact that both the long ton of 2,240 pounds and the short ton (2,000 pounds) are used in this chapter. This is unfortunate, but can not be avoided. Pennsylvania anthracite is always measured by the long ton. In cases where Pennsylvania bituminous coal is sold in the Eastern markets the long ton is used. The same is true of West Virginia and of the Tazewell and Wise County coals of Virginia. The laws of Maryland permit the use of the long ton only. In all other cases bituminous coal is sold by the short ton. For the sake of convenience the bituminous product has in this report been reduced to short tons, and when the anthracite and bituminous products are tabulated together the short ton is used. In the section deroted entirely to Pennsylvania anthracite the long ton only is used, and in the table of shipments from the Cumberland region this is also the case.

\section{THE COAI FIELDS OF THE CNITED STATES.}

For convenience the coal areas of the United States are divided into two great classes-the anthracite and the bituminous.

In a commercial sense, particularly in the East, when the anthracite fields are mentioned the fields of Pennsylvania are considered, though Colorado and New Mexico are now supplying anthracite coal of good 
quality to the Rocky Mountain region, and small amounts are mined annually in Virginia. This small quantity from Virginia and a semianthracite product from Arkansas are considered with the bituminous output. In previous years some coal which was classed as anthracite has been mined and sold in New England. The productive area was confined to the eastern part of Rhode Island and the counties of Bristol and Plymouth, in Massachusetts. The classing of this product as anthracite coal was erroneous. The original beds have been metamorphosed into graphite or graphitic coal, and the product requires such a high degree of heat for combustion that it can be used only with other combustible material or under a heavy draft. It is, therefore, not an economical practice to use this product for fuel in competition with the anthracite coal from Pennsylvania or the bituminous coals from the New River and Pocahontas fields, which are now sent in large quantities to New England points, and its mining for fuel purposes has been abandoned.

The bituminous division includes the following coal fields: (1) The Triassic field, embracing the coal beds of the Triassic or new red sandstone formation in the Richmond basin in Virginia and in the coal basins along the Deep and Dan rivers in North Carolina; (2) the Appalachian field, which extends from the State of New York on the north to the State of Alabama on the south, having a length northeast and southwest of over 900 miles, and a width ranging from 30 to 180 miles; (3) the northern field, which is confined exclusively to the central part of Michigan; (4) the central field, embracing the coal areas in Indiana, Illinois, and western Kentucky; (5) the western field, including the coal areas west of the Mississippi River, south of the forty-third parallel of north latitude, and east of the Rocky Mountains; (6) the Rocky Mountain field, containing the coal areas in the States and Territories lying along the Rocky Mountains; (7) the Pacific coast field, embracing the coal districts 'of Washington, Oregon, and California.

The various fields are described at some length in Mineral Resources for 1886, and also in the report for 1894. The latter also contains some historical information regarding the development of these fields. Mineral Resources for 1892 contains some interesting contributions from State geologists on the coal fields of several States. 
The following table contains the approximate areas of the coal fields in the various States, grouped according to the divisions mentioned, with the total output from each from 1887 to 1899 :

Classification of the coal fields of the Lnited States.

\begin{tabular}{|c|c|c|c|c|}
\hline \multirow{2}{*}{. } & \multirow{2}{*}{ A rea. } & \multicolumn{3}{|c|}{ Product in- } \\
\hline & & 1887. & 1888. & 1889. \\
\hline Anthracite. & & & & \\
\hline $\begin{array}{l}\text { New England }(\text { Rhode Jsland and } \\
\text { Massachusetts }) . \ldots \ldots \ldots \ldots \ldots \ldots \ldots \ldots \ldots\end{array}$ & $\begin{array}{r}\text { Sq. miles. } \\
500\end{array}$ & $\begin{array}{l}\text { Short tons. } \\
\qquad 6,000\end{array}$ & $\begin{array}{l}\text { Short tons. } \\
4,000\end{array}$ & $\begin{array}{l}\text { Short tons. } \\
\qquad 2,000\end{array}$ \\
\hline Pennsylvania $\ldots \ldots \ldots \ldots \ldots \ldots \ldots$ & 480 & $39,506,255$ & $43,922,897$ & $45,544,970$ \\
\hline Colorado and New Mexico....... & 15 & 36,000 & 44,791 & 53,517 \\
\hline . & 995 & $39,548,255$ & $43,971,688$ & $45,600), 487$ \\
\hline Bituminous. (a) & & & & \\
\hline Triassic: & & & & \\
\hline virginia................. & 180 & 30,000 & 33,000 & 49,411 \\
\hline North Carolina............ & 2,700 & $\ldots \ldots \ldots$ & .......... & 222 \\
\hline Appalachian: & & & & \\
\hline Pennsylvania ... & 9,003 & $31,516,856$ & $30,796,727$ & $36,174,089$ \\
\hline Ohio............ & 10,000 & $10,301,708$ & $10,910,951$ & $9,976,787$ \\
\hline Maryland ........... & 550 & $3,278,023$ & $3,479,470$ & $2,939,715$ \\
\hline Virginia......... & 2,000 & 795,263 & $1,040,000$ & 816,375 \\
\hline West Virginia..... & 16,000 & $4,881,620$ & $5,498,800$ & $6,231,880$ \\
\hline Kentucky ........ & 11,180 & 950,903 & $1,193,000$ & $1,108,770$ \\
\hline Tennessee ........ & 5,100 & $1,900,000$ & $1,967,297$ & $1,925,689$ \\
\hline Georgia...... & 200 & 313,715 & 180,000 & 225,934 \\
\hline Alabama........... & 8,660 & $1,950,000$ & $2,900,000$ & $3,572,983$ \\
\hline & 62,690 & 55, sss, $08 s$ & $60,966,245$ & $62,972,222$ \\
\hline Northern: & & & & \\
\hline Michigan.. & 6,700 & 71,461 & 81,407 & 67,431 \\
\hline Central: & & & & \\
\hline Indiana... & 6,450 & $3,217,711$ & $3,140,979$ & $2,845,057$ \\
\hline Kentucky ...... & 4,500 & 982,282 & $1,377,000$ & $1,290,985$ \\
\hline Illinois...$\ldots \ldots \ldots \ldots \ldots$ & 36,800 & $10,278,890$ & $14,655,188$ & $12,104,272$ \\
\hline & $\therefore \overline{7}, 750$ & $14,478,883$ & $19,173,167$ & $16,240,314$ \\
\hline
\end{tabular}

$a$ Including lignite, brown coal, and scattering lots of anthracite. 
COAL.

Clussification of the coal fields of the United States-Continued.

\begin{tabular}{|c|c|c|c|c|}
\hline & \multirow{2}{*}{ A ren. } & \multicolumn{3}{|c|}{ Product in- } \\
\hline \multicolumn{4}{|c|}{1889.} & \\
\hline \multicolumn{5}{|l|}{ Bituminous $(a)-$ Continued. } \\
\hline Western: & Sq. miles. & Short tons. & Short tons. & Short tons. \\
\hline Iowa .... & 18,000 & $4,473,828$ & $4,952,440$ & $4,045,358$ \\
\hline Missouri.. & 26,700 & $3,209,916$ & $3,909,967$ & $2,557, \$ 23$ \\
\hline Nebraska..... & 3,200 & 1,500 & 1,500 & \\
\hline Kansas .... & 17,000 & $1,596,879$ & $1,850,000$ & $2,222,643$ \\
\hline Arkansas ............ & 9,100 & 129,600 & 276,871 & 279,584 \\
\hline Indian Territory $: .$. & 20,000 & 685,911 & 761,986 & 752,832 \\
\hline \multirow[t]{2}{*}{ 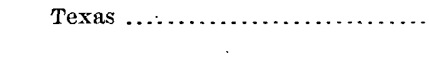 } & 4,500 & 75,000 & 90,000 & 128,216 \\
\hline & 98,500 & $10,172,634$ & $11,842,764$ & $10,036,356$ \\
\hline \multicolumn{5}{|l|}{ Rocky Mountain, etc:: } \\
\hline Dakota...... & & 21,470 & 34,000 & 28,907 \\
\hline Montana ........ & & 10,202 & 41,467 & 363,301 \\
\hline Idaho ....... & & 500 & 400 & $\ldots \ldots \ldots$ \\
\hline Wyoming. . & & $1,170,318$ & $1,481,540$ & $1,388,947$ \\
\hline Utah .......... & & 180,021 & 258,961 & 236,651 \\
\hline Colorado ....... & 2,913 & $1,755,785$ & $2,140,686$ & $2,544,144$ \\
\hline \multirow[t]{2}{*}{ New Mexico. } & & 508,034 & 626,665 & 486,463 \\
\hline & & $3,646,280$ & $4,583,719$ & $5,048,413$ \\
\hline \multicolumn{5}{|l|}{ Pacific coast: } \\
\hline Washington .... & & 772,612 & $1,215,750$ & $1,030,578$ \\
\hline Oregon ........ & $\cdots$ & 31,696 & - 75,000 & 64,359 \\
\hline \multirow[t]{2}{*}{ California.. } & $\cdots$ & 50,000 & 95,000 & 119,820 \\
\hline & & 854,308 & $1,385,750$ & $1,214,757$ \\
\hline $\begin{array}{l}\text { Total product sold.. } \\
\text { Colliery consumption .... }\end{array}$ & & $124,689,909$ & $142,037,740$ & \\
\hline Colliery consumption .... & .. & $5,960,302$ & $6,621,667$ & . \\
\hline $\begin{array}{l}\text { Total product, including colliery } \\
\text { consumption .................... }\end{array}$ & & $130,650,211$ & $148,659,407$ & $141,229,613$ \\
\hline
\end{tabular}

a Including lignite, brown coal, and scattering lots of anthracite. 
MINERAL RESOURCES.

Classification of the coal fields of the Inited States-Continued.

\begin{tabular}{|c|c|c|c|c|c|}
\hline & \multicolumn{5}{|c|}{ Product in- } \\
\hline & 1890. & 1891. & 1892. & 1893. & 1894. \\
\hline $\begin{array}{c}\text { Anthracite. } \\
\text { New England (Rhode Island } \\
\text { and Massachusetts) ............ }\end{array}$ & Short tons. & $\begin{array}{r}\text { Short tons. } \\
500\end{array}$ & Short tons. & Short tons. & Short tons. \\
\hline Pennsylvania $\ldots \ldots \ldots \ldots \ldots$ & $46,468,641$ & $50,665,431$ & $52,472,504$ & $53,967,543$ & $51,921,121$ \\
\hline \multirow[t]{2}{*}{ Colorado and New Mexico ....... } & (a) & $(a)$. & 64,963 & 93,578 & 71,550 \\
\hline & $46,468,641$ & $50,665,931$ & $52,537,467$ & $54,061,121$ & $51,992,671$ \\
\hline \multicolumn{6}{|l|}{ Bituminous. (b) } \\
\hline $\begin{array}{l}\text { Triassic: } \\
\quad \text { Virginia } \ldots . . . \ldots \ldots \\
\text { North Carolina...... }\end{array}$ & $\begin{array}{l}19,346 \\
10,262\end{array}$ & $\begin{array}{l}17,290 \\
20,355\end{array}$ & $\begin{array}{r}37,219 \\
6,679\end{array}$ & $\begin{array}{l}19,878 \\
17,000\end{array}$ & $\begin{array}{l}52,079 \\
16,900\end{array}$ \\
\hline \multicolumn{6}{|l|}{ Appalachian: } \\
\hline Pennsylvania & $42,302,173$ & $42,788,490$ & $46,694,576$ & $44,070,724$ & $39,912,463$ \\
\hline Ohio.......... & $11,494,506$ & $12,868,683$ & $13,562,927$ & $13,253,646$ & $11,909,856$ \\
\hline Maryland ...... & $3,357,813$ & $3,820,239$ & $3,419,962$ & $3,716,041$ & $3,501,428$ \\
\hline Virginia........ & 764,665 & 719,109 & 637,986 & 800,461 & $1,177,004$ \\
\hline West Virginia .. & $7,394,494$ & $9,220,665$ & $9,738,755$ & $10,708,578$ & $11,627,757$ \\
\hline Kentucky ........... & $1,206,120$ & $1,222,918$ & $1,231,110$ & $1,245,785$ & $\mathrm{z}, 218,072$ \\
\hline Tennessee ......... & $2,169,585$ & $2,413,678$ & $2,092,064$ & $1,902,258$ & $2,180,879$ \\
\hline Georgia..... & 228,337 & 171,000 & 215,498 & 372,740 & 354,111 \\
\hline \multirow[t]{2}{*}{ Alabama .................. } & $4,090,409$ & $4,759,781$ & $5,529,312$ & $5,136,935$ & $4,397,178$ \\
\hline & $73,008,102$ & $77,984,563$ & $83,122,190$ & $81,207,168$ & $76,278,748$ \\
\hline $\begin{array}{l}\text { Northern: } \\
\quad \text { Michigan } \ldots \ldots \ldots \ldots \ldots \ldots \ldots\end{array}$ & 74,977 & 80,307 & 77,990 & 45,979 & 70,002 \\
\hline \multicolumn{6}{|l|}{ Central: } \\
\hline Indiana .... & $3,305,737$ & $2,973,474$ & $3,345,174$ & $3,791,851$ & $3,423,921$ \\
\hline Kentucky ..... & $1,495,376$ & $1,693,151$ & $1,794,203$ & $1,761,394$ & $1,893,120$ \\
\hline \multirow[t]{2}{*}{ Illinois $\ldots \ldots \ldots \ldots \ldots \ldots$. } & $15,274,727$ & $15,660,698$ & $17,862,276$ & $19,949,564$ & $17,113,576$ \\
\hline & $20,075,840$ & $20,327,323$ & $23,001,653$ & $25,502,809$ & $22,430,617$ \\
\hline
\end{tabular}

$a$ Included in bituminous product.

$b$ Including lignite, brown coal, and scattering lots of anthracite. 
COAL.

Classification of the coal fields of the Linited States-Continued.

\begin{tabular}{|c|c|c|c|c|c|}
\hline & \multicolumn{5}{|c|}{ Product in- } \\
\hline & 1890. & 1891. & 1892. & 1893. & 1894. \\
\hline \multicolumn{6}{|l|}{ Bituminous (a)-Continued. } \\
\hline Western: & Short tons. & Short tons. & Short tons. & Short tons. & Short tons. \\
\hline Iowa & $4,021,739$ & $3,825,495$ & $3,918,491$ & $3,972,229$ & $3,967,253$ \\
\hline Missouri .............. & $2,735,221$ & $2,674,606$ & $2,733,949$ & $2,897,442$ & $2,245,039$ \\
\hline Nebraska. & 2.259 .922 & 1,500 & 1,500 & (n........... & 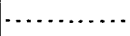 \\
\hline Kansas ..... & $2,259,922$ & $2,716,705$ & $3,007,276$ & $2,652,546$ & $3,388,251$ \\
\hline Arkansas ... & 399,888 & 542,379 & 535,558 & 574,763 & 512,626 \\
\hline Indian Territory ..... & 869,229 & $1,091,(132$ & $1,192,721$ & $1,252,110$ & 969,606 \\
\hline \multirow[t]{2}{*}{ Texas.......................... } & 184,440 & 172,100 & 245,690 & 302,206 & 420,848 \\
\hline & $10,470,439$ & $11,023,817$ & $11,635,185$ & $11,651,296$ & $11,503,623$ \\
\hline \multicolumn{6}{|l|}{ Rocky Mountain, etc.: } \\
\hline Dakota ...... & 30,000 & 30,000 & 40,725 & 49,630 & 42,015 \\
\hline Montana ..... & 517,477 & 541,861 & 564,648 & 892,309 & 927,395 \\
\hline Wyoming ..... & $1,870,366$ & $2,327,841$ & $2,508,839$ & $2,439,311$ & $2,417,463$ \\
\hline Utah & 318,159 & 371,045 & 361,013 & 413,205 & 431,550 \\
\hline Colorado ... & $3,094,003$ & $3,512,632$ & $3,447,967$ & $4,018,793$ & $2,776,817$ \\
\hline New Mexico........... & 375,777 & 462,328 & 659,230 & 655,112 & 580,238 \\
\hline \multirow[t]{2}{*}{ Nevada..................... } & & $\ldots \ldots \ldots \ldots$ & 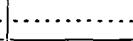 & (n) & 150 \\
\hline & $6,205,782$ & $7,245,707$ & $7,577,422$ & $8,468,360$ & $7,175,628$ \\
\hline \multicolumn{6}{|l|}{ Pacific coast: } \\
\hline Washington & $1,263,689$ & $1,056,249$ & $1,213,427$. & $1,264,877$ & $1,106,470$ \\
\hline Oregon ........ & 61,514 & 51,826 & 34,661 & 41,683 & 47,521 \\
\hline \multirow[t]{2}{*}{ California $\ldots \ldots \ldots \ldots \ldots$} & 110,711 & 93,301 & 85,178 & 72,603 & 67,247 \\
\hline & $1,435,914$ & $1,201,376$ & $1,333,266$ & 1,$379 ; 163$ & $1,221,238$ \\
\hline $\begin{array}{l}\text { Total product, including } \\
\text { colliery consumption.... }\end{array}$ & $157,770,963$ & $168,566,669$ & $179,329,071$ & $182,352,774$ & $170,741,526$ \\
\hline
\end{tabular}

$a$ Including lignite, brown coal, and scattering lots of anthracite. 
MINERAL RESOURCES.

Clnssification of the coal fields of the Lnited States-Continued.

\begin{tabular}{|c|c|c|c|c|c|}
\hline \multirow[b]{2}{*}{. } & \multicolumn{5}{|c|}{ Product in- } \\
\hline & 1595. & 1896. & 1897. & 1898. & 1899. \\
\hline $\begin{array}{l}\text { Anthracite. } \\
\text { New England (Rhode Is l and } \\
\text { and Massachusetts) } \ldots \ldots \ldots \ldots\end{array}$ & Short tons. & Short tons. & Short tons. & Short tons. & Short tons. \\
\hline Pennsylvania ....... & $57,999,337$ & $54,346,081$ & $52,611,680$ & $53,382,644$ & $60,418,005$ \\
\hline \multirow[t]{2}{*}{ Colorado and New Mexico..... } & 67,179 & 79,492 & 69,076 & 47,095 & 96,196 \\
\hline & $58,066,516$ & $54,425,573$ & $52,680,756$ & $53,429,739$ & $60,514,201$ \\
\hline \multicolumn{6}{|l|}{ Bituminous. (a) } \\
\hline \multicolumn{6}{|l|}{ Triassic: } \\
\hline Virginia..... & $5 \overline{7}, 782$ & 95,670 & 95,670 & 35.938 & $28 \quad 353$ \\
\hline North Carolina. & 24,900 & $7, \$ 13$ & 21,280 & & \\
\hline \multicolumn{6}{|l|}{ Appalachian: } \\
\hline Pennsylvania & $50,217,228$ & $49,55 \overline{7}, 453$ & $54,417,974$ & $65,165,133$ & $74,150,175$ \\
\hline ohio............. & $13,355,806$ & $12,875,202$ & $12,196,942$ & $14,516,867$ & $16,500,270$ \\
\hline Maryland ...... & $3,915, \overline{5} 85$ & $4,143,936$ & $4,442,128$ & $4,674,884$ & $4,807,396$ \\
\hline Virginia ....... & $1,310,542$ & $1,159,053$ & $1,432,632$ & $1,787,831$ & $2,104,334$ \\
\hline West Virginia .... & $11,387,961$ & $12,876,296$ & $14,248,159$ & $16,700,999$ & $19,252,995$ \\
\hline East Kentucky . & $1,490,05 \overline{7}$ & $1,4 \$ 6,016$ & $1,411,897$ & $1,591,076$ & $1, S_{71}, 550$ \\
\hline Tennessee. & $2,585,644$ & $2,663,106$ & $2,888,849$ & $3,022,896$ & $3,330,659$ \\
\hline Georgia.......... & 260,998 & 238,546 & 195,869 & 244,187 & 233,111 \\
\hline \multirow[t]{2}{*}{ 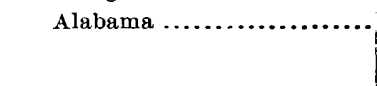 } & $5,693,775$ & $5,748,697$ & $5,893,770$ & $6,535,283$ & $7,593,416$ \\
\hline & $90,167,596$ & $90,748,305$ & $97,128,220$ & $114,239,156$ & $129,872,259$ \\
\hline $\begin{array}{l}\text { Northern: } \\
\text { Michigan. }\end{array}$ & \multicolumn{4}{|c|}{ Northern: } & 624,708 \\
\hline \multicolumn{6}{|l|}{ Central: } \\
\hline Indiana ......... & $3,995,892$ & $3,905,779$ & $4,151,169$ & $4,920,743$ & $6,006,523$ \\
\hline West Kentucky ...... & $1,867,713$ & $1,847,462$ & $2,190,200$ & $2,296,832$ & $2,735,705$ \\
\hline Illinois..$\ldots \ldots \ldots \ldots \ldots \ldots$ & $17,735,864$ & $19,756,626$ & $20,072,758$ & $18,599,299$ & $24,439,019$ \\
\hline - & $23,599,469$ & $25,539,867$ & $26,414,127$ & $25,816,874$ & $33,181,247$ \\
\hline
\end{tabular}

a Including lignite, brown coal, and scattering lots of anthracite. 
Classification of the coal fields of the Cinited States-Continued.

\begin{tabular}{|c|c|c|c|c|c|}
\hline & \multicolumn{5}{|c|}{ Product in- } \\
\hline & 1895. & 1896. & 1897. & 1898. & $1 S 99$. \\
\hline \multicolumn{6}{|l|}{ Bituminous $(a)-$ Continued. } \\
\hline Western: & Short tons. & Short tons. & Short tons. & Short tons. & Short tons. \\
\hline Iowa .................. & $4,156,074$ & $3,954,028$ & $4,611,865$ & $4,618,842$ & $5,177,479$ \\
\hline Missouri.......... & $2,372,393$ & $2,331, \overline{5} 42$ & $2,665,626$ & $2,688,321$ & $3,025,814$ \\
\hline Nebraska and Idaho. & $\ldots \ldots \ldots \ldots$ & $b 3,560$ & 645 & $c 1,039$ & $c 20$ \\
\hline Kansas ................ & $2,926,870$ & $2,854,801$ & $3,054,012$ & $3,406,555$ & $3,852,267$ \\
\hline Arkansas......... & 598,322 & 675,374 & 856,190 & $1,205,479$ & 843,554 \\
\hline Indian Territory ........ & $1,211,18 \tilde{5}$ & $1,366,646$ & $1,336,380$ & $1,381,466$ & $1,537,427$ \\
\hline \multirow[t]{2}{*}{ Texas....$\ldots \ldots \ldots \ldots \ldots$} & 484,959 & 544,015 & 639,341 & 686,734 & 883,832 \\
\hline & $11,749,803$ & $11,759,966$ & $13,164,059$ & $13,9 S 8,436$ & $15,320,393$ \\
\hline \multicolumn{6}{|l|}{ Rocky Mountain, etc.: } \\
\hline North Dakota... & 39,197 & $d 78,050$ & 77,246 & 83,895 & $9 \mathrm{~S}, \mathrm{~S} 09$ \\
\hline Montana ...... & $1,504,193$ & $1,543,445$ & $\cdot 1,647, S s 2$ & $1,479,803$ & $1,496,451$ \\
\hline Wyoming .... & $2,246,911$ & $2,229,624$ & $2,597,886$ & $2,863,812$ & $3,837,392$ \\
\hline Utah ............... & 471,836 & 418,627 & 521,560 & 593,709 & 786,049 \\
\hline Colorado $\therefore . .$. & $3,027,327$ & $3,054,711$ & $3,307,644$ & $4,053,210$ & $4,718,590$ \\
\hline New Mexico. & 709,130 & 600,823 & 701,964 & 968,330 & $1,012,152$ \\
\hline \multicolumn{6}{|l|}{ Nevada.... } \\
\hline & $7,998,594$ & $7,925,280$ & $8,854,182$ & $10,042,759$ & $11,949,443$ \\
\hline \multicolumn{6}{|l|}{ Pacific coast: } \\
\hline Washington & $1,191,410$ & $1,195,504$ & $1,434,112$ & $1,884,571$ & $2,029,881$ \\
\hline Oregon ... & 73,685 & 101,721 & 101,755 & 58,184 & 86,888 \\
\hline \multirow[t]{2}{*}{ California } & 75,453 & $e 93,776$ & $e 103,912$ & $e 160,288$ & $e 160,972$ \\
\hline & $1,340,548$ & $1,391,001$ & $1,639,779$ & $2,103,043$ & $2,2 \pi 7,741$ \\
\hline $\begin{array}{l}\text { Total product, including } \\
\text { colliery consumption... }\end{array}$ & $193,117,530$ & $191,986,357$ & $200,221,665$ & $219,974,667$ & $253,739,992$ \\
\hline
\end{tabular}

a Including lignite, brown coal, and scattering lots of anthracite. $\quad d$ Includes South Dakota. $b$ Nebraska only. $c$ Idaho only.

\section{RELATIVE IMPORTANCE OF VARIOUS FIELDS.}

It will be seen from the foregoing table that the output of anthracite coal, including the product of Colorado and New Mexico, has increased from $39,548,255$ short tons in 1887 to $60,514,201$ short tons in 1899 , or a little more than 50 per cent. In the ten years from 1889 to 1899 the product of anthracite coal increased about one-third. The product of anthracite coal in 1899 exceeded by nearly two and a half million tons the phenomenal yield of 1895 .

In point of area the Western is the most extensive of the bituminous fields, having an area of nearly 100,000 square miles. In point of production, however, the fields of the Appalachian system are by far the most important, the yield from these fields, with an area about twothirds of that of the Western, being over two-thirds of the total 
bituminous product of the United States. In 1899 the coal product of the Appalachian system was 129,872,259 short tons, an increase of $74,679,225$ short tons, or 135.3 per cent, over 1887 , and of $15,633,103$ short tons, or 13.7 per cent, over 1898. Next in importance is the Central field, having an area of 47,750 square miles, and a production in 1899 of $33,181,247$ short tons, about one-fourth of that of the Appalachian, and 17.2 per cent of the total bituminous product. The Western field is third in producing importance, although first in size. Its product in 1899 was $15,320,393$ shor't tons, about one-eighth of that of the Appalachian field and 8 per cent of the total. The areas of the coal fields in the Rocky Mountain and Pacific coast fields have not been determined. The former, fourth in producing importance, has increased its output from $3,646,280$ short tons in 1887 to $11,949,443$ short tons in 1899. The Pacific coast fields produced in 1899 $2,277,741$ short tons, 90 per cent of which was from the State of Washington. The production of these five fields in 1887,1898 , and 1899, with the increases in 1899 as compared with the other two years, is shown in the following table:

Production of the five principal bituminous coal fields in 1887, 1898, and 1899 compared.

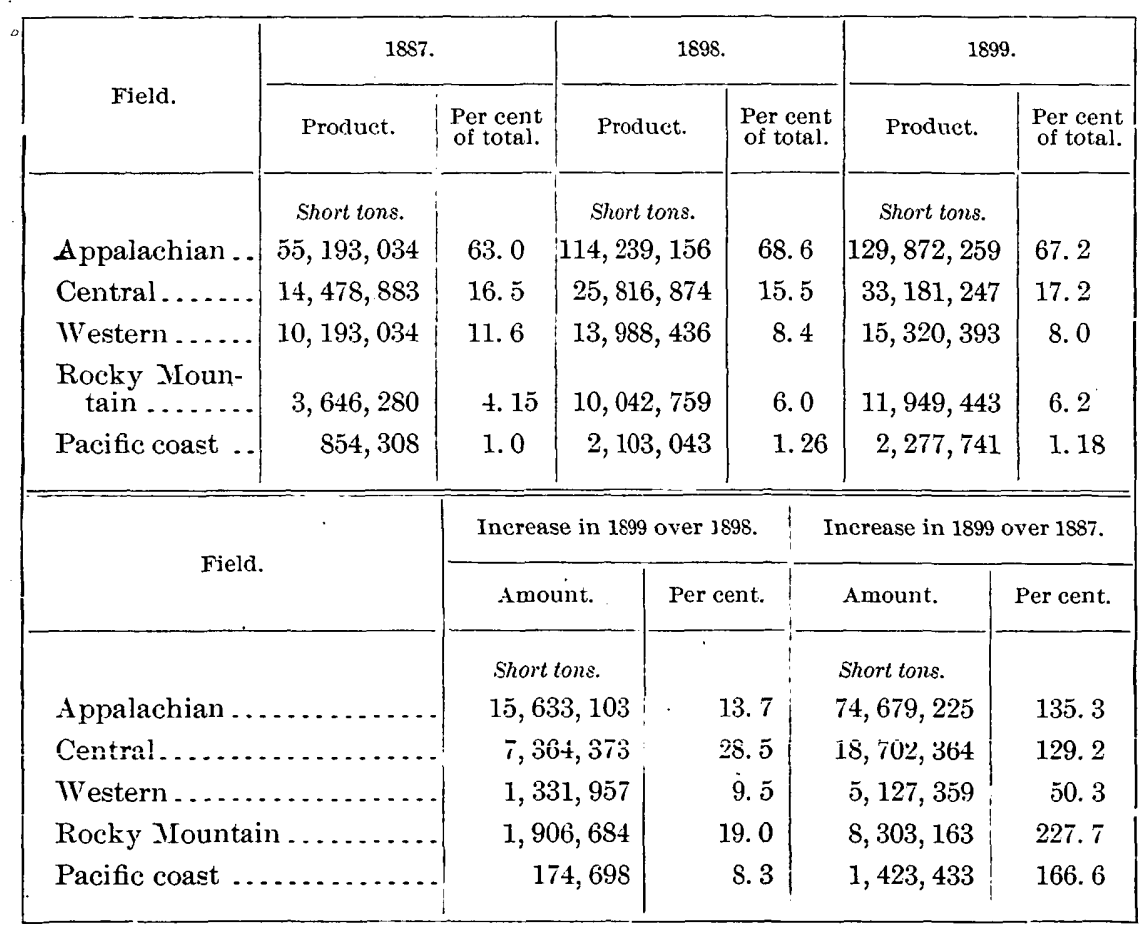




\section{PRODUCTION.}

The total product of anthracite coal in Pennsylvania in 1899 was $53,944,647$ long tons, equivalent to $60,418,005$ short tons, valued at the mines at $\$ 88,142,130$.

'The total product of bituminous coal in 1899 (including lignite or brown coal, cannel, splint, and block coals, and the small anthracite product of Colorado and New Mexico) was 172,608,917 long tons, or $193,321,987$ short tons, valued at the mines at $\$ 167,935,304$.

The aggregate product of anthracite and bituminous coal in 1899 was $226,553,564$ long tons, or $253,739,992$ short tons, valued at $\$ 256,077,434$.

The record made in 1899 is an important one. Not only did the production exceed all previous records, but it placed the United States at the head of the coal-producing countries of the world. The production in each of the last three years has been the largest up to that time. In 1897 the output reached for the first time a total of $200,000,000$ short tons. The product in 1898 was $219,974,667$ short tons, an increase of nearly 10 per cent over 1897 . The statistics for 1899 show an increase of $33,765,325$ short tons, or 15.35 per cent, over 1898 , and of $53,518,327$ short tons, or 26.73 per cent, over 1897 . Comparing the product in 1899 with some of the earlier years of our history, a still more remarkable advance is shown. In 1889 our total production of coal was $141,229,613$ short tons, showing an increase in ten years of $112,510,379$ short tons, or •nearly 80 per cent. In 1879 our production amounted to only $66,452,960$ short tons, compared with which the output in 1899 shows an increase of about 280 per cent, while in thirty years the production has increased about 700 per cent, the yield in 1899 being eight times that of 1869 , one generation ago. In the same period the production of Great Britain has about doubled, that of Germany has been multiplied by 4 , and that of France by 2.5 . In 1869 the coal product of Great Britain was nearly four times that of the United States, and that of Germany exceeded ours by about 20 per cent.

One of the interesting features of the history of coal production in the United States in the past three years is that the operators were prepared by the preceding years of depression to meet the demands made upon them by the period of prosperity through which the country has been passing. During the four or five years of "hard times" coal operators were contending with steadily declining prices, brought about by a continued overproduction and a keen competition for a market for the output. To meet these conditions, methods were adopted wherever possible for cheapening the cost of production by the installation of coal-cutting machines, mechanical haulage, etc., so that when the extraordinary demands of the past two years developed many operators were able to expand their production 25 or 50 per cent without materially increasing the lengths of their pay rolls. 
Another feature worthy of note, which is shown in the statistics for 1899 , is the advance in the average price per ton and a consequent increase in the value of the product proportionately greater than the increase in product. As shown in a subsequent table, this is the first time in a period of twelve years when there has been an advance in the general average price. The improvement in the price of coal, however, was not as marked as that shown in many other commodities. Much of the coal marketed in 1899 was sold on contracts made the preceding year, and it was not until the latter part of the year that the operators began to reap actual benefits from the improved conditions.

The statistics regarding the use of mining machines, presented in another part of this report, show that the amount of bituminous coal undercut by machines in 1899 was $43,963,933$ short tons, against $32,413,144$ short tons in $1898,22,649,220$ tons in 1897 , and $16,424,932$ tons in 1896.

The total number of men employed in all the coal mines of the United States in 1899 was 410,635 , working an average of two hundred and fourteen days, as compared with 401,221 men for one hundred and ninety days in 1898, and 397,701 for one hundred and seventynine days in 1897.

In considering the coal product these reports include not only the coal marketed, either by shipment to distant points or sold locally, but also that consumed by the mine employees and by the mine operators themselves in locomotives, under stationary boilers, etc., in working the mine, and technically known as colliery consumption. There are occasional exceptions, where operators use only slack or waste, which would otherwise be thrown on the dump and no record kept, the miner not even being paid for it. These exceptions are few and the amount so comparatively small as not to materially affect the total. Coal consumed in the manufacture of coke is also included in this report.

The coal shipped, sold to local trade and employees, and used in the manufacture of coke is considered the marketable product. The colliery consumption averages about 8 per cent of the total product in anthracite production and about $1 \frac{1}{2}$ per cent in bituminous mining. The marketable product in 1899 amounted to $244,612,654$ short tons, as compared with $212,053,378$ short tons in 1898 .

\section{ANTHRACITE.}

The production of anthracite coal in Pennsylvania amounted in 1899 to $53,9 \pm 4,6 \pm 7$ long tons, or $60,418,005$ short tons, ralued at the mines at $\$ 88,142,130$, against $47,663,076$ long tons, or $53,382,6 \pm 4$ short tons, worth $\$ 75,414,537$ in 1898 , and $46,974,714$ long tons, or $52,611,680$ short tons, valued at $\$ 79,301,954$ in 1897 . Compared with 1898 the product in 1899 shows an increase of $6,281,571$ long tons, or $\tau, 035,361$ 
short tons in amount, and of $\$ 12,727,893$. The percentage of increase in product was 13.2 , while the value increased 16.9 per cent, the year's business being marked by an advance of 5 cents per ton in the general average price.

The year 1899 made a new record for anthracite production, as it did for many other branches of industry. Previous to that the maximum output for any. one year was made in 1895, when, in spite of unfavorable market conditions, the production was pushed until it reached the then unprecedented total of $51,785,122 \mathrm{long}$ tons, more than $5,000,000$ tons in excess of the preceding year, and about $3,500,000$ tons more than the average product of the three years preceding and succeeding 1895. The evil effects of this overproduction was felt throughout the anthracite trade for the next three years, and its influence would probably have affected the trade for 1899 had it not been for the extraordinary industrial revival of that year. The statistics of anthracite production, shipments, distribution for consumption, etc., are fully discussed by Mr. William W. Ruley, the chief of the bureau of anthracite coal statistics, in another portion of this report (see "Pennsylvania," under "Production of coal by States"), and need not be treated more in detail here.

In addition to the anthracite product of Pernsylvania, a small amount of coal which is true anthracite is mined in Colorado and New Mexico. The amount produced, however, is comparatively insignificant $(96,196$ short tons in 1899 , and 47,095 tons in 1898), and has no appreciable effect upon the total. For the sake of convenience, therefore, this factor is included in the bituminous product, except in the preceding tables giving the production by fields. With this exception, reference to anthracite production throughout this and previous reports considers that of Pennsylvania only.

\section{BITUMINOUS.}

It has been customary in the preparation of these reports to include in the bituminous product all grades of coal. produced in the United States outside of the anthracite fields of Pennsylvania. The product consequently embraces, in addition to strictly bituminous coals, those classed as semianthracite, semibituminous, splint, block, cannel, and lignite or brown coals, and the anthracite coal of Colorado and New Mexico. An exception is noted in the case of the semianthracite coal of the Bernice Basin, in Sullivan County, Pennsylvania, which is included in the anthracite product.

The aggregate product of all the coals treated as bituminous amounted in 1899 to $193,321,987$ short tons, valued at $\$ 167,935,304$, as compared with $166,592,023$ short tons, worth $\$ 132,586,313$ in 1898 , and $147,609,985$ tons, valued at $\$ 119,567,224$ in 1897 . The activity which 
prevailed in the iron and steel and other metallurgical and manufacturing industries in 1899 had an immediate effect upon the production of bituminous coal. Throughout the entire year the demand was fully equal to and often in excess of the operators' ability to meet it. The principal difficulty cxperienced by operators in 1899 was that brought about by the shortness of car supply, and, in some regions, by lack of miners, the demand for labor in other industrial lines causing an exodus of men from the mines with their more hazardous and less congenial employment. The labor conditions in 1899 were carried forward from the preceding year, and in consequence thereof the close of 1899 found many mines being equipped with undercutting machines. The statistics regarding the use of machines for mining bituminous coal, which are presented in another portion of this report, show that the number of machines in use bad increased from 2,622 in 1898 to 3,125 in 1899 , and that the machine-mined product had increased from $32,413,144$ tons to $43,963,933$ tons, 43 per cent of the total increase in the bituminous product.

Production of bituminous coal in the United States has shown an almost uninterrupted increase each year since 1880 . In that year, according to the Tenth Census, the product was $42,831,758$ short tons. During the nineteen years ending with 1899 there have been only three years in which the product was less than the year before. These were in 1885,1889 , and 1894.

Comparing the product of 1899 with some of the previous years it is seen that over 1898 there was a gain of $26,729,964$ short tons, or 16 per cent in amount, and of $\$ 35,348,991$, or 26.7 per cent in value. As compared with 1897 the product in 1899 shows a gain of $45,712,002$ short tons, an increase in two years considerably in excess of the total bituminous product in 1880. At the time of taking the Eleventh Census, in 1889 , the total product of bituminous coal was $95,684,543$ short tons. The product in 1899 shows an increase of over 100 per cent in ten years. As compared with the product reported by the Tenth Census the record for 1899 shows an output 4.5 times as large. No other country in the world has exhibited such a record.

For the first time in a period of twelve years the increase in the value of the bituminous product has been greater in proportion to the increase in. tonnage. Since 1887 until the close of 1898 there had been no reaction against the decline in the arerage selling price obtained by the producers. The average price for all grades of coal included in the bituminous product in 1899 was 87 cents, as compared with 80 cents in 1898, 81 cents in 1897, and 83 cents in 1896. The price for 1899 would have shown a still greater improrement had it not been for the fact that most of the coal marketed in that year was sold on long contracts at prices made in 1898, and it was not until the latter part of the year that actual benefits of improved prices were secured. 
The statistics of production in 1898 and 1899, by States, are presented in the following tables:

Coal product of the Lniled States in 189S, by States.

\begin{tabular}{|c|c|c|c|c|c|}
\hline State. & $\begin{array}{l}\text { Num- } \\
\text { ber of } \\
\text { mines. }\end{array}$ & $\begin{array}{l}\text { Loaded at } \\
\text { mines for } \\
\text { shipment. }\end{array}$ & $\begin{array}{l}\text { Sold to local } \\
\text { trade and } \\
\text { used by: } \\
\text { employees. }\end{array}$ & $\begin{array}{c}\text { Used at } \\
\text { mines for } \\
\text { steam and } \\
\text { heat. }\end{array}$ & $\begin{array}{l}\text { Mrade into } \\
\text { coke. }\end{array}$ \\
\hline Alabama. & 82 & $\begin{array}{l}\text { Short toms. } \\
4,926,828\end{array}$ & $\begin{array}{r}\text { Short tons. } \\
107,576\end{array}$ & $\begin{array}{r}\text { Short tons. } \\
145,808\end{array}$ & $\begin{array}{l}\text { Short tons. } \\
1,355,0 \overline{1} 1\end{array}$ \\
\hline Arkansas . & 17 & $1,167,103$ & 13,256 & 25,120 & \\
\hline California and Alaska & 7 & 135,568 & 19,996 & 4,724 & \\
\hline Colorado . . . . . . & 101 & $3,132,676$ & 130,305 & 117,820 & 695,546 \\
\hline $\begin{array}{l}\text { Georgia and North } \\
\text { Carolina.......... }\end{array}$ & 3 & 145,778 & 1,194 & 6,989 & 101,721 \\
\hline Idaho..... & 2 & . & 1,039 & 每 & \\
\hline Illinois .... & 329 & $15,596,888$ & $2,149,808$ & 852,603 & \\
\hline Indiana ... & 141 & $4,398,078$ & 387,790 & 130,810 & 4,065 \\
\hline Indian Territory & 22 & $1,310,178$ & 16,632 & 34,055 & 20,601 \\
\hline Iowa ... & 187 & $3,981,362$ & 572,063 & 65,417 & \\
\hline Kansas .... & 110 & $3,079,601$ & 277,022 & 49,932 & \\
\hline Kentucky .. & 116 & $3,537,429$ & 253,629 & 55,206 & 41,644 \\
\hline Maryland & 31 & $4,618,990$ & 36,941 & 18,953 & \\
\hline Michigan . & 17 & 232,155 & 75,622 & 7,945 & \\
\hline Missouri... & 124 & $2,393,315$ & 249,662 & 45,344 & $\cdots . .$. \\
\hline Montana .... & 36 & $1,261,814$ & 29,493 & 19,386 & 169,110 \\
\hline New Mexico. & 16 & 949,903 & 7,660 & 17,601 & 17,124 \\
\hline North Dakota. & 18 & 71,223 & 11,525 & 1,147 & \\
\hline Ohio ......... & 431 & $13,053,427$ & $1,226,184$ & 222,913 & 14,343 \\
\hline Oregon ....... & 5 & 54,305 & 3,290 & 589 &.- \\
\hline Pennsylvania . & 689 & $48,019,561$ & $1,520,750$ & 732,984 & $14,891,838$ \\
\hline Tennessee ... & 51 & $2,199,075$ & 37,971 & 52,523 & 733,327 \\
\hline Texas ...... & 16 & 678,732 & 3,247 & 4,755 & \\
\hline Utah ........ & 20 & $\cdot 485,716$ & 11,542 & 9,845 & 86,606 \\
\hline Virginia .... & 20 & $1,029,185$ & 19,564 & 16,234 & 750,291 \\
\hline Washington & 23 & $1,748,411$ & 30,636 & 56,966 & 48,558 \\
\hline West Virginia & 225 & $12,965,903$ & 471,796 & 61,176 & $3,202,124$ \\
\hline Wyoming .... & 23 & $2,698,326$ & 21,655 & 108,447 & 35,384 \\
\hline $\begin{array}{l}\text { Total bitumi- } \\
\text { nous ...... }\end{array}$ & 2,862 & $133,871,530$ & $7,687,848$ & $2,865,292$ & $22,167,353$ \\
\hline $\begin{array}{c}\text { Pennsylvania an }- \\
\text { thracite } . . . . . . . . .\end{array}$ & 340 & $47,088,581$ & $1,238,066$ & $5,055,997$ & \\
\hline Grand total & 3,202 & $180,960,111$ & $8,925,914$ & $7,921,289$ & $22,167,353$ \\
\hline
\end{tabular}


Coal product of the Linited States in 1898, by States-Continued.

\begin{tabular}{|c|c|c|c|c|c|}
\hline State. & Total product. & Total value. & $\begin{array}{l}\text { Average } \\
\text { price per } \\
\text { ton. }\end{array}$ & $\left|\begin{array}{c}\text { A verage } \\
\text { number } \\
\text { of days } \\
\text { active. }\end{array}\right|$ & $\begin{array}{l}\text { Avernge } \\
\text { number of } \\
\text { employees. }\end{array}$ \\
\hline Alabama & $\begin{array}{l}\text { Short tons. } \\
6,535,283\end{array}$ & $\$ 4,932,776$ & $\$ 0.75$ & 250 & 10,733 \\
\hline Arkansas ... & $1,205,479$ & $1,238,778$ & 1.03 & 163 & 2,555 \\
\hline California and Alaska & 160,288 & 405,915 & 2.53 & 265 & 314 \\
\hline Colorado ....... & $4,076,347$ & $4,686,081$ & 1.15 & 220 & 6,440 \\
\hline $\begin{array}{c}\text { Georgia and North } \\
\text { Carolina........... }\end{array}$ & 255,682 & 212,537 & .83 & 292 & 534 \\
\hline Idaho .... & 1,039 & 2,675 & 2.57 & 157 & 7 \\
\hline Illinois & $18,599,299$ & $14,567,598$ & .78 & 175 & 35,026 \\
\hline Indiana & $4,920,743$ & $3,994,918$ & .81 & 199 & 8,971 \\
\hline Indian Territory & $1,381,466$ & $1,827,638$ & 1.32 & 198 & 3,216 \\
\hline Iowa ...... & $4,618,842$ & $5,260,716$ & 1.14 & 219 & 10,262 \\
\hline Kansas.... & $3,406,555$ & $3,703,014$ & 1.09 & 194 & 7,197 \\
\hline Kentucky & $3,887,908$ & $3,084,551$ & .79 & 187 & 7,614 \\
\hline Maryland & $4,674,884$ & $3,532,257$ & .76 & 253 & 4,818 \\
\hline Michigan ... & 315,722 & 462,711 & 1.47 & 245 & 715 \\
\hline Missouri. . & $2,688,321$ & $2,871,296$ & 1.07 & 198 & 6,542 \\
\hline Montana & $1,479,803$ & $2,324,207$ & 1.57 & 216 & 2,359 \\
\hline New Mexico. & 992,288 & $1,344,750$ & 1.35 & 242 & 1,873 \\
\hline North Dakota. & 83,895 & 93,591 & 1.12 & 187 & 151 \\
\hline Ohio..... & $14,516,867$ & $12,027,336$ & .83 & 169 & 26,986 \\
\hline Oregon & 58,184 & 212,184 & 3.65 & 142 & 199 \\
\hline Pennsylvania & $65,165,133$ & $43,352,588$ & .67 & 229 & 79,611 \\
\hline Tennessee & $3,022,896$ & $2,337,512$ & .77 & 234 & 6,643 \\
\hline Texas ... & 686,734 & $1,139,763$ & 1.66 & 245 & 2,130 \\
\hline Utah. & 593,709 & 752,252 & 1. 27 & 243 & 739 \\
\hline Virginia ... & $1,815,274$ & $1,070,417$ & .59 & 230 & 1,855 \\
\hline Washington . & $1,884,571$ & $3,352,798$ & 1. 78 & 270 & 3,145 \\
\hline West Virginia... & $16,700,999$ & $10,131,264$ & .61 & 218 & 21,607 \\
\hline Wyoming ... & $2,863,812$ & $3,664,190$ & 1.28 & 242 & 3,475 \\
\hline $\begin{array}{c}\text { Total bitumi- } \\
\text { nous ....... }\end{array}$ & $166,592,023$ & $132,586,313$ & .80 & 211 & 255,717 \\
\hline $\begin{array}{c}\text { Pennsylvania an - } \\
\text { thracite ......... }\end{array}$ & $53,382,644$ & $75,414,537$ & 1.41 & 152 & 115,504 \\
\hline Grand total. & $219,974,667$ & $208,000,850$ & .95 & 190 & 401,221 \\
\hline
\end{tabular}


Coal product of the United States in 1899 by States.

\begin{tabular}{|c|c|c|c|c|c|}
\hline State. & $\begin{array}{l}\text { Num- } \\
\text { ber of } \\
\text { mines. }\end{array}$ & $\begin{array}{l}\text { Loaded at } \\
\text { mines for ship- } \\
\text { ment. }\end{array}$ & $\begin{array}{l}\text { Sold to } \\
\text { local trade } \\
\text { and used } \\
\text { by em- } \\
\text { ployees. }\end{array}$ & $\begin{array}{l}\text { Used at } \\
\text { mines for } \\
\text { steam } \\
\text { and heat. }\end{array}$ & $\begin{array}{l}\text { Made into } \\
\text { coke. }\end{array}$ \\
\hline Alabamo & 100 & Short tons. & Short tons. & Short tons. & Short tons. \\
\hline Alanama & 100 & 4, 601,012 & 19,994 & 100,014 & $2,000,290$ \\
\hline Arkansas ........... & 22 & 811,366 & 10,296 & 21,892 & $\ldots \ldots \ldots$ \\
\hline California and Alaska & 7 & 151,265 & 5,275 & 4,432 & \\
\hline Colorado .......... & 108 & $3,681,341$ & 118,153 & 106,988 & 869,742 \\
\hline $\begin{array}{c}\text { Georgia and North } \\
\text { Carolina.......... }\end{array}$ & 3 & 174,080 & 926 & 8,434 & 76,567 \\
\hline Idaho... & 1 & $\ldots \ldots \ldots$. & 20 & $\ldots \ldots \ldots$ & $\cdots$ \\
\hline Illinois . & 550 & $21,871,930$ & $1,936,515$ & 630,574 & $\cdots$ \\
\hline Indiana ....... & 136 & $5,465,609$ & 376,574 & 160,621 & 3,719 \\
\hline Indian Territory - & 29 & $1,444,063$ & 12,280 & 54,222 & 26,862 \\
\hline Iowa .. & 230 & $4,479,743$ & 622,401 & 75,335 & $\cdots$ \\
\hline Kansas ...... . & 123 & $3,524,497$ & 276,918 & 50,852 & - \\
\hline Kentucky & 97 & $4,139,199$ & 282,736 & 67,136 & 118,184 \\
\hline Maryland & 34 & $4,716,581$ & 68,750 & 22,065 & \\
\hline Michigan ...... & 23 & 574,280 & 34,191 & 16,237 & \\
\hline Missouri. & 166 & $2,691,433$ & 289,826 & 44,555 & \\
\hline Montana & 34 & $1,294,614$ & 29,686 & 34,249 & 137,902 \\
\hline New Mexico.... & 18 & $1,021,801$ & 14,128 & 14,785 & $\cdots$ \\
\hline North Dakota. & 25 & 77,731 & 20,788 & 290 & 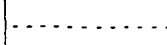 \\
\hline Ohio ... & 441 & $14,880,893$ & $1,393,025$ & 211,992 & 14,360 \\
\hline Oregon . & 3 & 78,608 & 6,656 & 1,624 & $\ldots \ldots$ \\
\hline Pennsylvania & 687 & $53,671,963$ & $1,525,772$ & 972,692 & $17,979,748$ \\
\hline Tennessee & $\check{5} 2$ & $2,444,655$ & 86,351 & 55,675 & 743,978 \\
\hline Texas - & 18 & 8399,166 & 34,690 & 9,976 & $\ldots \ldots$ \\
\hline Utah & 25 & 753,881 & 13,303 & 13,046 & 5,819 \\
\hline Virginia & 25 & $1,175,504$ & 23,634 & 19,004 & 887,649 \\
\hline Washington & 26 & $1,897,962$ & 20,281 & 61,443 & 50,195 \\
\hline West Virginia & 231 & $15,044,272$ & 476,996 & 87,022 & $3,644,705$ \\
\hline Wyoming & 31 & $3,584,667$ & 32,429 & 188,196 & 32,100 \\
\hline $\begin{array}{l}\text { Total bitumi- } \\
\text { nous } \ldots . .\end{array}$ & 3,245 & $155,192,716$ & $7,792,594$ & $3,088,851$ & $27,247,826$ \\
\hline $\begin{array}{l}\text { Peninsylvania an- } \\
\text { thracite } \ldots . . . .\end{array}$ & 359 & $53,562,030$ & $1,281,962$ & $5,574,013$ & \\
\hline Grand total. & 3,604 & $208,754,746$ & $9,074,556$ & $8,662,864$ & $27,247,826$ \\
\hline
\end{tabular}

21 GEOL, PT $6-22$ 
MINERAL RESOURCES.

Coal product of the United States in 1899 by States-Continued.

\begin{tabular}{|c|c|c|c|c|c|}
\hline State. & Total product. & - Total value. & $\begin{array}{l}\text { Aver- } \\
\text { age } \\
\text { price } \\
\text { per ton. }\end{array}$ & $\begin{array}{l}\text { Aver- } \\
\text { age } \\
\text { number } \\
\text { of days } \\
\text { active. }\end{array}$ & $\begin{array}{l}\text { Average } \\
\text { number of } \\
\text { employees. }\end{array}$ \\
\hline$\infty$ & Short tons. & & & & \\
\hline Alabama ......... & $7,593,416$ & $\$ 8,256,462$ & $\$ 1.09$ & 238 & 13,481 \\
\hline Arkansas ...... & 843,554 & 989,383 & 1. 17 & 156 & 2,313 \\
\hline California and Alaska & 160,972 & 430,636 & 2.68 & 287 & 369 \\
\hline Colorado . . . . . & $4,776,224$ & $5,363,667$ & 1. 12 & 246 & 7,166 \\
\hline $\begin{array}{c}\text { Georgia and North } \\
\text { Carolina.......... }\end{array}$ & 260,007 & 268,309 & 1.03 & 291 & 637 \\
\hline Idaho .... & 20 & 100 & 5.00 & $\ldots$ & $\ldots \ldots \ldots$ \\
\hline Illinois .... & $24,439,019$ & $20,744,553$ & .85 & 228 & 36,756 \\
\hline Indiana ........ & $6,006,523$ & $5,285,018$ & .82 & 218 & 9,712 \\
\hline Indian Territory & $1,53 \overline{7}, 427$ & $2,199,785$ & 1. 43 & 212 & 4,084 \\
\hline Iowa....... & $5,177,479$ & $6,397,338$ & 1.24 & 229 & 10,971 \\
\hline Kansas.......... & $3,852,267$ & $4,478,112$ & 1.16 & 226 & 8,000 \\
\hline Kentucky .. & $4,607,255$ & $3,618,222$ & .79 & $224^{-}$ & 7,461 \\
\hline Maryland ...... & $4,807,396$ & $3,667,056$ & .76 & 275 & 4,624 \\
\hline Michigan . . . . . . . . & 624,908 & 870,152 & 1. 39 & 232 & 1,291 \\
\hline Missouri....... . & $3,025,814$ & $3,591,945$ & 1.20 & 212 & 7,136 \\
\hline Montana .......... & $1,496,451$ & $2,347,757$ & 1.57 & 238 & 2,378 \\
\hline New Mexico ........ & $1,050,714$ & $1,461,865$ & 1.39 & 257 & 1,750 \\
\hline North Dakota.... & 98,809 & 117,500 & 1.19 & 154 & 210 \\
\hline Ohio .......... & $16,500,270$ & $14,361,903$ & .87 & 200 & 26,038 \\
\hline Oregon ........ & 86,888 & 260,917 & 3.00 & 238 & 1.24 \\
\hline Pennsylvania ..... & $74,150,175$ & $56,247,791$ & .76 & 245 & 82,812 \\
\hline Tennessee ...... & $3,330,659$ & $2,940,644$ & .88 & 252 & 6,949 \\
\hline Texas .... & 883,832 & $1,334,895$ & 1.51 & 256 & 2,410 \\
\hline Utah .... & 786,049 & 997,271 & 1.27 & 265 & 743 \\
\hline Virginia .... & $2,105,791$ & $1,304,241$ & .62 & 252 & 1,960 \\
\hline Washington & $2,029,881$ & $3,603,989$ & 1. 78 & 259 & 3,330 \\
\hline West Virginia & $19,252,995$ & $12,053,268$ & .63 & 242 & 23,625 \\
\hline Wyoming .. & $3,837,392$ & $4,742,525$ & 1.24 & 261 & 4,697 \\
\hline $\begin{array}{c}\text { Total bitumi- } \\
\text { nous } \ldots \ldots\end{array}$ & $193,321,987$ & $167,935,304$ & .87 & 234 & 271,027 \\
\hline $\begin{array}{c}\text { Pennsylvaniaan- } \\
\text { thracite.......... }\end{array}$ & $60,418,005$ & $88,142,130$ & 1. 46 & 173 & 139,608 \\
\hline Grand total... & $253,739,992$ & $256,077,434$ & 1.01 & 214 & 410,635 \\
\hline
\end{tabular}




\section{PRODUCTION IN PREVIOUS YEARS.}

In the following table is shown the annual production of anthracite and bituminous coal, with the value of each and of both combined, since 1880. The quantities are expressed both in long tons of 2,240 pounds and in short tons of 2,000 pounds. In the twenty years covered by this statement the yield of anthracite coal in Pennsylvania has increased from. $25,580,189$ long tons or $28,649,811$ short tons, valued at $\$ 42,196,678$, to $53,944,647$ long tons or $60,418,005$ short tons, valued at $\$ 88,142,130$ in 1899 , an increase in amount of $28,364,458$ long tons or $31,768,194$ short tons, and of $\$ 45,945,952$ in value. The product increased 111 per cent and the value $109 \mathrm{per}$ cent. It will also be observed that while the product in 1899 was the largest ever obtained, the value was nearly $\$ 1,000,000$ less than that of 1888 , in which year the average price was $\$ 2.16$ per long ton, the highest recorded in the last twenty. years.

The amount of bituminous coal produced in 1899 was 4.5 times that of 1880 , while the value was only a little over 3 times as much. The average price for bituminous coal in 1880 was about $\$ 1.25$ per short ton. In 1899 it was 87 cents.

Annual production of coal in the United States since 1880.

\begin{tabular}{|c|c|c|c|}
\hline \multirow{2}{*}{ Year. } & \multicolumn{3}{|c|}{ Bituminous coal. } \\
\hline & $\begin{array}{l}\text { Long tons of } \\
2,240 \text { pounds. }\end{array}$ & $\begin{array}{l}\text { Short tons of } \\
2,000 \text { pounds. }\end{array}$ & Value. \\
\hline $1880 \ldots$. & $38,242,641$ & $42,831,758$ & $\$ 53,443,718$ \\
\hline $1881 \ldots$ & $48,365,341$ & $53,961,012$ & $60,224,344$ \\
\hline $1882 \ldots .$. & $60,861,190$ & $68,164,533$ & $76,076,487$ \\
\hline $1883 \ldots$. & $68,531,500$ & $76,755,280$ & $82,237,800$ \\
\hline 1884 & $73,730,539$ & $82,578,204$ & $77,417,066$ \\
\hline $1885 \ldots$. & $64,840,668$ & $72,621,548$ & $82,347,648$ \\
\hline 1886 & $66,646,947$ & $74,644,581$ & $78,481,056$ \\
\hline $1887 \ldots$ & $79,073,227$ & $88,562,014$ & $98,004,656$ \\
\hline 1888. & $91,107,002$ & $102,039,843$ & $101,860,529$ \\
\hline 1889 & $85,432,717$ & $95,684,643$ & $94,504,745$ \\
\hline 1890 & $99,377,073$ & $111,302,322$ & $110,420,801$ \\
\hline 1891. & $105,268,962$ & $117,901,237$ & $117,188,400$ \\
\hline 1892. & $113,264,792$ & $126,856,567$ & $125,124,381$ \\
\hline 1893. & $114,629,671$ & $128,385,231$ & $122,751,618$ \\
\hline $1894 \ldots$ & $106,089,647$ & $118,820,405$ & $107,653,501$ \\
\hline $1895 \ldots$ & $120,641,244$ & $135,118,193$ & $115,779,771$ \\
\hline $1896 \ldots$ & $122,893,104$ & $137,640,276$ & $114,891,515$ \\
\hline $1897 \ldots$ & $131,794,630$ & $147,609,985$ & $119,567,224$ \\
\hline $1898 \ldots$ & $148,742,878$ & $166,592,023$ & $132,586,313$ \\
\hline $1899 \ldots$ & $172,608,917$ & $193,321,987$ & $167,935,304$ \\
\hline
\end{tabular}


Annual production of coal in the Lnited States since 1880-Continued.

\begin{tabular}{|c|c|c|c|}
\hline \multirow{2}{*}{ Year. } & \multicolumn{3}{|c|}{ Pennsylvania anthracite. } \\
\hline & $\begin{array}{l}\text { Long tons of } \\
2,240 \text { pounds. }\end{array}$ & $\begin{array}{l}\text { Short tons of } \\
2,000 \text { pounds. }\end{array}$ & value. \\
\hline 1880 & $25,580,189$ & $28,649,811$ & $\$ 42,196,678$ \\
\hline 1881 & $28,500,016$ & $31,920,018$ & $64,125,036$ \\
\hline 1882 & $31,358,264$ & $35,121,256$ & $70,556,094$ \\
\hline $1883 \ldots$ & $34,336,469$ & $38,456,845$ & $77,25 \overline{7}, 055$ \\
\hline $1884 \ldots$ & $33,175,756$ & $37,156,847$ & $66,351,512$ \\
\hline $1885 \ldots$ & $34,228,548$ & $38,335,974$ & $76,671,948$ \\
\hline $1886 \ldots$ & $34,853,077$ & $39,035,446$ & $76,119,120$ \\
\hline $1887 \ldots$ & $37,578,747$ & $42,088,197$ & $84,552,181$. \\
\hline 1888 & $41,624,611$ & $46,619, \tilde{5} 64$ & $89,020,483$ \\
\hline $1889 \ldots$ & $40,665,152$ & $45,544,970$ & $65,721,578$ \\
\hline $1890 \ldots$ & $41,489,858$ & $46,468,641$ & $66,383,772$ \\
\hline $1891 \ldots$ & $45,236,992$ & $50,665,431$ & $73,944,735$ \\
\hline $1892 \ldots$ & $46,850,450$ & $52,472,504$ & $82,442,000$ \\
\hline $1893 .$. & $48,185,306$ & $53,967,543$ & $85,687,078$ \\
\hline $1894 \ldots$ & $46,358,144$ & $51,921,121$ & $78,488,063$ \\
\hline $1895 \ldots$ & $51,785,122$ & $57,999,337$ & $82,019,272$ \\
\hline $1896 \ldots$ & $48,523,287$ & $54,346,081$ & $81,748,651$ \\
\hline 1897:- & $46,974,714$ & $52,611,680$ & $79,301,954$ \\
\hline $1898 \ldots$ & $47,663,076$ & $53,382,644$ & $75,414,537$ \\
\hline 1899 & $53,944,64 i$ & $60,418,005$ & $88,142,130$ \\
\hline
\end{tabular}


Annual production of coal in the Lnited States since 1880-Continued.

\begin{tabular}{|c|c|c|c|}
\hline \multirow{2}{*}{ Year. } & \multicolumn{3}{|c|}{ Total. } \\
\hline & Loug tons. & Short tons. & Value. \\
\hline 1880 & $63,822,830$ & $71,481,569$ & $\$ 95,640,396$ \\
\hline 1881. & $76,865,357$ & $85,881,030$ & $124,349,380$ \\
\hline 1882 & $92,219,454$ & $103,285,789$ & - $\quad 146,632,581$ \\
\hline 1883. & $102,867,969$ & $115,212,125$ & $159,494,855$ \\
\hline 1884 & $106,906,295$ & $119,735,051$ & $143,768,578$ \\
\hline 1885. & $99,069,216$ & $110,957,522$ & $159,019,596$ \\
\hline 1886. & $101,500,024$ & $113,680,027$ & $154,600,176$ \\
\hline $188 T$ & $116,651,974$ & $130,650,211$ & $182,498,737$ \\
\hline 1888. & $132,731,613$ & $148,659,407$ & $190,881,012$ \\
\hline 1889 & $126,097,869$ & $141,229,613$ & $160,226,323$ \\
\hline 1890 & $140,866,931$ & $157,770,963$ & $176,804,573$ \\
\hline 1891 & $150,505,954$ & $168,566,668$ & $191,133,135$ \\
\hline 1892 & $160,115,242$ & $179,329,071$ & $207,566,381$ \\
\hline 1893. & $162,814,977$ & $182,352,774$ & $208,438,696$ \\
\hline 1894. & $152,447,791$ & $170,741,526$ & $186,141,564$ \\
\hline 1895 . & $172,426,366$ & $193,117,530$ & $197,799,043$ \\
\hline 1896. & $171,416,390$ & $191,986,357$ & $196,640,166$ \\
\hline 1897 & $178,769,344$ & $200,221,665$ & $198,869,178$ \\
\hline 1898 & $196,405,953$ & $219,974,667$ & $208,000,850$ \\
\hline 1899. & $226,553,564$ & $253,739,992$ & $256,077,434$ \\
\hline
\end{tabular}

The statistics of production in the separate States for years prior to 1886 are so incomplete that a statement showing them would be largely a matter of guesswork and of no practical value. Since 1886 the statistics have been collected regularly and systematically by the Geological Survey, with the exception of 1889 , when the information was gathered by the Eleventh United States Census. The total amount and value of coal produced in the United States from 1886 to 1899, inclusive, is shown in the following table. The quantities are expressed uniformly in short tons of 2,000 pounds. 
Amount and value of coal produced in the Lnited States, by States and Territories, from 1886 to 1899.

\begin{tabular}{|c|c|c|c|c|}
\hline \multirow{2}{*}{ State or Territory. } & \multicolumn{2}{|c|}{1886.} & \multicolumn{2}{|c|}{1887.} \\
\hline & Produet. & Value. & Product. & Value. \\
\hline & Short tons. & & Short tons. & \\
\hline Alabama ........... & $1,800,000$ & $\$ 2,574,000$ & $1,950,000$ & $\$ 2,535,000$ \\
\hline Arkansas ... & 125,000 & 200,000 & 129,600 & 194,400 \\
\hline California ...... & 100,000 & 300,000 & 50,000 & 150,000 \\
\hline Colorado . . . . . . . . & $\mathbf{1}, 368,338$ & $3,215,594$ & $1,791,735$ & $3,941,817$ \\
\hline Georgia .... & 223,000 & 334,500 & 313,715 & 470,573 \\
\hline Idaho .......... & 1,500 & 6,000 & 500 & 2,000 \\
\hline Illinois . . . . . . . . . . . & $9,246,435$ & $10,263,543$ & $10,278,890$ & $11,152,596$ \\
\hline Indiana ....... & $3,000,000$ & $3,450,000$ & $3,217,711$ & $4,324,604$ \\
\hline Indian Territory ...... & 534,580 & 855,328 & 685,911 & $1,286,692$ \\
\hline Iowa $\ldots . . . . . .$. & $4,315,779$ & $5,391,151$ & $4,473,828$ & $5,991,735$ \\
\hline Kansas .... & $1,400,000$ & $1,680,000$ & $1,596,879$ & $2,235,631$ \\
\hline Kentucky ...... & $1,550,000$ & $1,782,500$ & $1,933,185$ & $2,223,163$ \\
\hline Maryland ...... & $2,517,577$ & $2,391,698$ & $3,278,023$ & $3,114,122$ \\
\hline Michigan ......... & 60,434 & 90,651 & 71,461 & 107,191 \\
\hline 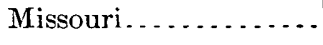 & $1,800,000$ & $2,340,000$ & $3,209,916$ & $4,298,994$ \\
\hline Montana ........ & 49,846 & 174,460 & 10,202 & 35,707 \\
\hline Nebraska....... & $\cdots \ldots \ldots$ & $\ldots \ldots \ldots$ & 1,500 & 3,000 \\
\hline New Mexico.......... & 271,285 & 813,855 & 508,034 & $1,524,102$ \\
\hline North Dakota........ & 25,955 & 41,277 & 21,470 & 32,205 \\
\hline Ohio $\ldots . . . . .$. & $8,435,211$ & $8,013,450$ & $10,301,708$ & $9,096,848$ \\
\hline Oregon $\ldots \ldots \ldots \ldots$ & 45,000 & 112,500 & 31,696 & 70,000 \\
\hline \multicolumn{5}{|l|}{ Pennsylvania: } \\
\hline Anthracite....... & $36,696,475$ & $71,558,126$ & $39,506,255$ & $79,365,244$ \\
\hline Bituminous .... & $27,094,501$ & $21,016,235$ & $31,516,856$ & $27,806,941$ \\
\hline Rhode Island . . . . . & $\ldots \ldots$ & $\ldots \ldots$ & 6,000 & 16,250 \\
\hline Tennessee . - & $1,714,290$ & $1,971,434$ & $1,900,000$ & $2,470,000$ \\
\hline 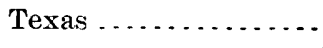 & 100,000 & 185,000 & 75,000 & 150,000 \\
\hline 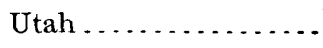 & 200,000 & 420,000 & 180,021 & 360,042 \\
\hline Virginia & 684,951 & 684,951 & 825,263 & 773,360 \\
\hline Washington .......... & 423,525 & 952,931 & 772,612 & $1,699,746$ \\
\hline West Virginia ....... & $4,005,796$ & $3,805,506$ & $4,881,620$ & $4,594,979$ \\
\hline Wyoming ..... & 829,355 & $2,488,065$ & $1,170,318$ & $3,510,954$ \\
\hline Total product sold. & $108,618,833$ & $147,112,755$ & $124,689,909$ & $173,537,896$ \\
\hline Colliery consumption.. & $5,061,194$ & . & $5,960,302$ & $8,960,841$ \\
\hline Total... & 113,$680 ; 027$ & $147,112,755$ & $130,650,211$ & $182,498,737$ \\
\hline
\end{tabular}


COAL.

Amount and value of coal produced in the United States, etc.-Continued.

\begin{tabular}{|c|c|c|c|c|}
\hline \multirow{2}{*}{ State or Territory. } & \multicolumn{2}{|c|}{1888.} & \multicolumn{2}{|c|}{1889.} \\
\hline & Product. & Value. & Product. & Value. \\
\hline & Short tons. & & Short tons. & \\
\hline Alabama & $2,900,000$ & $\$ 3,335,000$ & $3,572,983$ & $\$ 3,961,491$ \\
\hline Arkansas. & 276,871 & 415,306 & 279,584 & 395,836 \\
\hline California & 95,000 & 380,000 & 184,179 & 434,382 \\
\hline Colorado & $2,185,477$ & $4,808,049$ & $2,544,144$ & $3,843,992$ \\
\hline Georgia & 180,000 & 270,000 & 226,156 & 339,382 \\
\hline Idaho .... & 400 & 1,800 & (n........ & ......... \\
\hline Illinois .... & $14,655,188$ & $16,413,811$ & $12,104,272$ & $11,755,203$ \\
\hline Indiana .... & $3,140,979$ & $4,397,370$ & $2,845,057$ & $2,887,852$ \\
\hline Indian Territory & 761,986 & $1,432,072$ & 752,832 & $1,323,807$ \\
\hline Iowa ...... & $4,952,440$ & $6,438,172$ & $4,095,358$ & $5,426,509$ \\
\hline Kansas ........ & $1,850,000$ & $2,775,000$ & $2,221,043$ & $3,297,288$ \\
\hline Kentucky .... & $2,570,000$ & $3,084,000$ & $2,399,755$ & $2,374,339$ \\
\hline Maryland & $3,479,470$ & $3,293,070$ & $2,939,715$ & $2,517,474$ \\
\hline Michigan ... & 81,407 & $.135,221$ & 67,431 & 115,011 \\
\hline Missouri.... & $3,909,967$ & $8,650,800$ & $2,557,823$ & $3,479,057$ \\
\hline Montana ........ & 41,467 & 145,135 & 363,301 & 880,773 \\
\hline Nebraska ... . & 1,500 & 3,375 & 1,500 & 4,500 \\
\hline New Mexico.... & 626,665 & $1,879,995$ & 486,463 & 870,468 \\
\hline North Carolina.. & ….... & $\ldots \ldots \ldots$ & (a) & $\ldots$ \\
\hline North Dakota. & 34,000 & 119,000 & 28,907 & 41,431 \\
\hline Ohio ... & $.10,910,951$ & $10,147,180$ & $9,976,787$ & $9,355,400$ \\
\hline Oregon ...... & 75,000 & 225,000 & (b) & \\
\hline Pennsylvania: & & & & \\
\hline Anthracite. & $43,922,897$ & $85,649,649$ & $c 45,598,487$ & $65,873,514$ \\
\hline Bituminous & $33,796,727$ & $32,106,891$ & $36,174,089$ & $27,953,315$ \\
\hline Rhode Island. & 4,000 & 11,000 & 2,000 & 6,000 \\
\hline Tennessee & $1,967,297$ & $2,164,026$ & $1,925,689$ & $2,338,309$ \\
\hline Texas & 90,000 & 184,500 & 128,216 & 340,620 \\
\hline Utah & 258,961 & 543,818 & 236,651 & 377,456 \\
\hline Virginia & $1,073,000$ & $1,073,000$ & 865,786 & 804,475 \\
\hline Washington & $1,215,750$ & $3,647,250$ & $1,030,578$ & $2,393,238$ \\
\hline West Virginia. . & $5,498,800$ & $6,048,680$ & $6,231,880$ & $5,086,584$ \\
\hline Wyoming & $1,481,540$ & $4,444,620$ & $1,388,947$ & $1,748,617$ \\
\hline Total product sold. & $142,037,740$ & $204,222,790$ & $141,229,613$ & $160,226,323$ \\
\hline Colliery consumption.. & $6,621,667$ & $7,295,834$ & . & \\
\hline Total & $148,659,407$ & $211,518,624$ & $141,229,613$ & $160,226,323$ \\
\hline
\end{tabular}


MINERAL RESOURCES.

Amount and value of coal produced in the United States, elc--Continued.

\begin{tabular}{|c|c|c|c|c|}
\hline \multirow{2}{*}{ State or Territory. } & \multicolumn{2}{|c|}{1890.} & \multicolumn{2}{|c|}{1891.} \\
\hline & Product. & Value. & Product. & Value. \\
\hline & Short tons. & & Short tons. & \\
\hline Alabama . & $4,090,409$ & $\$ 4,202,469$ & $4,759,781$ & $\$ 5,087,596$ \\
\hline Arkansas. & 399,888 & 514,595 & 542,379 & 647,560 \\
\hline California & 110,711 & 283,019 & 93,301 & 204,902 \\
\hline Colorado & $3,094,003$ & $4,344,196$ & $3,512,632$ & $4,800,000$ \\
\hline Georgia & 228,337 & 238,315 & 171,000 & 256,500 \\
\hline Illinois .. & $15,274,727$ & $14,171,230$ & $15,660,698$ & $14,237,074$ \\
\hline Indiana & $3,305,737$ & $3,259,233$ & $2,973,474$ & $3,070,918$ \\
\hline Indian Territory & 869,229 & $1,579,188$ & $1,091,032$ & $1,897,037$ \\
\hline Iowa ...... & $4,021,739$ & $4,995,739$ & $3,825,495$ & $4,807,999$ \\
\hline Kansas .... & $2,259,922$ & $2,947,517$ & $2,716,705$ & $3,557,303$ \\
\hline Kentucky & $2,701,496$ & $2,472,119$ & $2,916,069$ & $2,715,600$ \\
\hline Maryland.. & $3,357,813$ & $2,899,572$ & $3,820,239$ & $3,082,515$ \\
\hline Michigan .. & 74,977 & 149,195 & 80,307 & 133,387 \\
\hline Missouri........ & $2,735,221$ & $3,382,858$ & $2,674,606$ & $3,283,242$ \\
\hline Montana ........ & 517,477 & $1,252,492$ & 541,861 & $1,228,630$ \\
\hline Nebraska......... & 1,500 & 4,500 & 1,500 & 4,500 \\
\hline New Mexico........ & 375,777 & 504,390 & 462,328 & 779,018 \\
\hline North Carolina....... & 10,262 & 17,864 & 20,355 & 39,365 \\
\hline North Dakota..... & 30,000 & 42,000 & 30,000 & 42,000 \\
\hline Ohio .... & $11,494,506$ & $10,783,171$ & $12,868,683$ & $12,106,115$ \\
\hline Oregon .... & 61,514 & 177,875 & 51,826 & 155,478 \\
\hline \multicolumn{5}{|l|}{ Pennsylvania: } \\
\hline Anthracite. & $46,468,641$ & $66,383,772$ & $50,665,431$ & $73,944,735$ \\
\hline Bituminous. & $42,302,173$ & $35,376,916$ & $42,788,490$ & $37,271,053$ \\
\hline Rhode Island & $\ldots$ & 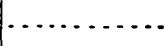 & 500 & 10,000 \\
\hline Tennessee ... & $2,169,585$ & $2,395,746$ & $2,413,678$ & $.2,668,188$ \\
\hline Texas ..... & 184,440 & 465,900 & 172,100 & 412,360 \\
\hline Utah. & $318 ; 159$ & 552,390 & 371,045 & 666,045 \\
\hline Virginia ...... & 784,011 & 589,925 & 736,399 & 611,654 \\
\hline Washington .... & $1,263,689$ & $3,426,590$ & $1,056,249$ & $2,437,270$ \\
\hline West Virginia... & $7,394,654$ & $6,208,128$ & $9,220,665$ & $7,359,816$ \\
\hline Wyoming ......... & $1,870,366$ & $3,183,669$ & $2,327,841$ & $3,555,275$ \\
\hline & $15 \bar{\tau}, 770,963$ & $176,804,573$ & $168,566,669$ & $191,133,135$ \\
\hline
\end{tabular}


Amount and value of coal produced in the Lnited States, etc.-Continued.

\begin{tabular}{|c|c|c|c|c|}
\hline \multirow{2}{*}{ State or Territory. } & \multicolumn{2}{|c|}{1892.} & \multicolumn{2}{|c|}{1893.} \\
\hline & Product. & Value. & Product. & Value. \\
\hline & Short tons. & & Short tons. & \\
\hline Alabama & $5,529,312$ & $\$ 5,788,898$ & $5,136,935$ & $\$ 5,096,792$ \\
\hline Arkansas .. & 535,558 & 666,230 & 574,763 & $773,34 \bar{\imath}$ \\
\hline California & 85,178 & 209,711 & 72,603 & 167,555 \\
\hline Colorado & $3,510,830$ & $5,685,112$ & $4,102,389$ & $5,104,602$ \\
\hline Georgia & 215,498 & 212,761 & 372,740 & 365,972 \\
\hline Illinois ... & $17,862,276$ & $16,243,645$ & $19,949,564$ & $17,827,595$ \\
\hline Indiana & $3,345,174$ & $3,620,582$ & $3,791,851$ & $4,055,372$ \\
\hline Indian Territory & $1,192,721$ & $2,043,479$ & $1,252,110$ & $2,235,209$ \\
\hline Iowa... & $3,918,491$ & $5,175,060$ & $3,972,229$ & $5,110,460$ \\
\hline Kansas. & $3,007,276$ & $3,955,595$ & $2,652,546$ & $3,375,740$ \\
\hline Kentucky. & $3,025,313$ & $2,771,238$ & $3,007,179$ & $2,613,569$ \\
\hline Maryland. & $3,419,962$ & $3,063,580$ & $3,716,041$ & $3,267,317$ \\
\hline Michigan . & 77,990 & 121,314 & 45,979 & 82,462 \\
\hline Missouri.. & $2,733,949$ & $3,369,659$ & $2,897,442$ & $3,562,757$ \\
\hline Montana. & · 564,648 & $1,330,847$ & 892,309 & $1,772,116$ \\
\hline Nebraska. & 1,500 & 4,500 & & . \\
\hline New Mexico .. & 661,330 & $1,074,601$ & 665,094 & 979,044 \\
\hline North Carolina. . & 6,679 & 9,599 & 17,000 & 25,500 \\
\hline North Dakota.. & 40,725 & 39,250 & 49,630 & 56,250 \\
\hline Ohio. & $13,562,927$ & $12,722,745$ & $13,253,646$ & $12 ; 351,139$ \\
\hline Oregon .. & 34,661 & 148,546 & 41,683 & 164,500 \\
\hline \multicolumn{5}{|l|}{ Pennsylvania: } \\
\hline Anthracite. & $52,472,504$ & $82,442,000$ & $53,967,543$ & $85,687,078$ \\
\hline Bituminous. & $46,694,576$ & $39,017,164$ & $44,070,724$ & $35,260,674$ \\
\hline Tennessee & $2,092,064$ & $2,355,441$ & $1,902,258$ & $2,048,449$ \\
\hline Texas. & 245,690 & 569,333 & 302,206 & 688,407 \\
\hline Utah.... & 361,013 & 562,625 & 413,205 & 611,092 \\
\hline Virginia .... . & 675,205 & 578,429 & 820,339 & 692,748 \\
\hline Washington .. & $1,213,427$ & $2,763,547$ & $1,264,877$ & $2,920,876$ \\
\hline West Virginia .. & $9,738,755$ & $7,852,114$ & $10,708,578$ & $8,251,170$ \\
\hline Wyoming .... & $2,503,839$ & $3,168,776$ & $2,439,311$ & $3,290,904$ \\
\hline Total. & $179,329,071$ & $207,566,381$ & $182,352,774$ & $208,438,696$ \\
\hline
\end{tabular}


MINERAL RESOURCES.

Amount and value of coal produced in the United States, etc.-Continued.

\begin{tabular}{|c|c|c|c|c|}
\hline \multirow{2}{*}{ State or Territory. } & \multicolumn{2}{|c|}{1894.} & \multicolumn{2}{|c|}{1895.} \\
\hline & Product. & Value. & Product. & Value. \\
\hline & Short tons. & & Short tons. & \\
\hline Alabama & $4,397,178$ & $\$ 4,085,535$ & $5,693,775$ & $\$ 5,126,822$ \\
\hline Arkansas. & 512,626 & 631,988 & 598,322 & 751,156 \\
\hline California & 67,247 & 155,620 & 75,453 & 175,778 \\
\hline Colorado. & $2,831,409$ & $3,516,340$ & $3,082,982$ & $3,675,185$ \\
\hline Georgia & 354,111 & 299,290 & 260,998 & 215,863 \\
\hline Illinois . & $17,113,576$ & $15,282,111$ & $17,735,864$ & $14,239,157$ \\
\hline Indiana & $3,423,921$ & $3,295,034$ & $3,995,892$ & $3,642,623$ \\
\hline Indian Territory & 969,606 & $1,541,293$ & $1,211,185$ & $1,737,254$ \\
\hline Iowa ....... & $3,967,253$ & $4,997,939$ & $4,156,074$ & $4,982,102$ \\
\hline Kansas . . & $3,388,251$ & $4,178,998$ & $2,926,870$ & $3,481,981$ \\
\hline Kentucky & $3,111,192$ & $2,749,932$ & $3,357,770$ & $2,890,247$ \\
\hline Maryland & $3,501,428$ & $2,687,270$ & $3,915,585$ & $3,160,592$ \\
\hline Michigan & 70,022 & 103,049 & 112,322 & 180,016 \\
\hline Missouri. & $2,245,039$ & $3,634,564$ & $2,372,393$ & $2,651,612$ \\
\hline Montana & 927,395 & $1,887,390$ & 1, 504, 193 & $2,850,906$ \\
\hline Nevada.. & 150 & 475 & $\ldots \ldots \ldots \ldots$ & $\ldots \ldots \ldots$ \\
\hline New Mexico... & 597,196 & 935,857 & 720,654 & $1,072,520$ \\
\hline North Carolina. & 16,900 & 29,675 & 24,900 & 41,350 \\
\hline North Dakota. & 42,015 & 47,049 & a 39,197 & $a 42,046$ \\
\hline Ohio ... & $11,909,856$ & $9,841,723$ & $13,355,806$ & $10,618,477$ \\
\hline Oregon & 47,521 & 183,914 & 73,685 & 247,901 \\
\hline \multicolumn{5}{|l|}{ Pennsylvania: } \\
\hline Anthracite. & $51,921,121$ & $78,488,063$ & $57,999,337$ & $82,019,272$ \\
\hline Bituminous. & $39,912,463$ & $29,479,820$ & $50,217,228$ & $35,980,357$ \\
\hline Tennessee & $2,180,879$ & $2,119,481$ & $2,535,644$ & $2,349,032$ \\
\hline Texas . . & 420,848 & 976,458 & 484,959 & 913,138 \\
\hline Ctah $\ldots$. & 431,550 & 603,479 & 471,836 & 617,349 \\
\hline Virginia .... & $1,229,083$ & 933,576 & $1,368,324$ & 869,873 \\
\hline Washington & $1,106,470$ & $2,578,441$ & ]$, 191,410$ & $2,577,958$ \\
\hline West Virginia & $11,627,757$ & $8,706,808$ & $11,387,961$ & $7,710,575$ \\
\hline W yoming & $2,417,463$ & $3,170,392$ & $2,246,911$ & $2,977,901$ \\
\hline Total. & $170,741,526$ & $186,141,564$ & $193,117,530$ & $197,799,043$ \\
\hline
\end{tabular}

a Includes South Dakota. 
COAL.

Amount and value of coal produced in the United States, etc.-Continued.

\begin{tabular}{|c|c|c|c|c|}
\hline \multirow{2}{*}{ State or Territory. } & \multicolumn{2}{|c|}{1896.} & \multicolumn{2}{|c|}{1897.} \\
\hline & Product. & value. & Product. & value. \\
\hline Alabama & $\begin{array}{l}\text { Short tons. } \\
5,748,697\end{array}$ & $\$ 5,174,135$ & $\begin{array}{l}\text { Short tons. } \\
5,893,770\end{array}$ & $\$ 5,192,085$ \\
\hline Arkansas. & 675,374 & 755,577 & 856,190 & 903,993 \\
\hline California & $a 93,776$ & 220,523 & a 103,912 & 265,236 \\
\hline Colorado... & $3,112,400$ & $3,606,642$ & $3,361,703$ & $3,947,186$ \\
\hline Georgia & $b 246,359$ & 179,770 & $b 217,149$ & 167,466 \\
\hline Idaho. & - $\ldots \ldots$ & $\cdots$ & 645 & 2,150 \\
\hline Illinois . & $19,786,626$ & $15,809,736$ & $20,072,758$ & $14,472,529$ \\
\hline Indiana . . . . . . & $3,905,779$ & $3,261,737$ & $4,151,169$ & $3,472,348$ \\
\hline Indian Territory & $1,366,646$ & $1,918,115$ & $1,336,380$ & $1,787,358$ \\
\hline Iowa......... & $3,954,028$ & $4,628,022$ & $4,611,865$ & $5,219,503$ \\
\hline Kansas...... & $2,884,801$ & $3,295,032$ & $3,054,012$ & $3,602,326$ \\
\hline Kentucky ... & $3,333,478$ & $2,684,306$ & $3,602,097$ & $2,828,329$ \\
\hline Maryland .... & $4,143,936$ & $3,299,928$ & $4,442,128$ & $3,363,996$ \\
\hline Michigan . . & 92,882 & 150,631 & 223,592 & 325,416 \\
\hline Missouri... & $2,331,542$ & $2,518,194$ & $2,665,626$ & $2,887,884$ \\
\hline Montana .... & $1,543,445$ & $2,279,672$ & $1,647,882$ & $2,897,408$ \\
\hline Nebraska.... & $(c)$ & $(c)$ & $(f)$ & $(f)$ \\
\hline New Mexico. & 622,626 & 930,381 & 716,981 & 991,611 \\
\hline North Carolina. . & $(d)$ & $(d)$ & (d). & $(d)$ \\
\hline North Dakota. . & 78,050 & 84,908 & 77,246 & 83,803 \\
\hline Ohio ......... & $12,875,202$ & $10,253,461$ & $12,196,942$ & $9,535,409$ \\
\hline Oregon . . . . . & 101,721 & 294,564 & 101,755 & 313,890 \\
\hline \multicolumn{5}{|l|}{ Pennsylvania:" } \\
\hline Anthracite & $54,346,081$ & $81,748,651$ & $52,611,680$ & $79,301,954$ \\
\hline Bituminous . & $49,557,453$ & $35,368,249$ & $54,417,974$ & $37,463,519$ \\
\hline Tennessee.. & $2,663,106$ & $2,281,295$ & $2,888,849$ & $2,329,534$ \\
\hline Texas ..... & 544,015 & 896,251 & 639,341 & 972,323 \\
\hline Utah. ...... & 418,627 & 500,547 & 521,560 & 618,230 \\
\hline Virginia.... . & $1,254,723$ & 848,851 & $1,528,302$ & $1,021,918$ \\
\hline Washington & $1,195,504$ & $2,396,078$ & $1,434,112$ & $2,777,687$ \\
\hline West Virginia.. & $12,876,296$ & $8,336,685$ & $14,248,159$ & $8,987,393$ \\
\hline Wyoming ....... & $e 2,233,184$ & $2,918,225$ & $2,597,886$ & $3,136,694$ \\
\hline Total. & $191,986,357$ & $196,640,166$. & $200,221,665$ & $198,869,178$ \\
\hline
\end{tabular}


Amount and value of coul produced in the Inited States, etc.-Continued.

\begin{tabular}{|c|c|c|c|c|}
\hline \multirow{2}{*}{ State or Territory. } & \multicolumn{2}{|c|}{1898.} & \multicolumn{2}{|c|}{1899.} \\
\hline & Product. & Value. & Product. & Value. \\
\hline & Short tons. & & Short tons. & \\
\hline Alabama & $6,535,283$ & $\$ 4,932,776$ & $7,593,416$ & $\$ 8,256,462$ \\
\hline Arkansas .. & $1,205,479$ & $1,238,778$ & 843,554 & 989,383 \\
\hline California .. & a 160,288 & 405,915 & 160,972 & 430,636 \\
\hline Colorado .. & $4,076,347$ & $4,686,081$ & $4,776,224$ & $5,363,667$ \\
\hline Georgia & $b 255,682$ & 212,537 & $b 260,007$ & 268,309 \\
\hline Idaho... & 1,039 & 2,675 & 20 & 100 \\
\hline Illinois .. & $18,599,299$ & $14,567,598$ & $24,439,019$ & $20,744,553$ \\
\hline Indiana ... & $4,920,743$ & $3,994,918$ & $6,006,523$ & $5,285,018$ \\
\hline Indian Territory & $1,381,466$ & $1,827,638$ & $1,537,427$ & $2,199,785$ \\
\hline Iowa ... & $4,618,842$ & $5,260,716$ & $5,177,479$ & $6,397,338$ \\
\hline Kansas .... & $3,406,555$ & $3,703,014$ & $3,852,267$ & $4,478,112$ \\
\hline Kentucky ..... & $3,887,908$ & $3,084,551$ & $4,60 \overline{7}, 255$ & $3,618,222$ \\
\hline Maryland .... & $4,674,884$ & $3,532,257$ & $4,807,396$ & $.3,667,056$ \\
\hline Michigan .... & 315,722 & 462,711 & 624,708 & 870,152 \\
\hline Missouri..... & $2,688,321$ & $2,871,296$ & $3,025,814$ & $3,591,945$ \\
\hline Montana ..... & $1,479,803$ & $2,324,207$ & $1,496,451$. & $2,347,757$ \\
\hline New Mexico... & 992,288 & $1,344,750$ & $1,050,714$ & $1,461,865$ \\
\hline North Carolina. & (c) & (c) & (c) & $(c)$ \\
\hline North Dakota.. & 83,895 & 93,591 & 98,809 & 117,500 \\
\hline Ohio ... & $14,516,867$ & $12,027,336$ & $16,500,270$ & $14,361,903$ \\
\hline Oregon .. & 58,184 & 212,184 & 86,888 & 260,917 \\
\hline \multicolumn{5}{|l|}{ Pennsylvania: } \\
\hline Anthracite. & $53,382,644$ & $75,414,537$ & $60,418,005$ & $88,142,130$ \\
\hline Bituminous. & $65,165,133$ & $43,352,588$ & $74,150,175$ & $56,247,791$ \\
\hline Tennessee & $3,022,896$ & $2,337,512$ & $3,330,659$ & $2,940,644$ \\
\hline Texas ... & 686,734 & $1,139,763$ & 883,832 & $1,334,895$ \\
\hline Utah .... & 593,709 & 752,252 & 786,049 & 997,271 \\
\hline Virginia ... & $1,815,274$ & $1,070,417$ & $2,105,791$ & $1,304,241$ \\
\hline Washington . & $1,884,571$ & $3,352,798$ & $2,029,881$ & $3,603,989$ \\
\hline West Virginia. & $16,700,999$ & $10,131,264$ & $19,252,995$ & $12,053,268$ \\
\hline Wyoming ... & $2,863,812$ & $3,664,190$ & $3,837,392$ & $4,742,525$ \\
\hline Total.. & $19,974,667$ & $208,000,850$ & $253,739,992$ & $256,077,434$ \\
\hline
\end{tabular}


COAL.

Amount and value of coal produced in the Lnited States, etc.-Continued.

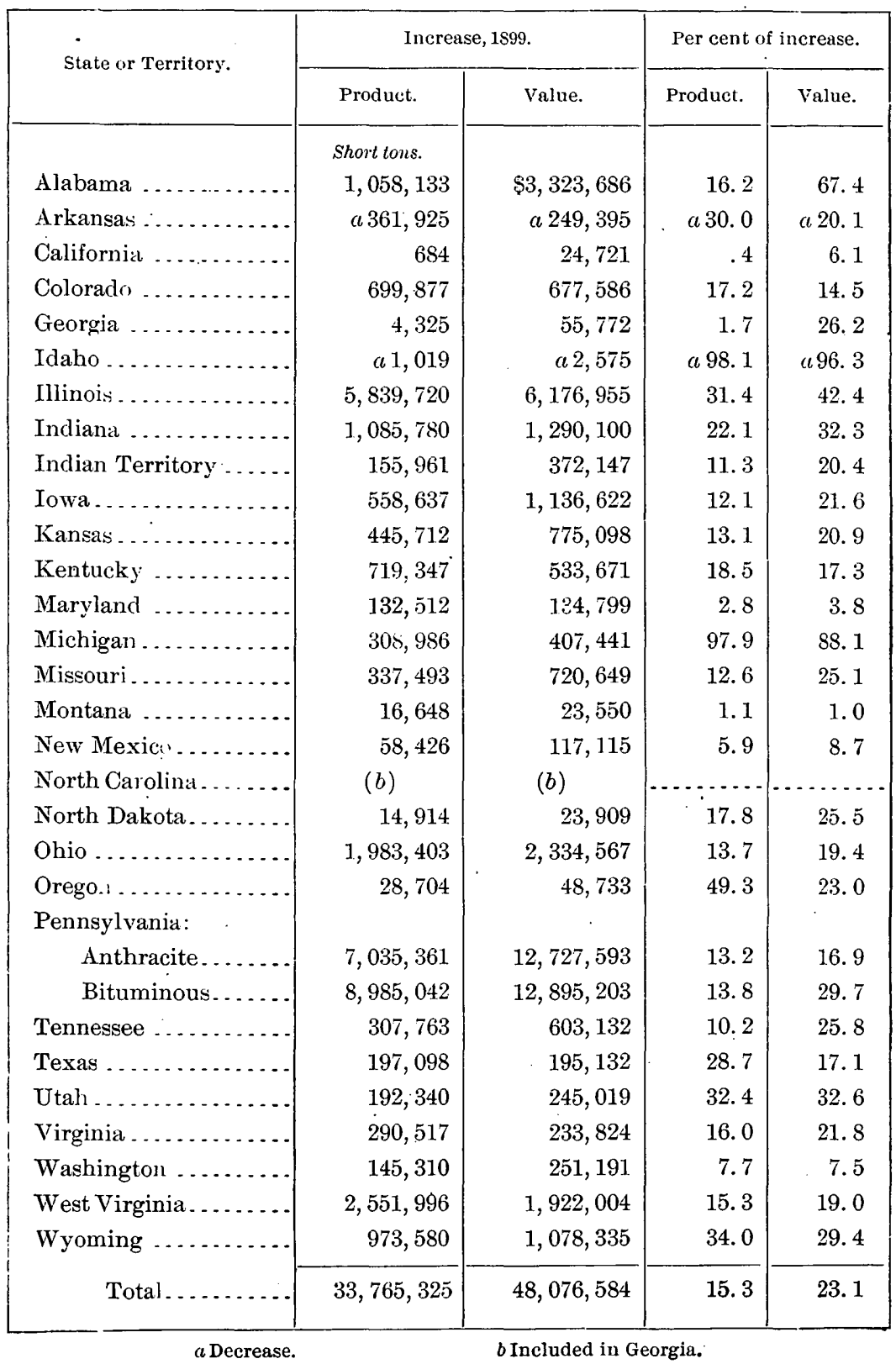


From the foregoing table it is seen that there was only one State of any importance in which the product of 1899 was less than that of the preceding year. Arkansas is the notable exception to the general increased production. The decrease in Arkansas was due to protracted strikes in a number of the largest mines in the State, so that in a year of exceptional activity in coal production Arkansas shows a loss of 30 per cent in output. Idaho shows a decrease of 98 per cent, but of insignificant amount. Alaska's product decreased, and there was also a slight falling off in the production in Georgia, but this latter does not show in the table, as the loss was made up by an increase in North Carolina, whose product is combined with Georgia's. The greatest increase was in the bituminous product of Pennsylvania, a natural result of the enormous production of iron and steel in 1899, as Pittsburg may be said to be the center of the iron industry. ${ }^{1}$ The next largest increase was in Pennsylvania anthracite, which added over $7,000,000$ short tons to its product in 1898. More than one-fourth of the total increase in 1899 was from the bituminous mines of Pennsylvania, while the combined increase of bituminous and anthracite coal in Pennsylvania made up nearly one-half of the total increase in the country. Illinois, the second State in total production, was second also in amount of increase, adding 5,839,720 short tons, or 31.4 per cent, to the product of 1898. Similarly West Virginia and Ohio, third and fourth in rank, were third and fourth, respectively, in amount of increased production. Indiana was fifth and Alabama sixth in point of increased tonnage. The honor of having the largest percentage of increase belongs to Michigan, whose product in 1899 was 97 per cent larger than it was in 1898 . With five exceptions, the product of each State and Territory in 1899 was the largest in its history. The exceptions are Alaska, Arkansas, Idaho, and Georgia, the four States whose product decreased in 1899 as compared with 1898, and Missouri, whose product both in 1887 and 1888 exceeded that of 1899 .

\footnotetext{
${ }^{1}$ It is estimated by Mr. James M. Swank, general manager of the American Iron and Steel Association, that 20,500,000 long tons of coal were used in making pig iron in 1899. The amount consumed in the manufacture of rolled iron and steel added about $10,500,000$ tons and foundry consumption 2,000,000 tons more; so that $33,000,000$ long tons, or about $37,000,000$ short tons, of the 1899 product went directly into the manufacture of iron and steel. In 1898, using the same bases for estimates, the consumption of coal in blast furnaces, rolling mills, and foundries was 28,500,000 long tons, or approximately $32,000,000$ short tons. Allegheny County, Pennsylvania, produced 24 per cent of the total pig-iron product in 1899, 34 per cent of the output of Bessemer steel ingots, 50 per cent of open-hearth steel ingots, nearly 40 per cent of the total steel product, over 26 per cent of the output of steel rails, and 64 per cent of the production of structural shapes.
} 
The distribution of the product for consumption, the value, and the statistics of labor employed for a period of eleven years is shown in the following table:

Production of coal in the United Stales from 1889 to 1899.

\begin{tabular}{|c|c|c|c|c|c|c|c|c|}
\hline Year. & $\begin{array}{l}\text { Number } \\
\text { of mines. }\end{array}$ & \multicolumn{2}{|c|}{$\begin{array}{l}\text { Loaded at mines } \\
\text { for shipment. }\end{array}$} & \multicolumn{2}{|c|}{$\begin{array}{c}\text { Sold to local } \\
\text { trade and used } \\
\text { by employees. }\end{array}$} & \multicolumn{2}{|c|}{$\begin{array}{l}\text { Used at mines } \\
\text { for steam and } \\
\text { heat. }\end{array}$} & $\begin{array}{l}\text { Manufactured } \\
\text { into coke. }\end{array}$ \\
\hline $18 s 9$ & & \multicolumn{2}{|c|}{ Short tons. } & \multicolumn{2}{|c|}{ Short tons. } & \multicolumn{2}{|c|}{ Short tons. } & $\begin{array}{c}\text { Short tons. } \\
13,561,848\end{array}$ \\
\hline 1890. & & \multicolumn{2}{|c|}{$128,383,658$} & \multicolumn{2}{|c|}{$9,009,285$} & \multicolumn{2}{|c|}{$5,063,953$} & $15,331,760$ \\
\hline 1891. & & \multicolumn{2}{|c|}{$92,615,738$} & \multicolumn{2}{|c|}{$7,816,891$} & \multicolumn{2}{|c|}{$1,750,169$} & $15,718,440$ \\
\hline 1892. & & \multicolumn{2}{|c|}{$146,372,098$} & \multicolumn{2}{|c|}{$9,704,678$} & \multicolumn{2}{|c|}{$6,210,767$} & $17,041,528$ \\
\hline 1893. & & \multicolumn{2}{|c|}{$152,941,890$} & \multicolumn{2}{|c|}{$9,728,815$} & \multicolumn{2}{|c|}{$6,712,284$} & $12,969,785$ \\
\hline 1894. & & \multicolumn{2}{|c|}{$142,833,319$} & \multicolumn{2}{|c|}{$8,764,538$} & \multicolumn{2}{|c|}{$6,307,296$} & $12,836,373$ \\
\hline 1895. & 2,904 & \multicolumn{2}{|c|}{$158,380,289$} & \multicolumn{2}{|c|}{$9,655,505$} & \multicolumn{2}{|c|}{$6,677,539$} & $18,404,197$ \\
\hline 1896 & 2,954 & \multicolumn{2}{|c|}{$159,176,155$} & \multicolumn{2}{|c|}{$9,502,927$} & \multicolumn{2}{|c|}{$7,184,832$} & $16,122,443$ \\
\hline 1897. & 2,804 & \multicolumn{2}{|c|}{$165,603,626$} & \multicolumn{2}{|c|}{$9,914,742$} & & 941,419 & $17,761,878$ \\
\hline 1898. & 3,202 & 180 & 60,111 & 8,9 & 914 & & 921,289 & $22,167,353$ \\
\hline 1899. & & 208 & 54,746 & 9,0 &, 556 & & 662,864 & $27,247,826$ \\
\hline Year. & Total pr & oduct. & Total v & alue. & $\begin{array}{l}\text { Avera } \\
\text { price } \\
\text { ton }\end{array}$ & & $\begin{array}{c}\text { Average } \\
\text { number of } \\
\text { days active. }\end{array}$ & $\begin{array}{c}\text { Average } \\
\text { number of em } \\
\text { ployees. }\end{array}$ \\
\hline & Short & & & & & & & \\
\hline 1889 & 141,2 & 9,513 & $\$ 160,22$ & 6,323 & $\$ 1$. & & & \\
\hline 1890. & 157,78 & 8,656 & 176,80 & 4,573 & 1. & & 216 & 318,204 \\
\hline 1891. & 117,90 & 1,238 & 117,18 & 8,400 & & 994 & 223 & 205,803 \\
\hline 1892. & 179,3 & 9,071 & 207,56 & 6,381 & 1. & & 212 & 341,943 \\
\hline $1893 .$. & 182,3 & 2,774 & 208,43 & 8,696 & 1. & & 201 & 363,309 \\
\hline 1894 & 170,7 & 1,526 & 186,14 & 1,564 & 1. & & 178 & 376,206 \\
\hline 1895 . & 193,1 & 7,530 & 197,79 & 9,043 & 1. & & 195 & 382,879 \\
\hline 1896. & $191,9 \varepsilon$ & 6,357 & 196,64 & 0,166 & 1. & & 185 & 386,656 \\
\hline 1897. & 200,2 & 1,665 & 198,86 & 9,178 &. & 99 & 179 & 397,701 \\
\hline 1898. & 219,9 & 4,667 & 208,00 & 0,850 & . & 95 & 190 & 401,221 \\
\hline 1899. & 253,7 & 9,992 & 256,07 & 7,434 & 1. & & 214 & 410,635 \\
\hline
\end{tabular}

RANK OF COAL-PRODUCING STATES.

In the following tables, which extend over a period of three years, the coal-producing States are arranged according to rank, first in amount of production, and then in the value of the product, with the percentage of both amount and value contributed by each State. Pennsylvania, of course, ranks first in both particulars, with. Illinois 
second. West Virginia stands third in amount in all three years, being followed by Ohio. In the value of their products, the rank of these two States is reversed each year, Ohio being third and West Virginia fourth. Alabama was fifth in production in all three year's, but sixth in value except in 1899. These five are the only States that have maintained their relative positions with any kind of regularity. Changes in the standing of each of the other States have occurred nearly every year without, however, exercising much influence on the total or altering materially the percentage contributed by each.

Rank of coal-producing States in 1897, with amount and value of product and percentage of each.

\begin{tabular}{|c|c|c|c|c|c|c|c|}
\hline \multicolumn{8}{|c|}{1597.} \\
\hline \multicolumn{4}{|c|}{ Production. } & \multicolumn{4}{|c|}{ Value. } \\
\hline Rank. & State or Territory. & Amount. & $\begin{array}{c}\text { Per } \\
\text { cent of } \\
\text { total } \\
\text { prod- } \\
\text { uct. }\end{array}$ & Rank. & State or Territory. & Value. & \begin{tabular}{|c} 
Per \\
cent of \\
total \\
value.
\end{tabular} \\
\hline \multirow{3}{*}{1} & Pennsylvania: & Short tons. & \multirow{3}{*}{$\begin{array}{l}26.3 \\
27.2\end{array}$} & \multirow{3}{*}{1} & (Pennsylvania: & \multirow{3}{*}{$\begin{array}{r}\$ 79,301,954 \\
37,463,519\end{array}$} & \multirow{3}{*}{$\begin{array}{l}39.9 \\
\text { J8. } 5\end{array}$} \\
\hline & Anthracite.. & $52,611,680$ & & & \multirow{2}{*}{ Bituminous ..... } & & \\
\hline & Bituminous. & $54,417,974$ & & & & & \\
\hline 2 & Illinois .......... & $20,072,758$ & 10.0 & 2 & Illinois .......... & $14,472,529$ & $\begin{array}{r}18.8 \\
7.3\end{array}$ \\
\hline 3 & West Virginia & $14,248,159$ & 7.1 & 3 & \multirow{3}{*}{ 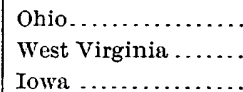 } & $9,535,409$ & 4.8 \\
\hline 4 & Ohio.............. & $12,196,942$ & 6.1 & 4 & & $8,987,393$ & 4.5 \\
\hline 5 & Alabama... & $5,893,770$ & 2.9 & 5 & & $5,219,503$ & 2.6 \\
\hline 6 & Iowa ....... & $4,611,865$ & 2.3 & 6 & Alabama & $5,192,055$ & \multirow{2}{*}{$\begin{array}{l}2.6 \\
2.0\end{array}$} \\
\hline 7 & Maryland & $4,442,128$ & 2.2 & 7 & Colorado & $3,947,186$ & \\
\hline 8 & Indiana ..... & $4,151,169$ & 2.1 & s & Kansas... & $3,602,326$ & 1.8 \\
\hline 9 & Kentucky ..... & $3,602,097$ & 1.8 & 9 & Indiana . & $3,472,348$ & 1.7 \\
\hline 10 & Colorado ...... & $3,361,703$ & 1.7 & 10 & Maryland . & $3,363,996$ & 1.7 \\
\hline 11 & Kansas ..... & $3,054,012$ & 1.5 & 11 & Wyoming & $3,136,694$ & 1.6 \\
\hline 12 & Tennessee..... & $2,888,849$ & 1.5 & 12 & Montann & $2,897,408$ & 1.5 \\
\hline 13 & Missouri......... & $2,665,626$ & 1.3 & 13 & Missouri..... & $2,887,884$ & 1.5 \\
\hline 14 & Wyoming ....... & $2,597,886$ & 1.3 & 14 & Kentucky... & $2,828,329$ & 1.4 \\
\hline 15 & Montana......... & $1,647,882$ & & 15 & Washington .. & $2,777,687$ & 1.4 \\
\hline 16 & Virginia.......... & $1,528,302$ & & 16 & Tennessee...... & $2,329,534$ & 1.2 \\
\hline 17 & Washington ........ & $1,431,112$ & & 17 & Indian Territory. & $1,787,358$ & \\
\hline 18 & Indian Territory .... & $1,336,380$ & & 18 & Virginia........ & $1,021,918$ & \\
\hline 19 & Arkansas.......... & 856,190 & & 19 & New Mexico..... & 991,611 & . \\
\hline 20 & New Mexico....... & 716,981 & & 20 & Texas ........... & 972,323 & \\
\hline 21 & Texas ...... & 639,341 & & 21 & Arkansas....... & 903,993 & \\
\hline 22 & Utah ......... & 521,560 & 4.7 & 22 & Utah ...... & 618,230 & \\
\hline 23 & Michigan..... & 223,592 & & 23 & Michigan .. & 325,416 & 3.7 \\
\hline 24 & Georgia ........... & $a 217,149$ & & 24 & Oregon ...... & 313,890 & \\
\hline 25 & California .... & $b 103,912$ & & 25 & California ........... & $b 265,236$ & \\
\hline 26 & Oregon ......... & 101,755 & & 26 & Georgia............. & $a 167,466$ & \\
\hline 27 & Forth Dakota ... & 77,246 & & 27 & North Dakota... & $\$ 3,803$ & \\
\hline 28 & Idaho ........... & $c 645$ & & 28 & Idaho.......... & $c 2,150$ & \\
\hline 1 & Tot: & $200,221,665$ & 100.0 & & Total. & $198,869,178$ & 100.0 \\
\hline
\end{tabular}


Rank of coul-producing States in 1898, with amound and value of product, and percentage of each.

\begin{tabular}{|c|c|c|c|c|c|c|c|}
\hline \multicolumn{8}{|c|}{$189 \mathrm{~s}}$. \\
\hline \multicolumn{4}{|c|}{ Production. } & \multicolumn{4}{|c|}{ Value. } \\
\hline Rank. & State or Territory. & Amount. & $\begin{array}{c}\text { Per } \\
\text { cent } \\
\text { of total } \\
\text { prod- } \\
\text { uct. }\end{array}$ & Rank. & State or Territory. & Value. & $\begin{array}{c}\text { Per } \\
\text { cent } \\
\text { of total } \\
\text { value. }\end{array}$ \\
\hline \multirow{3}{*}{1} & (Pennsylvania: & Short tons. & & & (Pennsylvania: & & \\
\hline & Anthracite.. & $53,382,644$ & 24.3 & 1. & Anthracite.. & $\$ 75,414,537$ & 36.3 \\
\hline & Bituminous ..... & $65,165,133$ & 29.6 & & Bituminous & $43,352,588$ & 20.8 \\
\hline 2 & 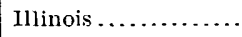 & $18,599,299$ & 8.5 & 2 & Illinois ......... & $14,567,598$ & 7.0 \\
\hline 3 & West Virginiu ...... & $16,700,999$ & 7.6 & 3 & Ohio......... & $12,027,336$ & 5.8 \\
\hline 4 & Ohio............... & $14,516,867$ & 6.6 & 4. & West Virginia .. & $10,131,264$ & 4.9 \\
\hline 5 & Alabama ....... & $6,535,283$ & 3.0 & 5 & Iowa ........ & $5,260,716$ & 2.5 \\
\hline 6 & Indiann ......... & $4,920,743$ & 2.2 & 6 & Alabama ....... & $4,932,776$ & 2.4 \\
\hline$\cdot 7$ & Maryland ..... & $4,674,884$ & 2.1 & $i$ & Colorado .. & $4,686,081$ & 2.2 \\
\hline 8 & Iowa ........... & $4,618,842$ & 2.1 & $s$ & Indiana ..... & $3,994,918$ & 1.9 \\
\hline 9 & Colorado .......... & $4,076,347$ & i.s & 9 & Kansas..... & $3,703,014$ & 1.8 \\
\hline 10 & Kentucky .......... & $3,887,908$ & 1.8 & 10 & Wyoming.... & $3,664,190$ & 1.8 \\
\hline 11 & Kansas ............ & $3,406,555$ & 1.5 & 11 & Märyland ... & $3,532,257$ & 1.7 \\
\hline 12 & Tennessee...... & $3,022,896$ & 1.4 & 12 & Washington ....... & $3,352,798$ & 1.6 \\
\hline 13 & Wyoming ...... & $2,86 \mathrm{~s}, 812$ & 1.3 & 13 & Kentucky... & $3,084,551$ & 1.5 \\
\hline 14 & Missouri......... & $2,688,321$ & 1.2 & 14 & Missouri ..... & $2,871,296$ & 1.4 \\
\hline 15 & Washington ........ & $1,884,571$ & \multirow{14}{*}{5.0} & 15 & Tennessee......... & $2,337,512$ & 1.1 \\
\hline 16 & Virginia........ & $1,815,274$ & & 16 & Montana .......... & $2,324,207$ & 1.1 \\
\hline 17 & Montana. & $1,479,803$ & & 17 & Indian Territory . & $1,827,638$ & \multirow{12}{*}{4.2} \\
\hline 18 & Indian Territory & $1,381,466$ & & 18 & New Mexico........ & $1,344,750$ & \\
\hline 19 & Arkansas ......... & $1,205,479$ & & 19 & Arkansas...... & $1,238,778$ & \\
\hline 20 & New Mexico... & 992,288 & & 20 & Texas ............... & $1,139,763$ & \\
\hline 21 & Texas .... & 686,734 & & 21 & Virginia.......... & $1,070,417$ & \\
\hline 22 & Utah .... & 593,709 & & 22 & Utah ........ & 752,252 & \\
\hline 23 & Michigan. & 315,722 & & 23 & Michigan....... & 462,711 & \\
\hline 24 & Georgia.. & a 255,682 & & 24 & California ....... & b 405,915 & \\
\hline 25 & California & $b 160,288$ & & 25 & Georgia........... & a 212,537 & \\
\hline 26 & North Dakota... & 83,895 & & 26 & Oregon .............. & 212,184 & \\
\hline 27 & Oregon ..... & 58,184 & & 27 & North Dakota. & 93,591 & \\
\hline \multirow[t]{2}{*}{28} & Idaho........... & 1,039 & & 28 & Idaho ...... & 2,675 & \\
\hline & Total . & $219,974,667$ & 100.0 & & Total & $208,000,850$ & 100.0 \\
\hline
\end{tabular}

a Includes North Carolina.

$b$ Includes Alaska.

21 GEOL, PT $6-23$ 
MINERAL RESOURCEŚ.

Rank of coal-producing States in 1899, with amount ard value of product, and percertage of each.

\begin{tabular}{|c|c|c|c|c|c|c|c|}
\hline \multicolumn{8}{|c|}{1899.} \\
\hline \multicolumn{3}{|c|}{ Production. } & 1 & \multicolumn{4}{|c|}{ Value. } \\
\hline Rank. & State or Territory. & Amount. & $\begin{array}{c}\text { Per } \\
\text { cent } \\
\text { of total } \\
\text { prod- } \\
\text { uct. }\end{array}$ & Rank. & State or Territory. & Value. & $\begin{array}{c}\text { Per } \\
\text { cent } \\
\text { of total } \\
\text { value. }\end{array}$ \\
\hline \multirow{3}{*}{1} & (Pennsylvania: & Short tons. & \multirow{3}{*}{$\begin{array}{l}23.8 \\
29.2\end{array}$} & \multirow{3}{*}{1} & \multirow{2}{*}{ Pennsylvania: } & \multirow[b]{2}{*}{$\$ 88,142,130$} & \multirow[b]{2}{*}{34.4} \\
\hline & Anthracite & $60,418,205$ & & & & & \\
\hline & Bituminous & $74,150,175$ & & & Bituminous & $56,247,791$ & 22.0 \\
\hline 2 & Illinois ...... & $24,439,019$ & 9.7 & 2 & Illinois. . & $20,744,553$ & 8.1 \\
\hline 3 & West Virginia & $19,252,995$ & 7.6 & 3 & 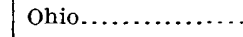 & $14,361,903$ & 5.6 \\
\hline$t$ & Ohio......... & $16,500,270$ & 6.5 & 4 & West Virgir & $12,053,268$ & 4.7 \\
\hline 5 & Alabama.. & $7,593,416$ & 3.0 & 5 & Alabe & $8,256,462$ & 3.2 \\
\hline 6 & Indiana ...... & $6,006,523$ & 2.4 & 6 & Iowa & $6,397,338$ & 2.5 \\
\hline 7 & Iowa ...... & $5,177,479$ & 2.1 & 7 & Colo & $5,363,667$ & 2.1 \\
\hline 8 & Maryland ... & $4,807,396$ & 1.9 & 8 & Indiana & $5,285,018$ & 2.1 \\
\hline 9 & Colorado ... & $4,776,224$ & 1.9 & 9 & Wyor & $4,742,525$ & 1.9 \\
\hline 10 & Kentucky ..... & $4,607,255$ & 1.8 & 10 & Kansas...... & $4,478,112$ & 1.8 \\
\hline 11 & Kansas .... & $3,852,267$ & 1.5 & 11 & Maryland .... & $3,667,056$ & 1.4 \\
\hline 12 & Wyoming... & $3,837,392$ & 1.5 & 12 & Kentucky ........ & $3,618,222$ & 1.4 \\
\hline 13 & Tennessee... & $3,330,659$ & 1.3 & 13 & Washington .. & $3,603,989$ & 1.4 \\
\hline 14 & Missouri ....... & $3,025,814$ & 1.2 & 14 & Missouri.... & $3,591,945$ & 1.4 \\
\hline 15 & Virginia...... & $2,105,791$ & 0.8 & 15 & Tennessee.. & $2,940,644$ & 1.1 \\
\hline 16 & Washington ... & $2,029,881$ & 0.8 & 16 & Montana .......... & $2,347,757$ & 0.9 \\
\hline 17 & Indian Territory & $1,537,427$ & & 17 & Indian Territory & $2,199,785$ & 0.9 \\
\hline 18 & Montana .. & $1,496,451$ & & 18 & New Mexico.... & $1,461,865$ & \\
\hline 19 & New Mexico.. & $1,050,714$ & & 19 & Texas ....... & $1,334,895$ & \\
\hline 20 & Texas ........ & 883,832 & & 20 & Virginia..... & $1,304,241$ & \\
\hline 21 & Arkansas.... & 843,554 & & 21 & Utah $\ldots \ldots$ & 997,271 & \\
\hline 22 & Utah ....... & 786,049 & 3.0 & 22 & Arkansas... & 989,383 & \\
\hline 23 & Michigan. & 624,708 & & 23 & Michigan.... & 870,152 & 3.1 \\
\hline 24 & Georgia...... & a 260,007 & & 24 & California... & $b 430,636$ & \\
\hline 25 & California ....... & $b 160,972$ & & 25 & Georgia...... & $a 268,309$ & \\
\hline 26 & North Dakota... & 98,809 & & 26 & Oregon ...... & 260,917 & \\
\hline 27 & Oregon ......... & 86,885 & & 27 & North Dakota.. & 117,500 & \\
\hline 28 & Idaho..... & 20 & & 28 & Idaho .............. & 100 & \\
\hline & Total & $253,739,992$ & 100.0 & & Total. & $256,077,434$ & 100.0 \\
\hline
\end{tabular}

$a$ Includes North Carolina.

$b$ Includes Alaska. 


\section{IAABOR STATISTICS.}

The following table shows under one head the total number of employees in the coal mines of the United States for a period of ten year's, and the average time made by each:

Slatistics of labor employed in coal mines of the United States since 1890.

\begin{tabular}{|c|c|c|c|c|c|c|}
\hline \multirow[b]{2}{*}{ State or Territory } & \multicolumn{2}{|r|}{1890.} & \multicolumn{2}{|r|}{1891.} & \multicolumn{2}{|r|}{1892.} \\
\hline & $\begin{array}{l}\text { Num- } \\
\text { ber of } \\
\text { days } \\
\text { active. }\end{array}$ & $\begin{array}{c}\text { Average } \\
\text { numberem- } \\
\text { ployed. }\end{array}$ & $\begin{array}{l}\text { Num- } \\
\text { ber of } \\
\text { days } \\
\text { active. }\end{array}$ & $\begin{array}{c}\text { Average } \\
\text { number em- } \\
\text { ployed. }\end{array}$ & $\begin{array}{c}\text { Num- } \\
\text { ber of } \\
\text { days } \\
\text { active. }\end{array}$ & $\begin{array}{c}\text { Average } \\
\text { number em } \\
\text { ployed. }\end{array}$ \\
\hline Alabama ... & 217 & 10,642 & 268 & 9,302 & 271 & 10,075 \\
\hline Arkansas .... & 214 & 938 & 214 & 1,317 & 199 & 1,128 \\
\hline California & 301 & 364 & 222 & 256 & 204 & 187 \\
\hline Colorado ... & 220 & 5,827 & $\ldots$. & 6,000 & 229 & 5,747 \\
\hline Georgia ... & 313 & 425 & 312 & 850 & 277 & 467 \\
\hline Illinois .... & 204 & 28,574 & $215 \frac{1}{2}$ & 32,951 & $219 \frac{1}{2}$ & 34,585 \\
\hline Indiana & 220 & 5,489 & 190 & 5,879 & 224 & 6,436 \\
\hline Indian Territory & 238 & 2,571 & $221 \frac{1}{2}$ & 2,891 & 311 & 3,257 \\
\hline Iowa ....... & 213 & 8,130 & 224 & 8,124 & 236 & 8,170 \\
\hline Kansas ..... & 210 & 4,523 & 222 & 6,201 & $208 \frac{1}{2}$ & 6,559 \\
\hline Kentucky ... & 219 & 5,259 & 225 & 6,355 & 217 & 6,724 \\
\hline Maryland........ & 244 & 3,842 & 244 & 3,891 & 225 & 3,886 \\
\hline Michigan $\ldots . .$. & 229 & 180 & 205 & 223 & 195 & 230 \\
\hline Missouri......... & 229 & 5,971 & 218 & 6,199 & 230 & 5,893 \\
\hline Montana & 218 & 1,251 & $\cdots$ & 1,119 & 258 & 1,158 \\
\hline Nevada....... & ....... & $\ldots$. & & & $\cdots$ & . \\
\hline New Mexico ..... & 192 & 827 & 265 & 806 & 223 & 1,083 \\
\hline North Carolina.... & 200 & 80 & 254 & 80 & 160 & 90 \\
\hline North Dakota... & $\cdots$ & $\cdots$ & $\cdots$ & $\cdots$ & 216 & 54 \\
\hline Ohio .... & 201 & 20,576 & 206 & 22,182 & 212 & 22,576 \\
\hline Oregon ............ & 305 & 208 & 125 & 100 & 120 & 90 \\
\hline $\begin{array}{l}\text { Pennsylvania bitumi- } \\
\text { nous ................... }\end{array}$ & 232 & 61,333 & 223 & 63,661 & 223 & 66,655 \\
\hline Tennessee .... . & 263 & 5,082 & 230 & 5,097 & 240 & 4,926 \\
\hline Texas ....... & 241 & 674 & 225 & 787 & 208 & 871 \\
\hline Utah ........ & 289 & 429 & $\ldots .$. & 621 & 230 & 646 \\
\hline Virginia ....... & 296 & 1,295 & 246 & 820 & 192 & 836 \\
\hline Washington .... & 270 & 2,206 & 211 & 2,447 & 247 & 2,564 \\
\hline West Virginia... & 227 & 12,236 & 237 & 14,227 & 228 & 14,867 \\
\hline Wyoming ...... & 246 & 3,272 & & 3,411 & 225 & 3,133 \\
\hline Total...... & 226 . & 192,204 & $a 223$ & 205,803 & 219 & 212,893 \\
\hline $\begin{array}{l}\text { Pennsylvania anthra- } \\
\text { cite } \ldots . . . \ldots \ldots \ldots \ldots\end{array}$ & 200 & 126,000 & 203 & 126,350 & 198 & 129,050 \\
\hline Grand total & 216 & 318,204 & 215 & 332,153 & 212 & 341,943 \\
\hline
\end{tabular}

$a$ General average obtained from the average days made in the different States, exclusive of Colorado, Montana, Utah, and Wyoming. 
Statistics of lator employed in roal mines of the Lnited States since 1890-Continued.

\begin{tabular}{|c|c|c|c|c|c|c|}
\hline \multirow[b]{2}{*}{ State or Turritory. } & \multicolumn{2}{|r|}{1893.} & \multicolumn{2}{|r|}{1894.} & \multicolumn{2}{|r|}{1895.} \\
\hline & $\begin{array}{c}\text { Num- } \\
\text { ber of } \\
\text { days } \\
\text { active. }\end{array}$ & $\begin{array}{c}\text { Average } \\
\text { number em- } \\
\text { ployed. }\end{array}$ & $\begin{array}{c}\text { Num- } \\
\text { ber of } \\
\text { days } \\
\text { active. }\end{array}$ & $\begin{array}{l}\text { Average } \\
\text { number em- } \\
\text { ployed. }\end{array}$ & $\begin{array}{l}\text { Num. } \\
\text { ber of } \\
\text { days } \\
\text { active. }\end{array}$ & $\begin{array}{l}\text { Avernge } \\
\text { numberem- } \\
\text { ployed. }\end{array}$ \\
\hline Alabama .. & 237 & 11,294 & 238 & 10,859 & 244 & $10,3+6$ \\
\hline Arkansas .... & 151 & 1,559 & 134 & 1,493 & 176 & 1,218 \\
\hline California & 208 & 158 & 232 & 125 & 262 & 190 \\
\hline Colorado ....... & 188 & 7,202 & 155 & 6,507 & 182 & 6,125 \\
\hline Gieorgia ........ & 342 & 736 & 304 & 729 & 312 & $8+8$ \\
\hline Illinois . . . . & 229 & 35,390 & 183 & 38,477 & 182 & $38,6: 30$ \\
\hline Indiana $\ldots . . . .$. & 201 & 7,644 & 149 & 8,603 & 189 & S, 530 \\
\hline Indian Territory . & 171 & 3,446 & 157 & 3,101 & 164 & 3,212 \\
\hline Iowa. & 204 & 8,863 & 170 & 9,995 & 189 & 10,066 \\
\hline Kansas.. & 147 & 7,310 & 164 & 7,339 & 159 & 7,482 \\
\hline Kentucky.. & 202 & 6,581 & 145 & 8,083 & 146 & 7,865 \\
\hline Maryland ..... & 240 & 3,935 & 215 & 3,974 & 248 & 3,912 \\
\hline Michigan ....... & 154 & 162 & 224 & 223 & 186 & 320 \\
\hline Missouri .... & 206 & 7,375 & 138 & 7,523 & 163 & 6,299 \\
\hline Montana $\ldots . . . .$. & 242 & 1,401 & 192 & 1,782 & 223 & 2,184 \\
\hline Nevada... & $\cdots$ & & 60 & 2 & & \\
\hline New Mexico.... & 229 & 1,011 & 182 & 985 & 190 & $1,38: 3$ \\
\hline North Carolina :.. & 80 & 70 & 145 & 95 & 226 & 61 \\
\hline North Daknta... & 193 & 88 & 156 & 77 & 139 & 65 \\
\hline Ohio ............ & 188 & 23,931 & 136 & 27,105 & 176 & 24,644 \\
\hline Oregon $\ldots \ldots \ldots \ldots . . . . . .$. & 192 & 110 & 243 & 88 & 69 & 414 \\
\hline $\begin{array}{l}\text { Pennsylvania bitumi- } \\
\text { nous } \ldots \ldots\end{array}$ & 190 & 71,931 & 165 & 75,010 & 206 & 71,130 \\
\hline Tennessee ....... & 232 & 4,976 & 210 & 5,542 & 224 & 5,120 \\
\hline Texas ........... & 251 & 996 & 283 & 1,062 & 171 & 1,642 \\
\hline Utah . . . . . . . & 226 & 576 & 199 & 671 & 203 & 670 \\
\hline Virginia .......... & 253 & 961 & 234 & 1,635 & 225 & $2,15 \mathrm{~S}$ \\
\hline Washington & 241 & 2,757 & 207 & 2,662 & 224 & 2,840 \\
\hline West Virginia . & 219 & 16,524 & 186 & 17,824 & 195 & 19,159 \\
\hline Wyoming .... & 189 & 3,378 & 190 & 3,032 & 184 & 3,449 \\
\hline Total....... & 204 & 230,365 & 171 & $\stackrel{24}{-4}, 603$ & 194 & 239,962 \\
\hline $\begin{array}{c}\text { Pennsylvania anthra- } \\
\text { cite } . . . . . . . . .\end{array}$ & 197 & 132,944 & 190 & 131,603 & 196 & 142,917 \\
\hline Grand total. & 201 & 363,309 & 178 & 376,206 & 195 & 382,879 \\
\hline
\end{tabular}


COAL.

Statistics of lubor employed in coul mines of the Liniled states since 1890-Continued.

\begin{tabular}{|c|c|c|c|c|c|c|c|c|}
\hline \multirow[b]{2}{*}{ State or Territory. } & \multicolumn{2}{|c|}{1896.} & \multicolumn{2}{|c|}{1897.} & \multicolumn{2}{|c|}{1898.} & \multicolumn{2}{|c|}{1899.} \\
\hline & $\begin{array}{c}\text { Num- } \\
\text { ber of } \\
\text { days } \\
\text { active. }\end{array}$ & $\begin{array}{l}\text { A verage } \\
\text { number } \\
\text { em- } \\
\text { ployed. }\end{array}$ & $\begin{array}{l}\text { Num- } \\
\text { ber of } \\
\text { days } \\
\text { active. }\end{array}$ & $\begin{array}{l}\text { A verage } \\
\text { number } \\
\text { em- } \\
\text { ployed. }\end{array}$ & $\begin{array}{l}\text { Num- } \\
\text { ber of } \\
\text { davs } \\
\text { active. }\end{array}$ & $\begin{array}{l}\text { A verage } \\
\text { number } \\
\text { em- } \\
\text { ployed. }\end{array}$ & $\begin{array}{c}\text { Num- } \\
\text { ber of } \\
\text { days } \\
\text { active. }\end{array}$ & $\begin{array}{c}\text { Average } \\
\text { number } \\
\text { em- } \\
\text { ployed. }\end{array}$ \\
\hline Alabana .. & 248 & 9,894 & 233 & 10,597 & 250 & 10,733 & 238 & 13,481 \\
\hline Arkansas. & 168 & 1,507 & 161 & 1,990 & 163 & 2,555 & 156 & 2,313 \\
\hline California & a.291 & 177 & « 156 & 381 & « 265 & 284 & a. 287 & 369 \\
\hline Colorado & 172 & 6,704 & 180 & 5,852 & 220 & 6,440 & $2+6$ & $\tau, 166$ \\
\hline Georgia & 6301 & 731 & $b 296$ & 520 & b, 292 & 534 & $b 291$ & 637 \\
\hline Idaho... & . & $\ldots . .$. & $c 91$ & 7 & 157 & 7 & $\cdots$ & $\ldots$ \\
\hline Illinois. & $18 t$ & 39,560 & 185 & 33,788 & 175 & 35,026 & 228 & 36,756 \\
\hline Indiana & 163 & 8,806 & 176 & 8,886 & 199 & $S, 971$ & 218 & 9,712 \\
\hline Indian Territor: & 170 & 3,549 & 176 & 3,168 & 198 & 3,216 & 212 & 4,084 \\
\hline Jowa .... & 178 & 9,672 & 201 & 10,703 & 219 & 10,262 & 229 & 10,971 \\
\hline Kansas.. & 168 & 7,127 & 194 & 6,639 & 194 & 7,197 & 226 & 8,000 \\
\hline Kentucky & 165 & 7,549 & 178 & 7,983 & 187 & 7,614 & 224 & 7,461 \\
\hline Marylanel & 204 & 4,039 & 262 & 4,719 & 253 & 4,818 & 275 & 4,624 \\
\hline Michigan . & $15 \pi$ & 320 & 230 & 537 & 245 & 715 & 232 & 1,291 \\
\hline Miss & 168 & $\tilde{5}, 982$ & 191 & 6,414 & 198 & 6,542 & 212 & 7,136 \\
\hline $\begin{array}{l}\text { Montana ... } \\
\text { Nevada.... }\end{array}$ & 234 & 2,335 & 252 & $2,33 \bar{\top}$ & 216 & 2,359 & 238 & 2,378 \\
\hline $\begin{array}{l}\text { New Mexico... } \\
\text { North Carolina. }\end{array}$ & 172 & 1,569 & $20 \mathrm{~s}$ & 1,659 & $2+2$ & 1,873 & $25 \overline{1}$ & $\begin{array}{r}.1,750 \\
\ldots . \ldots\end{array}$ \\
\hline North Dakota. & 166 & 141 & 168 & 170 & 187 & 151 & 154 & 210 \\
\hline Ohio.... & 161 & 25,500 & 148 & 26,410 & 169 & 26,986 & 200 & 26,038 \\
\hline Oregon ....... & 191 & 254 & 171 & 254 & $1+2$ & 199 & 238 & 124 \\
\hline $\begin{array}{c}\text { Pennsylvania } \\
\text { bituminous ... }\end{array}$ & 206 & 72,625 & 205 & $7 \pi, 272$ & 229 & $79,61.1$ & 245 & 82,812 \\
\hline Tennessee. & 211 & 6,531 & 221 & 6,337 & 234 & $6,6+3$ & 252 & 6,949 \\
\hline Texas .... . & 187 & $1,95: 3$ & 220 & 1,766 & 245 & 2,130 & 256 & 2,410 \\
\hline Utah. & 202 & 679 & 204 & 704 & $2+3$ & 739 & 265 & 743 \\
\hline Virginia.. & $19 \mathrm{~s}$ & 2,510 & 213 & $2, \dot{3} 44$ & 230 & 1,855 & 252 & 1,960 \\
\hline Washington & 221 & 2,622 & 236 & 2,739 & 270 & 3,145 & 259 & 3,330 \\
\hline West Virginia & 201 & 19,078 & 205 & 20,504 & 218 & $21 ; 607$ & 242 & 23,625 \\
\hline Wyoming & $: 210$ & 2,937 & 219 & 3,137 & 242 & 3,475 & 261 & 4,697 \\
\hline Total. . & 192 & 244,171 & 196 & 247,817 & 211 & 255,717 & 234 & 271,027 \\
\hline $\begin{array}{r}\text { Pennsylyania } \\
\text { anthracite.... }\end{array}$ & 174 & 148,991 & 150 & 149,884 & 152 & 145,504 & 173 & 139,608 \\
\hline Grand total. & 185 & 393,162 & 179 & 397,701 & 190 & 401,221 & 214 & 410,635 \\
\hline
\end{tabular}




\section{PRICES.}

The following table will be of interest as showing the fluctuations in the average prices ruling in each State since 1886. Prior to that year the statistics were not collected with sufficient accuracy to make a statement of the average prices of any practical value. These averages are obtained by dividing the total value by the total product, except for the years 1886,1887 , and 1888 , when the item of colliery consumption was not considered.

Average prices for coal at the mines since 1886 .

[Per short ton.]

\begin{tabular}{|c|c|c|c|c|c|c|c|}
\hline State or Territory. & 1886. & 1887. & $188 s$. & 1889. & 1890. & 1891. & 1592. \\
\hline Alabama & $\$ 1.43$ & $\$ 1.30$ & $\$ 1.15$ & $\$ 1.11$ & $\$ 1.03$ & $\$ 1.07$ & $\$ 1.05$ \\
\hline Arkansas & 1.60 & 1.68 & 1.50 & 1. 42 & 1. 29 & 1.19 & 1.24 \\
\hline California ... & 3.00 & 3.00 & 4.00 & 2.36 & 2.56 & 2.20 & 2.46 \\
\hline Colorado .. & 2.35 & 2.20 & 2.20 & 1.51 & 1. 40 & 1.37 & 1.62 \\
\hline Georgia & 1.50 & 1.50 & 1.50 & 1.50 & 1.04 & 1.50 & .99 \\
\hline Illinois. & 1. 11 & 1.09 & 1.12 & .97 & .93 & .91 & .91 \\
\hline Indiana ... & 1.15 & 1.34 & 1.40 & 1. 02 & .99 & 1.03 & 1.08 \\
\hline Indian Territory & 1.60 & 1.87 & 1. 88 & 1. 76 & 1. 82 & 1. 74 . & 1.71 \\
\hline Iowa... & 1.25 & 1. 34 & 1.30 & 1.33 & 1.24 & 1. 27 & 1. 32 \\
\hline Kansa: .... & 1.20 & 1. 40 & 1.50 & 1.48 & 1.30 & 1.31 & 1. $31 \frac{1}{2}$ \\
\hline Kentucky .... . & 1.15 & 1.15 & 1.20 & .99 & .92 & .93 & .92 \\
\hline Marylandl ..... & .95 & .95 & .95 & .86 & .86 & .81 & .89 \\
\hline Michigan ....... & 1. 50 & 1.50 & 1. 66 & 1.71 & 1.99 & 1.66 & 1.56 \\
\hline Missouri.... & 1.30 & 1.34 & 2.21 & 1.36 & 1. 24 & 1. 23 & 1.23 \\
\hline Montana ...... & 3.50 & 3.50 & 3.50 & 2.42 & 2.42 & 2.27 & 2. 36 \\
\hline New Mexicn... & 3.00 & 3.00 & 3.00 & 1.79 & 1.34 & 1.68 & 1. 62 \\
\hline North Carolina... & & $\cdots$ & & ....... & 1. 74 & 1.93 & 1.44 \\
\hline North Dakota.. & 1.59 & 1.50 & 3.50 & 1.43 & 1.40 & 1.40 & .96 \\
\hline Ohio .. & .95 & .88 & .93 & .93 & .94 & .94 & .94 \\
\hline Oregon .. & 2.50 & 2.20 & 3.00 & 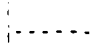 & 2. 89 & 3.00 & 4. 29 \\
\hline Pennsylrania bituminous & .80 & .90 & .95 & .77 & .84 & .87 & .84 \\
\hline Tennessee ... & 1.15 & 1.30 & 1.10 & 1.21 & 1.10 & 1.11 & 1.13 \\
\hline Texas .... & 1.85 & 2. 00 & 2.05 & 2. 66 & 2.53 & 2.40 & 2. 32 \\
\hline Utah & 2.10 & 2. 00 & 2.10 & 1.59 & 1. 74 & 1.80 & 1.56 \\
\hline Virginia. & 1.00 & .94 & 1.00 & .93 & .75 & .83 & .86 \\
\hline Washington & 2.25 & 2.20 & 3.00 & 2.32 & 2. 71 & 2.31 & 2. $2 \mathrm{~S}$ \\
\hline West Virginia. & .94 & .95 & 1.10 & .82 & .84 & .80 & .80 \\
\hline Wyoming .. & 3.00 & 3.00 & 3.00 & 1.26 & 1.70 & 1.53 & 1.27 \\
\hline Total bituminous. . & $a 1.06$ & a1. 12 & $a 1.00$ & 1.00 & .99 & .99 & .99 \\
\hline Pennsylvania anthracite. & $a 1.95$ & $a 2.01$ & $a 1.95$ & 1.44 & 1.43 & 1.46 & 1.57 \\
\hline General average & $a 1.30$ & $a 1.45$ & $a 1.42$ & 1.13 & 1.12 & 1.13 & 1.16 \\
\hline
\end{tabular}

a Exclusive of colliery consumption. 
COAL.

Average prices for coal at the mines since 1886-Continued.

[Per short ton.]

\begin{tabular}{|c|c|c|c|c|c|c|c|}
\hline State or Territory. & 1893. & 1894 & 1895. & 1896. & 1897. & 1898. & 1899. \\
\hline Alabama. & $\$ 0.99$ & $\$ 0.93$ & $\$ 0.90$ & $\$ 0.90$ & $\$ 0.88$ & $\$ 0.75$ & $\$ 1.09$ \\
\hline Arkansas ........... & 1.34 & 1.22 & 1.25 & 1.11 & 1.06 & 1.03 & 1. 17 \\
\hline California .............. & 2.31 & 2.31 & 2. 33 & a2. 35 & $a 2.55$ & $a 2.53$ & $a 2.68$ \\
\hline Colorado ......... & 1. 24 & 1. 24 & 1.20 & 1.16 & 1.17 & 1.15 & 1. 12 \\
\hline Georgia .... & .98 & .85 & .83 & .70 & .72 & .81 & 1.00 \\
\hline Idaho ....... & $\ldots$. & $\ldots .$. & $\cdots$ & $\ldots$ & b3. 33 & 2.57 & 5.00 \\
\hline Illinois . . . . . . . . . . . & .89 & .89 & .80 & .80 & .72 & .78 & .85 \\
\hline Indiana . . . . . & 1.07 & .96 & .91 & .84 & .84 & .81 & .88 \\
\hline Indian Territory ........... & 1. 79 & 1.59 & 1.43 & 1.40 & 1.34 & 1. 32 & 1. 43 \\
\hline 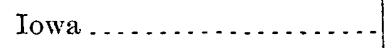 & 1.30 & 1.26 & 1.20 & 1.17 & 1.13 & 1.14 & 1. 24 \\
\hline Kansas ............ & 1.27 & 1. 23 & 1.20 & 1.15 & 1. 18 & 1. 09 & 1. 16 \\
\hline Kentucky ........ & .86 & .88 & .86 & .78 & .79 & .79 & .79 \\
\hline 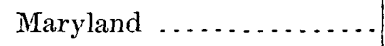 & .88 & .77 & .81 & .80 & .76 & .76 & .76 \\
\hline Michigan .............. & 1.79 & 1.47 & 1.60 & 1.62 & 1. 46 & 1.47 & 1. 39 \\
\hline Missouri ....... & 1. 23 & 1. 17 & 1.12 & 1. 08 & 1.08 & 1.07 & 1. 20 \\
\hline 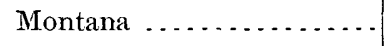 & 1.99 & 2.04 & 1. 89 & 1.47 & 1. 76 & 1.57 & 1.57 \\
\hline Nevada....... & $\cdots$ & 3.15 & & & & & \\
\hline New Mexico ............... & 1.47 & 1.57 & 1. 49 & 1. 49 & 1.38 & 1.35 & 1. 39 \\
\hline North Carolina ........... & 1.50 & 1. 76 & 1. 66 & 1.50 & 1.34 & 1.25 & 1. 30 \\
\hline 'North Dakota............. & 1. 13 & 1.12 & 1.07 & 1.09 & 1.08 & $1: 11$ & 1.19 \\
\hline Ohio & .92 & .83 & .79 & .79 & .78 & .83 & .87 \\
\hline 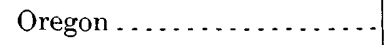 & 3.57 & 3.87 & 3.36 & 2. 90 & 3.09 & 3.65 & 3.00 \\
\hline Pennsylvania bituminous .. & .80 & .74 & .72 & .71 & .69 & .67 & .76 \\
\hline Tennessee .. & 1.08 & .97 & .93 & .86 & .81 & .77 & .88 \\
\hline Texas ...... & 2.28 & 2.32 & 1.88 & 1.65 & 1.52 & 1. 66 & 1.51 \\
\hline Utah . . . . . . . . . . . . & 1. 48 & 1. 40 & 1.31 & 1. 20 & 1.19 & 1.27 & 1. 27 \\
\hline Virginia .... & .84 & .76 & .63 & .68 & .67 & .59 & .62 \\
\hline Washington .......... & 2.31 & 2.33 & 2. 16 & 2.00 & 1.94 & 1.78 & 1. 78 \\
\hline West Virginia $\ldots$. & .77 & .75 & .68 & .65 & .63 & .61 & .63 \\
\hline Wyoming ...... & 1.35 & 1.31 & 1.3 .3 & $b 1.37$ & 1.21 & 1.28 & 1.24 \\
\hline Total bituminous.... & .96 & .91 & .86 & .83 & .81 & .80 & .87 \\
\hline Pennsylvania anthracite... & 1.59 & 1.52 & 1.41 & 1.50 & 1. 51 & 1. 41 & 1. 46 \\
\hline General average. & 1.14 & 1. 09 & 1.02 & 1.02 & .99 & .95 & 1.01 \\
\hline
\end{tabular}

a Includes Alaska

$b$ Includes Nebraska. 


\section{IMPORTS AND EXPORTS.}

The following tables have been compiled from official returns to the Bureau of Statistics of the Treasury Department, and show the imports and exports of coal from 1867 to 1899, inclusive. The values given in both cases are considerably higher than the average "spot" rates by which the values of the domestic production have been computed.

The tariff from 1824 to 1843 was 6 cents per bushel, or $\$ 1.68$ per long ton; from 1843 to $1846, \$ 1.75$ per ton; 1846 to 1857,30 per cent ad valorem; 1857 to 1861,24 per cent ad valorem; 1861 , bituminous and shale, $\$ 1$ per ton; all other, 50 cents per ton; 1862 to 1864 , bituminous and shale, $\$ 1.10$ per ton; all other, 60 cents per ton; 1864 to 1872 , bituminous and shale, $\$ 1.25$ per ton; all other, 40 cents per ton. By the act of 1872 the tariff on bituminous coal and shale was made 75 cents per ton, and so continued until the act of August, 1894, changed it to 40 cents per ton. On slack or culm the tariff was made 40 cents per ton by the act of 1872 ; was changed to 30 cents per ton by the act of Mareh, 1883, and so continued until the act of August, 1894, changed it to 15 cents per ton. The tariff act of 1897 provides that all coals containing less than 92 per cent fixed carbon, and which will pass over a half-inch screen, shall pay a duty of 67 cents per ton. Slack or culm was not changed by the act of 1897. Tons are all 2,240 pounds. Anthracite coal has been free of duty since 1870. During the period from June, 1854, to March, 1866, the reciprocity treaty was in force, and coal from the British possessions in North America was admitted into the United States duty free.

The exports consist both of anthracite and bituminous coal, the amount of bituminous being the greater in the last few years. They are made principally by rail over the international bridges and by lake and sea to the Canadian provinces. Exports are also made by sea to the West Indies, to Central and South America, and elsewhere.

The imports are principally from Australia and British Columbia to San Francisco, from Great Britain to the Atlantic and Pacific coasts, and from Nova Scotia to Atlantic coast points. 
COAL.

Coal imported and entered for consumption in the Lnited States, 1867 to 1899.

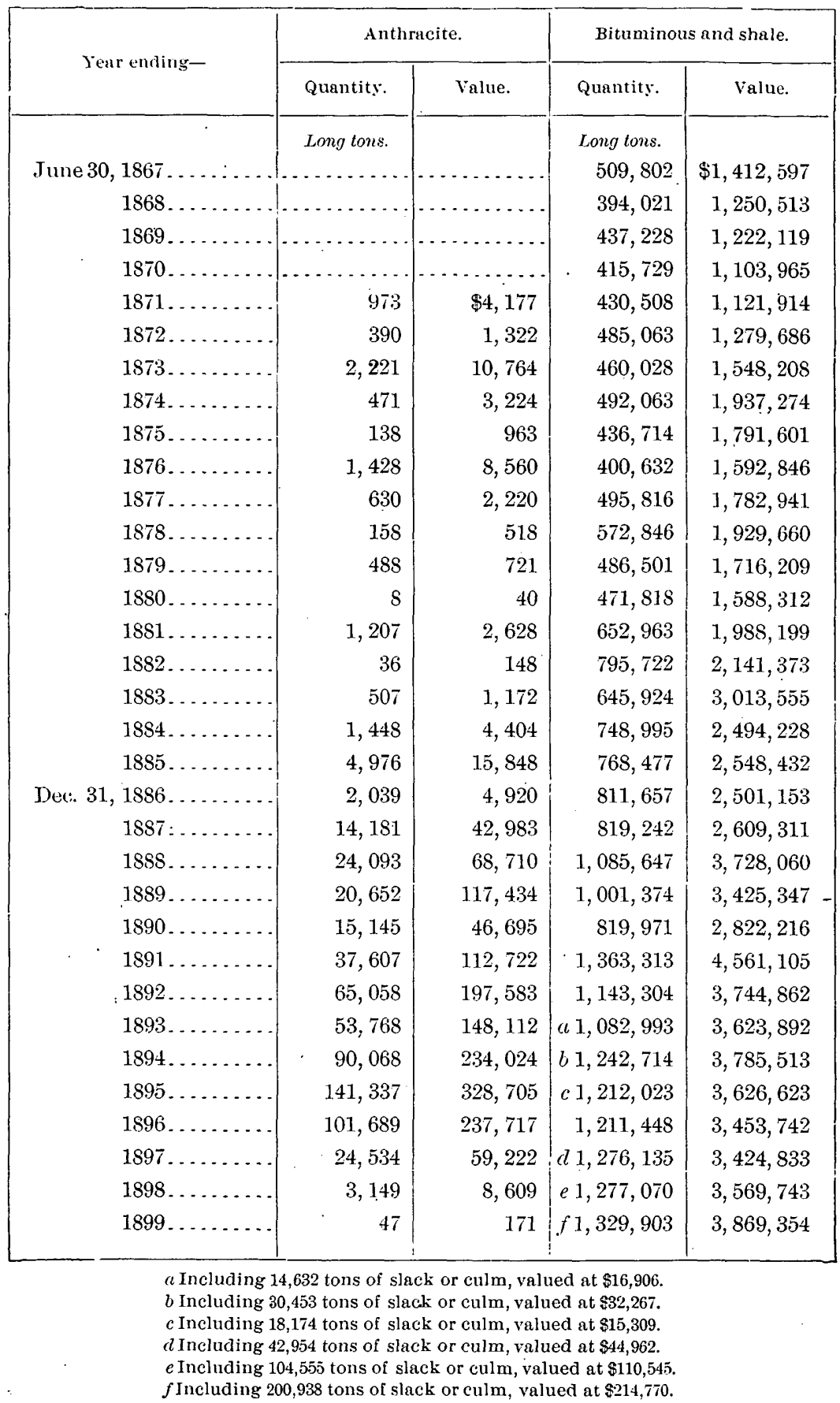


Coal of domestic production exported from the Cnited States, 1867 to 1899.

\begin{tabular}{|c|c|c|c|c|}
\hline \multirow{2}{*}{ Year ending- } & \multicolumn{2}{|c|}{ Anthracite. } & \multicolumn{2}{|c|}{ Bituminous and shale. } \\
\hline & Quantity. & Value. & Quantity. & value. \\
\hline & Long tons. & & Long tons. & \\
\hline June 30,1867 & 192,912 & $\$ 1,333,457$ & 92,189 & $\$ 512,742$ \\
\hline $186 \mathrm{~S}$ & 192,291 & $1,082,745$ & 86,367 & 433,475 \\
\hline $1869 \ldots$ & 283,783 & $1,553,115$ & $\ldots \ldots \ldots$ & $\ldots \ldots$ \\
\hline 1870 & 121,098 & 803,135 & 106,820 & 503,223 \\
\hline 1871 & 134,571 & S05, 169 & 133,380 & 564,067 \\
\hline 1872 & 259,567 & $1,375,342$ & 141,311 & 586,264 \\
\hline 1873. & 342,180 & $1, S 2 \overline{7}, 822$ & 242,453 & $1,086,253$ \\
\hline 1874 & 401,912 & $2,236,084$ & 361,490 & $1,587,666$ \\
\hline 1875. & 316,157 & $1,791,626$ & 203,189 & 828,943 \\
\hline 1876. & 337,934 & $1,869,434$ & 230,144 & 850,711 \\
\hline 1877 & 418,791 & $1,891,351$ & 321,665 & $1,024,711$ \\
\hline 1878 & 319,477 & $1,006,843$ & $3+0,661$ & $1,352,624$ \\
\hline 1879. & 386,916 & $1,427,886$ & 276,000 & 891,512 \\
\hline 1880 & 392,626 & $1,362,901$ & 222,634 & 695,179 \\
\hline 1881. & 462,208 & $2,091,928$ & 191,038 & 739,532 \\
\hline 1882. & 553,742 & $2, \check{5} 89,88 \bar{\imath}$ & 314,320 & $1,102,898$ \\
\hline 1883. & $557,81.3$ & $2,648,033$ & 463,051 & $1,593,214$ \\
\hline $1884 \ldots$ & 649,040 & $3,053,550$ & $6+6,265$ & 1, 977,959 \\
\hline 1885. & 588,461 & $2,586,421$ & 683,481 & $1,989,541$ \\
\hline Dec. $31,1886$. & $66 \overline{7}, 076$ & $2,718,143$ & $5+4,768$ & $1,440,631$ \\
\hline $1887 \ldots$ & 825,486 & $3,469,166$ & 706,364 & $2,001,966$ \\
\hline 1888. & 969,542 & $4,325,126$ & $S 60,462$ & $2,529,472$ \\
\hline 1889. & $85 \bar{i}, 632$ & $3,636,3+i$ & $.935,151$ & $2,783,592$ \\
\hline 1890. & 794,335 & $3,2\rceil 2,69 \bar{\imath}$ & $1,280,930$ & $4,004,995$ \\
\hline $1891 \ldots$ & $861,251$. & $3,577,610$ & $1,615,869$ & $5,104,850$ \\
\hline $1892 .$. & 851,639 & $3,722,903$ & $1,645,869$ & $4,999,289$ \\
\hline 1893. & $1,333,287$ & $6,2+1,00 \bar{\tau}$ & $2,324,591$ & $6,009,801$ \\
\hline $1894 \ldots$ & $1,440,625$ & $6,359,021$ & $2,195,716$ & $4,970,2 \bar{\imath} 0$ \\
\hline $1895 .$. & $1,470,710$ & $5,937,130$ & $2,211,983$ & $4,816,847$ \\
\hline 1896. & $1,350,000$ & $5,925,506$ & $2,276,202$ & $5,072,818$ \\
\hline 1897. & $1,298,768$ & $5,836,730$ & $2,399,263$ & $5,326,761$ \\
\hline 1898. & $1,350,948$ & $5,712,985$ & $3.152,453$ & $6,699,248$ \\
\hline 1899. & $1,707,796$ & $7,140,100$ & $4,044,354$ & $8,573,276$ \\
\hline
\end{tabular}




\section{WORLD'S PRODUCT OF COAL.}

In the following table is given the coal product of the principal countries for the years nearest the one under review for which figures could be obtained. For the sake of convenience the amounts are expressed in the unit of measurement adopted in each country and reduced for comparison to short tons of 2,000 pounds. In each case the year is named for which the product is given:

The world's production of coal.

\begin{tabular}{|c|c|c|}
\hline Country. & $\begin{array}{l}\text { Usual unit in pro- } \\
\text { ducing country. }\end{array}$ & $\begin{array}{l}\text { Equivalent in } \\
\text { short tons. }\end{array}$ \\
\hline United States (1899) ........... long tons. & $226,553,564$ & $253,739,992$ \\
\hline Great Britain (1899) .... & $220,085,303$ & $246,495,539$ \\
\hline Germany $(1899), \ldots \ldots \ldots \ldots$. metric tons.. & $135,824,427$ & $149,719,766$ \\
\hline Austria-Hungary $(1898) \ldots \ldots \ldots$. . . do. & $37,786,963$ & $41,652,569$ \\
\hline 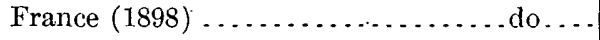 & $32,356,104$ & $35,656,426$ \\
\hline Belgium (1899) ................. do. & $21,917,740$ & $24,159,925$ \\
\hline Russia (1898)..... & $12,862,033$ & $14,173,960$ \\
\hline Canada $(1899) \ldots \ldots$. . . . . . short tons. . & $4,925,051$ & $4,925,051$ \\
\hline Japan $(1897) . . . \ldots \ldots . . . . .$. metric tons.. & $5,647,751$ & $6,225,516$ \\
\hline India $(1898) \ldots \ldots \ldots \ldots \ldots$. long tons.. & $4,203,199$ & $4,707,582$ \\
\hline New South Wales (1899) ........... do. & $4,597,028$ & $\tilde{5}, 148,671$ \\
\hline Spain $(1899) \ldots \ldots \ldots \ldots$. . . . metric tons.. & $2,742,389$ & $3,022,113$ \\
\hline New Zealand $(1898) \ldots \ldots \ldots \ldots$. . long tons... & 906,778 & $1,015,591$ \\
\hline Sweden $(1898) \ldots \ldots \ldots \ldots$. . . metric tons.. & 236,277 & 260,448 \\
\hline Italy (1.898) & 341,327 & 376,245 \\
\hline South African Republic (1898)... .long tóns.. & $1,907,271$ & $2,136,143$ \\
\hline Queensland $(1898) \ldots \ldots \ldots \ldots . . . .$. do. . & 407,819 & 456,757 \\
\hline Victoria (1898) & 245,659 & 275,138 \\
\hline 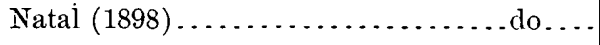 & 387,811 & 434,348 \\
\hline Cape Colony (1898) & 171,301 & 191,857 \\
\hline Tasmania $(1898) \ldots \ldots$. & 44,141 & 49,138 \\
\hline Other countries $(a) \ldots \ldots \ldots$. & $2,000,000$ & $2,240,000$ \\
\hline Total. . & & $797,062,775$ \\
\hline Percentage of the United States. & & 32 \\
\hline
\end{tabular}

$a$ Includes China, Turkey, Servia, Portugal, United States of Colombia, Chile, Borneo and Labua Mexico, Peru, Greece. etc. 
The preceding table shows that the United States has taken first place among the coal-producing countries of the world. Our product in 1899 exceeded that of Great Britain, our only real competitor, by $5,494,632$ long tons. The steps by which the United States has advanced to this position may be seen from the figures presented in the following table, showing the coal production of all the countries of the world since 1868. It is but fair to state that the product given for Great Britain does not include that of any of her colonies. If to the product of Great Britain is added that of Canada, India, New South Wales, New Zealand, etc., the United States would still be in second place. A glance at the succeeding table shows that in 1868 the coal product of Great Britain was 3.6 times that of the United States. In the same year the product of Germany was nearly 15 per cent larger than ours. In 1811 we passed Germany, leading her in that year by about 10 per cent. In 1875 and 1876 the United States fell back to third place, but took second place again in 1877 and continued to gain in comparison with Germany until in 1899 the product of the United States was 69 per cent more than that of her former rival. From 1868 to 1878 the product of the United States had increased from $28,258,000$ long tons to $51,655,000$ long tons. In the same time Great Britain's product had increased from 103,141,157 long tons to $132,612,063$ long tons, so that her tonnage in the latter year was not quite 2.6 times as great as that of the United States. In 1888 the output of the United States had risen to 132,731,613 long tons and that of Great Britain to $169,935,219$ long tons, 1.3 times the product of the United States. ' In 1898 the tonnage of the two countries was, respectively, 196,405,953 and 202,054,516, Great Britain leading the United States by less than 3 per cent. In 1899 the positions held in 1898 were reversed, the United States leading Great Britain by a little less than 3 per cent.

In 1868 the United States contributed 14.35 per cent of the world's coal supply; in $1878,18.17$ per cent; in $1888,28.52$ per cent, and in 1899, 31.83 per cent. 
COAL.

World's production of conl, by countries, since 1 S68.

\begin{tabular}{|c|c|c|c|c|}
\hline \multirow{2}{*}{ Yenr. } & \multicolumn{2}{|c|}{ United States. } & \multicolumn{2}{|c|}{ Great Britain. } \\
\hline & Long tons. & Short tons. & Long tons. & Short tons. \\
\hline $18668 \ldots$ & $28,258,000$ & $31,648,960$ & $103,141,157$ & $115,518,096$ \\
\hline $1869 \ldots$ & $28,268,000$ & $31,660,160$ & $107,427,557$ & $120,318,864$ \\
\hline 1870 & $32,863,000$ & $36,806,560$ & $110,431,192$ & $123,682,935$ \\
\hline 1871. & $41,384,000$ & $46,350,080$ & $117,352,02 \mathrm{~s}$ & $131,434,271$ \\
\hline 1872 & $45,416,000$ & $50,865,920$ & $123,497,316$ & $138,316,994$ \\
\hline 1873. & $51,004,000$ & $57,124,480$ & $128,680,131$ & $144,121,747$ \\
\hline $1874 \ldots$ & $46,916,000$ & $52,545,920$ & $126,590,108$ & $141,780,921$ \\
\hline 1875 & $46,686,000$ & $52,288,320$ & $133,306,485$ & $149,303,263$ \\
\hline 1876 & $47,500,000$ & $53,200,000$ & $134,125,166$ & $150,220,186$ \\
\hline $187 \pi$ & $53,948,000$ & $60,421,760$ & $134,179,968$ & $150,281,564$ \\
\hline 1878. & $51,655,000$ & $57,853,600$ & $132,612,063$ & $148,525,511$ \\
\hline $1879^{\circ}$ & $59,333,000$ & $66,452,960$ & $133,720,393$ & $149,766,840$ \\
\hline 1880. & $63,822,830$ & $71,481,569$ & $146,969,409$ & $164,605,738$ \\
\hline 1881. & $76,865,357$ & $85,881,030$ & $154,184,300$ & $172,686,416$ \\
\hline 1882 . & $92,219,454$ & $103,285,789$ & $156,499,97$ & $175,279,974$ \\
\hline 1883. & $102,867,969$ & $115,212,125$ & $163,737,327$ & $183,385,806$ \\
\hline $18 S 4$ & $106,906,295$ & $119,735,051$ & $160,757,779$ & $180,048,712$ \\
\hline $1885 \ldots$ & $99,069,216$ & $110,957,522$ & $159,351,418$ & $178,473,588$ \\
\hline $1886 \ldots$ & $101,500,024$ & $113,680,027$ & $157,518,482$ & $176,420,700$ \\
\hline $1887 \ldots$ & $116,651,974$ & $130,650,211$ & $162,119,812$ & 181., 574, 189 \\
\hline 1888. & $132,731,613$ & $148,6599,407$ & $169,935,219$ & $190,327,445$ \\
\hline $1889 \ldots$ & $126,097,869$ & $141,229,613$ & $176,916,724$ & $198,146,731$ \\
\hline 1890 & $140,866,931$ & $157,770,963$ & $181,614,288$ & $203,408,003$ \\
\hline $1891 \ldots$ & $150,505,954$ & $168,566,668$ & $185,479,126$ & $207,736,621$ \\
\hline $1892 \ldots$ & $160,115,242$ & $179,329,071$ & $181,786,871$ & $203,601,296$ \\
\hline $1893 \ldots$ & $162,814,977$ & $182,352,774$ & $164,325,795$ & $184,044,890$ \\
\hline $1894 \ldots$ & $152,447,791$ & $170,741,526$ & $188,277,525$ & $210,870,828$ \\
\hline $1895 \ldots$ & $172,426,366$ & $193,117,530$ & $189,661,362$ & $212,320,725$ \\
\hline $1896 \ldots$ & $171,416,390$ & $191,986,357$ & $195,361,260$ & $218,804,611$ \\
\hline $1897 \ldots \ldots$ & $178,769,344$ & $200,221,665$ & $202,129,931$ & $226,385,523$ \\
\hline 189S. & $196,405,953$ & $219,9 \overline{7} 4,667$ & $202,054,516$ & $226,301,058$ \\
\hline $1899 \ldots$ & $226,553,564$ & 253, 739, 992 & $220,085,303$ & $246,495,539$ \\
\hline
\end{tabular}


World's production of coal, by countries, since 1868-Continued.

\begin{tabular}{|c|c|c|c|c|}
\hline \multirow{2}{*}{ Year. } & \multicolumn{2}{|c|}{ Germany. } & \multicolumn{2}{|c|}{ Austria-Hungary. } \\
\hline & Netric tons. & Short tons. & Metric tons. & Short tons. \\
\hline 1868 & $32,879,123$ & $36,249,233$ & $7,021,756$ & $7,741,486$ \\
\hline 1869 & $34,343,913$ & $37,864,164$ & $7,663,043$ & $8,448,505$ \\
\hline 1870. & $34,003,004$ & $37,488,312$ & $8,355,945$ & $9,212,429$ \\
\hline 1871 & $37,856,110$ & $41,736,361$ & $8,437,401$ & $9,302,235$ \\
\hline 1872. & $42,324,467$ & $46,662,725$ & $8,825,896$ & $9,730,550$ \\
\hline 1873. & $46,145,194$ & $50,875,076$ & $10,104,769$ & $11,140,508$ \\
\hline 1874. & $46,658,145$ & $51,440,605$ & $12,631,364$ & $13,926,079$ \\
\hline 1875 . & $47,804,054$ & $52,703,970$ & $13,062,738$ & $14,395,137$ \\
\hline 1876. & $49,550,461$ & $54,629,383$ & $13,000,000$ & $14,327,300$ \\
\hline 1877. & $48,229,882$ & $53,173,445$ & $13,500,000$ & $14,883,750$ \\
\hline 1878 & $50,519,899$ & $55,698,188$ & $13,900,000$ & $15,324,750$ \\
\hline 1879 & $53,470,716$ & $58,951,464$. & $14,500,000$ & $15,986,250$ \\
\hline 1880 & $59,118,035$ & $65,177,634$ & $14,800,000$ & $16,317,000$ \\
\hline 1881. & $61,540,485$ & $67,848,385$ & $15,304,813$ & $16,873,556$ \\
\hline 1882. & $65,378,211$ & $72,079,478$ & $15,555,292$ & $17,149,709$ \\
\hline 1883. & $70,442,648$ & $77,663,019$ & $17,047,961$ & $18,795,377$ \\
\hline 1884 & $72,113,820$ & $79,505,487$ & $18,000,000$ & $19,845,000$ \\
\hline 1885 & $73,675,515$ & $81,227,255$ & $20,435,463$ & $22,530,098$ \\
\hline 1886 & $73,682,584$ & $81,235,049$ & $20,779,441$ & $22,909,334$ \\
\hline 1887 & $76,232,618$ & $84,046,461$ & $21,879,172$ & $24,121,787$ \\
\hline 1888. & $81,960,083$ & $90,360,992$ & $23,859,608$ & $26,305,218$ \\
\hline 1889 & $84,973,230$ & $93,640,500$ & $25,328,417$ & $27,924,580$ \\
\hline 1890 & $89,290,834$ & $98,398,500$ & $27,504,032$ & $30,323,195$ \\
\hline $1891 \ldots$ & $94,252,278$ & $103,913,136$ & $28,823,240$ & $31,777,622$ \\
\hline 1892 & $92,544,050$ & $102,029,815$ & $29,037,978$ & $32,014,371$ \\
\hline 1893 & $95,426,153$ & $105,207,334$ & $30,449,304$ & $33,570,358$ \\
\hline 1894 & $98,805,702$ & $108,883,884$ & $31,492,000$ & $34,704,184$ \\
\hline 1895. & $103,957,639$ & $114,561,318$ & $32,654,777$ & $35,985,564$ \\
\hline 1896 & $112,471,106$ & $123,943,159$ & $33,676,411$ & $37,111,405$ \\
\hline 1897 & $120,474,485$ & $132,762,882$ & $35,858,000$ & $39,515,516$ \\
\hline 1898 & $130,928,490$ & $144,283,196$ & $37,786,963$ & $41,652,569$ \\
\hline $1899^{\circ}$ & $135,824,427$ & $149,719,766$ & & $(a)$ \\
\hline
\end{tabular}

a Latest available figures are used in making up totals. 
COAL.

World's procluction of coal, by countries, since 1868-Continued.

\begin{tabular}{|c|c|c|c|c|}
\hline \multirow{2}{*}{ Year. } & \multicolumn{2}{|c|}{ France. } & \multicolumn{2}{|c|}{ Belgium. } \\
\hline & Métric tons. & Short tons. & Metric tons. & Short tons. \\
\hline 1868. & $13,330,826$ & $14,69 \bar{\gamma}, 236$ & $12,298,589$ & $13,559,194$ \\
\hline 1869. & $13,509,745$ & $14,894,494$ & $12,943,994$ & $14,270,753$ \\
\hline 1870 & $13,179,788$ & $14,530,716$ & $13,697,118$ & $15,101,073$ \\
\hline 1871 & $13,240,135$ & $14,597,249$ & $13,733,176$ & $15,140,827$ \\
\hline 1872. & $16,100,773$ & $17,751,102$ & $15,658,948$ & $17,263,990$ \\
\hline 1873. & $17,479,341$ & $19,270,973$ & $15,778,401$ & $17,395,687$ \\
\hline 1874 & $16,90 \bar{\tau}, 913$ & $18,640,974$ & $14,669,029$ & $16,172,604$ \\
\hline 1875 . & $16,956,840$ & $18,694,916$ & $15,011,331$ & $16,549,992$ \\
\hline 1876. & $1 \overline{7}, 101,448$ & $18,854,346$ & $14,329,578$ & $15,798,360$ \\
\hline 1877. & $16,804,529$ & $18,526,993$ & $13,669,077$ & $15,070,157$ \\
\hline 1878. & $16,960,916$ & $18,699,410$ & $14,899,175$ & $16,426,340$ \\
\hline 1879. & $17,110,979$ & $18,864,854$ & $15,447,292$ & $17,030,640$ \\
\hline 1880. & $19,361,564$ & $21,346,124$ & $16,886,698$ & $18,617,585$ \\
\hline 1881. & $19,765,983$ & $21,791,996$ & $16,873,951$ & $18,603,531$ \\
\hline 1882. & $20,603,704$ & $22,715,584$ & $17,590,989$ & $19,394,065$ \\
\hline 1883. & $21,333,884$ & $23,520,607$ & $18,177,754$ & $20,040,974$ \\
\hline 1884. & $20,023,514$ & $22,075,924$ & $18,051,499$ & $19,901,778$ \\
\hline 1885. & $19,510,530$ & $21,510,359$ & $17,437,603$ & $19,224,957$ \\
\hline 1886. & $19,909,894$ & $21,950,658$ & $17,285,543$ & $19,057,311$ \\
\hline 1887. & $21,287,589$ & $23,469,567$ & $18,378,624$ & $20,262,433$ \\
\hline 1888. & $22,602,894$ & $24,919,691$ & $19,218,481$ & $21,188,375$ \\
\hline 1889 & $24,303,509$ & $26,794,619$ & $19,869,980$ & $21,906,653$ \\
\hline 1890 . & $26,083,118$ & $28,756,638$ & $20,365,960$ & $22,453,471$ \\
\hline 1891 & $26,024,893$ & $28,692,444$ & $19,675,644$ & $21,692,398$ \\
\hline 1892 & $26,178,701$ & $28,862,018$ & $19,583,173$ & $21,590,448$ \\
\hline 1893. & $25,650,981$ & $28,280,207$ & $19,410,519$ & $21,400,097$ \\
\hline 1894. & $27,459,137$ & $30,273,699$ & $20,458,827$ & $22,555,857$ \\
\hline 1895 & $28,019,893$ & $30,877,922$ & $20,450,604$ & $22,536,566$ \\
\hline 1896. & $29,189,900$ & $32,167,270$ & $21,252,370$ & $23,420,112$ \\
\hline 1897 & $30,797,629$ & $33,938,987$ & $21,534,629$ & $23,731,161$ \\
\hline 1898. & $32,356,104$ & $35,656,426$ & $22,075,093$ & $24,326,752$ \\
\hline 1899. & & $(a)$ & $21,917,740$ & $24,159,925$ \\
\hline
\end{tabular}

a Latest available figures are used in making up totals. 
MINERAL RESOURCES.

World's produclion of coal, by countries, since 1S6S-Continued.

\begin{tabular}{|c|c|c|c|c|}
\hline \multirow{2}{*}{ Year. } & \multicolumn{2}{|c|}{ Russia. } & \multicolumn{2}{|c|}{ Japan. } \\
\hline & Metric tons. & Short tons. & Metrie tons: & Short tons. \\
\hline 1868. & & & & \\
\hline 1869. & & & & \\
\hline 1870 & 696,673 & 768,082 & & \\
\hline 1871. & & & & \\
\hline 1872. & & & & \\
\hline 1873. & & & & \\
\hline 1874 & $\ldots \ldots \ldots$ & $\ldots \ldots \ldots$ & & \\
\hline 1875 & $1,709,718$ & $1,884,964$ & & \\
\hline 1876 & & & & \\
\hline $1 S 7 \bar{i}$. & 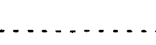 & & & \\
\hline 1878. & $2,483,575$ & $2,738,1+1$ & & \\
\hline 1879 & $2,874,790$ & $3,169,456$ & & \\
\hline $1880 \ldots$ & $3,238,470$ & $3,57 \mathrm{C}, 413$ & & \\
\hline $1881 \ldots$ & $3,439,787$ & $3,792,365$ & & \\
\hline $1882 \ldots$ & $3,672,782$ & $4,049,242$ & & \\
\hline 1883. & $3,916,105$ & $4,317,506$ & $1,021,000$ & $1,125,142$ \\
\hline 1884. & $3,869,689$ & $4,266,332$ & $1,159,000$ & $1,277,218$ \\
\hline $1885 \ldots$ & $4,207,905$ & $4,639,215$ & $1,314,000$ & $1,448,02 \mathrm{~S}$ \\
\hline 1886. & $4,506,027$ & $4,967,895$ & $1,402,000$ & $1,545,004$ \\
\hline 1887. & $4,464,174$ & $4,921,752$ & $1,785,000$ & $1,967,070$ \\
\hline 1885. & $5,187,312$ & $5,719,011$ & $2,044,000$ & $2,25 \cdot 2,488$ \\
\hline 1889. & $6,215,577$ & $6,852,674$ & $2,435,000$ & $2,683,370$ \\
\hline 1890 & $6,016,525$ & $6,633,219$ & $2,6553,000$ & $2,923,606$ \\
\hline 1891 & $6,233,020$ & $6,871,905$ & $3,230,000$ & $3,559,460$ \\
\hline 1892. & $6,816,323$ & $\tau, 514,996$ & $3,228,000$ & $3,557,256$ \\
\hline 1893 & $7,535,000$ & $8,307,337$ & $3,350,000$ & $3,691,700$ \\
\hline 1894 & $8,629,000$ & $9,509,158$ & $4,311,000$ & $4,750,722$ \\
\hline 1895 & $9,079,138$ & $10,005,210$ & $4,849,000$ & $5,343,598$ \\
\hline $1896=$ & $9,229,000$ & $10,170,358$ & $5,019,690$ & $5,531,698$ \\
\hline 1897. & $11,207,475$ & $12,350,63 \mathrm{~S}$ & $5,647,751$ & $6,225,516$ \\
\hline $189 S$ & $12, \$ 62,033$ & $14,173,960$ & & (a) \\
\hline 1899. & & (a) & & (a) \\
\hline
\end{tabular}

a Latest available figures ure used in making up totals. 
World's production of coal, by countries, since 1868-Continued.

\begin{tabular}{|c|c|c|c|}
\hline Year. & Other countries. & $\frac{\text { Total. }}{\text { Short tons. }}$ & $\begin{array}{l}\text { Per cent of } \\
\text { United Strtes. }\end{array}$ \\
\hline $1868 \ldots \ldots$ & $1,1+\frac{1}{7}, 330$ & $220,561,535$ & 14.35 \\
\hline $1869 \ldots \ldots \ldots \ldots \ldots$ & $1,104,563$ & $228,561,503$ & 13.85 \\
\hline $1870 \ldots \ldots \ldots \ldots \ldots \ldots$ & $1,063,121$ & $238,653,228$ & 15.42 \\
\hline $1871 \ldots \ldots \ldots$ & $1,114,248$ & $259,675,271$ & 17.85 \\
\hline $1872 \ldots \ldots \ldots \ldots \ldots$ & $1,268,115$ & $281,859,396$ & 18.05 \\
\hline $1873 \ldots \ldots \ldots \ldots \ldots \ldots$ & $1,502,516$ & $301,430,987$ & 18.95 \\
\hline $1874 \ldots \ldots \ldots \ldots \ldots$ & $2,708,756$ & $297,215,859$ & 17.68 \\
\hline $1875 \ldots \ldots \ldots \ldots \ldots$ & $2,639,104$ & $308,459,666$ & 16.95 \\
\hline $1876 \ldots \ldots \ldots \ldots \ldots \ldots$ & $2,597,143$ & $309,626,718$ & 17.18 \\
\hline $1877 \ldots \ldots \ldots \ldots$ & $2,821,155$ & $315,178,824$ & 19.17 \\
\hline$\ldots \ldots \ldots$ & $3,176,050$ & $318,441,990$ & 18.17 \\
\hline $1879 \ldots \ldots \ldots \ldots \ldots \ldots \ldots$ & $3,362,605$ & $333,585,069$ & 19. 92 \\
\hline $1880 \ldots \ldots \ldots \ldots \ldots \ldots$ & $3,621,342$ & $364,737,405$ & 19.60 \\
\hline $1881 \ldots \ldots \ldots \ldots \ldots \ldots$ & $5,185,974$ & $392,663,253$ & 21.87 \\
\hline $1882 \ldots \ldots \ldots \ldots \ldots \ldots \ldots$ & $6,128,631$ & $420,082,472$ & 24.58 . \\
\hline $1883 \ldots \ldots \ldots \ldots \ldots \ldots \ldots$ & $6,929,841$ & $450,990,397$ & $\dot{25} .505$ \\
\hline $1884 \ldots . . . . .$. & $\bar{\tau}, 36 \bar{\tau}, 309$ & $454,022,811$ & 26.37 \\
\hline $1885 \ldots . . . .$. & $\overline{7}, 570,507$ & $44 \bar{\gamma}, 581,529$ & 24.79 \\
\hline $1886 \ldots \ldots \ldots$ & $9,082,815$ & $450,848,791$ & 25.22 \\
\hline $188 \overline{7} \ldots \ldots \ldots$ & a $10,399,273$ & $481,362,743$ & 27.14 \\
\hline $1888 \ldots \ldots \ldots \ldots \ldots$ & $11,493,176$ & $521,225,803$ & 28.52 \\
\hline 1889 & $12,618,299$ & $531,797,039$ & 26.56 \\
\hline 1890. & $13,025,637$ & $563,693,232$ & 27.99 \\
\hline $1891 \ldots$ & $14,744,329$ & $587,554,583$ & 28.69 \\
\hline $1892 \ldots \ldots . . . .$. & $14,998,633$ & $593,49 \bar{\jmath}, 904$ & $30.2 \cdot 2$ \\
\hline $1893 \ldots \ldots . .$. & $15,783,599$ & $5 s 2,638,296$ & 31.30 \\
\hline $1894 \ldots \ldots \ldots \ldots \ldots \ldots \ldots . . . \ldots \ldots$ & $b 18,197,510$ & $610,487,368$ & 27.97 \\
\hline $1895 \ldots \ldots$ & (. $19,428,643$ & $644,177,076$ & 29.98 \\
\hline $1896 \ldots \ldots \ldots \ldots$. & (l2 $20,866,748$ & $664,001,718$ & 28.92 \\
\hline $1897 \ldots$ & $e 22,074,093$ & $696,512,163$ & 28.75 \\
\hline $1898 \ldots \ldots \ldots \ldots \ldots \ldots$ & $f 24,797,873$ & $f 737,392,017$ & 29.90 \\
\hline $1899 \ldots \ldots \ldots \ldots \ldots \ldots \ldots$ & y $25,239,082$ & $9797,062,775$ & 31.83 \\
\hline
\end{tabular}

a From 1887 to 1893 , inclusive, the total includes, in addition to the countries named on the following pages, the estimated output of countries not specified. The amounts added for this factor each year .

$b$ This includes, in addition to the countries named on the following pages, the output of Natal 169,702 tons; Cape Colony, 78,053 tons; Tasmania, 34,633 tons; China, Turkey, Servia, Portugal, etc.

$c$ This includes, in addition to the countries named on the following pages, the output of Natal, 172,425 tons; Cape Colony, 98,543 tons; Tasmania, 41,279 tons; China, Turkey, Servia, Portugal, etc,

dThis includes, in addition to the countries named on the following pages, the output of Natal, 241,920 tons; Cape Colony, 117,969 tons; Tasmania, 40,615 tons; China, Turkey, Servia, Portugal, etc. (estimated), 2,240,000 tons. Total, 2,640,504 tons. 273,235 includes, in addion to the countries. named on the following pages, the output of Natal, (estimated), $2,240,000$ tons. Total, $2,693,023$ tons.

$f$ This includes, in addition to the countries named on the following pages, the output of Yatal, 434,348 tons; Cape Colony, 191,857 tons; Tasmania, 49,13S tons; China, Turkey, Servia, Portugal, etc. (estimated), 2,240,000 tons. Total, 2,915,343 tons.

$g$ Latest available figures are used in making up total.

21 GEOL, PT $6-2 t$ 
Product of minor coal-producing countries since 1868 .

\begin{tabular}{|c|c|c|c|c|}
\hline \multirow{2}{*}{ Year. } & \multicolumn{2}{|c|}{ New South Wales. } & \multicolumn{2}{|c|}{ Queensland. } \\
\hline & Long tons. & Short tons. & Long tons. & Short tons. \\
\hline $1868 \ldots$ & 954,231 & $1,068,739$ & 19,611 & $21,96+$ \\
\hline 1869 & 919,774 & $1,030,147$ & 11,120 & $12,45 t$ \\
\hline $1870 \ldots$ & 868,564 & 972,791 & 22,639 & 25,356 \\
\hline $1871 \ldots$ & 898,784 & $1,006,638$ & 17,000 & 19,040 \\
\hline $1872 \ldots$ & $1,012,426$ & $1,133,917$ & 27,727 & 31,054 \\
\hline $1873 .$. & $1,192,862$ & $1,336,005$ & 33,613 & 37,647 \\
\hline $1874 \ldots$ & $1,304, \dot{5} 67$ & $1,461,115$ & 43,443 & 48,656 \\
\hline $1875 \ldots$ & $1,329,729$ & $1,489,296$ & $32,1.07$ & 35,960 \\
\hline $1876 \ldots$ & $1,319,918$ & $1,478,308$ & 50,627 & 56,702 \\
\hline $1877 \ldots$ & $1,444,271$ & $1,617,584$ & 60,918 & 68,228 \\
\hline 1878 & $1,575,497$ & $1,764,556$ & 52,580 & 58,890 \\
\hline $1879 \ldots$ & $1,583,381$ & $1,773,387$ & 55,012 & 61,613 \\
\hline $1880 \ldots$ & $1,466,180$ & $1,642,122$ & 58,052 & 65,018 \\
\hline $1881 \ldots$ & $1,769,597$ & $1,981,949$ & 65,612 & 73,485 \\
\hline $1882 \ldots$ & $2,109,282$ & $2,362,396$ & 74,436 & 83,368 \\
\hline $1883 \ldots$ & $2,521,457$ & $2,824,032$ & 104,750 & 117,320 \\
\hline 1884 & $2,749,109$ & $3,079,002$ & 120,727 & 135,214 \\
\hline $1885 \ldots$ & $2,878,863$ & $3,224,327$ & 209,698 & 234,862 \\
\hline $1886 \ldots$ & $2,830,175$ & $3,169,796$ & 228,656 & 256,094 \\
\hline $1887 \ldots$ & $2,922,497$ & $3,273,197$ & 238,813 & 267,470 \\
\hline 1888. & $3,203,444$ & $3,587,857$ & 311,412 & 348,781 \\
\hline 1889 & $3,655,632$ & $4,094,308$ & 265,507 & 297,368 \\
\hline $1890 \ldots$ & $3,060,876$ & $3,428,181$ & 338,344 & 378,945 \\
\hline 1891 & $4,037,929$ & $4,522,480$ & 271,603 & 304,195 \\
\hline 1892 & $3,780,968$ & $4,234,684$ & 265,086 & 296,896 \\
\hline $1893 \ldots$ & $3,278,328$ & $3,671,727$ & 264,403 & 296,131 \\
\hline 1894 & $3,672,076$ & $4,112,725$ & 270,705 & 303,190 \\
\hline $1895 \ldots$ & $3,737,536$ & $4,186,040$ & 322,977 & 361,734 \\
\hline 1896 & $3,909,517$ & $4,378,659$ & 371,000 & 415,520 \\
\hline 1897 & $4,383,591$ & $4,909,622$ & 358,407 & 401,416 \\
\hline $1898 \ldots$ & $4,736,000$ & $5,30+, 320$ & 407,819 & 456,757 \\
\hline $1899 \ldots$ & $4,597,028$ & $5,148,6 \overline{7} 1$ & & (a) \\
\hline
\end{tabular}

$a$ Latest a vailahle figures are used in making up totals. 
Product of mimor cont-producing conntries since 1868-Continued.

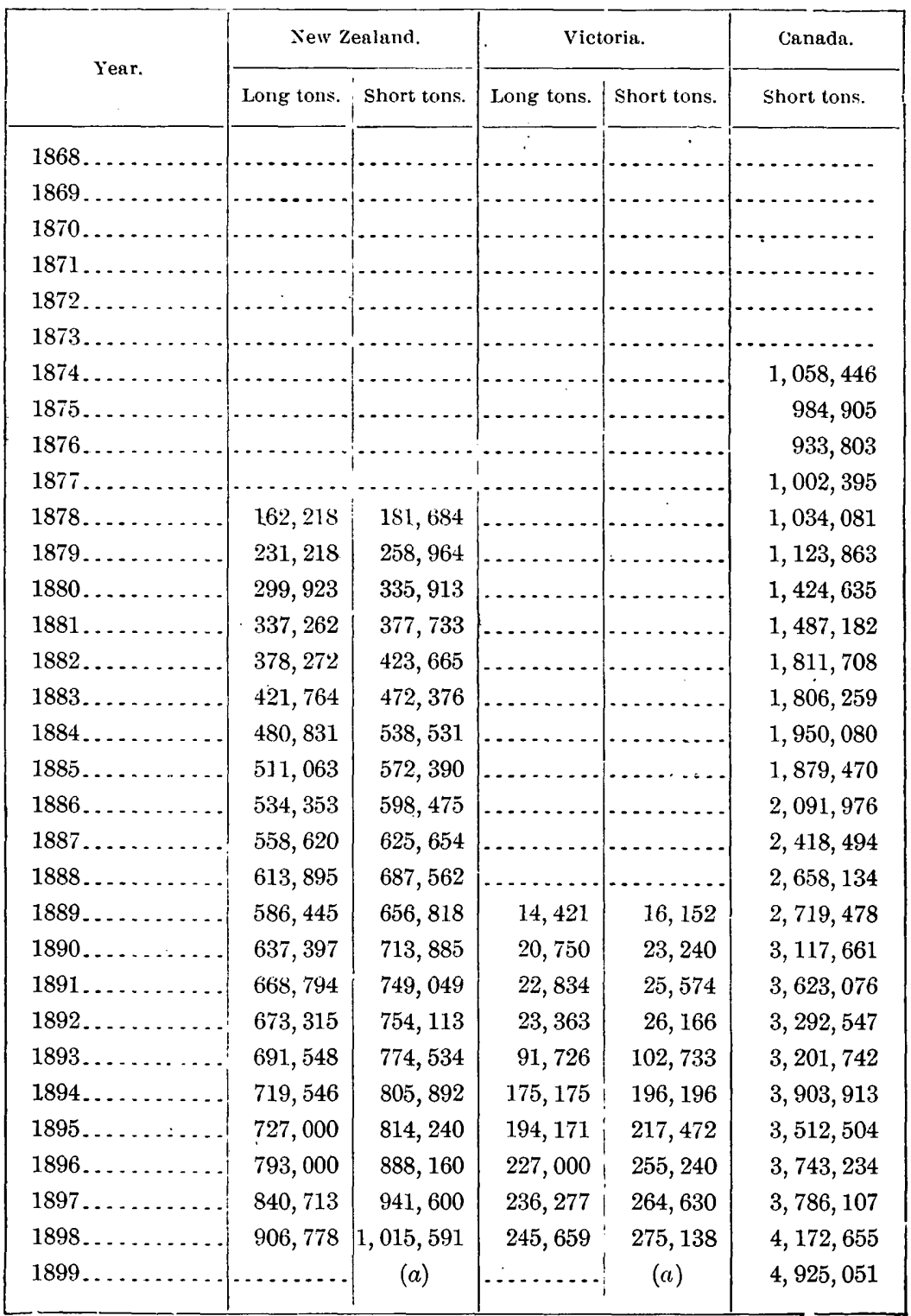

$a$ Latest arailable figures are used in making up totals. 
Produrt of minor coal-producing countries since 1868-Continued.

\begin{tabular}{|c|c|c|c|c|}
\hline \multirow{2}{*}{ Year. } & \multicolumn{2}{|c|}{ India. } & \multicolumn{2}{|c|}{ Spain. } \\
\hline & Long tons. & Short tons. & Metriot tons. & Short tons. \\
\hline 1868 & & & & \\
\hline 1869. & & & & \\
\hline 1870 & $\cdots$ & $\cdots .$. & & \\
\hline $1871 \ldots \ldots$ & $\cdots$ & & & \\
\hline 1872. & & $\cdots$ & $\ldots$ & \\
\hline 1873. & $\cdots$ & & & $\ldots$ \\
\hline $1874 \ldots$ & $\cdots$ & & & \\
\hline 1875. & & & & \\
\hline 1.876 & $\ldots$ & & & - \\
\hline $1877 \ldots$ & & & & \\
\hline 1878. & & & & \\
\hline 1879. & & & & \\
\hline 1880 & & $\cdots$ & & $\cdots$ \\
\hline 1881. & 997,543 & $1,117,248$ & & \\
\hline $1882 \ldots \ldots$ & $1,130,242$ & $1,265,871$ & 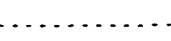 & \\
\hline 1883. & $1,315,976$ & $1,473,893$ & & \\
\hline 1884 & $1,266,312$ & $1,418,269$ & $\ldots$ & \\
\hline $1885 \ldots$ & $1,294,221$ & $1,449,528$ & $\ldots$ & $\ldots$ \\
\hline 1886. & $1,401,295$ & $1,569,450$ & $1,001,432$ & $1,104,079$ \\
\hline $1887 \ldots$ & $1,560,393$ & $1,747,640$ & $1,038,305$ & $1,144,731$ \\
\hline 1888. & $1,802,876$ & $2,019,221$ & $1,036,565$ & $1,142,813$ \\
\hline 1889. & $2,045,359$ & $2,290,802$ & 3., 153,755 & $1,272,015$ \\
\hline 1890. & $2,168,521$ & $2,438,744$ & $1,212,089$ & 1, 336, 328 \\
\hline 1891. & $2,328,577$ & $2,608,006$ & $1,287,988$ & ], 420,007 \\
\hline $1892 \ldots$. & $2,537,696$ & $2,842,220$ & $1,461,196$ & $1,610,969$ \\
\hline $1893 \ldots$ & $2,529,855$ & $2,833,438$ & $1,484,794$ & 1, 636, 986 \\
\hline $1894 \ldots$ & $2,810,929$ & $3,158,240$ & $1,657,010$ & $1,830,853$ \\
\hline $1895 \ldots .$. & $3,538,000$ & $3,962,560$ & $1,783,783$ & $1,965,729$ \\
\hline 1896 . & $3,848,000$ & $4,309,760$ & $1,878,399$ & $2,069,996$ \\
\hline $1897 \ldots$ & $4,063,127$ & $4,550,702$ & $1,939,400$ & $2,137,219$ \\
\hline 1898. & $4,203,199$ & $4,707,582$ & $2,526,600$ & $2,784,313$ \\
\hline 1899. & & (a) & $2,742,389$ & $3,022,113$ \\
\hline
\end{tabular}


Product of minor coal-producing countries since 1868-Continued.

\begin{tabular}{|c|c|c|c|c|c|c|}
\hline \multirow{2}{*}{ Year. } & \multicolumn{2}{|c|}{ Italy. } & \multicolumn{2}{|c|}{ Sweden. } & \multicolumn{2}{|c|}{ South African Republic. } \\
\hline & Netric tons. & Short tons. & Metric tons. & Short tons. & Long tons. & Short tons. \\
\hline 1868. & 51,386 & 56,627 & & & & \\
\hline $1 S 69$. & 56,201 & 61,962 & & & & \\
\hline 1870. & 58,770 & 64,794 & & & & \\
\hline 1871. & 80,336 & 88,570 & & & & \\
\hline 1872. & 93,555 & $103,14 t$ & & & & \\
\hline $1873 \ldots$ & 116,884 & 128,864 & & & & \\
\hline 1874 & 127,473 & 140,539 & & & & \\
\hline 1875 . & 116,955 & 128,943 & & & & \\
\hline 1876 & 116,399 & 128,330 & & & & \\
\hline $1877 \ldots$ & 120,588 & 132,948 & & & & \\
\hline 1878. & 124,117 & 136,839 & & & & \\
\hline 1879. & 131,318 & 144,778 & & & & \\
\hline 1880 & 139,369 & 153,654 & & $\cdots$ & & \\
\hline 1881 & 134,582 & 148,377 & & & & \\
\hline 1882 . & 164,737 & 181,623 & & & & \\
\hline $1883 \ldots$ & 214,121 & 235,961 & - & ..... & $\cdot$ & \\
\hline 188 & 223,322 & 246,213 & & & & \\
\hline 1885. & 190,413 & 209,930 & & & & \\
\hline 1886 & 243,325 & 268,266 & - & $\ldots$ & & \\
\hline 1887 & 327,665 & 361,251 & & & & \\
\hline 1888 & 366,794 & 404,390 & & & & \\
\hline $1889 \ldots$ & 390,320 & 432,533 & $\ldots$ & ..... & & \\
\hline 1890 . & 376,326 & 415,500 & 187,512 & 206,132 & & \\
\hline 1891. & 289,286 & $318,93 \mathrm{~S}$ & 198,033 & 218,331 & & \\
\hline $1892 \ldots$ & 295,713 & 326,024 & 199,380 & 219,816 & & \\
\hline $1893 \ldots$ & 317,249 & 349,767 & 199,933 & 220,426 & 548,534 & 614,358 \\
\hline 1894. & 271,395 & 299,103 & 213,633 & 235,532 & 791,358 & 886,321 \\
\hline 1895 & 305,321 & 336,563 & 223,652 & 246,464 & $1,133,466$ & $1,269,482$ \\
\hline $1896 \ldots$ & 276,197 & 304,369 & 226,000 & 249,052 & $1,437,297$ & $1,609,772$ \\
\hline $1897 \ldots$ & 314,222 & 346,273 & 224,343 & 251,264 & $1,600,212$ & $1,792,237$ \\
\hline 1898. & $341^{\prime}, 327$ & 376,245 & 236,277 & 260,448 & $1,907,271$ & $2,136,143$ \\
\hline 1899. & .. & $(a)$ & & $(a)$ & $\cdots$ & $(a)$ \\
\hline
\end{tabular}

a Latest available figures are used in making up totals. 


\section{COAL MINED BY MACHINES IN 1899}

The increase in the use of undercutting machines in the bituminous coal mines of the United States continues to be one of the most interesting features of the industry. The statistics relating to the machinemined tonnage have been collected for 1899 as for the three preceding years, and results are presented in the accompanying table. The statement shows that the amount of coal produced by machines in 1899 was $43,963,933$ short tons, an increase, as compared with 1898 , of $11,550,789$ tons. The increase in 1898 over 1897 was $9,763,924$ short tons; while the increase from 1896 to 1897 was $6,224,288$ short tons. In collecting the statistics of machine mining for 1896 the inquiries were made to cover also the year 1891. The results obtained show that in 1891 the total product by machines was 6,211,732 short tons, nearly half of which was in Illinois, while Ohio made up another fourth. In 1896 the machine-mined product had increased to $16,424,932$, a gain in five years of more than a million tons less than the gain each year from 1897 to 1899.

There were 22 States and Territories in which machines were used in 1899. Two States and one Territory in which a machine-mined tonnage was reported in one or more of the preceding years did not report any machines used in 1899. These were Alaska, Texas, and Utah. Maryland introduced machines for the first time in 1899, two companies installing a total of 8 air-driven pick machines, and having a product from them of 16,545 short tons. Washington, which did not report any machines in use in 1897 and 1898, is added again to the list of States using machines in 1899. The total number of States having machines in use last year was 22 , against 21 in 1898, 20 in 1897, and 16 in 1896. The number of firms employing machines has increased from 136 in 1896 to 335 in 1899, while the number of machines in use has increased in the same time from 1,446 to 3,125 . In the same period the total bituminous coal product of the United States has increased from 137,640,276 short tons to $193,321,987$ short tons, a gain of 55,681,711 tons, or 40 per cent. The total product in the States having machines in use has increased from $115,921,828$ short tons to $191,144,218$ short tons, a gain of $75,222,390$ tons, or 65 per cent, while the machine-mined product has increased from $16,424,932$ short tons to $43,963,933$ short tons, a gain of $27,539,102$ tons, or 168 per cent.

Considering the statistics by States, it is seen that there were 4 States in which the machine-won product in 1899 was less than in 1898. These States were Alabama, Arkansas, Iowa, and North Dakota. Satisfactory explanation for this decrease is not given except in Arkansas, where some of the large mines using machines were idle because of strikes a good part of the year. New Mexico reported a decrease from 29 to 15 in the number of machines in use. hut a substantial increase 
in the tonnage. Pennsylvania is credited with the largest increase, 258 machines and 5, 488,242 tons being added to the figures for 1898 . Illinois comes second in the increase of tonnage, adding $2,669,677$ tons to the machine-mined product of 1898 . Prior to 1899 , the amount of coal won by machines in Illinois had not reached $4,000,000$ tons in any one year. In 1899 it exceeded $6,000,000$ tons. This remabkable increase in 1899 is explained in part by the fact that a large number of machines reported in 1898 were not introduced until late in that year, and their influence on the tonnage was not apparent. Further explanation is found in the strikes which paralyzed the coal-mining industry of Illinois in 1898, causing a decrease of nearly 1,500,000 tons in the total product, and affecting particularly some of the mines in which machines were used. There was a decrease of over 500,000 tons in the machine-mined product of Illinois in 1898 as compared with the preceding year. West Virginia was next to Pennsylvania in the number of machines added in 1899. There was a gain of 68 machines in West Virginia in 1899 as compared with 1898, but as some of these were not installed until late in the year the tomnage did not increase in proportion. There was, however, an increase of over 550,000 tons in the machine-mined product. Ohio added 33 machines to the number reported in 1898 and $1,631,149$ tons to the product won by them. Colorado increased the number of machines in use from 43 to 63 , and added over 300,000 tons, or about 133 per cent, to the machine tonnage. In this State, as in Illinois, the product in 1898 was reduced by strikes. The changes made in the other States were unimportant.

The coal mined by machines in 1899 constituted 23.00 per cent of the total product as compared with 20.39 per cent in $1898,16.19$ per cent in 1897, and 14.17 per cent in 1896 . 
The statistics of the production of coal by machines in 1891, 1896, 1897,1898 , and 1899 are shown in the following table:

Bituminous coal mined by machimes in the United States in 1891, 1896, 1897, 1898, and 1899.

\begin{tabular}{|c|c|c|c|c|c|c|c|c|c|c|}
\hline \multirow{2}{*}{ State. } & \multicolumn{5}{|c|}{$\begin{array}{l}\text { Number of firms using ma- } \\
\text { chines. }\end{array}$} & \multicolumn{5}{|c|}{ Number of machines in use. } \\
\hline & 1891. & 1896. & 1897. & 1898. & 1899. & 1891. & 1896. & 1897. & 1898. & $1899^{\circ}$. \\
\hline Alabama. & & $\ldots$ & 3 & 2 & 5 & & $\cdots$ & 45 & 37 & 53 \\
\hline Alaska ... & $\cdots$ & 1 & 1 & (a) & (a) & & 6 & 6 & $(a)$ & (a) \\
\hline Arkansas. & - . & 1 & 1 & 1 & 1 & $\cdots$ & 14 & 15 & 21 & 16 \\
\hline Colorado. & 1. & 6. & 8 & 8 & 3 & 20 & 34 & 37 & 43 & 63 \\
\hline Illinois . .. & 16 & 21 & 35 & 40 & .64 & 241 & 307 & 320 & 392 & 440 \\
\hline Indiana .... & 3 & 11 & 11. & 13 & 15 & 47 & 186 & 174 & 233 & 247 \\
\hline Indian Territory. & $\cdots$ & 3 & 3 & 4 & 4 & $\cdots$ & 56 & 54 & 75 & 74 \\
\hline Iowa ...... & 2 & 5 & 7 & 9 & 4 & 9 & 45 & 49 & 56 & 41 \\
\hline Kansas ... & & $\cdots$ & 1 & 1 & 1 & & $\cdots$ & 1 & 2 & 3 \\
\hline Kentucky & & $\cdots$ & 13 & 16 & 16 & & - & 162 & 158 & 189 \\
\hline Maryland & & $\cdot-$ & $\cdots$ & $\cdots$ & 2 & & $\cdots$ & & $\cdots$ & 8 \\
\hline Michigan .. & & .. & $\cdots$ & 1 & 4 & & $\cdots$ & $\cdots$ & 7 & 25 \\
\hline Missouri... & 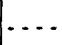 & 1 & 1 & 1 & 3 & $\cdots$ & 4 & 3 & 4 & 9 \\
\hline Montana & & 3 & 2 & 4 & 5 & & 62 & 61 & 62 & 75 \\
\hline New Mexico. & & $\cdots$ & $\cdots$ & 2 & 2 & & & $\cdots$ & 29 & 14 \\
\hline North Dakota. & $\cdots$ & 1. & 1 & 3 & 2 & $\cdots$ & 1 & 2 & 7 & 5 \\
\hline Ohio .... & 19 & 31 & 39 & 52 & 53 & 114 & 209 & 224 & $2+5$ & 278 \\
\hline Pennsylvania & 7 & 41 & 64 & 99 & 103 & 72 & 454 & 690 & 1,085 & 1,343 \\
\hline Tennessee & & $\cdots$ & 2 & 4 & 5 & & & 8 & 19 & 22 \\
\hline Texas ... & & $\cdots$ & 1 & 1 & $\ldots$ & &. & 5 & 5 & $\ldots$. \\
\hline Utah. & & 1 & & & & & 1. & & & \\
\hline Virginia.. & & .. & 1 & 1 & 1 & & & 8 & 8 & $s$ \\
\hline Washington & & 1 & & - & 1 & & 3 & & & 2 \\
\hline West Virginia. & 1. & 7 & 13 & 22 & 38 & 8 & 25 & 47 & 86 & 154 \\
\hline Wyoming & 2 & 2 & 4 & 3 & 3 & 34 & 39 & 45 & 48 & 56 \\
\hline Total... & 51 & 136 & 211 & 287 & 335 & 545 & 1,446 & 1,956 & 2,622 & 3,125 \\
\hline
\end{tabular}


COAL.

Bituminous coul mined by machines in the Lnited states im.1891, 1896, 1897, 189S, and 1899-Continued.

\begin{tabular}{|c|c|c|c|c|c|}
\hline \multirow{2}{*}{ State. } & \multicolumn{5}{|c|}{ Number of tons mined by machines. } \\
\hline & 1891. & .1896 & $189{ }^{\circ}$ & 1898. & 1899. \\
\hline Alabama & & & 294,384 & 298,170 & 260,444 \\
\hline Alaska & & 15,232 & 17,920 & $(a)$ & $(a)$ \\
\hline Arkansas .... & $\ldots$ & 21,094 & 87,532 & 152,192 & 146,899 \\
\hline Colorado ..... & 284,646 & 318,172 & 352,400 & 225,646 & 527,115 \\
\hline Illinois ..... & $3,027,305$ & $3,871,410$ & $3,946,257$ & $3,415,635$ & $6,085,312$ \\
\hline Indiana ....... & 212,830 & 964,378 & $1,023,361$ & $1 ; 414,342$ & $1,713,125$ \\
\hline Indian Territory & $\ldots \ldots$ & 191,585 & 263,811 & 274,370 & 276,180 \\
\hline Iowa ........ & 41,540 & 84,556 & 181,209 & 218,852 & 124,721 \\
\hline Kansas ....... & $\ldots \ldots \ldots$ & $\ldots \ldots \ldots$ & 4,500 & 11,722 & 40,271 \\
\hline Kentucky ... & $\ldots \ldots$ & $\ldots$ & $1,299,436$ & $1,366,676$ & $1,625,809$ \\
\hline Maryland... & & & 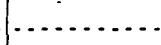 & $\cdots \ldots$ & 16,545 \\
\hline Michigan .... & . & 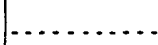 & $\ldots \ldots \ldots$ & 1,456 & 64,055 \\
\hline Missouri. & i- & 47,827 & 59,692 & $52, \delta 64$ & 55,154 \\
\hline Montana .. & $T$ & 579,414 & 720,345 & 681,613 & 843,710 \\
\hline New Mexico & . & $\cdots$ & $\ldots \ldots$ & 163,849 & 260,773 \\
\hline North'Dakota. & $\ldots \ldots$ & 15,000 & 20,000 & 65,030 & 38,066 \\
\hline Ohio ..... & $1,654,081$ & $3,368,349$ & $3,843,345$ & $5,191,375$ & $6,822,524$ \\
\hline Pennsylvania. & 431,440 & $6,092,644$ & $8,925,293$ & $16,512,480$ & $22,000,722$ \\
\hline Tennessee & & & 47,207 & 152,002 & 208,033 \\
\hline Texas ... & & & 11,750 & 15,340 & 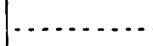 \\
\hline Utah ..... & & 760 & $\ldots$ & . . . . . . & $\ldots \ldots \ldots$ \\
\hline Virginia & & & 323,649 & 244,170 & 265,000 \\
\hline Washington - & & 3,920 & , & & 14,640 \\
\hline West Virginia... & 205,784 & 430,944 & - 673,523 & $1,323,929$ & $1,881,125$ \\
\hline Wyoming ... & 354,106 & 419,647 & 555,526 & 631,431 & 693,712 \\
\hline Total. & $6,211,732$ & $16,424,932$ & $22,649,220$ & $32,413,144$ & $43,963,933$ \\
\hline
\end{tabular}

$a$ Not reported. 
Bituminous coal mined b!l inuchines in the Lnited States in 1891, 1896, 1897, 18.9s, and 1899-Continued.

\begin{tabular}{|c|c|c|c|c|c|}
\hline \multirow{2}{*}{ State. } & \multicolumn{5}{|c|}{ Total tonnage. } \\
\hline & 1891. & 1896 & 1897 & 1898. & 1899. \\
\hline Alabania & & & $5,893,770$ & $6,535,283$ & $7,59: 3,+16$ \\
\hline Alaska & & 15,232 & 17,920 & $(a)$ & $(11)$ \\
\hline Arkansas. & $\ldots .$. & 675,374 & $85 \dot{6}, 190$ & $1,205,479$ & 843,554 \\
\hline Colorado & $3,512,632$ & $3,112,400$ & $3,361,703$ & $4,076,347$ & $4,776,224$ \\
\hline Illinois..... . & $15,660,698$ & $19,786,626$ & $20,072,758$ & $18,599,299$ & $24,439,019$ \\
\hline Indiana ... & $2,973,474$ & $3,905,779$ & $4,151,169$ & $4,920,743$ & $6,006,523$ \\
\hline Indian Territory & 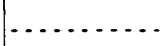 & $1,366,646$ & $1,336,380$ & $1,381,466$ & $1,537,427$ \\
\hline Iowa........ & $3,825,495$ & $3,954,028$ & $4,611,865$ & $4,618,842$ & $5,177, \pm 79$ \\
\hline Kansas .. & & & $3,054,012$ & $3,406,555$ & $3,852,267$ \\
\hline Kentucky & & & $3,602,097$ & $3,887,908$ & $4,607,255$ \\
\hline Maryland. & & & & & $4,807,396$ \\
\hline Milehigan. & & & & 315,722 & 624,708 \\
\hline Missomri .. & & $2,331,542$ & $2,665,626$ & $2,688,321$ & $3,025,814$ \\
\hline Montana ..... & $\ldots . . . . .$. & $1,543,445$ & $1,647,882$ & $1,479,803$ & $1,496,451$ \\
\hline Sew Míexico. & & & & 992,288 & $1,050,714$ \\
\hline North Dakota. & ' . . . . . . & 78,050 & 77,246 & 83,895 & 98,809 \\
\hline Ohio......... & $12,868,683$ & $12,875,202$ & $12,196,942$ & $14,516,867$ & $16,500,270$ \\
\hline Pennsylvania. - & $42,788,490$ & $49,557,453$ & $54,417,974$ & $65,165,133$ & $74,150,175$ \\
\hline Tennessee.. & & & $2,888,849$ & $3,022,896$ & $3,830,659$ \\
\hline Texas - & & & 639,341 & 686,734 & \\
\hline Ttah... & & 418,627 & 521,560 & , & $\cdots+\infty$ \\
\hline Tirginia. & & 1 & $1,528,302$ & $1,815,274$ & 1, 105,791 \\
\hline Washington & & $1,195,504$ & & & $2,029,881$ \\
\hline West Tirginia. - & $9,220,665$ & $12,876,296$ & $14,248,159$ & $16,700,999$ & $19,252,995$ \\
\hline Wyoming .... & $2,327,841$ & $2,229,624$ & $2,597,886$ & $2,863,812$ & $3,837,392$ \\
\hline Total. & 7,978 & 115,921 & $139,866,071$ & $158,963,666$ & 191,1 \\
\hline
\end{tabular}

a Sot rejorted. 
Bituminous coul mined by machines in the United States in 1891, 1896, 1897, 1898, and 1899-Continued.

\begin{tabular}{|c|c|c|c|c|c|}
\hline \multirow{2}{*}{ State. } & \multicolumn{5}{|c|}{ Percentage of total product mined by machines. } \\
\hline & 1891. & 1896. & 1897. & 1898. & 1899. \\
\hline Alabama ......... & $\ldots \ldots \ldots$ & $\ldots \ldots \ldots$ & 4.99 & 4.56 & 3.43 \\
\hline Alaska ........ & - & 100.00 & 100.00 & (a) & $(a)$ \\
\hline Arkansas . . . . . . & $\ldots \ldots .$. & 3.12 & 10.22 & 12.63 & 17.41 \\
\hline Colorado ........... & 8.10 & 10.22 & 10.48 & 5.54 & 11.03 \\
\hline Illinois . . . . . . . . . . . & 19.33 & 19.57 & 19.66 & 18.36 & 24.90 \\
\hline Indiana ........... & 7.16 & $24.69^{\circ}$ & 24.65 & 28.74 & 28.52 \\
\hline Indian Territory .... & $\ldots \ldots . .$. & 14.02 & 19.74 & 19.86 & 17.96 \\
\hline Iowa ............. & 1.09 & 2.14 & 3.93 & 4. 74 & 2.21 \\
\hline Kansas ............. & $\ldots \ldots \ldots$ & $\ldots \ldots \ldots$ & 0.15 & 0.34 & 1.04 \\
\hline Kentucky ......... & & $\ldots \ldots \ldots$ & 36.07 & 35.15 & 35.29 \\
\hline Maryland ....... & & 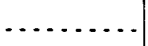 & $\ldots \ldots \ldots$ & $\cdots . .$. & 0.34 \\
\hline Michigan ....... &. & $\ldots . .$. & $\ldots .$. & 0.46 & 10.20 \\
\hline Missouri.... & - - & 2.56 & 2. 24 & 1.97 & 1.80 \\
\hline Montana ........... & $\ldots . .$. & 37.54 & 43.71 & 46.06 & 56.38 \\
\hline New Mexico ........ . & $\ldots \ldots$ & $\ldots \ldots \ldots$ & $\ldots \ldots \ldots$ & 16.51 & 24.81 \\
\hline North Dakota...... & $\ldots \ldots$ & 19.22 & 25.89 & 77.51 & 38.52 \\
\hline Ohio $\ldots . . . . . . .$. & 12.85 & 26.16 & 31.51 & 35.76 & 41. 35 \\
\hline Pennsylvania ....... & 1.01 & 12. 29 & 16.40 & 25.34 & 29.67 \\
\hline 'Tennessee .... . & $\ldots \ldots \ldots$ & $\ldots \ldots \ldots$ & 1.63 & 5.03 & 6.04 \\
\hline Texas .... & - . & $\ldots \ldots \ldots$ & 1.84 & 2.23 & $\ldots \ldots$ \\
\hline Utah .......... & & 0.18 & $\ldots \ldots \ldots$ & $\ldots \ldots$ & $\ldots \ldots$ \\
\hline Virginia ..... & & $\ldots \ldots . .$. & 21.18 & 13.45 & 23.06 \\
\hline Washington ....... & & 0.33 & $\ldots \ldots \ldots$ & $\cdots \ldots \ldots$ & 0.72 \\
\hline West Virginia ...... & 2.23 & 3.35 & 4.73 & 7.93 & 9.27 \\
\hline Wyoming ......... & 15.21 & 18.82 & 21.38 & 22.05 & 18.07 \\
\hline Average ...... & 6.66 & 14.17 & 16.19 & 20.39 & 23.00 \\
\hline
\end{tabular}


In the following table is exhibited a detailed statement of the number of machines of each make in use in the hituninous coal mines of the United States in 1899. The pick or "punching" machines exceed in number, there being 1,997 ont of a total of 3,125 . Of the remainder, 1,106 were chain breast machines and 22 "long wall." The latter are used only in the States west of the Mississippi River-Arkansas, Iowa, Kansas, and Missouri.

The pick machines include 992 Harrison, 317 Sullivan, 590 IngersollSargeant, and 98 "other" makes, or of which the make was not reported. The chain machines include 114 Jeffrey air, $450 \mathrm{Jeffrey}$ electric, 401 Morgan-Gardner electric, 95 Independent or Link-Belt electric, 15 Morgan-Standard electric, and 31 other.

In the following table is shown the number of each kind of machine in use in the bituminous coal fields of the United States in 1899.

Kinds of machines used in mining bituminous coal.

\begin{tabular}{|c|c|c|c|c|c|c|c|c|c|c|c|c|c|}
\hline \multirow[b]{2}{*}{ State. } & \multicolumn{4}{|c|}{ Pick machines. } & \multicolumn{6}{|c|}{ Chain breast machines. } & \multirow[b]{2}{*}{ 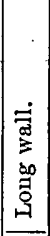 } & \multirow[b]{2}{*}{ 氶 } & \multirow[b]{2}{*}{$\begin{array}{c}\text { Tonnage } \\
\text { mined by } \\
\text { machines } \\
\text { in } 1899 .\end{array}$} \\
\hline & 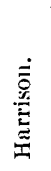 & 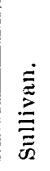 & 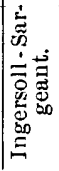 & 畩 & 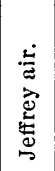 & 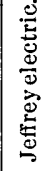 & 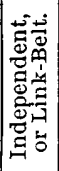 & 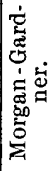 & 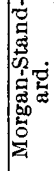 & 离 & & & \\
\hline Alabama .... & 2 & 1 & $3 s$ & & 10 & $\cdots$ & & & & & 2 & 53 & 260,442 \\
\hline Arkansas. & & & $\cdots$ & & & 12 & 4 & & & & & 16 & 146,899 \\
\hline Colorado ........... & 27 & 2 & 5 & 3 & 3 & 19 & $\cdots \cdot$ & 4 & & & & 63 & 527,115 \\
\hline Illinois ... & 180 & 35 & 130 & 18 & & 39 & 23 & 15 & & & & 440 & $6,085,312$ \\
\hline Indiana ............ & 149 & 6 & 8 & & & ... & 5 & 63 & 12 & 4 & ... & 247 & $a 1,713,125$ \\
\hline Indian Territory ... & 21 & 1 & 30 & & & 14 & 2 & & & & 6 & 74 & 276,180 \\
\hline Iowa $\ldots \ldots \ldots \ldots . . .$. & 22 & & & & 9 & 4 & & .. & & & 6 & 41. & 124,721 \\
\hline Kansas ...... & & & & & & $\cdots$ & $\cdots$ & 3 & & & & 3 & 40,271 \\
\hline Kentucky .......... & 89 & 11 & 39 & $\cdots$ & 8 & 14 & 15 & 13 & & & & 189 & $1,625,809$ \\
\hline Maryland ........... & & & 6 & & & & & & & & & 8 & 16,545 \\
\hline Michigan.......... & 12 & $\cdots$ & 5 & & & 1 & $\cdots$ & 7 & & & ... & 25 & 64,055 \\
\hline Missouri.. & & & $\cdots$ & 1 & & & & & & $\cdots$ & 8 & 9 & 55,154 \\
\hline Montana..... & $3 \overrightarrow{3}$ & $\cdots$ & 30 & & & 1 & 9 & $\cdots$ & & & & 75 & $b 843,710$ \\
\hline New Mexico....... & & & & & & 1 & 4 & 9 & & & & 14 & 260,773 \\
\hline North Dakota ... & $\cdots$ & 4 & & & & 1 & & & & & & 5 & 38,066 \\
\hline Ohio... & 16 & ... & 2 & $\cdots$ & 31 & 100 & 2 & 112 & 3 & 12 & & 278 & $6,822,524$ \\
\hline Pennsylvania ..... & 386 & 236 & 254 & 68 & 50 & 198 & 25 & 122 & & 4 & & 1,343 & $c 22,000,722$ \\
\hline Tennessee ...... & 2 & 4 & 10 & & & 6 & & & & & & 22 & 208,033 \\
\hline Virginia ....... & & & & & & & & & & & & 8 & 265,000 \\
\hline Washington .... & 2 & & & & & & & & & & & 2 & 14,640 \\
\hline West Virginia...... & 40 & 15 & & & & 40 & 6 & 53 & & $\ldots$ & & 154 & $d 1,881,125$ \\
\hline Wyoming. & 7 & 2 & 33 & $\cdots$ & 3 & & & & $\cdots$ & 11 & $\cdots$ & 56 & 693,712 \\
\hline Total. & 92 & 317 & 590 & 98 & 114 & 450 & 95 & 401 & 10 & 31 & 22 & 3,125 & $43,963,933$ \\
\hline
\end{tabular}




\section{COAJ-TRADE REVIEW.}

The year 1899 was the most remarkable one in the history of the coal-mining industry in the United States. Not only was the production the largest ever recorded by nearly $34,000,000$ short tons, but prices also showed a general improvement throughout the country. Anthracite experienced an unusual season of prosperity, as shown by a production of $53,944,647$ long tons, an output greater by $2,161,525$ long tons than the hitherto unprecedented record of 1895 , with an advance, considering all marketable sizes, of 5 cents per ton in the average price for the year. There was somewhat of an unusual demand for anthracite when the year opened, due partly to the severe winter weather, which caused a general increase in the household consumption, and, as stocks bad not accumulated to any extent, prices were at a profitable figure from the start. According to Mr. F. E. Saward, in his annual report, "The Coal Trade," the course of the anthracite coal trade during the year was entirely different from that of 1898, in that it proved stronger than was anticipated. During the spring months retail dealers adopted a waiting policy and bought only in small quantities, with the result that during the summer considerable coal began to accumulate in first hands, and, while circular prices were advanced July 1, most of the coal was sold at former prices, and there was some shading off from them. The change came in September, when buying began in unprecedented volume, and coal was shipped in such enormous quantities that the railroads were not able to satisfactorily handle it. This condition prevailed until the middle of December. Circular prices were again advanced in September, and, braced up by the exceptional demand, were readily maintained.

How the record of 1899 compared with former year's may be seen from the following table, showing the shipments from the anthracite region for the past six years and the average prices receired per long. ton at the mines:

Shipments of anthracite coul and average pricess at the mines for sia years.

\begin{tabular}{|c|c|c|}
\hline Jear. & Shipments. & $\begin{array}{c}\text { Avcrage } \\
\text { price. }\end{array}$ \\
\hline & Long tons. & \\
\hline $1894 \ldots$ & $41,391,200$ & $\$ 1.85$ \\
\hline 1895 & $46,511,477$ & 1.72 \\
\hline 1896 & $43,177,485$ & 1.85 \\
\hline $189 \pi \ldots$ & $41,637,864$ & 1.85 \\
\hline $1898 \ldots$ & $41,899,751$ & 1.75 \\
\hline $1899 \ldots \ldots \ldots \ldots$ & $47,823,241$ & 1.80 \\
\hline
\end{tabular}


In the bituminous trade the production and consunption were limited only by the ability of railroads to furnish the cars and provide the means of hauling them, and in some cases by the ability of operators to secure the labor sufficient to keep the tonnage up to the demand. It was the first time in many years that the productive capacity of the bituminous nines was not in excess of the market requirements for at least a portion of the year. In 1898 there were intervals when the demand was in excess of the supply, but in 1899 this condition prevailed practically from January to December. Naturally prices improved, and the year is noteworthy as recording the first reaction from a period of declining prices which had lasted for twelve years.

The wonderful activity which prevailed throughout the year in the iron and steel trade created a demand for coke that kept practically every available oven in the country operating to its full capacity and taxed the railroads entering the coking districts to provide transportation for the output. The entire year was one of remarkable activity in all branches of the coal business and will have a notable place in the history of the trade. One of the effects of the enormous increase in production was the placing of the United States ahead of Great Britain as the leading coal producer of the world.

A condensed statement of the receipts of coal at some of the important centers is shown in the following table. Statistics regarding the receipts at New York Harbor are not obtainable. In the statement given Cincinnati and Toledo, Ohio, are shown to be the only ones in which the receipts in 1899 were less than in 1898.

Coul receipts at important centers.

\begin{tabular}{|c|c|c|c|c|c|}
\hline & $1 \times 97$. & $1 \times 98$. & 1899. & $\begin{array}{c}\text { Increase, } \\
1899 .\end{array}$ & $\begin{array}{c}\text { Decrease, } \\
1899 .\end{array}$ \\
\hline $\begin{array}{l}\text { Philadelphia (long } \\
\text { tons): }\end{array}$ & & $i$ & & & \\
\hline Anthracite .... & $5,193,898$ & $4,981,697$ & $5,423,045$ & 441,348 & \\
\hline Bituminous ..... & $4,608,092$ & $5,156,602$ & $5,314,460$ & 157,858 & \\
\hline Boston (long tons) : & & & & & \\
\hline Anthracite ..... & $1,981,119$ & $1,866,877$ & $2,226,094$ & 359,217 & \\
\hline Bituminous ..... & $1,656,919$ & $1,768,442$ & $1,841,394$ & 72,952 & \\
\hline $\begin{array}{c}\text { Pittsburg }(a) \text { (short } \\
\text { tons) } \ldots \ldots \ldots \ldots\end{array}$ & $15,887,345$ & 18,467 & $22,784,206$ & $4,317,120$ & \\
\hline Buffalo: & & & & & \\
\hline Anthracite ..... & $4,109,052$ & $4,225,000$ & & & \\
\hline Bituminous .... & $2,616,185$ & $3,081,446$ & & & \\
\hline Cleveland: & & & & & \\
\hline Anthracite ..... & 201,756 & 179,891 & 202,782 & 22,891 & \\
\hline Bituminous ..... & $3,779,305$ & $4,533,721$ & $4,857,295$ & 323,574 & \\
\hline
\end{tabular}


('oul receipts at important centers-Continued.

\begin{tabular}{|c|c|c|c|c|c|}
\hline & 1897. & 1898. & 1899. & $\begin{array}{c}\text { Increase, } \\
1899 .\end{array}$ & $\begin{array}{c}\text { Decrease, } \\
1899 .\end{array}$ \\
\hline Tolerlo $(a) \ldots \ldots \ldots$ & $2,984,834$ & $3,877,678$ & $3,837,736$ & $\ldots \ldots . . . .$. & 39,942 \\
\hline Chicago (short tons) : & & & & & \\
\hline Anthracite ..... & $1,776,400$ & $1,840,858$ & $2,146,554$ & 305,696 & $\ldots \ldots \ldots$ \\
\hline Bituminous ..... & $5,373,852$ & $4,976,779$ & $6,463,506$ & $1,486,727$ & \\
\hline $\begin{array}{l}\text { Milwaukee (short } \\
\text { tons): }\end{array}$ & & & & & . \\
\hline Anthracite ..... & 645,432 & 768,150 & $922 ; 321$ & 154,171 & $\cdots$ \\
\hline Bituminous ..... & 910,376 & 920,911 & 997,543 & 76,632 & \\
\hline St. Louis (short tons) : & & & & & \\
\hline Anthracite ..... & 172,933 & 225,616 & 292,118 & 66,502 & . \\
\hline Bituminous .... & $3,349,239$ & $3,342,498$ & $4,124,629$ & 782,131 & \\
\hline $\begin{array}{l}\text { Cincinnati (short } \\
\text { tons): }\end{array}$ & & & . & & \\
\hline Anthracite ..... & 50,050 & 37,925 & 51,650 & 13,725 & $\ldots \ldots \ldots$ \\
\hline Bituminous .... & $3,100,431$ & $3,319,793$ & $3,100,011$ & $\ldots \ldots \ldots$ & 219,782 \\
\hline
\end{tabular}

a Anthracite and bituminons.

\section{NEW YORK CITY.}

The following review of the coal trade of New York has been prepared for this report by Mr. H. S. Fleming, secretary of the Anthracite Coal Operators' Association.

The anthracite coal market in New York at the beginning of 1899 was in an extremely unsatisfactory condition. During the first six months of the previous year, 1898, a strong effort had been made to keep the production. within the consumption, in order to prevent unprofitably low prices, but in July and August of that year some of the larger interests threw a large volume of coal upon the market, at the same time contracting for deliveries throughout the remainder of the year at even lower prices than those then current. The result was a demoralized market and low prices, which continued into 1899 . Toward the close of January and in the early part of February short periods of cold weather served to stimulate the market slightly, but the buying movement was altogether dependent upon weather conditions. There was, however, a stronger tone in the tide-water and New England markets, owing to the small tonnage produced in February, and March opened with improving prices and a somewhat greater activity. This recovery was almost lost during that month by an excessive tonnage sent to market, and prices sagged in consequence. April continued in about the same condition, though with a growing uncertainty on the part of buyer's as to the future course of prices. Toward the close of the month a new circular was announced by the 
selling companies, advancing prices 25 cents. This, together with the small production in that month, added further strength to the market, which was increased through May and June, a large tonnage being absorbed in both of these months without disturbing prices.

For the first six months of the year, from January 1 to June 30, the shipments from the mines had been as follows, as compared with 1897 and 1898:

Anthracite shipments in first six months of 1897, 1898, and 1899.

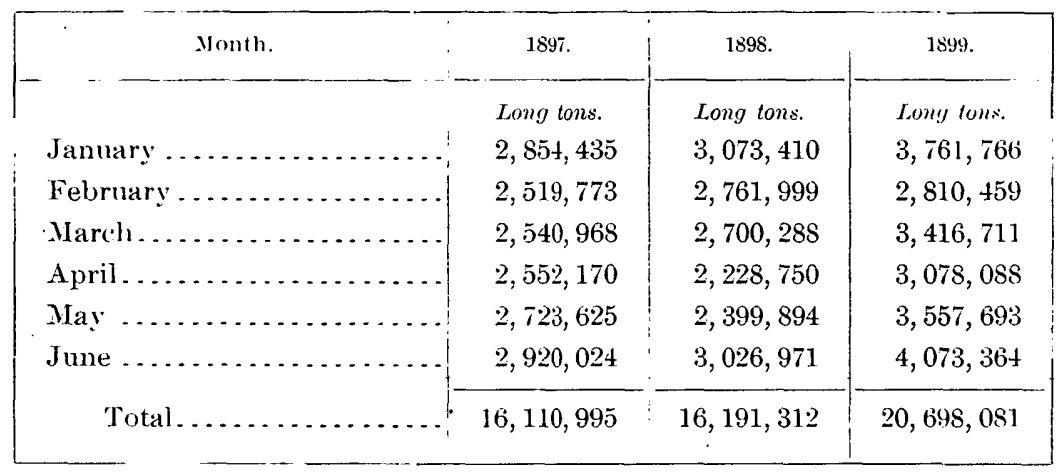

The tide-water prices for the same period were as below:

Prices of anthracile at tide water, New York, during first six months of 1897, 1898, and 1899.

[Per long ton.]

\begin{tabular}{|c|c|c|c|}
\hline Month and size. & 1897. & 1898. & 1899. \\
\hline January: & & . & \\
\hline Broken... . . . . . . . & $\$ 3.346$ & $\$ 3.289$ & $\$ 3.179$ \\
\hline Egg ..... & 3. 668 & 3.566 & 3.337 \\
\hline Stove............. & 3.867 & 3.742 & 3.536 \\
\hline Chestnut .......... & 3.544 & 3.430 & 3. 389 \\
\hline Pea ........ & 2. 066 & 2. 219 & ㄹ. 207 \\
\hline Buckwheat . . . . . . . . . & 1.816 & 1. 762 & 1. 784 \\
\hline Average of chestnut and larger..... & 3.656 & 3.542 & 3.395 \\
\hline February: & & & \\
\hline Broken. . & 3.373 & 3. 290 & 3.197 \\
\hline Egg & 3.683 & 3.601 & 3.310 \\
\hline Stove... & 3.908 & 3.835 & 3.573 \\
\hline Chestnut .... & 3.565 & 3.604 & 3.457 \\
\hline Pea & 2. 127 & 2.257 & 2.220 \\
\hline Buckwheat ....... & 1.819 & 1. 856 & 1. 794 \\
\hline Average of chestnut and larger... & 3.683 & 3.633 & 3.526 \\
\hline
\end{tabular}


Prices of anthracite at ticle water, New York, during first six months of 1897 1898, and 1899-Continued.

[Per long ton.]

\begin{tabular}{|c|c|c|c|}
\hline Month and size. & 1897 . & 1898. & 1899. \\
\hline \multicolumn{4}{|l|}{ March: } \\
\hline Broken $\ldots \ldots \ldots \ldots \ldots \ldots$ & $\$ 3.354$ & $\$ 3.312$ & $\$ 3.185$ \\
\hline Egg ..... & 3.678 & 3.653 & 3.337 \\
\hline Stove...................... & 3.918 & 3.879 & 3.556 \\
\hline Chestnut .................. & 3.570 & 3.635 & 3.536 \\
\hline Pea .......... & 2. 149 & 2.272 & 2.235 \\
\hline Buckwheat ......... & 1.826 & 1.815 & 1.783 \\
\hline Average of chestnut and larger ....... & 3.685 & 3.671 & 3.447 \\
\hline \multicolumn{4}{|l|}{ April: } \\
\hline Broken . . . . . $\ldots \ldots \ldots \ldots$ & 3.354 & 3.326 & 3. 186 \\
\hline Egg $\ldots \ldots \ldots \ldots \ldots \ldots \ldots$ & 3.676 & 3.669 & 3.340 \\
\hline Stove $\ldots \ldots \ldots \ldots \ldots \ldots \ldots \ldots$ & 3.934 & 3.877 & 3.619 \\
\hline Chestnut $\ldots \ldots \ldots \ldots \ldots \ldots \ldots \ldots$ & 3.602 & 3.631 & 3.594 \\
\hline Pea $\ldots \ldots \ldots \ldots \ldots \ldots \ldots$ & 2.184 & 2. 310 & 2.218 \\
\hline 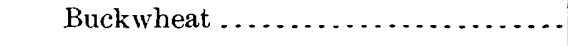 & 1.845 & 1.833 & 1. 785 \\
\hline Average of chestnut and larger ........ & 3. 699 & 3.676 & 3.486 \\
\hline \multicolumn{4}{|l|}{ May: } \\
\hline Broken . . . . . . . . . . . . . . . . & 3.378 & 3.339 & 3.185 \\
\hline $\operatorname{Egg} \ldots \ldots \ldots \ldots \ldots \ldots \ldots \ldots$ & 3.686 & 3.695 & 3.382 \\
\hline Stove $\ldots \ldots \ldots \ldots \ldots \ldots \ldots$ & 3.948 & 3.913 & 3.639 \\
\hline Chestnut $\ldots \ldots \ldots \ldots \ldots \ldots \ldots \ldots$ & 3.628 & 3.655 & 3.607 \\
\hline Pea $\ldots \ldots \ldots \ldots \ldots \ldots \ldots \ldots . . . . . . .$. & $2.196^{\circ}$. & 2.307 & 2. 192 \\
\hline Buckwheat . . . . . . . . . . . . . . . & 1.840 & 1.838 & 1. 763 \\
\hline Average of chestnut and Jarger ........ & 3.717 & 3. 702 & 3.506 \\
\hline \multicolumn{4}{|l|}{ June: } \\
\hline 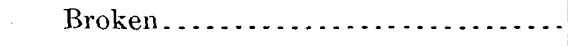 & 3.379 & 3.314 & 3.147 \\
\hline Fgg $\ldots \ldots \ldots \ldots \ldots$ & 3.714 & 3.709 & 3.397 \\
\hline Stove. . . . . . . . . . . . . . . & 3.967 & 3.907 & 3.662 \\
\hline Chestnut ........... & 3.663 & 3.648 & 3.631 \\
\hline Pea $\ldots . . . . . . .$. & 2.212 & 2.308 & 2.143 \\
\hline Buckwheat . . . . . . . . . . . . . & 1.853 & 1.832 & 1. 756 \\
\hline Average of chestnut and larger.... & 3.741 & 3.698 & 3.479 \\
\hline
\end{tabular}

21 GEOL, PT $6-25$ 
This large production, coupled with the facts that it was practically all for consumption and that interior and tide stocks were low, caused some alarm as to an adequate supply for the remainder of the year. Calculating in five-year periods the percentage of anthracite produced in the first and last six months of each has been as follows:

Percentage of anthracite produced in first and lust six months from 1884 to 1898 -aterage of fice-year periods.

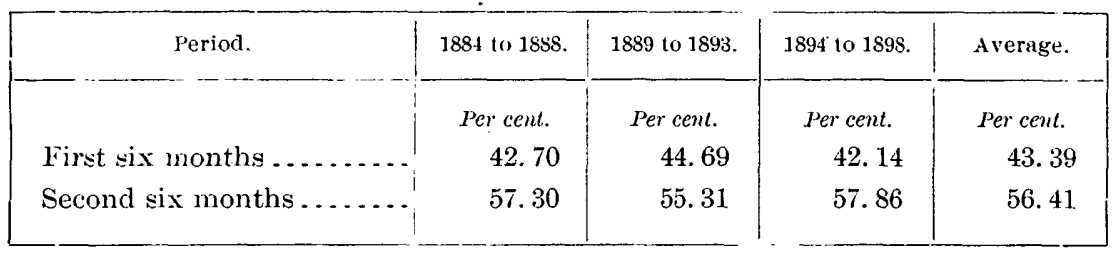

Assuming the tonnage produced in the first six months of 1899 as being 43.6 per cent of the year's output, it was calculated that nearly $27,000,000$ tons, or $4,500,000$ per month, would have to be produced in the remaining six months in order to meet the demand. As there was at this time much difficulty experienced in securing sufficient labor at the mines, and since the rolling stock and power of the various railroads was considered inadequate to meet such conditions, it was feared that there might be a scarcity of anthracite.

Notwithstanding this, there was little activity in the market during July or August, though prices were fairly well maintained. In September an active buying movement began, which increased with the announcement of a new circular, advancing prices 50 cents over the May circular. At the same time the selling companies announced that orders taken in preceding months and delivery not accepted prior to October 1 would be canceled. By the beginning of October the market had become exceedingly active. Water rates from New York and Philadelphia to New England points advanced over 50 per cent, and manufacturers were beginning to feel through the scarcity of fuel the results of insufficient motive power and cars on both the bituminous and anthracite railroads. During October and November these conditions were accentuated. The anthracite mines worked as nearly full time as could be done with the men and cars at command. From every point there were complaints of a shortage of coal, and tide prices showcd a stcady advance, in some cases even above the circular rates. Practically the same conditions existed throughout December, and into January, 1900, making the year 1899 the most satisfactory from the point of tonnage which had been known in the history of theindustry. 
The shipments during the last six months of the year as compared with the same period in the two preceding years were as follows:

- Irthracite shipments in last six months of 1897, 1898, and 1899.

\begin{tabular}{|c|c|c|c|}
\hline Month. & 1897. & 1898. & 1899. \\
\hline & Long tons. & Long tons. & Lomg tons. \\
\hline 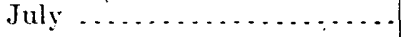 & $3,975,128$ & $3,777,406$ & $4,189,250$ \\
\hline August .. & $4,086,873$ & $3,783,288$ & $4,319,031$ \\
\hline September.. & $4,072,529$ & $4,270,163$ & $4,365,649$ \\
\hline October ..... & $5,120,892$ & $4,765,165$ & $4,899,303$ \\
\hline November ...... & $4,538,450$ & $4,854,517$ & $4,688,859$ \\
\hline December. & $3,732,991$ & $4,257,895$ & $4,505,025$ \\
\hline Total & $25,526,863$ & $25,708,434$ & $26,967,117$ \\
\hline
\end{tabular}

Tide-water prices for the last six months were as below:

Prices of anthracile at lide water, New York, during last six months of 1897, 1898, and 1899.

[Per long ton.].]

\begin{tabular}{|c|c|c|c|}
\hline Month and size. & 1897. & 1898. & 1899. \\
\hline \multicolumn{4}{|l|}{ July: } \\
\hline Broken $\ldots \ldots \ldots \ldots \ldots \ldots \ldots \ldots$ & $\$ 3.400$ & $\$ 3.296$ & $\$ 3.165$ \\
\hline Egg $\ldots \ldots \ldots \ldots \ldots \ldots$ & 3. 731 & 3.583 & 3.445 \\
\hline Stove .......................... & 3.989 & 3.850 & 3. 720 \\
\hline Chestnut & 3.682 & 3.603 & 3. 666 \\
\hline Pea $\ldots \ldots \ldots \ldots \ldots \ldots \ldots$ & 2. 194 & 2.219 & 2.095 \\
\hline Buckwheat $\ldots \ldots \ldots \ldots \ldots \ldots$ & 1.841 & 1.818 & 1.745 \\
\hline Average of chestnut and larger ....... & 3.760 & 3.635 & 3.562 \\
\hline August: & & & \\
\hline Broken ................. & 3.446 & 3.249 & 3.224 \\
\hline . $\operatorname{Egg} \ldots \ldots \ldots \ldots \ldots$ & · 3.779 & 3.581 & 3.501 \\
\hline Stove..... & 4.007 & 3.796 & 3. 752 \\
\hline Chestnut - & 3.690 & 3.543 & 3. 725 \\
\hline Pea $. . . \ldots \ldots \ldots \ldots \ldots \ldots \ldots . . . .$. & 2.186 & 2.208 & 2.065 \\
\hline Buckwheat . . . . . . . . . . . . . & 1.852 & 1.801 & 1. 755 \\
\hline Average of chestnut and larger... & 3. 786 & 3.591 & 3.521 \\
\hline
\end{tabular}


Prices of anthracite at tide water, New York, during last sivi months of 1897, 1898, and 1899-Continued.

[Per long ton.]

\begin{tabular}{|c|c|c|c|}
\hline Month and size. & 1897. & 1898. & 1899. \\
\hline \multicolumn{4}{|l|}{ September: } \\
\hline Broken & $\$ 3.427$ & $\$ 3.255$ & $\$ 3.193$ \\
\hline Egg .. & 3.813 & 3.515 & 3.490 \\
\hline Stove............... & 4. 034 & 3.724 & 3.832 \\
\hline Chestnut .. & 3. 700 . & 3.631 & 3. 822 \\
\hline Pea & 3. 167 & 2.170 & 2.052 \\
\hline Buckwheat & 1. 817 & 1.805 & 1. 753 \\
\hline Average of chestnut and larger. & 3.804 & 3.590 & 3. 660 \\
\hline \multicolumn{4}{|l|}{ October: } \\
\hline Broken .... & 3. 396 & 3.210 & 3. 209 \\
\hline Egg $\ldots \ldots \ldots \ldots$ & 3. 799 & 3.435 & 3.596 \\
\hline Stove...... & 4.000 & 3.638 & 3. 928 \\
\hline Chestnut .. & 3.567 & 3.414 & 3. 783 \\
\hline Pea ....... & 2. 162 & 2. 151 & 2. 065 \\
\hline Buckwheat ..... & 1. 788 & 1. 797 & 1. 750 \\
\hline Average of chestnut and larger.. & 3.745 & 3.461 & 3. 706 \\
\hline \multicolumn{4}{|l|}{ November: } \\
\hline Broken. & 3.355 & 3. 169 & 3.234 \\
\hline Egg ... & 3.717 & 3.373 & 3.567 \\
\hline Stove...... & 3.914 & 3.596 & 3.968 \\
\hline Chestnut ... & 3.570 & 3.373 & 3.959 \\
\hline Pea & 2.157 & 2.149 & 2.173 \\
\hline Buckwheat & 1. 767 & 1. 792 & 1. 769 \\
\hline Average of chestnut and larger. & 3. 718 & 3.416 & 3. 769 \\
\hline \multicolumn{4}{|l|}{ December: } \\
\hline Broken ..... & 3.263 & 3.133 & 3.229 \\
\hline Egg . . . . & 3.607 & 3.365 & 3. 656 \\
\hline Stove....... & 3. 780 & 3.561 & 4.028 \\
\hline Chestnut .... & 3.429 & 3.358 & 4. 042 \\
\hline Pea...... & 2. 160 & 2. 169 & 2.240 \\
\hline Buckwheat .. & 1.779 & $1.76 \overline{3}$ & 1. 827 \\
\hline Average of chestnut and larger & $3.56 \overline{7}$ & 3.393 & 3. $\$ 32$ \\
\hline
\end{tabular}




\section{Boston, MASSACHUSETTS.}

Mr. Elwyn G. Preston, secretary of the Boston Chamber of Commerce, has prepared the following statement in regard to the coal trade of that city.

The receipts of coal at Boston during 1899 were the largest on record, exceeding those of 1898 by 616,088 tons, or 17 per cent. The table of receipts of coal at Boston for a series of years is again presented:

Receipts of coal at Boston for seventeen years.

\begin{tabular}{|c|c|c|c|c|c|c|}
\hline \multirow{3}{*}{ Year. } & \multicolumn{4}{|c|}{ Domestic. } & \multirow{3}{*}{ Foreign. } & \multirow{3}{*}{ Total. } \\
\hline & \multicolumn{2}{|c|}{ By water. } & \multicolumn{2}{|c|}{ All rail. } & & \\
\hline & Anthracite. & Bituminous. & Anthracite. & Bituminous. & & \\
\hline $1883 \ldots$ & $\begin{array}{l}\text { Long tons. } \\
\ldots \ldots\end{array}$ & Long tons. & Long tons. & $\begin{array}{l}\text { Long tons. } \\
\ldots . . .\end{array}$ & Long tons. & $\begin{array}{c}\text { Long tons. } \\
2,273,068\end{array}$ \\
\hline 1884 & & & & & & $2,225,740$ \\
\hline 1885 & & & & & $\ldots$ & $2,221,220$ \\
\hline 1886. & & & & & 44,464 & $2,500,000$ \\
\hline $1887 \ldots$ & $\ldots . .$. & & & & 13,966 & $2,400,000$ \\
\hline 1888 & $2,057,279$ & $1,004,195$ & & & 10,081 & $3,071,555$ \\
\hline 1889 & $1,647,348$ & 914,966 & & & 5,538 & $2,567,852$ \\
\hline 1890. & $1,740,564$ & 964,857 & & 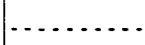 & 14,072 & $2,719,493$ \\
\hline $1891 \ldots$ & $2,039,443$ & $1,070,088$ & & & 5,842 & $3,115,373$ \\
\hline 1892. & $2,163,984$ & 919,815 & & ..... & 1,416 & $3,085,215$ \\
\hline 1893. & $2,227,086$ & $1,100,384$ & & $a 50,000$ & 17,097 & $3,394,567$ \\
\hline $1894 \ldots$ & $2,237,599$ & 958,701 & & a 71,303 & 41,779 & $3,309,382$ \\
\hline 1895. & $2,518,441$ & 977,762 & & a 90,999 & 21,009 & $3,608,211$ \\
\hline 1896. & $2,092,798$ & $1,391,949$ & 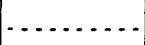 & $a 104,080$ & 61,071 & $3,649,898$ \\
\hline 1897. & $1,948,283$ & $1,591,245$ & 32,836 & 65,674 & 50,235 & $3,688,273$ \\
\hline 1898. & $1,835,806$ & $1,706,929$ & 31,071 & 62,143 & 17,122 & $3,653,071$ \\
\hline 1899 & $2,178,791$ & $1,746,780$ & 47,303 & 94,614 & 201,671 & $4,269,159$ \\
\hline
\end{tabular}

a Total anthracite and bituminous.

Of the gross receipts of domestic coal, 461,827 tons of anthracite and 647,533 tons of bituminous, a total of $1,109,360$ tons, were forwarded to interior New England points by rail, leaving the net receipts at Boston as follows: Anthracite, 1,764,267 tons; bituminous, 1,395,532 tons, a total of $3,159,799$ tons, or an increase in the net receipts at Boston, representing local consumption, of 538,696 tons, or 20 per cent. 
The year opened with a scarcity of tonnage and high rates, which prevented the replenishment of stocks, and at times during the early months of the year fears were entertained of a soft-coal famine. These fears were not, however, realized until late in the year, when, owing to a scarcity of tonnage and a shortage of cars, stocks were reduced to the vanishing point and phenomenally high prices were obtained. During this period, owing to the scarcity of water tonnage, the demurrage clause "after six days" was the usual feature of charter parties.

Carriers' rates covered an extraordinary range, as shown by the following table:

Coal freights to Boston, Massachusetts.

\begin{tabular}{|c|c|}
\hline From- & Per ton. \\
\hline Philadelphia_.... & $\$ 0.70$ to $\$ 2.10$ \\
\hline Baltimore ......... & .80 to 2.25 \\
\hline Norfolk and Newport News............ & .70 to 2.00 \\
\hline New York .................... & .45 to 1.50 \\
\hline
\end{tabular}

The extreme rates were secured during the last two months of the year and the lowest rates were obtained in May.

Prices in the local market have been governed almost entirely by the transportation conditions. The year opened with anthracite stove coal quoted at $\$ 5$, an increase to $\$ 6$ being secured during February, March, and April. A local rate quarrel reduced the prices to $\$ 4.50$ in May, from which it recovered to $\$ 5$ in July, and later advanced to $\$ 6$ per ton, at which figure the year closed.

Georges Creek Cumberland covered a range of from $\$ 3$ free on board cars to $\$ 5$ or more alongside at Mystic Wharf. During the last three months of the year the scarcity of this grade of coal caused the price to advance rapidly, and even the extreme figures named do not represent the highest price obtained at times for individual lots.

The soft coal shortage caused a large increase in the importations of Provincial coal, the total receipts being 201,671 tons as against 17,122 tons in 1898 , and 61,071 tons in 1896 , the largest previous year. 
The following table shows the receipts of coal at Boston for shipment to interior points and the net receipts for consumption, by months, during 1899:

Monthly receipts of coal at Boston for 1899, with comparisons.

\begin{tabular}{|c|c|c|c|c|c|c|}
\hline \multirow{2}{*}{ Nonth. } & \multicolumn{2}{|c|}{ Receipts, all routes. } & \multicolumn{2}{|c|}{$\begin{array}{l}\text { Amount forwarded } \\
\text { to interior } \\
\text { New England points. }\end{array}$} & \multicolumn{2}{|c|}{$\begin{array}{l}\text { Net receipts (for local } \\
\text { consumption). }\end{array}$} \\
\hline & Anthracite. & Bituminous. & Anthracite. & $\begin{array}{l}\text { Bitumi- } \\
\text { nous. }\end{array}$ & Anthracite. & Bituminous. \\
\hline January & $\begin{array}{l}\text { Tons. } \\
181,963\end{array}$ & $\begin{array}{l}\text { Tons. } \\
161,593\end{array}$ & $\begin{array}{c}\text { Tons. } \\
41,608\end{array}$ & $\begin{array}{l}\text { Tons. } \\
4 \dot{5}, 037\end{array}$ & $\begin{array}{l}\text { Tons. } \\
140,355\end{array}$ & $\begin{array}{l}\text { Tons. } \\
116,556\end{array}$ \\
\hline February .. & 101,554 & 100,538 & 31,663 & 33,317 & 69,891 & 67,221 \\
\hline March & 180,907 & 155,933 & 30,321 & 36,332 & 150,586 & 119,601 \\
\hline April. & 170,976 & 198,089 & 26,092 & 54,982 & 144,884 & 143,107 \\
\hline May & 208,896 & 208,809 & 42,650 & 71,194 & 166,246 & 137,615 \\
\hline June & 231,592 & 167,297 & 44,552 & 58,372 & 187,040 & 108,925 \\
\hline July & 226,355 & 188,692 & 36,748 & 58,199 & 189,607 & 130,493 \\
\hline August .... & 202,199 & 142,117 & 44,279 & 72,987 & 157,920 & 69,130 \\
\hline September. & 171,606 & 180,977 & 35,080 & 66,781 & 136,526 & 114,196 \\
\hline October... & 195,278 & 184,165 & 47,099 & 49,108 & 148,179 & 135,057 \\
\hline November. & 195,568 & 162,484 & 38,221 & 43,041 & 157,347 & 119,443 \\
\hline December & 159,200 & 192,371 & 43,514 & 58,183 & 115,686 & 134,188 \\
\hline Total, 1899 & $2,226,094$ & $2,043,065$ & 461,827 & 647,533 & $1,764,267$ & $1,395,532$ \\
\hline 1898. & $1,866,877$ & $1,786,194$ & 368,960 & 663,008 & $1,497,917$ & $1,123,186$ \\
\hline . $\quad 1897$. & $1,981,119$ & $1,707,154$ & 418,171 & 734,541 & $1,562,948$ & 972,613 \\
\hline
\end{tabular}

\section{PHILADELPHIA, PENNSYLVANIA.}

The following review has been prepared for this report by $\mathrm{Mr}$. Samuel R. 'Kirkpatrick, railroad editor of the Philadelphia Press:

During the latter part of 1899 there was a regular boom in the anthracite coal trade in Philadelphia. For the first time in years the large storage yards of the Philadelphia and Reading Railway Company at Port Richmond were without coal. Usually there is stored at this place from 250,000 to 350,000 tons of various sizes of anthracite; but on December 31,1899, and for many days prior thereto, there was no coal, and the daily arrivals were something less than a few hundred cars. Prices during the last six months were better, notwithstanding the production was greater than ever before. As a whole, 1899 was a prosperous anthracite coal year, and better prices were obtained. During the early months cutting was rampant, and while the year opened slightly better than in 1898 there was no cause for rejoicing, 
as cutting soon became in order, and prices for domestic sizes were from 10 to 25 cents below the figures for the corresponding period in the previous year. The dealers were buyers of only small lots, but the operators began to seek other markets, and the coal was diverted to other cities. After a few months of low prices there was a better undertone displayed, and the operators began to refuse to take orders unless for shipment within a stipulated time. In April the first signs of better prices began, and they kept steady until September, when the demand became greater than the local supply, and in December. the best prices of the year were obtained. While the prices of egg, stove, and nut sizes were strong, there was a disposition to shade the price of broken. During 1899 the aggregate of the shipments of anthracite and bituminous coal to this city was $10,737,505$ tons, a gain of 599,206 tons over the corresponding period in 1898, and considerably more than in 1897 .

The bituminous coal trade was in better shape than it has been for years, although up to September 1 prices were generally very low. The general prosperity created a big demand for soft coal. Furnaces that had been shut down for years were started up, and this, with a big demand by manufacturing establishments, caused a great rush for this fuel, and during the latter part of the year fancy prices prevailed. From January to September the price for Clearfield coal at the mines ran from 80 cents to $\$ 1$ a ton, from October to November from $\$ 1$ to $\$ 1.50$, and from that time on to December 31 from $\$ 1.50$ to $\$ 3.50$. During the last few months there was no regular price for bituminous coal; the price changed from day to day, and often a fancy price was paid by a consumer who wanted the coal very bad. Georges Creek coal brought from 25 to 50 cents a ton more than the Clearfield output.

Owing to the great wave of prosperity which swept over the country there was a big demand for bituminous coal, and while the consumption by the local manufacturers was only slightly in excess of 1898 many of the manufacturing establishments were compelled to use anthracite coal, as they could not secure enough bituminous to meet their wants. The soft coal companies in the South were not so anxious to break prices as heretofore, and the Pennsylvania operators were inclined to meet them more than half way. The tide-water tonnage from this port was larger than in 1898 , amounting to $3,373,047$ tons as against $3,229,000$ tons in the previous year, 2,630,000 tons in 1897, and $2,320,000$ tons in 1896 . The amount of bituminous coal sold for local use was $1,482,147$ as against $1,451,000$ for the previous year. The sharp advance in prices toward the close of the year caused many consumers of soft coal to purchase free-burning anthracite. There was also a great scarcity, as the operators were unable to secure enough coal car's to fill their orders. 
The local consumption of bituminous coal would have been considerably greater if the producers had been able to fill their orders. There was a good demand, but the operators at times were compelled to refuse any new orders, as it was impossible to procure the necessary cars. The consumption of bituminous coal by the local manufacturers, as stated above, was 1,482,147 tons, an increase over the pre. vious year of 31,147 tons. There would have been, no doubt, a greater increase in the amount of this fuel used if the manufacturers had been able to secure all they needed. Since the local gas works have become the property of the United Gas Improvement Company, there has been a tendency to cut down the amount of bituminous coal used, and while in former years about 300,000 tons were used annually by the city when it manufactured its own gas, it is stated that, although a greater quantity of gas is now made, there has been little, if any, increase in the amount of coal consumed. While the increase in bituminous coal is comparatively slight, the manufacturers are busier than they have been for years, and a number of them use large quantities of pea coal. Toward the close of the year fancy prices for bituminous coal were demanded, and it was almost impossible to secure spot coal at a reasonable figure. The outlook of the closing year was very encouraging, and as all the large soft-coal carrying companies have ordered additional cars, it is thought there will not be the trouble during the year of 1900 that there was in 1899 . The principal drawback was the inability of the railroads to supply enough cars to enable the producers to meet their orders.

Owing to the scarcity of bituminous coal there was a better market created for anthracite coal, but the competition between producers of both of these fuels is as keen as ever, and while there was not so much gain showed in the consumption of bituminous coal as it was thought there would be, it is understood that as soon as the soft coal operators can guarantee to furnish this coal regularly and at all times, more of it will be used. Owing to the frequent strikes in bituminous coal fields and the inability of the shippers to secure all the cars that are needed, there is not that disposition on the part of the consumer that there would be if he were sure of a steady supply. The introduction of soft coal as a fuel into a number of large factories has been a severe blow to anthracite dealers, and while the changes last year were not so great as they would otherwise have been, yet there are many manufacturers having plants within a short distance of Philadelphia who have introduced soft coal as a fuel. It is doubtful, however, if there will be as much change made as is expected, as, owing to the scarcity of this fuel and the low price at which some sizes of anthracite can be bought, it is thought many manufacturers who have contemplated a change will not be in a hurry to make it. The bituminous coal trade is quick to go off, and unless the combination of railroads 
that has lately entered into this business takes a firm stand it is not likely, in some sections of this city and the State, that bituminous coal will take the place of anthracite.

The anthracite coal trade, as a whole, was in better shape than it has been for a number of years, and while during the first few months there was a chaotic order of things, the situation cleared and during the last half the trade was at its best. At no time for several years, or since the time when President McLeod of the Philadelphia and Reading Railroad Company attempted to regulate prices, has the trade been in better shape. The production was the largest in the history of the anthracite coal trade, but at the close of the year few of the companies had much stock on hand. The Philadelphia and Reading Coal and Iron Company, which mines the largest amount of coal, had on December 31, 1899, only a small quantity of coal on hand at its various storage yards. At Port Richmond, where there is usually from 250,000 to 300,000 tons, there was not a ton. The shipments from this port to cities and towns was $1,947,483$ tons, as against $1,469,000$ tons in $1898,1,600,000$ tons in 1897 , and $1,770,000$ tons in 1896. This increase was due to the general prosperity throughout the New England States, the demand being greater than the supply. The local consumption of anthracite was placed at $3,457,482$, as against $3,500,000$ tons in 1898 and $3,570,000$ long tons in 1897 . It is, however, believed that, owing to the severe competition of the various coal companies in the city, there was more coal used in 1899 than they accounted for, and that the consumption in this city was equally as large as that of the previous year.

The price circulars of the Philadelphia Coal and Iron Company, which constitute the standard, quoted the following prices:

\begin{tabular}{|c|c|c|c|c|c|c|}
\hline \multirow{2}{*}{ Size. } & \multicolumn{2}{|c|}{1898.} & \multicolumn{4}{|c|}{1899.} \\
\hline & January. & April. & Mareh. & July. & October. & December. \\
\hline Lump and steamboat. & $\$ 2.50$ & $\$ 2.50$ & $\$ 2.50$ & $\$ 2.50$ & $\$ 2.50$ & $\$ 2.50$ \\
\hline Broken........ & 2.50 & 2. 25 & 2.25 & 2. 35 & 2.45 & 2. 45 \\
\hline Egg .. & 2.90 & 2.65 & 2. 40 & 2.60 & 2. 55 & 2.55 \\
\hline Stove.... & 3.00 & 2.75 & 2.50 & 2. 70 & 2.95 & 2.95 \\
\hline Chestuut & 2. 80 & 2.50 & 2.50 & 2.70 & 2.95 & 2.95 \\
\hline Pea .. & 1.50 & 1.50 & 1. 50 & 1.50 & 1. 50 & 1.75 \\
\hline Buckwheat . & .80 & .85 & .85 & .85 & .85 & 1.00 \\
\hline
\end{tabular}

Up to March the 1898 circulars prevailed, and there were circulars issued nearly each month, although the prices did not change much until near the end of the year. The above prices are subject to the usual agents' commission of 15 cents per ton. They are for coal free on board 
cars at the mines, and railroad freight charges must be paid in addition. During the first seven months of the year prices were freely cut. Toward the close of 1899 the market stiffened up, and even the individual operators maintained circular prices. During the last month there was a good demand for nearly all sizes of anthracite coal, and although the weather was moderate the dealers were kept busy. The lowest recorded prices were made in January and February, and from that time on there was a steady advance. In December, $\$ 2.95$ a ton was paid for stove coal, and there were a few orders delivered at a higher price, but outside of the usual commission the dealers and middlemen paid the regular circular prices. The following table shows the actual selling prices of prepared sizes for the years 1896, 1897, 1898, and 1899:

Selling prices of prepared anthracite coal at the mines for Philadelphia for four years.

\begin{tabular}{|c|c|c|c|c|c|}
\hline Month. & Sizes. & 1896. & 1897. & 1898. & 1899. \\
\hline \multirow[t]{5}{*}{ January .... } & Broken. & $\$ 2.25$ & $\$ 2.40$ & $\$ 2.00$ & $\$ 2.10$ \\
\hline & Egg . & 2.65 & 2.80 & 2.40 & 2.15 \\
\hline & Stove & 2.75 & 2.90 & 2.50 & 2.25 \\
\hline & Nut . & 2.50 & 2.65 & 2. 30 & 2.25 \\
\hline & Pea. & 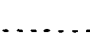 & & & 1.15 \\
\hline \multirow[t]{5}{*}{ February ... } & Broken. & 2.25 & 2. 40 & 2.00 & 2.10 \\
\hline & Egg.... & 2.65 & 2.80 & 2. 40 & 2.15 \\
\hline & Stove . & 2.75 & 2.90 & 2.50 & 2.25 \\
\hline & Nut.. & 2.50 & 2. 65 & 2. 30 & 2.25 \\
\hline & Pea.. & $\ldots$ & $\cdots$ & & 1.15 \\
\hline \multirow[t]{5}{*}{ March.. } & Broken. & 2.25 & 2.40 & 2.00 & . 2.25 \\
\hline & Egg . & 2.65 & 2. 80 & 2.40 & 2.40 \\
\hline & Stove .. & 2. 75 & 2.90 & 2.50 & 2.50 \\
\hline & Nut.... & 2.50 & 2.65 & 2.30 & 2.50 \\
\hline & Pea.... & $\ldots$. & $\cdots$ & & 1.15 \\
\hline \multirow[t]{5}{*}{ April. } & Broken. & 2.25 & 2. 40 & 2.00 & 2.25 \\
\hline & Egg .... & 2.65 & 2. 80 & 2.40 & 2. 40 \\
\hline & Stove .. & 2. 75 & 2. 90 & 2.50 & 2.50 \\
\hline & Nut.... & 2.50 & 2.65 & 2. 30 & 2.50 \\
\hline & Pea .... & $\cdots \ldots$ & $\ldots$. & $\ldots$ & 1.15 \\
\hline \multirow[t]{5}{*}{ May } & Broken. & 2.25 & 2.25 & 2.10 & 2.25 \\
\hline & Egg .... & 2.65 & 2.50 & 2.15 & 2.40 \\
\hline & Stove .. & 2. 75 & 2.75 & 2.25 & 2.50 \\
\hline & Nut .... & 2.50 & 2.65 & 2.10 & 2.50 \\
\hline & Pea .... & & & & 1.15 \\
\hline \multirow[t]{2}{*}{ June... } & Broken. & 2.25 & 2.25 & 2.10 & 2.25 \\
\hline & Egg . . . . & 2.65 & 2.65 & 2.30 & 2.30 \\
\hline
\end{tabular}


Selling prices of prepared anthracite coal at the mines for Philadelphia for four yearsContinued.

\begin{tabular}{|c|c|c|c|c|c|}
\hline Month. & Sizes. & 1896. & 1897. & 1598. & 1899. \\
\hline \multirow{8}{*}{ July } & Stove ..... & $\$ 2.75$ & $\$ 2.75$ & $\$ 2.25$ & $\$ 2.40$ \\
\hline & Nut . . . . . . & 2.50 & 2.50 & 2.10 & 2.40 \\
\hline & Pea ...... & ...... & $\ldots .$. & $\ldots \ldots$ & 1.00 \\
\hline & Broken.... & 2.40 & 2.40 & 2.10 & 2.15 \\
\hline & Egg $\ldots . . .$. & 2.80 & 2.80 & 2.30 & 2.30 \\
\hline & Stove .. & 2.90 & 2.90 & 2.25 & 2. 40 \\
\hline & Nut .... & 2.65 & 2. 65 & 2.10 & 2. 40 \\
\hline & Pea ... & $\ldots \ldots$ & $\ldots \ldots$ & $\ldots \ldots$ & 1.00 \\
\hline \multirow{5}{*}{ August ........... } & Broken.... & 2. 40 & 2.40 & $\cdot 2.00$ & 2.25 \\
\hline & Egg .. & 2.80 & 2.80 & 2.30 & 2. 40 \\
\hline & Stove. & 2.90 & 2.90 & 2.25 & 2.50 \\
\hline & Nut ... & 2.65 & 2.65 & 2.10 & 2.50 \\
\hline & Pea ... & ...... & ...... & $\ldots \ldots . .$. & 1.00 \\
\hline \multirow[t]{5}{*}{ September........ } & Broken.. & 2.50 & 2.40 & 2.00 & 2.25 \\
\hline & Egg .... & 2.90 & 2.80 & 2.30 & 2.50 \\
\hline & Stove... & 3.00 & 2.90 & 2.25 & 2.60 \\
\hline & Nut . . . . . & 2.80 & 2.65 & 2. 10 & 2. 60 \\
\hline & Pea .... & $\ldots . .$. & $\ldots \ldots$ & $\ldots . .$. & 1.00 \\
\hline \multirow[t]{5}{*}{ October ......... } & Broken.... & 2.50 & 2.50 & 2.00 & 2.25 \\
\hline & Egg . . . . & 2. 90 & 2.90 & 2.15 & 2.60 \\
\hline & Stove... & 3.00 & 3.00 & 2.25 & 2.70 \\
\hline & Nut .... & 2. 80 & 2.80 & 2.10 & 2.70 \\
\hline & Pea ... & $\cdots$ & 年 & $\ldots .$. & 1.00 \\
\hline \multirow[t]{5}{*}{ November ....... } & Broken.... & 2.50 & 2.25 & 2.00 & 2. 25 \\
\hline & Egg . . . . & 2.90 & 2.80 & 2.15 & 2.85 \\
\hline & Stove... & 3.00 & 2. 90 & 2.25 & 2.95 \\
\hline & Nut.. & 2.80 & 2.65 & 2. 10 & 2.95 \\
\hline & Pea... & $\ldots .$. & $\ldots .$. & $\ldots . .$. & 1.00 \\
\hline \multirow[t]{5}{*}{ December ....... } & Broken. & 2.50 & 2.25 & 2.00 & 2.25 \\
\hline & Egg ... & 2.90 & 2.80 & 2.15 & 2.85 \\
\hline & Stove...... & 3.00 & 2.90 & 2.25 & 2.95 \\
\hline & Nut ....... & 2.80 & 2.65 & 2.10 & 2.95 \\
\hline & Pea & & & & 1.75 \\
\hline
\end{tabular}


There was no change in freight rates for local delivery during the year. The charges, which vary according to the region from which the shipment is made and according to the size of coal, were as follows:

Freight rates on anthracite coal from regions to Philadelphia.

\begin{tabular}{|c|c|c|c|}
\hline Regions. & $\begin{array}{l}\text { Prepared } \\
\text { sizes. }\end{array}$ & Pea. & Buckwheat. \\
\hline Schuylkill .... & $\$ 1.70$ & $\$ 1.40$. & $\$ 1.25$ \\
\hline Lehigh $\ldots \ldots \ldots \ldots \ldots \ldots \ldots \ldots \ldots$ & 1. 75 & 1.45 & 1.30 \\
\hline Wyoming ..... & 1.80 & 1.50 & 1.35 \\
\hline
\end{tabular}

The consumption of pea coal by the householder grows larger every year, and in 1899 it was greater than ever before. This coal is cheaper and retails from $\$ 1.25$ to $\$ 1.75$ a ton below the selling price of egg coal and chestnut. Formerly it cost the dealer from $\$ 1.10$ to $\$ 1.40$ below the price of stove at the mines. It is used in a large measure by the passenger railway companies at their power houses, at the city pumping stations, at the water department, and in a number of instances by large manufacturers. The bulk of this coal, however, is sold by the dealers for domestic purposes. There was formerly great reluctance to use this coal, as it was full of dirt and slate, but recently the coal companies have made a number of improvements in the machinery for preparing it for the market, and it now comes to the dealer and consumer as uniform in size and free from slate and dirt as the so-called prepared sizes. Notwithstanding there is a disposition on the part of the coal companies to advance the price of this coal, there was little change made until December, when the price at the mines jumped from $\$ 1$ to $\$ 1.75$ a ton. At this time there was a good demand for this coal and the coal companies had trouble in filling their orders. Notwithstanding there was an increase in demand for this coal there was also more of chestnut size used, and this size is finding its way rapidly in every household. Pea coal was at one time more extensively used than it is now by manufacturers, but owing to the increasing demand for domestic purposes and a higher price the manufacturers are burning buckwheat coal, or what is known as No. 2 pea, and in many instances rice size is being used.

The shipments of coal to foreign countries out of this port were smaller than in 1898, which-is due in a measure to the ending of the war between this country and Spain, as at that time large quantities of coal were shipped south to be used on our war vessels. As heretofore, the majority of the anthracite coal exported was shipped to Cuba, 11,386 long tons, with a value of $\$ 35,677$, out of a total of 18,080 tons going to that island. Most of the bituminous coal was also sent to Cuba, a total of 223,008 long tons out of 459,266 tons being 
shipped there. Since the close of the war in Cuba and the starting up of a number of the idle factories there, there was a better demand for our coal. During the latter part of 1899 the supply of vessels for coastwise ports was inadaquate and freight rates were considerably higher, advancing from about 90 cents to $\$ 2.10$ a ton to Buston. To points this side the rate was from 10 to 15 cents less. The cause of this sharp advance in ocean freight rates was the scarcity of vessels, as the demand for all kinds of vessels which carry general merchandise was so great that few could be had to carry coal. During 1899 there was little change made in regard to the manner in which coal was carried to Boston and other New England ports. The railroad companies are constantly increasing their ocean fleets, and it is estimated that at least 80 per cent of the business is done by them. The Reading Company has been foremost in extending its transportation system, and it has a large fleet plying between this city and Boston.

Through the courtesy of the officers of the Pennsylvania Railroad Company, the Philadelphia and Reading Railway Company, and the Baltimore and Ohio Railroad Company, data have been furnished from which the following table has been compiled. It shows the distribution of coal at Philadelphia for the export trade, the coastwise and harbor trade, and the Philadelphia local trade. The figures of 1898 are also given for the purpose of comparison.

Distribution of coal at Philadelphia in 1898 and 1899.

[In tons of 2,240 pounds.]

\begin{tabular}{|c|c|c|c|c|}
\hline & \multicolumn{2}{|c|}{1898.} & \multicolumn{2}{|c|}{1899.} \\
\hline ' & Anthracite. & Bituminous. & Antbracite. & Bituminous. \\
\hline Export $\ldots \ldots \ldots \ldots$ & 12,697 & 476,602 & 18,080 & $4 \dot{5} 9,266$ \\
\hline Coastwise and harbor.. & $1,469,000$ & $3,229,000$ & $1,947,483$ & $3,373,047$ \\
\hline Local......... & $3,500,000$ & $1,451,000$ & $3,457,482$ & $1,482,147$ \\
\hline Total.. & $4,981,697$ & $5,156,602$ & $5,423,045$ & $5,314,460$ \\
\hline
\end{tabular}

\section{PITTSBLRG, PENNSYIVANIA.}

The accompanying statistics, showing the movement of coal in this most important shipping and manufacturing center, have been compiled from reports made to the Surrey by officials of the raiiroads entering Pittsburg and by the United States Army officers in charge of the Monongahela and Ohio River improvements. Although more coal is shipped to and through Pittsburg than is handled in any other city in the United States, there is no local bureau devoted to the collection of statistics of the city's manufacturing and transportation industries. The officials furnishing the information for this report, and to whom special acknowledgment is due, are Mr. J. G. Searles, 
coal freight agent, Pennsylvania Railroad, Philadelphia, Pennsylvania; Mr. W. L. Andrews, assistant coal and coke agent, Baltimore and Ohio Railroad, Pittsburg; Mr. James Means, division freight agent, Pittsburg, Cincinnati, Chicago and St. Louis Ra'lroad, Pittsburg; Mr. Edwin P. Bates, general freight agent, Allegheny Valley Railway, Pittsburg; Mr. F. A. Dean, general freight agent, Pittsburg and Lake Erie Railroad, Pittsburg; Maj. W. H. Bixby, United States Army, in charge of Ohio River improvements; Maj. Charles F. Powell, United States Army, in charge of Monongaheia River improvements.

The total movement of coal to and through Pittsburg in 1899 was $22,784,206$ short tons, an increase of $4,377,120$ tons, or 24 per cent over that of 1898 . The effect of the boom in the iron trade upon the coal is shown in this statement, as in other portions of this report. Pittsburg, as the center of the iron trade of the world, consumes enormous quantities of coal and coke. This statement does not include the coke movement, but it shows that the local consumption of coal at Pittsburg in 1899 increased 3,618,580 tons, about 44 per cent over 1898 .

It will be observed from the following table that 35 per cent of the total receipts and more than 50 per cent of the increases in 1899 were in "river" coal:

Shipments of coal to and through Pittsburg in 1896, 1897, 1898, and 1899.

\begin{tabular}{|c|c|c|c|c|c|c|}
\hline Transportation route. & 1896. & 1897. & 1898. & 1899. & $\begin{array}{c}\text { Increase, } \\
1899 .\end{array}$ & $\begin{array}{l}\text { Decrease, } \\
1899 .\end{array}$ \\
\hline Pennsylvania R. R.: & Tons. & Tons. & Tons. & Tons. & Tons. & Tons. \\
\hline $\begin{array}{r}\text { To Pittsburg and vi- } \\
\text { cinity } \ldots . . . . . . .\end{array}$ & $1,344,685$ & $1,379,718$ & $1,328,540$ & 1. 698,240 & 369,700 & \\
\hline To west of Pittsburg. & 688,740 & $1,206,598$ & $1,283,052$ & $1,459,546$ & 176,494 & \\
\hline \multicolumn{7}{|l|}{ Baltimore and Ohio R.R.: } \\
\hline To Pittsburg district. & 552,031 & $39 \overline{5}, 265$ & 430,139 & 546,679 & 116,540 & \\
\hline To west of Pittsburg. & 839,145 & 581,851 & 656,345 & 950,632 & 294,287 & \\
\hline $\begin{array}{l}\text { Pittsburg, Cincinnati, } \\
\text { Chicago, and St. Louis }\end{array}$ & & & & & & \\
\hline R. R. $a \ldots \ldots \ldots \ldots$ & $2,585,547$ & $2,369,022$ & $2,783,816$ & $3,322,227$ & $53 \dot{8}, 411$ & \\
\hline \multicolumn{7}{|l|}{ Allegheny Valley Rwy.: $b$} \\
\hline To Pittsburg district. & 162,945 & 125,445 & 125,180 & 145,924 & 20,744 & \\
\hline To west of Pittsburg. & 64,887 & 20,721 & 39,977 & 6,332 & $\ldots . .$. & 33,045 \\
\hline \multicolumn{7}{|l|}{$\begin{array}{l}\text { P'ittsburg and Lake Erie } \\
\text { R. R.: }\end{array}$} \\
\hline Local and Pittsburg. & $1,524,357$ & $1,506,296$ & $1,880,000$ & $2,125,173$ & 245,173 & \\
\hline To west of Pittsburg. & $3,048,715$ & $3,012,591$ & $3,759,237$ & $4,250,346$ & 491,109 & \\
\hline \multicolumn{7}{|l|}{$\begin{array}{l}\text { Monongahela River } \\
\text { locks: }\end{array}$} \\
\hline To Pittsburg district. & $1,607,062$ & $2,619,469$ & $3,141,306$ & $5,569,967$ & $2,428,661$ & \\
\hline \multirow{2}{*}{$\begin{array}{c}\text { To west of Pittsburg. } \\
\text { Total shipments... }\end{array}$} & $4,102,190$ & $2,670,369$ & $2,979,494$ & $2,709,140$ & 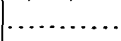 & $270,3 \overline{5} 4$ \\
\hline & $16,620,304$ & $15,887,345$ & $\overline{18,407,086}$ & $22,784,206$ & $\overline{c 4,377,120}$ & \\
\hline West of Pittsburg $a$ & $10,295,005$ & $8,661,152$ & $10,218,105$ & $10,976,645$ & 758,540 & \\
\hline Local consumption & 6,325 & $7,226,193$ & $8,188,981$ & $11,807,561$ & $3,618,580$ & \\
\hline
\end{tabular}

aShipments over the Pittsburg, Cincinnati, Chicago and St. Louis Railroad are separated in the same ratio as the totals of other lines. Total shipments only over this line were reported.

$b$ Coal originating on this road only. Does not include coal received from the Pennsylvania Railroad and forwarded over the Allegheny Valley Railway.

cNet increase. 


\section{MONONGAHELA RIVER SHIPNENTS.}

Maj. Charles F. Powell, Corps of Engineers, U. S. A., in charge of Monongahela River improvement, reports the tonnage passing through the locks in 1899 at $8,279,107$ tons of 2,000 pounds. Maj. W. H. Bixby, in charge of Ohio River improvement, reports that 2,709,140 tons passed through Davis Island dam. The difference between these amounts $(5,569,967$ tons) represents approximately the amount of river coal consumed at Pittsburg.

Movements of coal through Monongahela River locks and Davis Island dam.

\begin{tabular}{|c|c|c|c|}
\hline Year. & $\begin{array}{l}\text { Passed through } \\
\text { locks on Mononga- } \\
\text { hela River. }\end{array}$ & $\begin{array}{c}\text { Passed Davis Is- } \\
\text { land dam, Ohio } \\
\text { River, near Pitts- } \\
\text { burg. (From an- } \\
\text { nual reports, Ohio } \\
\text { River improve- } \\
\text { ment.) }\end{array}$ & $\begin{array}{l}\text { Difference, approx- } \\
\text { imate consumption } \\
\text { of river coll at } \\
\text { Pittsburg. }\end{array}$ \\
\hline 1890. & $\begin{array}{l}\text { Tons. } \\
4,652,104\end{array}$ & $\begin{array}{l}\text { Tons. } \\
3,420,357\end{array}$ & $\begin{array}{l}\text { Tons. } \\
1,231,747\end{array}$ \\
\hline 1891 & $4,276,588$ & $2,893,752$ & $1,382,836$ \\
\hline 1892. & $3,872,340$ & $2,299,294$ & $1,573,046$ \\
\hline 1893. & $3,860,072$ & $2,364,401$ & $1,495,671$ \\
\hline 1894. & $4,649,612$ & $2,453,787$ & $2,195,825$ \\
\hline 1895 & $4,183,596$ & $2,393,873$ & $1,789,723$ \\
\hline 1896. & $5,709,252$ & $4,102,190$ & $1,607,062$ \\
\hline 1897. & $5,289,838$ & $2,670,369$ & $2,619,469$ \\
\hline 1898. & $6,120,800$ & $2,979,494$ & $3,141,306$ \\
\hline $1899 \ldots$ & $8,279,107$ & $2,709,140$ & $5,569,967$ \\
\hline
\end{tabular}

\section{RECEIPTS AND SHIPMENTS BY RAIL.}

The following tables show the receipts and shipments of coal by railroads entering the Pittsburg district:

Receipts of coal via Pennsylvania Railroad in 1896, 1897, 1898, and 1899.

\begin{tabular}{|r|r|c|c|c|}
\hline To- & 1896. & 1897. & 1898. & 1899. \\
\hline & \multicolumn{1}{c|}{ Tons. } & Tons. & Tons. & Tons. \\
Pittsburg and vicinity .... & $1,344,685$ & $1,379,718$ & $1,328,540$ & $1,698,240$ \\
West of Pittsburg ........ & 688,740 & $1,206,598$ & $1,283,052$ & $1,459,546$ \\
Total.............. & $2,033,425$ & $2,586,316$ & $2,611,592$ & $3,157,786$ \\
\hline
\end{tabular}


Shipments of coal and coke via Baltimore and Ohio Railroad to and through Pittsburg.

\begin{tabular}{|c|c|c|c|c|}
\hline \multirow{2}{*}{ Year. } & \multicolumn{2}{|c|}{ Pittsburg district. } & \multicolumn{2}{|c|}{ Via Pittsburg to all points. } \\
\hline & Coal. & Coke. & Coal. & Coke. \\
\hline & Tons. & Tons. & Tons. & Tons. \\
\hline $1896 \ldots \ldots \ldots \ldots \ldots \ldots$ & 552,031 & 447,866 & 839,145 & 727,219 \\
\hline $1897 \ldots$ & 395,265 & 487,745 & 581,851 & $1,020,430$ \\
\hline $1898 \ldots$ & 430,139 & 437,343 & $656,3+5$ & $1,610,759$ \\
\hline $1899 \ldots .$. & 546,679 & 549,086 & 950,632 & $1,478,768$ \\
\hline
\end{tabular}

Shipments of coal via Allegheny Valley Railway to and through Pittsburg.

\begin{tabular}{|c|c|c|c|}
\hline Year. & $\begin{array}{l}\text { Pittsburg dis- } \\
\text { trict. }\end{array}$ & $\begin{array}{l}\text { Via Pittsburg } \\
\text { to all points. }\end{array}$ & Total. \\
\hline & Tons. & Tons. & Tons. \\
\hline 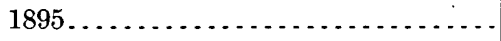 & 162,600 & 33,399 & 195,999 \\
\hline $1896 \ldots \ldots \ldots$ & 162,945 & 64,887 & 227,832 \\
\hline $1897 \ldots$ & 125,445 & 20,721 & 146,166 \\
\hline 1898. & 125,180 & 39,977 & 165,157 \\
\hline $1899 \ldots \ldots \ldots \ldots \ldots \ldots$ & 145,924 & 6,332 & 152,256 \\
\hline
\end{tabular}

Shipments of coal over the Pittsburg and Lake Erie Railroad.

\begin{tabular}{|c|c|}
\hline Year. & Tons. \\
\hline $1895 \ldots \ldots \ldots \ldots \ldots$ & $3,546,598$ \\
\hline $1896 \ldots \ldots$ & $4,573,072$ \\
\hline 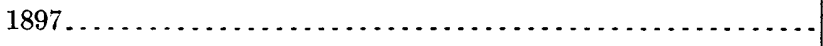 & $4,518,887$ \\
\hline $1898 \ldots \ldots \ldots \ldots \ldots \ldots$ & $5,639,237$ \\
\hline 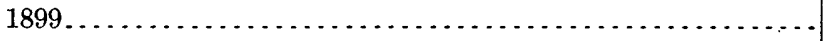 & $6,375,519$ \\
\hline
\end{tabular}

Shipments of coal over the Pittsburg, Cincinnati, Chicago and St. Louis Railroad.

\begin{tabular}{|c|c|}
\hline Year. & Tons. \\
\hline 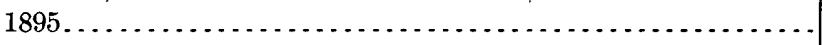 & $2,417,096$ \\
\hline $1896 \ldots \ldots \ldots \ldots \ldots \ldots$ & $2,585,547$ \\
\hline$\ldots \ldots \ldots \ldots \ldots \ldots \ldots \ldots \ldots . \ldots \ldots$ & $2,369,022$ \\
\hline 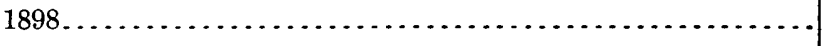 & $2,783,816$ \\
\hline 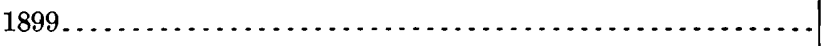 & $3,322,227$ \\
\hline
\end{tabular}

21 GEOL, PT $6-26$ 


\section{CLEVELAND, OHIO.}

The following summary of the coal trade of Cleveland has been prepared for this report by Mr. F. A. Scott, secretary of the Chamber of Commerce.

The Cleveland coal market for the year 1899 was very erratic as to price, ruling very low during the first eight months of the year, more particularly during June, July, and August, the supply exceeding the demand; but commencing in September a strong demand was created by reason of all the factories and iron works running to their capacity. This, together with the inadequate car supply and extraordinary heavy demand for domestic purposes, created almost a famine during the months of October and November, when prices were higher than at any time for many years, excepting during the memorable miners' strikes of 1894 and 1897.

The price obtained for Ohio coals during the fall of 1899 was helped and the Ohio tonnage increased by reason of the great demand made by the East on Pittsburg and the West Virginia fields, keeping a large tonnage out of Ohio markets. Labor troubles were not numerous during 1899 on account of the interstate agreement of operators and miners.

Coal and coke receipts and shipments at Cleveland since $188 \%$.

\begin{tabular}{|c|c|c|c|c|}
\hline \multicolumn{5}{|c|}{ RECEIPTS. } \\
\hline & 1887. & 1888. & 1889. & 1890. \\
\hline & Tons. & Tons. & Tons. & Tons. \\
\hline Bituminous . . . . . . . . & $1,454,744$ & $1,737,781$ & $1,600,000$ & $1,560,208$ \\
\hline Anthracite......... & 176,769 & 181,551 & 160,000 & 205,856 \\
\hline Coke. & 114,924 & 124,827 & 150,000 & 194,527 \\
\hline Total . & $1,746,437$ & $2,044,159$ & $1,910,000$ & $1,960,591$ \\
\hline \multicolumn{5}{|c|}{ SHIPMENTS. } \\
\hline Anthracite by rail. & 20,296 & 29,735 & 25,000 & 29,056 \\
\hline $\begin{array}{l}\text { Bituminous by rail. } \\
\text { Bituminous by lake. }\end{array}$ & 703,506 & $1,000,000$ & $1,100,000$ & $1,200,000$ \\
\hline Total... & 723,802 & $1,029,735$ & $1,125,000$ & $1,229,056$ \\
\hline
\end{tabular}


COAL.

Coal and coke receipts and shipments at Cleveland since 188\%-Continued.

\begin{tabular}{|c|c|c|c|c|}
\hline \multicolumn{5}{|c|}{ RECEIPTS. } \\
\hline & 1891. & 1892. & 1893. & 1894. \\
\hline $\begin{array}{l}\text { Bituminous } \ldots \ldots \ldots \\
\text { Anthracite } \ldots \ldots \\
\text { Coke } \ldots \ldots \ldots \ldots\end{array}$ & $\begin{array}{c}\text { Tons. } \\
2,838,586 \\
201,927 \\
189,640\end{array}$ & $\begin{array}{c}\text { Tons. } \\
3,651,080 \\
259,150 \\
351,527\end{array}$ & \begin{tabular}{|r} 
Tons. \\
$3,603,984$ \\
262,266 \\
235,248
\end{tabular} & $\begin{array}{c}\text { Tons. } \\
2,715,540 \\
207,604 \\
298,061\end{array}$ \\
\hline Total .............. & $3,230,153$ & $4,261,757$ & $4 ; 101,498$ & $3,221,205$ \\
\hline \multicolumn{5}{|c|}{ SHIPMENTS. } \\
\hline $\begin{array}{l}\text { Anthracite by rail... } \\
\text { Bituminous by rail .. } \\
\text { Bituminous by lake } \\
\text { Coke by rail ........ }\end{array}$ & $\begin{array}{r}34,910 \\
1,525,000\end{array}$ & $\begin{array}{r}50,742 \\
1,728,831\end{array}$ & $\left\{\begin{array}{r}49,497 \\
24,128 \\
1,257,326 \\
\hdashline \ldots\end{array}\right.$ & $\begin{array}{r}44,177 \\
30,000 \\
1,106,000 \\
42,048\end{array}$ \\
\hline Total. . & $1,559,910$ & $1,779,573$ & $1,330,951$ & $1,222,225$ \\
\hline
\end{tabular}

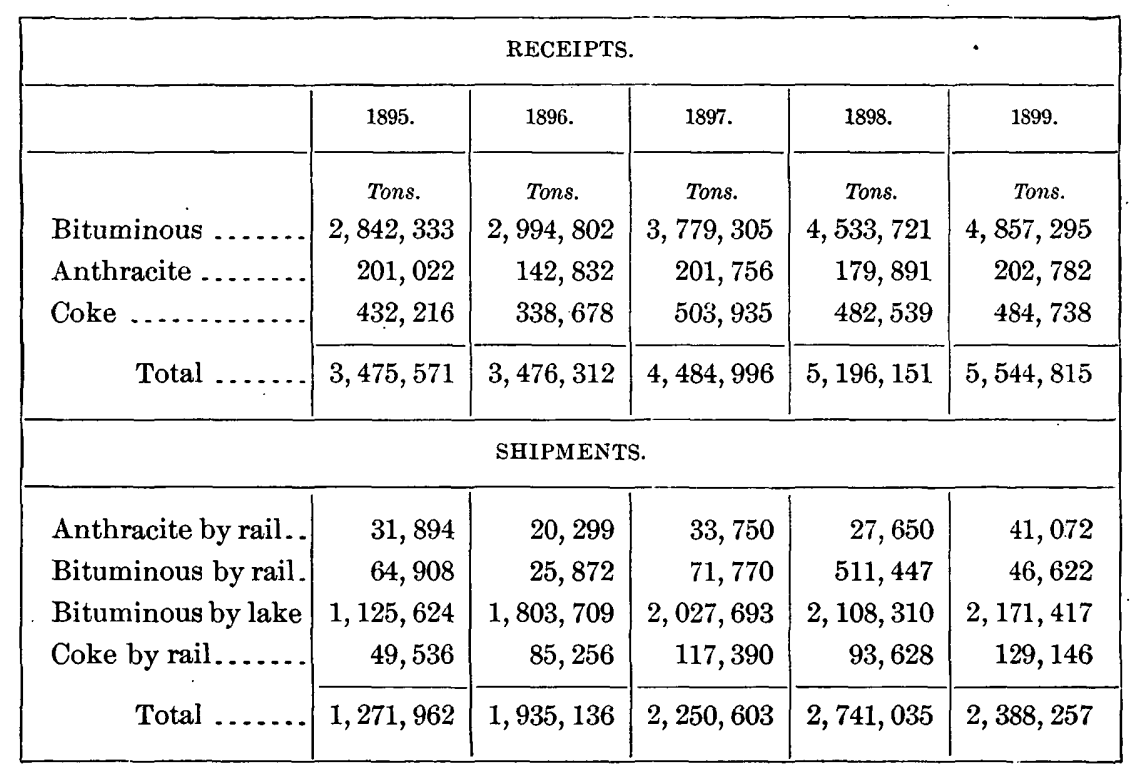


MINERAL RESOURCES.

Clearances of coal from the Cuyahoga(Ohio) district for thirteen years.

\begin{tabular}{|c|c|c|c|}
\hline Year. & Tons. & Year. & Tons. \\
\hline $1887 \ldots \ldots \ldots \ldots$ & $1,433,035$ & $1894 \ldots \ldots \ldots \ldots \ldots$ & $2,239,829$ \\
\hline $1888 \ldots \ldots \ldots$ & $1,855,260$ & $1895 \ldots \ldots \ldots$ & $2,948,324$ \\
\hline $1889 \ldots$ & $2,020,996$ & 1896. & $3,863,645$ \\
\hline $1890 \ldots . . .$. & $2,328,663$ & $1897 \ldots \ldots \ldots \ldots$ & $3,613,245$ \\
\hline $1891 \ldots \ldots \ldots \ldots$ & $2,635,461$ & $1898 \ldots$ & $3,844,239$ \\
\hline $1892 \ldots$ & $2,957,988$ & $1899 \ldots \ldots \ldots \ldots \ldots$ & $4,062,869$ \\
\hline $1893 \ldots \ldots \ldots$ & $3,052,342$ & & \\
\hline
\end{tabular}

TOLEDO, OHIO. ${ }^{1}$

The receipts of coal at Toledo in 1899 were within a small quantity of the aggregate of 1898 , which was 432,000 tons greater than any preceding year. Naturally an increase in the receipts for 1899 was looked for, and the reasons for a deficiency are found in the disturbed condition of lake transportation and large advance in cost of freight, which seriously lessened the demand. There appears to be no reason for expecting a decreased movement from this port, and as the harbor improvement progresses it is anticipated that both coal and iron ore will be attracted to Toledo. The receipts of coal at Toledo for a series of years are shown in the following table.

Coal receipts at Toledo since 1894.

\begin{tabular}{|c|c|c|c|c|c|c|}
\hline Railroad. & 1894. & 1895. & 1896. & 1897. & 1898. & 1899. \\
\hline & Shorttons. & Short tons. & Shorttons. & Short tons. & Short tons. & Short tons. \\
\hline Wabash R.R... & & 1,000 & 5,000 & 6,000 & 10,000 & 10,000 \\
\hline $\begin{array}{c}\text { Lake Shore and Michigan } \\
\text { Southern Rwy ................ }\end{array}$ & 22,126 & 38,000 & 44,000 & 50,000 & 60,000 & 75,000 \\
\hline 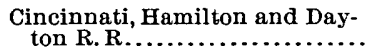 & 72,000 & 30,000 & 35,000 & 40,000 & 50,000 & 60,000 \\
\hline Pennsylvania Co.............. & 78,792 & & 529,968 & 573,000 & 782,000 & 838,736 \\
\hline 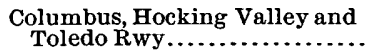 & 540,000 & 500,000 & 850,000 & 730,000 & $1,100,000$ & $1,200,000$ \\
\hline Toledo and Ohio Central Rwy.. & 767,670 & 721,914 & 705,272 & 777,129 & 883,692 & $1,039,000$ \\
\hline Lake........................ & 116,000 & 124,000 & 119,000 & 88,705 & 90,000 & 70,000 \\
\hline Wheeling and Lake Erie Rwy .. & 914,220 & 520,000 & 646,471 & 720,000 & 901,986 & 545,000 \\
\hline Total. & $2,510,808$ & $1,934,914$ & $2,934,711$ & $2,984,834$ & $3,877,678$ & $3,837,736$ \\
\hline
\end{tabular}

1 From the annual report of Denison B. Smith, Secretary, Produce Exchange. 
The total coal receipts at Toledo during the past fourteen years have been as follows:

Total coal receipts at Toledo since 1886.

\begin{tabular}{|c|c|c|c|}
\hline Year. & Short tons. & Year. & Short tons. \\
\hline $1886 \ldots$ & $2,340,859$ & $1893 \ldots$ & $3,445.995$ \\
\hline 1887. & $2,695,713$ & $1894 \ldots$ & $2,510,808$ \\
\hline $1888^{\circ}$. & $3,524,785$ & 1895 & $1,934,914$ \\
\hline 1889. & $2,840,314$ & $1896 \ldots$ & $2,934,711$ \\
\hline 1890. & $3,021,886$ & $1897 \ldots$ & $2,984,834$ \\
\hline $1891 .$. & $2,754,943$ & 1898 & $3,877,678$ \\
\hline 1892. & $2,291,355$ & 1899 & $3,837,736$ \\
\hline
\end{tabular}

\section{CHICAGO, ILLINOIS.}

The following tables are condensed from the statistical tables compiled by the Chicago Bureau of Coal Statistics and published in the Black Diamond. Anthracite receipts by lake fell off about 87,000 tons from 1898, but this was more than made up by an increase of over 392,000 tons in rail receipts. The total receipts of anthracite show a net gain of 305,696 tons.

Receipts of anthracite coal at Chicago in 1898 and 1899, by months.

\begin{tabular}{|c|c|c|c|c|}
\hline \multirow{2}{*}{ Month. } & \multicolumn{2}{|c|}{ Anthracite by lake. } & \multicolumn{2}{|c|}{ Anthracite by rail. } \\
\hline & 1898 & 1899. & 1898. & 1899. \\
\hline January .. & Tons. & Tons. & $\begin{array}{c}\text { Tons. } \\
43,066\end{array}$ & $\begin{array}{c}\text { Tons. } \\
87,204\end{array}$ \\
\hline February ... & $\ldots$ & 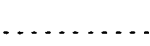 & 44,478 & 85,566 \\
\hline March..... & ...... & .. & 35,681 & 84,679 \\
\hline April... & 60,798 & 4,251 & 13,468 & 89,180 \\
\hline May ..... & $.140,260$ & 142,226 & 15,763 & 37,039 \\
\hline June ... & 92,772 & 174,376 & 17,979 & 25,975 \\
\hline July... & 93,551 & 128,118 & 54,499 & 45,030 \\
\hline August . & 248,304 & 153,807 & 70,633 & 73,202 \\
\hline September.. & 197,546 & 140,397 & 53,637 & 121,785 \\
\hline October ....... & 164,779 & 223,195 & 54,107 & 106,344 \\
\hline November.... & 228,143 & 180,480 & 48,449 & 67,923 \\
\hline December .... & 88,193 & 80,722 & 74,752 & 95,055 \\
\hline Total . & $1,314,346$ & $1,227,572$ & 526,512 & 918,982 \\
\hline
\end{tabular}


Receipts of anthracite coal at Chicago in 1898 and 1899, by months-Continued.

\begin{tabular}{|c|c|c|c|c|}
\hline \multirow{2}{*}{ Month. } & \multicolumn{2}{|c|}{ Total anthracite. } & \multicolumn{2}{|c|}{1899.} \\
\hline & 1898. & 1899. & Increase. & Decrease. \\
\hline & Tons. & Tons. & Tons. & Tons. \\
\hline January .... & 43,066 & 87,204 & 44,138 & \\
\hline February .. & 44,478 & 85,566 & 41,088 & \\
\hline March... & 35,681 & 84,679 & 48,998 & \\
\hline April......... & 74,266 & 93,431 & 19,165 & \\
\hline May..... & 156,023 & 179,265 & 23,242 & \\
\hline June .. & 110,751 & 200,351 & 89,600 & \\
\hline July.... & 148,050 & 173,148 & 25,098 & 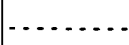 \\
\hline August . & 318,937 & 227,009 & - . . . & 91,928 \\
\hline September... & 251,183 & 262,182 & 10,999 & $\cdots$ \\
\hline October & 218,886 & 329,539 & 110,653 & . \\
\hline November... & 276,592 & 248,403 & $\ldots \ldots \ldots$ & 28,189 \\
\hline December ...... & 162,945 & 175,777 & 12,832 & 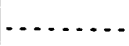 \\
\hline Total . & $1,840,858$ & $2,146,554$ & 305,696 & \\
\hline
\end{tabular}

The receipts of bituminous coal, practically all of which is by rail, together with the States from which shipped, is shown in the following table. A remarkable increase of $1,486,727$ tons, or nearly 30 per cent, is exhibited. The greatest proportionate increase was from Ohio mines, the operators in that State seeming to have taken hold of Chicago markets with a fresh grip. The receipts from Ohio increased more than 125 per cent over 1898. Receipts from West Virginia and Kentucky increased 69 per cent; from Indiana, 25 per cent; from Pennsylvania, 25 per cent, and from Illinois, 20 per cent. Indiana shipped the largest increase tonnage into Chicago, with Illinois second. More than 70 per cent of the coal received in Chicago is from mines in Illinois and Indiana, and more than 40 per cent is from Illinois alone. Coke receipts fell off 408,335 tons, or nearly 40 per cent.

Receipts of bituminous coal and coke at Chicago for four years.

\begin{tabular}{|c|c|c|c|c|c|}
\hline State from which received. & 1896. & 1897. & 1898. & 1899. & $\begin{array}{l}\text { Increase } \\
\text { in } 1899 .\end{array}$ \\
\hline \multirow{7}{*}{ 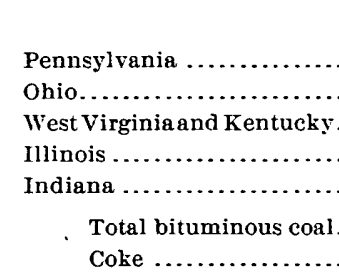 } & $\begin{array}{l}\text { Tons. } \\
184,655\end{array}$ & $\begin{array}{l}\text { Tons. } \\
211,158\end{array}$ & $\begin{array}{l}\text { Tons. } \\
410,801\end{array}$ & $\begin{array}{c}\text { Tons. } \\
a 516,087\end{array}$ & $\begin{array}{c}\text { Tons. } \\
105,286\end{array}$ \\
\hline & 330,837 & 313,632 & 240,592 & 550,157 & 309,565 \\
\hline & 394,549 & 649,441 & 475,738 & 805,122 & 329,384 \\
\hline & $2,589,737$ & $2,628,384$ & $2,275,118$ & $2,618,309$ & 343,191 \\
\hline & $1,351,848$ & $1,571,237$ & $1,574,530$ & $1,973,831$ & 399,301 \\
\hline & $4,851,626$ & $5,373,852$ & $4,976,779$ & $6,463,506$ & $1,486,727$ \\
\hline & 397,811 & 527,608 & 928,893 & 520,558 & $b 408,335$ \\
\hline
\end{tabular}

a Recejpts by lake, included in this amount, were 75,277 tons. $b$ Decrease. 
MILWAUKEE, WISCONSIN.

Mr. William J. Langson, secretary of the chamber of commerce, has prepared the following statement of the coal trade of that city:

The coal trade of Milwaukee for 1899 surpassed the record of all previous years, notwithstanding the fact that the scarcity of lake tonnage materially curtailed the supply. Receipts by lake and rail for the year were $1,919,864$ tons, an increase of 230,803 tons compared with the gross receipts of 1898 . The arrivals by lake amounted to $1,775,767$ net tons, consisting of 922,321 tons of anthracite or hard coal and 853,446 tons of bituminous or soft coal. Assuming the receipts by rail to have been all soft coal, the total receipts of the latter were equivalent to 997,543 tons.

A comparison of the lake receipts of hard and soft coal with 1898 shows an increase in the former of 154,171 tons and a decrease in the latter of 67,465 tons, making the net increase of arrivals by lake 86,706 tons.

While the total receipts of coal at Milwaukee in 1899 increased 230,803 tons and shipments by rail westward decreased 106,143 tons, the local yards were almost completely denuded of stocks before the opening of navigation, indicating a large increase in local consumption. Deducting from the total receipts the westward shipments, we have $1,346,149$ tons, representing approximately the local consumption of coal at Milwaukee.

- Total receipts of coal at Milwaukee, Wisconsin, for five years.

\begin{tabular}{|c|c|c|r|r|c|}
\hline Kind. & 1895. & 1896. & 1897. & 1898. & 1899. \\
\cline { 2 - 5 } & Short tons. & Short tons. & Short tons. & Short tons. & Short tons. \\
Anthracite........ & 853,680 & 813,487 & 645,432 & 768,150 & 922,321 \\
Bituminous ....... & 592,743 & 774,308 & 910,376 & 920,911 & 997,543 \\
\hline Total........ & $1,446,423$ & $1,587,795$ & $1,555,808$ & $1,689,061$ & $1,919,864$ \\
\hline
\end{tabular}

Deducting from the total receipts the amount forwarded westward by rail from this point shows that the local consumption of coal at Milwaukee in 1899 was approximately $1,346,149$ tons. 
A comparison of the receipts of coal at Milwaukee by decades with those of 1899 is interesting and is shown in the following table:

Growth of the coal trade of Milwaukee.

\begin{tabular}{|c|c|}
\hline Year: & Receipts. \\
\hline & Short tons. \\
\hline 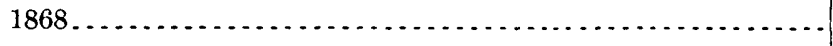 & 92,992 \\
\hline 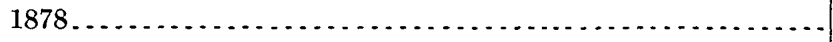 & 239,667 \\
\hline 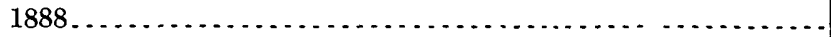 & $1,122,243$ \\
\hline 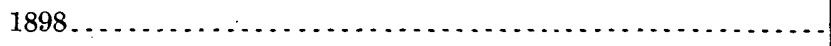 & $1,689,061$ \\
\hline 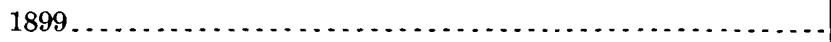 & $1,919,864$ \\
\hline
\end{tabular}

The tables following exhibit the details of receipts and shipments at Milwaukee for a series of years:

Receipts of coal at Milwaukee for six years.

\begin{tabular}{|c|c|c|c|c|c|c|}
\hline Source. & 1894. & 1895. & 1896. & 1897. & 1898. & 1899. \\
\hline By lake from- & Short tons. & Short tons. & Short tons. & Short tons. & Short tons. & Short tons. \\
\hline Buffalo... & 658,978 & 755,831 & 745,870 & 545,219 & 624,616 & 797,006 \\
\hline Erie ..... & 97,995 & 86,332 & 19,879 & 92,370 & 134,774 & 273,779 \\
\hline Oswego.... & 41,891 & 33,364 & 60,309 & $.38,319$ & 37,000 & 2,590 \\
\hline Cleveland & 105,800 & 105,469 & 232,689 & 305,435 & 341,898 & 354,900 \\
\hline Ashtabula . & 58,179 & 99,521 & 114,625 & 132,103 & 115,579 & 94,284 \\
\hline Lorain...... & 22,552 & 27,017 & 40,460 & 13,887 & 11,855 & 24,177 \\
\hline Sandusky . & 7,250 & 5,179 & 28,238 & 42,555 & 29,572 & 27,991 \\
\hline Toledo..... & 90,357 & 74,603 & 114,501 & 216,318 & 243,818 & 131,047 \\
\hline Charlotte. & $\ldots \ldots \ldots$ & 1,153 & ..... & ......... & 1,275 & 613 \\
\hline Fairport. & 122,573 & 126,955 & 97,532 & 44,621 & 37,094 & 38,530 \\
\hline Ogdensbuirg . & 2,065 & ........ & 2,800 & ......... & 1,133 & . \\
\hline Huron, Ohio...... & 3,275 & 11,229 & 29,605 & 44,378 & 4,159 & 5,400 \\
\hline Other ports.... & 18,395 & 9,950 & 975 & 18,323 & 4,192 & 25,450 \\
\hline Total, lake & $1,229,310$ & $1,336,603$ & $1,487,483$ & $1,493,528$ & $1,586,965$ & $1,775,767$ \\
\hline By railroad.... & 107,736 & 109,920 & 100,312 & 62,280 & 102,096 & 144,097 \\
\hline Receipts. & $1,337,046$ & $1,446,423$ & $1,587,795$ & $1,555,808$ & $1,689,061$ & $1,919,864$ \\
\hline
\end{tabular}

Shipments of coal from Milwankee for six years.

\begin{tabular}{|c|c|c|c|c|c|c|}
\hline Shipped by- & 1894. & 1895. & 1896. & 1897. & $1 \mathrm{~s} 9 \mathrm{~s}$. & 1899. \\
\hline $\begin{array}{l}\text { Chicago, Milwaukee and } \\
\text { St. Paul Rwy................ }\end{array}$ & $\begin{array}{c}\text { Short tons. } \\
246, \hat{0} 20\end{array}$ & $\begin{array}{c}\text { Short tons. } \\
398,053\end{array}$ & $\begin{array}{l}\text { Short tons. } \\
264,650\end{array}$ & $\begin{array}{c}\text { Short tons. } \\
362,751\end{array}$ & $\begin{array}{c}\text { Short toms. } \\
398,668\end{array}$ & $\begin{array}{l}\text { Short tons. } \\
327,369\end{array}$ \\
\hline Chicago and North western & & & & & & \\
\hline Rwy..................... & 167,753 & 221,257 & 169,409 & 247,979 & 245,472 & 210,495 \\
\hline Wisconsin Central R. R... & 12,377 & 17,990 & 12,318 & 42,017 & 31,538 & 35,851 \\
\hline Lake .... & 6,018 & 3,070 & 306 & 120 & 4,180 & \\
\hline Total .. & 432,768 & 640,470 & 446,683 & 652,867 & 679,858 & 573,715 \\
\hline
\end{tabular}


Receipts of coal at Miluaukee by luke and rail annually from 1862 to 1899, inclusive.

\begin{tabular}{|c|c|c|c|}
\hline Year. & Tons. & Year. & Tons. \\
\hline $1862 \ldots \ldots \ldots \ldots$ & 21,860 & $1881 \ldots \ldots \ldots \ldots$ & 550,027 \\
\hline $1863 \ldots \ldots \ldots$ & 43,215 & 1882 & 593,842 \\
\hline $1864 \ldots \ldots \ldots$ & 44,503 & 1883 & 612,584 \\
\hline 1865. & 36,369 & 1884 & 704,166 \\
\hline $1866 \ldots$ & 66,616 & 1885 & 775,750 \\
\hline 1867 & 74,568 & 1886 & 759,681 \\
\hline 1868. & 92,992 & $1887 \ldots$ & 842,979 \\
\hline$\ldots \ldots . . .$. & $8 \bar{t}, 690$ & $1888 \ldots \ldots \ldots \ldots$ & $1,122,243$ \\
\hline 1870 & 122,865 & 1889 & 980,678 \\
\hline $1871 \ldots$ & 175,526 & $1890 \ldots$ & 996,657 \\
\hline $1872 \ldots \ldots \ldots \ldots \ldots$ & 210,194 & $1891 \ldots \ldots$ & $1,156,033$ \\
\hline $1873 \ldots$ & 229,784 & 1892 & $1,374,414$ \\
\hline 1874 & 177,655 & $1893 \ldots \ldots$ & $1,249,732$ \\
\hline 1875 & 228,674 & $1894 \ldots \ldots \ldots$ & $1,337,046$ \\
\hline $1876 \ldots \ldots \ldots$ & 188,444 & $1895 \ldots \ldots$. & $1,446,423$ \\
\hline $1877 \ldots$ & 264,784 & $1896 \ldots . .$. & $1,587,795$ \\
\hline $1878 \ldots$ & 239,667 & $1897 \ldots . .$. & $1,555,808$ \\
\hline $1879 \ldots \ldots \ldots \ldots$ & 350,840 & $1898 \ldots \ldots$ & $1,689,061$ \\
\hline 1880 & 368,568 & 1899 & $1,919,864$ \\
\hline
\end{tabular}

Freight rates from Buffalo to upper lake ports in 1899.

\begin{tabular}{|c|c|c|c|c|}
\hline Month. & Chicago. & Milwaukee. & $\begin{array}{l}\text { Duluth and } \\
\text { Superior. }\end{array}$ & Gladstone \\
\hline April. . & $\$ 0.30$ & $\$ 0.30$ & $\$ 0.30$ & $\$ 0.30$ \\
\hline May... & $\$ 0.30$ to .50 & $\$ 0.30$ to .50 & .30 & $\$ 0.30$ to .40 \\
\hline June ... & .50 & .50 & $\$ 0.30$ to .40 & .40 \\
\hline July ... & .50 to .60 & .50 to .60 & .40 & .40 \\
\hline August .... & .60 to .80 & .60 tơ .80 & 40 to .60 & .40 to .60 \\
\hline September. . & .80 to 1.00 & .80 to 1.00 & .60 & .60 \\
\hline October ........ & .75 to 1.00 & .75 to 1.00 & .50 to .60 & .60 \\
\hline November to close. & .75 to 1.00 & .75 to 1.00 & & \\
\hline
\end{tabular}


Yard prices per ton of coal at Milwaukee during the year 1899, reported by $R . P$. Elmore Company.

\begin{tabular}{|c|c|c|c|c|c|}
\hline \multirow{2}{*}{ Month. } & \multicolumn{2}{|c|}{ House use. } & \multicolumn{2}{|c|}{ Cannel. } & \multirow{2}{*}{$\begin{array}{c}\text { Steam coal, Ohio and } \\
\text { Erie. }\end{array}$} \\
\hline & $\begin{array}{l}\text { Lackawana and } \\
\text { Scranton. }\end{array}$ & Pocahontas. & $\begin{array}{l}\text { Bird's- } \\
\text { eye. }\end{array}$ & Rutts. & \\
\hline January .... & $\$ 5.50$ & $\$ 4.50$ & $\$ 7.50$ & $\$ 6.50$ & $\$ 2.75$ to $\$ 2.90$ \\
\hline February ... & $\$ 5.75$ to 6.50 & $\$ 4.50$ to 4.75 & 7.50 & 6.50 & 2.75 to 2.90 \\
\hline March..... & 6.50 & 4.75 & 7.50 & 6.50 & 2.75 to 2.90 \\
\hline April... & 6.50 & 4.75 & 7.50 & 6.50 & 2.75 to 2.90 \\
\hline May .... & 6.00 & 4.75 & 7.50 & 6.50 & 2.75 to 2.90 \\
\hline June .... & 6.00 & 4.75 & 7.50 & 6.50 & 2.40 to 2.65 \\
\hline July ..... & 6.25 & 4.75 & 7.50 & 6.50 & 2.40 to 2.65 \\
\hline August ..... & 6.25 & 4.75 & 7.50 & 6.50 & 3.20 to 3.35 \\
\hline September.. & 6.75 & 4.75 & 7.50 & 6.50 & 3.45 to 3.60 \\
\hline October & 7.00 & 5. 25 & $\overline{7.50}$ & 6.50 & 3.45 to 3.60 \\
\hline November.. & 7.00 & 5.75 & 7.50 & 6.50 & 3.95 to 4.10 \\
\hline December .. & 7.00 & 5.75 & $\bar{i} .50$ & 6.50 & 3.95 to 4.10 \\
\hline
\end{tabular}

\section{CINCINNATI, OHIO.}

The Survey is indebted to Mr. Charles B. Murray, superintendent of the Chamber of Commerce, for the following review of the coal trade at Cincinnati:

Cincinnati is favorably situated with reference to supplies of coal from the Pittsburg and Kanawha districts, received by water and rail transportation, with also considerable quantities from Virginia and Ohio mines. The product is soft or bituminous coal, there being little consumption here of anthracite. In late years the West Virginia and Virginia mines have greatly advanced in importance in the resources for this market. The following tabulation indicates the quantities of coal separately received from the Pittsburg and Kanawha districts and from all other sources for the past ten years:

Receipts of coal at Cincinnati since 1890 .

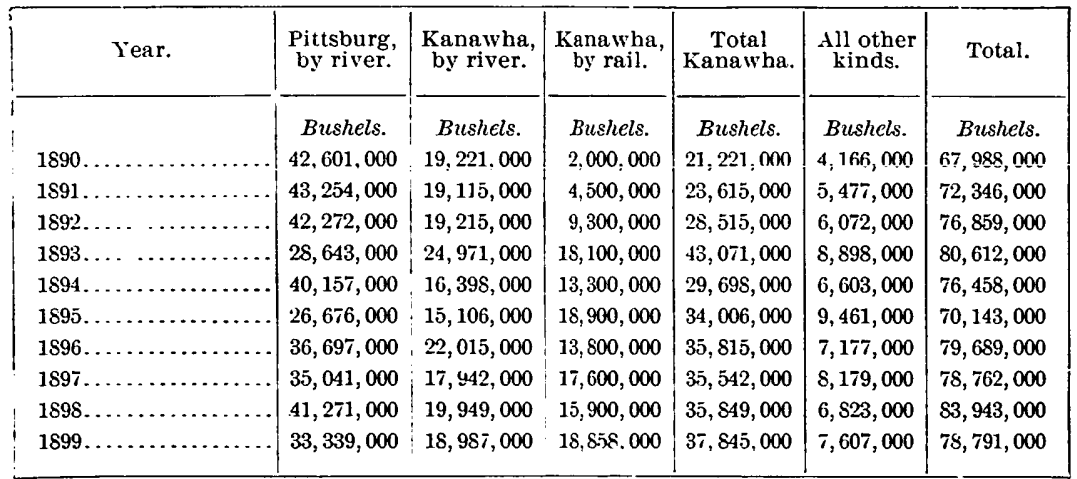


COAL.

Since 1871 the receipts of coal at Cincinnati have been as follows:

Receipts of coal at Cincinnati since September 1, 1871.

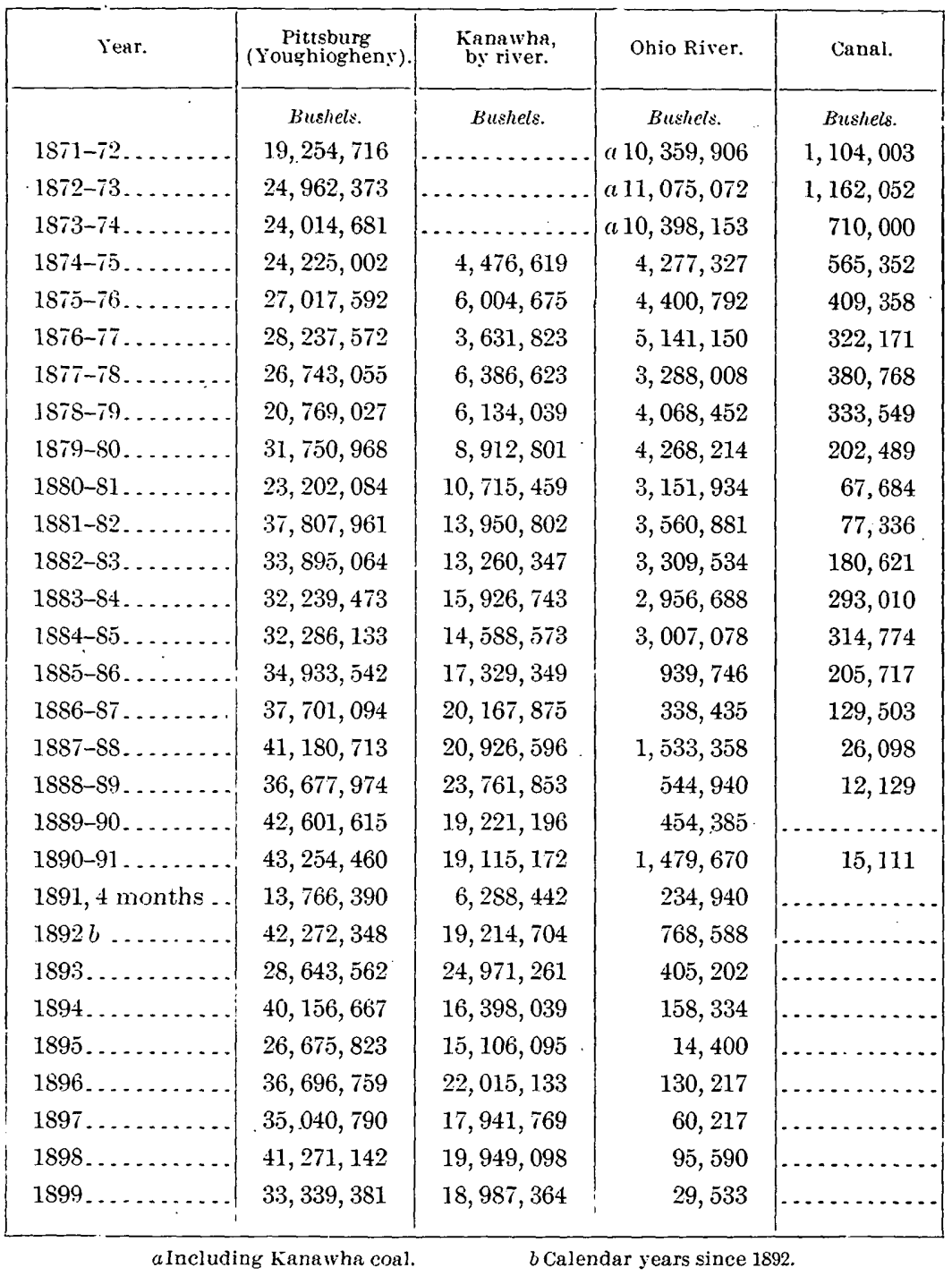


Receipts of coal at Cincinnati since September 1, 1871-Continued.

\begin{tabular}{|c|c|c|c|}
\hline Year. & Anthracite. & Other kinds. & Total. \\
\hline & Bushels. & Bushels. & Bushels. \\
\hline $1871-72$. & 72,171 & & $30,790,796$ \\
\hline $1872-73 \ldots$ & 75,000 & & $37,274,497$ \\
\hline $1873-74 \ldots$ & 112,000 & $\ldots \ldots$ & $35,234,834$ \\
\hline $1874-75 \ldots \ldots$ & 248,750 & $1,597,260$ & $35,390,310$ \\
\hline $1875-76 \ldots$ & 282,578 & $2,068,322$ & $40,183,317$ \\
\hline $1876-77 \ldots$ & 376,125 & $1,913,793$ & $39,622,634$ \\
\hline $1877-78 \ldots$ & 439,350 & $1,654,425$ & $38,892,229$ \\
\hline $1878-79 \ldots$ & 768,750 & $2,136,850$ & $34,210,667$ \\
\hline $1879-80 \ldots$ & 712,075 & $2,351,699$ & $48,198,246$ \\
\hline $1880-81 \ldots$ & 770,525 & $2,336,752$. & $40,244,438$ \\
\hline $1881-82: .$. & 779,925 & $3,090,715$ & $59,267,620$ \\
\hline $1882-83 \ldots$ & 977,250 & $2,997,216$ & $54,620,032$ \\
\hline $1883-84 \ldots$ & $1,085,350$ & $3,910,795$ & $56,412,059$ \\
\hline $1884-85 \ldots$ & $1,257,900$ & $2,683,864$ & $54,138,322$ \\
\hline $1885-86 \ldots$ & $1,287,925$ & $2,720,250$ & $57,416,529$ \\
\hline $1886-87 \ldots$ & $1,314,775$ & $3,693,850$ & $63,345,532$ \\
\hline $1887-88 \ldots$ & $1,328,225$ & $5,710,649$ & $70,705,639$ \\
\hline $1888-89 \ldots$ & $1,020,525$ & $3,075,000$ & $65,092,421$ \\
\hline $1889-90 \ldots$ & $1,001,175$ & $4,709,775$ & $67,988,146$ \\
\hline $1890-91 \ldots$ & $1,118,671$ & $7,362,698$ & $72,345,782$ \\
\hline 1891, 4 months.. & 402,528 & $4,437,139$ & $25,129,439$ \\
\hline $1892 a$ & $1,268,170$ & $13,335,006$ & $76,858,816$ \\
\hline $1893 \ldots$ & 759,626 & $25,832,374$ & $80,612,025$ \\
\hline $1894 \ldots$ & 661,548 & $19,083,527$ & $76,458,115$ \\
\hline $1895 \ldots$ & $1,227,000$ & $27,119,823$ & $70,143,141$ \\
\hline $1896 \ldots$ & $1,171,000$ & $19,676,000$ & $79,689,109$ \\
\hline $1897 \ldots$ & $1,251,250$ & $24,468,000$ & $78,762,026$ \\
\hline $1898 \ldots$ & 948,125 & $21,679,000$ & $83,942,955$ \\
\hline 1899. & $1,291,250$ & $25,144,000$ & $78,791,528$ \\
\hline
\end{tabular}

$a$ Calendar year since 1892 .

Note. - Since 1890-91 "Other kinds" represent Kanawha coal largely; in 1898, 15,885,000 bushels, or 73 per cent; in 1899, 18,858,000 bushels, or 75 per cent. (See preceding table.)

Prior to 1891 the rail receipts at Cincinnati did not reach as great a volume as $5,000,000$ bushels in a year, except in one instance.

The arrivals of coal at Cincinnati in 1899 were reduced $5,151,000$ bushels compared with the preceding year, the river receipts falling off $8,959,000$ bushels, under low-water conditions covering a period of several months; the rail receipts were increased 3,808,000 bushels. Under advanced prices in the latter part of the year the general average cost, afloat and for delivered lots, was about 40 cents per ton above the preceding year, which represented the lowest of such records. 
Coal consumption at Cincinnati in recent years has been something over $60,000,000$ bushels annually. So far as can be judged by available information from dealers the quantity is pretty evenly divided between factory and household uses. About $5 \frac{1}{2}$ per cent of the supply is absorbed in the local manufacture of gas, the quantity thus consumed in 1899 being 3,300,000 bushels. The quantity of gas supplied during the year by the local company was $1,129,645,000$ feet. The company having reduced the price for gas quite materially, especially for fuel purposes, it is to be expected that an enlarged quantity of coal will hereafter find consumption through this channel.

Standard lump coal was delivered to consumers early in the year, to some extent, at $\$ 2.25$ per ton, in the usual way, but $\$ 2.50$ prevailed most of the time until September, when the price was advanced to $\$ 2.75$, and subsequently to $\$ 3.25$. The general average for the year was $\$ 2.64$, against $\$ 2.23$ for the preceding year, and an annual average of $\$ 2.37$ for five years prior to 1899 . For coal afloat in barges the price ranged from $4 \frac{1}{2}$ to 7 cents per bushel previous to November, with some transactions late in the year at $7 \frac{1}{2}$ and 8 cents. The year's general average was 5.30 cents for Pittsburg, and 5.58 cents for Kanawha, the former representing 63 per cent and the latter 37 per cent of the supply afloat; and the average for both was 5.40 cents against the same general average for 1898 , equivalent to about $\$ 1.50$ per ton.

The yearly range and average prices of Pittsburg coal, afloat and delivered, per bushel, based on weekly records, compare for a series of years as shown in the following compilation:

Yearly range and average prices of Pittsburg coal at Cincinnati.

\begin{tabular}{|c|c|c|c|c|c|c|}
\hline \multirow{2}{*}{ Year. } & \multicolumn{3}{|c|}{ Afloat. } & \multicolumn{3}{|c|}{ Delivered. } \\
\hline & Lowest. & Highest. & Average. & Lowest. & Highest. & Average \\
\hline & Cents. & Cents. & Cents. & Cents. & Cents. & Cents. \\
\hline $1885-86 \ldots$ & $5 \frac{1}{4}$ & 8 & 6.58 & 9 & 11 & 10.05 \\
\hline $1886-87 \ldots$ & $6 \frac{1}{2}$ & 15 & 7.55 & $9 \frac{1}{2}$ & 16 & 11.04 \\
\hline 1887-88 & 7 & 18 & 10.01 & $10 \frac{3}{4}$ & 22 & 13.96 \\
\hline $1888-89 \ldots$ & 6 & $8 \frac{1}{2}$ & 6.71 & 9 & $11 \frac{3}{4}$ & 9.95 \\
\hline $1889-90 \ldots$ & 6 & 8 & 6.78 & 9 & $10 \frac{3}{4}$ & 9.69 \\
\hline . . & $6 \frac{1}{2}$ & $8 \frac{1}{2}$ & 7.28 & 10 & $10 \frac{3}{4}$ & 10.24 \\
\hline $1892 \ldots$ & $6 \frac{1}{2}$ & $8 \frac{1}{2}$ & 7.49 & 9 & $12 \frac{1}{2}$ & 10.36 \\
\hline $1893 \ldots$ & $6 \frac{1}{2}$ & $8 \frac{3}{4}$ & 7.58 & 9 & $19 \frac{3}{4}$ & 11.04 \\
\hline $1894 \ldots \ldots$ & $5 \frac{1}{4}$ & 9. & 6.34 & $7 \frac{1}{4}$ & $10 \frac{3}{4}$ & 9.11 \\
\hline $1895 \ldots$ & $5 \frac{1}{2}$ & $6 \frac{1}{2}$ & 6.00 & $8 \frac{1}{8}$ & $10 \frac{3}{4}$ & 9.00 \\
\hline $1896 \ldots$ & $5 \frac{1}{2}$ & 6 & 5.73 & $8 \frac{1}{8}$ & .9 & 8.21 \\
\hline $1897 \ldots$ & $5 \frac{1}{2}$ & $5 \frac{3}{4}$ & 5. 70 & $5 \frac{3}{4}$ & $10 \frac{3}{4}$ & 8.10 \\
\hline $1898 \ldots$ & 5 & 6 & 5.66 & $7 \frac{1}{4}$ & 9 & 8.05 \\
\hline $1899 \ldots \ldots$ & $4 \frac{1}{2}$ & $7 \frac{1}{2}$ & 5.30. & $8 \frac{1}{8}$ & $11 \frac{3}{4}$ & 9.50 \\
\hline
\end{tabular}


The bulk of coal from the Kanawha, Virginia and West Virginia region, sells at about the same prices as are obtained for the product from the Pittsburg district.

The receipts of coke for the year were 3,204,000 bushels, and the quantity locally manufactured was $3,981,000$ bushels, making a total of $7,185,000$ bushels, compared with $6,838,000$ bushels the preceding year. For city manufacture the average price for the year was 8.25 cents per bushel; of gas house, 7.33 cents; of Connellsville, $\$ 5.40$ per ton.

\section{ST. LOUIS, MISSOURI.}

The following summary of the coal trade of St. Louis for the year 1899 is furnished by Mr. James Cox, secretary of the Business Men's League of that city.

In previous reviews of the coal trade of St. Louis stress has been laid on the fact that the average price of coal for steam-producing purposes is lower in St. Louis than in any other large city in the country. The city which has been selected for the holding of the Louisiana Purchase Centennial Exposition more than maintained its reputation in this regard during 1899. Standard Illinois lump coal sold as low as 95 cents during several months in the year, as compared with the minimum price of $\$ 1.30$ in 1898 , a reduction of about 30 per cent. Prices stiffened somewhat during the early winter, and closed at $\$ 1.15$, as compared with $\$ 1.35$ in January of the same year. The year was one of phenomenal prosperity in commerce and manufactures, as is evinced by the great increase in the consumption of soft coal, which is used almost exclusively by factories. In 1899 the receipts for the year were $109,000,000$ bushels in excess of the best preceding year, a clear gain of 10 per cent. Factories were active at all seasons, and in many lines of business overtime was made and a great deal of night work was done. This was particularly notable in all lines connected with iron and steel. Street-car factories were overwhelmed with orders throughout the year, and this has continued in 1900. Tobacco factories worked to full capacity, and there was an immense increase in the production of shoes. In almost every other line there was a marked gain, which is reflected in the coal business.

As in past years, the great bulk of the inexpensive coal used in St. Louis came from the southern Illinois coal fields. The Illinois Central Railroad Company hauled in one-fifth of the entire suppis, or almost identically the same tonnage as in 1898 . The Wabash, the Louisville and Nashville, and the Louisville, Eransville, and St. Louis railroads between them hauled in another: one-fourth of the entire supply, as they did in 1898. The Baltimore and Ohio Southwestern Railroad brought in $13,600,000$ bushels, as compared with $10,500,000$ in 1898 . The receipts from the Ohio River showed a considerable gain over last year, but 
did not amount in the aggregate to a million bushels. The St. Louis and Iron Mountain Railroad, which has been hauling in about 100,000 tons of coal from points south of St. Louis, returns no business in this line at all for 1899, and the St. Louis and San Francisco Railroad, which reported 25,000 bushels in 1897 , reports only the nominal business of 850 bushels for 1899 . The Missouri Pacific, which has in past years hauled in considerable coal from the points west of St. Louis, only returns 11,500 bushels for 1899 , as compared with 61,000 bushels in 1897.

These figures seem to indicate that the prevailing low prices in the southern Illinois coal field shut out competition.

Anthracite coal sold from $\$ 5.70$ to $\$ 6.20$ during the year. This is on an average rather higher than 1898 , but the difference is not material. The gross receipts of anthracite in 1899 were 292,108 short tons. This is the largest return ever made for St. Louis, showing a gain of nearly 70,000 tons on 1898 and of 120,000 tons on 1897. Anthracite is being used much more generally in residences, but comparatively few firms find it profitable to substitute it for the much cheaper soft coal for commercial purposes. The heavy gain in the receipts of coke reported last year was not maintained, the total reported for 1899 being about a million bushels, of 40 pounds each, less than for the preceding year. This is largely accounted for by the fact that prices were considerably higher, especially in the cheaper varieties of coke, where there was an advance of 75 cents a ton.

The year ended with business active in every line, and the best pros. pects for increased demand. The following quotations show the range of prices during the year, the figures in each case being free on board St. Louis:

Coal prices at St. Louis, Missouri, during 1899.

\begin{tabular}{|c|c|c|c|}
\hline Kind. & Highest. & Lowest. & Closing. \\
\hline Standard Illinois lump coal $\therefore . . .$. . & $\$ 1.60$ & $\$ 0.95$ & $\$ 1.15$ \\
\hline High-grade Illinois lump coal.. & $1.87 \frac{1}{2}$ & $1.37 \frac{1}{2}$ & $1.87 \frac{1}{2}$ \\
\hline Anthracite, large.... & 5.95 & 5.70 & 5.95 \\
\hline Anthracite, smiall & 6.20 & 5.95 & 6.20 \\
\hline Connellsville coke. & 7.15 & 3.50 & 6.65 \\
\hline New River coke. & 6.90 & 3.25 & 6.30 \\
\hline Indiana coke... & .4 .00 & 3.00 & 3.00 \\
\hline Kentucky coke... & 3.75 & 2. 75 & 3.25 \\
\hline Gas coke & 4.00 & 3.25 & 4.00 \\
\hline
\end{tabular}


The following table shows the receipts of coal and coke at St. Louis during the last nine years:

Coal and coke receipts at St. Louis since 1891.

\begin{tabular}{|c|c|c|c|}
\hline Year. & Soft coal. & Hard coal. & Coke. \\
\hline & Bushels. & Tons. & . Bushels. \\
\hline 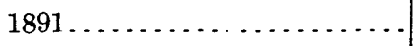 & $72,078,225$ & 139,050 & $6,924,250$ \\
\hline $1892 \ldots . .$. & $82,302,228$ & 187,327 & $8,914,400$ \\
\hline $1893 \ldots \ldots$ & $87,769,375$ & 173,653 & $7,807,000$ \\
\hline $1894 \ldots \ldots$ & $74,644,375$ & 186,494 & $6,365,900$ \\
\hline $1895 \ldots \ldots$ & $88,589,935$ & $2 \cap 7,784$ & $7,130,300$ \\
\hline 1896. & $87,677,600$ & 218,955 & $5,395,900$ \\
\hline $1897 \ldots \ldots$ & $83,730,980$ & 172,933 & $5,671,350$ \\
\hline $1898 \ldots . .$. & $83,562,450$ & 225,616 & $7,762,250$ \\
\hline $1899 \ldots \ldots$ & $103,115,730$ & 292,118 & $6,795,100$ \\
\hline
\end{tabular}

MOBILE, ALABAMA.

Mr. Edward E. England, secretary of the Chamber of Commerce, has prepared the following review of the coal trade at that port:

The receipts for a series of years have been as follows:

Receipts of coal at Mobile, Alabama, since 1883.

\begin{tabular}{|c|c|c|c|}
\hline Year. & $\underset{(a)}{\operatorname{Alabama}}$ coal. & $\begin{array}{c}\text { Anthracite and } \\
\text { English. }\end{array}$ & Total. \\
\hline & Tons. & Tons. & Tons. \\
\hline $1883 \ldots \ldots \ldots \ldots \ldots \ldots \ldots$ & 25,304 & 1,229 & 26,533 \\
\hline $1884 \ldots \ldots \ldots \ldots \ldots \ldots \ldots \ldots \ldots$ & 17,808 & 891 & 18,699 \\
\hline$\ldots \ldots \ldots \ldots \ldots$ & 40,301 & 775 & 41,076 \\
\hline $1886 \ldots \ldots \ldots \ldots \ldots \ldots \ldots \ldots$ & 30,310 & 2,022 & 32,332 \\
\hline$\ldots \ldots \ldots$ & 39,232 & 910 & 40,142 \\
\hline$\ldots \ldots \ldots \ldots \ldots$ & 38,785 & 648 & 39,433 \\
\hline $1889 \ldots \ldots \ldots \ldots \ldots$ & 43,620 & 1,454 & 45,074 \\
\hline $1890 \ldots$ & 39,320 & 1,327 & 40,647 \\
\hline $1891 \ldots \ldots \ldots \ldots \ldots$ & 51,267 & 1,775 & 53,042 \\
\hline $1892 \ldots \ldots \ldots$ & 70,298 & 1,500 & 71,798 \\
\hline $1893 \ldots \ldots$ & 90,000 & 4,130 & 94,130 \\
\hline $1894 \ldots \ldots \ldots \ldots$ & 104,340 & 3,600 & 107,940 \\
\hline $1895 \ldots . . .$. & $\mathbf{1 5 6 , 9 9 6}$ & 4,200 & 161,196 \\
\hline $1896 \ldots \ldots \ldots$ & 165,000 & 3,000 & 168,000 \\
\hline $1897 \ldots \ldots \ldots \ldots$ & $b 175,160$ & 1,600 & 176,760 \\
\hline $1898 \ldots . .$. & 122,500 & 4,425 & 126,925 \\
\hline $1899 \ldots \ldots$ & 187,300 & $c 2,000$ & 189,300 \\
\hline
\end{tabular}

$a$ This does not include the amount of coal used by the rail roads on their locomotives and at their shops. $b$ Includes 3.000 tons received by barges via Tombigbee River.

c Anthracite only. 
As Alabama is the fifth largest coal-producing State in the Union, and as its production increased from 5,893,770 tons in 1897 to $7,484,783$ tons in 1899, with an estimated production of 10,000,000 tons for 1900 , it would seem that there will be not only a sufficient amount produced to supply all demand in the State, but a generous product for export. Such was the case up to within the past two years, but in that time Alabama had forged to the front as a great iron-producing State, and the tremendous demands for iron in all of its forms has given such an impetus to the iron industries as to cause an unprecedented demand for coal for coking purposes, and any surplus that previous years may have shown has vanished. The opening up of thousands of coke ovens has made necessary also the opening up of new coal mines in order to supply this increased demand for coal by the iron industry alone.

In addition to these, many large manufacturing plants have been erected within the past year, not only in Alabama but in sections of other States near the coal fields, and extensive additions have been made to old plants. All of these depend on Alabama coals for steam purposes, and have added largely to the State production. In Alabama alone 52 cotton mills are now in operation, with several new ones in course of erection, to be completed by October 1,1900 .

Another factor is the increased demand by railroads, made necessary not only on account of the building of new lines, but by the increased commerce extended to them from the different industries as well as from the general building up of the State.

Though the receipts at Mobile exceeded those of any previous year yet the bulk of the coal has been barely sufficient to supply the home demand, leaving only 4,770 tons to be applied to export orders, which orders have aggregated several hundred thousand tons. Outside of exporting coal Mobile's business consists largely in supplying steamers with bunker coal. This branch of the trade in the past year has shown a considerable increase, .372 steamers having entered the port of Mobile in six months.

Mobile is fast becoming a manufacturing city, and the increase of manufacturing industries has increased the demand for coal for steam purposes. The consumption of coal for domestic use has also grown materially, owing to the increased population. This is more clearly shown by the statement that in 18992,048 new buildings were erected, yet to day there is not a desirable house or store for rent in the city. Prosperity is generally evident, and if there is or has been in the past two years a skilled or unskilled laborer idle in Mobile it is because he does not want work. The increase in foreign commerce is notable, the year ending June 30,1900 , showing $\$ 16,000,000$, as against less than $\$ 10,000,000$ for the same period in 1899 , and as against $\$ 2,832,690$ for the year 1894 .

21 GEOL, PT $6-27$ 
With the increase of shipping, the increase of different manufacturing plants, and the steady growth of population, the receipts of coal at Mobile for 1900 will exceed those of 1899 by at least 30 per cent, and if the mines produce a surplus over and above that needed for State use, our export orders will easily take care of the surplus.

\section{NORFOLK, . VIRGINIA.}

Col. William Lamb has furnished the following statement showing the shipments of coal from Lamberts Point piers.

Pocahontas coal shipments from Lamberts Point piers since 1890.

\begin{tabular}{|c|c|c|c|c|c|}
\hline Year. & Foreign. & Bunkers. & Coastwise. & Local. & Total. \\
\hline & Long tons. & Long tons. & Long tons. & Long tons. & Long tons. \\
\hline 1890 & 37,723 & 102,755 & 941,019 & 71,010 & $1,152,507$ \\
\hline 1891 & 27,997 & 135,112 & $1,215,028$ & 90,606 & $1,468,743$ \\
\hline 1892 & 25,653 & 129,627 & $1,400,984$ & 98,034 & $1,654,298$ \\
\hline 1893 & 34,969 & 125,688 & 1,$512 ; 931$ & 100,453 & $1,774,041$ \\
\hline 1894 & 44,328 & 105,382 & $1,810,480$ & 96,841 & $2,057,031$ \\
\hline 1895 & 34,174 & 75,714 & $1,430,144$ & 100,442 & $1,640,474$ \\
\hline 1896 & 41,600 & 99,867 & $1,433,069$ & 96,929 & $1,671,465$ \\
\hline $1897 \ldots$ & 44,103 & 104,966 & $1,473,710$ & 115,079 & $1,737,858$ \\
\hline 1898 & 200,283 & 107,154 & $1,450,943$ & 131,422 & $1,889,802$ \\
\hline 1899 & $207,649 \frac{1}{4}$ & $125,919 \frac{1}{2}$ & $1,497,297 \frac{1}{4}$ & 131,916 & $1,962,782$ \\
\hline
\end{tabular}

The large increase in foreign shipments in 1898 was attributed to the Spanish war and to coal-mining strikes in England. These causes were not operating in 1899 , but in spite of that the statistics show an increase in foreign shipments of 7,500 tons, and in December the orders for foreign shipment exceeded the ability of the Norfolk and Western Railroad to supply the demand.

\section{SAN FRANCISCO, CALIFORNIA.}

Mr. J. W. Harrison, in his annual report to the coal trade of San Francisco, says:

It is singular to report a smaller consumption of coal this year than last, in view of the large quantity delivered to the Government transports and the general belief here that every branch of trade is brisk, which invariably leads to a large fuel demand. The consumption of oil as a steam producer is being enlarged monthly. Fully 90 per cent of the coal now consumed here is produced by our northern collieries, and is under the absolute control of but five local managers, who could establish prices within one week 25 per cent above ruling rates. 
The following table of prices will show the half-yearly fluctuations of foreign coals for "spot" cargoes:

Half-yearly prices for coal at San Francisco in 1899.

\begin{tabular}{|c|c|c|c|}
\hline Kind. & January. & July. & December. \\
\hline Australian (gas) .. & $\$ 7.00$ & $\$ 7.25$ & $\$ 7.50$ \\
\hline English steam & 7.25 & 7.50 & 8.50 \\
\hline Scotch splint. & 7.50 & 7.75 & 7.75 \\
\hline West Hartley....... & 8.00 & 8.00 & 8.00 \\
\hline
\end{tabular}

Coast coal at the close was: For Wellington, $\$ 8$; for Seattle, $\$ 6$; for Coos Bay, $\$ 5$.

The various sources from which we have derived our supplies are as follows:

Sources of coal consumed in California.

\begin{tabular}{|c|c|c|c|c|c|}
\hline Source. & 1890. & 1891. & 1892. & 1893. & 1894. \\
\hline & Tons. & Tons. & Tons. & Tons. & Tons. \\
\hline British Columbia....... & 441,759 & 652,657 & 554,600 & 588,527 & 647,110 \\
\hline Australia ............. & 194,725 & 321,197 & 314,280 & 202,017 & 211,733 \\
\hline English and Welsh.... & 35,662 & 168,586 & 210,660 & 151,269 & 157,562 \\
\hline Scotch ............. & 1,610 & 31,840 & 24,900 & 18,809 & 18,636 \\
\hline $\begin{array}{l}\text { Eastern (Cumberland } \\
\text { and anthracite) ..... }\end{array}$ & 32,550 & 42,210 & 35,720 & 18,960 & 16,640 \\
\hline $\begin{array}{l}\text { Franklin, Green River, } \\
\text { Cedar River, etc ... }\end{array}$ & 216,760 & 178,230 & 164,930 & 167,550 & $a 153,199$ \\
\hline $\begin{array}{l}\text { Carbon Hill, South } \\
\text { Prairie, ete ......... }\end{array}$ & 191,109 & 196,750 & 218,390 & 261,435 & 241,974 \\
\hline MountDiabloand Coos & & & & . & \\
\hline Bay ...... & 74,210 & 90,684 & 66,150 & 63,460 & 65,263 \\
\hline Japan, etc.... & 13,170 & 20,679 & 4,220 & 7,758 & $b 15,637$ \\
\hline Total. & $1,201,555$. & $1,702,833$ & $1,593,850$ & $1,479,785$ & $1,527,754$ \\
\hline
\end{tabular}


MINERAL RESOURCES.

Sources of coal consumed in Californir-Continued.

\begin{tabular}{|c|c|c|c|c|c|}
\hline Source. & 1895. & 1896. & $189 \pi$. & 1898. & 1899. \\
\hline British Columbia. & $\begin{array}{l}\text { Tons. } \\
651,295\end{array}$ & $\begin{array}{c}\text { Tons. } \\
551,852\end{array}$ & $\begin{array}{c}\text { Tons. } \\
558,372\end{array}$ & $\begin{array}{l}\text { Tous. } \\
651,208\end{array}$ & $\begin{array}{c}T o m s . \\
623,133\end{array}$ \\
\hline Australia ......... & 268,960 & 273,851 & 281,666 & 201,931 & 139,333 \\
\hline English and Welsh.... & 201,180 & 156,368 & 107,969 & 75,115 & 93,263 \\
\hline Scotch $\ldots . .$. & 4,098 & 8,356 & 4,081 & 5,056 & 38,951 \\
\hline $\begin{array}{l}\text { Eastern (Cumberland } \\
\text { and anthracite) } \ldots . .\end{array}$ & 26,863 & 17,907 & 21,335 & 37,560 & 271,694 \\
\hline $\begin{array}{l}\text { Seattle (Franklin, } \\
\text { Green River, etc.)... }\end{array}$ & 150,888 & 128,919 & 220,175 & 283,963 & None. \\
\hline $\begin{array}{c}\text { Carbon Hill, South } \\
\text { Prairie, etc ......... }\end{array}$ & 256,267 & 255,923 & 286,205 & 348,474 & 355,756 \\
\hline Mount Diablo and Coos & & & & & \\
\hline Bay .. & 84,954 & 110,237 & 115,150 & 172,506 & 189,507 \\
\hline Japan, Alaska, etc.. & 9,015 & 2,247 & 6,587 & 26,560 & 28,390 \\
\hline Tota & $, 653,520$ & $1,505,660$ & $1,601,540$ & $1,802,373$ & $1,740,027$ \\
\hline
\end{tabular}

As it is necessary to include deliveries at Port Los Angeles and at San Diego to arrive at an accurate statement of the consumption of coal in the State, these are added in the above sources of supply. The total amount received by water at these two points aggregated 155,238 tons in 1897, 154,402 tons in 1898, and 184,747 tons in 1899.

Coke. - The total amount of coke received amounts to 31,091 tons, against 41,630 tons received last year. Three-fourths of the coke consumed here is imported from England and Belgium.

\section{SEATTLE, WASHINGTON:}

Mr. Lovett M. Wood, editor of the Trade Register, has furnished statistics of the coal movement at that port.

The coal trade of Seattle, that city being the most important coal market in the State, showed a substantial gain in 1899, as it has for several years past. The increasing population of Seattle and the State, noteworthy gains in coast and Asiatic commerce, and the fact that San Francisco finds it profitable and necessary to purchase Washington and other coast coals rather than foreign fuel, have been potent factors in giving greater activity to Washington mines. 
During 1899 ten mines shipped their product to Seattle, the record being as follows:

Shipments of coal from the mines to Seattle in 1899.

\begin{tabular}{|c|c|}
\hline Mine. & Tons. \\
\hline Issaquain Coal Co....... & 118,328 \\
\hline Black Diamond . . . . . . . . . . & 227,254 \\
\hline Newcastle........$\ldots$. & $\cdot 113,710$ \\
\hline Franklin .............. & 151,745 \\
\hline Renton Cooperative Co..... & 38,938 \\
\hline Cedar Mountain........ & 10,930 \\
\hline Sunset Coal Co.................. & 3,117 \\
\hline Over Northern Pacific R. R... & 79,802 \\
\hline Coal Creek $a . \ldots . . . .$. & 41,142 \\
\hline Lawson $b \ldots \ldots$ & 36,399 \\
\hline Total. & 821,365 \\
\hline
\end{tabular}

Receipts and exports of coal at Seattle, Washington, in 1899, by months.

\begin{tabular}{|c|c|c|}
\hline Month. & Receipts. & Exports. $a$ \\
\hline & Tons. & Tons. \\
\hline January .......... & 64,399 & 38,720 \\
\hline February . . . . . . . . & 62,250 & 36,090 \\
\hline March . . . . . . . & 70,566 & 40,630 \\
\hline April $\ldots \ldots \ldots \ldots . . . .$. & 59,095 & 28,970 \\
\hline May . . . . . . . . & 62,157 & 37,260 \\
\hline June ............ & 61,154 & 32,901 \\
\hline July ............... & 56,855 & 32,694 \\
\hline August . . . . . . . & 72,773 & 44,925 \\
\hline September....... & 73,778 & 39,876 \\
\hline October & 84,107 & 33,787 \\
\hline November....... & $\overline{7} \overline{7}, 099$ & 41,655 \\
\hline December & 77,132 & 36,920 \\
\hline Total 1899 . & 821,365 & $b 444,428$ \\
\hline Total $1898 \ldots$ & 622,284 & 378,578 \\
\hline Increase in 1899 & 199,081 & 65,850 \\
\hline
\end{tabular}

$a$ Foreign and domestic points (mostly San Francisco, California). $b 16,400$ tons to foreign. 
The total receipts and exports for a series of years at Seattle were as follows:

Coal receipts at Seattle, Washington, 1889 to 1899.

\begin{tabular}{|c|c|c|}
\hline Year. & & Exports. $a$ \\
\hline & Tons. & Tows. \\
\hline 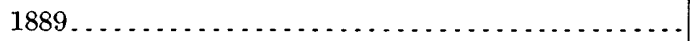 & 369,198 & $\ldots \ldots \ldots$ \\
\hline 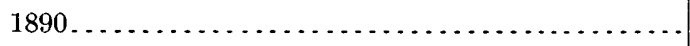 & 487,215 & $\ldots \ldots$ \\
\hline $1891 \ldots \ldots \ldots . . . \ldots$ & 421,587 & .... \\
\hline 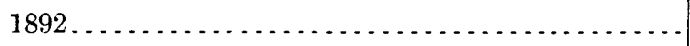 & 416,174 & . . . . . . . \\
\hline $1893 \ldots \ldots \ldots \ldots \ldots$ & 461,034 & 342,114 \\
\hline $1894 \ldots \ldots \ldots \ldots \ldots \ldots \ldots$ & 437,939 & 318,670 \\
\hline 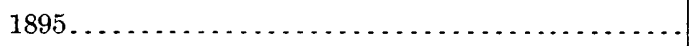 & 363,979 & 257,739 \\
\hline $1896 \ldots \ldots \ldots \ldots$ & 425,103 & 194,771 \\
\hline 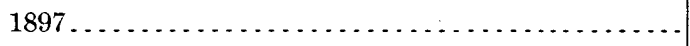 & 472,311 & 287,883 \\
\hline 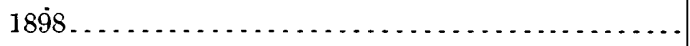 & 622,284 & 378,578 \\
\hline $1899 \ldots \ldots \ldots \ldots \ldots \ldots \ldots \ldots \ldots$ & 821,365 & $b 444,428$ \\
\hline
\end{tabular}

PRODUCTION OF COAL, BY STATES.

Including an insignificant product from Idaho and the Territory of Alaska, there were thirty States and Territories that contributed to the output in 1899, as in the preceding year. Of these thirty States nineteen produced over 1,000,000 tons each in 1899, seven had an output exceeding 5,000,000 tons each, four exceeded 10,000,000, and twoPennsylvania and Illinois-exceeded 20,000,000 tons. As is well known by all familiar with the coal trade, Pennsylvania stands preeminently at the head of the coal-producing States. The combined output of anthracite and bituminous coal in Pennsylvania has for many years exceeded 50 per cent of the total output of the United States. The lowest percentage contributed by Pennsylvania in any of the years for which statistics are available was 52 , in 1884 and 1888, while in 1880 it was as high as 65 . In 1899,53 per cent of the total product was from Pennsylvania mines; 29 per cent was Pennsylvania bituminous coal and 24 per cent Pennsylvania anthracite. With such a record it is not probable that Pennsylvania will be supplanted as the leading coal producer during the next fifty or one hundred years. It has been estimated that at the present rate of consumption the anthracite fields of Pennsylvania will last from one hundred and fifty to two hundred years. And while industrial activity does not affect anthracite operations as much as it does bituminous mines, the production and consumption is stimulated in seasons of business revival such as that which prevailed during the past year. Anthracite production in Pennsylvania in 1899 increased 13 per cent over 1898, as compared with an 
increase of 13.8 per cent in Pennsylvania bituminous coal and a gain of 16 per cent in the total bituminous product of the United States. Anthracite coal is becoming more an article of domestic consumption every year, while its use under boilers and for manufacturing purposes is being supplanted to a large extent by soft coal. It is not to be expected that its production will increase in the same proportion as bituminous coal, but with our increasing urban population its use as a domestic fuel may continue to increase for at least some time to come. Nor is it possible to predict what the rate of increase, if any, is going to be, but it is probable that for the next fifty years at least 20 per cent of our total product will be made up of Pennsylvania anthracite. The State will continue as the leading coal producer for many years, if the history of the past may be taken as a basis for judging of the future.

Next in importance to Pennsylvania as a coal producer is Illinois, whose product in 1899 was $24,439,019$ short tons, equivalent to 9.6 per cent of the total product, and a gain of nearly $6,000,000$ tons over the State's output in 1898. West Virginia, the third State in importance as a coal producer, increased her output 15.3 per cent, from 16,700,999 short tons in 1898 to $19,252,995$ short tons in 1899 ; and while this product in 1899 exceeded that of Illinois for 1898, the latter's increased output in 1899 continues the State in second place, with a lead of over $5,000,000$ tons ahead of West Virginia. Ohio remains in undisputed possession of fourth place, with a product of $16,500,270$ short tons in 1899 , a gain of nearly $2,000,000$ tons, or 13.6 per cent. Alabama remains as firmly fixed in fifth place, with a total of $7,593,416$ short tons in 1899 , against $6,535,283$ tons in 1898 , recording an increase for last year of over a million tons.

It will be observed that all of these five leading States are east of the Mississippi River, and all but one, Illinois, belong to the Appalachian system. The sixth State in importance is Indiana, also east of the Mississippi River. Iowa, the most important coal-producing State west of the river, is seventh in the list of all the States, having displaced Maryland in 1899. Following Iowa are, in order, Maryland, Colorado, and Kentucky, contending for supremacy, each with a product exceeding 4,500,000 tons and less than 5,000,000 tons.

Continuing the Mississippi River as a dividing line for a geographical distribution of the product between the eastern and western States, it is found that the production of the States east of the river produced $224,096,219$ short tons, or 88.3 per cent of the total, in 1899, as against 193,793,334 short tons, or 84.3 per cent, in 1898. The western States produced 29,643,773 short tons, or 11.7 per cent, in 1899 and 26,181,333 short tons, or 15.7 per cent, in 1898 . Subdividing the eastern division into northern and southern States by the Potomac and Ohio rivers, we find that the States north of the boundary produced 187,031,987 short 
tons, or 73.7 per cent, in 1899 , as compared with $161,575,292$, or 65 per cent of the total, in 1898. The southern States produced $37,064,232$ short tons, or 14.6 per cent of the total, in 1899, and $32,218,042$, or 19 per cent, in 1898.

The percentage of increase in production of the three divisions from 1898 to 1899 was as follows: Northern, 15.80 ; southern, 15.04 ; western, 13.22.

The production in the several States and Territories in 1899 and preceding years is discussed with more detail in the following pages.

\section{ALABAMA.}

Total product in $1899,7,593,416$ short tons; spot value, $\$ 8,256,462$.

The production of coal in Alabama in 1899 exceeded that of the preceding year by $1,058,133$ short tons, or 16.2 per cent. This increase in product, noteworthy in itself, was made comparatively insignificant by the increase in value, which advanced from $\$ 4,932,776$ in 1898 to $\$ 8,256,462$, a gain of $\$ 3,323,686$, or about 67 per cent. The operators in Alabama derived evident benefit from the "boom" in the iron trade, the average price per ton obtained for the product in 1899 being $\$ 1.09$, as against 75 cents in 1898 . The improvement in price was noticed in all the more important producing counties, and was most pronounced in Jefferson County, where the price advanced from 69 cents in 1898 to $\$ 1.08$ in 1899 . Jefferson County is the largest coalproducing county in the State, contributing about two-thirds of the State's total. The product in Jefferson County increased 15 per cent in 1899 over 1898, or in slightly less ratio than the total increase. The value of Jefferson County's product increased 81 per cent as compared with 67 per cent for the State. The price in Walker County increased from 80 cents in 1898 to 99 cents in 1899; in Bibb County the price advanced from 86 cents to $\$ 1.14$, and in Tuscaloosa County from 90 cents to $\$ 1.23$.

The tonnage won by machines in 1899 was less than that won by their use in 1898, although the number of machines in use increased from 37 to 53. In two instances where a small amount of machine-mined product was reported the machines were installed late in the year, one mine having its machine equipment in use only twenty days. One company reported that electric machines were being installed at the close of the year. Of the machines in use in 1899 , 52 were driven by air and one by electricity. The one electric machine was of the "long-wall" pattern. Of the 52 air machines, 41 were "pick" or "punching" machines, 10 were chain breast machines, and 1 long-wall machine.

The few instances of labor disaffection occurring in Alabama mines did not affect the industry as a whole. Strikes occurred in 10 mines, throwing 1,255 men out of employment for an average of fifty-seven days. The total working time lost by the strikes amounted to 71,715 days, a little more than 2 per cent of the total working time made by 
the 13,485 men employed in the mines. The average tonnage per day per man in 1899 was unusually large, being 2.57 as compared with 2.44 in 1898 , and 2.38 in 1897.

In considering the distribution of the product for consumption, as shown in the following tables, allowance must be made for the fact that a considerable portion of the product included in the shipments is made into coke at ovens located at points distant from mines. The total amount of coal made into coke in Alabama is something more than double the amounts shown in the tables.

Coal product of Alabama in 1898, by counties.

\begin{tabular}{|c|c|c|c|c|c|c|c|c|c|c|}
\hline County. & $\begin{array}{l}\text { Num- } \\
\text { ber of } \\
\text { mines. }\end{array}$ & $\begin{array}{l}\text { Loaded } \\
\text { at mines } \\
\text { for ship- } \\
\text { ment. }\end{array}$ & $\begin{array}{c}\text { Sold to } \\
\text { local } \\
\text { trade } \\
\text { and } \\
\text { used } \\
\text { by em- } \\
\text { ploy- } \\
\text { ees. }\end{array}$ & $\begin{array}{l}\text { Used at } \\
\text { mines } \\
\text { for } \\
\text { steam } \\
\text { and } \\
\text { heat. }\end{array}$ & $\begin{array}{c}\text { Made } \\
\text { into coke }\end{array}$ & $\begin{array}{c}\text { Total } \\
\text { product. }\end{array}$ & $\begin{array}{c}\text { Total } \\
\text { value. }\end{array}$ & $\begin{array}{c}\text { Aver- } \\
\text { age } \\
\text { price } \\
\text { per } \\
\text { ton. }\end{array}$ & $\begin{array}{l}\text { Aver- } \\
\text { age } \\
\text { num- } \\
\text { ber of } \\
\text { days } \\
\text { active. }\end{array}$ & $\begin{array}{l}\text { Aver- } \\
\text { age } \\
\text { num- } \\
\text { ber of } \\
\text { employ- } \\
\text { ees. }\end{array}$ \\
\hline $\mathrm{Bibb}$ & 4 & $\begin{array}{l}\text { Short } \\
\text { tons. } \\
771,264\end{array}$ & $\begin{array}{l}\text { Short } \\
\text { tons. } \\
2,992\end{array}$ & $\begin{array}{l}\text { Short } \\
\text { tons. } \\
27,437\end{array}$ & $\begin{array}{l}\text { Short } \\
\text { tons. } \\
9,198\end{array}$ & $\begin{array}{l}\text { Short } \\
\text { tons. } \\
810,891\end{array}$ & $\$ 701,049$ & $\$ 0.86$ & 257 & 1,104 \\
\hline $\begin{array}{c}\text { Blount and } \\
\text { Cullman ... }\end{array}$ & 2 & 15,600 & 2,700 & & & 18,300 & 19,626 & 1.07 & 230 & 44 \\
\hline Etowah ... & 2 & 4,384 & 1,500 & 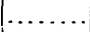 & $\cdots$ & 5,884 & 6,259 & 1.06 & 166 & 21 \\
\hline Jefferson ..... & 31 & $2,834,360$ & 44,098 & 84,762 & $1,241,370$ & $4,204,590$ & $2,921,411$ & .69 & 257 & $(i, 484$ \\
\hline St. Clair. & 2 & 69,361 & 604 & 2,843 & & 72,808 & 52,196 & .72 & 252 & 155 \\
\hline Shelby ....... & 7 & 63,361 & 3,995 & 1,631 & ( & 68,987 & 120,026 & 1.74 & 222 & $2 \leq 9$ \\
\hline Tuscaloosa ... & 10 & 140,782 & 11,099 & 4,450 & 82,623 & 238,954 & 215,467 & .90 & 253 & $5 ! 8$ \\
\hline Walker ...... & 21 & $1,020,647$ & 4,122 & 24,685 & 21,880 & $1,071,334$ & 854,330 & .80 & 226 & 2,067 \\
\hline Winston ..... & 3 & 7,069 & 1,466 & & .. & 8,535 & 7,412 & .87 & 212 & 21 \\
\hline $\begin{array}{c}\text { Small and } \\
\text { unreported } \\
\text { mines ....... }\end{array}$ & & & 35,000 & & & 35,000 & 35,000 & & & \\
\hline Total... & 82 & $4,926,828$ & 107,576 & 145,808 & $1,355,071$ & $6,535,283$ & $4,932,776$ & .75 & 250 & 10,733 \\
\hline
\end{tabular}

Coal product of Alabama in 1899, by counties.

\begin{tabular}{|c|c|c|c|c|c|c|c|c|c|c|}
\hline County. & $\begin{array}{l}\text { Num- } \\
\text { ber of } \\
\text { mines. }\end{array}$ & $\begin{array}{c}\text { Loaded } \\
\text { at mines } \\
\text { for ship- } \\
\text { ment. }\end{array}$ & $\begin{array}{c}\text { Sold to } \\
\text { local } \\
\text { trade } \\
\text { and } \\
\text { used } \\
\text { by em- } \\
\text { ploy- } \\
\text { ees. }\end{array}$ & $\begin{array}{l}\text { Used } \\
\text { at } \\
\text { mines } \\
\text { for } \\
\text { steam } \\
\text { and } \\
\text { heat. }\end{array}$ & $\begin{array}{c}\text { Made } \\
\text { into coke. }\end{array}$ & $\begin{array}{c}\text { Total } \\
\text { product. }\end{array}$ & $\begin{array}{l}\text { Total } \\
\text { value. }\end{array}$ & $\begin{array}{c}\text { Aver- } \\
\text { age } \\
\text { price } \\
\text { per } \\
\text { ton. }\end{array}$ & $\begin{array}{l}\text { Aver- } \\
\text { age } \\
\text { num- } \\
\text { ber of } \\
\text { days } \\
\text { active. }\end{array}$ & $\begin{array}{l}\text { Aver- } \\
\text { age } \\
\text { num- } \\
\text { ber of } \\
\text { em- } \\
\text { ploy- } \\
\text { ees. }\end{array}$ \\
\hline & - & $\begin{array}{l}\text { Short } \\
\text { tons. }\end{array}$ & $\begin{array}{l}\text { Short } \\
\text { tons. }\end{array}$ & $\begin{array}{l}\text { Short } \\
\text { tons. }\end{array}$ & $\begin{array}{l}\text { Short } \\
\text { tons. }\end{array}$ & $\begin{array}{l}\text { Short } \\
\text { tons. }\end{array}$ & & & & \\
\hline Bibb........ & 5 & 880,029 & 2,052 & 30,182 & $\ldots$ & 912,263 & $\$ 1,041,484$ & $\$ 1.14$ & 248 & 1,355 \\
\hline $\begin{array}{c}\text { Blount and } \\
\text { St. Clair.. }\end{array}$ & 3 & 62,976 & 150 & 1,825 & & 64,951 & 54,565 & .84 & 247 & 183 \\
\hline $\begin{array}{c}\mathrm{Cu} l \mathrm{~lm} \text { an } \\
\text { and Marion }\end{array}$ & 2 & 20,395 & 25 & & & 20,420 & 22,556 & 1.10 & 150 & 105 \\
\hline Etowah ..... & 2 & 9,078 & 200 & 300 & . & 9,578 & 10,215 & 1.07 & 227 & 28 \\
\hline Jefferson.... & 41 & $2,238,255$ & 34,598 & 105,244 & $2,500,599$ & $4,878,696$ & $5,289,676$ & 1.08 & 251 & 7,720 \\
\hline Shelby...... & 10 & 85,557 & 100 & 1,271 & $\ldots \ldots \ldots$ & 86,928 & 152,046 & 1.75 & 198 & 354 \\
\hline Tuscaloosa.. & 8 & 233,678 & 1,162 & 4,924 & 85,697 & 325,461 & 398,766 & 1.23 & 223 & 801 \\
\hline Walker ..... & 26 & $1,160,939$ & 6,607 & 11,748 & 70,000 & $1,249,294$ & $1,240,004$ & .99 & 214 & 2,900 \\
\hline Winston .... & 3 & 10,705 & 100 & 20 & & 10,825 & 12,150 & 1.12 & 185 & 35 \\
\hline Small mines & & $\cdots$ & 35,000 & & - & 35,000 & 35,000 & $\cdots$ & & \\
\hline Total & 100 & $4,701,612$ & 79,994 & 155,514 & $2,656,296$ & $7,593,416$ & $8,256,462$ & 1.09 & 238 & 13,481 \\
\hline
\end{tabular}


Distribution of the coal product of Alabama from 1889 to 1899.

\begin{tabular}{|c|c|c|c|c|c|c|c|c|c|c|}
\hline Year. & $\begin{array}{l}\text { Num- } \\
\text { ber of } \\
\text { mines. }\end{array}$ & $\begin{array}{c}\text { Loaded } \\
\text { at mines } \\
\text { for ship- } \\
\text { ment. }\end{array}$ & $\begin{array}{l}\text { Sold to } \\
\text { local } \\
\text { trade } \\
\text { and } \\
\text { used } \\
\text { by em- } \\
\text { ploy- } \\
\text { ees. }\end{array}$ & $\begin{array}{c}\text { Used at } \\
\text { mines } \\
\text { for } \\
\text { steam } \\
\text { and } \\
\text { heat. }\end{array}$ & $\begin{array}{c}\text { Made } \\
\text { in to coke. }\end{array}$ & $\begin{array}{c}\text { Total } \\
\text { product. }\end{array}$ & $\begin{array}{l}\text { Total } \\
\text { valuc. }\end{array}$ & $\begin{array}{l}\text { Aver- } \\
\text { age } \\
\text { price } \\
\text { per } \\
\text { ton. }\end{array}$ & $\begin{array}{c}\text { Aver- } \\
\text { age } \\
\text { num- } \\
\text { ber of } \\
\text { days } \\
\text { active. }\end{array}$ & $\begin{array}{l}\text { Average } \\
\text { number } \\
\text { of em- } \\
\text { ployees. }\end{array}$ \\
\hline & & $\begin{array}{l}\text { Short } \\
\text { tons. }\end{array}$ & $\begin{array}{l}\text { Short } \\
\text { tons. }\end{array}$ & $\begin{array}{l}\text { Short } \\
\text { tons. }\end{array}$ & $\begin{array}{l}\text { Short } \\
\text { tons. }\end{array}$ & $\begin{array}{l}\text { Short } \\
\text { tons. }\end{array}$ & & & & \\
\hline 1889. & ... & $2,327,209$ & 59,945 & 79,515 & $1,106,314$ & $3,572,983$ & $\$ 3,961,491$ & $\$ 1.10$ & ...... & 6,975 \\
\hline 1890 & .. & $2,487,983$ & 84,578 & 88,952 & $1,428,896$ & $4,090,409$ & $4,202,469$ & 1.03 & 217 & 10,691 \\
\hline 1891. & $\ldots$ & $2,882,813$ & 91,456 & 100,160 & $1,745,352$ & $4,759,781$ & $5,087,596$ & 1.07 & 268 & 9,302 \\
\hline 1892. & & $3,122,075$ & 37,843 & 135,627 & $2,233,767$ & $5,529,312$ & $5,788,898$ & 1.05 & 271 & 10,075 \\
\hline 1893. & $\ldots$ & $3,536,935$ & 59,599 & 96,412 & $1,443,989$ & $5,136,935$ & $5,096,792$ & .99 & 237 & 11,294 \\
\hline $1894 \ldots$ & $\ldots$ & $3,269,548$ & 43,911 & 130,404 & 953,315 & $4,397,178$ & $4,085,535$ & .93 & 238 & 10,859 \\
\hline $1895 \ldots$ & 64 & $3,610,433$ & 272,551 & 137,021 & $1,673,770$ & $5,693,775$ & $5,126,822$ & .90 & 244 & 10,346 \\
\hline 1896 & 80 & $3,555,493$ & 285,416 & 138,268 & $1,769,520$ & $5,748,697$ & $5,174,135$ & .90 & 248 & 9,894 \\
\hline $1897 \ldots$ & 78 & $4,543,597$ & 86,790 & 126,187 & $1,137,196$ & $5,893,770$ & $5,192,085$ & .88 & 233 & 10,597 \\
\hline $1898 \ldots$ & 82 & $4,926,828$ & 107,576 & 145,808 & $1,355,071$ & $6,535,283$ & $4,932,776$ & .75 & 250 & 10,733 \\
\hline 1899 & 100 & $4,701,612$ & 79,994 & 155,514 & $2,656,296$ & $7,593,416$ & $8,256,462$ & 1.09 & 238 & 13,481 \\
\hline
\end{tabular}

Coal product of Alabama since 1895, by counties.

\begin{tabular}{|c|c|c|c|c|c|c|c|}
\hline County. & 1895. & 1896. & 1897. & 1898. & 1899. & $\begin{array}{c}\text { Increase, } \\
1899 .\end{array}$ & $\begin{array}{c}\text { Decrease } \\
1899 .\end{array}$ \\
\hline & Short tons. & Short tons. & Short tons. & Short tons. & Short tons. & Short tons. & Short tons \\
\hline Bibb................... & 653,732 & 710,842 & 671,077 & 810,891 & 912,263 & 101,372 & \\
\hline Blount .............. & 62,400 & 32,760 & 37,350 & & (a) & & \\
\hline Cullman.. & $\cdots$ & 1,000 & & 18,300 & $\left\{\begin{array}{l}b 20,420 \\
0\end{array}\right.$ & 2,120 & \\
\hline Etowah ..... & 900 & 3,080 & 3,168 & 5,884 & 9,578 & 3,694 & \\
\hline Jefferson ............ & $3,726,325$ & $3,729,719$ & $3,714,676$ & $4,204,590$ & $4,878,696$ & 674,106 & \\
\hline St. Clair . . . . . . . . . & 30,806 & 33,368 & 67,584 & 72,808 & $c 64,951$ & .......... & 7,857 \\
\hline Shelby ............. & 52,754 & 52,923 & 84,673 & 68,987 & 86,928 & 17,941 & \\
\hline Tuscaloosa ......... & 208,117 & 205,223 & 234,488 & 238,954 & 325,461 & 86,507 & \\
\hline Walker.... & 946,241 & 952,642 & $1,037,516$ & $1,071,334$ & $1,249,294$ & 177,960 & \\
\hline Winston...... & 4,500 & 2,140 & 8,238 & 8,535 & 10,825 & 2,290 & \\
\hline Small mines. & 8,000 & 25,000 & 35,000 & 35,000 & 35,000 & ............... & \\
\hline Total & $5,693,775$ & $5,748,697$ & $5,893,770$ & $6,535,283$ & $7,593,416$ & $d 1,058,133$ & \\
\hline
\end{tabular}


The production of Alabama since 1870 has been as follows:

Annual coal product of Alabama since 1870.

\begin{tabular}{|c|c|c|c|c|c|}
\hline Year. & Short tons. & Value. & $\begin{array}{l}\text { Average } \\
\text { price per } \\
\text { ton. }\end{array}$ & $\begin{array}{c}\text { Average } \\
\text { number of } \\
\text { days } \\
\text { active. }\end{array}$ & $\begin{array}{c}\text { Average } \\
\text { number of } \\
\text { employees. }\end{array}$ \\
\hline $1870 \ldots \ldots \ldots$ & 13,200 & & & & \\
\hline $1873 \ldots \ldots \ldots \ldots$ & 44,800 & & & & $\cdots$ \\
\hline$\ldots \ldots . .$. & 50,400 & $\ldots \ldots . .$. & $\ldots$ & & $\cdots$ \\
\hline$\ldots \ldots \ldots$ & 67,200 & & & & \\
\hline $1876 \ldots \ldots \ldots . . .$. & 112,000 & & & & \\
\hline 1877. & 196,000 & - & & & - . \\
\hline 1878 & 224,000 & & & & \\
\hline$\ldots \ldots \ldots$ & 280,000 & - & & & $\cdots$ \\
\hline 1880. & 380,800 & - & $\cdots$ & & $\cdots$ \\
\hline 1881 & 420,000 & & & & \\
\hline 1882 & 896,000 & & & & $\ldots$ \\
\hline 1883. & $1,568,000$ & $\cdots$ & - & & $\cdots$ \\
\hline 1884 & $2,240,000$ & $\cdots$ & & & \\
\hline 1885 & $2,492,000$ & - & $\ldots$ & & \\
\hline 1886 & $1,800,000$ & $\$ 2,574,000$ & $\$ 1.43$ & & \\
\hline $1887 \ldots$ & $1,950,000$ & $2,535,000$ & 1.30 & & \\
\hline $1888 \ldots \ldots \ldots \ldots$ & $2,900,000$ & $3,335,000$ & 1.15 & $\cdots$ & $\ldots$ \\
\hline $1889 \ldots \ldots$ & $3,572,983$ & $3,961,491$ & 1.10 & 248 & 6,975 \\
\hline 1890. & $4,090,409$ & $4,202,469$ & 1.03 & 217 & 10,642 \\
\hline $1891 \ldots \ldots$ & $4,759,781$ & $5,087,596$ & 1.07 & 268 & 9,302 \\
\hline 1892 . & $5,529,312$ & $5,788,898$ & 1.05 & 271 & 10,075 \\
\hline 1893. & $5,136,935$ & $5,096,792$ & .99 & 237 & 11,294 \\
\hline $1894 \ldots \ldots \ldots$ & $4,397,178$ & $4,085,535$ & .93 & 238 & 10,859 \\
\hline 1895 . & $5,693,775$ & $5,126,822$ & .90 & 244 & 10,346 \\
\hline 1896. & $5,748,697$ & $5,174,135$ & .90 & 248 & 9,894 \\
\hline 1897 . & $5,893,770$ & $5,192,085$ & .88 & 233 & 10,597 \\
\hline 1898. & $6,535,283$ & $4,932,776$ & .75 & 250 & 10,733 \\
\hline $1899 \ldots$ & $7,593,416$ & $8,256,462$ & 1.09 & 238 & 13,481 \\
\hline
\end{tabular}

\section{ARKANSAS.}

Total product in $1899,843,554$ short tons; spot value, $\$ 989,383$.

Compared with 1898, the coal product of Arkansas in 1899 exhibits a decrease of 361,925 short tons, with a falling off of $\$ 249,395$ in value. This was the only instance worthy of note in which the product of last year was less than that of 1898 . There were small decreases in the production of Alaska, Idaho, and Georgia, but the aggregate losses in those States did not amount to 20,000 tons. The decrease in 
the output of Arkansas was due, not to any falling off in demand, but to strikes in the principal mines. Out of the 22 mines in the State, 11 had men on strike from 30 to 180 days. The 11 mines affected employed 2,195 men out of a total of 2,313 in the State. The total working time lost by the strikes was 220,105 days, an average of 100 idle days for each, and equal to 61 per cent of the total working time made, from which it can be calculated that but for the time lost by strikes, the product of the State would have been about $1,350,000$ tons, all other conditions being equal. Some of the miners of the Indian Territory were also on strike during the year, but in spite of that, the Territory increased its production by over 150,000 tons. This was not sufficient to supply the loss borne by Arkansas, the coal to supply the markets naturally fed by Arkansas being brought principally from Alabama.

In the following tables are presented the statistics of production in Arkansas, by counties, for the past two years:

Coal product of Arkansas in 1898, by counties.

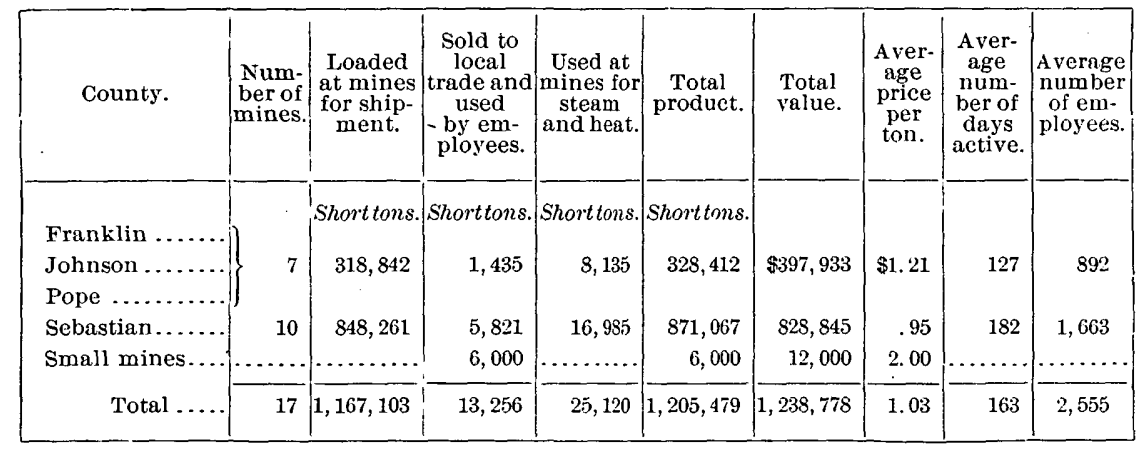

Coal product of Arkansas in 1899, by counties.

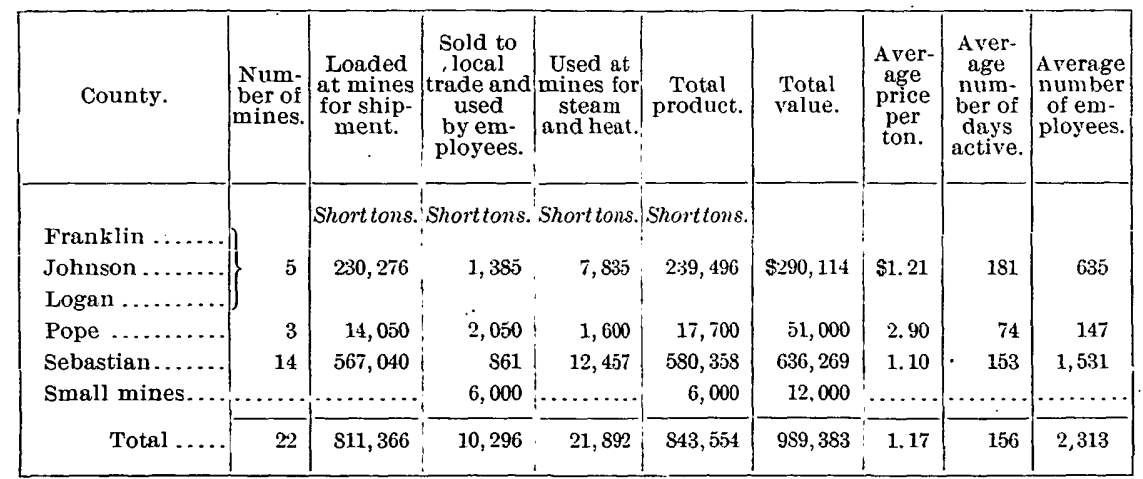


Distribution of the coal product of Arkansas from 1889 to 1899.

\begin{tabular}{|c|c|c|c|c|c|c|c|c|c|}
\hline Year. & $\begin{array}{l}\text { Num- } \\
\text { ber of } \\
\text { mines. }\end{array}$ & $\begin{array}{l}\text { Loaded } \\
\text { at mines } \\
\text { for ship- } \\
\text { ment. }\end{array}$ & $\begin{array}{c}\text { Sold to } \\
\text { local } \\
\text { trade and } \\
\text { used } \\
\text { by em- } \\
\text { ployees. }\end{array}$ & $\begin{array}{c}\text { Used at } \\
\text { mines for } \\
\text { steam } \\
\text { and heat. }\end{array}$ & $\begin{array}{c}\text { Total } \\
\text { product. }\end{array}$ & $\begin{array}{c}\text { Total } \\
\text { value. }\end{array}$ & $\begin{array}{l}\text { Aver- } \\
\text { age } \\
\text { price } \\
\text { per } \\
\text { ton. }\end{array}$ & $\begin{array}{l}\text { Aver- } \\
\text { age } \\
\text { num- } \\
\text { ber of } \\
\text { days } \\
\text { active. }\end{array}$ & $\begin{array}{l}\text { A verage } \\
\text { number } \\
\text { of em- } \\
\text { ployees. }\end{array}$ \\
\hline & & Short tons. & Shorttons. & Short tons. & Short tons. & & & & \\
\hline 1889. & & 268,518 & 6,820 & 4,246 & 279,584 & $\$ 395,836$ & $\$ 1.42$ & $\cdots$ & 677 \\
\hline 1890 & - & 374,969 & 9,240 & 15,679 & 399,888 & 514,595 & 1.29 & 214 & 938 \\
\hline 1891. & & 518,120 & 8,909 & 15,350 & 542,379 & 647,560 & 1. 19 & 214 & 1,317 \\
\hline 1892. & & 513,908 & 7,450 & 14,200 & 535,558 & 666,230 & 1.24 & 199 & 1,128 \\
\hline 1893. & . & 549,504 & 11,778 & 13,481 & 574,763 & 773,347 & 1.34 & 151 & 1,559 \\
\hline $1894 \ldots$ & 13 & 488,077 & 7,870 & 16,679 & 512,626 & 631,988 & 1.22 & 134 & 1,493 \\
\hline 1895. & 13 & 576,112 & 14,935 & 7,275 & 598,322 & 751,156 & 1.25 & 176 & 1,218 \\
\hline 1896 & 14 & 647,240 & 8,640 & 19,494 & 675,374 & 755,577 & 1.12 & 168 & 1,507 \\
\hline 1897. & 14 & 827,518 & 11,588 & 18,084 & 856,190 & 903,993 & 1.06 & 156 & 1,990 \\
\hline 1898. & 17 & $1,167,103$ & 13,256 & 25,120 & $1,205,479$ & $1,238,778$ & 1.03 & 163 & 2,555 \\
\hline 1899. & 22 & 811,366 & 10,296 & 21,892 & 843,554 & 989,383 & 1.17 & 156 & 2,313 \\
\hline
\end{tabular}

According to the Tenth United States Census, the coal product of Arkansas in 1880 was 14,778 short tons, valued at $\$ 33,535$. No statistics were obtained in 1881 . With this exception the statistics of production since 1880 have been as follows:

Annual production of coal in Arkansas since 1880.

\begin{tabular}{|c|c|c|c|c|c|}
\hline Year. & Short tons. & Value. & $\begin{array}{l}\text { Average } \\
\text { price per } \\
\text { ton. }\end{array}$ & $\begin{array}{c}\text { Average } \\
\text { number of } \\
\text { days } \\
\text { active. }\end{array}$ & $\begin{array}{l}\text { Average } \\
\text { number of } \\
\text { employees. }\end{array}$ \\
\hline $1880 \ldots \ldots \ldots$ & 14,778 & $\$ 33,535$ & $\ldots \ldots . .$. & $\ldots \ldots \ldots$ & $\ldots \ldots$ \\
\hline 1882. & 5,000 & $\ldots \ldots \ldots$ & $\ldots . . .$. & $\ldots \ldots . . .$. & $\ldots$ \\
\hline 1883. & 50,000 & $\cdots$ & $\cdots .$. & & $\cdots$ \\
\hline 1884. & 75,000 & $\ldots$ & $\ldots$. & $\ldots$. & \\
\hline 1885. & 100,000 & $\ldots \ldots$ & $\ldots \ldots$ & & . \\
\hline 1886 . & 125,000 & 200,000 & $\$ 1.60$ & & $\therefore$ \\
\hline 1887 & 129,600 & 194,400 & 1.50 & $\ldots$ & $\ldots \ldots$. \\
\hline 1888. & 276,871 & 415,306 & 1.50 & $\ldots .$. & 978 \\
\hline 1889. & 279,584 & 395,836 & 1. 42 & . & 677 \\
\hline 1890 . & 399,888 & 514,595 & 1.29 & 214 & 938 \\
\hline $1891 \ldots \ldots \ldots . . . .$. & 542,379 & 647,560 & 1.19 & 214 & 1,317 \\
\hline 1892. & 535,558 & 666,230 & 1. 24 & 199 & 1,128 \\
\hline 1893. & 574,763 & 773,347 & 1. 34 & 151 & 1,559 \\
\hline $1894 \ldots \ldots \ldots \ldots$ & วิ12, 626 & 631,988 & 1.22 & 134 & 1,493 \\
\hline $1895 \ldots \ldots \ldots$ & 598,322 & 751,156 & 1. 25 & 176 & 1,218 \\
\hline 1896. & 675,374 & 755,577 & 1. 12 & 168 & 1,507 \\
\hline 1897 & 856,190 & 903,993 & 1.06 & 156 & 1,990 \\
\hline $1898 \ldots$. & $1,205,479$ & $1,238,778$ & 1.03 & 163 & 2,555 \\
\hline $1899 \ldots$ & 843,554 & $989, ; 83$ & 1.17 & 156 & 2,313 \\
\hline
\end{tabular}


MINERAL RESUURCES.

Coal product of Arlansas sinre 1895, by counties.

\begin{tabular}{|c|c|c|c|c|c|c|}
\hline County. & 1895. & 1896. & 1897. & 1898. & 1899. & $\begin{array}{c}\text { Decrease, } \\
1899 .\end{array}$ \\
\hline & Short tons. & Short tons. & Short tons. & Short tons. & Short tons. & Short tons. \\
\hline Franklin .... & & & & & & \\
\hline Johnson.. & 252,938 & 222,711 & 281,299 & 328,412 & 257,196 & 71,216 \\
\hline Pope . & & & & & & \\
\hline Sebastian .... . & 339,384 & 446,663 & 568,891 & 871,067 & 580,358 & 290,709 \\
\hline Small mines .. & 6,000 & 6,000 & 6,000 & 6,000 & 6,000 & \\
\hline Total..... & 598,322 & 675,374 & 856,190 & $1,205,479$ & 843,554 & 361,925 \\
\hline
\end{tabular}

\section{CALIFORNIA.}

Total product in $1899,160,715$ short tons; spot value, $\$ 428,333$

In 1899 , as in 1898, the coal product of California reached its maximum figure. The product in 1898 was about 70 per cent more than that of 1897. The output in 1899 was only about 11 per cent over that of 1898 . It is not to be expected that California will ever become of any importance as a coal producer, but any increase in the domestic supply is of importance to the consumers in the State, as it has the tendency to lower prices of the imported fuel upon which the people have largely to depend. On the other hand, higher prices for imported coal stimulate domestic production, and as prices for the past two years have been advanced about 20 per cent encouragement has been given to the State mines.

Coal product of California in 1898, by counties.

\begin{tabular}{|c|c|c|c|c|c|c|c|c|c|}
\hline County. & $\begin{array}{l}\text { Num- } \\
\text { ber of } \\
\text { mines. }\end{array}$ & $\begin{array}{c}\text { Loaded } \\
\text { at mines } \\
\text { for ship- } \\
\text { ment. }\end{array}$ & $\begin{array}{l}\text { Sold to } \\
\text { local } \\
\text { trade and } \\
\text { used by } \\
\text { em- } \\
\text { ployees. }\end{array}$ & $\begin{array}{c}\text { Used at } \\
\text { mines for } \\
\text { steam } \\
\text { and heat. }\end{array}$ & $\begin{array}{r}\text { Total- } \\
\text { product }\end{array}$ & $\begin{array}{l}\text { Total } \\
\text { value. }\end{array}$ & $\begin{array}{l}\text { Aver- } \\
\text { age } \\
\text { price } \\
\text { per } \\
\text { ton. }\end{array}$ & $\begin{array}{l}\text { Aver- } \\
\text { age } \\
\text { num- } \\
\text { ber of } \\
\text { days } \\
\text { active. }\end{array}$ & $\begin{array}{l}\text { Average } \\
\text { number } \\
\text { of em- } \\
\text { ployees. }\end{array}$ \\
\hline $\begin{array}{r}\text { Alameda and Am- } \\
\text { ador............. } \\
\text { Contra Costa, } \\
\text { Kern, Orange, } \\
\text { and Riverside.. }\end{array}$ & 2 & $\begin{array}{l}\text { Short } \\
\text { tons. } \\
77,000\end{array}$ & $\begin{array}{l}\text { Short } \\
\text { tons. } \\
13,200\end{array}$ & $\begin{array}{l}\text { Short } \\
\text { tons. }\end{array}$ & $\begin{array}{l}\text { Short } \\
\text { tons. } \\
90,200\end{array}$ & $\begin{array}{r}\$ 205,600 \\
144,315\end{array}$ & $\$ 2.28$ & 292 & 145 \\
\hline Total ...... & 6 & 123,568 & 15,996 & 4,724 & 144,288 & 349,915 & 2.43 & 265 & 284 \\
\hline
\end{tabular}


COAL.

Coal product of California in 1899, by counties.

\begin{tabular}{|c|c|c|c|c|c|c|c|c|c|}
\hline County. & $\begin{array}{l}\text { Num- } \\
\text { ber of } \\
\text { mines. }\end{array}$ & $\begin{array}{l}\text { Loaded } \\
\text { at mines } \\
\text { for ship- } \\
\text { ment. }\end{array}$ & $\begin{array}{l}\text { Sold to } \\
\text { local } \\
\text { trade and } \\
\text { used by } \\
\text { em- } \\
\text { ployees. }\end{array}$ & $\begin{array}{l}\text { Used at } \\
\text { mines for } \\
\text { steam } \\
\text { and heat. }\end{array}$ & $\begin{array}{c}\text { Total } \\
\text { product }\end{array}$ & $\begin{array}{l}\text { Total } \\
\text { value. }\end{array}$ & $\begin{array}{l}\text { Aver- } \\
\text { age } \\
\text { price } \\
\text { per } \\
\text { ton. }\end{array}$ & $\begin{array}{l}\text { Aver- } \\
\text { age } \\
\text { num- } \\
\text { ber of } \\
\text { days } \\
\text { active. }\end{array}$ & $\begin{array}{l}\text { A verage } \\
\text { number } \\
\text { of em- } \\
\text { ployees. }\end{array}$ \\
\hline $\begin{array}{l}\text { Alameda, A ma - } \\
\text { dor, and Contra } \\
\text { Costa............ }\end{array}$ & 3 & 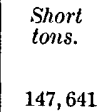 & $\begin{array}{l}\text { Short } \\
\text { tons. } \\
\\
137\end{array}$ & $\begin{array}{l}\text { Short } \\
\text { tons. }\end{array}$ & $\begin{array}{l}\text { Short } \\
\text { tons. }\end{array}$ & $\$ 406,771$ & $\$ 2.67$ & 292 & 345 \\
\hline $\begin{array}{l}\text { Kern, Orange, } \\
\text { and Riverside. }\end{array}$ & 3 & 3,400 & 5,105 & & 8,505 & 21,562 & 2.54 & 272 & 18 \\
\hline Total & 6 & 151,041 & 5,242 & 4,432 & 160,715 & 428,333 & 2.67 & 291 & 363 \\
\hline
\end{tabular}

Distribution of the coal product of California from 1889 to 1899.

\begin{tabular}{|c|c|c|c|c|c|c|c|c|c|}
\hline Year. & $\begin{array}{l}\text { Num- } \\
\text { ber of } \\
\text { mines. }\end{array}$ & $\begin{array}{c}\text { Loaded } \\
\text { at mines } \\
\text { for ship- } \\
\text { ment. }\end{array}$ & $\begin{array}{l}\text { Sold to } \\
\text { local } \\
\text { trade and } \\
\text { used by } \\
\text { em- } \\
\text { ployees. }\end{array}$ & $\begin{array}{l}\text { Used at } \\
\text { mines for } \\
\text { steam } \\
\text { and heat. }\end{array}$ & $\begin{array}{c}\text { Total } \\
\text { product. }\end{array}$ & $\begin{array}{l}\text { Total } \\
\text { value. }\end{array}$ & $\begin{array}{l}\text { Aver- } \\
\text { age } \\
\text { price } \\
\text { per } \\
\text { ton. }\end{array}$ & $\begin{array}{l}\text { Aver- } \\
\text { age } \\
\text { num- } \\
\text { ber of } \\
\text { days } \\
\text { active. }\end{array}$ & $\begin{array}{l}\text { Average } \\
\text { number } \\
\text { of em- } \\
\text { ployees. }\end{array}$ \\
\hline & & $\begin{array}{l}\text { Short } \\
\text { tons. }\end{array}$ & $\begin{array}{l}\text { Short } \\
\text { tons. }\end{array}$ & $\begin{array}{l}\text { Short } \\
\text { tons. }\end{array}$ & $\begin{array}{l}\text { Short } \\
\text { tons. }\end{array}$ & & & & \\
\hline 1889. & & 111,128 & 3,146 & 7,546 & 121,820 & $\$ 288,232$ & $\$ 2.37$ & & \\
\hline 1890. & & 103,436 & 2,121 & 5,154 & 110,711 & $283,0.19$ & 2.56 & 301 & 364 \\
\hline 1891. & $\ldots$ & 86,783 & 3,424 & 3,094 & 93,301 & 204,902 & 2.20 & 222 & 256 \\
\hline $189:$. & ... & 73,269 & 9,679 & 2,230 & 85,178 & 209,711 & 2.46 & 204 & 187 \\
\hline $189: 3$. & $\cdots$ & 64,733 & 5,336 & 2,534 & 72,603 & 167,555 & 2.31 & 208 & 158 \\
\hline 1894. & 6 & 52,736 & 8,143 & 6,368 & 67,247 & 155,620 & 2.31 & 232 & 125 \\
\hline 1895. & 5 & 60,440 & 12,171 & 2,842 & 75,453 & 170,778 & 2.33 & 262 & 190 \\
\hline $1890^{\circ} .$. & 4 & 69,608 & 4,537 & 4,399 & 78,544 & 166,123 & 2.12 & 297 & 157 \\
\hline $1897 .$. & 7 & 74,762 & 6,869 & 4,361 & 85,992 & 201,236 & 2.34 & 150 & 363 \\
\hline $1898 \ldots$ & 6 & 123,568 & 15,996 & 4,724 & 144,288 & 349,915 & 2.43 & 265 & 284 \\
\hline $1899 \ldots \ldots$ & 6 & 151,041 & 5,242 & 4,432 & 160,715 & 428,333 & 2.67 & 291 & 363 \\
\hline
\end{tabular}


MINERAL RESOURCES.

Coal product of California since'1883.

\begin{tabular}{|c|c|c|c|c|c|}
\hline Year. & Short tons. & value. & $\begin{array}{l}\text { A verage } \\
\text { price per } \\
\text { tun. }\end{array}$ & $\begin{array}{c}\text { Average } \\
\text { number of } \\
\text { days active. }\end{array}$ & $\begin{array}{c}\text { Average } \\
\text { number.of } \\
\text { employees. }\end{array}$ \\
\hline 1883. & 76,162 & & & & \\
\hline 1884 & 77,485 & & & & \\
\hline 1885 & 71,615 & $\cdots$ & $\cdots$ & & \\
\hline 1886 & 100,000 & $\$ 300,000$ & $\$ 3.00$ & & \\
\hline 1887 & 50,000 & 150,000 & 3.00 & & \\
\hline 1888. & 95,000 & 380,000 & 4.00 & & \\
\hline $1889 \ldots$ & 121,820 & 288,232 & 2.36 & & \\
\hline 1890. & 110,711 & 283,019 & 2.56 & 301 & 364 \\
\hline $1891 \ldots$ & 93,301 & 204,902 & 2.20 & 222 & 256 \\
\hline $1892 .$. & 85,178 & 209,711 & 2.46 & 204 & 187 \\
\hline 1893. & 72,603 & 167,555 & 2.31 & 208 & 158 \\
\hline 1894. & 67,247 & 155,620 & 2. 31 & 232 & 125 \\
\hline $1895 \ldots$ & 75,453 & 175,778 & 2.33 & 262 & 190 \\
\hline $1896 \ldots$ & 78,544 & 166,123 & 2. 12 & 297 & 157 \\
\hline 1897 & 85,992 & 201,236 & 2.34 & 150 & 363 \\
\hline $1898 \ldots$ & 144,288 & 349,915 & 2.43 & 265 & 284 \\
\hline $1899 \ldots$ & 160,715 & 428,333 & 2.67 & 291 & 363 \\
\hline
\end{tabular}

COLORADO.

Total product in $1899,4,776,224$ short tons; spot value, $\$ 5,363,667$.

Compared with 1898, the coal product of Colorado in 1899 increased practically 700,000 short tons, and as compared with 1893 , the year of previous maximum production, there was an increase of over 670,000 short tons. There was a marked increase in the use of mining machines in 1899. The number of machines in use increased from 43 to 63 , and the amount of coal mined by them from 225,646 tons to 527,115 tons. Of the machines in use in 1899,29 were driven by electricity. One of these was a shearing machine and 28 were chain undercutters. Thirty-four machines used air as a motive power, and of these 31 were of the type known as pick machines and 3 were chain cutters.

Two small mines in the State were idle practically throughout the entire year on account of labor troubles. Short-timed strikes occurred in 7 other mines, involving altogether 504 men for an average of 44 days. These did not have any material effect on the production.

The details of production by counties for the past two years are exhibited in the following tables: 
COAL.

Coal product of Colorado in 1898, by counties.

\begin{tabular}{|c|c|c|c|c|c|c|c|c|c|c|}
\hline County. & $\begin{array}{l}\text { Num- } \\
\text { ber of } \\
\text { mines. }\end{array}$ & $\begin{array}{l}\text { Loaded } \\
\text { at mines } \\
\text { for ship- } \\
\text { ment. }\end{array}$ & $\begin{array}{l}\text { Sold to } \\
\text { local } \\
\text { trade } \\
\text { and } \\
\text { used by } \\
\text { em- } \\
\text { ployees. }\end{array}$ & $\begin{array}{c}\text { Used at } \\
\text { mines } \\
\text { for } \\
\text { steam } \\
\text { and } \\
\text { heat. }\end{array}$ & $\begin{array}{l}\text { Made } \\
\text { into } \\
\text { coke. }\end{array}$ & $\begin{array}{c}\text { Total } \\
\text { product. }\end{array}$ & $\begin{array}{l}\text { Total } \\
\text { value. }\end{array}$ & $\begin{array}{l}\text { Aver- } \\
\text { age } \\
\text { price } \\
\text { per } \\
\text { ton. }\end{array}$ & $\begin{array}{l}\text { Aver- } \\
\text { age } \\
\text { num- } \\
\text { ber of } \\
\text { days } \\
\text { active. }\end{array}$ & $\begin{array}{l}\text { Aver- } \\
\text { age } \\
\text { num- } \\
\text { ber of } \\
\text { em- } \\
\text { ploy- } \\
\text { ees. : }\end{array}$ \\
\hline & & $\begin{array}{l}\text { Short } \\
\text { tons. }\end{array}$ & $\begin{array}{l}\text { Short } \\
\text { tons. }\end{array}$ & $\begin{array}{l}\text { Short } \\
\text { tons. }\end{array}$ & $\begin{array}{l}\text { Short } \\
\text { tons. }\end{array}$ & $\begin{array}{l}\text { Short } \\
\text { tons. }\end{array}$ & & & & \\
\hline Boulder ..... & 17 & 387,919 & 30,345 & 33,275 & ....... & 451,539 & $\$ 607,377^{\circ}$ & $\$ 1.35$ & 145 & 1,067 \\
\hline Delta........ & 4 & 140 & 4,742 & 170 & $\ldots \ldots$ & 5,052 & 6,560 & 1.30 & 221 & 10 \\
\hline Fremont & 7 & 404,884 & 5,290 & 16,379 & & 426,553 & 682,583 & 1.60 & 154 & $1, \dot{045}$ \\
\hline Garfield ..... & 6 & 205,999 & 7,910 & 8,571 & $\ldots \ldots$ & 222,480 & 234,554 & 1.05 & 224 & 345 \\
\hline Gunnison.... & $\check{5}$ & 193,643 & 8,588 & 5,185 & 115,905 & 323,321 & 417,607 & 1.29 & 252 & 477 \\
\hline Hueriano.... & 14 & 931,023 & 6,383 & 36,258 & 102,217 & $1,075,881$ & $1,185,244$ & 1.10 & 275 & 1,452 \\
\hline Jefferson ... & 3 & …..... & 12,006 & 360 & & 12,366 & 25,536 & 2.07 & 223 & 27 \\
\hline La Plata.... & 9 & 90,490 & 10,160 & $\ldots$ & $\ldots \ldots$ & 100,650 & 147,152 & 1.46 & 245 & 165 \\
\hline Las Animas & 9 & 820,579 & 21,691 & 14,778 & 354,292 & $1,211,340$ & $1,100,022$ & .91 & 255 & 1,465 \\
\hline Pitkin ..... & 3 & 70,016 & 912 & 1,436 & 123,132 & 195,496 & 210,376 & 1.08 & 286 & 198 \\
\hline Rio Blanco... & 4 & …....... & 1,321 & 20 & & 1,341 & 2,606 & 1.94 & 104 & 8 \\
\hline Routt....... & 7 & $\ldots \ldots \ldots$ & 1,339 & $\ldots$ & & 1,339 & 2,012 & 1.50 & 91 & 11 \\
\hline $\begin{array}{l}\text { Weld .......... } \\
\text { Arapahoe ... }\end{array}$ & 7 & 6,333 & 17,352 & 400 & & 24,085 & 34,000 & 1.41 & 214 & 68 \\
\hline $\begin{array}{l}\text { El Paso...... } \\
\text { Larimer .... } \\
\text { Mesa ........ }\end{array}$ & 3 & 12,650 & 576 & 988 & & 14,214 & 14,942 & 1.06 & 91 & 59 \\
\hline $\begin{array}{l}\text { Montezuma } \\
\text { Montrose... }\end{array}$ & 3 & 9,000 & 1,690 & & & 10,690 & 15,510 & 1.45 & 121 & 43 \\
\hline Total .. & 101 & $3,132,676$ & 130,305 & 117,820 & 695,546 & $4,076,347$ & $4,686,081$ & 1.15 & 220 & 6,440 \\
\hline
\end{tabular}

Coal product of Colorado in 1899, by counties.

\begin{tabular}{|c|c|c|c|c|c|c|c|c|c|c|}
\hline County. & $\begin{array}{l}\text { Num- } \\
\text { ber of } \\
\text { mines. }\end{array}$ & $\begin{array}{l}\text { Loaded } \\
\text { at mines } \\
\text { for ship- } \\
\text { ment. }\end{array}$ & $\begin{array}{l}\text { Sold to } \\
\text { local } \\
\text { trade } \\
\text { and } \\
\text { used by } \\
\text { em- } \\
\text { ployees. }\end{array}$ & \begin{tabular}{|} 
Used at \\
mines \\
for \\
steam \\
and \\
heat.
\end{tabular} & $\begin{array}{c}\text { Made } \\
\text { into } \\
\text { coke. }\end{array}$ & $\begin{array}{l}\text { Total } \\
\text { product. }\end{array}$ & $\begin{array}{l}\text { Total } \\
\text { value. }\end{array}$ & $\begin{array}{l}\text { Aver- } \\
\text { age } \\
\text { price } \\
\text { per } \\
\text { ton. }\end{array}$ & $\begin{array}{l}\text { Aver- } \\
\text { age } \\
\text { num- } \\
\text { ber of } \\
\text { days } \\
\text { active. }\end{array}$ & $\begin{array}{c}\text { Average } \\
\text { number } \\
\text { of em- } \\
\text { pioyees. } \\
\cdot\end{array}$ \\
\hline & & $\begin{array}{l}\text { Short } \\
\text { tons. }\end{array}$ & $\begin{array}{l}\text { Short } \\
\text { tons. }\end{array}$ & $\begin{array}{l}\text { Short } \\
\text { tons. }\end{array}$ & $\begin{array}{l}\text { Short } \\
\text { tons. }\end{array}$ & $\begin{array}{l}\text { Short } \\
\text { tons. }\end{array}$ & & & & \\
\hline Boulder. & 15 & 515,709 & 7,116 & 17,650 & . & 540,475 & $\$ 719,836$ & $\$ 1.33$ & 190 & 862 \\
\hline Delta... & 3 & 1,200 & 4,657 & 243 & & 6,100 & 8,400 & 1.38 & 283 & 12 \\
\hline El Paso... & 3 & 27,668 & $\cdots$ & 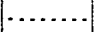 & & 27,668 & 33,937 & 1.23 & 131 & 93 \\
\hline Fremont & 6 & 592,582 & 8,174 & 19,853 & & 620,609 & 981,722 & 1.58 & 236 & 1,258 \\
\hline Garfield & 8 & 129,725 & 1,989 & 2,640 & & 134,354 & 149,447 & 1.11 & 158 & 275 \\
\hline Gunnison & 7 & 202,738 & 14,110 & 5,776 & 96,810 & 319,434 & 444,353 & 1.39 & 234 & 498 \\
\hline Huerfano.... & 13 & 590,845 & 4,185 & 37,547 & .. & 632,577 & 727,781 & 1.15 & 238 & 1,240 \\
\hline Jefferson & 3 & …..... & 9,900 & $\cdots \cdots$ & & 9,900 & 19,075 & 1.93 & 259 & 18 \\
\hline La Plata..... & 6 & 112,672 & 3,770 & 58 & $\cdots$ & 116,500 & 161,728 & 1.39 & 227 & 160 \\
\hline Las Animas & 14 & $1,435,931$ & 21,523 & 20,079 & 647,610 & $2,125,143$ & $1,863,876$ & .88 & 295 & 2,408 \\
\hline Routt.... & 7 & 300 & 911 & $\cdots$ & & 1,211 & 1,742 & 1.44 & 83 & 11 \\
\hline Weld ..... & 12 & 9,779 & 36,384 & 1,410 & $\cdots$ & 47,573 & 69,032 & 1.45 & 239 & 110 \\
\hline $\begin{array}{l}\text { Arapahoe } \\
\text { Larimer } \\
\text { Mesa .... }\end{array}$ & 2 & & 2,936 & & & 2,936 & 4,295 & 1.46 & 167 & 11 \\
\hline $\begin{array}{l}\text { Montezuma } \\
\text { Montrose .... }\end{array}$ & 4 & 17,072 & 500 & & & 17,572 & 26,910 & 1.53 & 256 & 18 \\
\hline $\begin{array}{l}\text { Pitkin ........ } \\
\text { Rio Blanco.. }\end{array}$ & 5 & 45,120 & 1,998 & 1,732 & 125,322 & 174,172 & 151,533 & .87 & 222 & 192 \\
\hline Tota & 108 & 681,341 & 118,153 & 106,988 & $i^{i} 869,742$ & $4,776,224$ & 63,667 & 1.12 & 246 & 7,166 \\
\hline
\end{tabular}

21 GEOL, PT 6-_-28 
Distribution of the coal product of Colorado from 1889 to 1899.

\begin{tabular}{|c|c|c|c|c|c|c|c|c|c|c|}
\hline Year. & $\begin{array}{l}\text { Num- } \\
\text { ber of } \\
\text { mines. }\end{array}$ & $\begin{array}{c}\text { Loaded } \\
\text { at mines } \\
\text { for ship- } \\
\text { ment. }\end{array}$ & $\begin{array}{c}\text { Sold to } \\
\text { local } \\
\text { trade and } \\
\text { usied by } \\
\text { em- } \\
\text { ployees. }\end{array}$ & $\begin{array}{l}\text { Used at } \\
\text { mines } \\
\text { for } \\
\text { steam } \\
\text { and } \\
\text { lieul. }\end{array}$ & $\begin{array}{l}\text { Made } \\
\text { into } \\
\text { coke. }\end{array}$ & $\begin{array}{c}\text { Total } \\
\text { product. }\end{array}$ & $\begin{array}{l}\text { Total } \\
\text { value. }\end{array}$ & $\begin{array}{c}\text { Aver- } \\
\text { age } \\
\text { price } \\
\text { per } \\
\text { ton. }\end{array}$ & $\begin{array}{c}\text { Aver- } \\
\text { age } \\
\text { num- } \\
\text { ber of } \\
\text { days } \\
\text { active. }\end{array}$ & $\begin{array}{c}\text { Aver- } \\
\text { age } \\
\text { num- } \\
\text { ber of } \\
\text { em- } \\
\text { ployees. }\end{array}$ \\
\hline & & $\begin{array}{l}\text { Short } \\
\text { tons. }\end{array}$ & $\begin{array}{l}\text { Short } \\
\text { tons. }\end{array}$ & $\begin{array}{l}\text { Short } \\
\text { tons. }\end{array}$ & $\begin{array}{l}\text { Short } \\
\text { tons. }\end{array}$ & $\begin{array}{l}\text { Short } \\
\text { tons. }\end{array}$ & & . & & \\
\hline 1889 & & $2,109,335$ & 91,248 & 88,537 & 308,061 & $2,597,181$ & $\$ 3,993,768$ & $\$ 1.54$ & $\cdots$ & 4,904 \\
\hline 1890 & & $2,636,939$ & 65,432 & 48,451 & 343,181 & $3,094,003$ & $4,344,196$ & 1.40 & & 5,827 \\
\hline 1891 & $\ldots$ & $2,934,332$ & 70,000 & 50,000 & 458,300 & $3,512,632$ & $4,800,000$ & 1.37 & .. & 6,000 \\
\hline 1892 & & $2,938,980$ & 126,748 & 55,721 & 389,381 & $3,510,830$ & $5,685,112$ & 1.62 & 229 & 5,747 \\
\hline 1893 & $\ldots$ & $3,345,951$ & 65,386 & 178,993 & 512,059 & $4,102,389$ & $5,104,60^{\circ}$ & 1.24 & 188 & $7,20^{\circ}$ \\
\hline 1894 & 79 & $2,181,048$ & 56,688 & 112,414 & 481,259 & $2,831,409$ & $3,516,340$ & 1.24 & 155 & 6,507 \\
\hline 1895 & 87 & $2,445,578$ & 49,088 & 99,055 & 489,261 & $3,082,982$ & $3,675,185$ & $1 . .20$ & 182 & 6,125 \\
\hline 1896 & 88 & $2,424,027$ & 65,755 & 93,128 & 529,490 & $3,112,400$ & $3,606,642$ & 1.16 & 172 & 6,704 \\
\hline 1897 & 97 & $2,649,042$ & 76,699 & 93,782 & 542,180 & $3,361,703$ & $3,947,186$ & 1.17 & 180 & 5,852 \\
\hline 1898 & 101 & $3,132,676$ & 130,305 & 117,820 & 695,546 & $4,076,347$ & $4,686,081$ & 1.15 & 220 & 6,440 \\
\hline 1899 & 108 & $3,681,341$ & 118,153 & 106,988 & 869,742 & $4,776,224$ & $5,363,667$ & 1.12 & 246 & 7,166 \\
\hline
\end{tabular}

Coal product of Colorado since 1895, by counties.

\begin{tabular}{|c|c|c|c|c|c|c|c|}
\hline County. & 1895. & $1896 .:$ & 1897. & 1898. & 1899 & $\begin{array}{c}\text { Increase, } \\
1899 .\end{array}$ & $\begin{array}{c}\text { Decrease, } \\
1899 .\end{array}$ \\
\hline & Short tons. & Short tons. & Short tons. & Short tons. & Short tons. & Short tons. & Short tons. \\
\hline Boulder .. & $\begin{array}{l}377,395 \\
315,344\end{array}$ & 448,706 & 477,790 & 451,539 & 540,475 & 88,936 & \\
\hline Garfield & $\begin{array}{l}310,344 \\
274,271\end{array}$ & $\begin{array}{l}294,022 \\
165,797\end{array}$ & $\begin{array}{l}504,589 \\
182,884\end{array}$ & $\begin{array}{l}420,003 \\
222,480\end{array}$ & $\begin{array}{l}020,009 \\
134,354\end{array}$ & 26 & $\$ 8,126$ \\
\hline Gunnison.. & 239,182 & 260,596 & 297,417 & 323,321 & 319,434 & 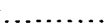 & 3,887 \\
\hline Hueriano.. & 386,696 & 353,338 & 367,894 & $1,075,881$ & 632,577 & . & 443,304 \\
\hline Jefferson & $\cdots$ & $\cdots \ldots \ldots$ & 10,445 & 12,366 & 9,900 & $\cdots$ & 2,466 \\
\hline Las Animas. . & $1,253,149$ & $1,261,555$ & $1,427,526$ & $1,211,340$ & $2,125,143$ & 913,803 & \\
\hline La Plata.. & 106,099 & 104,661 & 76,788 & 100,650 & 116,500 & 15,850 & $\theta$ \\
\hline Pitkin . & . & 168,413 & 171,111 & 195,496 & a 174,172 & & 21,324 \\
\hline Weld. & 27,934 & 4,300 & 8,310 & 24,085 & 47,573 & 23,488 & \\
\hline Other counties.. & 102,912 & 50,212 & 36,949 & 32,636 & 55,487 & 22,851 & \\
\hline Total & $3,082,982$ & $3,112,400$ & $3,361,703$ & $4,076,347$ & $4,776,224$ & $b 699,877$ & \\
\hline
\end{tabular}

aIncludes Rio Blanco County.

$b$ Net increase. 
COAL.

Coal product of Colorado since 1864.

\begin{tabular}{|c|c|c|c|}
\hline Year. & Short tons. & Year. & Short tons. \\
\hline $1864 \ldots \ldots \ldots \ldots \ldots$ & 500 & $1882 \ldots \ldots \ldots \ldots$ & $1,061,479$ \\
\hline $1865 \ldots \ldots \ldots$ & 1,200 & $1883 \ldots \ldots \ldots$ & $1,229,593$ \\
\hline 1866 & 6,400 & 1884 & $1,130,024$ \\
\hline $1867 \ldots \ldots \ldots \ldots$ & 17,000 & $1885 \ldots \ldots \ldots \ldots$ & $1,356,062$ \\
\hline $1868 \ldots \ldots \ldots \ldots$ & 10,500 & $1886 \ldots \ldots \ldots \ldots$ & $1,368,338$ \\
\hline $1869 \ldots$ & 8,000 & 1887 & $1,791,735$ \\
\hline $1870 \ldots \ldots$ & 13,500 & 1888 & $2,185,477$ \\
\hline $1871 \ldots . . . . . . .$. & 15,600 & $1889 \ldots \ldots$ & $2,597,181$ \\
\hline $1872 \ldots$. & 68,540 & 1890 & $3,077,003$ \\
\hline $1873 \ldots \ldots$ & 69,997 & $1891 \ldots \ldots \ldots \ldots$ & $3,512,632$ \\
\hline $1874 \ldots \ldots \ldots$ & 77,372 & $1892 \ldots \ldots \ldots$ & $3,510,830$ \\
\hline $1875 \ldots$ & 98,838 & 1893 & $4,102,289$ \\
\hline $1876 \ldots \ldots \ldots \ldots$ & 117,666 & $1894 \ldots \ldots \ldots \ldots$ & $2,831,409$ \\
\hline $1877 \ldots \ldots$. & 160,000 & $1895 \ldots \ldots \ldots \ldots$ & $3,082,982$ \\
\hline $1878 \ldots \ldots$ & 200,630 & $1896 \ldots \ldots . . . .$. & $3,112,400$ \\
\hline $1879 \ldots \ldots \ldots$ & 322,732 & $1897 \ldots \ldots \ldots \ldots$ & $3,361,703$ \\
\hline $1880 \ldots \ldots \ldots$ & 437,005 & $1898 \ldots \ldots \ldots \ldots$ & $4,076,347$ \\
\hline $1881 \ldots \ldots \ldots$ & 706,744 & $1899 \ldots \ldots$ & $4,776,224$ \\
\hline
\end{tabular}

\section{GEORGIA.}

Total product in $1899,233,111$ short tons; spot value, $\$ 233,344$.

'There was a slight falling off' in Georgia's tonnage in 1899, the product being 11,076 tons less than in 1898, but in spite of the decreased output there was a substantial gain in the value. The amount received by the operators for their product in 1899 exceeded the value of the 1898 product by $\$ 35,175$, and the average price per ton advanced from 81 cents to $\$ 1$, so that in revenue, if not in tonnage, the two companies in the State reaped the benefit of the improved trade conditions. The number of men employed in the mines and the average working time in 1899 were both more than in the preceding year, and under ordinary circumstances this should mean increased tonnage. The mining labor, bowever, is composed largely of State convicts, and the inference to be drawn is that the standard of efficiency in 1899 was lower by several degrees than that of 1898 . 
The statistics of production during the past eleven years is shown in the following table:

Coal product of Georgia since 1889.

\begin{tabular}{|c|c|c|c|c|c|c|c|c|c|}
\hline Year. & $\begin{array}{l}\text { Loaded } \\
\text { at mines } \\
\text { for ship- } \\
\text { ment. }\end{array}$ & $\begin{array}{c}\text { Sold to } \\
\text { local trade } \\
\text { and used } \\
\text { by em- } \\
\text { ployees. }\end{array}$ & $\begin{array}{l}\text { Used at } \\
\text { mines } \\
\text { for } \\
\text { steam } \\
\text { and } \\
\text { heat. }\end{array}$ & $\begin{array}{c}\text { Made } \\
\text { into } \\
\text { coke. }\end{array}$ & $\begin{array}{c}\text { Total } \\
\text { product. }\end{array}$ & $\begin{array}{l}\text { Total } \\
\text { value. }\end{array}$ & $\begin{array}{l}\text { Aver- } \\
\text { age } \\
\text { price } \\
\text { per } \\
\text { ton. }\end{array}$ & $\begin{array}{c}\text { Aver- } \\
\text { age } \\
\text { num- } \\
\text { ber of } \\
\text { days } \\
\text { active. }\end{array}$ & $\begin{array}{l}\text { Aver- } \\
\text { age } \\
\text { number } \\
\text { of em- } \\
\text { ployees. }\end{array}$ \\
\hline & $\begin{array}{l}\text { Short } \\
\text { tons. }\end{array}$ & $\begin{array}{l}\text { Short } \\
\text { tons. }\end{array}$ & $\begin{array}{l}\text { Short } \\
\text { tons. }\end{array}$ & $\begin{array}{l}\text { Short } \\
\text { tons. }\end{array}$ & $\begin{array}{l}\text { Short } \\
\text { tons. }\end{array}$ & & & & \\
\hline 1889. & 46,131 & 158 & 15,000 & 164,645 & 225,934 & $\$ 338,901$ & $\$ 1.50$ & $\cdots$ & $\cdots$ \\
\hline 1890. & 57,949 & ....... & $\ldots . .$. & 170,388 & 228,337 & 238,315 & 1.04 & 313 & 425 \\
\hline $1891 .$. & 15,000 & 1,000 & 5,000 & 150,000 & 171,000 & 256,500 & 1.50 & 312 & 850 \\
\hline 1892. & 52,614 & 250 & 3,756 & 158,878 & 215,498 & 212,761 & .99 & 277 & 467 \\
\hline $1893 \ldots \ldots$ & 196,227 & …….... & 4,869 & 171,644 & 372,740 & 365,972 & .98 & 342 & 736 \\
\hline $1894 \ldots$. & 178,610 & ......... & 8,978 & 166,523 & 354,111 & 299,290 & .85 & 304 & 729 \\
\hline $1895 \ldots$ & 135,692 & 150 & 6,256 & 118,900 & 260,998 & 215,863 & .83 & 312 & $a 848$ \\
\hline $1896 \ldots$ & 120,496 & 875 & 7,520 & 109,655 & 238,546 & 168,050 & .70 & 303 & $b 713$ \\
\hline $1897 \ldots$ & 120,398 & 1,481 & 5,500 & 68,490 & 195,869 & 140,466 & .72 & 304 & $c 469$ \\
\hline $1898 \ldots$ & 135,926 & 890 & 5,650 & 101,721 & 244,187 & 198,169 & .81 & 298 & $d 504$ \\
\hline $1899 \ldots$. & 149,954 & 440 & 6,150 & 76,567 & 233,111 & 233,344 & 1.00 & 302 & $e 567$ \\
\hline
\end{tabular}

The following table shows the total annual product since 1884:

Coal product of Georgia since 1884.

\begin{tabular}{|c|c|c|c|}
\hline Year. & Short tons. & Year. & Short tons. \\
\hline $1884 \ldots \ldots \ldots \ldots \ldots \ldots$ & 150,000 & $1892 \ldots \ldots \ldots \ldots \ldots$ & 215,498 \\
\hline $1885 \ldots \ldots \ldots$ & 150,000 & $1893 \ldots$ & 372,740 \\
\hline $1886 \ldots \ldots \ldots \ldots \ldots$ & 223,000 & $1894 \ldots \ldots \ldots \ldots \ldots$ & 354,111 \\
\hline $1887 \ldots$ & 313,715 & $1895 \ldots \ldots \ldots \ldots \ldots$ & 260,998 \\
\hline $1888 \ldots$ & 180,000 & $1896 \ldots \ldots \ldots$ & 238,546 \\
\hline $1889 \ldots \ldots \ldots$ & 225,934 & $1897 \ldots \ldots \ldots \ldots \ldots$ & 195,869 \\
\hline $1890 \ldots$ & 228,337 & $1898 \ldots \ldots \ldots$ & 244,187 \\
\hline $1891 \ldots$ & 171,000 & $1899 \ldots \ldots$. & 233,111 \\
\hline
\end{tabular}


ILLINOIS.

Total product in $1899,24,439,019$ short tons; spot value, $\$ 20,744,553$.

In 1899 the Geological Survey for the first time attempted the collection of the statistics of coal production in Illinois. Heretofore the statistics for Illinois have been taken from the reports of the State Bureau of Labor Statistics. The State bureau, however, compiles its reports for the fiscal year ending June 30, and it has been thought advisable, in order that better comparisons could be made with other States, to secure if possible the statistics of Illinois for the calendar year and uniform with the other features of this report. Considering that this was the first attempt the results were satisfactory. Reports were received from nearly every one of the commercial mines, and in the few instances where such reports were not received, the figures have been taken as reported for the fiscal year in the State report. More difficulty was encountered in securing reports from country banks. The production of most of these has been taken from the State report, and as the production from these varies very little from year to year, and is not influenced to any extent by business revivals or depressions, the difference between the tonnage of the fiscal year and that of the calendar year would be insignificant.

The Survey's compilation, with the estimates mentioned, shows the coal product of Illinois in 1899 to have been $24,439,019$ short tons, almost an even million tons over the $23,434,445$ tons given for the fiscal year in the State report. The value shows an increase of nearly $\$ 2,300,000$ over the value given in the State report, and an advance from 79 cents to 85 cents in the average price for the year. These figures indicate that in the latter half of 1899 there was more demand for Illinois coal than during the last six months of 1898, and that the improvement in prices was principally shown in the latter part of 1899.

Taking the Survey figures for 1899, and comparing the production with that of the fiscal year 1898, an increase in product of $5,839,720$ short tons, or over 31 per cent, is shown; while the value exhibits a gain of $\$ 6,176,955$, equivalent to 42 per cent.

The effects of the settlement of the labor troubles are shown in the fact that the average time made by each miner and laborer in 1899 was 228 days, against 175 days in 1898 . The number of employees increased from 35,026 to 36,756 . The tonnage won by use of undercutting machines increased from $3,415,635$ to $6,085,312$. 
The details of production in 1899 were as follows:

Coal product of Illinois in 1899, by counties.

\begin{tabular}{|c|c|c|c|c|c|c|c|c|c|}
\hline County. & $\begin{array}{l}\text { Num- } \\
\text { ber of } \\
\text { mines. }\end{array}$ & $\begin{array}{l}\text { Loaded at } \\
\text { mines for } \\
\text { shipment. }\end{array}$ & $\begin{array}{l}\text { Sold to } \\
\text { local } \\
\text { trade } \\
\text { and used } \\
\text { by em- } \\
\text { ployees. }\end{array}$ & $\begin{array}{c}\text { Used at } \\
\text { mines } \\
\text { forsteam } \\
\text { and heat. }\end{array}$ & $\begin{array}{l}\text { Total } \\
\text { product. }\end{array}$ & $\begin{array}{l}\text { Total } \\
\text { value. }\end{array}$ & $\begin{array}{c}\text { Aver- } \\
\text { age } \\
\text { price } \\
\text { per } \\
\text { ton. }\end{array}$ & $\begin{array}{l}\text { Aver- } \\
\text { age } \\
\text { num- } \\
\text { ber of } \\
\text { days } \\
\text { active. }\end{array}$ & $\begin{array}{l}\text { Average } \\
\text { number } \\
\text { of em- } \\
\text { ployees }\end{array}$ \\
\hline & & Short tons. & Short tons. & Shorttons. & Short tons. & & & & \\
\hline Bond. & 1 & 100,955 & $\ldots \ldots$. & & 100,955 & $\$ 5 T, 842$ & $\$ 0.57$ & 178 & 181 \\
\hline Brown. & 2 & $\ldots \ldots \ldots$ & 2,630 & & 2,630 & 3,945 & 1.50 & 91 & 30 \\
\hline Bureau . & 12 & $1,291,007$ & 60,638 & 49,263 & $1,400,908$ & $1,671,104$ & 1.19 & 227 & 3,565 \\
\hline Calhoun. & 1 & (2) & 6,113 & & 6,113 & 9,170 & 1.50 & 272 & 17 \\
\hline Cass ..... & 2 & $\ldots \ldots \ldots$ & 3,430 & ........ & 3,430 & 5,490 & 1.60 & 194 & 20 \\
\hline Christian & 6 & 547,218 & 49,386 & 20,423 & 617,027 & 469,183 & .76 & 161 & 928 \\
\hline Clinton.. & 5 & 532,738 & 22,819 & 21,897 & 577,454 & 413,216 & .72 & 234 & 760 \\
\hline Fulton & 29 & 586,787 & 53,745 & 11,162 & 651,694 & 614,739 & .94 & 194 & 1,126 \\
\hline Gallatin. & 5 & 10,728 & 5,833 & 275 & 16,836 & 16,289 & .97 & 163 & 52 \\
\hline Greene & 5 & 1,728 & 13,692 & $\ldots$ & 15,420 & 22,800 & 1.48 & 211 & 48 \\
\hline Grundy... & 19 & $1,182,837$ & 47,658 & 26,597 & $1,257,092$ & $1,426,803$ & 1.14 & 253 & 2,703 \\
\hline Hamilton. & 1 & & 640 & . & 640 & 900 & 1.40 & 71 & 11 \\
\hline Hancock. & 2 & ......... & 5,498 & 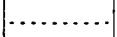 & 5,498 & 7,862 & 1.43 & 186 & 26 \\
\hline Henry ... & 21 & 45,972 & 45,991 & 466 & 92,429 & 140,431 & 1.52 & 291 & 209 \\
\hline Jackson . & 12 & 694,282 & 79,584 & 34,474 & 808,340 & 652,939 & .81 & 200 & 1,053 \\
\hline Jefferson & 1 & 61,265 & 800 & 945 & 63,010 & 63,010 & 1.00 & 210 & 83 \\
\hline Jersey .... & 2 & $\ldots$. & $4,0.50$ & & 4,050 & 6,075 & 1.50 & 150 & 20 \\
\hline Johnson & 1 & 1,030 & 2,501 & 10 & 3,541 & 2,751 & .78 & 124 & 19 \\
\hline Kankakee... & 2 & 121,164 & 3,854 & 4,244 & 129,262 & 127,932 & .99 & 248 & 207 \\
\hline Knox.. & 11 & . . . . & 55,820 & 104 & 55,924 & 74,613 & 1.33 & 185 & 180 \\
\hline Las & 23 & $1,736,624$ & 234,083 & 44,597 & $2,015,304$ & $1,991,741$ & .99 & 255 & 3,440 \\
\hline Livingston & 12 & 67,890 & 54,125 & 7,469 & 129,484 & 147,986 & 1.14 & 197 & 267 \\
\hline $\log$ & 3 & 147,654 & $37,3.76$ & 650 & 185,480 & 187,825 & 1.01 & 209 & 249 \\
\hline McDonough & 8 & 20,059 & 22,160 & 50 & 42,269 & 56,733 & 1.34 & 129 & 275 \\
\hline McLean & 5 & 165,724 & 8,087 & 12,676 & 186,487 & 245,209 & 1.31 & 254 & 421 \\
\hline $\mathrm{Mac}$ & 3 & 77,345 & 73,058 & ....... & 150,403 & 169,907 & 1.13 & 221 & 532 \\
\hline $\mathrm{Ma}$ & 15 & $1,629,811$ & 49,806 & 47,485 & $1,727,102$ & $1,243,388$ & .72 & 211 & 2,039 \\
\hline Mad & 15 & $1,432,069$ & 58,765 & 47,215 & $1,538,049$ & $1,057,975$ & .69 & 252 & 1,350 \\
\hline Mar & 6 & 653,938 & 29,695 & 26,854 & 710,487 & 475,081 & .67 & 226 & 955 \\
\hline Marshall. & 4 & 322,627 & 17,305 & 10,800 & 350,732 & 378,606 & 1.08 & 275 & 764 \\
\hline Men & 9 & 371,256 & 29,935 & 31,757 & 432,948 & 362,030 & .84 & 214 & 531 \\
\hline Mercer ....... & 14 & 450,120 & 36,368 & 16,986 & 503,474 & 570,218 & 1.13 & 233 & $\tau 81$ \\
\hline Montgomery & 6 & 288,374 & 9,120 & 3,930 & 301,424 & 186,615 & .62 & 263 & 399 \\
\hline Morgan..... & 2 & ........ & 4,500 & 6 & 4,506 & 6,759 & 1.50 & 250 & 14 \\
\hline Peoria... & 43 & 671,781 & 111,204 & 9,254 & 792,239 & 708,682 & .89 & 234 & 1,164 \\
\hline Per & 21 & 769,095 & 31,990 & 8,340 & 809,425 & 487,437 & .60 & 200 & 1,153 \\
\hline Randolph & 11 & 387,676 & 43,366 & 5,992 & 437,034 & 303,522 & .69 & 227 & 592 \\
\hline Rock Islan & 13 & ......... & 43,177 & 828 & 44,005 & 69,436 & 1.58 & 158 & 154 \\
\hline St. & 59 & $1,866,420$ & 159,977 & 52,956 & $2,079,353$ & $1,381,534$ & .66 & 219 & 2,325 \\
\hline Saline.... & 4 & 88,243 & 7,100 & 393 & 95,736 & 73,176 & .76 & 231 & 174 \\
\hline Sangamon. & 26 & $2,133,926$ & 115,940 & 39,842 & $2,289,708$ & $1,790,742$ & .78 & 229 & 2,793 \\
\hline Schuyler ... & 6 & …........ & 15,874 & $\cdots \cdot$ & 15,874 & 17,996 & 1.13 & 221 & 41 \\
\hline Scott $\ldots \ldots$ & 2 & 18,765 & $2.96^{2}$ & 500 & 22,227 & 27,979 & 1.26 & 283 & 55 \\
\hline Shelby.... & 4 & 79,057 & 20,352 & 6,000 & 105,409 & 118,490 & 1.12 & 207 & 154 \\
\hline Stark. & 11 & 515 & 24,375 & 540 & 25,430 & 34,206 & 1.35 & 192 & 83 \\
\hline Tazewell. & 11 & 80,491 & 17,351 & 250 & 98,092 & 88,645 & .90 & 208 & 200 \\
\hline Vermilion ... & 45 & $2,032,274$ & 130,775 & 28,018 & $2,191,067$ & $1,677,004$ & .77 & 244 & 2,549 \\
\hline Warr & 6 & $\ldots \ldots \ldots \ldots$ & 16,892 & 100 & 16,992 & $26,89 \dot{4}$ & 1.58 & 204 & 58 \\
\hline Wash & 4 & 28,000 & 3,960 & 400 & 32,360 & 27,213 & .84 & 175 & 87 \\
\hline will. & 3 & 32,368 & 6,309 & 3,598 & 42,275 & 59,524 & 1.41 & 252 & 131 \\
\hline williamson.... & -14 & 990,952 & 43,487 & 37,928 & $1,072,367$ & 779,316 & .73 & 223 & 1,350 \\
\hline Woodford .... & 2 & 151,165 & 12,559 & 15,300 & 179,024 & 205,590 & 1.15 & 248 & 438 \\
\hline Tot & 550 & $21,871,930$ & 936,515 & 630,574 & $24,439,019$ & $20,744,553$ & .85 & 228 & 36,756 \\
\hline
\end{tabular}


COAL.

Coal product of Illinois in 1896,1897, 1898, and 1899, by counties.

\begin{tabular}{|c|c|c|c|c|c|c|}
\hline County & 1896. & 1897. & 1898. & 1899. & $\begin{array}{c}\text { Increase, } \\
1899 .\end{array}$ & $\begin{array}{c}\text { Decrease, } \\
1899 .\end{array}$ \\
\hline & Short tons. & Short tons. & Short tons. & Short tons. & Short tons. & Short tons. \\
\hline Bond... & 71,058 & 104,256 & 96,314 & 100,955 & 4,641 & \\
\hline Brown & …........ & 1,760 & 1,940 & 2,630 & 690 & \\
\hline Bureau . & $1,042,304$ & $1,145,312$ & 865,892 & $1,400,908$ & 535,016 & \\
\hline Calhoun. & 6,000 & 3,868 & 4,893 & 6,113 & 1,220 & \\
\hline Cass . . . & 8,612 & 4,536 & 2,900 & 3,430 & 530 & \\
\hline Christian . & 763,228 & 837,897 & 495,616 & 617,027 & 121,411 & \\
\hline Clinton. & 309,504 & 328,184 & 417,584 & 577,454 & 159,870 & \\
\hline Fulton & 516,349 & 469,034 & 563,397 & 651,694 & 88,297 & \\
\hline Gallatin . & 26,350 & 19,945 & 16,812 & 16,836 & 24 & \\
\hline Greene ... & 8,270 & 7,200 & 8,520 & 15,420 & 6,900 & \\
\hline Grundy .. & $1,247,394$ & $1,077,576$ & 796,249 & $1,257,092$ & 460,843 & \\
\hline Hamilton. & 1,000 & 760 & 4,882 & 640 & & 4,242 \\
\hline Hancock .. & 4,497 & 4,160 & 5,600 & 5,498 & & 102 \\
\hline Henry ..... & 136,415 & 119,497 & 159,049 & 92,429 & & 66,620 \\
\hline Jackson ... & 771,384 & 675,21 & 911,194 & 808,340 & & 102,854 \\
\hline Jefferson & 10,100 & 51,355 & 46,060 & 63,010 & 16,950 & \\
\hline Jersey..... & $a 2,325$ & $\ldots \ldots$ & 1,680 & 4,050 & 2,370 & \\
\hline Johnson... & 1,250 & 2,778 & 2,030 & 3,541 & 1,511 & \\
\hline Kankakee & $7 \varepsilon, 395$ & 180,683 & 84,632 & 129,262 & 44,630 & \\
\hline Knox .... & 39,557 & 41,773 & 49,819 & 55,924 & 6,105 & \\
\hline Lasalle ... & $1,409,085$ & $1,508,833$ & $1,165,490$ & $2,015,304$ & 849,814 & \\
\hline Livingston & 218,953 & 145,206 & 122,087 & 129,484 & 7,397 & \\
\hline Logan & 166,000 & 168,917 & 177,935 & 185,480 & 7,545 & \\
\hline McDonough & 47,821 & 40,532 & 77,696 & 42,269 & $\ldots .$. & 35,427 \\
\hline McLean ... & 156,891 & 153,334 & 171,594 & 186,487 & 14,893 & \\
\hline Macon ... & 188,207 & 173,163 & 300,264 & 150,403 & $\cdots$. & 149,861 \\
\hline Macoupin & $2,097,539$ & $1,975,981$ & $1,264,926$ & $1,727,102$ & 462,176 & \\
\hline Madison. & $1,080,718$ & 780,921 & 630,769 & $1,538,049$ & 907,280 & \\
\hline Marion . & 643,561 & 626,850 & 714,513 & 710,487 & $\cdots \cdots$ & 4,026 \\
\hline Marshall . & 389,429 & 339,820 & 286,365 & 350,732 & 64,367 & \\
\hline Menard .. & 347,365 & 328,920 & 314,160 & 432,948 & 118,788 & \\
\hline Mercer ... & 450,071 & 425,518 & 384,345 & 503,474 & 119,129 & \\
\hline Montgomery .. & 171,099 & 251,249 & 294,667 & 301,424 & 6,757 & \\
\hline Morgan ...... & (a) & ...... & 1,800 & 4,506 & 2,706 & \\
\hline Peoria.... & 457,061 & 504,309 & 640,193 & 792,239 & 152,046 & \\
\hline Perry ... & 626,507 & 689,921 & 845,329 & 809,425 & & 35,904 \\
\hline Randolph & 202,838 & 150,647 & 274,072 & 437,034 & 162,962 & \\
\hline Rock Island .. & 34,065 & 35,651 & 47,490 & 44,005 & & 3,485 \\
\hline St. Clair ....... & $1,671,323$ & $1,718,194$ & $1,600,752$ & $2,079,353$ & 478,601 & \\
\hline
\end{tabular}

a Jersey County includes product of Morgan county. 
Coal product of Illinois in 1896, 1897, 1898, and 1899, by counties-Continued.

\begin{tabular}{|c|c|c|c|c|c|c|}
\hline County. & 1896. & 1897. & 1898. & 1899. & $\begin{array}{c}\text { Increase, } \\
1899 .\end{array}$ & $\begin{array}{c}\text { Decrease, } \\
1899 .\end{array}$ \\
\hline Saline... . . . . & $\begin{array}{r}\text { Short tons. } \\
46,495\end{array}$ & $\begin{array}{r}\text { Short tons. } \\
51,689\end{array}$ & $\begin{array}{l}\text { Shorl tons. } \\
100,005\end{array}$ & $\begin{array}{r}\text { Short tons. } \\
95,736\end{array}$ & Short tons. & $\begin{array}{c}\text { Short tons. } \\
4,269\end{array}$ \\
\hline Sangamon .... & $1,587,812$ & $1,838,453$ & $1,763,863$ & $2,289,708$ & 525,845 & \\
\hline Schuyler ... & 7,915 & 7,841 & 11,149 & 15,874 & 4,725 & \\
\hline Scott . . . . . & 18,410 & 25,125 & 21,337 & 22,227 & 890 & \\
\hline Shelby ... & 35,297 & 69,329 & 68,388 & 105,409 & 37,021 & \\
\hline Stark. . . . . & 18,085 & 19,472 & 21,936 & 25,430 & 3,494 & \\
\hline Tazewell .. & 113,541 & 86,669 & 84,507 & 98,092 & 13,585 & \\
\hline Vermilion & $1,822,344$ & $2,000,623$ & $\mathbf{1}, 520,699$ & $2,191,067$ & 670,368 & \\
\hline Warren .. & 12,696 & 10,099 & 12,245 & 16,992 & 4,747 & \\
\hline Washington & 33,360 & 25,715 & 43,808 & 32,360 & $\ldots \ldots$ & 11,448 \\
\hline Will & 86,950 & 25,682 & 40,904 & 42,275 & 1,371 & \\
\hline Williamson ... & 444,406 & 669,480 & 915,108 & $1,072,367$ & 157,259 & \\
\hline Woodford & 162,790 & 148,829 & 145,840 & 179,024 & 33,184 & \\
\hline Total & $19,786,626$ & $20,072,758$ & $18,599,299$ & $24,439,019$ & $a 5,839,720$ & \\
\hline
\end{tabular}

$a$ Net increase.

Distribution of the coal product of Illinois from 1889 to 1899.

\begin{tabular}{|c|c|c|c|c|c|c|c|c|c|c|}
\hline Year. & $\begin{array}{l}\text { Num- } \\
\text { ber of } \\
\text { mines. }\end{array}$ & $\begin{array}{c}\text { Loaded } \\
\text { at mines } \\
\text { for ship- } \\
\text { ment. }\end{array}$ & $\begin{array}{l}\text { Sold to } \\
\text { local } \\
\text { trade } \\
\text { and used } \\
\text { by em- } \\
\text { ployees. }\end{array}$ & $\begin{array}{l}\text { Used at } \\
\text { mines } \\
\text { for } \\
\text { steam } \\
\text { and } \\
\text { heat. }\end{array}$ & $\begin{array}{l}\text { Made } \\
\text { into } \\
\text { coke } \\
\text { at the } \\
\text { mines. }\end{array}$ & $\begin{array}{c}\text { Total } \\
\text { product. }\end{array}$ & $\begin{array}{l}\text { Total } \\
\text { value. }\end{array}$ & $\begin{array}{c}\text { Aver- } \\
\text { age } \\
\text { price } \\
\text { per } \\
\text { ton. }\end{array}$ & $\begin{array}{l}\text { Aver- } \\
\text { age } \\
\text { num- } \\
\text { ber of } \\
\text { days } \\
\text { active. }\end{array}$ & $\begin{array}{l}\text { A verage } \\
\text { number } \\
\text { of em- } \\
\text { ployees. }\end{array}$ \\
\hline & & $\begin{array}{l}\text { Short } \\
\text { tons. }\end{array}$ & $\begin{array}{l}\text { Short } \\
\text { tons. }\end{array}$ & $\begin{array}{l}\text { Short } \\
\text { tons. }\end{array}$ & $\begin{array}{l}\text { Short } \\
\text { tons. }\end{array}$ & $\begin{array}{l}\text { Short } \\
\text { tons. }\end{array}$ & & & & \\
\hline 1889. & $a 854$ & $9,884,883$ & $1,816,702$ & 395,787 & 12,900 & $12,104,272$ & $\$ 11,755,203$ & $\$ 0.97$ & $\ldots$ & \\
\hline 1890. & 936 & $12,5: 9,784$ & $2,130,539$ & 606,497 & 15,600 & $15,292,420$ & $14,171,230$ & .93 & 204 & 28,574 \\
\hline 1891. & 918 & $12,787,993$ & $2,246,705$ & 610,000 & 16,000 & $15,660,698$ & $14,237,074$ & .91 & 216 & 32,951 \\
\hline 1892. & 839 & $14,557,655$ & $2,624,821$ & 675,000 & 4,800 & $17,862,276$ & $16,243,645$ & .91 & 220 & 34,585 \\
\hline 1893. & 788 & $16,260,463$ & $2,931,846$ & 753,955 & 3,300 & $19,949,564$ & $17,827,595$ & .89 & 229 & 35,390 \\
\hline 1894. & 836 & $13,948,910$ & $2,590,414$ & 570,452 & 3,800 & $17,113,576$ & $15,282,111$ & .89 & 183 & 38,477 \\
\hline 1895. & $b 319$ & $14,456,524$ & $2,684,607$ & 591,133 & 3,600 & $17,735,864$ & $14,239,157$ & .80 & 182 & 38,630 \\
\hline $1890^{\circ}$. & 330 & $16,128,103$ & $2,995,0: 22$ & 659,601 & 3,900 & $19,786,626$ & $15,809,736$ & .80 & 186 & 33,054 \\
\hline 1897. & 310 & $16,358,221$ & $3,041,712$ & 669,012 & 3,813 & $20,072,758$ & $14,472,529$ & .72 & 185 & 33,788 \\
\hline 1898.. & 329 & $15,596,888$ & $2,149,80 \mathrm{~S}$ & 852,603 & & $18,599,299$ & $14,56 \bar{\imath}, 598$ & .78 & 175 & 35,026 \\
\hline 1899. & 550 & $21,871,930$ & $1,936,515$ & 630,574 & & $24,439,019$ & $20,744,553$ & .85 & 228 & 36,756 \\
\hline
\end{tabular}

$a$ From 1889 to 1894 , including shipping and local mines. $b$ Since 1894, shipping or commercial mines only. 
Total number of mines, men, and product, lump and other grades, since 1882.a

\begin{tabular}{|c|c|c|c|c|c|}
\hline $\begin{array}{l}\text { Fiscal year ending } \\
\text { June } 30-\end{array}$ & $\begin{array}{c}\text { Whole } \\
\text { number } \\
\text { of } \\
\text { mines. }\end{array}$ & $\begin{array}{l}\text { Whole } \\
\text { number of } \\
\text { men em- } \\
\text { ployed. }\end{array}$ & $\begin{array}{l}\text { Total product } \\
\text { in tons }(2,000 \\
\text { pounds). }\end{array}$ & $\begin{array}{l}\text { Total tons of } \\
\text { lump coal. }\end{array}$ & $\begin{array}{l}\text { Total tons } \\
\text { of other } \\
\text { grades. }\end{array}$ \\
\hline 1882. & 704 & 20,290 & $11,017,069$ & $9,115,653$ & $1,901,506$ \\
\hline 1883. & 639 & 23,939 & $12,123,456$ & $10,030,991$. & $2,092,465$ \\
\hline 1884 & 741 & 25,575 & $12,208,075$ & $10,101,005$ & $2,107,070$ \\
\hline 1885. & 778 & 25,946 & $11 ; 834,459$ & $9,791,874$ & $2,402,585$ \\
\hline 1886. & 787 & 25,846 & $11,175,241$ & $9,246,435$ & $1,928,806$ \\
\hline $1887 \ldots$ & 801 & 26,804 & $12,423,066$ & $10,278,890$ & $2,144,176$ \\
\hline 1888. & 822 & 29,410 & $14,328,181$ & $11,855,188$ & $2,472,993$ \\
\hline 1889. & 854 & 30,076 & $14,017,298$ & $11,597,963$ & $2,419,335$ \\
\hline $1890 \ldots$ & 936 & 28,574 & $15,292,420$ & $12,638,364$ & $2,654,056$ \\
\hline $1891 \ldots$ & 918 & 32,951 & $15,660,698$ & $12,960,224$ & $2,700,474$ \\
\hline 1892. & 839 & 34,585 & $17,862,276$ & $14,730,963$ & $3,131,313$ \\
\hline 1893. & 788 & 35,390 & $19,949,564$ & $16,112,899$ & $3,836,655$ \\
\hline $1894 \ldots$ & 836 & 38,477 & $17,113,576$ & $13,865,284$ & $3,248,292$ \\
\hline 1895. & 874 & 38,630 & $17,735,864$ & $14,045,962$ & $3,689,902$ \\
\hline 1896 & 901 & 33,054 & $19,786,626$ & $14,210,024$ & $5,576,602$ \\
\hline $1897 .$. & 853 & 33,788 & $20,072,758$ & $14,672,241$ & $5,400,517$ \\
\hline 1898. & 881 & 35,026 & $18,599,299$ & $14,208,795$ & $4,390,504$ \\
\hline $1899 \ldots$ & 889 & 36,991 & $23,434,445$ & $17,427,598$ & $6,006,847$ \\
\hline
\end{tabular}

$a$ Fiscal years taken from the State report.

\section{INDIANA.}

Total product in $1899,6,006,523$ short tons; spot value, $\$ 5,285,018$.

In the report for 1898 attention was called to the fact that Indiana in that year had reaped the benefit of the decreased production in Illinois brought about by the protracted strikes in that State, and that this had been the cause of the increase of 770,000 tons in the product for 1898 as compared with 1897 . It was suggested that with the return to normal conditions in Illinois, Indiana would probably lose the markets obtained in 1898. Such, however, does not seem to have been the case, if the statistics for 1899 may be taken as an indication, for in spite of an increase of approximately 6,000,000 tons in the output from Illinois mines, the product of Indiana increased 1,085,780 tons, and makes the State firmly fixed as the sixth in coal-producing importance in the country. In the value of the product the increase in 1899 is even more pronounced, $\$ 1,290,100$ being added to the value of the product in 1898 , and the average price advancing from 81 cents to 88 cents per ton.

The number of machines employed in Indiana mines increased from 233 in 1898 to 247 in 1899 , while the machine-mined product increased from $1,414,342$ tons to $1,713,125$ tons. 
The statistics of production in the past two years have been as follows: Coal product of Indiana in 1898, by counties.

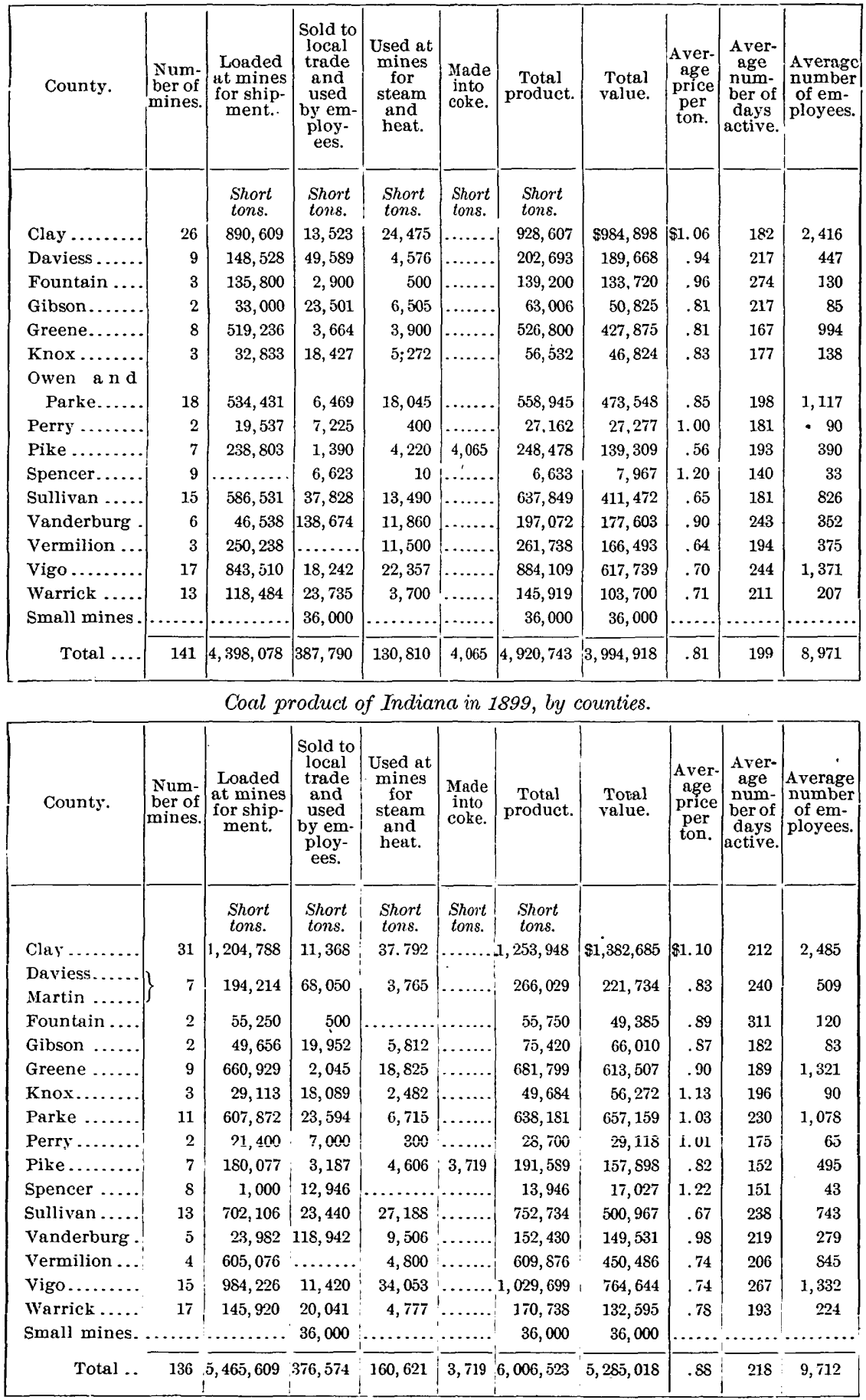


Distribution of the coal product of Indiana from 1889 to 1899.

\begin{tabular}{|c|c|c|c|c|c|c|c|c|c|c|}
\hline Year. & $\begin{array}{l}\text { Num- } \\
\text { ber of } \\
\text { mines. }\end{array}$ & $\begin{array}{l}\text { Loaded at } \\
\text { mines } \\
\text { for ship- } \\
\text { ment. }\end{array}$ & $\begin{array}{c}\text { Sold to } \\
\text { local } \\
\text { trade } \\
\text { and used } \\
\text { by em- } \\
\text { ployees. }\end{array}$ & $\begin{array}{l}\text { Used at } \\
\text { mines } \\
\text { for } \\
\text { steam } \\
\text { and } \\
\text { heat. }\end{array}$ & $\begin{array}{l}\text { Made } \\
\text { into } \\
\text { coke. }\end{array}$ & $\begin{array}{c}\text { Total } \\
\text { product. }\end{array}$ & $\begin{array}{l}\text { Total } \\
\text { value. }\end{array}$ & $\begin{array}{c}\text { Aver- } \\
\text { age } \\
\text { price } \\
\text { per } \\
\text { ton. }\end{array}$ & $\begin{array}{l}\text { Aver- } \\
\text { age } \\
\text { num- } \\
\text { ber of } \\
\text { days } \\
\text { active. }\end{array}$ & $\begin{array}{c}\text { Average } \\
\text { number } \\
\text { of em- } \\
\text { ployees. }\end{array}$ \\
\hline & & $\begin{array}{l}\text { Short } \\
\text { tons. }\end{array}$ & $\begin{array}{l}\text { Short } \\
\text { tons. }\end{array}$ & $\begin{array}{l}\text { Short } \\
\text { tons. }\end{array}$ & $\begin{array}{l}\text { Short } \\
\text { tons. }\end{array}$ & $\begin{array}{l}\text { Short } \\
\text { tons. }\end{array}$ & & & & \\
\hline 1889 & & $2,527,112$ & 237,935 & 67,210 & 12,800 & $2,845,057$ & $\$ 2,887,852$ & $\$ 1.02$ & ..... & 6,448 \\
\hline 1890. & & $3,036,737$ & 225,167 & 34,703 & $\dot{9}, 130$ & $3,305,737$ & $3,259,233$ & .91 & 220 & 5,489 \\
\hline 1891. & 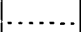 & $2,689,780$ & 211,854 & 63,152 & 8,688 & $2,973,474$ & $3,070,918$ & 1.03 & 190 & 5,879 \\
\hline 1892 & & $3,088,911$ & 208,220 & 42,621 & 5,422 & $3,345,174$ & $3,620,582$ & 1.08 & 225 & 6,436 \\
\hline $1893 .$. & $\ldots$ & $3,461,830$ & $25^{2}, 879$ & 69,797 & 7,345 & $3,791,851$ & $4,055,372$ & 1.07 & 201 & 7,644 \\
\hline $1894 \ldots$ & 107 & $3,085,664$ & $248,398^{\circ}$ & 67,545 & 22,314 & $3,423,921$ & $3,295,034$ & .96 & 149 & 8,603 \\
\hline $1895 \ldots$ & 117 & $3,488,876$ & 392,423 & 104,695 & 9,898 & $3,995,892$ & $3,642,623$ & .91 & 189 & 8,530 \\
\hline $1896 \ldots$ & 131 & $3,471,470$ & 311,911 & 113,442 & 8,956 & $3,905,779$ & $3,261,737$ & .84 & 163 & 8,806 \\
\hline $1897 \ldots$ & 115 & $3,639,758$ & 393,012 & 111,376 & 7,023 & $4,151,169$ & $3,472,348$ & .84 & 176 & 8,886 \\
\hline $1898 \ldots$ & 141. & $4,398,078$ & 387,790 & 130,810 & 4,065 & $4,920,743$ & $3,994,918$ & .81 & 199 & 8,971 \\
\hline $1899 .$. & 136 & $5,465,609$ & 376,574 & 160,621 & 3,719 & $6,006,523$ & $5,285,018$ & .88 & 218 & 9,712 \\
\hline
\end{tabular}

The product by counties during the past five years is presented in the following table, with the increase or decrease in each county in 1899:

Coal product of Indiana since 1895, by counties.

\begin{tabular}{|c|c|c|c|c|c|c|c|}
\hline County. & 1895. & 1896. & 1897. & 1898. & 1899. & $\begin{array}{c}\text { Increase, } \\
1899 .\end{array}$ & $\begin{array}{c}\text { Decrease, } \\
1899 .\end{array}$ \\
\hline - & Short tons. & Short tons. & Short tons. & Short tons. & Short tons. & Short tons. & Short tons. \\
\hline Clay ..... & $1,223,186$ & $1,232,435$ & 925,727 & 928,607 & $1,253,948$ & 325,341 & \\
\hline Daviess... & 81,380 & 192,775 & 211,797 & $202 ; 693$ & $a 266,029$ & 63,336 & \\
\hline Fountain. & $\ldots \ldots \ldots$ & 105,650 & 137,250 & 139,200 & 55,750 & ........ & 83,450 \\
\hline Gibson ... & 1,940 & 24,775 & 41,409 & 63,006 & 75,420 & 12,414 & \\
\hline Greene ......... & 409,080 & 290,046 & 448,873 & 526,800 & 681,799 & 154,999 & \\
\hline Knox........ & 26,443 & 30,500 & 36,752 & 56,532 & 49,684 & & 6,848 \\
\hline Owen.... & …..... & ......... & n....... & 7,808 & n....... & ............. & 7,808 \\
\hline Parke ... & 479,609 & 339,677 & 434,007 & 551,137 & 638,181 & 87,044 & \\
\hline Perry ..... & 18,960 & 26,227 & 23,712 & 27,162 & 28,700 & 1,538 & \\
\hline Pike.... . & 232,950 & 201,417 & 248,043 & 248,478 & - 191,589 & ....... & 56,889 \\
\hline Spencer.. & 10,879 & 16,703 & 4,339 & 6,633 & 13,946 & 7,313 & \\
\hline Sullivan ..... & 453,167 & 515,285 & 480,045 & 637,849 & 752,734 & 114,885 & \\
\hline Vanderburg ..... & 192,710 & 170,755 & 182,800 & 197,072 & 152,430 & .......... & 44,642 \\
\hline Vermilion... & 306,000 & 347,166 & 321,560 & 261,738 & 609,876 & 348,138 & \\
\hline Vigo............ & 402,335 & 237,647 & 442,531 & 884,109 & $1,029,699$ & 145,590 & \\
\hline Warrick. & 121,253 & 138,721 & 176,324 & 145,919 & 170,738 & 24,819 & \\
\hline Small mines... & 36,000 & 36,000 & 36,000 & 36,000 & 36,000 & & \\
\hline Total. & $3,995,892$ & $3,905,779$ & $4,151,169$ & $4,920,743$ & $6,006, \overline{5} 23$ & $b 1,085,780$ & \\
\hline
\end{tabular}

$a$ Includes Martin County.

$b$ Net increase. 
Product of coal in Indiana from 1873 to 1899.

\begin{tabular}{|c|c|c|c|}
\hline Year. & Short tons. & Year. & Short tons. \\
\hline $1873 \ldots$ & $1,000,000$ & 1887 & $3,217,711$ \\
\hline $1874 \ldots$ & 812,000 & 1888 & $3,140,979$ \\
\hline 1875 & 800,000 & 1889 & $2,845,057$ \\
\hline $1876 .$. & 950,000 & 1890 & $3,305,737$ \\
\hline 1877 & $1,000,000$ & 1891. & $2,973,474$ \\
\hline 1878 & $1,000,000$ & 1892. & $3,345,174$ \\
\hline 1879. & $1,196,490$ & 1893. & $3,791,851$ \\
\hline $1880 \ldots$ & $1,500,000$ & 1894 & $3,423,921$ \\
\hline $1881 \ldots$ & $1,771,536$ & 1895. & $3,995,892$ \\
\hline $1882 \ldots$ & $1,976,470$ & 1896. & $3,905,779$ \\
\hline $1883 \ldots$ & $2,560,000$ & $1897 \ldots$ & $4,151,169$ \\
\hline $1884 \ldots$ & $2,260,000$ & $1898 \ldots$ & $4,920,743$ \\
\hline $1885 \ldots$ & $2,375,000$ & 1899 & $6,006,523$ \\
\hline $1886 \ldots \ldots \ldots \ldots$ & $3,000,000$ & & \\
\hline
\end{tabular}

\section{INDIAN TERRITORY.}

Total product in $1899,1,537,427$ short tons; spot value, $\$ 2,199,785$.

In spite of strikes, which occurred in 19 out of the 29 mines in the Territory and gave enforced idleness to 1,825 men for an average of 154 days, the coal production in 1899 increased 155,961 short tons, or about 10 per cent, over that of 1898 . The value of the product increased in somewhat greater ratio, or 20 per cent, from $\$ 1,827,638$ in 1898 to $\$ 2,199,785$ in 1899 . The average price per ton advanced 11 cents, from $\$ 1.32$ to $\$ 1.43$.

The strikes in the mines of the Territory were precipitated by the demand of the miner's' union that it should be recognized as such, and the refusal of the operators to comply with the demand. So far as has been ascertained, the miners had no complaint to make in regard to wages, it being simply a question of whether the operators should deal with each employee individually or should recognize the union and deal with it. The struggle lasted during the greater part of the year, and while few of the mines were closed down entirely for any considerable length of time, the total time lost by the strike was equal to about onethird of the actual working time made by all the miners and other laborers in the Territory. The total average number of men on the pay rolls for the year was $4,08 t$, and the average working time made by them was 212 days, or a total of 864,196 working days. The total working time lost by the $1,825^{\circ}$ men on strike was 281,256 days, or an average of $15 \pm$ days each. 
The statistics of machine-mined coal in the Territory show that there was a decrease of one machine in the number in use ( 75 to 74 ) and a slight gain (less than 1 per cent) in the machine-mined tonnage.

The details of production during the past nine years are presented in the following table:

Distribution of the coal product of the Indian Territory since 1891.

\begin{tabular}{|c|c|c|c|c|c|c|c|c|c|c|}
\hline Year. & $\begin{array}{l}\text { Num- } \\
\text { ber of } \\
\text { mines. }\end{array}$ & $\begin{array}{l}\text { Loaded at } \\
\text { mines for } \\
\text { shipment. }\end{array}$ & $\begin{array}{l}\text { Sold to } \\
\text { local } \\
\text { trade and } \\
\text { used by } \\
\text { em- } \\
\text { ployees. }\end{array}$ & $\begin{array}{l}\text { Used at } \\
\text { mines for } \\
\text { steam } \\
\text { and heat. }\end{array}$ & $\begin{array}{l}\text { Made } \\
\text { into } \\
\text { coke. }\end{array}$ & $\begin{array}{c}\text { Total } \\
\text { product. }\end{array}$ & $\begin{array}{l}\text { Total } \\
\text { value. }\end{array}$ & $\begin{array}{l}\text { Aver- } \\
\text { age } \\
\text { price } \\
\text { per } \\
\text { ton. }\end{array}$ & $\begin{array}{l}\text { Aver- } \\
\text { age } \\
\text { num- } \\
\text { ber of } \\
\text { days } \\
\text { active. }\end{array}$ & $\begin{array}{c}\text { A verage } \\
\text { number } \\
\text { of em- } \\
\text { ployees. }\end{array}$ \\
\hline & & $\begin{array}{l}\text { Short } \\
\text { tons. }\end{array}$ & $\begin{array}{l}\text { Short } \\
\text { tons. }\end{array}$ & $\begin{array}{l}\text { Short } \\
\text { tons. }\end{array}$ & $\begin{array}{l}\text { Short } \\
\text { tons. }\end{array}$ & $\begin{array}{l}\text { Short } \\
\text { tons. }\end{array}$ & & & & \\
\hline 1891 & & $1,026,932$ & 9,405 & 22,163 & 32,532 & $1,091,032$ & $\$ 1,897,037$ & $\$ 1.74$ & 222 & 2,891 \\
\hline 1892. & $\cdots$ & $1,156,603$ & 10,840 & 18,089 & 7,189 & $1,192,721$ & $2,043,479$ & 1.71 & 211 & 3,257 \\
\hline j893. & & $1,197,468$ & 9,234 & 21,663 & 23,745 & $1,252,110$ & $2,235,209$ & 1.79 & 171 & 3,446 \\
\hline 1894. & ... & 923,581 & 4,632 & 30,878 & $10,51 j$ & 969,606 & $1,541,293$ & 1.59 & 157 & 3,101 \\
\hline 1895. & 16 & $1,173,399$ & 3,070 & 21,935 & 12,781 & $1,211,185$ & $1,737,254$ & 1.43 & 164 & 3,212 \\
\hline 1896. & 21 & $1,295,742$ & 12,648 & 45,560 & 12,696 & $1,366,646$ & $1,918,115$ & 1.40 & 170 & 3,549 \\
\hline $1897 \ldots$ & 19 & $1,250,066$ & 9,068 & 47,501 & 29,745 & $1,336,380$ & $1,787,358$ & 1.34 & 176 & 3,168 \\
\hline $1898 \ldots$ & 22 & $1,310,178$ & 16,632 & 34,055 & 20,601 & $1,381,466$ & $1,827,638$ & 1.32 & 198 & 3,216 \\
\hline $1899 \ldots$ & 29 & $1,444,063$ & 12,280 & 54,222 & 26,862 & $1,537,427$ & $2,199,785$ & 1.43 & 212 & 4,084 \\
\hline
\end{tabular}

Since 1885 the annual production has been as follows:

Product of coal in the Indian Territory from 1885 to 1899, inclusive.

\begin{tabular}{|c|c|c|c|c|c|}
\hline Year. & Quantity. & Value. & $\begin{array}{c}\text { Average } \\
\text { price per } \\
\text { ton. }\end{array}$ & $\begin{array}{c}\text { Average } \\
\text { number of } \\
\text { days active. }\end{array}$ & $\begin{array}{l}\text { Average } \\
\text { number o } \\
\text { employees }\end{array}$ \\
\hline 1885. & $\begin{array}{l}\text { Short tons. } \\
500,000\end{array}$ & & & & \\
\hline 1886 & 534,580 & $\$ 855,328$ & $\$ 1.60$ & & \\
\hline 1887 & 685,911 & $1,286,692$ & 1.88 & & \\
\hline 1888. & 761,986 & $1,432,072$ & 1. 89 & & \\
\hline 1889. & 752,832 & $1,323,807$ & 1.76 & $\ldots$ & 1,862 \\
\hline 1890 & 869,229 & $1,579,188$ & 1.82 & 238 & 2,571 \\
\hline $1891 \ldots$ & $1,091,032$ & $1,897,037$ & 1. 71 & 222 & 2,891 \\
\hline 1892. & $1,192,721$ & $2,043,479$ & 1.71 & 211 & 3,257 \\
\hline 1893. & $1,252,110$ & $2,235,209$ & 1. 79 & 171 & 3,446 \\
\hline 1894. & 969,606 & $1,541,293$ & 1.59 & 157 & 3,101 \\
\hline $1895 .$. & $1,211,185$ & $1,737,254$ & 1.43 & 164 & 3,212 \\
\hline 1896 & $1,366,646$ & $1,918,115$ & 1.40 & 170 & 3,549 \\
\hline $1897 \ldots$ & $1,336,380$ & $1,787,358$ & 1.34 & 176 & 3,168 \\
\hline $1898 \ldots$ & $1,381,466$ & $1,827,638$ & 1.32 & 198 & 3,216 \\
\hline $1899 \ldots$ & $1,537,427$ & $2,199,785$ & 1.43 & 212 & 4,084 \\
\hline
\end{tabular}


IOWA.

Total product in $1899,5,177, \pm 79$ short tons; spot value, $\$ 6,397,338$.

Iowa, for the first time in the history of the State, contributed over $5,000,000$ short tons to the total coal product of the country. Previous to 1899 the record of maximum yearly production was made in 1888 , when a total output of $4,952,440$ short tons was obtained. The value of the product in 1888 slightly exceeded that of 1899 . Compared with 1898 the production in 1899 shows an increase of 558,637 short tons, or about 12 per cent in quantity, and of $\$ 1,133,622$ or 21.6 per cent in value. The average price per ton, $\$ 1.24$, was the highest recorded in five years. Strikes of comparatively short duration occurred in 31 of the 230 active and reporting mines. The average working time lost by each man on strike was only 28 days, and although a total of 2,623 men were made idle the total working time lost was but 72,710 days-less than 3 per cent of the actual working time made by the 10,971 men employed in and about the mines. Notwithstanding the strikes the average number of days made in 1899 showed an increase of 10 over 1898.

The use of machines, according to the reports for 1899, shows a decided falling off. This may be due to incomplete returns, but the reports as received show that the number of machines in use decreased from 56 in 1898 to 41 in 1899 , and the machine-mined coal decreased from 218,852 to 124,721 tons. The number of firms reporting machines dropped from 9 to 4 .

Coal product of Iowa in 1898, by counties.

\begin{tabular}{|c|c|c|c|c|c|c|c|c|c|}
\hline County. & $\begin{array}{l}\text { Num- } \\
\text { ber of } \\
\text { mines. }\end{array}$ & $\begin{array}{l}\text { Loaded } \\
\text { at mines } \\
\text { for } \\
\text { shipment. }\end{array}$ & $\begin{array}{c}\text { Sold to } \\
\text { local } \\
\text { trade and } \\
\text { used } \\
\text { by em- } \\
\text { ployees. }\end{array}$ & $\begin{array}{c}\text { Used at } \\
\text { mines } \\
\text { for } \\
\text { steam } \\
\text { and } \\
\text { heat. }\end{array}$ & $\begin{array}{c}\text { Total } \\
\text { product. }\end{array}$ & $\begin{array}{l}\text { Total } \\
\text { value. }\end{array}$ & $\begin{array}{c}\text { Aver- } \\
\text { age } \\
\text { price } \\
\text { per } \\
\text { ton. }\end{array}$ & $\begin{array}{c}\text { Aver- } \\
\text { age } \\
\text { num- } \\
\text { ber of } \\
\text { days } \\
\text { active. }\end{array}$ & $\begin{array}{l}\text { Average } \\
\text { number } \\
\text { of em- } \\
\text { ployees. }\end{array}$ \\
\hline & & $\begin{array}{l}\text { Short } \\
\text { tons. }\end{array}$ & $\begin{array}{l}\text { Short } \\
\text { tons. }\end{array}$ & $\begin{array}{l}\text { Short } \\
\text { tons. }\end{array}$ & $\begin{array}{l}\text { Short } \\
\text { tons. }\end{array}$ & & & & \\
\hline Appanoose .... & 49 & 569,020 & $34,85 \overline{7}$ & 4,288 & 608,165 & $\$ 726,932$ & $\$ 1.20$ & 172 & 1,955 \\
\hline Boone ...... & 17 & 298,613 & 32,076 & 854 & 331,543 & 473,342 & 1.43 & 245 & 1,096 \\
\hline Dallas ..... & 2 & 2,964 & 4,013 & 930 & 7,907 & 12,653 & 1.60 & 227 & 32 \\
\hline Greene. & 5 & 665 & 11,480 & 775 & 12,920 & 21,318 & 1.65 & 194 & 60 \\
\hline Jasper ..... & 6 & 140,000 & 3,925 & 10 & 143,935 & 205,686 & 1.43 & 210 & $268^{\circ}$ \\
\hline Keokuk .. & 9 & 220,909 & 25,636 & 4,600 & 251,145 & 265,886 & 1.06 & 240 & 521 \\
\hline Mahaska ... & 21 & $1,238,810$ & 37,895 & 16,082 & $1,292,787$ & $1,304,727$ & 1.01 & 236 & 2,400 \\
\hline Marion .. & 15 & 114,954 & 11,822 & 517 & 127,293 & 113,329 & .89 & 217 & 245 \\
\hline Monroe.... & 7 & 558,479 & 11,947 & 14,152 & 584,578 & 594,980 & 1.02 & 232 & 1,086 \\
\hline Page and Story . & 3 & 4,990 & 6,295 & 400 & 11,685 & 20,124 & 1. 72 & 172 & 47 \\
\hline Polk............ & 16 & 428,824 & 194,217 & 12,565 & 635,606 & 787,940 & 1.24 & 234 & 1,353 \\
\hline Taylor.... & 2 & 5,660 & 880 & 15 & 6,555 & 12,485 & i. 90 & 182 & 26 \\
\hline Yan Buren .. & 2 & 4,220 & 2,280 & 100 & 6,600 & 9,600 & 1.45 & 257 & 14 \\
\hline Wapello.. & 8 & 229,544 & 13,190 & 6,890 & 249,624 & 254,661 & 1.02 & 212 & 472 \\
\hline Warren & 4 & 300 & 6,814 & 6 & 7,120 & 10,570 & 1.48 & 88 & 46 \\
\hline Wayne... & 3 & 38,643 & 12,352 & 555 & 51,550 & 68,633 & 1.33 & 201 & 205 \\
\hline Webster.. & 13 & 119,967 & 14,928 & 2,653 & 137,548 & 180,885 & 1.32 & 222 & 379 \\
\hline $\begin{array}{l}\text { Adams } \\
\text { Lucas . }\end{array}$ & 5 & 4,800 & 7,456 & 25 & 12,281 & 21,965 & 1.79 & 197 & 57 \\
\hline Small mines & & & 140,000 & & 140,000 & 175,000 & & & \\
\hline Total ... & 187 & $3,981,362$ & 572,063 & 65,417 & 42 & $5,260,716$ & 1.14 & 219 & 1 \\
\hline
\end{tabular}


Coal product of Iowa in 1899, by counties.

\begin{tabular}{|c|c|c|c|c|c|c|c|c|c|}
\hline County. & $\begin{array}{l}\text { Num- } \\
\text { ber of } \\
\text { mines. }\end{array}$ & $\begin{array}{l}\text { Loaded } \\
\text { at mines } \\
\text { for } \\
\text { shipment. }\end{array}$ & $\begin{array}{c}\text { Sold to } \\
\text { local } \\
\text { trade and } \\
\text { used } \\
\text { by em- } \\
\text { ployees. }\end{array}$ & $\begin{array}{c}\text { Used at } \\
\text { mines } \\
\text { for } \\
\text { steam } \\
\text { and } \\
\text { heat. }\end{array}$ & $\begin{array}{c}\text { Total } \\
\text { product. }\end{array}$ & $\begin{array}{l}\text { Total } \\
\text { value. }\end{array}$ & $\begin{array}{c}\text { Aver- } \\
\text { age } \\
\text { price } \\
\text { per } \\
\text { ton. }\end{array}$ & $\begin{array}{l}\text { Aver- } \\
\text { age } \\
\text { num- } \\
\text { ber of } \\
\text { days } \\
\text { active. }\end{array}$ & $\begin{array}{l}\text { Average } \\
\text { number } \\
\text { of em- } \\
\text { ployees. }\end{array}$ \\
\hline & & $\begin{array}{l}\text { Short } \\
\text { tons. }\end{array}$ & $\begin{array}{l}\text { Short } \\
\text { tons. }\end{array}$ & $\begin{array}{l}\text { Short } \\
\text { tons. }\end{array}$ & $\begin{array}{l}\text { Short } \\
\text { tons. }\end{array}$ & & & & \\
\hline Adams & 6 & $\ldots, \ldots$ & 12,556 & 104 & 12,660 & $\$ 22,319$ & $\$ 1.76$ & 139 & 45 \\
\hline Appanoose & 46 & 605,956 & 25,239 & 5,226 & 636,421 & 876,623 & 1.38 & 198 & 2,122 \\
\hline Boone. & 18 & 261,488 & 26,097 & 2,940 & 290,525 & 468,787 & 1.61 & 225 & 930 \\
\hline Dallas..... & 2 & 3,210 & 6,811 & 783 & 10,804 & 16,357 & 1.52 & $\dot{2} 54$ & 37 \\
\hline Davis and $L$ & 2 & ....... & 412 & ... & 412 & 724 & 1.76 & 82 & 5 \\
\hline Greene..... & 6 & 3,605 & 12,993 & 970 & 17,568 & 28,136 & 1.60 & 200 & 65 \\
\hline Jasper. & 9 & 173,504 & 15,738 & 2,686 & 191,928 & 221,655 & 1.15 & 264 & $286^{\circ}$ \\
\hline Keokuk & 13 & 273,267 & 33,432 & 8,201 & 314,900 & 362,946 & 1.15 & 235 & 530 \\
\hline Lucas.... & 3 & 28,566 & 2,742 & 1,111 & 32,419 & 44,752 & 1.38 & 178 & 126 \\
\hline Mahaska & 22 & $1,211,320$ & 44,464 & 17,689 & $1,273,473$ & $1,427,329$ & 1.12 & 262 & 2,258 \\
\hline Marion .... & 18 & 206,474 & 20,924 & 4,270 & 231,668 & 253,606 & 1.10 & 225 & 526 \\
\hline Monroe.... & 10 & 668,905 & 8,558 & 11,541 & 689,004 & 725,952 & 1.05 & 221 & 1,213 \\
\hline Page... & 3 & 1,320 & 2,680 & ........ & 4,000 & 9,000 & 2.25 & 152 & 26 \\
\hline Polk ... & .23 & 560,194 & 177,604 & 11,910 & 749,708 & 977,036 & 1.30 & 232 & 1,427 \\
\hline Scott....... & 2 & $\cdots \cdots$ & 7,053 & 295 & 7,348 & 12,895 & 1.75 & 262 & 34 \\
\hline Story ....... & 2 & 2,200 & 4,388 & 200 & 6,788 & 15,364 & 2.26 & 201 & 29 \\
\hline Taylor..... & 3 & 9,500 & 1,450 & 15 & 10,965 & 20,570 & 1.88 & 159 & 56 \\
\hline Van Buren. & 3 & 6,805 & 2,480 & 100 & 9,385 & 14,077 & 1.50 & 253 & 19 \\
\hline Wapello. & 14 & 277,733 . & 42,362 & 4,934 & 325,029 & 371,514 & 1.14 & 269 & 586 \\
\hline Warren.. & 5 & 22,260 & 12,525 & 30 & 34,815 & 64,138 & 1.84 & 238 & 71 \\
\hline Wayne & 4 & 53,319 & 8,999 & 500 & 62,818 & 88,548 & 1.41 & 205 & 229 \\
\hline Webster.... & 16 & 110,117 & 12,894 & 1,830 & 124,841 & 200,010 & 1.60 & 213 & 351 \\
\hline Small mines & & & 140,000 & & 140,000 & 175,000 & n..... & & \\
\hline 'Total & 230 & $4,479,743$ & 622,401 & 75,335 & $5,177,479$ & $6,397,338$ & 1.24 & 229 & 10,971 \\
\hline
\end{tabular}

Distribution of the coal product of Iowa from 1889 to 1899.

\begin{tabular}{|c|c|c|c|c|c|c|c|c|c|c|}
\hline Year. & $\begin{array}{l}\text { Num- } \\
\text { ber of } \\
\text { mines. }\end{array}$ & $\begin{array}{l}\text { Loaded at } \\
\text { mines } \\
\text { for ship- } \\
\text { ment. }\end{array}$ & $\begin{array}{l}\text { Sold to } \\
\text { local } \\
\text { trade } \\
\text { and used } \\
\text { by em- } \\
\text { ployees. }\end{array}$ & $\begin{array}{l}\text { Used at } \\
\text { mines } \\
\text { for } \\
\text { steam } \\
\text { and } \\
\text { heat. }\end{array}$ & $\begin{array}{l}\text { Made } \\
\text { into } \\
\text { coke. }\end{array}$ & $\begin{array}{c}\text { Total } \\
\text { product. }\end{array}$ & $\begin{array}{l}\text { Total } \\
\text { value. }\end{array}$ & $\begin{array}{l}\text { Aver- } \\
\text { age } \\
\text { price } \\
\text { per } \\
\text { ton. }\end{array}$ & $\begin{array}{c}\text { Aver- } \\
\text { age } \\
\text { num- } \\
\text { ber of } \\
\text { days } \\
\text { active. }\end{array}$ & $\begin{array}{l}\text { Average } \\
\text { number } \\
\text { of em- } \\
\text { ployees. }\end{array}$ \\
\hline & & $\begin{array}{l}\text { Short } \\
\text { tons. }\end{array}$ & $\begin{array}{l}\text { Short } \\
\text { tons. }\end{array}$ & $\begin{array}{l}\text { Short } \\
\text { tons. }\end{array}$ & $\begin{array}{l}\text { Short } \\
\text { tons. }\end{array}$ & $\begin{array}{l}\text { Short } \\
\text { tons. }\end{array}$ & & & & \\
\hline 1889 & & $3,530,373$ & 464,735 & 100,213 & 37 & $4,095,358$ & $\$ 5,426,509$ & $\$ 1.33$ & 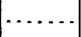 & 9,247 \\
\hline 1890 & 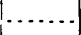 & $3,560,738$ & 397,503 & 63,498 & $\cdots$ & $4,021,739$ & $4,995,739$ & 1.24 & 213 & 8,130 \\
\hline 1891 & $\cdots$ & $3,263,347$ & 373,025 & 88,966 & 157 & $3,825,495$ & $4,867,999$ & 1.27 & 224 & 8,124 \\
\hline 1892 & $\cdots$ & $3,459,025$ & 401,855 & 57,611 & & $3,918,491$ & $5,175,060$ & 1.32 & 236 & 8,170 \\
\hline 1893. & $\ldots$. & $3,442,584$ & 449,639 & 80,006 & & $3,972,229$ & $5,110,460$ & 1.30 & 204 & 8,863 \\
\hline $1894 \ldots$ & 174 & $3,390,751$ & 511,683 & 64,819 & & $3,967,253$ & $4,997,939$ & 1.26 & 170 & 9,995 \\
\hline $1895 \ldots$ & 177 & $3,630,867$ & 460,820 & 64,387 & & $4,156,074$ & $4,982,102$ & 1.20 & 189 & 10,066 \\
\hline $1896 \ldots$ & 182 & $3,367,819$ & 494,443 & 91,766 & & $3,954,028$ & $4,628,022$ & 1.17 & 178 & 9,672 \\
\hline 1897. & 162 & $4,023,944$ & 516,427 & 71,494 & & $4,611,865$ & $5,219,503$ & 1.13 & 201 & 10,703 \\
\hline 1898 & 187 & $3,981,362$ & 572,063 & 65,417 & & $4,618,842$ & $5,260,716$ & 1.14 & 219 & 10,262 \\
\hline 1899. & 230 & $4,479,743$ & 622,401 & 75,335 & $\cdots \cdots$ & $5,177,479$ & $6,397,338$ & 1.24 & 229 & 10,971 \\
\hline
\end{tabular}


MINERAL RESOURCES.

Coal product of Iowa since 1895, by counties.

\begin{tabular}{|c|c|c|c|c|c|c|c|}
\hline County. & 1895. & 1896. & 1897. & 1898. & 1899. & $\begin{array}{c}\text { Increase, } \\
1899 .\end{array}$ & $\begin{array}{c}\text { Decrease, } \\
1899 .\end{array}$ \\
\hline & Short tons. & Short tons. & Short tons. & Short tons. & Short tons. & Shorttons. & Short tons. \\
\hline Appanoose ...... & 588,438 & 544,678 & 670,143 & 608,165 & 636,421 & 28,256 & \\
\hline Boone ........... & 268,422 & 316,756 & 292,218 & 331,543 & 290,525 & $\ldots \ldots$ & 41,018 \\
\hline Dallas... & 6,061 & & 6,853 & 7,907 & 10,804 & 2,897 & \\
\hline Greene .... & 7,197 & 9,624 & 9,245 & 12,920 & 17,568 & 4,648 & \\
\hline Jasper ........... & 155,707 & 164,110 & 175,316 & 143,935 & 191,928 & 47,993 & \\
\hline Keokuk .......... & 266,394 & 214,474 & 289,478 & 251,145 & 314,900 & 63,755 & . \\
\hline Mahaska ........ & $1,016,623$ & $1,047,241$ & $1,420,510$ & $1,292,787$ & $1,273,473$ & …...... & 19,314 \\
\hline Marion .......... & 193,768 & 93,023 & 129,502 & 127,293 & 231,668 & 104,375 & \\
\hline Monroe........... & 559,982 & 433,520 & 497,831 & 584,578 & 689,004 & 104,426 & \\
\hline Polk............. & 485,360 & 546,051 & 489,136 & 635,606 & 749,708 & 114,102 & \\
\hline Taylor............. & 14,062 & 8,400 & 10,726 & 6,555 & 10,965 & 4,410 & \\
\hline Van Buren ...... & 9,896 & 8,396 & 5,760 & 6,600 & 9,385 & 2,785 & \\
\hline Wapello.... & 261,510 & 227,077 & 229,470 & 249,624 & 325,029 & 75,405 & \\
\hline Warren.... & 6,116 & 12,824 & 6,610 & 7,120 & 34,815 & 27,695 & \\
\hline Wayne ...... & $46,31.5$ & 42,732 & 56,996 & 51,550 & 62,818 & 11,268 & \\
\hline Webster ......... & 123,882 & 134,704 & 168,899 & 137,548 & 124,841 & $\cdots$ & 12,707 \\
\hline $\begin{array}{c}\text { Other counties } \\
\text { and small } \\
\text { mines } \ldots \ldots \ldots\end{array}$ & 146,341 & 150,418 & 153,172 & 163,966 & 203,627 & 39,661 & \\
\hline Total. & $4,156,074$ & $3,954,028$ & $4,611,865$ & $4,618,842$ & $5,177,479$ & $a 558,637$ & \\
\hline
\end{tabular}

$a$ Net increase.

Iowa continues to hold first place among the coal-producing States west of the Mississippi River, and seventh place among all the coalproducing States. These relative positions have been held since 1893 . The development of the coal-mining industry can be seen from the following table, which shows that in thirty-nine years the annual output has increased more than 100 times. 
Product of coal in Iowa from 1860 to 1899, inclusive.

\begin{tabular}{|c|c|c|c|c|c|}
\hline Year. & Quantity. & value. & $\begin{array}{c}\text { Average } \\
\text { price per } \\
\text { ton. }\end{array}$ & $\begin{array}{c}\text { Average } \\
\text { number of } \\
\text { days active. }\end{array}$ & $\begin{array}{c}\text { Average } \\
\text { number of } \\
\text { employees. }\end{array}$ \\
\hline & Short tons. & & & & \\
\hline 1860 & 48,263 & $\$ 92,180$ & $\$ 1.91$ & .. & \\
\hline 1865 . & 69,574 & 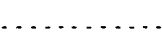 & 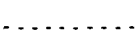 & & \\
\hline 1866 & 99,320 & & & & \\
\hline 1868. & 241,453 & & & $1 \cdots$ & \\
\hline 1870. & 283,467 & . & - & $\cdots$ & \\
\hline 1875. & $1,231,547$ & $2,500,140$ & 2.03 & & \\
\hline 1880. & $1,461,166$ & $2,507,453$ & 1. 72 & & \\
\hline 1882. & $3,920,000$ & $\therefore$ & & :- & \\
\hline 1883. & $4,457,540$ & & & & \\
\hline 1884 & $4,370,566$ & & & & \\
\hline 1885. & $4,012,575$ & $\cdots \cdots$ & $\cdots$ & $\because$ & \\
\hline 1886. & $4,315,779$ & $5,391,151$ & 1.25 & & \\
\hline 1887. & $4,473,828$ & $5,991,735$ & 1. 34 & & \\
\hline 1888 & $4,952,440$ & $6,438,172$ & 1. 30 & & $\cdots$ \\
\hline 1889. & $4,095,358$ & $5,426,509$ & 1. 33 & 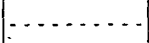 & 9,247 \\
\hline 1890 & $4,021,739$ & $4,995,739$ & 1. 24 & 213 & 8,130 \\
\hline 1891 & $3,825,495$ & $4,807,999$ & 1. 27 & 224 & 8,124 \\
\hline 1892. & $3,918,491$ & $5,175,060$ & 1. 32 & 236 & 8,170 \\
\hline 1893. & $3,972,229$ & $5,110,460$ & 1.30 & 204 & 8,863 \\
\hline $1894 \ldots$ & $3,967,253$ & $4,997,939$ & 1. 26 & 170 & 9,995 \\
\hline 1895 . & $4,156,074$ & $4,982,102$ & 1. 20 & 189 & 10,066 \\
\hline 1896. & $3,954,028$ & $4,628,022$ & 1.17 & 178 & 9,672 \\
\hline 1897 & $4,611,865$ & $5,219,503$ & 1. 13 & 201 & 10,703 \\
\hline 1898. & $4,618,842$ & $5,260,716$ & 1. 14 & 219 & 10,256 \\
\hline $1899 \ldots$ & $5,177,479$ & $6,397,338$ & 1. 24 & 229 & 10,971 \\
\hline
\end{tabular}

\section{KANSAS.}

Total product in $1899,3,852,267$ short tons; spot value, $\$ 4,478,112$. The coal product of Kansas in 1899 was the largest in the history of the State, both in amount and value. The State ranks third among the coal-producing States west of the Mississippi River and second among those comprising the Western coal field. Production in Kansas has increased each year since 1896 . The average price in 1899 , while higher than in 1898, was lower than in 1897 , or in any year previous to 1896 .

The use of mining machines in Kansas has not reached an important stage. The total number in use in 1899 was 3, a gain of one over 1898. The product won by machines amounted to 40,271 tons, as 21 GEOL, PT $6-29$ 
compared with 11,722 tons in 1898 and 4,500 tons in 1897 , the first year machines were used.

The working time lost by reason of strikes in 1899 amounted to about 5 per cent of the total time made. One strike lasted but three days, one lasted three hundred days, ten lasted between thirty and sixty days. The average time lost by the 1,986 men involved was forty-five days.

The details of production in 1898 and 1899, by counties, are shown in the following tables:

Coal product of Kansas in 1898 , by counties.

\begin{tabular}{|c|c|c|c|c|c|c|c|c|c|}
\hline County. & $\begin{array}{l}\text { Num- } \\
\text { ber of } \\
\text { mines. }\end{array}$ & $\begin{array}{c}\text { Loaded at } \\
\text { mines } \\
\text { for ship- } \\
\text { ment. }\end{array}$ & $\begin{array}{c}\text { Sold to } \\
\text { local } \\
\text { trade } \\
\text { and used } \\
\text { by em- } \\
\text { ployees. }\end{array}$ & $\begin{array}{l}\text { Used at } \\
\text { mines } \\
\text { for } \\
\text { steam } \\
\text { and } \\
\text { heat. }\end{array}$ & $\begin{array}{c}\text { Total } \\
\text { product. }\end{array}$ & $\begin{array}{l}\text { Total } \\
\text { value. }\end{array}$ & $\begin{array}{l}\text { Aver- } \\
\text { age } \\
\text { price } \\
\text { per } \\
\text { ton. }\end{array}$ & $\begin{array}{l}\text { Aver- } \\
\text { age } \\
\text { num- } \\
\text { ber of } \\
\text { days } \\
\text { active. }\end{array}$ & $\begin{array}{l}\text { Average } \\
\text { number } \\
\text { of em- } \\
\text { ployees. }\end{array}$ \\
\hline & & $\begin{array}{l}\text { Short } \\
\text { tons. }\end{array}$ & $\begin{array}{l}\text { Short } \\
\text { tons. }\end{array}$ & $\begin{array}{l}\text { Short } \\
\text { tons. }\end{array}$ & $\begin{array}{l}\text { Short } \\
\text { tons. }\end{array}$ & & & & \\
\hline Cherokee.. & 26 & $1,070,189$ & 22,142 & 18,196 & $1,110,527$ & $\$ 1,116,493$ & $\$ 1.01$ & 183 & 2,263 \\
\hline Craw ford $\ldots \ldots \ldots$ & 27 & $1,621,070$ & 16,777 & 16,646 & $1,654,493$ & $1,715,431$ & 1.04 & 225 & 2,887 \\
\hline Franklin. & 2 & 1,518 & 4,915 & $\cdots$ & 6,433 & 11,459 & 1.78 & 158 & 40 \\
\hline Leavenworth... & 5 & 207,399 & 83,532 & 14,645 & 305,576 & 401,892 & 1.32 & 207 & 759 \\
\hline Linn ........... & 2 & $1 \mathrm{~S}, 293$ & 2,249 & $\cdots$ & 20,542 & 21,769 & 1.06 & 251. & 74 \\
\hline Osage............. & 37 & 161,132 & 20,579 & 445 & 182,156 & 297,587 & 1.63 & 128 & 1,103 \\
\hline $\begin{array}{l}\text { Atchison, Cloud, } \\
\text { Coffey, and Elk... }\end{array}$ & 5 & . & 5,180 & & 5,180 & 14,005 & 2.70 & 121 & 42 \\
\hline $\begin{array}{l}\text { Ellsworth, Labette, } \\
\text { and Lincoln...... }\end{array}$ & 4 & & 845 & & 845 & 1,998 & 2.36 & 50 & 22 \\
\hline $\begin{array}{l}\text { Russell and Shaw- } \\
\text { nee............... }\end{array}$ & 2 & & S03 & & 803 & 2,380 & 2.96 & 111 & 7 \\
\hline Small mines.... & & & 120,000 & & 120,000 & 120,000 & n..... & . & $\cdots$ \\
\hline Total & 110 & $3,079,601$ & 277,022 & 49,932 & $3,406,55 \tilde{5}$ & $3,703,014$ & 1.09 & 194 & 7,197 \\
\hline
\end{tabular}

Coal product of Kansas in 1899, ly counties.

\begin{tabular}{|c|c|c|c|c|c|c|c|c|c|}
\hline County. & $\begin{array}{l}\text { Num- } \\
\text { ber of } \\
\text { mines. }\end{array}$ & $\begin{array}{l}\text { Loaded at } \\
\text { mines } \\
\text { for ship- } \\
\text { ment. }\end{array}$ & $\begin{array}{c}\text { Sold to } \\
\text { local } \\
\text { trade } \\
\text { and used } \\
\text { by em- } \\
\text { ployees. }\end{array}$ & $\begin{array}{l}\text { Used at } \\
\text { mines } \\
\text { for } \\
\text { steam } \\
\text { and } \\
\text { heat. }\end{array}$ & $\begin{array}{c}\text { Total } \\
\text { product. }\end{array}$ & $\begin{array}{l}\text { Total } \\
\text { value. }\end{array}$ & $\begin{array}{c}\text { Aver- } \\
\text { age } \\
\text { price } \\
\text { per } \\
\text { ton. }\end{array}$ & $\begin{array}{l}\text { Aver- } \\
\text { age } \\
\text { num- } \\
\text { ber of } \\
\text { days } \\
\text { active. }\end{array}$ & $\begin{array}{c}\text { Average } \\
\text { number } \\
\text { of em- } \\
\text { ployees. }\end{array}$ \\
\hline & & $\begin{array}{l}\text { Short } \\
\text { tons. }\end{array}$ & $\begin{array}{l}\text { Short } \\
\text { tons. }\end{array}$ & $\begin{array}{l}\text { Short } \\
\text { tons. }\end{array}$ & $\begin{array}{l}\text { Short } \\
\text { tons. }\end{array}$ & & & & \\
\hline Cherokee & 27 & $1,126,767$ & 18,613 & 16,762 & $1,162,142$ & $\$ 1,186,943$ & $\$ 1.02$ & 215 & 2,321 \\
\hline Cloud & 6 & 583 & 4,000 & $\ldots$ & 4,583 & 11,267 & 2.46 & 153 & 29 \\
\hline Crawford & 30 & $1,903,405$ & 22,166 & 25,933 & $1,951,504$ & $2,085,136$ & 1.07 & 253 & 3,335 \\
\hline Franklin & 2 & 2,225 & 11,800 & 25 & 14,050 & 28,100 & 2.00 & 265 & 40 \\
\hline Leavenworth & 4 & 247,270 & 58,094 & 7,481 & 312,845 & 540,073 & 1. 73 & 245 & 988 \\
\hline Linn...... & 2 & 11,595 & 5,665 & $\ldots$. & 17,260 & 19,941 & 1.16 & 203 & 62 \\
\hline Osage.............. & 41 & 229,212 & 32,468 & 651 & 262,331 & 464,839 & 1.77 & 159 & 1,168 \\
\hline $\begin{array}{l}\text { Atchison, Chautau- } \\
\text { qua, Coffey, Elk, } \\
\text { and Lyon.......... }\end{array}$ & 5 & 3,000 & 3,166 & & 6,166 & 17,658 & 2.86 & 135 & 37 \\
\hline $\begin{array}{l}\text { Ellsworth, Lincoln, } \\
\text { and Russell........ }\end{array}$ & 6 & 440 & 946 & & 1,386 & 4,155 & 3.00 & 95 & 20 \\
\hline Small mines....... & & & 120,000 & & 120,000 & 120,000 & & & 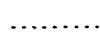 \\
\hline Total & 123 & 524,497 & 276,918 & $50, \$ 52$ & $3,852,267$ & $4,478,112$ & 1.16 & 226 & 8,000 \\
\hline
\end{tabular}


The distribution of the product for consumption, the total value, and the statistics of labor employed in Kansas coal mines for the past eleven years have been as follows:

Distribution of the coal product of Kansas from 1889 to 1899.

\begin{tabular}{|c|c|c|c|c|c|c|c|c|c|c|}
\hline Year. & $\begin{array}{l}\text { Num- } \\
\text { ber of } \\
\text { mines. }\end{array}$ & $\begin{array}{l}\text { Loaded at } \\
\text { mines for } \\
\text { shipment. }\end{array}$ & $\begin{array}{l}\text { Sold to lo- } \\
\text { cal trade } \\
\text { and used } \\
\text { by em- } \\
\text { ployees. }\end{array}$ & $\begin{array}{l}\text { Used at } \\
\text { mines } \\
\text { for } \\
\text { steam } \\
\text { and } \\
\text { heat. }\end{array}$ & $\begin{array}{c}\text { Made } \\
\text { into } \\
\text { coke. }\end{array}$ & $\begin{array}{l}\text { Total } \\
\text { product. }\end{array}$ & $\begin{array}{l}\text { Total } \\
\text { value. }\end{array}$ & $\begin{array}{l}\text { Aver- } \\
\text { age } \\
\text { price } \\
\text { per } \\
\text { ton. }\end{array}$ & $\begin{array}{l}\text { Aver- } \\
\text { age } \\
\text { num- } \\
\text { ber of } \\
\text { days } \\
\text { active. }\end{array}$ & $\begin{array}{c}\text { Average } \\
\text { number } \\
\text { of em- } \\
\text { ployees. }\end{array}$ \\
\hline & & $\begin{array}{l}\text { Short } \\
\text { tons. }\end{array}$ & $\begin{array}{l}\text { Short } \\
\text { tons. }\end{array}$ & $\begin{array}{l}\text { Short } \\
\text { tons. }\end{array}$ & $\begin{array}{l}\text { Short } \\
\text { tons. }\end{array}$ & $\begin{array}{l}\text { Short } \\
\text { tons. }\end{array}$ & & & & \\
\hline $1889^{\circ}$ & ... & $1,891,090$ & 300,207 & 29,246 & 500 & $2,221,043$ & $\$ 3,296,888$ & $\$ 1.48$ & 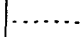 & 5,956 \\
\hline 1890. & - & $2,028,100$ & 224,839 & 6,983 & $\ldots$. & $2,259,922$ & $2,947,517$ & 1.30 & 210 & 4,523 \\
\hline 1891 & & $2,428,787$ & 255,839 & 31,946 & 133 & $2,716,705$ & $3,557,305$ & 1.31 & 222 & 6,201 \\
\hline 1892 & $\ldots$ & $2,756,812$ & 206,038 & 44,325 & 101 & $3,007,276$ & $3,955,595$ & 1.32 & 208 & 6,559 \\
\hline $1893 \ldots$ & .... & $2,364,810$ & 227,321 & 60,412 & 3 & $2,652,546$ & $3,375,740$ & 1.27 & 147 & 7,310 \\
\hline $1894 \ldots$ & 113 & $3,066,398$ & 275,565 & 45,523 & 765 & $3,388,251$ & $4,178,998$ & 1.23 & 164 & 7,339 \\
\hline 1895 & 106 & $2,587,602$ & 279,739 & 59,142 & 387 & $2,926,870$ & $3,481,981$ & 1.20 & 159 & 7,482 \\
\hline $1896 \ldots$ & 96 & $2,562,779$ & 256,906 & 63,901 & 1,215 & $2,884,801$ & $3,295,032$ & 1.15 & 168 & 7,127 \\
\hline $1897 \ldots$ & 71 & $2,745,101$ & 253,933 & 54,730 & 248 & $3,054,012$ & $3,602,326$ & 1.18 & 194 & 6,639 \\
\hline $1898 \ldots$ & 110 & $3,079,601$ & 277,022 & 49,922 & & $3,406,555$ & $3,703,014$ & 1.09 & 194 & 7,197 \\
\hline $1899 \ldots$ & 123 & $3,524,497$ & 276,918 & 50,852 & & $3,852,267$ & $4,478,112$ & 1.16 & 226 & 8,000 \\
\hline
\end{tabular}

The following table shows the production during the past four years, distributed by counties. It is observed that all of the coal-producing counties with one exception participated in the general business revival and increased production in 1899:

Coal product of Kansas in 1896,1897, 1898, and 1899, by counties.

\begin{tabular}{|c|c|c|c|c|c|c|}
\hline County. & 1896. & 1897. & 1898. & 1899. & $\begin{array}{c}\text { Increase, } \\
1899 .\end{array}$ & $\begin{array}{c}\text { Decrease, } \\
1899 .\end{array}$ \\
\hline Atchison .... & $\begin{array}{r}\text { Short tons. } \\
4,592\end{array}$ & $\begin{array}{r}\text { Short tons. } \\
7,250\end{array}$ & $\begin{array}{r}\text { Short tons. } \\
3,000\end{array}$ & $\begin{array}{r}\text { Short tons. } \\
3,000\end{array}$ & $\begin{array}{l}\text { Short tons. } \\
\text { - . . . . }\end{array}$ & $\begin{array}{l}\text { Short tons. } \\
\text {. . . . . . }\end{array}$ \\
\hline Cherokee..... & 985,132 & $1,004,921$ & $1,110,527$ & $1,162,142$ & 51,615 & \\
\hline Crawford... & $1,271,434$ & $1,352,923$ & $1,654,493$ & $1,951,504$ & 297,011 & \\
\hline Franklin ..... & 12,861 & 5,140 & 6,433 & 14,050 & 7,617 & \\
\hline Leavenworth & 284,700 & 366,362 & 305,576 & 312,845 & 7,269 & 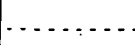 \\
\hline Linn .... & 14,534 & 27,432 & 20,542 & 17,260 & & 3,282 \\
\hline Osage ........ & 190,948 & 169,395 & 182,156 & 262,331 & 80,175 & \\
\hline $\begin{array}{l}\text { Other counties } \\
\text { and small } \\
\text { mines ...... }\end{array}$ & 120,600 & 120,589 & 123,828 & 129,135 & 5,307 & \\
\hline Total. & $2,884,801$ & $3,054,012$ & $3,406,555$ & $3,852,267$ & $a 445,712$ & \\
\hline
\end{tabular}

$a$ Net increase. 
The following table shows, in condensed form, the statistics of coal production in Kansas since 1880 . The increase in production has been remarkably regular, there being but three years in which the output was less than in the preceding year, and all of thesc years were during the period of trade depression-1893, 1895, and 1896:

Coul product of Kansas since 1880.

\begin{tabular}{|c|c|c|c|c|c|}
\hline Year. & Short tons. & Value. & $\begin{array}{l}\text { Average } \\
\text { price per } \\
\text { ton. }\end{array}$ & $\begin{array}{l}\text { Average } \\
\text { number } \\
\text { of days } \\
\text { active. }\end{array}$ & $\begin{array}{c}\text { Average } \\
\text { number } \\
\text { of men } \\
\text { employed. }\end{array}$ \\
\hline $1880 \ldots$ & 550,000 & & & & \\
\hline $1881 \ldots$ & 750,000 & & & & \\
\hline 1882. & 750,000 & & & & \\
\hline 1883 & 900,000 & & & & \\
\hline $1884 \ldots$ & $1,100,000$ & & 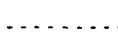 & & \\
\hline 1885. & $1,212,057$ & $\$ 1,485,002$ & $\$ 1.23$ & & \\
\hline 1886. & $1,400,000$ & $1,680,000$ & 1. 20 & & \\
\hline 1887 & $1,596,879$ & $2,235,631$ & 1. 40 & & \\
\hline 1888. & $1,850,000$ & $2,775,000$ & 1.50 & & \\
\hline 1889. & $2,221,043$ & $3,296,888$ & 1. 48 & 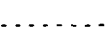 & 5,956 \\
\hline 1890 & $2,259,922$ & $2,947,517$ & 1. 30 & 210 & 4,523 \\
\hline 1891. & $2,716,705$ & $3,557,305$ & 1. 31 & 222 & 6,201 \\
\hline 1892. & $3,007,276$ & $3,955,595$ & 1.32 & 208 & 6,559 \\
\hline 1893. & $2,652,546$ & $3,375,740$ & 1.27 & 147 & 7,310 \\
\hline 1894. & $3,388,251$ & $4,178,998$ & 1. 23 & 164 & 7,339 \\
\hline 1895. & $2,926,870$ & $3,481,981$ & 1.20 & 159 & 7,482 \\
\hline 1896 & $2,884,801$ & $3,295,032$ & 1.15 & 168 & 7,127 \\
\hline 1897. & $3,054,012$ & $3,602,326$ & 1.18 & 194 & 6,639 \\
\hline 1898. & $3,406,555$ & $3,703,014$ & 1. 09 & 194 & $\bar{\tau}, 197$ \\
\hline 1899. & $3,852,267$ & $4,478,112$ & 1. 16 & 226 & 8,000 \\
\hline
\end{tabular}

\section{KENTUCKY.}

Total product in $1899,4,607,255$ short tons; spot value, $\$ 3,618,222$. Prior to 1899 the coal product in Kentucky had never reached a total of $4,000,000$ tons, and in only one year (1898) had the value of the output reached as high as $\$ 3,000,000$, while in 1899 an increase of more than half a million was added to the above figures both in the tonnage and in the value. The increases in product and value were in direct proportion, there being no change in the average value per ton as reported to the Survey. There were four other States in which there. was no change in price and five in which the price declined. 
Kentucky is the only State of the Union whose product is obtained from any two of the great fields. The eastern section of the State is crossed by the Appalachian system, while the central, or Illinois field, has its southern extremity in the coal-producing counties of western Kentucky. Exclusive of the estimated production of the small local mines, the product of eastern Kentucky was 1,810,450 short tons in 1899 against $1,520,710$ tons in 1898 ; the production in western Kentucky was 2,646,805 short tons in 1899 and 2,217,198 tons in 1898 . The increase in production of the two fields in 1899 was about in the proportion of their producing importance.

A few strikes occurred in the Kentucky coal mines in 1899, but they were not of sufficient importance to materially affect the production of the State for the year.

The use of mining machines increased somewhat; the number employed in 1899 being 189 as compared with 158 in 1898. The tonnage increased from 1,366,676 in 1898 to 1,625,809 in 1899 .

The details of production in 1898 and 1899 have been as follows:

Coal product of Kentucky in 1898, by counties.

\begin{tabular}{|c|c|c|c|c|c|c|c|c|c|c|}
\hline County. & $\begin{array}{l}\text { Num- } \\
\text { ber of } \\
\text { mines. }\end{array}$ & $\begin{array}{c}\text { Loaded } \\
\text { at mines } \\
\text { for ship- } \\
\text { ment. }\end{array}$ & $\left\{\begin{array}{c}\text { Sold to } \\
\text { local } \\
\text { trade } \\
\text { und used } \\
\text { by em- } \\
\text { ployees. }\end{array}\right.$ & $\begin{array}{l}\text { Used at } \\
\text { mines } \\
\text { for } \\
\text { steam } \\
\text { and } \\
\text { heat. }\end{array}$ & $\begin{array}{c}\text { Made } \\
\text { into } \\
\text { coke. }\end{array}$ & $\begin{array}{c}\text { Total } \\
\text { product. }\end{array}$ & $\begin{array}{l}\text { Total. } \\
\text { value. }\end{array}$ & $\begin{array}{l}\text { Aver- } \\
\text { age } \\
\text { price } \\
\text { per } \\
\text { ton. }\end{array}$ & $\begin{array}{l}\text { Aver- } \\
\text { age } \\
\text { num- } \\
\text { ber of } \\
\text { days } \\
\text { active. }\end{array}$ & $\begin{array}{l}\text { Average } \\
\text { number } \\
\text { of em- } \\
\text { ployees. }\end{array}$ \\
\hline & . & $\begin{array}{l}\text { Short } \\
\text { tons. }\end{array}$ & $\begin{array}{l}\text { Short } \\
\text { tons. }\end{array}$ & $\begin{array}{l}\text { Short } \\
\text { tons. }\end{array}$ & $\begin{array}{l}\text { Short } \\
\text { tons. }\end{array}$ & $\begin{array}{l}\text { Short } \\
\text { tons. }\end{array}$ & & & & \\
\hline Bell... & 8 & 79,539 & 4,343 & 1,562 & 100 & 85,544 & $\$ 109,782$ & $\$ 1.28$ & 151 & 271 \\
\hline Boyd.. & 2 & 204,836 & 1,141 & 2,785 & & 208,762 & 154,584 & .74 & 228 & 280 \\
\hline Butler... & 2 & 29,586 & 4,480 & ..... & 48 & 34,114 & 46,094 & 1.35 & 146 & 124 \\
\hline Carter.. & 7 & 62,576 & 269 & 900 & & 63,745 & 58,981 & .92 & 158 & 220 \\
\hline Hancock. & 2 & 9,390 & 60 & & & 9,450 & 15,064 & 1.90 & 243 & 52 \\
\hline Henderson. & 5 & 71,020 & 14,295 & 1,080 & & 86,395 & 69,847 & .81 & 201 & 200 \\
\hline Hopkins .. & 12 & 886,769 & 23,478 & 23,216 & 41,496 & $.974,959$ & 623,758 & .64 & 214 & 1,533 \\
\hline Johnson & 2 & 11,937 & 279 & $\cdots$ & & 12,216 & 31,066 & 2.54 & 241 & 83 \\
\hline Knox .... & 4 & 280,348 & 627 & 600 & & 281,575 & 215,217 & .76 & 253 & 324 \\
\hline Laurel .... & 13 & 286,690 & 699 & 1,089 & & 288,478 & 230,707 & .80 & 197 & 778 \\
\hline Lawrence... & 2 & 45,921 & 9,389 & 4,290 & & 59,600 & 42,938 & .72 & 224 & 118 \\
\hline Lee .... & 3 & 24,916 & 680 & 200 & & 25,796 & 24,950 & .97 & 254 & 66 \\
\hline MeLean. & 3 & 21,715 & 10 & $\cdots$ & & 21,725 & 16,364 & .75 & 112 & 49 \\
\hline Muhlenberg & 9 & 309,346 & $3, \varepsilon 20$ & 4,726 & & 317,392 & 229,540 & .72 & 148 & 689 \\
\hline Ohio .... & 9 & 429,575 & 4,250 & 6,186 & & 440,011 & 278,090 & .63 & 179 & 812 \\
\hline Pulaski .. & 6 & 84,815 & 640 & 1,315 & & 86,770 & 79,281 & .91 & 175 & 301 \\
\hline Union.... & 7 & $183, \$ 47$ & 5,398 & 4,420 & & 193,665 & 154,593 & .80 & 137 & 456 \\
\hline Webster... & 3 & 50,229 & 5,001 & 620 & & 55,850 & 36,418 & .65 & 179 & 117 \\
\hline Whitley.. & 12 & 377,378 & 7,929 & 1,977 & & 387,284 & 359,398 & .91 & 165 & 945 \\
\hline $\begin{array}{l}\text { Christian } \\
\text { Daviess .. }\end{array}$ & 3 & 66,496 & 17,141 & & & 83,637 & 101,221 & 1.21 & 225 & 136 \\
\hline $\begin{array}{l}\text { Breathitt.. } \\
\text { Greenup .. }\end{array}$ & 2 & 20,500 & 200 & 240 & & 20,940 & 19,158 & .91 & 137 & 60 \\
\hline Small mines. & & $\cdots$ & 150,000 & & & 150,000 & 187,500 & & & \\
\hline Total. & 116 & $3,537,429$ & 253,629 & 55,206 & 41,644 & 887,908 & 084,551 & .79 & 187 & 7,614 \\
\hline
\end{tabular}


Coal product of Kentucky in 1899, by counties.

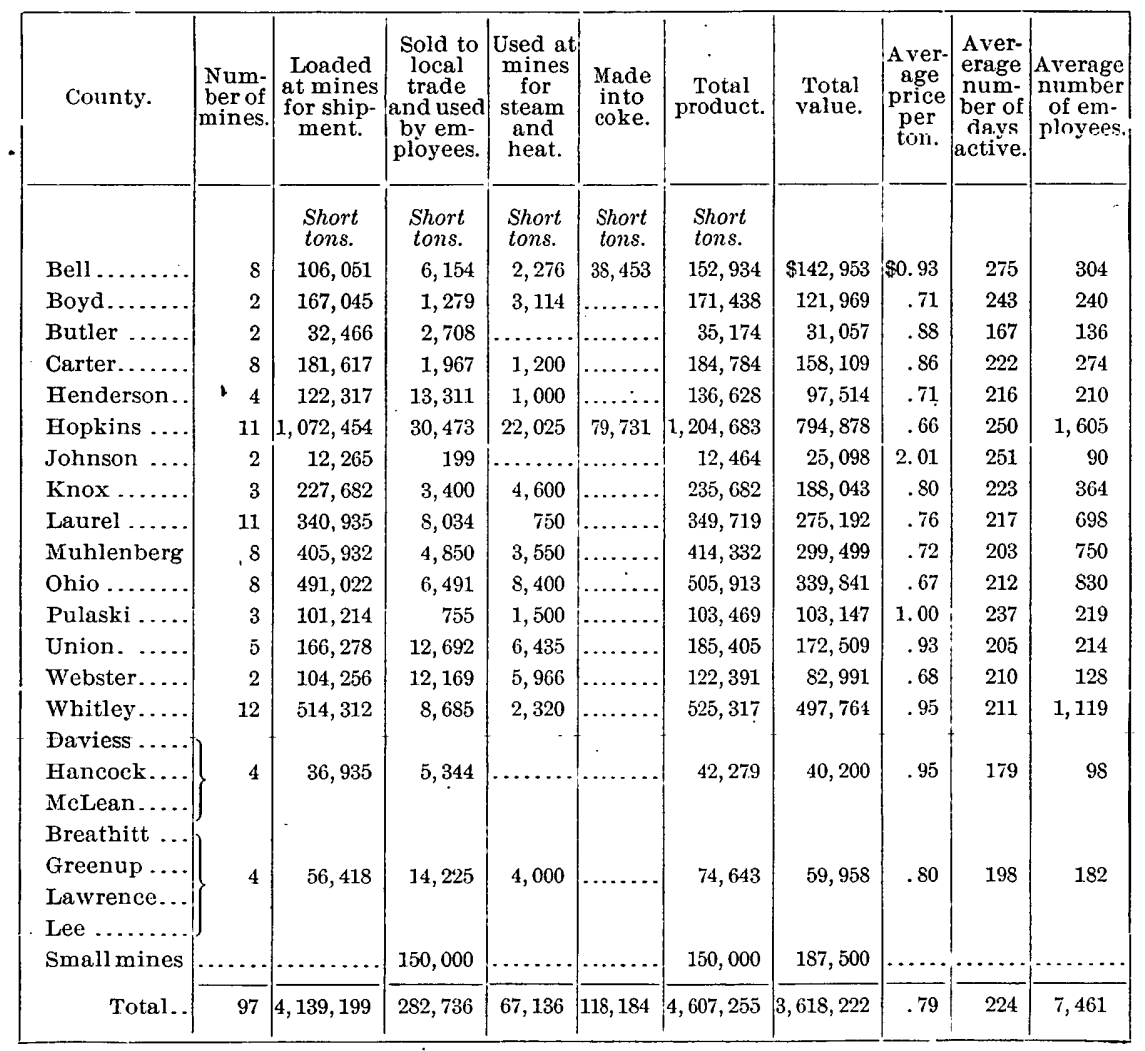

Distribution of the coal product of Kentucky from 1889 to 1899.

\begin{tabular}{|c|c|c|c|c|c|c|c|c|c|c|}
\hline Year. & $\begin{array}{l}\text { Num- } \\
\text { ber of } \\
\text { mines. }\end{array}$ & $\begin{array}{l}\text { Loaded at } \\
\text { mines for } \\
\text { shipment. }\end{array}$ & $\begin{array}{c}\text { Sold to } \\
\text { local } \\
\text { trade } \\
\text { and used } \\
\text { by em- } \\
\text { ployees. }\end{array}$ & $\begin{array}{l}\text { Used at } \\
\text { mines for } \\
\text { steam } \\
\text { and heat. }\end{array}$ & $\begin{array}{l}\text { Made } \\
\text { into } \\
\text { coke. }\end{array}$ & $\begin{array}{c}\text { Total } \\
\text { product. }\end{array}$ & $\begin{array}{l}\text { Total } \\
\text { value. }\end{array}$ & $\begin{array}{c}\text { Aver- } \\
\text { age } \\
\text { price } \\
\text { per } \\
\text { ton. }\end{array}$ & \begin{tabular}{|c|} 
Aver- \\
age \\
num- \\
ber of \\
days \\
active.
\end{tabular} & $\begin{array}{c}\text { Average } \\
\text { number } \\
\text { of em- } \\
\text { ployees. }\end{array}$ \\
\hline 1889 & & $\begin{array}{c}\text { Short tons. } \\
2,111,010\end{array}$ & $\begin{array}{c}\text { Short } \\
\text { tons. } \\
246,306\end{array}$ & $\begin{array}{c}\text { Short tons. } \\
23,981\end{array}$ & $\begin{array}{c}\text { Short } \\
\text { tons. } \\
18,458\end{array}$ & $\begin{array}{r}\text { Short tons. } \\
2,399 ; 755\end{array}$ & $\$ 2,374,339$ & $\$ 0.98$ & & \\
\hline 1890 & $\cdots$ & $2,357,989$ & 291,666 & 29,568 & 22,273 & $2,701,496$ & $2,472,119$ & .92 & 219 & 5,259 \\
\hline 1891. & & $2,559,263$ & 285,281 & 21,363 & 50,162 & $2,916,069$ & $2,715,600$ & .93 & 225 & 6,355 \\
\hline 1892. & & $2,620,556$ & 327,985 & 33,856 & 42,916 & $3,025,313$ & $2,771,23 S$ & .92 & 217 & 6,724 \\
\hline 1893 & & $2,613,645$ & 281,115 & 30,969 & 81,450 & $3,007,179$ & $2,613,569$ & .86 & 202 & 6,581 \\
\hline 1894 & $\cdots$ & $2,734,847$ & 281,235 & 47,344 & 47,766 & $3,111,192$ & $2,749,932$ & .88 & 145 & $S, 0 \$ 3$ \\
\hline $1895 \ldots$ & 120 & $3,012,610$ & 254,028 & 50,294 & 40,838 & $3,357,770$ & $2,890,247$ & .86 & 153 & 7,799 \\
\hline $1896 \ldots$ & 112 & $2,980,355$ & 251,897 & 55,447 & 45,779 & $3,333,47 \mathrm{~S}$ & $2,684,306$ & .78 & 165 & 7,549 \\
\hline $1897 \ldots$ & 109 & $3,085,132$ & 404,099 & 55,033 & 54,833 & $3,602,097$ & $2,828,329$ & .79 & 178 & 7,983 \\
\hline $1898 \ldots$ & 116 & $3,537,429$ & 253,629 & 55,206 & 41,644 & $3,887,908$ & $3,084,551$ & .79 & 187 & 7,614 \\
\hline $1899 \ldots$ & 97 & $4,139,199$ & 282,736 & 67,136 & 118,184 & $4,607,255$ & $3,618,222$ & .79 & 224 & 7,461 \\
\hline
\end{tabular}


The total production distributed by counties for the last four years, with the increases and decreases in 1899 as compared with 1898, is shown in the following table:

Coal product of Kentucky since 1896, by counties.

\begin{tabular}{|c|c|c|c|c|c|c|}
\hline County. & 1896. & 1897. & 1898. & 1899. & $\begin{array}{c}\text { Increase, } \\
1899 .\end{array}$ & $\begin{array}{c}\text { Decrease, } \\
1899 .\end{array}$ \\
\hline Bell .... & $\begin{array}{r}\text { Short tons. } \\
89,534\end{array}$ & $\begin{array}{r}\text { Short tons. } \\
103,261\end{array}$ & $\begin{array}{r}\text { Short tons. } \\
85,544\end{array}$ & $\begin{array}{r}\text { Short tons. } \\
152,934\end{array}$ & $\begin{array}{r}\text { Short tons. } \\
67,390\end{array}$ & Short tons. \\
\hline Boyd.... & 121,022 & 192,538 & 208,762 & 171,438 & $\ldots$ & 37,324 \\
\hline Butler. & 28,444 & 21,847 & 34,114 & 35,174 & 1,060 & \\
\hline Carter & 136,066 & 124,346 & 63,745 & 184,784 & 121,039 & \\
\hline Breathitt & 2,406 & 10,053 & 18,440 & 15,700 & & 2,740 \\
\hline Christian & 13,124 & 13,000 & 66,496 & …... & 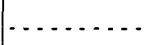 & 66,496 \\
\hline Daviess. & 3,232 & 3,200 & 17,141 & 2,464 & 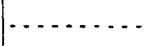 & 14,677 \\
\hline Greenup. & 854 & 852 & 2,500 & 4,225 & 1,725 & \\
\hline Hancock & 17,842 & 17,702 & 9,450 & 10,020 & 570 & \\
\hline Henderson & 119,540 & 107,187 & 86,395 & 136,628 & 50,233 & \\
\hline Hopkins. . & 777,182 & 976,412 & 974,959 & $1,204,683$ & 229,724 & \\
\hline Johnson .. & 6,762 & 9,541 & 12,216 & 12,464 & 248 & \\
\hline Knox ... & 217,040 & 158,445 & 281,575 & 235,682 & & 45,893 \\
\hline Laurel ... & 288,494 & 364,307 & 288,478 & 349,719 & 61,241 & \\
\hline Lawrence. & 47,474 & 48,061 & 59,600 & 49,418 & $\cdots$ & 10,182 \\
\hline Lee ..... & 9,847 & 35,711 & 25,796 & 5,300 & & 20,496 \\
\hline McLean . & 24,076 & 33,360 & 21,725 & 29,795 & 8,070 & \\
\hline Muhlenberg & 256,268 & 270,760 & 317,392 & 414,332 & 96,940 & \\
\hline Ohio & 368,094 & 466,295 & 440,011 & 505,913 & 65,902 & \\
\hline Pulaski. & 72,537 & 47,847 & 86,770 & 103,469 & 16,699 & \\
\hline Rockcastle. & $\cdots$ & 12,603 & 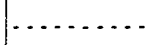 & & & \\
\hline Union. & 104,122 & 126,896 & 193,665 & 185,405 & & 8,260 \\
\hline Webster & 50,538 & 65,982 & 55,850 & 122,391 & 66,541 & \\
\hline Whitley & 428,980 & 241,891 & 387,284 & 525,317 & 138,033 & \\
\hline Small mines & 150,000 & 150,000 & 150,000 & 150,000 & & \\
\hline Total. & 33,478 & 602,097 & 387,908 & $4,607,255$ & $a 719,347$ & \\
\hline
\end{tabular}

$a$ Net increase. 
The production from the two fields in Kentucky luring the past three years has been as follows:

Coal product of the eastern district of Kentucky in 1897, 1898, and 1899, exclusive of small mines.

\begin{tabular}{|c|c|c|c|c|c|}
\hline County. & 1897. & 1898. & 1899 & $\begin{array}{c}\text { Increase, } \\
1899 .\end{array}$ & $\begin{array}{l}\text { Decrease, } \\
1899 .\end{array}$ \\
\hline & Short tons. & Short tons. & & & Short tons. \\
\hline Bell ............. & 103,261 & 85,544 & 152,934 & 67,390 & $\ldots \ldots$ \\
\hline Boyd........... & 192,538 & 208,762 & 171,438 & $\ldots \ldots \ldots$ & 37,324 \\
\hline Breathitt ...... & 10,053 & 18,440 & 15,700 & $\cdots \ldots \ldots$ & 2,740 \\
\hline Carter......... & 124,346 & 63,745 & 184,784 & 121,039 & $\ldots \ldots$ \\
\hline Greenup....... & 852 & 2,500 & 4,225 & 1,725 & $\therefore$ \\
\hline Johnson ........ & 9,541 & 12,216 & 12,464 & 248 & \\
\hline Knox ..... & 158,445 & 281,575 & 235,682 & $\ldots \ldots . . .$. & 45,893 \\
\hline Laurel...... & 364,307 & 288,478 & 349,719 & 61,241 & $\ldots$ \\
\hline Lawrence. . & 48,061 & 59,600 & 49,418 & & 10,182 \\
\hline Lee .... & 35,711 & 25,796 & 5,300 & $\cdots$ & 20,496 \\
\hline Pulaski... & 47,847 & 86,770 & 103,469 & 16,699 & \\
\hline Rockcastle. . & 12,603 & & & . & \\
\hline Whitley ...... & 241,891 & 387,284 & 525,317 & 138,033 & \\
\hline Total. . & $1,349,456$ & $1,520,7.10$ & $1,810,450$ & a 289,740 & \\
\hline
\end{tabular}

$a$ Net increase.

Coal product of the western district of Kentucky in 1897, 1898, and 1899, exclusive of small mines.

\begin{tabular}{|c|c|c|c|c|c|}
\hline County. & 1897. & 1898. & 1899 & $\begin{array}{c}\text { Increase, } \\
1899 .\end{array}$ & $\begin{array}{c}\text { Decrease, } \\
1899 .\end{array}$ \\
\hline & Short tons. & Short tons. & Short tons. & Short tons. & Short tons. \\
\hline Butler......... & 21,847 & 34,114 & 35,174 & 1,060 & $\ldots \ldots \ldots$ \\
\hline Christian .. & 13,000 & 66,496 & $\ldots \ldots$ & $\because$ & 66,496 \\
\hline Daviess...... & 3,200 & 17,141 & 2,464 & $\cdots$ & 14,677 \\
\hline Hancock ... & 17,702 & 9,450 & 10,020 & 570 & \\
\hline Henderson & 107,187 & 86,395 & 136,628 & 50,233 & \\
\hline Hopkins... & 976,412 & 974,959 & 1, 204,683 & 229,724 & \\
\hline McLean ... . & 33,360 & 21,725 & 29,795 & 8,070 & \\
\hline Mublenherg . . & 270,760 & 317,392 & 414,332 & 96,940 & \\
\hline Ohio .......... & 466,295 & 440,011 & 505,913 & 65,902 & \\
\hline Union . . . . . . . . & 126,896 & 193,665 & 185,405 & .. & 8,260 \\
\hline Webster.. & 65,982 & 55,850 & 122,391 & 66,541 & $\ldots$ \\
\hline Total .. & $2,102,641$ & $2,217,198$ & $2,646,805$ & $a 429,607$ & \\
\hline
\end{tabular}

a Net increase. 
The development of the coal-mining industry in Kentucky since 1873 may be seen from the following table:

Annual coal product of Kenlucky since $18 \%$.

\begin{tabular}{|c|c|c|c|}
\hline Year. & Short tons. & Year. & Short tons. \\
\hline $1873 \ldots$ & 300,000 & $1887 \ldots$ & $1,933,185$ \\
\hline $1874 \ldots$ & 360,000 & 1888 & $2,570,000$ \\
\hline $1875 \ldots \ldots$ & 500,000 & $1889 \ldots$ & $2,399,755$ \\
\hline $1876 .$. & 650,000 & $1890 \ldots \ldots$ & $2,701,496$ \\
\hline $1877 \ldots$ & 850,000 & $1891 \ldots$ & $2,916,069$ \\
\hline 1878. & 900,000 & $1892 \ldots$ & $3,025,313$ \\
\hline $1879 \ldots$ & $1,000,000$ & 1893. & $3,007,179$ \\
\hline $1880 \ldots$ & $1,000,000$ & $1894 \ldots$ & $3,111,192$ \\
\hline 1881. & $1,100,000$ & 1895 & $3,357,770$ \\
\hline 1882. & $1,300,000$ & $1896 \ldots$ & $3,333,478$ \\
\hline 1883. & $1,650,000$ & $1897 \ldots \ldots$ & $3,602,097$ \\
\hline $1884 \ldots$ & $1,550,000$ & $1898 \ldots$ & $3,887,908$ \\
\hline 1885 & $1,600,000$ & 1899 & $4,607,255$ \\
\hline $1886 \ldots$ & $1,550,000$ & & \\
\hline
\end{tabular}

\section{MARYLAND.}

Total product in $1899,4,807,396$ short tons; spot value, $\$ 3,667,056$.

There are only two coal-producing counties in Maryland-Allegany and Garrett-and 98 per cent of the product is from Allegany County. Notwithstanding the comparatively small area underlaid by coal in the State, Maryland has been an important coal producer for many years, and was one of the first States in the Union to produce bituminous coal. On account of the limited extent of its coal fields it is not to be expected that the coal product of Maryland will increase in the same proportion as that of other and more recently developed fields, but it is interesting to note that the tonnage from the State has increased each year since 1894 , and that the product in 1899 was 132,512 short tons larger than that of 1898 , with an increase in value of $\$ 134,799$. The average price remained unchanged.

Machine undercutting was introduced into the mines of Maryland in 1899 for the first time. Up to the close of 1898 the miners of Maryland had not been brought into direct competition with mechanical mining, but in 1899 two companies installed machines, eight in all, and all of the pick or punching type. The tonnage won by the machines, however, was not large, amounting in all to but 16,545 short tons. It is interesting, however, as noting the introduction of mechanical min- 
ing methods into a field heretofore exclusively hand-worked. Only one mine reported labor strikes in 1899,35 men being idle for twelve days.

Coal produrt of Maryland sine 1889.

\begin{tabular}{|c|c|c|c|c|c|c|c|c|}
\hline Year. & $\begin{array}{c}\text { Loaded } \\
\text { at mines } \\
\text { for ship- } \\
\text { ment. }\end{array}$ & $\begin{array}{c}\text { Sold to } \\
\text { local trade } \\
\text { and used } \\
\text { by em- } \\
\text { ployees. }\end{array}$ & $\begin{array}{c}\text { Used at } \\
\text { mines for } \\
\text { steam } \\
\text { and heat. }\end{array}$ & $\begin{array}{c}\text { Total } \\
\text { product. }\end{array}$ & $\begin{array}{l}\text { Total } \\
\text { value. }\end{array}$ & $\begin{array}{l}\text { Aver- } \\
\text { age } \\
\text { price } \\
\text { per } \\
\text { ton. }\end{array}$ & $\begin{array}{c}\text { Aver- } \\
\text { age } \\
\text { num- } \\
\text { ber of } \\
\text { days } \\
\text { active. }\end{array}$ & $\begin{array}{l}\text { Average } \\
\text { number } \\
\text { of em- } \\
\text { ployees. }\end{array}$ \\
\hline $1889 .$. & $\begin{array}{l}\text { Short tons. } \\
2,885,336\end{array}$ & $\begin{array}{r}\text { Short tons. } \\
44,217\end{array}$ & $\begin{array}{r}\text { Shorttons. } \\
10,162\end{array}$ & \begin{tabular}{|c|} 
Short tons. \\
$2,939,715$
\end{tabular} & $\$ 2,517,474$ & $\$ 0.86$ & & 3,702 \\
\hline 1890. & $3,296,393$ & 52,621 & 8,799 & $3,357,813$ & $2,899,572$ & .86 & 244 & 3,842 \\
\hline $1891 .$. & $3,771,584$ & 36,959 & 11,696 & $3,820,239$ & $3,082,515$ & - .80 & 244 & 3,891 \\
\hline 1892. & $3,385,384$ & 30,955 & 3,623 & $3,419,962$ & $3,063,580$ & .89 & 225 & 3,886 \\
\hline 1893. & $3,676,137$ & 26,833 & 13,071 & $3,716,041$ & $3,267,317$ & .88 & 240 & 3,935 \\
\hline 1894. & $3,435,600$ & 51,750 & 14,078 & $3,501,428$ & $2,687,270$ & .77 & 215 & 3,974 \\
\hline 1895. & $3,840,991$ & 59,950 & 14,644 & $3,915,585$ & $3,160,592$ & .81 & 248 & 3,912 \\
\hline $1896 \ldots$ & $4,068,558$ & 53,046 & 22,332 & $4,143,936$ & $3,299,928$ & .80 & 204 & 4,039 \\
\hline 1897. & $4,391,703$ & 27,762 & 22,663 & $4,442,128$ & $3,363,996$ & .76 & 262 & 4,719 \\
\hline 1898. & $4,618,990$ & 36,941 & 18,953 & $4,674,884$ & $3,532,257$ & .76 & 253 & 4,818 \\
\hline $1899 \ldots$ & $4,716,581$ & 68,750 & 22,065 & $4 ; 807,396$ & $3,667,056$ & .76 & 275 & 4,624 \\
\hline
\end{tabular}

Product of coal in Maryland from 1883 to 1899.

\begin{tabular}{|c|c|c|c|c|c|}
\hline Year. & Short tons. & Value. & $\begin{array}{l}\text { Average } \\
\text { price } \\
\text { per ton. }\end{array}$ & $\begin{array}{c}\text { Average } \\
\text { number of } \\
\text { days active. }\end{array}$ & $\begin{array}{c}\text { Average } \\
\text { number of } \\
\text { men } \\
\text { employed. }\end{array}$ \\
\hline $1883 \ldots \ldots \ldots$ & $2,476,075$ & $\ldots$ & & & \\
\hline $1884 \ldots \ldots$ & $2,765,617$ & $\ldots \ldots$ & & & \\
\hline $1885 \ldots \ldots \ldots$ & $2,833,337$ & $\ldots \ldots$ & $\ldots \ldots$ & & \\
\hline $1886 \ldots \ldots \ldots \ldots$ & $2,517,577$ & $\$ 2,391,698$ & $\$ 0.95$ & & \\
\hline 1887. & $3,278,023$ & $3,114,122$ & .95 & & \\
\hline 1888. & $3,479,470$ & $3,293,070$ & .95 & & \\
\hline 1889. & $2,939,715$ & $2,517,474$ & .86 & $\ldots$ & 3,702 \\
\hline 1890. & $3,357,813$ & $2,899,572$ & .86 & 244 & 2,842 \\
\hline 1891 & $3,820,239$ & $3,082,515$ & .80 & 244 & 3,891 \\
\hline 1892 & $3,419,962$ & $3,063,580$ & .89 & 225 & 3,886 \\
\hline 1893. & $3,716,041$ & $3,267,317$ & .88 & 240 & 3,935 \\
\hline 1894. & $3,501,428$ & $2,687,270$ & .77 & 215 & 3,974 \\
\hline 1895 & $3,915,585$ & $3,160,592$ & .81 & 248 & 3,912 \\
\hline 1896. & $4,143,936$ & $3,299,928$ & .80 & 204 & 4,039 \\
\hline 1897. & $4,442,128$ & $3,363,996$ & .76 & 262 & 4,719 \\
\hline 1898 . & $4,674,884$ & $3,532,257$ & .76 & 253 & 4,818 \\
\hline 1899 & $4,807,396$ & $3,667,056$ & .76 & 275 & 4,624 \\
\hline
\end{tabular}


The records of the Cumberland coal field, embracing all the coal area in Maryland and what is known as the Piedmont or Upper Potomac field in West Virginia, have been carefully preserved since 1842 and are shown in the following table. The reports of the Cumberland coal trade are published annually and the statements of shipments shown on the following page are obtained from these reports. They show that since $1842104,250,532$ long tons, or $116,760,596$ short tons, have been sent out of the region up to the close of 1899 . Of this total, $86,793,327$ long tons, or $97,208,526$ short tons, were from the Maryland mines. Adding to this amount 2 per cent for local trade and colliery consumption, Maryland's product is found to have amounted to about 100,000,000 short tons. 
Tutal shipments from the Cumberland coal field in

\begin{tabular}{|c|c|c|c|c|c|c|c|}
\hline \multirow[b]{3}{*}{ Year. } & \multicolumn{7}{|c|}{ Frostburg region. } \\
\hline & \multicolumn{4}{|c|}{ Cumberland and Penusylvania R.R. } & \multicolumn{3}{|c|}{$\begin{array}{l}\text { Cumberland Coal and Iron } \\
\text { Company's railroad. }\end{array}$} \\
\hline & 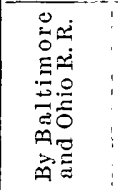 & 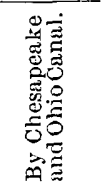 & 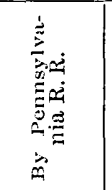 & 焉 & 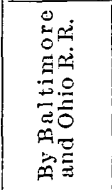 & 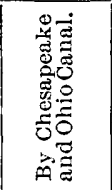 & 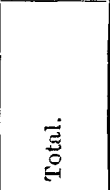 \\
\hline & $\begin{array}{l}\text { Long } \\
\text { tons. } \\
757\end{array}$ & $\begin{array}{l}\text { Long } \\
\text { tons. } \\
\end{array}$ & $\begin{array}{l}\text { Long } \\
\text { tons. } \\
\ldots . . .\end{array}$ & $\begin{array}{l}\text { Long } \\
\text { tons. } \\
\end{array}$ & $\begin{array}{l}\text { Long } \\
\text { tons. } \\
951\end{array}$ & $\begin{array}{l}\text { Long } \\
\text { tons. }\end{array}$ & $\begin{array}{l}\text { Long } \\
\text { tons. } \\
951\end{array}$ \\
\hline 1843 & 3,661 & & & 3,661 & $\begin{array}{l}6,421 \\
6,1\end{array}$ & & . 6,421 \\
\hline $\begin{array}{l}184 \\
184\end{array}$ & $\begin{array}{r}5,156 \\
13,738\end{array}$ & & & $\begin{array}{r}5,156 \\
13,738\end{array}$ & $\begin{array}{r}9,734 \\
10,915 \\
\end{array}$ & & $\begin{array}{r}9,734 \\
10,915\end{array}$ \\
\hline 1846. & 11,240 & & & . & $\begin{array}{l}18,710 \\
18,55\end{array}$ & & 18,555 \\
\hline 1847 & 20,615 & & & 20,615 & 32,325 & & 32,325 \\
\hline 1848. & 36,571 & & & 36,571 & 43,000 & & 43,000 \\
\hline 1849. & 63,676 & & & 63,676 & 78,773 & & 78,773 \\
\hline & 73,783 & 3,167 & & 76,950 & 119,023 & 875 & 119,898 \\
\hline $\begin{array}{l}1851 \\
185\end{array}$ & $\begin{array}{r}70,893 \\
\end{array}$ & 51,438 & & $.122,331$ & 103,808 & 31,540 & 135,348 \\
\hline $\begin{array}{l}18 \\
18\end{array}$ & $\begin{array}{l}128,534 \\
150,381\end{array}$ & $\begin{array}{l}46,357 \\
84.060\end{array}$ & & $\begin{array}{r}174,891 \\
234,441\end{array}$ & $\begin{array}{l}139,925 \\
155,278\end{array}$ & $\begin{array}{l}19,362 \\
70,535\end{array}$ & $\begin{array}{l}159,287 \\
225,813\end{array} \mid$ \\
\hline 18 & 148,953 & $\begin{array}{l}0,000 \\
63,731\end{array}$ & & 212,684 & $\begin{array}{l}173,580 \\
173\end{array}$ & 92,114 & 26,694 \\
\hline & 93,691 & 77,095 & & 170,786 & 97,710 & 100,691 & 198,401 \\
\hline & 86,994 & 80,387 & & 167,381 & 121,945 & 105,149 & 227,094 \\
\hline & 80,743 & 55,174 & & 135,917 & 88,573 & 54,000 & 142,573 \\
\hline 18 & 48,018 & 166,712 & & 214,730 & 66,009 & 87,539 & 153,548 \\
\hline & 48,415 & 211,639 & & 260,054 & 72,423 & 86,203 & 158,626 \\
\hline $\begin{array}{l}1860 . \\
1861\end{array}$ & $\begin{array}{l}70,669 \\
23,878\end{array}$ & $\begin{array}{r}232,278 \\
68,303\end{array}$ & & $\begin{array}{r}302,947 \\
92,181\end{array}$ & $\begin{array}{l}80,500 \\
25,983\end{array}$ & $\begin{array}{l}63,600 \\
29,296\end{array}$ & $\begin{array}{r}144,100 \\
55,279\end{array}$ \\
\hline & $\begin{array}{l}25,810 \\
71,745\end{array}$ & $\begin{array}{l}75,206 \\
75,005\end{array}$ & & $\begin{array}{r}92,101 \\
146,951\end{array}$ & $\begin{array}{r}21,703 \\
41,096\end{array}$ & $\begin{array}{l}23,478 \\
23,490\end{array}$ & $\begin{array}{r}04,574 \\
64,57\end{array}$ \\
\hline & 117,796 & 173,269 & & 291,065 & 111,087 & 43,523 & 154,610 \\
\hline 18 & 287,126 & 194,120 & & 481,246 & 67,676 & 64,522 & 132,198 \\
\hline 186 & 384,297 & 285,295 & & 669,592 & 104,651 & 57,907 & 162,558 \\
\hline & 592,938 & 291,019 & & 883,957 & 52,251 & 52,159 & 104,410 \\
\hline 186 & 623,031 & 385,249 & & $1,008,280$ & 40,106 & 72,904 & 113,010 \\
\hline \multirow[t]{4}{*}{$\begin{array}{l}1868 . \\
1869 .\end{array}$} & $\begin{array}{r}659,115 \\
1,016,777\end{array}$ & $\begin{array}{l}424,406 \\
573,243\end{array}$ & & $\begin{array}{l}1,083,521 \\
1,590,020\end{array}$ & $\begin{array}{l}100,345 \\
130,017\end{array}$ & $\begin{array}{l}57,919 \\
78,908\end{array}$ & $\begin{array}{l}158,264 \\
208,925\end{array}$ \\
\hline & & & & & 2092660 & 1192.224 & 3.284.884 \\
\hline & & & & & & & \\
\hline & & & & & \multicolumn{3}{|c|}{ Eckhart Branch R. R. } \\
\hline 1870 & 909,511 & 520,196 & & $1,429,707$ & 114,404 & 83,941 & 198,345 \\
\hline & $1,247,279$ & & & & 69,864 & 194,254 & 264,118 \\
\hline 18 & $1,283,956$ & 612,537 & 22,021 & $1,918,514$ & 26,586 & 203,666 & 230,252 \\
\hline 18 & $1,509,570$ & 641,220 & 114,589 & & 89,765 & 137,582 & 227,347 \\
\hline & $1,295,804$ & 631,882 & $\begin{array}{r}67,671 \\
170\end{array}$ & $\begin{array}{l}1,995,357 \\
1,971,766\end{array}$ & $\begin{array}{r}113,670 \\
52,505\end{array}$ & 135,182 & 248,852 \\
\hline & $1,099,8800$ & $\begin{array}{l}710,673 \\
443,435\end{array}$ & $\begin{array}{l}160,213 \\
131,866\end{array}$ & $\begin{array}{l}1,971,666 \\
1,514,563\end{array}$ & $\begin{array}{l}5,503 \\
15,285\end{array}$ & $\begin{array}{l}164,165 \\
189,005\end{array}$ & $\begin{array}{l}216,670 \\
204,290\end{array}$ \\
\hline & 755,278 & 473,646 & 170,884 & & 63,181 & 111,350 & 174,531 \\
\hline & 823,801 & 486 , & 145,864 & $1,455,703$ & 99,455 & 123,166 & 222,621 \\
\hline 18 & ' $933,240^{\prime}$ & 397,009 & 154,264 & $1,484,513$ & 141,907 & 104,238 & 246,145 \\
\hline & $1,05 \overline{2}, 491$ & 471,800 & 213,446 & $1,740,737$ & 197,525 & 131,325 & 328,850 \\
\hline 18 & $1,113,263$ & 270,156 & 153,501 & 1,53 & 271,570 & 151,526 & 423,096 \\
\hline 89. & 576,701 & 115 & 91,574 & $\begin{array}{r}783,619 \\
1\end{array}$ & 199,153 & 76,140 & 275,323 \\
\hline & $1,193,780^{\circ}$ & & $\begin{array}{l}211,065 \\
199,138\end{array}$ & $\begin{array}{l}1,37,728 \\
1,543,389\end{array}$ & $\begin{array}{l}191,235 \\
289.854\end{array}$ & $\begin{array}{l}141,390 \\
124,718\end{array}$ & $\begin{array}{l}338,620 \\
414,602\end{array}$ \\
\hline & 1,091 & & 206 , & 1,4 & 259,407 & 117,829 & 407,236 \\
\hline & 1,13 & 115 & 141 , & 1,3 & 243,321 & 113,791 & 357,112 \\
\hline & 1,5 & 132, & 176 & & 332,798 & & 458,103 \\
\hline & $1,660,406$ & 155,216 & 193,046 & $2,008,668$ & 374,888 & $9 \overline{0}, 191$ & 470,079 \\
\hline 1889. & $1,430,381$ & 26,886 & 177,152 & $1,634,419$ & 368,497 & 26,407 & 394,904 \\
\hline 91 & $1,511,415$ & & 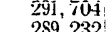 & 1,80 & 522,334 & 39001 & 522,334 \\
\hline & $1,628,574$ & $\begin{array}{r}9,070 \\
93,705\end{array}$ & 299,232 & $1,926,876$ & $\begin{array}{l}463,142 \\
349\end{array}$ & 39, 294 & 502,436 \\
\hline & $\begin{array}{l}1,42,994 \\
1,332,634 !\end{array}$ & 135, & $\begin{array}{l}214, \\
360\end{array}$ & $\begin{array}{l}1,2 \\
1,8\end{array}$ & $\begin{array}{l}349,301 \\
3421\end{array}$ & $\begin{array}{l}170,110 \\
201,947\end{array}$ & 268 \\
\hline & 1,068 & 95, & 372 & 1,53 & 436,216 & 208,914 & 645,130 \\
\hline & $\mathbf{1}, 193,834$ & 101, & 255 & & 464,407 & 212,534 & 676.941 \\
\hline 18 & $1,344,402$ & 169 & 163,471 & 1,67 & 610,418 & 195,279 & $805,697$. \\
\hline 1897. & $1,790,813$ & 96,536 & 169,679 & 2,057 & 586,592 & 166,691 & 753,283 \\
\hline & $2,131,626$ & $\begin{array}{l}24,997 \\
2570\end{array}$ & 116,195 & 2,272 & 507,196 & 213,139 & 720,335 \\
\hline 1899 & $2,334,109$ & 27,570 & 161,191 , & $2,022,570$ & 473,608 & 164,853 & 638,461 \\
\hline - & & & & $60,095,068$ & 37 & & 8,309 \\
\hline
\end{tabular}


COAL.

Mraryland and West Tirginia from 1842 to 1899.

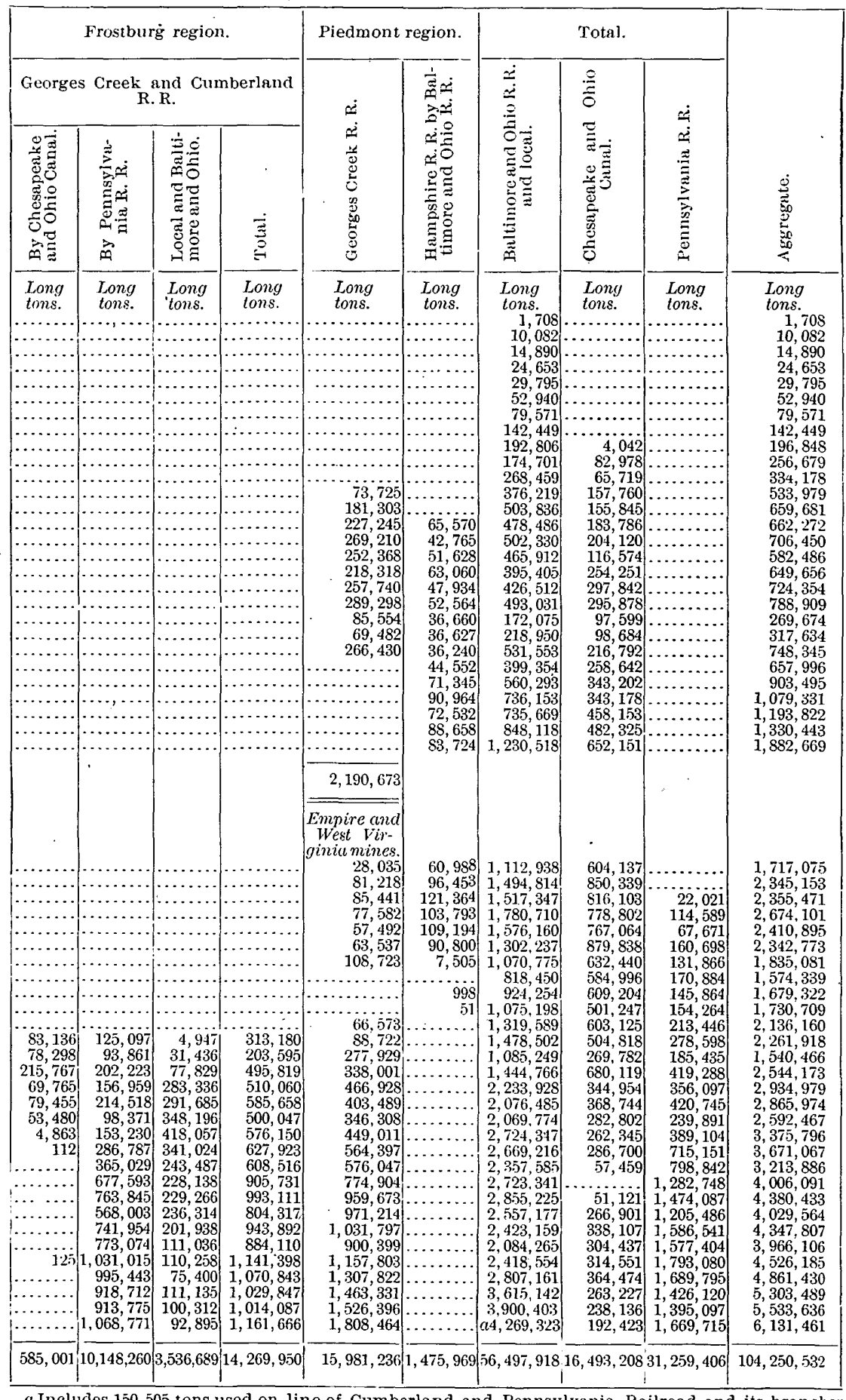

$a$ Includes 150,505 tons used on line of Cumberland and Pennsylvania Railroad and its branches and at Cumberland and Piedmont; also 536,913 tons used by the Baltimore and Ohio Railroad Company in locomotives, rolling mills, ete. 


\section{MICHIGAN}

Total product in $1899,624,708$ short tons; spot value, $\$ 870,152$.

With a coal product in 189998 per cent larger than the preceding year, Michigan easily outclassed all the other States in the percentage of increased tonnage. It is only in the past three years that the coal fields of Michigan have received any considerable attention. Up to the close of 1896 the operations had been confined to a few mines producing coal for the local trade of Saginaw, Jackson, and other towns in the vicinity. In 18972 new mines were opened and the product increased to 223,592 short tons from 92,882 tons in 1896 . Four more mines were opened in 1898 , bringing the total up to 17 , and the product increased to 315,722 short tons. In 1899 the number of mines was increased to 23 and the product nearly doubled. This rapid increase in production of Michigan coal may be taken as an indication of the rapid advancement in manufacturing industries in the lake cities contiguous to the Michigan fields.

The first machines were introduced into Michigan mines in 1898, one company installing 7 machines and producing with them 1,456 tons. In 18994 concerns were using 25 machines and the machinemined coal amounted to 64,055 tons, 10 per cent of the total product.

The production in Michigan by counties for the past two years was as follows:

Coal product of Michigan in 1898, by counties.

\begin{tabular}{|c|c|c|c|c|c|c|c|c|c|}
\hline County. & $\begin{array}{l}\text { Num- } \\
\text { ber of } \\
\text { mines. }\end{array}$ & $\begin{array}{l}\text { Loaded } \\
\text { at mines } \\
\text { for ship- } \\
\text { ment. }\end{array}$ & $\begin{array}{l}\text { Sold to } \\
\text { local } \\
\text { trade } \\
\text { and used } \\
\text { by em- } \\
\text { ployees. }\end{array}$ & $\begin{array}{c}\text { Used at } \\
\text { mines } \\
\text { for } \\
\text { steam } \\
\text { and } \\
\text { heat. }\end{array}$ & $\begin{array}{c}\text { Total } \\
\text { product. }\end{array}$ & $\begin{array}{l}\text { Total } \\
\text { value. }\end{array}$ & $\begin{array}{l}\text { Aver- } \\
\text { age } \\
\text { price } \\
\text { per } \\
\text { ton. }\end{array}$ & $\begin{array}{l}\text { Aver- } \\
\text { age } \\
\text { num- } \\
\text { ber of } \\
\text { days } \\
\text { active. }\end{array}$ & $\begin{array}{l}\text { Aver- } \\
\text { age } \\
\text { num- } \\
\text { ber of } \\
\text { em- } \\
\text { ployees. }\end{array}$ \\
\hline - & & $\begin{array}{l}\text { Short } \\
\text { tons. }\end{array}$ & $\begin{array}{l}\text { Short } \\
\text { tons. }\end{array}$ & $\begin{array}{l}\text { Short } \\
\text { tons. }\end{array}$ & $\begin{array}{l}\text { Short } \\
\text { tons. }\end{array}$ & & & & \\
\hline Bay..... & 2 & 45,601 & 49,944 & 1,268 & 96,813 & $\$ 127,121$ & $\$ 1.31$ & $\cdot 285$ & 175 \\
\hline Eaton .... & 4 & 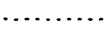 & 5,936 & 10 & 5,946 & 10,596 & 1.78 & 149 & 29 \\
\hline $\begin{array}{l}\text { Genesee } \\
\text { Huron... }\end{array}$ & 2 & 12,775 & 1,715 & 1,550 & 16,040 & 21,345 & 1.33 & 199 & 48 \\
\hline Jackson . & 2 & 24,000 & 14,104 & 2,287 & 40,391 & 64,092 & 1.59 & 261 & 110 \\
\hline Saginaw..... & 5 & 123,867 & 405 . & 630 & 124,902 & 192,112 & 1.54 & 237 & 246 \\
\hline Shiawassee.. & 2 & 25,912 & 3,518 & 2,200 & 31,630 & 47,445 & 1.50 & 207 & 107 \\
\hline Total & 17 & 232,155 & 75.622 & 7,945 & 315,722 & 462,711 & i. 47 & 245 & 715 \\
\hline
\end{tabular}


Coal product of Michigan in 1899, by counties.

\begin{tabular}{|c|c|c|c|c|c|c|c|c|c|}
\hline County. & $\begin{array}{l}\text { Num- } \\
\text { ber of } \\
\text { mines. }\end{array}$ & $\begin{array}{l}\text { Loaded } \\
\text { at mines } \\
\text { for ship- } \\
\text { ment. }\end{array}$ & $\begin{array}{l}\text { Sold to } \\
\text { local } \\
\text { trade } \\
\text { and used } \\
\text { by em- } \\
\text { ployees. }\end{array}$ & $\begin{array}{l}\text { Used at } \\
\text { mines } \\
\text { for } \\
\text { steam } \\
\text { and } \\
\text { heat. }\end{array}$ & $\begin{array}{c}\text { Total } \\
\text { product. }\end{array}$ & $\begin{array}{l}\text { Total } \\
\text { value. }\end{array}$ & $\begin{array}{c}\text { Aver- } \\
\text { age } \\
\text { price } \\
\text { per } \\
\text { ton. }\end{array}$ & $\begin{array}{c}\text { Aver- } \\
\text { age } \\
\text { num- } \\
\text { ber of } \\
\text { days } \\
\text { active. }\end{array}$ & $\begin{array}{l}\text { Aver- } \\
\text { age } \\
\text { num- } \\
\text { ber of } \\
\text { em- } \\
\text { ployees }\end{array}$ \\
\hline & & $\begin{array}{l}\text { Short } \\
\text { tons. }\end{array}$ & $\begin{array}{l}\text { Short } \\
\text { tons. }\end{array}$ & $\begin{array}{l}\text { Short } \\
\text { tons. }\end{array}$ & $\begin{array}{l}\text { Short } \\
\text { tons. }\end{array}$ & & & & \\
\hline Bay........... & 7 & 98,080 & 1,603 & 4,905 & 104,588 & $\$ 13 \$, 602$ & $\$ 1.33$ & 155 & 311 \\
\hline Eaton ........ & 4 & 1,100 & 2,317 & 4 & 3,421 & 6,710 & 1.96 & 145 & 26 \\
\hline Jackson ..... & 2 & $\ldots \ldots \ldots$ & 20,476 & 1,124 & 21,600 & 38,860 & 1.80 & 210 & 77 \\
\hline $\begin{array}{l}\text { Saginaw...... } \\
\text { Genesee ..... }\end{array}$ & 6 & 441,459 & 4,844 & 9,304 & 455,607 & 624,354 & 1.37 & 274 & 742 \\
\hline $\begin{array}{l}\text { Huron....... } \\
\text { Shiawassee.. }\end{array}$ & 4 & 33,641 & 4,951 & 900 & 39,492 & 61,626 & 1.56 & 209 & 135 \\
\hline Total & 23 & 574,280 & 34,191 & 16,237 & $624,70 \mathrm{~s}$ & 870,152 & 1.39 & 232 & 1,291 \\
\hline
\end{tabular}

The following tables show the distribution of the product during the past eight years and the total product of the State since 1877:

Coal product of. Michigan for eight years.

\begin{tabular}{|c|c|c|c|c|c|c|c|c|}
\hline Year. & $\begin{array}{l}\text { Loaded } \\
\text { at mines } \\
\text { for ship- } \\
\text { ment. }\end{array}$ & $\begin{array}{l}\text { Sold to } \\
\text { local } \\
\text { trade } \\
\text { and used } \\
\text { by em- } \\
\text { ployees. }\end{array}$ & $\begin{array}{c}\text { Used at } \\
\text { mines for } \\
\text { steam } \\
\text { and heat. }\end{array}$ & $\begin{array}{c}\text { Total } \\
\text { product. }\end{array}$ & $\begin{array}{l}\text { Total } \\
\text { value. }\end{array}$ & $\begin{array}{l}\text { Aver- } \\
\text { age } \\
\text { price } \\
\text { per } \\
\text { ton. }\end{array}$ & $\begin{array}{l}\text { Aver- } \\
\text { age } \\
\text { num- } \\
\text { ber of } \\
\text { days } \\
\text { active. }\end{array}$ & $\begin{array}{c}\text { Aver- } \\
\text { age } \\
\text { number } \\
\text { of em- } \\
\text { ployees. }\end{array}$ \\
\hline 1892. & $\begin{array}{c}\text { Short tons. } \\
27,200\end{array}$ & $\begin{array}{r}\text { Short tons. } \\
45,180\end{array}$ & $\begin{array}{r}\text { Short tons. } \\
5,610\end{array}$ & $\begin{array}{r}\text { Short tons. } \\
77,990\end{array}$ & $\$ 121,314$ & $\$ 1.56$ & 230 & 195 \\
\hline i 893. & 27,787 & 16,367 & 1,825 & 45,979 & 82,462 & 1.79 & 154 & 162 \\
\hline 1894. & 60,817 & 7,055 & 2,150 & 70,022 & 103,049 & 1.47 & 224 & 223 \\
\hline $1895 \ldots$ & 80,403 & 27,019 & 4,900 & 112,322 & 180,016 & 1.60 & 186 & 320 \\
\hline 1896. & 83,150 & 6,547 & 3,185 & 92,882 & 150,631 & 1.62 & 157 & 320 \\
\hline 1897 & 188,636 & 24,686 & 10,270 & 223,592 & 325,416 & 1.46 & 230 & 537 \\
\hline 1898. & 232,155 & 75,622 & 7,945 & 315,722 & 462,711 & 1.47 & 245 & 715 \\
\hline $1899 \ldots$ & 574,280 & 34,191 & 16,237 & 624,708 & 870,152 & I. 39 & 232 & 1,291 \\
\hline
\end{tabular}

Coal product of Michigan from $18 \% 7$ to 1899.

\begin{tabular}{|c|c|c|c|}
\hline Year. & Short tons. & Year. & Short tons. \\
\hline Previous to $1877 \ldots$ & 350,000 & $1888 \ldots \ldots \ldots \ldots \ldots$ & 81,407 \\
\hline $1877 \ldots \ldots \ldots \ldots$ & 69,197 & $1889 \ldots \ldots \ldots \ldots$ & 67,431 \\
\hline $1878 \ldots \ldots \ldots \ldots$ & 85,322 & $1890 \ldots \ldots \ldots \ldots$ & 74,977 \\
\hline $1879 \ldots \ldots \ldots \ldots$ & 82,015 & $\ldots \ldots \ldots$ & 80,307 \\
\hline $1880 \ldots . .$. & 129,053 & $1892 \ldots \ldots \ldots \ldots$ & 77,990 \\
\hline $1881 \ldots \ldots \ldots$ & 130,130 & $1893 \ldots \ldots \ldots$ & 45,979 \\
\hline $1882 \ldots \ldots \ldots$ & 135,339 & $1894 \ldots \ldots$ & 70,022 \\
\hline $1883 \ldots \ldots \ldots$ & 71,296 & $1895 \ldots \ldots \ldots$ & 112,322 \\
\hline $1884 \ldots \ldots . . . .$. & 36,712 & $1896 \ldots \ldots \ldots$ & 92,882 \\
\hline $1885 \ldots \ldots$ & 45,178 & $1897 \ldots \ldots \ldots \ldots$ & 223,592 \\
\hline $1886 \ldots \ldots$ & 60,434 & $1898 \ldots \ldots \ldots$ & 315,722 \\
\hline $1887 \ldots \ldots$ & 71,461 & $1899 \ldots \ldots \ldots \ldots$ & 624,708 \\
\hline
\end{tabular}


MISSOURI.

Total product in $1899,3,025,814$ short tons; spot value, $\$ 3,591,945$.

While Missouri's coal-mining industry shared in the general prosperity of 1899 and developed a product larger by 337,493 short tons than that of 1898 and larger than in any of the past ten years, there were three years in the earlier history of the State in which a heavier tonnage was obtained than that of last year. The banner year was 1888, when Missouri's mines were credited with a product of 3,909,967 short tons. The tonnage made in 1885 and 1887 was also larger than that of 1899. After the spurt of 1888 the production fell off to a marked extent, and for the next ten years remained quite steady at an average of about $2,600,000$ tons a year. During these ten years the smallest output was made in $1894(2,245,039$ short tons) and the largest in $1893(2,897,442$ short tons). Coal production in Missouri is not apt to show any notable increase in the near future. The State is surrounded by other large coal-producing States, and most of the larger Missouri cities draw their fuel supply from mines outside the State's boundaries. Practically all of the soft coal used in St. Louis and other cities in the eastern part of the State is imported from Illinois or Kentucky. Iowa on the north, Kansas on the west, and Arkansas and the Indian Territory to the south and southwest complete a barrier around the State which confines the product of Missouri to local markets.

Machine mining has not shown much progress in Missouri, although several machines were introduced last year. Up to 1899 only one mine in the State was equipped with machines. During 18992 more mines installed machines, and brought the number of machines in use from 4 up to 9 . Eight of these are of the Sperry type of long wall machine, and the other a "Paynter" air pick. The product won by the machines in 1899 was only 2,290 tons more than in 1898 , the newly installed machines being in operation for only a short time in 1899 .

Labor strikes occurred in 30 different mines during 1899 . The total number of men on strike was 2,197 , and the average time lost for each man was 53 days, or a total for all of 117,076 working days-about $7 \frac{1}{2}$ per cent of the working time made in all the mines.

The details of production in the last two years are presented in the following tables: 
Coal product of Missouri in 1898 , by counties.

\begin{tabular}{|c|c|c|c|c|c|c|c|c|c|}
\hline County. & $\begin{array}{l}\text { Num- } \\
\text { ber of } \\
\text { mines. }\end{array}$ & $\begin{array}{c}\text { Loaded } \\
\text { at mines } \\
\text { for ship- } \\
\text { ment. }\end{array}$ & $\begin{array}{l}\text { Sold to } \\
\text { local } \\
\text { trade } \\
\text { and } \\
\text { used by } \\
\text { em- } \\
\text { ployees. }\end{array}$ & $\begin{array}{c}\text { Used at } \\
\text { mines } \\
\text { for } \\
\text { steam } \\
\text { and } \\
\text { heat. }\end{array}$ & $\begin{array}{c}\text { Total } \\
\text { product. }\end{array}$ & $\begin{array}{l}\text { Total } \\
\text { value. }\end{array}$ & $\begin{array}{l}\text { Aver- } \\
\text { age } \\
\text { price } \\
\text { per } \\
\text { ton. }\end{array}$ & $\begin{array}{l}\text { Aver- } \\
\text { age } \\
\text { num- } \\
\text { ber of } \\
\text { days } \\
\text { active. }\end{array}$ & $\begin{array}{c}\text { Aver- } \\
\text { age } \\
\text { number } \\
\text { of em- } \\
\text { ployees. }\end{array}$ \\
\hline & & $\begin{array}{l}\text { Short } \\
\text { tons. }\end{array}$ & $\begin{array}{l}\text { Short } \\
\text { tons. }\end{array}$ & $\begin{array}{l}\text { Short } \\
\text { tons. }\end{array}$ & $\begin{array}{l}\text { Short } \\
\text { tons. }\end{array}$ & & & & \\
\hline Adair.. & 3 & 73,606 & 145 & 1,045 & 74,796 & $\$ 75,579$ & $\$ 1.01$ & 207 & 230 \\
\hline Audrain. & 3 & 27,200 & 3,066 & 710 & 30,976 & 35,702 & 1.15 & 237 & 77 \\
\hline Barton... & 5 & 63,010 & 6,294 & 1,247 & 70,551 & 84,411 & 1.20 & 293 & 164 \\
\hline Bates... & 13 & 308,793 & 4,815 & 5,365 & 318,973 & 285,111 & .89 & 150 & 605 \\
\hline Boone .... & 3 & 7,900 & 5,519 & 360 & 13,779 & 15,980 & 1.16 & 177 & 48 \\
\hline Callaway. & 9 & ......... & 21,210 & 5 & 21,215 & 33,036 & 1.56 & 178 & 86 \\
\hline Grundy .... & 2 & 31,691 & 6,050 & 1,791 & 39,532 & 68,247 & 1.73 & 223 & 173 \\
\hline Henry.... & 15 & 29,638 & 9,392 & 52 & 39,082 & 54,191 & 1.39 & 180 & 207 \\
\hline Lafayette. & 24 & 279,855 & 18,007 & 3,204 & 301,066 & 399,918 & 1.33 & 168 & 1,001 \\
\hline Linn & 5 & 59,726 & 7,979 & 938 & 68,643 & 100,931 & 1.47 & 182 & 241 \\
\hline Macon.... & 11 & 723,596 & 4,283 & 14,534 & 742,413 & 638,510 & .86 & 227 & 1,465 \\
\hline Putnam & 4 & 114,900 & 392 & 1,767 & 117,059 & 122,122 & 1.04 & 236 & 365 \\
\hline Randolph & 7 & 242,222 & 9,143 & 2,193 & 253,558 & 254,808 & 1.00 & 223 & 581 \\
\hline Ray ...... & 9 & 195,095 & 12,481 & 3,385 & 210,961 & 265,845 & 1.26 & 192 & 690 \\
\hline Vernon ....... & 4 & 174,703 & 2,086 & 4,548 & 181,337 & 168,941 & .93 & 114 & 342 \\
\hline Caldwell and Cole. & 2 & 22,000 & 4,000 & 1,000 & 27,000 & 41,000 & 1.52 & 222 & 102 \\
\hline Jackson and Johnson & 2 & 31,900 & 8,600 & 3,200 & 43,700 & 69,325 & 1.59 & 223 & 126 \\
\hline $\begin{array}{l}\text { Livingston, M on t- } \\
\text { gomery, and Ralls. }\end{array}$ & 3 & 7,480 & 6,200 & & 13,680 & 17,639 & 1.29 & 233 & 39 \\
\hline Small mines... & & & 120,000 & . & 120,000 & 140,000 & 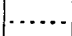 & . & \\
\hline Total & 124 & $2,393,315$ & 249,662 & 45,344 & $2,688,321$ & 871,296 & 1.07 & 198 & 6,542 \\
\hline
\end{tabular}

21 GEOL, PT $6-30$ 
Cocll product of Missouri in 1899 , by counties.

\begin{tabular}{|c|c|c|c|c|c|c|c|c|c|}
\hline County. & $\begin{array}{l}\text { Num- } \\
\text { ber of } \\
\text { mines. }\end{array}$ & $\begin{array}{l}\text { Loaded } \\
\text { at mines } \\
\text { for ship- } \\
\text { ment. }\end{array}$ & $\begin{array}{l}\text { Sold to } \\
\text { local } \\
\text { trade } \\
\text { und } \\
\text { used by } \\
\text { em- } \\
\text { ployees. }\end{array}$ & $\begin{array}{l}\text { Used at } \\
\text { mines } \\
\text { for } \\
\text { steam } \\
\text { and } \\
\text { heat. }\end{array}$ & $\begin{array}{c}\text { Total } \\
\text { product. }\end{array}$ & $\begin{array}{l}\text { Total } \\
\text { value. }\end{array}$ & $\begin{array}{l}\text { Aver- } \\
\text { age } \\
\text { price } \\
\text { per } \\
\text { ton. }\end{array}$ & $\begin{array}{l}\text { Aver- } \\
\text { age } \\
\text { num- } \\
\text { ber of } \\
\text { days } \\
\text { active. }\end{array}$ & $\begin{array}{c}\text { Aver- } \\
\text { age } \\
\text { number } \\
\text { of em- } \\
\text { ployees. }\end{array}$ \\
\hline & & $\begin{array}{l}\text { Short } \\
\text { tons. }\end{array}$ & $\begin{array}{l}\text { Short } \\
\text { tons. }\end{array}$ & $\begin{array}{l}\text { Short } \\
\text { tons. }\end{array}$ & $\begin{array}{l}\text { Short } \\
\text { tons. }\end{array}$ & & & 1 & 1 \\
\hline Adair.... & 5 & 172,677 & 1,265 & 1,510 & 175,452 & $\$ 199,846$ & $\$ 1.14$ & 248 & 345 \\
\hline Audrain.. & 5 & 20,865 & 24,539 & 503 & 45.907 & 61,263 & 1.33 & 211 & 118 \\
\hline Barton ...... & $7 \vdots$ & 107,256 & 2,112 & 2,100 & 111,468 & 144,771 & 1. 30 & 260 & 249 \\
\hline Bates...... & 16 & 446,387 & 7,340 & 3,070 & 456,797 & 432,778 & .95 & 210 & 595 \\
\hline Boone .... & 5 & 3,760 & 16,130 & 390 & 20,280 & 25,500 & 1. 26 & 226 & 53 \\
\hline Caldwell & 2 & 35,400 & 10,500 & 2,200 & 48,100 & 71,900 & I. 50 & 236 & 115 \\
\hline Callaway. & 9 & ….... & 23,193 & 17 & 23,210 & 39,165 & 1.69 & 177 & 76 \\
\hline Grundy... & 2 & 33,539 & 6,770 & 1,762 & 42,071 & 74,859 & 1. 78 & 212 & 176 \\
\hline Henry ...... & 19 & 86,844 & 8,011 & 216 & 95,071 & 142,505 & 1.50 & 198 & 322 \\
\hline Lafayette. & 36 & 342,770 & 21,433 & 5,050 & 369,253 & 565,470 & 1.53 & 195 & 1,118 \\
\hline Linn. & 6 & 70,321 & 13,553 & 1,054 & 84,928 & 132,782 & 1.56 & 235 & 272 \\
\hline Nacon.... & 14 & 520,182 & 5,312 & 14,049 & 539,543 & 523,003 & .97 & 202 & 1,438 \\
\hline Montgomery & 2 & 475 & 1,372 & $s$ & 1,855 & 2,604 & 1.40 & 229 & 7 \\
\hline Putnam .... & 5 & 131,679 & 526 & 2,450 & 134,655 & 161,028 & 1.20 & 270 & 372 \\
\hline Ralls. & 2 & 22,040 & 500 & 100 & 22,640 & 27,710 & 1.22 & 296 & 60 \\
\hline Randolph ............. & 10 & 294,775 & 8,907 & 1,280 & 304,962 & 300,260 & .98 & 214 & 703 \\
\hline Ray ........... & 10 & 198,536 & 4,992 & 3,094 & 206,622 & 282,399 & 1.37 & 193 & 70.5 \\
\hline Vernon................ & 6 & $179,4 \cdot 27$ & 1,585 & 4,202 & 185,214 & 177,463 & .96 & 167 & 313 \\
\hline Cole, Howard, and & & & & & & & & & \\
\hline Livingston ........ & 3 & 2,500 & 1,786 & $\cdots \cdots$ & 4,286 & 9,564 & 2.23 & 195 & 19 \\
\hline Jackson and Johnson & 2 & 22,000 & 10,000 & 1,500 & 33,500 & 77,075 & 2.30 & 251 & 80 \\
\hline Small mines.... & & $\cdots \cdots$ & 120,000 &. & 120,000 & 140,000 & & & \\
\hline Total & 166 & $2,691,433$ & 259,826 & 44,555 & $3,025,814$ & $3,591,945$ & 1.20 & 212 & 7,136 \\
\hline
\end{tabular}

Distritnution of the coal product of Missouri from 1889 to 1899.

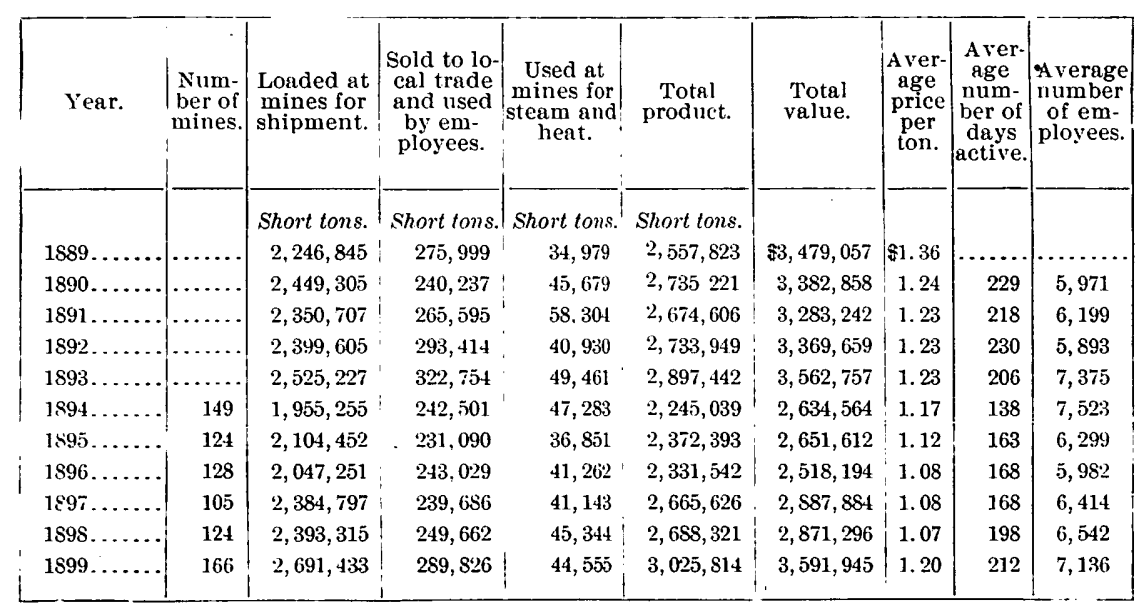


In the following table is shown the county distribution of the product during the past four years, with the increases and decreases in 1899 as compared with 1898 . There were five counties in which the product decreased, Macon being the principal loser, with a falling off of 202,870 short tons. The principal increases were in Bates and Adair counties, the former with 137,824 and the latter with 100,656 short tons. The net increase in the State was 337,493 short tons.

Coal product of Missouri since 1896, by counties.

[Short tons.]

\begin{tabular}{|c|c|c|c|c|c|c|}
\hline County. & 1896. & 1897. & 1898. & 1899. & $\begin{array}{c}\text { Increase, } \\
1899 .\end{array}$ & $\begin{array}{c}\text { Decrease, } \\
1899 .\end{array}$ \\
\hline Adair & 25,738 & 33,811 & 74,796 & 175,452 & 100,656 & \\
\hline Audrain .: & 21,857 & 45,972 & 30,976 & 45,907 & 14,931 & \\
\hline Barton ... & $13,731$. & 54,400 & 70,551 & 111,468 & 40,917 & \\
\hline Bates.... & 452,435 & 335,778 & 318,973 & 456,797 & 137,824 & \\
\hline Boone.... & 14,751 & 9,180 & 13,779 & 20,280 & 6,501 & \\
\hline Caldwell . - & 21,800 & 40,800 & 25,000 & 48,100 & 23,100 & \\
\hline Callaway ..... & 40,709 & 29,118 & 21,215 & 23,210 & 1,995 & \\
\hline $\begin{array}{l}\text { Cole .... } \\
\text { Cooper .. }\end{array}$ & ....... & $\begin{array}{r}2,500 \\
\ldots . . .\end{array}$ & $\begin{array}{r}2,000 \\
\ldots . . .\end{array}$ & 2,500 & 500 & \\
\hline Grundy . & 34,602 & 40,508 & 39,532 & 42,071 & 2,539 & \\
\hline Henry ...... & 35,505 & 44,276 & 39,082 & 95,071 & 55,989 & 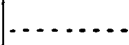 \\
\hline Jackson ... & 27,960 & 17,674 & 40,000 & 32,000 & & 8,000 \\
\hline Johnson .. & 200 & 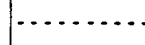 & 3,700 & 1,500 & $\therefore \ldots$. & 2,200 \\
\hline Lafayette. & 258,177 & 325,798 & 301,066 & 369,253 & 68,187 & \\
\hline Linn ...... & 64,504 & 81,598 & 68,643 & 84,928 & 16,285 & $\cdots$ \\
\hline Livingston. & 706 & ….... & 4,500 & 1,150 & & 3,350 \\
\hline Macon .... & 459,778 & 573,556 & 742,413 & 539,543 & & 202,870 \\
\hline Moniteau . & 250 & $\cdots$ & & & & \\
\hline Montgomery.. & 12,106 & 19,865 & 1,200 & 1,855 & 655 & \\
\hline Morgan .. & 200 & 6,000 & $\cdots$ & $\cdots$ & & \\
\hline Pettis & $\ldots \ldots$ & 800 & & $\cdots$ & & \\
\hline Putnam & 87,740 & 102,922 & 117,059 & 134,655 & 17,596 & \\
\hline Ralls ..... & - 10,628 & 8,700 & 7,980 & 22,640 & 14,660 & \\
\hline Randolph & 255,713 & 311,099 & 253,558 & 304,962 & 51,404 & $\cdots$ \\
\hline Ray ...... & 129,356 & 182,240 & 210,961 & 206,622 & $\cdots$ & 4,339 \\
\hline Saline.... & 400 & $\ldots \ldots$ & $\ldots$ & & & \\
\hline St. Clair ... & 80 & $\cdots$ & $\ldots$ & & & \\
\hline Vernon....... & 242,616 & 279,031 & 181,337 & 185,214 & 3,877 & \\
\hline $\begin{array}{l}\text { Other counties } \\
\text { and small } \\
\text { mines...... }\end{array}$ & 120,000 & 120,000 & 120,000 & 120,636 & 636 & \\
\hline Total.. & $2,331,542$ & $2,665,626$ & $2,688,321$ & $3,025,814$ & $a 337,493$ & \\
\hline
\end{tabular}

$a$ Net increase. 
The annual production since 1873 has been as follows:

Coal product of Missouri since 1873.

\begin{tabular}{|c|c|c|c|}
\hline Year. & Short tons. & Year. & Short tons. \\
\hline $1873 \ldots \ldots \ldots \ldots$ & 784,000 & $1887 \ldots \ldots \ldots \ldots \ldots$ & $3,209,916$ \\
\hline $1874 \ldots$ & 789,680 & $1888 \ldots \ldots$ & $3,909,967$ \\
\hline 1875 & 840,000 & 1889 & $2,557,823$ \\
\hline $1876 \ldots$ & $1,008,000$ & 1890 & $2,735,221$ \\
\hline $1877 \ldots$ & $1,008,000$ & $1891 \ldots$ & $2,674,606$ \\
\hline $1878 \ldots$ & $1,008,000$ & 1892 & $2,773,949$ \\
\hline $1879 \ldots \ldots \ldots \ldots$ & $1,008,000$ & $1893 \ldots$ & $2,897,442$ \\
\hline $1880 \ldots$ & $1,680,000$ & $1894 \ldots$ & $2,245,039$ \\
\hline $1881 \ldots$ & $1,960,000$ & 1895 & $2,372,393$ \\
\hline $1882 \ldots \ldots \ldots . . . .$. & $2,240,000$ & $1896 \ldots$ & $2,331,542$ \\
\hline $1883 \ldots \ldots$ & $2,520,000$ & $1897 \ldots \ldots \ldots$ & $2,665,626$ \\
\hline $1884 \ldots$ & $2,800,000$ & 1898 & $2,688,321$ \\
\hline $1885 \ldots \ldots \ldots$ & $3,080,000$ & $1899 \ldots \ldots \ldots \ldots$ & $3,025,814$ \\
\hline $1886 \ldots$ & $1,800,000$ & & \\
\hline
\end{tabular}

MONTANA.

Total product in $1899,1,496,451$ short tons; spot value, $\$ 2,347,757$.

Montana's coal product in 1899 increased but slightly over 1898 and did not reach the tonnage won in any of the three years preceding 1898. From 1887 to 1897 the coal product of Montana increased without exception each year. A decrease was noted for the first time in eleven years by the falling off in 1898, the bulk of which loss was borne by Cascade County. Cascade County showed a decrease also in 1899, but this was more than made up by increases in Carbon County.

In proportion to the amount of coal mined, Montana stands at the head in the use of mining machines, nearly 60 per cent of the total product being won by mechanical means. There were five concerns using machines in 1899, a gain of one over 1898; the number of machines in use increased from 62 to 75 , and the machine-won product increased from 681,613 to 843,710 short tons.

A strike which lasted fifty-two days, during the spring of 1899 , occurred at the mines of the Anaconda Copper Company, in Cascade County. The number of men made idle was 650 . This was the only instance of labor disaffection reported during the year. 
The production by counties in 1898 and 1899, together with the distribution of the product for consumption, and the statistics of labor employed, are shown in the following tables:

Coal product of Montana in 1898, by counties.

\begin{tabular}{|c|c|c|c|c|c|c|c|c|c|c|}
\hline County. & $\begin{array}{l}\text { Num- } \\
\text { ber of } \\
\text { mines. }\end{array}$ & $\begin{array}{l}\text { Loaded } \\
\text { at mines } \\
\text { for ship- } \\
\text { ment. }\end{array}$ & $\begin{array}{c}\text { Sold to } \\
\text { local } \\
\text { trade } \\
\text { and } \\
\text { used by } \\
\text { em- } \\
\text { ploy- } \\
\text { ees. }\end{array}$ & $\begin{array}{c}\text { Used at } \\
\text { mines } \\
\text { for } \\
\text { steam } \\
\text { and } \\
\text { heat. }\end{array}$ & $\begin{array}{l}\text { Made } \\
\text { into } \\
\text { coke. }\end{array}$ & $\begin{array}{c}\text { Total } \\
\text { product. }\end{array}$ & $\begin{array}{l}\text { Total } \\
\text { value. }\end{array}$ & $\begin{array}{l}\text { Aver- } \\
\text { age } \\
\text { price } \\
\text { per } \\
\text { ton. }\end{array}$ & $\begin{array}{l}\text { Aver- } \\
\text { age } \\
\text { num- } \\
\text { ber of } \\
\text { days } \\
\text { active. }\end{array}$ & $\begin{array}{l}\text { Aver- } \\
\text { age } \\
\text { number } \\
\text { of em- } \\
\text { ployees. }\end{array}$ \\
\hline & 1 & $\begin{array}{l}\text { Short } \\
\text { tons. }\end{array}$ & $\begin{array}{l}\text { Short } \\
\text { tons. }\end{array}$ & $\begin{array}{l}\text { Short } \\
\text { tons. }\end{array}$ & $\begin{array}{l}\text { Short } \\
\text { tons. }\end{array}$ & $\begin{array}{l}\text { Short } \\
\text { tons. }\end{array}$ & & & & \\
\hline Carìon.. & 2 & 264,176 & 3,920 & 4,300 & ........ & 272,396 & $\$ 393,884$ & $\$ 1.45$ & 270 & 410 \\
\hline Cascade.. & 8 & 920,122 & 14,227 & 13,994 & 40,478 & 988,821 & $1,523,932$ & 1.54 & 209 & 1,481 \\
\hline Choteau.. & 11 & 140 & 6,357 & 40 & $\ldots \ldots$ & 6,537 & 15,587 & 2.38 & 104 & 25 \\
\hline Fergus..... & 4 & ......... & 950 & $\cdots$ & $\cdots$ & 950 & 2,337 & 2.46 & 143 & 12 \\
\hline Gallatin... & 2 & 60,926 & 2,400 & 300 & $\ldots \ldots$ & 63,626 & 102,712 & 1.61 & 246 & 102 \\
\hline $\begin{array}{l}\text { Park } \ldots . . . \ldots \\
\text { Duwson ........ }\end{array}$ & 6 & 16,400 & 1,370 & 752 & 128,632 & 147,154 & 284,970 & 1.94 & 185 & 323 \\
\hline $\begin{array}{r}\text { Lew is and } \\
\text { Clarke ...... } \\
\text { Meagher..... }\end{array}$ & 3 & 50 & 269 & & & 319 & 785 & 2.46 & 44 & 6 \\
\hline Total. & 36 & $1,261,814$ & 29,493 & 19,386 & 169,110 & $1,479,803$ & $2,324,207$ & 1.57 & 216 & 2,359 \\
\hline
\end{tabular}

Coal product of Montana in 1899, by counties.

\begin{tabular}{|c|c|c|c|c|c|c|c|c|c|c|}
\hline \multirow[t]{2}{*}{ County. } & $\begin{array}{l}\text { Num- } \\
\text { ber of } \\
\text { mines. }\end{array}$ & $\begin{array}{c}\text { Loaded } \\
\text { at mines } \\
\text { for ship- } \\
\text { ment. }\end{array}$ & $\begin{array}{l}\text { Sold to } \\
\text { local } \\
\text { trade } \\
\text { and } \\
\text { used by } \\
\text { em- } \\
\text { ploy- } \\
\text { ees. }\end{array}$ & $\begin{array}{l}\text { Lised } \\
\text { ut } \\
\text { mines } \\
\text { for } \\
\text { steam } \\
\text { and } \\
\text { heat. }\end{array}$ & $\begin{array}{c}\text { Made } \\
\text { into } \\
\text { coke. }\end{array}$ & $\begin{array}{c}\text { Total } \\
\text { product. }\end{array}$ & $\begin{array}{l}\text { Total } \\
\text { value. }\end{array}$ & $\begin{array}{l}\text { Aver- } \\
\text { age } \\
\text { price } \\
\text { per } \\
\text { ton. }\end{array}$ & $\begin{array}{l}\text { Aver- } \\
\text { age } \\
\text { num- } \\
\text { ber of } \\
\text { days } \\
\text { active. }\end{array}$ & $\begin{array}{l}\text { Aver- } \\
\text { age } \\
\text { number } \\
\text { of em- } \\
\text { ployees. }\end{array}$ \\
\hline & & $\begin{array}{l}\text { Short } \\
\text { tons. }\end{array}$ & $\begin{array}{l}\text { Short } \\
\text { tons. }\end{array}$ & $\begin{array}{l}\text { Short } \\
\text { tons. }\end{array}$ & $\begin{array}{l}\text { Short } \\
\text { tons. }\end{array}$ & $\begin{array}{l}\text { Short } \\
\text { tons. }\end{array}$ & & & & \\
\hline Carbon....... & 4 & 318,451 & 7,174 & 11.900 & $\ldots \ldots$ & 337,525 & $\$ 456,518$ & $\$ 1.35$ & 310 & $490^{\circ}$ \\
\hline Cascade...... & 8 & 881,837 & 9,790 & 18,849 & 54,902 & 965,378 & $1,522,700$ & 1.58 & 212 & 1,496 \\
\hline Choteau...... & 10 & 1,550 & 5,335 & $\ldots$ & $\ldots$. & 6,885 & 18,143 & 2.64 & 118 & 33 \\
\hline Fergus ... & 3 & . & 900 & $\cdots \cdots$ & $\cdots \cdots$ & 900 & 2,700 & 3.00 & 138 & 8 \\
\hline Park ..... & 4 & 41,000 & 3,350 & 1,500 & 83,000 & 128,850 & 262,062 & 2.03 & 270 & 251 \\
\hline $\begin{array}{l}\text { Gallatin...... } \\
\text { Granite ...... }\end{array}$ & & & & & & & & & & \\
\hline $\begin{array}{c}\text { Lew is and } \\
\text { Clarke } \therefore . . .\end{array}$ & 5 & 51,776 & 3,137 & 2,000 & 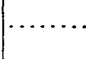 & 56,913 & 85,634 & 1.50 & 227 & $100^{\prime}$ \\
\hline Meagher & & & & & & & & & & \\
\hline Total.... & 34 & $1,294,614$ & 29,686 & $34,249^{\circ}$ & 137,902 & $1,496,451$ & $2,347,757$ & 1.57 & 238 & 2,378 \\
\hline
\end{tabular}


The distribution of the product for consumption during the past eleven years, and by counties for the past four years, are given below:

Distribution of the coal product of Montana from 1889 to 1899.

\begin{tabular}{|c|c|c|c|c|c|c|c|c|c|c|}
\hline Year. & $\begin{array}{l}\text { Num- } \\
\text { ber of } \\
\text { mines. }\end{array}$ & $\begin{array}{l}\text { Loaded } \\
\text { at mines } \\
\text { for ship- } \\
\text { ment. }\end{array}$ & $\begin{array}{c}\text { Sold to } \\
\text { local trade } \\
\text { and used } \\
\text { by em- } \\
\text { ployees. }\end{array}$ & $\begin{array}{l}\text { Used at } \\
\text { mines for } \\
\text { steam and } \\
\text { heat. }\end{array}$ & $\begin{array}{l}\text { Made } \\
\text { into coke. }\end{array}$ & $\begin{array}{c}\text { Total } \\
\text { product. }\end{array}$ & $\begin{array}{c}\text { Total } \\
\text { value. }\end{array}$ & $\begin{array}{l}\text { Aver } \\
\text { age } \\
\text { price } \\
\text { per } \\
\text { ton. }\end{array}$ & $\begin{array}{l}\text { Aver- } \\
\text { age } \\
\text { num- } \\
\text { ber of } \\
\text { days } \\
\text { active. }\end{array}$ & $\begin{array}{c}\text { Average } \\
\text { number } \\
\text { of em- } \\
\text { ployees. }\end{array}$ \\
\hline 1889 & & $\begin{array}{c}\text { Short tons. } \\
314,372\end{array}$ & $\begin{array}{r}\text { Short tons. } \\
12,917\end{array}$ & $\begin{array}{r}\text { Short tons } \\
5,436\end{array}$ & $\begin{array}{r}\text { Shorttons. } \\
30,576\end{array}$ & $\begin{array}{r}\text { Short tons. } \\
363,301\end{array}$ & $\$ 880,773$ & $\$ 2.42$ & & \\
\hline 1890. & $\cdots$ & 466,016 & 23,427 & 4,034 & 24,000 & 517,477 & $1,252,492$ & 2.42 & & 1,251 \\
\hline 1891. & $\ldots$ & 501,503 & 5,395 & 6,438 & 28,525 & 541,861 & $1,228,630$ & 2.27 & ... & 1,119 \\
\hline 1892. & $\ldots$ & 521,521 & 4,866 & 1,849 & 36,412 & 564,648 & $1,330,847$ & 2.36 & 258 & 1,158 \\
\hline 1893. & $\cdots$ & 789,516 & 27,063 & 17,960 & 57,770 & 892,309 & $1,772,116$ & 1.99 & 242 & 1,401 \\
\hline 1894. & 26 & 861,171 & 12,900 & 17,324 & 36,000 & 927,395 & $1,887,390$ & 2.04 & 192 & 1,782 \\
\hline 1895. & 22 & $1,404,862$ & 19,168 & 20,463 & 59,700 & $1,504,193$ & $2,850,906$ & 1.89 & 223 & 2,184 \\
\hline 1896. & 21 & $1,314,873$ & 27,476 & 17,676 & 183,420 & $1,543,445$ & $2,279,672$ & 1.47 & 234 & 2,335 \\
\hline 1897. & 22 & $1,434,858$ & 29,707 & 18,410 & 164,907 & $1,647,882$ & $2,897,408$ & 1.76 & 252 & 2,337 \\
\hline 1898. & 36 & $1,261,814$ & 29,493 & 19,386 & 169,110 & $1,479,803$ & $2,324,207$ & 1.57 & 216 & 2,359 \\
\hline 1899. & 34 & $1,294,614$ & 29,686 & 34,249 & 137,902 & $1,496,451$ & $2,347,757$ & 1.57 & 238 & 2,378 \\
\hline
\end{tabular}

Product and ralue of Montana coal since 1896, by counties.

\begin{tabular}{|c|c|c|c|c|c|c|}
\hline \multirow{2}{*}{ County. } & \multicolumn{2}{|c|}{1896.} & \multicolumn{2}{|c|}{1897.} & \multicolumn{2}{|c|}{1898.} \\
\hline & Product. & Value. & Product. & Value. & Product. & Value. \\
\hline Carbon .... & $\begin{array}{r}\text { Short tons. } \\
235,328\end{array}$ & $\$ 424,205$ & $\begin{array}{r}\text { Short tons. } \\
245,761\end{array}$ & $\$ 360,818$ & $\begin{array}{r}\text { Short tons. } \\
272,396\end{array}$ & $\$ 393,854$ \\
\hline Cascade ....... & $1,101,298$ & $1,473,532$ & $1,138,590$ & $1,999,104$ & 988,821 & $1,523,932$ \\
\hline Choteau ..... & 5,051 & 18,915 & 4,845 & 12,340 & 6,537 & 15,587 \\
\hline Fergus ...... & $\ldots \ldots \ldots$ & ......... & $\ldots \ldots$ & $\ldots \ldots \ldots$ & 950 & 2,337 \\
\hline Gallatin ... & $108,460 !$ & 214,535 & 132,413 & 223,024 & 63,626 & 102,712 \\
\hline Dawson .... & $\ldots \ldots \ldots$ & …..... & 2,800 & 6,250 & & \\
\hline Lewis and Clarke... & 56 & 250 & ........ & ...... & 319 & 785 \\
\hline Meagher .......... & 120 & 360 & 584 & 1,800 & & \\
\hline Park...... & 93,132 & 147,875 & 122,889 & 294,072 & 147,154 & 284,970 \\
\hline Total ... & $1,543,445$ & $2,279,672$ & $1,647,882$ & $2,897,408$ & $1,479,803$ & $2,324,207$ \\
\hline \multirow{2}{*}{ County. } & \multicolumn{2}{|c|}{1899.} & \multicolumn{2}{|c|}{ Increase, 1899.} & \multicolumn{2}{|c|}{ Decrease, 1899.} \\
\hline & Product. & Value. & Product. & Value. & Product. & Value. \\
\hline Carbon. & $\begin{array}{r}\text { Short tons. } \\
337,525\end{array}$ & $\$ 456,51 S$ & $\begin{array}{r}\text { Short tons. } \\
65,129\end{array}$ & $\operatorname{sen} 2,694$ & $\begin{array}{l}\text { Short tons. } \\
\text {.............. }\end{array}$ & \\
\hline Cascade ... & 965,378 & $1,522,700$ & & & 23,443 & $\$ 1,232$ \\
\hline Choteau....... & 6,885 & 18,143 & 348 & 2,556 & & \\
\hline Fergus ......... & 900 & 2,700 & & 363 & 50 & ….... \\
\hline Gallatin ............... & 56.671 & 84,961 & & & 6,955 & 17,751 \\
\hline $\begin{array}{l}\text { Dawson, Meagher, and } \\
\text { Lewis and Clarke .... }\end{array}$ & 242 & 673 & & & 77 & 112 \\
\hline Park ................... & 128,850 & 262,062 & $\cdots$ & & 18,304 & 22,908 \\
\hline Total .. & $1,496,451$ & $2,347,757$ & $a 16,648$ & $a 23,550$ & & \\
\hline
\end{tabular}

a Net increase. 
Since 1883 the total product of the State has been as follows:

Coal product of Montana since 1883 .

\begin{tabular}{|c|c|c|c|c|c|}
\hline Year. & Short tons. & Value. & Vear. & Short tons. & Valne. \\
\hline 1883. & 19,795 & & 1892 & 564,648 & $\$ 1,330,847$ \\
\hline 1884 & 80,376 & . & 1893 & 892,309 & $1,772,116$ \\
\hline $1885 \ldots$ & 86,440 & - & 1894 & 927,395 & $1,887,390^{\circ}$ \\
\hline $1886 \ldots$ & 49,846 & 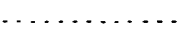 & 1895. & $1,504,193$ & $2,850,906$ \\
\hline $1887 \ldots$ & 10,202 & - & 1896 & $1,543,445$ & $2,279,672$ \\
\hline $1888 \ldots$ & 41,467 & 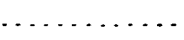 & $189 \overline{7}$ & $1,647,882$ & $2,897,408$ \\
\hline $1889 \ldots$ & 363,301 & . & 1898 & $1,479,803$ & $2,324,207$ \\
\hline $1890 \ldots$ & 517,477 & $\$ 1,252,492$ & 1899 & $1,496,451$ & $2,347,757$ \\
\hline $1891 \ldots$ & 541,861 & $1,228,630$ & & & \\
\hline
\end{tabular}

\section{NEBRASKA.}

The southwestern corner of Nebraska contains a portion of the western coal field, but the veins of coal being on the edge of the field are pinched to thin seams, varying from 6 to 22 inches. Some coal has been taken out for local consumption, but with the development of the fields of Iowa, Kansas, and Missouri, more favored both as to quality and conditions for economical mining, and with the operators of these mines seeking a market for their surplus product, such little work as has been done on Nebraska coal deposits has been practically abandoned. A small amount (3,560 short tons) was mined in Dixon County in 1896, all of which was consumed locally. The product in 1897 fell off to 495 tons, and no output was obtained in 1898 nor 1899.

\section{NEVADA.}

No product has been reported from this State since 1894, when a small amount ( 150 short tons) was mined in Esmeralda County.

\section{NEW MEXICO.}

Total production in $1899,1,050,714$ short tons; spot value, $\$ 1,461,865$.

Compared with 1898 the product of New Mexico in 1899 shows an increase of 58,426 short tons, and reaches a total exceeding a million tons for the first time in the history of the Territory. The value increased in slightly greater proportion than the product, or $\$ 117,115$. There was an advance of 4 cents in the average price per ton. 
Two interesting features of coal mining in New Mexico in 1899 are that no strikes at all were reported, and that there was a largely increased tonnage by machines, while the machines reported were reduced one-half in number. The number of machines were reduced from 29 to 14 , and the amount mined by them was increased from 163,849 tons in 1898 to 260,773 tons in 1899 .

The details of production in the past two years have been as follows:

Coal product of New Mexico in 1898, by counlies.

\begin{tabular}{|c|c|c|c|c|c|c|c|c|c|c|}
\hline County. & $\begin{array}{l}\text { Num- } \\
\text { ber of } \\
\text { mines. }\end{array}$ & $\begin{array}{l}\text { Loaded } \\
\text { at mines } \\
\text { for ship- } \\
\text { ment. }\end{array}$ & $\begin{array}{l}\text { Sold to } \\
\text { local } \\
\text { trade } \\
\text { and } \\
\text { used by } \\
\text { em- } \\
\text { ploy- } \\
\text { ees. }\end{array}$ & $\begin{array}{l}\text { Used at } \\
\text { mines } \\
\text { for } \\
\text { steam } \\
\text { and } \\
\text { heat. }\end{array}$ & $\begin{array}{l}\text { Made } \\
\text { into } \\
\text { coke. }\end{array}$ & $\begin{array}{c}\text { Total } \\
\text { product. }\end{array}$ & $\begin{array}{c}\text { Total } \\
\text { value. }\end{array}$ & $\begin{array}{l}\text { Aver } \\
\text { age } \\
\text { price } \\
\text { per } \\
\text { ton. }\end{array}$ & $\begin{array}{c}\text { A ver- } \\
\text { age } \\
\text { num- } \\
\text { ber of } \\
\text { days } \\
\text { active. }\end{array}$ & $\begin{array}{l}\text { Aver- } \\
\text { age } \\
\text { number } \\
\text { of em- } \\
\text { ployees. }\end{array}$ \\
\hline Bernalillo & 8 & $\begin{array}{l}\text { Short } \\
\text { tons. } \\
441,123\end{array}$ & $\begin{array}{l}\text { Short. } \\
\text { tons. } \\
1,580\end{array}$ & $\begin{array}{l}\text { Short } \\
\text { tons. } \\
2,855\end{array}$ & $\begin{array}{l}\text { Short } \\
\text { tons. }\end{array}$ & $\begin{array}{l}\text { Short } \\
\text { tons. } \\
445,558\end{array}$ & $\$ 625,052$ & $\$ 1.40$ & 234 & 919 \\
\hline $\begin{array}{l}\text { Colfax....... } \\
\text { Rio Arriba... }\end{array}$ & 3 & 243,173 & 4,577 & 4,341 & 17,124 & 269,215 & 320,443 & 1.19 & 259 & 408 \\
\hline $\begin{array}{l}\text { San Juan .. } \\
\text { Santa Fe... }\end{array}$ & $\overline{5}$ & $265,60 \overline{7}$ & 1,503 & 10,405 & & 277,515 & 399,255 & 3. 44 & 245 & 546 \\
\hline Total .. & 16 & 949,903 & 7,660 & 17,601 & 17,124 & 992,288 & $1,344,750$ & 1.35 & 242 & 1,873 \\
\hline
\end{tabular}

Coal product of New Mexico in 1899, by counties.

\begin{tabular}{|c|c|c|c|c|c|c|c|c|c|}
\hline County. & $\begin{array}{l}\text { Num- } \\
\text { ber of } \\
\text { mines. }\end{array}$ & $\begin{array}{c}\text { Loaded } \\
\text { at mines } \\
\text { for ship- } \\
\text { ment. }\end{array}$ & $\begin{array}{l}\text { Sold to } \\
\text { local } \\
\text { trade } \\
\text { and } \\
\text { used by } \\
\text { em- } \\
\text { ploy- } \\
\text { ees. }\end{array}$ & $\begin{array}{l}\text { Used at } \\
\text { mines } \\
\text { for } \\
\text { steam } \\
\text { and } \\
\text { heat. }\end{array}$ & $\begin{array}{c}\text { Total } \\
\text { product. }\end{array}$ & $\begin{array}{l}\text { Total } \\
\text { value. }\end{array}$ & $\begin{array}{c}\text { Aver- } \\
\text { age } \\
\text { price } \\
\text { per } \\
\text { ton. }\end{array}$ & $\begin{array}{l}\text { Aver- } \\
\text { age } \\
\text { num- } \\
\text { ber of } \\
\text { days } \\
\text { active. }\end{array}$ & $\begin{array}{l}\text { Aver- } \\
\text { age } \\
\text { number } \\
\text { of em- } \\
\text { ployees. }\end{array}$ \\
\hline & & $\begin{array}{l}\text { Short } \\
\text { tons. }\end{array}$ & $\begin{array}{l}\text { Short } \\
\text { tons. }\end{array}$ & $\begin{array}{l}\text { Short } \\
\text { tons. }\end{array}$ & $\begin{array}{l}\text { Short } \\
\text { tons. }\end{array}$ & & & & \\
\hline Bernalillo ... & 8 & 488,400 & 1,602 & 3,308 & 493,310 & $\$ 696,666$ & $\$ 1.41$ & 247 & 852 \\
\hline Colfax......... & 3 & 356,080 & 8,134 & 4,159 & 368,373 & 439,984 & 1.19 & 294 & 412 \\
\hline $\begin{array}{l}\text { Lincoln ..... } \\
\text { Rio Arriba... }\end{array}$ & 2 & 8,837 & 3,582 & 318 & 12,737 & 24,838 & 1.95 & 112 & 133 \\
\hline $\begin{array}{l}\text { San Juan .... } \\
\text { Santa Fe.... } \\
\text { Socorro...... }\end{array}$ & 5 & 168,484 & 810 & 7,000 & 176,294 & 300,377 & 1.70 & 292 & 353 \\
\hline Total .. & 18 & $1,021,501$ & 14,128 & 14,785 & $1,050,714$ & $1,461,865$ & 1.39 & 257 & 1,750 \\
\hline
\end{tabular}


Distribution of the roal product of New Mexico from 1889 to 1899.

\begin{tabular}{|c|c|c|c|c|c|c|c|c|c|c|}
\hline Yenr. & $\begin{array}{l}\text { Num- } \\
\text { ber of } \\
\text { mines. }\end{array}$ & $\begin{array}{l}\text { Loaded } \\
\text { at mines } \\
\text { for ship- } \\
\text { ment. }\end{array}$ & $\begin{array}{l}\text { Sold to } \\
\text { local } \\
\text { trade and } \\
\text { used } \\
\text { by em- } \\
\text { ployees. }\end{array}$ & $\begin{array}{c}\text { Csed at } \\
\text { mines for } \\
\text { steam } \\
\text { and heat. }\end{array}$ & $\begin{array}{c}\text { Made } \\
\text { into } \\
\text { coke. }\end{array}$ & $\begin{array}{c}\text { Total } \\
\text { product. }\end{array}$ & $\begin{array}{c}\text { Total } \\
\text { value. }\end{array}$ & $\begin{array}{l}\text { Aver- } \\
\text { age } \\
\text { price } \\
\text { per } \\
\text { ton. }\end{array}$ & $\begin{array}{l}\text { Aver- } \\
\text { age } \\
\text { num- } \\
\text { ber of } \\
\text { days } \\
\text { active. }\end{array}$ & $\begin{array}{c}\text { Aver- } \\
\text { age } \\
\text { number } \\
\text { of em- } \\
\text { ployees. }\end{array}$ \\
\hline & & $\begin{array}{l}\text { Short } \\
\text { tons. }\end{array}$ & $\begin{array}{l}\text { Short } \\
\text { tons. }\end{array}$ & $\begin{array}{l}\text { Short } \\
\text { tons. }\end{array}$ & $\begin{array}{l}\text { Short } \\
\text { tons. }\end{array}$ & $\begin{array}{l}\text { Short } \\
\text { tons. }\end{array}$ & & & & \\
\hline 1889. & .... & 466,127 & 8,953 & 6,383 & 6,000 & 486,463 & $\$ 870,468$ & $\$ 1.79$ & $\ldots$ & 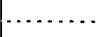 \\
\hline $1 \$ 90 \ldots$ & $\ldots$. & 358,332 & 11,360 & 6,085 & $\ldots \ldots$ & 375,777 & 504,390 & 1.34 & 192 & 827 \\
\hline $1891 \ldots$ & & 448,612 & 3,471 & 6,245 & 4,000 & 462,328 & 779,018 & 1.68 & 265 & 806 \\
\hline $1892 .$. & $\ldots$ & 645,557 & 8,776 & 6,997 & $\ldots$. & 661,830 & $1,074,601$ & 1.62 & 223 & 1,083 \\
\hline 1893. & $\ldots$ & 636,002 & 5,618 & 8,776 & 14,698 & 665,094 & 979,044 & 1.47 & 229 & 1,011 \\
\hline $1894 \ldots$ & 20 & 561,523 & 8,266 & $-14,365$ & 13,042 & 597,196 & 935,857 & 1.57 & 182 & 985 \\
\hline $1895 .$. & 22 & 695,634 & 13,045 & 11,292 & 683 & 720,654 & $1,072,520$ & 1.49 & 190 & 1,383 \\
\hline $1896 \ldots$ & 16 & 607,319 & 6,677 & 7,446 & 1,184 & 622,626 & 930,381 & 1.49 & 172 & 1,559 \\
\hline $1897 \ldots$ & 15 & 689,423 & 7,844 & 19,714 & & 716,981 & 991,611 & 1.38 & 208 & 1,659 \\
\hline $1898 \ldots$ & 16 & 949,903 & 7,660 & 17,601 & 17,124 & 992,288 & $1,344,750$ & 1.35 & 242 & 1,873 \\
\hline $1899 \ldots$ & 18 & $1,021,801$ & 14,128 & 14,785 & & $1,050,714$ & $1,461,865$ & 1. 39 & 257 & 1,750 \\
\hline
\end{tabular}

Coal product of New Mexico since 1896, by counties.

[Short tons.]

\begin{tabular}{|c|c|c|c|c|c|c|}
\hline County: & 1896. & 1897. & 1898. & 1899. & $\begin{array}{c}\text { Increase, } \\
1899 .\end{array}$ & $\begin{array}{c}\text { Decrease, } \\
1899 .\end{array}$ \\
\hline Pernalillo ... & 271,137 & 332,488 & 445,558 & 493,310 & 47,752 & \\
\hline Colfax ... & 179,415 & 163,463 & 269,215 & 368,373 & 99,158 & \\
\hline Lincoln ... & 2,535 & 75 & $\cdots$ & 12,737 & 12,737 & \\
\hline Rio Arriba. & $\dot{8}, 200$ & $a 12,300$ & 31,000 & 32,000 & 1,000 & \\
\hline Santa Fe... & a 161, 339 & 208,655 & 246,215 & 137,534 & & 108,681 \\
\hline Other counties. & 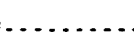 & $\ldots$. & 300 & 6,760 & 6,460 & \\
\hline Total & 622,626 & 716,981 & 992,288 & $1,050,714$ & 358,426 & \\
\hline
\end{tabular}

$a$ Including San Juan County. $b$ Net increase.

Coal product of New Merico since 1882.

\begin{tabular}{|c|c|c|c|c|c|}
\hline Year. & Short tons. & Value. & Year. & Short tons. & Value. \\
\hline 1882 & 157,092 & & 1891. & 462,328 & $\$ 779,018$ \\
\hline 1883. & 211,347 & & 1892 & 661,330 & $1,074,251$ \\
\hline 1884 & 220,557 & ... & 1893 & 665,094 & 979,044 \\
\hline 1885. & 306,202 & $\$ 918,606$. & 1894 & 597,196 & 935,857 \\
\hline 1886 & 271,285 & 813,855 & 1895 & 720,654 & $1,072,520$ \\
\hline 1887 & 508,034 & $1,524,102$ & 1896 & 622,626 & 930,381 \\
\hline 1888 & 626,665 & $1,879,995$ & 1897 & 716,981 & 991,611 \\
\hline $1889 \ldots$ & 486,943 & 872,628 & 1898. & 992,288 & $1,344,750$ \\
\hline 1890 & 375,777 & 504,390 & 1899. & $1,050,714$ & $1,461,865$ \\
\hline
\end{tabular}


NORTH CAROLINA.

Total product in $1899,26,896$ short tons; total value, $\$ 34,965$.

The entire production of North Carolina in 1899, as for several years past, was from the Cumnock mines in Chatham County. The output in 1898 was reduced by a fire in the mines.

Crul product of Nonth Curolinu jor nine years.

\begin{tabular}{|c|c|c|c|c|c|c|c|c|c|}
\hline Year. & $\begin{array}{l}\text { Num- } \\
\text { ber of } \\
\text { mines. }\end{array}$ & $\begin{array}{l}\text { Londed } \\
\text { at mines } \\
\text { for ship- } \\
\text { ment. }\end{array}$ & $\begin{array}{c}\text { Sold to } \\
\text { local } \\
\text { trade and } \\
\text { used } \\
\text { by em- } \\
\text { ployees. }\end{array}$ & $\begin{array}{l}\text { Csed at } \\
\text { mines for: } \\
\text { steam } \\
\text { and heat. }\end{array}$ & $\begin{array}{l}\text { Total } \\
\text { prod- } \\
\text { uct. }\end{array}$ & $\begin{array}{l}\text { Total } \\
\text { value. }\end{array}$ & $\begin{array}{l}\text { Aver- } \\
\text { age } \\
\text { price } \\
\text { per } \\
\text { ton. }\end{array}$ & $\begin{array}{c}\text { Aver- } \\
\text { age } \\
\text { num- } \\
\text { ber of } \\
\text { days } \\
\text { active. }\end{array}$ & $\begin{array}{l}\text { Average } \\
\text { number } \\
\text { of em- } \\
\text { ployees. }\end{array}$ \\
\hline & & $\begin{array}{l}\text { Short } \\
\text { tomss. }\end{array}$ & $\begin{array}{l}\text { short } \\
\text { toms. }\end{array}$ & $\begin{array}{l}\text { Showt } \\
\text { toms. }\end{array}$ & $\begin{array}{l}\text { Short } \\
\text { tons. }\end{array}$ & & & & \\
\hline $1891 \ldots \ldots \ldots \ldots \ldots$ & 1 & $18,7 \$ 0$ & 600. & 97.5 & 20,335 & $\$ 39,635$ & $\$ 1.93$ & 254 & 80 \\
\hline $1892 \ldots \ldots$ & 1 & 6,679 & 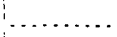 & $\ldots \ldots$ & 6,679 & 9,599 & 1.44 & 160 & 90 \\
\hline $1893 \ldots$ & 1 & 15.000 & $\ldots \ldots \ldots$ & 2,000 & 17,000 & 25,500 & 1.50 & 80 & 70 \\
\hline $1594 \ldots$ & 1 & 13,500 & 1,000 & 2.400 & 16,900 & 29,675 & 1.76 & 145 & 95 \\
\hline $1895 \ldots \ldots \ldots \ldots \ldots$ & 3 & 23,400 & 600 & 900 & 24,900 & 41,350 & 1.66 & 226 & 61 \\
\hline $1896 \ldots \ldots \ldots$ & 1 & 5,356 & 295 & $2,162^{+}$ & $7, \$ 13$ & 11,720 & 1.50 & 220 & 18 \\
\hline $1897 \ldots$ & 1 & 21,280 & $\cdots$ & 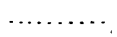 & 21,280 & 27,000 & 1.34 & 215 & 51 \\
\hline $1898 \ldots$ & 1 & 9,852 & 304 & 1,339 & 11,495 & 14,368 & 1.25 & $\ldots$ & .. \\
\hline $1899 \ldots$ & 1 & 24,126 & 486 & 2,284 & 26,896 & 34,965 & 1.30 & 210 & 70 \\
\hline
\end{tabular}

The history of coal mining in the state dates from 1889. The Egypt mines, now called the Cumnock, were opened in December of that yeur, and yielded 19.2 tons. Since that time the product annually has been as follows:

Coal product of North C'eruline simer 1889.

\begin{tabular}{|c|c|c|c|c|c|}
\hline Yeur. & Short tons. & Value. & Fear. & Short tons. & Value. \\
\hline $1889 \ldots \ldots \ldots$ & 192 & $\$ 451$ & $1895 \ldots$ & $2+, 900$ & $\$ 41,350$ \\
\hline $1890 \ldots \ldots$ & 10,262 & 17,864 & $1896 \ldots$ & 7,813 & 11,720 \\
\hline $1891 \ldots .$. & 20,355 & $39,63.5$ & 1897. & 21,280 & 27,000 \\
\hline $1892 \ldots$ & 6,679 & 9,599 & $1898 .$. & 11,495 & 14,368 \\
\hline $1893 \ldots \ldots$ & $1 \bar{i}, 000$ & 25,500 & $1899 \ldots$ & 26,896 & 34,965 \\
\hline $1894 \ldots \ldots \ldots$ & 16,900 & 29,675 & & & \\
\hline
\end{tabular}


NORTH DAKOTA.

Total product in $1899,98,809$ short tons; spot value, $\$ 117,500$.

The product increased 14,914 short tons, or 15 per cent over 1898 , and $\$ 23,909$, or about 25 per cent, in value. All the coals of North Dakota are lignite. The statistics of production are shown in the following tables: Coal product of North Dakota in 189s, by counties.

\begin{tabular}{|c|c|c|c|c|c|c|c|c|c|c|}
\hline County. & + & $\mid \begin{array}{c}\text { Num- } \\
\text { ber of } \\
\text { mines. }\end{array}$ & $\begin{array}{l}\text { Loaded } \\
\text { at mines } \\
\text { for ship- } \\
\text { ment. }\end{array}$ & $\begin{array}{c}\text { Sold to } \\
\text { local } \\
\text { trade and } \\
\text { used } \\
\text { by em- } \\
\text { ployees. }\end{array}$ & $\begin{array}{l}\text { Lsed at } \\
\text { mines for } \\
\text { steam } \\
\text { and heat. }\end{array}$ & $\begin{array}{l}\text { Total } \\
\text { prod- } \\
\text { uct. }\end{array}$ & $\begin{array}{c}\text { Total } \\
\text { value. }\end{array}$ & $\begin{array}{l}\text { Aver- } \\
\text { age } \\
\text { price } \\
\text { per } \\
\text { ton. }\end{array}$ & \begin{tabular}{|c|} 
Aver- \\
age \\
num- \\
ber of \\
days \\
active.
\end{tabular} & $\begin{array}{l}\text { Avernge } \\
\text { number } \\
\text { of em- } \\
\text { ployees. }\end{array}$ \\
\hline & & & $\begin{array}{l}\text { Short } \\
\text { tons. }\end{array}$ & $\begin{array}{l}\text { Short } \\
\text { tons. }\end{array}$ & $\begin{array}{l}\text { Short } \\
\text { tons. }\end{array}$ & $\begin{array}{l}\text { Short } \\
\text { tons. }\end{array}$ & & & & \\
\hline Burleigh. & & 4 & 800 & 1,325 & 20 & 2,145 & $\$ 1,912$ & $\$ 0.90$ & 106 & 14 \\
\hline Emmons. & & 2 & $\cdots$ & 560 & & 560 & 1,368 & 2.44 & 118 & 1 \\
\hline Morton & & 3 & 12,420 & 500 & $\cdots$ & 12,920 & 12,756 & .94 & 162 & 23 \\
\hline Stark ... & & 3 & 37,500 & 6,780 & 1,000 & 45,280 & 46,105 & 1.02 & 209 & ds \\
\hline $\begin{array}{l}\text { McLeau } \\
\text { Ward... }\end{array}$ & & 6 & 20,503 & 2,360 & $1: 27$ & 22,990 & 31,450 & 1.37 & 188 & (i) \\
\hline Total & & 18 & 71,223 & 11,525 & 1.147 & 83,895 & 93,591 & 1.12 & 187 & 151 \\
\hline
\end{tabular}

Coal product of North Dakota in 1899, by counties.

\begin{tabular}{|c|c|c|c|c|c|c|c|c|c|}
\hline County. & $\begin{array}{l}\text { Num- } \\
\text { ber of } \\
\text { mines. }\end{array}$ & $\begin{array}{c}\text { Loaded } \\
\text { at mines } \\
\text { for ship- } \\
\text { ment. }\end{array}$ & $\begin{array}{l}\text { Sold to } \\
\text { local } \\
\text { trade and } \\
\text { used } \\
\text { by em- } \\
\text { ployees. }\end{array}$ & $\begin{array}{c}\text { Used at } \\
\text { mines for } \\
\text { steam } \\
\text { and heat. }\end{array}$ & $\begin{array}{l}\text { Total } \\
\text { prod- } \\
\text { uct. }\end{array}$ & $\begin{array}{l}\text { Total } \\
\text { value. }\end{array}$ & $\begin{array}{l}\text { Aver- } \\
\text { age } \\
\text { price } \\
\text { per } \\
\text { ton. }\end{array}$ & \begin{tabular}{|} 
Aver- \\
age \\
num- \\
ber of \\
days \\
active.
\end{tabular} & $\begin{array}{l}\text { Average } \\
\text { number } \\
\text { of em- } \\
\text { ployees. }\end{array}$ \\
\hline & & $\begin{array}{l}\text { Short } \\
\text { tons. }\end{array}$ & $\begin{array}{l}\text { Short } \\
\text { tons. }\end{array}$ & $\begin{array}{l}\text { Short } \\
\text { tons. }\end{array}$ & $\begin{array}{l}\text { Short } \\
\text { tons. }\end{array}$ & & & & \\
\hline Burleigh & 5 & 500 & 1,050 & ... & 1,550 & $\$ 1,395$ & $\$ 0.90$ & 93 & 10 \\
\hline Emmons. & 2 & & 725 & & 725 & 1,820 & 2.51 & $\$ 5$ & 5 \\
\hline IcLean .. & 5 & ...... & 2,480 & & 2,480 & 2,459 & .99 & 147 & 9 \\
\hline Morton. & + & 17,400 & 1,400 & 50 & 18,850 & 19,190 & 1.02 & 153 & 30 \\
\hline Stark ..... . & 2 & 22,700 & 4,200 & & 26,920 & 28,015 & 1.04 & 191 & 29 \\
\hline Ward. & 7 & 37,131 & 10,913 & 240 & 48,284 & 64,621 & 1.34 & 154 & 1.27 \\
\hline Total & 25 & 77,731 & 20,788 & 290 & 98,809 & 117,500 & 1.19 & 154 & 210 \\
\hline
\end{tabular}

Distribution of the coal product of North Dakota from 1889 to 1899.

\begin{tabular}{|c|c|c|c|c|c|c|c|c|c|}
\hline Year. & $\begin{array}{c}\text { Num- } \\
\text { ber of } \\
\text { mines. }\end{array}$ & $\begin{array}{l}\text { Joaded } \\
\text { at mines } \\
\text { for ship- } \\
\text { ment. }\end{array}$ & $\begin{array}{l}\text { Sold to } \\
\text { local trade } \\
\text { and used } \\
\text { by em- } \\
\text { ployees. }\end{array}$ & $\begin{array}{l}\text { Used at } \\
\text { mines for } \\
\text { steam } \\
\text { and heat. }\end{array}$ & $\begin{array}{l}\text { Total } \\
\text { prod- } \\
\text { uct. }\end{array}$ & $\begin{array}{c}\text { Total } \\
\text { value. }\end{array}$ & $\begin{array}{c}\text { Aver- } \\
\text { age } \\
\text { price } \\
\text { per ton. }\end{array}$ & $\begin{array}{l}\text { Aver- } \\
\text { age } \\
\text { num- } \\
\text { ber of } \\
\text { days } \\
\text { active. }\end{array}$ & $\begin{array}{c}\text { Average } \\
\text { number } \\
\text { of em- } \\
\text { ployees. }\end{array}$ \\
\hline & & $\begin{array}{l}\text { Short } \\
\text { tons. }\end{array}$ & $\begin{array}{l}\text { Short } \\
\text { tons. }\end{array}$ & $\begin{array}{l}\text { Shont } \\
\text { tons. }\end{array}$ & $\begin{array}{l}\text { Short } \\
\text { tons. }\end{array}$ & & & & \\
\hline 1889. & & 18,610 & 10,297 & & 28,907 & $\$ 41,431$ & $\$ 1.43$ & & \\
\hline $1 S 90$. & & & 30,000 & & 30,000 & 42,000 & 1.40 & & \\
\hline 1891. & & $\cdots$ & 30,000 & & 30,000 & 42,000 & 1.40 & & . \\
\hline 1892. & & 38,000 & 2,725 & & 40,725 & 39,250 & .96 & 216 & 54 \\
\hline 1893. & & 47,968 & 1,612 & 50 & 49,630 & 56,250 & 1.13 & 193 & 88 \\
\hline $1894 \ldots$ & 8 & $3 \overline{7}, 311$ & 4,480 & 224 & 42,015 & $4 \overline{7}, 049$ & 1.12 & 156 & 77 \\
\hline $1895 \ldots$ & 8 & 35,380 & 3,617 & ... & 38,997 & 41,646 & 1.07 & 143 & 62 \\
\hline $1896 .$. & 10 & 71,447 & 6,183 & 420 & 78,050 & 84,908 & 1.09 & 166 & 141 \\
\hline $1897 .$. & 20 & 65,032 & 10,458 & 1,756 & 77,246 & 83,803 & 1.08 & 168 & 170 \\
\hline $1898 .$. & 18 & 71,223 & 11,525 & 2,147 & 83,895 & 93,591 & 1.12 & 187 & 151 \\
\hline $1899 \ldots \ldots$ & 25 & 77,731 & 20,788 & 290 & 98,809 & 117,500 & 1.19 & 154 & 210 \\
\hline
\end{tabular}


('oul product of North Dakota since 1884.

\begin{tabular}{|c|c|c|c|}
\hline Year. & Short tons. & Year. & Short tons. \\
\hline 1884 & 35,000 & 1892. & 40,725 \\
\hline $1885 \ldots$ & 25,000 & $1893 \ldots$ & 49,630 \\
\hline 1886 & 25,955 & $1894 \ldots \ldots$ & 42,015 \\
\hline $1887 \ldots$ & 21,470 & $1895 \ldots$ & 38,997 \\
\hline 1888 & $3+, 000$ & 1896 & 78,050 \\
\hline $1889 \ldots$ & 28,907 & 1897 & 77,246 \\
\hline $1890 \ldots \ldots$ & 30,000 & $1898 \ldots \ldots \ldots \ldots$ & 83,895 \\
\hline $1891 \ldots \ldots \ldots$ & 30,000 & $1899 \ldots \ldots \ldots \ldots$ & 98,809 \\
\hline
\end{tabular}

\section{OHIO.}

Total product in $1899,16,500,270$ short tons; spot value, $\$ 14,361,903$. Compared with 1898 the coal product of Ohio in 1899 shows an increase of $1,983,403$ short tons, or 14 per cent. The increase in value was $\$ 2,334,567$, or 19 per cent, there being an advance in the average price in the State from 83 cents to 87 cents per ton. The production of 1899, both in tonnage and value, was the largest in the history of the State. Ohio stands fourth in tonnage among the coal-producing States, being preceded by Pennsylvania, Illinois, and West Virginia. When the value of the product is taken as a basis for comparison, Ohio stands third, the amount received by the Ohio operators in 1899 exceeding the value of the West Virginia product by more than $\$ 2,300,000$, whereas the tonnage of West Virginia was larger than Ohio's by 2,750,000. Ohio stands third also in the number of machines used in the mines and second in the amount of machine-mined coal, the corresponding positions being held by Illinois. The number of machines in use in Ohio during 1899 was 278 as compared with 440 in Illinois mines. The coal won by machines in Ohio in 1899 was $6,822,524$ tons as against $6,085,312$ tons in Illinois.

Ohio was almost entirely free from coal-mining strikes in 1899. Only fifteen mines reported labor troubles last year and in some of these only a portion of the employees were idle. The total number of men made idle because of strikes was 877 , a little more than 3 per cent of all the employees; and the time lost amounted to 26.394 days, about one-half of one per cent of the total time made, and an average of 30 days' idleness for the striker's. 
PRODUCTION BY COUNTIES.

The record for increased production in 1898 was made by Guernsey County, whose tonnage increased nearly 50 per cent, to $1,326,480$ short tons from 910,554 short tons in 1897 . This record was beaten by Hocking County in 1899, not only in tonnage but in percentage of increase. Hocking County, in 1899, produced $2,018,865$ short tons, a gain of 749,079 tons, or 59 per cent, over the preceding year. In making this stride Hocking County steps over Athens, Guernsey, and Perry counties and becomes a close second to Jackson County, whose product in 1899 was $2,032,233$ short tons, not quite 14,000 tons more than Hocking County. Jackson County, in addition to resuming first place, from which it was deposed in 1896, was second in increased tonnage in 1899 , with a gain of 261,968 tons. Perry County's product decreased nearly 100,000 tons in a year of general improvement, and as a consequence that county drops from first to fourth place. Athens County remains in third place. Guernsey County is credited with an increase of 236,506 tons, the third in tonnage gain, but is forced from fourth to fifth place by the advance of Hocking County to first place. Belmont and Stark counties hold sixth and seventh places, respectively; the latter supplanting Tuscarawas County. Belmont's production in 1899 increased a little over 200,000 tons, and that of Stark County was augmented by a little less than that figure. The credit for the largest percentage of increase belongs to Trumbull County, whose output in 1899 exceeded that of 1898 by 362 per cent. Next to this was Washington County, with 181 per cent gain. Both counties, however, are small producers, their combined product in 1899 being less than 16,000 tons.

There were two counties in 1899 whoes product exceeded 2,000,000 tons. They were Hocking and Jackson. Once before, in 1895, Jackson County passed that figure. No other county of the State ever has. Five other counties exceeded 1,000,000 tons in 1899, making seven counties whose product is given in seven figures. Tuscarawas and Jefferson counties each produced over 900,000 tons in 1899, and Columbiana County was less than 15,000 tons short of that figure. No other county produced as much as 400,000 tons.

Athens, Hocking, and Perry counties combined form what is known as the Hocking Valley region. The output of the three counties in 1899 amounted to $5,540,393$ short tons, about one-third the total prod. uct of the State. 
The details of production by counties in 1898 and 1899, together with the distribution of the product for consumption, are shown in the following tables:

Coal product of Ohio in 1898, by counties.

\begin{tabular}{|c|c|c|c|c|c|c|c|c|c|c|}
\hline Comby. & $\begin{array}{c}\text { Num- } \\
\text { ber of } \\
\text { mines. }\end{array}$ & $\begin{array}{l}\text { Loaded } \\
\text { at mines } \\
\text { for ship- } \\
\text { ment. }\end{array}$ & $\begin{array}{c}\text { Sold to } \\
\text { local } \\
\text { trade and } \\
\text { used by } \\
\text { employ- } \\
\text { ees. }\end{array}$ & $\begin{array}{c}\text { Used at } \\
\text { mines } \\
\text { for } \\
\text { steam } \\
\text { and } \\
\text { heat. }\end{array}$ & $\begin{array}{l}\text { Made } \\
\text { into } \\
\text { coke. }\end{array}$ & $\begin{array}{c}\text { Total } \\
\text { product. }\end{array}$ & $\begin{array}{l}\text { Total } \\
\text { value. }\end{array}$ & $\begin{array}{c}\text { Aver- } \\
\text { age } \\
\text { price } \\
\text { per } \\
\text { ton. }\end{array}$ & $\begin{array}{l}\text { Aver- } \\
\text { age } \\
\text { num- } \\
\text { ber of } \\
\text { days } \\
\text { active. }\end{array}$ & $\begin{array}{l}\text { Average } \\
\text { number } \\
\text { of em- } \\
\text { ployees. }\end{array}$ \\
\hline & & Short tons. & Short toms. & $\begin{array}{l}\text { Short } \\
\text { tons. }\end{array}$ & $\begin{array}{l}\text { Short } \\
\text { tons. }\end{array}$ & Short tons. & & & & \\
\hline Athens ...... & 31 & $1,558,258$ & 28,512 & 51,420 & 13,259 & $1,651,449$ & $\$ 1,246,678$ & $\$ 0.75$ & 161 & 3,040 \\
\hline Belmont. & 32 & 912,113 & 121,766 & 2,223 & & $1,036,102$ & 752,542 & .73 & 177 & 1,715 \\
\hline Carroll . & 8 & 222,711 & 7,160 & 915 & & 230,786 & 172,268 & .75 & 181 & 412 \\
\hline Columbian & 20 & 862,183 & 20,435 . & 11,062 & & 893,680 & 673,000 & .75 & 222 & 1,445 \\
\hline Coshoc & 19 & 351,119 & 15,813 & 360 & & 367,292 & 332,592 & .91 & 229 & 630 \\
\hline Guernsey. & 14 & $1,294,297$ & 15,518 & 16,665 & & $1,326,480$ & 851,664 & .65 & 234 & 4) 1,700 \\
\hline Harrison & 2 & 28,307 & 385 & 420 & & 29,112 & 17,487 & .60 & 174 & 84 \\
\hline Hocking. & 17 & $1,244,587$ & 12,321 & 12,878 & & $1,269,786$ & 932,318 & .73 & 142 & 2,258 \\
\hline Jackson & 50 & $1,669,561$ & 69,839 & 30,865 & & $1,770,265$ & $1,593,553$ & .90 & 145 & 4,215 \\
\hline Jefferson & 22 & 668,222 & 126,485 & 4,749 & 1,084 & 800,540 & 641,079 & .80 & 240 & 1,150 \\
\hline Lawr & 7. & 57,341 & 7,458 & 50 & & 64,849 & 51,095 & .79 & 119 & 223 \\
\hline Mahoning & 11 & 20,720 & 14,313 & 752 & & 35,785 & 32,140 & .90 & 175 & 109 \\
\hline Med & 10 & 232,813 & 10,350 & 6,243 & & 249,406 & 267,943 & 1.07 & 196 & 770 \\
\hline Meigs & 15 & 46,913 & 125,329 & 1,974 & & 174,216 & 134,881 & .77 & 117 & 540 \\
\hline Mor & 2 & 26,730 & .. & & & 26,730 & 19,003 & .71 & 101 & 90 \\
\hline Muskingum . & 19 & 112,943 & 24,463 & 100 & & 137,506 & 109,847 & .80 & 164 & 327 \\
\hline Perry & 56 & $1.761,724$ & 30,573 & 39,678 & & $1,831,975$ & $1,494,885$ & .82 & 151 & 3,195 \\
\hline Portage....... & 4 & 76,138 & 3,826 & 2,695 & & 82,659 & 123,073 & 1.49 & 174 & 293 \\
\hline Stark & 34 & 814,700 & 45,826 & 27,632 & & 888,158 & $1,050,401$ & 1.18 & 151 & 2,304 \\
\hline Summit & 4 & 46,985 & 4,697 & 40 & & 51,722 & 60,827 & 1.18 & 187 & 199 \\
\hline Trumbull.... & 3 & 1,275 & 265 & 100 & & 1,640 & 2,869 & 1.75 & 40 & 29 \\
\hline Tuscarawas & 37 & 885,731 & 19,646 & 4,480 & & 909,857 & 692,205 & .76 & 163 & 3) 1,765 \\
\hline Vinton & 5 & 72,000 & 8,224 & 1,050 & & $\$ 1,274$ & 74,231 & .91 & 187 & 241 \\
\hline Washington. & 3 & 1,112 & 1,846 & $\ldots \ldots$ & & 2,958 & 2,734 & .92 & 151 & 17 \\
\hline $\begin{array}{l}\text { Wayne. } \\
\text { Gallia .. }\end{array}$ & 3 & 34,321 & 3,903 & 5,132 & & 43,356 & 54,333 & 1.25 & 164 & 125 \\
\hline Noble. & 3 & 50,623 & 7,231 & 1,430 & & 59,284 & 43,688 & .74 & 201 & 110 \\
\hline Scioto & & & & & & & & & & \\
\hline Small mines. & & & 500,000 & & & 500,000 & 600,000 & & & 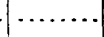 \\
\hline $\mathrm{T}$ & 431 & $13,053,427$ & $1,226,184$ & 222,913 & 14, & 3,867 & $12,027,336$ & .83 & 169 & 36 \\
\hline
\end{tabular}


COAL.

Coal product of Ohio in 1899 by counties.

\begin{tabular}{|c|c|c|c|c|c|c|c|c|c|c|}
\hline County. & $\begin{array}{l}\text { Num- } \\
\text { ber of } \\
\text { mines. }\end{array}$ & $\begin{array}{c}\text { Loaded } \\
\text { at mines } \\
\text { for ship- } \\
\text { ment. }\end{array}$ & \begin{tabular}{|} 
Sold to \\
local \\
trade \\
and used \\
by em- \\
ployees.
\end{tabular} & $\begin{array}{l}\text { Csed at } \\
\text { mines } \\
\text { for } \\
\text { steam } \\
\text { and } \\
\text { heat. }\end{array}$ & $\begin{array}{l}\text { Made } \\
\text { in to } \\
\text { coke. }\end{array}$ & \begin{tabular}{c|} 
Total \\
product.
\end{tabular} & $\begin{array}{c}\text { Total } \\
\text { value. }\end{array}$ & $\begin{array}{l}\text { Aver- } \\
\text { age } \\
\text { price } \\
\text { per } \\
\text { ton. }\end{array}$ & \begin{tabular}{|} 
Aver- \\
age \\
num- \\
ber of \\
days \\
active.
\end{tabular} & $\begin{array}{c}\text { Aver- } \\
\text { age } \\
\text { number } \\
\text { of em- } \\
\text { ployees. }\end{array}$ \\
\hline & & $\begin{array}{l}\text { Short } \\
\text { tons. }\end{array}$ & $\begin{array}{l}\text { Short } \\
\text { tons. }\end{array}$ & $\begin{array}{l}\text { Short } \\
\text { tons. }\end{array}$ & $\begin{array}{l}\text { Short } \\
\text { tons. }\end{array}$ & $\begin{array}{l}\text { Short } \\
\text { tons. }\end{array}$ & & & & \\
\hline Athens. & 33 & $1,709,923$ & 3,198 & 59,600 & 13,320 & $1,786,041$ & $\$ 1,389,136$ & $\$ 0.78$ & 189 & 2,963 \\
\hline Belmont & 38 & $1,044,282$ & 194,123 & $3,97 \mathrm{~S}$ & & $1,242,383$ & 944,870 & .76 & 234 & 1,837 \\
\hline Carroll .. & 10 & 217,424 & 8,467 & 1,300 & & 227,191 & 181,255 & .80 & 180 & 445 \\
\hline Columbian & 24 & 795,600 & 78,679 & 10,900 & & 885,179 & 820,930 & .93 & 250 & 1,422 \\
\hline Coshocton & 25 & 365,920 & 25,743 & 710 & & 392,373 & 355,888 & .91 & 231 & 647 \\
\hline Guernsey. & 15 & $1,543,127$ & 5,720 & 14,139 & & $1,562,986$ & $1,061,453$ & .68 & 227 & 1,693 \\
\hline Harrison & 2 & $\ldots \ldots \ldots$ & $1,380^{i}$ & 10 & & 1,390 & 1,354 & .97 & 143 & 7 \\
\hline Hocking. & 12 & $1,995,844$ & 14,141 & 8,880 & & $2,018,865$ & $1,497,461$ & .74 & 182 & 2,565 \\
\hline Jackson .. & 45 & $1,964,733$ & 39,770 & 27,730 & & $2,032,233$ & $2,131,422$ & 1.05 & 184 & 3,894 \\
\hline Jefferson & 26 & 782,228 & 134,170 & 6,776 & 1,040 & 924,214 & 707,648 & .77 & 265 & 1,139 . \\
\hline Lawrence & 10 & 102,056 & 14,746 & 170 & & 116,972 & 110,125 & .94 & 211 & 297 \\
\hline Mahoning . & 11 & 30,974 & 12,057 & 875 & & 43,906 & 45,543 & 1.04 & 198 & 107 \\
\hline Medinn. & 9 & 175,571 & 10,400 & 5,380 & & 191,351 & 224,095 & 1.17 & 210 & 414 \\
\hline Meigs & 14 & 168,745 & 102,878 & 2,107 & & 273,730 & 231,576 & .85 & 218 & 546 \\
\hline Morgan... & 2 & 24,855 & . & 50 & & 24,905 & 20,749 & .83 & 120 & 75 \\
\hline Muskingum . & 19 & 85,784 & 56,561 & 300 & & 142,645 & 117,499 & .82 & 200 & 338 \\
\hline Perry.... & 49 & $1,617,377$ & 89,895 & 28,215 & & $1,735,487$ & $1,366,056$ & .79 & 166 & \begin{tabular}{l|l}
6 & 2,799
\end{tabular} \\
\hline Stark & 35 & $1,009,568$ & 45,302 & 24,358 & & $1,079,228$ & $1,375,690$ & 1.27 & 185 & 2,350 \\
\hline Summit .. & 4 & 66,439 & 1,549 & 714 & & 68,702 & 86,564 & 1.26 & 150 & 233 \\
\hline Tuscarawas & 37 & 932,284 & 41,856 & 5,291 & & 979,431 & 783,324 & .80 & 202 & $\begin{array}{l}2,583 \\
\end{array}$ \\
\hline Vinton & 6 & 69,639 & 740 & 1,460 & & 71,839 & 70,204 & .98 & 184 & 166 \\
\hline Washington & 4 & 3,900 & 4,408 & 14 & & 8,322 & 8,322 & 1.00 & 139 & 27 \\
\hline Gall & 3 & 17,554 & $1,22 C$ & & & 18,774 & 15,150 & .81 & 207 & 39 \\
\hline $\begin{array}{l}\text { Scio } \\
\text { Gea }\end{array}$ & & & & & & & & & & \\
\hline Portng & 6 & 103,472 & 4,774 & 7,407 & & 115,653 & 164,913 & 1.43 & 190 & 337 \\
\hline Trun & & & & & & & & & & \\
\hline Noble. & 2 & 53,594 & 1,248 & 6 & & 56,470 & 50,676 & .90 & 221 & 115 \\
\hline Small m & & &, 000 & & & 500,000 & 000 & & & \\
\hline Total & 441 & $14,880,893$ & , 025 & 211,992 & $|14,360|$ & $16,500,270$ & $\mid 14,361,903$ & .87 & 200 & D) 26,038 \\
\hline
\end{tabular}

Distribution of the coal product of Ohio from 1889 to 1899.

\begin{tabular}{|c|c|c|c|c|c|c|c|c|c|c|}
\hline Yeur. & $\begin{array}{l}\text { Num- } \\
\text { ber of } \\
\text { mines. }\end{array}$ & $\begin{array}{l}\text { Loaded at } \\
\text { mines for } \\
\text { shipment. }\end{array}$ & $\begin{array}{c}\text { Sold to } \\
\text { local trade } \\
\text { and used } \\
\text { by em- } \\
\text { ployees. }\end{array}$ & $\begin{array}{l}\text { Used at } \\
\text { mines } \\
\text { for } \\
\text { steam } \\
\text { and } \\
\text { heat. }\end{array}$ & $\begin{array}{c}\text { Made } \\
\text { into } \\
\text { coke. }\end{array}$ & $\begin{array}{c}\text { Total } \\
\text { product. }\end{array}$ & $\begin{array}{l}\text { Total } \\
\text { value. }\end{array}$ & $\begin{array}{c}\text { Aver- } \\
\text { age } \\
\text { price } \\
\text { per } \\
\text { ton. }\end{array}$ & \begin{tabular}{|} 
Aver- \\
age \\
num- \\
ber of \\
days \\
active.
\end{tabular} & $\begin{array}{l}\text { Aver- } \\
\text { age } \\
\text { number } \\
\text { of em- } \\
\text { ployees. }\end{array}$ \\
\hline & & $\begin{array}{l}\text { Short } \\
\text { tons. }\end{array}$ & $\begin{array}{l}\text { Short } \\
\text { tons. }\end{array}$ & $\begin{array}{c}\text { Short } \\
\text { tons. }\end{array}$ & $\begin{array}{l}\text { Short } \\
\text { tons. }\end{array}$ & $\begin{array}{l}\text { Short } \\
\text { tons. }\end{array}$ & & & & \\
\hline 1889. & & $8,566,223$ & $1,196,872$ & 144,223 & 69,469 & $9,976,787$ & $\$ 9,355,400$ & $\$ 0.94$ & & 19,343 \\
\hline 1890. & & $10,161,887$ & $1,164,876$ & 143,984 & 23,759 & $11,494,506$ & $10,783,171$ & .94 & 201 & 20,576 \\
\hline $1891 \ldots$ & & $11,393,209$ & $1,281,568$ & 140,420 & 53,486 & $12,868,683$ & $12,106,115$ & .94 & 206 & 22,182 \\
\hline 1892. & & $11,995,256$ & $1,411,642$ & 117,486 & 38,543 & $13,562,927$ & $12,722,745$ & .94 & 212 & 22,576 \\
\hline 1893. & $\cdots$ & $11,713,116$ & $1,348,743$ & 167,002 & 24,785 & $13,253,646$ & $12,351,139$ & .92 & 188 & 23,931 \\
\hline $1894 \ldots$ & 374 & $10,636,402$ & $1,101,940$ & 120,397 & 45,117 & $11,909,856$ & $9,841,723$ & .83 & 136 & 27,105 \\
\hline $1895 .$. & 415 & $11,933,686$ & $1,227,224$ & $152,27 \bar{t}$ & 42,619 & $13,355,806$ & $10,618,477$ & .79 & 176 & 24,644 \\
\hline $1896 \ldots$ & 408 & $11,494,275$ & $1,181,610$ & 172,722 & 26,595 & $12,875,202$ & $10,253,461$ & .79 & 161 & 25,500 \\
\hline $1897 \ldots$ & 350 & $10,725,047$ & $1,259,290$ & 192,755 & 19,850 & $12,196,942$ & $9,535,409$ & .78 & 148 & 26,410 \\
\hline $1898 \ldots$ & 431 & $13,053,427$ & $1,226,184$ & 222,913 & 14,343 & $14,516,867$ & $12,027,336$ & .83 & 169 & 26,986 \\
\hline $1899 .$. & 441 & $14,880,893$ & $1,393,025$ & 211,992 & 14,360 & $16,500,270$ & $14,361,903$ & .87 & 200 & 26,038 \\
\hline
\end{tabular}


The production by counties for the past five years and the amount and per cent of increase or decrease in each county in 1899 as compared with 1898 are given below:

Coal product of Ohio since 1895, lyy counties.

[Short tons.]

\begin{tabular}{|c|c|c|c|c|c|c|c|c|c|}
\hline County. & 1895. & 1896. & 1897. & 1898. & 1899. & $\begin{array}{c}\text { Increase, } \\
1899 .\end{array}$ & $\begin{array}{c}\text { De- } \\
\text { crease, } \\
1899 .\end{array}$ & $\left\{\begin{array}{c}\text { Per } \\
\text { cent of } \\
\text { in- } \\
\text { crease. }\end{array}\right.$ & $\begin{array}{c}\text { Per } \\
\text { cent of } \\
\text { de- } \\
\text { crease. }\end{array}$ \\
\hline Athens & $1,433,226$ & $1,398,141$ & $1,153,642$ & $1,651,449$ & $1,786,041$ & 134,592 & & 8 & \\
\hline Belmont. & 846,643 & 919,076 & 827,420 & $1,036,102$ & $1,242,383$ & 206,281 & & 19.9 & $\mid \cdots \ldots$ \\
\hline Carroll. & 260,879 & 289,117 & 147,931 & 230,786 & 227,191 & 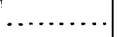 & 3,595 & 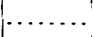 & 1.6 \\
\hline Columbiana. & 617,654 & 534,697 & 774,736 & 893,680 & 885,179 & $\cdots$ & 8,511 & & 1 \\
\hline Coshocton. & 207,620 & 359,379 & 343,589 & 367,292 & 392,373 & 25,081 & & 6.8 & \\
\hline Gallia . & 12,900 & 2,080 & 13,802 & 11,458 & 13,536 & 2,048 & & 17.8 & \\
\hline Guernsey... & 886,581 & 955,457 & 910,554 & $1,326,480$ & $1,562,986_{1}$ & 236,506 & & 17.8 & $\cdots$ \\
\hline Harrison & 3,472 & 2,504 & 5,886 & 29,112 & 1,390 & $\ldots \ldots$ & 27,722 & $\cdots$ & 95.2 \\
\hline Hocking. & $1,587,985$ & $1,415,468$ & $1,411,907$ & $1,269,786$ & $2,018,865$ & 749,079 & & 59 & \\
\hline Jackson & $2,005,384$ & $1,629,226$ & $1,562,651$ & $1,770,265$ & $2,032,233$ & 261,968 & & 14.8 & \\
\hline Jefferson & 885,322 & 687,912 & 751,848 & 800,540 & 924,214 & 123,674 & & 15.4 & \\
\hline Lawrence ... & 88,502 & 51,597 & 87,340 & 64,849 & 116,972 & 52,123 & & 80.4 & \\
\hline Mahoning. & 42,482 & 24,693 & 37,287 & 35,785 & 43,906 & 8,121 & & 22.7 & $\ldots$ \\
\hline Medina. & 264,171 & 194,104 & 170,412 & 249,406 & 191,351 & ...... & 58,055 & $\cdots \cdot$ & 23.3 \\
\hline Meigs. & 184,076 & 259,386 & 184,197 & 174,216 & 273,730 & 99,514 & & 57.7 & \\
\hline Morgan. & 16,000 & 16,294 & 21,965 & 26,730 & 24,905 & 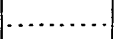 & 1,825 & $\cdots \cdot$ & 6.8 \\
\hline Muskingum & 103,860 & 112,333 & 131,606 & 137,506 & 142,645 & 5,139 & & 3.7 & \\
\hline Perry.... & $1,711,944$ & $1,722,572$ & $1,595,199$ & $1,831,975$ & $1,735,487$ & ….. & 96,488 & …... & 5.3 \\
\hline Portage. & 86,576 & 48,377 & 79,237 & 82,659 & 108,008 & 25,349 & & 30.6 & \\
\hline Stark. & 779,733 & 962,618 & 639,065 & 888,158 & $1,079,228$ & 191,070 & & 21.5 & \\
\hline Summit .... & 25,606 & 23,470 & 52,173 & 51,722 & 68,702 & 16,980 & & 32.8 & \\
\hline Trumbull ... & 15,801 & 2,280 & 12,607 & 1,640 & 7,575 & 5,935 & & 361.9 & \\
\hline Tuscarawas & 657,094 & 641,087 & 626,972 & 909,857 & 979,431 & 69,574 & & 7.6 & $\ldots .$. \\
\hline Vinton ...... & 18,005 & 39,439 & 54,005 & 81,274 & 71,839 & & 9,435 & $\cdots$ & 11.6 \\
\hline Washington & 3,489 & 3,320 & 2,130 & 2,958 & 8,322 & 5,364 & & 181 & $\ldots$ \\
\hline Wayne. & 110,801 & 55,438 & 61,773 & 43,356 & 13,754 & & 29,602 & & 68.3 \\
\hline Noble & & 25,137 & 37,008 & 47,796 & $a 48,024$ & 228 & & .48 & \\
\hline & & & & & & & & & \\
\hline Small mines. & 500,000 & 500,000 & 500,000 & 500,000 & 500,000 & & & & \\
\hline & 3 & $12,875,202$ & $12,196,942$ & $14,516,867$ & $16,500,270$ & $b 1,983,403$ & & 13.66 & \\
\hline
\end{tabular}


Records of the total production of Ohio are available only since 1872, since which time the annual output has been as follows:

Annual coal product of Ohio since $18 \%$.

\begin{tabular}{|c|c|c|c|}
\hline Year. & Short tons. & Year. & Short tons. \\
\hline $1872 \ldots$ & $5,315,294$ & $1886 \ldots \ldots \ldots$ & S, 435,211 \\
\hline $1873 \ldots \ldots \ldots$ & $4,550,028$ & $1887 \ldots \ldots \ldots \ldots$ & $10,300,708$ \\
\hline $1874 \ldots$ & $3,267,585$ & 1888 & $10,91.0,951$ \\
\hline $1875 \ldots .$. & $4,864,259$ & 1889 & $9,976,787$ \\
\hline $1876 \ldots \ldots \ldots$ & $3,500,000$ & $1890 \ldots$ & $11,494,506$ \\
\hline $1377 \ldots$ & $5,250,000$ & 1891 & $12,868,683$ \\
\hline $1878 \ldots$ & $5,500,000$ & 1892 & $13,562,927$ \\
\hline $1879 \ldots$ & $6,000,000$ & $1893 \ldots \ldots$ & $13,253,646$ \\
\hline $1880 \ldots$ & $7,000,000$ & $1894 \ldots \ldots \ldots$ & $11,909,856$ \\
\hline $1881 \ldots$ & $8,225,000$ & 1895 & $13,355,806$ \\
\hline $1882 \ldots$ & $9,450,000$ & $1896 \ldots \ldots$ & $12,875,202$ \\
\hline $1883 \ldots$ & $8,229,429$ & $1897 \ldots$ & $12,196,942$ \\
\hline $1884 \ldots \ldots \ldots \ldots$ & $7,640,062$ & $1898 \ldots \ldots$ & $14,516,867$ \\
\hline $1885 \ldots \ldots \ldots$ & $7,816,179$ & $1899 \ldots \ldots$ & $16,500,270$ \\
\hline
\end{tabular}

\section{OREGON.}

Total product in $1899,86,888$ short tons; spot value, $\$ 260,917$.

The coal product of Oregon in 1899 was 28,704 short tons, or 49 per cent larger than in 1898, but did not attain the figures reported in 1896 or 1897. It was, however, larger than in any year prior to 1896. The Beaver Hill mine, about which much was promised and which helped to swell the total for 1896 and 1897, did not produce in 1897 or 1898 .

The following tables show the statistics of production for the past eight years and the total output since 1885:

Coal product in Oregon since 1892.

\begin{tabular}{|c|c|c|c|c|c|c|c|}
\hline Year. & $\begin{array}{c}\text { Loaded } \\
\text { at mines } \\
\text { for ship- } \\
\text { ment. }\end{array}$ & $\begin{array}{c}\text { Sold to } \\
\text { local } \\
\text { trade and } \\
\text { used } \\
\text { by em- } \\
\text { ployees. }\end{array}$ & $\begin{array}{c}\text { Used at } \\
\text { mines } \\
\text { for steam } \\
\text { and heat. }\end{array}$ & $\begin{array}{c}\text { Total } \\
\text { product. }\end{array}$ & $\begin{array}{l}\text { Total } \\
\text { value. }\end{array}$ & $\begin{array}{l}\text { Average } \\
\text { number } \\
\text { of em- } \\
\text { ployees. }\end{array}$ & $\begin{array}{l}\text { Average } \\
\text { number } \\
\text { of days } \\
\text { worked. }\end{array}$ \\
\hline & $\begin{array}{l}\text { Short } \\
\text { tons. }\end{array}$ & $\begin{array}{l}\text { Short } \\
\text { tons. }\end{array}$ & $\begin{array}{l}\text { Short } \\
\text { tons. }\end{array}$ & $\begin{array}{l}\text { Short } \\
\text { tons. }\end{array}$ & & & \\
\hline $1892 \ldots$ & 31,760 & 2,353 & 548 & 34,661 & $\$ 148,546$ & 90 & 120 \\
\hline $1893 \ldots$ & 37,835 & 3,594 & 254 & 41,683 & 164,500 & 110 & 192 \\
\hline $1894 \ldots$ & 45,068 & 2,171 & 282 & 47,521 & 183,914 & 88 & 243 \\
\hline $1895 \ldots$ & 68,108 & 5,294 & 283 & 73,685 & 247,901 & 414 & $a 69$ \\
\hline $1896 \ldots$ & 88,116 & 12,951 & 654 & 101,721 & 294,564 & 254 & 191 \\
\hline $1897 \ldots \ldots \ldots \ldots$ & 92,921 & 5,207 & 9,161 & 107,289 & 291,772 & 375 & 200 \\
\hline $1898 \ldots$ & 54,305 & 3,290 & 589 & 58,184 & 212,184 & 142 & 199 \\
\hline $1899 \ldots$. & 78,608 & 6,656 & 1,624 & 86,888 & 260,917 & 124 & 238 \\
\hline
\end{tabular}

a The apparently large number of men employed and small average working time are due to the large force of men employed in developing the Beaver Hill mine, which was producing coal for shipment during only twenty days in 1895 . The average time made at the Newport mines was over two

$$
21 \text { GEOL, PT } 6-31
$$


Coal product of Oregon from 1885 to 1899.

\begin{tabular}{|c|c|c|c|}
\hline Year. & Short tons. & Year. & Short tons. \\
\hline 1885 & 50,000 & $1893 \ldots \ldots \ldots \ldots$ & 41,683 \\
\hline $1886 \ldots$ & 45,000 & $1894 \ldots \ldots \ldots \ldots$ & 47,521 \\
\hline $1887 \ldots$ & 37,696 & $1895 \ldots \ldots \ldots$ & 73,685 \\
\hline 1888 & 75,000 & $1896 \ldots$ & 101,721 \\
\hline $1889 \ldots$ & 64,359 & $1897 \ldots \ldots \ldots$ & 107,289 \\
\hline 1890 & 61,514 & $1898 \ldots$ & 58,184 \\
\hline $1891 \ldots$ & 51,826 & $\ldots \ldots \ldots$ & 86,888 \\
\hline $1892 \ldots$ & 34,661 & & \\
\hline
\end{tabular}

\section{PENNSYLVANIA.}

Tetal product in $1899,120,150,160$ long tons, or $134,568,180$ short tons; spot value, $\$ 144,389,921$. Anthracite: Total product, $53,944,647$ long tons, or $60,418,005$ short tons; spot value, $\$ 88,142,130$. Bituminous: Total product, $66,205,513$ long tons, or $74,150,175$ short tons; spot value, $\$ 56,247,791$.

Compared with 1898 the total product of anthracite and bituminous coal in Pennsylvania in 1899 developed an increase of 14,303,931 long tons, or $16,020,403$ short tons, in amount, and of $\$ 25,622,796$ in value. The increase of tonnage in Pennsylvania was not only larger than the total product of any other State except Illinois, West Virginia, and Ohio, but it was also larger than the combined product of any two States outside of the three mentioned. The increase in the value of Pennsylvania's product was larger than the total value of the product in any other one State and equal to nearly one-half of the total value of the combined product of Illinois, West Virginia, Ohio, and Alabama. The aggregate product of anthracite and bituminous coal in Pennsylvania in 1899 was 53 per cent of the total product in the United States. The increase in Pennsylvania's tonnage constituted 49 per cent of the total increase of coal production in 1899 over 1898. The total value of Pennsylvania's product was 56 per cent of the total value of all the coal produced in the United States in 1899 , and the $\$ 25,622,796$ increase in the value of Pennsylvania coal was 53 per cent of the total increase in value.

Of the increased product in $1899,6,281,572 \mathrm{long}$ tons, or $5,035,361$ short tons, and $\$ 12,727,593$ were in anthracite, and 8,022,359 long tons, or $8,985,042$ short tons, and $\$ 12,895,203$ were credited to bituminous. From this it appear's that 45 per cent of the increase in product was anthracite, 55 per cent bituminous, while the increase in value was nearly equally divided. There was an increase from $\$ 1.75$ to $\$ 1.80$ per long ton in the average price per ton for anthracite coal at the mines, and an advance from 67 cents to 76 cents per short ton in the selling price of Pennsylvania bituminous coal. 
Pennsylvania so completely outranks every other producing State, having in the combined product of anthracite and bituminous coal in 1899 nearly six times the output of Illinois, which stands second, that comparisons are only of interest when drawn with reference to the ratio of Pennsylvania's output to that of the total in the United States or of the combined product of the other States. It is not possible to carry such comparisons back to an earlier date than 1880, owing to incomplete statistics in a number of the States. During 1880 the total output of coal in the United States was $63,822,830$ long tons, or $71,481,569$ short tons, of which Pennsylvania produced 42,437,242 long tons, or $47,529,711$ short tons, or practically two-thirds of the total.

The product of Pennsylvania coal has always exceeded 50 per cent of the total product of the United States, the lowest percentage being 52, in 1884 and 1888. The average percentage for the twenty years from 1880 to 1899 , inclusive, was 55. In the following table is shown the total product of Pennsylvania and the United States since 1880, with the percentage of the total produced by Pennsylvania in each year:

Product of Pennsylvania coal compared with total United States since 1880.

\begin{tabular}{|c|c|c|c|}
\hline Year. & $\begin{array}{l}\text { Total United } \\
\text { States. }\end{array}$ & Penusylvania. & $\begin{array}{l}\text { Yer cent of } \\
\text { Pennsyl- } \\
\text { vania to } \\
\text { total. }\end{array}$ \\
\hline $1880 \ldots$ & $\begin{array}{l}\text { Short tons. } \\
71,481,569\end{array}$ & $\begin{array}{l}: \quad \text { Short tons. } \\
\quad 47,529,711\end{array}$ & 65 \\
\hline $1881 \ldots$ & $85,881,030$ & $54,320,018$ & 63 \\
\hline $1882 \ldots$ & $103,285,789$ & $57,254,507$ & 55 \\
\hline $1883 \ldots$ & $115,212,125$ & $62,488,190$ & 54 \\
\hline 1884. & $119,735,051$ & $62,404,488$ & 52 \\
\hline $1885 \ldots$ & $110,957,522$ & $62,137,271$ & 56 \\
\hline $1886 \ldots$ & $112,743,403$ & $62,857,210$ & 56 \\
\hline $1887 \ldots$ & $129,975,557$ & $70,372,857$ & 54 \\
\hline $1888 \ldots$ & $148,659,402$ & $77,719,624$ & 52 \\
\hline 1889 & $141,229,514$ & $81,719,059$ & 58 \\
\hline $1890 \ldots$ & $157,788,657$ & $88,770,814$ & 56 \\
\hline $1891 \ldots$ & $168,566,668$ & $93,453,921$ & 55 \\
\hline $1892 \ldots$ & $179,329,071$ & $99,167,080$ & 55 \\
\hline 1893. & $182,352,774$ & $98,038,267$ & 54 \\
\hline $1894 \ldots$ & $170,741,526$ & $91,833,584$ & 54 \\
\hline $1895 \ldots$ & $193,117,530$ & $108,216,565$ & 56 \\
\hline 1896 & $191,986,357$ & $103,903,534$ & 54 \\
\hline $1897 \ldots$ & $200,221,665$ & $107,029,654$ & 53 \\
\hline $1898 \ldots \ldots$ & $219,974,667$ & $118,547,777$ & 54 \\
\hline $1899 \ldots$ & $253,739,992$ & $134,568,180$ & 53 \\
\hline
\end{tabular}


The production of anthracite and bituminous coal is discussed separately in the subsequent pages. The paper on anthracite production, which will be found particularly interesting, has been prepared by Mr. William W. Ruley, of Philadelphia, chief of the Bureau of Anthracite Coal Statistics. Mr. Ruley is thoroughly familiar with the conditions affecting the anthracite trade, and has contributed this feature to this series of reports for a number of years.

\section{PENNSYLVANIA ANTHRACTTE. ${ }^{1}$}

The general commercial prosperity during the year 1899 was so great and of such recent date that it is unnecessary to call attention to it further than to say that the anthracite trade shared, if not to its proportional extent, at least largely, in the general improvement. This is the more noticeable in this industry for the reason that for three years previous to 1899 the superficial appearances rather indicated a lessening in the demand for anthracite as compared with a steady growth in the use of bituminous coal.

It was pointed out, however, in previous reports that these appearances were misleading and that the apparent falling off in the demand for anthracite was due partly to general industrial conditions and partly to extraordinary causes which had already ceased to exist and the influence of which was about exhausted. This extraordinary influence arose from the excessive tonnage during the year 1895, which amounted to $46,511,477$ tons. As was well known by those conversant with the trade, there was not a demand for anthracite to warrant any such tonnage, and the year 1895 closed with a large stock of coal on hand and the trade more or less demoralized. These unsold stocks continued to be a menace to the market for a long time, affecting prices and causing all buyers to be skeptical as to the future stability of the trade. This tonnage also affected the production for the ensuing years, and with a curtailment of output in order to dispose of the surplus an appearance of a declining demand for anthracite was produced and largely believed in by a considerable portion of the trade.

The above discussion of the 1895 production can probably be best appreciated by an exhibit of the market shipments of anthracite for the three years preceding and succeeding that year:

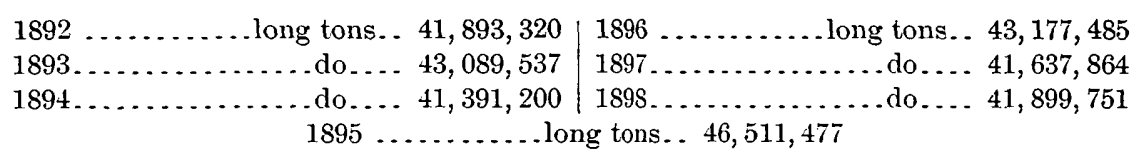

In four of the seven years from 1892 to 1898 , inclusive, the yearly tonnage did not reach 42,000,000 long tons, while in 1893 and 1896 it barely reached $43,000,000$ tons, but in 1895 it was $3,500,000$ tons

1 By William W. Ruley, chief of the Bureau of Anthracite Coal Statistics. 
greater than the latter figure. An output of $42,000,000$ tons was probably a normal consumption for the beginning of this seven-year period, and it is also probable that at no time during this period was there a normal demand for more than $43,000,000$ tons. It should be borne in mind, however, that in speaking of an average annual demand for anthracite it is not intended to be indicated that any such average could be adhered to, for the years of large production have occurred abruptly at intervals and have not been led up to by gradually increasing annual productions. This fact can be plainly seen from the table of annual shipments from 1820 to date, printed in another part of this report.

Leaving now the consideration of the effect of an abnormally large annual production on the shipments for succeeding years, it will be well to consider the general commercial conditions prevailing during the years immediately preceding 1899 . While there was a steady improvement in general business, the great burst of industrial activity did not start until the latter part of 1898 , and during the year, 1899 the country reached the height of commercial prosperity. The coal industry is somewhat peculiar in that it is about the last to be affected by general depression and also the last to revive. This is especially so in respect to anthracite, it being so largely consumed for domestic purposes. However, the trade in 1899 plainly showed the effect of the generally improved conditions by the largest tonnage in its history and a demand which fully kept pace with the production.

That the large production in 1899 was in response to actual demand was proved by the general steadiness of prices and the small surplus stocks remaining at the close of the year, with the prospects for quite as large a trade during 1900 . The marked contrast in this condition of affairs as compared with the large production and state of trade at the close of 1895 is so apparent that further comment is unnecessary.

It will be also readily seen that the contention of pessimists that the anthracite business was a declining one was not justified by the facts, and the belief expressed in previous reports that the anthracite industry would come in for at least a moderate share of the general improvement is plainly borne out by the condition of trade during the past year and the prospects for the future.

Of course, on the other hand, it must not be taken for granted that the anthracite production will continue indefinitely to show large yearly increases to anything like the extent of bituminous coal, as its field is much more limited than that of the latter coal. It will also, like all other great industries, show the effect of hard times when they come, but there can be no doubt that there is a good legitimate demand for anthracite coal, varying from year to year with the changing conditions surrounding it.

Passing now to a consideration of the statistics of production, it is to be noted that the total product of anthracite in 1899 amounted to 
$53,944,647$ long tons, an increase over 1898 of $6,281,571$ tons. Of this amount $47,823,241$ tons were actually shipped to market, 1,144,609 tons sold to local trade, and 4,976,797 tons used for steam and heat at the mines.

In addition to the large increase of tonnage, the average value per ton at the mines increased about 5 cents, resulting in a total increase of $\$ 12,727,593$ for the marketable product. In computing the total value of product the amount of coal used at mines for steam and heat is not taken into consideration, as it is composed mostly of culm and small sizes for which no value is given.

Below is given a table showing the total product and value of same, with the number of persons employed and the average number of days worked for the last five years:

Production of anthracite coal from 1895 to 1899.

\begin{tabular}{|c|r|r|r|r|r|}
\hline Year. & Total product. & Value at mines. & $\begin{array}{c}\text { Average } \\
\text { price per } \\
\text { ton. }\end{array}$ & $\begin{array}{c}\text { Number of } \\
\text { persons } \\
\text { employed. }\end{array}$ & $\begin{array}{c}\text { Average } \\
\text { number of } \\
\text { days } \\
\text { worked. }\end{array}$ \\
\hline & Long tons. & & & & \\
$1895 \ldots \ldots$ & $51,785,122$ & $\$ 82,019,272$ & $\$ 1.72$ & 142,917 & 196 \\
$1896 \ldots \ldots$ & $48,523,287$ & $81,748,651$ & 1.85 & 148,991 & 174 \\
$1897 \ldots \ldots$ & $46,974,715$ & $79,301,954$ & 1.85 & 149,557 & 150 \\
$1898 \ldots \ldots$ & $47,663,076$ & $75,414,537$ & 1.75 & 145,184 & 152 \\
$1899 \ldots \ldots$ & $53,944,647$ & $88,142,130$ & 1.80 & 139,608 & 173 \\
\hline
\end{tabular}

From the above table it will be seen that the value of coal at the mines in 1899 exceeded the next largest year, that of 1895 , hy over $\$ 6,000,000$, there being an increase in the average price per ton of 8 cents, in addition to the increased production.

In the following tables are sbown the details by counties of the production for the years 1898 and 1899:

\begin{tabular}{|c|c|c|c|c|}
\hline & Total product. & Shipments. & Local trade. & Used at mines. \\
\hline & Long tons. & Long tons. & Long tons. & Long tons. \\
\hline Susquehanna ...... & 400,857 & 375,121 & 7,736 & 18,000 \\
\hline Lackawanna . - & $12,130,122$ & $11,023,620$ & 317,382 & 789,120 \\
\hline Luzerne .... & $17,699,936$ & $15,658,233$ & 399,579 & $1,642,124$ \\
\hline Câìưn ............ & $\overrightarrow{1}, \pm 605,877$ & $1,224,449$ & 41,662 & 199,766 \\
\hline Schuylkill . . . . . . . & $11,215,997$ & $9,674,555$ & 224,025 & $1,317,417$ \\
\hline $\begin{array}{l}\text { Columbia . . . . . . . } \\
\text { Sullivan . . . . . . . }\end{array}$ & 582,222 & 529,330 & 9,703 & 43,189 \\
\hline Northumberland .... & $3,490,604$ & $3,02 \bar{\imath}, 5550$ & si, 399 & 375,655 \\
\hline 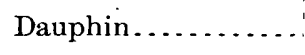 & 677,461 & 530,518 & 17,931 & 129,012 \\
\hline Total ......... & $47,663,076$ & $42,043,376$ & $1,105,417$ & $4,514,283$ \\
\hline
\end{tabular}


COAL.

Anthracite coal product in 1899 by counties.

\begin{tabular}{|c|c|c|c|c|}
\hline & Total product. & Shipments. & Local trade. & Used at mines. \\
\hline Susquehanna & $\begin{array}{l}\text { Long tons. } \\
\quad 620,067\end{array}$ & $\begin{array}{l}\text { Long tons. } \\
\quad 566,181\end{array}$ & $\begin{array}{l}\text { Long tons. } \\
\text { 8, } 8866\end{array}$ & $\begin{array}{l}\text { Long tons. } \\
\quad 45,000\end{array}$ \\
\hline Lackawanna. & $13,602,111$. & $12,489,526$ & 308,420 & 804,165 \\
\hline Luzerne. & $19,738,351$ & $17,449,294$ & 498,724 & $1,790,333$ \\
\hline Carbon ... & $1,683,825$ & $1,474,304$ & 23,654 & 185,867 \\
\hline Schuylkill ... & $12,470,688$ & $10,772,735$ & 193,156 & $1,504,797$ \\
\hline $\begin{array}{l}\text { Columbia. } \\
\text { Sullivan .. }\end{array}$ & 775,283 & 728,824 & 8,606 & 37,853 \\
\hline Northumberland.... & $4,337,129$ & $3,772,561$ & 83,248 & 481,320 \\
\hline Dauphin...... & 717,193 & 569,816 & 19,915 & 127,462 \\
\hline Total & $53,944,647$ & $47,823,241$ & $1,144,609$ & $4,976,797$ \\
\hline
\end{tabular}

In the above tables the columns headed "Shipments" show the coal actually loaded into cars for shipment to market. Of these shipments a record has been kept from the beginning of the industry, and in the table given below the shipment for each year from 1820 to 1899 , divided into the three general trade regions, are given. 
Annual shipments from the Schuylkill, Lehigh, and Wyoming regions from 1820 to 1899.

\begin{tabular}{|c|c|c|c|c|c|c|c|}
\hline \multirow{2}{*}{ Year. } & \multicolumn{2}{|c|}{ Schuylkill region. } & \multicolumn{2}{|c|}{ Lehigh region. } & \multicolumn{2}{|c|}{ Wyoming region. } & \multirow{2}{*}{ Total. } \\
\hline & Long tons. & $\begin{array}{l}\text { Per } \\
\text { cent. }\end{array}$ & Long tons. & $\begin{array}{l}\text { Per } \\
\text { cent. }\end{array}$ & Long tons. & $\begin{array}{l}\text { Per } \\
\text { cent. }\end{array}$ & \\
\hline 1820 & & & & & & & 365 \\
\hline 1821 & & & 1,073 & & & & 1,073 \\
\hline 1822. & 1,480 & $39.79^{\prime}$ & 2,240 & 60.21 & & & 3,720 \\
\hline 1823. & 1,128 & 16.23 & 5,823 & 83.77 & & & 6,951 \\
\hline 1824 & 1,567 & 14.10 & 9,541 & 85.90 & & & 11,108 \\
\hline 1825 & 6,500 & 18.60 & 28,393 & 81.40 & & & 34,893 \\
\hline 1826. & 16,767 & 34.90 & 31,280 & 65.10 & & & 48,047 \\
\hline $182 \pi$. & 31,360 & 49.44 & 32,074 & 50.56 & & & 63,434 \\
\hline 1828. & 47,284 & 61.00 & 30,232 & 39.00 & & & 77,516 \\
\hline 1829. & 79,973 & 71.35 & 25,110 & 22.40 & 7,000 & 6.25 & 112,083 \\
\hline 1830. & 89,984 & 51.50 & 41,750 & 23.90 & 43,000 & 24.60 & 174,734 \\
\hline 1831. & 81,854 & 46.29 & 40,966 & 23.17 & 54,000 & 30.54 & 176,820 \\
\hline 1832. & 209,271 & 57.61 & 70,000 & 19.27 & 84,000 & 23.12 & 363,271 \\
\hline 1833. & 252,971 & 51.87 & 123,001 & 25.22 & 111,777 & 22.91 & 487,749 \\
\hline 1834. & 226,692 & 60.19 & 106,244 & 28.21 & 43,700 & 11.60 & 376,636 \\
\hline 1835. & 339,508 & 60.54 & 131,250 & 23.41 & 90,000 & 16.05 & 560,758 \\
\hline 1836. & 432,045 & 63.16 & 148,211 & 21.66 & 103,861 & 15.18 & 684,117 \\
\hline 1837. & 530,152 & 60.98 & 223,902 & 25.75 & 115,387 & 13.27 & 869,441 \\
\hline 1838 & 446,875 & 60.49 & 213,615 & 28.92 & 78,207 & 10.59 & 738,697 \\
\hline 1839 & 475,077 & 58.05 & 221,025 & 27.01 & 122,300 & 14.94 & 818,402 \\
\hline 1840. & 490,596 & 56.75 & 225,313 & 26.07 & 148,470 & 17.18 & 864,379 \\
\hline 1841 & 624,466 & 60.07 & 143,037 & 14.90 & 192,270 & 20.03 & 959,773 \\
\hline $18+2$ & 583,273 & 52.62 & 272,540 & 24.59 & 252,599 & 22.79 & $1,108,412$ \\
\hline 1843. & 710,200 & 56.21 & 267,793 & 21.19 & 285,605 & 22.60 & $1,263,598$ \\
\hline 1844. & $887,93 \bar{\imath}$ & $5+.45$ & 377,002 & 23.12 & 365,911 & 22.43 & $1,630,850$ \\
\hline 1845. & $1,131,724$ & 56.22 & 429,453 & 21.33 & 451,836 & 22.45 & $2,013,013$ \\
\hline 1846. & $1,308,500$ & 55.82 & 517,116 & 22.07 & 518,389 & 22.11 & $2,344,005$ \\
\hline 1847 & $1,665,735$ & 57.79 & 633,507 & 21.98 & 583,067 & 20.23 & $2,882,309$ \\
\hline 1848 & $1,733,721$ & 56.12 & 670,321 & 21.70 & 685,196 & 22.18 & $3,089,238$ \\
\hline 1849 & $1,728,500$ & 53.30 & 781,556 & 24.10 & 732,910 & 22.60 & $3,242,966$ \\
\hline 1850 & $1,840,620$ & 54.80 & 690,456 & 20.56 & 827,823 & 24.64 & $3,358,899$ \\
\hline $1851 \ldots$ & $2,328,525$ & 52.34 & 964,224 & 21.68 & $1,156,167$ & 25.98 & $4,448,916$ \\
\hline $1852 \ldots$ & $2,636,835$ & 52.81 & $1,072,136$ & 21.47 & $1,284,500$ & 25.72 & $4,993,471$ \\
\hline 1853. & $2,665,110$ & 51.30 & $1,054,309$ & 20.29 & $1,475,732$ & 28.41 & $5,195,151$ \\
\hline 1854 & $3,191,670$ & $53.14^{\prime}$ & $1,207,186$ & 20.13 & $1,603,478$ & 26.73 & $6,002,334$ \\
\hline 1855. & $3,552,943$ & 53.77 & $1,284,113$ & 19.43 & $1,771,511$ & 26.80 & $6,608,567$ \\
\hline 1856. & $3,603,029$ & 52.91 & $1,351,970$ & 19.52 & $1,972,581$ & 28.47 & $6,927,580$ \\
\hline 1857. & $3,373,797$ & 50.77 & $1,318,541$ & 19.84 & $1,952,603$ & 29.39 & $6,644,941$ \\
\hline 1858. & $3,273,245$ & $4 \overline{7} .86$ & $1,380,030$ & 20.18 & $2,186,094$ & 31.96 & $6,839,369$ \\
\hline 1859. & $3,448,708$ & 44. 16 & $1,628,311$ & 20.86 & $2,731,236$ & 34.98 & $7,808,255$ \\
\hline 1860. & $3,749,632$ & 44.04 & $1,821,674$ & 21.40 & $2,941,817$ & 34.56 & $8,513,123$ \\
\hline
\end{tabular}


Annual shipments from the Schuylkill, Lehigh, and Wyoming regions, etc.-Continued.

\begin{tabular}{|c|c|c|c|c|c|c|c|}
\hline \multirow{2}{*}{ Year. } & \multicolumn{2}{|c|}{ Sehuylkill region. } & \multicolumn{2}{|c|}{ Lehigh region. } & \multicolumn{2}{|c|}{ Wyoming region. } & \multirow{2}{*}{$\begin{array}{c}\text { Total. } \\
\text { Long tons. }\end{array}$} \\
\hline & Long tons. & $\begin{array}{l}\text { Per } \\
\text { cent. }\end{array}$ & Long tons. & $\begin{array}{l}\text { Per } \\
\text { cent. }\end{array}$ & Long tons. & $\begin{array}{c}\text { Per } \\
\text { cent. }\end{array}$ & \\
\hline 1861 & $3,160,747$ & 39.74 & $1,738,377$ & 21.85 & $3,055,140$ & $3 S .41$ & $\bar{\tau}, 954,264$ \\
\hline 1862 & $3,372,583$ & 42.86 & $1,351,054$ & 17.17 & $3,145,770$ & 39.97 & $\bar{\tau}, 869,40 \overline{7}$ \\
\hline 1863. & $3,911,683$ & 40.90 & $1,894,713$ & 19.80 & $3,759,610$ & 39.30 & $9,566,006$ \\
\hline 1864 & $4,161,970$ & 40.89 & $2,054,669$ & 20.19 & $3,960,836$ & 38.92 & $10,177,475$ \\
\hline 1865 & $4,356,959$ & 45.14 & $2,040,913$ & 21.14 & $3,254,519$ & 33.72 & $9,652,391$ \\
\hline 1866 & $5,787,902$ & 45.56 & $2,179,364$ & 17.15 & $4,736,616$ & 37.29 & $12,703,882$ \\
\hline 1867. & $5,161,671$ & 39.74 & $2,502,054$ & 19.27 & $5,325,000$ & 40.99 & $12,988,725$ \\
\hline 1868 . & $5,330,737$ & 38.52 & $2,502,582$ & $18: 13$ & $5,968,146$ & 43.25 & $13,801,465$ \\
\hline 1869 & $5,775,138$ & 41.66 & $1,949,673$ & 14.06 & $6,141,369$ & 44.28 & $13,866,180$ \\
\hline 1870. & $4,968,157$ & 30.70 & $3,239,374$ & 20.02 & $7,974,660$ & 49.28 & $16,182,191$ \\
\hline 1871 & $6,552,772$ & 41.74 & $2,235,707$ & 14.24 & $6,911,242$ & 44.02 & $15,699,721$ \\
\hline 1872 & $6,694,890$ & 34.03 & $3,873,339$ & 19.70 & $9,101,549$ & 46.27 & $19,669,778$ \\
\hline 187 & $7,212,601$ & 33.97 & $3,705,596$ & 17.46 & $10,309,755$ & 48.57 & $21,227,952$ \\
\hline 187 & $6,866,877$ & 34.09 & $3,773,836$ & 18. 73 & $9,504,408$ & 47.18 & $20,145,121$ \\
\hline 1875 & $6,281,712$ & 31.87 & $2,834,605$ & 14.38 & 10,$596 ; 155$ & 53.75 & $19,712,472$ \\
\hline 187 & $6,221,934$ & 33. & $3,854,919$ & 20.84 & $8,424,158$ & 45.53 & $18,501,011$ \\
\hline 187 & $8,195,042$ & 39.35 & $4,332,760$ & 20.80 & $\mathrm{~s}, 300,377$ & 39.85 & $20,828,179$ \\
\hline 1878 & $6,282,226$ & 35.68 & $3,237,449$ & 18.40 & $8,085,587$ & 45.92 & $17,605,262$ \\
\hline 1879 & $8,960,829$ & 34.28 & $4,595,567$ & 17.58 & $12,586,293$ & 48.14 & $26,142,689$ \\
\hline 1880 & $7,554,742$ & 32.23 & $4,463,221$ & 19.05 & $11,419,279$ & 48.72 & $23,437,242$ \\
\hline 1881 & $9,253,958$ & & $5,294,676$ & 18.58 & $13,951,383$ & 48.96 & $28,500,017$ \\
\hline 1882 & $9,459,288$ & 32.48 & $5,689,437$ & 19.54 & $13,971,371$ & 47.98 & $29,120,096$ \\
\hline 1883. & $10,074,726$ & 31.69 & $6,113,809$ & 19.23 & $15,604,492$ & 49.08 & $31,793,027$ \\
\hline 1884. & $9,478,314$ & 30.85 & $5,562,226$ & 18. 11 & $a 15,677,753$ & 51.04 & $30,718,293$ \\
\hline 1885. & $9,488,426$ & 30.01 & $5,898,634$ & 18.65 & a $16,236,470$ & 51.34 & $31,623,530$ \\
\hline 1886. & $9,381,407$ & 29.19 & $5,723,129$ & 17.89 & $a 17,031,826$ & 52.82 & $32,136,362$ \\
\hline 188 & $10,609,028$ & 30.63 & $4,34 \overline{7}, 061$ & 12.55 & a $19,684,929$ & 56.82 & $34,641,018$ \\
\hline 1885. & $10,654,116$ & 27.93 & $5,639,236$ & 14.78 & $a 21,852,366$ & 57.29 & $38,145,718$ \\
\hline 1889. & $10,486,185$ & 29.28 & $6,294,073$ & 17.57 & $a 19,036,835$ & 53.15 & $35,817,093$ \\
\hline 1890 & $10,867,822$ & 29.68 & $6,329,658$ & 17.28 & a $19,417,979$ & 53.04 & $36,615,459$ \\
\hline 1891 & $12,741,258$ & 31.50 & $6,381,838$ & 15.78 & $21,325,240$ & 52.72 & $40,448,336$ \\
\hline 1892. & $12,626,784$ & 30.14 & $6,451,076$ & 15.40 & $22,815,480$ & 54.46 & $41,893,340$ \\
\hline 1893. & $12,357,444$ & 28.68 & $6,892,352$ & 15.99 & $23,839,741$ & 55.33 & $43,089,537$ \\
\hline 1894 & $12,035,005$ & 29.08 & $6,705,434$ & 16.20 & $22,650,761$ & 4. 72 & $41,391,200$ \\
\hline 1895 & $14,269,932$ & 30.68 & $\bar{\tau}, 298,124$ & 15.69 & $24,943,421$ & 56.63 & $46,511,477$ \\
\hline 1896 & $13,097,571$ & 30.34 & $6,490,441$ & 15.03 & $23,589,473$ & 54.63 & $43,177,485$ \\
\hline 1897 & $12,181,061$ & 29.26 & $6,249,540$ & 15.00 & $23,207,263$ & 55.74 & $41,637,864$ \\
\hline $189 \mathrm{~s}$. & $12,078,875$ & 28.83 & $6,253,109$ & 14.92 & $23,56 \bar{\imath}, 76 \overline{7}$ & 56.25 & $41,899,751$ \\
\hline 1899 . & $14,199,009$ & 29.79 & $6,887,909$ & 14.45 & $26,578,286$ & 55.76 & $47,665,204$ \\
\hline & $379,950,635$ & $33.71 !$ & $194,438,217$ & 17.26 & $552,516,312$ & 49.03 & $126,905,164$ \\
\hline
\end{tabular}

$a$ Includes Loyalsock field. 
In the heading of the above table it is noted that shipments indicated the coal loaded on cars for market; in the table given below is shown approximately the destination of these shipments for consumption in the several States of the Union.

Approximate distribution of anthracite coal shipments in 1899.

\begin{tabular}{|c|c|c|c|}
\hline State. & $\begin{array}{l}\text { Tons of } 2,240 \\
\text { pounds. }\end{array}$ & State. & $\begin{array}{l}\text { Tons of } 2,240 \\
\text { pounds. }\end{array}$ \\
\hline Alabama & $1,5(10$ & Nebraska & 149,850 \\
\hline Arkansas . & 500 & New Hampshire. & 370,810 \\
\hline California & 9,368 & New Jersey.... & $4,693,500$ \\
\hline Connecticut. & $1,185,882$ & New York ... & $12,503,896$ \\
\hline Delaware. & 249,405 & North and South & \\
\hline Georgia & 36,662 & Dakota ... & 2,000 \\
\hline Illinois . . & $2,188,294$ & Ohio .... & 672,370 \\
\hline Indiana & 198,998 & Oklahoma . & 893 \\
\hline Iowa. & 237,456 & Oregon.. & 4,000 \\
\hline Kansas. & 20,842 & Pennsylvania & $13,803,253$ \\
\hline Kentucky . & 19,425 & Rhode Island . & 553,495 \\
\hline Louisiana.. & 16,000 & South Carolina.. & 41,288 \\
\hline Maine ............ & 633,490 & Tennessee ..... & 6,760 \\
\hline Maryland and Dis- & & Texas ..... & 12,949 \\
\hline trict of Columbia.. & $1,252,832$ & Vermont . & 405,095 \\
\hline Massachusetts... & $3,994,859$ & Virginia ..... & 305,700 \\
\hline Michigan ...... . & 592,094 & Washington .... & 2,500 \\
\hline Minnesota ... & 518,163 & West Virginia... & 366 \\
\hline Mississippi.. & 535 & Wisconsin & 942,599 \\
\hline Missouri . . . & 318,316 & Exports. & $1,707,796$ \\
\hline Montana ...... & 200 & Tatal & 47.665 .203 \\
\hline North Carolina. & 11,262 & & \\
\hline
\end{tabular}

It is not intended that the above figures should be considered as absolutely accurate, as from the nature of the case it is impossible to secure complete returns, but it is believed that they represent very fairly the movements of anthracite to the various sections of the country. It is interesting to note the comparatively small section in which the bulk of the anthracite production is consumed. For instance, the three States of New York, Pennsylvania, and New Jersey take. nearly 65 per cent, while the New England States use nearly 15 per cent, and Delaware, Maryland, and Virginia about $3 \frac{3}{4}$ per cent, making the consumption of the States along the upper Atlantic seaboard over $83 \frac{1}{2}$ per cent. It will also be noticed that the territory east of the Mississippi River uses more than 93 per cent of the total shipments, and of the remain- 
ing $6 \frac{1}{2}$ per cent $3 \frac{1}{2}$ is exported, thus leaving less than 3 per cent for consumption in the territory west of the Mississippi River.

At first glance this seems to be a very uneven distribution of the product, but a little consideration will show it to be what would naturally be expected, for anthracite could hardly compete successfully in the West with cheap bituminous coal when to the high first cost of anthracite is added the large freight charges.

It is, therefore, in those sections within easy reach of the mines by rail or conveniently situated for water transportation that any con. siderable increase in the use of anthracite is to be looked for.

As has been customary in previous reports, a tabular arrangement of the various sections of the anthracite fields is given below, and a list of railroads entering the territory:

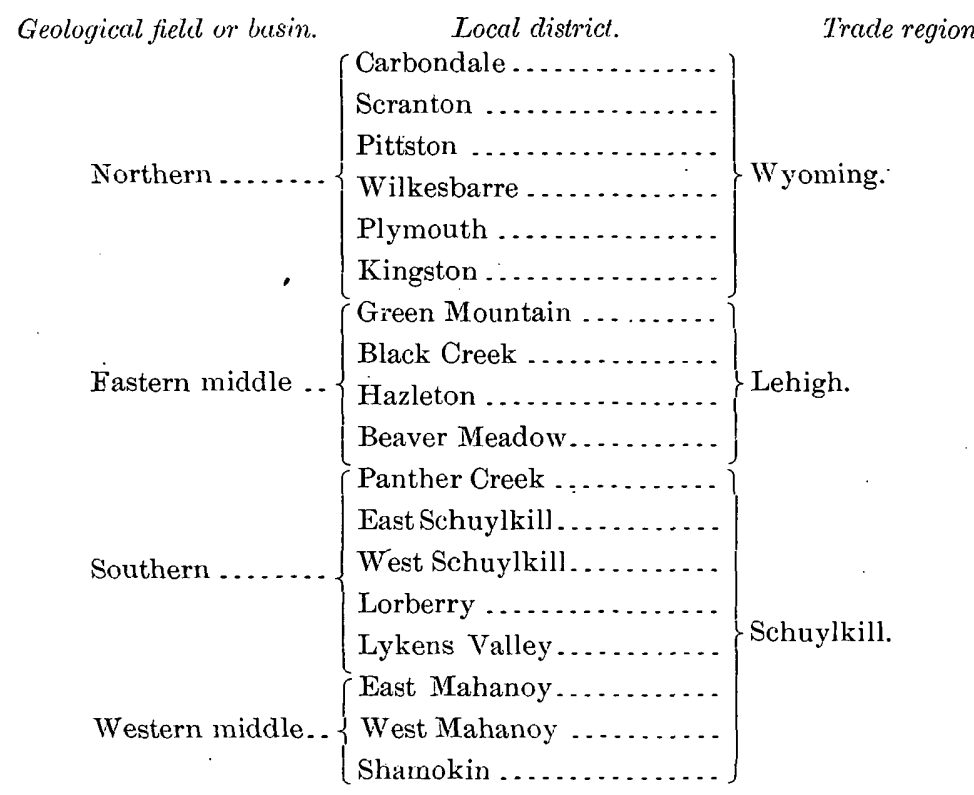

The above-named fields comprise an area of something over 480 square miles, and are located in the eastern middle part of the State, in the counties of Carbon, Columbia, Dauphin, Lackawanna, Luzerne, Northumberland, Schuylkill, and Susquehanna, and are classed under three general divisions, viz, Wyoming, Lehigh, and Schuylkill regions. Geologically they are divided into fields or basins, which are again subdivided into districts.

The Bernice field, in Sullivan County, is not included in any of these regions. The classification of the product of this field is a matter of some contention. The fracture of the coal and some of its physical characteristics are more like some bituminous or semianthracite coals than strict anthracite, but on account of its high percentage of fixed 
carbon and low percentage of moisture it is classed as anthracite by the Second Pennsylvania Geological Survey, and the product is so included in this report.

The above territory is reached by eleven so-called initial railroads, as follows :

Philadelphia and Reading Railway Company.

Lehigh Valley Railroad Company.

Central Railroad Company of New Jersey.

Delaware, Lackawanna and Western Railroad Company.

Delaware and Hudson Company's Railroad.

Pennsylvania Railroad Company.

Erie and Wyoming Valley Railroad Company.

Erie Railroad Company.

New York, Ontario and Western Railway Company.

Delaware, Susquehanna and Schuylkill Railroad Company.

New York, Susquehanna and Western Railroad Company.

\section{PENNSYLVANIA BITUMINOUS COAI.}

Total product in $1899,74,150,175$ short tons; spot value, $\$ 56,247.791$.

The production of bituminous coal in Pennsylvania in 1899 shows a gain over the output in 1898 of $8,985,042$ short tons, or 13.8 per cent. This increase in tonnage was not as large as that of 1898 over 1897 or of 1.895 over 1894, in both of which years the gain was over $10,000,000$ tons, but in each of those years the increased product was accompanied by a decline in price, while in 1899 the value per ton was advanced from 67 cents to 76 cents and the increase in the total value of the bituminous product in 1899 was more than the combined increase in value for the other two years mentioned. The increase in value of the Pennsylvania bituminous product in 1899 was larger than the value of the entire output of any other State with the exception of Illinois and Ohio. The average price per ton ( 76 cents) was the highest obtained since 1893.

Of the total bituminous product in 1899 , over $22,000,000$ tons, or about 30 per cent, was mined by machines. Machine mining has shown rapid development in the bituminous fields of Pennsylvania. In 1891 only 72 machines were reported in use in the State. The number had increased to 454 in 1896 , to 690 in 1897 , to 1,085 in 1898 , and to 1,343 in 1899 . The machine-won tonnage for the same years was: $1891,431,440 ; 1896,6,092,644 ; 1894,8,945,293 ; 1898,16,512,480$, and 1899, 22,000,722. Machines driven by compressed air appear to be the favorite type in Pennsylvania mines. Of the 1,343 machines in use in 1899, 944 were air pick or punching machines, 50 were airdriven chains, and 349 were electric chain machines. No long-wall machines were used. 
PRODUCTION BI' COUNTIES.

It was observed in the report for 1898 that the effect of the increased activity in the iron and steel trade was reflected in the bituminous coal production of Pennsylvania, and particularly upon that of the four leading counties-Fayette, Westmoreland, Allegheny, and Cambria. What was said for 1898 holds good for 1899. The first two counties embrace what is known as the Connellsville coking region, and the greater portion of the product is made into coke for blast furnace and foundry use. Allegheny County, in which Pittsburg is situated, is the center of the great iron-making district of Pennsylvania, and Cambria County contains Johnstown and its iron and steel industries. These four counties produce from 60 to 63 per cent of the State's total output of bituminous coal (62 per cent in 1899), and 69 per cent of the total . increase in the bituminous product for 1899 was contributed by them. The combined product of the four counties in 1899 was practically $46,000,000$ short tons, nearly double the entire output of Illinois. The largest increase in 1899 was in Westmoreland County, which added 2,766,280 tons, or 24 per cent, to its output for 1898 . Fayette County gained 1,913,226 tons, or 15 per cent. The third in increased production and first in percentage of gain among the important producers was Somerset County with an increment of $1,103,945$ short tons, or 60 per cent. The product of Somerset County has trebled in two years. Allegheny County gained 1,082,063 tons, or 12 per cent, and Cambria County gained 468,373 tons, or 7 per cent. There were only three counties which did not share in the general improvement. These were Lawrence, McKean, and Tioga. In the two first named the decreases were insignificant, Tioga bearing $98 \frac{1}{2}$ per cent of the total decrease. 
The statistics of production by counties in 1898 and 1899, with the distribution of the product for consumption, are presented in the following tables:

Bituminous coal procluct of Pennsylvania in 1898, by counties.

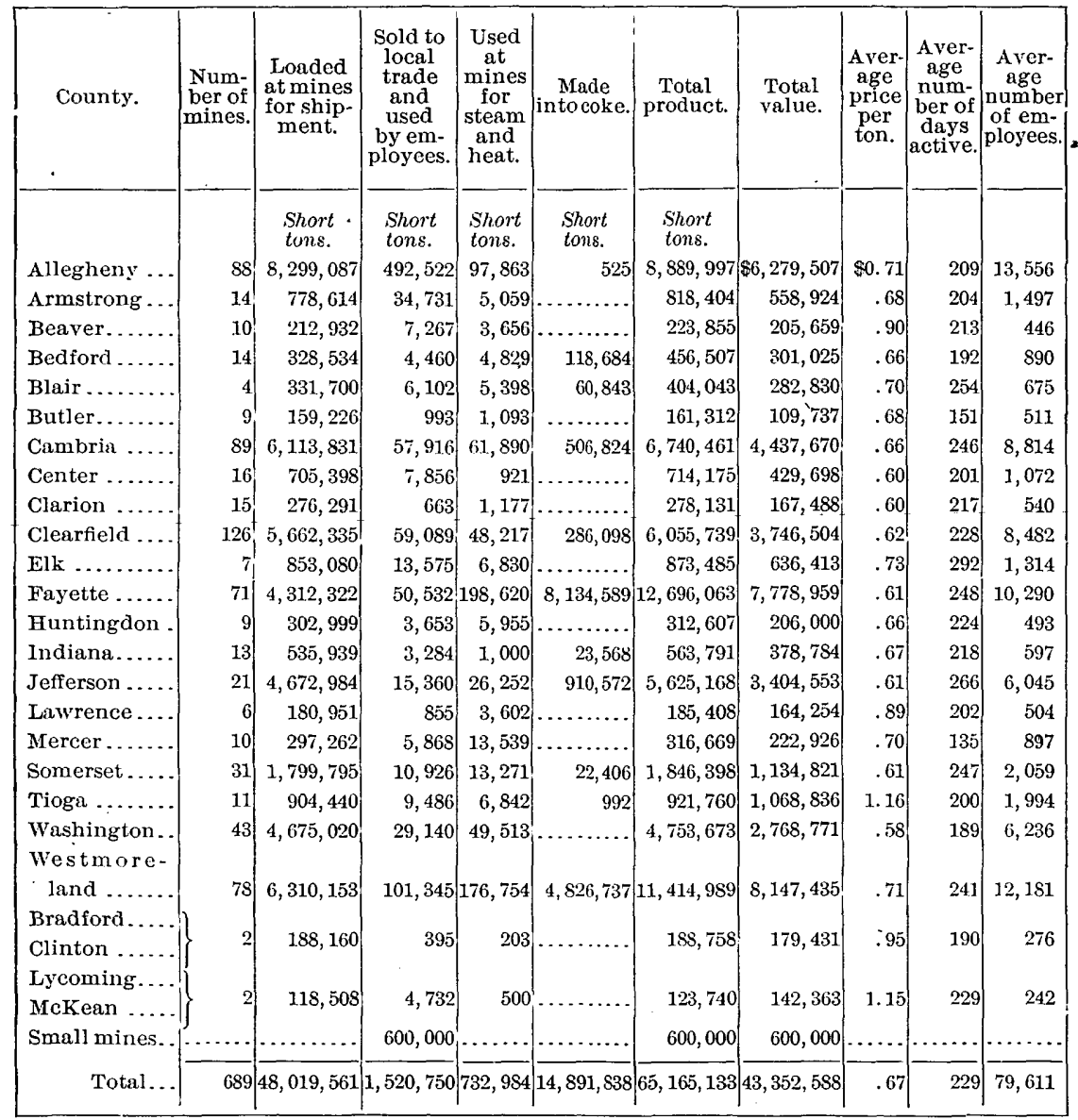


COAL.

Bituminous coal product of Pennsylvania in 1899, by counties.

\begin{tabular}{|c|c|c|c|c|c|c|c|c|c|c|}
\hline County. & $\begin{array}{l}\text { Num- } \\
\text { ber of } \\
\text { mines. }\end{array}$ & $\begin{array}{c}\text { Loaded } \\
\text { at mines } \\
\text { for ship- } \\
\text { ment. }\end{array}$ & $\begin{array}{c}\text { Sold to } \\
\text { local } \\
\text { trade } \\
\text { and } \\
\text { used } \\
\text { by em- } \\
\text { pioyees. }\end{array}$ & \begin{tabular}{|} 
Used \\
at \\
mines \\
for \\
steam \\
and \\
heat.
\end{tabular} & $\begin{array}{l}\text { Made } \\
\text { into } \\
\text { coke. }\end{array}$ & $\begin{array}{c}\text { Total } \\
\text { product. }\end{array}$ & $\begin{array}{l}\text { Total } \\
\text { value. }\end{array}$ & $\begin{array}{c}\text { Aver- } \\
\text { age } \\
\text { price } \\
\text { per } \\
\text { ton. }\end{array}$ & $\begin{array}{c}\text { Aver- } \\
\text { age } \\
\text { num- } \\
\text { ber of } \\
\text { days } \\
\text { active. }\end{array}$ & $\begin{array}{c}\text { Aver- } \\
\text { age } \\
\text { num } \\
\text { ber of } \\
\text { em- } \\
\text { ploy- } \\
\text { ees. }\end{array}$ \\
\hline & & $\begin{array}{l}\text { Short } \\
\text { tons. }\end{array}$ & $\begin{array}{l}\text { Short } \\
\text { tons. }\end{array}$ & $\begin{array}{l}\text { Short } \\
\text { tons. }\end{array}$ & $\begin{array}{l}\text { Short } \\
\text { tons. }\end{array}$ & $\begin{array}{l}\text { Short } \\
\text { tons. }\end{array}$ & & & & \\
\hline Allegheny .. & 92 & $9,605,292$ & 299,894 & 64,469 & 2,405 & $9,972,060$ & $\$ 7,390,534$ & $\$ 0.74$ & 224 & 12,751 \\
\hline Armstrong . . & 14 & $1,038,808$ & $9,32 \pi$ & 6,254 & $\ldots .$. & $1,054,389$ & 767,634 & .73 & 268 & 1,364 \\
\hline Beaver & 9 & 248,722 & 8,557 & 1,187 & $\ldots \ldots \ldots$ & 258,466 & 255,486 & .99 & 271 & 438 \\
\hline Bedford. & 12 & 405,926 & 3,549 & 4,066 & 80,424 & 493,965 & 371,113 & .75 & 238 & 777 \\
\hline Blair. & 4 & 327,881 & 2,379 & 4,309 & 72,787 & 407,356 & 325,883 & .80 & 237 & 639 \\
\hline Butler & 12 & 204,896 & 9,100 & 903 & ....... & 214,899 & 154,890 & .72 & 205 & 356 \\
\hline Cambria & 66 & $6,613,653$ & 120,877 & 63,796 & 410,508 & $7,208,834$ & $5,571,157$ & .77 & 261 & 9,188 \\
\hline Center... & 15 & 908,113 & 2,981 & 1,554 & & 912,648 & 675,031 & .74 & 218 & 1,170 \\
\hline Clarion & 14 & 285,610 & 1,663 & 2,480 & ….... & 289,753 & 196,758 & .68 & 239 & 536 \\
\hline Clearfield... & 114 & $5,808,125$ & 27,297 & 81,589 & 334,431 & $6,251,442$ & $4,319,916$ & .69 & 239 & 7,961 \\
\hline Elk & 10 & $1,198,411$ & 12,454 & 11,114 & $\cdots$ & $1,221,979$ & 697,356 & .57 & 261 & 1,837 \\
\hline Fayette..... & 75 & $4,886,253$ & 134,100 & 211,137 & $9,377,799$ & $14,609,289$ & $10,709,428$ & .73 & 279 & 11,517 \\
\hline Huntingdon & 9 & 338,985 & 3,336 & 7,117 & 8,374 & 357,812 & 280,365 & .78 & 256 & 528 \\
\hline Indiana..... & 19 & 557,870 & 5,383 & 1,908 & 51,750 & 616,911 & 436,687 & .71 & 210 & 712 \\
\hline Jefferson & 26 & $4,698,941$ & 15,539 & 125,508 & $1,001,972$ & $5,841,960$ & $3,553,306$ & .61 & 228 & 6,018 \\
\hline Lawrence & 5 & 178,663 & 4,374 & 518 & ........ & 183,555 & 163,364 & .89 & 263 & 332 \\
\hline Mercer . & 11 & 463,387 & 4,897 & 14,440 & 4,000 & 486,724 & 394,644 & .81 & 217 & 787 \\
\hline Somerset & 39 & $2,864,116$ & 20,865 & 31,353 & 34,009 & $2,950,343$ & $2,079,466$ & .70 & 261 & 3,575 \\
\hline Tioga & 12 & 650,562 & 15,293 & 4,271 & & 670,126 & 773,208 & 1.15 & 164 & 2,070 \\
\hline Washington. & 40 & $4,909,654$ & 41,146 & 36,560 & $\ldots \ldots$ & $4,987,360$ & $3,668,194$ & .74 & 222 & 5,648 \\
\hline Westmorel'd & 84 & $7,105,563$ & 177,474 & 296,943 & $6,601,289$ & $14,181,269$ & $12,485,659$ & .88 & 258 & 13,939 \\
\hline $\begin{array}{l}\text { Bradford.... } \\
\text { Clinton }\end{array}$ & 3 & 252,509 & 384 & 516 & & 253,409 & 229,663 & .91 & 274 & 362 \\
\hline Lycomin & & & & & & & & & & \\
\hline McKean & 2 & 120,023 & 4,903 & 700 & & 125,626 & 148,049 & 1.18 & 241 & 307 . \\
\hline Small m & & & 600,000 & & & 600,000 & 600,000 & & & \\
\hline $\mathrm{T}$ & 687 & 71,96 & $1,525,772$ & 972,692 & $17,979,748$ & $74,150,175$ & $56,247,791$ & .76 & 245 & 82,812 \\
\hline
\end{tabular}


In the following table are exhibited the total production by counties during the past four years, and the increases and decreases in 1899 as compared with 1898:

Bituminous coal product of Pennsylvania since 1896; by caunties.

[Short tons.]

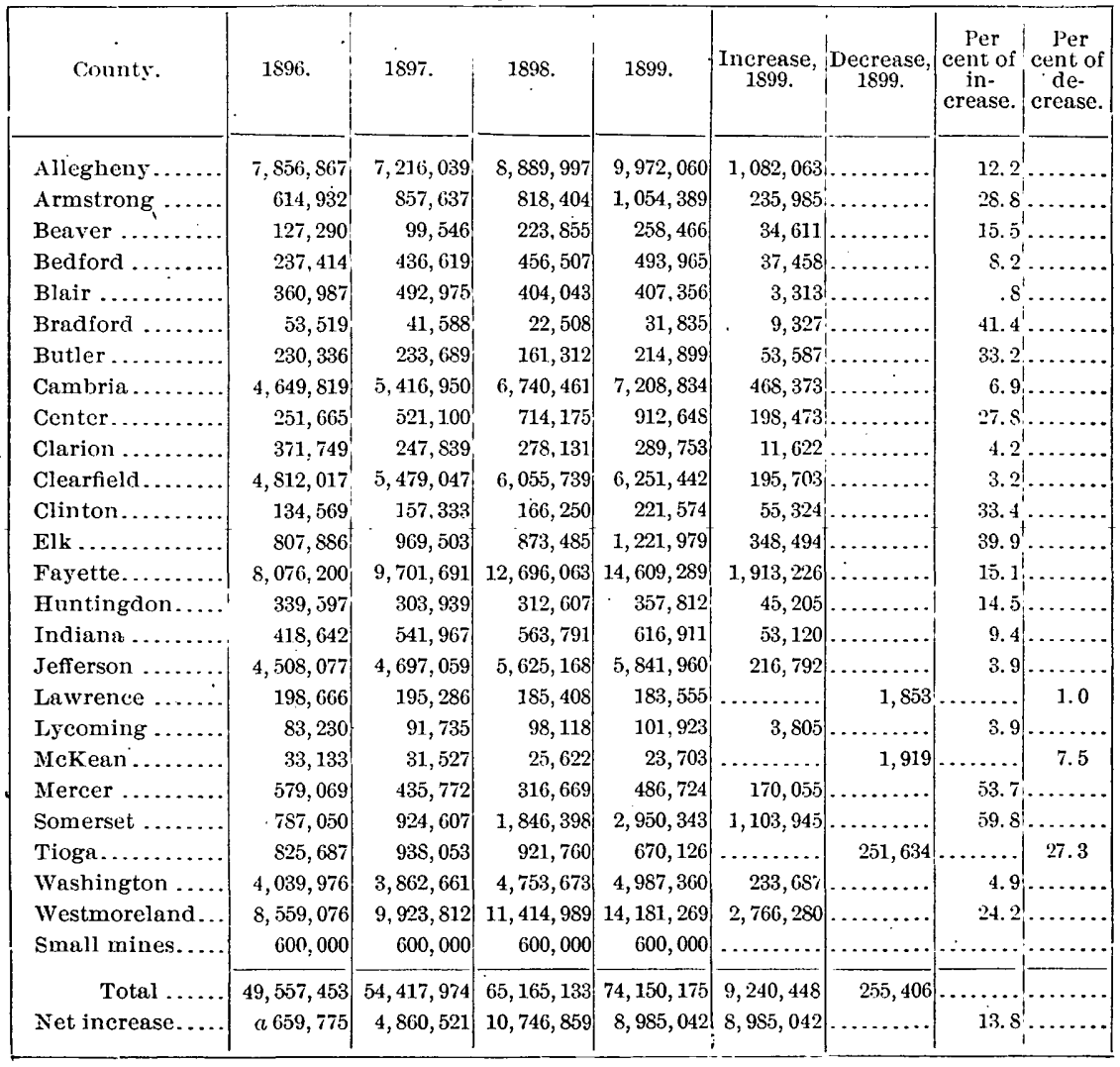

a Net decrease. 
The distribution of the product for the past eleven years has been as follows:

Distribution of the bituminous coal product of Pennsylvania from 1889 to 1899.

\begin{tabular}{|c|c|c|c|c|c|c|c|c|c|c|}
\hline Years. & $\begin{array}{l}\text { Num- } \\
\text { ber of } \\
\text { mines. }\end{array}$ & $\begin{array}{c}\text { Loaded } \\
\text { at mines } \\
\text { for ship- } \\
\text { ment. }\end{array}$ & $\begin{array}{c}\text { Sold to } \\
\text {-local } \\
\text { trade and } \\
\text { used by } \\
\text { em- } \\
\text { ployees. }\end{array}$ & $\begin{array}{l}\text { Used at } \\
\text { mines } \\
\text { for } \\
\text { steam } \\
\text { and } \\
\text { heat. }\end{array}$ & $\begin{array}{l}\text { Made } \\
\text { into } \\
\text { coke. }\end{array}$ & $\begin{array}{c}\text { Total } \\
\text { product. }\end{array}$ & $\begin{array}{l}\text { Total } \\
\text { value. }\end{array}$ & $\begin{array}{c}\text { Aver- } \\
\text { age } \\
\text { price } \\
\text { per } \\
\text { ton. }\end{array}$ & $\begin{array}{c}\text { Aver- } \\
\text { age } \\
\text { num- } \\
\text { ber of } \\
\text { days } \\
\text { active. }\end{array}$ & $\begin{array}{c}\text { Average } \\
\text { number } \\
\text { of em- } \\
\text { ployees. }\end{array}$ \\
\hline & & $\begin{array}{l}\text { Short } \\
\text { tons. }\end{array}$ & $\begin{array}{l}\text { Short } \\
\text { tons. }\end{array}$ & $\begin{array}{l}\text { Short } \\
\text { tons. }\end{array}$ & $\begin{array}{l}\text { Short } \\
\text { tons. }\end{array}$ & $\begin{array}{l}\text { Short } \\
\text { tons. }\end{array}$ & & & & \\
\hline 1889 & & $24,059,913$ & $1,590,651$ & 332,937 & $10,190,588$ & $36,174,089$ & $\$ 27,953,315$ & $\$ 0.77$ & & 53,780 \\
\hline 1890. & & $29,288,923$ & $1,473,317$ & 395,837 & $11,144,096$ & $42,302,173$ & $35,376,916$ & .84 & 232 & 61,333 \\
\hline 1891. & & $29,976,914$ & $2,007,348$ & 321,225 & $10,483,003$ & $42,788,490$ & $37,271,053$ & .87 & 223 & 63,661 \\
\hline 1892. & & $32,425,949$ & $2,207,827$ & 356,779 & $11,704,021$ & $46,694,576$ & $39,017,164$ & .84 & 223 & 66,655 \\
\hline 1893. & & $33,322,328$ & $1,934,429$ & 426,122 & $8,387,845$ & $44,070,724$ & $35,260,674$ & .80 & 190 & 71,931 \\
\hline 1894 & 613 & $29,722,803$ & $1,589,595$ & 342,294 & $8,257,771$ & $39,912,463$ & $29,479,820$ & .74 & 165 & 75,010 \\
\hline 1895. & 588 & $35,164,453$ & $1,732,803$ & 468,381 & $12,851,591$ & $50,217,228$ & $35,980,357$ & .72 & 206 & 71,130 \\
\hline $1896 \ldots$ & 569 & $37,696,555$ & $1,570,161$ & 504,224 & $9,786,513$ & $49,557,453$ & $35,368,249$ & .71 & 206 & 72,625 \\
\hline $1897 \ldots$ & 575 & $40,419,846$ & $1,653,049$ & 556,604 & $11,968,392$ & $54,597,891$ & $37,636,347$ & .69 & 205 & 77,599 \\
\hline $1898 \ldots$ & 689 & $48,019,561$ & $1,520,750$ & 732,984 & $14,891,838$ & $65,165,133$ & $43,352,588$ & .67 & 229 & 79,611 \\
\hline $1899 \ldots$ & 687 & $53,671,963$ & $1,525,772$ & 972,692 & $17,979,748$ & $74,150,175$ & $56,247,791$ & .76 & 245 & 82,812 \\
\hline
\end{tabular}

The following table exhibits the total production since 1873:

Product of bituminous coal in Pennsylvania since 1873.

\begin{tabular}{|c|c|c|c|}
\hline Year. & Short tons. & Year. & Short tons. \\
\hline $1873 \ldots \ldots \ldots \ldots$ & $13,098,829$ & $1887 \ldots \ldots \ldots \ldots \ldots$ & $31,516,856$ \\
\hline $1874 \ldots \ldots \ldots \ldots$ & $12,320,000$ & $1888 \ldots$ & $33,796,727$ \\
\hline $1875 \ldots \ldots$ & $11,760,000$ & $1889 \ldots \ldots$ & $36,174,089$ \\
\hline $1876 \ldots \ldots \ldots$ & $12,880,000$ & $1890 \ldots \ldots \ldots \ldots \ldots$ & $42,302,173$ \\
\hline $1877_{-}$ & $14,000,000$ & $1891 \ldots \ldots \ldots$ & $42,788,490$ \\
\hline $1878 \ldots \ldots \ldots \ldots$ & $15,120,000$ & $1892 \ldots \ldots \ldots$ & $46,694,576$ \\
\hline 1879. & $16,240,000$ & $1893 \ldots \ldots \ldots \ldots$ & $44,070,724$ \\
\hline 1880 & $21,280,000$ & $1894 \ldots \ldots \ldots \ldots \ldots$ & $39,912,463$ \\
\hline $1881 \ldots$ & $22,400,000$ & $1895 \ldots . . . \ldots \ldots$ & $50,217,228$ \\
\hline $1882 \ldots$ & $24,640,000$ & $1896 \ldots \ldots \ldots \ldots$ & $49,557,453$ \\
\hline $1883 \ldots$ & $26,880,000$ & $1897 \ldots$ & $54,417,974$ \\
\hline $1884 \ldots \ldots$ & $28,000,000$ & $1898 \ldots \ldots \ldots \ldots \ldots$ & $65,165,133$ \\
\hline $1885 \ldots \ldots \ldots$ & $26,000,000$ & $1899 \ldots \ldots \ldots$ & $74,150,175$ \\
\hline $1886 \ldots$ & $27,094,501$ & : & \\
\hline
\end{tabular}

21 GEOL, PT $6-32$ 


\section{TENNESSEE.}

Total product in $1899,3,330,659$ short tons; spot value, $\$ 2,940,644$.

Tennessee's coal production has exhibited an uninterrupted increase since 1893, the output in 1899 being 307,763 short tons, or a little more than 10 per cent larger than that of 1898 , which in turn was 134,047 short tons, or not quite 5 per cent greater than the 1897 product. The value of the product in 1899 was $\$ 603,132$, or nearly 26 per cent larger than that of the 1898 output which, notwithstanding its gain in tonnage over 1897 , was worth but $\$ 7,000$ more than the product of the former year. Sympathizing with the general business revival in 1899 the average price per ton for Tennessee coal advanced from 77 to 88 cents, the highest figure recorded since 1895. From $\$ 1.13$ in 1892 the price declined each year until in 1898 it was as low as 77 cents, a total decline in six years of 36 cents, or nearly one-third.

Machine mining showed a substantial increase in 1899 , so far as tonnage is concerned. The product won by machines last year amounted to 201,333 short tons against 152,002 tons in 1898 and 47,207 tons in 1897.

The statistics of production in the past two years are exhibited in the following tables:

Coal product of Tennessee in 1898 , by counties.

\begin{tabular}{|c|c|c|c|c|c|c|c|c|c|c|}
\hline County. & $\begin{array}{l}\text { Num- } \\
\text { ber of } \\
\text { mines. }\end{array}$ & $\begin{array}{l}\text { Loaded } \\
\text { at mines } \\
\text { for ship- } \\
\text { ment. }\end{array}$ & $\begin{array}{l}\text { Sold to } \\
\text { local } \\
\text { trade } \\
\text { and } \\
\text { used } \\
\text { by em- } \\
\text { ployees. }\end{array}$ & $\begin{array}{l}\text { Used at } \\
\text { mines } \\
\text { for } \\
\text { steam } \\
\text { and } \\
\text { heat. }\end{array}$ & $\begin{array}{c}\text { Made } \\
\text { into } \\
\text { coke. }\end{array}$ & $\begin{array}{c}\text { Total } \\
\text { product. }\end{array}$ & $\begin{array}{l}\text { Total } \\
\text { value. }\end{array}$ & $\begin{array}{c}\text { Aver- } \\
\text { age } \\
\text { price } \\
\text { per } \\
\text { ton. }\end{array}$ & $\begin{array}{l}\text { Aver- } \\
\text { age } \\
\text { num- } \\
\text { ber of } \\
\text { days } \\
\text { active. }\end{array}$ & $\begin{array}{l}\text { Aver- } \\
\text { age } \\
\text { num- } \\
\text { ber of } \\
\text { em- } \\
\text { ployees. }\end{array}$ \\
\hline & & $\begin{array}{l}\text { Short } \\
\text { tons. }\end{array}$ & $\begin{array}{l}\text { Short } \\
\text { tons. }\end{array}$ & $\begin{array}{l}\text { Short } \\
\text { tons. }\end{array}$ & $\begin{array}{l}\text { Short } \\
\text { tons. }\end{array}$ & $\begin{array}{l}\text { Short } \\
\text { tons. }\end{array}$ & . & & & . \\
\hline Anderson ... & 8 & 571,740 & 1,206 & 5,120 & 800 & 578,866 & $\$ 446,636$ & $\$ 0.77$ & 253 & 1,141 \\
\hline Campbell .. & 13 & 313,306 & 3,793 & 3,653 & 5,000 & 325,757 & 292,804 & .90 & 166 & 1,292 \\
\hline Claiborne.. & 4 & 254,674 & 3,000 & 1,700 & 39,200 & 298,574 & 224,815 & .75 & 228 & 411 \\
\hline Hamilton .. & 2 & 122,482 & 1,700 & 1,410 & 74,236 & 199,828 & 165,171 & .83 & 263 & 530 \\
\hline Marion & 6 & 206,887 & 2,885 & 1,201 & 98,692 & 309,665 & 266,020 & .86 & 268 & 616 \\
\hline Morgan ..... & 7 & 249,824 & 500 & 1,700 & 87,268 & 339,292 & 164,230 & .48 & 258 & 745 \\
\hline Rhea...... & 3 & 16,341 & 3,405 & 17,158 & 147,335 & 184,239 & 128,969 & .70 & 250 & 292 \\
\hline $\begin{array}{l}\text { Scott ............ } \\
\text { Cumberland }\end{array}$ & 3 & 106,711 & 11,128 & 3,500 & 23,877 & 145,216 & 122,268 & .84 & 194 & 314 \\
\hline $\begin{array}{l}\text { Grundy ..... } \\
\text { Putnam.... }\end{array}$ & 3 & 158,398 & 773 & 4,364 & 99,821 & 263,356 & 136,680 & .71 & 230 & 634 \\
\hline $\begin{array}{l}\text { Roane } . . . \\
\text { White..... }\end{array}$ & 2 & 198,712 & 5,081 & 12,712 & 157,098 & 373,603 & 335,419 & .90 & 273 & 668 \\
\hline Small mines & & & 4,500 & & & 4,500 & 4,500 & 1.00 & & \\
\hline Total. & 51 & $2,199,075$ & 37,971 & 52,523 & 733,327 & $3,022,896$ & $2,337,512$ & .77 & 234 & 6,643 \\
\hline
\end{tabular}


Coal product of Tennessee in 1899, by counties.

\begin{tabular}{|c|c|c|c|c|c|c|c|c|c|c|}
\hline County. & $\begin{array}{l}\text { Num- } \\
\text { ber of } \\
\text { mines. }\end{array}$ & $\begin{array}{c}\text { Loaded } \\
\text { at mines } \\
\text { for ship- } \\
\text { ment. } \\
\end{array}$ & $\begin{array}{c}\text { Sold to } \\
\text { local } \\
\text { trade } \\
\text { and } \\
\text { used } \\
\text { by em. } \\
\text { ployees. }\end{array}$ & $\begin{array}{l}\text { Used at } \\
\text { mines } \\
\text { for } \\
\text { steam } \\
\text { and } \\
\text { heat. }\end{array}$ & $\begin{array}{l}\text { Made } \\
\text { into } \\
\text { coke. }\end{array}$ & $\begin{array}{c}\text { Total } \\
\text { product. }\end{array}$ & $\begin{array}{l}\text { Total } \\
\text { value. }\end{array}$ & $\begin{array}{l}\text { A ver- } \\
\text { age } \\
\text { price } \\
\text { per } \\
\text { ton. }\end{array}$ & \begin{tabular}{|} 
Aver- \\
age \\
num- \\
ber of \\
days \\
active.
\end{tabular} & $\begin{array}{l}\text { Aver- } \\
\text { age } \\
\text { num- } \\
\text { ber of } \\
\text { em- } \\
\text { ployees }\end{array}$ \\
\hline & - & $\begin{array}{l}\text { Short } \\
\text { tons. }\end{array}$ & $\begin{array}{l}\text { Short } \\
\text { tons. }\end{array}$ & $\begin{array}{l}\text { Short } \\
\text { tons. }\end{array}$ & $\begin{array}{l}\text { Short } \\
\text { tons. }\end{array}$ & $\begin{array}{l}\text { Short } \\
\text { tons. }\end{array}$ & & & & \\
\hline Anderson. & 8 & 599,515 & 32,037 & 5,662 & ....... & $.637,214$ & $\$ 569,770$ & $\$ 0.89$ & 266 & 1,417 \\
\hline Campbell & 12 & 418,919 & 6,111 & 4,687 & ......... & 429,717 & 438,748 & 1.02 & 210 & 1,235 \\
\hline Claiborne & 5 & 331,047 & 9,862 & 3,100 & 43,490 & 387,499 & 319,399 & .82 & 223 & 615 \\
\hline Cumberland .. & 2 & 1,000 & 80 & 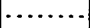 & ......... & 1,080 & 1,200 & 1.11 & 11 & 61 \\
\hline Hamilton ...... & 2 & 129,172 & 1,676 & 1,360 & 67,022 & 199,230 & 196,135 & .98 & 230 & 320 \\
\hline Marion..... & 6 & 228,682 & 5,562 & 1,467 & 103,655 & 339,366 & 297,525 & .88 & 264 & 672 \\
\hline Morgan . & 7 & 254,364 & 574 & …… & 95,398 & 350,336 & 250,501 & .72 & 271 & 672 \\
\hline Rher...... & 3 & 15,692 & 2,495 & 17,318 & 145,923 & 181,428 & 142,127 & .78 & 257 & 348 \\
\hline scott.......... & 3 & 113,389 & 16,886 & 6,718 & 20,263 & $157,2 \overline{\mathrm{n}} 6$ & 151,076 & .96 & 191 & 370 \\
\hline $\begin{array}{r}\text { Grundy, Put- } \\
\text { nam, Roane, } \\
\text { White........ }\end{array}$ & 4 & 352,875 & 6,568 & 15,363 & 268,227 & 643,033 & 569,663 & .89 & 309 & 1,239 \\
\hline Small mines .. & & $\cdots$ & 4,500 & $\cdots$ & ........ & 4,500 & 4,500 & & & …….. \\
\hline Total.... & 52 & $2,444,655$ & 86,351 & 55,675 & 743,978 & $3,330,659$ & $2,940,644$ & .88 & 252 & 6,949 \\
\hline
\end{tabular}

The distribution of the product for consumption in the past eleven years was as follows:

Distribution of the coal product of Tennessee from 1889 to 1899.

\begin{tabular}{|c|c|c|c|c|c|c|c|c|c|c|}
\hline Year. & $\begin{array}{l}\text { Num- } \\
\text { ber of } \\
\text { mines. }\end{array}$ & $\begin{array}{l}\text { Loaded at } \\
\text { mines for } \\
\text { shipment. }\end{array}$ & $\begin{array}{c}\text { Sold to lo- } \\
\text { cal trude } \\
\text { and used } \\
\text { by em- } \\
\text { ployees. }\end{array}$ & $\begin{array}{c}\text { Used at } \\
\text { mines } \\
\text { for } \\
\text { steam } \\
\text { and } \\
\text { heat. }\end{array}$ & $\begin{array}{c}\text { Made } \\
\text { into coke. }\end{array}$ & $\begin{array}{c}\text { Total } \\
\text { product. }\end{array}$ & $\begin{array}{l}\text { Total } \\
\text { value. }\end{array}$ & $\begin{array}{c}\text { Aver- } \\
\text { age } \\
\text { price } \\
\text { per } \\
\text { ton. }\end{array}$ & $\begin{array}{l}\text { Aver- } \\
\text { age } \\
\text { num- } \\
\text { ber of } \\
\text { days } \\
\text { active. }\end{array}$ & $\begin{array}{l}\text { Aver- } \\
\text { age } \\
\text { num- } \\
\text { ber of } \\
\text { em- } \\
\text { ployees. }\end{array}$ \\
\hline & & $\begin{array}{l}\text { Short } \\
\text { tons. }\end{array}$ & $\begin{array}{l}\text { Short } \\
\text { tons. }\end{array}$ & $\begin{array}{l}\text { Short } \\
\text { tons. }\end{array}$ & $\begin{array}{l}\text { Short } \\
\text { tons. }\end{array}$ & $\begin{array}{l}\text { Short } \\
\text { tons. }\end{array}$ & & & ' & \\
\hline 1889. & . & $1,334,424$ & 29,101 & 23,034 & 539,130 & $1,925,689$ & $\$ 2,238,309$ & $\$ 1.21$ & $\cdots$ & 4,108 \\
\hline 1890 & 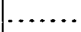 & $1,482,357$ & 41,932 & 23,583 & 621,713 & $2,169,585$ & $2,395,746$ & 1.10 & 263 & 5,082 \\
\hline 1891 & & $1,626,964$ & 100,478 & 33,302 & 652,934 & $2,413,678$ & $2,668,188$ & 1.105 & 230 & 5,097 \\
\hline 1892 . & $\cdots$ & $1,448,262$ & 55,452 & 17,037 & 571,313 & $2,092,064$ & $2,355,441$ & 1.13 & 240 & 4,926 \\
\hline 1893 & $\cdots$ & $1,427,219$ & 42,560 & 20,921 & 411,558 & $1,902,258$ & $2,048,449$ & 1.08 & 232 & 4,976 \\
\hline 1894 & 43 & $1,571,406$ & 59,985 & 28,993 & 520,495 & $2,180,879$ & $2,119,481$ & .97 & 210 & 5,542 \\
\hline $1895 \ldots$ & 44 & $1,808,056$ & 51,923 & 25,477 & 650,188 & $2,535,644$ & $2,349,032$ & .93 & 224 & 5,120 \\
\hline $1896 \ldots$ & 45 & $1,990,538$ & 43,752 & 40,343 & 588,473 & $2,663,106$ & $2,281,295$ & .86 & 211 & 6,531 \\
\hline $1897 \ldots$ & 45 & $2,150,179$ & 37,620 & 39,275 & 661,775 & $2,888,849$ & $2,329,534$ & .81 & 221 & 6,337 \\
\hline $1898 \ldots$ & 51 & $2,199,075$ & 37,971 & 52,523 & 733,327 & $3,022,896$ & $2,337,512$ & .77 & 234 & 6,643 \\
\hline $1899 \ldots$ & 52 & $2,444,655$ & 86,351 & 55,675 & 743,978 & $3,330,659$ & $2,940,644$ & .88 & 252 & 6,949 \\
\hline
\end{tabular}


Below is given the output by counties during the past four years with the increases and decreases in 1899 as compared with 1898:

Coal product of Tennessee since 1896, by counties.

[Short tons.]

\begin{tabular}{|c|c|c|c|c|c|c|}
\hline County. & 1896. & 1897. & 1898. & 1899. & $\begin{array}{c}\text { Increase, } \\
1899 .\end{array}$ & $\begin{array}{c}\text { Decrease, } \\
1899 .\end{array}$ \\
\hline Anderson .. & 456,510 & 557,696 & 578,866 & 637,214 & 58,348 & \\
\hline Campbell. & 384,337 & 328,494 & 325,757 & 429,717 & 103,960 & \\
\hline Claiborne & 203,926 & 270,927 & 298,574 & 387,499 & 88,925 & \\
\hline Cumberland & 120 & 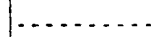 & $\ldots \ldots \ldots$ & 1,080 & 1,080 & \\
\hline Grundy & 330,648 & 317,924 & 251,806 & 305,736 & 53,930 & \\
\hline Hamilton. . & 163,810 & 211,959 & 199,828 & 199,230 & . & 598 \\
\hline Marion .... & 294,895 & 312,241 & 309,665 & 339,366 & 29,701 & \\
\hline Morgan & 217,948 & 301,694 & 339,292 & 350,336 & 11,044 & $\cdots$ \\
\hline Putnam & 10,900 & 10,816 & 11,450 & 8,586 & & 2,864 \\
\hline Rhea... & 91,615 & 139,072 & 184,239 & 181,428 & & 2,811 \\
\hline Roane... & 169,255 & 173,383 & 170,556 & 162,441 & & 8,115 \\
\hline Scott .... & 188,476 & 88,312 & 145,216 & 157,256 & 12,040 & \\
\hline White........ & 146,166 & 171,831 & 203,047 & 166,270 & & 36,777 \\
\hline $\begin{array}{l}\text { Other coun- } \\
\text { ties and } \\
\text { small mines. }\end{array}$ & 4,500 & 4,500 & 4,600 & 4,500 & & 100 \\
\hline Total. . & $2,663,106$ & $2,888,849$ & $3,022,896$ & $3,330,659$ & 359,028 & 51,265 \\
\hline Net increase . - & 127,462 & 225,743 & 134,047 & 307,763 & 307,763 & \\
\hline
\end{tabular}

The annual output of the State since 1873 has been as follows:

Coal product of Tennessee from. 1873 to 1899.

\begin{tabular}{|c|c|c|c|}
\hline Year. & Short tons. & Year. & Short tons. \\
\hline $1873 \ldots \ldots \ldots$ & 350,000 & $1887 \ldots \ldots \ldots \ldots$ & $1,900,000$ \\
\hline $1874 \ldots \ldots \ldots \ldots$ & 350,000 & $1888 \ldots \ldots \ldots \ldots$ & $1,967,297$ \\
\hline 1875 & 360,000 & $1889 \ldots \ldots \ldots \ldots$ & $1,925,689$ \\
\hline 1876 & 550,000 & $1890 \ldots \ldots$ & $2,169,585$ \\
\hline $1877 \ldots$ & 450,000 & $1891 \ldots \ldots$ & $2,413,678$ \\
\hline 1878 & 375,000 & 1892. & $2,092,064$ \\
\hline 1879 & 450,000 & 1893 & $1,902,258$ \\
\hline $1880 \ldots \ldots \ldots$ & 641,042 & $1894 \ldots \ldots \ldots \ldots \ldots$ & $2,180,879$ \\
\hline $1881 \ldots \ldots \ldots$ & 750,000 & $1895 \ldots \ldots$ & $2,535,644$ \\
\hline 1882 & 850,000 & $1896 \ldots \ldots$ & $2,663,106$ \\
\hline $1883 \ldots \ldots$. & $1,000,000$ & $1897 \ldots \ldots$ & $2,888,849$ \\
\hline $1884 \ldots . .$. & $1,200,000$ & $1898 \ldots$ & $3,022,896$ \\
\hline 1885 & $1,440,957$ & $1899 \ldots$ & $3,330,659$ \\
\hline $1886 \ldots$ & $1,714,290$ & & \\
\hline
\end{tabular}


TEXAS.

Total product in $1899,883,832$ short tons; spot value, $\$ 1,334,895$.

The year 1899 was the eighth successive year in which the coal product of Texas has shown an increase over the preceding one. Compared with 1898 the product increased 197,098 short tons, or 29 per cent, while since 1891 it has increased over five times. The increase in 1898 was altogether in bituminous coal, the lignite product differing from that made in 1898 by only 2 tons. Part of the increased production in 1899 was due to the product reported from Maverick County, no returns having been made from that county from 1893 to 1898 . The statistics of production in 1898 and 1899 have been as follows:

Coal product of Texas in 1898, by counties.

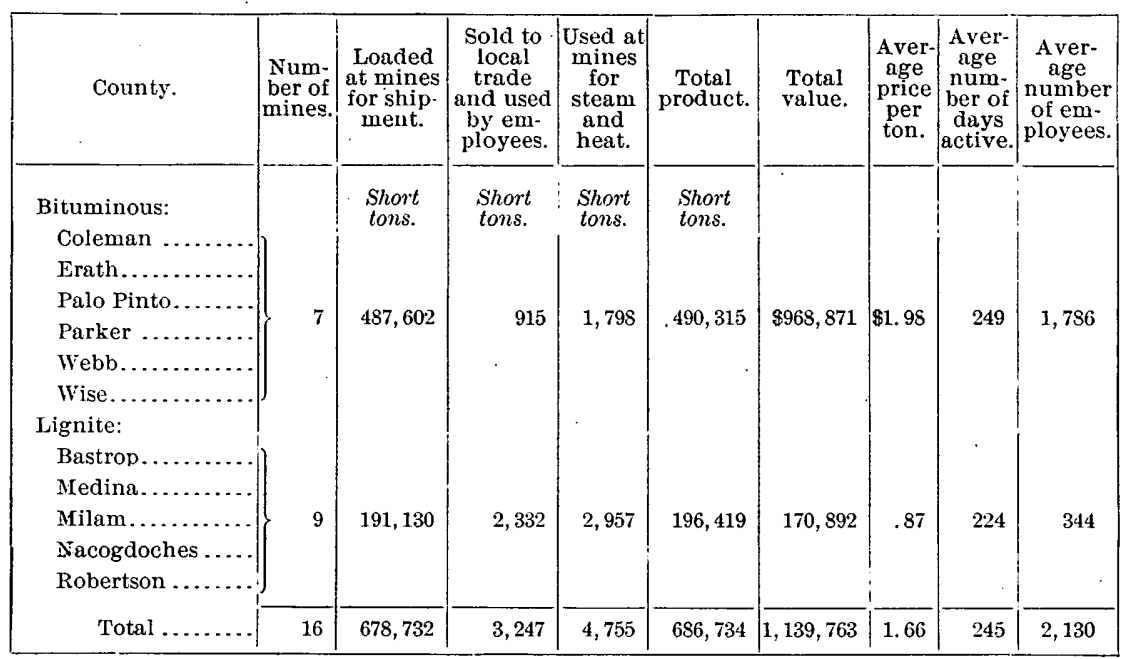

Coal product of Texas in 1899, by counties.

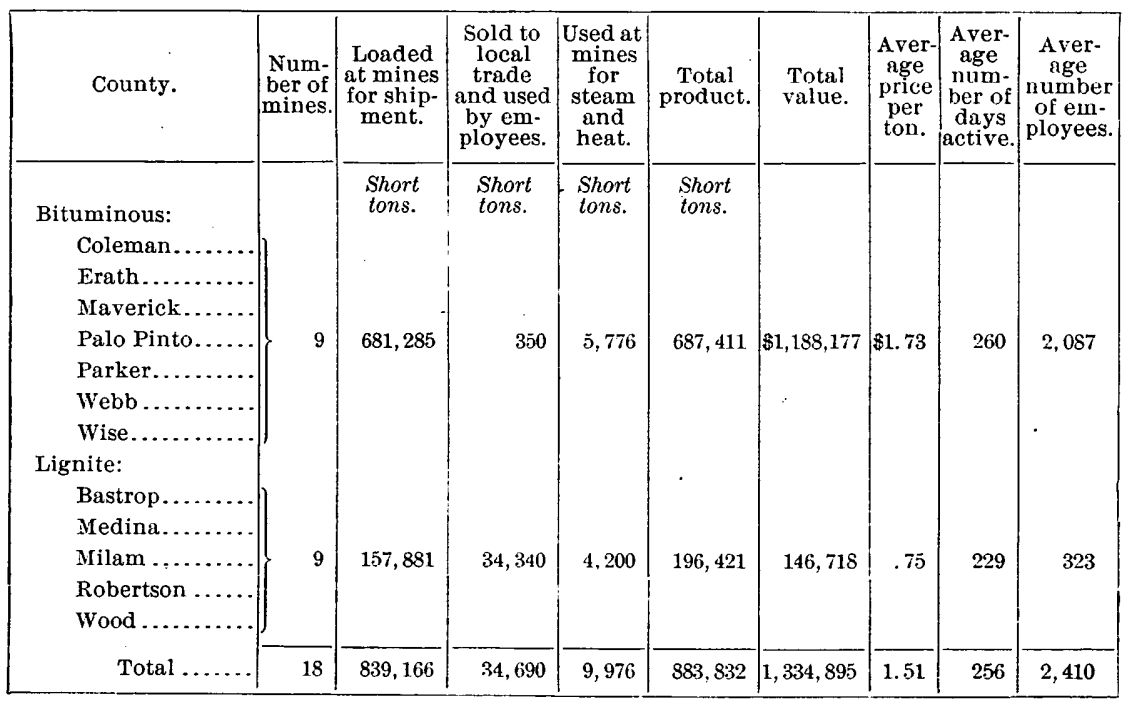


In the following table is shown the record of production since 1889: Coal product of Texas since 1889.

\begin{tabular}{|c|c|c|c|c|c|}
\hline Distribution. & 1889. & 1890. & 1891. & 1892. & 1893. \\
\hline Loaded at mines for shipment... & $\begin{array}{r}\text { Short tons. } \\
120,602\end{array}$ & $\begin{array}{r}\text { Short tons. } \\
180,800\end{array}$ & $\begin{array}{r}\text { Short tons. } \\
169,300\end{array}$ & $\begin{array}{r}\text { Short tons. } \\
241,005\end{array}$ & $\begin{array}{r}\text { Short tons. } \\
300,064\end{array}$ \\
\hline 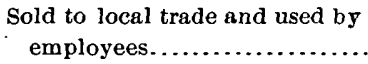 & 6,552 & 1,840 & 900 & 4,460 & 462 \\
\hline $\begin{array}{c}\text { Used at mines for steam and } \\
\text { heat } \ldots \ldots \ldots \ldots \ldots \ldots \ldots \ldots\end{array}$ & 1,062 & 1,800 & 1,900 & 225 & 1,680 \\
\hline Total & 128,216 & 184,440 & $\mathrm{i} 72,100$ & 245,690 & 302,206 \\
\hline Total value.... & $\$ 340,617$ & $\$ 465,900$ & $\$ 412,300$ & 8569,333 & $\$ 688,407$ \\
\hline
\end{tabular}

\begin{tabular}{|c|c|c|c|c|c|c|}
\hline Distribution. & 1894. & 1895. & 1896. & 1897. & 1898. & 1899. \\
\hline & Short tons. & Short tons. & Short tons. & Shorttons. & Short tons. & Short tons. \\
\hline Loaded at mines for shipment.. & 417,281 & 475,157 & 522,177 & 621,635 & 678,732 & 839,166 \\
\hline $\begin{array}{l}\text { Sold to local trade and used by } \\
\text { employees } \ldots \ldots \ldots\end{array}$ & 2,412 & 7,705 & 12,846 & 8,357 & 3,247 & 34,690 \\
\hline $\begin{array}{c}\text { Used at mines for steam and } \\
\text { heat. }\end{array}$ & 1,155 & 2,097 & 8,992 & 9,349 & 4,755 & 9,976 \\
\hline Total. & 420,848 & 484,959 & 544,015 & 639,341 & 686,734 & 883,832 \\
\hline Total value ...... & $\$ 976,458$ & $\$ 913,138$ & $\$ 896,251$ & $\$ 972,323$ & $\$ 1,139,763$ & $\$ 1,334,895$ \\
\hline
\end{tabular}

U.TAH.

Total product in $1899,786,049$ short tons; spot value, $\$ 997,271$.

Utah shared in the widespread business revival in 1899, as evinced by an increase of 32 per cent in her coal output over the product of 1898. The value increased proportionately, Utah being one of the half dozen States in which there was no advance in price, but as the average price per ton in 1898 was 8 cents higher than in 1897 and remained stationary in 1899 , conditions were decidedly favorable.

Carbon County is the only important coal-producing county in the State, nearly 95 per cent of the output both in 1898 and 1899 being from this one county.

Production by counties in the past two years was as follows:

Coal product of Utah in 1898, by counties.

\begin{tabular}{|c|c|c|c|c|c|c|c|c|c|c|}
\hline County. & $\begin{array}{l}\text { Num- } \\
\text { ber of } \\
\text { mines. }\end{array}$ & $\begin{array}{l}\text { Loaded } \\
\text { at mines } \\
\text { for ship- } \\
\text { ment. }\end{array}$ & $\begin{array}{c}\text { Sold to } \\
\text { local } \\
\text { trade } \\
\text { and used } \\
\text { by em- } \\
\text { nloyees. }\end{array}$ & $\begin{array}{l}\text { Used at } \\
\text { mines } \\
\text { for } \\
\text { steam } \\
\text { and } \\
\text { hes.t. }\end{array}$ & $\begin{array}{l}\text { Made } \\
\text { into } \\
\text { coke. }\end{array}$ & $\begin{array}{c}\text { Total } \\
\text { product. }\end{array}$ & $\begin{array}{l}\text { Total } \\
\text { value. }\end{array}$ & $\begin{array}{l}\text { Aver- } \\
\text { age } \\
\text { price } \\
\text { per } \\
\text { ton. }\end{array}$ & $\begin{array}{l}\text { Aver- } \\
\text { age } \\
\text { num- } \\
\text { ber of } \\
\text { days } \\
\text { active. }\end{array}$ & $\begin{array}{c}\text { Averagc } \\
\text { number } \\
\text { of em- } \\
\text { ployees. }\end{array}$ \\
\hline v & & $\begin{array}{l}\text { Short } \\
\text { tons. }\end{array}$ & $\begin{array}{l}\text { Short } \\
\text { tons. }\end{array}$ & $\begin{array}{l}\text { Short } \\
\text { tons. }\end{array}$ & $\begin{array}{l}\text { Short } \\
\text { tons. }\end{array}$ & $\begin{array}{l}\text { Short } \\
\text { tons. }\end{array}$ & & & & \\
\hline Carbon. & 6 & 460,082 & 4,138 & 6,600 & 86,606 & 557,426 & $\$ 697,683$ & $\$ 1.25$ & 262 & 611 \\
\hline Iron....... & 4 & an. & 605 & 10 & & 615 & 1,507 & 2.45 & 38 & 12 \\
\hline Sanpete... & 2 & 2,500 & 2,240 & & & 4,740 & 7,750 & 1.64 & 87 & 28 \\
\hline Summit. & 6 & 20,934 & 4,459 & 3,135 & & 28,528 & 41,712 & 1.46 & 180 & 79 \\
\hline $\begin{array}{l}\text { Emery } \\
\text { Uinta.. }\end{array}$ & 2 & 2,200 & 100 & 100 & & 2,400 & 3,600 & 1.50 & 222 & 9 \\
\hline Total... & 201 & 485,716 & 11,542 & 9,845 & 86,606 & 593,709 & 752,252 & 1.27 & 243 & 739 \\
\hline
\end{tabular}


Coal product of Utah in 1899, by counties.

\begin{tabular}{|c|c|c|c|c|c|c|c|c|c|c|}
\hline County. & $\begin{array}{l}\text { Num- } \\
\text { ber of } \\
\text { mines. }\end{array}$ & $\begin{array}{l}\text { Loaded } \\
\text { at mines } \\
\text { for ship- } \\
\text { ment. }\end{array}$ & $\begin{array}{l}\text { Sold to } \\
\text { local } \\
\text { trade } \\
\text { and } \\
\text { used by } \\
\text { employ- } \\
\text { ees. }\end{array}$ & $\begin{array}{l}\text { Used } \\
\text { at } \\
\text { mines } \\
\text { for } \\
\text { steam } \\
\text { and } \\
\text { heat. }\end{array}$ & $\begin{array}{c}\text { Made } \\
\text { into } \\
\text { coke. }\end{array}$ & $\begin{array}{c}\text { Total } \\
\text { product. }\end{array}$ & $\begin{array}{l}\text { Total } \\
\text { value. }\end{array}$ & $\begin{array}{c}\text { Aver- } \\
\text { age } \\
\text { price } \\
\text { per } \\
\text { ton. }\end{array}$ & $\begin{array}{l}\text { Aver- } \\
\text { age } \\
\text { num- } \\
\text { ber of } \\
\text { days } \\
\text { active. }\end{array}$ & $\begin{array}{l}\text { Average } \\
\text { number } \\
\text { of em- } \\
\text { ployees. }\end{array}$ \\
\hline & & $\begin{array}{l}\text { Short } \\
\text { tons. }\end{array}$ & $\begin{array}{l}\text { Short } \\
\text { tons. }\end{array}$ & $\begin{array}{l}\text { Short } \\
\text { tons. }\end{array}$ & $\begin{array}{l}\text { Short } \\
\text { tons. }\end{array}$ & $\begin{array}{l}\text { Short } \\
\text { tons. }\end{array}$ & & & & \\
\hline Carbon ........ & 7 & 719,544 & 4,972 & 10,000 & 5,819 & 740,335 & $\$ 926,523$ & $\$ 1.25$ & 283 & 610 \\
\hline Iron ........... & 3 & ............ & 629 & . & 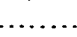 & 629 & 1,442 & 2.29 & 55 & 7 \\
\hline Summit....... & 4 & 31,262 & 1,554 & 3,046 & & 35,862 & 50,748 & 1.41 & 209 & 78 \\
\hline Uinta .......... & 9 & ........... & 5,478 & 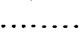 & & 5,478 & 12,214 & 2.23 & 156 & 35 \\
\hline $\begin{array}{l}\text { Emery ... } \\
\text { Sanpete. }\end{array}$ & 2 & 3,075 & 670 & & & 3,745 & 6,744 & 1.69 & 216 & 13 \\
\hline Total.... & 25 & 753,881 & 13,303 & 13,046 & 5,819 & 786,049 & 997,271 & 1. 27 & 265 & 743 \\
\hline
\end{tabular}

The distribution of the product since 1891 and the total output since 1885 are shown in the following tables:

Distribution of the conl product of Utah since 1891 .

\begin{tabular}{|c|c|c|c|c|c|c|c|c|c|}
\hline Year. & $\begin{array}{c}\text { Loaded } \\
\text { at mines } \\
\text { for ship- } \\
\text { ment. }\end{array}$ & $\begin{array}{c}\text { Sold to } \\
\text { local } \\
\text { trade } \\
\text { and used } \\
\text { by em- } \\
\text { ployees. }\end{array}$ & $\begin{array}{c}\text { Used at } \\
\text { mines for } \\
\text { steam } \\
\text { and heat. }\end{array}$ & $\begin{array}{c}\text { Made } \\
\text { into coke. }\end{array}$ & $\begin{array}{c}\text { Total } \\
\text { product. }\end{array}$ & $\begin{array}{l}\text { Total } \\
\text { value. }\end{array}$ & $\begin{array}{l}\text { Aver- } \\
\text { age } \\
\text { price } \\
\text { per } \\
\text { ton. }\end{array}$ & $\begin{array}{c}\text { Aver } \\
\text { age } \\
\text { number } \\
\text { of days } \\
\text { active. }\end{array}$ & $\begin{array}{c}\text { Average } \\
\text { number } \\
\text { of em- } \\
\text { ployees. }\end{array}$ \\
\hline & $\begin{array}{l}\text { Short } \\
\text { tons. }\end{array}$ & $\begin{array}{l}\text { Short } \\
\text { tons. }\end{array}$ & $\begin{array}{l}\text { Short } \\
\text { tons. }\end{array}$ & $\begin{array}{l}\text { Short } \\
\text { tons. }\end{array}$ & $\begin{array}{l}\text { Short } \\
\text { tons. }\end{array}$ & & & & \\
\hline 1891. & 315,711 & 8,233 & 21,650 & 25,451 & 371,045 & $\$ 666,646$ & $\$ 1.80$ & 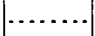 & 621 \\
\hline 1892. & 321,431 & 6,775 & 6,509 & 26,298 & 361,013 & 562,625 & 1.56 & . 230 & 646 \\
\hline 1893. & 350,423 & 7,649 & 4,258 & 50,875 & 413,205 & 611,092 & 1.48 & 226 & 576 \\
\hline $1894 .$. & 364,675 & 11,173 & 6,892 & 48,810 & 431,550 & 603,479 & 1.40 & 199 & 671 \\
\hline 1895. & 376,479 & 25,097 & 7,253 & 63,027 & 471,836 & 617,349 & 1.31 & 203 & 670 \\
\hline 1896. & 340,338 & 9,171 & 7,411 & 61,707 & 418,627 & 500,547 & 1.20 & 202 & 679 \\
\hline $1897 .$. & 424,770 & 22,667 & 9,198 & 64,925 & 521,560 & 618,230 & 1.19 & 204 & 704 \\
\hline $1898 .$. & 485,716 & 11,542 & 9,845 & 86,606 & 593,709 & 752,252 & 1.27 & 243 & 739 \\
\hline 1899. & 753,881 & 13,303 & 13,046 & 5,819 & 786,049 & 997,271 & 1.27 & 265 & 743 \\
\hline
\end{tabular}

Coal product of Utah since 1885.

\begin{tabular}{|c|c|c|c|}
\hline Year. & Short tons. & Year. & Short tons. \\
\hline $1885 \ldots \ldots \ldots \ldots$ & 213,120 & $1893 \ldots \ldots \ldots \ldots$ & 413,205 \\
\hline $1886 \ldots$ & 200,000 & $1894 \ldots \ldots \ldots \ldots \ldots$ & 431,550 \\
\hline $1887 \ldots \ldots \ldots$ & 180,021 & $1895 \ldots \ldots \ldots \ldots$ & 471,836 \\
\hline $1888 \ldots \ldots \ldots \ldots$ & 258,961 & $1896 \ldots \ldots \ldots \ldots$ & 418,627 \\
\hline $1889 \ldots$ & 236,651 & $1897 \ldots \ldots \ldots \ldots \ldots$ & 521,560 \\
\hline $1890 .$. & 318,159 & $1898 \ldots \ldots$ & 593,709 \\
\hline 1891. & 371,045 & $1899 \ldots \ldots \ldots \ldots$ & 786,049 \\
\hline $1892 \ldots$ & 361,013 & & \\
\hline
\end{tabular}




\section{VIRGINIA.}

Total product in $1899,2,105,791$ short tons; spot value, $\$ 1,304,241$.

With an increased product of nearly 300,000 tons over the tonnage of 1898 , Virginia reached a total output of over $2,000,000$ short tons for the first time in her history. Tazewell and Wise counties, which together contribute about 98 per cent of the product, made up the entire increase for 1899, a slight falling off in tonnage being reported in the other counties. The developments in Wise County have been particularly noticeable, the product in this county reaching a total of $1,232,613$ tons in 1899, as against 992,723 tons in 1898 and 712,011 tons in 1897.

Coal product of Virginia in 1898 , by counties.

\begin{tabular}{|c|c|c|c|c|c|c|c|c|c|c|}
\hline County. & $\begin{array}{l}\text { Num- } \\
\text { ber of } \\
\text { mines. }\end{array}$ & $\begin{array}{c}\text { Loaded } \\
\text { at } \\
\text { mines } \\
\text { for } \\
\text { ship- } \\
\text { ment. }\end{array}$ & $\begin{array}{l}\text { Sold to } \\
\text { local } \\
\text { trade } \\
\text { and } \\
\text { used } \\
\text { by em- } \\
\text { ployees. }\end{array}$ & $\begin{array}{l}\text { Used at } \\
\text { mines } \\
\text { for } \\
\text { steam } \\
\text { and } \\
\text { heat. }\end{array}$ & $\begin{array}{l}\text { Made } \\
\text { into } \\
\text { coke. }\end{array}$ & $\begin{array}{c}\text { Total } \\
\text { product. }\end{array}$ & $\begin{array}{l}\text { Total } \\
\text { value. }\end{array}$ & $\begin{array}{l}\text { Aver- } \\
\text { age } \\
\text { price } \\
\text { per } \\
\text { ton. }\end{array}$ & \begin{tabular}{|c|} 
Aver- \\
age \\
num- \\
ber of \\
days \\
active.
\end{tabular} & $\begin{array}{c}\text { Aver- } \\
\text { age } \\
\text { number } \\
\text { of em- } \\
\text { ployees. }\end{array}$ \\
\hline $\begin{array}{l}\text { Chesterfield, } \\
\text { H e n r i o, } \\
\text { M o ntgom- } \\
\text { ery, an d } \\
\text { Pulaski..... }\end{array}$ & 10 & $\begin{array}{l}\text { Short } \\
\text { tons. }\end{array}$ & $\begin{array}{l}\text { Short } \\
\text { tons. }\end{array}$ & $\begin{array}{l}\text { Short } \\
\text { tons. }\end{array}$ & $\begin{array}{l}\text { Short } \\
\text { tons. }\end{array}$ & $\begin{array}{l}\text { Short } \\
\text { tons. }\end{array}$ & $\$ 54,999$ & $\$ 1.36$ & 189 & 119 \\
\hline Tazewell.... & 2 & 528,024 & 7,726 & 8,792 & 237,473 & 782,015 & 453,000 & .58 & 210 & 752 \\
\hline Wise ........ & 8 & 468,215 & 4,448 & 7,242 & 512,818 & 992,723 & 562,418 & .57 & 250 & 984 \\
\hline Total.. & 20 & $1,029,185$ & 19,564 & 16,234 & 750,291 & $1,815,274$ & $1,070,417$ & .59 & 230 & 1,355 \\
\hline
\end{tabular}

Coal product of Virginia in 1899, by counties.

\begin{tabular}{|c|c|c|c|c|c|c|c|c|c|c|}
\hline County. & $\begin{array}{l}\text { Num- } \\
\text { ber of } \\
\text { mines. }\end{array}$ & $\begin{array}{c}\text { Loaded } \\
\text { at mines } \\
\text { for ship- } \\
\text { ment. }\end{array}$ & $\begin{array}{c}\text { Sold to } \\
\text { local } \\
\text { trade } \\
\text { and } \\
\text { used by } \\
\text { em- } \\
\text { ploy- } \\
\text { ees. }\end{array}$ & $\begin{array}{l}\text { Used at } \\
\text { mines } \\
\text { for } \\
\text { steam } \\
\text { and } \\
\text { heat. }\end{array}$ & $\begin{array}{l}\text { Made } \\
\text { into } \\
\text { coke. }\end{array}$ & $\begin{array}{c}\text { Total } \\
\text { product. }\end{array}$ & $\begin{array}{l}\text { Total } \\
\text { value. }\end{array}$ & $\begin{array}{c}\text { Aver- } \\
\text { age } \\
\text { price } \\
\text { per } \\
\text { ton. }\end{array}$ & $\begin{array}{c}\text { Aver- } \\
\text { age } \\
\text { num- } \\
\text { ber of } \\
\text { days } \\
\text { active. }\end{array}$ & $\begin{array}{l}\text { Aver- } \\
\text { age } \\
\text { num- } \\
\text { ber of } \\
\text { em- } \\
\text { ploy- } \\
\text { ees. }\end{array}$ \\
\hline & & $\begin{array}{l}\text { Short } \\
\text { tons. }\end{array}$ & $\begin{array}{l}\text { Short } \\
\text { tons. }\end{array}$ & $\begin{array}{l}\text { Short } \\
\text { tons. }\end{array}$ & $\begin{array}{l}\text { Short } \\
\text { tons. }\end{array}$ & $\begin{array}{l}\text { Short } \\
\text { tons. }\end{array}$ & & & & \\
\hline Montgomery . & 10 & 7,230 & 12,785 & 523 & 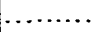 & 20,538 & $\$ 40,781$ & $\$ 1.99$ & 152 & 70 \\
\hline Tazewell... & 2 & 603,916 & 4,127 & 10,920 & 295,064 & 844,027 & 461,288 & .54 & 219 & 730 \\
\hline Wise...$\ldots \ldots$ & 11 & 557,202 & 5,265 & 7,561 & 662,585 & $1,232,613$ & 793,174 & .64 & 284 & 1,113 \\
\hline $\begin{array}{l}\text { Henrico..... } \\
\text { Pulaski ..... }\end{array}$ & 2 & 7,156 & 1,457 & & & 8,613 & 8,998 & 1.04 & 110 & 47 \\
\hline Total... & 25 & $1,175,504$ & 23,634 & 19,004 & 887,649 & $2,105,791$ & $1,304,241$ & .62 & 252 & 1,960 \\
\hline
\end{tabular}


Distribution of the coal product of Virginia from 1889 to 1899.

\begin{tabular}{|c|c|c|c|c|c|c|c|c|c|c|}
\hline Year. & $\begin{array}{l}\text { Num- } \\
\text { ber of } \\
\text { mines. }\end{array}$ & $\begin{array}{l}\text { Loaded at } \\
\text { mines for } \\
\text { shipment. }\end{array}$ & $\begin{array}{c}\text { Sold to } \\
\text { local trade } \\
\text { and used } \\
\text { by em-- } \\
\text { ployees. }\end{array}$ & $\begin{array}{l}\text { Used at } \\
\text { mines } \\
\text { for } \\
\text { steam } \\
\text { and } \\
\text { heat. }\end{array}$ & $\begin{array}{l}\text { Made } \\
\text { into } \\
\text { coke. }\end{array}$ & $\begin{array}{c}\text { Total } \\
\text { product. }\end{array}$ & $\begin{array}{l}\text { Total } \\
\text { value. }\end{array}$ & $\begin{array}{l}\text { Aver- } \\
\text { age } \\
\text { price } \\
\text { per } \\
\text { ton. }\end{array}$ & $\begin{array}{c}\text { Aver- } \\
\text { age } \\
\text { num- } \\
\text { ber of } \\
\text { days } \\
\text { active. }\end{array}$ & $\begin{array}{c}\text { Aver- } \\
\text { age } \\
\text { number } \\
\text { of em- } \\
\text { ployees. }\end{array}$ \\
\hline & & $\begin{array}{l}\text { Short } \\
\text { tons. }\end{array}$ & $\begin{array}{l}\text { Short } \\
\text { tons. }\end{array}$ & $\begin{array}{l}\text { Short } \\
\text { tons. }\end{array}$ & $\begin{array}{l}\text { Short } \\
\text { tons. }\end{array}$ & $\begin{array}{l}\text { Short } \\
\text { tons. }\end{array}$ & & & & \\
\hline 1889. & & 732,881 & 13,179 & 7,516 & 112,210 & 865,786 & $\$ 804,475$ & $\$ 0.93$ & $\cdots$ & $1,5 \overline{55}$ \\
\hline $1890 .$. & ... & 608,641 & 17,002 & 4,908 & 153,460 & 784,011 & 589,925 & .75 & 296 & 1,295 \\
\hline $1891 .$. & -. & 583,082 & 16,685 & 3,178 & 133,454 & 736,399 & 611,654 & .83 & 246 & $\$ 20$ \\
\hline 1892. & $\therefore$ & 527,304 & 20,721 & 6,611 & 120,569 & 675,205 & 578,429 & .86 & 192 & 836 \\
\hline 1893. & $\ldots$ & $714,18 s$ & 20,578 & 4,609 & 80,964 & 820,339 & 692,748 & .84 & 253 & 961 \\
\hline $1894 \ldots$ & 28 & $1,015,713$ & 21,162 & 4,690 & 187,518 & $1,229,083$ & 933,576 & .76 & 234 & 1,635 \\
\hline 1895. & 22 & $1,024,200$ & 15,173 & 22,338 & 306,613 & $1,368,324$ & 869,873 & .63 & 225 & 2,158 \\
\hline $1896 \ldots$ & 29 & 824,042 & 40,951 & 38,540 & 351,190 & $1,254,723$ & 848,851 & .68 & 198 & 2,510 \\
\hline $1897 .$. & 21 & 969,973 & 29,017 & 43,087 & 486,225 & $1,528,302$ & $1,021,918$ & .67 & 213 & 2,344 \\
\hline 1898 & 20 & $1,029,185$ & 19,564 & 16,234 & 750,291 & $1,815,274$ & $1,070,417$ & .59 & 230 & 1,855 \\
\hline 1899 & 25 & $1,175,504$ & 23,634 & 19,004 & 887,649 & $2,105,791$ & $1,304,241$ & .62 & 252 & 1,960 \\
\hline
\end{tabular}

Coal product of Virginia since 1880.

\begin{tabular}{|c|c|c|c|c|c|}
\hline Year. & Short tous. & Value. & $\begin{array}{l}\text { Average } \\
\text { price } \\
\text { per ton. }\end{array}$ & $\begin{array}{c}\text { Average } \\
\text { number of } \\
\text { days } \\
\text { active. }\end{array}$ & $\begin{array}{c}\text { Average } \\
\text { number } \\
\text { of em- } \\
\text { ployees. }\end{array}$ \\
\hline $1880 \ldots$ & 112,000 & & & & \\
\hline $1881 \ldots \ldots \ldots \ldots$ & 112,000 & & & -- & \\
\hline 1882 & 112,000 & & & & \\
\hline $1883 \ldots$ & 252,000 & & & & \\
\hline$\ldots \ldots$ & 336,000 & & & & \\
\hline 1885. & 567,000 & & & & \\
\hline $1886 \ldots$ & 684,951 & & & & \\
\hline $1887 \ldots$ & 825,263 & & & & \\
\hline 1888 & $1,073,000$ & $\cdots$ & $\cdots \ldots$ & & ..... \\
\hline $1889 \ldots \ldots \ldots$ & 865,786 & $\$ 804,475$ & $\$ 0.93$ & $\ldots$. & 1,555 \\
\hline 1890 & 784,011 & 589,925 & .75 & 296 & 1,295 \\
\hline $1891 \ldots \ldots$ & 736,399 & 611,654 & .83 & 246 & 820 \\
\hline $1892 \ldots \ldots$ & 675,205 & 578,429 & .86 & 192 & 836 \\
\hline $1893 \ldots$ & 820,339 & 692,748 & .84 & 253 & 961 \\
\hline $1894 \ldots$ & $1,299,083$ & 933,576 & .76 & 234 & 1,635 \\
\hline $1895 \ldots \ldots \ldots$ & $1,368,324$ & 869,873 & .63 & 225 . & 2,158 \\
\hline $1896 \ldots$ & $1,254,723$ & 848,851 & .68 & 198 & 2,510 \\
\hline 1897. & $1,528,302$ & $1,021,918$ & .67 & 213 & 2,344 \\
\hline 1898 & $1,815,274$ & $1,070,417$ & .59 & 230 & 1,855 \\
\hline 1899. & $2,105,791$ & $1,304,241$ & .62 & 252 & 1,960 \\
\hline
\end{tabular}




\section{WASHINGTON.}

Total product in $1899,2,029,881$ short tons; spot value, $\$ 3,603,989$.

Washington is the only one of the Pacific coast States whose coal product amounts to as much as 1 per cent of the total bituminous output. It is also the only State on the Pacific coast producing true bituminous coal, the entire product of California and Oregon being lignite or brown coals. Some of the Washington coals are true coking coals, over 50,000 tons in 1899 being made into coke. Some of the coals produced in Washington approach anthracite in character, and some "natural coke" has been observed. Production in the State has exceeded 1,000,000 tons annually since 1888 , and has increased steadily each year since 1894. It exceeded 2,000,000 tons in 1899 for the first time. The three principal producing counties are King, Kittitas, and Pierce, the combined tonnage from all the other four counties being less than 1 per cent of the total output of the State.

The statistics of production are shown in the following tables:

Coal product of Washington in 1898 , by counties.

\begin{tabular}{|c|c|c|c|c|c|c|c|c|c|c|}
\hline County. & $\begin{array}{l}\text { Num- } \\
\text { ber of } \\
\text { mines. }\end{array}$ & $\begin{array}{l}\text { Loaded } \\
\text { at mines } \\
\text { for ship- } \\
\text { ment. }\end{array}$ & $\begin{array}{l}\text { Sold to } \\
\text { local } \\
\text { trade } \\
\text { and } \\
\text { used } \\
\text { by em- } \\
\text { ploy- } \\
\text { ees. }\end{array}$ & $\begin{array}{l}\text { Used at } \\
\text { mines } \\
\text { for } \\
\text { steam } \\
\text { and } \\
\text { heat. }\end{array}$ & $\begin{array}{l}\text { Made } \\
\text { into } \\
\text { coke. }\end{array}$ & $\begin{array}{c}\text { Total } \\
\text { product. }\end{array}$ & $\begin{array}{l}\text { Total } \\
\text { value. }\end{array}$ & $\begin{array}{c}\text { Aver- } \\
\text { age } \\
\text { price } \\
\text { per } \\
\text { ton. }\end{array}$ & $\begin{array}{c}\text { Aver- } \\
\text { age } \\
\text { num- } \\
\text { ber of } \\
\text { days } \\
\text { active. }\end{array}$ & $\begin{array}{l}\text { Aver- } \\
\text { age } \\
\text { number } \\
\text { of em- } \\
\text { ploy- } \\
\text { ees. }\end{array}$ \\
\hline & & $\begin{array}{l}\text { Short } \\
\text { tons. }\end{array}$ & $\begin{array}{l}\text { Short } \\
\text { tons. }\end{array}$ & $\begin{array}{l}\text { Short } \\
\text { tons. }\end{array}$ & $\begin{array}{l}\text { Short } \\
\text { tons. }\end{array}$ & $\begin{array}{l}\text { Short } \\
\text { tons. }\end{array}$ & & & & \\
\hline King ........ & 11 & 725,811 & 22,742 & 37,253 & & 785,806 & $\$ 1,626,318$ & $\$ 2.07$ & 268 & 1,542 \\
\hline Kittitas . & 3 & 555,742 & 3,699 & 6,955 & ......... & 566,396 & 702,948 & 1.24 & 259 & 735 \\
\hline Pierce..... & 4 & 458,351 & 1,941 & 11,364 & 37,486 & 509,142 & 965,197 & 1.90 & 283 & 795 \\
\hline $\begin{array}{l}\text { Cownitz... } \\
\text { Lewis.... }\end{array}$ & 3 & 228 & 1,620 & & & 1,848 & 4,070 & 2.20 & 135 & 13 \\
\hline $\begin{array}{l}\text { Skagit .... } \\
\text { Whatcom. }\end{array}$ & 2 & 8,279 & 634 & 1,394 & 11,072 & 21,379 & 54,265 & 2.54 & 309 & 60 \\
\hline Total. & 23 &, 411 & 30,636 & 56,966 & 48,558 & $1,884,571$ & $3,352,798$ & 1.78 & 270 & 3,145 \\
\hline
\end{tabular}


Coal product of Washington in 1899, by counties.

\begin{tabular}{|c|c|c|c|c|c|c|c|c|c|c|}
\hline County. & $\begin{array}{l}\text { Num- } \\
\text { ber of } \\
\text { mines. }\end{array}$ & $\begin{array}{l}\text { Loaded } \\
\text { at mines } \\
\text { for ship- } \\
\text { ment. }\end{array}$ & $\begin{array}{c}\text { Sold to } \\
\text { local } \\
\text { trade } \\
\text { and } \\
\text { used by } \\
\text { em- } \\
\text { ployees. }\end{array}$ & $\begin{array}{l}\text { Used at } \\
\text { mines } \\
\text { for } \\
\text { steam } \\
\text { and } \\
\text { heat. }\end{array}$ & $\begin{array}{l}\text { Made } \\
\text { into } \\
\text { coke. }\end{array}$ & $\begin{array}{c}\text { Total } \\
\text { product. }\end{array}$ & $\begin{array}{l}\text { Total } \\
\text { value. }\end{array}$ & $\begin{array}{c}\text { Aver- } \\
\text { age } \\
\text { price } \\
\text { per } \\
\text { ton. }\end{array}$ & $\begin{array}{c}\text { Aver- } \\
\text { age } \\
\text { num- } \\
\text { ber of } \\
\text { days } \\
\text { active. }\end{array}$ & $\begin{array}{c}\text { Aver- } \\
\text { age } \\
\text { number } \\
\text { of em- } \\
\text { ployees. }\end{array}$ \\
\hline & & $\begin{array}{l}\text { Short } \\
\text { tons. }\end{array}$ & $\begin{array}{l}\text { Short } \\
\text { tons. }\end{array}$ & $\begin{array}{l}\text { Short } \\
\text { tons. }\end{array}$ & $\begin{array}{l}\text { Short } \\
\text { tons. . }\end{array}$ & $\begin{array}{l}\text { Short } \\
\text { tons. }\end{array}$ & - & & & \\
\hline king & 13 & 795,512 & 10,982 & 40,809 & ......... & 847,303 & $\$ 1,786,033$ & $\$ 2.11$ & 238 & 1,434 \\
\hline Kittitas.. & 4 & 648,820 & 5,934 & 6,456 & …… & 661,210 & 811,597 & 1.23 & 272 & 912 \\
\hline Pierce & 5 & 446,429 & 2,915 & 12,360 & 44,681 & 506,385 & 969,564 & 1.91 & 278 & 919 \\
\hline $\begin{array}{l}\text { Cowlit\%. } \\
\text { Lewis ... }\end{array}$ & 2 & 150 & 450 & 180 & - & 780 & 1,620 & 2.08 & 62 & 8 \\
\hline $\begin{array}{l}\text { Skagit .... } \\
\text { Whateom. }\end{array}$ & 2 & 7,051 & $\cdots$ & 1,638 & 5,514 & 14,203 & 35,175 & 2.48 & 289 & 57 \\
\hline Total .. & 26 & $1,897,962$ & 20,281 & 61,443 & 50,195 & $2,029,881$ & $3,603,989$ & 1.78 & 259 & 3,330 \\
\hline
\end{tabular}

Distribution of the coal product of Washington from 1889 to 1899.

\begin{tabular}{|c|c|c|c|c|c|c|c|c|c|c|}
\hline Year. & $\begin{array}{l}\text { Num- } \\
\text { ber of } \\
\text { mines. }\end{array}$ & $\begin{array}{l}\text { Loaded at } \\
\text { mines for } \\
\text { shipment. }\end{array}$ & $\begin{array}{l}\text { Sold to } \\
\text { local } \\
\text { tradeand } \\
\text { used } \\
\text { by em- } \\
\text { ployees. }\end{array}$ & $\begin{array}{c}\text { Used at } \\
\text { mines } \\
\text { for } \\
\text { steam } \\
\text { and } \\
\text { heat. }\end{array}$ & $\begin{array}{l}\text { Made } \\
\text { into } \\
\text { coke. }\end{array}$ & $\begin{array}{c}\text { Total } \\
\text { product. }\end{array}$ & $\begin{array}{l}\text { Total } \\
\text { value. }\end{array}$ & $\begin{array}{l}\text { Aver } \\
\text { age } \\
\text { price } \\
\text { per } \\
\text { ton. }\end{array}$ & $\begin{array}{l}\text { Aver- } \\
\text { age } \\
\text { num- } \\
\text { ber of } \\
\text { days } \\
\text { active. }\end{array}$ & $\begin{array}{l}\text { Average } \\
\text { number } \\
\text { of em- } \\
\text { ployees. }\end{array}$ \\
\hline & & $\begin{array}{l}\text { Short } \\
\text { tons. }\end{array}$ & $\begin{array}{l}\text { Short } \\
\text { tons. }\end{array}$ & $\begin{array}{l}\text { Short } \\
\text { tons. }\end{array}$ & $\begin{array}{l}\text { Short } \\
\text { tons. }\end{array}$ & $\begin{array}{l}\text { Short } \\
\text { tons. }\end{array}$ & & & . & \\
\hline 1889. & & 956,046 & 15,574 & 19,958 & 39,000 & $1,030,578$ & $\$ 2,393,238$ & $\$ 2.32$ & ..... & 2,657 \\
\hline 1890. & & $1,212,621$ & 17,249 & 17,019 & 16,800 & $1,263,689$ & $3,426,590$ & 2.71 & 270 & 2,206 \\
\hline 1891. & & $1,008,496$ & 12,025 & 20,428 & 15,300 & $1,056,249$ & $2,437,270$ & 2.31 & 211 & 2,447 \\
\hline 1892 & & $1,150,865$ & 9,802 & 40,085 & 12,675 & $1,213,427$ & $2,763,547$ & 2.28 & 247 & 2,564 \\
\hline 1893. & .... & $1,186,109$ & 18,888 & 48,506 & 11,374 & $1,264,877$ & $2,920,876$ & 2.31 & 241 & 2,757 \\
\hline $1894 .$. & 19 & $1,030,232$ & 10,822 & 56,853 & 8,563 & $1,106,470$ & $2,578,441$ & 2.33 & 207 & 2,662 \\
\hline $1895 \ldots$ & 22 & $1,108,868$ & 16,320 & 43,249 & 22,973 & $1,191,410$ & $2,577,958$ & 2.16 & 224 & 2,840 \\
\hline 1896 & 21 & $1,095,484$ & 16,722 & 44,613 & 38,685 & $1,195,504$ & $2,396,078$ & 2.00 & 221 & 2,622 \\
\hline $1897 .$. & 23 & $1,347,915$ & 7,149 & 39,902 & 39,146 & $1,434,112$ & $2,777,687$ & 1.94 & 236 & 2,739 \\
\hline $1898 .$. & 23 & $1,748,411$ & 30,636 & 56,966 & $48,55 \mathrm{~S}$ & $1,884,571$ & $3,352,798$ & 1.78 & 270 & 3,145 \\
\hline 1899.. & 26 & $1,897,962$ & 20,281 & 61,443 & 50,195 & $2,029,881$ & $3,603,989$ & 1.78 & 259 & 3,330 \\
\hline
\end{tabular}

Product of coal in Washington since 1895, by counties.

[Short tons.]

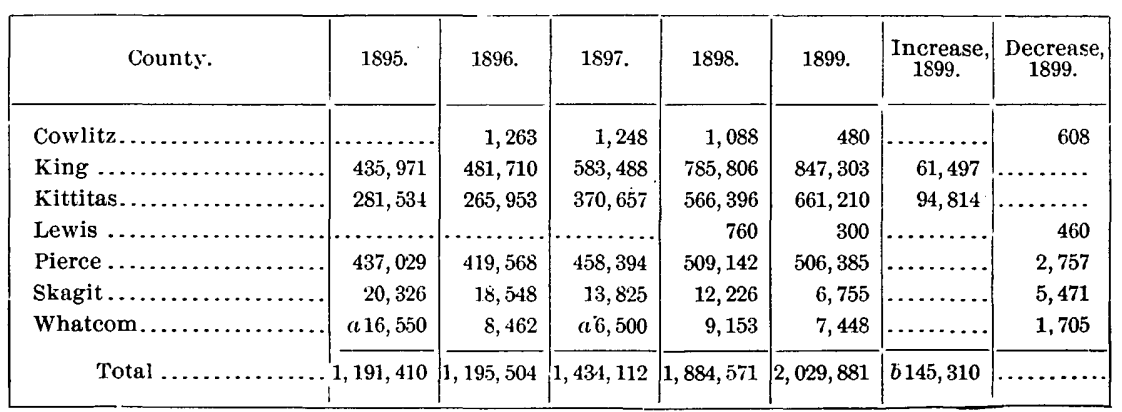


MINERAL RESOURCES.

Product of coal in Washington since 1885.

\begin{tabular}{|c|c|c|c|c|c|}
\hline Year. & $\begin{array}{c}\text { Total } \\
\text { product. }\end{array}$ & Total value. & $\begin{array}{l}\text { Average } \\
\text { price per } \\
\text { ton. }\end{array}$ & $\begin{array}{c}\text { Average } \\
\text { number of } \\
\text { days } \\
\text { active. }\end{array}$ & $\begin{array}{l}\text { Average } \\
\text { number of } \\
\text { of em- } \\
\text { ployees. }\end{array}$ \\
\hline 1885 . & $\begin{array}{l}\text { Short tons. } \\
\quad 380,250\end{array}$ & & & & \\
\hline 1886 & 423,525 & $\$ 952,931$ & $\$ 2.25$ & & \\
\hline 1887 & 772,601 & $1,699,746$ & 2. 19 & & 1,571 \\
\hline 1888 & $1,215,750$ & $3,647,250$ & 3.00 & & -. \\
\hline 1889. & $1,030,578$ & $2,393,238$ & 2.32 & $\cdots$ & 2,657 \\
\hline 1890 & $1,263,689$ & $3,426,590$ & 2. 71 & 270 & 2,006 \\
\hline $1891 \ldots$ & $1,056,249$ & $2,437,270$ & 2. 31 & 211 & 2,447 \\
\hline $1892 \ldots$ & $1,213,427$ & $2,763,547$ & 2. 28 & 247 & 2,564 \\
\hline 1893. & $1,264,377$ & $2,920,876$ & 2.31 & 241 & 2,757 \\
\hline $1894 \ldots$ & $1,106,470$ & $2,578,441$ & 2.33 & 207 & 2,662 \\
\hline $1895 \ldots$ & $1,191,410$ & $2,577,958$ & 2. 16 & 224 & 2,840 \\
\hline $1896 \ldots$ & $1,195,504$ & $2,396,078$ & 2. 00 & 221 & 2,622 \\
\hline $1897 .$. & $1 ; 434,112$ & $2,777,687$ & 1.94 & 236 & 2,739 \\
\hline 1898 & $1,884,571$ & $3,352,798$ & 1. 78 & 270 & 3,145 \\
\hline $1899 \ldots$ & $2,029,881$ & $3,603,989$ & 1. 78 & 259 & 3,330 \\
\hline
\end{tabular}

WEST VIRGINIA.

Total product in $1899,19,252,995$ short tons; spot value, $\$ 12,053,268$.

Compared with 1898, the coal product of West Virginia in 1899 exhibited an increase of $2,551,996$ short tons. This was the largest increase in tonnage made by the State in any one year, although the increase in 1898 orer 1897 was within 10,000 tons or 0.4 per cent of the 1899 increase. During the last four years West Virginia has held third place among the coal-producing States, having supplanted Ohio in 1896, and by continually augmented production retained the lead then gained. The statistics of production in 1898 indicated that West Virginia would probably equal if not exceed Illinois as a coal producer before the end of the present century, but production in the latter State took a bound in 1899 , increased the output by the unprecedented gain of $5,839,720$ short tons over 1898 , reached a total excecding $24,400,000$ tons, and attained a lead of West Virginia by more than $5,000,000$ short tons. Unless unforeseen conditions develop in the present year Illinois will enter the new century as the State second only to Pennsylvania in its production of coal, and West Virginia.will follow a close third.

And while West Virginia holds third place in rank in the tonnage of coal, she is still outclassed by Ohio and drops to fourth place when the comparisons are drawn according to the value of the coal produced. The value of Ohio's product exceeded that of West Virginia by $\$ 2,308,635$ or 19.15 per cent. 
In the steady and almost unbroken series of increase in annual production each year the record of West Virginia stands without a parallel in the history of coal mining in the United States. From 1878 to 1899 , a period of twenty-one years, there has been only one instance in which the output during one year was less than that of the preceding one. The one exception was in 1895 when, because of labor troubles in the Pocahontas field (McDowell and Mercer counties), the product from that region was so reduced that it caused a decrease in the total for the State.

A few unimportant strikes occurred in West Virginia during the past year. The total number of mines in which strikes occurred was 34 , the number of men made idle was 3,468 , and the aggregate time lost was 76,829 working days, less than 1.5 per cent of the time made, and an average loss of 22 days for the strikers.

The use of mining machines showed a substantial increase in 1899. The number of machines reported in 1899 was 154 , a gain of 68 machines, or 79 per cent. The machine-mined tonnage increased nearly 43 per cent, from $1,323,929$ to $1,881,125$ tons, and the percentage of machine-mined product to the total increased from 7.93 to 9.27.

In the following tables are presented the statistics of production in 1898 and 1899:

Coal product of West Virginia in 1898, by counties.

\begin{tabular}{|c|c|c|c|c|c|c|c|c|c|c|}
\hline County. & $\begin{array}{c}\text { Num- } \\
\text { ber of } \\
\text { mines. }\end{array}$ & $\begin{array}{l}\text { Loaded } \\
\text { at mines } \\
\text { for ship- } \\
\text { ment. }\end{array}$ & $\begin{array}{c}\text { Sold to } \\
\text { local } \\
\text { trade } \\
\text { and } \\
\text { used by } \\
\text { em- } \\
\text { ployees. }\end{array}$ & $\begin{array}{c}\text { Used at } \\
\text { mines } \\
\text { for } \\
\text { steam } \\
\text { and } \\
\text { heat. }\end{array}$ & $\begin{array}{l}\text { Made } \\
\text { into } \\
\text { coke. }\end{array}$ & $\begin{array}{c}\text { Total } \\
\text { product. }\end{array}$ & $\begin{array}{l}\text { Total } \\
\text { value. }\end{array}$ & $\mid \begin{array}{c}\text { Aver- } \\
\text { age } \\
\text { price } \\
\text { per } \\
\text { ton. }\end{array}$ & \begin{tabular}{|c|} 
Aver- \\
age \\
num- \\
ber of \\
days \\
active.
\end{tabular} & $\begin{array}{c}\text { Aver- } \\
\text { age } \\
\text { number } \\
\text { of em- } \\
\text { ployees. }\end{array}$ \\
\hline Barbour & 3 & $\begin{array}{l}\text { Short } \\
\text { tons. } \\
33,076\end{array}$ & $\mid \begin{array}{r}\text { Short } \\
\text { tons. }\end{array}$ & $\begin{array}{r}\text { Short } \\
\text { tons. } \\
301\end{array}$ & $\begin{array}{c}\text { Short } \\
\text { tons. } \\
1,680\end{array}$ & $\begin{array}{l}\text { Short } \\
\text { tons. } \\
35,643\end{array}$ & $\$ 19,566$ & $\$ 0.55$ & 157 & 96 \\
\hline Brooke. & 3 & 64,875 & $5 \quad 13,100$ & 80 & $\ldots \ldots \ldots$ & 78,055 & 59,013 & .76 & 309 & 132 \\
\hline Fayette. & 59 & $3,785,569$ & 946,211 & 18,682 & 742,310 & $4,592,772$ & $2,927,487$ & .64 & 198 & 6,737 \\
\hline Hancock & 2 & ........... & 40,912 & ....... & ........ & 40,912 & 40,162 & .98 & 245 & 78 \\
\hline Harrison & 13 & 384,077 & 7. 14,065 & 2,608 & 10,192 & 410,942 & 207,327 & .50 & 232 & 542 \\
\hline Kanawha. & 30 & $1,320,140$ & $0 \quad 12,561$ & 4,191 & 17,608 & $1,354,500$ & 924,105 & .68 & 194 & 2,737 \\
\hline McDowell & 32 & $2,414,745$ & $5 \quad 25,647$ & 11,102 & $1,453,482$ & $3,904,976$ & $2,110,759$ & .54 & 215 & 3,661 \\
\hline Marion & 19 & $1,847,402$ & 2. 13,563 & 9,536 & 243,851 & $2,114,352$ & $1,128,376$ & .53 & 254 & 2,120 \\
\hline Marshall & 3 & 183,293 & 9,983 & 1,956 & $\ldots$ & 195,232 & 127,946 & .66 & 254 & 245 \\
\hline Mason & 6 & $48,25 \overline{7}$ & 67,525 & 244 & $\ldots$ & 116,026 & 94,443 & .81 & 226 & 267 \\
\hline Mercer & s & 602,001 & 5,189 & 2,141 & 224,838 & 834,169 & 466,041 & .56 & 241 & 901 \\
\hline Mineral. & 6 & 580,466 & 5,637 & 242 & …..... & 586,345 & 413,746 & .71 & 253 & 552 \\
\hline Mingo & 10 & 373,436 & 3,155 & 940 & ......... & 377,531 & 224,685 & .60 & 219 & 749 \\
\hline Ohio.. & 7 & 75,885 & 59,247 & $x, 797$ & ......... & 136,929 & 95,611 & .70 & 243 & 173 \\
\hline Preston & 5 & 163,104 & 1,104 & 2,118 & 66,277 & 232,603 & 130,746 & .56 & 287 & 275 \\
\hline Putnam. & 2 & 203,278 & 3,129 & ...... & ....... & 206,407 & 132,261 & .64 & 237 & 472 \\
\hline Taylor. & 5 & 242,114 & 17,920 & 112 & $\ldots \ldots \ldots$ & 260,146 & 139,200 & .54 & 204 & 353 \\
\hline Tucker & 7 & 541,252 & 4,867 & 4,008 & 395,090 & 945,217 & 656,575 & .70 & 255 & 1,278 \\
\hline $\begin{array}{l}\text { Grant....... } \\
\text { Monongalia }\end{array}$ & 3 & 28,914 & 784 & 112 & 6,500 & 36,310 & 19,643 & .54 & 208 & 77 \\
\hline $\begin{array}{l}\text { Raleigh... } \\
\text { Randolph }\end{array}$ & 2 & 74,019 & 1,611 & 1,006 & 40,296 & 116,932 & 88,572 & .76 & 197 & 162 \\
\hline Small mines. & . & & 125,000 & & & 125,000 & 125,000 & & & \\
\hline Total & 225 & $12,965,903$ & 471,796 & 61,176 & $3,202,124$ & $16,700,999$ & $10,131,264$ & .61 & 218 & 21,607 \\
\hline
\end{tabular}


Coal product of West Virginia in 1899, by counties.

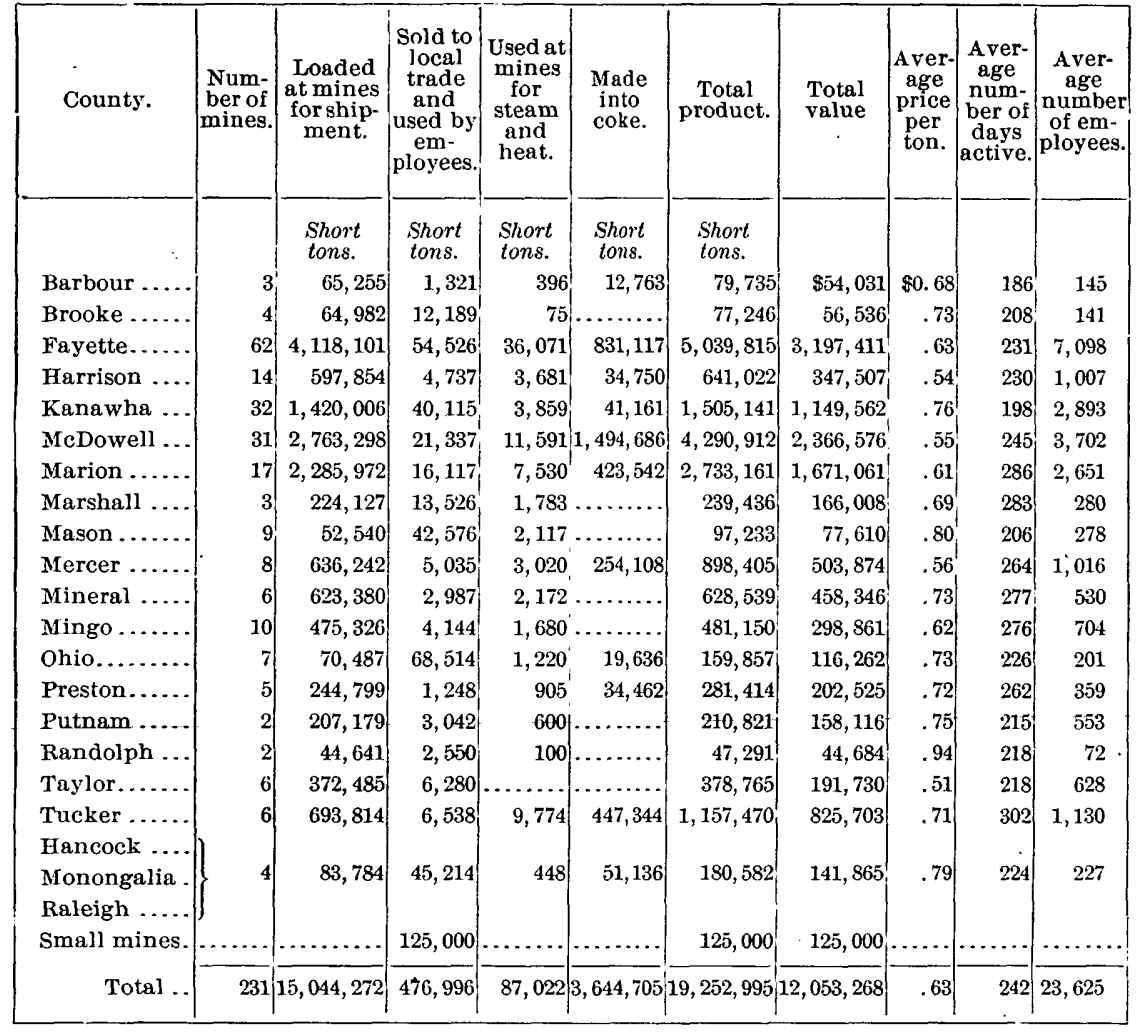

The distribution of the total product since 1889 has been as follows:

Distribution of the coal product of West Virginia from 1889 to 1899.

\begin{tabular}{|c|c|c|c|c|c|c|c|c|c|c|}
\hline Year. & $\begin{array}{l}\text { Num- } \\
\text { ber of } \\
\text { mines. }\end{array}$ & $\begin{array}{c}\text { Loaded } \\
\text { at mines } \\
\text { for ship- } \\
\text { ment. }\end{array}$ & $\begin{array}{c}\text { Sold to } \\
\text { local } \\
\text { trade } \\
\text { and used } \\
\text { by em- } \\
\text { ployees. }\end{array}$ & $\begin{array}{l}\text { Used at } \\
\text { mines } \\
\text { for } \\
\text { steam } \\
\text { and } \\
\text { heat. }\end{array}$ & $\begin{array}{c}\text { Made } \\
\text { into coke. }\end{array}$ & $\begin{array}{c}\text { Total } \\
\text { product. }\end{array}$ & $\begin{array}{c}\text { Total } \\
\text { value. }\end{array}$ & $\begin{array}{c}\text { Aver- } \\
\text { age } \\
\text { price } \\
\text { per } \\
\text { ton. }\end{array}$ & $\begin{array}{l}\text { Aver- } \\
\text { age } \\
\text { num- } \\
\text { ber of } \\
\text { days } \\
\text { active. }\end{array}$ & $\begin{array}{l}\text { Aver- } \\
\text { age } \\
\text { number } \\
\text { of em- } \\
\text { ployees. }\end{array}$ \\
\hline & & $\begin{array}{l}\text { Short } \\
\text { tons. }\end{array}$ & $\begin{array}{l}\text { Short } \\
\text { tons. }\end{array}$ & $\begin{array}{l}\text { Short } \\
\text { tons. }\end{array}$ & $\begin{array}{l}\text { Short } \\
\text { tons. }\end{array}$ & $\begin{array}{l}\text { Short } \\
\text { tons. }\end{array}$ & & & & \\
\hline 1889. & & $4,764,900$ & 493,287 & 37,368 & 936,325 & $6,231,880$ & $\$ 5,086,584$ & $\$ 0.82$ & - & 9,952 \\
\hline 1890. & & $5,614,752$ & 438,527 & 30,594 & $1,310,781$ & $7,394,654$ & $6,208,128$ & .84 & 227 & 12,236 \\
\hline 1891. & & $6,887,151$ & 420,878 & $4 \bar{i}, 163$ & $1,856,473$ & $9,220,6005$ & $\overline{7}, 3 \overline{5} \bar{y}, 8 \mathbf{1} \mathbf{1} \hat{x}$ & .80 & 237 & 14,227 \\
\hline 1892. & & $7,560,790$ & 441,159 & 49,563 & $1,687,243$ & $9,735,755$ & $7,852,114$ & .80 & 228 & 14,867 \\
\hline 1893. & & $8,591,962$ & 390,689 & 46,898 & $1,679,029$ & $10,708,578$ & $8,251,170$ & .77 & 219 & 16,524 \\
\hline 1894. & 187 & $9,116,314$ & 428,202 & 64,126 & $2,019,115$ & $11,627,757$ & $8,706,808$ & .75 & 186 & 17,824 \\
\hline 1895. & 190 & $8,858,256$ & 445,023 & 50,595 & $2,034,087$ & $11,357,961$ & $7,710,575$ & .68 & 195 & 19,159 \\
\hline 1896. & 189 & $9,838,053$ & 426,441 & 56,395 & $2,555,407$ & $12,876,296$ & $8,336,685$ & .65 & 201 & 19,078 \\
\hline 189 & 198 & $11,312,408$ & 446,795 & $58,694^{\prime}$ & $2,430,262$ & $14,248,159$ & $8,987,393$ & .63 & 205 & 20,504 \\
\hline 1598. & 225 & $12,965,903$ & 471,796 & 61,176 & $3,202,124$ & $16,700,999$ & $10,131,264$ & .61 & 218 & 21,607 \\
\hline 1899. & 231 & $15,044,272$ & 476,996 & $87,022^{\prime}$ & $3,644,705$ & $19,252,995$ & $12,053,268$ & .63 & 242 & 23,625 \\
\hline
\end{tabular}


The statement presented in the following table exhibits the county production during the past five years, with the increases and decreases in 1899 as compared with 1898 . It will be observed that out of the 23 counties included in the table there were only 4 in which a loss of tonnage was recorded. In 2 of these the loss in each was less than 1,000 tons, and the aggregate of all the decreases did not reach 35,000 tons. Marion County enjoys the distinction of having the largest increase, followed by Fayette, McDowell, Harrison, Tucker, Kanawha, Taylor, and Mingo in the order named. In each of these counties the product in 1899 exceeded that of 1898 by over 100,000 tons.

Coal product of West Virirginia from 1895 to 1899, by counties.

[Short tons.]

\begin{tabular}{|c|c|c|c|c|c|c|c|c|c|}
\hline County. & 1895. & 1896. & 1897. & $189 \mathrm{~s}$. & 1899. & $\begin{array}{c}\text { Increase, } \\
1899 .\end{array}$ & $\begin{array}{c}\text { De- } \\
\text { crease, } \\
1899 .\end{array}$ & $\begin{array}{c}\text { Per } \\
\text { cent of } \\
\text { in- } \\
\text { crease. }\end{array}$ & $\begin{array}{c}\text { Per } \\
\text { cent of } \\
\text { de- } \\
\text { crease. }\end{array}$ \\
\hline Barbour & 13,306 & 24,064 & 56,054 & 35,643 & 79,735 & 44,092 & & 123.7 & \\
\hline Brooke. & 74,841 & 43,424 & 49,453 & 78,055 & 77,246 & & 809 & & 1.04 \\
\hline Fayette. & $3,264,825$ & $3,533,572$ & $4,001,540$ & $4,592,772$ & $5,039,815$ & 447,043 & & 9.7 & \\
\hline Grant.. & 392 & 8,720 & & 560 & & & 560 & 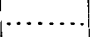 & 100.0 \\
\hline Harrison .... & 292,693 & 231,687 & 334,817 & 410,942 & 641,022 & 230,080 & & 56.0 & \\
\hline Kanawha ... & $1,134,798$ & $1,116,883$ & 920,161 & $1,354,500$ & $1,505,141$ & 150,641 & & 11.1 & \\
\hline Logan ... & 24,648 & $\cdots$ & $\cdots \cdots$ & 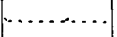 & & & & & \\
\hline MeDowell... & $2,395,365$ & $2,883,686$ & $3,235,344$ & $3,904,976$ & $4,290,912$ & 385,936 & & 9.8 & \\
\hline Marion ... & $1,257,563$ & $1,511,903$ & $1,739,846$ & $2,114,352$ & $2,733,161$ & 618,809 & & 29.3 & \\
\hline Marshall .... & 194,077 & 181,610 & 147,532 & 195,232 & 239,436 & 44,204 & & 22.6 & \\
\hline Mason ........ & 120,766 & 100,136 & 120,945 & 116,026 & 97,233 & . & 18,793 & $\cdots \cdots$ & 16.2 \\
\hline Mercer . & 687,364 & 939,082 & 915,691 & 834,169 & 898,405 & 64,236 & & 7.7 & \\
\hline Mineral .. & 675,610 & 556,586 & 580,520 & 586,345 & 628,539 & 42,194 & & 7.2 & \\
\hline Mingo ... & 26,370 & 211,593 & 368,520 & 377,531 & 481,150 & 103,619 & & 27.4 & \\
\hline Monongalia . & 67,510 & 43,297 & 51,307 & 35,750 & 51,520 & 15,770 & & 44.1 & \\
\hline Ohio......... & 169,834 & 133,525 & 111,909 & 136,929 & 159,857 & 22,928 & & 16.7 & \\
\hline Preston...... & 107,053 & 139,759 & 169,610 & 232,603 & 281,414 & 48,811 & & 21.0 & \\
\hline Putnam ..... & 120,482 & 185,953 & 110,971 & 206,407 & 210,821 & 4,414 & & 2.1 & \\
\hline Raleigh & 88,188 & 92,136 & 83,178 & 99,852 & 86,088 & …... & 13,764 & $\cdots \cdots$ i $_{i}$ & 13.8 \\
\hline Randolph ... & 200 & $\cdots \cdots \cdots$ & $\ldots \ldots$ & 17,080 & 47,291 & 30,211 & & 176.9 & \\
\hline Taylor.. & 93,252 & 123,354 & 281,227 & 260,146 & 378,765 & 118,619 & & 45.6 & \\
\hline Tucker... & 449,991 & 688,426 & 844,506 & 945,217 & $1,157,470$ & 212,253 & & 22.5 & \\
\hline Wayne & 3,833 & 1,900 & & & & & & & \\
\hline $\begin{array}{l}\text { Other coun- } \\
\text { ties and } \\
\text { small mines. }\end{array}$ & 125,000 & 125,000 & 125,000 & 165,912 & 167,974 & 2,062 & & 1.24 & \\
\hline To & $11,387,961$ & $12,876,296$ & $14,248,159$ & $16,700,999$ & $19,252,995$ & $a 2,551,996$ & & 15.3 & \\
\hline
\end{tabular}

a Net increase.

In the preceding tables the production has been treated by counties arranged in alphabetical order, but in comparing the production in 1899 with that of preceding years and discussing the wonderful development of the coal-mining industry of the State during recent 
years a more comprehensive idea may be obtained by an arrangement of certain important fields according to geographical distribution. With this end in view the following table has been prepared showing the productive development of four principal districts in the State which have been designated as the New and Kanawha River district, the Pocahontas or Flat Top, the Fairmont, and the Upper Potomac or Elk Garden field. The first two districts are in the southern part of the State and are reached by the Chesapeake and Ohio and the Norfolk and Western railroads, respectively. The Fairmont and Upper Potomac fields are in the northern part of the State and are reached by the Baltimore and Ohio and West Virginia Central and Pittsburg railroads. According to the present rate of production the New and Kanawha River district is the most important of the four. It includes the counties of Fayette and Kanawha, and while the coal of the two counties is drawn from two different areas they are drained by the same waters and sent to market over the same railroad, and are considered as one district in this report. In thirteen years the output of this district has nearly trebled, from $2,290,563$ short tons in 1886 to 6,544,956 short tons in 1899 .

The Pocahontas or Flat Top district embraces McDowell and Mercer counties in West Virginia, and Tazewell County, Virginia. The openings to the mines in Tazewell County are in Virginia, and that county and State are credited with the total product, but most of the coal is taken from the West Virginia side of the line. Prior to 1889 all of the coal from this district was mined in Mercer County, West Virginia, and Tazewell County, Virginia. The mines of McDowell County, opened in 1889, produced in 1891 more than either of the other counties, and since 1893 have produced more than half the total tonnage of the district. In thirteen years the output of this district has increased seven times from 968,484 short tons in 1886 to $6,033,344$ short tons in 1899 .

The Fairmont region, embracing Harrison and Marion counties, has shown the largest ratio of increase of all the coal-producing districts of West Virginia. The output of this district in 1899 was more than eight times what it was in 1886 . The product in 1899 was $3,374,183$ short tons as against $2,525,294$ short tons in $1898,2,074,663$ tons in 1897, and 406,976 in 1886.

The Upper Potomac or Elk Garden district belongs to an isolated basin, of which the Cumberland field of Maryland forms a part. It is of comparatively limited area, but an important producer. Most of the coal in the district is drawn from the "big vein" which has furnished nearly all of Maryland's product. During the last few years a great deal of development has been done in Tucker County on the Thomas and Davis seams, which are found at a lower horizon than the 
"big vein." The production of the district in West Virginia amounted to $1,786,009$ tons, as compared with $1,531,562$ tons in 1898 .

Coal product of the principal districts of West Virginia.

\begin{tabular}{|c|c|c|c|c|}
\hline Year. & $\begin{array}{l}\text { New and Ka- } \\
\text { nawha River } \\
\text { district. }\end{array}$ & $\begin{array}{l}\text { Pocahontas or } \\
\text { Flat Top dis- } \\
\text { trict. }\end{array}$ & $\begin{array}{c}\text { Fairmont or } \\
\text { Upper Monon- } \\
\text { gahela district. }\end{array}$ & $\begin{array}{l}\text { Upper Potomac } \\
\text { or Elk Garden } \\
\text { district. }\end{array}$ \\
\hline 1886. & $\begin{array}{l}\text { Short tons. } \\
2,290,563\end{array}$ & $\begin{array}{l}\text { Short tons. } \\
968,484\end{array}$ & $\begin{array}{l}\text { Short tons. } \\
406,976\end{array}$ & $\begin{array}{l}\text { Short tons. } \\
383,712\end{array}$ \\
\hline 1887. & $2,379,296$ & $1,357,040$ & 520,064 & 503,343 \\
\hline 1888 & $2,840,630$ & $1,912,695$ & 473,489 & 518,878 \\
\hline $1889 \ldots$ & $2,669,016$ & $2,290,270$ & 456,582 & 666,956 \\
\hline $1890 \ldots$ & $3,012,414$ & $2,702,092$ & 600,131 & $\$ 19,062$ \\
\hline 1891. & $3,632,209$ & $3,137,012$ & $1,150,569$ & $1,052,308$ \\
\hline $1892 \ldots$ & $3,773,021$ & $3,503,260$ & $1,141,430$ & 942,154 \\
\hline 1893 & $4,099,112$ & $3,815,280$ & $1,255,956$ & $1,129,39 \bar{i}$ \\
\hline $1894 \ldots$ & $3,650,971$ & $5,059,025$ & $1,655,532$ & $92 \bar{t}, 220$ \\
\hline 1895 & $4,399,623$ & $4,044,998$ & $1,550,256$ & $1,125,601$ \\
\hline 1896 & $4,650,455$ & $4,608,113$ & $1,743,590$ & $1, \dot{245}, 012$ \\
\hline $1897 \ldots$ & $4,921,701$ & $4,859,373$ & $2,074,663$ & $1,425,026$ \\
\hline 1898 . & $5,947,272$ & $5,521,160$ & $2,525,294$ & $1,531,562$ \\
\hline 1899. & $6,544,956$ & $6,033,344$ & $3,374,183$ & $1,786,009$ \\
\hline
\end{tabular}

The annual product of coal in West Virginia is shown in the following table:

Coal product of West Virginia since 1873.

\begin{tabular}{|c|c|c|c|}
\hline year. & Short tons. & Year. & Short tons. \\
\hline $1873 \ldots \ldots \ldots \ldots \ldots$ & 672,000 & $1887 \ldots \ldots \ldots \ldots \ldots$ & $4,881,620$ \\
\hline $1874 \ldots \ldots \ldots$ & $1,120,000$ & $1888 \ldots \ldots \ldots$ & $5,498,800$ \\
\hline $1875 \ldots$ & $1,1.20,000$ & $1889 \ldots$ & $6,231,880$ \\
\hline $1876 \ldots \ldots$ & $\$ 96,000$ & 1890 & $\overline{7}, 394,654$ \\
\hline $1877 \ldots \ldots \ldots \ldots \ldots$ & $1,120,000$ & $1891 \ldots$ & $9,220,665$ \\
\hline $1878 \ldots . .$. & $1,120,000$ & 1892 & $9,738,755$ \\
\hline $1879 \ldots$ & $1,400,000$ & $1893 \ldots \ldots \ldots$ & $10,708,578$ \\
\hline $1880 \ldots .$. & $1,568,000$ & $1894 \ldots \ldots \ldots \ldots$ & $11,627,757$ \\
\hline $1881 \ldots .$. & $1,680,000$ & $1895 \ldots . . . .$. & $11,387,961$ \\
\hline $1882 \ldots$ & $2,240,000$ & $1896 \ldots$ & $12,876,296$ \\
\hline $1883 \ldots . .$. & $2,335,833$ & $1897 \ldots \ldots \ldots$ & $14,248,159$ \\
\hline $1884 \ldots \ldots$ & $3,360,000$ & $1898 \ldots \ldots$ & $16,700,999$ \\
\hline $1855 \ldots$ & $3,369,062$ & 1899 & $19,252,995$ \\
\hline $1886 \ldots . .$. & $4,005,796$ & & \\
\hline
\end{tabular}

21 GEOL, PT $6-33$ 
In order to show how steady and regular has been the growth of the coal-mining industry of West Virginia the following table has been prepared, exhibiting the increases each year since 1880. There has been only one break in the series, and the average annual increase has been nearly 1,000,000 short tons:

Annual increase in the coal product of West Virginia since 1880.

\begin{tabular}{|c|c|}
\hline Yeur. & Short tons. \\
\hline 1881 over 1880 & 112,000 \\
\hline 1882 over $1881 \ldots$ & 560,000 \\
\hline 1883 over 1882 & 95,833 \\
\hline 1884 over $1883 \ldots$ & $1,024,167$ \\
\hline 1885 over $1884 \ldots$ & 9,062 \\
\hline 1886 over $1885 \ldots$ & 636,734 \\
\hline 1887 over $1886 \ldots$ & 875,824 \\
\hline 1888 over $1887 \ldots$ & 617,180 \\
\hline 1889 over $1888 \ldots$ & 733,080 \\
\hline 1890 over $1889 \ldots$ & $1,162,774$ \\
\hline 1891 over $1890 \ldots$ & $1,826,011$ \\
\hline 1892 over $1891 \ldots$ & 518,090 \\
\hline 1893 over $1892 \ldots$ & 969,823 \\
\hline 1894 over $1893 \ldots$ & 919,179 \\
\hline Total increase in fourteen years. & $10,059,757$ \\
\hline Decrease in $1895 \ldots . .$. & 239,796 \\
\hline Total increase in fifteen years. & $9,819,961$ \\
\hline 1896 over $1895 \ldots$. . . & $1,488,335$ \\
\hline 1897 over $1896 \ldots$ & $1,371,863$ \\
\hline 1898 over $1897 \ldots$ & $2,452,840$ \\
\hline 1899 over $1898 \ldots .$. & $2,551,996$ \\
\hline Total increase in nineteen years. & $17,684,995$ \\
\hline Average annual increase. & 930,789 \\
\hline
\end{tabular}

WYOMING.

Total product in $1899,3,837,392$ short tons; total value, $\$ 4,742,525$.

Wyoming ranks second among the coal-producing States of the Rocky Mountain region and third among all the States west of the Mississippi River. In the amount of increased tonnage during 1899 as compared with 1898 Wyoming excelled all the other Western States. Wyoming's output in 1899 was nearly $1,000,000$ tons larger than in 1898, and was nearly three times as large as it was ten years before. 
The increased production in 1899 was distributed among all the counties of any producing importance, the greatest gain being made by Uinta County, with an augmented output of 462,034 tons, or nearly 80 per cent, over 1898 . Sweetwater County increased its production 388,887 tons, or nearly 30 per cent.

. The number of mining machines in use increased from 48 to 56 , and the effect of this increase was shown in the tonnage, as the machinewon product increased $10^{\circ}$ per cent, from 631,431 tons in 1898 to 693,712 tons in 1899

Coal product of Wyoming in 1898, by counties.

\begin{tabular}{|c|c|c|c|c|c|c|c|c|c|c|}
\hline Connty. & $\begin{array}{c}\text { Num- } \\
\text { ber of } \\
\text { mines. }\end{array}$ & $\begin{array}{c}\text { Loaded } \\
\text { at mines } \\
\text { for ship- } \\
\text { ment. }\end{array}$ & $\begin{array}{c}\text { Sold to } \\
\text { local } \\
\text { trade } \\
\text { and } \\
\text { used } \\
\text { by em- } \\
\text { ployees. }\end{array}$ & $\begin{array}{c}\text { Used at } \\
\text { mines } \\
\text { for } \\
\text { steam } \\
\text { and } \\
\text { heat. }\end{array}$ & $\begin{array}{l}\text { Made } \\
\text { into } \\
\text { coke. }\end{array}$ & $\begin{array}{c}\text { Total } \\
\text { product. }\end{array}$ & $\begin{array}{l}\text { Total } \\
\text { value. }\end{array}$ & $\begin{array}{l}\text { Aver- } \\
\text { age } \\
\text { price } \\
\text { per } \\
\text { ton. }\end{array}$ & $\begin{array}{l}\text { Aver- } \\
\text { age } \\
\text { num- } \\
\text { ber of } \\
\text { days } \\
\text { active. }\end{array}$ & $\begin{array}{l}\text { Average } \\
\text { number } \\
\text { of em- } \\
\text { ployees. }\end{array}$ \\
\hline & & $\begin{array}{l}\text { Short } \\
\text { tons. }\end{array}$ & $\begin{array}{l}\text { Short } \\
\text { tons. }\end{array}$ & $\begin{array}{l}\text { Short } \\
\text { tons. }\end{array}$ & $\begin{array}{l}\text { Short } \\
\text { tons. }\end{array}$ & $\begin{array}{l}\text { Short } \\
\text { tons. }\end{array}$ & & & & \\
\hline Carbon. & 5 & 350,450 & 5,434 & 16,466 & & 372,350 & $\$ 482,449$ & $\$ 1.30$ & 219 & 441 \\
\hline Sweetwater... & s & $1,200,403$ & 5,072 & 40,400 & $\cdots$ & $1,245,875$ & $1,394,766$ & 1.12 & 243 & 1,474 \\
\hline Uinta ....... & 3 & 582,450 & 4,383 & 7,000 & 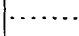 & 593,833 & 869,866 & 1.46 & 243 & 770 \\
\hline $\begin{array}{l}\text { Converse... } \\
\text { Crook..... }\end{array}$ & 2 & 48,318 & 1,100 & $6,0 \mathrm{N0}$ & $\cdots \cdots$ & 55,418 & 69,000 & 1.25 & 194 & $8 \check{~}$ \\
\hline $\begin{array}{l}\text { Fremont... } \\
\text { Johnson ... }\end{array}$ & 2 & & 4,350 & 25 & & 4,375 & 8,750 & 2.00 & 188 & 8 \\
\hline $\begin{array}{l}\text { Sheridan.... } \\
\text { Weston ..... }\end{array}$ & 3 & 516,705 & 1,316 & 38,556 & 35,384 & 591,961 & 839,359 & 1.42 & 258 & 697 \\
\hline Total... & 23 & $2,698,326$ & 21,655 & 108,447 & 35,384 & $2,863,812$ & $3,664,190$ & 1.28 & 242 & 3,475 \\
\hline
\end{tabular}

Coal product in Wyoming in 1899, by counties.

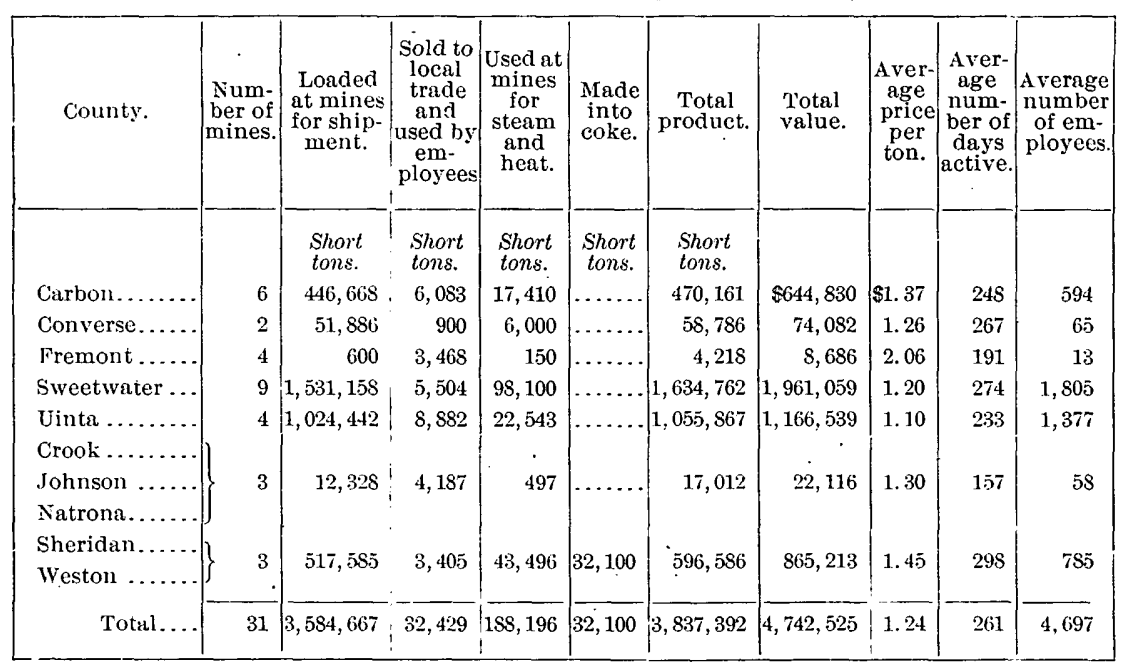


Distribution of the coal product of Wyoming from 1889 to 1899.

\begin{tabular}{|c|c|c|c|c|c|c|c|c|c|c|}
\hline Year. & $\begin{array}{l}\text { Num- } \\
\text { ber of } \\
\text { mines. }\end{array}$ & $\begin{array}{l}\text { Loaded } \\
\text { at mines } \\
\text { for ship- } \\
\text { ment. }\end{array}$ & $\begin{array}{l}\text { Sold to } \\
\text { local } \\
\text { trade } \\
\text { and } \\
\text { used by } \\
\text { employ } \\
\text { ees. }\end{array}$ & $\begin{array}{l}\text { Used at } \\
\text { mines } \\
\text { for } \\
\text { steam } \\
\text { and } \\
\text { heat. }\end{array}$ & $\begin{array}{c}\text { Made } \\
\text { into } \\
\text { coke. }\end{array}$ & $\begin{array}{l}\text { Total } \\
\text { product. }\end{array}$ & $\begin{array}{l}\text { Total } \\
\text { value. }\end{array}$ & $\begin{array}{c}\text { Aver- } \\
\text { age } \\
\text { price } \\
\text { per } \\
\text { ton. }\end{array}$ & $\begin{array}{c}\text { Aver- } \\
\text { age } \\
\text { num- } \\
\text { ber of } \\
\text { days } \\
\text { active. }\end{array}$ & $\begin{array}{l}\text { Average } \\
\text { number } \\
\text { of em- } \\
\text { ployees. }\end{array}$ \\
\hline & & $\begin{array}{l}\text { Short } \\
\text { tons. }\end{array}$ & $\begin{array}{l}\text { Short } \\
\text { tons. }\end{array}$ & $\begin{array}{l}\text { Short } \\
\text { tons. }\end{array}$ & $\begin{array}{l}\text { Short } \\
\text { tons. }\end{array}$ & $\begin{array}{l}\text { Short } \\
\text { tons. }\end{array}$ & & & & \\
\hline 1889. & $\cdots$ & $1,354,443$ & 15,433 & 19,071 & ....... & $1,388,947$ & $\$ 1,748,617$ & & . & 2,675 \\
\hline 1890 & & $1,835,299$ & 28,540 & 6,527 & ${ }_{2}^{*}$, & $1,870,366$ & $3,183,669$ & & 246 & 3,272 \\
\hline 1891. & & $2,229,401$ & 33,558 & 60,392 & 4,490 & $2,327,841$ & $3,555,275$ & $\$ 1.53$ & 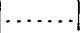 & 3,411 \\
\hline 1892. & & $2,378,657$ & 27,054 & 96,128 & 2,000 & $2,503,839$ & $3,168,776$ & 1.27 & 225 & 3,133 \\
\hline 1893. & . & $2,280,685$ & 64,188 & 87,086 & 7,352 & $2,439,311$ & $3,290,904$ & 1.35 & 189 & 3,378 \\
\hline ]894.. & 34 & $2,309,934$ & 21,482 & 72,362 & 13,685 & $2,417,463$ & $3,170,392$ & 1.31 & 190 & 3,032 \\
\hline $1895 .$. & 25 & $2,106,937$ & 35,628 & 81,065 & 23,281 & $2,246,911$ & $2,977,901$ & 1.33 & 184 & 3,449 \\
\hline 1.896. & 28 & $2,102,468$ & 17,867 & 68,251 & 41,038 & $2,229,624$ & $2,904,185$ & 1.30 & 209 & 2,949 \\
\hline $1897 \ldots$ & 20 & $2,435,091$ & 17,845 & 93,974 & 50,976 & $2,597,886$ & $3,136,694$ & 1.21 & 219 & 3,137 \\
\hline $1898 .$. & 23 & $2,698,326$ & 21,655 & 108,447 & 35,384 & $2,863,812$ & $3,664,190$ & 1. 28 & 242 & 3,475 \\
\hline $1899 \ldots$ & 31 & $3,584,667$ & 32,429 & 188,196 & 32,100 & $3,837,392$ & $4,742,525$ & 1.24 & 261 & 4,697 \\
\hline
\end{tabular}

The output by counties during the past five years, with the increases and decreases in 1899 as compared with 1898 , is presented in the following table:

Coal product of Wyoming since 1895, by counties.

[Short tons.]

\begin{tabular}{|c|c|c|c|c|c|c|c|}
\hline County. & 189.5. & 1896. & 1897. & 1898. & 1899. & $\begin{array}{c}\text { Increase, } \\
1899 .\end{array}$ & $\begin{array}{c}\text { Decrease, } \\
1899 .\end{array}$ \\
\hline Carbon .. & 350,504 & 363,257 & 403,891 & 372,350 & 470,161 & 97,811 & \\
\hline Converse .. & 65,090 & 78,000 & 79,000 & 54,818 & 58,786 & 3,968 & \\
\hline Sweetwater. & $1,158,125$ & $1,047,042$ & $1,133,434$ & $1,245,875$ & $1,634,762$ & 385,857 & \\
\hline Uinta....... & 230,684 & 313,433 & 417,984 & 593,833 & $1,055, \$ 67$ & 462,034 & \\
\hline Weston ............. & 348,611 & 371,528 & 498,997 & 508,199 & 542,649 & 34,450 & \\
\hline Other counties .... & 93,897 & 56.364 & 64,580 & 88,737 & 75,167 & & 13,570 . \\
\hline Total & $2,246,911$ & $2,229,624$ & $2,597,886$ & $2,863,812$ & $3,837,392$ & $a 973,5 \mathrm{~S} 0$ & \\
\hline
\end{tabular}

$a$ Net increase. 
In the following table is shown the total product for the State each year since 1868 :

Total product of coal in Wyoming.

\begin{tabular}{|c|c|c|c|c|c|}
\hline Year. & Short tons. & value. & Year. & Short tons. & Value. \\
\hline $1868 .$. & 6,925 & & 1884 & 902,620 & \\
\hline 1869. & 49,382 & & 1885 & 807,328 & $\$ 2,421,984$ \\
\hline $1870 \ldots$ & 105,295 & & 1886 & 829,355 & $2,488,065$ \\
\hline $1871 \ldots$ & 147,328 & & 1887 & $1,170,318$ & $3,510,954$ \\
\hline 1872. & 221,745 & & 1888 & $1,481,540$ & $4,444,620$ \\
\hline 1873. & 259,700 & & 1889 & $1,388,276$ & $1,748,617$ \\
\hline $1874 \ldots$ & 219,061 & & 1890 & $1,870,366$ & $3,183,669$ \\
\hline 1875. & 300,808 & & 1891 & $2,327,841$ & $3,555,275$ \\
\hline $1876 \ldots$ & 334,550 & & 1892 & $2,503,839$ & $3,168,776$ \\
\hline $1877 \ldots$ & 342,853 & & 1893. & $2,439,311$ & $3,290,904$ \\
\hline 1878. & 333,200 & & 1894 & $2,417,463$ & $3,170,392$ \\
\hline $1879 \ldots$ & 400,991 & & 1895 & $2,246,911$ & $2,977,901$ \\
\hline $1880 \ldots$ & 527,811 & & 1896. & $2,229,624$ & $2,904,185$ \\
\hline $1.881 .$. & 628,181 & & 1897. & $2,597,886$ & $3,136,694$ \\
\hline $1882 \ldots$ & 707,764 & & 1898. & $2,863,812$ & $3,664,190$ \\
\hline 1883. & 779,689 & & 1899 & $3,837,392$ & $4,742,525$ \\
\hline
\end{tabular}

\section{IABBOR TROUBLES IN $1899 .^{1}$}

In proportion to the number of men employed and the relative production, the regions most seriously affected by labor strikes in 1899 were Arkansas and the Indian Territory. In Arkansas the idleness caused by the strikes was directly responsible for a decrease of 361,925 tons in the product of the State, and made Arkansas one of the two coalproducing States which failed to share in the revival of the industrial activity of 1899 . The operators in the Indian Territory were more fortunate than their neighbors in Arkansas, in that they were able, by the importation of nonunion labor from other States, to keep their mines in operation the greater part of the year. This strike grew out of the refusal of mine operators to accede to a demand for recognition of the miners' union. It began about the first of March and had not been settled at the close of the year, although most of the mines affected had resumed operations, some with a full complement of miners and laborers. The total number of men made idle by the struggle was 3,866 , of which 2,041 were in Arkansas and 1,825 in the Indian Territory. The aggregate working time lost was 497,521 days, of which 
216,265 were lost in Arkansas and 281,256 in the Territory. The average time lost per man was 106 days in Arkansas and 154 days in the Territory. In no other State did the average time lost per man amount to as much as 65 days. The nearest approach to that figure was made in Colorado, where 504 men were on strike, an average of 62 days, and in Alabama, where 1,135 men were idle, an average of 61 days.

Pennsylvania naturally, on account of its supremacy as a coal producer, reported the largest number of men on strike and the largest total for time lost, but the average time lost per man was only 42 days. Moreover, the strikes were distributed among 70 mines out of a total of 687 , so that only 10 per cent of the total number were affected. The 15,131 men on strike represented only 18 per cent of the total number employed and the total days lost only 3 per cent of the total time made. In Arkansas and the Territory, on the other hand, out of 53 mines, 31 , or 60 per cent, reported strikes; 3,866 men, or 60 per cent of the total average number employed, were idle, and the total time lost was equivalent to 40 per cent of all the time made.

Taking the country as a whole, 359 mines out of a total of 3,245 were idle some portion of the year by strikes; 45,981 men out of a total of 271,027 employed in the bituminous coal mines of the United States were participants in the strikes, and the total time lost was $2,124,154$ working days, as compared with $63,420,318$ working days made.

As stated in the footnote, the statistics presented herewith include only the strikes occurring in bituminous mines. No statements regarding the strikes in the anthracite mines. of Pennsylvania were obtained. The details of men made idle, time lost, etc., by strikes during 1899 are presented in tabular form in the following statement: 
COAL.

Statistics of labor strikes in the Lnited States in 1899.

\begin{tabular}{|c|c|c|c|c|}
\hline State or Territory. & $\begin{array}{c}\text { Number of } \\
\text { mines re- } \\
\text { porting } \\
\text { strikes. }\end{array}$ & $\begin{array}{l}\text { Number of } \\
\text { men on } \\
\text { strike. }\end{array}$ & Total days lost. & $\begin{array}{c}\text { Average } \\
\text { number of } \\
\text { days lost per } \\
\text { man. }\end{array}$ \\
\hline Alabama .............. & 11 & 1,135 & 68,925 & 61 \\
\hline Arkansas . . . . . . . . . & 12 & 2,041 & 216,265 & 106 \\
\hline Colorado ........... & 9 & 504 & 31,520 & 62 \\
\hline Illinois . . . . . . . . . & 47 & 7,133 & 267,171 & 37 \\
\hline Indiana $\ldots \ldots \ldots \ldots . . .$. & 30 & 3,272 & 132,825 & 40 \\
\hline Indian Territory . . . . . . & 19 & 1,825 & 281,256 & 154 \\
\hline Iowa ........ & 34 & 2,623 & 72,710 & $2 S$ \\
\hline Kansas .... & 16 & 1,986 & 88,798 & 45 \\
\hline Kentucky ............ & 12 & 837 & 24,598 & 29 \\
\hline 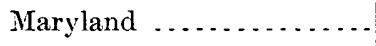 & 1 & 35 & 420 & 12 \\
\hline Michigan ..... & 5 & 487 & 9,547 & 20 \\
\hline Missouri . . . . . . . . . . . . & 30 & 2,197 & 117,076 & 53 \\
\hline Montana ..... & 1. & 650 & 33,800 & 52 \\
\hline 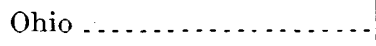 & 15 & 877 & 26,394 & 30 \\
\hline Pennsylvania ........... & 70 & 15,131 & 636,160 & 42 \\
\hline Tennessee. & 11 & 1,595 & 37,085 & 23 \\
\hline Texas .................. & 2 & 185 & 2,775 & 15 \\
\hline West Virginia............. & 34 & 3,468 & 76,829 & 22 \\
\hline Total & 359 & 45,981 & $2,124,154$ & 46 \\
\hline
\end{tabular}





\section{COKF.}

Br Edward W. Parker.

[The unit used in this report is uniformly the ton of 2,000 pounds.]

\section{IN'TRODUCTION.}

This report, dealing primarily with the production of coke in 1.899 , follows the general style of the preceding reports of the series. In collecting the statistics of production during the past year the writer has acted also as a special agent of the Twelfth Census of the United States, the census schedules being prepared so as to include the inquiries usually made by the Geological Survey. The delay in the publication of the report has been due to difficulty experienced in getting complete replies to the extended inquiries required for the Census report. It is not considered necessary to include in this paper the statistics of capital, labor, wages, etc., as collected for the Census, and readers interested in these subjects are referred to the Census report, which will be published in bulletin form at practically the same time as this report.

In both Census and Survey reports the use of the word "coke" is limited to the product which is obtained from the distillation or partial combustion of bituminous coal in retorts, oven's, or pits, and which may be termed "oven coke." Ordinary gas-house coke, obtained as a by-product in the manufacture of illuminating gas from coal, is not included. Retort-oven coke, however, although the gas may be, as it is in a few instances, the primary product, is considered as coming within the scope of this report. There seems to be no reason to doubt that the by-product ovens will eventually supersede the beehive, at least in great part. The question as to whether the coke from these retort ovens is the primary product or the by-product is determined by the location of the plant and the demands of the particular locality. All of the Semet-Solvay ovens so far erected in this country have been for the production of metallurgical coke with gas as a by-product. The Otto-Hoffman ovens at Johnstown and at Otto, near Pittsburg, Pennsylvania, have also been constructed for coke as the primary product. The four hundred ovens at Everett, Massachusetts, on the other hand, which have put in blast since our last report, make the gas the primary and coke the secondary product. Other plants in 
contemplation or under contract at Philadelphia and other cities will also make the gas the primary product. The coke product from these ovens is certainly not to be considered in the same category as gashouse coke, and it has been decided to include it with the production of blast-furnace and foundry cokes, although not made strictly for that purpose. A large amount of beehive-oven coke is now prepared each year for domestic use, so it is not possible to confine the report to the discussion of metallurgical coke.

The coal used in the manufacture of coke in the United States is drawn from all the five great bituminous coal fields, which are (1) the Appalachian, (2) the Central, (3) the Western, (4) the Rocky Mountain, and (5) the Pacific coast. No coke is produced from the coal of the Triassic fields in North Carolina and eastern Virginia, or of the northern field in Michigan. Fully 95 per cent of the total production is taken from the Appalachian fields, which embrace the great coking regions of Pennsylvania, West Virginia, Alabama, Virginia, and Tennessee, and less important districts in Ohio and eastern Kentucky. About $3 \frac{1}{2}$ per cent of the total product is from the Rocky Mountain States, leaving only $1 \frac{1}{2}$ per cent to be distributed among the other three fields.

\section{PRODUC'TION OF COKE IN THE UNITED STATES.}

\section{PRODUCTION IN 1899.}

The phenomenal activity in the iron trade during 1899 naturally stimulated the production of coke, and resulted in a coke product of $19,668,569$ short tons. This was an increase of $3,621,360$ tons, or nearly 23 per cent, over the product of 1898 , which was in turn 20 per cent in excess of any previous year. As compared with 1895, the year of largest production prior to 1898 , the product in 1899 shows an increase of over 47 per cent. The unusual demand for coke throughout the entire year caused also an advance in price, the average for the year being $\$ 1.75$ per ton, the highest point attained with one exception since 1892. The total value of the product in 1899 was $\$ 34,670,417$, an increase of $\$ 9,083,718$, or 35.5 per cent, as compared with 1898 , and of over 50 per cent as compared with 1897 . In spite of this proportionately larger gain in value, many coke producers found the year's business an unprofitable and in some cases a decidedly losing one. This was due to the advanced wages and higher cost of coal, while most of the coke was sold on long contract at prices which were below the cost of production in 1899 .

It will be seen from the following tables that all of the more important coke-producing States shared in the increased production in 1899. In order to preserve the confidential nature of the returns, the production of New York and Massachusetts is included with Pennsylvania; Illinois is combined with Indiana, and Utah with Colorado. The com- 
bined product of Illinois and Indiana was less than the two States produced in 1898. Several ovens were abandoned in each State during 1899. The product of the Indian Territory also showed a decrease, as did the product of Ohio, Wisconsin and Wyoming. The total decrease in all of these States, however, amounted to but 17,771 tons, an insignificant amount when considered with the increases in other States.

The number of establishments in 1899 was 344 , an increase of 2 over 1898 , and of 8 over 1897. The total number of ovens in existence at the close of 1889 was 49,667 , against 48,447 in 1898 , and 47,668 in 1897. The number of ovens building on December 31,1899 , was 4,037 as compared with 1,048 in 1898 , and 545 in 1897 . The ovens operated in 1899 included 280 Semet-Solvay, 680 Otto-Hoffman, and 60 Newton-Chambers, a total of 1,020 by-product ovens, as compared with 520 in 1898, and 280 in 1897 . There were 65 by-product ovens building at the close of 1899 .

In the following table is shown a statement of the production of coke in 1899, by States, followed, for purposes of comparison, by similar tables for 1898 and 1897 :

Manufacture of coke in the United States, by States and Territories, in 1899.

\begin{tabular}{|c|c|c|c|c|c|c|c|c|}
\hline \multirow{2}{*}{ State or Territory. } & \multirow{2}{*}{$\begin{array}{c}\text { Estab- } \\
\text { lish- } \\
\text { ments. }\end{array}$} & \multicolumn{2}{|c|}{ Ovens. } & \multirow{2}{*}{ Coal used. } & \multirow{2}{*}{$\begin{array}{l}\text { Yield of } \\
\text { coal in } \\
\text { coke. }\end{array}$} & \multirow{2}{*}{$\begin{array}{l}\text { Coke pro- } \\
\text { duced. }\end{array}$} & \multirow{2}{*}{$\begin{array}{c}\text { Total value } \\
\text { of coke. }\end{array}$} & \multirow{2}{*}{$\begin{array}{l}\text { Value } \\
\text { of coke } \\
\text { per ton. }\end{array}$} \\
\hline & & Built. & $\begin{array}{c}\text { Build. } \\
\text { ing. }\end{array}$ & & & & & \\
\hline Alabama & 25 & 5,599 & 850 & $\begin{array}{r}\text { Short tons. } \\
3,028,472\end{array}$ & $\begin{array}{c}\text { Per cent. } \\
59\end{array}$ & $\begin{array}{r}\text { Short tons. } \\
1,787,809\end{array}$ & $\$ 3,634,471$ & $\$ 2.03$ \\
\hline Colorado $(a) .$. & 12 & 1,243 & 50 & 898,207 & 59 & 530,424 & $1,333,769$ & 2.51 \\
\hline Georgia........... & 2 & 350 & 100 & 78,098 & 65.2 & 50,907 & 116,917 & 2.30 \\
\hline Illinois .... & 3 & 130 & 26 & & & & & \\
\hline 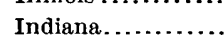 & 2 & 52 & 0 & 4,217 & 56.2 & 2,370 & 5,565 & 2.35 \\
\hline Indian Territory .. & 3 & 130 & 100 & 59,255 & 41 & 24,339 & 71,965 & 2.96 \\
\hline Kansas ........... & 9 & 95 & 0 & 26,988 & 53.6 & 14,476 & 30,817 & 2.13 \\
\hline Kentucky ......... & 6 & 300 & 130 & 151,503 & 53.5 & 81,095 & 161,454 & 1.99 \\
\hline Massachusetts (b).. & 1 & 400 & 0 & ......... & ...... & ....... & ........ & ........ \\
\hline Missouri ........... & 4 & 12 & 0 & 5,320 & 53.8 & 2,860 & 5,520 & 1.93 \\
\hline Montana........ & 3 & 303 & 0 & 110,274 & 51 & $56), 376$ & 356,190 & 6.32 \\
\hline New Mexico....... & 3 & 190 & 0 & 68,594 & 64.3 & 44,134 & 99,217 & 2.25 \\
\hline New York $(b) \ldots$. & 1 & 25 & 5 & ........ & ...... & ........ & ........ & $\cdots \ldots$ \\
\hline Ohio............ & 8 & 385 & 0 & 142,678 & 58.8 & 83,878 & 255,129 & 3.04 \\
\hline Pennsylvania ..... & 150 & 27,591 & 1,666 & $19,930,419$ & 68.1 & $13,577,870$ & $22,881,910$ & 1.69 \\
\hline Tennessee......... & 14 & 2,040 & 62 & 779,995 & 55.8 & 435,308 & 850,686 & 1.95 \\
\hline $\operatorname{Utah}(a) \ldots \ldots \ldots$ & 1 & 104 & 0 & $\ldots \ldots \ldots$ & $\ldots \ldots$ & $\ldots \ldots \ldots$ & $\ldots \ldots \ldots \ldots$ & .......... \\
\hline Virginia .......... & 6 & 1,588 & 429 & 994,635 & 62.2 & 618,707 & $1,071,284$ & 1.73 \\
\hline Washington ........ & 2 & 90 & 0 & 50,813 & 59.8 & 30,372 & 151,216 & 4. 98 \\
\hline West Virginia ..... & 87 & 8,846 & 619 & $3,802,825$ & 60 & $2,278,577$ & $3,480,408$ & 1.53 \\
\hline Wisconsin ......... & 1 & 120 & 0 & 54,950 & 60.8 & 33,437 & 125,389 & 3.75 \\
\hline Wyoming ......... & 1 & 74 & 0 & 32,100 & 48.7 & 15,630 & 38,510 & 2.46 \\
\hline Total & 344 & $c 49,667$ & $d 4,037$ & $30,219,343$ & 65.1 & $19,668,569$ & $34,670,417$ & 1.76 \\
\hline
\end{tabular}

$a$ Colorado includes production of Utah.

$b$ Production included in Pennsylvania.

$c$ Includes 280 Semet-Solvay, 680 Otto-Hoffman, and 60 Newton-Chambers by-product ovens.

d Includes 65 Semet-Solvay ovens. 
Manufacture of coke in the United States, by States and Territories, in 1898.

\begin{tabular}{|c|c|c|c|c|c|c|c|c|}
\hline \multirow{2}{*}{ State or Territory. } & \multirow{2}{*}{$\begin{array}{c}\text { Estab- } \\
\text { lish- } \\
\text { ments. }\end{array}$} & \multicolumn{2}{|c|}{ Ovens. } & \multirow{2}{*}{ Coal used. } & \multirow{2}{*}{$\begin{array}{c}\text { Yield of } \\
\text { coal } \\
\text { in coke. }\end{array}$} & \multirow{2}{*}{$\begin{array}{l}\text { Coke pro- } \\
\text { duced. }\end{array}$} & \multirow{2}{*}{$\begin{array}{l}\text { Total value } \\
\text { of coke. }\end{array}$} & \multirow{2}{*}{$\begin{array}{l}\text { Value } \\
\text { of coke } \\
\text { per ton. }\end{array}$} \\
\hline & & Built. & $\begin{array}{l}\text { Build- } \\
\text { ing. }\end{array}$ & & & & & \\
\hline Alabama. & 25 & 5,456 & 100 & $\begin{array}{r}\text { Short tons. } \\
2,814,615\end{array}$ & $\begin{array}{c}\text { Per cent. } \\
59\end{array}$ & $\begin{array}{r}\text { Short tons. } \\
1,663,020\end{array}$ & $\$ 3,378,946$ & $\$ 2.03$ \\
\hline Colorado $(a)$ & 12 & 1,253 & 3 & 803,686 & 59.1 & 474,808 & $1,230,428$ & 2.59 \\
\hline Georgia........... & 2 & 350 & 0 & 81,108 & 61 & 49,529 & 77,230 & 1.56 \\
\hline Illinois ...... & 2 & 126 & 0 & 6,650 & 35 & 2,325 & 4,686 & 2.02 \\
\hline Indiana ..... & .2 & 94 & 0 & 4,065 & 44.9 & 1,825 & 3,194 & 1.75 \\
\hline Indian Territory... & 2 & 130 & 0 & 73,330 & 46.5 & 34,110 & 96,639 & 2.833 \\
\hline Kansas ......... & 6 & 47 & 50 & 7,856 & 53 & 4,180 & 6,455 & 1.544 \\
\hline Kentucky ....... & 5 & 292 & 2 & 44,484 & 50 & 22,242 & 32,213 & 1.448 \\
\hline Massachusetts..... & 1 & 0 & 400 & 0 & 0 & 0 & 0 & 0 \\
\hline Missouri........... & 3 & 8 & 0 & 1,500 & 49.3 & 740 & 1,050 & 1.42 \\
\hline Montana ......... & 4 & 318 & 0 & 92,552 & 56 & 52,009 & 359,174 & 6.906 \\
\hline New Mexico....... & 3 & 190 & 0 & 12,557 & 55.6 & 6,980 & 14,625 & 2.095 \\
\hline New York (b)...... & 1 & 25 & 0 & $\cdots$ & & & & \\
\hline ohio........... & 10 & 44.1 & 0 & 134,757 & 63.5 & 85,535 & 211,558 & 2.47 \\
\hline Pennsylvania $(c) .$. & 151 & 27,157 & 292 & $16,307,841$ & 65.7 & $10,715,302$ & $16,078,505$ & 1.50 \\
\hline Tennessee.... & 15 & 1,949 & 40 & 722,356 & 54.6 & 394,545 & 642,920 & 1.63 \\
\hline $\mathrm{U} \operatorname{tah}(d) \ldots \ldots$ & 1 & 104 & 0 & .......... & .... & & & $\ldots$ \\
\hline Virginia...... & 6 & 1,564 & 0 & 852,972 & 62 & 531,161 & 699,781 & 1.317 \\
\hline Washington... & 2 & 90 & 0 & 48,559 & 62.2 & 30,197 & 128,933 & 4.27 \\
\hline West Virginia . & 87 & 8,659 & 161 & $3,145,398$ & 61.2 & $1,925,071$ & $2,432,657$ & 1.26 \\
\hline Wisconsin .... & 1 & 120 & 0 & 59,900 & 59 & 35,280 & 123,480 & 3.50 \\
\hline Wyoming... & 1 & 74 & 0 & 35,384 & 51.9 & 18,350 & 64,225 & 3.50 \\
\hline Total .. & 342 & $e 48,447$ & $f 1,048$ & $25,249,570$ & 63.6 & $16,047,209$ & $25,586,699$ & 1.594 \\
\hline
\end{tabular}

$a$ Includes production of Utah.

$b$ Production included with Pennsylvania.

$c$ Includes production of New York.

$d$ Production included with Colorado.

$e$ Includes 280 Semet-Solvay, 180 Otto-Hoffman, and 60 Newton-Chambers by-product ovens.

$f$ Includes 500 Otto-Hoffman ovens. 
Manufacture of coke in the United States, by States and Territories, in 1897.

\begin{tabular}{|c|c|c|c|c|c|c|c|c|}
\hline \multirow{2}{*}{ State or Territory. } & \multirow{2}{*}{$\begin{array}{l}\text { Estab- } \\
\text { lish- } \\
\text { ments. }\end{array}$} & \multicolumn{2}{|c|}{ Ovens. } & \multirow{2}{*}{ Coal used. } & \multirow{2}{*}{$\begin{array}{l}\text { Yield of } \\
\text { coal } \\
\text { in coke. }\end{array}$} & \multirow{2}{*}{$\begin{array}{l}\text { Coke pro- } \\
\text { duced. }\end{array}$} & \multirow{2}{*}{$\begin{array}{c}\text { Total value } \\
\text { of coke. }\end{array}$} & \multirow{2}{*}{$\begin{array}{l}\text { Value } \\
\text { of coke } \\
\text { perton. }\end{array}$} \\
\hline & & Built. & $\begin{array}{l}\text { Build- } \\
\text { ing. }\end{array}$ & & & & & \\
\hline Alabama....... & 25 & 5,365 & a 120 & $\begin{array}{r}\text { Short tons. } \\
2,451,475\end{array}$ & $\begin{array}{r}\text { Per cent } \\
58.8\end{array}$ & $\begin{array}{r}\text { Short tons. } \\
1,443,017\end{array}$ & $. \$ 3,094,461$ & $\$ 2.14$ \\
\hline Colorado $(b) \ldots . .$. & $12^{\circ}$ & $c 1,273$ & 0 & 616,592 & 55.6 & 342,653 & 999,216 & 2.916 \\
\hline Georgia........ & 1 & 300 & 0 & 67,000 & 49.3 & 33,000 & 42,240 & $1.2 S$ \\
\hline Illinois .......... & 2 & 126 & 0 & 3,591 & 43 & 1,549 & 2,895 & 1.87 \\
\hline Indiana ......... & 2 & 94 & 0 & 7,022 & 41.4 & 2,904 & 5,795 & 1.995 \\
\hline Indian Territory.. & 2 & 130 & 0 & 68,495 & 44.3 & 30,364 & 104,725 & 3.45 \\
\hline Kansas ........ & 4 & 57 & 0 & 11,772 & 52.5 & 6,181 & 9,272 & 1.50 \\
\hline Kentucky ..... & 5 & 268 & 0 & 64,234 & 50 & 32,117 & 45,454 & 1.41 \\
\hline Missouri ......... & 3 & 15 & 0 & 4,627 & 56 & 2,593 & 3,890 & 1.50 \\
\hline Montana ......... & 3 & 303 & 0 & 139,907 & 48.5 & 67,849 & $46 \overline{7}, 481$ & 6.89 \\
\hline New Mexico...... & 2 & 126 & 0 & 2,585 & 55.6 & 1,438 & 3,232 & 2.25 \\
\hline New York $(d) \ldots$. & 1 & 25 & 0 & ....... & $\cdots$ & ....... & .. & $\cdots$ \\
\hline Ohio............. & 9 & 433 & 0 & 151,545 & 62.7 & 95,087 & 235,784 & 2.48 \\
\hline Pennsylvania $(e)$. & 153 & 26,910 & 307 & $13,538,646$ & 66.2 & $8,966,924$ & $13,727,966$ & 1.53 \\
\hline Tennessee..... & 15 & 1,948 & 0 & 667,996 & 55 & 368,769 & 667,656 & 1.81 \\
\hline Texas........... & 1 & 20 & 0 & 700 & 56.3 & 394 & & \\
\hline $\operatorname{Utah}(f) \ldots \ldots$ & 1 & 104 & 0 & ….... & ....... & $\cdots \cdots \cdots$ & ........ & $\cdots \cdots$ \\
\hline Virginia ...... & 6 & 1,453 & 110 & 574,542 & 61.6 & 354,067 & 495,864 & 1.40 \\
\hline Washington ...... & 3 & 120 & 0 & 39,124 & 67 & 26,189 & 115,754 & 4.42 \\
\hline West Virginia.. & 84 & 8,404 & 38 & $2,413,283$ & 61 & $1,472,666$ & $1,933,808$ & 1.31 \\
\hline Wisconsin ..... & 1 & 120 & 0 & 29,207 & 59 & 17,216 & 75,000 & 4.36 \\
\hline Wyoming..... & 1 & 74 & 0 & 54,976 & 43.7 & 24,007 & 72,021 & 3.00 \\
\hline Total .... & 336 & 47,668 & 575 & $20,907,319$ & 63.5 & $13,288,984$ & $22,102,514$ & 1.663 \\
\hline$a$ & $\begin{array}{l}\text { udes } \\
\text { udes } \\
\text { ducti } \\
\text { ludes }\end{array}$ & $\begin{array}{l}\text { al use } \\
\text { gas re } \\
\text { inclu } \\
\text { al use }\end{array}$ & $\begin{array}{l}\text { coke } \\
\text { rts. } \\
\text { d wit } \\
\text { coke }\end{array}$ & $\begin{array}{l}\text { duced, a } \\
\text { ennsylva } \\
\text { duced, a } \\
\text { olorado. }\end{array}$ & $\begin{array}{l}\text { its val } \\
\text { its val }\end{array}$ & $\begin{array}{l}\text { in Utah. } \\
\text { in New } Y\end{array}$ & rk. & \\
\hline
\end{tabular}


The increases and decreases in the several States during 1899, as compared with 1898 , are shown in the following table:

Increases and decreases in coke production, by States, in 1899, as compared with 1898 .

\begin{tabular}{|c|c|c|c|c|}
\hline \multirow{2}{*}{ State or Territory. } & \multicolumn{2}{|c|}{ Increase, 1899.} & \multicolumn{2}{|c|}{ Decrease, 1899.} \\
\hline & $\begin{array}{l}\text { Amount of } \\
\text { increase. }\end{array}$ & $\begin{array}{l}\text { Per cent of } \\
\text { increase. }\end{array}$ & $\begin{array}{l}\text { Amount of } \\
\text { decrease. }\end{array}$ & $\begin{array}{l}\text { Per cent of } \\
\text { decrease. }\end{array}$ \\
\hline & Short tons. & & Short tons. & \\
\hline Alabama . . . . . . . . . & 124,789 & 7.5 & $\ldots \ldots \ldots$. & $\ldots \ldots \ldots$ \\
\hline Colorado $(a) \ldots \ldots \ldots \ldots$ & 55,616 & 11.7 & .. & $\cdots$ \\
\hline Georgia ......... & 1,378 & 2. 78 & & \\
\hline $\begin{array}{l}\text { Illinois . . . . . . . . } \\
\text { Indiana . . . . . . . }\end{array}$ & \} & & 1,780 & 42.89 \\
\hline Indian Territory . . . . . . . . . & $\ldots \ldots \ldots$ & $\ldots \ldots \ldots$ & 9,771 & 28.65 \\
\hline 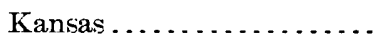 & 10,296 & 246.3 & $\ldots \ldots \ldots$ & $\ldots \ldots . . . .$. \\
\hline Kentucky .............. & 58,853 & 264.6 & - $\cdots$ & $\cdots$ \\
\hline Missouri ..... & 2,120 & 286.49 & & \\
\hline Montana ............... & 4,367 & 8.4 & & \\
\hline New Mexico ............. & 37,154 & 532.29 & $\cdots$ & $\cdots$ \\
\hline Ohio $\ldots . . . . . . .$. & $\cdots$ & $\ldots \ldots$ & 1,657 & 1.94 \\
\hline $\begin{array}{l}\text { Pennsylvania, New York, } \\
\text { and Massachusetts ...... }\end{array}$ & $2,862,568$ & 26.7 & $\ldots . .$. & $\cdots$ \\
\hline Tennessee . . . . . . . . . & 40,763 & 10.3 & - & 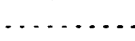 \\
\hline Virginia... & 87,546 & 16.5 & & [- \\
\hline Washington ............. & 175 & .58 & - & $\cdots$ \\
\hline West Virginia...... & 353,506 & 18.36 & $\ldots \ldots$ & $\cdots$ \\
\hline Wisconsin & $\ldots \ldots$ & $\ldots .$. & 1,843 & 5.22 \\
\hline Wyoming $\ldots . . . . . .$. & $\ldots \ldots \ldots$ & $\ldots \ldots$ & 2,720 & 14.82 \\
\hline Total... & $b 3,621,360^{\circ}$ & 22.57 & - & $\cdots$ \\
\hline
\end{tabular}

$a$ Including Utah.

$b$ Net increase. 
In the following table are consolidated the statistics of the manufacture of coke in the United States from 1880 to 1899, inclusive:

Statistics of the manufaciure of coke in the United States, 1880 to 1899, inclusire.

\begin{tabular}{|c|c|c|c|c|c|c|c|c|}
\hline \multirow{2}{*}{ Year. } & \multirow{2}{*}{$\begin{array}{l}\text { Estab- } \\
\text { lish- } \\
\text { ments. }\end{array}$} & \multicolumn{2}{|c|}{ Ovens. } & \multirow{2}{*}{ Coal used. } & \multirow{2}{*}{$\begin{array}{l}\text { Coke pro- } \\
\text { duced. }\end{array}$} & \multirow{2}{*}{$\begin{array}{l}\text { Total } \\
\text { value of coke } \\
\text { at ovens. }\end{array}$} & \multirow{2}{*}{$\begin{array}{c}\text { Value } \\
\text { of coke } \\
\text { at } \\
\text { ovens } \\
\text { per ton. }\end{array}$} & \multirow{2}{*}{$\begin{array}{l}\text { Yield } \\
\text { of conal } \\
\text { in coke. }\end{array}$} \\
\hline & & Built. & $\begin{array}{l}\text { Build- } \\
\text { ing. }\end{array}$ & & & & & \\
\hline 1880 & 186 & 12,372 & 1,159 & $\begin{array}{l}\text { Short tons. } \\
5,237,741\end{array}$ & $\begin{array}{l}\text { Short tons. } \\
3,338,300\end{array}$ & $\$ 6,631,267$ & $\$ 1.99$ & $\begin{array}{l}\text { Per ct. } \\
63\end{array}$ \\
\hline 1881 & 197 & 14,119 & 1,005 & $6,546,662$ & $4,113,760$ & $7,725,175$ & 1.88 & 63 \\
\hline 1882 & 215 & 16,356 & 712 & $7,577,648$ & $4,793,321$ & $8,462,167$ & 1. 77 & 63 \\
\hline 1883 & 231 & 18,304 & 407 & $8,516,670$ & $5,464,721$ & $8,121,607$ & 1.49 & 64 \\
\hline 1884 & 250 & 19,557 & 812 & $7,951,974$ & $4,873,805$ & $7,242,878$ & 1. 49 & 61 \\
\hline 1885 & 233 & 20,116 & 432 & $8,071,126$ & $5,106,696$ & $7,629,118$ & 1.49 & 63 \\
\hline 1886 & 222 & 22,597 & 4,154 & $10,688,972$ & $6,845,369$ & $11,153,366$ & 1.63 & 64 \\
\hline 1887 & 270 & 26,001 & 3,584 & $11,859,752$ & $7,611,705$ & $15,321,116$ & 2.01 & 64 \\
\hline 1888 & 261 & 30,059 & 2,587 & $12,945,350$ & $8,540,030$ & $12,445,963$ & 1. 46 & 66 \\
\hline 1889 & 252 & 34,165 & 2,115 & $15,960,973$ & $10,258,022$ & $16,630,301$ & 1.62 & 64 \\
\hline 1890 & 253 & 37,158 & 1,547 & $18,005,209$ & $11,508,021$ & $23,215,302$ & 2.02 & 64 \\
\hline 1891. & 243 & 40,245 & 911 & $16,344,540$ & $10,352,688$ & $20,323,216$ & 1.97 & 63 \\
\hline 1892 & 261 & 42,002 & 1,893 & $18,813,337$ & $12,010,829$ & $23,536,141$ & 1.96 & 64 \\
\hline 1893 & 258 & 44,201 & 717 & $14,917,146$ & $9,477,580$ & $16,523,714$ & 1.74 & 63.5 \\
\hline 1894 & 260 & 44,772 & 591 & $a 14,348,750$ & $9,203,632$ & $a 12,328,856$ & 1.34 & 64 \\
\hline 1895 & 265 & 45,565 & 638 & $20,848,323$ & $13,333,714$ & $b 19,234,319$ & 1.44 & 64 \\
\hline 1896 & 341 & 46,944 & 383 & $18,694,422$ & $11,788,773$ & $21,660,729$ & 1.837 & 63 \\
\hline 1897 & 336 & 47,668 & 575 & $20,907,319$ & $13,288,984$ & $22,102,514$ & 1.663 & 63.5 \\
\hline 1898 & 342 & 48,447 & 1,048 & $25,249,570$ & $16,047,209$ & $25,586,699$ & 1.594 & 63.6 \\
\hline 1899 & 344 & 49,667 & 4,037 & $30,219,343$ & $19,668,569$ & $34,670,417$ & 1.76 & 65.1 \\
\hline
\end{tabular}

TOTAL NUMBER OF COKE WORKS IN THE UNITED STATES.

The following table gives the number of establishments manufacturing coke in the United States at the close of each year from 1880 to 1899 , by States. According to this table the number of establishments in the last four years has largely increased. The increase is only apparent. Prior to 1896 it was customary to include under one establishment all coke works reported from one general office, and to consider them separate establishments when reported individually from the central office. In the statistics for 1896, 1897, 1898, and 1899, the word "establishment" is used to designate the number of banks or batteries of ovens which were in operation, whether reported from one office or not. When one company reported production at two or more banks of ovens, each is considered a separate establishment. 
Number of establishments in the Lnited States manufacturing coke on. December 31 of each year from 1880 to 1899.

\begin{tabular}{|c|c|c|c|c|c|c|c|c|c|c|}
\hline State or Territory. & 1880 & 1881. & 1882. & 1883. & 1884. & 1885. & 1886. & 1887. & 1888. & 1889 \\
\hline Alabama ... & 4 & $t$ & б & 6 & 8 & 11 & 14 & 15 & 18 & 19 \\
\hline Colorado ....... & 1 & 2 & 5 & 7 & S & 7 & 7 & 7 & 7 & 9 \\
\hline Georgia ...... & 1 & 1 & 1 & 1 & 1 & 2 & 2 & 2 & 1 & 1 \\
\hline Illinois . . & 6 & 6 & 7 & $\bar{t}$ & 9 & 9 & 9 & 8 & 8 & 4 \\
\hline Indiana ...... & 2 & 2 & 2 & 2 & 2 & 2 & 4 & 4 & 3 & 4 \\
\hline Indian Territory . & 1 & 1 & 1 & 1 & 1 & 1 & 1 & 1 & 1 & 1. \\
\hline Kansas ...... & 2 & 3 & 3 & 4 & 4 & 4 & 4 & 4 & 6 & 6 \\
\hline Kentucky .... & 5 & 5 & 5 & 5 & 5 & 5 & 6 & 6 & $10 i$ & 9 \\
\hline Missouri..... & 0 & 0 & 0 & 0 & 0 & 0 & 0 & 1 & 1 & 3 \\
\hline Montana ....... & 0 & 0 & 0 & 1 & 3 & 2 & 4 & 2 & 1. & 2 \\
\hline New Mexico .... & 0 & 0 & 2 & 2 & 2 & 2 & 2 & 1 & 1 & 2 \\
\hline Ohio ....... & 15 & .15 & 16 & 18 & 19 & 13 & 15 & 15 & 15 & 13 \\
\hline Pennsylvania .. & 124 & 132 & 137 & 140 & 145 & 133 & 108 & 1.51 & 120 & 109 \\
\hline Tennessee ... . . & 6 & 6 & 8 & 11 & 13 & 12 & 12 & 11 & 11 & 12 \\
\hline Texas ... & 0 & 0 & 0 & 0 & 0 & 0 & 1 & 0 & $0^{\circ}$ & 0 \\
\hline Utah....... & 1 & 1 & 1 & 1 & 1 & 1 & 1 & 0. & 0 & 1. \\
\hline Virginia $\ldots . . .$. & 0 & 0 & 0 & 1 & 1 & 1 & 2 & 2 & 2 & 2 \\
\hline Washington .... & 0 & 0 & 0 & 0 & 1 & 1 & 1 & 1 & 3 & 1. \\
\hline West Virginia .. & 18 & 19 & 22 & 24 & 27 & 27 & 29 & 39 & 52 & 53 \\
\hline Wisconsin ..... & 0 & 0 & 0 & 0 & 0 & 0 & 0 & 0 & 1. & 1 \\
\hline Wyoming ...... & 0 & 0 & 0 & 0 & 0 & 0 & 0 & 0 & 0 . & 1 \\
\hline Total. & 186 & 197 & 215 & 231 & 250 & 233 & 222 & 270 & 261 & 253 \\
\hline State or Territory. & 1890. & 1891. & 1892. & 1893. & 1894. & 1895. & 1896 . & 1897 & 1898 & 1899 \\
\hline Alabama. & 20 & 21 & 20 & 23 & 22 & 22 & 24 & 25 & 25 & 25 \\
\hline Colorado . & 8 & 7 & 9 & 8 & 8 & 9 & 11 & 12 & 12 & 12 \\
\hline Georgia & 1 & 1 & 1. & 1. & 1 & 1 & 1 & 1 & 2 & 2 \\
\hline Illinois . & 4 & 1 & 1 & 1 & 1. & 3 & 3 & 2 & 2 & 3 \\
\hline Indiana ..... . . & 4 & 2 & 2 & 2 & 2 & 2 & 2 & 2 & 2 & 2 \\
\hline Indian Territory & 1 & 1 & 1 & 1 & 1 & 1 & 2 & 2 & 2 & 3 \\
\hline Kansas . . . . . & 7 & 6 & 6 & 6 & 6 & 5 & 6 & 4 & 6 & 9 \\
\hline Kentucky .... & 9 & 7 & 5 & 4 & 6 & $\bar{j}$ & 4 & j & 5 & 6 \\
\hline Massachusetts. & 0 & 0 & 0 & 0 & 0 & 0 & 0 & 0 & 1 & 1. \\
\hline Missouri. & 3 & 3 & 3 & 3 & 3 & 3 & 3 & 3 & 3 & 4 \\
\hline Montana .... & 2 & 2 & 2 & 2 & 2 & 3 & 3 & 3 & 4 & 3 \\
\hline New Mexico .... & 2 & 1 & 1 & 1 & 1 & 1. & 1 & 2 & 3 & 3 \\
\hline New York.... & 0 & 0 & 0 & 1 & 1. & 1 & 1 & 1 & 1 & 1 \\
\hline Ohio .......... & 13 & 9 & 10 & 9 & s & s & 9 & 9 & 10 & $\varepsilon$ \\
\hline
\end{tabular}


Number of establishments in the United States manufacturing coke on December 31 of each year from 1880 to 1899 -Continued.

\begin{tabular}{|c|r|r|r|r|r|r|r|r|r|r|}
\hline State or Territory. & 1890 & 1891. & 1892. & 1893. & 1894. & 1895. & 1896. & 1897. & 1898. & 1899. \\
\hline Pennsylvania ........ & 106 & 109 & 109 & 102 & 101 & 99 & 158 & 153 & 151 & 150 \\
Tennessee .......... & 11 & 11 & 11 & 11 & 11 & 12 & 15 & 15 & 15 & 14 \\
Texas ............. & 0 & 0 & 0 & 0 & 0 & 1 & 1 & 1 & 0 & 0 \\
Utah .............. & 1 & 1 & 1 & 1 & 1 & 1 & 1 & 1 & 1 & 1 \\
Virginia ............ & 2 & 2 & 2 & 2 & 2 & 5 & 7 & 6 & 6 & 6 \\
Washington ......... & 2 & 2 & 3 & 3 & 3 & 3 & 3 & 3 & 2 & 2 \\
West Virginia....... & 55 & 55 & 72 & 75 & 78 & 78 & 84 & 84 & 87 & 87 \\
Wisconsin ........... & 1 & 1 & 1 & 1 & 1 & 1 & 1 & 1 & 1 & 1 \\
Wyoming ........... & 1 & 1 & 1 & 1 & 1 & 1 & 1 & 1 & 1 & 1 \\
\hline Total ........... & 253 & 243 & 261 & 258 & 260 & 265 & 341 & 336 & 342 & 344 \\
\hline
\end{tabular}

The number of establishments in the country for each year since 1850 for which there are any returns is as follows:

Number of coke establishments in the United States since 1850.

\begin{tabular}{|c|c|c|c|}
\hline Year. & Number. & Year. & Number. \\
\hline 1850 (census year) ........ & 4 & 1888, Decembèr $31 \ldots \ldots$. & 261 \\
\hline 1860 (census year) ........ & 21 & 1889, December $31 \ldots$ & 253 \\
\hline 1870 (census year) ........ & 25 & 1890, December $31 \ldots$ & 253 \\
\hline 1880 (census year) . ....... & 149 & 1891, December $31 \ldots$ & 243 \\
\hline 1880, December $31 \ldots$ & 186 & 1892, December $31 \ldots \ldots$ & 261 \\
\hline 1881, December $31 \ldots \ldots$ & 197 & 1893, December $31 \ldots$ & 258 \\
\hline 1882, December $31 \ldots \ldots$ & 215 & 1894, December $31 \ldots$ & 260 \\
\hline 1883, December $31 \ldots \ldots$ & 231 & 1895, December $31 \ldots$ & 265 \\
\hline 1884, December $\$ 1 \ldots \ldots \ldots$ & 250 & 1896, December $31 \ldots$ & 341 \\
\hline 1885, December $31 \ldots \ldots$ & 233 & 1897, December $31 \ldots$ & 336 \\
\hline 1886, December $31 \ldots \ldots$ & 222 & 1898, December $31 \ldots$ & 342 \\
\hline 1887, December 31 ....... & 270 & 1899, December 31 . . . . . . & 344 \\
\hline
\end{tabular}

As previously stated, the "number of establishments" in the last four years refers to the number of banks or batteries of ovens from which reports were received. Previously it was used to designate the number of firms or corporations engaged in coke making. The number of firms engaged in the industry in 1899 was 273 , an increase in sixteen years of only a little more than 18 per cent, whereas, as shown in the next table, the number of coke ovens has increased 176 per cent: In the same period the coke product has increased over 200 per cent, illustrating very clearly the tendency of carrying on large indus-

21 GEOL, PT $6-34$ 
trial enterprises under one management rather than to distribute the business among a larger number of smaller concerns. In 1883 the average number of ovens to each firm or corporation was 79 , and the average yearly production by each firm about 23,600 tons. In 1899 the average number of ovens to a firm was 182 , and the average production per firm 72,046 tons, showing that while the number of firms has increased only about 18 per cent in sixteen years, the average number of ovens to each has increased 130 per cent, and the average production per firm 205 per cent.

Of the 273 firms and corporations from whom reports were received in 1899,22 produced no coke. The total number of ovens owned by these 22 firms was 1,302, an average of 54 ovens each. Nearly all of the idle concerns were small producers. In addition to these there were 2,252 ovens idle, which were portions of plants that produced coke in 1899. The total number of ovens idle in 1899 was 3,554, which deducted from the whole number of 49,667 , leaves 46,113 ovens in active operation during the year. These distributed among the 251 active firms made an average of 188 ovens to each, as against an average of 54 for the idle ones.

\section{NUMBER OF COKE OVENS IN THE UNITED STATES.}

In the following table is presented a statement showing the number of ovens in existence in each State and Territory on December 31 of each year since 1880 . In the earlier years covered by this table some coke was made in pits and on the ground, but in later years little, if any, coke has been made except in ovens. Even when testing the adaptability of certain coals for coke making, it has been found advisable to ship the coals, frequently considerable distances, to where the experiments were to be made in ovens, beehive and by-product, so that a better judgment may be formed as to the proper kind of oven to be constructed.

The last four years have seen a noticeable increase in the number of by-product ovens built in the United States. In 1896 there were 160 by-product ovens in operation, exclusive of 30 Newton-Chambers ovens at Latrobe, Pennsylvania, and 3 Slocum ovens at Bolivar, which have not been operated as by-product ovens. At the close of 1897 there were 280 by-product ovens in operation. In December, 1898, there were 520 in existence and 500 more under construction. The statistics for 1899 show 1,020 retort ovens in operation and 65 building. 
COKE.

Number of coke ovens in the United States on December 31 of each year from 1880 to 1899.

\begin{tabular}{|c|c|c|c|c|c|c|c|c|c|c|}
\hline State or Territory. & 1880. & 1881. & 1882. & 1883. & 1884 & 1885. & 1886. & 1887. & 1888. & 1889. \\
\hline Alabama... & 316 & 416 & 536 & 767 & 976 & 1,075 & 1,301 & 1,555 & 2,475 & 3,944 \\
\hline Colorado... & 200 & 267 & 344 & 352 & 409 & 434 & 483 & 532 & 602 & 834 \\
\hline Georgia........ & 140 & 180 & 220 & 264 & 300 & 300 & 300 & 300 & 290 & 300 \\
\hline Illinois........ & 176 & 176 & 304 & 316 & 325 & 320 & 335 & 278 & 221 & 149 \\
\hline Indiana........ & 45 & 45 & 37 & 37 & 37 & 37 & 100 & 119 & 103 & 111 \\
\hline Indian Ter..... & 20 & 20 & 20 & 20 & 20 & 40 & 40 & 80 & 80 & 78 \\
\hline Kansas...... & 6 & 15 & 20 & 23 & 23 & 23 & 36 & 39 & 58 & 68 \\
\hline Kentucky.. & 45 & 45 & 45 & 45 & 45 & 33 & 76 & 98 & 132 & 166 \\
\hline Missouri ...... & 0 & 0 & 0 & 0 & 0 & 0 & 0 & 4 & 4 & 9 \\
\hline Montana.... & 0 & 0 & 0 & 2 & 5 & 2 & 16 & 27 & 40 & 90 \\
\hline New Mexico. & 0 & 0 & 0 & 12 & 70 & 70 & 70 & 70 & 70 & 70 \\
\hline New York.... & $\mathbf{0}$ & 0 & 0 & 0 & 0 & 0 & 0 & 0 & 0 & 0 \\
\hline Ohio ........ & 616 & 641. & 647 & 682 & 732 & 642 & 560 & 585 & 547 & 462 \\
\hline Pennsylvania. & 9,501 & 10,881 & 12,424 & 13,610 & 14,285 & 14,553 & 16,314 & 18,294 & 20,381 & 22,143 \\
\hline Tennessee ..... & 656 & 724 & 861 . & 992 & 1,105 & 1,387 & 1,485 & 1,560 & 1,634 & 1,639 \\
\hline Texas......... & 0 & 0 & 0 & 0 & 0 & 0 & 0 & 0 & 0 & 0 \\
\hline Utah ........... & 20 & 20 & 20 & 20 & 20 & 20 & 20 & 0 & 0 & 34 \\
\hline Virginia & 0 & 0 & 0 & 200 & 200 & 200 & 350 & 350 & 550 & 550 \\
\hline Washington. & 0 & 0 & 0 & 0 & 0 & 2 & 11 & 30 & 30 & 30 \\
\hline West Virginia. & 631 & 689 & 878 & 962 & 1,005 & 978 & 1,100 & 2,080 & 2,792 & 3,438 \\
\hline Wisconsin...... & 0 & 0 & 0 & 0 & 0 & 0 & 0 & 0 & 50 & 50 \\
\hline Wyoming .. & 0 & 0 & 0 & 0 & 0 & 0 & 0 & 0 & 0 & 0 \\
\hline Total. & 12,372 & 14,119 & 16,356 & 18,304 & 19,557 & 20,116 & 22,597 & 26,001 & 30,059 & 34,165 \\
\hline State or Territory. & 1890. & 1891. & 1892. & 1893. & 1894. & 1895. & 1896. & 1897. & 1898. & 1899. \\
\hline Alabama. & 4,805 & 5,068 & 5,320 & 5,548 & 5,551 & 5,658 & 5,363 & 5,365 & 5,456 & 5,599 \\
\hline Colorado.. & 916 & 948 & 1,128 & 1,154 & 1,154 & 1,169 & 1,275 & 1,273 & 1,253 & 1,243 \\
\hline Georgia .... & 300 & 300 & 300 & 338 & 338 & 330 & 334 & 300 & 350 & 350 \\
\hline Illinois.... & 148 & 25 & 24 & 24 & 24 & 129 & 127 & 126 & 126 & 130 \\
\hline Indiana....... & 101 & 84 & 84 & 94 & 94 & 94 & 94 & 94 & 94 & 52 \\
\hline Indian Ter... & 78 & 80 & 80 & 80 & 80 & 80 & 130 & 130 & 130 & 130 \\
\hline Kansas....... & 68 & 72 & 75 & 75 & 61 & 55 & 55 & 57 & 47 & 95 \\
\hline Kentucky...... & 175 & 115 & 287 & 283 & 293 & 293 & 264 & 268 & 292 & 300 \\
\hline Massachusetts & & & & & & & & & & 400 \\
\hline Missouri ....... & 10 & 10 & 10 & 10 & 10 & 10 & 7 & 15 & 8 & 12 \\
\hline Montana...... & 140 & 140 & 153 & 153 & 153 & 303 & 303 & 303 & 318 & 303 \\
\hline New Mexico... & 70 & $a 0$ & 50 & 50 & 50 & 50 & 50 & 126 & 190 & 190 \\
\hline New York.... & 0 & 0 & 0 & 12 & 12 & 12 & 25 & 25 & 25 & 25 \\
\hline Ohio ....... & 443 & 421 & 436 & 435 & 363 & 377 & 431 & 433 & 441 & 385 \\
\hline Pennsylvania & 23,430 & 25,324 & 25,366 & 25,744 & 25,824 . & 26,042 & 26,658 & 26,910 & 27,157 & 27,591 \\
\hline Tennessee ..... & 1,664 & 1,995 & 1,941 & 1,942 & 1,860 & 1,903 & 1,861 & 1,948 & 1,949 & 2,040 \\
\hline Texas............ & 0 & 0 & 0 & 0 & 0 & 6 & 60 & 20 & 0 & 0 \\
\hline Utah ....... & 80 & 80 & 83 & 83 & 83 & 84 & 104 & 104 & 104 & 104 \\
\hline Virginia. & 550 & 550 & 594 & 594 & 736 & 832 & 1,138 & 1,453 & 1,564 & 1,588 \\
\hline Washington.... & 30 & 80 & $84^{\circ}$ & 84 & 84 & 110 & 120 & 120 & 90 & 90 \\
\hline West Virginia.. & 4,060 & 4,621 & 5,843 & 7,354 & 7,858 & 7,834 & 8,351 & 8,404 & 8,659 & 8,846 \\
\hline Wisconsin...... & 70 & 120 & 120 & 120 & 120 & 120 & 120 & 120 & 120 & 120 \\
\hline Wyoming ....... & 20 & 24 & 24 & 24 & 24 & 74 & 74 & 74 & 74 & 74 \\
\hline Total. & 37,158 & 40,057 & 42,002 & 44,201 & 44,772 & 45,565 & 46,944 & 47,668 & 48,447 & 49,667 \\
\hline
\end{tabular}

$a$ Coke was made in pits. 
It will seem from the above table that the total number of ovens in the United .States in 1899 was 49,667 as against 48,447 in 1898 , an increase of 1,220 ovens, of which increase 500 ovens were of the by-product types. The increase in the number of ovens from 1898 to 1899 was the largest yearly increase since 1893 . Pennsyvania showed the greatest increase. Massachusetts appears in the list for the first time, with a total of 400 Otto-Hoffman ovens.

Of the total number of ovens given in the foregoing table 3,554 were not operated in 1899. The idle ovens were distributed as follows: Pennsylvania, 941; West Virginia, 1,040; Alabama, 543; Ohio, 150; Illinois, 126; Georgia, 150; Kentucky, 10; Tennessee, 280; New Mexico, 76; Montana, 100; Colorado, 18; Washington, 30; Kansas, 46; Indiana, 40; Missouri, 4.

\section{NUMBER OF COKE OVENS BUILDING IN THE UNITED STATES.}

In the following table is presented a statement showing the number of ovens in course of construction at the close of each year since 1880 . It does not represent the increase in new ovens from year to year, nor does it include the number of new ovens completed during any one year. It is intended to show only the condition of the industry at the close of each year as represented by the works in course of construction. It will be observed that there were 4,037 ovens building at the close of 1899 , the largest number, with one exception, in the twenty years covered by these reports. There were twelve States in which ovens were building in 1899 against eight in 1898. Of the 4,037 ovens building, 3,514 , or nearly 90 per cent, were in the five principal coke-producing States.

Number of coke ovens building in the United States at the close of each year from 1880 to 1899.

\begin{tabular}{|c|c|c|c|c|c|c|c|c|c|c|}
\hline State or Territory. & 1880. & 1881. & 1882. & 1883. & 1884. & 1885. & 1886. & 1887. & 1888. & 1889 \\
\hline Alabama . & 100 & 120 & 0 & 122 & 242 & 16 & 1,012 & 1,362 & 406 & 427 \\
\hline Colorado & 50 & 0 & 0 & 0 & 24 & 0 & 0 & 0 & 100 & 50 \\
\hline Georgia & 40 & 40 & 44 & 36 & 0 & 0 & 0 & 0 & 0 & 0 \\
\hline Illinois...... & 0 & 0 & 0 & 0 & 0 & 0 & 0 & 0 & 0 & 0 \\
\hline Indiana ....... & 0 & 0 & 0 & 0 & 0 & 0 & 18 & 0 & 0 & 0 \\
\hline Indian Territory & 0 & 0 & 0 & 0 & 0 & 0 & 0 & 0 & 0 & 0 \\
\hline Kansas... & 0 & 0 & 0 & 0 & 0 & 0 & 0 & 0 & 0 & 0 \\
\hline Kentucky & 0 & 0 & 0 & 0 & 0 & 0 & 2 & 0 & 2 & 100 \\
\hline Missouri........ & 0 & 0 & 0 & 0 & 0 & 0 & 0 & 0 & 0 & 0 \\
\hline Montana & 0 & 0 & 0 & 0 & 12 & 0 & 0 & 0 & 0 & 50 \\
\hline New Mexico.... & 0 & 0 & 12 & 28 & 0 & 0 & 0 & 0 & 0 & 0 \\
\hline New York .... & 0 & 0 & 0 & 0 & 0 & 0 & 0 & 0 & 0 & 0 \\
\hline Ohio . . . . . . & 25 & 0 & 0 & 0 & 0 & 0 & 0 & 223 & 12 & 0 \\
\hline
\end{tabular}


COKE.

Number of coke ovens building in the United States at the close of each year from 1880 to 1899-Continued.

\begin{tabular}{|c|c|c|c|c|c|c|c|c|c|c|}
\hline State or Territory. & 1880. & 1881. & 1882 & 1883. & 1884. & 1885. & 1886. & 1887. & 1888. & 1889. \\
\hline Pennsylvania & 836 & 761 & 642 & 211 & 232 & 317 & 2,558 & 802 & 1,565 & 567 \\
\hline Tennessee & 68 & 84 & 14 & 10 & 175 & 36 & 126 & 165 & 84 & 40 \\
\hline Texas ....... & 0 & 0 & 0 & 0 & 0 & 0 & 0 & 0 & 0 & 0 \\
\hline Virginia .... & 0 & 0 & 0 & 0 & 0 & 0 & 100 & 300 & 0 & 250 \\
\hline Washington .... & 0 & 0 & 0 & 0 & 0 & 0 & 21 & 0 & 100 & 0 \\
\hline West Virginia. & 40 & 0 & 0 & 0 & 127 & 63 & 317 & 742 & 318 & 631 \\
\hline Wisconsin & 0 & 0 & 0 & 0 & 0 & 0 & 0 & 0 & 0 & 0 \\
\hline Wyoming & 0 & 0 & 0 & 0 & 0 & 0 & 0 & 0 & 0 & 0 \\
\hline Total. . & 1,159 & 1,005 & 712 & 407 & 812 & 432 & 4,154 & 3,594 & 2,587 & 2,115 \\
\hline State or Territory. & 1890. & 1891. & 1892. & 1893. & 1894. & 1895. & 1896. & 1897. & 1898. & 1899. \\
\hline Alabama .. & 371 & 50 & 90 & 60 & 50 & 50 & 0 & $a 120$ & 100 & 850 \\
\hline Colorado ... & 30 & 21 & 220 & 200 & 250 & 0 & 0 & 0 & 3 & 50 \\
\hline Georgia . & 0 & 0 & 0 & 0 & 0 & 0 & 0 & 0 & 0 & 100 \\
\hline Illinois .... & 0 & 0 & 0 & 0 & 0 & 0 & 0 & 0 & 0 & 26 \\
\hline Indiana ..... & 0 & 0 & 0 & 0 & 0 & 0 & 0 & 0 & 0 & 0 \\
\hline Indian Territory & 0 & 0 & 0 & 0 & 0 & 0 & 0 & 0 & 0 & 100 \\
\hline Kansas ..... & 0 & 0 & 0 & 0 & 0 & 0 & 0 & 0 & 50 & 0 \\
\hline Kentucky .. & 303 & 24 & 100 & 100 & 0 & 0 & 0 & 0 & 2 & 130 \\
\hline Massachusetts... & 0 & 0 & 0 & 0 & 0 & 0 & 0 & 0 & $b 400$ & 0 \\
\hline Missouri..... & 0 & 0 & 0 & 0 & 0 & 0 & 0 & 0 & 0 & 0 \\
\hline Montana .... & 0 & 0 & 0 & 0 & 0 & 0 & 0 & 0 & 0 & 0 \\
\hline New Mexico. & 0 & 0 & 0 & 0 & 0 & 0 & 0 & 0 & 0 & 0 \\
\hline New York ... & 0 & 0 & 0 & 0 & $a 13$ & $a 13$ & 0 & 0 & 0 & $f 5$ \\
\hline Ohio ......... & 1 & 0 & 0 & 0 & 0 & 0 & 0 & 0 & 0 & 0 \\
\hline Pennsylvania. & 74 & 11 & 269 & 19 & 118 & $c 170$ & $d 154$ & 307 & $e 292$ & 1,666 \\
\hline Tennessee & 292 & 0 & 0 & 0 & 0 & 0 & 100 & 0 & 40 & 62 \\
\hline Texas .... & 0 & 0 & 0 & 0 & 0 & 0 & 0 & 0 & 0 & 0 \\
\hline Utah ....... & 0 & 0 & 0 & 0 & 0 & 0 & 0 & 0 & 0 & 0 \\
\hline Virginia .... & 250 & 250 & 206 & 206 & 100 & 350 & 101 & 110 & 0 & 429 \\
\hline Washington . & 80 & 0 & 30 & 0 & 0 & 0 & 0 & 0 & 0 & 0 \\
\hline West Virginia... & 334 & 555 & 978 & 132 & 60 & 55 & 28 & 38 & 161 & $g 619$ \\
\hline Wisconsin ...... & 0 & 0 & 0 & 0 & 0 & 0 & 0 & 0 & 0 & 0 \\
\hline Wyoming ... & 0 & 0 & 0 & 0 & 0 & 0 & 0 & 0 & 0 & 0 \\
\hline Total. & 1,735 & 911 & 1,893 & 717 & 591 & 638 & 383 & 575 & 1,048 & 4,037 \\
\hline
\end{tabular}




\section{PRODUCTION OF COKE SINCE I880, BY STATES}

A statement of the amount of coke produced in each State and Territory during the last twenty years is presented in the following table. It exhibits an interesting history of the growth of the industry in each State. The total production in 1899 was 20 per cent in excess of that of 1898 , double that of 1894 , more than three times that of 1886 , four times that of 1882, and nearly six times that of 1880 .

Amount of coke produced in the United States from 1880 to 1899, inclusive, by States and Territories.

[Short tons.]

\begin{tabular}{|c|c|c|c|c|c|}
\hline State or Territory. & 1880. & 1881. & 1882. & 1883. & 1884. \\
\hline Alabama ..... & 60,781 & 109,033 & 152,940 & 217,531 & 244,009 \\
\hline Colorado . ..... & 25,568 & 48,587 & 102,105 & 133,997 & 115,719 \\
\hline Georgia ..... & 38,041 & 41,376 & 46,602 & 67,012 & 79,268 \\
\hline Illinois ...... & 12,700 & 14,800 & 11,400 & 13,400 & 13,095 \\
\hline Indiana ...... & 0 & 0 & 0 & $\theta$ & $\boldsymbol{0}$ \\
\hline Indian Territory ... & 1,546 & 1,768 & 2,025 & 2,573 & 1,912 \\
\hline Kansas ....... & 3,070 & 5,670 & 6,080 & 8,430 & 7,190 \\
\hline Kentucky .... & 4,250 & 4,370 & 4,070 & 5,025 & 2,223 \\
\hline Missouri....... & 0 & 0 & 0 & 0 & 0 \\
\hline Montana ......... & 0 & 0 & 0 & 0 & 75 \\
\hline New Mexico... & 0 & 0 & 1,000 & 3,905 & 18,282 \\
\hline New York.... & 0 & 0 & 0 & 0 & 0 \\
\hline Ohio .......... & 100,596 & 119,469 & 103,722 & 87,834 & 62,709 \\
\hline Pennsylvania .. & $2,821,384$ & $3,437,708$ & $3,945,034$ & $4,438,464$ & $3,822,128$ \\
\hline Tennessee .... & 130,609 & 143,853 & 187,695 & 203,691 & 219,723 \\
\hline Texas ....... & 0 & 0 & 0 & 0 & 0 \\
\hline Utah ......... & 1,000 & 0 & 250 & 0 & 0 \\
\hline Virginia ....... & 0 & 0 & 0 & 25,340 & 63,600 \\
\hline Washington ... & 0 & 0 & 0 & $\cdots$ & 400 \\
\hline West Virginia. - & 138,755 & 187,126 & 230,398 & 257,519 & 223,472 \\
\hline Wisconsin ........ & 0 & 0 & 0 & 0 & 0 \\
\hline Wyoming .......... & 0 & 0 & 0 & 0 & 0 \\
\hline Total. & $3,338,300$ & $4,113,760$ & $4,793,321$ & $5,464,721$ & $4,873,805$ \\
\hline
\end{tabular}


COKE.

Amount of coke produced in the United States from 1880 to 1899, inclusive, by States and Territories-Continued.

[Short tons.]

\begin{tabular}{|c|c|c|c|c|c|}
\hline State or Territory. & 1885. & 1886. & 1887. & 1888. & 1889. \\
\hline Alabama ......... & 301,180 & 375,054 & 325,020 & 508,511 & $1,030,510$ \\
\hline Colorado ...... & 131,960 & 142,797 & 170,698 & 179,682 & 187,638 \\
\hline Georgia ...... & 70,669 & 82,680 & 79,241 & 83,721 & 94,727 \\
\hline Illinois ....... & 10,350 & 8,103 & 9,198 & 7,410 & 11,583 \\
\hline Indiana ...... & 0 & 6,124 & 17,658 & 11,956 & $8 ; 301$ \\
\hline Indian Territory .. & 3,584 & 6,351 & 10,060 & 7,502 & 6,639 \\
\hline Kansas .... & 8,050 & 12,493 & 14,950 & 14,831 & 13,910 \\
\hline Kentucky ..... & 2,704 & 4,528 & 14,565 & 23,150 & 13,021 \\
\hline Missouri ....... & 0 & 0 & 2,970 & 2,600 & 5,275 \\
\hline Montana ...... & 175 & 0 & 7,200 & 12,000 & 14,043 \\
\hline New Mexico .... & 17,940 & 10,236 & 13,710 & 8,540 & 3,460 \\
\hline New York ..... & 0 & 0 & 0 & 0 & 0 \\
\hline 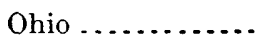 & 39,416 & 34,932 & 93,004 & 67,194 & 75,124 \\
\hline Pennsylvania ..... & $3,991,805$ & $5,406,597$ & $5,832,849$ & $6,545,779$ & $7,659,055$ \\
\hline Tennessee ..... & 218,842 & 368,139 & 396,979 & 385,693 & 359,710 \\
\hline Texas .......... & 0 & 0 & 0 & 0 & 0 \\
\hline Utah ........... & 0 & 0 & 0 & 0 & 761 \\
\hline Virginia . . . . . & 49,139 & 122,352 & 166,947 & 149,199 & 146,528 \\
\hline Washington ...... & 311 & 825 & 14,625 & 0 & 3,841 \\
\hline West Virginia.. & 260,571 & 264,158 & 442,031 & 531,762 & 607,880 \\
\hline Wisconsin .. & 0 & 0 & 0 & 500 & 16,016 \\
\hline Wyoming .... & 0 & 0 & 0 & 0 & 0 \\
\hline Total & $5,106,696$ & $6,845,369$ & $7,611,705$ & $8,540,030$ & $10,258,022$ \\
\hline State or Territory. & 1890. & 1891. & 1892. & 1893. & 1894. \\
\hline Alabama.. & $1,072,942$ & $1,282,496$ & $1,501,571$ & $1,168,085$ & 923,817 \\
\hline Colorado .. & 245,756 & 277,074 & 365,920 & 346,981 & 301,140 \\
\hline Georgia ... & 102,233 & 103,057 & 81,807 & 90,726 & 92,029 \\
\hline Illinois ... & 5,000 & 5,200 & 3,170 & 2,200 & 2,200 \\
\hline Indiana .... & 6,013 & 3,798 & 2,207 & 5,724 & 6,551 \\
\hline Indian Territory... & 6,639 & 9,464 & 3,569 & 7,135 & 3,051 \\
\hline Kansas .... & 12,311 & 14,174 & 9,132 & 8,565 & 8,439 \\
\hline Kentucky . & 12,343 & 33,777 & 36,123 & 48,619 & 29,748 \\
\hline Missouri... & 6,136 & 6,872 & 7,299 & 5,905 & 2,250 \\
\hline Montana .. & 14,427 & 29,009 & $34, \dot{5} 57$ & 29,945 & 17,388 \\
\hline New Mexico. & 2,050 & 2,300 & 0 & 5,803 & 6,529 \\
\hline New York.... & 0 & 0 & 0 & 12,850 & 16,500 \\
\hline Ohio ... & 74,633 & 38,718 & 51,818 & 22,436 & 32,640 \\
\hline
\end{tabular}


Amount of coke produced in the United States, from 1880 to 1899, inclusive, by Slates and Territories-Continued.

[Short tons.]

\begin{tabular}{|c|c|c|c|c|c|}
\hline State or Territory. & 1890. & 1891. & 1892. & 1893. & 1894. \\
\hline Pennsylvania ..... & $8,560,245$ & $6,954,846$ & $8,327,612$ & $6,229,051$ & $6,063,777$ \\
\hline Tennessee ........ & 348,728 & 364,318 & 354,096 & 265,777 & 292,646 \\
\hline Texas ............ & 0 & 0 & 0 & 0 & 0 \\
\hline 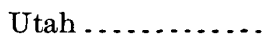 & 8,528 & 7,949 & 7,309 & 16,005 & 16,056 \\
\hline Virginia ........ & 165,847 & 167,516 & 147,912 & 125,092 & 180,091 \\
\hline Washington ...... & 5,837 & 6,000 & 7,177 & 6,731 & 5,245 \\
\hline West Virginia .... & 833,377 & $1,009,051$ & $1,034,750$ & $1,062,076$ & $1,193,933$ \\
\hline Wisconsin ...... & 24,976 & 34,387 & 33,800 & 14,958 & 4,250 \\
\hline Wyoming .... & 0 & 2,682 & 0 & 2,916 & 4,352 \\
\hline Total ... & $11,508,021$ & $10,352,688$ & $12,010,829$ & $9,477,580$ & $9,203,632$ \\
\hline State or Territory. & 1895. & 1896. & 1897. & 1898. & 1899. \\
\hline Alabama ..... & $1,444,339$ & $1,479,437$ & $1,443,017$ & $1,663,020$ & $1,787,809$ \\
\hline Colorado ...... & 317,838 & 343,313 & 319,036 & 445,982 & $c 530,424$ \\
\hline Georgia ......... & 60,212 & 53,673 & 33,000 & 49,529 & 50,907 \\
\hline Illinois. . . . . . . . & 2,250 & 2,600 & 1,549 & 2,325 & $? 270$ \\
\hline Indiana ..... & 4,804 & 4,353 & 2,904 & 1,825 & 2,370 \\
\hline Indian Territory.. & 5,175 & 21,021 & 30,364 & 34,110 & 24,339 \\
\hline Kansas ...... & 5,287 & 4,785 & 6,181 & 4,180 & 14,476 \\
\hline Kentucky ...... & 25,460 & 27,107 & 32,117 & 22,242 & 81,095 \\
\hline Massachusetts .. & 0 & 0 & 0 & - 0 & $(a)$ \\
\hline Missouri.... & $2, .028$ & 2,500 & 2,593 & 740 & 2,860 \\
\hline Montana ... & 25,337 & 60,078 & 67,849 & 52,009 & 56,376 \\
\hline New Mexico... & 14,663 & 24,228 & 1,438 & 6,980 & 44,134 \\
\hline New York ... & 18,521 & $(a)$ & (a) & $(a)$ & $(a)$ \\
\hline Ohio ............ & 29,050 & 80,868 & 95,087 & 85,535 & 83,878 \\
\hline Pennsylvania .. & $9,404,215$ & $b 7,356,502$ & $b 8,966,924$ & $610,715,302$ & $b 13,577,870$ \\
\hline Tennessee .. & 396,790 & 339,202 & 368,769 & 394,545 & 435,308 \\
\hline Texas .......... & 286 & 0 & 394 & 0 & 0 \\
\hline Utah .......... & 22,519 & 20,447 & 23,617 & 28,826 & $(c)$ \\
\hline Virginia ..... & 244,738 & 268,081 & 354,067 & 531,161 & 618,707 \\
\hline Washington ...... & 15,129 & 25,949 & 26,189 & $\overline{30}, 1 \overline{9} 7$ & 30,372 \\
\hline West Virginia..... & $1,285,206$ & $1,649,755$ & $1,472,666$ & $1,925,071$ & $2,278,577$ \\
\hline Wisconsin .. & 4,972 & 5,332 & 17,216 & 35,280 & 33,437 \\
\hline Wyoming & 4,895 & 19,542 & 24,007 & 18,350 & 15,630 \\
\hline Total. & $13,333,714$ & $11,788,773$ & $13,288,984$ & $16,047,209$ & $19,668,569$ \\
\hline
\end{tabular}


VALUE AND AVERAGE SELLING PRICE OF COKE.

In the following table is given the total value of coke produced in the United States in each year from 1880 to 1899, inclusive. The great increase in 1899 as compared with any previous year is especially worthy of note:

Total value at the ovens of the coke made in the United States from 1880 to 1899, inclusive, by States and Territories.

\begin{tabular}{|c|c|c|c|c|c|}
\hline State or Territory. & 1880. & 1881. & 1882. & 1883. & 1884. \\
\hline Alabama .. & $\$ 183,063$ & $\$ 326,819$ & $\$ 425,940$ & $\$ 598,473$ & $\$ 609,185$ \\
\hline Colorado ...... & 145,226 & 267,156 & 476,665 & 584,578 & 409,930 \\
\hline Georgia ....... & 81,789 & 88,753 & 100,194 & 147,166 & 169,192 \\
\hline Illinois... & 41,950 & 45,850 & 29,050 & 28,200 & 25,639 \\
\hline Indiana ....... & 0 & 0 & 0 & 0 & 0 \\
\hline Indian Territory . & 4,638 & 5,304 & 6,075 & 7,719 & 5,736 \\
\hline Kansas .......... & 6,000 & 10,200 & 11,460 & 16,560 & 14,580 \\
\hline Kentucky .... & 12,250 & 12,630 & 11,530 & 14,425 & 8,760 \\
\hline Missouri..... & 0 & 0 & 0 & 0 & 0 \\
\hline Montana ....... & 0 & 0 & 0 & 0 & 900 \\
\hline New Mexico.... & 0 & 0 & 6,000 & 21,478 & 91,410 \\
\hline New York.... & 0 & 0 & 0 & 0 & 0 \\
\hline Ohio ....... & 255,905 & 297,728 & 266,113 & 225,660 & 156,294 \\
\hline Pennsylvania .. & $5,255,040$ & $5,898,579$ & $6,133,698$ & $5,410,387$ & $4,783,230$ \\
\hline Tennessee .... & 316,607 & 342,585 & 472,505 & 459,126 & 428,870 \\
\hline Utah ...... & 10,000 & 0 & 2,500 & 0 & 0 \\
\hline Virginia ...... & 0 & 0 & 0 & 44,345 & 111,300 \\
\hline Washington .... & 0 & 0 & 0 & 0 & 1,900 \\
\hline West Virginia... & 318,797 & 429,571 & 520,437 & 563,490 & 425,952 \\
\hline Wisconsin .. & 0 & 0 & 0 & 0 & 0 \\
\hline Wyoming . & 0 & 0 & $\cdot 0$ & 0 & 0 \\
\hline Total. & $6,631,265$ & $7,725,175$ & $8,462,167$ & $8,121,607$ & $7,242,878$ \\
\hline State or Territory. & 1885. & 1886. & 1887. & 1888. & 1889. \\
\hline Alabama & $\$ 755,645$ & $\$ 993,302$ & $\$ 775,090$ & $\$ 1,189,679$ & $\$ 2,372,417$ \\
\hline Colorado ... & 512,162 & 569,120 & 682,778 & 716,305 & 643,479 \\
\hline Georgia .... & 144,198 & 179,031 & 174,410 & 177,907 & 149,059 \\
\hline Illinois ...... & 27,798 & 21,487 & 19,594 & 21,038 & 29,764 \\
\hline Indiana ........ & 0 & 17,953 & 51,141 & 31,993 & 25,922 \\
\hline Indian Territory & 12,902 & 22,229 & 33,435 & 21,755 & 17,957 \\
\hline Kansas ..... & 13,255 & 19,204 & 28,575 & 29,073 & 26,593 \\
\hline Kentucky ..... & 8,499 & 10,082 & 31,730 & 47,244 & 29,769 \\
\hline
\end{tabular}


Total value at the ovens of the coke made in the United States from 1880 to 1899, inclusive, by States and Territories-Continued.

\begin{tabular}{|c|c|c|c|c|c|}
\hline State or Territory. & 1885. & 1886. & 1887. & 1888. & 1889. \\
\hline Missouri...... & 0 & 0 & $\$ 10,395$ & $\$ 9,100$ & $\$ 5,800$ \\
\hline Montana .... & $\$ 2,063$ & 0 & 72,000 & 96,000 & 122,023 \\
\hline New Mexico & 89,700 & $\$ 51,180$ & 82,260 & 51,240 & 18,408 \\
\hline New York & 0 & 0 & 0 & 0 & 0 \\
\hline Ohio ......... & 109,723 & 94,042 & 245,981 & 166,330 & 188,222 \\
\hline Pennsylvania & $4,981,656$ & $7,664,023$ & $10,746,352$ & $8,230,759$ & $10,743,492$ \\
\hline Tennessee .... & 398,459 & 687,865 & 870,900 & 490,491 & 731,496 \\
\hline Utah. & 0 & 0 & 0 & 0 & 3,042 \\
\hline Virginia ...... & 85,993 & 305,880 & 417,368 & 260,000 & 325,861 \\
\hline Washington .. & 1,477 & 4,125 & 102,375 & 0 & 30,728 \\
\hline West Virginia.. & 485,588 & 513,843 & 976,732 & 905,549 & $1,074,177$ \\
\hline Wisconsin & 0 & 0 & 0 & 1,500 & 92,092 \\
\hline Wyoming . & 0 & 0 & 0 & 0 & 0 \\
\hline Tota & $7,629,118$ & $11,153,366$ & $15,321,116$ & $12,445,963$ & $16,630,301$ \\
\hline State or Territory. & 1890. & 1891. & 1892. & 1893. & 1894. \\
\hline Alabama & $\$ 2,589,447$ & $\$ 2,986,242$ & $\$ 3,464,623$ & $\$ 2,648,632$ & $\$ 1,871,348$ \\
\hline Colorado: & 959,246 & 896,984 & $a 1,234,320$ & $u 1,137,488$ & $a 903,970$ \\
\hline Georgia .... & 150,995 & 231,878 & 163,614 & 136,089 & 116,286 \\
\hline Illinois ..... & 11,250 & 11,700 & 7,133 & 4,400 & 4,400 \\
\hline Indiana ... & 19,706 & 7,596 & 6,472 & 9,048 & 13,102 \\
\hline Indian Territory & 21,577 & 30,483 & 12,402 & 25,072 & 10,693 \\
\hline Kansas.... . & 29,116 & 33,296 & 19,906 & 18,640 & 15,660 \\
\hline Kentucky .. & 22,191 & 68,281 & 72,563 & 97,350 & 51,566 \\
\hline Missouri...... & 9,240 & 10,000 & 10,949 & 9,735 & 3,563 \\
\hline Montana .... & 125,655 & 258,523 & 311,013 & 239,560 & 165,187 \\
\hline New Mexico... & 10,025 & 10,925 & 0 & 18,476 & 28,213 \\
\hline New York.. & 0 & 0 & 0 & 35,925 & . \\
\hline Ohio ......... & 218,090 & 76,901 & 112,907 & 43,671 & 90,875 \\
\hline Pennsylvania . & $16,333,674$ & $12,679,826$ & $15,015,336$ & $9,468,036$ & $6,585,489$ \\
\hline Tennessee .... & 684,116 & 701,803 & 724,106 & 491,523 & 480,124 \\
\hline Utah ..... & 37,196 & 35,778 & (b) & (b) & $(b)$ \\
\hline Virginia . . .... & 278,724 & 265,107 & 322,486 & 282,898 & $2 \hat{9} 5,747$ \\
\hline Washington ... & 46,696 & 42,000 & 50,446 & 34,207 & 18,249 \\
\hline West Virginia. . & $1,524,746$ & $1,845,043$ & $1,821,965$ & $1,716,907$ & $1,639,687$ \\
\hline Wisconsin & 143,612 & 192,804 & 185,900 & 95,851 & 19,465 \\
\hline Wyoming & 0 & 8,046 & 0 & 10,206 & 15,232 \\
\hline Total. & $23,215,302$ & $20,393,216$ & $23,536,141$ & $16,523,714$ & 28,856 \\
\hline
\end{tabular}


COKE.

Total value at the ovens of the coke made in the United States from 1880 to 1899, inclusive, by States and Territories-Continued.

\begin{tabular}{|c|c|c|c|c|c|}
\hline State or Territory. & 1895 . & 1896. & 1897. & 1898. & 1899. \\
\hline Alabama & $\$ 3,033,521$ & $\$ 3,064,960$ & $\$ 3,094,461$ & $\$ 3,378,946$ & $\$ 3,634,471$ \\
\hline Colorado .... & $a 940,987$ & $a 1,046,306$ & $a 999,216$ & $a 1,230,428$ & $a 1,333,769$ \\
\hline Georgia ....... & 70,580 & 68,486 & 42,240 & 77,230 & 116,917 \\
\hline Illinois ........ & 4,500 & 5,200 & 2,895 & 4,686 & 5.565 \\
\hline Indiana ....... & 9,333 & 8,647 & 5,795 & 3,194 & \\
\hline Indian Territory & 17,657 & 73,574 & 104,725 & 96,639 & 71,965 \\
\hline Kansas....... & 11,289 & 8,676 & 9,272 & 6,455 & 30,817 \\
\hline Kentucky ..... & 37,249 & 42,062 & 45,454 & 32,213 & 161,454 \\
\hline Massachusetts. & $\cdots \cdots$ & n....... & $\cdots$ & $\cdots$ & (b) \\
\hline Missouri..... & 2,442 & 4,131 & 3,890 & 1,050 & 5,520 \\
\hline Montana ...... & 189,856 & 425,483 & 467,481 & 359,174 & 356,190 \\
\hline New Mexico... & 29,491 & 48,453 & 3,232 & 14,625 & 99,217 \\
\hline New York & $\ldots \ldots \ldots$ & - $\quad(b)$ & (b) & (b) & (b) \\
\hline Ohio .... & 69,655 & 208,789 & 235,784 & 211,558 & 255,129 \\
\hline Pennsylvania . & $11,908,162$ & $c 13,182,859$ & $c 13,727,966$ & $c 16,078,505$ & $d 22,881,910$ \\
\hline Tennessee .... & 754,926 & 624,011 & 667,656 & 642,920 & 850,686 \\
\hline Utah....... & (e) & $(e)$ & (e) & (e). & $(e)$ \\
\hline Virginia .... & 322,564 & 404,573 & 495,864 & 699,781 & $1,071,284$ \\
\hline Washington ... & 64,632 & 104,894 & 115,754 & 128,933 & 151,216 \\
\hline West Virginia.. & $1,724,239$ & $2,259,999$ & $1,933,808$ & $2,432,657$ & $3,480,408$ \\
\hline Wisconsin & 26,103 & 21,000 & 75,000 & 123,480 & 125,389 \\
\hline Wyoming & 17,133 & 58,626 & 72,021 & 64,225 & 38,510 \\
\hline Total. & $19,234,319$ & $21,660,729$ & $22,102,514$ & $25,586,699$ & $34,670,417$ \\
\hline
\end{tabular}

While this table gives the totals of the value as returned in the schedules, the figures do not always represent the same thing. A statement as to the actual selling price of the coke was asked for, and in most cases, including possibly 80 per cent of all the coke produced, the figures are the actual selling price. In some cases, however, the value is an estimate. A considerable amount of the coke made in the United States is produced by proprietors of blast furnaces for consumption in their own furnaces, none being sold. The value, therefore, given for this coke would be an estimate, based, in some instances, where there are coke works in the neighborhood selling coke for the general market, upon the price obtained for this coke; in other cases the cost is estimated at the cost of the coke at the furnace plus a small percentage for profit on the coking operation, while in still other cases the value given is only the actual cost of the coke at the ovens. 
In the following table is given the average value per short ton of the coke made in the United States for each year from 1880 to 1899 , inclusive, by States and Territories:

Average value per short ton at the ovens of the coke made in the United States from 1880 to 1899, inclusive, by States and Territories.

\begin{tabular}{|c|c|c|c|c|c|c|c|}
\hline State or & 1880. & 1881. & 1882. & 1883. & 1884. & 1885. & 1886. \\
\hline Alabama & $\$ 3.01$ & $\$ 3.00$ & $\$ 2.79$ & $\$ 2.75$ & $\$ 2.50$ & $\$ 2.50$ & $\$ 2.65$ \\
\hline Colorado & 5.68 & 5.29 & 4.67 & 4. 36 & 3.45 & 3.88 & 3.99 \\
\hline Georgia . & 2.15 & 2.15 & 2.15 & 2.20 & 2.13 & 2.04 & 2.17 \\
\hline Illinois ..... & 3.30 & 3.10 & 2.55 & 2.10 & 1.96 & 2.68 & 2.65 \\
\hline Indiana $\ldots . . .$. & ..... & $\ldots . .$. & $\cdots$ & $\cdots$ & $\cdots$ & ${ }_{1}$ & 2.93 \\
\hline Indian 'Territory & 3.00 & 3.00 & 3.00 & 3.00 & 3.00 & 3.60 & 3.50 \\
\hline Kansas ........... & 1.95 & 1.80 & 1.70 & 1.96 & 2.02 & 1.65 & 1.54 \\
\hline Kentucky ... & 2.88 & 2. 89 & 2.83 & 2.87 & 3.94 & 3.14 & 2.23 \\
\hline Missouri... & ... & $\cdots$ & $\cdots$ & .... & .... & ..... & $\cdots$ \\
\hline Montana & $\cdots$ & $\cdots$ & .. & ..... & 12.00 & 11.72 & $\ldots$ \\
\hline New Mexico. & .... & 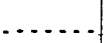 & 6.00 & 5.50 & 5.00 & 5.00 & 5.00 \\
\hline Ohio .... & 2. 54 & 2.49 & 2.57 & 2.57 & 2.49 & 2.78 & 2.69 \\
\hline Pennsylvania & 1.86 & 1. 70 & 1.55 & 1. 22 & 1.25 & 1.25 & 1.42 \\
\hline Tennessee. & 2. 42 & 2.33 & 2.52 & 2.25 & 1.95 & 1.31 & 1.87 \\
\hline Utah.. & 10.00 & & 10.00 & & & & \\
\hline Virginia . & & & & 1.75 & 1.75 & 1.75 & 2.50 \\
\hline Washington. & ... & & & & 4. 75 & 4.75 & 5.00 \\
\hline West Virginia & 2.30 & 2.30 & 2.26 & 2.19 & 1.19 & 1.86 & 1.94 \\
\hline Wisconsin & ..... & & & $\cdots$ & & $\cdots$ & ;.... \\
\hline Average.. & 1.99 & 1.88 & 1.77 & $1.4 \mathrm{c}$ & 1.49 & 1.49 & 1.63 \\
\hline State or Territory. & 1887. & 1888. & 188 & & 1890. & 1891. & 1892. \\
\hline Alabama & $\$ 2.39$ & $\$ 2.34$ & & .30 & $\$ 2.41$ & $\$ 2.33$ & $\$ 2.31$ \\
\hline Colorado . & 4.00 & 4.00 & & 3.43 & 3.90 & 3.24 & 3.31 \\
\hline Georgia . & 2.20 & 2.12 & & 1.57 & 1.48 & 2.25 & 2.00 \\
\hline Illinois. & 2.13 & 2.84 & & .57 & 2.25 & 2.25 & 2.25 \\
\hline Indiana & 2.81 & 2.68 & & 3.12 & 3.28 & 2.00 & 2.02 \\
\hline Indian Territory & 3.33 & 2.90 & & .70 & 3.25 & 3. 22 & 3.47 \\
\hline Kansas .......... & 1.91 & 1.96 & & 1.91 & 2.37 & 2. 35 & 2.18 \\
\hline Kentucky .... & 2.18 & 2.04 & & 28 & 1.80 & 2.02 & 2.01 \\
\hline Missouri....... & 3.50 & 3.50 & & 1.10 & 1.51 & 1.46 & 1.50 \\
\hline Montana ...... & 10.00 & 8. 00 & & 3.69 & 8. 71 & 8.91 & 9.00 \\
\hline New Mexico... & 6.00 & 6.00 & & 5.32 & 4. 89 & 4.75 & \\
\hline New York & & & & & & & \\
\hline Ohio. & 2. $6 \overline{5}$ & 2.48 & & 2.50 & 2.92 & 1.99 & 2.18 \\
\hline
\end{tabular}


COKE.

Average value per short ton at the ovens of the coke made in the United States from 1880 to 1899, inclusive, by States and Territories-Continued.

\begin{tabular}{|c|c|c|c|c|c|c|c|}
\hline State or Territory. & 1887. & 1888. & \multicolumn{2}{|c|}{1889.} & 1890. & 1891. & 1892. \\
\hline Pennsylvania ..... & $\$ 1.84$ & $\$ 1.26$ & \multicolumn{2}{|c|}{$\$ 1.40$} & $\$ 1.91$ & $\$ 1.82$ & $\$ 1.80$ \\
\hline Tennessee ..... & 2. 19 & 1.27 & \multicolumn{2}{|c|}{2.03} & 1.96 & 1.93 & 2.05 \\
\hline Utah .............. & $\therefore \ldots$ & $\ldots \ldots$ & \multicolumn{2}{|c|}{4.00} & 4. 36 & 4.50 & $\ldots \ldots$ \\
\hline Virginia ......... & 2.50 & 1. 74 & \multicolumn{2}{|c|}{2.22} & 1.68 & 1.58 & 2.18 \\
\hline Washington ...... & 7.00 & 0 & & 00 & 8.00 & 7.00 & 7.03 \\
\hline West Virginia .... & 2.22 & 1. 70 & & 76 & 1. 83 & 1.83 & 1. 76 \\
\hline Wisconsin .. & $\ldots$. & 3.00 & \multicolumn{2}{|c|}{5.75} & 5.75 & 5.61 & 5.50 \\
\hline Wyoming . & & & $-1-$ & $\ldots$ & $\ldots . .$. & 3.00 & ...... \\
\hline Average . & 2.01 & 1.46 & \multicolumn{2}{|c|}{ 1. 62} & 2.02 & 1.97 & 1.96 \\
\hline State or Territory. & 1893. & 1894. & 1895. & 896. & 1897. & 1898. & 1899. \\
\hline Alabama ......... & $\$ 2.27$ & $\$ 2.025$ & $\$ 2.10$ & $\$ 2.07$ & $\$ 2.14$ & $\$ 2.03$ & $\$ 2.03$ \\
\hline Colorado ... & a 3.13 & $a 2.85$ & $a 2.76$ & $a 2.88$ & a2.916 & $a 2.59$ & $a 2.51$ \\
\hline Georgia .......... & 1.50 & 1.25 & 1.17 & 1.276 & 1.28 & 1.56 & 2.30 \\
\hline Illinois . . . . . . . & 2.00 & 2.00 & 2.00 & 2.00 & 1.87 & 2.02 & 0.25 \\
\hline Indiana ....... & 1.58 & 2.00 & 1.94 & 1.99 & 1. 995 & 1.75 & 2.35 \\
\hline Indian Territory ... & 3.51 & 3.50 & 3.41 & 3.50 & 3.45 & 2.833 & 2.96 \\
\hline Kansas . . . . . . . . . & 2.18 & 1.855 & 2.14 & 1.813 & 1. 50 & 1.544 & 2.13 \\
\hline Kentucky ... & 2.00 & 1. 73 & 1.46 & 1.55 & 1. 41 & 1.448 & 1.99 \\
\hline Massachusetts & $\cdots$ & $\ldots$ & $\cdots$ & $\cdots$ & $\ldots \ldots$ & $\ldots \ldots$ & $\ldots \ldots$ \\
\hline Missouri... & 1.65 & 1.58 & 1. 20 & 1.65 & 1.50 & 1.42 & 1.93 \\
\hline Montana .......... & 8.00 & 9.50 & 7.49 & 7.08 & 6.89 & 6.906 & 6.32 \\
\hline New Mexico ....... & 3.18 & 4. 32 & 2.01 & 2.00 & 2.25 & 2.095 & 2.25 \\
\hline New York & 2.80 & $\ldots \ldots \ldots$ & $\ldots \ldots$ & $\ldots \ldots$ & $\ldots \ldots$ & $|\ldots \ldots|$ & $\ldots \ldots$ \\
\hline Ohio .... & 1.95 & 2.78 & 2.40 & 2.58 & 2.48 & 2.47 & 3.04 \\
\hline Pennsylvania ..... & 1.52 & 1.086 & 1. 266 & $b 1.792$ & 61.53 & $b 1.50$ & $b 1.69$ \\
\hline Tennessee & 1.85 & 1. 64 & 1. 90 & 1.84 & 1.81 & 1. 63 & 1.95 \\
\hline Utah ...... & $\ldots$ & $\ldots \ldots$ & $\cdots \cdots$ & & & $\cdots$ & - \\
\hline Virginia $\ldots . . . . .$. & 2.26 & 1. 64 & 1.32 & 1.509 & 1. 40 & 1.317 & 1.73 \\
\hline Washington ....... & 5.08 & 3.48 & 4. 27 & 4.04 & 4. 42 & 4.27 & 4. 98 \\
\hline West Virginia..... & 1.62 & 1.373 & 1.34 & 1.37 & 1.31 & 1.26 & 1.53 \\
\hline Wisconsin ......... & 6.41 & 4.58 & 5.25 & 3.94 & 4. 36 & 3.50 & 3.75 \\
\hline Wyoming . & 3.50 & 3.50 & 3.50 & 3.00 & 3.00 & 3.50 & 2. 46 \\
\hline Average ..... & 1.74 & 1.34 & 1.44 & 1.837 & 1. 663 & 1.594 & 1. 76 \\
\hline
\end{tabular}

$a$ Average value, including Utah.

$b$ Average value, including New York, and in 1899 Massachusetts also. 
The preceding table shows that the average price (obtained by dividing the total value by the total product) advanced from $\$ 1.59$ in 1898 to $\$ 1.76$ in 1899 , a gain of 17 cents, or a little more than 10 per cent. That the improvement in prices was general throughout the country is shown by the fact that out of twenty-two States there were only four instances in which a decline in price was shown. The most conspicuous of these were in Montana and Wyoming.

\section{RANK OF COKE-PRODUCING STATES.}

The following table gives the relative rank of the States and Territories in the production of coke from 1880 to 1899, inclusive:

Rank of the States and Territories in production of coke from 1880 to 1899.

\begin{tabular}{|c|c|c|c|c|c|c|c|c|c|c|}
\hline State or Territory. & 1880. & 1881. & 1882. & 1883. & 1884. & 1885. & 1886. & 1887. & 1888. & 1889. \\
\hline Pennsylvania. & 1 & 1 & 1 & 1 & 1 & 1 & 1 & 1 & 1 & 1 \\
\hline West Virginia. & 2 & 2 & 2 & 2 & 3 & 3 & 4 & 2 & 2 & 3 \\
\hline Alabama & 5 & 5 & 4 & 3 & 2 & 2 & 2 & 4 & 3 & 2 \\
\hline Colorado ..... & 7 & 6 & 6 & 5 & 5 & $\cdot 5$ & 5 & 5 & 5 & 5 \\
\hline Tennessee ... & 3 & 3 & 3 & 4 & 4 & 4 & 3 & 3 & 4 & 4 \\
\hline Virginia... & $\cdots$ & & $\cdots$ & 8 & 7 & 7 & 6 & 6 . & 6 & 6 \\
\hline Ohio ...... & 4 & 4 & 5 & 6 & 8 & 8 & 8 & 7 & 8 & 8 \\
\hline Montana .... & $\ldots$. & $\cdots$ & $\cdots$ & & 15 & 15 & $\cdots$ & 16 & 12 & 10 \\
\hline Georgia ..... & 6 & 7 & 7 & 7 & 6 & 6 & 7 & 8 & 7 & 7 \\
\hline Kentucky .... & 9 & 10 & 10 & 11 & 12 & 13 & 14 & 12 & 9 & 12 \\
\hline Washington .... & $\cdots$ & $\cdots$ & ... & $\cdots$ & 14 & 14 & 15 & 11 & 10 & 17 \\
\hline New Mexico.... & $\ldots$. & $\cdots$ & 12 & 12 & 9 & 9 & 10 & 13 & 14 & $18^{\circ}$ \\
\hline Indian Territory & 11 & 11 & 11 & 13 & 13 & 12 & 12 & 14 & 15 & 15 \\
\hline Utah .......... & 12 & & 13 & & & & & & $\cdots$ & 19 \\
\hline Wisconsin .... & $\cdots$ & & & .. & &. & $\cdots$ & $\cdots$ & 18 & 9 \\
\hline Kansas ........ & 10 & 9 & 9 & 10 & 11 & 11 & 9 & 10 & 11 & 11 \\
\hline Indiana & $\cdots$ & & & 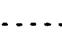 & $\cdots$ & , & 13 & 9 & 13 & 14 \\
\hline Illinois ....... & 8 & 8 & 8 & 9 & 10 & 10 & 11 & 15 & 16 & 13 \\
\hline Missouri...... & - & $\cdots$ & & & & & $\cdots \cdot$ & 17 & 17 & 16 \\
\hline Texas & & & & & & & & & & \\
\hline
\end{tabular}


COKE.

Rank of the States and Territories in production of coke from 1880 to 1899-Continued.

\begin{tabular}{|c|c|c|c|c|c|c|c|c|c|c|}
\hline State or Territory. & 1890. & 1891. & 1892. & 1893. & 1894. & $189 \overline{0}$. & 1896. & 1897. & 1896. & 1899 \\
\hline Pennsylvania & 1 & 1 & 1 & 1 & 1 & 1 & 1 & 1 & 1 & 1 \\
\hline West Virginia & 3 & 3 & 3 & 3 & 2 & 3 & 2 & 2 & 2 & 2 \\
\hline Alabama .... & 2 & 2 & 2 & 2 & 3 & 2 & 3 & 3 & 3 & 3 \\
\hline Virginia ... & 6 & 6 & 6 & 6 & 6 & 6 & 6 & 5 & 4 & 4 \\
\hline Colorado & 5 & 5 & 4 & 4 & 4 & 5 & 4 & 6 & 5 & 5 \\
\hline Tennessee ..... & 4 & 4 & 5 & 5 & 5 & 4 & 5 & 4 & 6 & 6 \\
\hline Massachusetts & $\cdots$ & $\cdots$ & & $\ldots$ & & & $\cdots$ & .. & .. & 7 \\
\hline Ohio & 8 & 8 & 8 & 10 & 8 & 8 & 7 & 7 & 7 & 8 \\
\hline Kentucky & 11 & 10 & 9 & 8 & 9 & 9 & 10 & 10 & 15 & 9 \\
\hline Montana ... & 10 & 11 & 10 & 9 & 10 & 10 & 8 & 8 & 8 & 10 \\
\hline Georgia ...... & 7 & 7 & 7 & 7 & 7 & 7 & 9 & 9 & 9 & 11 \\
\hline New & 19 & 20 & $\cdots$ & 18 & 15 & 14 & 12 & 21 & 17 & 12 \\
\hline Wisconsin . & 9 & 9 & 11 & 12 & 18 & 17 & 17 & 16 & 10 & 13 \\
\hline Washington .. & 17 & 16 & 15 & 16 & 16 & 13 & 11 & 13 & 12 & 14 \\
\hline New York .... & $\ldots \ldots$ & $\ldots$ & $\ldots$ & 13 & 11 & 12 & 16 & 12 & 14 & 15 \\
\hline Utah ...... & 13 & 14 & 13 & 11 & 12 & 11 & 14 & 15 & 13 & 16 \\
\hline Indian Territory & 14 . & 13 & 16 & 15 & 19 & 16 & 13 & 11 & 11 & 17 \\
\hline Wyoming & $\cdots$ & 19 & $\cdots$ & 20 . & 17 & 18 & 15 & 14 & 16 & 18 \\
\hline Kansas ....... & 12 & 12 & 12 & 14 & 13 & 15 & 18 & 17 & 18 & 19 \\
\hline Missouri.... & 15 & 15 & 14 & 17 & 20 & 21 & 21 & 19 & 21 & 20 \\
\hline Indiana ..... & 16 & 18 & 17 & 19 & 14 & 19 & 19 & 18 & 20 & 21 \\
\hline Illinois .... & 18 & 17 & 18 & 21 & 21 & 20 & 20 & 20 & 19 & 22 \\
\hline Texas .... & - & . & - & & & 22 & 22 & 22 & & \\
\hline
\end{tabular}

It will be seen from this table that the six leading States held in 1899 the same relative positions as in 1898. Massachusetts, appearing for the first time, takes seventh place; Kentucky advances from fifteenth to ninth, and New Mexico from seventeenth to twelfth; Indian Territory drops from eleventh to seventeenth. These are the only important changes. 
COAL CONSUMED IN THE MANUFACTURE OF COKE.

In the following table is given the total number of tons of coal used in the manufacture of coke in the United States for the years 1880 to 1899:

Amount of coal used in the manufacture of cole in the United States from 1880 to 1899, inclusive, by States and Territories.

[Short tons.]

\begin{tabular}{|c|c|c|c|c|c|}
\hline State or Territory. & 1880. & 1881. & 1882. & 1883. & 1884. \\
\hline Alabama . & 106,283 & 184,881 & 261,839 & 359,699 & 413,184 \\
\hline Colorado & 51,891 & 97,508 & 180,549 & 224,089 & 181,968 \\
\hline Georgia . & 63,402 & 68,960 & 77,670 & 111,687 & 132,113 \\
\hline Illinois ... & 31,240 & 35,240 & 25,270 & 31,370 . & 30,168 \\
\hline Indian Territory . & 2,494 & 2,852 & 3,266 & 4,150 & 3,084 \\
\hline Kansas ....... & 4,800 & 8,800 & 9,200 & 18,400 & 11,500 \\
\hline Kentucky ... & 7,206 & 7,406 & 6,006 & 8,437 & 3,451 \\
\hline Montana ....... & , & 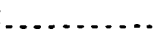 & t & , n & 165 \\
\hline New Mexico.. & $\ldots \ldots$ & ...... & 1,500 & 6,941 & 29,990 \\
\hline Ohio .... & 172,453 & 201,145 & 181,577 & 152,502 & 108,164 \\
\hline Pennsylvania. & $4,347,558$ & $5,393,503$ & $6,149,179$ & $6,823,275$ & $6,204,604$ \\
\hline Tennessee & $21.7,656$ & 241,644 & 313,537 & 330,961 & 348,295 \\
\hline Utah.... & 2,000 & 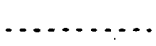 & 500 & $\ldots$ & . . . . \\
\hline Virginia . & & & & 39,000 & 99,000 \\
\hline Washington & & $\cdots$ & $\cdots$ & $\ldots \ldots$ & 700 \\
\hline West Virginia & 230,758 & 304,823 & 366,653 & 411,159 & 385,588 \\
\hline Total. & $5,237,741$ & $6,546,762$ & $7,577,646$ & $8,516,670$ & $7,951,974$ \\
\hline State or Territory. & 1885. & 1886. & 1887. & 1888. & 1889. \\
\hline Alabama. & 507,934 & 635,120 & 550,047 & 858,608 & $1,746,277$ \\
\hline Colorado ... & 208,069 & 228,060 & 267,487 & 274,212 & 299,731 \\
\hline Georgia .... . & 117,781 & 136,133 & 158,482 & 140,000 & 157,878 \\
\hline Illinois . . & 21,487 & 17,806 & 16,596 & 13,020 & 19,250 \\
\hline Indiana .. & ….. & 13,030 & 35,600 & 26,547 & 16,428 \\
\hline Indian Territory & 5,781 & 10,242 & 20,121 & 13,126 & 13,277 \\
\hline Kansas ... & 15,000 & 23,062 & 27,604 & 24,934 & 21,600 \\
\hline Kentucky .. & 5,075 & 9,055 & 29,129 & 42,642 & 25,129 \\
\hline Missouri. & .... & $\cdots \cdots$ & 5,400 & 5,000 & 8,485 \\
\hline Montana & 300 & $\ldots \ldots$ & 10,800 & 20,000 & 30,576 \\
\hline New Mexico... & 31,889 & 18,194 & 22,549 & 14,628 & 7,162 \\
\hline Ohio ... & 68,796 & 59,332 & 164,974 & 124,201 & 132,828 \\
\hline Pennsylvania. & $6,178,500$ & $8,290,849$ & $8,938,438$ & $9,673,097$ & $11,581,292$ \\
\hline Tennessee ..... & 412,538 & 621,669 & 665,857 & 630,099 & 626,016 \\
\hline
\end{tabular}


Amount of coal used in the manufacture of coke in the United States from 1880 to 1899, inclusive, by States and Territories-Continued.

[Short tons.]

\begin{tabular}{|c|c|c|c|c|c|}
\hline State or Territory. & 1885. & 1886. & 1887. & 1888. & 1889. \\
\hline Utah. & & & $\cdots$ & $\cdots$ & 2,217 \\
\hline Virginia ... & 81,899 & 200,018 & 235,841 & 230,529 & 238,793 \\
\hline Washington ... & 544 & 1,400 & 22,500 & $\ldots \ldots \ldots$ & 6,983 \\
\hline West Virginia.. & 415,533 & 425,002 & 698,327 & 863,707 & $1,001,372$ \\
\hline Wisconsin & ......... & ..... & - . . n & 1,000 & 25,616 \\
\hline Total.. & $8,071,126$ & $10,688,972$ & $11,859,752$ & $12,945,350$ & $15,960,973$ \\
\hline State or Territory. & 1890. & 1891. & 1892. & 1893. & 1894. \\
\hline Alabama & $1,809,964$ & $2,144,277$ & $2,585,966$ & $2,015,398$ & $1,574,245$ \\
\hline Colorado ... & 407,023 & 452,749 & $a 599,200$ & $a .628,935$ & a 542,429 \\
\hline Georgia .... & 170,388 & 164,875 & 158,978 & 171,645 & 166,523 \\
\hline Illinois ... & 9,000 & 10,000 & 4,800 & 3,300 & 3,800 \\
\hline Indiana & 11,753 & 8,688 & 6,456 & 11,549 & 13,489 \\
\hline Indian Territory & 13,278 & 20,551 & 7,138 & 15,118 & 7,274 \\
\hline Kansas ....... & 21,809 & 27,181 & 15,437 & 13,645 & 13,288 \\
\hline Kentucky . & 24,372 & 64,390 & 70,783 & 97,212 & 66,418 \\
\hline Missouri.. & 9,491 & 10,377 & $11,088^{\circ}$ & 8,875 & 3,442 \\
\hline Montana .... & 32,148 & 61,667 & 64,412 & 61,770 & 33,313 \\
\hline New Mexico.. & 3,980 & 4,000 & 0 & 14,698 & 13,042 \\
\hline New York... & …..... & 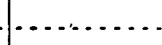 & $\cdots \cdots \cdots$ & 15,150 & $\cdots$ \\
\hline Ohio ........ & 126,921 & 69,320 & 95,236 & 42,963 & 55,324 \\
\hline Pennsylvania . & $13,046,143$ & $10,588,544$ & $12,591,345$ & $9,386,702$ & $9,059,118$ \\
\hline Tennessee .... & 600,387 & 623,177 & 600,126 & 449,511 & 516,802 \\
\hline Utah..... & 24,058 & 25,281 & $\ldots$ & $\cdots$ & $\cdots \cdot$ \\
\hline Virginia ... & 251,683 & 285,113 & 226,517 & 194,059 & 280,524 \\
\hline Washington & 9,120 & 10,000 & 12,372 & 11,374 & 8,563 \\
\hline West Virginia.. & $1,395,266$ & $1,716,976$ & $1,709,183$ & $1,745,757$ & $1,976,128$ \\
\hline Wisconsin ... & 38,425 & 52,904 & 54,300 & 24,085 & 6,343 \\
\hline Wyoming .. & ............. & 4,470 & 0 & 5,400 & 8,685 \\
\hline Total. & $18,005,209$ & $16,344,540$ & $18,813,337$ & $14,917,146$ & $14,348,750$ \\
\hline
\end{tabular}

$a$ Includes coal consumed in Utah.

21 GEOL, PT $6-35$ 
Amount of coal used in the manufacture of coke in the United States from 1880 to 1899, inclusive, by States ard Territories-Continued.

[Short tons.]

\begin{tabular}{|c|c|c|c|c|c|}
\hline State or Territory. & 1895. & 1896. & 1897. & 1898. & 1899. \\
\hline Alabama ...... & $2,459,465$ & $2,573,713$ & $2,451,475$ & $2,814,615$ & $3,028,472$ \\
\hline Colorado ...... & $a 580,584$ & $a 639,238$ & $a 616,592$ & $a 803,686$ & $a 898,207$ \\
\hline Georgia ...... & 118,900 & 109,655 & 67,000 & 81,108 & 78,098 \\
\hline Illinois .... & 3,600 & 3,900 & 3,591 & 6,650 & 4217 \\
\hline Indiana ....... & 9,898 & 8,956 & 7,022 & 4,065 & 4,218 \\
\hline Indian Territory & 11,825 & 53,028 & 68,495 & 73,330 & 59,255 \\
\hline Kansas . . . . . . . & 8,424 & 8,940 & 11,772 & 7,856 & 26,988 \\
\hline Kentucky .... & 63,419 & 55,719 & 64,234 & 44,484 & 151,503 \\
\hline Massachusetts.. & $\ldots .$. & ....... & $\ldots \ldots$ & (b) & $(b)$ \\
\hline Missouri...... & 3,120 & 4,471 & 4,627 & 1,500 & 5,320 \\
\hline Montana ..... & 55,770 & 113,165 & 139,907 & 92,552 & 110,274 \\
\hline New Mexico.. & 22,385 & 39,286 & 2,585 & 12,557 & 68,594 \\
\hline New York.... & 22,207 & $(b)$ & $(b)$ & $(b)$ & $(b)$ \\
\hline Ohio ......... & 51,921 & 128,923 & 151,545 & 134,757 & 142,678 \\
\hline Pennsylvania & $14,211,567$ & $c 11,124,610$ & $c 13,538,646$ & $c 16,307,841$ & $d 19,930,419$ \\
\hline Tennessee ... & 684,655 & 600,379 & 667,996 & 722,356 & 779,995 \\
\hline Texas. & 530 & 0 & 700 & 0 & \\
\hline Utah . ..... & $\ldots \ldots \ldots$ & $(e)$ & $(e)$ & $(e)$ & $(e)$ \\
\hline Virginia .... & 410,737 & 454,964 & 574,542 & 852,972 & 994,635 \\
\hline Washington . & 22,973 & 38,685 & 39,124 & 48,559 & 50,813 \\
\hline West Virginia. - & $2,087,816$ & $2,687,104$. & $2,413,283$ & $3,145,398$ & $3,802,825$ \\
\hline Wisconsin .... & 8,287 & 8,648 & 29,207 & 59,900 & 54,950 \\
\hline Wyoming ..... & 10,240 & 41,038 & 54,976 & 35,384 & 32,100 \\
\hline Total. & $20,848,323$ & $18,694,422$ & $20,907,319$ & $25,249,570$ & $30,219,343$ \\
\hline
\end{tabular}

In regard to this table, it is well to repeat what has been stated in some of the previous reports. In the first place, it is to be noted that in many cases the statement as to the amount of coal used in the production of coke is an estimate. At but few works is the coal weighed before being charged. into the ovens. A great deal of the coke made in the United States is from run of mine-that is, all of the product of mining, lump, nut, and slack, as it comes to the mouth of the pit in the mine car, is charged into the ovens-and if no coal is sold as coal it is comparatively easy to ascertain from the amounts paid for mining what is the amount of coal charged into the ovens. But even in such cases considerable difficulty arises, from the fact that mining is paid for by the measured bushel or ton of so many cubic feet, while our statistics 
are by weight, and the measured bushel or ton is often not the equivalent of the weighed bushel or ton. It is also true that in certain districts where the men are paid by the car the car contains, even of measured tons, more than the men are paid for. Under such circumstances it is not to the interest of the operator to weigh the coal as it is charged into the oven.

Further, in many districts coke making is simply for the purpose of utilizing the slack coal produced in mining or that which falls through the screen at the tipple when lump is sold. In such cases the slack is rarely, if ever, weighed, as it is charged into the ovens, so that any statement as to the amount of coal used at such works will be an estimate. At some works the coal is often weighed for a brief period, and, the coke being weighed as it is sold, a percentage of yield is ascertained which is used in statements as to the amount of coal used and the yield of this coal in coke.

It is to be observed, however, that producers, particularly of the larger class where system and order are maintained, are each year keeping more accurate account of the coal charged into the ovens and of the coke obtained from it, whether used by themselves or marketed. For this reason the figures of the last few years are obtained from more exact data, but the comparatively slight changes shown in the next two tables indicate that the estimates made for earlier years were quite close.

Attention is here called to what appears to be a marked discrepancy between the figures contained in the above table and those shown in the chapter on the production of coal. In the coal report the amount of coal made into coke in the United States in 1899 is given as 27,247,826 short tons, nearly 3,000,000 tons less than that shown in the above table. In explanation of this it may be stated that this difference is in coal which is not made into coke at the mines, but it is shipped to ovens at a distance, much of it being sold as coal, and is therefore included in the statement of shipments. For instance, the coal report shows no coal made into coke in Illinois, Kansas, Missouri, or Wisconsin. In the last State mentioned coal is not even mined, the coke being made from coal purchased in Pennsylvania. In some cases the coal report shows a larger amount of coal made into coke than the coke report does. In this case the difference is due to the washing of the coal before coking, the weight of the coal before washing being reported in the one case and the washed coal in the other case. In some of the less important States the figures are identical in both reports. 
The amount of coal necessary to produce a ton of coke, assuming that the above tables are approximately correct, was as follows:

Coal required to produce a ton of coke, in tons or pounds.

\begin{tabular}{|c|c|c|c|c|c|}
\hline Year. & Tons. & Pounds. & Year. & Tons. & Pounds \\
\hline 1880 & 1.57 & 3,140 & 1890. & 1.56 & 3,120 \\
\hline $1881 \ldots$ & 1.59 & 3,180 & $1891 \ldots \ldots \ldots$ & 1.58 & 3,160 \\
\hline $1882 \ldots \ldots \ldots$ & 1.58 & 3,160 & $1892 \ldots$ & 1.57 & 3,140 \\
\hline $1883 \ldots$ & 1.56 & 3,120 & 1893. & 1.57 & 3,140 \\
\hline $1884 \ldots$ & 1.63 & 3,260 & 1894 & 1.56 & 3,120 \\
\hline $1885 \ldots$ & 1.58 & 3,160 & $1895 \ldots \ldots$ & 1.56 & 3,120 \\
\hline $1886 \ldots . .$. & 1.56 & 3,120 & $1896 \ldots$ & $1.58 \frac{1}{2}$ & 3,170 \\
\hline $1887 \ldots$. & 1.56 & 3,120 & $1897 \ldots$ & 1.57 & 3,140 \\
\hline $1888 \ldots$ & 1.51 & 3,020 & $1898 \ldots$ & 1.57 & 3,140 \\
\hline $1889 \ldots \ldots \ldots$ & 1.55 & 3,100 & $1899 \ldots$ & 1.54 & 3,080 \\
\hline
\end{tabular}

The following table exhibits the percentage yield of coal in the manufacture of coke for the years 1880 to 1899, inclusive. By the "yield" is meant the percentage of the constituents of the coal that remains as coke after the process of coking. The table shows that the general average for most of the years given is about 64 per cent, but it is believed that even this is a little too high. It is not possible to acquire exact information on this point, for the reason that in many instances the coal is not weighed before being charged into the ovens. As stated in regard to the table showing the amount of coal made into coke, the percentage yield, like the amount, is largely estimated. Probably the actual yield of coke throughout the United States, if the actual weight of the coal charged into the ovens and the actual weight of the coke drawn had been taken, would not have exceeded 60 or 61 per cent. 
Percentage yield of coal in the manufacture of coke in the United States from 1880 to 1899 , inclusive, by States and Territories.

\begin{tabular}{|c|c|c|c|c|c|c|c|c|c|c|}
\hline State or Territory. & 1880. & 1881. & 1882. & 1883. & 1884 & 1885. & 1886. & 1887. & 1588. & 1889. \\
\hline Alabama. & 57 & 59 & 58 & 60 & 60 & 59 & 59 & 59 & 60 & 59 \\
\hline Colorado .... & 49 & 50 & 57 & 60 & 64 & 63 & 62.6 & 64 & 65.6 & 63 \\
\hline Georgia & 60 & 60 & 60 & 60 & 60 & 60 & 60 & 50 & 60 & 60 \\
\hline Illinois . . & 41 & 42 & 45 & 43 & 43 & 48 & 46 & 55.5 & 56.9 & 60 \\
\hline Indiana .... & 0 & 0 & 0 & 0 & 0 & 0 & 47 & 50 & 45 & 51 \\
\hline Indian Territory. & 62 & 62 & 62 & 62 & 62 & 62 & 62 & 50 & 57 & 50 \\
\hline Kansas..... & 64 & 64.4 & 65 & 62.9 & 62.3 & 53.7 & 54.2 & 54 & 59 & 64 \\
\hline Kentucky . & 60 & 60 & 59 & 60 & 64 & 53 & 50 & 50 & 54 & '52 \\
\hline Missouri... & 0 & 0 & 0 & 0 & 0 & 0 & 0 & 55 & 52 & 62 \\
\hline Montana .... & 0 & 0 & 0 & 0 & 46 & 58.5 & 0 & 66.7 & 60 & 46 \\
\hline New Mexico & 0 & 0 & 66.7 & 57.3 & 57.5 & 56.3 & 56 & 61 & 58 & 48 \\
\hline Ohio. & 58 & 59 & 57 & 58 & 58 & 57 & 59 & 56 & 54 & 56 \\
\hline Pennsylvania & 65 & 64 & 64 & 65 & 62 & 64.6 & 65.2 & 65.3 & 68 & 66 \\
\hline Tennessee & 60 & 60 & 60 & 62 & 63 & 53 & 59 & 61 & 61 & 57 \\
\hline Texas & 0 & 0 & 0 & 0 & 0 & 0 & 50 & 0 & 0 & 0 \\
\hline Utah ... & 50 & 0 & 50 & 0 & 0 & 0 & 0 & 0 & 0 & 34 \\
\hline Virginia .... & 0 & 0 & 0 & 64.5 & 64.3 & 60 & 61.1 & 70.8 & 64.7 & 61 \\
\hline Washington . & 0 & 0 & 0 & 0 & 57.5 & 57 & 58.9 & 65 & 0 & 55 \\
\hline West Virginia & 60 & 61 & 63 & 63 & 62 & 63 & 62 & 63.3 & 61.6 & 61. \\
\hline Wisconsin & 0 & 0 & 0 & 0 & 0 & 0 & 0 & 0 & 50 & 62.5 \\
\hline Wyoming. & 0 & 0 & 0 & 0 & 0 & 0 & 0 & 0 & 0 & 0 \\
\hline Total average. & 63 & 63 & 63 & 64 & 61 & 63 & 64 & 64.2 & 66 & 64 \\
\hline State or Territory. & 1890. & 1891. & 1892. & 1893. & 1894. & 1895. & 1896. & 1897. & 1898. & 1899. \\
\hline Alabama & 59 & 60 & 58 & 50 & 58.7 & 58.7 & 57.5 & 58.8 & 59 & 59 \\
\hline Colorado .... & 60 & 61 & 63. & $a 57.7$ & $a 58.5$ & $a 58.6$ & $a 56.9$ & $a 55.6$ & $a 59.1$ & $\alpha 59$ \\
\hline Georgia ..... & 60 & 62.5 & 51.5 & 52.8 & 55.9 & 50.6 & 49 & 49.3 & 61 & 65.2 \\
\hline Illinois.. & 55 & 52 & 66 & 66.7 & 57.9 & 62.5 & 66.7 & 43 & 35 & \\
\hline Indiana $\ldots . .$. & 51 & 44 & 49.7 & 49.6 & 48.6 & 48.5 & 49 & 41.4 & 44.9 & \\
\hline Indian Territory & 50 & 46 & 50 & 47 & 42 & 43.8 & 40 & 44.3 & 46.5 & 41 \\
\hline Kansas...... & 56 & 52 & 59.2 & 62.8 & 63.5 & 62.8 & 53.5 & 52.5 & 53 & 53.6 \\
\hline $\begin{array}{l}\text { Kentucky .... } \\
\text { Massachusetts }\end{array}$ & 51 & 52 & 51 & 50 & 44.8 & 40.1 & 48.6 & 50 & 50 & 53.5 \\
\hline Missouri.. & 65 & 66 & 65.8 & 66.5 & 65.4 & 65 & 55.9 & 56 & 49.3 & 53.8 \\
\hline Montana . & 45 & 47 & 53.6 & 48.5 & 52.2 & 45.4 & 53 & 48.5 & 56 & 51 \\
\hline New Mexico. & 51.5 & 57.5 & 0 & 39.5 & 50 & 65.5 & 61.7 & 55.6 & 55.6 & 64.3 \\
\hline New York & & & & 84.8 & & 83.4 & & & & \\
\hline
\end{tabular}


Percentage yield of coal in the manufacture of coke in the United States from 1880 to 1899, inclusive, by States and Territories-Continued.

\begin{tabular}{|c|c|c|c|c|c|c|c|c|c|c|}
\hline State or Territory. & 1890. & 1891. & 1892. & 1893. & 1894. & 1895. & 1896. & 1897. & 1898. & 1899. \\
\hline Ohio.. & 59 & 56 & 54.4 & 52 & 59 & 56 & 62.7 & 62.7 & 63.5 & 58.8 \\
\hline Pennsylvania & 65 & 66 & 66.1 & 66 & 66.9 & 66.2 & $b 66.1$ & $b 66.2$ & $b 65.7$ & 68.1 \\
\hline Tennessee & 58 & 58 & 59 & 59 & 56.6 & 57.9 & 56.5 & 55 & 54.6 & 55.8 \\
\hline Texas .... & 0 & 0 & 0 & 0 & 0 & 54 & 0 & 56.3 & 0 & 0 \\
\hline Utah .. & 35 & 31 & & & & & & & & \\
\hline Virginia . & 66 & 58.8 & 65.3 & 64.5 & 64.2 & 59.6 & 58.9 & 61.6 & 62 & 62.2 \\
\hline Washington & 64 & 60 & 58 & 59 & 61.2 & 65.9 & 67 & 67 & 62.2 & 59.8 \\
\hline West Virginia. & 59 & 58.8 & 60.5 & 60.8 & 60.4 & 61.6 & .61 .4 & 61 & 61.2 & 60 \\
\hline Wisconsin ... & 65 & 65 & 62.2 & 62 & 67 & 60 & 62 & 59 & 59 & 60.8 \\
\hline Wyoming & 0 & 60 & 0 & 54 & 50 & 47.8 & 47.6 & 43. 7 & 51.9 & 48. 7 \\
\hline Total average. & 64 & 63 & 64 & 63.5 & 64 & 64 & 63 & 63.5 & 63.6 & 65.1 \\
\hline
\end{tabular}

a Average, including Utah.

$b$ Average, including New York, also Massachusetts for 1899.

AMOUNT AND VALUE OF COAL USED IN COKE MAKING.

The amount and value of coal used in making coke during the last three years, by States, together with the amount and value of coal used per ton of coke made, are shown in the following table. The value of the coal used in 1899 was $\$ 18,290,453$ and the value of the coke made from it, as shown in a preceding table, was $\$ 34,670,417$. The amount of coal used was $30,219,343$ tons, yielding $19,668,569$ tons of coke. The loss of weight by coking was 35 per cent; the increase in value of the coke over the value of the coal was 89.5 per cent. About one-fourth of the coal used in coke making is slack coal, which has little or no value at the mine. In late years there has been a considerable increase in the percentage of washed coal, particularly the slack, used. This improves the quality of the resultant coke and increases the yield from the coal charged into the ovens, but it also increases the expense of the coking operations and must be taken into account when considering the difference between the value of the coal used and that of the coke made. 


\section{COKE.}

Amount and value of coal used in the manufacture of coke in the United States in 1899, and. amount and value of same per ton of coke.

\begin{tabular}{|c|c|c|c|c|c|}
\hline State or Territory. & Coal used. & $\begin{array}{c}\text { Total value of } \\
\quad \text { coal. }\end{array}$ & $\begin{array}{l}\text { Value of } \\
\text { coal per } \\
\text { ton. }\end{array}$ & $\begin{array}{c}\text { Amount of } \\
\text { coal per ton } \\
\text { of coke. }\end{array}$ & $\begin{array}{l}\text { Value of } \\
\text { coal toa ton } \\
\text { of coke. }\end{array}$ \\
\hline & Short tons. & & & Short tons. & \\
\hline Alabama ...... & $3,028,472$ & $\$ 2,596,718$ & $\$ 0.857$ & 1.69 & $\$ 1.45$ \\
\hline Colorado $(a), \ldots \ldots$ & 898,207 & 544,772 & .607 & 1. 69 & 1.03 \\
\hline Georgia . . . . . . & 78,098 & 62,893 & .805 & 1.53 & 1.24 \\
\hline $\begin{array}{l}\text { Illinois } . . . \ldots \ldots \\
\text { Indiana } \ldots \ldots \ldots \ldots\end{array}$ & 4,217 & 2,520 & .598 & 1.78 & 1.06 \\
\hline Indian Territory .. & 59,255 & 29,396 & .496 & 2.43 & 1. 21 \\
\hline Kansas .......... & 26,988 & 26,079 & .97 & 1.86 & 1.80 \\
\hline Kentucky ... & 151,503 & 72,196 & .477 & 1.87 & .89 \\
\hline Missouri...... & 5,320 & 2,256 & .424 & 1.86 & .79 \\
\hline Montana ......... & 110,274 & 189,232 & 1.716 & 1. 96 & 3.36 \\
\hline New Mexico...... & 68,594 & 35,229 & .514 & 1.55 & .80 \\
\hline Ohio .......... & 142,678 & 102,540 & .719 & 1.70 & 1.22 \\
\hline Pennsylvania $(b)$ & $19,930,419$ & $11,514,614$ & .578 & 1.47 & .85 \\
\hline Tennessee .... & 779,995 & 530,774 & .68 & 1. 79 & $1.22^{\circ}$ \\
\hline Virginia .......... & 994,635 & 523,979 & .53 & 1.61 & .85 \\
\hline Washington ...... & $.50,813$. & 79,770 & 1.57 & 1.67 & 2.63 \\
\hline West Virginia $\ldots$. & $3,802,825$ & $1,869,110$ & .49 & 1.67 & .82 \\
\hline Wisconsin ...... & 54,950 & 93,415 & 1. 70 & 1. 64 & 2. 79 \\
\hline Wyoming ..... & 32,100 & 14,960 & .466 & 2.05 & .96 \\
\hline $\begin{array}{l}\text { Total and aver- } \\
\text { ages.......... }\end{array}$ & $30,219,343$ & $18,290,453$ & .605 & 1.54 & .93 \\
\hline
\end{tabular}

$a$ Figures given for Colorado include the statistics of Utah.

o Figures for Pennsylvania include the statistics of New York and Massachusetts. 
Amount and value of coal used in the manufacture of coke in the United States in 1898, and amount and value of same per ton of coke.

\begin{tabular}{|c|c|c|c|c|c|}
\hline State or Territory. & Coal used. & $\begin{array}{l}\text { Total value } \\
\text { of coal. }\end{array}$ & $\begin{array}{l}\text { Value of } \\
\text { coal per } \\
\text { ton. }\end{array}$ & $\begin{array}{c}\text { Amount of } \\
\text { coal per ton } \\
\text { of coke. }\end{array}$ & $\begin{array}{l}\text { Value of } \\
\text { coal to a ton } \\
\text { of coke. }\end{array}$ \\
\hline & Short tons. & & & Short tons. & \\
\hline Alabama ..... & $2,814,615$ & $\$ 2,142,210$ & $\$ 0.76$ & 1.69 & $\$ 1.28$. \\
\hline Colorado $(a)$ & 803,686 & 548,038 & .68 & 1.69 & 1.15 \\
\hline Georgia ..... & 81,108 & 40,554 & .50 & 1.637 & .82 \\
\hline Illinois ..... & 6,650 & 1,662 & .25 & 2.86 & .715 \\
\hline Indiana ....... & 4,065 & 1,423 & .35 & 2.23 & .78 \\
\hline Indian Territory & 73,330 & 51,908 & .708 & 2.15 & 1.52 \\
\hline Kansas ... & 7,856 & 4,015 & .51 & 1.88 & .96 \\
\hline Kentucky . & 44,484 & 6,235 & .14 & 2.00 & .28 \\
\hline Missouri..... & 1,500 & 650 & .433 & 2.03 & .88 \\
\hline Montana ..... & 92,552 & 253,011 & 2.73 & 1.78 & 4. 86 \\
\hline New Mexico... & 12,557 & 6,279 & .50 & 1.80 & .90 \\
\hline Obio $\ldots . . . .$. & 134,757 & 127,924 & .95 & 1.575 & 1.50 \\
\hline Pennsylvania $(b)$. & $16,307,841$ & $10,346,448$ & .634 & 1.52 & .96 \\
\hline Tennessee & 722,356 & 418,598 & .58 & 1.83 & 1.06 \\
\hline Virginia..... & 852,972 & 495,539 & .58 & 1.606 & .93 \\
\hline Washington & 48,559 & 89,155 & 1.836 & 1.61 & 2.956 \\
\hline West Virginia & $3,145,398$ & $1,619,575$ & .51 & 1.634 & .84 \\
\hline Wisconsin .... & 59,900 & 88,850 & 1.483 & 1.70 & 2.52 \\
\hline Wyoming & 35,384 & 17,692 & .50 & 1.93 & .965 \\
\hline $\begin{array}{c}\text { Total and aver- } \\
\text { ages........... }\end{array}$ & $25,249,570$ & $16,259,766$ & .644 & 1.573 & 1.013 \\
\hline
\end{tabular}

a Figures given for Colorado include the statistics of Utah.

$b$ Figures given for Pennsylvania include the statistics of New York. 
COKE.

Amount and value of coal used in the manufacture of coke in the United States in 1897, and amount and value of same per ton of colie.

\begin{tabular}{|c|c|c|c|c|c|}
\hline State or Territory. & Coal used. & $\begin{array}{l}\text { Total value } \\
\text { of coal. }\end{array}$ & $\begin{array}{l}\text { Value of } \\
\text { coal per } \\
\text { ton. }\end{array}$ & $\begin{array}{l}\text { Amount of } \\
\text { coal pert ton } \\
\text { of coke. }\end{array}$ & $\begin{array}{c}\text { Value of } \\
\text { coal to a ton } \\
\text { of coke. }\end{array}$ \\
\hline & Short tons. & & & Short tons. & \\
\hline Alabama ......... & $2,451,475$ & $\$ 2,047,975$ & $\$ 0.83 \frac{1}{2}$ & 1. 70 & $\$ 1.42$ \\
\hline Colorado $(a) \ldots .$. & 616,592 & 441,450 & .716 & 1. 80 & 1. 29 \\
\hline Georgia ...... & 67,000 & 33,500 & .50 & 2.03 & 1.02 \\
\hline Illinois . . . . . . . . . & 3,591 & 1,436 & .40 & 2.32 & .93 \\
\hline Indiana ....... & 7,022 & 3,511 & .50 & 2.49 & 1.25 \\
\hline Indian Territory... & 68,495 & 57,581 & .84 & 2.25 & 1.89 \\
\hline Kansas ............ & 11,772 & 5,886 & .50 & 1.90 & .95 \\
\hline Kentucky ..... & 64,234 & 12,621 & .20 & 2.00 & .40 \\
\hline Missouri..... & 4,627 & 2,698 & .583 & 1. 78 & 1.04 \\
\hline Montana ........... & 139,907 & 301,046 & 2.15 & 2.06 & 4. 43 \\
\hline New Mexico....... & 2,585 & 2,282 & .88 & 1.80 & 1.58 \\
\hline Ohio ............ & 151,545 & 141,197 & .93 & 1.59 & 1. 48 \\
\hline Pennsylvania $(b) \ldots$ & $13,538,646$ & $7,825,569$ & .578 & 1.51 & .87 \\
\hline Tennessee ........ & 667,996 & 525,755 & .787 & 1.81 & 1. 42 \\
\hline Texas ... & 700 & $\ldots$ & $\cdots$ & 1. 78 & 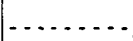 \\
\hline Virginia....... & 574,542 & 315,986 & .55 & 1.62 & .89 \\
\hline Washington ....... & 39,124 & 77,377 & 1.98 & 1. 49 & 2.95 \\
\hline West Virginia & $2,413,283$ & $1,290,468$ & .53 & 1. 64 & .87 \\
\hline Wisconsin .......... & 29,207 & 55,000 & 1.88 & 1.70 & 3.20 \\
\hline Wyoming $\ldots$ : & 54,976 & 43,980 & .80 & 2.29 & 1.83 \\
\hline $\begin{array}{l}\text { Total and aver- } \\
\text { ages.......... }\end{array}$ & $20,907,319$ & $13,185,318$ & .63 & 1.57 & .99 \\
\hline
\end{tabular}

a Figures given for Colorado include the statistics of Utah. $b$ Figures given for Pennsylvania include the statistics of New York. 
CONDITION IN WHICH COAL IS CHARGED INTO OVENS.

In the following table will be found a statement of the condition of coal when charged into ovens-that is, whether it is run of mine, slack, washed, or unwashed. The tables for 1899, 1898, and 1897, are given. The headings explain themselves. It is only necessary to state that run of mine, washed, includes that run-of-mine coal which is crushed before being washed.

Character of coal used in the manufacture of coke in 1899.

\begin{tabular}{|c|c|c|c|c|c|}
\hline \multirow{2}{*}{ State or Territory. } & \multicolumn{2}{|c|}{ Run of mine. } & \multicolumn{2}{|c|}{ Slack. } & \multirow{2}{*}{ Total. } \\
\hline & Unwashed. & Washed. & Unwashed. & Washed. & \\
\hline Alabama ..... & $\begin{array}{l}\text { Short tons. } \\
1,656,226\end{array}$ & $\begin{array}{r}\text { Short tons. } \\
725,238\end{array}$ & $\begin{array}{r}\text { Short tons. } \\
9,898\end{array}$ & $\begin{array}{r}\text { Short tons. } \\
637,110\end{array}$ & $\begin{array}{l}\text { Short tons. } \\
3,028,472\end{array}$ \\
\hline Colorada $(a) \ldots$ & 125,322 & 0 & 468,196 & 304,689 & 898,207 \\
\hline Georgia ...... & 0 & 48,521 & 0 & 29,577 & 78,098 \\
\hline $\begin{array}{l}\text { Illinois . . . . . . } \\
\text { Indiana ........ }\end{array}$ & 300 & 0 & 404 & 3,513 & 4,217 \\
\hline Indian Territory & 0 & 0 & 0 & 59,255 & 59,255 \\
\hline Kansas . ....... & .0 & 6,210 & 20,778 & 0 & 26,988 \\
\hline Kentucky ..... & 21,600 & 0 & 30,263 & 99,640 & 151,503 \\
\hline Massachusetts & $\cdots$ & & 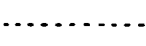 & & ............ \\
\hline Missouri. . . ....... & 0 & 0 & 5,320 & 0 & 5,320 \\
\hline Montana .......... & 0 & 0 & 0 & 110,274 & 110,274 \\
\hline New Mexico .... & 0 & 0 & 68,594 & 0 & 68,594 \\
\hline New York ..... & $\ldots . .$. & & - & ......... & 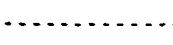 \\
\hline Ohio ............ & 88,771 & 0 & 23,907 & 30,000 & 142,678 \\
\hline Pennsylvania $(b)$ & $16,854,706$ & 366,206 & $1,824,784$ & 884,723 & $19,930,419$ \\
\hline Tennessee ... & 140,804 & 267,105 & 31,850 & 340,236 & 779,995 \\
\hline Utah ............... & $\ldots \ldots$. & $\cdots$ & $\ldots \ldots$ & - & .......... \\
\hline Virginia ....... & 612,267 & 0 & 225,118 & 157,250 & 994,635 \\
\hline Washington ...... & 0 & 44,681 & 0 & 6,132 & 50,813 \\
\hline West Virginia. & $1,336,239$ & 0 & $2,215,255$ & 251,331 & $3,802,825$ \\
\hline Wisconsin .... & 34,680 & 0 & 20,270 & 0 & 54,950 \\
\hline Wyoming .... & 0 & 0 & 32,100 & 0 & 32,100 \\
\hline Total... & $20,870,915$ & $1,457,961$ & $4,976,737$ & $2,913,730$ & $30,219,343$ \\
\hline
\end{tabular}


COKE:

Character of coal used in the manufacture of colie in 1898.

\begin{tabular}{|c|c|c|c|c|c|}
\hline \multirow{2}{*}{ State or Territory. } & \multicolumn{2}{|c|}{ Run of mine. } & \multicolumn{2}{|c|}{ Slack. } & \multirow{2}{*}{ Total. } \\
\hline & Unwashed. & Washed. & Unwashed. & Washed. & \\
\hline Alabama ......... & $\begin{array}{c}\text { Short tons. } \\
1,290,794\end{array}$ & $\begin{array}{l}\text { Short tons. } \\
828,294\end{array}$ & $\begin{array}{r}\text { Short tons. } \\
25,000\end{array}$ & $\begin{array}{r}\text { Short tons. } \\
670,527\end{array}$ & $\begin{array}{l}\text { Short tons. } \\
2,814,615\end{array}$ \\
\hline Colorado $(a) \ldots$ & 122,983 & 0 & 415,298 & 265,405 & 803,686 \\
\hline Georgia ..... & 0 & 61,844 & 0 & 19,264 & 81,108 \\
\hline Illinois .... . & 0 & 0 & 0 & 6,650 & 6,650 \\
\hline Indiana ......... & 0 & 0 & 0 & 4,065 & 4,065 \\
\hline Indian Territory .. & 0 & 15,353 & 0 & 57,977 & 73,330 \\
\hline Kansas ........... & 0 & 0 & 7,856 & 0 & 7,856 \\
\hline Kentucky ... & 0 & 1,800 & 0 & 42,684 & 44,484 \\
\hline Missouri....... & 0 & 0 & 1,500 & 0 & 1,500 \\
\hline Montana ...... & 12,000 & 60,000 & 0 & 20,552 & 92,552 \\
\hline New Mexico ... & 0 & 0 & 12,557 & 0 & 12,557 \\
\hline New York. & $\ldots \ldots \ldots$ & $\ldots \ldots$ & $\ldots \ldots$ & $\ldots \ldots \ldots$ & (............. \\
\hline Ohio .......... & 92,963 & 0 & 19,794 & 22,000 & 134,757 \\
\hline Pennsylvania $(b) \ldots$ & $14,083,073$ & 350,153 & $1,472,347$ & 402,268 & $16,307,841$ \\
\hline Tennessee. & 37,217 & 306,969 & 122,756 & 255,414 & 722,356 \\
\hline Virginia ...... & 405,399 & 0 & 237,474 & 210,099 & 852,972 \\
\hline Washington & 0 & 48,559 & 0 & -.0 & $48,559^{\circ}$ \\
\hline West Virginia. . ... & 713,815 & 0 & $2,137,983$ & 293,600 & $3,145,398$ \\
\hline Wisconsin ... & 0 & 0 & 0 & 59,900 & 59,900 \\
\hline Wyoming - & 0 & 0 & . $\quad 35,384$ & 0 & 35,384 \\
\hline Total. & $16,758,244$ & $1,672,972$ & $4,487,949$ & $2,330,405$ & $25,249,570$ \\
\hline
\end{tabular}

a Includes Utah's consumption of coal. $\quad b$ Includes coal coked in New York. 
Character of coal used in the manufacture of coke in $189 \%$.

\begin{tabular}{|c|c|c|c|c|c|}
\hline \multirow{2}{*}{ state or Territory. } & \multicolumn{2}{|c|}{ Run of mine. } & \multicolumn{2}{|c|}{ Slack. } & \multirow{2}{*}{ Total. } \\
\hline & Unwashed. & Washed. & Unwashed. & Washed. & \\
\hline Alabama & $\begin{array}{l}\text { Short tons. } \\
902,310\end{array}$ & $\begin{array}{r}\text { Short tons. } \\
120,420\end{array}$ & $\begin{array}{l}\text { Short tons. } \\
91,200\end{array}$ & $\begin{array}{r}\text { Short tons. } \\
1,337,545\end{array}$ & $\begin{array}{l}\text { Short tons. } \\
2,451,475\end{array}$ \\
\hline Colorado $(a) \ldots$ & 0 & 0 & 393,214 & 223,378 & 616,592 \\
\hline Georgia ...... & 0 & 67,000 & 0 & 0 & 67,000 \\
\hline Illinois ...... & 0 & 0 & 3,591 & 0 & 3,591 \\
\hline Indiana .... & 0 & 0 & 0 & 7,022 & 7,022 \\
\hline Indian Territory & 0 & 6,923 & 0 & 61,572 & 68,495 \\
\hline Kansas...... & 0 & 0 & 11,772 & 0 & 11,772 \\
\hline Kentucky ... & 4,176 & 0 & 0 & 60,058 & 64,234 \\
\hline Missouri.... & 0 & 0 & 4,627 & 0 & 4,627 \\
\hline Montana .... & 0 & 75,000 & 0 & 64,907 & 139,907 \\
\hline New Mexico .... & 0 & 0 & 2,585 & 0 & 2,585 \\
\hline Ohio ........ & 92,192 & 0 & 29,353 & 30,000 & 151,545 \\
\hline Pennsylvania $(b)$ & $11,540,459$ & 301,052 & $1,441,611$ & 255,524 & $13,538,646$ \\
\hline Tennessee .. & 36,485 & 400,166 & 119,755 & 111,590 & 667,996 \\
\hline Texas ...... & 0 & 0 & 0 & 700 & 700 \\
\hline Virginia..... & 286,158 & 0 & 227,363 & 61,021 & 574,542 \\
\hline Washington & 0 & 39,124 & 0 & 0 & 39,124 \\
\hline West Virginia . & 373,205 & 28,145 & $1,800,528$ & 211,405 & $2,413,283$ \\
\hline Wisconsin .... & 0 & $\mathbf{0}$ & 0 & 29,207 & 29,207 \\
\hline Wyoming & 0 & 0 & 54,976 & 0 & 54,976 \\
\hline Total. & $13,234,985$ & $1,037,830$ & $4,180,575$ & $2,453,929$ & $20,907,319$ \\
\hline
\end{tabular}

In the following table the statistics regarding the character of the coal for the year's 1890 to 1899 ; inclusive, are consolidated:

Character of coal used in the manufacture of coke in the Cnited States since 1890.

\begin{tabular}{|c|c|c|c|c|c|}
\hline \multirow{2}{*}{ Year. } & \multicolumn{2}{|c|}{ Run of mine. } & \multicolumn{2}{|c|}{ Slack. } & \multirow{2}{*}{ Total. } \\
\hline & Unwashed. & Washed. & Unwashed. & Washed. & \\
\hline 1890. & $\begin{array}{c}\text { Short tons. } \\
14,060,907\end{array}$ & $\begin{array}{c}\text { Short tons. } \\
338,563\end{array}$ & $\begin{array}{l}\text { Short tons. } \\
2,674,492\end{array}$ & $\begin{array}{c}\text { Short tons. } \\
931,247\end{array}$ & $\begin{array}{c}\text { Short tons. } \\
18,005,209\end{array}$ \\
\hline 1891. & $12,255,415$ & 290,807 & $2,945,359$ & 852,959 & $16,344,540$ \\
\hline 1892 & $14,453,638$ & 324,050 & $3,256,493$ & 779,156 & $18,813,337$ \\
\hline $1893 \ldots$ & $10,306,082$ & 350,112 & $3,049,075$ & $1,211,877$ & $14,917,146$ \\
\hline $1894 .$. & $9,648,750$ & 405,266 & $3,102,652$ & $1,192,082$ & $14,348,750$ \\
\hline 1895 & $15,609,875$ & 237,468 & $3,052,246$ & $1,948,734$ & $20,848,323$ \\
\hline 1896. & $11,307,905$ & 763,244 & $4,685,832$ & $1,937,441$ & $18,694,422$ \\
\hline 1897 & $13,234,985$ & $1,037,830$ & $4,180,575$ & $2,453,929$ & $20,907,319$ \\
\hline 1898. & $16,758,244$ & $1,672,972$ & $4,487,949$ & $2,330,405$ & $25,249,570$ \\
\hline $1899 \ldots$ & $20,870,915$ & $1,457,961$ & $4,976,737$ & $2,913,730$ & $30,219,343$ \\
\hline
\end{tabular}




\section{IMPORTS AND EXPORTS.}

The following table gives the quantities and value of coke imported and entered for consumption in the United States from 1869 to 1899, inclusive. In the reports of the Treasury Department the quantities given are long tons. These have been reduced to short tons to make the tables consistent with the other tables in this report:

Coke imported and entered for consumption in the United States, 1869 to 1899, inclusive.

\begin{tabular}{|c|c|c|c|c|c|}
\hline $\begin{array}{l}\text { Year ending } \\
\text { June } 30-\end{array}$ & Quantity. & Value. & $\begin{array}{l}\text { Year ending } \\
\text { Dec. } 31-\end{array}$ & Quantity. & Value. \\
\hline & Short tons. & & & Short tons. & \\
\hline 1869 & $\ldots$ & $\$ 2,053$ & $1886 \ldots$ & 28,124 & $\$ 84,801$ \\
\hline 1870 & $\ldots \ldots$ & 6,388 & 1887 & 35,320 & 100,312 \\
\hline 1871 & .......... & 19,528 & $1888 \ldots$ & 35,201 & 107,914 \\
\hline $1872 \ldots$ & 9,575 & 9,217 & 1889 & 28,608 & 88,008 \\
\hline $1873 \ldots$ & 1,091 & 1,366 & $1890 \ldots$ & 20,808 & 101,767 \\
\hline $1874 \ldots$ & 634 & 4,588 & $1891 \ldots$ & 50,753 & 223,184 \\
\hline 1875 & 1,046 & 9,648 & 1892. & 27,420 & 86,350 \\
\hline $1876 \ldots$ & 2,065 & 8,657 & $1893 \ldots$ & 37,183 & 99,683 \\
\hline $1877 \ldots$ & 4,068 & 16,686 & $1894 \ldots$ & 32,566 & 70,359 \\
\hline $1878 \ldots$ & 6,616 & 24,186 & $1895 \ldots$ & 29,622 & 71,366 \\
\hline $1879 \ldots$ & 6,035 & 24,748 & $1896 \ldots$ & 43,372 & 114,713 \\
\hline $1880 \ldots$ & 5,047 & 18,406 & $1897 \ldots$ & 34,937 & 98,077 \\
\hline 1881 & 15,210 & 64,987 & $1898 \ldots$ & 46,127 & 142,334 \\
\hline $1882 \ldots$ & 14,924 & 53,244 & $1899 \ldots$ & 31,197 & 142,504 \\
\hline $1883 \ldots$ & 20,634 & 113,114 & & & \\
\hline $1884 \ldots$ & 14,483 & 36,278 & & & \\
\hline 1885 & 20,876 & 64,814 & & & \\
\hline
\end{tabular}

The amount and value of coke exported from the United States since 1895 are shown in the following table:

Coke exported from the United States since 1895.

\begin{tabular}{|c|c|c|c|}
\hline Year. & . & Quantity. & Value. \\
\hline $1895 \ldots \ldots \ldots$ & & $\begin{array}{r}\text { Short tons. } \\
131,368\end{array}$ & $\$ 425,174$ \\
\hline $1896 \ldots \ldots \ldots \ldots \ldots$ & & 169,189 & 553,600 \\
\hline $1897 \ldots \ldots \ldots \ldots$ & & 173,034 & 546,066 \\
\hline $1898 \ldots \ldots \ldots \ldots$ & & 199,562 & 600,931 \\
\hline $1899 \ldots \ldots \ldots \ldots \ldots \ldots$ & $\ldots$ & 280,196 & 858,856 \\
\hline
\end{tabular}




\section{BY-PRODUCT COKE MAKING IN 1899.}

The amount of coke made in by-product ovens in 1899 was more than three times as large as that of the preceding year, and, as shown in the following table, the number of completed ovens was nearly double. The reason for this large increase in production, as compared with the increase in the number of completed ovens, lies in the fact that the 240 ovens reported as under construction at the close of 1897 and in operation during 1898 were not put in blast until late in 1898 , and consequently did not add materially to the production, whereas, the new ovens finished in 1899 were completed early in the year, and their product, as well as those completed in the latter part of 1898, helped to swell the new production in 1899 . The new plants were fully described in the report for 1898.

Reduced to tabular form, the record of by-product coke making in the United States since 1893, when the first plant was constructed, at Syracuse, has been as follows:

Record of by-product coke making since 1893.

\begin{tabular}{|c|c|c|c|}
\hline \multirow{2}{*}{ Year. } & \multicolumn{2}{|c|}{ Ovens. ' } & \multirow{2}{*}{ Product. } \\
\hline & Built. & Building. & \\
\hline $1893 \ldots \ldots \ldots$ & 12 & 0 & $\begin{array}{c}\text { Short tons. } \\
12,850\end{array}$ \\
\hline $1894 \ldots \ldots \ldots$ & 12 & 60 & 16,500 \\
\hline $1895 \ldots \ldots \ldots \ldots \ldots$ & $a 72$ & 60 & 18,521 \\
\hline $1896 \ldots \ldots \ldots$ & 160 & 120 & 83,038 \\
\hline $1897 \ldots . .$. & 280 & 240 & 261,912 \\
\hline $1898 \ldots . . . . . .$. & $b 520$ & $c 500$ & 294,445 \\
\hline $1899 \ldots \ldots \ldots \ldots \ldots$ & $d 1,020$ & $e 65$ & 906,534 \\
\hline
\end{tabular}

$a$ Sixty of these ovens did not begin making coke until 1896.

$b$ Includes 280 Semet-Solvay, 180 Otto-Hoffman, and 60 Newton-Chambers. $c$ All Otto-Hoffman.

$d$ Includes 280 Semet-Solvay, 680 Otto-Hoffman, and 60 Newton-Chambers. $e$ Semet-Solvay.

The foregoing statement regarding the number of ovens includes for 1899 only those actually in existence or building at the close of the year. The ovens built include the plants at the following places:

Semet-Solvay ovens. - Syracuse, New York, 25 ovens; Dunbar, Pennsylvania, 50 ovens; Sharon, Pennsylvania, 25 ovens; Ensley, Alabama, 120 ovens, and Wheeling, West Virginia, 60 ovens. Total, 280.

Otto-Hoffman ovens.-Johnstown, Pennsylvania, 160 ovens; Otto, near Pittsburg, Pennsylvania, 120 ovens; Everett, Massachusetts, 400 ovens. Total, 680 . 
Nevton-Chambers ovens.-Pocahontas, Virginia, 60 ovens.

All of the ovens building at the close of 1899 were Semet-Solvay ovens- 5 at Syracuse, New York, and 60 at Wheeling, West Virginia; but since the statistics for 1899 were completed there has been a considerable activity in the building of by-product ovens. The Solvay。 Process Company is building at its works in Detroit, Michigan, 30 Semet-Solvay ovens, and these ovens will be in operation during 1901.

Since the close of 1899,50 Otto-Hoffman ovens have been constructed at Hamilton, Ohio, and there are at present in course of construction of the Otto-Hoffman ovens-at Buffalo, New York, 564; at Lebanon, Pennsylvania, 232, and at Camden, New Jersey, 100; so that there are now in existence or under construction a total of 2,061 by-product ovens. This doubles the number in existence at the close of 189? and is nearly four times the number in existence in 1898. These statistics do not include the 400 Otto-Hoffman ovens erected at Sidney, Nova Scotia, for the Dominion Iron and Steel Company of that city, as these ovens are not within the United States. Of the plants in existence or in course of construction, the ones at Everett, Massachusetts; Hamilton, Ohio; and Camden, New Jersey, are constructed with the idea of making gas the primary product. They are manufacturing or will manufacture an illuminating gas of 18 to 20 candlepower, and a number of other plants of this class are reported as under consideration. The daily capacity of one of these ovens varies from 5 to 6 short tons of coal.

The percentages of products from by-product ovens vary about as follows: Coke, 73 to 87 per cent; tar, 1.8 to 5.5 per cent; sulphate of ammonia, 0.8 to 1.3 per cent. The surplus gas varies considerably, according to the volatile contents of the coal carbonized, the maximum being about 5,000 cubic feet per short ton. This gas has a calorific value up to 700 B. H. U., and the gas produced at Everett, Massachusetts, has at times even exceeded this figure. The gas produced is usually the same in composition as the illuminating gas made in gashouse retorts, as follows:

Composition of coke-oven gas, Otto-Hoffman system, at Everett, Massachusetts.

\begin{tabular}{|c|c|}
\hline Constituent. & Percentage. \\
\hline Carbon dioxide $\ldots \ldots \ldots \ldots$ & 1.3 \\
\hline Illuminants.......... & 3.4 \\
\hline Oxygen $\ldots \ldots \ldots \ldots \ldots$ & .45 \\
\hline Carbon monoxide...$\ldots \ldots \ldots \ldots \ldots \ldots \ldots$ & 6. \\
\hline Methane...... & 33.5 \\
\hline Hydrogen ... & 50.45 \\
\hline Nitrogen........... & 4.9 \\
\hline Total .. & 100. \\
\hline
\end{tabular}


The total quantity of gas obtained is about 10,000 cubic feet per ton of coal, varying, as before stated, according to whether the coal is high or low in volatile matter. It is customary to use about 6,500 cubic feet for heating the ovens; the balance is used for various purposes, - either as fuel or for illuminating.

In the foregoing statement no account is taken of the 30 NewtonChambers ovens constructed at Latrobe, Pennsylvania, in 1896, and which have not been operated as by-product ovens, nor of 3 experimental Slocum ovens at Bolivar, which have never been operated at all.

In connection with the statistics of the production of coke in by-product ovens, it is pertinent to consider the disposition of the gas, tar, and ammonia recovered in the process. According to the reports made jointly to the Census Office and the Geological Survey, the total value of the by-products recovered in the manufacture of coke in retort ovens in 1899 amounted to $\$ 944,537$. These were distributed as follows:

Amount and ralue of gas, tar, and ammonia recovered in by-product coke making in 1899.

\begin{tabular}{|c|c|c|}
\hline By-product. & Amount. & Value. \\
\hline Tar $\ldots \ldots \ldots \ldots \ldots$ pounds.. & $104,687,330$ & $\$ 207,952$ \\
\hline Ammonia liquor.............. gallons.. & $1,572,325$ & 180,642 \\
\hline Ammonium sulphate.......... pounds.. & $11,984,931$ & 330,921 \\
\hline Surplus gas . . . . . . . . . . . . cubic feet. & $1,996,124,697$ & 225,022 \\
\hline Total & & 944,537 \\
\hline
\end{tabular}

The continued success of the by-product coke-making establishments already in existence, and the extension of this system of coke manufacture, necessarily depends upon the ability of the producers to secure profitable markets for the by-products. There is at the present time sufficient demand for the gas and ammonia products to eliminate those factors from the problem. The market for the surplus gas (i. e., the gas not required for the generation of the heat in the oven flues) is determined by the location of each plant. Most of the byproduct ovens constructed in the United States have coke for the primary product, with gas as one of the by-products. In such cases no attempt is made to produce an illuminating gas, and this by-product is sold for fuel purposes. The Semet-Solvay plants at Wheeling, West Virginia; Sharon and Dunbar, Pennsylvania, and Ensley, Alabama, are located near iron or steel works, and the gas as well as the coke is consumed in these works. The gas from the Otto-Hoffman ovens, at Otto, near Pittsburg, Pennsyliania, and at Johnstown; and from the Semet-Solvay ovens at Syracuse, is also used for fuel, the coke in each case being the primary product. The Otto-Hoffman 
plant at Everett, Massachusetts, which makes gas its primary product, has its ready market in the city of Boston. Since the close of 1899 a bank of 50 Otto-Hoffman ovens has been completed at Hamilton, Ohio, which makes gas the primary product, and another plant of 100 ovens of the same type now building at Camden, New Jersey, will also make gas of illuminating quality the principal product. The markets for the gas product are assured in advance.

The United Coke and Gas Company, operating the Otto-Hoffman ovens, has adopted a method of fractionally separating the gases of distillation at those plants where gas is the principal product, as at Everett, Massachusetts, and Hamilton, Ohio. By this process a gas of high illuminating power is obtained. In order to maintain a uniform high candle power in the gas and to allow a sufficient flexibility to follow the varying demand in a city's gas consumption an auxiliary producer plant is employed, by means of which more coke-oven gas becomes available. This gas is necessarily of lower candle power, to correct which and maintain a gas of uniform illuminating quality the illuminants (chiefly benzole) are removed from the poorer gas burned in the oven flues and transferred to the gas sent into the city mains.

There is also a steady and remunerative demand for the ammonia, and the production of large quantities of ammonia from the various coking plants has had no material influence on the market price.

Ammonia is obtained in the form of a weak liquor containing ammonium sulphide and ammonium carbonate. It is concentrated into a crude, impure liquor containing from 20 to 25 per cent $\mathrm{NH}_{3}, 40$ to 45 grams per liter of $\mathrm{H}_{2} \mathrm{~S}$, and from 100 to 120 grams per liter of $\mathrm{CO}_{2}$. Some of this liquor is sold as ammonia liquor and some is worked up into various ammonium compounds, such as ammonium chloride, ammonium carbonate, ammonium sulphate, aqua ammonia, and anhydrous ammonia.

At some works all the liquor is worked up into ammonium sulphate and sold as such.

Considerable quantities of ammonium chloride and carbonate are imported into the United States, the former being used for galvanizing and electrical purposes and the latter in the manufacture of baking powders, etc. With a regular supply of these compounds from domestic sources, which will be provided by the extension of the use of hy-product ovens, a decrease in the importations may be anticipated. Aqua and anhydrous ammonia are used extensively for refrigerating purposes. Recent discoveries have shown that potassium cyanide, largely used in the treatment of certain classes of gold ores, can be profitably made from ammonia. Any excess of production will be readily taken, though at lower prices, for fertilizing purposes.

Another important by-product, a constituent of the gas, and thus far not yet recovered, is cyanogen. It is an impurity in the gas and may

$$
21 \text { GHUL, PT } \dot{b}-3 \dot{b}
$$


be removed by the use of an alkaline iron salt. The cyanogen is formed into a ferrocyanide of potassium or sodium in solution; the solution is evaporated to the crystallizing point and the crystals then purified. The amount of cyanogen obtained varies according to the amount of volatile matter in the coal and the percentage of nitrogen and the temperature to which the ovens are heated, high temperature tending to increase the cyanogen in the gas.

The method of preparing potassium ferrocyanide by heating animal matter, potassium carbonate and, iron is still used in three German and some English and American works; but in Europe the main source of supply is coal gas. When a mixture of calcium hydroxide and iron sulphate is used to remove the hydrogen sulphide, the following reactions take place:

$$
\begin{aligned}
& \mathrm{FeSO}_{4}+\mathrm{Ca}(\mathrm{OH})_{2}=\mathrm{CaSO}_{4}+\mathrm{Fe}(\mathrm{OH})_{2} ; \\
& 2 \mathrm{Fe}(\mathrm{OH})_{2}+\mathrm{O}+\mathrm{H}_{2} \mathrm{O}=\mathrm{Fe}_{2}(\mathrm{OH})_{6} ; \\
& \mathrm{Fe}_{2}(\mathrm{OH})_{6}+3 \mathrm{H}_{2} \mathrm{~S}=\mathrm{Fe}_{2} \mathrm{~S}_{3}+6 \mathrm{H}_{2} \mathrm{O} ; \\
& \mathrm{Fe}_{2} \mathrm{~S}_{3}+3 \mathrm{O}+3 \mathrm{H}_{2} \mathrm{O}=\mathrm{Fe}_{2}(\mathrm{OH})_{6}+3 \mathrm{~S} .
\end{aligned}
$$

During this process the cyanogen compounds are also absorbed by the ferric hydroxide, and, after the mass has become useless on account of the accumulation of sulphur, they are isolated in the following manner: The mass, which contains sulphide of iron, sulphur, salts of lime and free lime, ferrocyanides, and sulphocyanides of iron and ammonia, is treated with water to remove the soluble part, and the residue, after treatment with lime to form the calcium ferrocyanide, is converted, by the action of potassium chloride, into an insoluble compound of potassium and calcium ferrocyanide, which is decomposed by potassium carbonate with the formation of potassium ferrocyanide. In one English factory the gas is passed through a solution of an iron salt and the prussian blue formed is decomposed by caustic potash. In one factory in Germany the "vinasses" are heated, and the cyanogen compounds formed from the decomposition of the trimethylamine are converted into prussian blue as in the other method. In 1899 the production of potassium ferrocyanide in France, Germany, England, Belgium, Holland, and the United States amounted to 10,500 tons, of which 50 per cent was conrerted into potassium cyanide. Potassium sulphocyanide, which is also obtained from the coal gas, is also made in comparatively smạll quantity and is converted into a copper salt, which is used as a constituent of paint for the hulls of vessels. This copper salt acts as a poison to the crustacea which foul the hulls of ships. ${ }^{1}$

The most urgent demand in connection with by-product coke making is the building up in the United States of chemical manufacturing establishments, based upon coal tar as a raw material for the manufacture of colors, dyes, and other articles now obtained solely from foreign sources. At present the principal use to which coal tar is put in the Cnited States is the manufacture of roofing paper, the creosoting of lumber, and for street paving. As shown in the preceding table, the amount of tar produced at by-product coke ovens in the United States during 1899 was $104,687,330$ pounds, valued at $\$ 207,952$. The extent to which this material is manufactured may be briefly summarized as follows:

${ }^{1}$ Am. Chem. Jour., Vol. XXIV, No. 6, pp. 530-531. 
The tar is distilled, yielding (1) light oil, (2) heavy oil, and (3) pitch. The points of distillation are for light oils up to $220^{\circ} \mathrm{C}$. Oils d distilled above this point sink into the water, and are classed among heavy oils, which are distilled at temperatures from $220^{\circ} \mathrm{C}$. to $295^{\circ}$ or $300^{\circ} \mathrm{C}$., according to the quality of the pitch required.

According to the practice in the United States, a portion of the light oil is again distilled for the benzol and toluene contained. These in turn are nitrified and sold as nitro-benzol, or oil of myrbane, which is converted into aniline and aniline salts. But a very small portion of the light oils are so used.

By a further distillation of the oils and pitch a series of valuable products are obtainable, but so far as the industry in this country is concerned there is very little utilized. The continued distillation of the tar will produce the following:

$$
\text { Tar .... }\left\{\begin{array}{l}
\text { Light oil.... }\left\{\begin{array}{l}
\text { Benzol ... } \\
\text { Toluene ... } \\
\text { Xylene... }
\end{array}\right\} \begin{array}{l}
\text { Nitro-benzol, aniline, aniline salts, oil } \\
\text { of myrbane. }
\end{array} \\
\text { Heavy oil... }\left\{\begin{array}{l}
\text { Phenol .... } \\
\text { Cresol .... } \\
\text { Pyridine . }
\end{array}\right\} \\
\text { Pitch........... Anthracene, alizarine. }
\end{array}\right.
$$

The extension of the use of by-product coke ovens in the United States and the regular supply of the coal tar as a raw material in the manufacture of aniline colors, salts, etc., should be followed by the establishment of the chemical industries for the manufacture of these valuable products which are now imported to the value of several millions of dollars annually.

The Bureau of Statistics of the Treasury Department reports that there were imported in the United States during the fiscal year ending June $30,1900, \$ 6,773,152$ worth of coal-tar products. Upon these duty was paid to the amount of $\$ 1,516,689$, making a total cost at the port of entry exclusive of freight charges of $\$ 8,289,741$. There has been almost uninterrupted increase in the importation of these coaltar products during the last five years. In 1896 the value of the coaltar products imported in the United States amounted to $\$ 4,713,200$, upon which duty to the amount of $\$ 729,583$ was paid - a total cost at the port of entry of $\$ 5,442,783$, showing that the increase in the value of these products in the five years is something over 50 per cent. 
In the following table is shown the imports of the coal-tar products for each year from 1896 to 1900 , the figures being for the fiscal year ending June 30:

Coal-tar products imported into the United States during the fiscal years 1896 to 1900.

1896.

\begin{tabular}{|c|c|c|c|}
\hline Article. & Amount. & Value. & Duty. \\
\hline Salicylic $\ldots \ldots \ldots \ldots$ & $\begin{array}{l}\text { Pounds. } \\
335,354\end{array}$ & $\$ 138,013$ & Free. \\
\hline $\begin{array}{l}\text { Alizarine and colors or dyes, natural } \\
\text { and artificial } \ldots \ldots \ldots \ldots \ldots \ldots\end{array}$ & $6,154,156$ & 994,395 & Free. \\
\hline Aniline salts . . . . . . . . . & 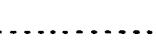 & 662,459 & Free. \\
\hline 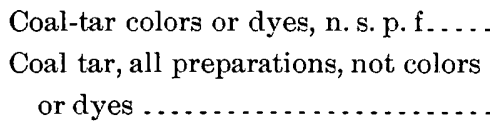 & r & $2,918,333$ & $\$ 729,583$ \\
\hline $\begin{array}{l}\text { Coal-tar products, not medicinal, } \\
\text { notdyes, known as benzol, toluol, } \\
\text { etc } \ldots \ldots \ldots \ldots \ldots \ldots\end{array}$ & & - & \\
\hline Total. & 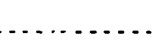 & $4,713,200$ & 729,583 \\
\hline
\end{tabular}

1897.

\begin{tabular}{|c|c|c|c|}
\hline Article. & Amount. & Value. & Duty. \\
\hline Salicylic $\ldots \ldots \ldots \ldots \ldots \ldots \ldots$ & $\begin{array}{l}\text { Pounds. } \\
616,187\end{array}$ & $\$ 201,980$ & Free. \\
\hline $\begin{array}{l}\text { Alizarine and colors or dyes, natural } \\
\text { and artificial } \ldots \ldots\end{array}$ & $6,169,018$ & $1,023,425$ & Free. \\
\hline Aniline salts...$\ldots \ldots \ldots \ldots \ldots$. & ... & 812,884 & Free. \\
\hline Coal-tar colors or dyes, n. s. p. f.... & & $3,163,182$ & $\$ 790,796$ \\
\hline $\begin{array}{l}\text { Coal tar, all preparations, not colors } \\
\text { or dyes } \ldots \ldots \ldots \ldots\end{array}$ & & & \\
\hline 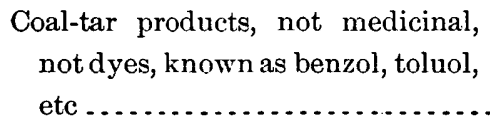 & & & \\
\hline Totaì...... & & $\overline{5}, \hat{z} 0 \hat{1}, 4 \overline{7} \overline{1}$ & 790,796 \\
\hline
\end{tabular}


Coal-tar products imported into the Lnited States during the fiscal years 1896 to 1900-Continued.

1898.

\begin{tabular}{|c|c|c|c|}
\hline Article. & Amount. & Value. & Duty. \\
\hline Salicylic $\ldots \ldots \ldots \ldots \ldots \ldots \ldots$ & $\begin{array}{l}\text { Pounds. } \\
\quad 92,943\end{array}$ & $\$ 28,688$ & $\$ 6,794$ \\
\hline $\begin{array}{l}\text { Alizarine and colors or dyes, natural } \\
\text { and artificial.......................... }\end{array}$ & $5,871,962$ & 886,349 & Free. \\
\hline Aniline salts $\ldots \ldots \ldots \ldots \ldots$ & & $1,087,704$ & Free. \\
\hline Coal-tar colors or dyes, n. s. p. f... & ….... & $.3,723,288$ & $1,098,532$ \\
\hline $\begin{array}{l}\text { Coal tar, all preparations, not colors } \\
\text { or dyes. } \ldots \ldots\end{array}$ & & 134,416 & 26,883 \\
\hline $\begin{array}{l}\text { Coal-tar products, not medicinal, } \\
\text { not dyes, known as benzol, toluol, } \\
\text { etc } \ldots \ldots \ldots \ldots \ldots \ldots \ldots \ldots \ldots\end{array}$ & & 228,037 & Free. \\
\hline Total. & & $6,088,482$ & $1,132,209$ \\
\hline
\end{tabular}

1899.

\begin{tabular}{|c|c|c|c|}
\hline Article. & Amount. & Value. & Duty. \\
\hline Salicylic $\ldots \ldots \ldots \ldots$ & $\begin{array}{l}\text { Pounds. } \\
185,359\end{array}$ & $\$ 57,192$ & $\$ 18,536$ \\
\hline $\begin{array}{l}\text { Alizarine and colors or dyes, natural } \\
\text { and artificial } \ldots \ldots \ldots \ldots \ldots \ldots\end{array}$ & $5,226,452$ & 700,786 & Free. \\
\hline Aniline salts $\ldots \ldots \ldots \ldots \ldots \ldots \ldots$ & $7,930,172$ & 743,130 & Free. \\
\hline Coal-tar colors or dyes, n. s. p. f..... & ............ & $3,900,099$ & $1,170,030$ \\
\hline 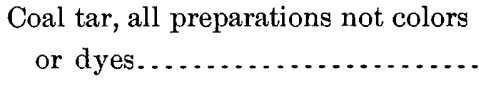 & & 221,101 & 44,220 \\
\hline $\begin{array}{l}\text { Coal-tar products not medicinal, } \\
\text { not dyes, known as benzol, toluol, } \\
\text { etc } \ldots \ldots \ldots \ldots \ldots \ldots \ldots \ldots \ldots\end{array}$ & $\cdots \cdots \cdots$ & 393,602 & Free. \\
\hline Total. & & $6,015,910$ & $1,232,786$ \\
\hline
\end{tabular}


Coal-tar products imported into the United States during the fiscal years 1896 to 1900-Continued.

1900 .

\begin{tabular}{|c|c|c|c|}
\hline Article. & Amount. & Value. & Duty. \\
\hline Salicylic $\ldots \ldots \ldots \ldots$ & $\begin{array}{l}\text { Pounds. } \\
240,687\end{array}$ & $\$ 89,175$ & $\$ 24,069$ \\
\hline $\begin{array}{l}\text { Alizarine and colors or dyes, natural } \\
\text { and artificial } \ldots \ldots \ldots \ldots \ldots \ldots\end{array}$ & $6,009,552$ & 771,336 & Free. \\
\hline Aniline salts . . . . . . . . . & $7,522,819$ & 537,812 & Free. \\
\hline Coal-tar colors or dyes, n. s. p. f. . . & 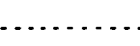 & $4,792,103$ & $1,437,631$ \\
\hline $\begin{array}{l}\text { Coal tar, all preparations not colors } \\
\text { or dyes.......... }\end{array}$ & & 274,946 & 54,989 \\
\hline $\begin{array}{l}\text { Coal-tar products not medicinal, } \\
\text { not dyes, known as benzol, toluol, } \\
\text { etc } \ldots \ldots\end{array}$ & & 307,780 & Free. \\
\hline Total. & & $6,773,152$ & $1,516,689$ \\
\hline
\end{tabular}

The countries shipping these products to the United States are Germany, England, and France. The greater portion comes from Germany. It is claimed that the reason Germany is better able to manufacture the colors and other coal-tar products than the United States is on account of her large supply of chemical labor, the chemists in that country being satisfied to work for a lower compensation than the American chemists. Against this may be set the cheaper coal, and consequently cheaper tar as a raw material than it is possible to obtain in any of the European countries. It is claimed, also, that the coals of the United States will yield a larger percentage of by-products per ton of coal carbonized, and the higher price of chemical labor and skilled labor in the United States is more than offset by the ability of the American manufacturer to replace with machinery the hand labor of Europe. The other raw materials which are used in the color works - such as sulphuric, nitric, and hydrochloric acids, carbonate of soda and caustic of soda-are all as cheap in this country as in Europe. Many of the patents previously existing and which protected the manufacturers of the coal-tar colors have expired, and the processes are free to anyone engaging in the industry. Among the colors which are now produced in foreign countries and imported in large quantities into the United States may be mentioned the following:

I. Aniline dyes:

(a) Rosaniline group; in which class are magenta, or fuchsine, malachite green, aniline blue, methyl green, and others. 
I. Aniline dyes-Continued.

(b) Indulines and safranines.

(c) Oxazines.

(d) Aniline black.

II. Phenol dyes:

(a) Nitro bodies, chief of which is picric acid.

(b) Coloring matters which are formed by the action of nitrous acid on the phenols; for example, fluorescent resorcin blue.

(c) Rosolic acid, yellow, and red corallin.

(d) Phthaleins and indophenols. Under this heading are phenolphthalein, fluorescein, and the various eosins, which are used in large quantities.

III. Azo dyes:

(a) Amido azo, crysoidine aniline yellow.

(b) Amidoazosulphonic acids, helianthine, tropaeoline, etc.

(c) Oxyazo dyes; among these are the most important dyes of the coal-tar colors.

IV. Artificial indigo.

V. Anthracene dyes, such as alizarine, purpurin, flavopurpurin.

The writer is under many obligations to Dr. F. Schniewind, of the United Gas and Coke Company, and to Mr. J. D. Pennock, chemist for the Solvay Process Company, for notes on the present and future condition of the by-product ovens and the utilization of the by-products, which are summarized in the foregoing discussion.

\section{PRODUCTIÓN OF COKE BY STATES.}

ALABAMA.

The coke production of Alabama in 1899 amounted to $1,787,809$. short tons, valued at $\$ 3,634,471$, against $1,663,020$ tons, valued at $\$ 3,378,946$, in 1898 , indicating a gain of 124,789 tons, or 7.5 per cent, in amount, and of $\$ 255,525$, or 7.6 per cent, in value. The increase in Alabama was not equal either in amount or percentage to the increase shown in West Virginia, and the latter. State seems now to have become as firmly established in second place in coke production as it is in third place among the coal-producing States. The coke product of Alabama in 1899, while the largest in the history of the State, was nearly $\check{0} 00,000$ tons short of that of West Virginia. The number of completed ovens in West Virginia in 1899 was over 50 per cent larger than that of Alabama, but there were 850 ovens building at the close of the year in Alabama to 619 in West Virginia. The indications are that the manufacture of coke in Alabama will continue to increase, but it is not likely that the lead taken by West Virginia will be overcome.

Alabama was one of the few States in which the average price in 1899 was not more than that of 1898 , the production and value showing practically the same percentage of increase. 
The total number of orens in operation during 1899 was 5,056 , in addition to which there were $5+3$ idle all the year, making a total for the State of 5,599 , against 5,456 in 1898 , of which 386 were idle. There were 130 ovens abandoned during the year, from which it appears that 273 new ovens were constructed during 1899 .

The coal fields of Alabama are divided into three subdistricts, known as the Warrior, the Coosa, and the Cahaba, these districts being named from the rivers which drain them. Coke ovens are built in all three districts, but coke has been made for the last four years in but twothe Warrior and the Cahaba. The most important of these districts, both as a coal producer and coke maker, is the Warrior, the ovens in this district being located near Birmingham.

Of the 5,599 ovens in the State, 5,132 are in the Warrior district, and of the total production of $1,787,809$ tons in $1899,1,712,035$ tons were made in the Warrior district.

While most of the ovens built in the State are of the ordinary beehive pattern-the more recent ones being of the usual dimensious, 12 feet in diameter and 7 feet high-it is evident from the frequent attempts that have been made to introduce other ovens that the beehive oven as a coker of Alabama coal is not entirely satisfactory. The ovens other than beehive, which had up to 1898 been introduced successfully into Alabama, are solid-wall ovens, or ovens in which there are no flues in the walls, and in which the coking chamber or combustion chamber, wherein the heat for coking is produced, are the same. Two forms of these modified solid-wall ovens are in use in Alabama at the present time, one known as the "Thomas" oven, which has already been described in this series of reports, and the other as the "double oblong." These ovens are 21 feet long and 9 feet wide, open at both ends. The ovens are charged from the top and drawn at the ends. They produce in a given time about 75 per cent more coke than the ordinary beehive oven. The most recent and most important departure from the beehive type of ovens has been the completion of a bank of 120 Semet-Solvay ovens at Ensley, which were put into operation in December, 1898. The buildings were destroyed by fire a few days afterwards, but were immediately rebuilt and, by February, 1899, operations were resumed. The plant has been in active operation ever since; the coke and surplus gas are consumed by the Ensley furnaces of the Tennessee Coal, Iron, and Railroad Company. 
The statistics of coke production in Alabama since 1880 are as follows:

Stalistics of the manufacture of coke in Alabama from 1880 to 1899, inclusive.

\begin{tabular}{|c|c|c|c|c|c|c|c|c|}
\hline \multirow{2}{*}{ Year. } & \multirow{2}{*}{$\begin{array}{l}\text { Estab- } \\
\text { lish- } \\
\text { ments. }\end{array}$} & \multicolumn{2}{|c|}{ Ovens. } & \multirow{2}{*}{ Coal used. } & \multirow{2}{*}{$\begin{array}{l}\text { Coke pro- } \\
\text { duced. }\end{array}$} & \multirow{2}{*}{$\begin{array}{l}\text { Total value } \\
\text { of coke at } \\
\text { ovens. }\end{array}$} & \multirow{2}{*}{$\mid \begin{array}{c}\text { Value } \\
\text { of } \\
\text { coke at } \\
\text { ovens, } \\
\text { per ton. }\end{array}$} & \multirow{2}{*}{$\begin{array}{c}\text { Yield } \\
\text { of coal } \\
\text { in } \\
\text { coke. }\end{array}$} \\
\hline & & Built. & Building. & & & & & \\
\hline $1880 \ldots$ & 4 & 316 & 100 & $\begin{array}{c}\text { Short tons. } \\
106,283\end{array}$ & $\begin{array}{l}\text { Short tons. } \\
\quad 60,781\end{array}$ & $\$ 183,063$ & $\$ 3.01$ & $\begin{array}{l}p_{e r} \cdot c t . \\
57\end{array}$ \\
\hline $1881 \ldots$ & 4 & 416 & 120 & 184,881 & 109,033 & 326,819 & 3.00 & 59 \\
\hline 1882. & 5 & 536 & $\ldots$ & 261,839 & 152,940 & 425,940 & 2. 79 & 58 \\
\hline 1883. & 6 & 767 & 122 & 359,699 & 217,531 & 598,473 & 2. 75 & 60 \\
\hline $188+$. & 8 & $a 976$ & 242 & 413,184 & 244,009 & 609,185 & 2.50 & 60 \\
\hline 1885 & 11 & 1,075 & 16 & 507,934 & 301,180 & 755,645 & 2.50 & 59 \\
\hline 1886 & 14 & $a 1,301$ & 1,012 & 635,120 & 375,054 & 993,302 & 2.65 & 59 \\
\hline 1887. & 15 & 1,555 & 1,362 & 550,047 & 325,020 & 775,090 & 2. 39 & 59 \\
\hline $188 s$ & 18 & 2,475 & 406 & 848,608 & 508,511 & $1,189,579$ & 2.34 & 60 \\
\hline $18 \$ 9$. & 19 & 3,944 & 427 & $1,746,277$ & $1,030,510$ & $2,372,417$ & 2.30 & 59 \\
\hline 1890 & 20 & 4,805 & 371 & $1,809,964$ & $1,072,942$ & $2,589,447$ & 2.41 & 59 \\
\hline 1891. & 21 & 5,068 & 50 & $2,144,277$ & $1,282,496$ & $2,986,242$ & 2.33 & 60 \\
\hline $1892 \ldots$ & 20 & 5,320 & 90 & $2,585,966$ & $1,501,571$ & $3,464,623$ & 2.31 & 58 \\
\hline $1893 \ldots$ & 23 & 5,548 & 60 & $2,015,398$ & $1,168,085$ & $2,648,632$ & 2.27 & 58 \\
\hline 1894 & 22 & 5,551 & 50 & $1,574,245$ & 923,817 & $1,871,348$ & 2.025 & 58.7 \\
\hline $1895 \ldots$ & 22 & 5,658 & 50 & $2,459,465$ & $1,444,339$ & $3,033,521$ & 2.10 & 58.7 \\
\hline 1896 & 24 & 5,363 & & $2,573,713$ & $1,479,437$ & $3,064,960$ & 2.07 & 57.5 \\
\hline $1897 \ldots$ & 25 & 5,365 & $b 120$ & $2,451,475$ & $1,443,017$ & $3,094,461$ & 2.14 & 58.8 \\
\hline $1898 .$. & 25 & $c 5,456$ & 100 & $2,814,615$ & $1,663,020$ & $3,378,946$ & 2.03 & 59 \\
\hline $1899 \ldots$ & 25 & $c 5,599$ & 850 & $3,028,472$ & $1,787,809$ & $3,634,471$ & 2.03 & 59 \\
\hline
\end{tabular}

$a$ One establishment made coke on the ground.

$c$ Includes 120 Semet-Solvay ovens. 
The character of the coal used in the manufacture of coke in Alabama since 1890 is shown in the following table:

Character of coal used in the manufacture of coke in Alabana since 1890.

\begin{tabular}{|c|c|c|c|c|c|}
\hline \multirow{2}{*}{ Year. } & \multicolumn{2}{|c|}{ Run of mine. } & \multicolumn{2}{|c|}{ Slack. } & \multirow{2}{*}{ Total. } \\
\hline & Unwashed. & Washed. & Unwashed. & Washed. & \\
\hline 1890 & $\begin{array}{c}\text { Short tons. } \\
1,480,669\end{array}$ & Short tons. & Short tons. & Short tons. & Short tons. \\
\hline 1891. & $1,943,469$ & 0 & 192,238 & 8,570 & $2,144,277$ \\
\hline 1892. & $2,463,366$ & 0 & 11,100 & 111,500 & $2,585,966$ \\
\hline 1893. & $1,246,307$ & 51,163 & 292,198 & 425,730 & $2,015,39 \mathrm{~s}$ \\
\hline 1894. & 411,097 & 7,429 & 477,820 & 677,899 & $1,574,245$ \\
\hline 1895. & $1,208,020$ & 0 & 32,068 & $1,219,377$ & $2,459,465$ \\
\hline 1896. & $1,292,191$ & 70,125 & 51,674 & $1,159,723$ & $2,573,713$ \\
\hline 1897. & 902,310 & 120,420 & 91,200 & $1,337,545$ & $2,451,475$ \\
\hline 1898 & $1,290,794$ & 828,294 & 25,000 & 670,527 & $2,814,615$ \\
\hline 1899 & $1,656,226$ & 725,238 & 9,898 & 637,110 & $3,028,472$ \\
\hline
\end{tabular}

As shown in the above table, practically 50 per cent of the coal used in making coke in Alabama during the last four years has been washed before being charged into the ovens. Experience has shown that the coke product from some of the Alabama coal is much improved by washing the coal. Not only is the percentage of ash and sulphur reduced, but the physical structure of the coke is improved. From 1890 to 1892 washing the coal was done in an experimental manner. The next three years showed a rapid increase in the amount of washed coal used, and now about half the coal charged into the ovens is washed.

\section{COLORADO.}

Colorado is by far the most important coke-producing State west of the Mississippi River, and stands fifth among all the States in this regard. The total amount of coke produced by the States west of the Mississippi River in 1899 was 714,850 short tons, of which Colorado produced 530,424 tons, or practically 75 per cent. Compared with 1898, the coke production of Colorado in 1899 increased 55,616 short tons, or 11.7 per cent, with an increase in value of $\$ 103,3 \pm 1$, or a little over 8 per cent. The average price declined slightly from $\$ 2.59$ per ton in 1898 to $\$ 2.51$ in 1899 . The statistics for 1899 sbow no increase in the number of coke-making establishments and a reduction of 10 in the number of completed ovens. There were 18 ovens idle in 1899 against 33.in 1898 . 
The statistics of the production of coke in Colorado from 1880 to 1899 are given in the following table. From 1892 to 1899, both inclusive, the statements of production of coke in Utah are included in Colorado:

Statistics of the manufacture of coke in Colorado from 1880 to 1899.

\begin{tabular}{|c|c|c|c|c|c|c|c|c|}
\hline \multirow{2}{*}{ Year. } & \multirow{2}{*}{$\begin{array}{c}\text { Estab- } \\
\text { lish- } \\
\text { ments. }\end{array}$} & \multicolumn{2}{|c|}{ Ovens. } & \multirow{2}{*}{ Cóal used. } & \multirow{2}{*}{$\begin{array}{l}\text { Coke pro- } \\
\text { duced. }\end{array}$} & \multirow{2}{*}{$\begin{array}{l}\text { Total value } \\
\text { of coke at } \\
\text { ovens. }\end{array}$} & \multirow{2}{*}{$\begin{array}{l}\text { Value of } \\
\text { coke at } \\
\text { ovens, } \\
\text { per ton. }\end{array}$} & \multirow{2}{*}{$\begin{array}{l}\text { Yield of } \\
\text { coal in } \\
\text { coke. }\end{array}$} \\
\hline & & Built. & \begin{tabular}{|c|} 
Build- \\
ing.
\end{tabular} & & & & & \\
\hline 1880 & 1 & 200 & 50 & $\begin{array}{r}\text { Short tons. } \\
51,891\end{array}$ & $\begin{array}{r}\text { Short tons. } \\
25,568\end{array}$ & $\$ 145,226$ & $\$ 5.68$ & $\begin{array}{c}\text { Per cent. } \\
49\end{array}$ \\
\hline 1881. & 2 & 267 & 0 & 97,508 & 48,587 & 267,156 & 5.29 & 50 \\
\hline 1882 & 5 & 344 & 0 & 180,549 & 102,105 & 476,665 & 4. 67 & 57 \\
\hline 1883 & 7 & 352 & 0 & 224,089 & 133,997 & 584,578 & 4. 36 & 60 \\
\hline 1884 & 8 & 409 & 24 & $\mathbf{1 8 1}, 968$ & 115,719 & 409,930 & 3.45 & 64 \\
\hline $1885 \ldots$ & 7 & 434 & 0 & 208,069 & 131,960 & 512,162 & 3.88 & 63 \\
\hline $1886 \ldots$ & 7 & 483 & 0 & 228,060 & 142,797 & 569,120 & 3.99 & 62.6 \\
\hline $1887 \ldots$ & 7 & 532 & 0 & 267,487 & 170,698 & 682,778 & 4. 00 & 64 \\
\hline $1888 \ldots$ & 7 & 602 & 100 & 274,212 & 179,682 & 716,305 & 4.00 & 65.6 \\
\hline 1889. & 9 & 834 & 50 & 299,731 & 187,638 & 643,479 & 3.43 & 63 \\
\hline 1890. & 8 & 916 & 30 & 407,023 & 245,756 & 959,246 & 3.90 & 60 \\
\hline $1891 \ldots$ & 7 & 948 & 21 & 452,749 & 277,074 & 896,984 & 3.24 & 61 \\
\hline $1892 a$ & 9 & $b 1,128$ & 220 & 599,200 & $373 ; 229$ & $1,234,320$ & 3.31 & 62.3 \\
\hline $1893 a$ & 8 & 1,154 & 200 & 628,935 & 362,986 & $1,137,488$ & 3.13 & 57.7 \\
\hline $1894 a$ & 8 & 1,154 & 250 & 542,429 & 317,196 & 903,970 & 2.85 & 58.5 \\
\hline $1895 a$ & 9 & 1,169 & 0 & 580,584 & 340,357 & 940,987 & 2. 76 & 58.6 \\
\hline $1896 a^{!}$ & 11 & 1,275 & 0 & 639,238 & 363,760 & $1,046,306$ & 2.88 & 56.9 \\
\hline $1897 a^{\prime}$ & 12 & 1,273 & 0 & 616,592 & 342,653 & 999,216 & 2.916 & 55.6 \\
\hline $1898 a$ & 12 & 1,253 & 3 & 803,686 & 474,808 & $1,230,428$ & 2.59 & 59.8 \\
\hline $1899 a$ & 12 & 1,243 & 50 & 898,207 & 530,424 & $1,333,769$ & 2.51 & 59 \\
\hline
\end{tabular}

$a$ Includes production and value of coke in Utah, and of coal coked. $b$ Includes 36 gas retorts since 1892 .

Washing the slack coal before coking has been found to improve the quality and value of the resultant coke, and the amount of washed coal used has steadily increased since washeries were introduced in 1895. Light demand for coke in 1897 caused all of the product to be made from slack coal. Improved conditions in 1898 made it necessary to resume using mine-run coal. 
The character of the coal used in the manufacture of coke in Colorado and Utah since 1890 is shown in the following table:

Character of coal used in the manufacture of coke in Colorado and Utah since 1890.

\begin{tabular}{|c|c|c|c|c|c|}
\hline \multirow{2}{*}{ Year. } & \multicolumn{2}{|c|}{ Run of mine. } & \multicolumn{2}{|c|}{ Slack. } & \multirow{2}{*}{ Total. } \\
\hline & Unwashed. & Washed. & Unwashed. & Washed. & \\
\hline & Short tons. & Short tons. & Short tons. & Short tons. & Short tons. \\
\hline 1890. & 36,058 & 0 & 395,023 & 0 & 431,081 \\
\hline $1891 \ldots$ & 93,752 & 0 & 384,278 & 0 & 478,030 \\
\hline 1892. & 82,098 & 0 & 517,102 & 0 & 599,200 \\
\hline 1893. & 109,915 & 0 & 519,020 & 0 & 628,935 \\
\hline 1894. & 126,642 & 0 & 415,787 & 0 & 542,429 \\
\hline 1895. & 119,868 & 0 & 453,597 & 7,119 & 580,584 \\
\hline 1896. & 143,604 & 0 & 378,776 & 116,858 & 639,238 \\
\hline $1897 \ldots$ & 0 & 0 & 393,214 & 223,378 & 616,592 \\
\hline 1898. & 122,983 & 0 & 415,298 & 265,405 & 803,686 \\
\hline 1899. & 125,322 & 0 & 468,196 & 304,689 & 898,207 \\
\hline
\end{tabular}

\section{GEORGIA}

Coke production in Georgia seems to have taken on a new lease of life, revived probably by the increased demand and higher prices in 1899. The revival is not so much shown in the statistics of production, as the output in 1899 was less than 1,400 tons, or not quite 3 per cent, more than that of 1898 , but is indicated by an additional 100 new ovens building at the close of the year. Of the 350 ovens in existence in 1899,150 were idle. This is the first time in sixteen years that any new ovens have been reported as building. The actual production in 1899 was a little less than half the product in either 1890 or 1891.

The coal from which Georgia's coke is made is mined in the northwestern corner of the State on the eastern border of the Appalachian coal field. The coal is all washed before being coked, but the weight of the coal used is the weight before being washed.

Although the coke product in 1899 showed an increase of less than 3 per cent over the preceding year, the value was augmented by $\$ 39,687$, or a little more than 50 per cent, the aggregate value received being the largest since 1893, when the product exceeded by 80 per cent the output for 1899 . 
The statistics of the production of coke in Georgia, 1880 to 1899, are as follows:

Statistics of the manufacture of coke in Gieorgia, 1880 to 1899.

\begin{tabular}{|c|c|c|c|c|c|c|c|c|}
\hline \multirow{2}{*}{ Year. } & \multirow{2}{*}{$\begin{array}{l}\text { Estab- } \\
\text { lish- } \\
\text { ments. }\end{array}$} & \multicolumn{2}{|c|}{ Ovens. } & \multirow{2}{*}{ Coal used. } & \multirow{2}{*}{$\begin{array}{l}\text { Coke pro- } \\
\text { duced. }\end{array}$} & \multirow{2}{*}{$\begin{array}{l}\text { Total value } \\
\text { of coke at } \\
\text { ovens. }\end{array}$} & \multirow{2}{*}{$\begin{array}{l}\text { Value of } \\
\text { coke at } \\
\text { ovens, } \\
\text { per ton. }\end{array}$} & \multirow{2}{*}{$\begin{array}{l}\text { Yield of } \\
\text { coal in } \\
\text { coke. }\end{array}$} \\
\hline & & Built. & $\begin{array}{c}\text { Build- } \\
\text { ing. }\end{array}$ & & & & & \\
\hline 1880 & 1 & 140 & 40 & Short tons. & Short tons. & 881780 & 8915 & Per ccnt. \\
\hline 1881. & $\begin{array}{l}1 \\
1\end{array}$ & $\begin{array}{l}140 \\
180\end{array}$ & 40 & $\begin{array}{l}08,404 \\
68,960\end{array}$ & $\begin{array}{l}38,041 \\
41,376\end{array}$ & $\begin{array}{r}\$ 81,789 \\
88,753\end{array}$ & $\begin{array}{r}\$ .10 \\
2.15\end{array}$ & 60 \\
\hline 1882. & 1 & 220 & 44 & 77,670 & 46,602 & 100,194 & 2.15 & 60 \\
\hline 1883 & 1 & 264 & 36 & 111,687 & 67,012 & 147,166 & 2.20 & 60 \\
\hline 1884. & 1 & 300 & 0 & 132,113 & 79,268 & 169,192 & 2.13 & 60 \\
\hline 1885. & 2 & 300 & 0 & 117,781 & 70,669 & 144,198 & 2.04 & 60 \\
\hline 1886 & 2 & 300 & 0 & 136,133 & 82,680 & 179,031 & 2.17 & 60 \\
\hline 1887. & 2 & 300 & 0 & 158,482 & 79,241 & 174,410 & 2.20 & 50 \\
\hline 1888 & 1 & 290 & 0 & 140,000 & 83,721 & $17 \overline{7}, 907$ & 2. 12 & 60 \\
\hline 1889. & 1 & 300 & 0 & 157,878 & 94,727 & 149,059 & 1.57 & 60 \\
\hline $1890 \ldots$ & 1 & 300 & 0 & 170,388 & 102,233 & 150,995 & 1.48 & 60 \\
\hline $1891 \ldots$ & 1 & 300 & 0 & 164,875 & 103,057 & 231,878 & 2.25 & 62.5 \\
\hline 1892 & 1 & 300 & 0 & 158,978 & 81,807 & 163,614 & 2.00 & 51.5 \\
\hline 1893. & 1 & 338 & 0 & 171,645 & 90,726 & 136,089 & 1.50 & 52.8 \\
\hline $1894 \ldots$ & 1 & 338 & 0 & 166,523 & 93,029 & 116,286 & 1.25 & 55.9 \\
\hline $1895 \ldots$ & 1 & 330 & 0 & 118,900 & 60,212 & 70,580 & 1.17 & 50.6 \\
\hline $1896 \ldots$ & 1 & 334 & 0 & 109,655 & 53,673 & 68,486 & 1.276 & 49 \\
\hline $1897 \ldots$ & 1 & 300 & 0 & 67,000 & 33,000 & 42,240 & 1.28 & 49.3 \\
\hline $1898 \ldots$ & 2 & 350 & 0 & 81,108 & 49,529 & 77,230 & 1.56 & 61 \\
\hline $1899 \ldots$ & 2 & 350 & 100 & 78,098 & 50,907 & 116,917 & 2.30 & 65.2 \\
\hline
\end{tabular}


As shown in the following table, all of the coal used in the manufacture of coke in Georgia since 1891 was washed before being coked.

Character of coal used in the manufacture of coke in Georgia since 1890.

\begin{tabular}{|c|c|c|c|c|c|}
\hline \multirow{2}{*}{ Year. } & \multicolumn{2}{|c|}{ Run of mine. } & \multicolumn{2}{|c|}{ Slack. } & \multirow{2}{*}{ Total. } \\
\hline & Unwashed. & Washed. & Unwashed. & Washed. & \\
\hline & Short tons. & Short tons. & Short tons. & Short tons. & Short tons. \\
\hline $1890 \ldots$ & $0^{\circ}$ & 0 & 0 & 170,388 & 170,388 \\
\hline 1891. & 106,131 & 0 & 0 & 58,744 & 164,875 \\
\hline 1892 & 0 & 0 & 0 & 158,978 & 158,978 \\
\hline 1893. & 0 & 0 & 0 & 171,645 & 171,645 \\
\hline 1894 & 0 & 166,523 & 0 & 0 & 166,523 \\
\hline 1895 & 0 & 118,900 & 0 & 0 & 118,900 \\
\hline 1896. & 0 & 109,655 & 0 & 0 & 109,655 \\
\hline 1897 & 0 & 67,000 & 0 & 0 & 67,000 \\
\hline $1898 \ldots \ldots$ & 0 & 61,844 & 0 & 19,264 & 81,108 \\
\hline $1899 \ldots \ldots \ldots$ & 0 & 48,521 & 0 & 29,577 & 78,098 \\
\hline
\end{tabular}

\section{ILLINOIS}

The production of coke from. Illinois coal continues to be insignificant. Laboratory tests have shown that some of the Illinois coals are true coking coals, but their coking qualities vary greatly, and their successful use upon a large scale has not been demonstrated. The impurities in Illinois coals have worked against it in the manufacture of metallurgical coke, and as New River and Pennsylvania cokes can be obtained at reasonable cost in the markets that would be fed by the Illinois product, consumers find it economy to use the superior article.

Of the 3 establishments and 130 ovens in the State in 18992 establishments having 126 ovens were idle during the entire year, and the statistics of the production at the one active plant of 4 ovens has been included with those of Indiana. There were 26 new ovens building by the Universal Fuel Company, of Chicago, at the close of the year. These ovens will be operated under the Hemingway patents, by which many of the dry noncoking coals of the interior States, and even some lignites, are said to have been successfully coked. 
COKE.

Statistics of the manufacture of coke in Illinois since 1880.

\begin{tabular}{|c|c|c|c|c|c|c|c|c|}
\hline \multirow{2}{*}{ Year. } & \multirow{2}{*}{$\begin{array}{l}\text { Estab- } \\
\text { lish- } \\
\text { ments. }\end{array}$} & \multicolumn{2}{|c|}{ Ovens. } & \multirow{2}{*}{ Coal used. } & \multirow{2}{*}{$\begin{array}{l}\text { Coke pro- } \\
\text { duced. }\end{array}$} & \multirow{2}{*}{$\begin{array}{l}\text { Total value } \\
\text { of coke at } \\
\text { ovens. }\end{array}$} & \multirow{2}{*}{$\begin{array}{l}\text { Value of } \\
\text { coke at } \\
\text { ovens, } \\
\text { per ton. }\end{array}$} & \multirow{2}{*}{$\begin{array}{l}\text { Yield of } \\
\text { coal in } \\
\text { coke. }\end{array}$} \\
\hline & & Built. & $\begin{array}{l}\text { Build- } \\
\text { ing. }\end{array}$ & & & & & \\
\hline 1880. & 6 & 176 & 0 & $\begin{array}{r}\text { Short tons. } \\
31,240\end{array}$ & $\begin{array}{r}\text { Short tons. } \\
12,700\end{array}$ & $\$ 41,950$ & $\$ 3.30$ & $\begin{array}{l}\text { Per cent. } \\
\quad 41\end{array}$ \\
\hline 1881. & 6 & 176 & 0 & 35,240 & 14,800 & 45,850 & 3.10 & 42 \\
\hline 1882. & 7 & 304 & 0 & 25,270 & 11,400 & 29,050 & 2.55 & 45 \\
\hline 1883. & 7 & 316 & 0 & 31,170 & 13,400 & 28,200 & 2.10 & 43 \\
\hline 1884. & 9 & 325 & 0 & 30,168 & 13,095 & 25,639 & 1. 96 & 43 \\
\hline 1885. & 9 & 320 & 0 & 21,487 & 10,350 & 27,798 & 2.68 & 48 \\
\hline 1886. & 9 & 335 & 0 & 17,806 & S, 103 & 21,487 & 2.65 & 46 \\
\hline 1887. & 8 & 278 & 0 & 16,596 & 9,108 & 19,594 & 2. 13 & 55.5 \\
\hline 1888. & 8 & 221 & 0 & 13,020 & 7,410 & 21,038 & 2.84 & 56.9 \\
\hline 1889. & 4 & 149 & 0 & 19,250 & 11,583 & 29,764 & 2.57 & 60 \\
\hline 1890 & 4 & 148 & 0 & 9,000 & 5,000 & 11,250 & 2.25 & 55 \\
\hline 1891. & 1 & 25 & 0 & 10,000 & 5,200 & 11,700 & 2.25 & 52 \\
\hline 1892 & 1 & 24 & 0 & 4,800 & 3,170 & 7,133 & 2.25 & 66 \\
\hline $1893 \ldots$ & 1 & 24 & 0 & 3,300 & 2,200 & 4,400 & 2.00 & 66.7 \\
\hline $1894 \ldots$ & 1 & 24 & 0 & 3,800 & 2,200 & 4,400 & 2.00 & 57.9 \\
\hline $1895 \ldots$ & 3 & 129 & 0 & 3,600 & 2,250 & 4,500 & 2.00 & 62.5 \\
\hline $1896^{\circ}$ & 3 & 127 & 0 & 3,900 & 2,600 & 5,200 & 2.00 & 66.7 \\
\hline 1897 & 2 & 126 & 0 & 3,591 & 1, 549 & 2,895 & 1.87 & 43 \\
\hline $1898 \ldots$ & 2 & 126 & 0 & 6,650 & 2,325 & 4,686 & 2.02 & 35 \\
\hline 1899. & 3 & 130 & 26 & $(a)$ & $(a)$ & $(a)$ & & \\
\hline
\end{tabular}

a Included with Indiana 
The character of the coal used in the manufacture of coke in Illinois since 1890 is shown in the following table:

Character of coal used in the manufacture of coke in Illinois since 1890.

\begin{tabular}{|c|c|c|c|c|c|}
\hline \multirow{2}{*}{ Year. } & \multicolumn{2}{|c|}{ Run of mine. } & \multicolumn{2}{|c|}{ Slack. } & \multirow{2}{*}{ Total. } \\
\hline & Unwashed. & Washed. & Unwashed. & Washed. & \\
\hline $1890 \ldots \ldots \ldots$ & $\begin{array}{c}\text { Short tons. } \\
0\end{array}$ & $\begin{array}{c}\text { Short tons. } \\
0\end{array}$ & $\begin{array}{c}\text { Short tons. } \\
0\end{array}$ & $\begin{array}{c}\text { Short tons. } \\
9,000\end{array}$ & $\begin{array}{r}\text { Shart tons } \\
9,000\end{array}$ \\
\hline $1891 \ldots$ & 0 & 0 & 10,000 & 0 & 10,000 \\
\hline $1892 \ldots$ & 0 & 0 & 4,800 & 0 & 4,800 \\
\hline 1893. & 0 & 0 & 0 & 3,300 & 3,300 \\
\hline $1894 \ldots$ & 0 & 0 & 0 & 3,800 & 3,800 \\
\hline 1895. & 0 & 0 & 0 & 3,600 & 3,600 \\
\hline $1896 \ldots$ & 0 & 0 & 0 & 3,900 & 3,900 \\
\hline $1897 \ldots$ & 0 & 0 & 3,591 & 0 & 3,5991 \\
\hline $1898 \ldots$ & 0 & 0 & 0 & 6,650 & 6,650 \\
\hline $1899 a$. & & & & & \\
\hline
\end{tabular}

$a$ Included with Indiana

\section{INDIANA.}

Conditions very similar to those which have discouraged coke making in Illinois prevail in Indiana. Good coking coals exist in the State, but the product obtained is not equal to that of Connellsville, New River, or Pocahontas, any of which can be purchased at very little difference in cost, and consumers prefer to pay the slightly higher prices for the Pennsylvania and West Virginia cokes. There are only two banks of ovens in the State, and only one of these produced coke in 1897,1898 , and 1899. The production of Indiana in 1898 was the smallest on record and the culmination of five years of steadily decreas. ing output. An apparent increase is shown in the production for 1899 , due to the inclusion of the production of Illinois. 
The statistics of the manufacture of coke in Indiana from 1886 to 1899 , both inclusive, are given in the following table:

Statistics of the manufacture of cole in Indiana from 1886 to 1899.

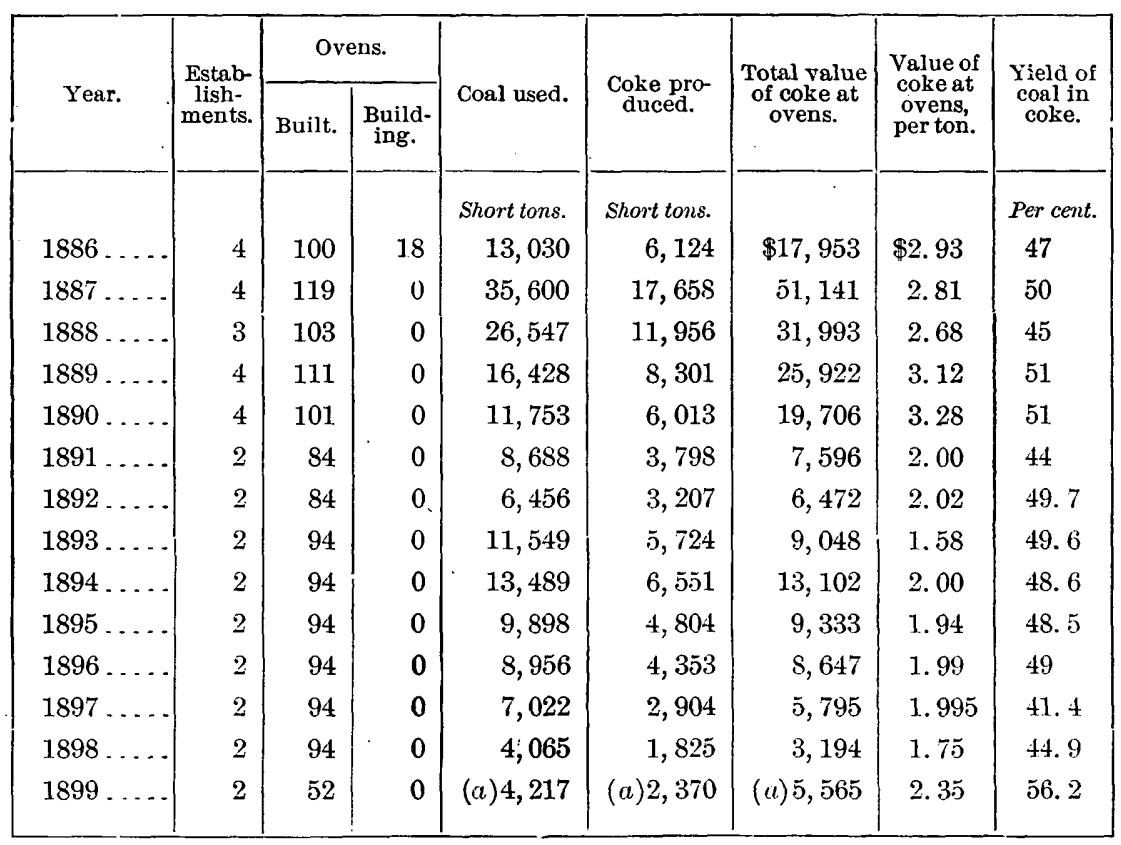

$a$ Includes Illinois

All of the coal made into coke in Indiana is slack, and since 1895 all of this has been wasked, as shown in the following table:

Character of coal used in the manufacture of coke in Indiana since 1890.

\begin{tabular}{|c|c|c|c|c|c|}
\hline \multirow{2}{*}{ Year. } & \multicolumn{2}{|c|}{ - Run of mine. } & \multicolumn{2}{|c|}{ Slack. } & \multirow{2}{*}{ 'Total. } \\
\hline & Unwashed. & Washed. & Unwashed. & Washed. & \\
\hline & Short tons. & Short tons. & Short tons. & Short tons. & Short tons. \\
\hline $1890 \ldots \ldots \ldots \ldots \ldots$ & 0 & 0 & 0 & 11,753 & 11,753 \\
\hline $1891 \ldots . . . . .$. & 0 & 0 & 0 & $8,6 \varnothing 0$ & 8,688 \\
\hline $1892 \ldots$ & 0 & 0 & 0 & 6,456 & 6,456 \\
\hline 1893. & 0 & 0 & 930 & 10,619 & 11,549 \\
\hline $1894 \ldots \ldots \ldots$ & 0 & 0 & S, 689 & 4,800 & 13,489 \\
\hline $1895 \ldots$ & 0 & 0 & 0 & 9,898 & 9,898 \\
\hline 1896. & 0 & 0 & 0 & 8,956 & 8,956 \\
\hline $1897 \ldots$ & 0 & 0 & 0 & 7,022 & 7,022 \\
\hline 1898 & 0 & 0 & 0 & 4,065 & 4,065 \\
\hline $1899(a)$ & . 300 & 0 & 404 & 3,513 & 4,217 \\
\hline
\end{tabular}

21 GEOL, PT $6-37$

Includes Illinois. 


\section{INDIAN TERRITORY.}

The production of coke in the Indian Territory in 1899 was 9,771 short tons less than in 1898, the output decreasing from 34,110 tons to 24,339 tons. The decrease may be attributed to the augmented demand for Territory coal, induced partly by the generally improved trade conditions and partly by the strikes in the Arkansas coal mines which curtailed the production in that State. The Territory operators had all they could do to fill their coal orders, and there was no mine-run coal, available for coke making. Only slack coal, an otherwise waste product, was used, the result of which is shown in the decrease in the percentage yield of coal in coke. All of the coal used in coking is washed before being charged into the ovens.

The 100 ovens reported as building in December, 1899, were completed in 1900, and an increased coke production in the future may be anticipated. The new ovens were built at Howe by the Mexican Gulf Coal and Transportation Company.

The statistics of the manufacture of coke in the Indian Territory from 1880 to 1899 are as follows:

Statistics of the manufacture of coke in the Indian Territory from 1880 to 1899.

\begin{tabular}{|c|c|c|c|c|c|c|c|c|}
\hline \multirow{2}{*}{ Year. } & \multirow{2}{*}{$\begin{array}{c}\text { Estab- } \\
\text { lish- } \\
\text { ments. }\end{array}$} & \multicolumn{2}{|c|}{ Ovens. } & \multirow{2}{*}{ Coal used. } & \multirow{2}{*}{$\begin{array}{l}\text { Coke pro- } \\
\text { duced. }\end{array}$} & \multirow{2}{*}{$\begin{array}{l}\text { Total value } \\
\text { of coke at } \\
\text { ovens. }\end{array}$} & \multirow{2}{*}{$\begin{array}{l}\text { Value of } \\
\text { coke at } \\
\text { ovens, } \\
\text { per ton. }\end{array}$} & \multirow{2}{*}{$\begin{array}{l}\text { Yield of } \\
\text { coal in } \\
\text { coke. }\end{array}$} \\
\hline & & Built. & $\begin{array}{c}\text { Build- } \\
\text { ing. }\end{array}$ & & & & & \\
\hline & & & & Short tons. & Short tons. & & - & Per cent. \\
\hline 1880 & 1 & 20 & 0 & 2,494 & 1,546 & $\$ 4,638$ & $\$ 3.00$ & 62 \\
\hline 1881 & 1 & 20 & 0 & 2,852 & 1,768 & 5,304 & 3.00 & 62 \\
\hline 1882 & 1 & 20 & 0 & 3,266 & 2,025 & 6,075 & 3.00 & 62 \\
\hline 1883 & 1 & 20 & 0 & 4,150 & 2,573 & 7,719 & 3.00 & 62 \\
\hline 1884 & 1 & 20 & 0 & 3,084 & 1,912 & 5,736 & 3. 00 & 62 \\
\hline 1885. & 1 & 40 & 0 & 5,781 & 3,584 & 12,902 & 3. 60 & 62 \\
\hline 1886 & 1 & 40 & 0 & 10,242 & 6,351 & 22,229 & 3.30 & 62 \\
\hline 1887. & 1 & 80 & 0 & 20,121 & 10,060 & 33,435 & 3.33 & 50 \\
\hline 1888 & 1 & 80 & 0 & 13,126 & 7,502 & 21,755 & 2.90 & 57 \\
\hline $1889 \ldots$ & " & 80 & 0 & 13,277 & 6,639 & 17,957 & 2.70 & 50 \\
\hline $1890 \ldots$ & 1 & 80 & 0 & 13,278 & 6,639 & 21,577 & 3.25 & 50 \\
\hline 1891. & 1 & 80 & 0 & 20,551 & 9,464 & 30,483 & 3.22 & 46 \\
\hline 189.2. & 1 & 80 & 0 & 7,138 & 3,569 & 12,402 & 3.47 & 50 \\
\hline $1893 \ldots$ & 1 & 80 & 0 & 15,118 & 7,135 & 25,072 & 3.51 & 47 \\
\hline $1894 \ldots$ & 1 & 80 & 0 & 7,274 & 3,051 & 10,693 & 3.50 & 42 \\
\hline 1895. & 1 & 80 & 0 & 11,825 & 5,175 & 17,657 & 3.41 & 43.8 \\
\hline 1896. & 2 & 130 & 0 & 53,028 & 21,021 & 73,574 & 3.50 & 40 \\
\hline 1897 & 2 & 130 & 0 & 68,495 & 30,364 & 104,725 & 3.45 & 44.3 \\
\hline $1898 \ldots$ & 2 & 130 & 0 & 73,330 & 34,110 & 96,639 & 2.833 & 46.5 \\
\hline 1599 & 3 & 130 & 100 & 59,255 & 24,339 & 71,965 & 2.96 & 41 \\
\hline
\end{tabular}


The character of the coal used in the manufacture of coke in the Indian Territory since 1890 is shown in the following table:

Character of coal used in the manufacture of coke in the Indian Territory since 1880.

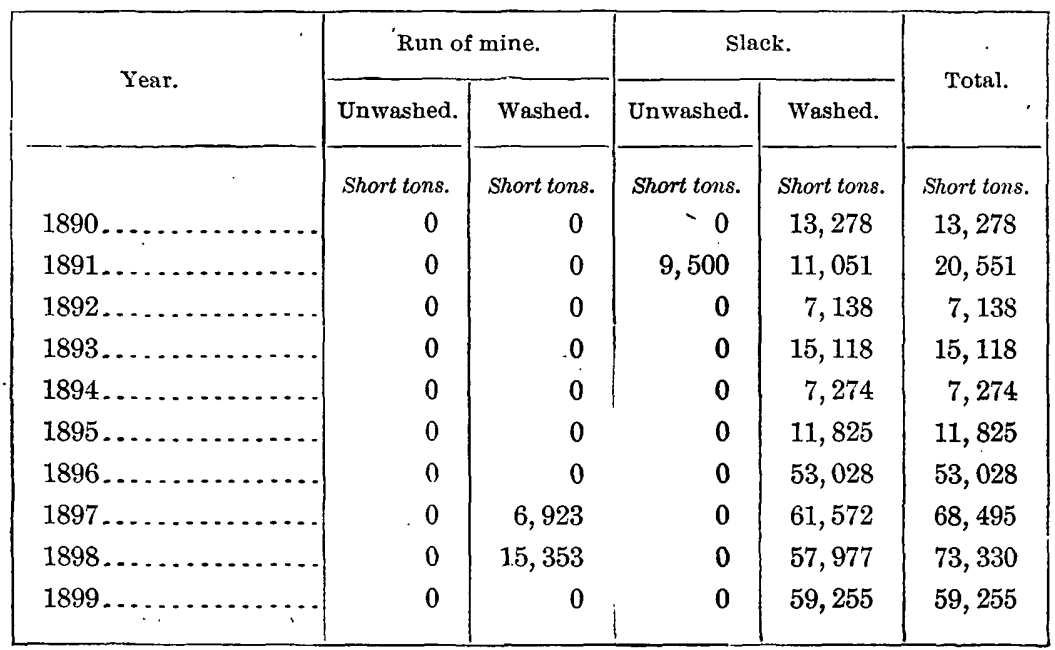

KANSAS.

The coke industry of Kansas is only of local importance, the production of coke in this State being chiefly for domestic purposes and the smelting of lead and zinc. Most of the coke produced in the State is made by the lead and zinc smelters for their own use.

As will be seen from the following table, there were 50 ovens in course of construction at the close of 1898 and 47 ovens built. Fourteen of the old ovens were abandoned in 1899 . The ovens building at the close of 1898 were completed and 12 more constructed during 1899 , making the total number in the State 95 , twenty more than the 75 ovens reported in 1892 and 1893 . Of the 95 ovens, 49 were operated and 46 idle during the year. 
The statistics of the manufacture of coke in Kansas from 1880 to 1899 are as follows:

Statistics of the manufacture of coke in Kansas from 1880 to 1899.

\begin{tabular}{|c|c|c|c|c|c|c|c|c|}
\hline \multirow{2}{*}{ Year. } & \multirow{2}{*}{$\begin{array}{l}\text { Estab- } \\
\text { lish- } \\
\text { ments. }\end{array}$} & \multicolumn{2}{|c|}{ Ovens. } & \multirow{2}{*}{ Coal used. } & \multirow{2}{*}{$\begin{array}{l}\text { Coke pro- } \\
\text { duced. }\end{array}$} & \multirow{2}{*}{$\begin{array}{l}\text { Total value } \\
\text { of coke at } \\
\text { ovens. }\end{array}$} & \multirow{2}{*}{$\begin{array}{l}\text { Value of } \\
\text { coke at } \\
\text { ovens, } \\
\text { per ton. }\end{array}$} & \multirow{2}{*}{$\begin{array}{l}\text { Yield of } \\
\text { coal in } \\
\text { coke. }\end{array}$} \\
\hline & & Built. & $\begin{array}{c}\text { Build- } \\
\text { ing. }\end{array}$ & & & & & \\
\hline 1880 & 2 & 6 & & $\begin{array}{c}\text { Short tons. } \\
4,800\end{array}$ & $\begin{array}{c}\text { Short tons. } \\
3,070\end{array}$ & $\$ 6,000$ & $\$ 1.95$ & $\begin{array}{l}\text { Per cent. } \\
.64\end{array}$ \\
\hline 1881 & 3 & 15 & & 8,800 & 5,670 & 10,200 & 1.80 & 64.4 \\
\hline 1882 & 3 & 20 & & 9,200 & 6,080 & 11,460 & 1.70 & 66 \\
\hline 1883 & 4 & 23 & & 13,400 & 8,430 & 16,560 & 1.96 & 62.9 \\
\hline 1884 & 4 & 23 & & 11,500 & 7,190 & 14,580 & 2.02 & 62.5 \\
\hline 1885. & 4 & 23 & & 15,000 & 8,050 & 13,255 & 1.65 & 53.7 \\
\hline 1886 & 4 & 36 & & 23,062 & 12,493 & 19,204 & 1.54 & 54.2 \\
\hline 1887 & 4 & 39 & & 27,604 & 14,950 & 28,575 & 1.91 & 54 \\
\hline 1888 & 6 & 58 & & 24,934 & 14,831 & 29,073 & 1.96 & 59.5 \\
\hline 1889 & 6 & 68 & & 21,600 & 13,910 & 26,593 & 1. 91 & 64 \\
\hline $1890 \ldots$ & 7 & 68 & & 21,809 & 12,311 & 29,116 & 2.37 & 56 \\
\hline $1891 \ldots$ & 6 & 72 & & 27,181 & 14,174 & 33,296 & 2.35 & 52 \\
\hline 1892 & 6 & 75 & $\cdots$ & 15,437 & 9,132 & 19,906 & 2.18 & 59.2 \\
\hline 1893 & 6 & 75 & 0 & 13,645 & 8,565 & 18,640 & 2. 18 & 62.8 \\
\hline 1894 & 6 & 61 & 0 & 13,288 & 8,439 & 15,660 & 1.855 & 63.5 \\
\hline $1895 \ldots$ & 5 & 55 & 0 & 8,424 & 5,287 & 11,289 & 2.14 & 62.8 \\
\hline $1896 \ldots$ & 6 & 55 & 0 & 8,940 & 4,785 & 8,676 & 1.813 & 53.5 \\
\hline $1897 \ldots$ & 4 & 57 & 0 & 11,772 & 6,181 & 9,272 & 1.50 & 52.5 \\
\hline 1898 & 6 & 47 & 50 & 7,856 & 4,180 & 6,455 & 1.545 & 53 \\
\hline $1899 \ldots$ & 9 & 95 & 0 & 26,988 & 14,476 & 30,817 & 2.13 & 53.6 \\
\hline
\end{tabular}


The character of the coal used in the manufacture of coke in Kansas since 1890 is shown in the following table:

Character of coal used in the manufacture of coke in Kansas since 1890.

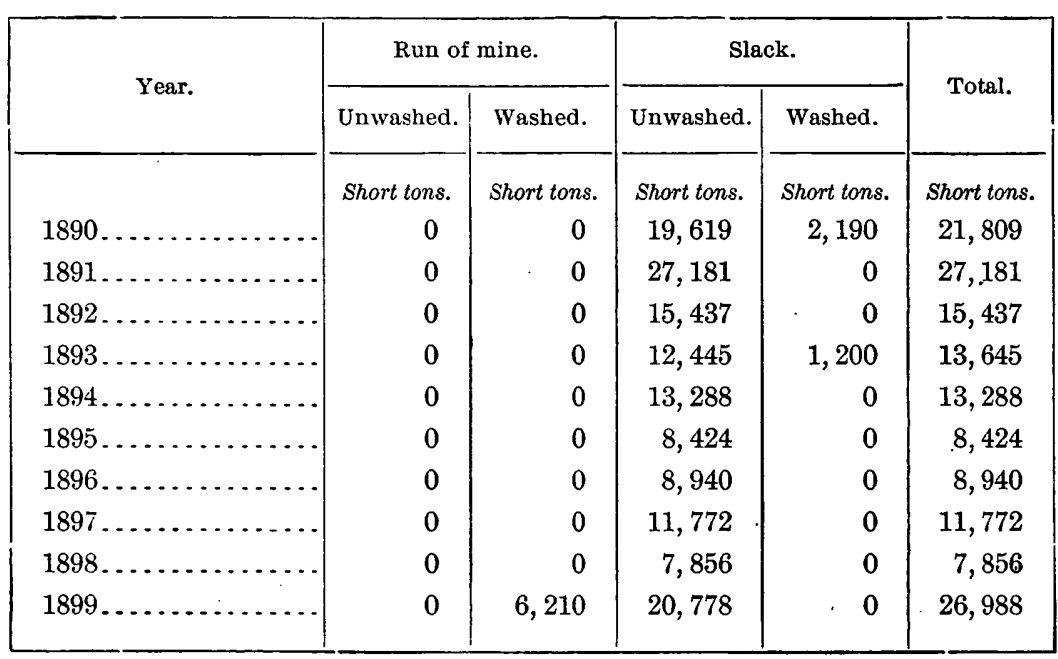

\section{KENTUCKY.}

Coke making can not be considered an important industry in Kentucky. It consists principally in the utilization of the slack produced at the mines in the western part of the State. The production in 1899 was the largest on record and was nearly four times the output in 1898. Nearly all of the coal used, whether run of mine or slack, is washed before coking. An experimental plant of Keneval patent ovens was constructed at Knoxville during 1899. 
The statistics of the manufacture of coke in Kentucky from 1880 to $\mathbf{1 8 9 9}$ are as follows:

Statistics of the manufacture of coke in Kentucky from 1880 to 1899.

\begin{tabular}{|c|c|c|c|c|c|c|c|c|}
\hline \multirow{2}{*}{ Year. } & \multirow{2}{*}{$\begin{array}{l}\text { Estab- } \\
\text { lish- } \\
\text { ments. }\end{array}$} & \multicolumn{2}{|c|}{ Ovens. } & \multirow{2}{*}{ Coal used. } & \multirow{2}{*}{$\begin{array}{l}\text { Coke pro- } \\
\text { duced. }\end{array}$} & \multirow{2}{*}{$\begin{array}{c}\text { Total value } \\
\text { of coke at } \\
\text { ovens. }\end{array}$} & \multirow{2}{*}{$\begin{array}{l}\text { Value of } \\
\text { coke at } \\
\text { ovens, } \\
\text { per ton. }\end{array}$} & \multirow{2}{*}{$\begin{array}{l}\text { Yield of } \\
\text { coal in } \\
\text { coke. }\end{array}$} \\
\hline & & Built. & $\begin{array}{c}\text { Build- } \\
\text { ing. }\end{array}$ & & & & & \\
\hline 1880 & 5 & 45 & & $\begin{array}{c}\text { Short tons. } \\
\quad 7,206\end{array}$ & $\begin{array}{c}\text { Short tons. } \\
4,250\end{array}$ & $\$ 12,250$ & $\$ 2.88$ & $\begin{array}{l}\text { Per cent. } \\
59\end{array}$ \\
\hline 1881. & 5 & 45 & 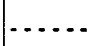 & 7,406 & 4,370 & 12,630 & 2.89 & 59 \\
\hline 1882 & 5 & 45 & 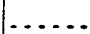 & 6,906 & 4,070 & 11,530 & 2.83 & 59 \\
\hline 1883 & 5 & 45 & 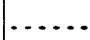 & 8,437 & 5,025 & 14,425 & 2.87 & 60 \\
\hline 1884. & 5 & 45 & $\cdots$ & 3,451 & 2,223 & 8,760 & 3.94 & 64 \\
\hline 1885 . & 5 & 33 & $\ldots .$. & 5,075 & 2,704 & 8,489 & 3.14 & 53 \\
\hline 1886. & 6 & 76 & 2 & 9,055 & 4,528 & 10,082 & 2.23 & 50 \\
\hline $188 \%$ & 6 & 98 & . & 29,129 & 14,565 & 31,730 & 2.18 & 50 \\
\hline 1888 & 10 & 132 & 2 & 42,642 & 23,150 & 47,244 & 2.04 & 54 \\
\hline $1889 \ldots$ & 9 & 166 & 100 & 25,192 & 13,021 & 29,769 & 2.28 & 52 \\
\hline 1890. & 9 & 175 & 103 & 24,372 & 12,343 & 22,191 & 1.80 & 51 \\
\hline 1891. & 7 & 115 & 24 & 64,390 & 33,777 & 68,281 & 2.02 & 52 \\
\hline 1892 & 5 & 287 & 100 & 70,783 & 36,123 & 72,563 & 2.01 & 51 \\
\hline 1893 & 4 & 283 & 100 & 97,212 & 48,619 & 97,350 & 2.00 & 50 \\
\hline 1894 & 6 & 293 & 0 & 66,418 & 29,748 & 51,566 & 1.73 & 44.8 \\
\hline 1895 & 5 & 293 & 0 & 63,419 & 25,460 & 37,249 & 1.46 & 40.1 \\
\hline $1896 \ldots$ & 4 & 264 & 0 & 55,719 & 27,107 & 42,062 & 1.55 & 48.6 \\
\hline 1897. & 5 & 268 & 0 & 64,234 & 32,117 & 45,454 & 1.41 & 50 \\
\hline 1898 & 5 & 292 & 2 & 44,484 & 22,242 & 32,213 & 1.448 & 50 \\
\hline 1899. & 6 & 300 & 130 & 151,503 & 81,095 & 161,454 & 1.99 & 53.5 \\
\hline
\end{tabular}


The character of the coal used in the manufacture of coke in Kentucky since 1890 is shown in the following table:

Character of coal used in the manufacture of cole in Kentucky since 1890.

\begin{tabular}{|c|c|c|c|c|c|}
\hline \multirow{2}{*}{ Year. } & \multicolumn{2}{|c|}{ Run of mine. } & \multicolumn{2}{|c|}{ Slack. } & \multirow{2}{*}{ Total. } \\
\hline & Unwashed. & Washed. & Unwashed. & Washed. & \\
\hline $1890 \ldots \ldots \ldots$ & $\begin{array}{c}\text { Short tons. } \\
0\end{array}$ & $\begin{array}{c}\text { Short tons. } \\
\quad 3,000\end{array}$ & $\begin{array}{c}\text { Short tons. } \\
2,100\end{array}$ & $\begin{array}{c}\text { Short tons. } \\
19,272\end{array}$ & $\begin{array}{c}\text { Short tons. } \\
24,372\end{array}$ \\
\hline $1891 \ldots \ldots \ldots$ & 11,000 & 0 & 3,500 & 49,890 & 64,390 \\
\hline $1892 \ldots$ & 0 & 5,955 & 7,883 & 56,945 & 70,783 \\
\hline $1893 \ldots$ & 825 & 11,973 & 26,759 & 57,655 & 97,212 \\
\hline $1894 \ldots \ldots$ & 0 & 2,980 & 7,900 & 55,538 & 66,418 \\
\hline $1895 \ldots . .$. & 0 & 502 & 624 & $62, \cdot 293$ & 63,419 \\
\hline $1896 \ldots$ & 16,271 & 0 & 0 & 39,448 & 55,719 \\
\hline $1897 \ldots \ldots$ & 4,176 & 0 & 0 & 60,058 & 64,234 \\
\hline $1898 \ldots$ & 0 & 1,800 & 0 & 42,684 & 44,484 \\
\hline $1899 \ldots$ & 21,600 & 0 & 30,263 & 99,640 & 151,503 \\
\hline
\end{tabular}

MASSACHUSETTS.

The plant of Otto-Hoffman ovens at Everett was fully described in this report for 1898. The coal from which the coke is made is drawn from Nova Scotia mines. This being the only plant in the State, the statistics of production are included with Pennsylvania.

\section{MISSOURI.}

Missouri coke production is insignificant. The ovens in this State, like those in Kansas, are operated by lead and zinc smelters who consume the product. There were four'firms or establishments in the State in 1899, having a total of 12 ovens, one establishment of four ovens being idle all the year. The production in 1899 amounted to only 2,860 short tons, which was, however, the largest in six years, and four times that of 1898 . 
The statistics of the production of coke in Missouri from 1887, when coking began in this State, to 1899 are as follows:

Statistics of the manufacture of coke in Missouri from 1887 to 1899.

\begin{tabular}{|c|c|c|c|c|c|c|c|c|}
\hline \multirow{2}{*}{ Year. } & \multirow{2}{*}{$\begin{array}{l}\text { Estab- } \\
\text { lish- } \\
\text { ments. }\end{array}$} & \multicolumn{2}{|c|}{ Ovens. } & \multirow{2}{*}{ Coal used. } & \multirow{2}{*}{$\begin{array}{l}\text { Coke pro- } \\
\text { duced. }\end{array}$} & \multirow{2}{*}{$\begin{array}{l}\text { Total value } \\
\text { of coke at } \\
\text { ovens. }\end{array}$} & \multirow{2}{*}{$\begin{array}{l}\text { Value of } \\
\text { coke at } \\
\text { ovens, } \\
\text { per ton. }\end{array}$} & \multirow{2}{*}{$\begin{array}{l}\text { Yield of } \\
\text { coal in } \\
\text { coke. }\end{array}$} \\
\hline & & Built. & $\begin{array}{c}\text { Build- } \\
\text { ing. }\end{array}$ & & & & & \\
\hline $1887 \ldots$ & 1 & 4 & & $\begin{array}{c}\text { Short tons. } \\
5,400\end{array}$ & $\begin{array}{c}\text { Short tons. } \\
2,970\end{array}$ & $\$ 10,395$ & $\$ 3.50$ & $\begin{array}{l}\text { Per cent. } \\
55\end{array}$ \\
\hline 1888 & 1 & 4 & & 5,000 & 2,600 & 9,100 & 3.50 & 52 \\
\hline 1889 & 3 & 9 & & 8,485 & 5,275 & 5,800 & 1.10 & 62 \\
\hline 1890 . & 3 & 10 & & 9,491 & 6,136 & 9,240 & 1.51 & 65 \\
\hline $1891 \ldots$ & 3 & 10 & & 10,377 & 6,872 & 10,000 & 1.45 & 66 \\
\hline $1892 \ldots$ & 3 & 10 & $\cdots$ & 11,088 & 7,299 & 10,949 & 1.50 & 65.8 \\
\hline 1893 & 3 & 10 & 0 & 8,875 & 5,905 & 9,735 & 1.65 & 66.5 \\
\hline $1894 \ldots$ & 3 & 10 & 0 & 3,442 & 2,250 & 3,563 & 1.58 & 65.4 \\
\hline $1895 \ldots$ & 3 & 10 & 0 & 3,120 & 2,028 & 2,442 & 1.20 & 65 \\
\hline $1896 \ldots$ & 3 & 7 & 0 & 4,471 & 2,500 & 4,131 & 1.65 & 55.9 \\
\hline $1897 \ldots$ & 3 & 15 & 0 & 4,627 & 2,593 & 3,890 & 1.50 & 56 \\
\hline $1898 \ldots$ & 3 & 8 & 0 & 1,500 & 740 & 1,050 & 1.42 & 49.3 \\
\hline $1899 \ldots$ & 4 & 12 & 0 & 5,320 & 2,860 & 5,520 & 1.93 & 53.8 \\
\hline
\end{tabular}

The character of the coal used for coke in Missouri since 1890 is shown in the following table:

Character of coal used in the manufacture of coke in Missouri since 1890.

\begin{tabular}{|c|c|c|c|c|c|}
\hline \multirow{2}{*}{ Year. } & \multicolumn{2}{|c|}{ Run of mine. } & \multicolumn{2}{|c|}{ Slack. } & \multirow{2}{*}{ Total. } \\
\hline & Unwashed. & Washedi. & Unwashed. & Washed. & \\
\hline 1890 & $\begin{array}{c}\text { Short tons. } \\
0\end{array}$ & $\begin{array}{c}\text { Short tons. } \\
0\end{array}$ & $\begin{array}{c}\text { Shont tons. } \\
9.491\end{array}$ & $\begin{array}{c}\text { Short tons. } \\
0\end{array}$ & $\begin{array}{c}\text { Short tons. } \\
9.491\end{array}$ \\
\hline $1891 \ldots$ & 0 & 0 & 10,377 & 0 & 10,377 \\
\hline $1892 .$. & 0 & 0 & 11,088 & 0 & 11,088 \\
\hline $1893 \ldots$ & 0 & 0 & 8,875 & 0 & 8,875 \\
\hline $1894 .$. & 0 & 0 & 3,442 & 0 & 3,442 \\
\hline $1895 .$. & 0 & 0 & 3,120 & 0 & 3,120 \\
\hline 1896. & 0 & 0 & 4,471 & 0 & 4,471 \\
\hline $1897 .$. & 0 & 0 & 4,627 & 0 & 4,627 \\
\hline 1898 & 0 & 0 & 1,500 & 0 & 1,500 \\
\hline $1899 \ldots$ & 0 & 0 & 5,320 & 0 & 5,320 \\
\hline
\end{tabular}




\section{MONTANA.}

The production of coke in Montana in 1899 increased slightly over 1898 , but was not equal to that of either 1896 nor 1897 , while the value fell off about $\$ 3,000$. Fifteen ovens were abandoned in 1899 , reducing the total number from 318 to 303 , and of these 100 were not operated during the year.

The statistics of the manufacture of coke in Montana from 1883, when ovens were first reported, to 1899 are as follows:

Statistics of the manufacture of coke in Montana from 1889 to 1899.

\begin{tabular}{|c|c|c|c|c|c|c|c|c|}
\hline \multirow{2}{*}{ Year. } & \multirow{2}{*}{$\begin{array}{c}\text { Estab- } \\
\text { lish- } \\
\text { ments. }\end{array}$} & \multicolumn{2}{|c|}{ Ovens. } & \multirow{2}{*}{ Coal used. } & \multirow{2}{*}{$\begin{array}{l}\text { Coke pro- } \\
\text { duced. }\end{array}$} & \multirow{2}{*}{$\begin{array}{l}\text { Total value } \\
\text { of coke at } \\
\text { ovens. }\end{array}$} & \multirow{2}{*}{$\begin{array}{l}\text { Value of } \\
\text { coke at } \\
\text { ovens, } \\
\text { per ton. }\end{array}$} & \multirow{2}{*}{$\begin{array}{l}\text { Yield of } \\
\text { coal in } \\
\text { coke. }\end{array}$} \\
\hline & & Built. & $\begin{array}{c}\text { Build- } \\
\text { ing. }\end{array}$ & & & & & \\
\hline & & & & Short tons. & Short tons. & & & Per cent. \\
\hline $1883 \ldots$ & 1 & 2 & 0 & 0 & 0 & 0 & 0 & 0 \\
\hline 1884 & 3 & 5 & 12 & 165 & 75 & $\$ 900$ & $\$ 12.00$ & 46 \\
\hline $1885 \ldots$ & 2 & 2 & 0 & 300 & 175 & 2,063 & 11. 72 & 58.5 \\
\hline 1886 & 4 & 16 & 0 & 0 & 0 & 0 & 0 & 0 \\
\hline 1887 & 2 & 27 & 0 & 10,800 & 7,200 & 72,000 & 10.00 & 66.7 \\
\hline 1888. & 1 & 40 & 0 & 20,000 & 12,000 & 96,000 & 8.00 & 60 \\
\hline $1889 \ldots$ & 2 & 90 & 50 & 30,576 & 14,043 & 122,023 & 8.69 & 46 \\
\hline $1890 \ldots$ & 2 & 140 & 0 & 32,148 & 14,427 & 125,655 & 8. 71 & 45 \\
\hline 1891 . & 2 & 140 & 0 & 61,667 & 29,009 & 258,523 & 8. 91 & 47 \\
\hline 1892. & 2 & 153 & 0 & 64,412 & 34,557 & 311,013 & 9.00 & 53.6 \\
\hline 1893 & 2 & 153 & 0 & 61,770 & 29,945 & 239,560 & 8.00 & 48.5 \\
\hline 1894 & 2 & 153 & 0 & 33,313 & 17,388 & 165,187 & 9.50 & 52.2 \\
\hline 1895 & 3 & 303 & 0 & 55,770 & 25,337 & 189,856 & 7.49 & 45.4 \\
\hline 1896 & 3 & 303 & 0 & 113,165 & 60,078 & 425,483 & 7.08 & 53 \\
\hline $1897 \ldots$ & 3 & 303 & 0 & 139,907 & 67,849 & 467,481 & 6.89 & 48.5 \\
\hline 1898 & 4 & 318 & 0 & 92,552 & 52,009 & 359,174 & 6. 91. & 56 \\
\hline 1899 & 3 & 303 & 0 & 110,274 & 56,376 & 356,190 & 6.32 & 51 \\
\hline
\end{tabular}


The character of the coal used in the manufacture of coke in Montana since 1890 is shown in the following table:

Character of coal used in the manufacture of coke in Montana.

\begin{tabular}{|c|c|c|c|c|c|}
\hline \multirow{2}{*}{ Year. } & \multicolumn{2}{|c|}{ Run of mine. } & \multicolumn{2}{|c|}{ Slack. } & \multirow{2}{*}{ Total. } \\
\hline & Unwashed. & Washed. & Unwashed. & Washed. & \\
\hline $1890 \ldots$ & $\begin{array}{c}\text { Short tons. } \\
0\end{array}$ & $\begin{array}{c}\text { Short tons. } \\
22,852\end{array}$ & $\begin{array}{c}\text { Short tons. } \\
0\end{array}$ & $\begin{array}{c}\text { Short tons. } \\
9,296\end{array}$ & $\begin{array}{c}\text { Short tons. } \\
32,148\end{array}$ \\
\hline $1891 \ldots$ & 0 & 34,000 & 0 & 27,667 & 61,667 \\
\hline $1892 \ldots$ & 0 & 28,000 & 0 & 36,412 & 64,412 \\
\hline 1893. & 0 & 44,000 & 0 & 17,770 & 61,770 \\
\hline 1894 & 0 & 33,313 & 0 & 0 & 33,313 \\
\hline 1895. & 0 & 0 & 0 & 55,770 & 55,770 \\
\hline 1896. & 0 & 50,000 & 0 & 63,165 & 113,165 \\
\hline $1897 \ldots$ & 0 & 75,000 & 0 & 64,907 & 139,907 \\
\hline 1898. & 12,000 & 60,000 & 0 & 20,552 & 92,552 \\
\hline 1899. & 0 & 0 & 0 & 110,274 & 110,274 \\
\hline
\end{tabular}

NEW MEXICO.

In the report for 1898 it was stated that a considerable increase could be expected in the production of coke in New Mexico as a result of the completion of a new bank of 64 ovens at Blossburg, constructed by the Colorado Fuel and Iron Company. The returns for 1899 show a product of 44,134 short tons, more than six times that of 1898 . The value of the product was nearly seven times as large in 1899 as it was in 1898 , the average price adrancing 15 cents per ton. The coal used for coke making in New Mexico is entirely unwashed slack. A notable increase is shown in the percentage yield of coal in coke. There were 190 ovens in existence at the cluse of 1899 ; of these 76 were idle throughout the year. 
The statistics of the production of coke in New Mexico from 1882, when coke ovens were first reported, until 1.899 are as follows:

Statistics of the munufacture of cole in New Mexico from 1882 to 1899.

\begin{tabular}{|c|c|c|c|c|c|c|c|c|}
\hline \multirow{2}{*}{ Year. } & \multirow{2}{*}{$\begin{array}{l}\text { Estab- } \\
\text { lísh- } \\
\text { ments. }\end{array}$} & \multicolumn{2}{|c|}{ Ovens. } & \multirow{2}{*}{ Coal used. } & \multirow{2}{*}{$\begin{array}{l}\text { Coke pro- } \\
\text { duced. }\end{array}$} & \multirow{2}{*}{$\begin{array}{l}\text { Total value } \\
\text { of coke at } \\
\text { ovens. }\end{array}$} & \multirow{2}{*}{$\begin{array}{l}\text { Value of } \\
\text { coke at } \\
\text { ovens. } \\
\text { per ton. }\end{array}$} & \multirow{2}{*}{$\begin{array}{l}\text { Yield of } \\
\text { coal in } \\
\text { coke. }\end{array}$} \\
\hline & & Built. & $\begin{array}{l}\text { Build- } \\
\text { ing. }\end{array}$ & & & & & \\
\hline 1882 & & 0 & 12 & Short tons. & Short tons. & $\$ 6000$ & $\$ 600$ & Per cent. \\
\hline 1883. & 2 & 12 & 28 & 6,941 & 3,905 & 21,478 & 5.50 & $57 \frac{1}{4}$ \\
\hline 1884. & 2 & 70 & 0 & 29,990 & 18,282 & 91,410 & 5.00 & $57 \frac{1}{4}$ \\
\hline 1885 & 2 & 70 & 0 & 31,889 & 17,940 & 89,700 & 5.00 & $56 \frac{1}{4}$ \\
\hline $1886 \ldots$ & 2 & 70 & 0 & 18,194 & 10,236 & 51,180 & 5.00 & 56 \\
\hline 1887 & 1 & 70 & 0 & 22,549 & 13,710 & 82,260 & 6.00 & 61 \\
\hline 1888. & 1 & 70 & 0 & 14,628 & 8,540 & 51,240 & 6.00 & 58 \\
\hline 1889 & 2 & 70 & 0 & 7,162 & 3,460 & 18,408 & 5.32 & 48 \\
\hline $1890 \ldots$ & 2 & 70 & 0 & 3,980 & 2,050 & 10,025 & 4.89 & 51.5 \\
\hline 1891 & 1 & 70 & 0 & 4,000 & 2,300 & 10,925 & 4.75 & 57.5 \\
\hline $1892 \ldots$ & 1 & 50 & 0 & 0 & 0 & 0 & 0 & 0 \\
\hline $1893 \ldots$ & 1 & 50 & 0 & 14,698 & $\check{5}, 803$ & 18,476 & 3.18 & $39 . \tilde{5}$ \\
\hline $1894 \ldots$ & 1 & 50. & 0 & 13,042 & 6,529 & 28,213 & 4. 32 & 50 \\
\hline $1895 \ldots$ & 1 & 50 & 0 & 22,385 & 14,663 & 29,491 & 2.01 & 65.5 \\
\hline $1896 \ldots$ & 1 & 50 & 0 & 39,286 & 24,228 & 48,453 & 2.00 & 61.7 \\
\hline 1897 & 2 & 126 & 0 & 2,585 & 1,438 & 3,232 & 2.25 & .55 .6 \\
\hline $1898 \ldots$ & 3 & 190 & 0 & 12,557 & 6,980 & 14,625 & 2.095 & 55.6 \\
\hline 1899 . & 3 & 190 & 0 & 68,594 & 44,134 & 99,217 & 2.25 & 64.3 \\
\hline
\end{tabular}


The character of the coal used in the manufacture of coke in New Mexico since 1890 is shown in the following table:

Character of coal used in the manufacture of coke in New Mexico since 1890.

\begin{tabular}{|c|c|c|c|c|c|}
\hline \multirow{2}{*}{ Year. } & \multicolumn{2}{|c|}{ Run of mine. } & \multicolumn{2}{|c|}{ Slack. } & \multirow{2}{*}{ Total. } \\
\hline & Unwashed. & Washed. & Unwashed. & Washed. & \\
\hline 1890 & Short tons. & Short tons. & Short tons. & Short tons. & Short tons. \\
\hline $1891 .$. & 4,000 & 0 & 0 & 0 & 4,000 \\
\hline 1892. & 0 & 0 & 0 & 0 & 0 \\
\hline 1893 & 14,698 & 0 & 0 & 0 & 14,698 \\
\hline 1894. & 0 & 0 & 13,042 & 0 & 13,042 \\
\hline 1895. & & & & & 22,385 \\
\hline $1896 \ldots$ & 0 & 0 & 39,286 & 0 & 39,286 \\
\hline 1897. & 0 & 0 & 2,585 & 0 & 2,585 \\
\hline $1898 \ldots$ & 0 & 0 & 12,557 & 0 & 12,557 \\
\hline 1899. & 0 & 0 & 68,594 & 0 & 68,594 \\
\hline
\end{tabular}

NEW YORK.

The production of coke at Syracuse, New York, is included in that of Pennsylvania, from whose fields the coal is drawn, as the reports of operations have been furnished the Survey with the understanding that they would not be divulged. The plant at Syracuse was being increased by 5 new ovens at the close of 1899 .

Statistics of the manufacture of coke in New York.

\begin{tabular}{|c|c|c|c|c|c|c|c|}
\hline & 1893. & 1894. & 1895. & 1896. & 1897. & 1898. & 1899. \\
\hline Establishments $\ldots \ldots \ldots$. . & 1 & 1 & 1 & 1 & 1 & 1 & 1 \\
\hline Ovens built ................ & 12 & 12 & 12 & 25 & 25 & 25 & 25 \\
\hline Ovens building..$\ldots \ldots \ldots$ & 13 & 13 & 13 & 0 & 0 & 0 & 5 \\
\hline Coke produced.......tons. & 12,850 & 16,500 & 18,521 & & & & \\
\hline Coal used. . . . . . . . . . do ... & 15,150 & & 22,207 & & & & \\
\hline $\begin{array}{l}\text { Yield of coal in coke, per } \\
\text { cent } \ldots \ldots \ldots\end{array}$ & 84.8 & & 83.4 & & & & \\
\hline
\end{tabular}

\section{OHIO.}

Notwithstanding the large consumption of coke in Ohio and the large fields of coking coals in the State, the coking industry is of slight importance. This is doubtless due to the same cause that obtains in Illinois and Indiana, the proximity of the Connellsville, New River, 
and Pocahontas fields, and the cheapness with which these cokes can be procured.

In previous reports of Mineral Resources the State has been divided into two coke-producing districts, called the Ohio and the Cincinnati. This division is continued in the present chapter. Two establishments, having 175 ovens, in the Cherry Valley iron district are included in the Ohio coke district.

The coke production of the State in 1897 was the largest in fifteen years, most of the increase being in the Cincinnati district. A decrease of 2,349 tons was shown in the production of 1898, and a further decrease of 6,000 tons is observed in the production for 1899, the record made in 1897 remaining the maximum since 1882 .

In the following table the statistics of the production of coke in the two districts of Ohio for the years 1880 to 1899 are consolidated:

Statistics of the manufacture of coke in Ohio from 1880 to 1899.

\begin{tabular}{|c|c|c|c|c|c|c|c|c|}
\hline \multirow{2}{*}{ Year. } & \multirow{2}{*}{$\begin{array}{l}\text { Estab- } \\
\text { lish- } \\
\text { ments. }\end{array}$} & \multicolumn{2}{|c|}{ Ovens. } & \multirow{2}{*}{ Coal used. } & \multirow{2}{*}{$\begin{array}{l}\text { Coke pro- } \\
\text { duced. }\end{array}$} & \multirow{2}{*}{$\begin{array}{l}\text { Total value } \\
\text { of coke at } \\
\text { ovens. }\end{array}$} & \multirow{2}{*}{$\begin{array}{l}\text { Value of } \\
\text { coke at } \\
\text { ovens, } \\
\text { per ton. }\end{array}$} & \multirow{2}{*}{$\begin{array}{l}\text { Yield of } \\
\text { coal in } \\
\text { coke. }\end{array}$} \\
\hline & & Built. & $\begin{array}{c}\text { Build- } \\
\text { ing. }\end{array}$ & & & & & \\
\hline 1880 & 15 & 616 & 25 & $\begin{array}{r}\text { Short tons. } \\
172,453\end{array}$ & $\begin{array}{r}\text { Short tons. } \\
100,596\end{array}$ & $\$ 255,905$ & $\$ 2.54$ & $\begin{array}{l}\text { Per cent. } \\
58\end{array}$ \\
\hline 1881 & 15 & 641 & 0 & 201,045 & 119,469 & 297,728 & 2.49 & 59 \\
\hline 1882 & 16 & 647 & 0 & 181,577 & 103,722 & 266,113 & 2.57 & 57 \\
\hline 1883. & 18 & 682 & 0 & 152,502 & 87,834 & 225,660 & 2.57 & 58 \\
\hline 1884. & 19 & 732 & 0 & 108,164 & 62,709 & 156,294 & 2. 49 & 58 \\
\hline 1885 & 13 & 642 & 0 & 68,796 & 39,416 & 109,723 & 2. 78 & 57 \\
\hline 1886 & 15 & 560 & 0 & 59,332 & 34,932 & 94,042 & 2.69 & 59 \\
\hline 1887 & 15 & 585 & 223 & 164,974 & 93,004 & 245,981 & 2.65 & 56 \\
\hline 1888 & 15 & 547 & 12 & 124,201 & 67,194 & 166,330 & 2.48 & 54 \\
\hline 1889. & 13 & 462 & 0 & 132,828 & 75,124 & 188,222 & 2.50 & 56 \\
\hline 1890. & 13 & 443 & 1 & 126,921 & 74,633 & 218,090 & 2.92 & 59 \\
\hline 1891 & 9 & 421 & 0 & 69,320 & 38,718 & 76,901 & 1.99 & 56 \\
\hline 1892 & 10 & 436 & 0 & 95,236 & 51,818 & 112,907 & 2.18 & $54.4^{\prime}$ \\
\hline 1893 & 9 & 435 & 0 & 42,963 & 22,436 & 43,671 & 1.95 & 52 \\
\hline 1894. & 8 & 363 & 0 & 55,324 & 32,640 & 90,875 & 2.78 & 59 \\
\hline $1895 \ldots$ & 8 & 377 & 0 & 51,921 & 29,050 & 69,655 & 2.40 & 56 \\
\hline $1896 \ldots$ & 9 & 431 & 0 & 128,923 & 80,868 & 208,789 & 2.58 & 62.7 \\
\hline 1897. & 9 & 433 & 0 & 151,545 & 95,087 & 235,784 & 2.48 & 62.7 \\
\hline 1898 & 10 & 441 & 0 & 134,757 & 85,535 & 211,558 & 2.47 & 63.5 \\
\hline 1899 & 8 & 385 & 0 & 142,678 & 83,878 & 255,129 & 3.04 & 58.8 \\
\hline
\end{tabular}




\section{PRODUCTION BY DISTRICTS.}

Cincinnati district.-All the coke made in this district is from the dust and screenings of the coal yards at Cincinnati and from the coal boats and barges that bring coal from the Upper Ohio, chiefly from the Pittsburg and the Kanawha regions of West Virginia. When the ovens are in operation, some run of mine and slack from Pittsburg mines is used in the North Bend block of ovens, situated on the Ohio River a short distance below Cincinnati.

The statistics of the manufacture of coke in the Cincinnati district from 1880 to 1899 are as follows:

Statistics of the manufacture of coke in the Cincinnati district, Ohio, from 1880 to 1899.

\begin{tabular}{|c|c|c|c|c|c|c|c|c|}
\hline \multirow{2}{*}{ Year. } & \multirow{2}{*}{$\begin{array}{c}\text { Estab- } \\
\text { lish- } \\
\text { ments. }\end{array}$} & \multicolumn{2}{|c|}{ Ovens. } & \multirow{2}{*}{ Coal used. } & \multirow{2}{*}{$\begin{array}{l}\text { Coke pro- } \\
\text { duced. }\end{array}$} & \multirow{2}{*}{$\begin{array}{c}\text { Total value } \\
\text { of coke at } \\
\text { ovens. }\end{array}$} & \multirow{2}{*}{$\begin{array}{l}\text { Value of } \\
\text { coke at } \\
\text { ovens, } \\
\text { per ton. }\end{array}$} & \multirow{2}{*}{$\begin{array}{l}\text { Yield of } \\
\text { coal in } \\
\text { coke. }\end{array}$} \\
\hline & & Built. & $\begin{array}{c}\text { Build- } \\
\text { ing. }\end{array}$ & & & & & \\
\hline 1880 & 4 & 32 & 0 & $\begin{array}{r}\text { Short tons. } \\
16,141\end{array}$ & $\begin{array}{r}\text { Short tons. } \\
10,326\end{array}$ & $\$ 42,255$ & $\$ 4.09$ & $\begin{array}{c}\text { Per cent. } \\
64\end{array}$ \\
\hline 1881. & 4 & 32 & 0 & 20,607 & 13,237 & 54,439 & 4. 11 & 64 \\
\hline 1882 & 4 & 32 & 0 & 19,687 & 12,045 & 47,437 & 3.78 & 61 \\
\hline 1883 & 5 & 57 & 0 & 33,978 & 20,106 & 65,990 & 3.28 & 59 . \\
\hline 1884 & 5 & 57 & 0 & 32,134 & 18,840 & 61,072 & 3.24 & 59 \\
\hline 1885 & 5 & 82 & 0 & 17,480 & 10,962 & 35,873 & 3.27 & 63 \\
\hline 1886 & 5 & 82 & 0 & 17,015 & 10,566 & 31,633 & 2.99 & 62.1 \\
\hline 1887. & 5 & 150 & 20 & 56,723 & 32,894 & 95,754 & 2.91 & 58 \\
\hline 1888 & 6 & 156 & 12 & 63,217 & 35,868 & 95,618 & 2.67 & 57 \\
\hline 1889 & 5 & 146 & 0 & 75,892 & 45,108 & 120,899 & 2.68 & 59.4 \\
\hline 1890 . & 5 & 150 & 0 & 68,266 & 43,278 & 171,848 & 3.97 & 63 \\
\hline 1891. & 3 & 130 & 0 & 13,403 & 9,080 & 31,529 & 3.47 & 67.7 \\
\hline 1892 & 4 & 146 & 0 & 31,330 & 19,320 & 64,319 & 3.33 & 61.3 \\
\hline 1893 & 3 & 142 & 0 & 13,700 & 9,000 & 27,000 & 3.00 & 65.7 \\
\hline 1894 . & 3 & 92 & 0 & 42,995 & 26,417 & 81,751 & 3.09 & 61 \\
\hline 1895. & 3 & 92 & 0 & 9,628 & 5,657 & 16,971 & 3.00 & 58.8 \\
\hline 1896 & 3 & 92 & 0 & 16,495 & 10,181 & 31,068 & 3.05 & 61.7 \\
\hline 1897 & 3 & 92 & 0 & 40,200 & 23,532 & 67,079 & 2.85 & 59 \\
\hline 1898 & 3 & 92 & 0 & 27,451 & 16,329 & 46,179 & 2.828 & 59.5 \\
\hline 1899 & 2 & 92 & 0 & 34,176 & 20,678 & 69,373 & 3.35 & 60.5 \\
\hline
\end{tabular}

Ohio district. - The district, as noted above, includes all of the ovens coking Ohio coal and the ovens at Leetonia, in Columbiana County, and in the vicinity of Steubenville and Bridgeport, which latter place is opposite Wheeling, West Virginia. It also includes 125 ovens of the Marietta Run Coal and Coke Company and 50 orens of the Black Diamond Coal and Coke Company in the Federal Valley district. 
COKE.

Statistics of the manufacture of coke in the Ohio district, Ohio, from 1880 to 1899.

\begin{tabular}{|c|c|c|c|c|c|c|c|c|}
\hline \multirow{2}{*}{ Year. } & \multirow{2}{*}{$\begin{array}{c}\text { Estab- } \\
\text { lish- } \\
\text { ments. }\end{array}$} & \multicolumn{2}{|c|}{ Ovens. } & \multirow{2}{*}{ Coal used. } & \multirow{2}{*}{$\begin{array}{l}\text { Coke pro- } \\
\text { duced. }\end{array}$} & \multirow{2}{*}{$\begin{array}{c}\text { Total value } \\
\text { of coke at } \\
\text { ovens. }\end{array}$} & \multirow{2}{*}{$\begin{array}{l}\text { Value of } \\
\text { coke at } \\
\text { ovens, } \\
\text { per ton. }\end{array}$} & \multirow{2}{*}{$\begin{array}{l}\text { Yield of } \\
\text { coal in } \\
\text { coke. }\end{array}$} \\
\hline & & Built. & $\begin{array}{l}\text { Build- } \\
\text { ing. }\end{array}$ & & & & & \\
\hline & & & & Short tons. & Short tons. & & & Per cent. \\
\hline $1880 \ldots$ & 11 & 584 & 25 & 156,312 & 90,270 & $\$ 213,650$ & $\$ 2.37$ & 57 \\
\hline 1881 . & 11 & 609 & 0 & 180,438 & 106,232 & 243,289 & 2. 39 & 59 \\
\hline 1882. & 12 & 615 & 0 & 161,890 & 91,677 & 218,676 & 2.39 & 57 \\
\hline 1883. & 13 & 625 & 0 & 118,524 & 67,728 & 459,670 & 2.36 & 57 \\
\hline 1884 . & 14 & 675 & 0 & 76,030 & 43,869 & 95,222 & 2.17 & 58 \\
\hline 1885 & 8 & 560 & 0 & 51,316 & 28,454 & 73,850 & 2.60 & 55 \\
\hline 1886 & 10 & 478 & 0 & 42,317 & 24,366 & 62,409 & 2.56 & 57.7 \\
\hline 1887. & 10 & 435 & 203 & 108,251 & 60,110 & 150,227 & 2.50 & 55.5 \\
\hline 1888. & 9 & 391 & 0 & 60,984 & 31,326 & 70,712 & 2.25 & 51 \\
\hline 1889 & 8 & 316 & 0 & 56,936 & 30,016 . & 67,323 & 2.24 & 52.7 \\
\hline 1890 & 8 & 293 & 1 & 58,655 & 31,335 & 46,242 & 1. 47 & 53.4 \\
\hline 1891 . & 6 & 291 & 0 & 55,917 & 29,638 & 45,372 & 1.53 & 53 \\
\hline 1892. & 6 & 290 & 0 & 63,906 & 32,498 & 48,588 & 1.50 & 50.9 \\
\hline 1893. & 6 & 293 & 0 & 29,263 & 13,436 & 16,671 & 1. 24 & 46 \\
\hline 1894. & 5 & 271 & 0 & 12,329 & 6,223 & 9,124 & 1. 466 & 50.5 \\
\hline 1895. & 5 & 285 & 0 & 42,293 & 23,393 & 52,684 & 2.25 & 55.3 \\
\hline 1896 & 6 & 339 & 0 & 112,428 & 70,687 & 177,721 & 2.51 & 62.8 \\
\hline 1897 . & 6 & 341 & 0 & 111,345 & 71,555 & 168,705 & 2.36 & 64 \\
\hline 1898. & 7 & 349 & 0 & 107,306 & 69,206 & 165,379 & 2.39 & 64.5 \\
\hline 1899. & 6 & 293 & 0 & 108,502 & 63,200 & 185,756 & 2. 94 & 58.2 \\
\hline
\end{tabular}


The character of the coal used in the manufacture of coke in Ohio since 1890 is shown in the following table:

Character of coal used in the manufacture of coke in Ohio since 1890.

\begin{tabular}{|c|c|c|c|c|c|}
\hline \multirow{2}{*}{ Year. } & \multicolumn{2}{|c|}{ Run of mine. } & \multicolumn{2}{|c|}{ Slack. } & \multirow{2}{*}{ Total. } \\
\hline & Unwashed. & Washed. & Unwashed. & Washed. & \\
\hline & Short tons. & Short tons. & Short tons. & Short tons. & Short tons. \\
\hline 1890. & 34,729 & 0 & 54,473 & 37,719 & 126,921 \\
\hline $1891 \ldots$ & 5,200 & 0 & 64,120 & 0 & 69,320 \\
\hline 1892. & 35,334 & 0 & 32,402 & 27,500 & 95,236 \\
\hline 1893. & 0 & 0 & 24,859 & 18,104 & 42,963 \\
\hline $1894 .$. & 0 & 0 & 14,845 & 40,479 & 55,324 \\
\hline $1895 .$. & 28,053 & 0 & 10,868 & 13,000 & 51,921 \\
\hline $1896 .$. & 88,616 & 0 & 24,325 & 15,982 & 128,923 \\
\hline $1897 \ldots$ & 92,192 & 0 & 29,353 & 30,000 & 151,545 \\
\hline $1898 \ldots$ & 92,963 & 0 & 19,794 & 22,000 & 134,757 \\
\hline $1899 \ldots$ & 88,771 & 0 & 23,907 & 30,000 & 142,678 \\
\hline
\end{tabular}

\section{PENNSYLVANIA.}

The production of coke in Pennsylvania in 1899 amounted to $13,577,870$ short tons, valued at $\$ 22,881,910$, an increase of $2,862,568$ tons, or 26.7 per cent, in quantity, and of $\$ 6,803,405$, or 42.3 per cent, in value over the record for 1898, when the product was 10,715,302 tons, valued at $\$ 16,078,505$. The production in 1899 was over 50 per cent more than that of 1897.

Pennsylvania's coke product in 1899 represented 68 per cent of the total amount made in the United States, and of the total increase from 1898 to 1899 more than 75 per cent was in the output from Pennsylvania ovens. The Connellsville district alone produced 10,390,395 tons of coke in 1899, which was considerably more than 50 per cent of the total product in the United States, and more than three times the combined output of all the other districts of Pennsylvania.

The total coke production of Pennsylvania was nearly six times that of West Virginia, the second State in producing importance, and more than seven times that of Alabama, which comes third; and notwithstanding the extraordinary development in the two latter States during the past few years, there is nothing to indicate that Pennsylvania will occupy any other than her present preeminent position for many years to come.

The total number of ovens in existence on December 31, 1899, was 27,616 , against 27,157 in 1898 , a net gain of 459 . The largest gain was in the Connellsville district, where a total of 367 new ovens was 
added to the number reported in 189S. The number in the Upper Connellsville district increased 29. The Allegheny Mountain district added 100 new ovens (the Otto-Hoffman plant at Johnstown being increased by that number) and a decrease of 2 was reported in the number of beehive ovens, making a net gain of 98 . The Pittsburg district shows a gain of 212 ovens, the Greensburg a gain of 89 , the Broad Top a gain of 19, and the Irwin a gain of 1. Two districts, the Clearfield-Center and the Reynoldsville-Walston, showed a decrease in the number of ovens, the former from 668 to 450 , a loss of 218 , and the latter from 1,942 to 1,779 , a loss of 163 . The former also shows a decrease in production, but an apparently substantial increase is exhibited in the output of the Reynoldsville-Walston district, due to the inclusion of the production of the Semet-Solvay ovens at Syracuse, New York, and the Otto-Hoffman plant at Everett, Massachusetts, in the total for this district. There was no change in the number of ovens in the Allegheny Valley district, and all of them were idle. The completion and putting in blast, during 1899, of the 100 Otto-Hoffman ovens at Johnstown brings the total number of by-product ovens in the State up to 355 .

Of the total number of ovens in Pennsylvania 941 were idle during the entire year, leaving 26,675 active, as compared with 25,626 active and 1,531 idle ovens in 1898. It is possible that there may have been more ovens idle in both years, as some of the larger operators make only one report for all the ovens in a certain county or district, stating the total number of ovens, but not indicating how many, if any, were not in operation. The figures quoted include only those actually reported as idle; but, assuming these to be approximately correct, we find that the average production for each active oven in 1898 was 418 tons and in 1899 was 509 tons.

The total number of establishments in the State was 150 in 1899 and 151 in 1898. Of these 17 were idle in 1898 and 7 in 1899. All of the idle concerns were comparatively small producers.

One of the apparently satisfactory conditions affecting the industry in 1899 was the advance in price, in which every district shared. This was due to a natural cause-the increased demand-and was not the result of arbitrary action in putting up the price, as was the case in 1896. Notwithstanding the increased values, however, much of the business was done at a loss, as the advances in mining and other wages largely increased the cost of production, and a large quantity of coke was sold at long contract prices which were below the cost of making.

21 GEOL, PT $6-38$ 
In the following table the statistics are given of the production of coke in Pennsylvania for the years 1880 to 1899:

Statistics of the manufacture of coke in Pennsylvania from 1880 to 1899.

\begin{tabular}{|c|c|c|c|c|c|c|c|c|}
\hline \multirow{2}{*}{ Year. } & \multirow{2}{*}{$\begin{array}{l}\text { Estab- } \\
\text { lish- } \\
\text { ments. }\end{array}$} & \multicolumn{2}{|c|}{ Ovens. } & \multirow{2}{*}{ Coal used. } & \multirow{2}{*}{$\begin{array}{l}\text { Coke pro- } \\
\text { duced. }\end{array}$} & \multirow{2}{*}{$\begin{array}{l}\text { Total value } \\
\text { of coke at } \\
\text { ovens. }\end{array}$} & \multirow{2}{*}{$\begin{array}{l}\text { Value } \\
\text { of coke } \\
\text { at } \\
\text { ovens, } \\
\text { perton. }\end{array}$} & \multirow{2}{*}{$\begin{array}{l}\text { Yield of } \\
\text { coal in } \\
\text { coke. }\end{array}$} \\
\hline & & Built. & $\begin{array}{c}\text { Build- } \\
\text { ing. }\end{array}$ & & & & & \\
\hline 1880 & 124 & 9,501 & 836 & $\begin{array}{c}\text { Short tons. } \\
4,347,558\end{array}$ & $\begin{array}{l}\text { Short tons. } \\
2,821,384\end{array}$ & $\$ 5,255,040$ & $\$ 1.86$ & $\begin{array}{l}\text { Per cent. } \\
65\end{array}$ \\
\hline 1881. & 132 & 10,881 & 761 & $5,393,503$ & $3,437,708$ & $5,898,579$ & $1.70^{\circ}$ & 64 \\
\hline 1882 & 137 & 12,424 & 642 & $6,149,179$ & $3,945,034$ & $6,133,698$. & 1.55 & 64 \\
\hline 1883. & 140 & 13,610 & 211 & $6,823,275$ & $4,438,464$ & $5,410,387$ & 1.22 & 65 \\
\hline 1884 & 145 & 14,285 & 232 & $6,204,604$ & $3,822,128$ & $4,783,230$ & 1.25 & 62 \\
\hline 1885 & 133 & 14,553 & 317 & $6,178,500$ & $3,991,805$ & 4,$981 ; 656$ & 1.25 & 64.6 \\
\hline 1886. & 108 & 16,314 & 2,558 & $8,290,849$ & $5,406,597$ & $7,664,023$ & 1.42 & 65.2 \\
\hline 1887 & 151 & 18,294 & 802 & $8,938,438$ & $5,832,849$ & $10,746,352$ & 1.84 & 65.3 \\
\hline 1888 & 120 & 20,381 & 1,565 & $9,673,097$ & $6,545,779$ & $8,230,759$ & 1.26 & 68 \\
\hline $1889 \ldots$ & 109 & 22,143 & 567 & $11,581,292$ & $7,659,055$ & $10,743,492$ & 1.40 & 66 \\
\hline $1890 \ldots$ & 106 & 23,430 & 74 & $13,046,143$ & $8,560,245$ & $16,333,674$ & 1.91 & 65.6 \\
\hline 1891 & 109 & 25,324 & 11 & $10,588,544$ & $6,954,846$ & $12,679,826$ & 1. 82 & 66 \\
\hline 1892. & 109 & 25,366 & 269 & $12,591,345$ & $8,327,612$ & $15,015,336$ & 1.80 & 66.1 \\
\hline $1893 \ldots$ & 102 & 25,744 & 19 & $9,386,702$ & $6,229,051$ & $9,468,036$ & 1.52 & 66 \\
\hline $1894 \ldots$ & 101 & 25,824 & 118 & $9,059,118$ & $6,063,777$ & $6,585,489$ & 1.086 & 66.9 \\
\hline $1895 \ldots$ & 99 & 26,042 & 170 & $14,211,567$ & $9,404,215$ & $11,908,162$ & 1. 266 & 66.2 \\
\hline $1896 a$ & 158 & 26,658 & 154 & $11,124,610$ & $7,356,502$ & $13,182,859$ & 1. 792 & 66.1 \\
\hline $1897 a$. & 153 & 26,910 & 307 & $13,538,646$ & $8,966,924$ & $13,727,966$ & 1.53 & 66.2 \\
\hline $1898 a$ & 151 & 27,157 & 292 & $16,307,841$ & $10,715,302$ & $16,078,505$ & 1.50 & 65.7 \\
\hline $1899 b$. & 150 & 27,591 & 1,666 & $19,930,419$ & $13,577,870$ & $22,881,910$ & 1. 69 & 68.1 \\
\hline
\end{tabular}

The quality of the coal produced in the principal coking regions of Pennsylvania is such that little or no preparation is necessary before charging into the ovens. For this reason it is found that by far the larger portion of the coal used in the manufacture of coke in Pennsylvania is unwashed, generally from 80 to 90 per cent of the coal coked being unwashed run of mine. There was more coal washed in 1899 than ever before, both in amount and percentage. The amount of washed slack coal used in 1899 was 2.2 times that used in 1898. The total amount of washed coal used in 1899 was 1,250,929 short tons, or 6.3 per cent of the total. In 1898 the washed coal used was 752,421 tons, or $4 \frac{1}{2}$ per cent of the total. In $1897,556,576$ tons, or a little orer 4 per cent, was washed, while in 1896 only about 3.5 per cent of the total was washed. 
The character of the coal used in the manufacture of coke in Pennsylvania since 1890 is shown in the following table:

Character of coal used in the manufacture of coke in Pennsylvania since 1890.

\begin{tabular}{|c|c|c|c|c|c|}
\hline \multirow{2}{*}{ Year. } & \multicolumn{2}{|c|}{ Run of mine. } & \multicolumn{2}{|c|}{ Slack. } & \multirow{2}{*}{ Total. } \\
\hline & Unwashed. & Washed. & Unwashed. & Washed. & \\
\hline & Short tons. & Short tons. & Short tons. & Short tons. & Short tons. \\
\hline $1890 \ldots \ldots$ & $11,788,625$ & 303,591 & 630,195 & 323,732 & $13,046,143$ \\
\hline $1891 \ldots$ & $9,470,646$ & 256,807 & 558,106 & 302,985 & $10,588,544$ \\
\hline $1892 \ldots$ & $11,237,253$ & 159,698 & $1,059,994$ & 134,400 & $12,591,345$ \\
\hline $1893 \ldots$ & $8,302,307$ & 216,762 & 739,128 & 128,505 & $9,386,702$ \\
\hline $1894 \ldots$ & $8,671,534$ & 118,279 & 204,811 & 64,494 & $9,059,118$ \\
\hline $1895 \ldots$ & $13,618,376$ & 34,728 & 440,869 & 117,594 & $14,211,567$ \\
\hline $1896 a$ & $9,289,089$ & 273,082 & $1,463,047$ & 99,392 & $11,124,610$ \\
\hline $1897 a$ & $11,540,459$ & 301,052 & $1,441,611$ & 255,524 & $13,538,646$ \\
\hline $1898 a$ & $14,083,073$ & 350,153 & $1,472,347$ & 402,268 & $16,307,841$ \\
\hline $1899 b$ & $16,854,706$ & 366,206 & $1,824,784$ & 884,723 & $19,930,419$ \\
\hline
\end{tabular}

PRODUCTION, BY DISTRICTS.

It is, perhaps, well to repeat briefly, for the sake of convenience, the statement published in previous volumes regarding the territory included within the several coking districts of the State. For more detailed descriptions the reader is referred to the earlier volumes of Mineral Resources.

The Allegheny Mountain district includes the ovens along the line of the Pennsylvania Railroad from Gallitzin eastward over the crest of the Alleghenies to beyond Altoona. The Allegheny Valley district includes the coke works of Armstrong and Butler counties and one of those in Clarion County, the other ovens in the latter county being included in the Reynoldsville-Walston district. What was previously known as the Beaver district included the ovens in Beaver and Mercer counties, but all the ovens in Beaver County have been abandoned and the operations of the 25 Semet-Solvay ovens in Mercer County are now included in the Pittsburg district. The Blossburg and Broad Top district embraces the Blossburg and Broad Top coal fields. The ovens of the Clearfield-Center district are chiefly in the two counties from which it derives its name. The Connellsville district is the wellknown region in western Pennsylvania, in Westmoreland and Fayette counties, extending from just south of Latrobe to Fairchance. The Greensburg, Irwin, Pittsburg, and Reynoldsville-Walston districts include the ovens near the towns which bave given the names to these districts. The Upper Connellsville district, sometimes called- the Latrobe district, is near the town of Latrobe. 
The Allegheny Valley district produced no coke in 1899, all the ovens being idle for the fifth time in its history. The ovens have not been reported as abandoned, however, and the number of ovens in the district are shown in the following tables. The Beaver district has been eliminated. All of the districts except the Irwin show an increased production in 1899 , although part of the increase in the Reynoldsville-Walston district is due to the inclusion of the production in Massachusetts. An advance in price is shown in all the districts.

Coke production in Pennsylvania in 1899, by districts.

\begin{tabular}{|c|c|c|c|c|c|c|c|c|}
\hline \multirow{2}{*}{ District. } & \multirow{2}{*}{$\begin{array}{c}\text { Estab- } \\
\text { lish- } \\
\text { ments. }\end{array}$} & \multicolumn{2}{|c|}{ Ovens. } & \multirow{2}{*}{ Coal used. } & \multirow{2}{*}{$\begin{array}{l}\text { Coke pro- } \\
\text { duced. }\end{array}$} & \multirow{2}{*}{$\begin{array}{c}\text { Total value } \\
\text { of coke } \\
\text { at ovens. }\end{array}$} & \multirow{2}{*}{$\begin{array}{c}\text { Aver- } \\
\text { age } \\
\text { price } \\
\text { per } \\
\text { ton. }\end{array}$} & \multirow{2}{*}{$\begin{array}{c}\text { Yield } \\
\text { of coal } \\
\text { in } \\
\text { coke. }\end{array}$} \\
\hline & & Built. & $\begin{array}{l}\text { Build- } \\
\text { ing. }\end{array}$ & & & & & \\
\hline Allegheny Mountain .. & 13 & $a 1,256$ & 8 & $\begin{array}{r}\text { Short tons. } \\
730,843\end{array}$ & $\begin{array}{r}\text { Short tons. } \\
478,340\end{array}$ & $\$ 959,740$ & $\$ 2.01$ & $\begin{array}{l}\text { Per ct. } \\
65.5\end{array}$ \\
\hline Allegheny Valley...... & 2 & 116 & 0 & 0 & 0 & 0 & 0 & 0 \\
\hline Broad Top ............ & 5 & 519 & 3 & 161,196 & 107,258 & 197,895 & 1.85 & 66.5 \\
\hline Clearfield-Center ...... & 6 & 450 & 50 & 198,110 & 130,965 & 234,527 & 1.79 & 66.1 \\
\hline Connellsville ....... & 86 & $b 19,294$ & 792 & $14,974,018$ & $10,390,335$ & $17,075,411$ & 1.64 & 69.4 \\
\hline Greensburg ........ & 4 & 307 & 240 & 173,811 & 110,594 & 247,421 & 2.24 & 63.6 \\
\hline Irwin $\ldots \ldots \ldots$ & 5 & 697 & 0 & 223,457 & 133,085 & 197,694 & 1.48 & 59.6 \\
\hline Pittsburg $\ldots \ldots \ldots \ldots$ & 10 & $c 1,312$ & 505 & 954,028 & 644,467 & $1,189,117$ & 1.84 & 67.6 \\
\hline $\begin{array}{l}\text { Reynoldsville }- \text { W a } 1- \\
\text { ston } d \ldots \ldots \ldots \ldots \ldots \ldots\end{array}$ & 6 & 1,779 & 0 & $1,581,164$ & 972,933 & $1,793,807$ & 1.84 & 61.5 \\
\hline Upper Connellsville ... & 13 & 1,861 & 68 & 933,792 & 609,893 & 986,298 & 1.62 & 65.3 \\
\hline 10 & 150 & 27,591 & 1,666 & $19,930,419$ & $13,577,870$ & $22,881,910$ & 1.69 & 68.1 \\
\hline
\end{tabular}

$a$ Includes 160 Otto-Hoffman ovens.

$c$ Includes 120 Otto-Hoffman and 25 Semet-Solvay ovens.

$d$ Includes production and value of coke in Massachusetts and New York.

Coke production in Pennsylvania in 1898, by districts.

\begin{tabular}{|c|c|c|c|c|c|c|c|c|}
\hline \multirow{2}{*}{ District. } & \multirow{2}{*}{$\begin{array}{c}\text { Estab- } \\
\text { lish- } \\
\text { ments. }\end{array}$} & \multicolumn{2}{|c|}{ Ovens. } & \multirow{2}{*}{ Coal used. } & \multirow{2}{*}{$\begin{array}{l}\text { Coke pro- } \\
\text { duced. }\end{array}$} & \multirow{2}{*}{$\begin{array}{c}\text { Total value } \\
\text { of coke } \\
\text { at ovens. }\end{array}$} & \multirow{2}{*}{$\begin{array}{c}\text { Aver- } \\
\text { age } \\
\text { price } \\
\text { per } \\
\text { ton. }\end{array}$} & \multirow{2}{*}{$\begin{array}{c}\text { Yield } \\
\text { of coal } \\
\text { in } \\
\text { coke. }\end{array}$} \\
\hline & & Built. & $\begin{array}{c}\text { Build- } \\
\text { ing- }\end{array}$ & & & & & \\
\hline Allegheny Mountain .. & 13 & $a 1,158$ & $b 100$ & $\begin{array}{r}\text { Shoirt tons. } \\
572,568\end{array}$ & $\begin{array}{r}\text { Short tons. } \\
378,410\end{array}$ & $\$ 511,202$ & $\$ 1.35$ & $\begin{array}{l}\text { Per ct. } \\
66\end{array}$ \\
\hline Allegheny Valley...... & 2 & 116 & 0 & 0 & 0 & 0 & 0 & 0 \\
\hline 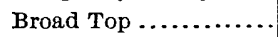 & 5 & 500 & 4 & 122,820 & 80,935 & 124,882 & 1.543 & 65.9 \\
\hline Clearfield-Center ...... & 7 & 668 & 0 & 215,208 & 137,265 & 195,836 & 1.43 & 63.8 \\
\hline Connellsville .......... & 88 & $c 18,927$ & 20 & $12,454,969$ & $8,315,350$ & $12,626,292$ & 1.518 & 66.8 \\
\hline Greensburg...$\ldots \ldots \ldots$ & 3 & 218 & 0 & 112,487 & 64,295 & 96,443 & 1.50 & 57 \\
\hline Irwin $\ldots . . \ldots \ldots \ldots \ldots$ & $\overline{5}$ & 696 & 0 & 332,368 & 183,176 & 239,583 & 1. 308 & 55 \\
\hline Pittsburg $\ldots \ldots \ldots \ldots$ & 10 & $d 1,100$ & 168 & 836,948 & 552,742 & 899,537 & 1.627 & 66 \\
\hline $\begin{array}{l}\text { Reynoldsville - W a } 1- \\
\text { ston } e . . . . . . . . . . .\end{array}$ & 5 & 1,942 & 0 & $1,022,196$ & 600,084 & 846,121 & 1.41 & 58.7 \\
\hline Upper Connellsville.... & 13 & 1,832 & 0 & 638,277 & 403,045 & 538,609 & 1.34 & 63 \\
\hline Total.. & 151 & 27,157 & 292 & $16,307,841$ & $10,715,302$ & $16 ; 078,505$ & 1.50 & 65.7 \\
\hline
\end{tabular}

$e$ Includes production and value of coke in New York. 
Coke production in Pennsylvania in 1897, by districts.

\begin{tabular}{|c|c|c|c|c|c|c|c|c|}
\hline \multirow{2}{*}{ District. } & \multirow{2}{*}{$\begin{array}{l}\text { Estab- } \\
\text { lish- } \\
\text { ments. }\end{array}$} & \multicolumn{2}{|c|}{ Ovens. } & \multirow{2}{*}{ Coal used. } & \multirow{2}{*}{$\begin{array}{l}\text { Coke pro- } \\
\text { duced. }\end{array}$} & \multirow{2}{*}{$\begin{array}{c}\text { Total value } \\
\text { of coke } \\
\text { at ovens. }\end{array}$} & \multirow{2}{*}{$\begin{array}{l}\text { Arer- } \\
\text { age } \\
\text { price } \\
\text { per } \\
\text { ton. }\end{array}$} & \multirow{2}{*}{$\begin{array}{c}\text { Yield } \\
\text { of coal } \\
\text { in } \\
\text { coke. }\end{array}$} \\
\hline & & Built. & $\begin{array}{l}\text { Build- } \\
\text { ing. }\end{array}$ & & & & & \\
\hline Allegheny Mountain & 13 & $a 1.185$ & 0 & $\begin{array}{r}\text { Short tons. } \\
417,470\end{array}$ & $\begin{array}{r}\text { Short tons. } \\
278.578\end{array}$ & $\$ 365,191$ & $\$ 1,31$ & $\begin{array}{c}\text { Per ct. } \\
66.7\end{array}$ \\
\hline Allegheny valley...... & 2 & 116 & 0 & 8,300 & 5,000 & 10,000 & 2.00 & 60.2 \\
\hline Beaver............. & 3 & $b 33$ & 0 & 42,200 & 27,276 & 61,646 & 2.26 & 64.6 \\
\hline Broad Top ............... & 5 & 491 & 15 & 106,706 & 66,949 & 107,430 & 1.60 & 62.7 \\
\hline Clearfield-Center ...... & 7 & 668 & 0 & 230,395 & 153,517 & 197,139 & 1.28 & 66 \\
\hline Connellsville ........... & 86 & $c 18,467$ & 92 & $10,243,690$ & $6,860,826$ & $10,662,428$ & 1.55 & 67 \\
\hline Greensburg ..... & 3 & 178 & 0 & 81,927 & 52,495 & 65,619 & 1.25 & 64 \\
\hline Irwin ........... & 5 & 696 & 0 & 207,704 & 136,663 & 189,869 & 1.39 & 65.8 \\
\hline Pittsburg ............. & 9 & $d 1,233$ & 200 & 832,505 & 548,981 & 864,326 & 1.57 & 66 \\
\hline $\begin{array}{l}\text { Reynoldsville }-\mathrm{W} \text { a } 1- \\
\text { ston } e . \ldots \ldots \ldots \ldots \ldots\end{array}$ & 6 & 1,980 & 0 & 810,808 & 491,267 & 759,609 & 1.55 & 60.6 \\
\hline Upper Connellsville.... & 14 & 1,863 & 0 & 556,941 & 345,372 & 444,709 & 1.29 & 62 \\
\hline Total. & 153 & 26,910 & 307 & $13,538,646$ & $8,966,924$ & $13,727,966$ & 1.53 & 66.2 \\
\hline
\end{tabular}

$a$ Includes 60 Otto-Hoffman ovens.

$b$ Includes 25 Semet-Solvay ovens.

$c$ Includes 50 Semet-Solvay ovens.

$d$ Includes 120 Otto-Hoffman ovens.

$e$ Includes production and value of coal and coke in New York.

Allegheny Mountain district.-In this district are included all the ovens along the line of the Pennsylvania Railroad east of Blairsville and those in Somerset County. The district embraces the city of Johnstown and the coke ovens at that place. It enjoys the distinction of haring the largest plant of by-product ovens in the State, and, with the exception of the plant at Everett,.Massachusetts, the largest in the United States. The 100 Otto-Hoffman ovens, mentioned in the report for 1898 as under construction, were put in blast in 1899, making a total of 160 of these ovens at Johnstown. Two beehive ovens were abandoned, so that the district shows a net gain of 98 over 1898. The production in 1899 was the largest in the history of the district and about one-third larger than the record for 1898, while the value was nearly double that of the preceding year. The reports for 1899 show that 224 of the 1,256 ovens in the district were idle during the entire year. 
The statistics of the manufacture of coke in the Allegheny Mountain district from 1880 to 1899 are as follows:

Statistics of the manufacture of coke in the Allegheny Mountain district of Pennsylvania from 1880 to 1899.

\begin{tabular}{|c|c|c|c|c|c|c|c|c|}
\hline \multirow{2}{*}{ Year. } & \multirow{2}{*}{$\begin{array}{c}\text { Estab- } \\
\text { lish- } \\
\text { ments. }\end{array}$} & \multicolumn{2}{|c|}{ Ovens. } & \multirow{2}{*}{ Coal used. } & \multirow{2}{*}{$\begin{array}{l}\text { Coke pro- } \\
\text { duced. }\end{array}$} & \multirow{2}{*}{$\begin{array}{c}\text { Total value } \\
\text { of coke at } \\
\text { ovens. }\end{array}$} & \multirow{2}{*}{$\begin{array}{l}\text { Value of } \\
\text { coke at } \\
\text { ovens, } \\
\text { per ton. }\end{array}$} & \multirow{2}{*}{$\begin{array}{l}\text { Yield of } \\
\text { coal in } \\
\text { coke. }\end{array}$} \\
\hline & & Built. & $\begin{array}{c}\text { Build- } \\
\text { ing. }\end{array}$ & & & & & \\
\hline $1880 \ldots$ & 8 & 291 & 0 & $\begin{array}{r}\text { Short tons. } \\
201,345\end{array}$ & $\begin{array}{r}\text { Short tons. } \\
127,525\end{array}$ & $\$ 289,929$ & $\$ 2.27$ & $\begin{array}{l}\text { Per cent. } \\
63\end{array}$ \\
\hline $1881 \ldots$ & 9 & 371 & 0 & 225,563 & 144,430 & 329,198 & 2.28 & 64 \\
\hline 1882. & 10 & 481 & 0 & 284,544 & 179,580 & 377,286 & 2.10 & 63 \\
\hline 1883. & 10 & 532 & 0 & 200,343 & 135,342 & 240,641 & 1. 78 & 68 \\
\hline $1884 \ldots$ & 12 & 614 & 0 & 241,459 & 156,290 & 203,213 & 1. 30 & 65 \\
\hline 1885 & 11 & 523 & 82 & 327,666 & 212,242 & 286,539 & 1.30 & 65 \\
\hline 1886. & 10 & 579 & 14 & 351,070 & 227,369 & 374,013 & 1. 64 & 64.8 \\
\hline $1887 \ldots$ & 10 & 694 & 150 & 461,922 & 297,724 & 671,437 & 2.25 & 64.4 \\
\hline 1888. & 12 & 950 & 145 & 521,047 & 335,689 & 479,845 & 1. 43 & 64.4 \\
\hline 1889 & 16 & 1,069 & 20 & 564,112 & 354,288 & 601,964 & 1.69 & 63.5 \\
\hline $1890 \ldots$ & 16 & 1,171 & 0 & 633,974 & 402,514 & 730,048 & 1.81 & 63.5 \\
\hline 1891 & 16 & 1,201 & 0 & 708,523 & 448,067 & 782,175 & 1.75 & 63 \\
\hline 1892. & 16 & 1,260 & 0 & 724,903 & 448,522 & 775,927 & 1.73 & 61.9 \\
\hline 1893. & 15 & 1,260 & 0 & 275,865 & 173,131 & 264,292 & 1.53 & 62.8 \\
\hline 1894 & 15 & 1,253 & 0 & 92,965 & 58,823 & 71,161 & 1. 21 & 63.3 \\
\hline 1895 & 13 & 1,233 & 60 & 271,096 & 173,965 & 214,741 & 1. 23 & 64 \\
\hline 1896. & 13 & a 1,188 & 0 & 408,827 & 266,473 & 349,373 & 1.31 & 65 \\
\hline $1897 \ldots$ & 13 & a 1,185 & 0 & 417,470 & 278,578 & 365,191 & 1.31 & 66.7 \\
\hline 1898 & 13 & a 1,158 & $b 100$ & 572,568 & 378,410 & วั11, ?02 & 1.35 & 66 \\
\hline 1899. & 13 & $c 1,256$ & S & 730,843 & 478,340 & 959,740 & 2. 01 & 65.5 \\
\hline
\end{tabular}

$a$ Includes 60 Otto-Hoffman ovens.

$b$ Otto-Hoffman ovens.

$c$ Includes 160 Otto-Hoffman ovens.

Connellsville district. - In the counties of Fayette and Westmoreland, which contain what is known as the Connellsville coking region, is produced annually more than 50 per cent of the total coke output of the United States. There has been only one exception to this in twenty years, the one exception being in 1896, when, because of the high prices arbitrarily placed on Connellsville coke by some of the larger producers, consumers were driven to other sources and the production of this region fell off one-third as compared with 1895 . Lower prices and the beginning of the industrial revival in 1897 stimulated the demand somewhat in that year and the output was $1, \pm 00,000$ tons more than in 1896, but was still $1,320,000$ tons short of the production in 1895. The boom in the iron and steel trade which began in 1898 continued with increasing strength until October, 1899, and tested the pro- 
ductive capacity of the region and the abilities of the transportation companies to the utmost. The production rose from $6,860,826$ tons in 1897 to $8,315,350$ tons in 1898 , and to $10,390,395$ tons in 1899 , the output in 1899 being more than 20 per cent larger than that of 1898 , and both years being the largest up to that time. The value of the product in 1899 was 30 per cent more than that of the preceding year, the price advancing from $\$ 1.52$ to $\$ 1.64$.

There was an increase of 367 in the number of ovens reported, and at the close of the year 792 ovens were in course of construction, the largest numker of ovens building since 1888, and the largest, with two exceptions, in the history of the region.

The following are the statistics of the manufacture of coke in the Connellsville region from 1880 to 1899:

Statistics of the manufacture of coke in the Connellsville region, Pennsylvanin, from.18so to 1899 .

\begin{tabular}{|c|c|c|c|c|c|c|c|c|}
\hline \multirow{2}{*}{ Year. } & \multirow{2}{*}{$\begin{array}{l}\text { Estab- } \\
\text { lish- } \\
\text { ments. }\end{array}$} & \multicolumn{2}{|c|}{ Ovens. } & \multirow{2}{*}{ Coal used. } & \multirow{2}{*}{$\begin{array}{l}\text { Coke pro- } \\
\text { duced. }\end{array}$} & \multirow{2}{*}{$\begin{array}{c}\text { Total value } \\
\text { of coke at } \\
\text { ovens. }\end{array}$} & \multirow{2}{*}{$\begin{array}{l}\text { Value of } \\
\text { coke at } \\
\text { ovens, } \\
\text { per ton. }\end{array}$} & \multirow{2}{*}{$\begin{array}{l}\text { Yield of } \\
\text { coal in } \\
\text { coke. }\end{array}$} \\
\hline & & Built. & $\begin{array}{c}\text { Build- } \\
\text { ing. }\end{array}$ & & & & & \\
\hline- & & & & Short tons. & Short tons. & & & Per cent. \\
\hline 1880 & 67 & 7,211 & 731 & $3,367,856$ & $2,205,946$ & $\$ 3,948,643$ & $\$ 1.79$ & 65.5 \\
\hline 1881. & 70 & $\$, 208$ & 654 & $4,018,782$ & $2,639,002$ & $4,301,573$ & 1.63 & 65.7 \\
\hline 1882 & 72 & 9,283 & 592 & $4,628,736$ & $3,043,394$ & $4,473,789$ & 1.47 & 65.8 \\
\hline 1883 & 74 & 10,176 & 101 & $5,355,380$ & $3,552,402$ & $4,049,738$ & 1. 14 & 66.3 \\
\hline 1884 & 76 & 10,543 & 200 & $4,829,054$ & $3,192,105$ & $3,607,078$ & 1. 13 & 66.1 \\
\hline 1885 & 68 & 10,471 & 48 & $4,683,831$ & $3,096,012$ & $3,776,388$ & 1. 22 & 66.1 \\
\hline 1886 & $36^{\prime}$ & 11,324 & 1,895 & $6,305,460$ & $4,180,521$ & $5,701,086$ & 1.36 & 66.3 \\
\hline 1887 & 73 & 11,923 & 98 & $6,182,846$ & $4,146,989$ & $7,437,669$ & 1. 79 & 67 \\
\hline 1888 & 38 & 12,818 & 1,320 & $7,191,708$ & $4,955,553$ & $5,884,081$ & 1. 19 & 69 \\
\hline 1889 & 29 & 14,458 & 430 & $8,832,371$ & $5,930,428$ & $7,974,633$ & 1. 34 & 67 \\
\hline 1890 & 28 & 15,865 & 30 & $9,748,449$ & $6,464,156$ & $11,537,370$ & 1.94 & 66.3 \\
\hline 1891 & 33 & 17,551 & 0 & $7,083,705$ & $4,760,665$ & $8,903,454$ & 1.87 & 67 \\
\hline 1892 & 31 & 17,309 & 0 & $9,389,549$ & $6,329,452$ & $11,598,407$ & 1.83 & 67.4 \\
\hline 1893 & 28 & 17,504 & 5 & $7,095,491$ & $4,805,623$ & $7,141,031$ & 1.49 & 67.7 \\
\hline 1894 & 29 & 17,829 & 0 & $7,656,169$ & $5,192,080$ & $5,405,691$ & 1.04 & 67.8 \\
\hline 1895 & 29 & 18,028 & 80 & $12,174,597$ & $8,181,179$ & $10,122,458$ & 1.237 & 67.2 \\
\hline 1896 & 88 & $a 18,347$ & 0 & $8,107,536$ & $5,462,490$ & $10,018,946$ & 1.834 & 67.4 \\
\hline 1897 & 86 & $a 18,467$ & 92 & $10,243,690$ & $6,860,826$ & $10,662,428$ & 1.55 & 67 \\
\hline 1898 & 88 & $a 18,927$ & 20 & $12,454,969$ & $8,315,350$ & $12,626,292$ & 1.518 & 66.8 \\
\hline . 1899 & 86 & $a 19,294$ & 792 & $14,974,018$ & $10,390,335$ & $17,075,411$ & 1.64 & 69.4 \\
\hline
\end{tabular}

As will be seen in the above table, the number of ovens increased from 18,927 to 19,294, a gain of 367 over 1898. All of these are of the beehive type, with the exception of 50 Semet-Solvay ovens operated by the Dunbar Furnace Company at Dunbar. 
The following table, compiled by the Connellsville Courier, of Connellsville, Pa., shows the shipments of coke from the Connellsville region in 1899, by months, in cars and tons, with the average number of cars shipped each working day in the month:

Shipments of coke from the Connellsville region in 1899, by months.

\begin{tabular}{|c|c|c|c|}
\hline Month. & Cars. & $\begin{array}{c}\text { Daily } \\
\text { average. }\end{array}$ & Tons. \\
\hline January .. & 40,320 & 1,550 & 779,792 \\
\hline February . & 36,297 & 1,512 & 699,474 \\
\hline March... & 43,602 & 1,615 & 839,763 \\
\hline April .. & 43,401 & 1,736 & 831,964 \\
\hline May ...... & 41,655 & 1,543 & 804,023 \\
\hline June .... & 43,344 & 1,667 & 837,123 \\
\hline July ...... & 46,019 & 1,770 & 883,735 \\
\hline August & 46,593 & 1,726 & 889,078 \\
\hline September.. & 42,387 & 1,630 & 813,190 \\
\hline October & 45,100 & 1,735 & 874,357 \\
\hline November. & 47,538 & 1,828 & 935,608 \\
\hline December & 46,947 & 1,805 & 941,657 \\
\hline Total. & 523,203 & 1,676 & $10,129,764$ \\
\hline
\end{tabular}

The monthly shipments of coke from this region in the years 1896 , 1897,1898 , and 1899, as reported by the Courier, are given in the following table:

Monthly shipments of coke from the Connellsville region in the years 1896,1897, 1898, and 1899.

[Short tons.]

\begin{tabular}{|c|c|c|c|c|}
\hline Month. & 1896 & 1897. & 1898. & 1899. \\
\hline January & 617,458 & 485,624 & 727,739 & 779,792 \\
\hline February - & 529,347 & 466,206 & 667,287 & 699,474 \\
\hline March.... & 550,470 & 521,484 & 744,987 & 839,763 \\
\hline April.. & 547,625 & 493,027 & 701,317 & 831,964 \\
\hline May & 528,822 & 501,857 & 680,754 & 804,023 \\
\hline June... & 477,227 & 500,483 & 636,877 & 837,123 \\
\hline July & 470,988 & 583,867 & 646,065 & 883,735 \\
\hline August . & 330,468 & 562,703 & 662,880 & 889,078 \\
\hline September. & 257,547 & 625,902 & 644,422 & 813,190 \\
\hline October & 304,998 & 737,498 & 731,602 & 874,357 \\
\hline November.. & 323,419 & 700,352 & 844,907 & 935,608 \\
\hline December & 473,296 & 736,049 & 771,275 & 941,657 \\
\hline Total. & $5,411,665$ & $6,915,052$ & $8,460,112$ & $10,129,764$ \\
\hline
\end{tabular}


The total shipments as given in the foregoing statement show comparatively insignificant differences between them and the total production as compiled by the Survey. In 1896 and 1899 the shipments reported by the Courier were less than the production, and in 1897 and 1898 slightly greater.

The same authority gives the monthly shipments of coke from the Connellsville region in cars during the years 1896, 1897, 1898, and 1899 to the three chief points of general distribution, with the total monthly output and the average daily shipment for each working day in the month, as follows:

Monthly shipments of coke from the Connellsville region, in cars, to points of distribution during 1896, 1897, 1898, and 1899.

[Cars.]

\begin{tabular}{|c|c|c|c|c|c|}
\hline Month. & Pittsburg. & West. & East. & Total. & $\begin{array}{c}\text { Daily } \\
\text { average. }\end{array}$ \\
\hline 1896. & & & & & \\
\hline January ... & 9,454 & 15,455 & 6,946 & 31,855 & 1,180 \\
\hline February .. & 8,524 & 13,670 & 5,240 & 27,434 & 1,093 \\
\hline March & 8,454 & 15,879 & 4,345 & 28,678 & 1,103 \\
\hline April.... & 9,332 & 15,522 & 3,823 & 28,677 & 1,103 \\
\hline May ..... & 8,992 & 15,458 & 3,551 & 28,001 & 1,077 \\
\hline June .... & 8,440 & 12,892 & 4,295 & 25,627 & 985 \\
\hline July & 8,535 & 12,406 & 4,613 & 25,554 & 946 \\
\hline August . & 7,014 & 7,442 & 3,833 & 18,289 & 703 \\
\hline September. . & 6,954 & 4,747 & 2,864 & 14,565 & 560 \\
\hline October ...... & 8,653 & 5,714 & 2,670 & 17,037 & 655 \\
\hline November. & 8,771 & 6,967 & 2,171 & 17,909 & 716 \\
\hline December . & 11,195 & 11,750 & 2,566 & 25,511 & 945 \\
\hline Total... & 104,318 & 137,902 & 46,917 & 289,137 & 920 \\
\hline 1897. & & & & & \\
\hline January . & 10,583 & 11,856 & 3,755 & 26,194 & 1,008 \\
\hline February . & 9,727 & 11,487 & 4,146 & 25,360 & 1,056 \\
\hline March.... & 10,881 & 12,808 & 4,754 & 28,443 & 1,053 \\
\hline April... & 11,787 & 10,610 & 4,573 & 26,970 & 1,037 \\
\hline May & 11,574 & 10,228 & 5,767 & 27,569 & 1,060 \\
\hline June ... & 11,900 & 9,923 & 5,855 & 27,678 & 1,065 \\
\hline July .... & 13,841 & 11,663 & 5,784 & 31,288 & 1,159 \\
\hline August ...... & 13,210 & 10,900 & 5,597 & 29,707 & 1,140 \\
\hline September. . & 13,370 & 14,692 & 5,259 & 33,321 & 1,281 \\
\hline October ....... & 12,682 & 17,811 & 5,685 & 36,178 & 1,391 \\
\hline November .... & 13,248 & 18,130 & 5,073 & 36,451 & 1,458 \\
\hline December .... & 12,640 & 20,516 & 5,068 & 38,224 & 1,470 \\
\hline Total. & 145,443 & 160,624 & 61,316 & 367,383 & 1,181 \\
\hline
\end{tabular}


Monthly shipments of coke from the Connellsville region, in cars, to points of distribution during 1896, 1897, 1898, and 1899-Continued.

[Cars.]

\begin{tabular}{|c|c|c|c|c|c|}
\hline Month. & Pittsburg. & West. & East. & Total. & $\underset{\text { average. }}{\text { Daily }}$ \\
\hline 1898. & & & & & \\
\hline January ...... & 14,051 & 19,044 & 5,253 & 38,348 & 1,475 \\
\hline February ... & 12,009 & 17,685 & 5,431 & 35,125 & 1,463 \\
\hline March...... & 13,323 & 19,257 & 6,414 & 38,994 & 1,454 \\
\hline April.... & 12,758 & 18,235 & 5,825 & 36,818 & 1,416 \\
\hline May ...... & 13,047 & 17,347 & 5,387 & 35,781 & 1,376 \\
\hline June ..... & 12,023 & 16,325 & 5,241 & 33,589 & 1,292 \\
\hline July . . . . . . & 13,201 & 15,655 & 5,492 & 34,348 & 1,321 \\
\hline A ligust .... & 13,603 & 15,801 & 5,552 & 34,956 & 1,295 \\
\hline September. & 11,856 & 16,547 & 5,448 & 33,851 & 1,302 \\
\hline October ... & 13,250 & 19,330 & 5,892 & 38,472 & 1,480 \\
\hline November .... & 13,387 & 20,923 & 6,681 & 40,991 & 1,576 \\
\hline Đecember . & 14,453 & 18,847 & 6,676 & 39,976 & 1,537 \\
\hline Total. & 156,961 & 214,996 & 69,292 & . 441,249 & 1,415 \\
\hline 1899. & & & & & \\
\hline January ... & 13,826 & 20,559 & 5,935 & 40,320 & 1,550 \\
\hline February .. & 12,402 & 18,694 & 5,201 & 36,297 & 1,512 \\
\hline March... & 13,886 & 22,741 & 6,975 & 43,602 & 1,615 \\
\hline April.... & 13,738 & 22,699 & 6,964 & 43,401 & 1,736 \\
\hline May .... & 14,154 & 20,850 & 6,651 & 41,655 & 1,543 \\
\hline June .... & 13,905 & 22,194 & 7,245 & 43,344 & 1,667 \\
\hline July .... & 15,052 & 22,674 & 8,293 & 46,019 & 1,770 \\
\hline August ... & 13,348 & 25,118 & 8,127 & 46,593 & 1,726 \\
\hline September. & 13,852 & 21,708 & 6,827 & 42,387 & 1,630 \\
\hline October ... & 14,753 & 22,895 & 7,452 & 45,100 & 1,735 \\
\hline November & 13,925 & 25,542 & 8,071 & 47,538 & 1,828 \\
\hline December & 13,741 & 25,258 & 7,948 & 46,947 & 1,805 \\
\hline Total. & 166,582 & 270,932 & 85,689 & 523,203 & 1,676 \\
\hline
\end{tabular}


The total shipments in cars for the last twelve years were as follows:

Total and daily average shipments in cars from 1888 to 1899.

\begin{tabular}{|c|c|c|c|c|c|}
\hline Year. & $\begin{array}{c}\text { Daily } \\
\text { average. }\end{array}$ & Total cars. & Year. & $\begin{array}{c}\text { Daily } \\
\text { average. }\end{array}$ & Total cars. \\
\hline 1888 & 905 & 282,441 & $1894 \ldots$ & 900 & 281,677 \\
\hline 1889 & 1,046 & 326,220 & 1895. & 1,410 & 441,243 \\
\hline $1890 \ldots$ & 1,147 & 355,070 & 1896. & 920 & 289,137 \\
\hline $1891 \ldots$ & 884 & 274,000 & $1897 \ldots$ & 1,181 & 367,383 \\
\hline 1892. & 1,106 & 347,012 & 1898 & 1,415 & 441,249 \\
\hline 1893. & 874 & 270,930 & 1899. & 1,676 & 523,203 \\
\hline
\end{tabular}

The following table shows how prices were quoted througbout the year 1899:

Average monthly prices of Connellsville coke, per short ton, during 1899.

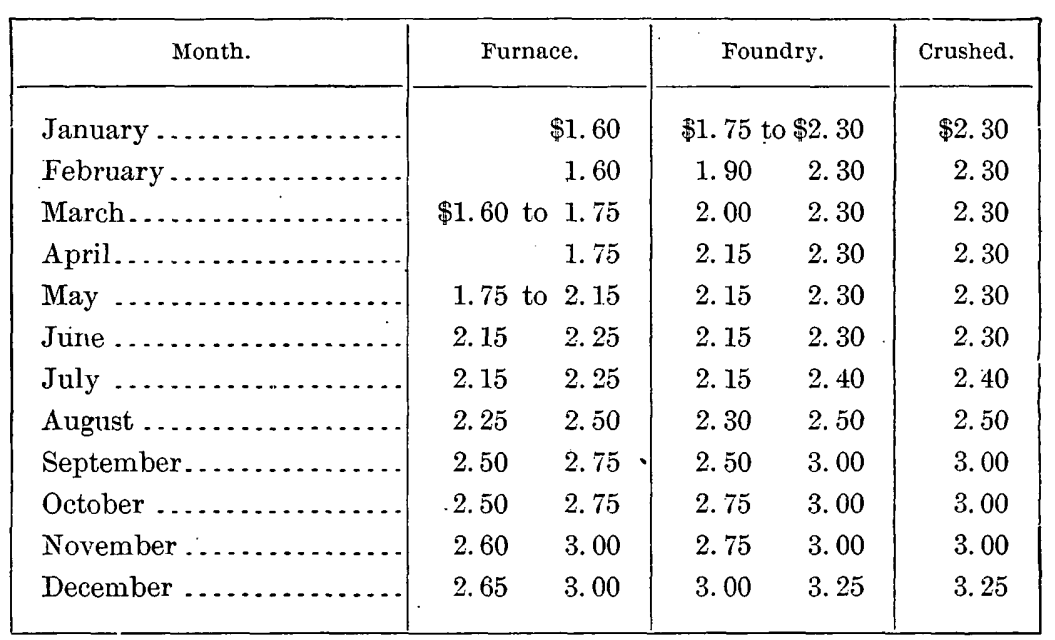


How the above compares with the prices for the corresponding months in 1898 may be seen below:

Average monthly prices of Connellsville coke, per short ton, during 1898.

\begin{tabular}{|c|c|c|c|}
\hline Month. & Furnace. & Foundry. & Crushed. \\
\hline January ............. & $\$ 1.75$ & $\$ 2.15$ & $\$ 2.30$ \\
\hline February $\ldots \ldots \ldots \ldots$ & 1.75 & 2.15 & 2. 30 \\
\hline March................ & 1.75 & 2.15 & 2.30 \\
\hline April............ & 1.75 & 2.15 & 2.30 \\
\hline May ........... & 1.75 & 2.15 & 2.30 \\
\hline June ........... & $\$ 1.50$ to 1.75 & 2.15 & 2.30 \\
\hline July . .............. & 1.75 & $\$ 2$ to 2.15 & 2.30 \\
\hline August ............. & 1.75 & 2.15 & 2.30 \\
\hline September....... & 1. 75 & 2.15 & 2.30 \\
\hline October .......... & 1.75 & 2.15 & 2,30 \\
\hline November $\ldots \ldots \ldots \ldots \ldots$ & 1.75 & 2.15 & 2.30 \\
\hline December.$\ldots \ldots \ldots \ldots \ldots$ & 1.75 & 2.15 & 2.30 \\
\hline
\end{tabular}

The following table gives the ruling and circular prices of blastfurnace coke free on board at the ovens for the last nineteen years:

Monthly prices of Connellsville blast-furnace coke free on board at ovens.

[Per short ton.]

\begin{tabular}{|c|c|c|c|c|c|c|c|}
\hline Month. & \multicolumn{2}{|c|}{1881.} & \multicolumn{2}{|c|}{1882.} & \multicolumn{2}{|c|}{1883.} & 1884. \\
\hline January ...... & \multicolumn{2}{|c|}{$\$ 1.50$ to $\$ 1.75$} & \multicolumn{2}{|c|}{$\$ 1.70$ to $\$ 1.80$} & \multicolumn{2}{|c|}{$\$ 1.15$ to $\$ 1.20$} & $\$ 1.00$ \\
\hline February ... & 1.50 & 1.75 & 1.70 & 1.80 & 1.10 & 1.20 & 1.00 \\
\hline March ......... & 1.50 & 1.75 & 1.70 & 1.75 & & 1.05 & 1.00 \\
\hline April.......... & 1. 60 & 1.75 & 1. 70 & 1. 75 & & 1.05 & 1. 10 \\
\hline May ......... & 1.60 & 1.65 & 1.65 & 1. 70 & .95 & 1.05 & 1. 10 \\
\hline June .... & 1. 60 & 1.65 & 1.50 & 1.65 & & .90 & 1. 10 \\
\hline July ..... & 1. 50 & 1. 60 & 1.35 & 1.50 & & .90 & 1.10 \\
\hline August .... & & 1.60 & & 1.35 & & .90 & 1. 10 \\
\hline September.... & & 1.60 & 1.25 & 1.35 & & 1.00 & 1. 10 \\
\hline October ... & 1.60 & 1.65 & & 1.25 & & 1.00 & 1. 10 \\
\hline Norember .... & 1. 60 & 1.65 & 1.25 & 1.35 & & 1.00 & 1. 10 \\
\hline December .... & 1.60 & 1.70 & 1.15 & 1.35 & & 1.00 & 1.10 \\
\hline
\end{tabular}


COKE.

Monthly prices of Connellsville blast-furnace coke free on board at ovens-Continued.

[Per short ton.]

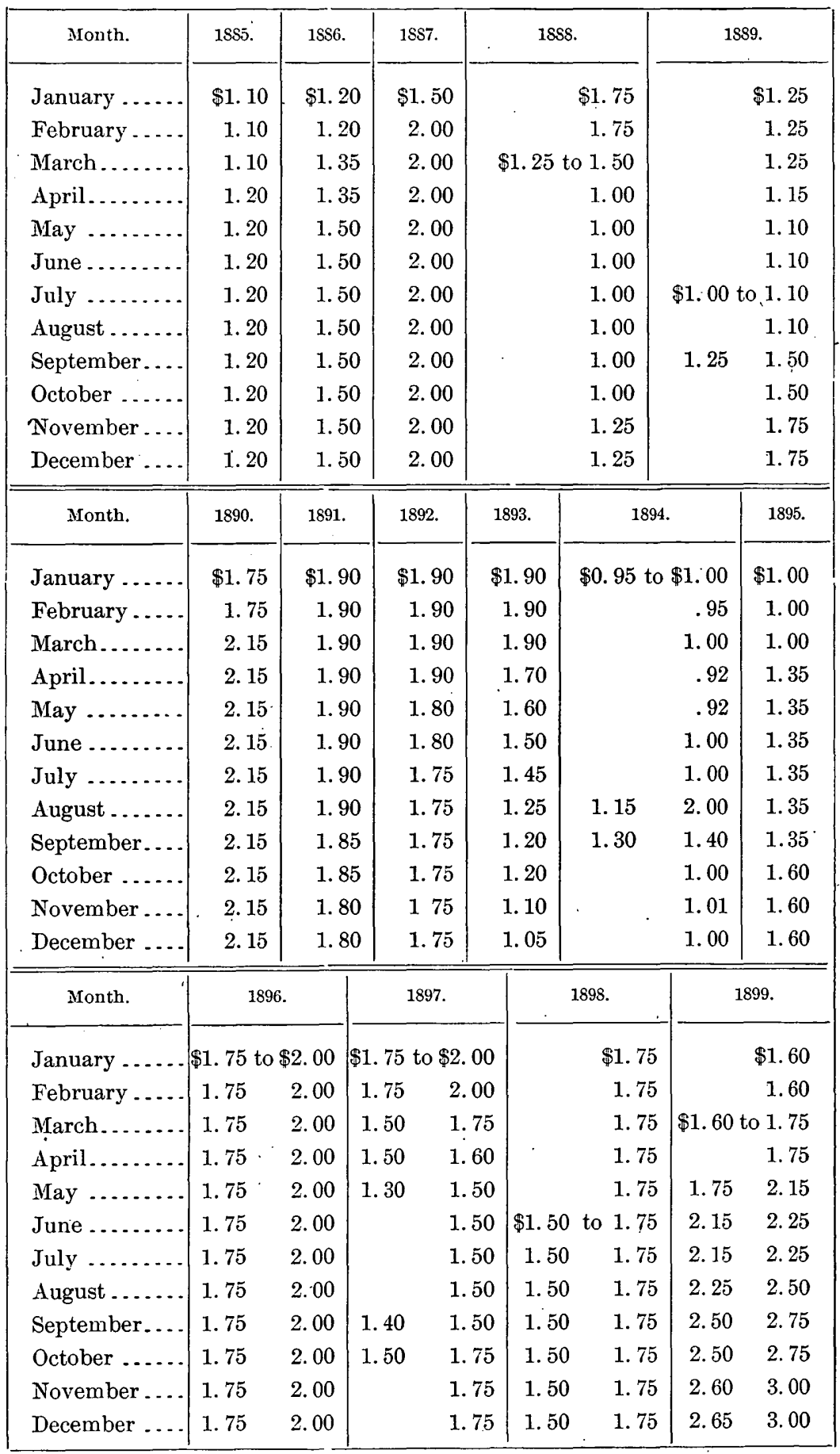


Beaver district.-All the ovens in Beaver County, eight in number, were abandoned in 1898, and the statistics of production of coke in Mercer County have been included with the Pittsburg district.

The following are the statistics of the manufacture of coke in the Beaver district, Pennsylvania, for the years 1880 to 1897:

Statistics of the manufacture of coke in the Beaver district, Pennsylvania, from 1880 to 1897.

\begin{tabular}{|c|c|c|c|c|c|c|c|c|}
\hline \multirow{2}{*}{ Year. } & \multirow{2}{*}{$\begin{array}{l}\text { Estab- } \\
\text { lish- } \\
\text { ments. }\end{array}$} & \multicolumn{2}{|c|}{ Ovens. } & \multirow{2}{*}{ Coal used. } & \multirow{2}{*}{$\begin{array}{l}\text { Coke pro- } \\
\text { duced. }\end{array}$} & \multirow{2}{*}{$\begin{array}{l}\text { Total value } \\
\text { of coke at } \\
\text { ovens. }\end{array}$} & \multirow{2}{*}{$\begin{array}{l}\text { Value of } \\
\text { coke at } \\
\text { ovens, } \\
\text { per ton. }\end{array}$} & \multirow{2}{*}{$\begin{array}{l}\text { Yield of } \\
\text { coal in } \\
\text { coke. }\end{array}$} \\
\hline & & Built. & $\begin{array}{l}\text { Build- } \\
\text { ing. }\end{array}$ & & & & & \\
\hline $1880 \ldots$ & 5 & 106 & 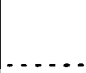 & $\begin{array}{r}\text { Short tons. } \\
8,013\end{array}$ & $\begin{array}{r}\text { Short tons. } \\
4,880\end{array}$ & $\$ 10,150$ & $\$ 2.08$ & $\begin{array}{c}\text { Per cent. } \\
61\end{array}$ \\
\hline 1881. & 5 & 106 & . & 6,887 & 4,333 & 9,013 & 2.08 & 63 \\
\hline 1882 & 5 & 106 & $\ldots$. & 11,699 & $7, .960$ & 15,124 & 1.90 & 68 \\
\hline 1883 & 5 & 107 & & 19,510 & 12,395 & 21,062 & 1. 70 & 64 \\
\hline 1884. & 4 & 89 & & 2,250 & 1,390 & 2,168 & 1. 56 & 62 \\
\hline 1885 & 4 & 89 & $\ldots \ldots$ & 686 & 438 & 696 & 1.59 & 63 \\
\hline 1886. & 3 & 87 & $\ldots .$. & 698 & 411 & 646 & 1.57 & 59 \\
\hline 1887. & 3 & 65 & - & 25,207 & 13,818 & 24,137 & 1.75 & 55 \\
\hline $1888 \ldots$ & 4 & 145 & & 262 & 175 & 260 & 1. 48 & 66.6 \\
\hline 1889 & 3 & 90 & & 3,100 & 1,853 & 3,848 & 2.07 & 60 \\
\hline 1890 . & 3 & 90 & & 4,010 & 2,148 & 4,564 & 2.12 & 53.5 \\
\hline 1891. & 3 & 88 & & 4,224 & 2,332 & 6,663 & 2.86 & 55 \\
\hline 1892. & 2 & 10 & 0 & 3,925 & 2,154 & 6,270 & 2.91 & 54.9 \\
\hline 1893. & 2 & 10 & 0 & 2,998 & 1,644 & 4,446 & 2. 70 & 54.8 \\
\hline 1894. & 2 & 8 & 0 & 2,968 & 1,624 & 4,251 & 2.62 & 54.7 \\
\hline $1895 \ldots$ & 2 & 8 & 0 & 2,888 & 1,584 & 3,940 & 2.49 & 54.8 \\
\hline 1896. & 3 & $\alpha 35$ & 0 & 13,845 & 9,004 & 17,200 & 1.91 & 65 \\
\hline $1897 \ldots$ & 3 & a 33 & 0 & 42,200 & 27,276 & 61,646 & 2.26 & 64.6 \\
\hline
\end{tabular}

$a$ Includes 25 Semet-Solvay ovens in Mercer County.

Allegheny Valley district.-The ovens in Armstrong and Butler counties are included in this district. Production is irregular, all of the ovens having been idle five years in the last eight. They were idle in 1898 and 1899. 
The statistics of the manufacture of coke in the Allegheny Valley district since 1880 are as follows:

Statistics of the manufacture of coke in the Allegheny Valley district, Pennsylvania, from 1880 to 1899.

\begin{tabular}{|c|c|c|c|c|c|c|c|c|}
\hline \multirow{2}{*}{ Yeqr. } & \multirow{2}{*}{$\begin{array}{c}\text { Estab- } \\
\text { lish- } \\
\text { ments. }\end{array}$} & \multicolumn{2}{|c|}{ Ovens. } & \multirow{2}{*}{ Coal used. } & \multirow{2}{*}{$\begin{array}{l}\text { Coke pro- } \\
\text { duced. }\end{array}$} & \multirow{2}{*}{$\begin{array}{l}\text { Total value } \\
\text { of coke at } \\
\text { ovens. }\end{array}$} & \multirow{2}{*}{$\begin{array}{l}\text { Value of } \\
\text { coke at } \\
\text { ovens, } \\
\text { per ton. }\end{array}$} & \multirow{2}{*}{$\begin{array}{l}\text { Yield of } \\
\text { coal in } \\
\text { coke. }\end{array}$} \\
\hline & & Built. & $\begin{array}{c}\text { Build- } \\
\text { ing. }\end{array}$ & & & & & \\
\hline 1880 & 5 & 97 & 0 & $\begin{array}{r}\text { Short tons. } \\
45,355\end{array}$ & $\begin{array}{r}\text { Short tons. } \\
23,470\end{array}$ & $\$ 49,068$ & $\$ 2.10$ & $\begin{array}{l}\text { Per cent. } \\
52\end{array}$ \\
\hline 1881. & 5 & 109 & 0 & 55,676 & 29,650 & 64,664 & 2.18 & 53 \\
\hline 1882 & 6 & 159 & 0 & 76,000 & 41,897 & 80,294 & 1.92 & 55 \\
\hline 1883 & 6 & 159 & 0 & 64,810 & 34,868 & 62,982 & 1.81 & 54 \\
\hline 1884 . & 7 & 209 & 0 & 55,110 & 31,430 & 54,859 & 1.75 & 57 \\
\hline 1885 & 5 & 208 & 0 & 28,630 & 15,326 & 30,151 & 1.97 & 53.5 \\
\hline 1886 & 5 & 208 & 0 & 51,580 & 28,948 & 44,422 & 1.54 & 56 \\
\hline 1887 & 5 & 288 & 88 & 77,666 & 44,621 & 84,913 & 1.90 & 57.1 \\
\hline 1888 & 5 & 376 & 0 & 37,792 & 21,719 & 36,008 & 1. 66 & 57.5 \\
\hline 1889 & 4 & 198 & 0 & 13,105 & 6,569 & 10,538 & 1.62 & 50 \\
\hline $1890 \ldots$ & 3 & . 148 & 0 & 33,049 & 18,733 & 40,204 & 2.15 & 56.7 \\
\hline 1891 & 3 & 148 & 0 & 21,833 & 11,314 & 25,909 & 2. 29 & 52 \\
\hline 1892 & 3 & 148 & 0 & 0 & 0 & 0 & 0 & 0 \\
\hline $1893 \ldots$ & 2 & 116 & 0 & 10,927 & 6,557 & 11,147 & 1. 70 & 60 \\
\hline $1894 \ldots$ & 2 & 116 & 0 & 0 & 0 & 0 & 0 & 0 \\
\hline $1895 \ldots$ & 2 & 116 & 0 & 0 & 0 & 0 & 0 & 0 \\
\hline 1896 & 2 & 116 & 0 & 12,445 & 7,467 & 14,934 & 2.00 & 60 \\
\hline $1897 \ldots$ & 2 & 116 & 0 & 8,300 & 5,000 & 10,000 & 2.00 & 60.2 \\
\hline $1898 \ldots$ & 2 & 116 & 0 & 0 & 0 & 0 & 0 & 0 \\
\hline $1899 \ldots$ & 2 & 116 & 0 & 0 & 0 & 0 & 0 & 0 \\
\hline
\end{tabular}

Reynoldsville-Walston district.-This district includes all the ovens on the Rochester and Pittsburg Railroad, as well as those on the Low Grade Division of the Allegheny Valley Railway, and the mines of the New York, Lake Erie and Western Railroad. Production in this district has increased regularly for the last five years. The production in 1899 includes that of Massachusetts, which makes an apparent increase of about 62 per cent over 1898. One hundred and sixty-three ovens in the district proper were abandoned in 1899, reducing the number from 1,942 to 1,779 . 
The following are the statistics of the manufacture of coke in the Reynoldsville-Walston district for the years 1880 to 1899:

Statistics of the manufacture of coke in the Reynoldsille- Halston district, Pennsylvania, from 1880 to 1899 .

\begin{tabular}{|c|c|c|c|c|c|c|c|c|}
\hline \multirow{2}{*}{ Year. } & \multirow{2}{*}{$\begin{array}{l}\text { Estab- } \\
\text { lish- } \\
\text { ments. }\end{array}$} & \multicolumn{2}{|c|}{ Ovens. } & \multirow{2}{*}{ Coal used. } & \multirow{2}{*}{$\begin{array}{l}\text { Coke pro- } \\
\text { duced. }\end{array}$} & \multirow{2}{*}{$\begin{array}{c}\text { Total ralue } \\
\text { of coke at } \\
\text { ovens. }\end{array}$} & \multirow{2}{*}{$\begin{array}{l}\text { Value of } \\
\text { coke at } \\
\text { ovens, } \\
\text { per ton. }\end{array}$} & \multirow{2}{*}{$\begin{array}{l}\text { Yield of } \\
\text { cool in } \\
\text { coke. }\end{array}$} \\
\hline & & Built. & $\begin{array}{c}\text { Build } \\
\text { ing. }\end{array}$ & & & & & \\
\hline 1880. & 3 & 117 & 0 & $\begin{array}{r}\text { Short tons. } \\
45,055\end{array}$ & $\begin{array}{r}\text { Short tons. } \\
28,090\end{array}$ & $\$ 46,359$ & $\$ 1.65$ & $\begin{array}{l}\text { Per cent } \\
62\end{array}$ \\
\hline 1881. & 4 & 125 & 2 & 99,489 & 44,260 & 80,785 & 1.85 & 44 \\
\hline 1882 & 5 & 177 & 0 & 87,314 & 44,709 & 80,339 & 1.80 & 51 \\
\hline 1883 & 6 & 229 & 0 & 76,580 & 37,044 & 65,584 & 1.77 & 48 \\
\hline 1884 & 7 & 321 & 0 & 159,151 & 78,646 & 113,155 & 1.44 & 49 \\
\hline 1885 & 8 & 600 & 143 & 183,806 & 114,409 & 153,795 & 1.35 & 62 \\
\hline 1886 & 9 & 783 & 500 & 271,037 & 161,828 & 217,834 & 1.35 & 59.7 \\
\hline 1887 & 11 & 1,492 & 134 & 507,320 & 316,107 & 592,728 & 1.88 & 62.3 \\
\hline 1888 & 9 & 1,636 & 100 & 404,346 & 253,662 & 320,203 & 1.26 & 62.7 \\
\hline $1889 \ldots$ & 8 & 1,747 & 0 & 514,461 & 313,011 & 436,857 & 1.40 & 60.8 \\
\hline 1890 & 8 & 1,737 & 0 & 652,966 & 406,184 & 771,996 & 1.90 & 62 \\
\hline 1891 & 7 & 1,747 & 0 & 769,100 & 470,479 & 744,098 & 1.58 & 61 \\
\hline 1892. & 8 & 1,734 & 0 & 683,539 & 425,250 & 743,227 & 1.75 & 62.2 \\
\hline 1893 & 8 & 1,755 & 0 & 562,033 & 339,314 & 586,212 & 1. 73 & 60.4 \\
\hline 1894 & 8 & 1,755 & 0 & 336,554 & 207,238 & 297,596 & 1.44 & 61.6 \\
\hline $1895 \ldots$ & 8 & 1,637 & 0 & 504,092 & 296,820 & 357,266 & 1. 20 & 58.9 \\
\hline $1896 a$ & 7 & 1,852 & 34 & 770,104 & 445,998 & 673,625 & 1.51 & 57.9 \\
\hline $1897 a$ & 6 & 1,980 & 0 & 810,808 & 491,267 & 759,609 & 1.55 & 60.6 \\
\hline $1898 a$ & 5 & 1,942 & 0 & $1,022,196$ & 600,084 & 846,121 & 1. 41 & 58.7 \\
\hline $1899 a$ & 6 & 1,779 & 0 & $1,581,164$ & 972,933 & $1,793,807$ & 1.84 & 61.5 \\
\hline
\end{tabular}

$a$ Includes coal used, coke produced, and its value in New York; also in Nassachusetts for 1899.

Blossburg district. - This district, which was at one time of considerable importance as a coke-producing district, especially to central and western New York, produced very little coke in 1894 and 1895, and none in the last four years. The ovens have been abandoned. 
Statistics of the manufacture of coke in the Blossburg district, Pennsylvania, from 1880 to 1895.

\begin{tabular}{|c|c|c|c|c|c|c|c|c|}
\hline \multirow{2}{*}{ Year. } & \multirow{2}{*}{$\begin{array}{l}\text { Estab- } \\
\text { lish- } \\
\text { ments. }\end{array}$} & \multicolumn{2}{|c|}{ Ovens. } & \multirow{2}{*}{ Coal used. } & \multirow{2}{*}{$\begin{array}{l}\text { Coke pro- } \\
\text { duced. }\end{array}$} & \multirow{2}{*}{$\begin{array}{l}\text { Total value } \\
\text { of coke at } \\
\text { ovens. }\end{array}$} & \multirow{2}{*}{$\begin{array}{l}\text { Value of } \\
\text { coke at } \\
\text { ovens, } \\
\text { per ton. }\end{array}$} & \multirow{2}{*}{$\begin{array}{c}\text { Yield of } \\
\text { coal in } \\
\text { coke. }\end{array}$} \\
\hline & & Built. & $\begin{array}{c}\text { Build- } \\
\text { ing. }\end{array}$ & & & & & \\
\hline 1880 & 1 & 200 & 0 & Short tons. & $\begin{array}{r}\text { Short tons. } \\
44836\end{array}$ & $\$ 134,500$ & $\$ 3.00$ & $\begin{array}{l}\text { Per cent. } \\
62\end{array}$ \\
\hline $1881 \ldots$ & 1 & 200 & 0 & 88,055 & 56,085 & 168,250 & 3.00 & 64 \\
\hline $1882 \ldots$ & 1 & 200 & 0 & 100,119 & 64,526 & 193,500 & 3.00 & 64 \\
\hline 1883. & 2 & 344 & 0 & 71,028 & 44,690 & 122,450 & 2.74 & 63 \\
\hline 1884. & 2 & 344 & 32 & 62,365 & 39,043 & 93,763 & 2.40 & 63 \\
\hline $1885 \ldots$ & 2 & 296 & 0 & 46,489 & 26,975 & 59,423 & 2.17 & 58 \\
\hline $1886 \ldots$ & 2 & 405 & 0 & 136,136 & 81,801 & 174,532 & 2.13 & 60 \\
\hline $1887 \ldots$ & 2 & 406 & 0 & 182,623 & 103,873 & 234,622 & 2.26 & 56.9 \\
\hline $1888 \ldots$ & 2 & 407 & 0 & 62,063 & 38,052 & 81,400 & 2.14 & 61. \\
\hline 1889. & 2 & 407 & 0 & 31,806 & 18,422 & 47,765 & 2.59 & 58 \\
\hline $1890 \ldots$ & 2 & 407 & 0 & 41,785 & 23,196 & 62,804 & 2.71 & 55.5 \\
\hline $1891 \ldots$ & 2 & 407 & 0 & 46,084 & 24,351 & 66,195 & 2.72 & 53 \\
\hline $1892 \ldots$ & 2 & 407 & 0 & 30,746 & 16,675 & 45,855 & 2.75 & 54.2 \\
\hline $1893 \ldots$ & 2 & 407 & 0 & 22,176 & 11,463 & 31,427 & 2.74 & 51.7 \\
\hline $1894 \ldots$ & 1 & 250 & 0 & 670 & 332 & 896 & 2.70 & 50 \\
\hline 1895. & 1 & 200 & 0 & 976 & 488 & 1,220 & 2.50 & 50 \\
\hline
\end{tabular}

Greensburg district.-A small number of ovens in the Greensburg coal basin is reported separately by this district. The district is not an important one, but considerable activity was exhibited there in 1899 . The number of establishments was increased from 3 to 4 , and the number of ovens from 218 to 307 , while 240 were building at the close of the year. The production increased 50 per cent over 1898 , and has increased each year since 1894. The 307 completed ovens in 1899 included 80 that were not in operation during the year.

21 GEOL, PT $6-39$ 
Statistics of the manufacture of coke in the Greensburg district, Pennsylvania, from 1889 to 1899.

\begin{tabular}{|c|c|c|c|c|c|c|c|c|}
\hline \multirow[b]{2}{*}{ Year. } & \multirow{2}{*}{$\begin{array}{c}\text { Estab- } \\
\text { lish- } \\
\text { ments. }\end{array}$} & \multicolumn{2}{|c|}{ Ovens. } & \multirow[b]{2}{*}{ Coal used. } & \multirow{2}{*}{$\begin{array}{c}\text { Coke pro- } \\
\text { duced. }\end{array}$} & \multirow{2}{*}{$\begin{array}{l}\text { Total value } \\
\text { of coke at } \\
\text { ovens. }\end{array}$} & \multirow{2}{*}{$\begin{array}{l}\text { Value of } \\
\text { coke at } \\
\text { ovens, } \\
\text { per ton. }\end{array}$} & \multirow{2}{*}{$\begin{array}{c}\text { Yield of } \\
\text { coal in } \\
\text { coke. }\end{array}$} \\
\hline & & Built. & $\begin{array}{c}\text { Build- } \\
\text { ing. }\end{array}$ & & & & & \\
\hline 1889. & 2 & 50 & 16 & $\begin{array}{r}\text { Short tons. } \\
32,070\end{array}$ & $\begin{array}{r}\text { Short tons. } \\
20,459\end{array}$ & $\$ 21,523$ & $\$ 1.05$ & $\begin{array}{c}\text { Per cent } \\
63.8\end{array}$ \\
\hline 1890 . & 2 & 58 & 0 & 44,000 & 30,261 & 44,290 & 1.46 & 68.7 \\
\hline $1891 \ldots$ & 2 & 58 & 0 & 38,188 & 22,441 & 36,627 & 1. 63 & 59 \\
\hline $1892 \ldots$ & 2 & 58 & 0 & 15,005 & 9,037 & 13,173 & 1.46 & 60.2 \\
\hline 1893. & 3 & 88 & 0 & 29,983 & 18,393 & 26,303 & 1.43 & 61 \\
\hline 1894 & 3 & 118 & 0 & 27,290 & 15,872 & 18,413 & 1.16 & 58.2 \\
\hline 1895 & 3 & 118 & 0 & 31,300 & 20,309 & 22,340 & 1. 10 & 65 \\
\hline $1896 \ldots$ & 3 & 178 & 0 & 36,963 & 24,642 & 30,928 & 1.255 & 66 \\
\hline $1897 \ldots$ & 3 & 178 & 0 & 81,927 & 52,495 & 65,619 & 1.25 & 64 \\
\hline 1898. & 3 & 218 & 0 & 112,487 & 64,295 & 96,443 & 1.50 & 57 \\
\hline 1899. & 4 & 307 & 240 & 173,811 & 110,594 & 247,421 & 2.24 & 63.6 \\
\hline
\end{tabular}

Pittsburg district.-Much of the coal made into coke in the Pittsburg district is slack, usually obtained from the mines along the several pools of the Monongahela River and brought to Pittsburg by barges. Some run-of-mine coal is also brought from the fourth pool of the Monongahela River for coking at Pittsburg. The production of the district has increased steadily each year since 1890 , and it is now the third district in the State as a producer of coke. The number of ovens in existence increased from 1,100 in 1898 to 1,312 in 1899 , and 505 additional ovens were building at the close of the year. These include 120 Otto-Hoffman and 25 Semet-Solvay by-product ovens. Of the 1,312 ovens in the district 108 were idle in 1899 . 
The statisties of the manufacture of coke in the Pittsburg district, Pennsylvania, for the years 1880 to 1899 are stated in the following table:

Statistics of the manufacture of coke in the Pittsburg district, Pennsylvania, from 1880 to 1899.

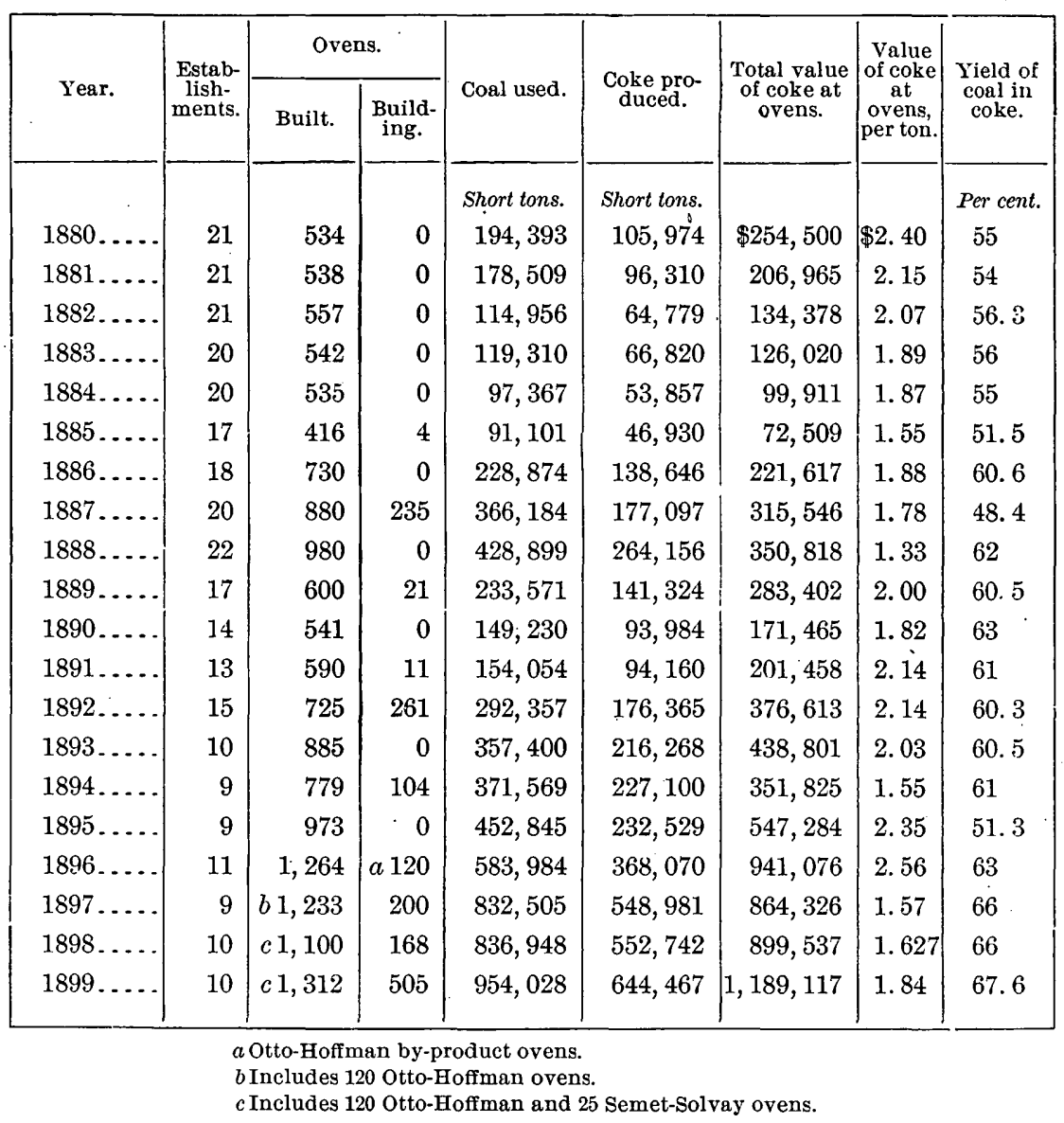

Clearfield-Center district.-This district includes the ovens in Clearfield and Center counties, including Snow Shoe, Moshannon, and other well-known coal districts. The number of establishments was reduced from 7 to 6 in 1899, the number of ovens from 668 to 450 , and the production from 137,265 to 130,965 tons. There were, however, 50 new ovens in course of construction at the close of 1899 . The plant of 218 ovens abandoned in 1899 had not been in active operation for some time. In addition to these there were 30 ovens not running during 1899. 
The statistics of the manufacture of coke in the Clearfield-Center district for the years 1880 to 1899 are as follows:

Stutistics of the manufacture of coke in the Clearfield-Center district, Pennsylvania, from 1880 to 1899.

\begin{tabular}{|c|c|c|c|c|c|c|c|c|}
\hline \multirow{2}{*}{ Year. } & \multirow{2}{*}{$\begin{array}{l}\text { Estab- } \\
\text { lish- } \\
\text { ments. }\end{array}$} & \multicolumn{2}{|c|}{ Ovens. } & \multirow{2}{*}{ Coal used. } & \multirow{2}{*}{$\begin{array}{l}\text { Coke pro- } \\
\text { duced. }\end{array}$} & \multirow{2}{*}{$\begin{array}{c}\text { Total value } \\
\text { of coke at } \\
\text { ovens. }\end{array}$} & \multirow{2}{*}{$\begin{array}{l}\text { Value of } \\
\text { coke at } \\
\text { ovens, } \\
\text { per ton. }\end{array}$} & \multirow{2}{*}{$\begin{array}{l}\text { Yield of } \\
\text { coal in } \\
\text { coke. }\end{array}$} \\
\hline & & Built. & $\begin{array}{l}\text { Build- } \\
\text { ing. }\end{array}$ & & & & & \\
\hline 1880 . & 1 & 0 & 0 & $\begin{array}{r}\text { Short tons. } \\
200\end{array}$ & $\begin{array}{r}\text { Short tons. } \\
100\end{array}$ & $\$ 200$ & $\$ 2.00$ & $\begin{array}{c}\text { Per cent. } \\
50\end{array}$ \\
\hline 1881. & 2 & 50 & 0 & 20,025 & 13,350 & 22,695 & 1.70 & 67 \\
\hline $1882 \ldots$ & 1 & 50 & 0 & 25,000 & 17,160 & 27,406 & 1.60 & 69 \\
\hline $1883 \ldots$ & 1 & 60 & 0 & 26,500 & 18,696 & 28,844 & 1.50 & 71 \\
\hline $1884 \ldots$ & 1 & 60 & 0 & 33,000 & 23,431 & 32,849 & 1.40 & 71. \\
\hline $1885 \ldots$ & 2 & 245 & 0 & 69,720 & 48,103 & 70,331 & 1.46 & 69 \\
\hline $1886 \ldots$ & 3 & 299 & 20 & 84,870 & 55,810 & 94,877 & 1. 70 & 66 \\
\hline $1887 \ldots$ & 6 & 523 & 10 & 154,566 & 97,852 & 198,095 & 2.02 & 63.3 \\
\hline 1888 & 6 & 601 & 0 & 172,999 & 115,338 & 174,220 & 1.51 & 66.6 \\
\hline $1889 \ldots$ & 6 & 671 & 0 & 195,473 & 120,734 & 215,112 & 1. 78 & 61.7 \\
\hline $1890 \ldots$ & 7 & 701 & 0 & 331,104 & 212,286 & 391,957 & 1.85 & 64 \\
\hline $1891 \ldots$ & 7 & 666 & 0 & 293,542 & 183,911 & 339,082 & 1. 84 & 63 \\
\hline $1892 \ldots$ & 7 & 731 & 0 & 231,357 & 147,819 & 264,422 & 1. 79 & 63.9 \\
\hline $1893 \ldots$ & 8 & 695 & 0 & 155,119 & 98,650 & 171,482 & 1. 74 & 63.6 \\
\hline $1894 \ldots$ & 8 & 694 & 0 & 61,428 & 38,825 & 51,482 & 1. 33 & 63 \\
\hline $1895 \ldots$ & 8 & 695 & 0 & 155,088 & 99,469 & 131,188 & 1. 32 & 64 \\
\hline $1896 \ldots$ & 7 & 666 & 0 & 183,056 & 118,155 & 164,266 & 1. 39 & 64.5 \\
\hline $1897 \ldots$ & 7 & 668 & 0 & 230,395 & 153,517 & 197,139 & 1. 28 & 66 \\
\hline $1898 \ldots$ & 7 & 668 & 0 & 215,208 & 137,265 & 195,836 & 1.43 & 63.8 \\
\hline $1899 \ldots$ & 6 & 450 & 50 & 198,110 & 130,965 & 234,527 & 1. 79 & 66.1 \\
\hline
\end{tabular}

Broad Top district.-This district includes the ovens situated in Bedford and Huntingdon counties, comprising what is known as the Broad Top coal field. There were 519 completed ovens in the field in 1899, a gain of 19 over 1898 . Of these, 208 were idle in 1899 , as compared with 232 idle ovens in 1898 . The production of the district increased 25 per cent, but was not up to the record made from 1883 to 1890 . 
The statistics of the manufacture of coke in the Broad Top region from 1880 to 1899 are shown in the following table:

Statistics of the manufacture of coke in the Broad Top region, Pernsylvania, from $18 S 0$ to 1899.

\begin{tabular}{|c|c|c|c|c|c|c|c|c|}
\hline \multirow{2}{*}{ Year. } & \multirow{2}{*}{$\begin{array}{l}\text { Estab- } \\
\text { lish- } \\
\text { ments. }\end{array}$} & \multicolumn{2}{|c|}{ Ovens. } & \multirow{2}{*}{ Coal used. } & \multirow{2}{*}{$\begin{array}{l}\text { Coke pro- } \\
\text { duced. }\end{array}$} & \multirow{2}{*}{$\begin{array}{l}\text { Total value } \\
\text { of coke at } \\
\text { ovens. }\end{array}$} & \multirow{2}{*}{$\begin{array}{l}\text { Value of } \\
\text { coke at } \\
\text { ovens, } \\
\text { per ton. }\end{array}$} & \multirow{2}{*}{$\begin{array}{l}\text { Yield of } \\
\text { coul in } \\
\text { coke. }\end{array}$} \\
\hline & & Built. & $\begin{array}{l}\text { Build- } \\
\text { ing. }\end{array}$ & & & & & \\
\hline 1880. & 5 & 188 & 105 & $\begin{array}{r}\text { Short tons. } \\
92,894\end{array}$ & $\begin{array}{r}\text { Short tons. } \\
51,130\end{array}$ & $\$ 123,748$ & $\$ 2.40$ & $\begin{array}{l}\text { Per cent. } \\
555\end{array}$ \\
\hline 1881 & 5 & 188 & 105 & 111,593 & 66,560 & 167,074 & 2.51 & 59 \\
\hline 1882 & 5 & 293 & 50 & 170,637 & 105,111 & 215,079 & 2.05 & 62 \\
\hline 1883. & 5 & 343 & 110 & 220,932 & 147,154 & 271,692 & 1.84 & 66 \\
\hline 1884. & 5 & 453 & 0 & 227,954 & 151,959 & 264,569 & 1.74 & 66 \\
\hline 1885. & 5 & 537 & 0 & 190,836 & 112,073 & 185,656 & 1.65 & 58 \\
\hline 1886. & 5 & 562 & 100 & 171,137 & 108,294 & 187,321 & 1. 73 & 63.3 \\
\hline $1887 \ldots$ & 5 & 581 & 0 & 262,730 & 164,535 & 347,061 & 2. 11 & 62.6 \\
\hline 1888. & 5 & 591 & 0 & 196,015 & 119,469 & 286,655 & 2.40 & 61 \\
\hline 1889 & 5 & 589 & 0 & 152,090 & 91,256 & 186,718 & 2.05 & 60 \\
\hline 1890 & 5 & 482 & 16 & 247,823 & 157,208 & 314,416 & 2.00 & 63 \\
\hline $1891 \ldots$ & 5 & 448 & 0 & 146,008 & 90,728 & 197,048 & 2. 17 & 62 \\
\hline $1892 \ldots$ & 5 & 448 & 8 & 185,600 & 117,554 & 216,090 & 1.84 & 63.3 \\
\hline $1893 \ldots$ & 5 & 456 & 14 & 136,069 & 86,752 & 150,196 & 1. 73 & 63.8 \\
\hline 1894 & 5 & 454 & 14 & 53,216 & 34,089 & 51,815 & 1.52 & 64 \\
\hline 1895 & 5 & 460 & 0 & 133,276 & 85,842 & 150,224 & 1. 75 & 64.4 \\
\hline $1896 \ldots$ & 5 & 480 & 0 & 111,145 & 72,175 & 126,306 & 1. 75 & 64.9 \\
\hline 1897. & 5 & 491 & 15 & 106,706 & 66,949 & 107,430 & 1.60 & 62.7 \\
\hline 1898 & 5 & 500 & 4 & 122,820 & 80,935 & 124,882 & 1. 543 & 65.9 \\
\hline 1899 & 5 & 519 & 3 & 161,196 & 107,258 & 197,895 & 1. 84 & 66.5 \\
\hline
\end{tabular}

Upper Connellsville district.-The Upper Connellsville district includes that portion of the Connellsville trough or basin lying north of a point a short distance below Latrobe. The coal differs somewhat from that of the lower part of the basin, so that in addition to its geo. graphical position there is another reason for the separation of the production of this field from that of the Connellsville field proper. The production of this district in 1899 was 609,893 short tons, the largest in any one year except in 1891, when the product exceeded that of last year by nearly 40,000 tons. Compared with 1898 , the production in 1899 showed an increase of over 50 per cent, while the value of the product increased over 80 per cent. The average price obtained in the district during 1899 was $\$ 1.61$, an advance of 27 cents over 1898 , and the highest figure recorded since 1891. A gain of 29 ovens is shown in the number credited to the district, and 68 others were in course of 
construction at the close of the year. Of the 1,861 ovens in the district at the close of 1899,174 were idle throughout the year.

The following are the statistics of the manufacture of coke in the Upper Connellsville region for the years 1880 to 1899:

Statistics of the manufacture of coke in the Upper Connellsville clistrict, Pennsylvania, from 1880 to 1899.

\begin{tabular}{|c|c|c|c|c|c|c|c|c|}
\hline \multirow{2}{*}{ Year. } & \multirow{2}{*}{$\begin{array}{c}\text { Estab- } \\
\text { lish- } \\
\text { ments. }\end{array}$} & \multicolumn{2}{|c|}{ Ovens. } & \multirow{2}{*}{ Coal used. } & \multirow{2}{*}{$\begin{array}{l}\text { Coke pro- } \\
\text { duced. }\end{array}$} & \multirow{2}{*}{$\begin{array}{c}\text { Total value } \\
\text { of coke at } \\
\text { ovens. }\end{array}$} & \multirow{2}{*}{$\begin{array}{c}\text { Value of } \\
\text { coke at } \\
\text { ovens, } \\
\text { per ton. }\end{array}$} & \multirow{2}{*}{$\begin{array}{l}\text { Yield of } \\
\text { coal in } \\
\text { coke. }\end{array}$} \\
\hline & & Built. & $\begin{array}{c}\text { Build- } \\
\text { ing. }\end{array}$ & & & & & \\
\hline 1880 & 8 & 757 & 0 & $\begin{array}{r}\text { Short tons. } \\
319,927\end{array}$ & $\begin{array}{r}\text { Short tons. } \\
229,433\end{array}$ & $\$ 397,945$ & $\$ 1.73$ & $\begin{array}{c}\text { Per cent. } \\
72\end{array}$ \\
\hline $1881 \ldots$ & 10 & 986 & 0 & 588,924 & 343,728 & 548,362 & 1. 60 & 58 \\
\hline $1882 \ldots$ & 11 & 1,118 & 0 & 650,174 & 375,918 & 536,503 & 1.43 & 58 \\
\hline $1883 \ldots$ & 11 & 1,118 & 0 & 668,882 & 389,053 & 422,174 & 1.08 & 58 \\
\hline $1884 \ldots$ & 11 & 1,118 & 0 & 496,894 & 294,477 & 311,665 & 1.06 & 59 \\
\hline 1885 & 11 & 1,168 & 40 & 555,735 & 319,297 & 346,168 & 1.08 & 57 \\
\hline 1886. & 12 & 1,337 & 29 & 691,331 & 442,968 & 572,073 & 1. 29 & 64.1 \\
\hline $188 \pi$ & 16 & 1,442 & 87 & 717,274 & 470,233 & 840,144 & 1. 79 & 65.6 \\
\hline $1888 \ldots$ & 16 & 1,977 & 0 & 657,966 & 441,966 & 617,189 & 1.40 & 67 \\
\hline $1889 \ldots$ & 13 & 1,568 & 80 & 635,220 & $41.7,263$ & 609,828 & 1.46 & 65.6 \\
\hline $1890 \ldots$ & 14 & 1,569 & 28 & 889,277 & 577,246 & $1,008,102$ & 1. 75 & 64.9 \\
\hline $1891 \ldots$ & 14 & 1,724 & 0 & $1,000,184$ & 649,316 & $1,111,056$ & 1. 71 & 65 \\
\hline $1892 \ldots$ & 14 & 1,843 & 0 & 706,171 & 451,975 & 691,323 & 1.53 & 64 \\
\hline $1893 \ldots$ & 14 & 1,843 & 0 & 499,809 & 320,793 & 447,090 & 1. 39 & 64 \\
\hline $1894 \ldots$ & 14 & 1,843 & 0 & 279,971 & 176,799 & 212,595 & 1. 20 & 63 \\
\hline $1895 \ldots$ & 14 & 1,849 & 30 & 319,285 & 208,158 & 251,892 & 1. 21 & 65 \\
\hline $1896 \ldots \ldots$ & 14 & 1,863 & 0 & 617,601 & 406,112 & 570,687 & 1.405 & 65.7 \\
\hline $1897 \ldots$. & 14 & 1,863 & 0 & 556,941 & 345,372 & 444,709 & 1. 29 & 62 \\
\hline $1898 \ldots$ & 13 & 1,832 & 0 & 638,277 & 403,045 & 538,609 & 1.34 & 63 \\
\hline $1899 \ldots$. & 13 & 1,861 & 68 & 933,792 & 609,893 & 986,298 & 1.62 & 65.3 \\
\hline
\end{tabular}

Irwin district.-The Irwin district comprises the ovens situated near the town of that name; also those located in what may be termed the Irwin basin, on the Youghiogheny River. Most of the coke made in the district is produced by the Carnegie Steel Company, Limited, at Larimer and Douglas, where slack from the gas coal mined in the immediate vicinity is made into coke. The production in 1899 was the smallest in four years, and with two exceptions the smallest since 1889. Compared with 1898 there was a decrease of 50,091 tons, or 27.4 per cent. The number of ovens reported for the district in 1899 was 697, of which 117 were idle. 
The statistics of the manufacture of coke in the Irwin district from 1889 to 1899 are shown in the following table:

Statistics of the manufacture of cole in the Irwin district, Pennsylvania, from 1889 to 1899.

\begin{tabular}{|c|c|c|c|c|c|c|c|c|}
\hline \multirow{2}{*}{ Year. } & \multirow{2}{*}{$\begin{array}{l}\text { Estab- } \\
\text { lish- } \\
\text { ments. }\end{array}$} & \multicolumn{2}{|c|}{ Ovens. } & \multirow{2}{*}{ Coal used. } & \multirow{2}{*}{$\begin{array}{l}\text { Coke pro- } \\
\text { duced. }\end{array}$} & \multirow{2}{*}{$\begin{array}{l}\text { Total value } \\
\text { of coke at } \\
\text { ovens. }\end{array}$} & \multirow{2}{*}{$\begin{array}{l}\text { Value of } \\
\text { coke at } \\
\text { ovens, } \\
\text { per ton. }\end{array}$} & \multirow{2}{*}{$\begin{array}{l}\text { Yield of } \\
\text { coal in } \\
\text { coke. }\end{array}$} \\
\hline & & Built. & $\begin{array}{l}\text { Build- } \\
\text { ing. }\end{array}$ & & & & & \\
\hline & & & & Short tons. & Short tons. & & & Per cent. \\
\hline 1889 & 4 & 696 & 0 & 373,913 & 243,448 & $\$ 351,304$ & $\$ 1.44$ & 65 \\
\hline 1890. & 4 & 661 & 0 & 270,476 & 172,329 & 256,458 & 1. 49 & 63.7 \\
\hline 1891. & 4 & 696 & 0 & 323,099 & 197,082 & 266,061 & 1.35 & 61 \\
\hline 1892 . & 4 & 669 & 0 & 328,193 & 202,809 & 284,029 & 1. 40 & 61.8 \\
\hline $1893 \ldots$ & 5 & 725 & 0 & 238,832 & 150,463 & 175,609 & 1. 30 & 63 \\
\hline 1894. & 5 & 725 & 0 & 176,318 & 110,995 & 119,764 & 1.08 & 63 \\
\hline 1895. & 5 & 725 & 0 & 166,124 & 103,872 & 105,609 & 1. 017 & 62.5 \\
\hline 1896 & 5 & 696 & 0 & 279,104 & 175,916 & 275,518 & 1.566 & 63 \\
\hline $1897 \ldots$ & 5 & 696 & 0 & 207,704 & 136,663 & 189,869 & 1. 39 & 65.8 \\
\hline 1898 . & 5 & 696 & 0 & 332,368 & 183,176 & 239,583 & 1. 308 & 55 \\
\hline 1899 & 5 & 697 & 0 & 223,457 & 133,085 & 197,694 & 1.48 & 59.6 \\
\hline
\end{tabular}

TENNESSEE.

Tennessee now ranks sixth among the coke-producing States, having dropped behind Colorado and Virginia in 1898. As was the case throughout the United States generally, the production in 1899 showed a substantial increase over 1898, and exceeded that of any previous year. As compared with 1898 the product increased 40,763 short tons, or 10.3 per cent, accompanied by an increase of $\$ 207,766$, or nearly 33 per cent, in value.

The number of establishments operating in the State has been reduced by one, from 15 to 14, the East Tennessee Iron and Coal Company, at Pioneer, having discontinued the manufacture of coke and abandoned the 18 ovens at that place. There were, however, 109 new ovens constructed in other parts of the State, making a net gain of 91, and increasing the total number in the State from 1,949 to 2,040. The ovens reported as idle in 1899 were 280, as compared with 198 in 1898 and 170 in 1897. 
The following are the statistics of the manufacture of coke in Tennessee for the years 1880 to 1899 :

Statistics of manufacture of coke in Tennessee from 1880 to 1899.

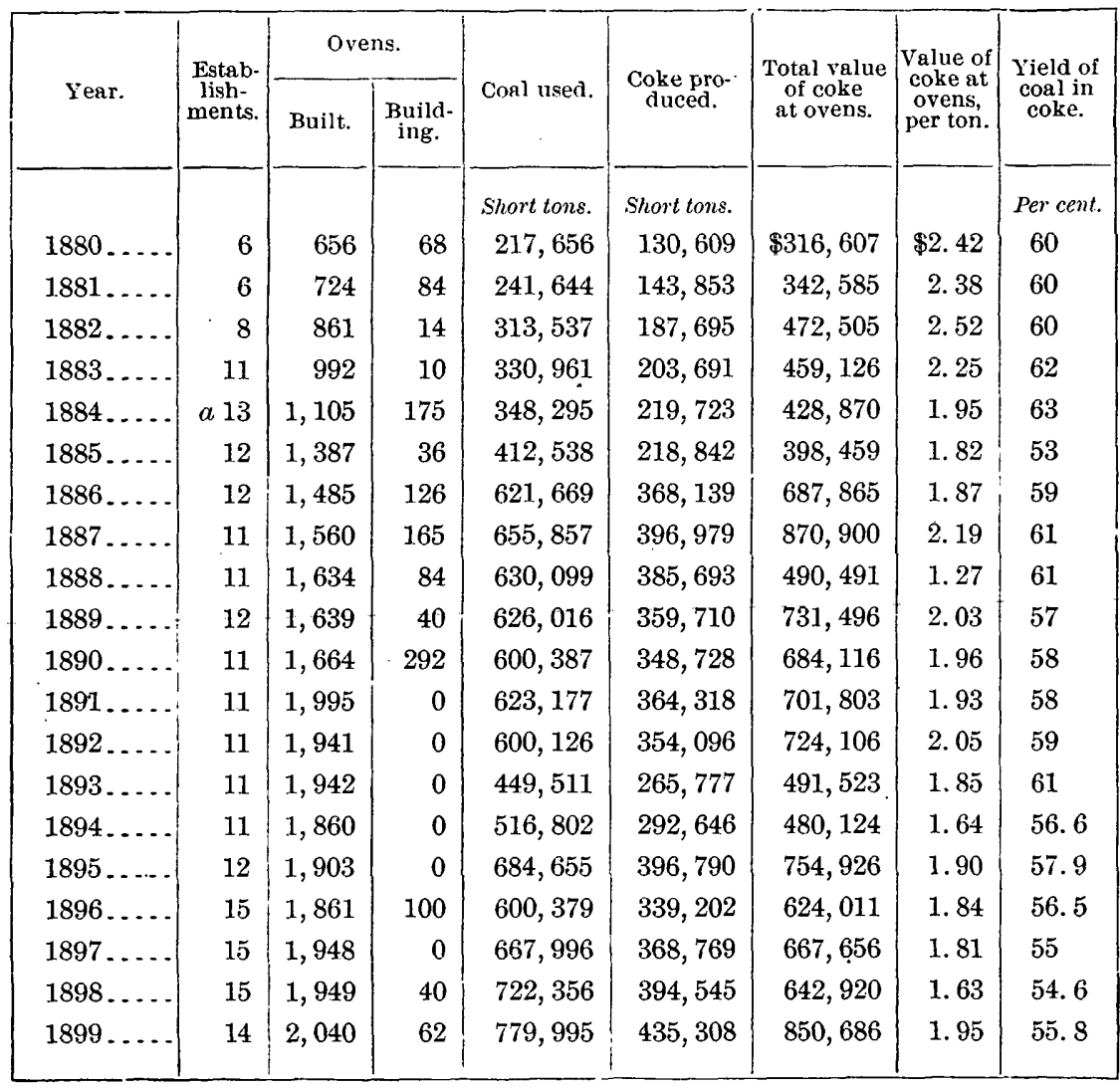

$a$ One establishment made coke in pits.

The coal used in the manufacture of coke in Tennessee is about equally divided between run of mine and slack, and the larger part of both is washed before coking. In 1899 about 75 per cent of all the coal used was washed. Of the slack coal used 86 per cent was washed, as was nearly two-thirds of the run of mine. 
The character of the coal used in the manufacture of coke in Tennessee since 1890 is shown in the following table:

Character of coal used in the manufacture of coke in Tennessee since 1890.

\begin{tabular}{|c|c|c|c|c|c|}
\hline \multirow{2}{*}{ Year. } & \multicolumn{2}{|c|}{ Run of mine. } & \multicolumn{2}{|c|}{ Slack. } & \multirow{2}{*}{ Total. } \\
\hline & Unwashed. & Washed. & Unwashed. & Washed. & \\
\hline & Short tons. & Short tons. & Short tons. & Short tons. & Short tons. \\
\hline $1890 \ldots$ & 255,359 & 0 & 273,028 & 72,000 & 600,387 \\
\hline 1891. & 184,556 & 0 & 377,914 & 60,707 & 623,177 \\
\hline 1892 & 176,453 & 15,000 & 367,827 & 40,846 & 600,126 \\
\hline 1893. & 179,126 & 0 & 137,483 & 132,902 & 449,511 \\
\hline 1894. & 166,990 & 61,841 & 149,958 & 138,013 & 516,802 \\
\hline 1895. & 96,744 & 59,284 & 285,906 & 242,721 & 684,655 \\
\hline 1896. & 0 & 206,319 & 219,231 & 174,829 & 600,379 \\
\hline 1897 . & 36,485 & 400,166 & 119,755 & 111,590 & 667,996 \\
\hline 1898 & 37,217 & 306,969 & 122,756 & 255,414 & 722,356 \\
\hline 1899 & 140,804 & 267,105 & 31,850 & 340,236 & 779,995 \\
\hline
\end{tabular}

TEXAS.

The 20 ovens mentioned in the report for 1897 as having been erected by the Texas and Pacific Coal Company for converting its slack coal into coke have not proved the success that was hoped for, and they have been abandoned.

\section{UTAH.}

As there is but one establishment making coke in Utah, detailed statistics of production have been included with that of Colorado in order to preserve the confidential nature of the producer's report and as the coals in this State are practically identical in character with those of western Colorado. 
The following is the amount of coke produced in Utah from 1889 to 1899:

Production of coke in Utah from 1889 to 1899.

\begin{tabular}{|c|c|c|c|}
\hline Year. & Tons. & Year. & Tons. \\
\hline $1889 \ldots \ldots$ & 761 & $1895 \ldots$ & 22,519 \\
\hline $1890 \ldots$ & 8,528 & $1896 \ldots$ & 20,447 \\
\hline $1891 \ldots$ & 7,949 & $1897 \ldots$ & 23,617 \\
\hline $1892 \ldots$ & 7,309 & $1898 \ldots \ldots \ldots \ldots . . . \ldots . . .$. & 28,826 \\
\hline 1893. & 16,005 & $1899: \ldots \ldots \ldots \ldots \ldots$ & 26,881 \\
\hline $1894 \ldots$ & 16,056 & & \\
\hline
\end{tabular}

VIRGINIA.

Virginia is rapidly coming to the front as a producer of coke, the development in the State having been particularly active during the last six years, and ranks now as the fourth among the coke-producing States. The production in 1899 amounted to 618,707 short tons, an increase of 87,546 tons, or 16.5 per cent, over that of 1898 , and of 264,724 tons, or 75 per cent, over 1897. Practically all of this increase has been the result of the development in Wise County, on the Clinch River division of the Norfolk and Western Railroad. The returns for 1899 indicate that the production from this region is likely to show a considerable further increase in 1900 , as 429 new ovens (the entire number reported for the State) were building in the district at the close of 1899. Twenty-eight ovens were added to the number of ovens in the State during 1899. Prior to 1895 there were only two establishments in the State, one of which was at Pocahontas, in the Flat Top coal region, the other at Low Moor, just east of the West Virginia line. The coal for the Pocahontas ovens is drawn from mines which extend beyond the boundary line between Virginia and West Virginia, and much if not the greater part of the product belongs of right to the latter State. It has been customary, however, to credit all of the product to Virginia, as the openings are in that State. The ovens at Low Moor are fed entirely by coal mined in the New River district of West Virginia. The Clinch Valley or Wise County product belongs entirely to Virginia, and the manufacture of coke from coal mined in the State really began with the building of the orens in Wise County in 1895 . Over 60 per cent of the coke product in 1897, 1898, and 1899 was from this region. 
The following are the statistics of the manufacture of coke in Virginia from 1883 to 1899 :

Statistics of the manufacture of coke in Virginia from 1883 to 1899.

\begin{tabular}{|c|c|c|c|c|c|c|c|c|}
\hline \multirow{2}{*}{ Year. } & \multirow{2}{*}{$\begin{array}{c}\text { Estab- } \\
\text { lish- } \\
\text { ments. }\end{array}$} & \multicolumn{2}{|c|}{ Ovens. } & \multirow{2}{*}{ Coal used. } & \multirow{2}{*}{$\begin{array}{l}\text { Coke pro- } \\
\text { duced. }\end{array}$} & \multirow{2}{*}{$\begin{array}{l}\text { Total value } \\
\text { of coke at } \\
\text { ovens. }\end{array}$} & \multirow{2}{*}{$\begin{array}{l}\text { Value of } \\
\text { coke at } \\
\text { ovens, } \\
\text { per ton. }\end{array}$} & \multirow{2}{*}{$\begin{array}{l}\text { Yield of } \\
\text { coal in } \\
\text { coke. }\end{array}$} \\
\hline & & Built. & $\begin{array}{c}\text { Build- } \\
\text { ing. }\end{array}$ & & & & & \\
\hline 1883. & 1 & 200 & 0 & $\begin{array}{r}\text { Short tons. } \\
39,000\end{array}$ & $\begin{array}{r}\text { Short tons. } \\
25,340\end{array}$ & $\$ 44,345$ & $\$ 1.75$ & $\begin{array}{l}\text { Per cent. } \\
65\end{array}$ \\
\hline 1884. & 1 & 200 & 0 & 99,000 & 63,600 & 111,300 & 1.75 & 64.3 \\
\hline 1885. & 1 & 200 & 0 & 81,899 & 49,139 & 85,993 & 1. 75 & 60 \\
\hline 1886 . & 2 & 350 & 100 & 200,018 & 122,352 & 305,880 & 2.50 & 61.2 \\
\hline 1887. & 2 & 350 & 300 & 235,841 & 166,947 & 417,368 & 2.50 & 70.8 \\
\hline $188 S$. & 2 & 550 & 0 & 230,529 & 140,199 & 260,000 & 1. 74 & 64.7 \\
\hline 1889. & 2 & 550 & 250 & 238,793 & 146,528 & 325,861 & 2.22 & 61 \\
\hline 1890 . & 2 & 550 & 250 & 251,683 & 165,847 & 278,724 & 1.68 & 66 \\
\hline 1891. & 2 & 550 & 250 & 285,113 & 167,516 & 265,107 & 1.58 & 58.8 \\
\hline 1892. & 2 & 594 & 206 & 226,517 & 147,912 & 322,486 & 2.18 & 65.3 \\
\hline 1893. & 2 . & 594 & 206 & 194,059 & 125,092 & 282,898 & 2.26 & 64.5 \\
\hline 1894. & 2 & 736 & 100 & 280,524 & 180,091 & 295,747 & 1.64 & 64.2 \\
\hline 1895 & 5 & 832 & 350 & 410,737 & 244,738 & 322,564 & 1.32 & 59.6 \\
\hline $1896 \ldots$ & 7 & 1,138 & 101 & 454,964 & 268,081 & 404,573 & 1. 509 & 58.9 \\
\hline $1897 \ldots$ & 6 & 1,453 & 110 & 574,542 & 354,067 & 495,864 & 1.40 & 61.6 \\
\hline $1898 \ldots$ & 6 & $a 1,564$ & 0 & 852,972 & 531,161 & 699,781 & 1. 317 & 62 \\
\hline $1899 \ldots$ & 6 & $a 1,588$ & 429 & 994,635 & 618,707 & $1,071,284$ & 1.73 & 62.2 \\
\hline
\end{tabular}

$a$ Includes 60 Newton-Chambers by-product ovens. 
Up to 1895 all of the coal used in coke making in Virginia was unwashed. Washing slack coal began in 1896 and 13,584 tons, or about 4 per cent of the slack used in that year was washed. The next year over 60,000 tons of slack were washed, and in 1898 the washed slack coal used amounted to over 210,000 tons. The amount of washed slack used in 1899 was about 25 per cent less than in 1898, the decrease being probably due to the extraordinary demand for coke in 1899, which made it necessary to use a larger amount of run of mine coal, which was used without washing. The run of mine coal used in 1899 was 50 per cent more than that of 1898.

The character of the coal used in the manufacture of coke in Virginia since 1890 is shown in the following table:

Character of coal used in the manufacture of coke in Virginia since 1890

\begin{tabular}{|c|c|c|c|c|c|}
\hline \multirow{2}{*}{ Year. } & \multicolumn{2}{|c|}{ Run of mine. } & \multicolumn{2}{|c|}{ Slack. } & \multirow{2}{*}{ Total. } \\
\hline & Lnwashed. & Washed. & Unwashed. & Washed. & \\
\hline & Short tons. & Short tons. & Short tons. & Short tons. & Short tons. \\
\hline$\ldots \ldots$ & 98,215 & 0 & 153,468 & 0 & 251,683 \\
\hline $1891 \ldots$ & 107,498 & 0 & 177,615 & 0 & 285,113 \\
\hline 1892 & 106,010 & 0 & 120,507 & 0 & 226,517 \\
\hline 1893. & 107,498 & 0 & 86,561 & 0 & 194,059 \\
\hline 1894 & 103,874 & 0 & 176,650 & 0 & 280,524 \\
\hline 1895 . & 114,802 & 0 & 295,935 & 0 & 410,737 \\
\hline 1896. & 70,756 & 0 & 370,624 & 13,584 & 454,964 \\
\hline 1897. & 286,158 & 0 & 227,363 & 61,021 & 574,542 \\
\hline 1898. & 405,399 & 0 & 237,474 & 210,099 & 852,972 \\
\hline $1899 \ldots \ldots$ & 612,267 & 0 & 225,118 & 157,250 & 994,635 \\
\hline
\end{tabular}

\section{WASHINGTON.}

The production of coke in Washington dúring 1899 was only a fraction of 1 per cent more than that of 1898 , so that except for an increase of about $\$ 22,000$ in value the industry may be said to have remained practically stationary. There were the same number of establishments, the same number of ovens, the same production, and no new ovens were building. The operations in Washington are not important when considered with the production in some of the Eastern States, but they are the only ovens on the Pacific coast, and are interesting as establishing the adaptability of Washington coals for coke making. 
The industry was started in 1884, since which time the production has been as follows:

Statistics of the production of coke in Washington from 1884 to 1899.

\begin{tabular}{|c|c|c|c|c|c|c|c|c|}
\hline \multirow{2}{*}{ Year. } & \multirow{2}{*}{$\begin{array}{l}\text { Estab- } \\
\text { lish- } \\
\text { ments. }\end{array}$} & \multicolumn{2}{|c|}{ Ovens: } & \multirow{2}{*}{ Coal used. } & \multirow{2}{*}{$\begin{array}{l}\text { Coke pro- } \\
\text { duced. }\end{array}$} & \multirow{2}{*}{$\begin{array}{c}\text { Total value } \\
\text { of coke at } \\
\text { ovens. }\end{array}$} & \multirow{2}{*}{$\begin{array}{l}\text { Value of } \\
\text { coke at } \\
\text { ovens, } \\
\text { per ton. }\end{array}$} & \multirow{2}{*}{$\begin{array}{l}\text { Yield of } \\
\text { coal in } \\
\text { coke. }\end{array}$} \\
\hline & & Built. & $\begin{array}{c}\text { Build- } \\
\text { ing. }\end{array}$ & & & & & \\
\hline & & & & Short tons. & Short tons. & & & Per cent. \\
\hline $18 S 4$ & 1 & 0 & 0 & 700 & 400 & $\$ 1,900$ & $\$ 4.75$ & 57.5 \\
\hline 1885 & 1 & 2 & 0 & 544 & 311 & 1,477 & 4.75 & 57 \\
\hline 1886 & 1 & 11 & 21 & 1,400 & 825 & 4,125 & 5.00 & 58.9 \\
\hline 1887 & 1 & 30 & 0 & 22,500 & 14,625 & 102,375 & 7.00 & 65 \\
\hline $1888 .$. & 1 & 30 & 100 & 0 & 0 & 0 . & 0 & 0 \\
\hline 1889 & 1 & 30 & 0 & 6,983 & 3,841 & 30,728 & 8.00 & 55 \\
\hline 1890 & 2 & 30 & 80 & 9,120 & 5,837 & 46,696 & 8. 00 & 64 \\
\hline 1891 & 2 & 80 & 0 & 10,000 & 6,000 & 42,000 & 7.00 & 60 \\
\hline $1892 \ldots$ & 3 & 84 & 30 & 12,372 & 7,177 & 50,446 & 7.03 & 58 \\
\hline $1893 \ldots$ & 3 & 84 & 0 & 11,374 & 6,731 & 34,207 & 5.08 & 59 \\
\hline $1894 \ldots$ & 3 & 84 & 0 & 8,563 & 5,245 & 18,249 & 3.48 & 61.2 \\
\hline 1895 & 3 & 110 & 0 & 22,973 & 15,129 & 64,632 & 4.27 & 65.9 \\
\hline $1896 \ldots$ & 3 & 120 & 0 & 38,685 & 25,949 & 104,894 & 4.04 & 67 \\
\hline $1897 \ldots$ & 3 & 120 & 0 & 39,124 & 26,189 & 115,754 & 4.42 & 67 \\
\hline $189 \mathrm{~s} .$. & 2 & 90 & 0 & 48,559 & 30,197 & 128,933 & 4.27 & 62.2 \\
\hline $1899 \ldots$ & 2 & 90 & 0 & 50,813 & 30,372 & 151,216 & 4.98 & 59.8 \\
\hline
\end{tabular}

The character of the coal used in the manufacture of coke in Washington since 1890 is shown in the following table:

Character of coal used in the manufacture of coke in Washington since 1890.

\begin{tabular}{|c|c|c|c|c|c|}
\hline \multirow{2}{*}{ Year. } & \multicolumn{2}{|c|}{ Run of mine. } & \multicolumn{2}{|c|}{ Slack. } & \multirow{2}{*}{ Total. } \\
\hline & Unwashed. & Washed. & Unwashed. & Washed. & \\
\hline & Short tons. & Short tons. & Short tons. & Short tons. & Short tons. \\
\hline $1890 \ldots$ & 0 & 9,120 & 0 & 0 & 9,120 \\
\hline $1891 \ldots$ & 0 & 0 & 10,000 & $: 0$ & 10,000 \\
\hline $1892 \ldots \ldots$ & 0 & 0 & 0 & 12,372 & 12,372 \\
\hline $1893 \ldots$. & 0 & 10,974 & 0 & 405 & 11,379 \\
\hline $1894 \ldots$ & 0 & 0 & 0 & 8,563 & 8,563 \\
\hline $1895 \ldots$ & 0 & 0 & 0 & 22,973 & 22,973 \\
\hline $1896 \ldots$ & 0 & 20,967 & 0 & 17,718 & 38,685 \\
\hline $1897 \ldots$ & 0 & 39,124 & 0 & 0 & 39,124 \\
\hline $189 S .$. & 0 & 48,559 & 0 & 0 & 48,559 \\
\hline $1899 \ldots$ & 0 & 44,681 & 0 & 6,132 & 50,813 \\
\hline
\end{tabular}




\section{WEST VIRGINIA.}

West Virginia ranks next to Pennsylvania as a coke-producing State, having in 1899 an output nearly 500,000 tons more than Alabama, which ranks third in importance, and which, until passed by West Virginia in 1896, stood next to Pennsylvania. The production in West Virginia in 1899 amounted to 2,278,577 short tons, an increase as compared with 1898 of 353,506 tons, or 18.36 per cent. The value of the product increased from $\$ 2,432,657$ in 1898 to $\$ 3,480,408$, a gain of $\$ 1,047,751$, or 43 per cent. With only two exceptions the production of coke in West Virginia has shown a steady annual increase since 1880. The average price obtained in 1899 was the highest since 1893, but lower than in any year from 1880 to 1893 . The advance in price from 1898 to 1899 would have been considerably more than it was except for the fact that the product was largely sold on contracts made in 1898, and the prices, owing to the advance in mining and other wages, was in many cases less than the cost of production.

The coking regions of West Virginia have been separated by the late Joseph $\mathrm{D}$. Weeks into five distinct districts, and the nomenclature adopted by Mr. Weeks has become generally recognized, viz, the Kanawha, the New River, the Flat Top, the Upper Monongahela, and the Upper Potomac. The first two are compact and continuous. They include the ovens along the line of the Chesapeake and Ohio Railroad from west of Lowmoor, in Virginia, to the Kanawha Valley. The Flat Top region includes the ovens in what is sometimes called the Pocahontas district. The fourth district, the Upper Monongahela or Northern, is a scattered one, including the ovens in Preston, Taylor, Harrison, and Marion counties, on the upper waters of the Monongahela River. The district which has been termed the Upper Potomac includes the coke ovens in the Elk Garden and Upper Potomac fields. These districts have been so frequently described that it is not necessary to repeat the description at this point, but those interested are referred to previous volumes of Mineral Resources.

Production in 1899 was larger than in 1898 in four out of the five districts mentioned. There was a slight falling off in the New River district but all the others made substantial gains, the most significant of which was in the Upper Monongahela district, where the product in 1899 was nearly double that of 1898 , and the district advanced from fourth in importance in 1897 and 1898 to second place in 1899. The production of the 60 Semet-Solway ovens at Wheeling which were put in blast in December, 1898, are included in this district for want of a better classification. All five of the districts shared in the general advance in price, the advances ranging from 13 cents in the Flat Top district to 58 cents in the Upper Monongahela district. The total value of the prcduct in the latter district was in 1899 more than three times what it was in 1898. 
The following table exhibits the statistics of coke production in West Virginia since 1880 :

Statistics of the manufacture of coke in West Virginia from 1880 to 1899.

\begin{tabular}{|c|c|c|c|c|c|c|c|c|}
\hline \multirow{2}{*}{ Year. } & \multirow{2}{*}{$\begin{array}{l}\text { Estab- } \\
\text { lish- } \\
\text { ments. }\end{array}$} & \multicolumn{2}{|c|}{ Ovens. } & \multirow[b]{2}{*}{ Coal used. } & \multirow{2}{*}{$\begin{array}{l}\text { Coke pro- } \\
\text { duced. }\end{array}$} & \multirow{2}{*}{$\begin{array}{l}\text { Total value } \\
\text { of coke at } \\
\text { ovens. }\end{array}$} & \multirow{2}{*}{$\begin{array}{l}\text { Value of } \\
\text { coke at } \\
\text { ovens, } \\
\text { per ton. }\end{array}$} & \multirow{2}{*}{$\begin{array}{l}\text { Yield of } \\
\text { coal in } \\
\text { coke. }\end{array}$} \\
\hline & & Built. & $\begin{array}{l}\text { Build- } \\
\text { ing. }\end{array}$ & & & & & \\
\hline 1880. & 18 & 631 & 40 & $\begin{array}{l}\text { Short tons. } \\
230,758\end{array}$ & $\begin{array}{l}\text { Short tons. } \\
138,755\end{array}$ & $\$ 318,797$ & $\$ 2.30$ & $\begin{array}{c}\text { Per cent. } \\
60\end{array}$ \\
\hline 1881. & 19 & 689 & 0 & 304,823 & 187,126 & 429,571 & 2. 30 & 61 \\
\hline 1882. & 22 & 878 & 0 & 366,653 & 230,398 & 520,437 & 2. 26 & 63 \\
\hline 1883 & 24 & 962 & 9 & 411,159 & 257,519 & 563,490 & 2. 19 & 63 \\
\hline 1884. & 27 & 1,005 & 127 & 385,588 & 223,472 & 425,952 & 1. 91 & 62 \\
\hline 1885. & 27 & 978 & 63 & 415,533 & 260,571 & 485,588 & 1.86 & 63 \\
\hline 1886. & 29 & 1,100 & 317 & 425,002 & 264,158 & 513,843 & 1.94 & 62 \\
\hline 1887. & 39 & 2,080 & 742 & 698,327 & 442,031 & 976,732 & 2.21 & 63.3 \\
\hline 1888 & 51 & 2,764 & 318 & 854,531 & 525,927 & 896,797 & 1. 71 & 61.5 \\
\hline 1889. & 53 & 3,438 & 631 & $1,001,372$ & 607,880 & $1,074,177$ & 1. 76 & 60 \\
\hline 1890 & 55 & 4,060 & 334 & $1,395,266$ & 833,377 & $1,524,746$ & 1.83 & 60 \\
\hline 1891. & 55 & 4,621 & 555 & $1,716,976$ & $1,009,051$ & $1,845,043$ & 1.83 & 58.8 \\
\hline 1892. & 72 & 5,843 & 978 & $1,709,183$ & $1,034,750$ & $1,821,965$ & 1. 76 & 60.5 \\
\hline 1893. & 75 & 7,354 & 132 & $1,745,757$ & $1,062,076$ & $1,716,907$ & 1. 62 & 60.8 \\
\hline 1894. & 78 & 7,858 & 60 & $1,976,128$ & $1,193,933$ & $1,639,687$ & 1. 373 & 60.4 \\
\hline 1895. & 78 & 7,834 & 55 & $2,087,816$ & $1,285,206$ & $1,724,239$ & 1. 34 & 61.6 \\
\hline 1896 & 84 & 8,351 & 28 & $2,687,104$ & $1,649,755$ & $2,259,999$ & 1. 37 & 61.4 \\
\hline $1897 \ldots$ & 84 & 8,404 & 38 & $2,413,283$ & $1,472,666$ & $1,933,808$ & 1. 31 & 61 \\
\hline $1898 \ldots$ & 87 & $a 8,659$ & 161 & $3,145,398$ & $1,925,071$ & $2,432,657$ & 1.26 & 61.2 \\
\hline $1899 \ldots$ & 87 & $a 8,846$ & $b 619$ & $3,802,825$ & $2,278,577$ & $3,480,408$ & 1.53 & 60 \\
\hline
\end{tabular}

$a$ Includes 60 Semet-Solvay ovens at Wheeling.

$b$ Includes 60 Semet-Solvay ovens building at Wheeling.

It will be seen from the foregoing table that there have been only two exceptions in nineteen years to a steadily increasing production. The first instance was in 1884, and was unimportant; the second was in 1897 , and was due to a natural reaction from an exceptional production in 1896 caused by high prices and a restricted production in the Connellsville region of Pennsylvania.

It appears also from this table that the number of completed ovens in West Virginia in 1899 was 8,846 against 8,659 in 1898, a gain of 187. The number of idle ovens reported in 1899 was 1,040 against 568 ovens idle in 1898. The idle ovens in 1899 were distributed among the different districts as follows: Flat Top, 419; Kanawha, 12; New River, 151; Upper Monongahela, 458; Upper Potomac, 0. It will be seen from this that all of the ovens in the Upper Potomac district were in operation during the year. 
The following table shows that the larger part of the coal used in the manufacture of coke in West Virginia is slack, and the most of this is unwashed. It will be noted that there was a significant increase in the amount of run of mine coal used in 1899. This was undoubtedly due to the enormous demand for coke during the year and to an insufficient supply of slack coal to meet the requirements.

The character of the coal used in the manufacture of coke in West Virginia since 1890 is shown in the following table:

Character of coal used in the manufacture of coke in West Virginia since 1890.

\begin{tabular}{|c|c|c|c|c|c|}
\hline \multirow{2}{*}{ Year. } & \multicolumn{2}{|c|}{ Run of mine. } & \multicolumn{2}{|c|}{ Slack. } & \multirow{2}{*}{ Total. } \\
\hline & Unwashed. & Washed. & Unwashed. & Washed. & \\
\hline & Short tons. & Short tons. & Short tons. & Short tons. & Short tons. \\
\hline 1890 & 324,847 & 0 & 930,989 & 159,430 & $1,395,266$ \\
\hline $1891 \ldots \ldots$ & 276,259 & 0 & $1,116,060$ & 324,657 & $1,716,976$ \\
\hline 1892. & 298,824 & 115,397 & $1,108,353$ & 186,609 & $1,709,183$ \\
\hline 1893. & 324,932 & 15,240 & $1,176,656$ & 228,929 & $1,745,757$ \\
\hline $1894 \ldots$ & 162,270 & 14,901 & $1,607,735$ & 191,222 & 1, 976,128 \\
\hline $1895 \ldots$ & 405,725 & 24,054 & $1,476,003$ & 182,034 & $2,087,816$ \\
\hline 1896. & 407,378 & 33,096 & $2,079,237$ & 167,393 & $2,687,104$ \\
\hline $1897 \ldots$ & 373,205 & 28,145 & $1,800,528$ & 211,405 & $2,413,283$ \\
\hline $1898 \ldots$ & 713,815 & 0 & $2,137,983$ & 293,600 & $3,145,398$ \\
\hline 1899 & $1,336,239$ & 0 & $2,215,255$ & 251,331 & $3,802,825$ \\
\hline
\end{tabular}

PRODUCTION BY DISTRICTS.

Three of the coke-producing districts of West Virginia are in the southern part of the State and two are in the northern portion. All three of the southern districts-the Flat Top, the New River, and the Kanawha-are drained by the New River, or its western end, the Kanawha. The northern districts, as their names imply, are drained respectively by the headwaters of the Potomac and Monongahela rivers. The Upper Potomac is the only district on the eastern slope of the Allegheny Mountains, and is the nearest coking field to the seaboard in the United States. The Flat Top district is by far the most important, and bears a similar relation to the other districts of West Virginia as the Connellsville district does to those of Pennsylvania. Of the total product in West Virginia in 1899,50 per cent was in the Flat Top district, as against 55 per cent in 1898 . The phenomenal increase in the Upper Monongahela district in 1899 puts that district in second place instead of the New River district, which drops back to fourth place, the Upper Potomac district maintaining its position as third in importance. The value of the product in each district except the Kanawha exceeded $\$ 500,000$ in 1899. 
In the following tables are exhibited the statistics of coke production in West Virginia, by districts, during the last three years:

Production of cole in W'est Virginia in 1899, by districts.

\begin{tabular}{|c|c|c|c|c|c|c|c|c|}
\hline \multirow{2}{*}{ District. } & \multirow{2}{*}{$\begin{array}{l}\text { Estab- } \\
\text { lish- } \\
\text { ments. }\end{array}$} & \multicolumn{2}{|c|}{ Ovens. } & \multirow{2}{*}{ Coal used. } & \multirow{2}{*}{$\begin{array}{l}\text { Coke pro- } \\
\text { duced. }\end{array}$} & \multirow{2}{*}{$\begin{array}{l}\text { Total ralue } \\
\text { of coke } \\
\text { produced. }\end{array}$} & \multirow{2}{*}{$\begin{array}{c}\text { Aver- } \\
\text { age } \\
\text { price } \\
\text { of coke } \\
\text { per ton. }\end{array}$} & \multirow{2}{*}{$\begin{array}{c}\text { Yield } \\
\text { of coal } \\
\text { in } \\
\text { coke. }\end{array}$} \\
\hline & & Built. & $\begin{array}{l}\text { Build- } \\
\text { ing. }\end{array}$ & & & & & \\
\hline Flat Top $\ldots \ldots \ldots \ldots \ldots$ & 35 & 4,623 & 214 & $\begin{array}{r}\text { Short tons. } \\
1,861,570\end{array}$ & $\begin{array}{r}\text { Short tons. } \\
1,138,389\end{array}$ & ' $\$ 1,453,601$ & $\$ 1.2 S$ & $\begin{array}{c}\text { Per ct. } \\
61.1\end{array}$ \\
\hline Kanawha...... & 8 & 653 & 88 & 323,506 & 190,337 & 364,148 & 1.91 & 58.8 \\
\hline New River........... & 22 & 1,444 & 167 & 503,160 & 281,134 & 533,996 & 1.90 & 56 \\
\hline Upper Monongahela. & 19 & $a 1,453$ & $b 60$ & 607,796 & 362,872 & 596,305 & 1.64 & 59.7 \\
\hline Upper Potomac ...... & 3 & 673 & 90 & 506,793 & 305,845 & 532,358 & 1.74 & 60.3 \\
\hline Total. & 87 & 8,846 & 619 & $3,802,825$ & $2,278,577$ & $3,480,408$ & 1.53 & 60 \\
\hline
\end{tabular}

Production of coke in West Virginia in 1898, by districts.

\begin{tabular}{|c|c|c|c|c|c|c|c|c|}
\hline \multirow{2}{*}{ District. } & \multirow{2}{*}{$\begin{array}{l}\text { Estab- } \\
\text { lish. } \\
\text { ments. }\end{array}$} & \multicolumn{2}{|c|}{ Ovens. } & \multirow{2}{*}{ Coal used. } & \multirow{2}{*}{$\begin{array}{l}\text { Coke pro- } \\
\text { duced. }\end{array}$} & \multirow{2}{*}{$\begin{array}{c}\text { Total value } \\
\text { of coke } \\
\text { produced. }\end{array}$} & \multirow{2}{*}{$\begin{array}{l}\text { Aver- } \\
\text { age } \\
\text { price } \\
\text { of coke } \\
\text { per ton }\end{array}$} & \multirow{2}{*}{$\begin{array}{c}\text { Yield } \\
\text { of coal } \\
\text { in } \\
\text { coke. }\end{array}$} \\
\hline & & Built. & $\begin{array}{l}\text { Build- } \\
\text { ing. }\end{array}$ & & & & & \\
\hline Flat Top. - & 36 & 4,667 & 27 & $\begin{array}{r}\text { Short tons. } \\
1,701,404\end{array}$ & $\begin{array}{r}\text { Short tons. } \\
1,057,626\end{array}$ & $\$ 1,216,059$ & $\$ 1.15$ & $\begin{array}{c}\text { Per ct. } \\
62.2\end{array}$ \\
\hline Kanawha.. & 8 & 622 & 100 & 225,240 & 135,867 & 208,949 & 1.538 & 60 \\
\hline New River.......... & 18 & 1,299 & 4 & 519,937 & 317,998 & 484,001 & 1. 52 & 61 \\
\hline Upper Monongahela. & 23 & $a 1,449$ & 30 & 319,590 & 183,430 & 194,277 & 1.06 & 57 \\
\hline Upper Potomac ...... & 2 & 622 & 0 & 379,227 & 230,150 & 329,371 & I. 43 & 60.7 \\
\hline Total. & 87 & 8,659 & 161 & $3,145,398$ & $1,925,071$ & $2,432,657$ & 1.26 & 61.2 \\
\hline
\end{tabular}

a Includes 60 Semet-Solvay ovens.

Production of coke in West Virginia in 1897, by districts.

\begin{tabular}{|c|c|c|c|c|c|c|c|c|}
\hline \multirow{2}{*}{ District. } & \multirow{2}{*}{$\begin{array}{l}\text { Estab- } \\
\text { lish- } \\
\text { ments. }\end{array}$} & \multicolumn{2}{|c|}{ Ovens. } & \multirow{2}{*}{ Coal used. } & \multirow{2}{*}{$\begin{array}{l}\text { Coke pro- } \\
\text { duced. }\end{array}$} & \multirow{2}{*}{$\begin{array}{c}\text { Total value } \\
\text { of coke } \\
\text { produced. }\end{array}$} & \multirow{2}{*}{$\begin{array}{c}\text { Aver- } \\
\text { age } \\
\text { price } \\
\text { of coke } \\
\text { per ton. }\end{array}$} & \multirow{2}{*}{$\begin{array}{c}\text { Yield } \\
\text { of coal } \\
\text { in } \\
\text { coke. }\end{array}$} \\
\hline & & Built. & $\begin{array}{l}\text { Build- } \\
\text { ing. }\end{array}$ & & & & & \\
\hline Flat Top...... & 36 & 4,648 & 18 & $\begin{array}{r}\text { Short tons. } \\
1,172,206\end{array}$ & $\begin{array}{r}\text { Short tons. } \\
720,988\end{array}$ & $\$ 868,484$ & $\$ 1.20$ & $\begin{array}{c}\text { Perct. } \\
61.5\end{array}$ \\
\hline Kanawha ............. & 7 & 576 & 20 & 199,312 & 117,849 & 187,359 & 1.59 & 59.1 \\
\hline New River..... & 17 & 1,225 & 0 & 439,103 & 268,263 & 419,151 & 1.56 & 61.1 \\
\hline Upper Monongahela. & 22 & 1,363 & 0 & 289,678 & 175,165 & 180,802 & 1.03 & 60.5 \\
\hline Upper Potomac ...... & 2 & 592 & 0 & 312,984 & 190,401 & 278,012 & 1.46 & 60.8 \\
\hline Total. & 84 & 8,404 & 38 & $2,413,283$ & $1,472,666$ & $1,933,808$ & 1.31 & 61 \\
\hline
\end{tabular}

Pocahontas-Flat Top district.-Next to the Connellsville district, this is the most important coking region in the United States. Outside of Pennsylvania and Alabama, it produces more coke than any

21 GEOL, PT $6-40$ 
other single State and nearly as much as any two. Like the Connellsville region, it produces a typical blast-furnace coke, and as a steam coal the coal used has only one rival-the Clearfield coal of Pennsylvania. Flat Top coke is chemically superior to Connellsville, as it is lower in ash, and is regarded by some ironmasters as the equal in physical properties to Connellsville coke. The production of coke in the district in 1899 amounted to $1,138,389$ short tons, an increase of 80,763 tons over that of 1898 , up to that time the largest in its history, which dates from 1886. There was a decrease of 1 in the number of establishments and of 44 in the number of ovens in the district, but there were 214 new ovens in course of construction at the close of the year. In addition to the 44 ovens abandoned, 419 others were idle, which will account for the comparatively small increase in production in 1899. All of the ovens in the district were operated in 1898.

The statistics of production in the district from its beginning in 1886 are exhibited in the following table:

Statistics of the manufacture of coke in the Flat Top district of West Virginia from 1886 to 1899.

\begin{tabular}{|c|c|c|c|c|c|c|c|c|}
\hline \multirow{2}{*}{ Year. } & \multirow{2}{*}{$\begin{array}{c}\text { Estab- } \\
\text { lish- } \\
\text { ments. }\end{array}$} & \multicolumn{2}{|c|}{ Ovens. } & \multirow{2}{*}{ Coal used. } & \multirow{2}{*}{$\begin{array}{l}\text { Coke pro- } \\
\text { duced. }\end{array}$} & \multirow{2}{*}{$\begin{array}{c}\text { Total value } \\
\text { of coke at } \\
\text { ovens. }\end{array}$} & \multirow{2}{*}{$\begin{array}{l}\text { Value of } \\
\text { coke at } \\
\text { ovens, } \\
\text { per ton. }\end{array}$} & \multirow{2}{*}{$\begin{array}{l}\text { Yield of } \\
\text { coal in } \\
\text { coke. }\end{array}$} \\
\hline & & Built. & $\begin{array}{c}\text { Build- } \\
\text { ing. }\end{array}$ & & & & & \\
\hline & & & & Short tons. & Short tons. & & & Per cent. \\
\hline 1886 & 2 & 10 & 38 & 1,075 & 658 & $\$ 1,316$ & $\$ 2.00$ & 61.2 \\
\hline 1887. & 5 & 348 & $6+2$ & 76,274 & 51,071 & 100,738 & 1.97 & 67 \\
\hline 1888. & 13 & 882 & 200 & 164,818 & 103,947 & 183,938 & 1. 77 & 63 \\
\hline 1889 & 16 & 1,433 & 431 & 387,533 & 240,386 & 405,635 & 1.69 & 64 \\
\hline 1890. & 17 & 1,584 & 252 & 566,118 & 325,576 & 571,239 & 1. 75 & 57.5 \\
\hline $1891 \ldots$ & 19 & 1,889 & 358 & 537,847 & 312,421 & 545,367 & 1. 70 & 58 \\
\hline $1892 \ldots$ & 30 & 2,848 & 933 & 595,734 & 353,696 & 596,911 & 1.69 & 59.3 \\
\hline $1893 .$. & 34 & 4,349 & 80 & 746,051 & 451,503 & 713,261 & 1.58 & 60.5 \\
\hline 1894. & 36 & 4,648 & 18 & $1,229,136$ & 746,762 & 989,876 & 1.325 & 60.7 \\
\hline $1895 \ldots$ & 36 & 4,648 & 18 & 858,913 & 524,252 & 656,494 & 1.25 & 61 \\
\hline 1896. & 36 & 4,648 & 18 & $1,400,369$ & 852,120 & $1,100,312$ & 1. 291 & 60.8 \\
\hline $1897 \ldots$ & 36 & 4,648 & 18 & $1,172,206$ & 720,988 & 868,484 & 1.20 & 61.5 \\
\hline $1898 \ldots$ & 36 & 4,667 & 27 & $1,701,404$ & $1,057,626$ & $1,216,059$ & 1.15 & 62.2 \\
\hline 1899 & 35 & 4,623 & 214 & $1,861,570$ & $1,138,389$ & $1,453,601$ & 1.28 & 61.1 \\
\hline
\end{tabular}

New River district. - This district is second in importance to the Flat Top and adjoins it on the west. It includes the ovens along the Chesapeake and Ohio Railroad from Quinnimont to Nuttallburg. The coal makes an excellent coke, which is in good demand, its market being 
chiefly east of the mountains. The coke made at Lowmoor, Virginia, really belongs to this district, as the coal is drawn from it.

There was a decrease of 36,864 tons in the production for 1899 , and this, taken in connection with the increased production of the two districts in the northern part of the State, reduces it from second to fourth place among the coke-producing districts of the State. The decrease in 1899 may be considered a tempurary check only, as there were four new establishments started in 1899, 145 new ovens were completed during the year, and 167 were in course of construction on December 31. There were 151 ovens idle in 1899, against 130 in 1898.

The statistics of the manufacture of coke in the New River district from 1880 to 1899 are as follows:

Statistics of the manufacture of cole in the New River district, West Virginic, from 1880 to 1899 .

\begin{tabular}{|c|c|c|c|c|c|c|c|c|}
\hline \multirow[b]{2}{*}{ Year. } & \multirow{2}{*}{$\begin{array}{l}\text { Estab- } \\
\text { lish- } \\
\text { ments. }\end{array}$} & \multicolumn{2}{|c|}{ Ovens. } & \multirow[b]{2}{*}{ Coal used. } & \multirow[b]{2}{*}{$\begin{array}{l}\text { Coke pro- } \\
\text { duced. }\end{array}$} & \multirow{2}{*}{$\begin{array}{c}\text { Total value } \\
\text { of coke at } \\
\text { ovens. }\end{array}$} & \multirow{2}{*}{$\begin{array}{l}\text { Value of } \\
\text { coke at } \\
\text { ovens, } \\
\text { per ton. }\end{array}$} & \multirow{2}{*}{$\begin{array}{l}\text { Yield of } \\
\text { coal in } \\
\text { coke. }\end{array}$} \\
\hline & & Built. & $\begin{array}{l}\text { Build- } \\
\text { ing. }\end{array}$ & & & & & \\
\hline 1880. & 6 & 468 & 40 & $\begin{array}{r}\text { Short tons. } \\
159,032\end{array}$ & $\begin{array}{r}\text { Short tons. } \\
98,427\end{array}$ & $\$ 239,977$ & $\$ 2.14$ & $\begin{array}{l}\text { Per cent. } \\
62\end{array}$ \\
\hline $1881 \ldots$ & 6 & 499 & 0 & 219,446 & 136,423 & 334,652 & 2.45 & 62 \\
\hline 1882. & 6 & 518 & 0 & 233,361 & 148,373 & 352,415 & 2.38 & 64 \\
\hline $1883 \ldots$ & 6 & 546 & 0 & 264,171 & 167,795 & 384,552 & 2.29 & 64 \\
\hline 1884. & 8 & 547 & 12 & 219,839 & 135,335 & 274,988 & 2.03 & 62 \\
\hline $1885 \ldots$ & 8 & 519 & 0 & 244,769 & 156,007 & 325,001 & 2.08 & 63.8 \\
\hline 1886. & 8 & 513 & 5 & 203,621 & 127,006 & 281,778 & 2.22 & 62 \\
\hline 1887. & 11 & 518 & 50 & 253,373 & 159,836 & 401,164 & 2.51 & 63 \\
\hline 1888 & 12 & 743 & 0 & 334,695 & 199,831 & 390,182 & 1.95 & 60 \\
\hline 1889. & 12 & 773 & 0 & 268,185 & 157,186 & 351,132 & 2.23 & 58.6 \\
\hline 1890. & 12 & 773 & 4 & 275,458 & 174,295 & 377,847 & 2.17 & 63 \\
\hline $1891 \ldots$ & 13 & 787 & 102 & 309,073 & 193,711 & 426,630 & 2.20 & 63 \\
\hline 1892. & 14 & 965 & 0 & 315,511 & 196,359 & 429,376 & 2.19 & 62 \\
\hline 1893. & 13 & 947 & 10 & 281,600 & 178,049 & 355,965 & 2.00 & 63 \\
\hline $1894 \ldots$ & 14 & 1,089 & 0 & 222,900 & 140,842 & 245,154 & 1. 74 & 63.2 \\
\hline 1895 & 14 & 978 & 0 & 385,899 & 244,815 & 404,978 & 1.65 & 63.4 \\
\hline 1896. & 17 & 1,259 & 0 & 425,219 & 269,372 & 443,072 & 1.64 & 63.3 \\
\hline $1897 \ldots$ & 17 & 1,225 & 0 & 439,103 & 268,263 & 419,151 & 1.56 & 61.1 \\
\hline 1898 & 18 & 1,299 & 4 & 519,937 & 317,998 & 484,001 & 1.52 & 61 \\
\hline 1899 & 22 & 1,444 & 167 & 503,160 & 281,134 & 533,996 & 1.90 & 56 \\
\hline
\end{tabular}

Kanawha district.-The Kanawha district includes all the ovens along the Kanawha River from its formation by the junction of the New and Gauley rivers at Gauley to the western limit of the coal 
fields. There are $S$ establishments in the district, with a total of 653 ovens, all but 12 of which were operated during the year. The production in 1899 was the largest in the history of the district, exceeding that of 1895 , the year of previous maximum production, by over 25,000 tons. Compared with 1898 the production in 1899 exhibits an increase of 54,470 tons.

The statistics of the manufacture of coke in the Kanawha district from 1880 to 1899 are as follows:

Statistics of the manufacture of coke in the Kunctwha district, West Virginia, from 1880 to 1899.

\begin{tabular}{|c|c|c|c|c|c|c|c|c|}
\hline \multirow{2}{*}{ Year. } & \multirow{2}{*}{$\begin{array}{l}\text { Estab- } \\
\text { lish- } \\
\text { ments. }\end{array}$} & \multicolumn{2}{|c|}{ Ovens. } & \multirow{2}{*}{ Coal used. } & \multirow{2}{*}{$\begin{array}{l}\text { Coke pro- } \\
\text { duced. }\end{array}$} & \multirow{2}{*}{$\begin{array}{l}\text { Total value } \\
\text { of coke at } \\
\text { ovens. }\end{array}$} & \multirow{2}{*}{$\begin{array}{l}\text { Value of } \\
\text { coke at } \\
\text { ovens, } \\
\text { per ton. }\end{array}$} & \multirow{2}{*}{$\begin{array}{l}\text { Yield of } \\
\text { coal in } \\
\text { coke. }\end{array}$} \\
\hline & & Bivilt. & $\begin{array}{c}\text { Build- } \\
\text { ing. }\end{array}$ & & & & & \\
\hline & & & & Short tons. & Short tons. & & & Per cent. \\
\hline $18 s 0$ & 4 & 18 & 0 & 6,789 & 4,300 & $\$ 9,890$ & $\$ 2.30$ & 63.3 \\
\hline 1881. & 4 & 18 & 0 & 11,516 & 6,900 & 16,905 & 2.45 & 60 \\
\hline 1882 & 5 & a 138 & 0 & 40,782 & 26,170 & 62,808 & 2.40 & 64 \\
\hline 1883. & 5 & $a 147$ & 0 & 58,735 & 37,970 & 88,090 & 2.32 & 64.6 \\
\hline $188 t$ & 6 & $a 177$ & 15 & 60,281 & 39,000 & 76,070 & 1.95 & 64.6 \\
\hline 1885. & 7 & $b 181$ & 63 & 65,348 & 37,551 & 63,082 & 1.68 & 57 \\
\hline 1886 & $T$ & 302 & 170 & 89,410 & 54,329 & 117,649 & 2.17 & 60.7 \\
\hline 1887 & 7 & 548 & 0 & 153,784 & 96,721 & 201,418 & 2.08 & 63 \\
\hline 1888 & 9 & 572 & S & 141,641 & 84,052 & 146,837 & 1.75 & 59 \\
\hline 1889 & 6 & 474 & 0 & 109,466 & 63,678 & 117,340 & 1.84 & 58 \\
\hline 1890 & 6 & $4 \bar{i} 4$ & 0 & 182,340 & 104,076 & 196,583 & 1.89 & 57 \\
\hline 1891 & 6 & 474 & 0 & 241,427 & 134,715 & 276,420 & 2.05 & 56 \\
\hline 1892 & 6 & 506 & 0 & 242,627 & 140,641 & 284,174 & 2.02 & 58 \\
\hline 1893 & 6 & 506 & 0 & 215,108 & 122,241 & 237,308 & 1.94 & 56.8 \\
\hline 1894. & 6 & 506 & 0 & 176,746 & 104,160 & 181,586 & 1. 74 & 58.9 \\
\hline $1895 \ldots$ & 6 & 506 & 0 & 267,520 & 164,729 & 270,879 & 1.64 & 61.6 \\
\hline 1896 & 7 & 576 & 10 & 259,715 & 157,741 & 263,210 & 1.67 & 60.7 \\
\hline $1897 \ldots$ & 7 & 576 & 20 & 199,312 & 117,849 & $18 \bar{i}, 359$ & 1.59 & 59.1 \\
\hline 1898 & $s$ & 622 & 100 & 225,240 & 135,867 & 208,949 & 1.538 & 60 \\
\hline $1899 .$. & 8 & 653 & S8 & 323,506 & 190,337 & 364,148 & 1.91 & 58.8 \\
\hline
\end{tabular}

$a$ Eighty of these ovens are Coppée, the balance beehive.

$b$ Sixty of these ovens are Coppée, the balance beehive.

Tpper Potomac district. - In the Upper Potomac district are included the ovens along the line of the West Virginia Central and Pittsburg Railway, running south from near Cumberland, Maryland. This district has been thoughly described, not only in previous rolumes of Mineral Resources, but also in a separate publication by the Survey.

With one exception the coke production of this district has increased 
each year since it began in 1887 . The product in 1899 was nearly three times that of 1895 , a year of exceptional activity in coke production. All of the ovens in this district made coke in 1899, as they did in 1898.

Statistics of the production of coke in the Upper Potomac district of West Virginia are as follows:

Statistics of the manufacture of cole in the Upper Potomac district of West Virginia from 1887 to 1899.

\begin{tabular}{|c|c|c|c|c|c|c|c|c|}
\hline \multirow{2}{*}{ Year. } & \multirow{2}{*}{$\begin{array}{c}\text { Estab- } \\
\text { lish- } \\
\text { ments. }\end{array}$} & \multicolumn{2}{|c|}{ Ox̣ens. } & \multirow{2}{*}{ Coal used. } & \multirow{2}{*}{$\begin{array}{l}\text { Coke pro- } \\
\text { duced. }\end{array}$} & \multirow{2}{*}{$\begin{array}{l}\text { Total value } \\
\text { of coke at } \\
\text { ovens. }\end{array}$} & \multirow{2}{*}{$\begin{array}{l}\text { Value of } \\
\text { coke at } \\
\text { ovens, } \\
\text { per ton. }\end{array}$} & \multirow{2}{*}{$\begin{array}{l}\text { Yield of } \\
\text { coal in } \\
\text { coke. }\end{array}$} \\
\hline & & Built. & $\begin{array}{c}\text { Build- } \\
\text { ing. }\end{array}$ & & & & & \\
\hline 1887 & 1 & 20 & 50 & $\begin{array}{r}\text { Short tons. } \\
3,565\end{array}$ & $\begin{array}{r}\text { Short tons. } \\
2,211\end{array}$ & $\$ 4,422$ & $\$ 2.00$ & $\begin{array}{l}\text { Per cent. } \\
62\end{array}$ \\
\hline 1888. & 1 & 28 & 0 & 9,176 & 5,835 & 8,752 & 1.50 & 64 \\
\hline 1889. & 2 & 84 & 0 & 26,105 & 17,945 & 28,559 & 1.58 & 69 \\
\hline 1890. & 2 & 178 & 28 & 94,983 & 61,971 & 118,503 & 1.91 & 65 \\
\hline 1891. & 2 & 390 & 39 & 111,014 & 76,599 & 133,549 & 1.75 & 69 \\
\hline 1892. & 3 & 395 & 0 & 114,045 & 78,691 & 121,208 & 1.54 & 69 \\
\hline 1893. & 3 & 394 & 0 & 123,492 & 84,607 & 115,250 & 1.36 & 68.5 \\
\hline 1894. & 2 & 394 & 0 & 66,598 & 43,546 & 43,546 & 1.00 & 65.4 \\
\hline 1895 . & 2 & 442 & 0 & 183,187 & 110,753 & 126,595 & 1.14 & 60.5 \\
\hline 1896 & 2 & 482 & 0 & 270,275 & 164,093 & 242,133 & 1.476 & 60.7 \\
\hline 1897. & 2 & 592 & 0 & 312,984 & 190,401 & 278,012 & 1.46 & 60.8 \\
\hline $1898 \ldots$ & 2 & 622 & 0 & 379,227 & 230,150 & 329,371 & 1.43 & 60.7 \\
\hline 1899 . & 3 & 673 & 90 & 506,793 & 305,845 & 532,358 & 1. 74 & 60.3 \\
\hline
\end{tabular}

Upper Monongahela district.-The Upper Monongahela district includes the ovens in the group of counties lying along the line of the Baltimore and Ohio Railroad, near the headwaters of the Monongahela River-Preston, Taylor, Harrison, and Marion counties. It embraces the Clarksburg and Fairmont mining regions, in which some of the most important developments in the State have been made during the last few years. The production of coke in this district in 1899 showed an increase of nearly 100 per cent over 1898, and reached a total of 362,872 short tons, making this district the second in importance in the State. This was accomplished in spite of a reduction from 23 to 19 in the number of establishments, and of the fact that 458 out of 1,453 ovens in the district were idle, as compared with 400 idle ovens out of a total of $1,449 \mathrm{in} 1898$. The production of this district includes the output from the bank of 60 Semet-Solvay ovens at Wheeling. These ovens were put in blast in December, 1898. 
The statistics of coke production in the Upper Monongahela district since 1880 are shown in the following table:

Statistics of the manufacture of coke in the Upper Monongahela district, West Virginia, from 1880 to 1899.

\begin{tabular}{|c|c|c|c|c|c|c|c|c|}
\hline \multirow{2}{*}{ Year. } & \multirow{2}{*}{$\begin{array}{l}\text { Estab- } \\
\text { lish- } \\
\text { ments. }\end{array}$} & \multicolumn{2}{|c|}{ Ovens. } & \multirow{2}{*}{ Coal used. } & \multirow{2}{*}{$\begin{array}{l}\text { Coke pro- } \\
\text { duced. }\end{array}$} & \multirow{2}{*}{$\begin{array}{l}\text { Total value } \\
\text { of coke at } \\
\text { ovens. }\end{array}$} & \multirow{2}{*}{$\left|\begin{array}{c}\text { Value of } \\
\text { coke at } \\
\text { ovens, } \\
\text { per ton. }\end{array}\right|$} & \multirow{2}{*}{$\begin{array}{l}\text { Yield of } \\
\text { coal in } \\
\text { coke. }\end{array}$} \\
\hline & & Built. & $\begin{array}{c}\text { Build- } \\
\text { ing. }\end{array}$ & & & & & \\
\hline 1880 & 8 & 145 & 0 & $\begin{array}{r}\text { Short tons. } \\
64,937\end{array}$ & $\begin{array}{r}\text { Short tons. } \\
36,028\end{array}$ & $\$ 68,930$ & $\$ 1.91$ & $\begin{array}{l}\text { Per cent. } \\
55\end{array}$ \\
\hline 1881. & 9 & 172 & 0 & 73,863 & 43,803 & 78,014 & 1.78 & 59 \\
\hline $1882 \ldots$ & 11 & 222 & 0 & 92,510 & 55,855 & 105,214 & 1.88 & 60 \\
\hline $1883 \ldots$ & 13 & 269 & 0 & 88,253 & 51,754 & 90,848 & 1. 76 & 59 \\
\hline 1884 & 13 & 281 & 100 & 78,468 & 49,139 & 74,894 & 1.52 & 63 \\
\hline 1885 & 12 & 278 & 0 & 105,416 & 67,013 & 97,505 & 1.45 & 63.5 \\
\hline 1886 & 12 & 275 & 104 & 131,896 & 82,165 & 113,100 & 1.38 & 62.3 \\
\hline $1887 \ldots$ & 15 & 646 & 0 & 211,330 & 132,192 & 268,990 & 2.03 & 62.5 \\
\hline 1888 & 17 & 567 & 110 & 213,377 & 138,097 & 175,840 & 1. 27 & 64.7 \\
\hline 1889 & 17 & 674 & 200 & 210,083 & 128,685 & 171,511 & 1.33 & 62.5 \\
\hline $1890 \ldots$ & 18 & 1,051 & 50 & 276,367 & 167,459 & 260,574 & 1.56 & 60 \\
\hline $1891 \ldots$ & 15 & 1,081 & 56 & 517,615 & 291,605 & 462,677 & 1.58 & 56 \\
\hline 1892 & 19 & 1,129 & 45 & 441,266 & 265,363 & 390,296 & 1.47 & 60.1 \\
\hline $1893 \ldots$ & 19 & 1,158 & 42 & 379,506 & 225,676 & 295,123 & 1. 31 & 59 \\
\hline $1894 \ldots$ & 20 & 1,221 & 42 & 280,748 & 158,623 & 179,525 & 1.13 & 56.5 \\
\hline $1895 \ldots$ & 20 & 1,260 & 37 & 392,297 & 240,657 & 265,293 & 1.10 & 61.3 \\
\hline 1896 & 22 & 1,386 & 0 & 331,526 & 206,429 & 211,272 & 1.023 & 62.3 \\
\hline 1897. & 22 & 1,363 & 0 & 289,678 & 175,165 & 180,802 & 1.03 & 60.5 \\
\hline $1898 \ldots$ & 23 & $a 1,449$ & 30 & 319,590 & 183,430 & 194,277 & 1.06 & 57 \\
\hline $1899 \ldots$ & 19 & $a, 1,453$ & $b 60$ & 607,796 & 362,872 & 596,305 & 1. 64 & 59.7 \\
\hline
\end{tabular}

a Includes 60 Semet-Solvay ovens at Wheeling.

$b$ All Semet-Solvay ovens at Wheeling.

\section{WISCONSIN.}

All the coke made in Wisconsin is from Connellsville (Pennsylvania) coal, and the coke is standard Connellsville. Its production, therefore, is not of much interest, except as showing that coal can be carried to a distance and successfully made into coke. 
The statistics of the manufacture of coke in Wisconsin from 1888 to 1899, inclusive, are as follows:

Statistics of the manufacture of coke in Wisconsin.

\begin{tabular}{|c|c|c|c|c|c|c|c|c|}
\hline \multirow{2}{*}{ Year. } & \multirow{2}{*}{$\begin{array}{l}\text { Estab- } \\
\text { lish- } \\
\text { ments. }\end{array}$} & \multicolumn{2}{|c|}{ Ovens. } & \multirow{2}{*}{ Coal used. } & \multirow{2}{*}{$\begin{array}{l}\text { Coke pro- } \\
\text { duced. }\end{array}$} & \multirow{2}{*}{$\begin{array}{l}\text { Total value } \\
\text { of coke at } \\
\text { ovens. }\end{array}$} & \multirow{2}{*}{$\begin{array}{c}\text { Value of } \\
\text { coke at } \\
\text { ovens, } \\
\text { per ton. }\end{array}$} & \multirow{2}{*}{$\begin{array}{l}\text { Yield of } \\
\text { conl in } \\
\text { coke. }\end{array}$} \\
\hline & & Built. & $\begin{array}{l}\text { Build- } \\
\text { ing. }\end{array}$ & & & & & \\
\hline $1888 \ldots$ & 1 & 50 & & $\begin{array}{c}\text { Short tons. } \\
1,000\end{array}$ & $\begin{array}{c}\text { Short tons. } \\
500\end{array}$ & $\$ 1,500$ & $\$ 3.00$ & $\begin{array}{l}\text { Per cent. } \\
50\end{array}$ \\
\hline 1889 & 1 & 50 & . & 25,616 & 16,016 & 92,092 & 5.75 & 62.5 \\
\hline $1890 \ldots$ & 1 & 70 & .. & 38,425 & 24,976 & 143,612 & 5.75 & 65 \\
\hline $1891 \ldots$ & 1 & 120 & 0 & 52,904 & 34,387 & 192,804 & 5.61 & 65 \\
\hline $1892 \ldots$ & 1 & 120 & 0 & 54,300 & 33,800 & 185,900 & 5.50 & 62.2 \\
\hline $1893 \ldots$ & 1 & 120 & 0 & 24,085 & 14,958 & 95,851 & 6.41 & 62 \\
\hline 1894 & 1 & 120 & 0 & 6,343 & 4,250 & 19,465 & 4.58 & 67 \\
\hline 1895. & 1 & 120 & 0 & 8,287 & 4,972 & 26,103 & 5.25 & 60 \\
\hline $1896 \ldots$ & 1 & 120 & 0 & 8,648 & 5,332 & 21,000 & 3.94 & 62 \\
\hline $1897 \ldots$ & 1 & 120 & 0 & 29,207 & 17,216 & 75,000 & 4.36 & 59 \\
\hline $1898 \ldots$ & 1 & 120 & 0 & 59,900 & 35,280 & 123,480 & 3.50 & 59 \\
\hline $1899 \ldots$ & 1 & 120 & 0 & 54,950 & 33,437 & 125,389 & 3.75 & 60.8 \\
\hline
\end{tabular}

The character of the coal used in the manufacture of coke in Wis. consin since 1890 is shown in the following table:

Character of coal used in the manufacture of coke in Wisconsin since 1890.

\begin{tabular}{|c|c|c|c|c|c|}
\hline \multirow{2}{*}{ Year. } & \multicolumn{2}{|c|}{ Run of mine. } & \multicolumn{2}{|c|}{ Slack. } & \multirow{2}{*}{ Total. } \\
\hline & Unwashed. & Washed. & Unwashed. & Washed. & \\
\hline & Short tons. & Short tons. & Short tons. & Short tons. & Short tons. \\
\hline $1890 \ldots$ & 38,425 & 0 & 0 & 0 & 38,425 \\
\hline $1891 \ldots \ldots \ldots \ldots \ldots$ & 52,904 & 0 & 0 & 0 & 52,904 \\
\hline 1892 & 54,300 & 0 & 0 & 0 & 54,300 \\
\hline $1893 \ldots$ & 20,474 & 0 & 3,611 & 0 & 24,085 \\
\hline $1894 \ldots$ & 6,343 & 0 & 0 & 0 & 6,343 \\
\hline $1895 \ldots$ & 8,287 & 0 & 0 & 0 & 8,287 \\
\hline 1896 & 0 & 0 & 5,183 & 3,465 & 8,648 \\
\hline $1897 \ldots$ & 0 & 0 & 0 & 29,207 & 29,207 \\
\hline $1898 \ldots$ & 0 & 0 & 0 & 59,900 & 59,900 \\
\hline $1899 \ldots$ & 34,680 & 0 & 20,270 & 0 & 54,950 \\
\hline
\end{tabular}




\section{WYOMING.}

There is but one establishment making coke in Wyoming, that of the Cambria Mining Company, located at Cambria, Weston County. This establishment began the manufacture of coke in 1891, but produced no coke in 1892. Manufacture was resumed in 1893 and increased each year until 189S, when it decreased about 25 per cent. A further decrease of 15 per cent is shown in the figures for 1899 .

All of the coal used in coking is unwashed slack, which does not give as good a result as washed slack. When the latter is used the coke is of fine texture and very strong. It is dense and capable of sustaining any weight ordinarily required of coke used, as this is, in silver smelting. As at present produced, however, the coke is very high in ash.

The statistics of the production of coke in Wyoming from 1891 to 1899, inclusive, are as follows:

Statistics of the production of coke in Wyoming from 1891 to 1899.

\begin{tabular}{|c|c|c|c|c|c|c|c|c|}
\hline \multirow{2}{*}{ Year. } & \multirow{2}{*}{$\begin{array}{l}\text { Estab- } \\
\text { lish- } \\
\text { ments. }\end{array}$} & \multicolumn{2}{|c|}{ Ovens. } & \multirow{2}{*}{ Coal used. } & \multirow{2}{*}{$\begin{array}{l}\text { Coke pro- } \\
\text { duced. }\end{array}$} & \multirow{2}{*}{$\begin{array}{l}\text { Total value } \\
\text { of coke at } \\
\text { ovens. }\end{array}$} & \multirow{2}{*}{$\begin{array}{l}\text { Value of } \\
\text { coke at } \\
\text { ovens, } \\
\text { per ton. }\end{array}$} & \multirow{2}{*}{$\begin{array}{l}\text { Yield of } \\
\text { coal in } \\
\text { coke. }\end{array}$} \\
\hline & & Built. & $\begin{array}{l}\text { Build- } \\
\text { ing. }\end{array}$ & & & & & \\
\hline $1891 \ldots$ & 1 & 24 & 0 & $\begin{array}{c}\text { Sliort tons. } \\
4,470\end{array}$ & $\begin{array}{c}\text { Short tons. } \\
2,682\end{array}$ & $\$ 8,046$ & $\$ 3.00$ & $\begin{array}{c}\text { Per cent. } \\
60\end{array}$ \\
\hline 1892. & 1 & 24 & 0 & 0 & 0 & 0 & 0 & 0 \\
\hline 1893. & 1 & 24 & 0 & 5,400 & 2,916 & 10,206 & 3.50 & 54 \\
\hline $1894 \ldots$ & 1 & 24 & 0 & 8,685 & 4,352 & 15,232 & 3.50 & 50 \\
\hline $1895 .$. & 1 & 74 & 0 & 10,240 & 4,895 & 17,133 & 3.50 & $4 \overline{7} .8$ \\
\hline $1896 .$. & 1 & 74 & 0 & 41,038 & 19,542 & 58,626 & 3.00 & 47.6 \\
\hline 1897. & 1 & 74 & 0 & 54,976 & 24,007 & 72,021 & 3.00 & 43.7 \\
\hline $1898 .$. & 1 & 74 & 0 & 35,384 & 18,350 & 64,225 & 3.50 & 51.9 \\
\hline $1899 .$. & 1 & 74 & 0 & 32,100 & 15,630 & 38,510 & 2.46 & 48.7 \\
\hline
\end{tabular}


The character of the coal used in the manufacture of coke in Wyoming is shown in the following table:

Character of coal used in the manufacture of coke in Wyoming since 1891.

\begin{tabular}{|c|c|c|c|c|c|}
\hline \multirow{2}{*}{ Year } & \multicolumn{2}{|c|}{ Run of mine. } & \multicolumn{2}{|c|}{ Slack. } & \multirow{2}{*}{ Total. } \\
\hline & Enwashed. & Washed. & Unwashed. & Washed. & \\
\hline & Short tons. & Short tons. & Short tons. & Short tons. & Short tons. \\
\hline $1891 \ldots \ldots \ldots \ldots$ & 0 & 0 & 4,470 & 0 & 4,470 \\
\hline $1892 \ldots$ & 0 & 0 & 0 & 0 & 0 \\
\hline $1893 \ldots$ & 0 & 0 & 5,400 & 0 & 5,400 \\
\hline $1894 \ldots$ & 0 & 0 & 8,685 & 0 & 8,685 \\
\hline 1895.: & 0 & 0 & 10,240 & 0 & 10,240 \\
\hline $1896 \ldots \ldots \ldots \ldots$ & 0 & 0 & 41,038 & 0 & 41,038 \\
\hline $1897 \ldots$ & 0 & 0 & 54,976 & 0 & 54,976 \\
\hline $1898 \ldots$ & 0 & 0 & 35,384 & 0 & 35,384 \\
\hline $1899 \ldots \ldots \ldots$ & 0 & 0 & 32,100 & 0 & 32,100 \\
\hline
\end{tabular}





\section{N D EX.}

\begin{tabular}{|c|c|}
\hline Page. & Page. \\
\hline bott quicksilver mine, California, pro- & Allouez mine copper production ........ 175,176 \\
\hline duction...................... & Altai mine copper production............. \\
\hline brasive materials, summary ............ & Altoona quicksilver mine, California, pro- \\
\hline cknowledgments ....................... & duction........................ \\
\hline Adventure copper mine, production ....... & Aluminum and bauxite................... \\
\hline Aetna quicksilver mine, California, produc- & Aluminum, imports ........... \\
\hline tion $\ldots \ldots \ldots \ldots \ldots \ldots \ldots \ldots$ & new use for.. \\
\hline Africa, copper $\ldots \ldots \ldots \ldots \ldots \ldots \ldots \ldots \ldots 207,222$ & production $\ldots \ldots \ldots \ldots \ldots \ldots \ldots \ldots \ldots$ \\
\hline Alabama, basic pig iron, production ....... & summary $\ldots \ldots \ldots \ldots \ldots \ldots \ldots \ldots \ldots \ldots$ \\
\hline bauxite......................... 270 & American and foreign iron trades in 1899 \\
\hline $\begin{array}{r}\text { coal } \ldots \ldots \ldots \ldots \ldots \ldots \ldots .335,336,337,338, \\
342,343,344,345,346,347,348,349,424-427\end{array}$ & $\begin{array}{l}\text { by James M. Swank.......... 69-118 } \\
\text { Ammonia, coke by-product, amount and }\end{array}$ \\
\hline fields, production............... $324-328$ & value $\ldots \ldots \ldots \ldots \ldots \ldots \ldots \ldots$ \\
\hline labor statistics................ 355-357 & Amount and value copper ore exports.... \\
\hline$d \ldots \ldots \ldots \ldots 376-379,380,424$ & Analyses, carnotite, Colorado ............ \\
\hline total ............. $352-354$ & gummite $\ldots \ldots \ldots \ldots \ldots \ldots \ldots \ldots \ldots$ \\
\hline strikes in mines .............. 424,518 & iron ores, cargo lots, Lake Supericr .... $37-43$ \\
\hline coke.......... $534,535,536,542,543,567-570$ & manganese ores, Brazil................ \\
\hline by-product ovens................. 558 & uraninite ........................ \\
\hline character of coal used in making ... 554, & 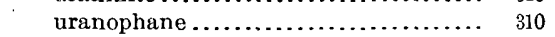 \\
\hline $555,556,570$ & Anthracite coal, by William W. Ruleg . . . 4S4-492 \\
\hline coal used in making $\ldots \ldots 544-546,551-553$ & distribution by States ................ \\
\hline$\ldots \ldots \ldots \ldots \ldots .65$ & fields .............................. 324,328 \\
\hline 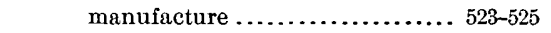 & prices at Philadelphia, Pa............. \\
\hline ovens................. 531, 532,533 & tidewater.................. \\
\hline percentage yield of coal in making. $\quad 549$ & production ................. \\
\hline production, increases and decreases. & and shipments ............... 486-489 \\
\hline value............ $537,538,539,540,541$ & shipments and average price at mines. \\
\hline $\begin{array}{r}\text { gold and silver production and value. } \begin{array}{r}125, \\
126,127\end{array}\end{array}$ & $\begin{array}{l}\text { ent of coal fields and } \\
\text { s reaching them ........ }\end{array}$ \\
\hline gold production. & ds, production. ........... \\
\hline$\ldots \ldots \ldots \ldots 34,45,52$ & Antimony, by Edward W. Parker....... 291-297 \\
\hline stocks & Arkansas ...... \\
\hline value... & lifornia.... \\
\hline iron and steel, production.... & ption . \\
\hline manganese ores $. . . . . \ldots \ldots .$. & $\ldots \ldots \ldots \ldots$ \\
\hline$\ldots \ldots \ldots \ldots \ldots \ldots \ldots \ldots \ldots \ldots \ldots, 90,95$ & 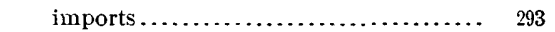 \\
\hline 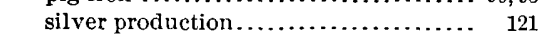 & (n) \\
\hline Alaska, coal............... $335,336,337,338$ & prices.............................. \\
\hline machine-mined ............... 376-379 & production ..................... \\
\hline gold production ................... 123,124 & 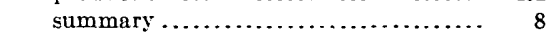 \\
\hline gold and silver production and value.. 125 , & uses \\
\hline 126,127 & Appalachian coal fields, production........ \\
\hline lead ore, contents. & Argentina copper production........... 204, 206 \\
\hline$\ldots \ldots \ldots \ldots \ldots 121,122$ & blic, vanadium ........... 315 \\
\hline Alba Camp, production of zinc and lead ore. $\quad 252$ & Arizona copper $. \ldots \ldots \ldots \ldots 166,167,168,169,170,185$ \\
\hline 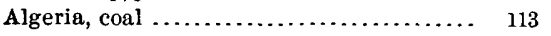 & gold and silver production and value.. 125 , \\
\hline 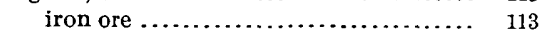 & 126,127 \\
\hline Algiers, copper production.............. 205,206 & gold production \\
\hline Allegheny County, Pennsylvania, iron and & lead-ore contents... \\
\hline , & ............... \\
\hline $\begin{aligned} \text { Allegheny Mountain coke district, Penn- } & \\
& \text { sylvania..................... } 597\end{aligned}$ & $\begin{array}{l}\text { silver production } \ldots \ldots \\
\text { tungsten.............. }\end{array}$ \\
\hline
\end{tabular}


['age. bauxite............................. 270,271 coal ................... 335, 336, 337, 338, $342,343,344,345,346,347,348,349,427-430$ fields, production........... 325, 327, 329 labor statistics.............. 355, 356, 357 machine-mined ...... 376, 377, 378, 379, 380 percentage of totals.......... $352,353,354$ strikes....................428,517

manganese ores................. 130,155

Asbestos, summary ......................... 15

Ash bed mine, copper production ......... 176

Asia, copper....................... $\quad 207$

Asphaltum, summary .................. 15

Atlantic mine, copper production.... 175, 176,177

cost, copper, per ton............... 182

Aurora Camp, production of zinc and lead ore...................... 252

Australasia, copper.................... 219

Australasia copper, imports of, into Germany..................... 210 into Great Brituin ................ 210,211 recapitulation of ................ 207

Anstralia, coal......... 419 lead producticn ................. 245,246

Austria copper consumption ............ 218 copper exports to................... 198 production .................. 204, 205

A ustria-Hungary coal ............. 113, 363, 366 copper, imports of, into Germany....... 216 iron ore......................... 113 lead consumption ................... 247 manganese ores .................. $\quad 157$ pig iron............................ 114 steel ...................... 114

A ustria lead production............... 245,246 manganese ores, production ............ 162

Baltimore, Maryland, importation of copper 193

Barytes, summary .................... 14

Bauxite, Alabama ...................... 270

Arkansas .

Georgia-Alabama field............... 270

i roduction ......................... 270

summary ...

Beaver coke district, Pennsy.lvania. ........ 606

Belgium coal .................... 113, 363,367 copper, exports to .................. imports of, into Germany.......... $\quad 216$

iron ore.......................... 113

lead consumption ................... 247

production ..................... 245,246

manganiferous iron ores, production ... 154

pig iron............................. 114

steel ............................. 114

zinc exports . ....................... 261

Belt mine, copper production ............. 176

Belville Camp, production of zinc and lead

$$
\text { ore......................... }
$$

Bessemer pig iron, Colorado, production... Illinois, production.................... Kentucky, production.

Maryland, production ................. Michigan, production

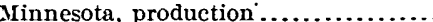

Mrissouri, production.

New Jerses, production.
Bessemer pig iron, New York, producti North Carolina, production ........... Ohio, production .................. 92 Pennsylvania, production............. 92 Tennessee, production................ 92 West Virginia, production............ 92

Visconsin, production ...................... Bessemer steel ingots and rails, Great Britain $\ldots \ldots \ldots \ldots \ldots \ldots \ldots \ldots \ldots .116$

ingots, Illinois, production........... 97

Ohio, production ................. 97

Pennsylvania, production........... 97 production ........................ 96

rails, production ................... 100

Birkinbine, John, paper on iron cres...... 31-67

manganese ores ................. 129-162

Bituminous coal fields................ 324-329

Blossburg coke district, Pennsylvania..... $\quad 608$

Boleo mine, copper production. . ........ 204-206

Bolivia, copper production............ 204-206

Borax, summary ...................... $\quad 12$

Bosnia, manganese ores, production ....... 162

Boston, Massachusetts, coal receipts....... 382

coal trade ........................ 389-391 Branner, John C., quoted on manganese deposits of Brazil .............. 149-151

Brazil, manganese, exports.............. 151 manganese ores .............. 149-151, 162 British Africa, zinc exports.............. 261 British Australasia, copper imports from... 194

British Columbia, coal .................. 419 British North America, copper exports to.. 198 lead imports from into the United States 239 Broad Top coke district ................ Bromine, summary.................. 13

Buffalo, coal receipts.................... 382

California, antimony .................. 291 coal ................. $335,336,337,338,339$ $342,343,344,345,346,347,348,349,430-432$ fields, production........... 325,327,329 labor statistics............... 355, 356,357 percentage of total .......... 352, 353,354 copper........... 166, 167, 165, 162, 170, 187 cut nails, production ................ 104 gold and silver, production and value .. 125 126,127 gold, production................... 123, 12 lead ore contents .................... 229 manganese ores ................... 130, 136 quicksilver, production by mines...... 276 silver production .................121,122 Calumet and Hecla mine, copper production.................... 175, 176

Canada, coal.................... 113,363,371

copper.................... 204, 206, 222

copper imports from............... 194 copper, imports of, into Great Britain. 210, 211

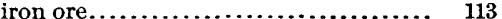
iron trade .................... 111, 112 manganese ores ................. 144, 162 molybdenum ...................... 307 nickel, production.................. 288 pig iron........................ 114 steel ............................... $\quad 114$

Canadian lead ore, contents............. 229 Cape Colony, coal, production.............. 363 
INDEX.

Page.

Cape Company mine, copper production. 205, 200 Cape of Good Hope, copper imports of, into

$$
\text { Great Britain }
$$
210,211

copper production 210,211
205,206 Carnotite, Colorado. analyses...

Carterville Camp, production of zinc and lead ore.

Carthage Camp, production of zinc and lead ore ....................... Caucasus mine, copper production. Cave Springs Camp, production of zine and lead ore

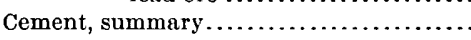

Central American States, zinc exports .....

Central City Camp, production of zinc and lead ore .................. 252

Central coal fields, production ............ 330 Central mine, copper production........ 175-177 Champlain, N. Y., importation of copper... 193 Chemical materials, summary............ 13 Chicago, Illinois, coal receipts............ 383 coal trade...................... 405

Chile, copper, imports of, in to Germany.... 210 into Great Britain ............ 209-211 into France ..................... 213

copper production................ 204, 206 manganese ores .................. 152 exports ....................... 152

Cincinnati, ohio, coal receipts ............ 383 conl trade .................... 410-414 coke district...................... 590 Clays, summary ..................... I1 Clearfield-Center coke district, Pennsylvania ........................ 61

Cleveland, Ohio, coßl receipts............ 38 coal trade .................... 402-404 Cliff mine, copper production ............ 175 Coal, by Edward w. Parker ............ 321-519 Alabama................ $335,336,337,338$, $342,343,344,345,346,347,348,349,424-427$ character of, used in making coke . $\quad 570$ labor statistics............... 355, 356,357 machine-mined .. $376,377,378,379,380,424$ percentage ................ 352, 353, 354 strikes in mines ................ 424,518

Alaska, machine-mined..... 376, 377, 378, 379 product.............. 335, 336, 337, 338 amount and value used in making coke ..................... 550-553

amount necessary to produce a ton of coke........................ 548

amount used in making coke, by States................... 544-546

anthracite ....................... 322, 484-492 distribution, by States.......... 490 fields ...................... 324, 328 prices at Philadelphia, Pennsylvania...................... 395 prices at tidewater................ 384 production and shipments....... 486-489 shipments and price............. 381

Arkansas ............ 335, 336, 337, 338 $342,343,344,345,346,347,348,349,427-430$ labor statistics............ $355,356,357$ machine-mined ...... $376,377,378,379,380$ strikes in mines ............... 428
Page.

Coal, Australia ....................... 419 Austria-Hungary, production ....... 363,366 Belgium, production ..................363,367 bituminous fields.................... 324-329 production $\ldots \ldots \ldots \ldots \ldots \ldots \ldots \ldots \ldots \ldots \ldots \ldots . . .333-354$ British Columbia .................. 419 California.............. 335, 336, 337, 338, $342,343,344,345,346,347,348,349,430-432$ labor statistics...............355, 356, 357 percentage of total........... 352, 353,354 Canada, production .................363,371 Cape Colony, production ............. 363 character used in coke manufacture.. 554-556 Colorado................. 335, 336, 337, 338, $342,343,344,345,346,347,348,349,432-435$ character of, used in making coke.. $\quad 572$ labor statistics............. 355, 356, 357 machine-mined .. $376,377,378,379,380,432$ percentage of total ............352,353,354 strikes in mines ............... 432,518 distribution at Philadelphia, Pennsylvania........................ 398

English......................... 419 exports .......................... 362 exports at Seattle, Washington.......... 421 fields, Alabama, production ...... 324, 326, 328 anthracite, production ....... 324, 326, 328 Appalachian, production :........ 330 Arkansas, production........ 325, 327,329 California, production....... . 325, 327, 329 Central, production............. $\quad 330$ Colorado, production ........ $325,327,329$ Dakota, production.......... 325, 327, 329 Georgia, production .......... 324, 326, 328 Idaho, production ................ 325,329 Illinois, production.......... 324, 326, 328 Indiana, production........ 324, 326, 328 Indian Territory, production. $325,327,329$ Iowa, production ........... 325, 327, 329 Kansas, production .......... 325, 327,329 Kentucky production....... $324,326,328$ Maryland, production ........ 324, 326, 328 Michigan, production ........ 324, 326, 328 Missouri, production ......... 325, 327, 328 Montana, production........ 325, 327, 328 Nebraska, production ........ 325, 327,329 Nevada, production ............ 327, 329 New Mexico, production ..... 325, 327, 329 North Carolina, production .. $324,326,328$ of the United States, classification and production.............. 322-330 of the United States, relative im-

portance.................... 329 Ohio, production ........... 324,326,328 Oregon, production............ 325, 327, 328 Pacific coast, production .......... 330 Pennsylvania, production.... 324, 326, 328 Rocky Mountains, production..... 330 Tennessee, production....... . 324, 326, 328 Texas, production ........... 325, 327, 329 Utah, production ........... 325, 327, 329 Virginia, production ........ 324, 326, 328 Washington, production...... 325, 327, 329 Western, production............. 330 West Virginia, production.... 324, 326, 328 Wyoming, production ........ 325, 327, 328 France, production ............... 363, 367 
Page.

Coal, Georgia .................. 335, 336, 337 , $338,342,343,344,345,346,347,348,349,435$ character of, used in coke making.. $\quad 574$ labor statistics.............. $355,356,357$ percentage of total .......... 352, 353,354 Germany, production ............... 363, 366 Great Britain, production........... 363, 365 Idaho, percentage of total ....... 352, 353, 354 product ....................... 335, 336, $337,338,342,343,344,345,346,347,348,349$ Illinois................ $335,336,337,338$ $342,343,344,345,346,347,348,349,437-441$ character of, used in coke making. . $\quad 576$ labor statistics............ 355, 356, 357 machine-mined ...... $376,377,378,379,380$ percentage of total .......... 352,353,354 imports ...................... 360 Indiana................... $335,336,337,338$, $342,343,344,345,346,347,348,349,441-444$ character of, used in coke making.. $\quad 579$ labor statistics............. 355, 356, 357 machine-mined .. 376, 377, 378, 379, 380, 441 percentage of total ......... 352,353,354 Indian Territory............. 335, 336, 337, $338,342,343,344,345,346,347,348,349,444$ character of, used in coke making.. $\quad 579$ labor statistics.............. 355, 356, 357 machine-mined .. $376,377,378,379,380,445$ percentage of total ........... 352, 353, 354 strikes in mines ................ 444 India, production.................. 363,372 Iowa .................... $335,336,337,338$, $342,343,344,345,346,347,348,349,446-449$ labor statistics............. 355, 356, 357 machine-mined ............... $376,378,379,380$ percentage of total .......... 352,353, 354 strikes in mines ................ 446

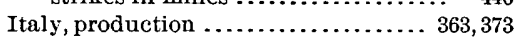
Japan ...................... 363,368,419 Kansas.................. $335,336,337,338$, $342,343,344,345,346,347,348,349,449-452$ character of, used in coke making. . 581 labor statistics.............. 355, 356, 357 machine-mined ... $376,377,378,379,380,449$ percentage of total ........... 352, 353,354 strikes in mines ................ 450

Kentucky ............... 335, 336, 337, 338 , $342,343,344,345,346,347,348,349,452-457$ character of, used in coke making. . $\quad 583$ labor statistics............. 355, 356, 357 machine-mined .. $376,377,378,379,380,453$ percentage of total .......... 352, 353, 354 strikes in mines . ................ 453

labor in mines since $1890 \ldots \ldots \ldots \ldots .355-357$ statistics.................... $355-357$ Alabama ............. $355,356,357$

Arkansas ............... $355,356,357$

California ............. $355,356,357$

Colorado .............. 355, 356, 357

Georgia................ 355, 356,357

Illinois .............. 355, 356,357

Indiana . .............. 355, 356,357

Indian Territory.......... 355,356,357

Iowa $\ldots \ldots \ldots \ldots \ldots \ldots \ldots . \ldots \ldots \ldots, 356,357$

Kansas .................. 355, 356, 357

Kentucks ............... 355, 356,357
Page.

Coal, labor statistics, Maryland ...... 355, 356,357

Michigan...

Missouri ................ 355, 356, 357

Montana .............. 355, 356, 357

Nevada.............. 355, 356,357

New Mexico............ 355, 356, 35\%

North Carolina............ 355, 356, 357

North Dakota ........... 355, 356, 357

ohio..................... 355, 356,357

Oregon ................ 355, 356, 357

Pennsylvania, bituminous $355,356,357$

Tennessee .............. 355, 356, 357

Texas.................. 355, 356, 357

Ctah ................ 355, 356, 357

Virginia ............... 355, 356, 357

Washington ............ 355, 356, 357

West Virginia ............ $355,356,357$

Wyoming............... 355, 356, 357

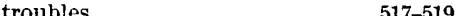

Maryland .................. 335, 336, 337, 338, $342,343,344,345,346,347,348,349,457-461$

labor statistics..............355, 356, 357 machine-mined .. $376,377,378,379,380,457$ percentage of total .......... 352, 353, 354 Michigan .................. $335,336,337$, $338,342,343,344,345,346,347,348,349,462$ labor statistics............. 355, 356, 357 machine-mined .. $376,462,477,478,479,480$ percentage of total.......... 352,353,354 mined by machines .............. 374-380 Missouri ................ 335, 336, 337, 338 , $342,343,344,345,346,347,348,349,464-468$ character of, used in coke making. . $\quad 584$ labor statistics............... 355, 356, 357 machine-mined .. $376,377,378,379,380,464$ percentage of total.......... 352, 353, 354 strikes in mines................ 464 Montana................ 335, 336, 337, 338, $342,343,344,345,346,347,348,349,468-471$ character of, used in coke making.. $\quad 586$ labor statistics. . . ........... 355, 356, 357 machine-mined .. $376,377,378,379,380,468$ percentage of total .......... 352, 353, 354 strikes in mines .................. 468 Natal, production ..................... 363 Nebraska.. $342,343,344,345,346,347,348,349,471$

Nevada....................... 471 labor statistics ..................... $355,35,357$ New Mexico............. 335, 336, 337, 338 , $342,343,344,345,346,347,348,349,471-473$ character of, used in coke making.. 588 labor statistics............ 355, 356, 357 machine-mined .. $376,377,378,379,350,472$ percentage of total .......... 352, 353,354 New South Wales, production......... 363,370

New Zealand, production ........... 363, 371

North Carolina ................. 335, 336, $337,338,343,344,345,346,347,348,349,474$ labor statistics.............. 355, 356, 357 North Dakota...............335, 336, 337, 338 $339,342,343,344,345,346,347,348,349,475$ labor statisties.............. 355, 356,357 machine-mined ....... 376, 377, 378, 379, 380 percentage of total.......... $352,353,354$ Ohio ................... 335, 336, 337, 338 , $342,343,344,345,346,347,348,349,476-482$ 
Coal, Ohio, character of, used in coke making ........................ 592 labor statistics............. 355, 356, 357 machine-mined .. $376,377,378,379,380,476$ percentage of total......... 352,353,354 strikes in mines ................ 476

Oregon ............................... $335,336,337$, $338,342,343,344,345,346,347,348,349,481$ labor statistics ............. 355, 356,357 percentage of total .......... 352, 353, 354 Pennsylvania .............. 335, 336, 337, 338, $342,343,344,345,346,347,348,349,482-497$ anthracite, by William W. Ruley. 484-492 bituminous .................... 492-497 bituminous, machine-mined ....... 492 bituminous, production by coun-

ties ..................... 493-496 character of, used in coke making.. $\quad 595$ labor statistics.............. 355, 356, 357 machine-mined ...... 376, 377, 378, 379, 380 percentage of total........... 352, 353,354 strikes in coal mines.

percentage yield in manufacture of coke...................... 549 prices at mines, by States, since $1886 \ldots . . \quad 358$ production ..................... 331-354 and value, by States, from 1886 to 1899, with increase in $1899 . . .342-349$ by fields .................... 324-330 by States.. 324-329, 335-338, 342-348, 421-517 since $1880 \ldots \ldots \ldots \ldots \ldots \ldots \ldots . . . \ldots \ldots 39-341$ Queensland, production.................. 363-370 receipts and shipments at Pittsburg, Pa. 400 receipts, Boston.................... 382 Buffalo

Chicago .

Cincinnati...................... 383

Cleveland ..................... 382

Milwaukee ...................... 383

Philadelphia .................... 382

Pittsburg ..................... 382

St. Louis....................... 383

Toledo

Rhode Island, production.......... 342, $343,344,345,346,347,348,349$

Russia, production ............... 363, 368 Scotch........................... $\quad 419$ sources of, at San Francisco, Cal........ 419 South Africa, production............ 363,373 Spain, production ................ 363,372 standards of measurement ........... $\quad 322$ statistics, how obtained ................ 321 summary .......................... $8-10$ Sweden, production .............. 363,373 tar products....................... 563 imports....................... 564-566

Tasmania, production .............. 363 Tennessee ....... 335, 336, 337, 338, 342, 343, 344, $345,346,347,348,349,498-500$ character of, used in coke making. . 617 labor statistics............... 355, 356, 357 machine-mined .................. 376 $377,378,379,380,498$ percentage of total ......... 352, 353, 354 Texas............ 335, 336, 337, 338, 342, 343 , $344,345,346,347,348,349,501$
Coal, Texas, machine-mined..... $376,377,378,379$ percentage of total........... $352,353,354$

trade, Boston, Mass................. 389-391 Chicago, Ill..................... 405

Cincinnati, Ohio .................. 410-414

Cleveland, Ohio............... 402-404

Milwaukee, Wis............... 407-410

Mobile, Ala................... 416-418

New York City................. 383-388

Norfolk, Ya..................... 418

Philadelphia, Pa................ 391-398

Pittsburg, Pa................. 398-401

review ..................... 381-422

San Francisco, Cal.............. 418-420

St. Louis, Mo ................... 414-416

Seattle, Wash.................. 420-422

Toledo, Ohio................... 404

United States, production ............. 336 , $338,339,340,342-348,363,365$

Utah.............. 335, 336, 337, 338, 342, 343, $344,345,346,347,348,349,502$

labor statistics............. 355, 356, 357

machine-mined ......... 376, 377, 378, 379 percentage of total ............ $352,353,354$ Victoria, production.............. 363,371 Virginia ........... 335, 336, 337, 338, 342, 343, $344,345,346,347,348,349,504$ character of, used in coke making. . $\quad 620$ labor statistics................. 355, 356 machine-mined ...... 376, 377, 378, 379, 380 percentage of total ......... $352,353,354$ Washington ....... $335,336,337,338,342,343$, $344,345,346,347,348,349,506$ character of, used in coke making. . 621 labor statistics.............. 355, 356, 357 machine-mined ...... 376, 377, 378, 379, 380 percentage of total .......... $352,353,354$ Welsh ........................ 419 West Virginia.... 335, 336, 337, 338, 342, 343, 344, $345,346,347,348,349,508-514$ character of, used in coke making.. 624 labor statistics.............. 355, 356, 357 machine-mined .. $376,377,378,379,380,509$ percentage of total ........... 352, 353, 354 strikes in mines ................. 509

Wisconsin, character of, used in coke making.................... 631 world's product . ............... 113,363-373 Wyoming....... 335, 336, 337, 338, 342, 343, 344, $345,346,347,348,349,514-517$ character of, used in coke making.. 633 labor statistics.............. 355, 356, 357 machine-mined .. $376,377,378,379,380,515$ percentage of total .......... 352,353,354 Cobalt. (See Nickel and cobalt.)

oxide, imports...................... 286 production ...................... 286 summary ....................... 14 Coke, by Edward W. Parker............ 521-633

Alabama ......................... 567-570 by-product, ovens .............. 558 character of coal used in making .. 573 Allegheny Mountain district, Pennsylvania.................... 597 Allegheny Valley district, Pennsylvania.

Beaver district, Pennsylvania......... 606 


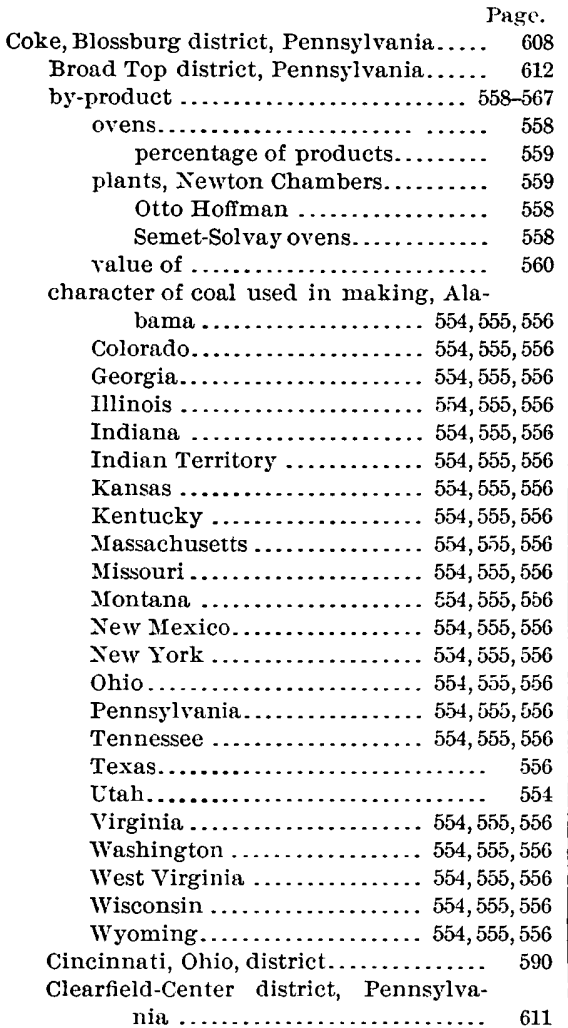

nia .......................

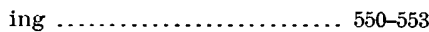

character used in manufacture... 554-556 consumed in manufacture .......54t used in making, Alabama.... 551,552,553 Colorado..... 544, 545, 546, 551, 552, 553 Georgin...... 544,545, 516,551,552, 553 Illinois ....... 544,545,546,551, 552,553 Indiana ...... 544,545,546,551,552,553 Indian Territory.

$545,546,551,55$ Kansas ...... 544, 545, 546,551,552,553 Kentucky .... 544, 545,546,551,552,553 Massachusetts

Mrissouri..... 544, 545,546,551,552,553 Montana ..... 544,545, 546,551, 552, 553 New Mexico. . 544, 545, 546, 551, 552, 553 New York ........ Ohio....... 544,545, 546,551,552,553 Pennsylvania 544, 545, 546, 551, 552, 553 Tennessee .... 544, 545, 546, 551, 552,553 Texas ................... 546, 553 ttah............... $544,545,546$ Virginia ...... 544,545,546,551,552,553

Washington .. 544,545,546,551,552, 553 West Virginia . 544, 545, 546, 551, 552, 553 Wisconsin ........5 545,546,551,552,553 Wroming........ 545, $546,551,552,553$ Colorado $\ldots \ldots \ldots . \ldots \ldots \ldots \ldots . .570-572$ character of coal used in making... 572 Connellsville district, Pennsylrania. 598,605
Page. Coke, definition of................... 52 establishments, Alabama............. 528 Colorado .... Georgia....................... 528

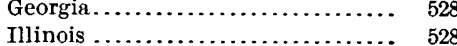

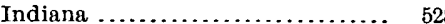
Indian Territory . . . . . . . . . . . . . . 528 Kansas ...................... 528 Kentucky ..................... 528 Massachusetts .................. 528 Missouri ..................... 528 Montana ..................... 528 New Mexico................... 528

New York ...................... 528 Ohio........................ 528 Pennsylvania ................. 528,529 Tennessee ...................... 528,529 Texas..................... 528, 529 Utah....................... 528, 529 Virginia ...................... 528, 529 Washington ................. 528,529 West Virginia ................. 528, 529 Wisconsin ................... 528,529 Wyoming.................. 528,529 exports ........................ 557 Georgia......................... 572-574

character of coal used in making... 574 Greensburg district, Pennsylvania.... 609 Illinois ...................... 574-576 character of coal used in making... 576 imports.......................... 557 Indiana $\ldots \ldots \ldots \ldots \ldots \ldots \ldots \ldots \ldots . \quad 576$ character of coal used in making... $\quad 577$ Indian Territory ................... 578 $\begin{array}{ll}\text { character of coal used in making... } & 579\end{array}$ Irwin district, Pennsylvania.......... 614

Kanawha district, West Virginia....... 627 Kansas ......................... 579-581 character of coal used in making... 581 Kentucky .................... 581-583 character of coal used in making... 583 manufacture, Alabama.......... 523,524, 525 Colorado ................ 523,524,525 Georgia.................. 523,524,525 Illinois .................. 523,524,525 Indian Territory ............ 523,524,525 Kansas ................... 523,524,525 Kentucky ............... 523,524,525 Massachusetts .............. 523,524 Missouri ................. 523,524,525 Montana ................. 523, 524, 525 New Mexico.............. 523,524,525 New York ............... 523,524,525 Ohio........... 523,524,525 Pennsylvania ............. 523,524,525 Tennessee ............... 523,524,525 Texas.......................... 525 Utah.................... 523,524,525 Virginia ................. 523,524,525 Washington ............... 523,524,525 West Virginia . ............. 523,524,525 Wisconsin ................. 523,524,525 Wyoming................... 523,524,525 Massachusetts ................... 583 by-product ovens ............... 558 Missouri ....................... . 583 character of coal used in making... 58 - 
Page.

Coke, Montana ........................ 585 character of coal used in making .. 586 New Mexico....................... 586 character of coal used in making .. 588 New River district, West Virginia ....... 626 New York ....................... 588 by-product coke ovens ........... 558

Ohio .......... 588-592 character of coal used in making .. $\quad 592$ district, Ohio .................. 590

ovens, Alabama ................ 531,582,533 by States ................. 527,532-534 Colorado ................. 531,532,533 Georgia................. 531,532,533 Illinois .................... 531,532,533 Indiana ................ 531,532,533 Indian Territory ............. 531, 532, 533 Kansas .................. 531,532,533 Kentucky ................ 531,532,533 Massachusetts ................. 533 Missouri ................. 531,532,533 Montana .................. 531,532,533 New Mexico............... 531, 532, 533 New York ................ 531,532,533 Ohio ........ 531, 532,533 Pennsylvania ................... 531,533 Tennessee ................... 531,533

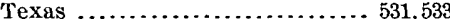
Utah........................ 531, 533 Virginia ................... 531, 533 Washington ................. 531,533 West Virginia . ................. 531,533 Wisconsin .................. 531,533 Wyoming ..................... 531,533

Pennsylvania ..................... 592-615 by-product ovens............... 558 character of coal used in making .. $\quad 595$ Connellsville district prices...... 603-605 shipments .....................600-603 production, by districts.......... 595-597 percentage yield of coal in manufacture 549 Alabama ........................ 549 $\begin{array}{ll}\text { Alabama } \ldots \ldots \ldots \ldots \ldots \ldots \ldots \ldots \ldots \ldots & 549 \\ \text { Colorado } \ldots \ldots \ldots \ldots \ldots \ldots \ldots \ldots \ldots . & 549\end{array}$ Georgia......................... 549 Illinois ......................... 549 Indiana ....................... 549 Indian Territory ................. 549 Kansas ......................... 549

Kentucky ..................... 549 Massachusetts .................. 549 Missouri ........................ 549 Montana ...................... 549 New Mexico....................... 549 New York ..................... 549 Ohio..... 549,550 Pennsylvania ................. 549,550 Tennessee .................... 549,550 Texas......................... 549,550 Utah......................... 549,550 Virginia ................... 549,550 Washington .................. 549,550

West Virginia .................. 549,550

Wisconsin ................. 549,550 Wyoming .................... 549,550 Pittsburg district, Pennsylvania ....... 610 Pocahontas Flat Top district, West Virginia
Page

Coke, prices, Connellsville, Pa., district.. 603-605 production ..................... 522 Alabama ........... 534, 535, 536, 542,543 Colorado ............ 534,535,536,542,543 Georgia............. 534, 535, 536, 542, 543 Illinois ............ 534, 535, 536, 542,543 Indiana ............ 534, 535, 536, 542, 543 Indian Territory ..... 534, 535,536, 542,543 Kansas ............. 534,535,536,542,543 Kentucky ........... 534, 535,536,542,543 Massachusetts ............. 536,543 Missouri............ 534, 535, 536, 542, 543 Montana............ 534, 535,536, 542, 543 New Mexico......... 534, 535, 536, 542, 543 New York ............ 534,535,536,543 Ohio............. 534, 535,536,542,543 Pennsylvania......... 534, 535, 536, 542,543 Tennessee ............ 534,535,536,542,543 Texas.............. 534, 535, 536, 542,543 Utah............... 534, 535, 536,542,543 Virginia ............ 534, 535, 536, 542,543 Washington ......... 534,535,536,542,543 West Virginia ....... 534, 535, 536, 542, 543 Wisconsin .......... 534, 535,536,542,543 Wyoming............. 534, 585, 536,543 rank of States in production........... 542 receipts at San Francisco............ 420 Reynoldsville-Walston district, Pennsylvania .................. 607 shipments ......................... 76 Connellsville district, Pennsylva-

nia ......................600-603

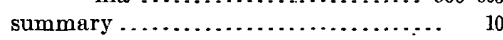

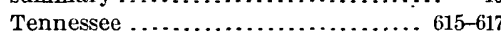
$\begin{array}{ll}\text { character of coal used in making ... } & 617\end{array}$ Texas........................ 617 Upper Connellsville district, Pennsylvania ...................... 613

Upper Monongahela district, West Virginia..................... 629

Upper Potomac district, West Virginia...................... 628

Utah ............................ 617 value, Alabama............... 537, 538, 539 value and selling price, by States.... 537-542 Colorado................... 537, 538, 539 Georgia .................... 537, 538, 539 Illinois........... 537,538,539 Indiana ................. 537, 538,539 Indian Territory ............ 537, 538,539 Kansas ................... 537,538, 539 Kentucky ................ 537, 538, 539 Massachusetts................. $\quad 539$ Missouri ................. 537, 538, 539 Montana ................. 537,538,539 New Mexico............... 537,538,539 New York ................. 537,538,539 Ohio.................... 537,538,539 Pennsylvania.............. 537,538,539 Tennessee ............... 537,538,539 Utah.................. 537,538,539

Virginia .................. 537,538,539 Washington .............. 537,538,539 West Virginia ............. 537,538,539 Wisconsin ............... 537,538,539 wyoming. . . . . . . . . . . . . 537,538, 539 per ton, by States............. 540,541

\section{GEOL, PT $6-41$}




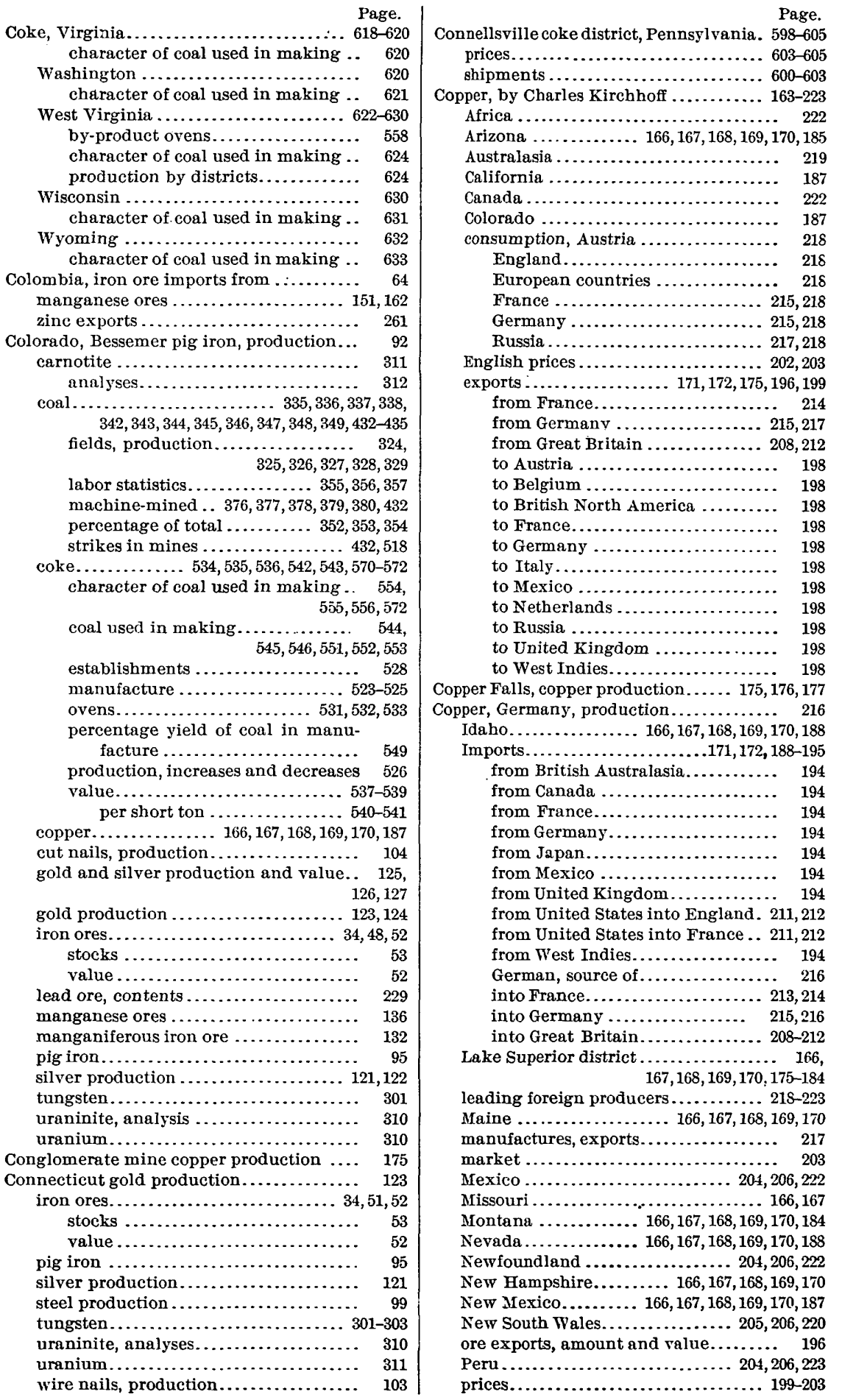




\begin{tabular}{|c|c|}
\hline Page. & $a_{0}$ \\
\hline opper, production........................... & Copper, production, Steppes district mine.. \\
\hline Adventure mine. & Sweden.. \\
\hline Algiers ........ & Tamarack, jr., mine.. \\
\hline Allouez mine. - & Tamarack mine... \\
\hline Altai mine....................... 218 & Tharsis mine .................. 204,205 \\
\hline Argentina $\ldots \ldots \ldots \ldots \ldots \ldots \ldots \ldots, 204,206$ & United States.................. 204,206 \\
\hline Ash Bed mine ................... 176 & Ural mine $\ldots \ldots \ldots \ldots \ldots \ldots \ldots \ldots \ldots . . \ldots \ldots$ \\
\hline Atlantic mine ............. $175,176,177$ & Venezuela......... \\
\hline 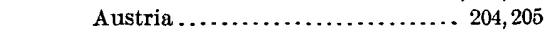 & Wolverine mine................ 175,177 \\
\hline Belt mine .................... 176 & 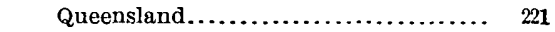 \\
\hline Boleo mine. & Russia ................ \\
\hline Bolivia $\ldots \ldots \ldots \ldots \ldots \ldots \ldots \ldots \ldots \ldots \ldots \ldots \ldots \ldots$ & South Australia .............. 205, 206,222 \\
\hline California ........... 166,167, $168,169,170$ & South Dakota........................ \\
\hline Calumet and Hecla mine....... 175, 176 & 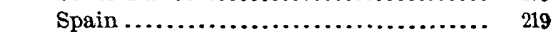 \\
\hline Canada .................... 204,206 & summary $\ldots \ldots \ldots \ldots \ldots \ldots \ldots \ldots \ldots \ldots \ldots$ \\
\hline Cape Company mine .......... 205,206 & 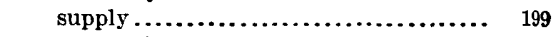 \\
\hline Cape of Good Hope............ 205,206 & Tasmania....................... \\
\hline Caucasus mine .................. 218 & Tennessee $. . . \ldots \ldots \ldots \quad 166,167,168,169,170,188$ \\
\hline Central mine $\ldots \ldots \ldots \ldots \ldots \ldots . \ldots 175,176,177$ & trade, England .................... 208-212 \\
\hline Chile ...................... 204,206 & France..$\ldots \ldots \ldots \ldots \ldots \ldots \ldots \ldots \ldots \ldots \ldots \ldots \ldots \ldots$ \\
\hline Cliff mine $\ldots \ldots \ldots \ldots \ldots \ldots \ldots \ldots \ldots \ldots$ & Germany ............ \\
\hline Colorado............ 166,167,168, 169,170 & 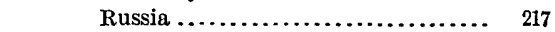 \\
\hline Conglomerate mine ............. $\quad 175$ & Utah.............. 166,167,168,169,170,186 \\
\hline Copper Falls............. 175, 176,177 & Vermont $\ldots \ldots \ldots \ldots \ldots 166,167,168,169,170,188$ \\
\hline ro mine................ 204, 206 & Washington $\ldots \ldots \ldots \ldots \ldots \ldots \ldots \ldots \ldots \ldots \ldots \ldots \ldots \ldots, 169$ \\
\hline Evergreen Bluff mine ............. 176 & world's production .................. 204-207 \\
\hline Finland-Pitkaranda mine.......... & Wyoming ............ $166,167,168,169,170,187$ \\
\hline Franklin mine $\ldots \ldots \ldots \ldots \ldots . \ldots 175,176,177$ & Cornwall iron ore, shipments ............. 83 \\
\hline Germany $. \ldots \ldots \ldots \ldots \ldots \ldots \ldots \ldots \ldots \ldots \ldots \ldots, 205$ & Corocoro mine, copper production ....... 204, 206 \\
\hline Grand Portage mine.............. 175 & Corpus Christi, Tex., importation of copper. \\
\hline Great Britain .................. 204,205 & Corundum and emery, summary........... \\
\hline Hancock mine ................... 175 & Cost copper per ton, Atlantic mine......... \\
\hline$\ldots \ldots \ldots \ldots \ldots \ldots \ldots \ldots 204,205$ & Cox, James, on coal trade of St. Louis, Mo. 414-416 \\
\hline mine $\ldots \ldots \ldots \ldots \ldots \ldots 175,176,177$ & Crucible steel, production. ................. \\
\hline Isle Royale mine ................. & Cuba, iron ore $\ldots \ldots \ldots \ldots \ldots \ldots \ldots \ldots \ldots \ldots$ \\
\hline Italy $\ldots \ldots \ldots \ldots \ldots \ldots \ldots \ldots \ldots \ldots \ldots \ldots \ldots \ldots \ldots$ & imports from $\ldots \ldots \ldots \ldots \ldots$ \\
\hline Japan ..................... 205,206 & shipments ...................... \\
\hline Kearsarge mine $\ldots \ldots \ldots \ldots \ldots \ldots \ldots \quad 176,177$ & manganese ores $\ldots \ldots \ldots \ldots \ldots \ldots \ldots$ 146-149, 162 \\
\hline Mansfield mine................ 204,205 & exports .......................... 146 \\
\hline and Barry mine........... 204,205 & Cut nails, California, production.............. \\
\hline ine................ 175, 176 & Colorado, production................ \\
\hline States....... 166,167,168, 169,170 & Illinois, production...$\ldots \ldots \ldots \ldots \ldots$ \\
\hline Minnesota mine ............... 176 & Indiana, production............. \\
\hline National mine.................. & Kentucky, production................ \\
\hline Namaque Company mine....... 205,206 & Maryland, production............... \\
\hline New Quebrada mine .......... 204, 206 & Massachusetts, production ........... \\
\hline Nonesuch mine.................. & Missouri, production $\ldots \ldots \ldots \ldots \ldots \ldots$ \\
\hline Norway ...................... 204,205 & New Jersey, production ................ \\
\hline Ogima mine................. 176 & Ohio, production ................... \\
\hline Osceola mine............ 175, 176,177 & Pennsylvania, production.............. \\
\hline Peninsula mine .............. 176,177 & Virginia, production $. . . . \ldots \ldots \ldots \ldots . . . .$. \\
\hline Pewabic mine ................. 175 & West Virginia, production ............. \\
\hline Phoenix mine.................... & Wyoming, production ............... \\
\hline Quiney mine $\ldots \ldots \ldots \ldots \ldots \ldots 175,176,177$ & Dakota coal fields, production....... 325, 327,329 \\
\hline recapitulation, Africa ............ 207 & Detroit, Mich., importation of copper ...... 193 \\
\hline Asia $\ldots \ldots \ldots \ldots \ldots \ldots \ldots \ldots \ldots \ldots$ & Dominion of Canada, zinc exports ......... \\
\hline Australasia $\ldots \ldots \ldots \ldots \ldots \ldots \ldots$ & Duenweg Camp, production of zinc and \\
\hline Europe...$\ldots \ldots \ldots \ldots \ldots \ldots$ & lead ore $\ldots \ldots \ldots \ldots \ldots \ldots \ldots \ldots$ \\
\hline North America ................ & Eastern States, zinc production ......... 250,251 \\
\hline South America.............. & Ecuador, zinc exports ................ \\
\hline Ridge mine................ 175, 176 & Emery. (See Corundum and emery.) \\
\hline Rio Tinto mine.............. 204, 205 & 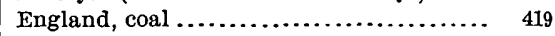 \\
\hline St. Clair mine.................... 175 & copper consumption................. \\
\hline Seville mine.................. 204, 205 & imports into France.............. \\
\hline Sheldon and Columbia mine...... 176 & into Germany ................ \\
\hline Southern States ..... 166, 167, 168, 169, 170 & from United States......... 211, 212 \\
\hline Spain and Portugal ............ 204, 205 & prices...................... 202,203 \\
\hline
\end{tabular}




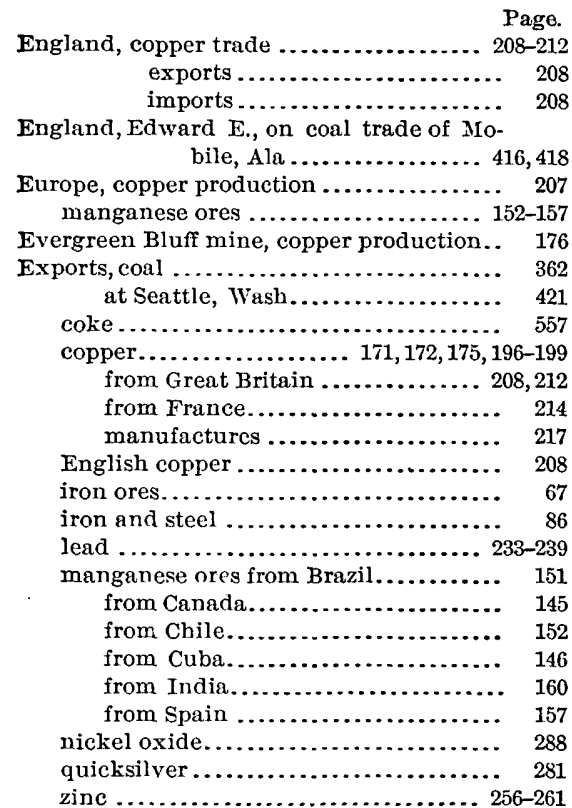

Fairmont coal field, West Virginia........ 512

Feldspar, summary.................... 15

Ferromanganese and spiegeleisen production...........................

Fibrous talc, summary ..................

Finland, pig iron.. steel .

Finland, Pitkaranda mine copper production....................... 218

Fleming, H.S., on coal trade of New York City ...................... 381-383

Flint, summary ........................ 15

Fluorspar, summary................... 13

France, coal ...................... 113,363, 367

copper consumption...............215,218 exports from .................... 214 exports to....................... 198 imports ........................ 214 imports from, to United Statcs..... 94 from United States ........... 211, 212 into Germany ................ 216 trade $\ldots \ldots . .213-215$

iron ore......................... 113 lead consumption ..................... 247 production ..................... 245, 246 manganese ores .................. 153,162 nickel, production................... 289 pig iron............................ 114 steel ................ 114

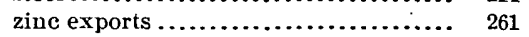
Franklin mine copper production.... 175, 176,177 French Africa, iron ore imports from ...... 64 Fuels, summary ..................... 8-11 Fuller's earth, summary.

Galena Camp, production of zinc and lead ore........................ 252

Galena-Joplin zinc district............. 252-255 Garnet, summary.
Gas, coke by-product, value................. Page.

, value............ 560

Georgia, bauxite ..................... 270

coal..................... $335,336,337$, $338,342,343,344,345,346,347,348,349,435$ fields, production........... 324, 326, 328 labor statistics. ............... 355, 356, 357 percentage of total .......... 352, 353, 354 coke ........... 534, 535, 536, 542,543,572-574 character of coal used in making .. $\quad 554$ $555,556,574$ coal used in making............ 544 $545,546,551,552,553$ establishments ................. 528 manufacture ............... 523, 524,525 ovens.................... 531,532, 533 percentage yield of coal in making. $\quad 549$ production, increases and decreases 526 value ...................... 537, 538, 539 value per short ton .............. 540,541 gold and silver production and value .. 125 , 126,127
123,124 .... 123, 124 iron ores................... 34,49-51,52 stocks......................... 53

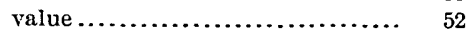
manganese ores ................. 130, 137 pig iron.......................... 95 silver production...................... 121, 122 Germany and Luxemburg coal........... I13 iron ore....................... 113 pig iron........................ 114 steel ........................... 114

coal, production ................... 363-366

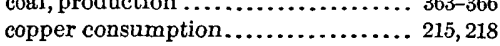
exports ....................... 215, 217 to........................... 198 imports........................ 215 from $\ldots \ldots \ldots \ldots \ldots \ldots \ldots \ldots \ldots . .194$ source of.................... 216 production ................ 204, 205, 216 trade ......................... 215 lead consumption .................. 247 imports into United States ........ $\quad 239$ production .................... 245, 246 manganese ores .................. 154, 162 nickel, production.................. $\quad 289$ zinc exports ........................ 261 Gold and silver..................... 119-127 Gold and silver, production and value--

Alabama .................... 125, 126, 127

Alaska...................... 125, 126, 127

Arizona ...................... 125,126,127

California ..................... 125, 126,127

Colorado ..................... 125, 126, 127

Georgia...................... 125, 126, 127

Idaho ...................... 125, 126, 127

Iown ........................... 125, 126

Maine ............................ 127

Maryland ................... 125, 126, 127

Michigan...................... 125, 126, 127

Minnesota ...................... 125, 126

Missouri ........................... 127

Montana ...................... 125, 126, 127

Nevada..................... 125, 126, 127

New Arexico...................... 125, 126, 127

North Carolina.................. 125, 126, 127 
Gold and silver, production and value-C't'd. Oregon ............ 125, 126, 127 South Carolina ................ 125, 126,127 South Dakota ............... 125, 126, 127 Tennessee ......................125, 126

Texas ....................... 125, 126, 127 Utah ....................... 125, 126, 127 Vermont .................... 125, 126,127 Virginia...................... 125, 126, 127 Washington ................. 125, 126, 127 Wyoming.................... 125, 126, 127

Gold production-

Alabama ......................... 123

Alaska............................. 123, 124

Arizona ........................... 123, 124

by States, with increase and decrease over $1898 \ldots \ldots \ldots \ldots \ldots \ldots \ldots . . \ldots \ldots$ California .................... 123,124 Colorado ....................... 123,124 Connecticut ................... 123 Georgia.................... 123, 124

Idaho ....................... 123, 124

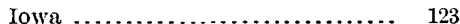

Maine ....................... 124

Maryland ....................... 123

Michigan.................... 123, 124

Minnesota................... 123

Montana .................... 123, 124

Nebraska...................... 123

Nevada ....................... 123, 124

New Mexico.................. 123, 124

North Carolina ................. 123, 124

Oregon ..................... 123,124

South Carolina ................ 123, 124

South Dakota. ................. 123,124

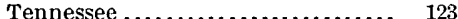

Texas........................... 123, 124

Utah........................ 123,124

Vermont ....................... 123

Virginia ..................... 123

Washington ................. 123, 124

Wyoming.................... 123, 124

summary

Granby Camp, production of zinc and lead ore...................... 252

Grand Portage mine, copper production ... $\quad 175$

Graphite, summary ..................... 16

Great Britain, coal .................. 113, 363, 365

copper, exports from ............... 208-212

production ................... 204, 205

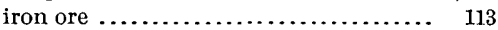

lead consumption ................... 247

production .................... 245,246

manganese ores ................. 152

pig iron ........................... 114

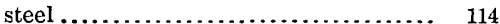

steel, Bessemer, ingots and rails ........ 116

open-hearth ................... 116

Great Eastern Quicksilver mine, California, production .................. 276

Great Western Quicksilver mine, California, production ................. 274

Greece, coal ........................ 113

ron ore $\ldots \ldots \ldots \ldots \ldots \ldots \ldots \ldots \ldots \ldots . .113$

imports from

lead production ..................... 245,246

manganese ores $\ldots \ldots \ldots \ldots \ldots \ldots \ldots \ldots . \ldots \ldots, 160,162$
Page.

Greensburg coke district, Pennsylvania.... 609 Gregg camp, production of zinc and lead ore $\quad 252$ Grindstones, summary .................. 12 Gummite, analysis .................... $\quad 310$ Gypsum, summary .................... 13 Hamburg, copper imports into Germany ... 216 Hancock mine, copper production ........ 175 Harrison, J. W., on coal trade of San Francisco, Cal ................. 418-420

Herzegovina, manganese ores, production.. $\quad 162$. Hübnerite. (See Tungsten.)

Hungary, copper production ............. 204, 205

lead production .................. 245,246

manganese ores, production . .......... 162

Huron mine, copper production...... 175, 176, 177

Idaho, antimony ....................... 291 coal .............................. 335, 336 $337,338,342,343,344,345,346,347,348,349$ fields, production ............... 325-329 percentage of total .............. $352-354$ copper............ 166, 167, 168, 169, 170,188 gold and silver production and value.. 125 126,127 gold production ................. 123,124 lead ore, contents.................. 229 molybdenum silver production .................... 121,122 tungsten......................... 301

Illinois, basic pig iron, production......... 92 Bessemer pig iron, production......... 92 steel ingots, production.......... 97 coal................... 335, 336, 337, 338 , $342,343,344,345,346,347,348,349,437-441$ fields, production........... $324,326,328$ labor statistics............. 355, 356,357 machine-mined ...... 376, 377, 378, 379, 380 percentage of total .......... 352, 353,354 coke............ 534, 535, 536, 542,543, 574-576 character of coal used in making ... 554 $555,556,576$ coal used in making............... 544 , $545,546,551,552,553$ establishments ................. 528 manufacture .............. 523, 524, 525 ovens..................... 531,532,533 percentage yield of coal in making. 549 production, increases and decreases. $\quad 526$ value $\ldots \ldots \ldots \ldots \ldots \ldots \ldots \ldots .537,538,539$ value per short ton............. 540,511 cut nails, production ................ 104 lead ore, contents.................... $\quad 229$ pig iron........................... 90,95 steel production ................... 97,98 Importation of copper, Arizona ........... 193 Baltimore, Maryland ................ 193 Champlain, New York............... 193 Corpus Christi, Texas................. 193 Detroit, Michigan .................... 193 Newark, New Jersey................. 193 New York, New York .............. 193 Passamaquoddy, Maine .............. 193 Perth Amboy, New Jersey ............ 193 San Francisco, California ............. 193 Imports, aluminum..................... 269 antimony ........................... 293 coal............................. 360 coal-tar products $\ldots \ldots \ldots \ldots \ldots \ldots \ldots \ldots, 564-566$ 


\begin{tabular}{|c|c|}
\hline ( & 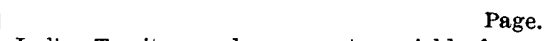 \\
\hline balt oxide & percentage yield of \\
\hline$\ldots \ldots \ldots \ldots$ & coal in making ............... \\
\hline$\ldots \ldots 171,172,188-195$ & production, increases and decreases. \\
\hline$f \ldots \ldots \ldots \ldots \ldots$ & value $\ldots \ldots \ldots \ldots \ldots \ldots \ldots \ldots, 537,538,5$ \\
\hline copper, into France... & value per short ton....$\ldots \ldots$ \\
\hline copper, into Great Britain & Infusorial earth, summary ................ \\
\hline English copper .......... & Iowa, coal $\ldots \ldots \ldots \ldots \ldots \ldots \ldots \ldots \ldots, 335,336,337$ \\
\hline iron and steel.. & $338,342,343,344,345,346,347,348,349,446-449$ \\
\hline iron ores....... & fields, production... \\
\hline from Colombia.. & labor statistics.............. $355,356,35$ \\
\hline uba ............ & machine-mined ...... $376,377,378,379,38$ \\
\hline rench Africa. & percentage of total $\ldots \ldots \ldots \ldots 352,353,34$ \\
\hline 64 & ines ........... \\
\hline 64 & gold pro \\
\hline 64 & d value.... \\
\hline liar & $\ldots \ldots \ldots .22$ \\
\hline 64 & etion..................... \\
\hline 64 & $d \ldots \ldots . . . . .$. \\
\hline$\cdots$ & (................ \\
\hline$\ldots \ldots \ldots \ldots .233-239$ & ............... \\
\hline ......... 239 & ports .............. \\
\hline$\ldots 86,141-143$ & imports, decrease in ............. \\
\hline 287 & oduction........... \\
\hline 280 & $\ldots \ldots \ldots$ \\
\hline 107 & 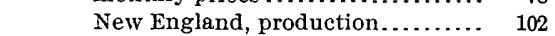 \\
\hline .... 256-261 & roduction.......... \\
\hline 258 & roduction .............. \\
\hline al .................. 113,363,372 & Pennsylvania, Allegheny County, \\
\hline$\ldots \ldots \ldots \ldots \ldots \ldots \ldots \ldots \ldots$ & $\ldots \ldots \ldots \ldots \ldots \ldots \ldots$ \\
\hline$\ldots \ldots \ldots \ldots \ldots \ldots \ldots 160,162$ & production.......... \\
\hline xports............. 160 & duction ....... \\
\hline$\ldots \ldots \ldots \ldots 335,336,337,338$, & leading articles...... \\
\hline $344,345,346,347,348,349,441-444$ & \\
\hline on $\ldots \ldots \ldots \ldots \ldots 324,326,328$ & $\ldots \ldots \ldots 104,10$ \\
\hline ........... $355,356,357$ & . \\
\hline d .. $376,377,378,379,380,441$ & pes................. \\
\hline total ........ $352,353,354$ & . $6,75-78,10$ \\
\hline$\ldots \ldots 534,535,536,542,543,576$ & duction.............. \\
\hline f coal used in making.. 554, & (n.............. \\
\hline $555,556,577$ & countries.... \\
\hline coal used in making.. & production........ \\
\hline $545,546,551,552,553$ & an, in $1899 . \ldots \ldots \ldots \ldots$ \\
\hline establishments ................. 528 & Birkinbine........... 31-6 \\
\hline$\ldots \ldots \ldots \ldots \ldots \ldots 523,524,525$ & $\ldots \ldots \ldots \ldots \ldots \ldots \ldots 34,45,5$ \\
\hline$\ldots \ldots \ldots \ldots \ldots \ldots \ldots \ldots 531,532,533$ & .... \\
\hline ield of coal in making. & n.................. \\
\hline n, increases and decreases. $\quad 526$ & Lake Superior .......... 37- \\
\hline$\ldots \ldots \ldots \ldots \ldots 537,538,539$ & on $\ldots \ldots \ldots \ldots \ldots \ldots$ \\
\hline$\ldots \ldots \ldots 540,541$ & Colorado................... 34,48 \\
\hline on $\ldots . . . \ldots \ldots \ldots \ldots . .104$ & s........................ \\
\hline & value.... \\
\hline coal ............. 335, 336, 337, & Connecticut. \\
\hline $344,345,346,347,348,349,444$ & \\
\hline on.......... & \\
\hline 355,35 & (n, \\
\hline .. $376,377,378,379,380,445$ & shipments ............ \\
\hline ........ 352-354 & shipments .................. \\
\hline$\ldots \ldots \ldots 444,517$ & 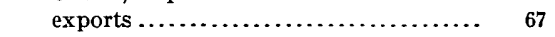 \\
\hline$\ldots \ldots 534,535,536,542,543,578$ & Georgia ............... \\
\hline of coal used in making... 554 , & ........... \\
\hline $555,556,579$ & $\ldots \ldots \ldots$ \\
\hline coal used in making............... 544, & imports $\ldots \ldots \ldots \ldots \ldots \ldots \ldots \ldots \ldots \ldots 63-66,8$ \\
\hline $545,546,551,552,553$ & n Colombia ..................... \\
\hline establishments ... & from Cuba........................ \\
\hline $523,524,52$ & from French Africa ............. \\
\hline $531,532,533$ & from Greece ................... \\
\hline
\end{tabular}




\begin{tabular}{|c|c|}
\hline Page. & Page. \\
\hline on imports, from Italy .................. & Iron, value by States ........ \\
\hline from Labrador ............... & Vermont, stocks . ............ \\
\hline from Newfoundland ............. & Virginia.......... \\
\hline ortugal . & stocks \\
\hline ain ......... & value. \\
\hline from United Kingdom............ & West Virginia $\ldots \ldots \ldots \ldots \ldots \ldots \ldots \ldots, 34,46,52$ \\
\hline Kentucky $\ldots \ldots \ldots \ldots \ldots \ldots \ldots \ldots \ldots, 34,51,5$ & stocks $\ldots \ldots \ldots \ldots \ldots \ldots \ldots \ldots \ldots$ \\
\hline stocks $\ldots \ldots \ldots \ldots \ldots \ldots \ldots \ldots \ldots \ldots$ & value $\ldots \ldots \ldots \ldots \ldots \ldots \ldots \ldots \ldots \ldots$ \\
\hline$\ldots \ldots \ldots \ldots \ldots \ldots$ & Wisconsin $\ldots \ldots \ldots \ldots \ldots$ \\
\hline lake shipping and receiving docks, dis- & stocks ......... \\
\hline petween............... & value $\ldots \ldots \ldots \ldots \ldots \ldots \ldots$ \\
\hline or prices...$\ldots \ldots \ldots \ldots \ldots$ & world's production by countries ....... \\
\hline Lake Superior region................. & Wyoming $\ldots \ldots \ldots \ldots \ldots \ldots \ldots \ldots, 34,51,52$ \\
\hline Maryland $\ldots \ldots \ldots \ldots \ldots \ldots \ldots \ldots \ldots, 34,51,5$ & stocks $\ldots \ldots \ldots \ldots \ldots \ldots \ldots \ldots \ldots$ \\
\hline$\ldots \ldots \ldots \ldots \ldots \ldots \ldots \ldots \ldots \ldots$ & . \\
\hline value $\ldots \ldots \ldots \ldots \ldots \ldots \ldots \ldots \ldots \ldots$ & Iron trade, boom in $\ldots \ldots \ldots \ldots \ldots \ldots \ldots \ldots \ldots \ldots+73$ \\
\hline Massachusetts $\ldots \ldots \ldots \ldots \ldots \ldots \ldots, 34,51,5$ & Canada......................... 111,112 \\
\hline$\ldots \ldots \ldots \ldots \ldots \ldots \ldots \ldots \ldots \ldots \ldots$ & trict, Pennsylvania ..... \\
\hline vall & er mine production ... \\
\hline$\ldots \ldots \ldots \ldots \ldots \ldots \ldots .34,43,5$ & $\ldots \ldots \ldots \ldots \ldots \ldots \ldots \ldots . .113,363,373$ \\
\hline (n) & orts to........................ 198 \\
\hline n................... & s into Great Britain ....... 210,211 \\
\hline Aucing 50,000 tons or more... & ion $\ldots \ldots \ldots \ldots \ldots \ldots \ldots 204,205$ \\
\hline$\ldots \ldots \ldots \ldots \ldots \ldots \ldots \ldots \ldots \ldots \ldots, 34,44,5$ & n............................. \\
\hline$\ldots \ldots \ldots \ldots \ldots \ldots \ldots \ldots, \ldots$ & imports from...$\ldots \ldots \ldots \ldots \ldots \ldots$ \\
\hline$\ldots \ldots \ldots \ldots \ldots \ldots \ldots \ldots \ldots$ & lead consumption................... \\
\hline$\ldots \ldots \ldots \ldots \ldots \ldots \ldots \ldots \ldots \ldots+34,51,5$ & production....$\ldots \ldots \ldots$ \\
\hline 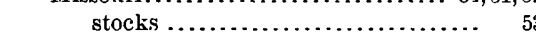 & 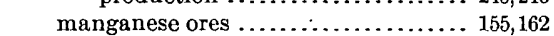 \\
\hline 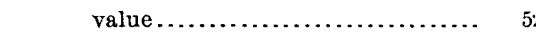 & manganiferous iron ores ............. 155 \\
\hline Nevada....................... $34,51,5$ & pig iron................................ \\
\hline$\ldots \ldots \ldots \ldots \ldots \ldots \ldots \ldots \ldots \ldots+5$ & steel $\ldots \ldots \ldots \ldots \ldots \ldots, \ldots \ldots \ldots \ldots \ldots \ldots$ \\
\hline 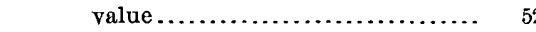 & Japan, coal................. $113,363,368,419$ \\
\hline$c 0 \ldots \ldots \ldots \ldots \ldots \ldots \ldots \ldots 34,51,5$ & copper imports from $\ldots \ldots \ldots \ldots \ldots \ldots, 194$ \\
\hline$\ldots \ldots \ldots \ldots \ldots \ldots \ldots \ldots$, & ermany $\ldots \ldots \ldots \ldots \ldots \ldots$ \\
\hline$\ldots \ldots \ldots \ldots \ldots \ldots \ldots \ldots \ldots$ & reat Britain............ 210,211 \\
\hline$\ldots \ldots \ldots \ldots \ldots \ldots \ldots \ldots \ldots+34,49,5$ & 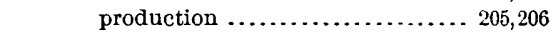 \\
\hline n.................. 8 & 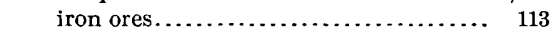 \\
\hline (5) & se ores $\ldots \ldots \ldots \ldots \ldots \ldots$. \\
\hline$\ldots \ldots \ldots \ldots \ldots \ldots \ldots \ldots \ldots \ldots \ldots \ldots$ & production...$\ldots \ldots \ldots \ldots \ldots$ \\
\hline New York $\ldots \ldots \ldots \ldots \ldots \ldots \ldots \ldots \ldots \ldots \ldots, 48,5$ & pig iron...$\ldots \ldots \ldots \ldots \ldots \ldots \ldots \ldots \ldots \ldots \ldots$ \\
\hline 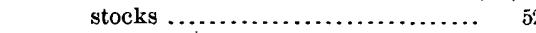 & steel $\ldots \ldots \ldots \ldots \ldots \ldots \ldots \ldots \ldots \ldots \ldots \ldots$ \\
\hline 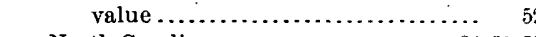 & Java, manganese ores $\ldots \ldots \ldots \ldots \ldots \ldots \ldots \ldots \ldots \ldots$ \\
\hline ina $\ldots \ldots \ldots \ldots \ldots \ldots \ldots \ldots \ldots .34,51,5$ & Joplin Camp, production of zinc and Jead \\
\hline$\ldots \ldots \ldots \ldots \ldots \ldots \ldots \ldots \ldots$ & ore $\ldots \ldots \ldots \ldots \ldots \ldots \ldots \ldots \ldots \ldots \ldots$ \\
\hline$\ldots \ldots \ldots \ldots \ldots \ldots \ldots \ldots \ldots \ldots$ & Kanawha coke district, West Virginia ..... \\
\hline$\ldots \ldots \ldots \ldots \ldots \ldots \ldots \ldots \ldots \ldots \ldots+34,51,5$ & Kansas, coal $\ldots \ldots \ldots \ldots \ldots \ldots \ldots . \ldots 335,336,337,338$, \\
\hline stoc & $342,343,344,345,346,347,348,349,449-452$ \\
\hline n....................... & oduction........... $325,327,329$ \\
\hline Pennsylvania................... $34,46,5$ & labor statistics............ $355,356,357$ \\
\hline$\ldots \ldots \ldots \ldots \ldots \ldots \ldots \ldots \ldots$ & e-mined .. $376,377,378,379,380,449$ \\
\hline$\ldots \ldots \ldots \ldots \ldots \ldots \ldots \ldots \ldots, \ldots$ & percentage of total. ........ $352,353,354$ \\
\hline$\ldots \ldots \ldots \ldots \ldots \ldots \ldots \ldots \ldots \ldots \ldots+31,8$ & strikes in mines ................ 450 \\
\hline ke Erie ports ........ & coke.......... 534, 535,536, 542, 543, 579-581 \\
\hline Lake Superior . . . . . $57,76,8$ & character of coal used in making... 554 , \\
\hline n.................. & $555,556,581$ \\
\hline lake ports........... & coal used in making............ 544, \\
\hline$\ldots \ldots \ldots \ldots \ldots \ldots \ldots \ldots \ldots \ldots$ & $545,546,551,552,553$ \\
\hline$\ldots \ldots \ldots \ldots \ldots \ldots 34,48,52$ & establishments ................ 528 \\
\hline , & manufacture $\ldots \ldots \ldots \ldots \ldots \ldots 523,524,525$ \\
\hline value $\ldots \ldots \ldots \ldots \ldots \ldots \ldots \ldots \ldots$ & $\ldots \ldots \ldots \ldots \ldots \ldots \ldots 531,532,533$ \\
\hline Texas....................... $34,51,52$ & percentage yield of coal in making - 549 \\
\hline stocks & production, increases and decreases. 526 \\
\hline (1) & value ..................... 537, 538,539 \\
\hline transportation...................... & value per short ton $\ldots \ldots \ldots \ldots \ldots \ldots 540,541$ \\
\hline$\ldots \ldots \ldots \ldots \ldots \ldots \ldots \ldots \ldots, 34,51,52$ & lead ore, contents................. 229 \\
\hline 53 & zinc production $\ldots \ldots \ldots \ldots \ldots \ldots \ldots \ldots \ldots \ldots \ldots, 250,251$ \\
\hline 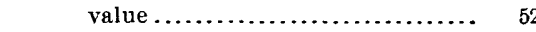 & arsarge mine, copper production $\ldots \ldots . .176,177$ \\
\hline
\end{tabular}




\begin{tabular}{|c|c|}
\hline & age. \\
\hline ig iron, production .. & Lead ore contents, California .... \\
\hline conl............... $335,336,337,338$ & Canada ................. \\
\hline $342,343,344,345,346,347,348,349,452-457$ & Colorado.................. \\
\hline fields, eastern production..... $324,326,328$ & Idaho..... \\
\hline labor statistics .................. 355-357 & Illinois .. \\
\hline machine-mined .. $376,377,378,379,380,453$ & Iowa.... \\
\hline percentage of total ............. $352-354$ & Kansas .. \\
\hline strikes in mines . ............... 453 & $\ldots \ldots \ldots \ldots \ldots \ldots$ \\
\hline coke.......... 534, 535, 536, 542,543,581-583 & Missouri ........................ \\
\hline character of coal used in making... 554, & 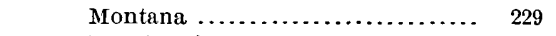 \\
\hline $555,556,583$ & New Mexico.................... \\
\hline coal used in making.... & 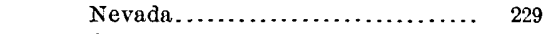 \\
\hline $545,546,551,552,553$ & Oregon ......... \\
\hline establishments. & South Dakota \\
\hline manufacture $\ldots \ldots \ldots \ldots \ldots \ldots 523,524,525$ & 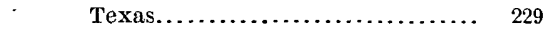 \\
\hline ovens ..................... 531, 532, 533 & $\operatorname{Utah} \ldots \ldots \ldots \ldots \ldots \ldots \ldots \ldots \ldots \ldots \ldots \ldots \ldots$ \\
\hline percentage yield of coal in making. 549 & Virginia ........................... \\
\hline production, increases and decreases. & Washington .................... \\
\hline value $\ldots \ldots \ldots \ldots \ldots \ldots \ldots \ldots 537,538,539$ & Wisconsin $\ldots \ldots \ldots \ldots \ldots \ldots \ldots \ldots$ \\
\hline value per short ton $. . \ldots \ldots \ldots \ldots \ldots .540,541$ & prices............................ 241-243 \\
\hline cut nails, production .......... & production $\ldots \ldots \ldots \ldots \ldots \ldots \ldots \ldots, 229,245,246$ \\
\hline iron and steel, production..... & $\ldots \ldots \ldots \ldots \ldots 245,246$ \\
\hline iron ores..................... $34,51,52$ & Austria $\ldots \ldots \ldots \ldots \ldots \ldots \ldots \ldots \ldots \ldots \ldots \ldots \ldots \ldots \ldots \ldots, 246$ \\
\hline$\ldots \ldots 5$ & Belgium .................. 245,246 \\
\hline value $\ldots \ldots \ldots \ldots \ldots \ldots \ldots \ldots \ldots$ & France................... 245,246 \\
\hline pig iron.............................. & Germany .................... 245, 246 \\
\hline Kirchhoff, Charles, pafer on copper ...... 163-223 & Great Britain . . . . . . . . . . \\
\hline 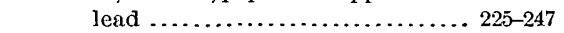 & 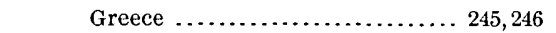 \\
\hline zinc $\ldots \ldots \ldots \ldots \ldots \ldots \ldots \ldots \ldots \ldots \ldots \ldots \ldots \ldots \ldots \ldots+249-266$ & Hungary $\ldots \ldots \ldots \ldots \ldots \ldots \ldots \ldots \ldots \ldots \ldots \ldots, 245$ \\
\hline R., on coal trade of & $\ldots \ldots \ldots \ldots \ldots \ldots 245,246$ \\
\hline Philadelphia ............. 391-398 & $\ldots \ldots \ldots \ldots \ldots \ldots 245,246$ \\
\hline Labrador, iron-ore imports from .......... & Spsin $\ldots \ldots \ldots \ldots \ldots \ldots \ldots \ldots \ldots \ldots \ldots \ldots \ldots$ \\
\hline Lake Superior copper ................. & sources ..... \\
\hline prices................... 199, 200,201 & 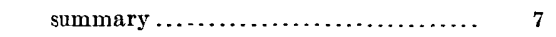 \\
\hline production $\ldots \ldots \ldots \ldots 166,167,168,169,170$ & warehouse transactions ............... \\
\hline$\ldots \ldots \ldots \ldots \ldots \ldots \ldots \ldots+36-45$ & world's consumption ................. \\
\hline analyses ............... & world's production ............... 244-246 \\
\hline prices. . & Limestone for iron flux, summary ...... 1,696 \\
\hline shipments .... & Litharge, summary $\ldots \ldots \ldots \ldots \ldots \ldots \ldots \ldots$ \\
\hline manga & Machine-mined coal................ 374-380 \\
\hline manganiferous iron ores.............. & Magnesite, summary ..................... \\
\hline Lamb, Col. William, on coal trade of Nor- & Maine, copper production $\ldots . .166,167, \mathbf{I} 68,169,170$ \\
\hline folk, Va .................. 418 & gold and silver production and value.. 127 \\
\hline Lead, by Charles Kirchhoff ............. 225-247 & gold production...$\ldots \ldots \ldots \ldots \ldots \ldots$ \\
\hline$\ldots \ldots \ldots \ldots \ldots \ldots \ldots 232,247$ & silver production.................... \\
\hline consumption, Austria-Hungars ....... 247 & Manganese and manganiferous ores, pro- \\
\hline Belgium $\ldots \ldots \ldots \ldots \ldots \ldots \ldots$ & duction.................... \\
\hline France......................... & Manganese ores, by John Birkinbine..... 129-162 \\
\hline Germany ............... & Alabama ............................ 130 \\
\hline Great Britain ... & analyses, Brazil.................... \\
\hline Italy ........... & Arkansas ....................... 130,135 \\
\hline Netherlands.... & $\operatorname{ary} \ldots \ldots \ldots \ldots \ldots \ldots \ldots$ \\
\hline Russia $\ldots \ldots \ldots \ldots \ldots \ldots \ldots \ldots \ldots$ & oduction................... \\
\hline Switzerland ................... & Bosnia, production .................. \\
\hline domestic producers............. . 230-232 & Brazil .................... 149-151,162 \\
\hline exports . . . . . . . . . . . . . . . . . . . . 233-239 & exports..$\ldots \ldots \ldots \ldots \ldots \ldots \ldots \ldots \ldots$ \\
\hline imports . . . . . . . . . . . . . . . . . . 233-239 & California $\ldots \ldots \ldots \ldots \ldots \ldots \ldots \ldots \ldots \ldots \ldots \ldots \ldots \ldots$ \\
\hline into United States from British & $\ldots \ldots \ldots \ldots \ldots \ldots \ldots \ldots 144,162$ \\
\hline North America ........... & $\ldots \ldots \ldots \ldots \ldots \ldots \ldots \ldots, 152,162$ \\
\hline from Germany ......... & $\ldots \ldots$ \\
\hline Mexico ....................... & Colombia $\ldots \ldots \ldots \ldots \ldots \ldots \ldots \ldots \ldots, 151,162$ \\
\hline United Kingdom .......... & Colorado ......................... 136 \\
\hline sources of $\ldots \ldots \ldots \ldots \ldots \ldots \ldots \ldots$ & Cuba ...................... 146-149,162 \\
\hline market .... & Europe ....................... 152-157 \\
\hline ts, Alaska..... & exports from Brazil ................ 151 \\
\hline Arizona............................ & Canada...$\ldots \ldots \ldots \ldots \ldots \ldots \ldots$ \\
\hline
\end{tabular}




\begin{tabular}{|c|c|}
\hline & age. \\
\hline 146 & Mason and Barry copper mine, \\
\hline India & tion..................... 204,205 \\
\hline Spain . & Mass copper mine, production...... \\
\hline France $\ldots \ldots \ldots \ldots \ldots \ldots \ldots \ldots \ldots \ldots \ldots \ldots \ldots \ldots \ldots \ldots \ldots \ldots, 162$ & Massachusetts coal fields, anthracite, pro- \\
\hline . 144-162 & $324,326,328$ \\
\hline Georgia....... & coke............. \\
\hline Germany ..... & coke, character of coal used in making 554 , \\
\hline Great Britain............ & 555,556 \\
\hline Greece...................... 160,162 & coal used in making.. \\
\hline Herzegovina, production ............ 162 & establishments ........ \\
\hline Hungary, production............. 162 & manufacture ................ 523,524 \\
\hline$\ldots \ldots \ldots \ldots \ldots \ldots, 86,141,143$ & ovens...................... 533 \\
\hline$\ldots \ldots \ldots \ldots \ldots \ldots 160,362$ & percentage yield of coal in mak- \\
\hline$\ldots \ldots \ldots 155,162$ & ing $\ldots \ldots \ldots \ldots \ldots \ldots \ldots \ldots \ldots \ldots \ldots$ \\
\hline$\ldots 161,162$ & production, increase and decrease.. \\
\hline ... 161,162 & value $\ldots \ldots \ldots \ldots \ldots \ldots \ldots \ldots \ldots \ldots$ \\
\hline$\ldots \ldots \ldots \ldots \ldots \ldots \ldots \ldots .138$ & value per short ton............... \\
\hline (n.................... & cut nails, production...$\ldots \ldots \ldots \ldots$ \\
\hline$\ldots \ldots \ldots \ldots \ldots \ldots \ldots \ldots$ & iron ores.................... \\
\hline lland $\ldots \ldots \ldots \ldots \ldots \ldots \ldots \ldots, 146,162$ & stocks ............ \\
\hline les, production .......... 162 & value..... \\
\hline 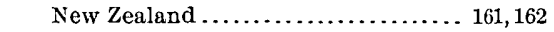 & pig iron...... \\
\hline ... 130,139 & steel, production . \\
\hline$\ldots 130,139$ & wire nails, \\
\hline$\ldots \ldots \ldots \ldots \ldots 160,162$ & n............... \\
\hline$\ldots \ldots \ldots \ldots \ldots \ldots .85,129-131$ & $\ldots \ldots \ldots \ldots \ldots \ldots$ \\
\hline$\ldots \ldots \ldots \ldots \ldots \ldots \ldots \ldots .135-141$ & Mexican lead ore, contents.............. \\
\hline on................ & $\ldots \ldots \ldots 204,206,222$ \\
\hline production ................. & exports to $\ldots \ldots \ldots \ldots \ldots \ldots \ldots \ldots \ldots, 198$ \\
\hline . & imports from .... \\
\hline .. 149-152 & into Great Britain . . . . . . . . 210,211 \\
\hline$\ldots 156,162$ & lead imports into United States....... $\quad 239$ \\
\hline (n................... & production .................... 245,246 \\
\hline 158,162 & zinc exports ...................... 261 \\
\hline$\ldots \ldots \ldots \ldots \ldots \ldots \ldots \ldots 130,140$ & 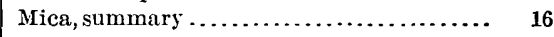 \\
\hline$\ldots \ldots \ldots \ldots \ldots \ldots \ldots \ldots \ldots \ldots \ldots, 159,162$ & Michigan, Bessemer pig iron, production .. \\
\hline uction ............ 162 & coal..................... 335, 336, 337, 338, \\
\hline$\ldots \ldots \ldots \ldots \ldots \ldots \ldots 130,140$ & $342,343,344,345,346,347,348,349$ \\
\hline$\ldots \ldots \ldots \ldots \ldots \ldots 130,146-149$ & fields, production . ......... 324,326,328 \\
\hline roduction ........... 162 & labor statistics............. 355, 356,357 \\
\hline , Belgium, produc- & $376,377,378,379,380,453$ \\
\hline$\ldots \ldots \ldots \ldots \ldots \ldots$ & ... $352-354$ \\
\hline$\ldots \ldots \ldots \ldots \ldots \ldots$ & gold and silver production and value.. 125 , \\
\hline$\ldots \ldots \ldots \ldots \ldots$ & 126,127 \\
\hline erior region.................. & gold production. \\
\hline$\ldots \ldots \ldots \ldots \ldots \ldots \ldots .132-134$ & $\ldots \ldots \ldots \ldots .34,43,52$ \\
\hline res $\ldots . . . \ldots \ldots \ldots . .$. & stocks ......... \\
\hline esiduum, New Jersey. & value.... \\
\hline n...... 204,205 & manganese ores $\ldots \ldots \ldots \ldots \ldots \ldots \ldots$ \\
\hline ue exports ....... & pig iron......... \\
\hline$\cdots \cdots \cdots$ & silver production................ 121,122 \\
\hline tion ........ & Middle States, copper production......... 166, \\
\hline n, production........... & $167,168,169,170$ \\
\hline$\ldots \ldots \ldots \ldots \ldots 335,336,337,338$, & Mills \\
\hline $344,345,346,347,348,349,457-461$ & Milwaukee, Wisconsin, coal receipts ...... 383 \\
\hline$\ldots \ldots \ldots \ldots 324,326,328$ & $407-410$ \\
\hline$\ldots 355,356,357$ & mmary...$\ldots \ldots \ldots \ldots$. \\
\hline $376,377,378,379,380,457$ & Minnesota, Bessemer pig iron, production . \\
\hline .. $352-354$ & tion $\ldots \ldots \ldots \ldots \ldots, 176$ \\
\hline .......... 104 & er production and value. 125,126 \\
\hline$\ldots \ldots \ldots \ldots \ldots \ldots \quad 123$ & gold production $\ldots \ldots \ldots \ldots \ldots \ldots \ldots \ldots$ \\
\hline and value...... 125, 126, 127 & iron ores... \\
\hline $34,51,52$ & stocks \\
\hline 53 & value.. \\
\hline & molybdenum. \\
\hline$\cdots \cdots, \ldots$ & $\ldots \ldots \ldots \ldots \ldots \ldots 9,90,95$ \\
\hline 103 & \\
\hline
\end{tabular}


Mirabel quicksilver mine, California, pro-

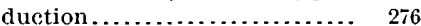

Missouri, Bessemer pig iron, production.... 92 coal.................. 335, 336, 337, 338, 342, $343,344,345,346,347,348,349,464-468$ fields, production........... $325,327,329$ labor statistics............. $355,356,357$ machine-mined ... $376,377,378,379,380,464$ percentage of total . . ......... 352, 353, 354 strikes in mines ................ 464

coke............. 534, 535, 536, 542, 543, 583 character of coal used in making .. 554 $555,556,584$ coal used in making ............ 544 ,

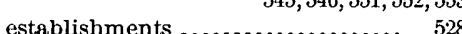
manufacture .................. 523,524,525 ovens...................... 531, 532,533 percentage yield of coal in making. $\quad 549$ production, increases and decreases 526 value ................... 537,538, 539 value per short ton ............. 540,541 copper production................ 166,167 cut nails, production ............... 104 gold production and value.......... 127

iron ores....................... 34,51,52 stocks......................... 53

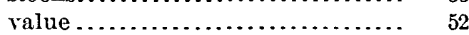

lead ore, contents .................. 229 manganese ores ..................... 130, 139 pig iron.......................... 95 zinc production ................. 250,251

Mobile, Alabama, coal trade ........... 416-418

Molybdenum ...................... 305-308

Arizona.......................... 307

Canada.......................... 307

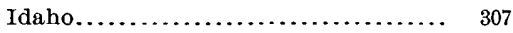

Minnesota........................ 307

Newfoundland ................... 307

New Mexico...................... 307

Washington ....................... 307

Monazite, summary ................... 16

Montana, coal . $335,336,337,338$, $342,343,344,345,346,347,348,349,468-471$ fields, production........... $325,327,329$ labor statistics.............. $355,356,357$ machine-mined .. 376, 377, 378, 379, 380, 468 percentage of total .......... 352, 353,354 strikes in mines ................ 468

coke .........534, 535, 536, 542,543,585 character of coal used in making .. 554 , $555,556,586$ coal used in making . $545,546,551,552,553$ establishments ................. 528 manufacture ............... 523, 524,525 ovens................... 531,532, 533 percentage yield of coal in making. $\quad 549$ production, increases and decreases. $\quad 526$ value ...................... 537,538,539 value per short ton ............. 540,541 copper............. 166, 167, 168, 169, 170,184 gold and silver production and value.. 125 126,127

gold production 123,124

lead ore cont
Montana, silver production Murray, Charles B., on coal trade of Cincin-

nati....................... 410-414

Namaque Company mine, copper production.................... 205, 206

Napa Consolidated quicksilver mine, California, production ............ 274

Natal, coal production.................. 113,363

National mine, copper production......... $\quad 176$

Natural gas, summary ................. 11

Nebraska, coal............... 325, 327, 329, 342, 471

gold production ................... 123

silver production................... 121

Neck Camp, production of zinc and lead ore. 252

Netherlands, copper, exports to.......... 198 imports into Germany............ 216

lead consumption .................... 247

zinc exports ...................... 261

Nevada, antimony..................... 291

coal................................ 471

production ................... $327-329$

labor statistics................. 355-357

copper production .... 166, 167, 168, 169,170, 188

gold production .................. 123, 124 and value $\ldots \ldots \ldots \ldots \ldots \ldots \ldots 125,126,127$

iron ores....................... $34,51,52$ stocks....................... 53

lead ore, contents................... 229

silver production................. 121, 122

tungsten......................... 301

ore............................ 319

New Almaden quicksilver mine, California,

production .................. 274

New and Kanawha river coal field, West Virginia .................. 512

Newark, New Jersey, importation of copper. $\quad 193$

New England, basic pig iron, production... 92 coal fields, anthracite, production. $324,326,328$ iron and steel, production ............ 102

steel, production..................... 97,98

Newfoundland, copper.................. 222 imports into Great Britain from .. 210, 211 production .................... 204-206 iron ores, imports from .............. 64 manganese ores ................... 146, 162 molybdenum..................... $\quad 307$ New Hampshire, copper production...... 166, $167,168,169,170$

New Idria quicksilver mine, California, production...................... 274

New Jersey basic pig iron, production....... 92 Bessemer pig iron, production ......... 92 cut nails, production ................ 104 iron and steel, production .............. 102 iron ores..................... $34,48,49,52$ production ..................... 34 shipments ..................... 82 stocks ............................ 53 value......................... 52 manganiferous zinc residuum ......... $\quad 133$ pig iron, production $\ldots \ldots \ldots \ldots \ldots \ldots \ldots . \quad 95$ steel, production................ 97, 98, 99 wire nails, production ................ 103 Tew Mexico coal........ 335-339, 342-349, 471-473 fields, anthracite, production . $324,326,328$ production ............. 325, 327, 329 
Page.

New Mexico coal, labor statistics........ 355-357 machine-mined .. $376,377,378,379,380,472$ percentage total of . . . . . . . . . . . 352-354

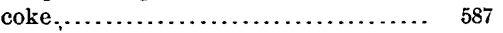
character of coal used in making... 554 $555,556,588$ coal used in making ............. 544 $545,546,551,552,553$ establishments .................. 528 manufacture .............. 523,524,525 ovens.................... 531, 532,533 percentage yield of coal in making. $\quad 549$ production ...............534,535,536 production, increases and decreases. $\quad 526$ value.................... 537,538, 539 value per short ton.............5540,541 copper............. 166,167, 168, 169, 170, 187 gold, production................. 123, 124 gold, production and value....... 125, 126, 127 iron ores........................ 34,51,52

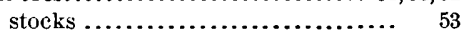
value ........................... 52

lead ore, contents ................... 229 molybdenum ..................... 307 silver, production................ 121, 122 uranium................................ 311

New Quebrada copper mine, production. 204,206 New River coke district, West Virginia..... 626 New South Wales, coal............ 113, 363, 370 copper....................... 205, 206, 220 iron ores....................... 113 manganese ores, production........... 162

New York, basic pig iron, production...... 92 Bessemer pig iron, production ......... 92 by-product coke ovens................ 558 coke ........................... 588 character of coal used in making. 555,556 coal used in making............. 545,546 establishments . manufacture $\ldots \ldots \ldots \ldots \ldots .523,524,525$ ovens................... 531, 532,533 percentage yield of coal in making. $\quad 549$ production ..... 534,535,536,543 production, increases and decreases. $\quad 526$ value ............ 537, 538,539,540,541.

iron and steel, production........... 102 iron ore, stocks..................... 53

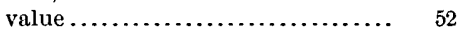

pig-iron, production............... 90-95 steel, production .................. 97,98,99 wire nails, production............... 103 New Zealand, coal production .......... 363-371 manganese ores, production.......... 161,162

Nickel and cobalt, production............ 285

Nickel, Canada........................ 288

France, production................... 289

Germany, production ............... $\quad 289$

imports ........................... 287

oxide, exports .................... 288

summary .......................... 8

Nonesuch copper mine, production ....... 175

Norfolk, Virginia, coal trade............ 418

North America, recapitulation of copper production .................

North Carolina, Bessemer pig, iron, production......................... 92
North Carolina, coal........ 335, 339, 343, 349,474 fields, production........... 324, 326, 328

labor statistics.................. 355-357 gold, production and value.......... 123, $124,125,126,127$ gummite, analyses .................. 310

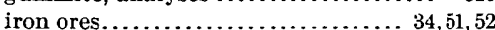

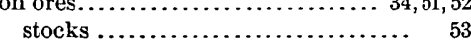
value ............................... 52

manganese ores ................... 130-139

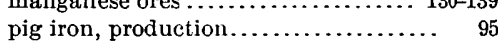
silver, production ................. 121, 122 tungsten........................... 303 uraninite, analysis ................ 310 uranium........................ 311 uranophane, analysis.............. 310 North Dakota, coal.......... 335, 339, 342, 349,475 labor stratistics..................... 355-357 machine-mined ................ $376,379,380$ pecentage of total ................. 352-354 Norway, copper imports into Germany..... 216 into Great Britain .............. 210,211

production ......................... 204,205

Nova Scotia, manganese ores............. $\quad 145$ tungsten......................... 303 Occurrence of tungsten ore in eastern $\mathrm{Ne}$ vada, by F. B. Weeks ......... 319 ocher, summary .................... 14 Ogima copper mine, production.......... 176 Ohio, basic pig iron, production........... 92 Bessemer steel ingots, production...... 97 pig iron, production ............ 92 coal ..................... 335,336,337,338, $342,343,344,345,346,347,348,349,476-482$ fields, production ........... 324,326,328 labor statistics............... 355, 356,357 machine-mined... $376,377,378,379,380,476$ percentage of total ............ 352-354 production by counties.......... 477-480 strikes in mines. .................. 476

coke............ 534,535, 536, 542, 543, 558-592 character of coal used in making .. 554 , $555,556,592$ coal used in making............ 544 $545,546,551,552,553$

Cincinnati district ............. 590 district, Ohio................... 590 establishments ................ 528 manufacture ............. 523,524,525 ovens.................... 531,532,533 percentage yield of coal in mak-

ing $\ldots \ldots \ldots \ldots \ldots \ldots \ldots \ldots \ldots .549,550$ production,increases and decreases. $\quad 526$ value................. 537,538,539 value per short ton.......... 540,541 cut nails, production................ 104 iron ores....................... $34,51,52$

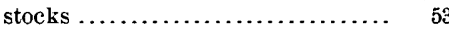
value $\ldots \ldots \ldots \ldots \ldots \ldots \ldots \ldots \ldots, 52$

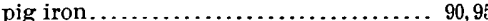
steel, production $\ldots \ldots \ldots \ldots \ldots \ldots \ldots \ldots \ldots .97,98$ wire nails, production.............. 103 Oilstones, summary ...................... 12 Open-hearth steel ingots and rails, Great Britain ................... 116

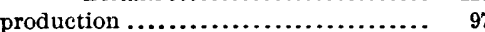


Pig iron, stocks unsold ............... Page. Tennessee, production

.......... 90, 95

95

Virginia, production ............... 90,95

West Virginia, production........... 90,95

Wisconsin, production............... 90, 95

Pigments, summary ................... 14

Pittsburg, Pennsylvania, coke district..... 610

coal receipts........................ 382

coal trade ....................... 398-401

Plata River copper, imports into Great Britain $\ldots \ldots \ldots \ldots \ldots \ldots \ldots \ldots \ldots \ldots \ldots \ldots \ldots \ldots, 211$

Platinum, summary ..................... 8

Pocahontas-Flat Top coke district, West Virginia....................

Pocahontas or Flat Top coal field, West Vir-

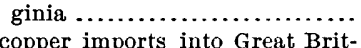

Portugal, copper imports into Great Britain ................... 209, 210, 211

iron ores, imports from ............... 64 manganese ores ................. 160,162

Pratt, Joseph Hyde, paper on tungsten, molybdenum, uranium and vanadium .................. 299-318

Precious stones, summary.

Preston, Elwyn G., on coal trade of Boston, Massachusetts .............. 389-391

Prices, anthracite coal at Philadelphia, Pennsylvania ................. 395

antimony ....................... 295

coal, anthracite, at mines ........... 381 at tide water ................ 384,387

at mines.................... 358, 359 by States, since $1886 \ldots \ldots \ldots \ldots . \quad 355$

coke at ovens..................... 540

Connellsville, Pennsylvania, district .................... 603-605

copper........................... 199-203

iron and steel ...................... $78-80$

iron ore, Lake Superior.............. 80

lake copper.................. 199, 200, 201

lead ............................ 241-243

quicksilver........................... 282

zinc ........................... 262-265

Production of zinc and lead ore........... 252

Prussia, manganese ores, production...... 155

nickle, production................... $\quad 289$

Pumice stone, summary ................. 17

Pyrite, summary ..................... 13

Queensland, coal, production.......... 363-370 copper.......................... 221 manganese ores, production ........... 162

Quicksilver, by Edward W. Parker....... 273-283 prices............................ 282 production ........................ 273 summary

Texas.......................... 278-280

Quincy copper mine, production......... 175 operations ..................... 179, 180

Redington quicksilver mine, California, production .................. 274

Red lead, summary.

Reynoldsville-Walston coke district, Pennsylvania .................... 607

Rhode Island coal fields, anthracite.. $324,326,328$ wire nails, production ................. 103

Ridge copper mine, production ........... 175,176
Page.

Rio Tinto copper mine, production ..... 204,205 Rocky Mountain coal fields, production.... 330 Ruley, William W., paper on Pennsylvania anthracite coal ............. 484-492 Russia and Finland, pig iron............ 114 steel............................. 114 Russia, Baltic, and White seas, zinc exports. $\quad 261$ coal.......................... 113, 363, 368 copper consumption............... 217,218 copper exports to................... 198 production ..................... 204, 205, 218 trade ......................... 217

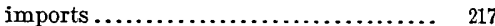
iron ore............................ 113 lead consumption .................... 247 manganese ores .................. 159,162 Rutile, summary ..................... 17 Saint Clair copper mine, production ........ $\quad 175$ Saint Louis, Mrissouri, coal receipts........ 383 trade ........................414-416 Salt, summary....................... 13 San Francisco, California, coal trade..... 418-420 importation of copper ............... $\quad 193$ Scheelite. (See Tungsten.)

Scotch coal.

Scott, F. A., on coal trade of Cleveland, Ohio ...................... 402-404 Seattle, Washington, coal trade........... 420-422 Semet-Solvay by-product coke ovens....... $\quad 558$ Seville copper mine, production......... 204,205 Sheldon and Columbia mine copper production ..................... 176

Sienna, summary..................... 14 Silver production, by States............ 121-122 summary $\ldots \ldots \ldots \ldots \ldots \ldots \ldots \ldots \ldots \ldots . \quad 7$ Soapstone, summary ................... 17 South African Republic, coal ....... 113, 363, 373 South America, manganese ores........... 149-152 recapitulation of copper production.... 207 South Australia, copper............. 205, 206,222 South Carolina, gold and silver production and value $\ldots \ldots \ldots \ldots \ldots . .125,126,127$ gold production ..................... 123,124 silver production ................ 121,122 South Dakota, copper production .......... 170 gold and silver production and value.. 125 126,127 gold production ................... 123,124 lead ore, contents.................... 229 silver production.................. 121,122 tungsten........................ 301 uranium......................... 310 Southern States, copper production ....... 166, $167,168,169,170$ zinc production .................. 250,251 Spain and Portugal, copper production .. 204, 205 Spain, coal...................... 113, 363,372

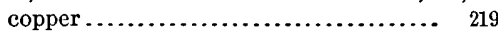
copper imports into Germany ......... 216 copper imports in1o Great Britain. 209, 210, 211 iron ore....................... 113 imports from $\ldots \ldots \ldots \ldots \ldots \ldots \ldots \ldots .64$ lead production ................... 245, 246 manganese ores .................. 156,162 exports ...................... 157 pig iron.......................... 114 steel ................................. 114 
Spiegeleisen and ferro-manganese......... $\begin{array}{r}\text { Page. } \\ \text {, } 93\end{array}$ Stanton, John, quoted on copper product. 172,175 Steel. (See also Iron and steel.)

all kinds, production ........... 76,97,98,99 rails, Bessemer, production

monthly prices

world's production by countries ........ 114

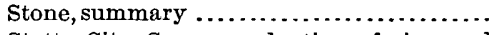

Stotts City Camp, production of zinc and lead ore.................... 252

Strikes in coal mines, Alabama.......424,518,519

Arkansas . . . ................ 428,517

Colorado..................... 432,518,519

Indian Territory ..................444,517

Iowa.

Kansas

Kentucky ....................... 453

Mrissouri .......................... 464

Montana ....................... 468

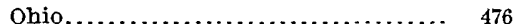

Pennsylvania ...................... 518

West Virginia . ...................... 509

Structural materials, summary .............

Sulphur Bank quicksilver mine, California, production ...................

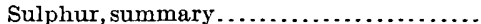

Summary of mineral products............ $5-29$

Swank, James M., paper on the American and foreign iron trades in 1899. 69-118

Sweden, coal production .................. $363-373$ copper production................. 204,205

imports into Germany............ 216

iron ores......................... 113

manganese ores ................. 158, 162

pig iron $\ldots \ldots \ldots \ldots \ldots \ldots \ldots \ldots \ldots \ldots, 114$

steel............................. $\quad 114$

Switzerland, copper imports into Germany. $\quad 216$ lead consumption ................. 247

Tamarack copper mine, production....... 176

Tamarack, jr., copper mine, production .... 177

Tar, coke by-product, amount and value... $\quad 560$

Tasmania, coal production ............... 363 copper......................... 221

Tennessee, Bessemer pig iron production.

coal $\ldots . .2 .335,336,337,338,342,343$ $344,345,346,347,348,349,498-500$ fields, production............ 324, 326, 328 labor statistics................. 355-357 machine-mined .......... $376,379,380,498$ percentage of total . . ........... 352-354

coke............................615-617 character of coal used in making. 554 556,617

coal used in making..... 544-546,551-553 establishments ................ 528, 529 ovens......................... 531,533 percentage yield of coal in mak-

ing $\ldots \ldots \ldots \ldots \ldots \ldots \ldots \ldots \ldots .549,550$ production ............. 534-536,542,543 production, increases and decreases 526 value ................... 537, 538, 539 value per short ton ............. 540,541

copper........................ 188 production .......... 166, 167, 168, 169, 170 gold production ..................... 123 gold production and ralue ......... 125, 126
Page.

Tennessee, iron ores ................ 34,48,52 stocks.......................... 53 value $\ldots \ldots \ldots \ldots \ldots \ldots \ldots \ldots \ldots \ldots . \ldots \ldots, 52$

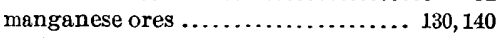
pig iron......................... 90,95 production ..................... 90 silver production ..................... 121 Texas coal ................. 335,336,337,338, $342,343,344,345,346,347,348,349,501$ fields, production........... $325,327,329$ labor statistics................... 355-357 machine-mined ................ 376-379 percentage of total .............. 352-354

coke............................. 617 coal used in making........ 546,553,556 establishments . ............... 528,529 manufacture ................... 525 ovens ...................... 531, 533 percentage yield of coal in making 549,550 production .......... 534, 535,536,542,543 gold production and value .......... 123, $124,125,126,127$ iron ores...................... $34,51,52$ stocks.......................... 53

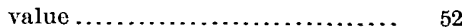

lead ore, contents .................. $\quad 229$ pig iron........................... 95 quicksilver ........................ 278-280 silver production.................. 121, 122 uranium......................... 311

Tharsis copper mine, production.......... 204, 205 Tin plates, imports ................. 107 production .......................... 106

Toledo, Ohio, coal receipts ................ 383 coal trade........................ 405

Tripoli, summary ......................... 12 Tungsten molybdenum, uranium, and vanadium, by Joseph Hyde Pratt. 299-318

Tungsten .......................... 299-305 Arizona............................. 300

Colorado......................... 301

Connecticut ..................... 301-303

Idaho............................ 301

Nevada......................... 301

North Carolina .................... 303

Nova Scotia ...................... 303

occurrence ........................ $\quad 300$

Oregon $\ldots \ldots \ldots \ldots \ldots \ldots \ldots \ldots \ldots \ldots . \quad 301$

South Dakota.................... 301

tests for........................... 305

uses............................... 304

Turkey, manganese ores, production...... 159, 162

Umber, summary ..................... 14

United Kingdom, copper exports to....... 198 imports from .................. 194 iron ores, imports from.............. 64 lead imports into United States ........ $\quad 239$ zinc exports ...................... 261 United States, coal production ........... 363-365 copper imports into France ........... 213 into Germany .............. 216 into Great Britain............ 210, 211 production ................... 204, 206 supply ......................... 199

lead consumption ................. 232, 247 production ..................... 245, 246 manganese ores, production.......... 162 
Upper Connellsville coke district, Pennsylvania ......................

Upper Monongahela coke district, West Virginia

Upper Potomae coke district, West Virginia Upper Potomac or Elk Garden coal field, West Virginia ................ 512

Ural mine, copper production............ 218 Uraninite, analyses................... $\quad 310$

Uranium ....... 308-314

Colorado........................... $\quad 310$

Connecticut ...................... 311

minerals, list of ..................... 313

New Mexico...................... 311

North Carolina. ................... 311

occurrence ....................... 309-313

South Dakota. ................... 310

tests for.............................. 318

Texas............................ $\quad 311$

uses............................... 308

Uranophane, analysis ................. 310

Utah, coal .................. 335, 336, 337, $338,342,343,344,345,346,347,348,349,502$ fields, production........... $325,327,329$ labor statistics.............. $355,356,357$ machine mined......... $376,377,378,379$ percentage of total ............. 352-354 coke............... 534, 535, 536, 542, 543, 617 character of coal used in making... 554 coal used in making......... 544,545,546 establishments ................ 528,529 manufacture ................ 523, 524,525 ovens ....................... 531,533 percentage yield of coal in making. 549,

550

value $. . \ldots \ldots \ldots \ldots \ldots \ldots \ldots . \ldots 537,538,539$ value per short ton ........... 540,541 copper............ 166, 167, 168, 169, 170, 186 gold and silver production and value.. 125, 126,127 gold production .................... 123,124 iron ores......................... $34,51,52$

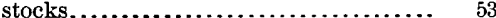

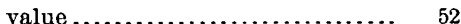

lead ore, contents ................ 229

silver production ................. 121,122

Vanadium . $314-318$

Argentine Republic ................. 315

minerals, list of ..................... 316

North Carolina .................... 315

occurrence ........................ $\quad 315$

Peru ........................... $\quad 315$

tests for......................... 318

Venetian red, summary ................ 14

Venczuela, copper imports into Great Brit-

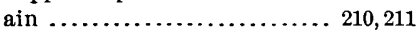
production $\ldots \ldots \ldots \ldots \ldots \ldots \ldots .204,206$

Vermont, copper ......... 166, 167, 168,169,170, 188 gold production ..................... 123 gold production and value .......... 125-127 iron ores, stocks ................... 53

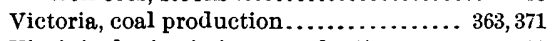

Virginia, basic pig iron, production....... 92 corl .......................... $338,342,343,344,345,346,347,348,349,504$ fields, production........... 324, 326, 328 labor statistics ............... 355, 356, 357
Page.

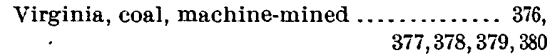
percentage of total............. $352-354$ coke............ 534, 535, 536, 542,543, 618-620 coal used in making ............ 544, $545,546,551,552,553,620$ establishments ................. 528,529 manufacture ................. $523,524,525$ ovens ....................... 531, 533 percentage yield of coal in making. 549 , 550 production, increase and decrease.. $\quad 526$ value ................... 537, 538, 539 value per short ton ............ 540,541 cut nails, production ............... 104 gold and silver production and value.. 125,

126,127

gold production ................... 123

iron ores......................... $34,46,52$

stocks.......................... 53

value .......................... 52

lead ore, contents.................. 229

manganese ores .................. 130,140

pig iron ......................... 90,95

silver production ..................... 121

Washington coal ............... 335, 336, 337,

$338,342,343,344,345,346,347,348,349,506$ fields, production........... $325,327,328$ labor statistics.............. 355, 356, 357 machine-mined ...... 376, 377, 378, 379, 380 percentage of total............ 352-354 coke............... 534, 535, 536,542,543,620 character of coal used in making ... 554,

$555,556,621$

coal used in making............. 544, $545,546,551,552,553$ establishments ............... 528,529 manufacture .............. 523, 524,525 ovens........................ 531, 533 percentage yield of coal in making. 549 ,

production, increase and decrease.. $\quad 526$ value .................... 537,538,539 value per short ton.............540,541 copper production.............. 168,169 gold and silver production and value.. 125, 126,127

lead ore, contents .................. 229 molybdenum ....................... 307 silver production................. 121,122 Webb City Camp, production of zinc and lead ore ................... 252 Weeks, F. B., paper on an occurrence of tungsten ore in eastern Nevada. $\quad 319$

Welsh coal ......................... $\quad 419$ Western coal fields, production ............. 330

West Indies, copper exports to. ........... 198 imports from ................. 194 manganese ores .................... 146-149 zinc exports ...................... 261 West Kentucky coal fields, production..... 324 West Virginia, Bessemer pig iron, produc-

tion $\ldots \ldots \ldots \ldots \ldots \ldots \ldots \ldots . . .62$ coal.................. 335, 336, 337, 338 , $342,343,344,345,346,347,348,349,508-514$

Fairmont field ................. 512 
West Virginia, coal fields, production. $324,326,328$ labor statistics machine-mined .. 376, 377, 378, 379, 380, 509 New and Kanawha River field. percentage of total.............. 352-354 Pocahontas or Flat Top field ...... 512 strikes in mines ................ 509 Upper Potomac or Elk Garden field. $\quad 512$

coke . 534, 535, 536, 542, 543, 622-630 by-product ovens............... 558 character of coal used in making .. 554, $555,556,624$ coal used in making ............ 544, establishments $\quad 545,546,551,552,553$ Kanawha district ................ 627 manufacture ............... 523, 524, 525 New River district.............. 626 Pocahontas Flat Top district ...... $\quad 625$ production by districts........... 624 production, increasesand decreases. $\quad 526$ Upper Monongahela district ....... 629 Upper Potomac district .......... 628 value................. 537, 538, 539 value per short ton . . . . . . . . . . . . 540,541

cut nails, production ................ 104 iron ores........................ 34, 46,52 stocks ........................ 53 value manganese ores .................. 130 pig iron ....................... 90,95 wire nails, production .............. 103

White lead, summary .................... $\quad 15$

Wire nails, production by States......... 103

Wisconsin, basic pig iron, production...... $\quad 92$

Bessemer pig iron, production ......... 92 coke................ 534, 535, 536, 542, 543, 630 character of coal used in making .. 554 , $555,556,631$ coal used in making.. 545, 546, 551, 552, 553 establishments ............... 528,529 manufacture ............. 523,524,525 ovens. . . percentage yield of coal in making. 549 , production, increases and decreases. $\quad 526$ value............ 537,538, 539 value per short ton........... 540,541 iron ores...................... $34,48,52$ stocks ......................... 53

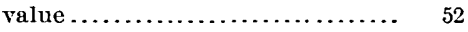

lead ore, contents ............... 229 pig iron, production

Wood, Lovett I., on coal trade of Seattle, Page.

Wash ..................... 420-422

World's coal production, by countries...... 113 copper production................. 204-207 great pig-iron producers, by countries.. $\quad 115$ iron-ore production, by countries...... 113 lead consumption .................. 247 lead production .................. 244-246 manganese production ............... 162 product of coal .................. 363-373 production of pig iron and steel, by countries................... 114 zinc production ..................... 266 Wyoming coal ................ 335, 336, 337, 338 , $342,343,344,345,346,347,348,349,514-517$ fields, production............ 325, 327, 328 labor statistics................. $355-357$ machine-mined .. $376,377,378,379,380,515$ percentage of total .......... 352,353,354 coke................ 534, 535, 536, 543,632 character of coal used in making .. 554 , $555,556,633$ coal used in making.. 545,546,551,552,553 establishments .............. 528, 529 manufacture ............. 523,524,525 ovens........................ 531,533 percentage yield of coal in making. 549 , production, increases and decreases value ...................537,538, 539 value per short ton ............. 541 copper............ 166,167, 168, 169, 170,187 cut nails, production............... 104 gold and silver production and value.. 125 , 126,127 gold production $\ldots \ldots \ldots \ldots \ldots \ldots \ldots \ldots 123,124$ iron ores..................... $34,51,52$ stocks ........................ 53 value $\ldots \ldots \ldots \ldots \ldots \ldots \ldots \ldots \ldots \ldots$ silver production.................. 121 Zinc, by Charles Kirchhoff ............. 249-266 consumption ..................... 255 exports, by countries ................. 261 imports ......................... 256-261 mining in the Galena-Joplin district. 252-255 oxide, imports..................... 258 prices............................ 262-265 production by half-yearly periods..... 250 Eastern States ................ 250,251 Kansas ......................... 250,251 Missouri .................... 250, 251 Southern States ............. 250,251 summary ......................... 7 white, summary.................. 15 world's production $\ldots \ldots \ldots \ldots \ldots \ldots \ldots . \quad 266$ 